
DAVID MARCOS DIEZ 
DAVID MARCOS DIEZ

\section{LA ABADÍA DE SANTA MARÍA DE HUSILLOS: ESTUDIO Y COLECCIÓN DOCUMENTAL (904 - 1608)}

TESIS DOCTORAL DIRIGIDA POR EL PROF. DR. JOSÉ MANUEL RUIZ ASENCIO 
DAVID MARCOS DIEZ 


\section{ÍNDICE GENERAL}

INTRODUCCIÓN

15-18

ESTADO DE LA CUESTIÓN

19-30

1. ESTUDIO HISTÓRICO

31

\subsection{EVOLUCIÓN HISTÓRICA DE SANTA MARÍA DE HUSILLOS}

I. EL ORIGEN DE SANTA MARÍA DE HUSILLOS

21. Fuentes documentales

2. Fuentes arqueológicas

3. Informaciones de testigos y canónigos

$36-38$

4. Conclusiones

$38-44$

II. SANTA MARÍA DE HUSILLOS BAJO LOS CONDES DE MONZÓN

1. El condado de Monzón

2. Las donaciones de los condes de Monzón

$46-48$

3. La primera restauración de la diócesis de Palencia en

Husillos: el obispo Julián de Husillos

4. Las campañas de Almanzor. Desaparición del condado de Monzón y de Santa María de Husillos

III. SANCHO EL MAYOR DE NAVARRA

1. La segunda restauración de la diócesis de Palencia: el obispo Poncio y Santa María de Husillos

2. El abad Raimundo de Santa María de Husillos

IV. DE FERNANDO I A SANCHO III

1. El concilio legatino de Husillos 
2. Urraca I

$62-64$

3. Alfonso VII

4. Sancho III

64-66

V. SANTA MARÍA DE HUSILLOS DESDE LOS SIGLOS XIII

$66-70$ AL XVI

VI. SANTA MARÍA DE HUSILLOS Y EL OBISPADO DE

$70-72$ PALENCIA

VII. SANTA MARÍA DE HUSILLOS Y FELIPE II

1. La desamortización de Felipe II $72-74$

2. Patronazgo real de Husillos 74-76

3. Visita de Felipe II a Santa María de Husillos 76-77

4. La reliquia del pie de San Lorenzo

VIII. EL ABAD FRANCISCO DE REINOSO

IX. TRASLADO A AMPUDIA DE SANTA MARÍA DE $82-85$ HUSILLOS

\subsection{EL DOMINIO DE SANTA MARÍA DE HUSILLOS}

\section{LA FORMACIÓN DEL DOMINIO}

II. EVOLUCIÓN DEL DOMINIO

1. El dominio de Husillos a fines del siglo XII

2. El dominio de Husillos a fines del siglo XIV

3. El dominio de Husillos a mediados del siglo XVI

4. Evolución del dominio

4.1. Evolución del dominio de Santa María de Husillos entre fines del siglo XII y fines del siglo XIV

4.2. Evolución del dominio de Santa María de Husillos 
entre fines del siglo XIV y mediados del siglo XVI

5. Conclusiones

$102-103$

III. ELEMENTOS FORMATIVOS DEL DOMINIO 103

1. Villas 103

2. Iglesias 103-104

3. Préstamos 104

4. Heredades 104-105

5. Recursos hidráulicos 105-106

6. Salinas 106

7. Pedreras o canteras 106-107

8. Recursos forestales 107

IV. ESTRUCTURA DEL DOMINIO DE SANTA MARÍA DE HUSILLOS

1. Iglesias y heredades diversas

107-108

2. La reserva

108-109

3. El coto

$109-112$

V. EL SEÑORÍO JURISDICCIONAL

VI. RENTAS MONÁSTICAS

1. Rentas procedentes de la explotación de la propiedad real

114-116

2. Rentas señoriales

$117-118$

3. Rentas de iglesia

4. Ingresos percibidos por los canónigos

$119-120$

5. Otros ingresos 
HUSILLOS

II. CANÓNICA, PRIVILEGIOS, ESTATUTOS Y VISITAS

1. Canónica y privilegios

$138-140$

2. Estatutos

$140-147$

3. Visitas

$147-148$

III. ABADES, DIGNIDADES, CANÓNIGOS Y RACIONEROS

DE SANTA MARÍA DE HUSILLOS

1. El nombramiento de abades en Santa María de Husillos

$148-150$

2. Abadologio de Santa María de Husillos

$150-159$

3. Dignidades, canónigos y oficiales de Santa María de

$159-166$ Husillos

1.4. NOTAS SOBRE LA BIBLIOTECA Y EL ARCHIVO DE SANTA MARÍA DE HUSILLOS

I. LA BIBLIOTECA

II. EL ARCHIVO

$167-169$

1.5. CONCLUSIONES

2.1. CRITERIOS DE EDICIÓN

175-176

\subsection{FUENTES}

I. FUENTES MANUSCRITAS

177-180

II. FUENTES IMPRESAS 
1. Donaciones

\subsection{Donaciones propiamente dichas}

1.2. Concesiones

2. Confirmaciones

2.1. Confirmaciones reales

3. Testamentos

4. Compraventas

5. Permutas

6. Traslados 199-200

7. Arrendamientos

8. Censos

9. Mandatos

10. Inventarios de bienes

10.1 Libro Becerro

10.2 Relación de rentas de la abadía 205-206

11. Nombramientos 
12. Documentos de organización, ordenación interna,

regulación jurídica y control de la institución

13. Acuerdos del cabildo

14. Poderes

207-208

15. Autorizaciones y licencias

208-209

16. Reconocimientos

209

17. Documentos pontificios

209-210

18. Documentos judiciales

210-211

18.1. Litigantes

18.2. Jueces y árbitros

211-212

18.3. Asuntos y motivos de los pleitos

212

18.4. Tipología documental

18.4.1. Documentación de procesos judiciales de primera y segunda instancia

18.4.2. Documentación de procesos judiciales de

213-216 tercera instancia producidos por la Real Audiencia y Chancillería de Valladolid

18.5. Pleitos de Santa María de Husillos en la Real

Chancillería de Valladolid

18.5.1. Pleitos fenecidos

18.5.2. Pleitos olvidados

18.5.3. Ejecutorias

217-218

18.5.4. Motivos y causas de los pleitos

18.5.5. Recursos de fuerza

218-219

18.5.6. Conclusiones

219

19. Otros tipos documentales

20. Evolución de los tipos documentales: conclusiones

IX. FECHA CRONOLÓGICA

1. Eras y estilos cronológicos

2. Fecha del mes y del día

3. Día de la semana

224-225

4. Calendario litúrgico 
5. Otras formas cronológicas

6. Errores cronológicos

X. FECHA TÓPICA

XI. ESCRIBANOS Y NOTARIOS DE SANTA MARÍA DE HUSILLOS

XII. VALIDACIÓN DE LOS DOCUMENTOS: CARTAS

PARTIDAS POR ABC Y SELLOS

1.Cartas partidas por $\mathrm{ABC}$ o por alfabeto

2. Sellos

XIII. DIPLOMÁTICA MONÁSTICA DE SANTA MARÍA DE

HUSILLOS

\subsection{ESTUDIO PALEOGRÁFICO}

II. SISTEMAS DE ESCRITURA

1 Escritura visigótica

2. Escritura carolina

3. Escritura gótica documental

4. Escritura de albalaes

5. Escritura gótica de privilegios

6. Escritura precortesana

7. Escritura cortesana

8. Escritura procesal

9. Escritura gótica de cancillería pontificia

235-236

10. Escritura humanística

11. Escritura gótica de juros o de ejecutorias 
DEL LIBRO DE LOS PRIVILEGIOS

3. LOS DOCUMENTOS OTORGADOS POR LOS CONDES DE MONZÓN Y SANCHO EL MAYOR DE NAVARRA

I. INTRODUCCIÓN

1.1. Invocación simbólica o monogramática

1.3. Intitulación

1.4. Dirección

1.5. Salutación

1.6. Preámbulo

255

1.7. Notificación

255

1.8. Exposición

255

1.9. "Narrationes" de contenido histórico

255-256

1.10. Disposición

256-258

1.11. Sanción

259

1.12. Cláusula preceptiva final

260

1.13. Data

260-261

1.14. Corroboración

1.15. Suscripciones

261-264

1.16. Signos 
2. Definición y génesis de los documentos

2.1. Clasificación en cuanto a los otorgantes

265-266

2.2. Génesis de los documentos

2.2.1. Donaciones 266-267

2.2.2. Confirmaciones

$267-268$

3. Tipos diplomáticos según características formales

268-269

4. Tipos diplomáticos según la naturaleza jurídica

4.1. Donaciones

269

4.2. Confirmaciones

269-270

4.2.1. Suscripción confirmativa

270-272

IV. ANÁLISIS PALEOGRÁFICO

272-273

V. CRÍTICA DIPLOMÁTICA

273-288

VI. CONCLUSIONES

288-290

4. COLECCIÓN DOCUMENTAL

I. NORMAS DE EDICIÓN Y TRANSCRIPCIÓN

293

1. Normas de edición

295-296

2. Normas de transcripción

296-298

II. COLECCIÓN DIPLOMÁTICA

299-

1213

III. ÍNDICES

1215

1. Índice de personas

$1217-$

1263

2. Índice de lugares

$1265-$ 


\section{ÍNDICE DE SIGLAS}

ACL.: Archivo de la Catedral de León.

ACP.: Archivo de la Catedral de Palencia.

AGS.: Archivo General de Simancas.

AHDP.: Archivo Histórico Diocesano de Palencia.

AHN.: Archivo Histórico Nacional.

AHV.: Archivo Histórico Vaticano.

AMP.: Archivo Municipal de Palencia.

AMV.: Archivo Municipal de Valladolid.

APA.: Archivo Parroquial de Ampudia.

ARCHV.: Archivo de la Real Chancillería de Valladolid.

BN.: Biblioteca Nacional.

BRAH.: Biblioteca de la Real Academia de la Historia.

LPH.: Libro de los Privilegios de Husillos. 
LA ABADÍA DE SANTA MARÍA DE HUSILLOS: ESTUDIO Y COLECCIÓN DOCUMENTAL (904 - 1608)

\section{INTRODUCCIÓN}


DAVID MARCOS DIEZ 
La iglesia colegial o abadía de Santa María de Husillos es una más de las numerosas instituciones eclesiásticas que existieron en la diócesis de Palencia en las edades Media y Moderna. Enclavada en Husillos, localidad que se sitúa a 11 kilómetros al norte de Palencia y a cuatro kilómetros al suroeste de Monzón de Campos, y a una altitud de 791 metros, se encontraba así en plena Tierra de Campos palentina y en la baja ribera del río Carrión. Junto con la catedral de Palencia, San Zoilo de Carrión y San Isidro de Dueñas, era una de las más importantes instituciones eclesiásticas del ámbito sur de la diócesis de Palencia.

Dichas instituciones han sido estudiadas en mayor o menor profundidad, encontrándose publicadas sus colecciones documentales, junto con otras instituciones palentinas como Santa María de Aguilar de Campóo o Santa María de Benevívere. Santa María de Husillos es actualmente la única institución eclesiástica importante de la diócesis de Palencia cuya colección diplomática no ha sido editada ni estudiada, si bien hay algunos estudios históricos sobre ciertos aspectos de la citada iglesia.

La historia de Santa María de Husillos presenta varios aspectos controvertidos de difícil explicación e interpretación histórica. Nos referimos en primer lugar a sus orígenes, envuelto en un halo mítico y de leyenda, al igual que en el caso de la mayoría de las instituciones eclesiásticas altomedievales. También es notable el grado de complejidad que encierra su evolución en los primeros siglos de la Edad Media. Sólo a partir del primer tercio del siglo XII, cuando comienzan a tener continuidad las fuentes documentales con referencia a la abadía, se puede alcanzar una mayor objetividad en cuanto a su evolución histórica. Otros puntos oscuros son las relaciones de dependencia mantenidas con la catedral de Palencia y con la Santa Sede, la evolución de las reglas monásticas observadas en la abadía, la crisis del siglo XIV, las consecuencias del concilio de Trento, y la desamortización llevada a cabo por Felipe II a finales del siglo XVI.

La colección diplomática de Santa María de Husillos está formada por 351 documentos, abarcando sus fechas extremas desde el año 904 hasta 1608. 
Estamos ante una colección diplomática de tamaño medio pero de una gran importancia cualitativa, tanto a nivel general, ya que sus documentos son fuente imprescindible para muchos de los principales acontecimientos políticos y religiosos de los siglos X y XI, como a nivel particular del ámbito palentino, pues constituyen, junto a la documentación de la citada catedral de Palencia, San Zoilo de Carrión y San Isidro de Dueñas, la fuente principal para el estudio de la evolución histórica del ámbito territorial del Bajo Carrión desde la Alta Edad Media hasta la plena Edad Moderna. Es en este aspecto en el que la colección de Husillos muestra su carácter innovador con respecto a otras colecciones documentales de catedrales o cenobios de su ámbito geográfico editadas hasta el momento. Así, abarca desde el nacimiento de la institución eclesiástica hasta su fin como institución autónoma, al ser integrada en la nueva colegiata de Ampudia en 1606. Vemos cómo en la mayoría de los casos las colecciones documentales de las instituciones eclesiásticas abarcan períodos cronológicos concretos que suelen centrarse en la parte altomedieval y suelen acabar, en el mejor de los casos, hacia el año 1500, lo que impide hacer un estudio evolutivo de dichas instituciones a lo largo del tiempo. Esta problemática ya la recogía García de Cortázar en su estudio del monasterio de San Millán de la Cogolla, cuando afirmaba que un medievalismo exclusivista había tendido a monopolizar la vida de los cenobios, deteniéndola a mediados del siglo XV o antes de terminar el siglo XIII. Aunque Cortázar reconocía haber caído en dicha tendencia, veía la necesidad de hacer una investigación completa de una institución eclesiástica para elaborar una historia íntegra del señorío eclesiástico ${ }^{1}$.

\footnotetext{
${ }^{1}$ GARCÍA DE CORTAZAR, El dominio del Monasterio de San Millán de la Cogolla, 38.
} 
LA ABADÍA DE SANTA MARÍA DE HUSILLOS: ESTUDIO Y COLECCIÓN DOCUMENTAL (904 - 1608)

ESTADO DE LA CUESTIÓN 
DAVID MARCOS DIEZ 


\section{LA ABADÍA DE SANTA MARÍA DE HUSILLOS: ESTUDIO Y COLECCIÓN DOCUMENTAL $(904-1608)$}

Dos son los autores sobre los que descansa la mayor parte de lo escrito sobre Santa María de Husillos. Nos referimos a Ambrosio de Morales y a Jesús San Martín Payo. Morales fue el primer autor que trató sobre Santa María de Husillos, y lo que escribió sobre ésta en relación a su fundación fue tomado como base de partida por el resto de autores. San Martín Payo es en realidad quien más ha escrito y aportado sobre esta abadía, con notable diferencia sobre los demás. El resto de autores, la mayoría del siglo XX al igual que San Martín Payo, han tratado la abadía de forma somera o indirecta, en artículos de divulgación de su historia o bien relacionados con algún aspecto o acontecimiento concreto.

Ambrosio de Morales trató sobre Santa María de Husillos en dos de sus obras: el Viaje Santo $^{2}$ y en la Crónica general de España ${ }^{3}$. En la primera se centró en dos aspectos: la fundación de la abadía y las reliquias existentes. Para lo primero se basó en las informaciones de los miembros de la iglesia, ya que la escritura fundacional no se encontraba en aquel momento en la abadía, y en las falsas donaciones de los condes de Monzón. Por la importancia de lo escrito por Morales al ser la base de las afirmaciones e interpretaciones de los autores posteriores, trascribimos parte de lo que escribió en el Viaje Santo, ya que lo que escribió en la Crónica General de España se basó en lo que ya había escrito en dicha obra.

"Iglesia colegial de abad, dignidades y canónigos, en un lugarejo deste nombre, dos leguas de Palencia.

La fundación es de lo más antiguo de España, mas no es real, sino de un conde, don Fernando Ansúrez, y otros dos hermanos suyos, señores de Monzón, que alli llaman Monteson, y está media legua de allí. La reyna doña Teresa de León, hermana de los fundadores, y la infanta doña Urraca, hija de don Fernando el I, dieron alguna hacienda y por ellas hacen en particular entre año algunas memorias".4.

\footnotetext{
${ }^{2}$ MORALES, Viaje Santo.

${ }^{3}$ MORALES, Crónica general de España.

${ }^{4}$ MORALES, Viaje Santo, 23.
} 
Así, Morales establece claramente que los fundadores de Husillos son los condes de Monzón Fernando Ansúrez y dos hermanos, mencionando donaciones reales de la reina Teresa Ansúrez de León y la infanta doña Urraca, hija de Fernando I.

Al hablar de las reliquias que le mostraron en la abadía, dice textualmente:

"Antes del año de nuestro Redentor DCCCCL, un cardenal Raymundo vino acá, siendo ya viejo, sin que se entienda por qué ocasión. Traía muchas reliquias que el Papa le había dado, y pidió a la reyna doña Teresa de León, hija de los fundadores ya dichos y muger del rey don Ramiro de León, que le diese alguna iglesia en lugar desierto donde se recogiese con aquellas reliquias para ponerlas dignamente y acabar alli la vida. La reyna le respondió que ella no tenía cosa semejante que le satisfaciese. Mas mío hermano (dixo prosiguiendo adelante) vos dará, si él quisiere, la su iglesia de Santa María de Defesa Brava (que así se llamaba entoces aquel sitio). Todo esto se refiere así al principio en la escritura de fundación. Y luego entraron el conde y sus hermanos dándola al dicho cardenal. Yo no ví esta escritura original porque estaba fuera del archivo, presentada en pleytos, mas túvelo por relación de las dignidades y canónigos de alli, que muchas veces la han visto",

Morales se equivocó al afirmar que la reina Teresa Ansúrez era la esposa de Ramiro III de León, ya que en realidad era su madre. En la Crónica general de España corregirá dicho error al expresar que Teresa Ansúrez era la mujer del rey de León Sancho el Craso. A este error pudo contribuir también el hecho de que no viera personalmente la escritura por encontrarse como probanza en algún pleito, posiblemente en la Real Chancillería de Valladolid.

Aunque no llegó a ver directamente el documento, Morales omitió ciertos datos anacrónicos e ilógicos, como la presencia de Alfonso $\mathrm{VI}^{6}$, aunque es extraño que

\footnotetext{
${ }_{6}^{5}$ MORALES, Viaje Santo, 25.

${ }^{6}$ Ya el redactor del Libro de los Privilegios de Husillos apreció datos erróneos a su entender que en notas marginales trató corregir. Así, en el margen del folio 10 de Libro de los Privilegios de Husillos aparece escrito:

"Ojo. Adviértase que esta señora doña Teresa es hermana de los condes Ançures, reyna de León casada con el rey don Sancho "El Gordo" y madre del rey don Ramyro, y no muger como diçe la
} 


\section{LA ABADÍA DE SANTA MARÍA DE HUSILLOS: ESTUDIO Y COLECCIÓN \\ DOCUMENTAL $(904-1608)$}

cometiera el error sobre el esposo de la reina Teresa siquiera indirectamente, ya que además tal dato no aparece en el documento.

Tanta fue la fama en su tiempo del abad Francisco de Reinoso ${ }^{7}$ que al poco de su muerte, Gregorio de Alfaro, amigo de Pedro de Reinoso, sobrino del abad, hizo la biografía del abad de Husillos a partir de unos apuntes de Juan García, secretario que fue de Francisco de Reinoso. En fechas recientes, Marcial Castro Sánchez ha realizado una edición facsímil de la obra de Alfaro con una profundización en la biografía del abad ${ }^{8}$.

En la obra de Alfaro se aportan algunos datos sobre la fundación de la abadía que debían corresponder a la tradición oral de su tiempo y que se transmitieron a los autores posteriores. Así deja traslucir la tradición de un origen visigótico de Husillos como pequeña ermita sita dentro de una densa masa forestal, por lo que era llamada de Dehesa Brava. Al mencionar la general destrucción de España se puede referir a las incursiones de Tariq y Muza entre los años 711-715, y que gracias a la gran masa forestal de la zona, la iglesia pasó inadvertida para los invasores. En lo referente a Reinoso, gracias a esta obra conocemos al detalle la vida de este abad y de otros aspectos de importancia como fue el interés de Felipe II por la abadía, y la situación de ésta a finales del siglo XVI.

En el primer tercio del siglo XX hay una serie de autores que, en mayor o menor grado, han tratado sobre Santa María de Husillos, si bien es verdad que se trata de pequeños artículos en los que se hace una somera evolución histórica de la abadía enumerando los principales personajes y hechos históricos relacionados con ésta, tomando como base fundamentalmente la obra de Ambrosio de Morales y en menor medida la de Gregorio de Alfaro, aunque profundizan en lo que respecta a los aspectos artísticos y arquitectónicos, estableciendo las bases de futuras investigaciones.

\footnotetext{
carta de la fundación de la yglesia, que es falsa. Véase al arzobispo don Rodrigo y los demás cronistas", aunque en realidad dicha información no aparezca en el documento fundacional. En nota marginal se expresa también que quizá la Urraca que aparece en dicho documento sea la hija de Alfonso VI, después que casara con Alfonso "El Batallador"; aunque de forma obvia se aprecia que dicha Urraca era la hija de Fernando I y hermana de Alfonso VI.

${ }^{8}$ CASTRO SÁNCHEZ, Vida de Francisco de Reinoso.
} 
Nos referimos a los artículos publicados por Ramón Álvarez de la Braña y Matías Vielva en el Boletín de la Sociedad Castellana de Excursiones, y a lo escrito por Ambrosio Garrachón Bengoa, que trató de Santa María de Husillos en sus dos guías-catálogos de Palencia y su provincia ${ }^{9}$, siendo en la segunda donde ofreció más información, basándose en la obra de Ambrosio de Morales, aunque aporta datos interesantes por lo erróneo al afirmar que en Husillos tuvieron lugar dos concilios. Con Alfonso VI (1088) y Alfonso VII (1136), y que en el siglo XVIII con el traslado de la abadía a Ampudia se convirtió en iglesia parroquial ${ }^{10}$.

Sin embargo, la obra de Garrachón tiene interés por la información que aporta sobre la consulta que Regino Inclán Inclán hizo en el archivo diocesano de Palencia. Así dice que había encontrado varios documentos y que en uno de ellos se leía: "Que el sr. Conde de Ansúrez, conde que era de Monzón, por la era de 945, que corresponde al año 907, edificó en el sitio que ahora es la villa de Husillos, un monasterio con la advocación de Nuestra Señora de Dehesa Brava, y que motivó a ello el haberse aparecido allí la imagen de Nuestra Señora, que al presente también se venera en la iglesia del expresado lugar con el mencionado nombre. Que allí se fundó la villa de Husillos por estar su situación dentro del territorio y jurisdicción del dominio y señorío del condado de Monzón”. A continuación hace relación del documento fundacional.

No aparece ningún trabajo historiográfico con alguna aportación sobre Santa María de Husillos hasta 1972, con el Diccionario de Historia Eclesiástica de España ${ }^{11}$. Según éste existieron dos monasterios: uno llamado de Santa María de Husillos, que ya existía en el año 933, y otro con el nombre de Dehesa Brava, fundado por los Ansúrez en 950. Tal afirmación carece de toda lógica además de ser superficial. En todo caso se puede adelantar que en la documentación de Husillos aparece en casi todos los casos la referencia a nuestra abadía como Santa María de Husillos. Posiblemente la advocación primitiva de la iglesia y por la que se conocería la abadía en sus primeros tiempos sería de Santa María de Dehesa

\footnotetext{
${ }^{9}$ GARRACHÓN BENGOA, Palencia y su provincia, 188-189; y Palencia. Guia del turista, 351354.

${ }^{10}$ Claramente se trata de un lapsus de Garrachón, ya que en realidad se referiría al siglo XVII.

${ }^{11}$ ALDEA - MARÍN - VIVES, DHEE, III, 1864-1865 (Jesús San Martín Payo)
} 


\section{LA ABADÍA DE SANTA MARÍA DE HUSILLOS: ESTUDIO Y COLECCIÓN \\ DOCUMENTAL $(904-1608)$}

Brava. Con el tiempo, y sobre todo a la hora de expresar la advocación de la abadía en la documentación, la mención predominante quedaría como Santa María de Husillos. La mención de Dehesa Brava aparece en pocas ocasiones: en las falsas donaciones y confirmaciones de los condes Ansúrez y Sancho el Mayor respectivamente, en el relato fundacional, en la fundación de la cofradía de Dehesa Brava, en que se hace referencia a que Dehesa Brava era como se llamaba en tiempos pasados ${ }^{12}$, y en un acuerdo entre el prior y cabildo por el que aprueban la unión de su iglesia con San Miguel de Ampudia ${ }^{13}$.

Es a finales de la década de los setenta del siglo XX cuando el canónigo archivero de la catedral de Palencia Jesús San Martín Payo comienza a escribir sobre Santa María de Husillos. Si bien es cierto que Jesús San Martín realizó gran número de estudios referentes en general a la catedral y diócesis de Palencia, se puede decir que los artículos y estudios que dedicó a Santa María de Husillos delatan que fue esta abadía uno de los temas que más le apasionó, hecho que quizá tuviera que ver con el hecho de que fue el descubridor de la colección de documentos de Husillos en un cajón del archivo catedralicio de Palencia, y del libro becerro de Ampudia por información del cura párroco de dicho pueblo. Parece ser que tenía preparada la edición de la colección documental de la abadía, cosa que impidió su muerte $^{14}$.

Entre 1979 y 1993 escribió varios artículos sobre Santa María de Husillos en los que edita varios documentos, publicados en la revista de la institución Tello Téllez de Meneses, a excepción de uno que se publicó en las Actas del II Congreso de Historia de Palencia. Así en Santa María de Husillos y su colección diplomática (1979) ${ }^{15}$ traza una historia general de la abadía, deteniéndose en los momentos históricos más importantes. En su artículo Cardenales abades de Santa María de Husillos (1984) ${ }^{16}$ realiza una biografía de los abades de Husillos que llegaron a ser cardenales. En Apasionante historia de cinco casas que poseían en

\footnotetext{
12 Doc. núm. 243.

${ }^{13}$ Doc. núm. 347.

${ }^{14}$ De que San Martín Payo tenía preparada la edición de la colección documental de Husillos da noticia, además de que él mismo lo diga en alguno de sus artículos, el hecho de que en la edición de varios documentos en alguno de sus artículos, les numere correlativamente dentro de un conjunto más amplio.

${ }^{15}$ SAN MARTÍN PAYO, Santa María de Husillos y su colección diplomática.

${ }^{16}$ SAN MARTÍN PAYO, Cardenales abades de Santa María de Husillos.
} 
Valladolid los abades de Husillos $(1988)^{17}$ se centra en un conjunto de casas que Santa María de Husillos poseía en Valladolid por permuta de unas heredades en Burgos. En su artículo Las primeras donaciones de los condes de Monzón $(1988)^{18}$ aborda las problemáticos documentos otorgados por los condes de Monzón y Sancho el Mayor, si bien se limita a repetir lo escrito en artículos anteriores. En Villaldavín en la Colección Diplomática de Santa María de Husillos $(1990)^{19}$ estudia el origen y evolución histórica de esta villa perteneciente al dominio de Husillos. En El libro becerro de las propiedades de Santa María de Husillos $(1990)^{20}$ hace un importante estudio sobre el becerro de las propiedades de Husillos de fines del siglo XIV. Por último, en Notas históricas sobre la abadía de Husillos $(1993)^{21}$ hace un resumen de la mayor parte de los anteriores artículos.

Julio González y González, en el capítulo que redactó dentro de la Historia de Palencia, Siglos de Reconquista, dedicó unas líneas a Santa María de Husillos ${ }^{22}$. Así analiza de forma somera el documento del año 906 por el que el presbítero Gratón hace ciertas donaciones en el castro de Monzón al infante Gonzalo, hijo de Alfonso III, entre ellas la iglesia de Santa María. Habla de la importancia del elemento mozárabe atestiguándose también en Husillos, con la donación a Husillos de Abohamor, del silencio documental provocado por las incursiones de Almanzor y de la residencia del obispo Poncio de Palencia en Husillos. Hace relación de varios abades como Poncio Guitardo, Bernardo y Raimundo; donaciones como las de Urraca I y Sancho III; los estatutos otorgados por el abad Raimundo en 1163. Se refiere también a las obras acometidas a mediados del siglo XIII por el prior Miguel y la capilla mandada construir por Gómez de Monzón, y de la despoblación y problemas económicos de la abadía, al mencionar la despoblación "a fumo muerto" de las aldeas de Pajares y San Adrián.

\footnotetext{
${ }^{17}$ SAN MARTÍN PAYO, Apasionante historia de cinco casas.

18 SAN MARTÍN PAYO, Las primeras donaciones de los condes de Monzón.

19 SAN MARTÍN PAYO, Villaldavín.

20 SAN MARTÍN PAYO, El Libro Becerro de Husillos.

21 SAN MARTÍN PAYO, Notas históricas de Husillos.

22 J. GONZÁLEZ, Siglos de Reconquista, 171-172 y 197-198.
} 


\section{LA ABADÍA DE SANTA MARÍA DE HUSILLOS: ESTUDIO Y COLECCIÓN \\ DOCUMENTAL $(904-1608)$}

Margarita Ausín Iñigo realizó en 1990 un pequeño estudio sobre los intentos de traslado de Santa María de Husillos a Tordesillas ${ }^{23}$.

Ángel Sancho Campo escribió en 1994 una monografía sobre los aspectos arquitectónicos y artísticos de la iglesia de Santa María de Husillos, de forma didáctica y bien acompañada de fotografías y planos $^{24}$.

Aurora Cruz Pérez y José Ignacio Guerra Aragón realizaron en 1995 un estudio sobre las excavaciones arqueológicas realizadas en el antiguo claustro de Santa María de Husillos ${ }^{25}$.

Faustino Narganes Quijano y Jesús Herrero Marcos, en su obra sobre los monumentos histórico-artísticos y bienes de interés cultural de la provincia ${ }^{26}$, se refieren de forma somera a la iglesia colegiata de Santa María de Husillos, declarada monumento histórico-artístico desde el día 3 de junio de 1931, propiedad del obispado y ayuntamiento. En la relación de hechos históricos de la abadía y en los datos artísticos se basan en Julio González y en Angel Sancho Campo. Hacen mención de que en la zona del nuevo claustro, construido por Francisco de Reinoso, aparecieron varios sepulcros romanos que tuvieron gran influencia para los maestros escultores que trabajaron en Frómista.

Miguel Ángel García Guinea trata a Santa María de Husillos en dos obras referidas al arte románico en la provincia de Palencia ${ }^{27}$, siendo en la segunda donde aporta más datos. Es consciente de la importancia de la institución y de la escasez de trabajos históricos sobre ella.

Santiago Francia Lorenzo en sus Notas de $\operatorname{Archivo}^{28}$ y en la revista de la Asociación de Amigos del Castillo de Fuentes de Valdepero ${ }^{29}$, realizó varios

\footnotetext{
${ }^{23}$ AUSÍN ÍNIIGO, Intento y memoriales para trasladar la iglesia de Husillos a Tordesillas.

${ }^{24}$ SANCHO CAMPO, Husillos. Iglesia de Santa María.

${ }^{25}$ CRUZ y GUERRA, Excavaciones arqueológicos en el claustro de Husillos.

${ }^{26}$ NARGANES y HERRERO, Palencia Monumental, 74.

${ }^{27}$ GARCÍA GUINEA, El Arte Románico en Palencia, 296-297; y Románico en Palencia, 321324.

${ }^{28}$ FRANCIA LORENZO, Notas de Archivo 1, 2 y 3.

${ }^{29}$ FRANCIA LORENZO, Pleito entre Husillos y Fuentes de Valdepero.
} 
pequeños estudios sobre aspectos varios de Santa María de Husillos, como la reliquia del pie de San Lorenzo, el traslado a Ampudia y los estatutos otorgados por el abad Francisco de Reinoso en 1588.

Manuel Carriedo Tejedo publicó varios artículos en la revista de la Asociación de Amigos del Castillo de Fuentes de Valdepero relativos al obispo Poncio ${ }^{30}$ y al concilio de Husillos del año $1088^{31}$.

Carlos Reglero de la Fuente, en el capítulo sobre la Edad Media en la diócesis de Palencia que redactó dentro de la Historia de las diócesis españolas, en el epígrafe sobre las abadías anejas a la catedral palentina, hace referencia en unas pocas líneas a Santa María de Husillos, centrándose en la secularización de la abadía a partir del siglo XII a imagen y semejanza de la catedral, mencionando además importantes hitos en la historia de la abadía como la constitución de la canónica (1183), y la fijación del número de dignidades, canónigos y racioneros ${ }^{32}$.

Nicolás Villa Calvo ${ }^{33}$ y Gonzalo Martínez Díez ${ }^{34}$ utilizaron en mayor o menor medida, al abordar el estudio del condado de Monzón, los documentos otorgados por los condes de Monzón a Santa María de Husillos, siendo sus conclusiones de gran importancia para establecer la evolución histórica de la citada iglesia en los siglos IX-X.

Por último, David Marcos Diez publicó dos artículos relativos al archivo monástico de Husillos ${ }^{35}$ y a las relaciones de la abadía con la Santa Sede ${ }^{36}$.

- Conclusiones:

Destaca en primer lugar la escasez de estudios historiográficos sobre Husillos. A excepción de Jesús San Martín Payo, son pocos los autores que han realizado

\footnotetext{
${ }^{30}$ CARRIEDO TEJEDO, Poncio, obispo de Husillos, y Un obispo poco conocido de Palencia.

${ }^{31}$ CARRIEDO TEJEDO., El concilio de Husillos.

${ }^{32}$ EGIDO, Historia de las diócesis españolas. Iglesias de Palencia, Valladolid y Segovia. "La Iglesia de Palencia, La Edad Media”, 36-37.

${ }^{33}$ VILLA CALVO, Historia del condado de Monzón.

${ }^{34}$ MARTÍNEZ DÍEZ, El condado de Castilla.

${ }^{35}$ MARCOS DÍEZ, Los archivos monásticos y sus fondos documentales.

${ }^{36}$ MARCOS DÍEZ, Documentación diócesis de Palencia en el Archivo Vaticano.
} 
algún artículo monográfico sobre algún aspecto de la abadía. A pesar de ello, no se escapa la importancia que tiene Husillos y su documentación en sus primeros siglos de historia para el estudio de los condados de Monzón y de Castilla, como se muestra en las obras de Villa Calvo y Martínez Díez.

Por otra parte, son varios los autores, entre otros Santiago Francia Lorenzo y Miguel Ángel García Guinea, que han hecho hincapié en la importancia histórica de la abadía y en la necesidad que había de hacer un estudio histórico monográfico sobre ella. 
DAVID MARCOS DIEZ 
LA ABADÍA DE SANTA MARÍA DE HUSILLOS: ESTUDIO Y COLECCIÓN DOCUMENTAL (904 - 1608)

1

ESTUDIO HISTÓRICO 
DAVID MARCOS DIEZ 


\subsection{EVOLUCIÓN HISTÓRICA DE SANTA MARÍA DE HUSILLOS}

\section{EL ORIGEN DE SANTA MARÍA DE HUSILLOS}

Al igual que en la mayor parte de las instituciones eclesiásticas altomedievales, el origen de Santa María de Husillos ha permanecido rodeado de un halo de misterio y leyenda al que varios cronistas e historiadores, desde Ambrosio de Morales en la segunda mitad del siglo XVI hasta la actualidad, de manera más o menos afortunada, han tratado de dar una explicación científica. No obstante son las informaciones que tomó Ambrosio de Morales, cronista del rey Felipe II, en sus dos obras principales: el Viaje Santo y Crónica General de España ${ }^{37}$, las que, con más o menos matices, fueron aceptadas por los autores que han tratado sobre la abadía, dentro de los cuales hay que destacar a Jesús San Martín Payo.

Así quizá es el origen y fundación de Santa María de Husillos el aspecto histórico que más controversia y dudas ha suscitado por la mayoría de los autores. Por otra parte no hay duda de que es realmente complejo tratar de dar una explicación exacta del origen de esta iglesia, aunque sí se puede ofrecer una interpretación aproximada. Para ello nos serviremos del análisis, por orden de importancia y preferencia, de las fuentes documentales, fuentes arqueológicas, las informaciones dadas en diversos contextos por los miembros de la abadía de Husillos y de su sucesora, la colegiata de Ampudia, y del estudio de instituciones similares tanto en el ámbito geográfico como en el temporal.

\section{Fuentes documentales}

Son dos los documentos sobre los que se sustentan nuestras teorías sobre el origen de Husillos ${ }^{38}$.

El documento número 1 de la colección se conserva en el Libro-tumbo de la catedral de León. Su data es el año 904, y ya ha sido estudiado por autores clásicos como Emilio Sáez, Sánchez Albornoz, Floriano Cumbreño y Julio González, que han constatado su autenticidad. Por este documento, el presbítero

\footnotetext{
${ }^{37}$ MORALES, Viaje Santo; y Crónica general de España

${ }^{38}$ Docs. núm. 1 y 2.
} 
Gratón dona a su señor, el infante y diácono Gonzalo, hijo de Alfonso III, todos lo bienes que tiene en el suburbio del castro de Monzón, entre otros, la iglesia llamada de Santa María, que había sido destruida por los infieles y él mismo había restaurado.

Así pues se menciona una iglesia de Santa María sita en las cercanías de Monzón, como iglesia de procedencia visigótica, destruida por los musulmanes y reconstruida en los primeros años del siglo X. Todo apunta a que se trata de Santa María de Husillos. No obstante hay que advertir de la presencia de una iglesia con la advocación de Santa María cerca de Monzón documentada por primera vez en $1179^{39}$ y de una iglesia con la advocación de María Magdalena en Villazalama, despoblado sito entre Husillos y Monzón.

Nos inclinamos por creer que la iglesia de Santa María mencionada en el documento se refiere a Santa María de Husillos por varios aspectos: el primero se refiere a la procedencia visigoda de dicha iglesia, relacionándolo con los posibles restos visigodos hallados en el claustro de Husillos, como se verá más adelante, y la convicción de que no debían ser numerosas las iglesias visigodas en la zona. La segunda se basa en la fecha tardía en que se documenta tanto la iglesia de Santa María cercana a Monzón como la de María Magdalena de Villazalama. De la primera pronto desaparecen sus menciones documentales. La segunda aparece en la documentación de Husillos en tres ocasiones: en el Libro Becerro de Husillos $(1374-1376)^{40}$ y en dos documentos de $1386^{41}$ y $1391^{42}$, fechas que sugieren un origen más moderno para dicha iglesia que seguramente desde sus orígenes no pasaría de ser una pequeña ermita ${ }^{43}$. Existe la posibilidad también de que la

\footnotetext{
${ }^{39}$ Doc. núm. 37.

${ }^{40}$ Doc. núm. 185.

${ }^{41}$ Doc. núm. 207.

${ }^{42}$ Doc. núm. 211.

${ }^{43}$ Julio González afirma que el presbítero Gratón donó al diácono Gonzalo la iglesia de Santa María, destruida por los moros y que él había reconstruido, y además le dio la iglesia de Santa María de Carelias. Expresa que la iglesia de Santa María que se menciona puede ser la que después se conoció como la de Husillos, siendo la titular del pueblo de Monzón la del Salvador (J. GONZÁLEZ, Siglos de Reconquista, 171).

Por otra parte, Carlos Reglero afirma que el presbítero Gratón fundó la iglesia de Santa María de Carejas. Sin embargo el documento no sitúa la iglesia de Santa María en Carejas (despoblado sito en las cercanías de Paredes de Nava del que se conserva actualmente una ermita), sino que menciona este topónimo con otros como Campo y Quintana Mediana. (REGLERO, La iglesia de Palencia en la Edad Media, 7).
} 


\section{LA ABADÍA DE SANTA MARÍA DE HUSILLOS: ESTUDIO Y COLECCIÓN \\ DOCUMENTAL $(904-1608)$}

iglesia de Santa María cercana a Carrión fuera la posterior iglesia de Santa María Magdalena de Villazalama.

El documento número 2 de la colección de Husillos es un rehecho de principios del siglo XII de un documento fechado el 30 de mayo de $938^{44}$, por el que Abo Hamor, su mujer, Speciosa, y Zalama, presbítero y hermano del primero, donan a Santa María de Husillos y a su abad Fernando, en remedio de sus almas y las de sus antepasados, su iglesia de Santa María, sita entre Castrillo y Ampudia. Ha sido estudiado, entre otros, por autores como Menéndez Pidal, Pérez de Úrbel y Julio González.

Estamos ante el primer documento en el que se menciona expresamente a Santa María de Husillos y a un abad de nombre Fernando. De este documento se extraen dos conclusiones: la primera es que en el año 938 ya existía la abadía de Husillos; la segunda es la importancia de la repoblación mozárabe en el ámbito palentino, ya atestiguado por otros autores ${ }^{45}$.

\section{Fuentes arqueológicas}

En el Museo Arqueológico Provincial de Palencia se encuentran depositados restos de elementos arquitectónicos y decorativos procedentes del claustro de Santa María de Husillos, como capiteles y sillares con elementos decorativos. Después de contemplar en un principio una posible procedencia visigótica, se llegó a la conclusión de que dichos materiales deberían encuadrarse en un marco románico, aunque sobre tres de dichos restos no se descarta un origen visigodo ${ }^{46}$. Por otra parte, vemos como bastante improbable que proceda de Santa María de Husillos una pieza epigráfica sacada a la luz recientemente ${ }^{47}$.

\footnotetext{
${ }^{44}$ El estudio diplomático e histórico de este documento se encuentra en el documento número 2.

${ }^{45}$ Principalmente por Julio González (J. GONZÁLEZ, Siglos de Reconquista, 161) y por Gonzalo Martínez Díez (MARTÍNEZ DÍEZ, El condado de Castilla, I, 166). Son varias las pruebas documentales que aporta la colección de Husillos acerca del protagonismo mozárabe en el ámbito palentino. Además de los nombres de los donantes de dicho documento, hay que mencionar topónimos como Villazalama y Villa Abdala, nombre primitivo de Villaudilla, ambos lugares del señorío de Husillos.

${ }^{46}$ Miguel Ángel García Guinea intuye la existencia de un primitiva iglesia anterior a la actual, de mediados del siglo XIII, a la que pudieron pertenecer unos capiteles que vio Sancho Pradilla en 1912 y que habían aparecido en el terreno del antiguo claustro (GARCÍA GUINEA, El arte románico en Palencia, 323 ).

${ }^{47}$ En el mes de marzo de 2008, el periódico "El Diario Palentino" sorprendió a la comunidad científica con la subasta que se iba a celebrar en los días siguientes en la casa Fernando Durán de
} 


\section{Informaciones de testigos y canónigos}

Nos referimos en este apartado a las informaciones dadas por el cabildo de la colegiata de San Miguel de Ampudia y por el canónigo Manuel Pérez de Ampudia $^{48}$.

El 12 de junio de 1733, el cabildo de la colegiata de San Miguel de Ampudia ordena dar información sobre la historia de Santa María de Husillos a don Manuel Prudencio de Garma y Durán, residente en Valencia, que tenía el propósito de escribir la "Historia de las iglesias"49. El 19 de junio de 1733 se envía dicha información, quedando copia en el archivo de la colegiata. La información que se le manda al dicho Garma y Durán representa la primera sistematización de la historia de la abadía. Hace relación de la fundación y de su fundador, privilegios y donaciones que le fueron otorgadas, número de canónigos y capellanes, advocación de la iglesia, estados monásticos, traslado de Husillos a Ampudia, estatutos, etc. Es la sistematización que hace de las fases monásticas por las que pasó la abadía, la información de mayor interés. Así establece tres estados o fases en la historia de Husillos, en base a los instrumentos documentales:

La primera o fundacional: fundada en la era de 905 por don Ansúrez, conde de Monzón, quien pobló la villa de Husillos. Relata que el motivo de la fundación fue la aparición de una imagen de la Virgen María en el paraje llamado de Dehesa Brava, nombre que tenía por la gran cantidad de sauces y espinos del lugar, conservándose la memoria de dicho suceso en la capilla que fundó el abad Francisco de Reinoso en la iglesia de Husillos con el nombre de Nuestra Señora de Dehesa Brava. Pero manifiesta dudas al expresar que no consta en los

\footnotetext{
Madrid de una pieza epigráfica de gran valor histórico sobre la refundación del monasterio de Santa María de Husillos realizada en el año 1039 por el abad Munio al frente de su comunidad en tiempos del obispo Bernardo y del príncipe García.

Sin embargo es probable que dicha pieza epigráfica no proceda de Santa María de Husillos, ya que hacia el año 1039 hacía ya tiempo que estaba revitalizada, como lo demuestran el privilegio de confirmación de Sancho el Mayor, las mención de Husillos como sede de la segunda restauración de la diócesis palentina, y el privilegio de restauración de Sancho el Mayor de la diócesis de Palencia, en el que se relacionaba a Husillos como propiedad de la diócesis.

${ }^{48}$ APA, leg. 152, carp. 1.

${ }^{49}$ No tenemos noticia sobre la realización de dicha obra.
} 
documentos el orden monástico de la abadía: si fue de canónigos regulares de San Agustín o benedictina.

La segunda, a partir de la era de 985, de colegiata secularizada: se basa en la escritura fundacional, al igual que Ambrosio de Morales, haciendo relación del abad-cardenal Raimundo, de las donaciones de los condes-hermanos Ansúrez de Monzón, de la presencia de Alfonso VI en las cortes de Carrión, del pleito del abad Raimundo con el obispo de Palencia. En referencia a dicho abad difiere de la escritura fundacional y por lo tanto de Ambrosio de Morales, al relatar que dicho abad por motivo del pleito con el obispo viajó dos veces a Roma, una de las cuales el papa Agapito II le dio reliquias que más tarde se venerarían en Husillos. Sigue diciendo, perdiendo un tanto la conexión con la información anterior, que la abadía se agregó a la catedral de Palencia. Habla de la jurisdicción espiritual y temporal de Santa María de Husillos y de los lugares sobre los que la ejercía, del número de abades habido, del número de dignidades, canonjías y raciones, y de la provisión del abad y demás prebendas.

La tercera, la del traslado a Ampudia y transformación de la iglesia parroquial de San Miguel en colegiata del mismo nombre, gracias a la acción del duque de Lerma, por bula de Paulo V de 25 de septiembre de 1606, llevándose a cabo el traslado el 22 de abril de 1607, a causa de la despoblación de la villa de Husillos. Relata el número de dignidades, canonjías y prebendas y otros aspectos del estatuto otorgado por el duque de Lerma, aunque no se exprese directamente dicho estatuto, y de los lugares donde la colegiata tiene jurisdicción espiritual y temporal.

La segunda información fue realizada por Manuel Pérez, canónigo de San Miguel de Ampudia, con fecha de 16 de junio de 1745. Hace testimonio notarial de cuatro escrituras del archivo de la colegiata de Ampudia referentes a Husillos que a su entender debían ser las que marcaban la historia de Santa María de Husillos. Por la primera hace constar que el conde de Monzón don Ansúrez, por la era de 947, edificó en el paraje del actual Husillos un monasterio con la advocación de Nuestra Señora de Dehesa Brava, por motivo de haberse aparecido allí una 
imagen de la Virgen María. El nombre del lugar derivaba del carácter de gran vegetación que tenía el lugar en aquella época.

La segunda escritura a la que hace referencia es la de la fundación de la abadía, datándola en la era de 988, no haciendo crítica histórica alguna sobre ella, cayendo en los mismos errores que el amanuense de dicha escritura y que Ambrosio de Morales. A continuación hace relación de las escrituras de exención del papa Alejandro III y de traslado a Ampudia de Paulo V, las cuales data correctamente.

Por estas informaciones se clarifica la noticia dada por Garrachón Bengoa acerca de la consulta por Regino Inclán Inclán de un documento por el que el conde Ansúrez fundaba Santa María de Husillos en la era de 945. Así parece ser que existía, al menos hasta la época del dicho Regino Inclán, una escritura independiente fechada por la era hispánica en el año 947, año 909, por la que el conde Ansúrez de Monzón fundaba la iglesia de Santa María de Dehesa Brava en un paraje de gran vegetación y de difícil acceso en donde había tenido lugar una aparición de la Virgen María ${ }^{50}$.

A primera vista, a diferencia de los personajes y sucesos de la escritura fundacional, podría no haber anacronismos entre la fecha y el personaje que citaría el perdido documento. Así un conde Ansur de Monzón, origen de la saga de los Banû-Ansur, podría haber vivido entre finales del siglo VIII y principios del siglo IX ${ }^{51}$. Sin embargo, sí habría contradicción con la escritura de Gratón por la que restauraba la iglesia de Santa María de Husillos, datada ésta en 904.

\section{Conclusiones}

Basándonos en el documento de Gratón y en los posibles restos arqueológicos visigodos aparecidos en el claustro de Husillos, creemos como posible que Santa

\footnotetext{
${ }^{50}$ Tomamos como fecha válida de la perdida escritura, sobre las dadas por Regino Inclán Inclán y la información dada a Garma y Durán, la fecha dada por el canónigo Manuel Pérez, ya que data perfectamente las dos escrituras siguientes.

${ }^{51}$ Villa Calvo documenta un personaje de nombre Ansur como padre de Fernando Ansúrez, este último documentado ya antes del 932 con dignidad condal y considerado como el primer conde de Monzón (VILLA CALVO, Historia del condado de Monzón, 29-31).
} 


\section{LA ABADÍA DE SANTA MARÍA DE HUSILLOS: ESTUDIO Y COLECCIÓN \\ DOCUMENTAL $(904-1608)$}

María de Husillos tenga un origen visigodo ${ }^{52}$. En dicho documento se dice que el presbítero Gratón restauró la iglesia que había sido destruida por los árabes. En realidad en el año 904 no se podía saber con certeza si el aspecto de ruina que presentaría la iglesia de Santa María había sido causada por la invasión y campañas islámicas de 711-714, o bien causada por el efecto del paso del tiempo, quedando por otra parte la tradición oral muy lejana al momento de los hechos.

Para afinar más sobre este origen visigodo de Husillos, hay que contextualizar dicha iglesia con la ocupación visigoda en general en el ámbito palentino, con los edificios religiosos conservados y con los estudios arqueológicos realizados hasta la actualidad.

Monserrat Molina expresa las dificultades que existen para estudiar la ocupación visigoda en el ámbito palentino ${ }^{53}$. En primer lugar porque no es alto el número de elementos arqueológicos conservados, muchas veces sin un contexto arqueológico preciso. También por la ausencia de estudios exhaustivos, a excepción de San Juan de Baños, y de excavaciones metódicas. No obstante hace una sistematización de las manifestaciones arqueológicas y artísticas de la zona:

\section{Edificios religiosos importantes: San Juan de Baños y cripta de San Antolín.}

2. Edificios religiosos secundarios: sencillas basílicas construidas junto a las necrópolis: Herrera de Pisuerga, El Castellar (Villajimena) ${ }^{54}$.

3. Hallazgos aislados: Mave, Saldaña, Astudillo, Monte Cildá, Cervera de Pisuerga, Aguilar de Campoo, etc.

Al hablar del templo de El Castellar indica que debió ser un centro de culto de poblaciones próximas, actualmente desconocidas, cuyos habitantes utilizaron su interior y contorno exterior como lugar de enterramiento. En las conclusiones expresa que en el ámbito palentino existen dos edificios religiosos de cierta categoría, como son la basílica de San Juan de Baños y la cripta de San Antolín,

\footnotetext{
${ }^{52}$ Varios autores han visto un origen visigodo en Santa María de Husillos basándose en Berganza, pero sin ofrecer en ningún caso una explicación objetiva o científica.

${ }_{53}$ MOLINA, Las tierras de Palencia durante la monarquía goda, 129-154.

${ }^{54}$ Sobre El Castellar existe un clásico estudio de García Guinea en el que aportó nuevos enfoques acerca de la despoblación del valle del Duero (GARCÍA GUINEA, El Castellar, 123-158).
} 
ambos fundaciones reales. Que al observar en el mapa la localización de restos arqueológicos se comprueba una predilección por las zonas cercanas a los ríos, especialmente a lo largo del Pisuerga, preguntándose si no ocurrirá lo mismo a ambas márgenes del Carrión.

Alonso Ávila se basa para realizar su estudio, además de en los testimonios arqueológicos, en las actas de los concilios celebrados durante la monarquía visigoda. Centra los asentamientos visigodos de forma preferente en las zonas nordeste y sureste de la provincia palentina, en las proximidades del curso del Pisuerga $^{55}$.

Atendiendo a las conclusiones de las anteriores autoras, es posible que en época visigoda existiera en Husillos una pequeña basílica similar a la que existió en El Castellar, que daría cobertura religiosa y de enterramiento a alguna población o poblaciones cercanas. Hay que añadir además que el emplazamiento se sitúa a escasos trescientos metros del río Carrión, por lo que corroboraría la tesis de Monserrat Molina sobre posibles restos visigodos en las cercanías de dicho río. Hay que tener en cuenta además que la iglesia de Husillos se asentaría dentro de un ámbito con fuerte presencia visigoda constatada, como indican San Juan de Baños (Baños de Cerrato), El Castellar (Villajimena), y la cripta de San Antolín (Palencia).

La invasión islámica de 711 supuso en muchos lugares la destrucción de numerosos vestigios monumentales visigodos. Tarik en fines del 711 y comienzos del 712 hizo campaña por valle del Duero: tomó Amaya y a través de los campos góticos, por la Vía Aquitana romana, que desde Burdeos iba a Astorga, se dirigió a dicha ciudad y la tomó. Según los historiadores islámicos, la meseta norte y con ella el solar castellano-leonés, fue sometido al poder musulmán durante las expediciones de Tarik del 711-712 y de Muza del 714. Por otra parte, Carriedo Tejedo afirma que Muza tomó Palencia en el año 714, respetando la basílica de San Juan de Baños y la primitiva iglesia de San Antolín ${ }^{56}$.

\footnotetext{
${ }_{55}^{55}$ ALONSO ÁVILA, La visigotización de la provincia palentina, 267-295.

${ }^{56}$ CARRIEDO, El solar de Fuentes de Valdepero, 10-11.
} 


\section{LA ABADÍA DE SANTA MARÍA DE HUSILLOS: ESTUDIO Y COLECCIÓN \\ DOCUMENTAL $(904-1608)$}

Es en el paso de este segundo general donde se podría situar la destrucción, si damos por verídica la información del documento de Gratón, de la primitiva basílica visigoda de Husillos. Pero una serie de observaciones nos hace pensar que quizá no se produjo tal destrucción.

En primer lugar, como anteriormente se ha apuntado, en el año 904 no se podía saber con certeza si el estado de abandono y de destrucción en que se hallaría la iglesia de Husillos a la llegada de Gratón había sido causada por la invasión musulmana o por los efectos del paso del tiempo, teniendo en cuenta además la tendencia tanto en las crónicas como en los documentos cristianos a exagerar los efectos destructivos de los musulmanes ${ }^{57}$.

En segundo lugar hay que tener en cuenta que los ejércitos islámicos respetaron algunas iglesias de la zona, como San Juan de Baños o el conjunto arqueológico de El Castellar, ya fuera por voluntad propia, como parece que fue el caso en San Juan de Baños, o porque simplemente estarían tan aisladas y escondidas que no se toparían con ellas en sus correrías, como pudo ser en el caso de la primitiva basílica de San Antolín, El Castellar y la basílica de Husillos.

La invasión musulmana en 711 tendría como resultado un éxodo de la población del llano palentino a las montañas del norte. La despoblación de la zona aumentaría con la política de Alfonso I de Asturias de vaciar de pobladores el valle del Duero, para crear así un desierto estratégico que ayudara a preservar a su pequeño reino de las acometidas ismaelitas, despoblación a la que ayudó también la rebelión de los bereberes contra los árabes del sur y su marcha hacia el sur, abandonando así sus posiciones y asentamientos en el valle del Duero. Conocida es la polémica historiográfica entre Sánchez Albornoz y Menéndez Pidal sobre el grado de despoblación. Sánchez Albornoz abogaba por una casi total despoblación, quedando tan sólo lugares habitados de difícil acceso y aislados que habrían escapado tanto al control amirí como a las incursiones de Alfonso I ${ }^{58}$. Menéndez Pidal, basándose en aspectos lingüísticos, aboga por una continuidad de población. Gonzalo Martínez Díez, en su estudio sobre el condado de Castilla,

\footnotetext{
57 A este respecto, Julio González afirma que la referencia del documento de Gratón a la destrucción de los moros parece corresponder a los efectos de una razia, aunque tampoco se descarta que al posesionarse ya estuviese abandonada la iglesia desde tiempos antiguos (J. GONZÁLEZ, Siglos de Reconquista, 171).

${ }^{58}$ SÁNCHEZ ALBORNOZ, Repoblación y despoblación del Valle del Duero, 275-276.
} 
resuelve en gran parte la cuestión con el respaldo de las fuentes documentales ${ }^{59}$. Se posiciona con la teoría de Sánchez Albornoz sobre la despoblación efectiva del Valle del Duero, por el efecto despoblador de Alfonso I, la retirada de la población bereber y los efectos del hambre y las plagas, constatados todos estos factores por la ausencia de toponimia de origen romano o anterior a la invasión islámica, y a la ausencia en las fuentes documentales de la repoblación de noticias sobre antiguos pobladores. Refuerza esta tesis resaltando la ausencia en las fuentes a antiguos pobladores, y que en los documentos de la repoblación, en los primeros tiempos realizada por presura, no hay nunca protestas de pobladores ya afincados. Además las continuas razias tanto de árabes como de cristianos, harían casi imposible la existencia de pobladores, a la vez que tampoco sería posible la existencia de poblaciones autónomas en un territorio abierto y de difícil defensa sin estar insertas en ninguno de los dos polos de poder. Según Martínez Díez, los autores del estudio del poblado de El Castellar ${ }^{60}$, hasta ahora la principal baza de los defensores de la teoría continuista, no están seguros si los restos secuenciales que aparecen después de los visigodos son del siglo VIII-IX o de a partir del siglo $\mathrm{X}$.

En el reinado de Alfonso III de Asturias se inicia la repoblación de las yermas tierras del valle del Duero. El rey dirigía el proceso, confiando la dirección sobre el terreno a un conde o infante, que representaba la autoridad real. Estos fortificaban lugares de difícil acceso, en torno a los cuales se iban asentando los nuevos pobladores, ocupando las tierras mediante presuras. En la repoblación participaban todos los estamentos sociales: nobles, eclesiásticos, hombres libres, collazos y dependientes.

La donación de Gratón al infante Gonzalo aporta importantes datos para reconstruir el proceso repoblador en las tierras palentinas. Así mediante presura, Gratón, que tenía el grado eclesiástico de presbítero, a finales del siglo IX ocupó un buen número de heredades además de la antigua basílica de Husillos, todas ellas dentro del ámbito del suburbio de Monzón. Esto indica que en el año 904 la

\footnotetext{
${ }^{59}$ MARTINEZ DÍEZ, El condado de Castilla, I, 89-98.

${ }^{60}$ GARCÍA GUINEA, El Castellar, 123-158.
} 
fortaleza de Monzón ya daría cobertura defensiva a los nuevos repobladores, en torno a la cual irían surgiendo las nuevas villas.

Gratón pudo actuar bien como representante o líder de una pequeña comunidad eclesiástica, bien como cabeza de un clan familiar que colonizaría dichas tierras y que revitalizaría la antigua basílica de Husillos convirtiéndola en una iglesia propia, en una época en que estaban muy extendidas este tipo de iglesias privadas, familiares o propias ${ }^{61}$. Lo cierto es que en el año 904 Gratón dona todas sus heredades y bienes, con la iglesia de Santa María en el suburbio de Monzón, al diácono Gonzalo, hijo de Alfonso III, desconociéndose si éste acudiría a residir a sus posesiones en Monzón como cabeza de alguna comunidad religiosa, o bien residiría en la corte. Este documento también refleja una ausencia total o importante de población anterior a la llegada del presbítero Gratón, ya que toma las tierras por presura, es decir que estaban despobladas y sin explotar, lo que se enmarcaría en la teoría de Martínez Díez sobre ausencia de pobladores anteriores a la repoblación en las fuentes documentales, al menos en la zona del llano palentino $^{62}$.

Del siguiente documento de la colección, fechado el 30 de mayo del año 938, por el que Abo Hamor, junto a su mujer, Speciosa, y su hermano Zalama dona a Santa María de Husillos y a su abad Fernando, la iglesia de Santa María, sita entre Castrillo y Ampudia ${ }^{63}$, se extraen también importantes conclusiones sobre el tema en cuestión, como que en el año 938 Santa María de Husillos ya está establecida como iglesia monacal y que su abad tenía por nombre Fernando.

En conclusión, podemos afirmar que entre los años anteriores al 904 y el año 938 tiene lugar el nacimiento de Husillos como institución monástica que se iba a vincular al condado de Monzón desde el momento de su creación.

${ }^{61}$ ORLANDIS ROVIRA, Los monasterios familiares en España durante la Alta Edad Media, 546.

${ }_{62}^{62}$ MARTÍNEZ DÍEZ, El condado de Castilla, I, 89-98.

${ }^{63}$ Doc. núm. 2. 
Así, atendiendo a la posible configuración del condado de Monzón con su primer conde, Ansur, en el período cronológico comprendido entre el año 904, fecha del documento de Gratón, en el que no aparece mención alguna del condado de Monzón aunque sí a una estructura político-administrativa con el nombre de Monzón, y los años cercanos al 932, en que se documenta a Fernando Ansúrez, primer conde de Monzón documentado, podemos establecer la hipótesis de que el conde Asur de Monzón tomaría la ya restaurada unos años antes basílica de Husillos como iglesia propia. Posiblemente la transformaría en cenobio propio al establecer allí una comunidad monástica, y que desempeñaría también la función de panteón familiar de su familia. A esta hipótesis contribuiría el perdido documento fechado en el año 909 de la fundación de Santa María de Dehesa Brava por el conde Ansur. No obstante dicho documento, aunque no presenta anacronismos aparentes, sí que ofrecería un motivo bastante repetido en cuanto a la fundación y redescubrimiento de antiguas iglesias visigodas se refiere ${ }^{64}, y$ entraría en contradicción con la donación de Gratón.

Otra posible hipótesis más plausible es que Fernando Ansúrez, primer conde de Monzon documentado, transformara la revitalizada iglesia en un monasterio propio en los años inmediatamente anteriores al 938.

\section{SANTA MARÍA DE HUSILLOS BAJO LOS CONDES DE MONZÓN}

Ya sea determinando la vinculación de Santa María de Husillos al condado de Monzón con el hipotético fundador de la saga de los Banû-Ansur, don Ansur, hacia el año 909, o con el conde Fernando Ansúrez I, lo cierto es que la evolución y devenir de Santa María de Husillos durante todo el siglo X van a estar ligados de manera total a los condes de Monzón.

\section{El condado de Monzón}

Dicho ha quedado cómo posiblemente el origen de los Banû-Ansur sea un personaje que debió de vivir entre finales del siglo IX y comienzos del siglo $\mathrm{X}^{65}$.

\footnotetext{
${ }^{64}$ Ángel Vaca Lorenzo indica que en las narraciones fundacionales de muchas instituciones eclesiásticas suelen aparecer elementos sobrenaturales (VACA LORENZO, El obispado de Palencia desde sus orígenes, 49).

${ }^{65}$ VILLA CALVO, Historia del condado de Monzón, 29-31.
} 


\section{LA ABADÍA DE SANTA MARÍA DE HUSILLOS: ESTUDIO Y COLECCIÓN \\ DOCUMENTAL $(904-1608)$}

A su inmediato sucesor, Fernando Ansúrez I, que pudo fallecer hacia el año 929, se le puede encontrar de forma fehaciente en las crónicas como conde de Castilla, mas no como conde de Monzón, aunque es de suponer que también sería titular de dicho condado. Su hijo y sucesor, Asur Fernández (943-957), llevaría al condado a la cima de su poder político y militar, siendo su momento culminante la gran victoria de Simancas junto al rey Ramiro II de León y el conde castellano Fernán González. Asur Fernández tuvo seis hijos: Fernando, Oveco, Munio, Nuño, Gutier y Gonzalo; y una hija: Teresa Ansúrez, que casaría con el rey de León Sancho I (956-958 y 960-966), convirtiéndose así en reina de León. Su sucesor será Ramiro III (966-984), teniendo así Fernando Ansúrez II (950-978), primogénito y sucesor de Asur Fernández, una gran importancia política durante el reinado de estos reyes.

Los cinco hermanos varones de Fernando Ansúrez debieron de morir antes que él, en cualquier caso no tuvieron ningún papel político de importancia, ya que a la muerte de Fernando Ansúrez II, nunca aparecen en las fuentes al frente del condado $^{66}$. Tampoco parece que Fernando Ansúrez II tuviera descendencia de su matrimonio con doña Toda ${ }^{67}$, como así parece demostrar un documento de 8 de agosto del año 980, en el que dicha condesa figura gobernando Dueñas, que pertenecía al condado de Monzón: "et principe Ranimiru in sedis catedram patris sui et domna Tota cometissa iudicante ciui Domnas" ${ }^{\text {68 }}$.

Muerto Fernando Ansúrez II, parece que la sucesión condal recayó en su hermana la reina de León Teresa Ansúrez, y en su sobrino, el rey Ramiro III, según se desprende de una noticia aportada por una confirmación de Sancho el Mayor a Santa María de Husillos:

"Transitus est illo comite Ferdinando Ansurez. Venit sua germana domina Tarasia regina et rex Ramiro, qui erat in Legione, venit a Montesone" 69.

\footnotetext{
${ }^{66}$ VILLA CALVO, Historia del condado de Monzón, 162. Afirma que Fernando Ansúrez II murió defendiendo Cuéllar frente a Almanzor, aunque no aporte fundamentos justificativos.

${ }^{67}$ Aunque Nicolás Villa habla de un hijo que se criaría en la corte castellana: Asur Fernández II (VILLA CALVO, Historia del condado de Monzón, 235).

${ }^{68}$ E. SÁEZ-C. SÁEZ, Colección documental de la catedral de León, II, 281-283, núm. 478.

${ }^{69}$ Doc. núm. 6.
} 
La muerte de Ramiro III en 985, la victoria de su rival, Vermudo II, y la retirada de Teresa Ansúrez a Oviedo, dejará al condado de Monzón a merced de las apetencias territoriales y políticas de los condes de Castilla y de Saldaña-Carrión. Ello explicaría una donación de García Fernández al monasterio de San Isidro de Dueñas de varias villas, entre ellas Santiago del Val, sita en el condado de Monzón $^{70}$. En otro documento de dicho monasterio del año 990, aparece reinando en León el rey Vermudo, y en Castilla, el conde García Fernández.

Pero es otra noticia de Husillos, insertada en el mismo documento que la anterior, la que constata la transferencia del condado de Monzón a los condes de Castilla, por el que Sancho III El Mayor de Navarra, junto con su esposa, Urraca de Castilla; su madre, la reina Jimena de Navarra; y su cuñado, el conde García Sánchez de Castilla, confirma las donaciones realizadas por los condes de Monzón, la reina Teresa Ansúrez de León y el rey Ramiro III de León a Santa María de Husillos, a partir de las noticias dadas por testigos locales:

"Possedit comite Santio Gartianez Castella et Monteson, transitus est. Venit rex Santius de Pampilona cum sua matre, illa regina domina Ximena, et illa comitiva, domina Euraca et comite Garsia Sanchez confirmauerunt illas villas por sua anima de illo comite Sanctius Garciannez a Sanctae Mariae,71.

Solamente habría que matizar que entre Fernando Ansúrez II y Sancho García, habrían estado como titulares de Monzón Teresa Ansúrez y García Fernández. La entrada de este último a Monzón debió de producirse entre los años 985, muerte de Ramiro III, y entrada de Vermudo II en León, y 990, fecha en que dicho conde disponía de una villa del condado de Monzón, Santiago del Val, a favor de San Isidro de Dueñas ${ }^{72}$.

\section{Las donaciones de los condes de Monzón}

\footnotetext{
${ }^{70}$ PÉREZ DE ÚRBEL, Historia del condado de Castilla, III, núm. 518.

${ }^{71}$ Doc. núm. 6.

${ }^{72}$ PÉREZ DE ÚRBEL, Historia del condado de Castilla, III, núm. 518.
} 


\section{LA ABADÍA DE SANTA MARÍA DE HUSILLOS: ESTUDIO Y COLECCIÓN \\ DOCUMENTAL $(904-1608)$}

Fueron los condes de Monzón los que agraciaron a Santa María de Husillos con las posesiones más importantes, conformando así su señorío dominical. La confirmación por Sancho el Mayor de las posesiones antiguas de Santa María de Husillos donadas por dichos condes, y los reyes de León Teresa Ansúrez, hermana de los anteriores, y su hijo Ramiro III, a partir de testigos locales, enumera las villas donadas: Pajares, Gutiérrez Álvarez, Pajarejos, San Julián y Villaudilla $^{73}$.

Así pues, Santa María de Husillos se consolidó al calor del condado de Monzón en el momento de su máximo esplendor, siendo una de las más importantes entidades político-administrativas del reino de León. Al tiempo que el condado de Monzón se iba consolidando, al igual que otros poderes condales de la época, tendría la necesidad de contar con un centro eclesiástico que ayudara a potenciar la estructura de poder y vertebración administrativa del condado, a la vez que ayudara en el proceso repoblador del territorio, además de que satisficiera las necesidades religiosas de sus habitantes, ya que por esta época la diócesis palentina era inexistente. De ahí que los distintos condes de Monzón procedieran a dotar a Husillos de buen elenco de donaciones territoriales y jurisdiccionales.

Aunque los condes y personajes reales que se nos han transmitido como donantes fueran los hijos de Asur Fernández de Monzón, estando el primogénito, Fernando Ansúrez II, a la cabeza, junto al rey Ramiro III de León, es de suponer que ya el dicho Asur Fernández de Monzón, y el más que presumible también conde de Monzón Fernando Ansúrez I, junto con el hipotético fundador de la saga, don Ansur, hicieran también gran número de donaciones, que bien pudieron ser algunas de las que los testigos de la confirmación de Sancho el Mayor de Navarra atribuyeron a Fernando Ansúrez II y a sus hermanos.

Un elemento a tener en cuenta sería la situación jurídica que tendría Santa María de Husillos como institución eclesiástica dentro del condado de Monzón, esto es durante el siglo X. Fue normal en los primeros tiempos de la reconquista, ya con precedentes en la época visigoda, la apropiación de las iglesias y cenobios por

\footnotetext{
${ }^{73}$ Doc. núm. 6.
} 
personas privadas, sobre todo gente poderosa, como sin duda lo era la familia Ansur. Cabe la posibilidad de que Santa María de Husillos llegara a ser apropiada por algún conde de la familia Ansur, convirtiéndose de esta manera en iglesia propia de dicha familia, donde tendría su panteón familiar ${ }^{74}$, al igual que otras familias condales del reino de Léon tenían en alguna iglesia o monasterio de sus $\operatorname{dominios}^{75}$.

Lo cierto y como conclusión a este apartado es que Santa María de Husillos, bien como iglesia propia de los condes, bien como institución autónoma, se convirtió en el centro religioso más importante del condado de Monzón, siendo su importancia posiblemente superior a la del otro gran cenobio del condado, San Isidoro de Dueñas ${ }^{76}$, recibiendo de sus condes importantes donaciones, y que ayudó también en la consolidación del condado de Monzón y en la repoblación de su territorio.

\section{La primera restauración de la diócesis de Palencia en Husillos: el obispo Julián de Husillos ${ }^{77}$}

Tras la victoria leonesa-castellana-navarra de Simancas en el año 939 sobre el califa Abdherraman III, la línea del Duero quedaba asegurada. El conde Asur Fernández, titular del condado de Monzón y brazo derecho del rey de León Ramiro II, hacía avanzar las fronteras de su condado hasta las estribaciones de la sierra de Guadarrama, como parte de la estrategia de Ramiro II de León para contrarrestar el creciente poder castellano de Fernán González. Al condado de

\footnotetext{
${ }^{74}$ Así para algunos autores el sepulcro romano de Husillos, que hoy se conserva en el Museo Arqueológico Nacional de Madrid, fue usado como tumba por algún conde de Monzón, aunque en ningún caso aporten pruebas objetivas.

${ }^{75}$ Así, en el condado de Castilla hay tres monasterios que conforman tres panteones condales: San Pedro de Arlanza, con el sepulcro de Fernán González; San Pedro de Cardeña, que acogerá los restos de García Fernández; y San Salvador de Oña, donde se enterrarían Sancho García, García Sánchez y Sancho el Mayor.

${ }^{76}$ Lo demostraría el hecho de que fue Santa María de Husillos el lugar eclesiástico elegido como sede obispal por los Ansúrez.

${ }^{77}$ La primera restauración palentina ha sido estudiada en mayor o menor grado por varios autores, como Martínez Díez, que fue el que redescubrió al obispo Julián (MARTíNEZ DÍEZ, El obispado de Palencia en el siglo X), Manuel Carriedo Tejedo (CARRIEDO, Un obispo poco conocido de Palencia), y Ángel Vaca Lorenzo (VACA LORENZO, El obispado de Palencia desde sus origenes).
} 


\section{LA ABADÍA DE SANTA MARÍA DE HUSILLOS: ESTUDIO Y COLECCIÓN DOCUMENTAL $(904-1608)$}

Monzón le correspondería desde ahora la defensa de la marca central ${ }^{78}$. Se imponía al mismo tiempo una imperiosa necesidad de repoblar el territorio y de verterbrarlo desde el punto de vista administrativo y también religioso. Para este fin el rey leonés se decidió por revitalizar la antigua diócesis visigoda de Palencia, bajo el manto protector del condado de Monzón, siendo su titular, Asur Fernández, el encargado de llevar a cabo dicha revitalización. La importancia que tuvo la revitalización de la antigua diócesis lo demuestra el hecho de que la primera vez que aparece su obispo, "Iulianus", sea en un documento posterior en un año a la batalla de Simancas. Así el 11 de abril de 940, Ramiro II hace una donación al monasterio de Santiago de Peñalba. Entre los obispos confirmantes aparece: "Iulianus, Palentine sedis episcopus"79. También vemos a este obispo confirmando en una donación de Ramiro II al monasterio de Sahagún, el 11 de noviembre de 944: "Iulianus, Palentine sedis episcopus"

Asur Fernández de Monzón sanciona el 24 de noviembre de 944, actuando como conde de Castilla, una venta del monasterio de Santa Eulalia de Agés al monasterio de San Salvador de Loberuela. En la lista de otorgantes y confirmantes, aparecen Ramiro II de León, Asur Fernández como conde de Castilla, y "Iulianus, episcopus Palentia sedis"

También las fuentes musulmanas se hacen eco del obispo Julián ${ }^{82}$. Con la embajada de paz que se formó para formalizar una tregua tras la victoria de Simancas, entre el 28 de julio y el 26 de agosto de 941, estuvieron entre otros, como testigos y embajadores en la corte califal, el obispo Julián, cuyo posible origen mozárabe ha sido visto por Gonzalo Martínez Díez, que ve en éste un anterior obispo de Sevilla huido hacia el norte, donde el rey de León le encomendaría la restauración del obispado palentino. Este origen mozárabe el

\footnotetext{
${ }^{78}$ Esta contextualización histórica se basa en Pérez de Úrbel (PÉREZ DE ÚRBEL, Historia del condado de Castilla), siendo conscientes de la necesidad de revisión de algunos de los planteamientos de dicho autor.

${ }^{79}$ QUINTANA PRIETO, Peñalba, núm. I, 120.

${ }^{80}$ MÍNGUEZ, Sahagún, I, núm. 93, 123-124.

${ }^{81}$ DEL ÁLAMO, Colección de San Salvador de Oña, I, núm. 2, 6. Aparece como único obispo confirmante.

${ }^{82}$ IBN HAYYAN, al-Muqtabis $V, 351$.
} 
obispo Julián sería aprovechado por Asur Fernández, que utilizaría los servicios de su obispo para la embajada a Córdoba.

Demostrada queda así la existencia de una primera restauración de la sede palentina en la figura del obispo Julián, documentada entre 940 y 944, siendo su vida paralela a la del condado de Monzón, aunque dicha restauración duraría poco tiempo. Ángel Vaca Lorenzo desvincula la pérdida de autonomía del condado de Monzón y su integración al condado de Castilla del fracaso de la primera restauración de la diócesis de Palencia. Según este autor, al igual que lo sucedido en otros obispados como los de Bamba y Dueñas, al desaparecer el obispo sobre el que se había formado, desapareció también la sede episcopal ${ }^{83}$. A ello habría que añadir la grave crisis que se cernió en el último tercio del siglo X sobre el reino de León, agravada con las campañas de Almanzor, que hizo que obispados como el de Simancas no llegaran a cuajar, y que la definitiva restauración de la sede palentina se tuviera que postergar hasta bien entrado el siglo $\mathrm{XI}^{84}$.

En cuanto a la ubicación física de la primera restauración palentina, los posibles lugares se reducirían a tres: Monzón, como capital y plaza fuerte más importante del condado en el que se apoyaba la diócesis; Palencia, como antigua sede y titular de la tradición episcopal visigoda; y el monasterio de Santa María de Husillos, como principal centro religioso del condado, o al menos el más cercano a la capital del condado y el más favorecido por sus condes.

Sin duda que por estas fechas la ciudad de Palencia estaría casi abandonada y despoblada, siendo probablemente una pequeña aldea a orillas del Carrión sin entidad suficiente como para poder albergar la revitalizada sede, además de no contar con ningún centro religioso de importancia. De esta manera el lugar más lógico e idóneo para la ubicación de la sede episcopal sería el monasterio de Santa María de Husillos, como centro religioso de base sólida forjado por los condes de Monzón, y que además contaba con la cercana protección de los

\footnotetext{
${ }^{83}$ VACA LORENZO, El obispado de Palencia desde sus orígenes, 44-45.

${ }^{84}$ VACA LORENZO, El obispado de Palencia desde sus origenes, 44-45.
} 
condes desde su fortaleza de Monzón. A este hecho se une además la tónica general en los primeros siglos de la Alta Edad Media de instauración de sedes episcopales en los monasterios más importantes, como San Millán de la Cogolla para la diócesis de Calahorra ${ }^{85}$, y San Martín de Dumio para la de Braga.

En apoyo a esta primera sede episcopal palentina en Husillos está el hecho de que cuando casi un siglo más tarde tenga lugar la segunda restauración de la sede episcopal palentina, será Santa María de Husillos el lugar de residencia de sus obispos.

La primera restauración episcopal palentina en Husillos desaparecería, al igual que el condado que la sustentaba, a consecuencia de las campañas de Almanzor.

\section{Las campañas de Almanzor. Desaparición del condado de Monzón y de Santa María de Husillos}

Desde su fundación, el condado de Monzón viviría en constante peligro y temor a causa de las razias e incursiones musulmanas. $\mathrm{Y}$ aunque estas se dirigirían en su mayor parte hacia las plazas fuertes del condado en el valle del Duero, también algunas incursiones antes de Almanzor pudieron haber llegado hasta el mismo corazón del condado, como deja traslucir Ibn Hayyan de Córdoba cuando afirma que en el año 925, Abd al'Rahman III destruye y asalta "la fortaleza de Palencia y su 1lano" ${ }^{86}$. Pero sin duda alguna será Almanzor y sus campañas los que pongan contra las cuerdas a los centros cristianos, entre ellos el condado de Monzón.

El 1 de octubre de 976 muere el califa de Córdoba Al-Hakam II. Muhammad ibn Abî 'Âmir, quien será conocido por los musulmanes como al-Mansur y por los cristianos como Almanzor, es nombrado visir. Se iniciaba así el mandato del hombre que haría temblar los cimientos de la cristiandad hispánica en los siguientes años. La reconquista, repoblación y puesta en marcha de las macroestructuras político-administrativas, que tanto esfuerzo había costado a los cristianos, verían derrumbarse en unos pocos años con el renovado poder

${ }^{85}$ GARCÍA DE CORTÁZAR, El dominio del Monasterio de San Millán de la Cogolla, 95.

${ }^{86}$ IBN HAYYAN, al-Muqtabis $V, 351$ 
musulmán, siendo el reflejo más paradigmático de este hecho el condado de Monzón. Las 56 campañas que Almanzor realizó afectaron, en mayor o menor grado, a todos los centros de poder cristiano, pero el único que dejó de existir como entidad autónoma y que perdió definitivamente su importancia cualitativa, fue el condado de Monzón.

De las 56 campañas militares de Almanzor, fueron dos los que afectaron de manera más directa al condado de Monzón, sin descartar que otras campañas contra León o Castilla afectaran a dicho condado de forma indirecta, al pasar por sus tierras los ejércitos de Almanzor ${ }^{87}$. Así, la segunda campaña realizada por Almanzor acontenció entre los días 23 de mayo y 26 de junio del año 977, siendo su objetivo Cuéllar, plaza fuerte avanzada del condado de Monzón que constituía la primera línea de defensa de la marca central, enmarcándose esta campaña en las realizadas por el amirí en un primer momento, hasta finales de la década de los ochenta, contra las defensas cristianas del valle del Duero. Es posible que defendiendo la mencionada plaza perdiera la vida el conde Fernando Ansúrez II $^{88}$, como parece traslucir el documento ya citado de la catedral de León de 8 de agosto del año 980, en el que se menciona a la condesa doña Toda gobernando en Dueñas, lo cual indicaría su viudedad por muerte de Fernando Ansúrez II ${ }^{89}$.

La campaña 45 que Almanzor realizó en 995 se dirigió contra el castillo de San Román de Entrepeñas $^{90}$, y ha sido estudiada por Ruiz Asencio, que establece que es este castillo, que protegería a la villa del mismo nombre y al monasterio de San Román, el que da nombre a la campaña, en contra de la opinión de Luis Molina, que cree que es San Román de Hornija, en la provincia de Valladolid ${ }^{91}$. Cree Ruiz Asencio que en el trascurso de esta campaña Almanzor atacaría, además de San Román, Saldaña que era en realidad la capital de los Banu-Gómez, familia

\footnotetext{
${ }^{87}$ Las campañas de Almanzor han sido estudiadas, entre otros, por José Manuel Ruiz Asencio (RUIZ ASENCIO, Campañas de Almanzor) y Luis Molina (MOLINA, Las campañas de Almanzor a la luz de un nuevo texto).

${ }^{88}$ Así lo afirma Nicolás Villa Calvo, aunque sin aportar fundamentos (VILLA CALVO, Historia del condado de Monzón, 162).

${ }^{89}$ E. SÁEZ-C. SÁEZ, Colección documental de la catedral de León, II, 281-283, núm. 478.

${ }^{90}$ Ruiz Asencio identificó la campaña de San Román que aparece en Dikr bilad al-Andalus, con San Román de Entrepeñas, monasterio del condado de Saldaña-Carrión, gobernado por los Banu Gómez (RUIZ ASENCIO, San Román de Entrepeñas, 12-13).

${ }^{91}$ MOLINA, Las campañas de Almanzor a la luz de un nuevo texto, 227.
} 
gobernante del condado de Saldaña-Carrión, en contra de lo opinado por Luis Molina, que basándose en Dozy cree que en una campaña anterior, la número 44, se atacaría Santa María o Carrión de los Condes. En contra de dichos autores, Ruiz Asencio estableció que ambas campañas fueron en realidad desarrolladas en una, la número 45, y que el objetivo de Almanzor fue la destrucción del condado de Saldaña.

Pero para atacar el condado de Saldaña-Carrión y ocupar su capital, Saldaña, inevitablemente Almanzor tuvo que atacar y ocupar el condado de Monzón, ya que era lugar obligado de paso hacia Santa María y San Román, y quedaba a la retaguardia de éste, pues probablemente utilizaría como ruta el valle del Carrión. Por ello consideramos que en el año 995 la capital del condado de Monzón fue al menos ocupada y puede que también destruida, siendo posiblemente también destruida Santa María de Husillos. Por todo ello se puede decir que los objetivos de esta campaña fueron no solo la destrucción del condado de Saldaña-Carrión, sino también el de Monzón, aunque dicho condado no tenga el "honor" de ser mencionado en ninguna de las campañas del amirí. La tesis de la destrucción conjunta de los condados de Saldaña y Monzón puede explicar la información sobre la campaña 45 de Almanzor del "Dikr bilad al-Andalus", en la que se expresa que hubo una gran matanza y se hicieron muchos cautivos ${ }^{92}$.

Por otra parte, el objetivo de la destrucción de ambos condados ya supondría un objetivo de envergadura para Almanzor, merecedor de ser blanco de una de sus campañas, pudiendo apoyar quizá esta reflexión la respuesta que da Ruiz Asencio a su sorpresa por ser San Román de Entrepeñas el nombre de la campaña 45 de Almanzor.

La tesis de la destrucción de Monzón y de la abadía de Santa María de Husillos se confirma por datos arqueológicos y documentales Así en el antiguo claustro de la abadía la secuencia de inhumaciones entre los siglos X y XI está interrumpida por un nivel de escombros que bien podría explicarse por uno de los ataques de

\footnotetext{
${ }^{92}$ MOLINA, Las campañas de Almanzor a la luz de un nuevo texto, 234-235.
} 
Almanzor ${ }^{93}$.. Al mismo tiempo el documento ya citado de la catedral de León del año 980 en el que se menciona a la condesa doña Toda gobernando en Dueñas, indicaría su viudedad por muerte de Fernando Ansúrez II y que la antigua capital, Monzón, estaría destruida ${ }^{94}$.

Las campañas de Almanzor tuvieron como resultado el fin del condado de Monzón como entidad autónoma con condes propios. A partir de este momento, sería presa fácil de los condados limítrofes de Saldaña-Carrión y Castilla, siendo este último el que lograría anexionar su territorio, confirmando este supuesto las noticias de Husillos en las que se menciona a los castellanos Sancho García y García Sánchez, y al navarro Sancho el Mayor, como posesores de Monzón. Al mismo tiempo desaparecería también la diócesis de Palencia, aunque puede ser que hubiera ya desaparecido con la figura del obispo Julián, al igual que lo hicieron otras diócesis como Salamanca y Zamora, al mismo tiempo de que con la destrucción de la plaza fuerte de Monzón y la más que probable de Santa María de Husillos, no se darían ya las condiciones ni la cobertura suficientes para su manutención.

En cuanto a Santa María de Husillos, su destrucción como resultado de la campaña 44 de Almanzor, sería bastante probable. Posiblemente los monjes huirían llevándose los bienes más preciados del monasterio, entre ellos su archivo. Aun en el caso de que durante los condes castellanos hasta Sancho el Mayor siguiera existiendo, lo haría con una intensidad e importancia mucho menor a la época de los Banu-Ansur.

Por otra parte, se habría producido también una emigración de la población de la Tierra de Campos hacia las montañas del norte, quedándose las tierras del condado de Monzón semidespobladas, como ya observó Ángel Vaca Lorenzo ${ }^{95}$.

\footnotetext{
${ }^{93}$ CRUZ PÉREZ y GUERRA ARAGÓN, Las excavaciones arqueológicas en el claustro de la Abadia de Santa María de Husillos (Palencia), 493-504. Posibilidad que también apuntó Nicolás Villa Calvo (VILLA CALVO, Historia del condado de Monzón, 163).

${ }^{94}$ E. SÁEZ-C. SÁEZ, Colección documental de la catedral de León, II, 281-283, núm. 478.

95 VACA LORENZO, El obispado de Palencia desde sus orígenes, 46. Sin embargo no compartimos la interpretación que realiza de un documento de Vermudo III sobre la restauración de la sede palentina: "uilla uocitata Palencia, in territorio Monteson, prope alueo Karrion". Según Vaca Lorenzo, esta frase indica que las razias de Almanzor habrían supuesto la destrucción de
} 


\section{SANCHO EL MAYOR DE NAVARRA}

Sancho Garcés III (1004-18 de octubre de 1035) ascendió al trono de Navarra en el año 1004, tras la muerte de su padre, García “El Temblón”. Durante su minoría de edad, estuvo tutelado por su madre, Jimena Fernández, y por su abuela Urraca Fernández, que formarían el consejo de regencia. A partir del año 1011, casado con Muniadonna, primogénita del conde castellano Sancho García, y ejerciendo ya plenitud de poderes, fue cuando comenzó a demostrar su gran capacidad política y diplomática, llegando a alcanzar el reino de Pamplona durante su reinado el predominio sobre el resto de reinos y condados cristianos.

En 1017 muere Sancho García, siendo su heredero, García Sánchez, un niño de siete años al que asiste un consejo de regencia presidido por Urraca, abadesa de Covarrubias, hermana del difunto conde. Próximo al consejo de regencia que se formó mientras durase su minoría de edad se encontraría Sancho el Mayor, cuñado del conde-niño, comenzando a gestarse así una influencia de Pamplona sobre Castilla. Así con el tiempo Sancho el Mayor, en nombre de su mujer, iría ocupando oficialmente el condado de Castilla y también el de Monzón, anexionado a Castilla desde los tiempos de García Fernández. Reflejo de esto fue el viaje que el rey navarro realizó a Monzón con la corte condal castellana y con su madre, la reina Jimena. Dicho viaje se debió de producir antes de que García Sánchez cumpliera la mayoría de edad, ya que también viajaban miembros de la curia castellana. Según Gonzalo Martínez Díez, ésta la alcanzó en el año 1025, por lo que el viaje acontecería hacia el año 1023 o $1024^{96}$. Dicho viaje se refleja en la noticia que aporta la confirmación de Sancho el Mayor a Santa María de Husillos de todas sus posesiones, que manifiesta la ocupación del condado de Monzón por el rey navarro:

Palencia y la pérdida de su carácter de centro administrativo. En nuestra opinión, fue con las campañas de Tarik y Muza de 711-714, cuando Palencia sería destruida o abandonada, dejando de ser centro administrativo. Con la formación del condado de Monzón, sería una villa integrada en dicho condado que durante el siglo $\mathrm{X}$ no destacaría en importancia debido a su difícil defensa militar.

${ }^{96}$ MARTÍNEZ DÍEZ, Sancho III el Mayor, 119. 
"Regnante rex Santius in Castela et in Pampilona et in Monteson"

El 13 de mayo de 1029, García Sánchez fue asesinado en León, donde se encontraba para contraer matrimonio, por miembros de la familia Vela. Ello dejaba libre definitivamente el camino a Sancho el Mayor para apoderarse de Castilla y Monzón.

A la llegada del rey navarro, probablemente el condado de Monzón se encontraría en una situación caótica y semianárquica, fruto de las consecuencias que serían aún palpables de las campañas de Almanzor, que sin duda habrían causado una importante despoblación al huir los aterrorizados colonos a las tierras más seguras del norte; y también porque el núcleo de poder se hallaba ahora en Castilla, desde donde sus condes no podrían gobernar Monzón con tanta eficacia como si tuvieran su sede allí mismo. Por otra parte, aunque Santa María de Husillos pudo seguir existiendo bajos los condes castellanos, sin duda su antiguo esplendor monástico, que se vio agrandado al ser sede episcopal de la primera restauración episcopal de Palencia, se habría visto irremediablemente extinguido.

Sancho el Mayor trató de revitalizar el condado de Monzón, al comprender su importancia geoestratégica como territorio limítrofe con el reino de León. De ello da constancia ciertas noticias, como la existencia de un palacio del rey en Monzón $^{98}$ y sobre todo la revitalización del monasterio de Santa María de Husillos.

En efecto, al igual que los condes de Monzón, el rey navarro vio la necesidad de organizar el territorio desde el punto de vista religioso y también repoblador. Para ello revitalizó el decaído monasterio, confirmando a través de las informaciones de los testigos locales todas sus antiguas posesiones, entre las que destacaban las donaciones de los condes de Monzón, de la reina Teresa Ansúrez y del rey Ramiro III de León ${ }^{99}$.

\footnotetext{
${ }^{97}$ Doc. núm. 6.

${ }^{98}$ HERRERO DE LA FUENTE, Sahagún, II, núm. 433, 87-88.

${ }^{99}$ Doc. núm. 6.
} 
Como hizo anteriormente Ramiro II de León, vio la necesidad de restaurar nuevamente la diócesis de Palencia, para lo cual utilizaría la infraestructura religiosa que le brindaba Santa María de Husillos.

\section{La segunda restauración de la diócesis de Palencia: el obispo Poncio y Santa María de Husillos}

Han sido varios los autores que han abordado de forma más o menos extensa la segunda restauración de la diócesis de Palencia por Sancho el Mayor de Navarra. Pero es el estudio de Gonzalo Martínez Díez sobre Sancho el Mayor el que aborda la cuestión de forma más extensa y definitiva, sobre todo en lo que se refiere a la figura de su restaurador, Poncio ${ }^{100}$.

La restauración oficial de la diócesis palentina por Sancho el Mayor tuvo lugar el 21 de diciembre de 1034. Pero con anterioridad el rey navarro había encomendado la restauración al monje catalán Poncio, que había sido monje de Ripoll bajo el abadiato de Oliba, y más tarde abad del monasterio de San Sadurní de Tavèrnoles, cercano a Andorra. En el año 1025 fue promovido al obispado de Oviedo, desde donde en torno al año 1030 partió hacia tierras palentinas para organizar la segunda restauración de la diócesis. Para ello se asentaría en la revitalizada abadía de Santa María de Husillos, de forma similar al obispo Julián en la primera restauración, ya que la ciudad de Palencia presentaría una ausencia total de infraestructuras. Por otra parte es un hecho el asentamiento de varios obispos de los siglos X y XI en monasterios importantes de su diócesis: San Martín de Dumio, junto a Braga; Santa María de Wamba, junto a Simancas ${ }^{101}$; y la misma primera restauración de Palencia en Santa María de Husillos.

Son varios los testimonios documentales en los que se reflejan a Poncio como obispo-restaurador palentino y con sede en Husillos. Así el 30 de junio de 1033: "Pontius, Dei gratia Palentine ecclesie episcopus"; el 15 de noviembre de 1033,

\footnotetext{
${ }^{100}$ MARTÍNEZ DÍEZ, Sancho III el Mayor.

${ }^{101}$ CARRIEDO TEJEDO, Poncio, obispo de Husillos, 13-14.
} 
una carta de Sahagún expresa: "Pontius episcopus in Sancta Maria de Fusellos" ${ }^{\prime 102}$.

Así pues, Sancho el Mayor restaura la diócesis de Palencia en la persona del catalán Poncio, abad de Tavèrnoles y obispo de Oviedo. Le encomienda la recuperación religiosa de la diócesis, incluso de forma prioritaria y anterior a la restauración canónica ${ }^{103}$. Declara a Bernardo como primer pontífice sin que Poncio pierda, como expresa Gonzalo Martínez Díez, "el papel de promotor o protector que venía desempeñando desde Santa María de Husillos"104.

\section{El abad Raimundo de Santa María de Husillos}

Estamos quizá ante el abad más enigmático de los que existieron en Santa María de Husillos. El abad Raimundo es mencionado como abad fundador en las donaciones falsas de los condes de Monzón ${ }^{105}$ y en la confirmación falsa de Sancho el Mayor de las donaciones de dichos condes ${ }^{106}$. En el documento fundacional, aunque no se le menciona explícitamente, sí aparece implícitamente al relatarse que un cardenal llegado desde Roma con reliquias pidió una merced al rey. Por último, en el arcón de las reliquias de Husillos aparece en una leyenda:

"Cardinales Raimundus, primus huius Sancte basilice abbas sanctus hic reliquias a domino Agapito papa II donatas portavit ac recondidit. Anno Domini DCCCCL”.

Ambrosio de Morales y Jesús San Martín Payo lo presentaron como el primer abad de Santa María de Husillos, cardenal que vino desde Roma en tiempos del papa Agapito II. Así, al basarse en el documento fundacional, Morales considera al abad Raimundo como el primer abad de Husillos. San Martín Payo, utilizando también la información dada por dicho documento y la leyenda existente en la iglesia de Santa María de Husillos, enmarca al abad Raimundo en la época del

\footnotetext{
102 HERRERO DE LA FUENTE, Sahagún, II, núm. 435, 89-90.

${ }^{103}$ En relación al documento por el que se restaura la diócesis de Palencia, existe un trabajo de Félix Martínez Llorente (MARTÍNEZ LLORENTE, Sancho III el Mayor).

${ }^{104}$ MARTÍNEZ DÍEZ, Sancho III el Mayor, 226.

105 Docs. núm. 3, 4, 8, 9 y 10.

106 Doc. núm. 7.
} 
papa Agapito II (946-955). En su estudio sobre las primeras donaciones de los condes de Monzón, que considera auténticas desde el punto de vista diplomático e histórico, y aun reconociendo que el relato fundacional pueda parecer legendario, concluye que no debe ser puesto en duda, explicando cómo dicho papa dio al abad las reliquias y narrando las difíciles circunstancias que vivía en esos momentos la Santa Sede, que hicieron que el cardenal Raimundo tratara de establecerse en tierras hispanas, tras su peregrinación a Santiago de Compostela. Pero en el análisis que efectúa de los documentos de los condes de Monzón concluye que debieron realizarse entre los años 970 y 975, años en los que el papa Agapito II ya no existía. Además, seguramente el redactor de dicha leyenda, que debió efectuarse en la época del abadiato de Francisco de Reinoso, a finales del siglo XVI, insertó el nombre del papa al comprobar que en el año 950, fecha de varias donaciones de los Ansúrez y de las confirmaciones de Sancho el Mayor, Agapito II ejercía su pontificado.

Vemos así como San Martín Payo en su intento de enmarcar a Raimundo como abad fundador hizo una simbiosis entre las donaciones falsas de los Ansúrez, el documento fundacional de la abadía y la leyenda sobre el cardenal Raimundo, tomando de las primeras el nombre del abad, de la segunda la historia de su llegada desde Roma, y de la tercera el nombre del papa.

Llegados a este punto, se hace necesario un análisis de la escritura fundacional en que Morales y San Martín Payo, sobre todo este último, se basaron para contextualizar al abad Raimundo y la fundación de Santa María de Husillos.

Realizada entre fines del siglo XIII y comienzos del XIV, el escriba se basó para su confección en las donaciones falsas de los Ansúrez de Monzón y en un buen conocimiento del reinado de Alfonso VI. Falta la data del documento, suponiendo que debía estar en las tres últimas líneas que el transcriptor no trasladó al Libro de los Privilegios al no poder leerlas por el deficiente estado de conservación de la parte inferior de la escritura. 
En primer lugar confunde a los Ansúrez del siglo XI-XII, descendientes de los Beni-Gómez de Saldaña-Carrión del siglo X, con los Ansúrez de Monzón del siglo X. Así pues, enlaza la fundación de Santa María de Dehesa Brava por el conde Ansur de Monzón, con los Ansúrez del siglo XI-XII, aunque también pudiera ser que se refiriera como fundador de la iglesia a Ansur Díaz, padre de los condes Pedro, Fernando y Gonzalo Ansúrez. Por otra parte, comprobamos cómo todos los acontecimientos y personajes mencionados en la escritura de fundación tuvieron lugar y existieron en efecto en el reinado de Alfonso VI (1072-1109): cortes de Carrión, los condes Ansúrez, infanta Urraca, obispo Alonso Martínez, Cid Campeador. Con respecto a las cortes de Carrión, en realidad podría referirse al concilio legatino que tuvo lugar en Carrión de los Condes en enero del año 1103, en el que, al igual que en el concilio de Husillos, estaría presente Alfonso $\mathrm{VI}^{107}$.

Creemos que el abad Raimundo puede enmarcarse tanto en la época de Sancho el Mayor como el primer abad tras la restauración realizada por dicho monarca, como en la de Alfonso VI, tomando por cierta la información del documento fundacional en lo que se refiere a la venida del mismo desde Roma y su nombramiento como abad de Husillos por el rey, dejando de lado las donaciones de los Ansúrez y la misma fundación de la iglesia.

Aunque no tenemos argumentos convincentes, creemos como más probable el encuadramiento del abad Raimundo en el reinado de Sancho el Mayor. Así, aunque dicho abad no aparece en el único documento de Sancho el Mayor que confirmó Alfonso VII; creemos que la tradición oral mantendría el recuerdo del abad que designó Sancho el Mayor y que pudo coincidir en el tiempo con el obispo Poncio y la segunda restauración de la diócesis palentina. Cuando se realicen las falsas donaciones de los Ansúrez de Monzón y las falsas confirmaciones de Sancho el Mayor a partir de una confirmación de Sancho el Mayor de las donaciones de los Ansúrez, se incluirá el nombre del abad

\footnotetext{
${ }^{107}$ Aunque la historiografía sitúe las cortes a partir del reinado de Alfonso VIII, el dato de las cortes de Carrión puede tener cierto fondo, ya que en el Cantar de Mio Cid se dice que Alfonso VI celebró cortes en Burgos y Carrión, a pesar de que éste no sea una fuente histórica fiable.
} 
Raimundo. El redactor que escribió el relato fundacional añadiría la historia de la procedencia y viaje del cardenal-abad Raimundo.

\section{DE FERNANDO I A SANCHO III}

Los sucesores de Sancho el Mayor seguirán potenciando la influencia de la reforma cluniacense en las instituciones eclesiásticas hispanas, llegando a su máximo esplendor en el reinado de Alfonso VI.

Durante el reinado de Fernando I (1016-1065) tiene lugar el concilio de Coyanza, en el que se intentaron unificar las distintas reglas monásticas haciendo desaparecer los particularismos hispanos bajo una benedictización general, siendo el movimiento cluniacense el gran favorecido ${ }^{108}$. El concilio supuso también una vigorización del "ius episcopale" frente al régimen de iglesias propias, proceso que había comenzado ya con Sancho el Mayor, al disponer que los laicos no podían tener potestad sobre las iglesias, tratando de favorecer con esto la incorporación a los cenobios de las fundaciones particulares. En cualquier caso, el retorno a manos eclesiásticas de las fundaciones particulares sería un proceso muy lento, existiendo aún en la Baja Edad Media numerosas iglesias propias. Es en este proceso en el que debemos contextualizar las donaciones de iglesias por particulares a Santa María de Husillos en los siglos XI y XII principalmente. Así, nos constan por una confirmación de Sancho III las iglesias propias que hasta el 4 de mayo de 1158 habían sido donadas a Husillos ${ }^{109}$ : San Pedro de Valdepero, San Jacobo de Calabazanos, San Mamés, San Román y San Martín en Frechilla, iglesias éstas de Frechilla donadas posiblemente por la infanta Urraca, hija de Fernando I ${ }^{110}$; San Miguel de Pozuelos, San Miguel de Fuentes de don Bermudo y Santa María de Castrillo. También los reyes, como posesores de iglesias propias, las fueron transfiriendo a los distintos cenobios y catedrales. Así en el caso de Husillos, Alfonso VII donó el 25 de enero de 1140 a dicho cenobio la iglesia de San Boal en Villagarcía de Campos ${ }^{111}$.

\footnotetext{
${ }^{108}$ GARCÍA GAYO, El concilio de Coyanza, 275-633.

${ }^{109}$ Doc. núm. 27.

${ }^{110}$ Así lo recoge el documento fundacional (doc. núm. 17).

${ }^{111}$ Doc. núm. 21.
} 
El reinado de Alfonso VI marcará uno de los momentos de máximo esplendor de la abadía, al celebrarse durante su reinado el concilio legatino de Husillos de 1088 y como refleja también la escritura fundacional de la abadía, que enmarca en su reinado la fundación de la iglesia, y que en cualquier caso sería un testimonio de la fuerte tradición oral que debía existir en Husillos sobre el reinado de dicho rey y su importancia para la abadía.

\section{El concilio legatino de Husillos}

Presidido por el cardenal-legado pontificio Ricardo de Milhaud, abad de San Víctor, contó con la asistencia de Alfonso VI y de su Curia. Se fijaron los límites entre las diócesis de Burgos y Osma y se depuso al obispo Diego Peláez de Compostela por su apoyo a la rebelión del magnate gallego Rodrigo Ovéquiz. Según Andrés Gambra, el concilio de Husillos refleja una transición por parte de los sínodos eclesiásticos hacia una adquisición por éstos de un estatus diferenciado de las asambleas plenarias tradicionales ${ }^{112}$.

La celebración del concilio en Husillos reflejaría el estatus e importancia que había alcanzado Santa María de Husillos a finales del siglo XI.

\section{Urraca I}

La reina Urraca sucedió a su padre Alfonso VI en 1109. Su matrimonio con Alfonso el Batallador de Aragón pronto se iba a encontrar con numerosos oponentes. Se diferenciaron dos tendencias en la facción opuesta al matrimonio. Una apoya a Alfonso de Aragón, y está formada por la baja nobleza y las ciudades que bordean el camino de Santiago. Su denominador común es su oposición a los grandes señoríos eclesiásticos. La otra tendencia apoya a la reina Urraca, estando formada por la alta nobleza y el clero, que tratará de anular el matrimonio argumentando ante el papa Pascual II que era incestuoso al ser los dos cónyuges biznietos de Sancho el Mayor de Navarra. El papa llega a amenazar con la excomunión a los dos reyes si éstos no anulaban el matrimonio.

${ }^{112}$ GAMBRA, Alfonso VI, I, 543-544. 


\section{LA ABADÍA DE SANTA MARÍA DE HUSILLOS: ESTUDIO Y COLECCIÓN \\ DOCUMENTAL $(904-1608)$}

Santa María de Husillos, como señorío eclesiástico, apoyó a la reina Urraca. Este apoyo se evidencia en las donaciones que realizó la reina a Husillos, en las que se menciona al abad de Husillos Poncio Guitardo como fidelísimo a su causa. Así, el 28 de mayo de 1114 la reina otorgó, junto a su hijo Alfonso Raimúndez, dos documentos. En uno de ellos donaba a Santa María de Husillos y a su abad, Villaldavín y la pesquera de Ronada ${ }^{113}$; en el otro, Celanova y el arroyo de los Frailes ${ }^{114}$. El primero de los documentos es en realidad una venta encubierta, ya que en confirmación la reina recibió cuarenta y cinco marcas de plata. Ello indica que la generosidad de la reina estaba matizada por sus necesidades económicas derivadas de la guerra que mantenía con su marido Alfonso el Batallador, que en la fecha de dichos documentos estaba en curso, ya que los documentos los otorga junto a su hijo Alfonso Raimúndez.

El apoyo de Santa María de Husillos a la reina Urraca resultaría sin duda peligroso para aquella, debido a su cercanía al camino de Santiago, eje del apoyo al rey aragonés, siendo además la cercana Carrión de los Condes una de las principales ciudades castellanas que apoyaba al aragonés. Julio González afirma también que los primeros años del reinado de Urraca I estuvieron marcados por el hambre, incendios, matanzas y persecuciones, que contribuyeron a la despoblación de muchas aldeas, siendo quizá la zona de Palencia la que más sufrió los efectos de la guerra ${ }^{115}$.

Muestra de dicho peligro y de que la guerra afectó de lleno a los dominios de Husillos, justificando la tesis de Julio González, es un documento fechado el 5 de noviembre de 1127 por el que el obispo Pedro I Pérez de Palencia y Poncio Guitardo, abad de Husillos, conceden el fuero de Palencia a los pobladores de Villaudilla, que había sido destruida por las sucesivas guerras y quemada por Martín Bernaldi ${ }^{116}$. Estamos ante un documento que refleja como pocos los efectos de la guerra entre Urraca de Castilla y Alfonso de Aragón. Martín Bernaldi pudo ser algún capitán de los ejércitos del rey aragonés, o bien algún

\footnotetext{
113 Doc. núm. 18.

${ }^{114}$ Doc. núm. 19.

115 J. GONZÁLEZ, Siglos de Reconquista, 181.

${ }^{116}$ Doc. núm. 20.
} 
miembro de la baja nobleza palentina que apoyaba a dicho rey. El documento menciona los efectos de las guerras anteriores. En efecto, tras la muerte de su madre, Alfonso VII había sido coronado el 10 de marzo de 1126. En 1127 reconquista algunas de las ciudades más importantes que apoyaban a Alfonso el Batallador, como eran Carrión de los Condes y Burgos. La retirada de las guarniciones aragonesas de la zona del Bajo Carrión conllevaría una nueva época de tranquilidad y estabilidad, en la que se trataría de recuperar la población y las aldeas destruidas. Es en este marco en el que debemos encuadrar el fuero otorgado a Villaudilla por el obispo de Palencia y el abad de Husillos.

\section{Alfonso VII}

Al igual que su madre, Alfonso VII sería un gran benefactor de Santa María de Husillos. Así, por un documento otorgado en Palencia el 25 de enero 1140, dona a Santa María de Husillos y a su abad Bernardo, juntamente con su esposa Berenguela, la iglesia de San Baudilio de Villagarcía de Campos ${ }^{117}$. El mismo día confirmó a la sede episcopal palentina todos sus bienes y derechos, entre los que estaba Santa María de Husillos, con sus villas, decanías y términos antiguos ${ }^{118}$. Alfonso VII también confirmó a Husillos todos sus derechos y bienes. Así el apócrifo de Sancho el Mayor por el que confirma las donaciones realizadas por los Ansúrez de Monzón, los reyes Ramiro III y Teresa Ansúrez de León, contiene una suscripción confirmativa de Alfonso VII y su esposa Berenguela, que hemos datado entre los años 1131 y $1133^{119}$.

\section{Sancho III}

Muerto Alfonso VII en 1157, le sucedió en Castilla Sancho III y en León Fernando II. Fue quizá Sancho III el Deseado el rey que más se interesó por la abadía de Santa María de Husillos, sin que haya una explicación clara a este respecto. Quizá el hecho de que fuese sobrino del obispo palentino Raimundo II de Minerva, a cuya sede pertenecía Santa María de Husillos, podría orientar tal generosidad. Lo cierto es que entre mayo y junio del año 1158, Sancho III concedió una serie de confirmaciones y privilegios a Santa María de Husillos.

\footnotetext{
117 Doc. núm. 21.

${ }^{118}$ Doc. núm. 22.

${ }^{119}$ Doc. núm. 6.
} 
Así, el 4 de mayo de 1158 otorga dos documentos en Carrión de los Condes a favor de Santa María de Husillos. Por uno de ellos confirma las posesiones que Husillos recibió de la reina Urraca I, los condes Ansúrez de Monzón y otros particulares ${ }^{120}$. Por el otro concede a los canónigos de Husillos el privilegio de los infanzones, del que ya disfrutaban los canónigos de la catedral de Palencia, haciéndoles exentos además de todo servicio real ${ }^{121}$. De esta forma los canónigos de Husillos pasaban a tener los mismos privilegios que los infantes reales.

Por un documento otorgado en Cuéllar, el 28 de junio de 1158, Sancho III confirma a Husillos el coto que él mismo había donado anteriormente, concediendo también la inmunidad jurídica en dicho coto ${ }^{122}$.

Pero es quizá un documento fechado en Sahagún el 23 de mayo de 1158 el que refleja mejor el estrecho lazo que unía al rey con Husillos. En éste Sancho III suscribe un pacto de paz y amistad con su hermano Fernando II de León ${ }^{123}$. Se trata de un original múltiple, conservándose el ejemplar perteneciente a Fernando II de León en el fondo del monasterio de San Facundo y Primitivo de Sahagún, actualmente en el Archivo Histórico Nacional ${ }^{124}$, y el perteneciente a Sancho III, que es el que nos ocupa, en el archivo de Santa María de Husillos. La presencia de dicho documento en Husillos refleja un grado de devoción especial de Sancho III por este cenobio, que no pasó desapercibida al redactor del Libro de los Privilegios de Husillos cuando expresa que el rey depositó dicho documento en Husillos por la especial devoción que el rey profesaba por el monasterio. A esto habría que admitir el hecho de que, al igual que Fernando II depositó su ejemplar en el monasterio más importante de su reino, el rey castellano lo hizo en uno de los monasterios más al alza de Castilla, gracias también a sus acciones protectoras para con dicho cenobio. Posiblemente el hecho de que el tío materno del rey y también de Fernando II de León, Raimundo II de Minerva, fuera el obispo de Palencia, influyó en la predisposición de Sancho III a otorgar privilegios y confirmaciones a la catedral de Palencia y a Santa María de Husillos, iglesia esta

\footnotetext{
${ }^{120}$ Doc núm. 27.

${ }^{121}$ Doc. núm. 28.

${ }^{122}$ Doc núm. 30.

${ }^{123}$ Doc. núm. 23.

${ }^{124}$ FERNÁNDEZ FLÓREZ, Sahagún,, IV, 275-277, núm. 1332.
} 
última de la que Raimundo II era "senior"125. Tal generosidad derivaría en la confianza del rey para depositar aquí tan importante documento.

El recuerdo de la generosidad de Sancho III con Santa María de Husillos perduraría en la abadía con el paso del tiempo, como refleja una inscripción conservada en el interior del templo de Husillos:

"Era M C LXXXX VI rex Sancius, dompni Aldefonsi imperatoris Hispaniarum filius, dedit cautos ecclesie Sancte Marie de Fusellis, Raymundo Gilaberti existente abbate eiusdem ecclesie et eadem era. Predictus rex domnus Sancius obiit ultimo die Augusti".

\section{SANTA MARÍA DE HUSILLOS DESDE LOS SIGLOS XIII AL XVI}

Entre finales del siglo XII y mediados del siglo XIII el dominio territorial de Husillos y con él la importancia de la abadía van a llegar a su máximo apogeo, siendo protegida y confirmados sus privilegios y derechos por Alfonso VIII $(1178)^{126}$, y por los papas Alejandro III $(1178)^{127}$ e Inocencio III $(1210)^{128}$. Asimismo Inocencio IV en 1252 hacía exenta a la abadía del pago del subsidio a la Santa Sede, a la vez que reforzaba la autoridad del abad Esteban al ordenar que éste no pudiera ser excomulgado ni puesto en entredicho por ningún juez ordinario $^{129}$.

Ya en los años finales del siglo XIII y de comienzos del XIV, se producen las confirmaciones de Sancho IV ${ }^{130}$ y Fernando IV ${ }^{131}$, anticipo de las confirmaciones reales del siglo XIV, como reflejo de inseguridad enmarcada en la crisis generalizada de dicho siglo.

\footnotetext{
125 Doc. núm. 25.

126 Docs. núm.. 35 y 36.

${ }^{127}$ Doc. núm. 37.

${ }^{128}$ Doc. núm. 48.

${ }^{129}$ Doc. núm. 68.

${ }^{130}$ Docs. núm. 82 y 84.

${ }^{131}$ Docs. núm. 92, 97, 100.
} 


\section{LA ABADÍA DE SANTA MARÍA DE HUSILLOS: ESTUDIO Y COLECCIÓN \\ DOCUMENTAL $(904-1608)$}

A pesar de los efectos globales de la crisis del siglo XIV, Santa María de Husillos no sufrió en exceso. En efecto, se aprecia que su patrimonio territorial incluso aumentó en términos generales, y que los despoblados existentes a fines de la citada centuria quizá se habían producido por factores como la concentración de la población, más que por la mortandad de las epidemias o la emigración, permaneciendo así la mano de obra necesaria para la explotación del dominio.

Al igual que lo observado en otros cenobios como Santa María de Trianos ${ }^{132}$, entre principios del siglo XV y mediados del XVI, Santa María de Husillos iba a perder gran número de heredades, acabándose por despoblar la mayor parte de sus villas, como se refleja en la relación de rentas realizada en $1555^{133}$. Es por tanto en este período de tiempo, en especial en el siglo XV, cuando se produce una crisis total en Santa María de Husillos.

Es a través del análisis de la documentación producida por Santa María de Husillos durante los siglos XV y XVI como mejor se aprecia la gran crisis que sufrió la abadía en dichos siglos, especialmente en el siglo XV. Todos los tipos diplomáticos son escasos en esta centuria, destacando la inexistencia de donaciones. Incluso un tipo diplomático propio de tiempos de crisis como es la confirmación real de privilegios anteriores, es prácticamente inexistente, ya que solamente se contabiliza una, hecho que refleja el grado de crisis e incluso de desdén total hacia su dominio al que había llegado la abadía. El tipo diplomático con mayor presencia es el judicial, aunque en un porcentaje algo menor que en el siglo XIV, lo que refuerza la idea de la época de total crisis que atravesó la abadía.

Los pleitos en los que tuvo que litigar la abadía son similares a los del siglo XIV, tratando sobre impuestos señoriales, diezmos y deslindes y amojonamientos. Es el caso del pleito en el año 1402 con Çag Çidicario de Villadiego, arrendador de las tercias reales, por el pago de dicho impuesto por el concejo de Gutiérrez

\footnotetext{
${ }^{132}$ Según Susana Royer de Cardinal, la crisis del XIV no afectó mucho a Trianos. Así en el XIV adquiere heredades y acrecienta su patrimonio. Sus problemas afloran a fines de Edad Media, durante el reinado de los Reyes Católicos (ROYER DE CARDINAL, Santa María de Trianos, 7-33).

${ }^{133}$ Doc. núm. 298.
} 
Álvarez ${ }^{134}$. En 1428 se litigó pleito con el concejo de Palencia por el deslinde y amojonamiento de ciertos términos, siendo resuelto por juez real ${ }^{135}$. En 1470, continuando los pleitos acaecidos ciento veinte años antes, el prior y cabildo mantuvieron pleito con el concejo de Villaumbrales sobre el término de Santillán de la Cuesta, resolviéndose que dicho concejo debería pagar un censo anual por el término de Santillán, de lo que se deduce que Santillán de la Cuesta debía estar ya despoblada $^{136}$.

Según avanzaba el siglo XV, la situación debía ser cada vez más desesperante, ya que se registran litigios entre los mismos miembros de la abadía. Así, en 1478 se produjo un pleito entre el prior y cabildo con el tesorero de Fernando de Corral, por los diezmos de Pajares ${ }^{137}$.

Aunque las sentencias de los anteriores litigios fueron favorables a Santa María de Husillos, no siempre se resolvían a favor de la abadía. Es el caso del pleito litigado con el concejo de Hérmedes sobre el aprovechamiento de unos montes y términos, resuelto a favor de dicho concejo, y cuya sentencia fue reacia la abadía a cumplirla $^{138}$.

Por otra parte, se iban a seguir produciendo las intromisiones de las autoridades intermedias, de la nobleza y de los concejos en los términos de Husillos, que iban a llegar a su máxima expresión durante el reinado de los Reyes Católicos. Así en 1483 dichos reyes liberan a la abadía de la encomienda que ejercía sobre ella el conde de Rivadavia y su alcaide de Fuentes de Valdepero, esgrimiendo que, a excepción de los reyes, nadie podía ejercer encomienda sobre el abadengo ${ }^{139}$. También dichos reyes en 1485 iban a ordenar amojonar y deslindar el término de

\footnotetext{
${ }^{134}$ Doc. núm. 220.

${ }^{135}$ Doc. núm. 224. Según Santos García Larragueta, el apeo como tipo diplomático se consolidó en el siglo XIV-XV, extendiendo desde el siglo XV la autoridad real su facultad de administración de justicia en la delimitación de términos (GARCÍA LARRAGUETA, El apeo, documento diplomático, 617-639).

${ }^{136}$ Doc. núm. 232.

${ }^{137}$ Doc. núm. 236.

${ }^{138}$ Docs. núm. 247 y 248.

${ }^{139}$ Doc. núm. 238.
} 


\section{LA ABADÍA DE SANTA MARÍA DE HUSILLOS: ESTUDIO Y COLECCIÓN \\ DOCUMENTAL $(904-1608)$}

Villaudilla, ya que sus límites eran violados constantemente por los vecinos de Paredes de Nava y Fuentes de Nava ${ }^{140}$.

Aunque en el siglo XVI hubo una ligera recuperación en Santa María de Husillos, que se refleja en su mayor producción documental con respecto al siglo $\mathrm{XV}$, siendo prácticamente del triple, la decadencia y pobreza de la institución era palpable e irreversible, como dan fe dos donaciones a la abadía de los abades Francisco de Carvajal y Francisco de Reinoso, realizadas en $1533^{141}$ y $1589^{142}$ respectivamente, en las que aducen como causa de sus donaciones, el estado de gran pobreza en el que se encuentra la abadía.

La pérdida continua de población de la villa de Husillos constituía un importante problema para la abadía, ya que el mantenimiento de ésta y de sus beneficiados dependía de la existencia de una cierta población. Ya en 1474 Husillos debía de estar casi despoblada, explicándose así el privilegio por el que Enrique IV eximía a los vecinos de dicha villa del pago de impuestos para favorecer su repoblación ${ }^{143}$.

En el siglo XVI siguieron produciéndose algunas intromisiones de los concejos en los términos de Husillos, de lo que derivaban pleitos, como el litigado con el concejo de Valdespina en 1522 por cierta parte del término de Gutiérrez Álvarez ${ }^{144}$, del habido en 1533 con el concejo de Becerril de Campos por el arroyo de Frades $^{145}$, o los acontecidos a mediados del siglo XVI con Villaldavín ${ }^{146}$ y Husillos ${ }^{147}$, concejos de su señorío, sobre derechos de pasto, censos, tributos, jurisdicción y nombramientos de oficiales de justicia, aunque en el fondo estos concejos lo que trataron fue de escapar, infructuosamente, del dominio señorial de la abadía, amparándose en el dominio de la corona, aprovechándose así de la situación de decadencia y debilidad de la abadía.

\footnotetext{
${ }^{140}$ Doc. núm. 240.

141 Doc. núm. 268. La generosidad del abad Francisco de Carvajal alcanzó también a otras instituciones, como el hospital de San Antolín y San Bernabé de Palencia, al que donó unos objetos de plata para ayuda de los niños y pobres (ACP, Arm. III, leg. 15-28).

${ }^{142}$ Doc. núm. 331.

143 Doc. núm. 234.

144 Doc. núm. 265.

${ }^{145}$ Doc. núm. 267.

146 Docs. núm. 275 y 299.

${ }^{147}$ Docs. núm. 276, 281 y 283.
} 
La escasa población y la pobreza de Santa María de Husillos, causada sobre todo por una mala gestión de su dominio que había llevado a la pérdida de muchas de sus heredades y a una escasa rentabilidad de las existentes, provocaron los intentos de los beneficiados de trasladar la abadía a otros lugares más poblados y con más recursos económicos. Así, entre 1524 y 1525 se intentó el traslado a Carrión de los Condes, y a Peñafiel entre 1525 y 1537. Finalmente, entre 1537 y 1550 se intentó el traslado a Tordesillas, siendo este último rechazado por el obispo de Palencia, al igual que probablemente los dos anteriores ${ }^{148}$.

En el último tercio del siglo XVI iban a tener lugar acontecimientos importantes en la abadía, como fueron el patronazgo de Felipe II de la misma y el traslado de la reliquia del pie de San Lorenzo al Escorial, todo ello enmarcado en el abadiato de Francisco de Reinoso.

\section{SANTA MARÍA DE HUSILLOS Y EL OBISPADO DE PALENCIA}

Desde la restauración de la diócesis de Palencia por Sancho el Mayor en el año 1034 Santa María de Husillos pasó a formar parte y depender jurisdiccionalmente del obispo de Palencia ${ }^{149}$. Esta dependencia fue confirmada por reyes y papas posteriores, como Fernando I (1059) ${ }^{150}$, Alfonso VI (1090) ${ }^{151}$, Alfonso VII $(1140)^{152}$, Inocencio II (1143) ${ }^{153}$ y Lucio III $(1182)^{154}$. El señorío del obispo de Palencia sobre Santa María de Husillos se expresa también en ciertos documentos como el fundacional de la abadía ${ }^{155}$, el fuero de Villaudilla, otorgado juntamente por el obispo Pedro I Pérez y el abad Poncio Guitardo ${ }^{156}$, y en una mención del

\footnotetext{
${ }^{148}$ Doc. núm. 292.

${ }^{149}$ Doc. núm. 11.

${ }^{150}$ Doc. núm. 13.

151 Doc. núm. 15.

152 Doc. núm. 22.

153 Doc. núm. 23.

154 Doc. núm. 39.

155 Doc. núm. 17.

${ }^{156}$ Doc. núm. 20.
} 
obispo Raimundo II de Minerva de 1151, en la que aparece como "senior" en Santa María de Husillos ${ }^{157}$.

No obstante, el 18 de noviembre de 1179 Alejandro III hace exenta a Santa María de Husillos de la jurisdicción del obispo de Palencia y la hace dependiente de la Santa Sede, confirmando todos sus bienes y defendiendo sus posesiones y pertenencias de todo infractor ${ }^{158}$. La exención jurídica se traducía en que le correspondía al abad la jurisdicción civil y criminal en primera instancia sobre los beneficiados de su abadía, correspondiendo al obispo solamente la apelación o segunda instancia. Esta exención parece entrar dentro de la tónica desarrollada por la Santa Sede en el siglo XII de conceder a los cenobios privilegios de libertad y protección contra la intromisión de los obispos en el régimen interno de los monasterios, y como medio de estos últimos de defensa de su patrimonio ${ }^{159}$.

La exención jurídica del obispo de Palencia y dependencia directa de la Santa Sede daría lugar a pleitos y litigios entre Santa María de Husillos y el obispo de Palencia, casi hasta el fin de los días de la institución. García de Cortázar hace común estos litigios a todas las iglesias de la época: "No hay colección diplomática monacal donde no aparezcan durante el siglo XII reiterados litigios con la autoridad episcopal sobre jurisdicción" ${ }^{\prime 60}$. De los pleitos entre Husillos y el obispo de Palencia en los primeros tiempos dan fe el falso documento fundacional de la abadía ${ }^{161}$ y un acta notarial de 1327 en el que se refleja un pleito entre ambas instituciones que iba a ser resuelto en la Santa Sede ${ }^{162}$.

Aunque los litigios entre ambas instituciones pudieron ser frecuentes desde finales del siglo XII, lo cierto es que la relación de dependencia de Santa María de Husillos con el obispo, al ser su abad dignidad del cabildo catedralicio, hizo que nunca fueran importantes. Sólo a raíz del concilio de Trento surgieron controversias que dieron lugar a dos pleitos entre ambas instituciones.

\footnotetext{
${ }^{157}$ Doc. núm. 25.

${ }^{158}$ Doc. núm. 37.

${ }^{159}$ GARCÍA DE CORTÁZAR, El dominio del Monasterio de San Millán de la Cogolla, 319

${ }^{160}$ GARCÍA DE CORTÁZAR, El dominio del Monasterio de San Millán de la Cogolla, 319.

161 Doc. núm. 17.

162 Doc. núm. 109.
} 
En el primero litigaron Pedro Lagasca, obispo de Palencia, y Francisco de Carvajal, abad de Husillos, sobre el derecho del obispo a visitar la abadía y su jurisdicción ordinaria sobre ésta. El obispo se apoyaba en las cláusulas del concilio de Trento relativas a las visitas eclesiásticas y en una cédula real que le facultaba para visitar la abadía, mientras que el abad esgrimía la exención jurídica de la abadía, suplicando al rey le otorgase el derecho de visita sobre ésta, en virtud también de las cláusulas del concilio de Trento. Por sentencia del consejo real de 14 de junio de 1554, se reconoce la jurisdicción ordinaria del abad sobre su iglesia, es decir, la jurisdicción en primera instancia sobre sus beneficiados, y el derecho de visita sobre ésta ${ }^{163}$.

A pesar de este revés, los obispos de Palencia no dejarían de intentar conseguir el derecho de visita sobre Husillos. Así en 1573, tuvo lugar un nuevo pleito entre el obispo Juan Zapata de Cárdenas y el abad Francisco de Vargas Carvajal, con motivo de la visita que pretendía hacer dicho obispo, apoyado también en las cláusulas del concilio de Trento ${ }^{164}$. Una vez más, el abad se apoyó en la exención de Alejandro III y en la práctica secular. Fue la Congregación de cardenales intérpretes del Concilio Tridentino la que encontró una vía de conciliación en el año 1575. Así, considerando la exención de la abadía, el obispo no podría visitarla a través de su vicario o provisor, como había intentado, sino personalmente $^{165}$.

\section{SANTA MARÍA DE HUSILLOS Y FELIPE II}

\section{La desamortización de Felipe II}

El primer proceso desamortizador de bienes eclesiásticos de la Historia de España se produjo durante los reinados de Carlos I y Felipe II, justificado por las graves crisis monetarias de la época de los Austrias mayores, y tendrían como consecuencia la ampliación del señorío laico o nobiliario, en sustitución del abadengo o la encomienda. En esta primera desamortización se pueden diferenciar dos fases: en la primera se produjo la desamortización de los bienes

\footnotetext{
${ }^{163}$ Doc. núm. 294.

${ }^{164}$ ACP, Arm. III, leg. 13, doc. 1.

165 Doc. núm. 310.
} 


\section{LA ABADÍA DE SANTA MARÍA DE HUSILLOS: ESTUDIO Y COLECCIÓN \\ DOCUMENTAL $(904-1608)$}

raíces de las Órdenes militares, en virtud de una bula de Adriano VI de 4 de mayo de 1523. Pero como las necesidades económicas de la Corona no hacían más que aumentar, Carlos I se vio en la necesidad de pedir nuevos subsidios al papa. Así, Julio III expidió el 1 de febrero de 1551 una bula en la que autorizaba al emperador "por los cuantiosos gastos bélicos que se veía forzado a realizar, a enajenar lugares, fortalezas y villas, pertenecientes a monasterios y conventos, de hombres y mujeres, de la Orden de San Benito, San Agustín, San Jerónimo y cualquier otra, hasta el valor de 40.000 ducados de renta" ${ }^{\text {166. }}$.

No obstante, la fiebre desamortizadora de este siglo llegaría en 1574 ya con Felipe II, que logra del papa Gregorio XIII la bula de 6 de abril de 1574 por la que se da licencia al rey de España para "desempeñar, quitar, apartar y vender perpetuamente cualesquiera villas y lugares, jurisdicciones, fortalezas y otros heredamientos, con sus rentas, derechos y aprovechamientos pertenecientes en cualquier manera a cualesquiera iglesia catedrales de estos reinos, aunque fuesen metropolitanas, primaciales, colegiales, y a cualesquier monasterios, cabildos, conventos y dignidades, y desmembrado, darlo, donarlo, y venderlo y disponer de ello, con tal que no excediese la renta de las villas y lugares que así se desmembrasen y vendiesen del valor de 40.000 ducados de renta en cada un año, y que la desmembración la pudiese hacer sin consentimiento de los prelados, abades, priores, prepósitos, rectores, conventos, cabildos, y las otras personas que las poseyesen, dándoles la justa recompensa y equivalencia que hubiesen de haber por las rentas que así desmebrasen y vendiesen”.

Esta bula sería reforzada pocos años más tarde por una nueva disposición pontificia de 14 de marzo de 1579.

En la diócesis de Palencia, la desamortización de Felipe II afectó a numerosas iglesias y monasterios, además de a la propia catedral de San Antolín ${ }^{167}$. Aunque no hemos localizado testimonios y documentos que constaten sobre Husillos los efectos de esta desamortización, una noticia sobre la compra por el abad

\footnotetext{
${ }^{166}$ Para los efectos de la desamortización de Felipe II en Palencia, véase: MARCOS MARTÍN, Economía, sociedad, pobreza en Castilla, I, 280-285; y NARGANES, El señorio de abadengo en Palencia, 261-284.

${ }^{167}$ MARCOS MARTÍN, Economía, sociedad, pobreza en Castilla, I, 280-285.
} 
Francisco de Reinoso a Felipe II de la heredad realenga del término de Husillos, y que dicho abad donaba en 1591, junto a unos censos sobre los vecinos de la villa de Husillos, a la fábrica de la iglesia, nos hace sospechar que la desarmortización de Felipe II también afectó a algunos dominios de Santa María de Husillos ${ }^{168}$. Seguramente que al igual que otras instituciones eclesiásticas palentinas, Santa María de Husillos pagara a la hacienda real para conservar sus jurisdicciones ${ }^{169}$. Aunque puede ser también que la especial relación que tenía Felipe II con Francisco de Reinoso y que llegó a desembocar en cierta devoción del rey por Santa María de Husillos, cimentada por la cesión de la reliquia del pie de San Lorenzo para el monasterio de San Lorenzo del Escorial, el 5 de octubre de 1592, y por la visita realizada por el rey a la abadía el 1 de septiembre de $1592^{170}$, Felipe II vendiera al abad las heredades de Husillos que años atrás había desamortizado, seguramente por un precio simbólico. Quizá fuera consecuencia de la visita de dos beneficiados al rey, entre ellos el prior, decidida por cabildo ordinario de 9 de abril de 1593, para suplicarle, teniendo como memoria la donación de la reliquia de San Lorenzo, alguna merced para la abadía por el estado de pobreza total en el que se encontraba ${ }^{171}$.

\section{Patronazgo real de Husillos}

Por bula concedida por el papa Adriano VI, en 1523, a Carlos I, la corona española obtuvo el derecho de presentación sobre todas las catedrales del reino. El nombramiento real de los obispos permitía a la Corona el control de la Iglesia, favoreciendo con ello su política reformista para con ésta. Los papas sucesivos confirmaron el privilegio a los reyes españoles ${ }^{172}$. El derecho de patronato real se circunscribía a los beneficios consistoriales, es decir, a los beneficios que eran proveídos por el consistorio pontificio.

Santa María de Husillos fue también objeto de deseo de la monarquía para circunscribirla al patronato regio. Esta apetencia culminaría en el reinado de Felipe II. El proceso por el que Husillos fue declarada de patronato real duró

\footnotetext{
${ }^{168}$ Doc. núm. 332.

${ }^{169}$ FAYA, Los señorios eclesiásticos del obispado de Palencia, 768.

${ }^{170}$ APA, Actas Capitulares, Libro 226.

${ }^{171}$ APA, Actas Capitulares, Libro 226.

${ }^{172}$ CATALÁN, El derecho de patronato, 135-168.
} 
cinco años, desde el 10 de agosto de 1592 hasta el 27 de febrero de 1597, coincidiendo el proceso con el abadiato de Francisco de Reinoso.

El 10 de agosto de 1592 Felipe II, habiendo sido informado de que Santa María de Husillos tenía una renta de hasta dos mil ducados anuales, que era consistorial y por ello de su patronazgo, ordenó a Juan Chacón, corregidor de Palencia, que se informase sobre dicha abadía en cuestiones como su fundación, orden de los canónigos, rentas, elección del abad, derechos y obligaciones, privilegios pontificios, y reliquias, en especial sobre el pie de San Lorenzo ${ }^{173}$. Además el rey ordenaba al abad que permitiese sacar traslado de las escrituras que el corregidor considerara.

Entre el 19 de agosto de 1592 y el 19 de enero de 1593, el escribano del número y apostólico Hernando de Castro realizó un testimonio notarial sobre el proceso de patronazgo regio en Husillos, a instancia de Juan de Chacón, corregidor de Palencia, y del licenciado San Román de Tapia, teniente-corregidor de Palencia ${ }^{174}$. Tras hacer un inventario de las reliquias, procede a continuación a realizar un cuestionario en base a las preguntas que Felipe II había sugerido anteriormente en su cédula de 10 de agosto de 1592.

El 19 de enero de 1593, el licenciado San Román de Tapia hace un informe al rey dando su opinión sobre el posible patronazgo real de Husillos en base a las informaciones averiguadas. Así, entiende que la Corona participa de la dotación de la abadía, al haber realizado la reina Urraca I donaciones y a su instancia los condes de Monzón; que fue de canónigos regulares de San Agustín y que aunque algunos creían que es consistorial, los abades han sido nombrados por resignación papal. Teniendo en cuenta además que la renta anual excede de los sesenta y seis florines y dos tercios, opinaba que la abadía era de patronazgo real ${ }^{175}$.

El posible patronazgo real de Santa María de Husillos no debía ser una opción del gusto de las dignidades de Husillos, ya que suponía la intromisión de un poder

\footnotetext{
173 Doc. núm. 333.

174 Doc. núm. 335.

175 Doc. núm. 336,
} 
laico ajeno. De ello se deriva la carta fechada el 2 de octubre de 1596 por Pedro de Reinoso, señor de Autillo y sobrino del abad Francisco de Reinoso, en la que informaba que su tío le había promovido ante el papa como abad de Husillos, informando asimismo que sobre la pretensión real de patronazgo en Husillos existía un libro becerro y documentos que podían aclarar la cuestión ${ }^{176}$.

Por fin, el 30 de diciembre de 1596, habiendo sido informado favorablemente acerca del patronazgo real de Santa María de Husillos, procede a declarar "de facto" dicha iglesia de su patronazgo, justificando su acción en base a las bulas pontificias concedidas a su abuela Juana I y a su padre Carlos I ${ }^{177}$.

Poco después, por testimonio notarial de Hernando de Castro, escribano del número de Palencia, de 27 de febrero de 1597, el prior Baltasar de Chaves y otras dignidades y canónigos acatan el patronazgo regio sobre su abadía y nombramiento real de Sancho González de Heredia, hermano de Francisco González de Heredia, secretario de Felipe II, como nuevo abad ${ }^{178}$. Se comprueba así la rapidez con que el rey ejerció su derecho de presentación de abad sobre Santa María de Husillos.

\section{Visita de Felipe II a Santa María de Husillos}

El 1 de septiembre de 1592 Felipe II, de paso por la ciudad de Palencia, visitó la abadía de Santa María de Husillos ${ }^{179}$, lo cual debió de suponer un acontecimiento de gran importancia en la vida tanto de Palencia como de la propia villa y abadía de Husillos. Ya en días anteriores, el 27 de agosto de 1592 se había tratado dicha visita en el cabildo de Husillos, acordándose que el prior y cabildo debían tratar con el abad Reinoso el orden de la visita, acordándose también que el día de la visita no podría faltar ningún beneficiado, bajo multa de 4 escudos.

La visita fue relatada por Gregorio de Alfaro, biógrafo de Francisco de Reinoso:

\footnotetext{
${ }^{176}$ Doc. núm. 338.

${ }^{177}$ Doc. núm. 339.

${ }^{178}$ Doc. núm. 340.

179 APA, Actas Capitulares, Libro 226.
} 
"Passando el rey Felipe segundo por Castilla la Vieja, llegó a la ciudad de Palencia y sin deternerse en ella más de solo un día, se fue a Husillos, donde sabía que don Francisco le esperaua. Y con ser aquel monarca del mundo de gran magestad, que nadie se atreuió a ofrecerle su casa y mesa, ni él con su gravedad increible la recibiera de nadie, solamente la virtud tan conocida y prouada de don Francisco le pudo humanar y rendir para que fuesse su huésped, y para que comiesse vn día a su costa y en su mesa (...) Nadie quedó descontento, porque huuo grande abundancia de todo género de regalos, y diferentes vinos, muy estremados, no solo para la gente de palacio, sino también para la que venía de toda la tierra a ver al rey a Husillos. Y como el lugar es pequeño y la gente fue mucha, perecieran de hambre, si la providencia de don Francisco no lo remediara con tiempo (...) aviendo sido tan grande la deuoción deste príncipe, que quisiesse rodear el camino que lleuaua por visitar las santas reliquias de aquella iglesia y ver a vn hombre tan celebrado en España (...) el rey con su deuoción, porque llegando a Husillos, oyó missa, que se la dixo don Francisco, que, acabada, le mostró las reliquias, que las miró el rey con particular consideración, y adoró con gran deuoción. Después de auer comido y sesteado su magestad, prosiguió su jornada, celebrando el hospedaje y liberalidad del huésped". 180

De la visita del rey se entiende que en realidad se desvió de su camino para ir a conocer al abad Francisco de Reinoso y las reliquias de Santa María de Husillos, debiendo de suponer que ambos gozaban de una amplia fama que habría llegado hasta la corte.

\section{La reliquia del pie de San Lorenzo}

Un capítulo especial de la relación de Felipe II con Santa María de Husillos y que acabaría desembocando en una especial devoción de dicho rey por esta iglesia fue el acontecido sobre la reliquia del pie de San Lorenzo que se conservaba en Husillos. Gregorio de Alfaro, biógrafo de Francisco de Reinoso, hace una descripción de dicha reliquia:

${ }^{180}$ CASTRO SÁNCHEZ, Vida de Francisco de Reinoso, ff. 61r-62r. 
"Estaba el pie en vna caxita, tan entero y bien formado como si se acabara entonces de cortar. Veíanse pegados los carbones que le abrasaron y las señales del fuego, que todo mueue a devoción" 181 .

Otra descripción es la que se hace en la donación de la reliquia a Francisco de Reinoso para donarla al rey:

"Dentro de una caja de plata de la forma y medida del santo pie, entero como siempre a estado en esta iglesia con sus cinco dedos, soltadas las uñas con la fuerza del fuego, con sus nierbos y ligamentos e señales del fuego",182.

Felipe II había mandado construir el monasterio de San Lorenzo del Escorial tras el triunfo español en la batalla de San Quintín sobre Francia, terminándose oficialmente en 1584. El rey estaba informado de la existencia en la abadía palentina de Santa María de Husillos de la reliquia del santo, como se comprueba en su petición al corregidor de Palencia Juan Chacón de información especial sobre ésta ${ }^{183}$.

El asunto de la petición real de la reliquia de San Lorenzo se trató en la abadía en tres capítulos del cabildo presidido por el abad Francisco de Reinoso, celebrados en los días 5, 6 y 7 de octubre de 1592 , respectivamente ${ }^{184}$.

En el primer sínodo o capítulo, Francisco de Reinoso informa al cabildo cómo en la visita que realizó el rey a la abadía, el 1 de septiembre de 1592, mostró una especial devoción por dicha reliquia:

"El rey nuestro señor, movido con ánimo religioso y de veto en primero de setiembre deste año de noventa y dos, visitó las reliquias desta yglesia con la devoción que de tan [...] rey se entendía particularmente mostró este celo santísimo en la veneración del pie de San Lorencio, de quien a sido siempre tan devoto; y ansí mismo mueve con quanta humanidad visitó la pobreza de nuestra

\footnotetext{
${ }^{181}$ CASTRO SÁNCHEZ, Vida de Francisco de Reinoso, f. 63r.

${ }^{182}$ APA, Leg. 152, carp. 3.

183 Doc. núm. 333.

184 APA, Actas Capitulares, Libro 226.
} 
iglesia, venerando las antigüedades que en ella ay [...] con la tristeza de su partida dissimuló el dicho que siempre se dijo que tenía de transferir en San Lorencio el Real el pie deste vendito señor. Después me escribió García de Loaisa, escribano del príncipe nuestro señor, escribió de que a Su Magestad le gustaría de que de nuestra parte se le ofreciesse esta santa reliquia como en este cabildo lo referí, y de la consulta recibió que no se diese sin que primero $\mathrm{Su}$ Majestad lo pidiesse por su carta, y para ello invié al licenciado Bernabé García, mi prouissor a Burgos que trujo una carta de Su Magestad, que es lo que aqui se ha leido" $" 185$.

En el primer tratado el abad y cabildo deciden hacer la merced de donación de la reliquia al rey, confirmándose esta decisión en los otros dos tratados. Pocos días más tarde, el 20 de octubre de 1592, Felipe II escribe al abad Francisco de Reinoso agradeciendo su licencia y la del cabildo para el traslado de la reliquia al Escorial, instando al abad a que la trasladase personalmente ${ }^{186}$. El 17 de junio de 1593, Baltasar de Chávez, prior de Husillos y procurador general del cabildo, hace entrega con presencia de notario público de la reliquia al abad ${ }^{187}$. Finalmente, el 23 de junio de 1593, Francisco de Reinoso hizo entrega personalmente al rey de tan preciada reliquia en el monasterio de San Lorenzo del Escorial $^{188}$.

\section{EL ABAD FRANCISCO DE REINOSO}

Francisco de Reinoso es quizá el abad de Santa María de Husillos más recordado, debido a su mayor cercanía en el tiempo y sobre todo por la grandes donaciones y obras que mandó realizar en la iglesia. Tanta fue la fama del abad de Husillos y futuro obispo de Córdoba, que poco después de su muerte, Gregorio de Alfaro, amigo de Pedro de Reinoso, señor de Autillo y sobrino del abad, por encargo de

\footnotetext{
185 APA, Actas Capitulares, Libro 226.

${ }^{186}$ Doc. núm. 334.

${ }^{187}$ APA, Leg. 152, carp. 3.

${ }^{188}$ CASTRO SÁNCHEZ, Vida de Francisco de Reinoso, f. 63v.
} 
este último hizo la biografía de Francisco de Reinoso a partir de unos apuntes que había dejado Juan García, canónigo de Palencia y secretario de Reinoso ${ }^{189}$.

Francisco de Reinoso tomó el abadiato de Husillos desde Roma, donde tenía gran influencia al estar al frente de la dataría apostólica, desde donde controlaba las provisiones y beneficios que se concedían. Aprovechando esta situación, consiguió importantes beneficios de Pío V, como el arcedianato de Toledo y de Sepúlveda, delegando para éstos en otras personas ${ }^{190}$.

Reinoso es nombrado abad de Husillos el 23 de agosto de 1576, por permuta del arcedianato de Sepúlveda con Francisco de Carvajal, anterior abad de Husillos, rompiendo así el monopolio de la familia Carvajal sobre el abadiato de Husillos. Reinoso también era canónigo de la catedral de Palencia, condición esta imprescindible para ser abad de Husillos.

Al tomar posesión de su abadía, se percató del estado total de ruina y decadencia en el que se encontraba la iglesia y el claustro, la falta total de ornamentos, misales y objetos del culto divino, y la mala conservación de los retablos. Al ser tan grande el estado de ruina que presentaba la abadía, Reinoso pensó en levantarla de nueva construcción en un lugar más poblado y rico que la villa de Husillos que pudiera dar mejor acomodo a la iglesia. El lugar elegido era Becerril de Campos, lugar cercano y mucho más grande y poblado que Husillos. Para ello propuso acabar a su costa la iglesia de Santa Eugenia y convertirla en la nueva abadía. Finalmente Reinoso entendió que no debía realizar el traslado, sino restaurar y renovar la iglesia de Husillos. Para ello inició labores de limpieza, restauración, compra de libros y ropa. Aunque dio a entender a los canónigos que las obras y restauración se iban a hacer con la venta de unos tapices de la iglesia y con un censo de cuatrocientos ducados, en realidad el abad pagaría de sus propias rentas los más de cuatro mil ducados que finalmente supusieron las obras del nuevo claustro. Se construyó también un nuevo coro, capilla mayor, dos capillas laterales, y remodelación del resto de la iglesia. En agradecimiento al abad, el

${ }^{189}$ CASTRO SÁNCHEZ, íbid., f. 63v.
${ }^{190}$ CASTRO SÁNCHEZ íbid., f. 63v. 
cabildo acordó poner las armas del abad sobre el arco de entrada a la capilla mayor.

La beneficiencia de Reinoso para con su abadía se expresó también en un amplio número de donaciones de su patrimonio que realizó a la iglesia. Así el 24 de marzo de 1586 dona a la fábrica de la iglesia una casa en Husillos llamada de Los Provisores $^{191}$. El 2 de abril de 1586 dona unas casas en Husillos para residencia de los abades, ya que la dignidad abacial no tenía casa para residir en Husillos, viéndose esto como una de las causas del gran absentismo de los abades. Dona también al prior y cabildo un solar en Husillos ${ }^{192}$.

El 8 de octubre de 1589 dona a la fábrica de la abadía un censo de 406.000 maravedís que tiene sobre los vecinos de Husillos, movido por el estado de gran pobreza que tenía la abadía, que apenas era capaz de hacer frente a sus gastos ${ }^{193}$. Finalmente, en 1591 hace otra donación a la fábrica de la heredad que compró a Felipe II en Husillos y de una serie de censos sobre los vecinos de dicha villa ${ }^{194}$.

Además de dar un nuevo impulso a la abadía con la realización de obras y ampliación de sus rentas, Reinoso trató también de reforzar la abadía desde dentro, renovando la observancia canónica de los beneficiados, sus costumbres y reglas. Para ello dotó a la abadía de unos nuevos estatutos, establecidos el 8 de abril de 1588 y formados por 27 constituciones, reglamentándose el servicio del altar y el coro, los oficios de los prebendados, y la hacienda de la mesa capitular y de la fábrica ${ }^{195}$. Además trató también de controlar periódicamente el correcto y buen funcionamiento de la abadía y del hospital de Husillos a través de visitas, de las que se conservan tres, realizadas el 24 y 28 de marzo de 1577, y el 5-6 de abril de 1579 , respectivamente ${ }^{196}$.

\footnotetext{
${ }^{191}$ Doc. núm. 327.

192 Doc. núm. 328.

193 Doc. núm. 331.

${ }^{194}$ Doc. núm. 332.

195 Doc. núm. 330.

196 Docs. núm. 311, 312, 320.
} 
Por acta capitular de marzo de 1581, Reinoso propuso como patrona de Husillos a Nuestra Señora; y como santo patrono y abogado, a San Lorenzo, por la reliquia del santo que se custodiaba en la iglesia ${ }^{197}$.

El 22 de octubre de 1596 se documenta por primera vez a Reinoso como abad de Husillos y obispo electo de Córdoba, cargo este último para el que había sido elegido por Felipe II $^{198}$, tomando su sucesor, Sancho González de Heredia, posesión de la abadía el 27 de febrero de 1597.

\section{TRASLADO A AMPUDIA DE SANTA MARÍA DE HUSILLOS}

La situación de Santa María de Husillos en los primeros años del siglo XVII debía ser agónica, como se trasluce del acta del cabildo ordinario de 1 de agosto de 1603, en el que se decide enviar un memorial al rey Felipe III exponiendo la necesidad de la iglesia y lugar de Husillos, y la obligación real de favorecerla por el servicio que hizo el cabildo al rey al entregar la reliquia del pie de San Lorenzo $^{199}$.

En el contexto de la gravísima situación económica que atravesaba la abadía, en cabildo extraordinario de 30 de enero de 1604, Alonso de Lis, chantre y canónigo de Santa María de Husillos, leyó una carta de Francisco Gómez de Sandoval y Rojas, duque de Lerma, datada el 17 de enero de 1604, en la que expresaba su deseo de trasladar la abadía a su villa de Ampudia para dar mayor magnificiencia a la iglesia parroquial de San Miguel de de dicha villa, garantizando ventajas para la iglesia y para los beneficiados. El contenido de la carta es el siguiente:

"Ha muchos días que tengo deuoción a esa yglesia por saber que fue suelo de mis pasados y fundaçión suya. Y deseando agora haçer una collegial en la mi villa de Empudia, e puesto los ojos en esa, querría que vuestras mercedes lo quisiesen ansí y pasarse a Ampudia con las ventajas que an de creer y fiar de mí, que haré asi en la yglesia como en cada uno de vuestras mercedes. Para esto

${ }^{197}$ APA, Actas Capitulares, Libro 225 (1580-1586).

${ }^{198}$ CASTRO SÁNCHEZ, Vida de Francisco de Reinoso, 60-69.

${ }^{199}$ APA, Actas Capitulares, Libro 227 (1593-1606). 
enbio al padre fray Prudencio de Sandoual como cosa mayor que tratará el orden que se a de tener. Siendo vuestras mercedes seruidos dello, désele entero crédito, que yo tendré por bueno lo que [... Dios] guarde a nuestro señor marqués de Denia. 17 de henero de 1604 años. El duque" ${ }^{\text {200. }}$

Lerma enviaría como procurador a Prudencio de Sandoval, el cual enviaba también al cabildo una carta fechada igualmente el 17 de enero de 1604, en la que aseguraba el cumplimiento de la oferta del duque.

El prior y cabildo aprobaron el traslado en el mismo cabildo de 30 de enero de 1604, estimulados por el aumento del número de beneficiados y rentas:

"E vistas las dichas cartas y lo en ellas contenido, los dichos señores procurador y cabildo de la dicha yglesia recibieron muy gran fabor y merçed de que tubiese su excelencia memoria de renovar estos edificios antiguos de sus progenitores con la translación que pretende a la villa de Enpudia con el aumento del culto diuino e personas eclesiásticas desta yglesia. E ansí todos, "rem animas nemine discrepante", dijeron que estimauan y estimaron y açeptauan y aceptaron la merçed que su excelencia les ofrecía"201.

Finalmente, el 24 de febrero de 1604, el prior y cabildo de Santa María de Husillos aprueban la unión de su abadía con la iglesia parroquial de San Miguel de Ampudia, convirtiéndose así esta última en colegiata, dando poder a Alonso Manrique y Pedro Gómez Murillo para realizar la petición al papa ${ }^{202}$.

No le debió resultar difícil al duque de Lerma convencer a Felipe III para que primero le donase el patronazgo de Husillos, que poseía la corona desde Felipe II, y después le apoyase en su deseo de trasladar la iglesia a Ampudia. Así, a principios de abril de 1610, Felipe III escribió al duque de Escalona, embajador de España en la Santa Sede, ordenándole hacer petición al papa Clemente VIII

\footnotetext{
${ }^{200}$ Doc. núm. 346.

201 APA, Actas Capitulares, Libro 227 (1593-1606).

202 Doc. núm. 347.
} 
para realizar dicho traslado ${ }^{203}$. Al mismo tiempo, Felipe III escribía al papa para que recibiese en audiencia a su embajador y aceptase la creación de las nuevas iglesias colegiales de Ampudia y Lerma, ambas del patronazgo del duque de Lerma $^{204}$.

Finalmente, mediante bula de 25 de septiembre de 1606, Paulo V autorizaba el traslado de Santa María de Husillos a la iglesia parroquial de San Miguel de Ampudia y la transformación de ésta en colegiata bajo el patronato del duque de Lerma, que debería entregar a la nueva colegiata un estipendio anual de mil ducados $^{205}$.

El martes 18 de abril de 1607, tuvo lugar el último cabildo extraordinario en Santa María de Husillos ${ }^{206}$. El traslado a Ampudia se realizó el domingo 22 de abril de dicho año:

"Dominica in albis, a veinte y dos de abril de este presente año de mill y seiscientos y siete años, se trasladó la iglesia collegial de la villa de Hussillos a esta de señor San Miguel de esta villa de Ampudia, y ansí de aquí adelante entran los acuerdos capitulares echos en esta villa de Ampudia" ${ }^{207}$.

Por último, si bien los canónigos y beneficiados de Husillos estuvieron desde un primer momento a favor del traslado debido a los estímulos económicos prometidos por el duque de Lerma, el deán y cabildo catedralicio de Palencia mostraron su rechazo, según consta por un documento de 17 de abril de $1608^{208}$, aduciendo que la nueva iglesia colegial de Ampudia estaba libre de la jurisdicción ordinaria del obispo de Palencia al depender directamente de la Santa Sede, y que se había sacado la dignidad de abad de Husillos del cabildo catedralicio, expresándose también que el traslado se había hecho amparado en el poder e influencia del duque de Lerma sobre el rey.

\footnotetext{
${ }^{203}$ Doc. núm. 348.

${ }^{204}$ Doc. núm. 349.

${ }^{205}$ Doc. núm. 350.

${ }^{206}$ APA, Actas capitulares (1593-1606), Libro 227.

${ }^{207}$ APA, Actas Capitulares (1593-1606), Libro 227.

${ }^{208}$ Doc. num. 351.
} 


\section{LA ABADÍA DE SANTA MARÍA DE HUSILLOS: ESTUDIO Y COLECCIÓN \\ DOCUMENTAL $(904-1608)$}

A pesar de las protestas del cabildo palentino, el traslado estaba ya consumado y amparado por el poder del duque de Lerma.

Tras la absorción de Santa María de Husillos por San Miguel de Ampudia, las villas y heredades que habían pertenecido a Husillos pasaron a ser administradas por el cabildo de Ampudia. La antigua abadía de Husillos se transformó en una simple iglesia parroquial, una más del dominio territorial y jurisdiccional del dominio de Ampudia, y fue regida por un canónigo o beneficiado de dicha colegiata a modo de gobernador ${ }^{209}$.

Se puede decir que la base del dominio territorial de la nueva colegiata descansaba sobre el dominio transferido de Husillos, al menos en lo que se refiere a las mejores heredades y medios de transformación ${ }^{210}$.

Parece que existió en la tradición de los canónigos de Ampudia ${ }^{211}$, y más tarde en algunos autores, la convicción de que fue la despoblación de la villa de Husillos el motivo final del traslado a Ampudia. Sin embargo, aunque la villa de Husillos tuviera escasa población, fue sin duda el deseo y poder del duque de Lerma los que materializaron el traslado.

En 1851, con motivo del concordato entre España y la Santa Sede, tuvo lugar la desamortización de la colegiata de Ampudia, y con ella de todos los dominios que anteriormente habían pertenecido a Husillos ${ }^{212}$.

\footnotetext{
${ }^{209}$ Se desprende de un pleito olvidado de 1735-1736 de la colegiata de Ampudia con el concejo de Husillos, en donde se nombra a Marcelo Antonio de Tovar, canónigo de la colegiata de Ampudia, como gobernador de la iglesia de Husillos (ARCHV, Salas de lo Civil. Pérez Alonso (OLV). Caja 136-1).

${ }^{210}$ GARCÍA COLMENARES, La Desamortización de Palencia, 73. Destaca la gran importancia económica que tenían los tres molinos asentados en el río Carrión a su paso por la ciudad de Palencia, de los que dos eran del cabido catedralicio y uno, el de Pajares, de la colegiata de Ampudia, el cual había pertenecido anteriormente a Santa María de Husillos.

${ }^{211}$ Se desprende de un informe realizado por el cabildo de la colegiata de Ampudia en el año 1733 (APA., leg. 152, carp. 1).

${ }^{212}$ COLMENARES-MORENO-SÁNCHEZ, Historia de Palencia, 291.
} 
DAVID MARCOS DIEZ 


\subsection{EL DOMINIO DE SANTA MARÍA DE HUSILLOS}

\section{LA FORMACIÓN DEL DOMINIO}

Al igual que la mayor parte de las instituciones eclesiásticas, la formación del dominio de Santa María de Husillos va a seguir unas pautas determinadas en cuanto a las formas de formación del mismo, quedando configurado de forma total a finales del siglo XII, en concordancia con otros cenobios del territorio palentino como San Zoilo de Carrión ${ }^{213}$ o Santa María de Aguilar ${ }^{214}$. La principal forma de conformación del dominio va a ser a través de las donaciones, quedando en un segundo lugar las compras y permutas. Las adquisiciones de Husillos por cualquiera de las tres formas anteriores, se pueden categorizar en villas, iglesias, heredades, tierras, viñas, casas, recursos hidráulicos como pesqueras, aceñas o molinos, salinas, pedreras, censos, diezmos y también dinero en metálico.

El núcleo del dominio de Husillos se va a formar por las donaciones territoriales de los condes de Monzón, que van a estar comprendidas por las villas de Pajares, Gutiérrez Álvarez, Pajarejos, San Julián y Villaudilla ${ }^{215}$. Estas primeras donaciones se completarán con varias donaciones reales y de particulares, correspondiendo las primeras a las villas de Villaldavín y Celanova, donadas por Urraca I; iglesias de San Boal de Villagarcía, donada por Alfonso VII; San Pedro de Valdepero, San Jacobo de Calabazanos, San Mamés, San Román y San Martín en Frechilla, todas en Frechilla, donadas posiblemente por la infanta Urraca, hija de Fernando I; y las segundas, a las villas de Pozuelos de Amianos, Foyales y Fuente Alisendo; iglesias de San Pedro de Valdepero, San Jacobo de Calabazanos, San Miguel de Pozuelos, San Miguel de Fuentes de Nava y Santa María de Castrillo. Posiblemente fueran donadas también por particulares la iglesia de San Sebastián de Hérmedes y el lugar no identificado de Corrales, que aparecen donados en los documentos falsos de los condes de Monzón por dichos condes.

\footnotetext{
${ }^{213}$ Según Pérez Celada, entre mediados del siglo XI y 1213, San Zoilo configura su patrimonio territorial (PÉREZ CELADA, Documentación de San Zoilo de Carrión, I, LXIX).

${ }^{214}$ Según Rodríguez de Diego, los dominios monásticos se consolidan a mediados del siglo XIII (RODRÍGUEZ DE DIEGO, Colección diplomática de Santa María de Aguilar, 31-32).

${ }^{215}$ Doc. núm. 6.
} 
Las donaciones de villas e iglesias corresponden a los primeros siglos de vida de la abadía. El grueso de las donaciones se produce entre los siglos X y XIII, período en el que se forma el dominio de Husillos, descendiendo considerablemente en los siglos XIV y XV para iniciar un ligero repunte en el siglo XVI sobre todo a través de los testamentos. Los donantes más importantes van a ser la nobleza y realeza, cuyas donaciones van a constituir la piedra angular del dominio de Husillos. La transferencia de iglesias de particulares a Husillos, como en el resto de instituciones eclesiásticas, se potenció a partir del concilio de Coyanza, que prohibía a los particulares la posesión de iglesias propias, favorecida en el caso palentino por el obispo Tello Téllez de Meneses ${ }^{216}$, terminándose el proceso antes de mediados del siglo $\mathrm{XIV}^{217}$.

La compra como forma de ampliación del dominio va a ser importante en los siglos XIV y XVI, empleándose sobre todo en coyunturas de crisis económica en los que la abadía se aprovecharía comprando a la baja nobleza y al campesinado heredades con el dinero líquido que le proporcionaba las mandas testamentarias y donaciones en dinero más numerosas en épocas de crisis al aumentar la piedad religiosa. Los objetos de compra de la abadía van a ser principalmente aquellos de los que obtiene más rentabilidad, como son las viñas, casas, tierras de calidad cercanas a la abadía, y molinos.

Por último, la permuta como forma de reestructuración del dominio para una mejor gestión y explotación del mismo fue poco empleada por Santa María de Husillos. Entre las más importantes figura la realizada entre 1232 y 1243 entre las mismas mesas abacial y capitular, por la que aquella entregaba a ésta Pajares a cambio de las iglesias de San Pedro de Fuentes de Valdepero y de Santa María de Nava, y la mitad de las aldeas de Hoyales de Roa y Fuentelisendo, entre otras

\footnotetext{
${ }^{216}$ BARÓN FARALDO, Grupos y dominios aristocráticos, 511.

${ }^{217}$ Jesús San Martín comprueba que en el libro de los beneficios de la diócesis de Palencia elaborado en el año 1345 por el obispo don Vasco, ninguna de las iglesias de propiedad particular eran de seglares, sino que pertenecían al obispo, cabildo catedralicio, a algunos monasterios y a las órdenes militares y hospitalarias (SAN MARTÍN PAYO, La más antigua estadística de la diócesis de Palencia, 8).
} 
heredades y rentas ${ }^{218}$; y la realizada en 1376 con Juan González de Avellaneda, caudillo mayor de los escuderos del rey, de sus villas burgalesas de Hoyales de Roa, por cinco casas en Valladolid ${ }^{219}$, reflejando dicha permuta un intento de mejora en la gestión del patrimonio de Husillos ante la escasa rentabilidad que tenían sus heredades burgalesas.

\section{EVOLUCIÓN DEL DOMINIO}

Las propiedades territoriales de Santa María de Husillos se extienden por un marco territorial que en líneas generales se concentra en el tercio sur de la actual provincia de Palencia ${ }^{220}$. Para la reconstrucción del dominio territorial de Husillos y su evolución, hemos de acudir a cuatro momentos correspondientes cada uno de ellos a actos jurídicos de confirmación y relación de dicho dominio. Nos referimos a las confirmaciones de las propiedades de Santa María de Husillos por Sancho III de 4 de mayo de $1158^{221}$, y por el papa Alejandro III de 18 de noviembre de $1179^{222}$, al libro becerro de las propiedades realizado entre fines de 1374 y fines de $1376^{223}$, y la relación de rentas realizada en $1555^{224}$. A través de estos documentos podemos establecer el dominio de Husillos en tres momentos definidos: fines del siglo XII, fines del siglo XIV, y mediados del siglo XVI.

\section{El dominio de Husillos a fines del siglo XII}

Es en la confirmación por el papa Alejandro III de las posesiones de Husillos donde mejor se puede extraer la primera relación detallada y de referencia del dominio de Husillos:

"Fusellis, cum omnibus / decimus, rusticis et ceteris pertinentiis suis; ecclesiam de Vilabdela, cum tota villa et ominibus decimis et pertinenciis ipsius; ecclesias de / Paliares, de Vilagoterre, de Vilandavid et Sancti Iuliani et Sancte Marie de

\footnotetext{
${ }^{218}$ Doc. núm. 59.

${ }^{219}$ Doc. núm. 183.

${ }^{220}$ A partir de los mapas de las heredades de Santa María de Husillos (Anexos), se puede realizar una rápida visión de la localización de sus heredades y derechos.

${ }_{221}^{221}$ Doc. núm. 27.

${ }^{222}$ Doc. núm. 37.

${ }^{223}$ Doc. núm. 185.

${ }^{224}$ Doc. núm. 71.
} 
Cellerolo et ipsas villas omnes in quibus ecclesie site $\rho$ sunt, cum omnibus decimis et pertinentiis earum; ecclesiam Sancte Euphemie, cum omnibus decimis et pertinenciis eius; ecclesiam Sanc/ti Sabastiani de Ermides, cum omnibus decimis, possessionibus ac pertinenciis eius; in Fontibus de don Bermudo, ecclesiam Sancti Michaelis, cum / omnibus decimis, rusticis, possessionibus atque pertinenciis suis; in Fontibus de Vallepero, ecclesiam Sancti Petri, cum omnibus decimis, solaribus, terris, $I^{2}$ vineis et omnibus pertinenciis suis; ecclesiam Sancti Iacobi, in Calabazanos, cum omnibus decimis, rusticis, possessionibus ac pertinenciis eius; ecclesiam Sancte Ma/rie, prope Monzon, cum omnibus decimis, possessionibus ac pertinenciis eius; ecclesiam Sancti Adriani et totam villam, cum omnibus decimis ac pertinenciis suis; ecclesiam / Sancti Facundi de Paredes, cum omnibus decimis et pertinenciis suis; ecclesiam Sancte Marie de Castrello, cum omnibus decimis et pertinenciis suis; ecclesiam Sancte ${ }^{15}$ Eugenie de Pinna, cum omnibus pertinenciis suis; quicquid, etiam, iuris habetis in ecclesia de Fontepudia et eius pertinenciis; ad hec, Villan Alberez, cum omnibus per/tinentiis; Celamnouam, cum omnibus suis pertinentiis; in Turre de Astudelo, unum palacium, solares, terras, vineas et prata preterea; quicquid habetis in Palen/cia, in Bezerrileios, in Populacione, in Ripis, in Mazaregos, in Ecclesiota, in Quintanella, in Berbesca, in Celata, in Villacastin, in Motera, in Sancto Martino, in Sancto ${ }^{18}$ Ouio, in Cellata, in Fonte Quinana, in Villa Vnbrales, in Castro Viridi, in Villa Garcia Sancti Basilii in Palacio, in Villa Ximena”.

En base a la confirmación de Sancho III y sobre todo a la de Alejandro III, el dominio de Husillos en la segunda mitad del siglo XII se puede estructurar en las siguientes villas, iglesias, y heredades.

- Villas:

Husillos, Sahagún el Viejo, Gutiérrez Álvarez, Pajarejos, Pajares, San Julián, Pozuelos de Amianos, Villaldavín, Celanova, y San Adrián. La villa de Villálvarez, donada por Gonzalo a los canónigos de Husillos en $1171^{225}$, no aparece en la confirmación de Alejandro III ni en las confirmaciones posteriores,

${ }^{225}$ Doc. núm. 33. 
por lo que debemos suponer que dejó pronto de formar parte del dominio de Husillos.

- Iglesias:

San Boal de Villagarcía, San Pedro de Valdepero, San Jacobo de Calabazanos; en Frechilla: San Mamés, San Román y San Martín; San Pedro de Valdepero, San Miguel de Pozuelos, San Miguel de Fuentes de don Bermudo, San Sebastián de Hérmedes, Santa María, cerca de Monzón, Santa Eugenia de Piña, Santa María de Ampudia, Santa María de Castrillo.

- Heredades y rentas:

Santa María de Husillos posee heredades y rentas en los siguientes lugares: Torre de Astudillo, Palencia, Becerrilejos, Población, Ribas, Mazariegos, Grijota, Quintanilla, Brevesca, Celada, Villacastín, Motera, San Martín, San Ovio, Cellada, Fuente Quintana, Villaumbrales, Castro Verde de Cerrato, Palacios y Villajimena. Por una donación de 1198, va a poseer también heredades en Villatoquite $^{226}$.

Así pues, se observa cómo el dominio de Santa María de Husillos se extiende por un marco geográfico que engloba el tercio sur de la actual provincia de Palencia, con alguna posesión fuera del marco palentino como la iglesia de San Boal de Villagarcía de Campos, en la actual provincia de Valladolid.

- Canónica de Santa María de Husillos:

El 22 de diciembre de 1183, siguiendo la corriente de las iglesias catedrales y de otras iglesias colegiales, el obispo de Palencia Ramundo II, con el consenso del abad de Husillos, Gonzalo Pérez, y de los canónigos, establece la canónica o mesa capitular de Santa María de Husillos, además de conceder a los canónigos las mismas libertades y derechos que tenían los canónigos de Palencia. De esta manera el dominio territorial y dominical de Santa María de Husillos se va a reestructurar en las mesas abacial, capitular y de fábrica.

${ }^{226}$ Doc. núm. 42. 
La relación de propiedades y rentas que van a componer la mesa capitular de Husillos es la siguiente:

"Decimas tocius laboris domus Fusellensis, tam panis quam vini, ovi/ um et ceterorum animalium et omnium fructuum ortorum et arborum. Similiter de linaribus et cannamariis et de leguminibus duas quoque partes oblationis quas ad ecclesiam attulerint, nam tercia sacricustodis erit. Et omnes elemosinas et lectos qui cum mortuis ad ecclesiam / allati fuerint. Et duos molendinos in maiori domo, et terciam partem in piscaria de supra de illa, et in capite vinee $V$ molendinos et medium et decimas omnes eiusdem ville, panis et vini et ortorum, arborum et animalium, similiter de linaribus et cannamariis, / et de leguminibus; et Sanctum Facundum de Paredis, cum hereditate et pertinenciis suis; et monasterium Sancti Petri de Fontibus; et ex solidis marcii de Villa Abdela terciam partem; et villam Sancti Iuliani cum omnibus pertinenciis suis in integrum et ecclesiam cum decimis / et oblationibus suis; et villam Sancte Marie de Celleroso cum ecclesia et pertinenciis suis; et totum rivum a ponte de Monzon usque ad vadum quod est sub molendinis Palacii; et omnes vineas et terras et pratos et saltus et omnem hereditatem et omnia quecumque iuri eiusdem / canonice sunt in presenti vel in futuro fuerint deputada,"227

De esta manera, entre las propiedades y rentas que se concede a la mesa capitular, destacan los diezmos de Husillos, las iglesias de Sahagún el Viejo y San Pedro de Fuentes $^{228}$, y las villas de San Julián y Cilleruelo, con su iglesia de Santa María de Cilleruelo y el señorío dominical; varios molinos, y el señorío de un tramo del río Carrión.

En 1210, el papa Inocencio III confirma al cabildo sus derechos y heredades, entre las que figuran, además de las que formaban parte de la mesa capitular

\footnotetext{
${ }^{227}$ Doc. núm 40.

${ }^{228}$ Aunque se le denomina en el documento como monasterio, no tenemos constancia de que dicha iglesia fuese en realidad un cenobio. Hay que tener en cuenta además de que en la Alta Edad Media en ocasiones se denominaba como monasterio a simples iglesias o viceversa.
} 
desde 1183, la villa de Villa Alarigo y las iglesias de Santa María de Nava y de Torre Marte, próxima a Astudillo ${ }^{229}$.

\section{El dominio de Husillos a fines del siglo XIV}

El libro becerro de las propiedades de Santa María de Husillos es la más amplia y detallada relación de bienes y derechos de la mesa abacial y capitular de la abadía realizada en toda su historia ${ }^{230}$. De ahí que sea fundamental para establecer y fijar el dominio de Husillos en el momento de su realización. Relaciona las propiedades y rentas del abad, prior, y cabildo, y las iglesias dependientes. Las propiedades se ordenan según los lugares donde se localizan, detallándose las heredades, viñas, casas, molinos, censos, diezmos, préstamos, y los lugares donde Husillos ejercía también el dominio señorial.

A. Mesa abacial:

- Las villas donde el abad ejerce el domino señorial van a ser Husillos, Villaudilla, San Sebastián de Hérmedes, Hoyales de Roa, Fuentelisendo y Villaldavín.

- Los lugares donde el abad posee heredades y rentas son Husillos, Villaudilla, San Adrián, Fuentes de Valdepero, Torre de Astudillo, San Sebastián de Hérmedes, Hoyales de Roa, Fuentelisendo y Villaldavín

B. Prior y cabildo:

- Las villas donde el cabildo ejerce el domino señorial son Santillán de la Cuesta $^{231}$ y Cilleruelo.

- Los lugares donde el cabildo va a poseer heredades y rentas son Husillos, Monzón, Santillán de la Cuesta, Fuente Quintana, Vega de Valdepero, Sahagún el Viejo de Paredes, Torquemada, Pozuelos de Amianos, Villacid, Frechilla, Pajares, Santa Eufemia, Fuentes de Valdepero, Becerrilejos, Villaldavín, Cilleruelo, San Felices y Amayuelas de Abajo.

C. Iglesias:

${ }^{229}$ Doc. núm. 48.

${ }^{230}$ Doc. núm. 185.

${ }^{231}$ Se trata del nombre evolucionado de San Julián. 
- Abad:

Las iglesias pertenecientes al abad son Santa María de Husillos, San Adrián, Santa Eugenia de Piña, San Pedro de Fuentes de Valdepero, Santa Olalla de Villaldavín y Santa María de $\mathrm{Nava}^{232}$.

- Cabildo:

Las iglesias pertenecientes al cabildo son San Julián y San Facundo, ambas en Paredes de Nava, Santa María de Cilleruelo, Santa Eufemia de Brevesca, San Andrés de Fuente Quintana, Santa María de Villagutiérrez ${ }^{233}$ y San Julián de Santillán de la Cuesta.

D. Préstamos:

Los lugares e iglesias donde Santa María de Husillos tiene préstamos o beneficios simples, que se identifican con diezmos mayores, son: Santa Eugenia de Piña de Campos, Santa María, cerca de Ampudia, San Sebastián de Becerril de Campos, Santiago de Calabazanos, San Mamés, San Román y San Martín, todas en Frechilla; San Miguel de Pozuelos de Amianos, San Miguel de Fuentes de Nava, Santa María de Castrillo, y Santa María Magdalena de Villazalama. La abadía también posee heredades en préstamo situadas en Mazariegos, Grijota, Celanova y Pajares $^{234}$.

A diferencia de las iglesias propias del abad y cabildo, que eran beneficios curados en las que se tenía que designar eclesiásticos para atender las necesidades litúrgicas de los feligreses de dichas iglesias, las iglesias en préstamo eran aquellas en las que la abadía tenía beneficios simples que no acarreaban la obligación de ofrecer el servicio litúrgico, limitándose a la percepción del diezmo. De ahí que los préstamos se acabaran identificando con los diezmos mayores.

\footnotetext{
${ }^{232}$ Esta iglesia, junto con la de San Pedro de Fuentes de Valdepero, pasaría a formar parte de la mesa abacial por una permuta realizada con la mesa capitular entre 1232 y 1243 (Doc. núm. 59).

${ }^{233}$ Se trata del nombre evolucionado de Gutiérrez Álvarez.

${ }^{234}$ Sería la villa de Pajarejos, cercana a Becerril de Campos.
} 


\section{LA ABADÍA DE SANTA MARÍA DE HUSILLOS: ESTUDIO Y COLECCIÓN \\ DOCUMENTAL $(904-1608)$}

Santa María de Husillos poseía también una importante heredad en las salinas de Salinas de Añana, formada por doce eras con sus pozos, exentas de tributos, que proveería de tan necesario elemento a la iglesia.

\section{E. Sacristanía:}

La sacristanía de Husillos va a disponer como sostén para sus necesidades de una mesa formada por heredades situadas en general en las cercanías a la villa de Husillos, estando formadas principalmente por tierras y viñas de escasas dimensiones.

\section{F. Capellanías:}

Las cuatro capellanías de Santa María de Husillos: San Juan de Pajares, Santa Brígida, de Pedro Fernández y García Pérez ${ }^{235}$, al igual que la capellanía de San Julián de Santillán de la Cuesta, van a disponer de heredades en las proximidades de Husillos formadas también principalmente por tierras y viñas y algunas casas en Husillos. La capellanía de San Julián de Santillán de la Cuesta va a disponer de heredades también en los alrededores de Husillos, y alguna casa en Husillos.

G. Fábrica, obra y lámparas:

La fábrica de Santa María de Husillos está dotada con heredades y rentas principalmente en Husillos, Poblacioneja ${ }^{236}$ y Ribas de Campos. Igualmente las lámparas de Husillos van a estar dotadas con heredades situadas en las cercanías a Husillos.

\section{H. Hospital:}

La cofradía del hospital de Husillos va estar dotada con heredades, principalmente tierras, en las proximidades a Husillos ${ }^{237}$.

\footnotetext{
${ }^{235}$ Las dos últimas, del mismo nombre que los abades de Husillos a las que están dedicadas.

${ }^{236}$ Sería la anterior villa de Población.

${ }^{237}$ El hospital de Husillos va a tener la connotación de un hospital medieval, dedicado a dar cobijo y hospedaje a pobres de solemnidad y peregrinos. Parece ser que fue mandado construir por Gonzalo González, racionero y arcipreste de Burgos, y hermano de Domingo González, chantre de Husillos, en fechas cercanas a la realización del libro becerro (1374-1376), ya que el 9 de abril de 1386 hacía testamento en el que dejaba unas heredades al citado hospital (Doc. núm. 207).
} 
En cualquier caso, las heredades y rentas con que están dotadas la fábrica, sacristanía y hospital de Husillos son de escasa cuantía e importancia.

\section{El dominio de Husillos a mediados del siglo XVI}

A consecuencia de la visita realizada a Santa María de Husillos por el obispo de Placencia Gutierre de Carvajal entre el 1 y 18 de enero de 1555, se realizó una relación o inventario de propiedades, rentas y derechos de las mesas abacial y capitular, fábrica y hospital de Santa María de Husillos ${ }^{238}$. El motivo era el grave estado de deterioro en el que se encontraba el dominio de Husillos, en el que numerosas propiedades y rentas habían quedado olvidadas o tomadas por actores externos. De ahí que el objetivo de dicha relación fuera fijar el dominio de la abadía en ese momento.

A. Mesa abacial:

- Las villas en las que el abad ejerce el dominio señorial son Husillos y Villadavín.

- Los lugares en los que el abad posee heredades y rentas son Husillos, Fuentes de Nava, Astudillo, Fuentes de Valdepero, Villaldavín, Becerril, Hérmedes, Tardajos, Valladolid, y Mazariegos.

B. Mesa capitular:

- Solamente posee el dominio señorial en Villagutierre ${ }^{239}$.

- Posee heredades y rentas en Sahagún el Viejo, Santa Eufemia, Palencia, Villaldavín, Amayuelas, Ribas, Castromocho y Monzón. Posee las iglesias de San Juan de Pajares ${ }^{240}$, Santa María de Cilleruelo ${ }^{241}$, Santa María del Castillo, San Martín, San Román y San Mamés en Frechilla. Posee también préstamos en las iglesias de Husillos, Piña de Campos, Fuentes de Nava, Villaumbrales y Grijota.

C. Préstamos:

\footnotetext{
${ }^{238}$ Doc. núm. 298.

${ }^{239}$ Se trata de Gutiérrez Álvarez, villa que estaría semidespoblada ya en el momento de la redacción del Libro de las Propiedades.

${ }^{240}$ Situada en el término de Palencia.

${ }^{241}$ Próxima a Villamartín de Campos.
} 
Santa María de Husillos posee préstamos en las iglesias de Santiago de Calabazanos, San Miguel de Fuentes de don Bermudo, Santa Eugenia de Piña, San Sebastián de Pajarejos, Santa María del Castillo, San Martín, San Román y San Mamés en Frechilla, y en iglesias de Grijota y de Villaumbrales..

D. Fábrica y hospital de Husillos:

La fábrica de la iglesia posee heredades y rentas en el término de Husillos y de Monzón, mientras que el hospital las posee en las cercanías de Husillos.

Poco antes, en noviembre de 1554, se había realizado una información “ad perpetuam rei memoriam" de las casas, tierras, viñas y rentas que poseía la fábrica en Husillos y Monzón, seguramente también a instancia de Gutierre de Carvajal $^{242}$. Entre las rentas figuraban, en calidad de limosna, los derechos de entrada del abad, dignidades, canónigos y racioneros, siendo de diez mil maravedís el abad, cuatro mil la dignidad si tiene doble prebenda, dos mil maravedís el canónigo y racionero, y mil el medio racionero. Estas cantidades eran idénticas a las relacionadas en un memorial de $1561^{243}$.

\section{Evolución del dominio}

La fijación del dominio de Santa María de Husillos a fines del siglo XII, XIV y mediados del XVI, hace que podamos contar con referencias sobre el estado del dominio monástico separadas entre sí por dos siglos aproximadamente, con lo que se puede hacer una evolución del dominio basada en tres momentos claves de su existencia: el estado del dominio en su máximo apogeo, el dominio a fines del siglo XIV y las consecuencias sobre éste de la crisis del siglo XIV, y estado del dominio en un momento cercano al final de su existencia. Así, tomando como referencia el estado del dominio a fines del siglo XII y a fines del XIV, se puede hacer una evolución existencial de las villas, iglesias y lugares donde la abadía poseía heredades y renta.

${ }^{242}$ Doc. núm. 295. 
El punto de partida es el dominio fijado a fines del siglo XII, que estaría cercano a su momento más álgido, que se situaría a mediados del siglo XIII. Afortunadamente, el segundo momento de referencia del dominio, a fines del siglo XIV, se produce cuando ya serían visibles las negativas consecuencias de la crisis del siglo XIV, que llegaría a su máximo apogeo a mediados del citado siglo. El tercer momento de referencia se produce a mediados del siglo XVI, estableciendo el estado del dominio en la fase final de su existencia.

\subsection{Evolución del dominio de Santa María de Husillos entre fines del siglo XII y fines del siglo XIV}

Las villas que formaban parte del dominio de Husillos a fines del siglo XII y que no aparecen como tales a fines del XIV, son Gutiérrez Álvarez ${ }^{244}$, Pajarejos, Celanova, Sahagún el Viejo y Villa Alarigo ${ }^{245}$. Sí se constatan en cambio la iglesia de Santa María de Gutiérrez Álvarez y heredades sitas en los términos de Pajarejos, Celanova y Sahagún el Viejo. Las iglesias que no se constatan a fines del XIV son San Boal de Villagarcía y Santa María, cerca de Monzón.

Por último, no se constatan heredades en los lugares de Celada, Villacastín, Motera, San Martín, San Ovio, Cellada y Villatoquite.

Observamos así cómo ciertas villas que habían pertenecido al dominio territorial y señorial de Santa María de Husillos desde el momento de su fundación, como eran Pajarejos, Pajares, y Sahagún el Viejo, y algunas desde un momento algo posterior, como Celanova, no se citan como tales en el Libro de las Propiedades de Husillos. Esto quiere decir que ya no existían a fines del siglo XIV como lugares de población, habiéndose despoblado posiblemente a lo largo del siglo XIV. Sin embargo sí se constatan iglesias y heredades en los términos antiguos de las villas ya despobladas. Esto indica que se había producido un abandono del núcleo de población, pero no un abandono de los campos de labor, ni siquiera parcial, máxime teniendo en cuenta la cercanía de estos términos a Husillos, en

\footnotetext{
${ }^{244}$ Gutiérrez Álvarez, Villagutierre, o Villagutiérrez Álvarez, era una villa de la mesa abacial que pasó a la mesa capitular por una permuta realizada entre 1232 y 1243 (Doc. núm. 59). Aunque ya no aparece en el libro becerro de las behetrías ni en el libro becerro de las propiedades de Husillos como villa, en un documento de 1402 se documenta nuevamente (Doc. núm. 220).

${ }^{245}$ Villa Alarigo aparece como villa del cabildo de Santa María de Husillos en una confirmación del papa Inocencio III datada en 1210, de las villas e iglesias del cabildo (Doc. núm.48).
} 
consonancia con la teoría de Ángel Vaca Lorenzo sobre la distinción entre el abandono del núcleo de población y de los campos de labor ${ }^{246}$. En cuanto a la villa de Gutiérrez Álvarez, aparece documentada su iglesia de Santa María. Pero aunque la villa de Gutiérrez Álvarez no se cita como villa en el Libro de las Propiedades, sí aparece en un documento de 1402, por lo que debemos pensar que no se habría despoblado ${ }^{247}$.

Las iglesias que no se constatan a fines del siglo XIV tienen distinta explicación. En el caso de la iglesia de San Boal de Villagarcía, dejó de pertenecer al dominio de Husillos por una resolución del papa Honorio III de 11 de marzo de 1225 por la que restituía al monasterio de Sahagún la iglesia de San Boal de Villagarcía, que había sido objeto de litigio entre el dicho monasterio de Sahagún y Santa María de Husillos ${ }^{248}$.

En cuanto a la iglesia de Santa María, cerca de Monzón, pudo ser cedida o transferida, o bien desaparecer, aunque posiblemente sea la posteriormente documentada iglesia de Santa María Magdalena de Villazalama.

Por último, no se documentan ciertos lugares de población donde la abadía había tenido heredades y rentas: Celada, Villacastín, Motera, San Martín, Ovio y Cellada, lo cual puede tener dos causas. O bien dichas heredades fueron transferidas o permutadas con anterioridad, o bien dichos lugares se despoblaron muy anteriormente habiendo sido olvidados los nombres de los pagos donde se localizaban las heredades que Santa María de Husillos podía seguir teniendo.

Con independencia de la despoblación, desaparición o transferencia de ciertas villas, iglesias y heredades, Husillos siguió siendo objeto de la piedad de la realeza y de los particulares, lo que unido a su actividad compradora, hizo que a fines del siglo XIV aparecieran nuevas villas, iglesias y heredades en su domino. Es el caso de las aldeas de Hoyales de Roa y Fuentelisendo, que ingresan a su

\footnotetext{
${ }^{246}$ VACA LORENZO, La estructura socioeconómica de la tierra de Campos, 233-398.

${ }^{247}$ Doc. núm. 220.

${ }^{248}$ Doc. núm. 21.
} 
dominio por donación del abad de Husillos Gonzalo Pérez a los canónigos de su abadía $^{249}$.

Las nuevas iglesias que aparecen en el dominio de Husillos son Santa Olalla de Villaldavín, Santa María de Nava, Santa Eufemia de Brevesca, San Andrés de Fuente Quintana y Santa María de Villazalama ${ }^{250}$, comprobándose así cómo en los siglos XIII y XIV existían todavía numerosa iglesias de propietarios laicos que acababan transfiriendo su propiedad o patronato a las instituciones eclesiásticas. Por último, aparecen nuevas heredades situadas en los términos de Villacid, San Felices, Mazariegos, Grijota, Amayuelas de Abajo, Vega de Valdepero y Torquemada. Seguramente las posesiones del cabildo en Amayuelas de Abajo serían las dejadas en testamento por Martín Alfonso, hijo de Alfonso Téllez de Alburquerque, en $1285^{251}$, o bien las donadas por Gómez Ruiz de Sandoval y su esposa, Mayor Sánchez, en $1310^{252}$, mientras que las situadas en Vega de Valdepero y en Torquemada pueden ser las dejadas por testamento por el obispo de Osma Juan Álvarez ${ }^{253}$.

\subsection{Evolución del dominio de Santa María de Husillos entre fines del siglo XIV y mediados del siglo XVI}

En el Libro de las Propiedades de Husillos aparece una estructuración de las heredades y rentas entre el abad y el cabildo, además de los préstamos que poseía la abadía. Igualmente, en la relación de rentas de 1555 las heredades y rentas se estructuran en las mesas abacial y capitular, de ahí que se pueda establecer una evolución de éstas de forma separada para ambas mesas.

Así, las villas donde el abad ejercía el dominio señorial que no aparecen en 1555 son: Villaudilla, San Sebastián de Hérmedes, Hoyales de Roa y Fuentelisendo. Las iglesias que ya no se documentan en este año son: Santa Olalla de

\footnotetext{
${ }^{249}$ Docs. núm. 54 y 55.

${ }^{250}$ Seguramente se trate de la anterior iglesia documentada de Santa María, cerca de Monzón.

${ }^{251}$ Docs. núm. 79 y 81. También dejó heredades al cabildo en Castellanos, cerca de Lerones, villa cercana a Potes (Cantabria). Seguramente la lejanía del lugar hizo que la abadía probablemente vendiera dichas heredades en un corto plazo de tiempo.

252 Doc. núm. 99.

253 Doc. núm 91.
} 
Villaldavín, Santa María de Nava, San Adrián y San Pedro de Fuentes de Valdepero. Por último, los lugares de heredades que ya no se documentan son: Villaudilla, San Adrián, Hoyales de Roa y Fuentelisendo.

Las villas de dominio señorial del cabildo que ya no se documentan son Santillán de la Cuesta y Cilleruelo. Las iglesias del cabildo que no aparecen son San Facundo de Sahagún el Viejo, Santa Eufemia de Brevesca, Santa María de Cilleruelo, San Andrés de Fuente Quintana y Santa María de Villagutiérrez. ${ }^{254}$, aunque de las tres primeras sí se documentan heredades. Los lugares de heredades que ya no se documentan son Torquemada, Santillán de la Cuesta, Fuente Quintana, Vega de Valdepero, Pozuelos de Amianos, Villacid, Santa Eufemia, Becerrilejos y San Felices.

Con respecto a los préstamos que no se documentan a mediados del siglo XVI son los situados en las iglesias de San Miguel de Pozuelos de Amianos y Santa María Magdalena de Villazalama. Tampoco se documentan las importantes salinas que Husillos poseía en Salinas de Añana.

En conclusión, las villas de Villaudilla, San Sebastián de Hérmedes, Santillán de la Cuesta, Cilleruelo, Foyales y Fuente Alisendo, ya no se documentan en 1555, debiéndose pensar que terminaron por despoblarse en este período de tiempo, probablemente a fines del siglo XIV. Con respecto a las aldeas burgalesas de Hoyales de Roa y Fuentelisendo, fueron permutadas por unas casas en Valladolid el 12 de octubre de $1376^{255}$.

Las iglesias que a mediados del siglo XVI ya no se documentan son: Santa Olalla de Villaldavín, Santa María de Nava, San Adrián, San Pedro de Fuentes de Valdepero, San Facundo de Sahagún el Viejo, Santa Eufemia de Brevesca, Santa María de Cilleruelo, San Andrés de Fuente Quintana y Santa María de Villagutiérrez, San Miguel de Pozuelos de Amianos y Santa María Magdalena de Villazalama. Por último, los lugares de heredades que no se documentan son:

${ }^{254}$ La primitiva villa de Gutiérrez Álvarez se llegó a denominar Villagutiérrez, según se constata en el Libro de las Propiedades.

${ }^{255}$ Doc. núm. 183. 
Villaudilla, San Adrián, Torquemada, Santillán de la Cuesta, Fuente Quintana, Vega de Valdepero, Pozuelos de Amianos, Villacid, Santa Eufemia, Becerrilejos y San Felices.

Las causas de omisión de las iglesias puede ser su total desaparición al haber desaparecido también la villa o aldea en donde prestaban servicio litúrgico, aunque en algunos casos se transformaran en pequeñas ermitas, como puede ser en todos los casos a excepción de Santa Olalla de Villaldavín, o bien porque fueron transferidas o cedidas a otras instituciones eclesiásticas o porque se desprendieron de la dependencia de Husillos.

En cuanto a los lugares de heredades que ya no se documentan, se puede deber a que dichos lugares desaparecieron hace tiempo, desapareciendo más tarde también la memoria de su nombre en la denominación de los pagos, como puede ser los casos de Villaudilla, Santillán de la Cuesta, y Santa Eufemia, o bien porque dichas heredades acabaron siendo vendidas u olvidadas con el paso del tiempo, como puede ser en los casos de San Adrián, Torquemada, Fuente Quintana, Vega de Valdepero, Pozuelos de Amianos, Villacid, Becerrilejos y San Felices $^{256}$.

\section{Conclusiones}

Se observa cómo las villas bajo el dominio señorial de Santa María de Husillos van desapareciendo con el paso de los siglos, existiendo a mediados del siglo XVI solamente Husillos y Villaldavín. No obstante, a mediados del siglo XIV la abadía había ampliado sus iglesias dependientes y sus heredades, apreciándose una cierta dispersión geográfica de éstas al poseer heredades en Hoyales de Roa y Fuentelisendo, ambas en Burgos, Toquemada y Villacid de Campos.

La situación a mediados del siglo XVI era de total crisis, que se refleja en la pérdida y desaparición de gran número de villas, iglesias y propiedades, aunque algunas de éstas fueran objeto de reestructuración del patrimonio a través de la

\footnotetext{
${ }^{256}$ Esta consideración se realiza sobre la base de que algunas de estas villas como Torquemada y Villacid existen en la actualidad y de que los nombres de las restantes villas han permanecido como pagos hasta la actualidad o hasta fechas cercanas.
} 
permuta o compraventa, como fue el caso de Hoyales de Roa y Fuentelisendo, y pudo serlo también en las heredades sitas en Torquemada y Villacid de Campos.

\section{ELEMENTOS FORMATIVOS DEL DOMINIO}

El dominio de Husillos va a estar formado por villas, iglesias, heredades, préstamos, viñas, casas, recursos hidráulicos como pesqueras, aceñas o molinos, salinas, pedreras o canteras y recursos forestales.

\section{Villas}

La concepción altomedieval de villa es similar a la de época tardorromana. Así, se trataría de unidades de explotación o granjas formadas por unas pocas cabezas de familia que se instalarían en el lugar al calor de la reconquista y con la estimulación de los fueros concedidos por los poderes laicos y eclesiásticos. Las villas van a constituir la base del dominio monástico de Husillos y se van a localizar en las cercanías del cenobio. De la escasa población de éstas, que en la mayoría de los casos no pasarían de ser simples granjas agropecuarias, nos da idea el fuero concedido el 21 de septiembre de 1161 al concejo de San Julián por el abad de Husillos Raimundo Giliberti ${ }^{257}$. De su contenido se deduce que los habitantes de dicha villa eran ocho. Teniendo en cuenta que se refieren a los cabeza de familia obligados a realizar sernas, y que el número de miembros por familia sería de cuatro o cinco, el número total de habitantes de San Julián no pasaría de cuarenta. El escaso número de habitantes de esta villa y de otras similares del dominio de Husillos explicaría su desaparición con el tiempo, especialmente durante la crisis del siglo XIV.

\section{Iglesias}

En la documentación medieval, especialmente en los primeros siglos de la Edad Media, los términos iglesia y monasterio se usan indistintamente y al mismo tiempo ya sea para denominar una iglesia o bien un monasterio. Este fenómeno se complica con el hecho de que lo que en origen pudo ser un cenobio, acabara convirtiéndose en una iglesia parroquial o ermita, o viceversa.

${ }^{257}$ Doc. núm. 31. 
En el caso de Husillos sólo nos vamos a encontrar con el caso de un monasterio que pudo acabar convirtiéndose en iglesia parroquial o ermita. Nos referimos al caso de la iglesia de San Sebastián de Hérmedes, que aparece como monasterio en un apócrifo de Sancho el Mayor ${ }^{258}$.

La iglesia medieval va a tener una connotación mucho más amplia que el simple edificio y el servicio litúrgico que va a ofrecer. Así, engloba también un dominio territorial y un conjunto de rentas formado por las donaciones de laicos residentes generalmente en las proximidades.

\section{Préstamos}

Los préstamos son los beneficios simples de los que disponía Santa María de Husillos en varias iglesias, cobrando de éstos la renta del diezmo, de ahí que fueran identificados con los diezmos mayores. Los ingresos de éstos se repartían entre los beneficiados de la abadía.

\section{Heredades}

El término heredad tenía en Edad Media un sentido vago con el que se podía referir a una serna o tierra de cultivo de gran extensión, tierras en general, huertos, viñas e incluso casas. Las tierras son las posesiones que en ocasiones aparecen en la documentación, y que se solían dedicar casi en su totalidad a cereal, sobre todo trigo y cebada, aunque también avena y centeno. Su delimitación y dimensiones se hacen más detalladas conforme va transcurriendo el tiempo, aunque las dimensiones de las tierras solamente aparezcan fielmente en el Libro becerro de las propiedades de Husillos, siendo la obrada la medida de superficie utilizada en dicho libro.

En consonancia con otros monasterios, las tierras más cercanas a Husillos y de mejor calidad solían ser explotadas por la misma abadía a través de sus criados y dependientes, o bien a través de las sernas de sus vasallos, arrendando o encensando las de peor calidad y las más lejanas.

${ }^{258}$ Doc. núm. 7. 


\section{LA ABADÍA DE SANTA MARÍA DE HUSILLOS: ESTUDIO Y COLECCIÓN \\ DOCUMENTAL $(904-1608)$}

Las huertas son de gran importancia para la alimentación monástica, ya que proporciona alimentos frescos a la dieta de la comunidad de Husillos. Se localizan en general en los alrededores de la abadía, en la misma villa de Husillos, y a lo largo del curso del río Carrión hasta la ciudad de Palencia, y son trabajadas directamente por los criados y dependientes de la abadía.

Las viñas tenían gran importancia en la economía monástica al proporcionar el alimento básico que era el vino, de ahí que la abadía las explotara también directamente $^{259}$.

Finalmente, la abadía poseía gran número de casas en la villa de Husillos, que cedía en gran parte a los canónigos y beneficiados, poseyendo también algunas en la ciudad de Palencia y en Valladolid.

Con el tiempo, especialmente ya en el siglo XVI, las casas y viñas se convertirían en las propiedades más rentables de la abadía, en consonancia con otras instituciones eclesiásticas. Tanto es así que los contratos de censo realizados en dicho siglo se hacen sobre casas y viñas de la abadía ${ }^{260}$, y que las escasas compras que se realizan en dicha centuria tienen por objeto casas en Husillos y Palencia, y viñas en las proximidades de Husillos ${ }^{261}$.

\section{Recursos hidráulicos}

Santa María de Husillos dispuso de dos complejos molineros que le proporcionaba harina para consumo propio a la vez que importantes rentas por el uso de éstos por los pequeños propietarios y una relación de dependencia de estos últimos para con la abadía. Estaban situados en la margen derecha del río Carrión, en Cabo de Viña, lugar cercano a Husillos, y en Pajares, villa cercana a Palencia. Si bien en 1243 el abad de Husillos Pedro Martínez compró dos molinos en Villagudiel $^{262}$, éstos no se documentan ya en el libro becerro de las propiedades

\footnotetext{
${ }^{259}$ De la importancia que tenían las viñas y su cuidado da fe un censo realizado en 1549 por el cabildo de Husillos de una viña en Villaumbrales por el que, entre otras condiciones, el censatario debía mantener la viña podada y trabajada, debiendo de ser juzgado el trabajo por dos hombres buenos (Doc. núm. 290).

${ }^{260}$ Docs. núm. 250, 253, 278, 279, 290, 314, 315, 316, 317, 323, 324, 325, 344.

${ }^{261}$ Docs. núm. 256, 260, 263, 264, 266, 289.

${ }^{262}$ Doc. núm. 63. Posiblemente Villagudiel se localizara en las proximidades de Becerril de Campos.
} 
$(1374-1376)^{263}$, por lo que hemos de suponer que ya no formaban parte del patrimonio de la abadía.

Dispuso también de varias pesqueras que permitían el funcionamiento de los molinos. La abadía también explotó los recursos alimenticios que proporcionaba el río Carrión en forma de pescado, sobre todo en la parte del río de su señorío, a su paso por Husillos. De la importancia de la pesca da fe una cláusula de la concordia realizada en 1472 entre el abad Luis de Carvajal y el prior y cabildo, por la que se determinaban los límites del río en los que el abad y cabildo podían explotar los recursos pesqueros, resolviéndose así las disputas entre ambas partes por este aspecto ${ }^{264}$. No obstante, dichas disputas seguirían, regulándose también sobre éstas en una concordia entre el abad Francisco de Carvajal y el prior y cabildo sobre jurisdicción y otros temas económicos ${ }^{265}$.

\section{Salinas}

Santa María de Husillos dispuso de una importante participación en las salinas de Salinas de Añana según aparece en el Libro becerro de las propiedades, que iban a proporcionar a la abadía tan preciado condimento, ya que la sal era un elemento básico al permitir la conservación de la carne y del pescado mediante la salazón. Por otra parte, en las reglas monásticas el pescado era un alimento primordial por la abstinencia en comer carne. De ahí el interés de los poderes laicos y sobre todo eclesiásticos en disponer de participación en la explotación de salinas.

Podemos concluir diciendo que la participación de Husillos en las salinas de Salinas de Añana a fines del siglo XIV refleja el status económico de la abadía respecto a otros poderes laicos y eclesiásticos de su entorno.

\section{Pedreras o canteras}

El material pétreo necesario para la construcción y reparación de edificios, casas, molinos y aceñas, era obtenido en gran medida de unas pedreras o canteras que Santa María de Husillos disponía en el término de Fuentes de Valdepero, según consta por varios documentos fechados en $1245^{266}$ y $1377^{267}$, y especialmente por

\footnotetext{
${ }^{263}$ Doc. núm. 185.

${ }^{264}$ Doc. núm. 233.

265 Doc. núm. 269.

${ }^{266}$ Doc. núm. 65.
} 
uno de 1384 por el que el concejo de Fuentes de Valdepero autorizaba a Santa María de Husillos a sacar piedra, por un período de cuatro años, de unas canteras que poseía en su término ${ }^{268}$.

\section{Recursos forestales}

De los diversos montes y zonas arboladas existentes en el dominio, la abadía obtendría la tan necesaria leña y otros productos relacionados con la silvicultura. Entre los montes en los que Santa María de Husillos obtendría importantes recursos, destacan los existentes en los alrededores de Gutiérrez Álvarez y el monte de La Reyerta, situado entre Paredes de Nava y Becerril de Campos ${ }^{269}$. De la importancia de la leña en aquel tiempo da testimonio la vigésimo segunda constitución aprobada por el abad Francisco de Reinoso en el año 1588, dedicada a la leña del monte, estableciéndose que solamente los beneficiados que harían residencia durante un mínimo de medio año, ganarían el derecho a repartimiento de leña, debiéndola tener en su casa un mínimo de tres días antes de que la pudiese vender $^{270}$.

\section{ESTRUCTURA DEL DOMINIO DE SANTA MARÍA DE HUSILLOS}

\section{Iglesias y heredades diversas}

Las iglesias y en general todas las heredades de Santa María de Husillos se distribuían por un amplio espacio geográfico que abarcaba "grosso modo" el tercio sur de la actual provincia de Palencia y la Tierra de Campos palentina, con posesiones también en otras provincias como Valladolid y Burgos. Si desde el punto de vista cuantitativo el patrimonio territorial de Husillos era inferior al de otros cenobios castellanos, desde el punto de vista cualitativo era de gran calidad, debido a la gran cantidad de posesiones en la ribera del río Carrión y en la fértil Tierra de Campos.

\footnotetext{
${ }^{267}$ Doc. núm. 188.

${ }^{268}$ Doc. num. 206.

${ }^{269}$ Doc. núm. 146 ,

${ }^{270}$ Doc. núm. 330.
} 
Las numerosas iglesias del dominio de Husillos eran en sí unidades de administración señorial que solían estar dirigidas por un beneficiado normalmente con cura de almas como rector. Los ingresos de estas iglesias se repartían entre la fábrica y necesidades del culto, el rector de dicha iglesia y Santa María de Husillos.

Las heredades de todo tipo que poseía Husillos eran explotadas normalmente indirectamente, en especial las más alejadas de Husillos y las menos productivas, por vía de arrendamiento o por censo sobre todo a partir del siglo XIV.

\section{La reserva}

La reserva del dominio de Husillos estaba constituida en general por las villas que formaban parte de su dominio señorial y que fueron la base sobre la que se edificó el dominio de la abadía. Nos referimos a las villas de Pajarejos, Pajares, San Adrián, Celanova, Cilleruelo, San Sebastián de Hérmedes, Gutiérrez Álvarez y Sahagún el Viejo, estando todas en los alrededores de la abadía, a excepción de las dos últimas. Normalmente las tierras de la reserva eran explotadas directamente por la abadía a través de sus criados, dependientes y de las sernas de los habitantes de dichos lugares sujetos al dominio señorial de la abadía.

Un ejemplo de las sernas que tenían que aportar los dependientes de la abadía se encuentra en el fuero concedido a San Julián en $1161^{271}$. Así, cada hombre de esta villa debía hacer dieciocho sernas anuales, pagando de multa un carnero en caso de que no las hiciera. El trabajo en las viñas computaría por dos sernas, lo cual indica la importancia de éstas para Husillos. Cada hombre recibiría a cambio dos panes, vino y queso.

Al igual que otras instituciones laicas o eclesiásticas, Santa María de Husillos otorgó fueros a algunas villas de su reserva, en concreto a Villaudilla en el año $1127^{272}$, y a San Julián en el año $1161^{273}$, que tenían por fin en última instancia potenciar su población, lo que se traduciría en un aumento de los ingresos de la abadía por impuestos señoriales y rentas eclesiásticas, y en un aumento de la

${ }^{271}$ Doc. núm. 31.

${ }^{272}$ Doc. núm. 20.

${ }^{273}$ Doc. núm. 20.. 
fuerza productiva, aunque para fijar a la población existente y atraer a posibles pobladores se tratara precisamente de rebajar los impuestos señoriales, junto a otros privilegios de tipo jurídico. Así, en el fuero concedido a San Julián, además de regular las sernas, se exime del pago de huesas por fallecimiento; los merinos o sayones no podrían actuar violentamente contra sus pobladores; las muertes accidentales no pagarían homicidio; nadie podía ser apresado si daba fiadores para satisfacer la caloña o multa; y se facilitaba también la marcha de los pobladores de la villa al concederse nueve días para la venta de las casas y posesiones de los emigrantes, disponiendo después la abadía de dichos bienes, siendo lo normal que los señores dispusiesen de los bienes en el momento en el que el poblador emigraba.

Con el concejo de Villaudilla habría litigios con el tiempo sobre la aplicación del fuero, que se resolverían en 1243 por una avenencia entre ambas partes ordenada por el rey Fernando III que establecía un nuevo fuero para dicha villa ${ }^{274}$.

\section{El coto}

El coto es el epicentro territorial y jurisdiccional de un monasterio, formando parte de la reserva pero con unas características definidas, diferenciándose de ésta. Alberga los edificios de la comunidad eclesiástica y la proporciona alimentos frescos como pescado y hortalizas. Así, en Husillos el tramo del río Carrión que trascurre desde Husillos hasta Cabo de Viña formaba parte del coto monástico, aprovechándose especialmente para la pesca. También los huertos más productivos estaban en el coto, que era atravesado por numerosos arroyos como el arroyo de Frades o de los Frailes. En el coto solían estar también los molinos, situándose uno de ellos en el caso de Husillos en el dicho lugar de Cabo de Viña.

La mayor parte de los cotos monásticos se solían dedicar a la ganadería. En el caso de Husillos existían dehesas dentro de su coto que se aprovechaban como pasto para la importante cabaña ovina de la iglesia ${ }^{275}$.

${ }^{274}$ Doc. núm. 62. 
Posiblemente el coto de Santa María de Husillos se configurara durante el reinado de Fernando I o de Alfonso VI, pues es durante el reinado del primero cuando los cotos monásticos se configuran jurídicamente, aunque las falsas confirmaciones de Sancho el Mayor realizadas posiblemente entre 1133 y $1135^{276}$ atribuyan a los condes Ansúrez de Monzón su configuración. Dichos documentos dan dos versiones del coto donado por los condes de Monzón:

\section{Documento núm. 5:}

"vadit terminus eius ex vna parte de illa carrera que venit de Monçon ad Donnas contra Fontes, et per illum montem super de Ronadas super villam Zalama et per planum illum et viam que vadit ad illum oterum quod dicitur Miranda contra Palentiam, et vadit apud Sanctum Facundum ad illum pontonem angustum circa vadum de Quintanilla et deinde per flumen de Carrione, et per illam viam que vadit de Palentia contra Carrionem usque ad viam que vadit de Bezerril contra Monçonem, et per eamdem viam de Bezerril usque ad caminum que venit de Bezerrileios ad Fusellos, et deinde descendit ad caminum que venit de Villaumbrales ad Monçon, et postea venit ad caminum que venit de Ribas contra Fusellos via recta ad Foyum de Andrinos et deinde ad vineam Colubreram et postea ad cotarrum iunctum cum flumine de Carrione, ${ }^{\text {277. }}$.

\section{Documento núm. 7:}

"Et vadit terminus eius ex qua parte vsque ad carrera quem venit de Sancta Maria per açennas que sunt in illo flumine de Carrion, et sic per eius montem vsque quo descendit ad illa carrera que venit de Monçon et sic per eius viam vsque descendit ad ipso flumine iam dicto et venit ad illa carrera de Carrion, ${ }^{278}$.

\footnotetext{
${ }^{275}$ De la cabaña ganadera del cabildo de Santa María de Husillos ya da fe la canónica de 1183 (Doc. núm. 40), y una cláusula de la concordia realizada en el año 1536 entre el abad Francisco de Carvajal y el prior y cabildo, sobre jurisdicción y otros temas económicos, en la que se regulaba el derecho de pasto del ganado ovino y vacuno del abad y cabildo en los términos de Husillos (Doc. núm. 269).

La mesa abacial dispuso en algunos momentos de un importante número de cabezas de ganado ovino. Es el caso del abad Francisco de Carvajal, que en 1540 disponía de cuatrocientas cabezas (Doc. núm. 275).

${ }^{276}$ Docs. núm. 5 y 7.

${ }^{277}$ Doc. núm. 5.

${ }^{278}$ Doc. núm. 7.
} 
El coto que se delimita en la segunda versión es de menores dimensiones que el primero, ajustándose más a la realidad del que pudo ser el coto concedido en el reinado de Fernando I o Alfonso VI. La delimitación del primero correspondería al coto existente en el momento de realización del falso, ya entrado el siglo XII. Así, el coto original de Santa María de Husillos pudo tener una forma triangular, siendo sus vértices la villa de Husillos, Cabo de Viña, junto al río Carrión, lugar situado a tres kilómetros aproximadamente desde Husillos siguiendo el curso del Carrión hacia Palencia, y Monzón de Campos. El coto de la primera versión ampliaría los límites de la segunda, ya que llegarían hasta La Miranda, ya en término de Palencia, las cercanías de Villaumbrales y Monzón.

Aunque Santa María de Husillos disponía de un territorio enclavado en el centro de su dominio territorial, que identificaba a modo práctico como su coto monástico, como cualquier otro monasterio, la realidad era que para justificar su existencia disponía de los privilegios falsos de Sancho el Mayor. Además en principio en dicho coto no existía inmunidad jurídica. De ahí que Sancho III, como una muestra más de su generosidad con Santa María de Husillos, otorgara a la abadía un coto territorial con plena inmunidad jurídica, estableciendo que no se pudieran sacar prendas de dicho coto y que ningún hombre pudiera ser perseguido ni asesinado dentro de éste, estableciendo las penas que deberían pagar aquellos que lo violaran. Poco después lo confirmaría por un privilegio del año $1158^{279}$. Los límites de dicho coto estarían marcados por el puente sobre el río Carrión existente en Husillos, Cabo de Viña, Villazalama y la pesquera de Ronada, situada en el curso del Carrión a unos cuatro kilómetros antes de llegar a Husillos. Comprobamos así como el coto donado por Sancho III sería de dimensiones más pequeñas que el que la misma abadía identificaba anteriormente.

"cautos quos ego dedi ecclesie Sancte Marie de / Fuseliis, scilicet: a ponte de Munzum usque ab Cab de Uinea et inde ad Uillam Zaleimam et per Sanctum Christoforum usque ad Derronadam et inde ad predictum pontem. Et testor et ratum perhenniter aberi uolo ut nullus sit ausus de infra cautos istos aliquam

${ }^{279}$ Doc. núm. 30. 
pignoram $\beta$ extrahere uel aliquem hominem intra persequi uel interficere. Et quicumque hos cautos istis de causis uiolare presumpserit, pectet duos mille solidos regi, et abbati predicte ecclesie quicumque fuerit pignora duplicata restituatu".

La abadía tratará a lo largo del tiempo de ampliar la inmunidad jurídica de su coto a otras villas y lugares de su dominio, en un proceso similar al de otras instituciones monásticas castellanas ${ }^{280}$. Así, por un privilegio de Alfonso VIII de 1181, dicho rey ordena que no se embarguen los bienes de los habitantes de Cilleruelo y San Julián salvo por deudas propias, entre otros supuestos ${ }^{281}$.

\section{EL SEÑORÍO JURISDICCIONAL}

El señorío eclesiástico de Santa María de Husillos era uno más de las treinta instituciones eclesiásticas titulares de señoríos en la diócesis de Palencia, entre las que destacaban por el número de vasallos, el obispo de Palencia y monasterios como el de San Benito de Sahagún, San Andrés de Arroyo, San Zoilo de Carrión, Santa María de Aguilar de Campóo, San Isidro de Dueñas, y el hospital de San Antolín y San Bernabé de Palencia.

Como señores jurisdiccionales, el abad y cabildo de Husillos ejercen funciones públicas, emanando de su poder una serie de facultades de tipo judicial, administrativo y tributario.

En relación a las primeras, eran la instancia judicial de primer y segundo grado sobre los moradores seglares de los lugares de su señorío (Husillos, Villaldavín, Santillán de la Cuesta, Gutiérrez Álvarez, Villaudilla, Pajares, Pajarejos, Sahagún el Viejo), y el abad la instancia de primer grado sobre los eclesiásticos gracias al privilegio de exención jurídica concedido por el papa Alejandro III en $1179^{282}$. En general, los litigios acaecidos en su señorío eran juzgados en primera instancia bien por el abad o su provisor directamente, bien por los alcaldes mayores y

\footnotetext{
${ }^{280}$ Es el caso del monasterio de San Millán de la Cogolla (GARCÍA DE CORTÁZAR, El dominio del Monasterio de San Millán de la Cogolla, 318).

${ }^{281}$ Doc. núm. 38.

${ }^{282}$ Doc. núm. 37.
} 
ordinarios de los lugares de su señorío. La sentencia de estos últimos se podía apelar en segundo grado al tribunal abacial. De su sentencia se podía apelar, tanto en lo civil como en lo criminal, a la justicia real, representada desde fines del siglo XV en la Real Chancillería de Valladolid, que era la última instancia para las causas criminales. Todavía quedaba una última apelación al tribunal de las Mil Quinientas Doblas del Consejo de Castilla para las causas de alta cuantía. En este sentido, el fuero de Villaudilla surgido en 1243 por avenencia entre Santa María de Husillos y dicha villa, y promulgado por Fernando III, da idea del esquema jurisdiccional a mediados del siglo XIII, al establecer la primera instancia en los alcaldes de Villaudilla, puestos por el abad de Husillos, la segunda instancia en el adelantado real, y la última en el rey ${ }^{283}$.

Los litigios acaecidos entre Santa María de Husillos como institución con otros concejos o instituciones, podían ser juzgados por los tribunales intermedios de los adelantados y merinos reales, de cuya sentencia se podía apelar al rey, y después a la Real Chancillería de Valladolid. La abadía contaba con un procurador que le representaba en todos sus pleitos. El estatuto otorgado por el abad Francisco de Reinoso en 1588 estipulaba el oficio del procurador ${ }^{284}$. Este debía tener memoriales de todos los pleitos de la abadía, debiendo dar cuenta en el primer cabildo de cada mes del estado en el que se encontraban.

Sobre las facultades administrativas, el abad y cabildo elegían a los oficiales administrativos y judiciales de su señorío, tales como los alcaldes mayores y ordinarios, merinos, escribanos, mayordomos y alguaciles. Como era característico en los señoríos eclesiásticos, la elección de éstos la monopolizaba el abad y el cabildo, sin participación de los concejos, inspeccionando y fiscalizando sus actividades y cuentas.

En relación a las facultades tributarias, percibían una variada tipología impositiva que descansaba en su dominio sobre la tierra y sobre las personas. Entre las primeras se encuentran impuestos como la martiniega, infurción, marzadga y

${ }^{283}$ Doc. núm. 62. 
fumazga. Entre las segundas, las prestaciones en trabajo o sernas y el yantar. A todos estos habría que sumarles los derivados de las penas judiciales o caloñas.

Aunque en el siglo XVI los impuestos señoriales se habían ido diluyendo en paralelo al debilitamiento y crisis del dominio territorial de Husillos ${ }^{285}$, el abad y cabildo siguieron conservando prácticamente intactas sus facultades administrativas, en concordancia con la tónica general de los abadengos de Palencia en el citado siglo ${ }^{286}$.

\section{RENTAS MONÁSTICAS}

Para sistematizar las rentas de Santa María de Husillos, utilizamos el esquema que fijó Moreta Velayos en su obra sobre las rentas monásticas en Castilla ${ }^{287}$. Según este autor, la renta dominical monástica se conformaría con "todos los ingresos que perciben con regularidad los monasterios por cualquier concepto, dado que lo que caracteriza a estas instituciones de rentistas feudales es la percepción de diversas categorías de rentas: renta propietaria o real, renta señorial y renta decimal o eclesiástica".

\section{Rentas procedentes de la explotación de la propiedad real}

La explotación del dominio monástico se podía realizar directa o indirectamente, mediante trabajo servil o asalariado o por cesión por arrendamiento o censo. La elección de un sistema u otro dependería de factores como la calidad de la tierra y la lejanía con respecto el cenobio.

La explotación directa del dominio se fue haciendo cada vez menos importante, quedando limitada ya en la Baja Edad Media a las tierras de cereal del coto monástico, los viñedos y las huertas próximas a la abadía. Los primeros contratos de censo y arrendamiento aparecen a mediados del siglo XIII. Así, en 1244 el abad Pedro Martínez da en censo a Fernando, arcipreste de Torre de Astudillo, para toda su vida, su heredad en dicho lugar, en precio de quince maravedís

\footnotetext{
${ }^{285}$ A finales del siglo XVI, el número de vecinos del señorío de Husillos sería de ochenta (FAYA, Los señoríos eclesiásticos del obispado de Palencia, 757).

${ }^{286}$ NARGANES, El señorío de abadengo en Palencia, 261-284.

${ }^{287}$ MORETA, Rentas monásticas en Castilla, 21-22.
} 
anuales $^{288}$. Un año más tarde, dicho abad arrienda por cuatro años a Pedro Ibáñez, clérigo de Fuentes de Valdepero, a Martín Velasco y a Miguel, la heredad de San Adrián, próxima a Fuentes de Valdepero, en precio de ciento veinticinco maravedís $^{289}$.

El trabajo para la explotación directa se obtenía a través de los trabajadores domésticos, asalariados temporales y las sernas. Los trabajadores domésticos de la abadía eran los que realizaban la mayor parte del trabajo en la explotación directa. Se empezaron asentando en casas construidas en los alrededores del edificio monacal, surgiendo así con el tiempo la villa de Husillos. Trabajarían los huertos y las tierras de cereal del coto.

Los trabajadores asalariados, menos importantes que los anteriores, trabajarían especialmente los viñedos. Por último, los habitantes de las villas donde la abadía ejercía el dominio señorial deberían tributar a ésta con sernas o días de trabajo, entre otros tributos, y se aplicarían sobre todo en los viñedos que la abadía poseería en dichas villas. No obstante, el sistema de sernas fue perdiendo importancia, permutándose por pagos en especie o en dinero.

La explotación indirecta se aplicaría a la mayor parte del dominio de Husillos, en consonancia con otros señoríos eclesiásticos, si bien son escasos los contratos de arrendamiento y censo hasta el siglo XVI, y se aplicaría sobre todas las heredades, como las tierras, viñas alejadas de Husillos, casas y molinos. Los molinos proporcionaban a los dominios señoriales sus ingresos en proporción más altos. Los dos molinos de Husillos, situados en Cabo de Viña y Pajares, estaban arrendados, según se desprende de sendos documentos de $1480^{290}$ y $1505^{291}$. Los arrendatarios, además de pagar el correspondiente censo o renta, debían realizar los reparamientos necesarios, según se desprende del arrendamiento del molino de Pajares en $1505^{292}$. La importancia de los molinos para Santa María de

\footnotetext{
288 Doc. núm. 64.

${ }^{289}$ Doc. núm. 66.

${ }^{290}$ Doc. núm. 241.

${ }^{291}$ Doc. núm. 259.

292 Doc. núm. 259..
} 
Husillos se refleja en la existencia de un mayordomo de los molinos de la iglesia, elegido por cabildo general.

A pesar de lo afirmado por Alberto Marcos Martín, sobre que en la Edad Moderna en Palencia el principal sistema más extendido de explotación de la tierra es el arrendamiento porque permitía ajustar el alquiler a la coyuntura ${ }^{293}$, en el caso de Santa María de Husillos observamos que predomina claramente el censo sobre el arrendamiento, ya que contabilizamos un total de dieciséis censos y ningún arrendamiento. Entre las propiedades más importantes de Husillos que se encontraban encensadas en dicho siglo, se encuentran el término de San Sebastián de Hérmedes, encensado al concejo de Hérmedes en $1497^{294}$, y las casas que poseía en Valladolid la mesa abacial, de las que se hicieron numerosos contratos de censo a lo largo del siglo $\mathrm{XVI}^{295}$, aunque en realidad los únicos contratos de censo que se realizan a lo largo del siglo XVI tienen por objeto las citadas casas de Valladolid, a excepción de una viña sita Villaumbrales en el año $1549^{296}$.

Los censos fueron perjudiciales para Santa María de Husillos, al igual que lo observado por Graciliano Roscales para el monasterio de Santa María de Vega ${ }^{297}$ y por Alberto Marcos para el hospital de San Antolín de Palencia ${ }^{298}$, por la larga duración de los contratos en similares condiciones a lo largo del tiempo. Así, se observan sobre todo en el siglo XVI varios litigios a los que tuvo que hacer frente la abadía derivados de los censos que tenía sobre sus casas y tierras, ya que la lejanía en el tiempo de la mayor parte de éstos, hizo que los arrendadores se acabaran apropiando de su propiedad, todo ello favorecido por la mala gestión de su dominio por Santa María de Husillos, que podía reflejarse en la pérdida de las escrituras de propiedad y de censo ${ }^{299}$.

\footnotetext{
${ }^{293}$ MARCOS MARTÍN, Economía, sociedad, pobreza en Castilla, I, 203.

294 Doc. núm. 250.

295 Docs. núm. 253, 278, 279, 290, 314, 315, 316, 317, 323, 324, 325, 344.

296 Doc. núm. 290.

297 ROSCALES OLEA, Santa María de la Vega, 201-202.

298 MARCOS MARTÍN, Economía, sociedad, pobreza en Castilla, I, 224-225.

299 Docs. núm. 305 y 321.
} 


\section{LA ABADÍA DE SANTA MARÍA DE HUSILLOS: ESTUDIO Y COLECCIÓN \\ DOCUMENTAL $(904-1608)$}

\section{Rentas señoriales}

Las rentas señoriales eran aquellas que provenían del señorío de Santa María de Husillos sobre los habitantes de los lugares en donde ejercía el dominio señorial. Estas se pagaban en especie, trabajo o dinero, o de forma mixta, aunque la mayor parte de ellas se acabaron pagando en dinero. Los más importantes de los tributos señoriales en especie o dinero eran la martiniega, marzadga, infurción, fumazga y yantar, según se desprende del Libro becerro de las propiedades de Husillos y del Becerro de las Behetrías. La serna era el tributo en trabajo más importante.

Aunque las rentas señoriales suponían una importante fuente de ingresos para la abadía, eran en cualquier caso mucho menores que las producidas por la explotación del dominio territorial, debiendo suponer como mucho entre un 10$20 \%$ de los ingresos totales ${ }^{300}$.

Por el Becerro de las behetrías, realizado en 1352, podemos hacer una cuantificación de los tributos señoriales percibidos por Santa María de Husillos a mediados del siglo XIV. De Santillán de la Cuesta, lugar del cabildo, recibía de yantar 80 maravedís, y de infurción 8 dineros por casa ${ }^{301}$. Además el concejo debía entregar seis carros de paja al año. De los vecinos de Mazariegos recibía 18 maravedís anuales $^{302}$. De San Sebastián de Hérmedes recibe 12 maravedís ${ }^{303}$. Villaldavín pecha con 100 maravedís de yantar, 9 maravedís de martiniega y 8 dineros por cada corral ${ }^{304}$. De Husillos, villa central del señorío, recibe 60 maravedís y ocho dineros de fumazga por casa ${ }^{305}$.

En el libro becerro de las propiedades de Husillos, confeccionado entre 1374 y 1376, se hace relación de los derechos señoriales de Santa María de Husillos ${ }^{306}$. Así, sobre Villaudilla el abad tiene derecho a las penas y caloñas, 30 maravedís

\footnotetext{
300 Esta proporción es la estimada por Moreta Velayos para el conjunto de los dominios monásticos (MORETA, Rentas monásticas en Castilla, 106).

${ }^{301}$ MARTÍNEZ DÍEZ, Becerro de las behetrías, I, núm. 64, 297-298.

${ }^{302}$ MARTÍNEZ DÍEZ, íbid., núm. 49, 291.

${ }^{303}$ MARTÍNEZ DÍEZ, íbid., núm. 48, 142.

${ }^{304}$ MARTÍNEZ DÍEZ, ibid., núm. 65, 298.

${ }^{305}$ MARTÍNEZ DÍEZ, ibid., núm. 66, 298.

306 Doc. núm. 185. No se hace relación de Husillos ya que cuando se realizó el traslado no se conservaría la parte referente a dicha villa.
} 
de martiniega, 30 maravedís de marzadga, 8 dineros de fumazga y 4 dineros por cada suelo de huerta ${ }^{307}$. Sobre San Sebastián de Hérmedes tiene el abad las penas y caloñas, 18 maravedís de yantar, 12 maravedís de martiniega, y 16 dineros de infurción por cada solar. De Villaldavín se expresa que el abad tiene ciertos derechos sobre los vecinos, aunque sin detallarse. De Santillán de la Cuesta el cabildo recibe, además de las penas y caloñas, 90 maravedís de martiniega. De Gutiérrez Álvarez recibía el cabildo anualmente una carga de pan, mitad trigo mitad cebada, por cada par de bueyes, además de las penas y caloñas. De Cilleruelo el cabildo recibe las penas y caloñas. De Mazariegos recibía el cabildo 18 maravedís de martiniega.

Comprobamos cómo solamente la martiniega pagada por Mazariegos y San Sebastián de Hérmedes es idéntica en el libro becerro de las behetrías y en el libro becerro de las propiedades de Husillos, elaborado 25 años más tarde. De Santillán de la Cuesta y Villaldavín se hace relación diferente de pechos. De Gutiérrez Álvarez, Cilleruelo y Villaudilla no se hace relación en el libro becerro de las behetrías $^{308}$.

Estas cantidades variarían a lo largo del tiempo, aumentándose los impuestos de algunas villas y desapareciendo las de otras al desaparecer las mismas villas. Así por ejemplo en 1540 la martiniega que pagaba la villa de Husillos era de 250 maravedís anuales ${ }^{309}$.

\section{Rentas de iglesia}

Las más importante era el diezmo que Santa María de Husillos percibía de las rentas de todos los habitantes de su dominio territorial. Otras rentas procedían de los entierros, las oblaciones, los aniversarios y las limosnas.

\footnotetext{
${ }^{307}$ En el Libro Becerro de las Behetrías, en el lugar de Andiella se expresa que pertenece al abad de Husillos y que está despoblado, no haciéndose por ello relación de impuestos, lo cual está en contradicción con lo expuesto por el libro becerro de las propiedades de Husillos (MARTíNEZ DÍEZ, Becerro de las behetrías, I, núm. 54, 293).

${ }^{308}$ Por ello llamamos la atención sobre los riesgos de utilizar el libro becerro de las behetrías para estudiar la despoblación del siglo XIV, como han hecho numerosos autores.

${ }^{309}$ Doc. núm. 276.
} 


\section{LA ABADÍA DE SANTA MARÍA DE HUSILLOS: ESTUDIO Y COLECCIÓN \\ DOCUMENTAL $(904-1608)$}

\section{Ingresos percibidos por los canónigos}

Los canónigos de Santa María de Husillos percibían una serie de ingresos que se pueden ajustar a la siguiente tipología: participación en la gruesa de la mesa capitular y en los ingresos derivados de los bienes de dicha mesa, formada por los diezmos, heredades, censos y arrendamientos ${ }^{310}$.

Para acceder a la gruesa de la mesa capitular, formada por pitanzas, leña, centeno, gallinas y vino, los beneficiados antiguos que no fueran primeros residentes debían residir anualmente un mínimo de medio año. Los beneficiados modernos que tomaran posesión debían residir un mínimo de un año y un día para hacer residencia, no pudiendo ganar entretanto más que unos pocos frutos.

El resto de la renta capitular y las distribuciones cotidianas, se ganaban y repartían entre los beneficiados que residieran o los que justificaran su ausencia en algún asunto de la abadía, estuvieran en romería o peregrinación, estudiando o enfermos. Las distribuciones cotidianas se asignaban a vestuario y a las horas del oficio divino, reservadas estas últimas a los asistentes. Las mejor dotadas eran las mayores (prima, tercia, sexta y la misa mayor). Las peores eran las menores (nona, vísperas, completas) ${ }^{311}$.

Los diezmos de la mesa capitular eran aquellos con los que se dotó la mesa capitular en el momento de la creación de la canónica en $1183^{312}$ más los que se irían agregando a ésta a lo largo del tiempo, producto de donaciones. Muchos de estos diezmos provenían de los beneficios simples que poseía el cabildo en diferentes lugares, llegándose a identificar como diezmos mayores, cobrados casi siempre en especie, sobre todo en trigo o cebada. Los préstamos se asignaban anualmente a los prebendados en suertes. Los diezmos menudos solían arrendarse en dinero, y provenían sobre todo de explotaciones de huerta y silvicultura.

\footnotetext{
${ }^{310}$ La tipología de ingresos sería similar a la existente en la mesa capitular de la catedral de Palencia (CABEZA, Ingresos percibidos por los eclesiásticos de la catedral de Palencia, 483498).

${ }^{311}$ Esta relación de rentas de los canónigos de Husillos es la dispuesta en el estatuto otorgado por el abad Francisco de Reinoso en el año 1588 (Doc. núm. 330).

${ }^{312}$ Doc. núm. 40.
} 
Las asignaciones en dinero o planas mayores dentro de la prebenda se obtenían del diezmo de menudos y de los préstamos de pan que no se hubieran distribuido en suertes, y de los arrendamientos y censos de las heredades del cabildo.

En cuanto a la gestión y contabilidad de las rentas de la mesa capitular, eran realizadas por el mayordomo de dinero, oficio dado a arrendamiento, siendo realizados los libros de mayordomía por el secretario del cabildo ayudado por uno o dos contadores nombrados entre los propios canónigos, que inspeccionaba la labor de dicho mayordomo.

\section{Otros ingresos}

En ocasiones las instituciones eclesiásticas se veían en la necesidad de recurrir a préstamos monetarios para solventar necesidades económicas de urgencia, en especial en las épocas de crisis. Aunque en Santa María de Husillos no hay constancia de petición de préstamos de forma regular, sí se han conservado varios testimonios de éstos. Es el caso de un documento del fondo del monasterio de Sandoval por el que el abad Gonzalo de Husillos, recibe de dicho monasterio un préstamo de seiscientos maravedís de buen oro $^{313}$, que pudo deberse a una necesidad puntual de dicho abad dentro de su patrimonio personal o bien dentro de la dignidad abacial. También por cabildo ordinario de 17 de marzo de 1587, se acordó tomar a censo al quitar 300 ducados $^{314}$.

Pero en ocasiones también las instituciones eclesiásticas, las más saneadas, prestaban dinero en contratos de censo de los que obtenía una buena fuente de ingresos en forma de intereses. En el caso del ámbito palentino, el hospital de San Antolín y San Bernabé de la ciudad de Palencia realizaba entre los siglos XVI al XVIII una importante actividad crediticia, como ha mostrado Alberto Marcos Martín, lo que reflejaba la importancia económica de dicha institución ${ }^{315}$. En el caso de Husillos, la práctica inexistencia de dicha actividad crediticia en el siglo XVI es un síntoma más del estado total de crisis en el que se encontraba. Solamente tenemos constancia de un censo de 100.000 maravedís de principal

\footnotetext{
${ }^{313}$ Doc. núm. 41.

${ }^{314}$ APA, Actas Capitulares, Libro 226 (1586-1598).

${ }^{315}$ MARCOS MARTíN, Economía, sociedad, pobreza en Castilla, I, 300-328.
} 
realizado a Diego de Sarmiento y su mujer, Isabel de Montoya, que además derivó en pleito en 1563 al adeudar la citada Isabel de Montoya, 7144 maravedís de réditos ${ }^{316}$.

\section{LA CRISIS DEL SIGLO XIV}

Se denomina como crisis del siglo XIV a un período de la historia de Europa que abarcó la parte final de la Edad Media y que terminaría con el inicio del cambio de coyuntura, con la recuperación de la población y el impulso cultural que supuso el Renacimiento y la Era de los Descubrimientos. Según la historiografía tradicional, las causas se debieron a una amalgama de factores como fueron el cambio climático, que supuso un enfriamiento generalizado del clima, la presión de un crecimiento demográfico que estaba amenazado con la cada vez menor productividad de la tierra, donde se haría palpable la ley de rendimientos decrecientes de las actividades agrícolas y ganaderas, unida a la incapacidad tecnológica de la época, y a las epidemias generalizadas, principalmente la peste negra de 1348, que diezmaron la población europea en aproximadamente la tercera parte.

Según la historiografía tradicional hispana, las causas y características de la crisis fueron similares en el caso español. No obstante, diversos autores difieren en cuanto a la importancia y peso específico de las diversas causas. Es precisamente el territorio palentino y la Tierra de Campos unas de las áreas geográficas que más han sido estudiadas a este respecto desde el punto de vista de la despoblación, última consecuencia de la crisis generalizada, con los estudios de Nicolás Cabrillana ${ }^{317}$, Ángel Vaca Lorenzo ${ }^{318}$ y Julio Valdeón Baruque ${ }^{319}$.

Las causas que estos autores establecen como más importantes varían de unos a otros: Cabrillana establece las epidemias, especialmente la peste negra de 1348, como la más importante en la despoblación que sufrió el obispado palentino. Se

\footnotetext{
${ }^{316}$ Doc. núm. 304.

${ }^{317}$ CABRILLANA, La peste negra en Palencia.

${ }^{318}$ VACA LORENZO, La estructura socioeconómica de la tierra de Campos.

${ }^{319}$ VALDEÓN, La crisis bajomedieval en tierras palentinas.
} 
basa en una comparación entre la estadística diocesana mandada realizar en 1345 por el obispo de Palencia don Vasco ${ }^{320}$ y el Becerro de las Behetrías de 1352, estableciendo que los lugares que no aparecen en el segundo se habrían despoblado por la peste.

Ángel Vaca Lorenzo se basa también en estas dos fuentes, pero establece como causas de la despoblación de las veintiocho villas que documenta, una amalgama de causas como la concentración de la población, la crisis económica, las guerras, epidemias y especialmente el movimiento emigratorio estimulado por la Reconquista y por el aumento de la fiscalidad señorial, que provocaba que la población emigrara a lugares exentos de fiscalidad.

Es importante también la reflexión que realiza Manuel Carriedo Tejedo en su estudio sobre el castillo de Fuentes de Valdepero, sobre que en tiempos difíciles y de despoblación, las villas con castillo y amuralladas daban seguridad a los pobladores de los alrededores, debiéndose tener este hecho en cuenta también como una de las causas de la despoblación de las pequeñas villas y aldeas ${ }^{321}$.

Finalmente Rafael Oliva se suma a la tesis de Vaca Lorenzo sobre la concentración de la población y de la emigración al sur como una de las causas más importantes de la despoblación del campo palentino ${ }^{322}$.

La crisis del siglo XIV incidió no solamente en los aspectos demográficos y socioeconómicos, sino también en los culturales y en la moralidad y costumbres del clero, que se vio rebajada profundamente. Afectó así a todos los órdenes y estamentos de la sociedad.

Al igual que en otros monasterios palentinos como el de San Zoilo de Carrión ${ }^{323}$, la documentación de Husillos refleja directamente los efectos y consecuencias socioeconómicas de la crisis sobre su dominio, con la existencia de numerosas

\footnotetext{
${ }^{320}$ SAN MARTÍN PAYO, La más antigua estadistica de la diócesis de Palencia.

${ }^{321}$ CARRIEDO, El solar de Fuentes de Valdepero, 10-11.

${ }^{322}$ OLIVA HERRER, La Tierra de Campos a fines de la Edad Media, 155.

${ }^{323}$ PÉREZ CELADA, Documentación de San Zoilo de Carrión, II, XXXV.
} 


\section{LA ABADÍA DE SANTA MARÍA DE HUSILLOS: ESTUDIO Y COLECCIÓN \\ DOCUMENTAL $(904-1608)$}

confirmaciones reales de privilegios anteriores, de exenciones reales y de mandatos reales a las autoridades intermedias para que respeten y hagan respetar los derechos y propiedades de la abadía, y para que no se embarguen los bienes dependientes de los monjes y de sus vasallos. Pero también hay documentación que refleja el estado de bajeza moral, de indisciplina y de abandono de funciones eclesiásticas que afligió a la abadía en este período.

Para el estudio de la crisis del siglo XIV en el dominio de Husillos hemos de fijarnos en primer lugar en la evolución y cuantificación de varios tipos documentales que aumentan en importancia en épocas de crisis, como es el caso de las confirmaciones reales de privilegios anteriores, concesiones de exención fiscal y de protección real, documentos judiciales, testamentos, traslados, compraventas, y de inventarios de bienes, en concreto del Libro becerro de las propiedades de Husillos. Así, observamos como se produce un importante repunte de estos tipos en el siglo XIV, especialmente en el caso de los documentos judiciales. También refleja la crisis el escaso número de donaciones realizadas en este siglo a Husillos.

\section{Confirmaciones y concesiones reales:}

En un período de estancamiento económico y de continuos ataques $\mathrm{e}$ intromisiones de las autoridades intermedias, los concejos y los particulares a sus propiedades, Santa María de Husillos va a sentir la necesidad de llevar a confirmar los privilegios y donaciones anteriores que acreditaban sus propiedades y derechos, y de solicitar a los reyes exención fiscal de varios tributos señoriales.

\section{Documentos judiciales:}

Es la cuantificación de la documentación judicial el mejor termómetro para determinar la duración y alcance de una crisis. Así se comprueba en el caso de los monasterios palentinos en general $^{324}$ y de Husillos en particular, donde la cantidad y proporción de documentos judiciales en el siglo XIV es extremadamente alta, producto de los numerosos litigios que tuvo que sostener la

\footnotetext{
${ }^{324}$ PALACIO, Monasterio de San Zoilo y monasterios palentinos, 145-166. Observa un aumento del número de pleitos en el conjunto de los monasterios palentinos durante el siglo XIV.
} 
abadía con otras instituciones eclesiásticas, concejos y particulares sobre propiedades y rentas.

\section{Traslados:}

Consciente de la importancia de los documentos justificativos de sus propiedades y rentas, y a causa también de los numerosos litigios que tuvo que realizar, Santa María de Husillos ordenó sacar gran cantidad de traslados notariales de las escrituras de sus propiedades y rentas, siendo muy alto en proporción con otros siglos el número de traslados realizado en el siglo XIV:

\section{Testamentos:}

La piedad religiosa aumentó en el siglo XIV producto de la crisis existencial, y con ella las cláusulas testamentarias a favor de las instituciones eclesiásticas, de ahí que aumentase también el número de testamentos y cláusulas a favor de Santa María de Husillos.

\section{Compraventas:}

La disponibilidad por parte de Santa María de Husillos de dinero líquido proveniente de los testamentos y donaciones derivadas del aumento de la piedad religiosa, y de la protección de su patrimonio por los reyes, hizo que estuviese mejor preparada para hacer frente a la crisis, y que incluso se aprovechase de la situación mucho más adversa del campesinado, comprando a éste numerosas heredades que pasaron a engrosar su patrimonio. De ahí que el número de compras tanto de Santa María de Husillos como de sus dignidades y beneficiados aumente considerablemente en dicho siglo.

\section{Inventarios de bienes:}

Los inventarios de propiedades y rentas realizados en Santa María de Husillos a lo largo de su historia, responden a momentos de crisis económica de la institución y de fijación de su patrimonio ante el aumento de la litigosidad. Esto es claro en el segundo inventario realizado en 1555, pero también serían una de las causas de la confección del inventario de 1372. . 
- La despoblación y abandono de villas del dominio de Husillos:

En el análisis del estado del patrimonio de Husillos a finales del siglo XIV, concluíamos que se había producido el abandono o despoblación de varias villas de su dominio, como eran Pajares, Pajarejos, Celanova y Sahagún el Viejo, con independencia de que se continuasen trabajando sus campos de labor o de que permaneciesen sus antiguas iglesias parroquiales como ermitas. Aunque la primera intuición es pensar que tal abandono se produjo a lo largo del siglo XIV, en consonancia con la coyuntura de crisis y también con las conclusiones de la historiografía tradicional, un análisis de los documentos de Husillos nos lleva a concluir que la tendencia a la despoblación y emigración de las villas y lugares del dominio de Husillos se produjo ya desde mediados del siglo XIII. Así, en 1268 Alfonso X ordena a los habitantes de Pajares y San Adrián, que habían emigrado a otros lugares, que volvieran a sus lugares de origen bajo pena de perder sus posesiones a favor de Santa María de Husillos ${ }^{325}$. En 1297 Fernando IV confirma el anterior mandato de Alfonso $\mathrm{X}^{326}$, haciéndolo extensible a los habitantes de Cilleruelo. La confirmación de Fernando IV es confirmada también por Alfonso XI en $1318^{327}$, lo cual indica que no se había logrado el retorno de los emigrados tiempo atrás.

Se deduce por ello que la despoblación en estos lugares se comenzó a producir antes del siglo XIV y se produciría por causas como la emigración al sur aprovechando el gran avance de la Reconquista y la posibilidad de colonizar nuevas tierras, la emigración a otros señoríos con mayores incentivos fiscales o bien la emigración a otras villas cercanas más grandes y seguras como podían ser Becerril de Campos, Paredes de Nava y Palencia, decantándonos más por esta última posibilidad, ya que el hecho de que el rey exigiera a los emigrados el retorno a las villas bajo amenaza de perder sus posesiones, indica que no debían haber emigrado lejos. Por otra parte, el escaso número de habitantes que tendrían estas villas, no más de cincuenta, como se desprende del fuero de San Julián, hacía fácil su despoblación total. En apoyo a esta idea se puede presentar la avenencia producida en 1353 entre Santa María de Husillos y el concejo de

\footnotetext{
${ }^{325}$ Doc. núm. 76.

${ }^{326}$ Doc. núm. 92.

${ }^{327}$ Doc. núm. 101.
} 
Villaumbrales sobre el aprovechamiento de pastos en los lugares de Santillán de la Cuesta y sobre que los vecinos de Santillán pudieran emigrar a Villaumbrales y viceversa, como ya sucedía desde tiempo atrás ${ }^{328}$. Se observa así que las emigraciones locales eran frecuentes y que suponían realmente una reconcentración de la población y no su desaparición. En dicho documento se dice que la población de Santillán era inferior a diez labradores, es decir, que no sobrepasaría los cuarenta habitantes. Vemos así cómo la población de Santillán estaba prácticamente estancada desde el fuero de 1161, momento en el que la población era de ocho cabezas de familia, comprendiendo por ello el temor de la abadía a la despoblación de su villa, aunque hacia 1370 debía de estar totalmente despoblada, al igual que la villa de Fuente Quintana, como se desprende del arrendamiento por un precio simbólico de dichas villas por el cabildo a Fernán Martínez de Cantoral, con la condición de que las repoblase, debiendo comenzar dicha repoblación con cinco labradores y cinco pares de bueyes ${ }^{329}$

Solamente hay un ejemplo de despoblación por causas achacables directamente a los efectos de la crisis del siglo XIV: en 1347 Alfonso XI ordena a los merinos que respeten los privilegios que posee Santa María de Husillos, ya que habían sido denunciados por ésta de continuas intromisiones y atropellos, derivándose de esto la despoblación que se estaba produciendo en Husillos ${ }^{330}$.

Por último, tenemos también noticias de la escasa población de Villaudilla hacia el año 1372, según se desprende de un privilegio de Enrique II por el que hacía exentos a diez vecinos de dicha villa de toda contribución durante diez años, debido a la despoblación que afectaba a la villa ${ }^{331}$.

Como conclusión, creemos que la mayor parte de las villas integrantes del dominio de Husillos estarían a finales del siglo XIV en una situación de despoblación total o parcial. Consideramos también que el principal factor de despoblación de la mayor parte de villas y aldeas que se despoblaron en el siglo XIV y en general en la Baja Edad Media en el ámbito palentino se debió sobre

\footnotetext{
${ }^{328}$ Doc. núm. 145.

${ }^{329}$ Doc. núm 161,

${ }^{330}$ Doc. núm. 131 .

${ }^{331}$ Doc. núm. 171.
} 


\section{LA ABADÍA DE SANTA MARÍA DE HUSILLOS: ESTUDIO Y COLECCIÓN \\ DOCUMENTAL $(904-1608)$}

todo a la concentración de la población en ciertas villas y lugares, sobre todo las más importantes y las que se encontraban amuralladas o defendidas por una fortaleza, comenzándose así a romper el equilibro poblacional entre la mayor parte de las villas del ámbito palentino, teniendo en cuenta además los efectos negativos de las epidemias, las malas cosechas y las guerras. Y es que si en la Alta Edad Media la mayor parte de las villas palentinas, aunque muy numerosas, no pasaban de ser simples granjas de explotación agropecuaria que no pasarían de los cincuenta habitantes, respondiendo a la necesidad de la Repoblación, la concentración de población que se va a producir a partir de finales del siglo XIII va a alterar el equilibro poblacional al aparecer villas con una gran población, tendencia que continuará en la Edad Moderna, cuando las villas palentinas tengan una población media de entre mil a dos mil habitantes. Así se puede decir que la concentración de la población que comenzó a fines del siglo XIII ha llegado prácticamente hasta la actualidad.

Santa María de Husillos trató de repoblar nuevamente los lugares de su dominio que se iban despoblando progresivamente. Así, en 1370 arrendó a Fernán Martínez de Cantoral las aldeas de Santillán de la Cuesta y Fuente Quintana con la condición de que el arrendador repoblase en dos años el lugar de Santillán de la Cuesta, la primitiva San Julián, debiendo comenzar dicha repoblación con cinco labradores y cinco pares de bueyes ${ }^{332}$. Se demuestra así la teoría de Vaca Lorenzo sobre la diferenciación entre despoblación de los núcleos de labor y de las tierras de labor.

Uno de los aspectos que más refleja el estado de crisis es el aumento de la litigosidad, en especial en relación con la apropiación de las rentas importantes de ciertos lugares e iglesias como el diezmo. En relación a esto, José Manuel Nieto Soria observa en la crisis bajomedieval, una constante conflictividad en la percepción del diezmo, que se traduciría en una resistencia a entregarlos y en usurpaciones de éste ${ }^{333}$. En el caso de Husillos observamos también dicha conflictividad. Es el caso de la sentencia dada en 1302 del pleito habido entre el

\footnotetext{
${ }^{332}$ Doc. núm. 161.

${ }^{333}$ NIETO SORIA, La conflictividad en torno al diezmo, 211-236.
} 
cabildo de Husillos y la iglesia de Santa Olalla de Paredes de Nava por los diezmos de Sahagún el Viejo, resuelto a favor del cabildo ${ }^{334}$; del tenido con la catedral de Palencia en 1324 por el derecho al préstamo de la cuarta parte de los diezmos de la iglesia de Santa María de Pozuelo de Amianos ${ }^{335}$, resuelto también a favor del cabildo; del habido en 1325 con el monasterio de Santa María de Benavides por los diezmos de la iglesia de San Mamés de Villacid ${ }^{336}$, estableciendo la sentencia que ambas abadías lo debían compartir; del litigado en 1336 con las iglesias de Santa María, Santa Olalla, San Martín y San Juan, todas en Paredes de Nava, por los diezmos de Villaudilla ${ }^{337}$, debiéndose repartir también ambas partes el diezmo; en fin, del habido en 1375 entre el prior y cabildo con los clérigos de Fuentes de Valdepero por el diezmo de una tierra en Husillos ${ }^{338}$.

Los pleitos con el cabildo catedralicio de Palencia por los diezmos de heredades y lugares situados en los límites de las posesiones de ambas instituciones fueron frecuentes. Es el caso de pleito litigado en 1376 por el diezmo de una tierra llamada del Congosto y que se resolvió a favor de la abadía, aunque la sentencia fue apelada al papa, lo que da idea de la importancia de dicho diezmo ${ }^{339}$; o del habido en 1433 entre el cabildo de Husillos y la catedral de Palencia por los diezmos de Santa Eufemia y San Juan de Pajares, resuelto a favor del cabildo de Husillos.

Pero la litigosidad iba a afectar también a la propiedad y disfrute de tierras, pastos y montes. Es el caso de la avenencia anteriormente citada del año 1353 entre el cabildo de Husillos y la iglesia de Santa Olalla de Villaldavín por el aprovechamiento de los pastos de Santillán de la Cuesta ${ }^{340}$; la disputa entre Santa María de Husillos y los concejos de Paredes de Nava y Becerril producida entre 1353 y 1355 sobre el monte de La Reyerta, que pertenecía a la abadía ${ }^{341}$; o el

\footnotetext{
${ }^{334}$ Doc. núm. 96.

${ }^{335}$ Doc. núm. 106.

${ }^{336}$ Docs. núm. 107 y 108.

${ }^{337}$ Doc. núm. 127.

${ }^{338}$ Doc. núm. 179.

${ }^{339}$ Doc. núm. 182.

${ }^{340}$ Doc. núm. 145.

${ }^{341}$ Doc. núm. 146.
} 
pleito litigado en 1380 con el concejo de Monzón de Campos sobre el arroyo de los Frailes y sobre términos y pastos entre ambos lugares ${ }^{342}$.

Además del aumento de los pleitos, otro de los factores que más reflejan el estado de crisis de la abadía dentro de la coyuntura de crisis general es la protección real de los ataques exteriores, ya fueran de los propios delegados regios, de los concejos o de particulares, y las exenciones fiscales que obtuvo de la corona para poder así hacer frente a las dificultades económicas y atraer población a los lugares de su dominio. Es el caso del privilegio de Enrique II anteriormente citado sobre la exención fiscal a diez vecinos de Villaudilla ${ }^{343}$, y el privilegio concedido por Juan I en 1388 poniendo bajo su protección a la abadía ante las constantes amenazas y desagravios sufridos por ésta sobre sus heredades y posesiones por parte de caballeros, hidalgos y $\operatorname{concejos}^{344}$, siendo confirmado este último privilegio por Enrique III en $1392^{345}$. Testimonio de los ataques de los concejos y de las autoridades intermedias como los merinos, son dos sentencias a favor de Santa María de Husillos. En la primera el litigio es contra los concejos de Fuentes, Vega y Quintanilla de Valdepero, sobre los quebrantamientos y deshonras que los segundos habían hecho a la abadía ${ }^{346}$; en la segunda se litiga con los merinos de Campos y Cerrato por el derecho a impartir justicia, cobrar yantar y martiniega en varias villas del dominio de Husillos ${ }^{347}$.

Por otra parte la realeza puso a Santa María de Husillos bajo su protección jurídica. Así, Sancho IV puso bajo su amparo y protección a la abadía en $1292^{348}$, al igual que Enrique II en 1378, estipulando además que su abad, canónigos, beneficiados y vasallos solo pudieran ser apresados y prendidos por deudas

\footnotetext{
342 Doc. núm. 195.

${ }^{343}$ Doc. núm. 171.

${ }^{344}$ Doc. núm. 210.

${ }^{345}$ Doc. núm. 212.

${ }^{346}$ Doc. núm. 112.

${ }^{347}$ Doc. núm. 128.

${ }^{348}$ Doc. núm. 85.
} 
demostradas $^{349}$. Este privilegio fue confirmado más tarde por Juan I en $1379^{350} \mathrm{y}$ por Enrique III en $1392^{351}$.

De las intromisiones de las autoridades territoriales al dominio de Husillos y en general a los dominios eclesiásticos, aprovechando la situación de debilidad y desamparo de éstos, da fe un documento de 1396 por el que el abad de Husillos Pedro Fernández, exige al adelantado mayor de Castilla Gómez Manrique que si quiere entrar en la villa de Husillos, debía respetar las libertades de los vecinos ${ }^{352}$. También hay noticias de intromisiones e intentos de apropiación de lugares del señorío de Husillos por otros señores laicos o eclesiásticos. Es el caso del obispo de Orense Juan Manrique y de su hermana Teresa Manrique, que habían ocupado Villaldavín, aunque en 1375 rectificaran y reconocieran el señorío de Husillos ${ }^{353}$.

Los privilegios de exención fiscal por parte de los reyes para intentar evitar la despoblación de las villas del dominio de Husillos se extendieron también a lo largo del siglo XV. Así, Enrique IV exime en 1474 a los vecinos de Husillos del pago de impuestos tomando como motivo el estado de despoblación en el que se encontraba la villa, esperando que tal medida estimulara su repoblación ${ }^{354}$. Este documento respalda así la teoría de que fue la concentración de la población, una tendencia que se inició a fines del siglo XIII, como una de las causas principales de la despoblación de la mayor parte de las villas del dominio de Husillos y por extensión de Palencia, pudiéndose extrapolar en líneas generales al resto de villas castellanas.

La crisis del siglo XIV, además de producir un descenso del número de monjes y canónigos en las catedrales y monasterios, se dejó notar también en la crisis de moralidad y de disciplina del clero en general, reflejándose esto en situaciones de clientelismo, simonía, absentismo, acumulación de beneficios y prebendas, y endogamia en ocasiones escandalosas. Ya tenemos noticias de situaciones

\footnotetext{
${ }^{349}$ Doc. núm. 190.

${ }^{350}$ Doc. núm. 191.

351 Doc. núm. 214.

${ }^{352}$ Doc. núm. 217.

${ }^{353}$ Doc. núm. 175.

${ }^{354}$ Doc. núm. 234.
} 


\section{LA ABADÍA DE SANTA MARÍA DE HUSILLOS: ESTUDIO Y COLECCIÓN \\ DOCUMENTAL $(904-1608)$}

escandalosas de acumulación de beneficios y de absentismo de los abades, incluso para la visión de la época, desde finales del siglo XIII. Así, el 13 de noviembre de 1295, el papa Bonifacio VIII comunicaba al abad de Husillos Sancho González que le había privado del arzobispado de Sevilla por haberse demostrado que había cometido diversas irregularidades, como recibir indebidamente dinero de los clérigos de Lebanza sometidos a su jurisdicción, el haber recibido la abadía de Husillos sin dispensa apostólica y también otros beneficios sin abandonar sus anteriores prebendas, y haberse inmiscuido en materias eclesiásticas para las que no estaba autorizado ${ }^{355}$.

Otras veces los papas iban a permitir e incluso promover la acumulación de beneficios. Es el caso del mismo papa Bonifacio VIII, que el 11 de junio de 1301 concede a Alfonso Rodríguez el arcedianato de Carrión, dispensándole del impedimento canónico de la multiplicidad de beneficios, ya que también era canónigo de Compostela y beneficiado de Santa María de Husillos ${ }^{356}$. En la misma tónica, el 31 de mayo de 1302 concedía a Bartolomé de Carrión la chantría de la catedral de Palencia, que también era canónigo de Palencia, Salamanca y Coimbra, y beneficiado de Santa María de Husillos ${ }^{357}$.

En realidad la Santa Sede contribuyó sobremanera a la acumulación de prebendas en el siglo XIV. Según Saturnino Ruiz de Loaizaga, casi ocho décimas partes de los documentos pontificios expedidos a la diócesis de Palencia en los siglos XIV y XV son relativos a beneficios eclesiásticos ${ }^{358}$, observándose también que en los siglos XIII y XIV hay numerosas concesiones de algunos beneficios de Husillos por la Santa Sede ${ }^{359}$. Todo ello se enmarcaría en un aumento de la fluidez de las relaciones entre la Santa Sede y las diócesis castellanas ${ }^{360}$.

El obispo de Palencia don Gutierre hizo a su sobrino Gutierre Gómez abad de Husillos y canónigo de Palencia, el cual era además racionero de Toledo y

\footnotetext{
${ }^{355}$ DOMÍNGUEZ SÁNCHEZ, Bonifacio VIII, núm. 164, 236.

${ }^{356}$ DOMÍNGUEZ SÁNCHEZ, íbid., núm. 809, 812-813.

${ }^{357}$ DOMÍNGUEZ SÁNCHEZ, ibid., núm. 906, 900-901.

${ }^{358}$ LOAIZAGA, Documentos vaticanos de la diócesis de Palencia, 359-386.

${ }^{359}$ Es el caso de la concesión hacia el año 1353 por Inocencio VI a Fernando Rodríguez de Vayllo, de media porción en Santa María de Husillos (TRENCHS ODENA, Diplomatario del Cardenal Gil de Albornoz, núm. 441, 412).

${ }^{360}$ MARCOS DIEZ, Documentación vaticana de Santa María de Husillos, 119.
} 
capellán mayor de la reina doña Juana Manuel $^{361}$. El citado abad se excusaría de una elección de prior en 1370, aduciendo su servicio a la reina y al infante, y por ser canciller de la reina ${ }^{362}$.

Pero el ejemplo más claro de dejadez moral absoluta lo tenemos en un testamento de 30 de septiembre de 1382 por el que Juan Martínez de Villaviudas, canónigo de la catedral de Palencia, sobrino de Sancho Martínez, abad de Santa María de Husillos, y de Fernán Martínez, abad de Hérmedes, deja heredades y dinero a las principales iglesias de la ciudad de Palencia, a diversos criados y a varios miembros de su familia, entre otros: los susodichos Sancho Martínez y Fernán Martínez; sus primos Sanchuelo, monje del monasterio de Hornillos; Fernando y Leonor, los tres hijos del abad de Husillos; su tío Alfonso Martínez, hermano del abad de Husillos. Manda además a Fernando Diez de Husillos las casas, tierras y viñas que posee en Husillos, debiendo pasar éstas después de la muerte de éste al cabildo de Husillos, obligándose el cabildo a rogar a Dios por su alma y por la de su tío Juan Martínez, difunto, abad que había sido de Husillos ${ }^{363}$.

Este documento muestra como pocos el grado de decadencia, corrupción, clientelismo y de monopolio familiar de beneficios al que había llegado la iglesia palentina, dentro de un contexto general, en la segunda mitad del siglo XIV: así, constatamos que el tío del testador, Sancho Martínez, abad de Husillos, tenía tres hijos: Sanchuelo, Fernando y Leonor, siendo el primero monje en Hornillos; que el testador era a su vez canónigo en la catedral palentina, y que también era sobrino del anterior abad de Husillos, Juan Martínez, ya difunto. Así vemos que los dos últimos abades de Husillos y el de Hérmedes eran hermanos.

No obstante, la situaciones de absentismo de los abades, clientelismo y endogamia en la concesión de beneficios, fueron constantes a lo largo de la Baja Edad Media y siglo XVI, hasta que el concilio de Trento intentó corregir estos vicios. Por otra parte, el absentismo no era sólo propio de los abades, sino también las dignidades y canónigos de Husillos.

\footnotetext{
${ }^{361}$ REGLERO, La iglesia de Palencia en la crisis siglo XIV 46.

${ }^{362}$ Doc. núm. 150.

363 Doc. núm. 201.
} 


\subsection{REGULACIÓN Y ORDENACIÓN INTERNA DE SANTA MARÍA DE HUSILLOS. ABADES Y CANÓNIGOS}

\section{REGLAS MONÁSTICAS EN SANTA MARÍA DE HUSILLOS}

La identificación de las reglas monacales por las que se rigió Santa María de Husillos a lo largo de su historia es una tarea compleja sobre todo en lo que se refiere a los primeros siglos de su existencia, ya que en la documentación no ha quedado rastro de ninguna de éstas ${ }^{364}$. Solamente en el informe sobre la historia de Santa María de Husillos elaborado en 1733 para Garma y Durán por el cabildo de la colegiata de Ampudia se hace una relación somera de lo que se creía habían sido las fases por las que había pasado la abadía desde su fundación. Así en la primera fase o fundacional, el redactor tiene dudas sobre si la regla había sido la benedictina o de canónigos regulares de San Agustín. En una segunda fase establece la secularización de la abadía ${ }^{365}$.

Lo cierto es que Santa María de Husillos iba a tener una compleja evolución en lo que se refiere a sus reglas monásticas, en paralelo a su compleja evolución histórica.

Su fundación y crecimiento al abrigo de los condes de Monzón, hace que tenga alta probabilidad la configuración de la abadía en sus principios como una iglesia propia que derivó en un monasterio propio donde dichos condes tendrían posiblemente su panteón familiar. Cabe la posibilidad también de que ya desde sus primeros tiempos se implantara la regla benedictina, como sucedió en el cercano monasterio de San Isidro de Dueñas ${ }^{366}$.

Con la restauración de Sancho el Mayor, Santa María de Husillos se adaptaría probablemente a la coyuntura religiosa que dicho rey iba a establecer. Así, fue el primer rey de Navarra que estableció contactos directos con la Santa Sede y abrió las instituciones eclesiásticas de su reino, especialmente los monasterios, a la

\footnotetext{
${ }^{364}$ De la ausencia de información sobre las reglas seguidas en Husillos, ya se hacía eco en el informe elaborado en 1733 por el cabildo de la colegiata de Ampudia (APA, leg. 152, carp. 1).

${ }^{365}$ APA, leg. 152, carp. 1.

${ }^{366}$ REGLERO, San Isidro de Dueñas, núm. 1, 285-288.
} 
influencia del movimiento cluniacense. La influencia cluniacense iba a tener varios grados en función del tipo de relación establecida con la casa madre francesa. Desde los monasterios que se subyugaban al monasterio francés convirtiéndose en prioratos, hasta las abadías que, manteniendo su total independencia, se sometían a la "observantia cluniacensis", es decir, a los usos y costumbres que regían en la abadía de San Pedro de Cluny, que en conclusión era una interpretación de la regla dada en el siglo VI por San Benito de Nursia, modificada a principios del siglo IX por San Benito de Aniano e interpretada por la abadía de Cluny $^{367}$.

Existen testimonios de la introducción del Ordo cluniacensis por Sancho el Mayor en el monasterio de San Juan de la Peña, y la más que probable introducción en los monasterios de San Salvador de Oña y de San Salvador de Leire, siendo más dudosa en otros monasterios como Irache, Albelda, San Millán de la Cogolla y San Pedro de Cardeña ${ }^{368}$.

Aunque quizá más importante que la influencia cluniacense durante el reinado del rey navarro fuera la introducción e influencia de las ideas religiosas de los obispados y monasterios catalanes. En estos se había implantado la regla de San Benito desde su misma fundación, al calor del reino carolingio, de ahí que fuera más fácil la aceptación de la reforma auspiciada por Cluny ${ }^{369}$. Así, la influencia de Cluny en el reino de Navarra pudo venir a través de una doble vía: a través de los Pirineos, y a través de destacadas personalidades religiosas catalanas, como el abad Oliba de Ripoll, y del monje y futuro obispo Poncio. Será este último el que contribuirá de forma más importante a la introducción en los reinos cristianos occidentales de las nuevas corrientes religiosas.

Por ello, la reforma monástica que alcanzará a los monasterios más importantes del reino, se configurará jurídicamente al estilo de los monasterios catalanes más que al de Cluny, en el que se promovía la exención jurídica del poder secular y de los obispos, pasando a una dependencia directa de la Santa Sede. Esta exención

\footnotetext{
${ }^{367}$ MARTÍNEZ DÍEZ, Sancho el Mayor, 209.

${ }^{368}$ MARTÍNEZ DÍEZ, íbid., 213-214.

${ }^{369}$ MARTÍNEZ DÍEZ, íbid., 215.
} 
no se dio en ninguna institución eclesiástica durante el reinado de Sancho el Mayor $^{370}$.

No obstante la regla benedictina no era extraña a la llegada de Sancho el Mayor. Así, el primer documento conservado del monasterio de San Isidro de Dueñas, otorgado por García I en el año 911, menciona la regla de San Benito como rectora de la vida monástica, habiendo más casos de monasterios que dicen seguir la regla de San Benito en los siglos X y $\mathrm{XI}^{371}$.

A la vista del contexto religioso general, creemos que la regla adoptada por Santa María de Husillos en su restauración por Sancho el Mayor, en el caso de que no estuviese ya implantada desde su fundación a principios del siglo $\mathrm{X}$, al igual que en el cercano monasterio de San Isidoro de Dueñas, fue la regla benedictina interpretada por Cluny, más si cabe al ser el mismo rey el que realizó personalmente la restauración y al hecho de que el mismo Poncio residiera en Husillos en su labor de promoción de la diócesis palentina. Husillos se configuraría jurídicamente al estilo de los monasterios catalanes, sin perder su dependencia de la autoridad episcopal. Esto se ve constatado en los privilegios de restauración y confirmación de la diócesis palentina por Sancho el Mayor y los reyes sucesores, en los que se presenta al monasterio de Santa María de Husillos y sus pertenencias como una propiedad más del obispo de Palencia.

Posiblemente también la catedral de Palencia se restaurara según el modelo eclesiástico catalán, estableciéndose un cabildo de monjes-canónigos, máxime teniendo en cuenta el protagonismo del obispo Poncio ${ }^{372}$.

Lo cierto es que pocas décadas más tarde, Santa María de Husillos se iba a convertir en una iglesia colegial integrada por canónigos secularizados que disponían de su propia mesa y que se regían posiblemente por la regla de San Agustín. Esta evolución hay que explicarla en paralelo a la evolución del cabildo catedralicio palentino y de otros cabildos catedralicios castellanos como el de Osma.

\footnotetext{
${ }^{370}$ MARTÍNEZ DÍEZ, íbid., 217.

${ }^{371}$ REGLERO, San Isidro de Dueñas, num. 1, 285-288.

${ }^{372}$ GUIJARRO, La enseñanza en la Edad Media, 61-96.
} 
Carlos Reglero afirma que a mediados del siglo XI, los clérigos de la catedral palentina vivían bajo la autoridad del obispo como un "collegium fratrum", denominándose éstos como canónigos también por estos años. Pero en las últimas décadas del siglo XI se produciría un distanciamiento entre el obispo y el cabildo con la erección de la canónica o mesa capitular en el año 1082, que permitía a los canónigos tener hacienda y recursos propios. Alfonso VI en 1095 les concedería el fuero de los infanzones. Dentro del cabildo irían surgiendo distintas dignidades y oficios ${ }^{373}$.

Por otro lado, Teófilo Portillo Capilla determina que desde los siglos XII al XVI, la vida administrativa de las catedrales es estatutaria de esquema monástico por el género de vida comunitario de los canónigos del cabildo en la observancia de la Regla Tercera de San Agustín. De aquí su nombre de reglares, regulares y canónigos de San Agustín. Establece que la introducción de la regla de San Agustín en el cabildo de Osma, en donde los primeros obispos habían introducido la regla benedictina, es consecuencia de la reforma del obispado, dentro de un proceso que se desarrolla entre el concilio de Husillos (1088) y de Burgos $(1136)^{374}$.

Tomás Villacorta Rodríguez, basándose en Demetrio Mansilla entre otros autores, traza una evolución general sobre la secularización de los cabildos catedralicios. Según éste, después de la reforma gregoriana en el siglo XI comienza a desarrollarse durante el siglo XII en los cabildos catedrales, un movimiento de alejamiento de la vida común, teniendo su origen este proceso en el mismo régimen de vida común y en la relajación progresiva del cumplimiento de sus exigencias. Junto a la tendencia a liberarse de los vínculos que unían a los canónigos con el obispo, como eran la administración común de los bienes y la forma de vida en común, hay un deseo de liberarse también de la regla, que ordenaba su vida canónica. El escaso interés por la vida canónica llevó a la constitución de dos mesas, episcopal y capitular, independientes entre sí, a la vez

\footnotetext{
${ }^{373}$ REGLERO, La iglesia de Palencia en la Edad Media, 26.

${ }^{374}$ PORTILLO, Vida administrativa en las catedrales, 85-99.
} 


\section{LA ABADÍA DE SANTA MARÍA DE HUSILLOS: ESTUDIO Y COLECCIÓN \\ DOCUMENTAL $(904-1608)$}

que se iba permitiendo a los canónigos la posesión de bienes propios independientes de la mesa capitular. En el siglo XII los obispos y la Santa Sede tratarían de normalizar la situación con la reforma de los cabildos, que consolidaría la ya comenzada secularización ${ }^{375}$.

Creemos que la evolución de Santa María de Husillos es similar a la de los cabildos de Palencia y Osma, y a la general trazada por Tomás Villacorta. Desde un estado de benedictismo en el que estaría integrada por el abad y un número determinado de monjes o canónigos, durante el siglo XII se produciría un alejamiento de la vida en común y un deseo de liberación de los vínculos que unían a los canónigos con el abad, basándose estos en la administración común de los bienes y en la misma vida en común y en la regla que la regulaba. Dicho alejamiento culminaría con la aprobación de la canónica en $1183^{376}$, y de otros privilegios como el fuero de los infanzones ${ }^{377}$ en 1158 , a la vez que los beneficiados iban adquiriendo bienes propios. Probablemente a partir de la instauración de la canónica se adoptara la regla tercera de San Agustín ${ }^{378}$.

Sobre el número de beneficiados antes de la aprobación de la canónica, no se ha conservado ningún documento estatutario, aunque en una permuta de 1146 se nos haya transmitido una relación en los confirmantes del documento que puede dar una estimación:

"De canonicis Sancte Marie de Fusellis: Petrus Comes, prior, testis; Andreas, precentor, testis; Andreas, sacricustos, testis. Et omnes canonici eiusdem ecclesie: don Miro, testis; Pexon de Socouia, testis; Richard de Olea, testis"379.

De este modo, además del prior, existirían también un preceptor y un sacristán más al menos tres canónigos.

\footnotetext{
${ }^{375}$ VILLACORTA, El cabildo Catedral de León, 35.

${ }^{376}$ Doc. núm. 40.

377 Doc. núm. 28.

${ }^{378}$ A partir del concilio de Letrán (1059), los canónigos regulares se organizarán jurídicamente tomando la regla de San Agustín. A la cabeza de la reforma se colocará la congregación de San Rufo de Aviñón. El modelo canonical se difundió en dos vertientes: la autónoma (catedrales y colegiatas) y la que integra a las congregaciones federadas. Los siglos de oro del movimiento canonical son el siglo XI y XII, iniciándose en el XIII su decadencia.

${ }^{379}$ Doc. núm. 24.
} 


\section{CANÓNICA, PRIVILEGIOS, ESTATUTOS Y VISITAS}

\section{Canónica y privilegios}

El primer elemento ordenador de Santa María de Husillos documentado es la canónica o separación de los bienes del abad y cabildo de Husillos, enmarcándose en un contexto generalizado de extensión de canónicas en las colegiatas castellanas a partir de mediados del siglo XII ${ }^{380}$. Así, el 22 de diciembre de 1183 , el obispo de Palencia Raimundo II, con el consenso del abad de Husillos, Gonzalo Pérez, y de los canónigos de dicha iglesia, establece que estos últimos tengan sus propios réditos por separado del abad y de la fábrica, haciendo una detallada enumeración de éstos. Asimismo les concede las mismas libertades que disfrutan los canónigos de la catedral de Palencia, entre éstas que ningún merino o sayón pueda entrar en las casas de dichos canónigos, cuyo número fija en dieciséis, incluido el prior, y ocho porcioneros ${ }^{381}$. Vemos así que la canónica de Santa María de Husillos tiene además un privilegio de inmunidad jurídica y un estatuto organizador sobre el número de beneficiados en Santa María de Husillos. Las libertades e inmunidades concedidas a los canónigos de Husillos ampliaban las otorgadas en 1158 por Sancho III, que les concedió el privilegio de los infanzones y la exención de todo servicio real ${ }^{382}$.

El 28 de junio de 1202, el abad Gonzalo estableció el estatuto sobre la forma de realizar testamento por los canónigos ${ }^{383}$, estatuto que ya había sido aprobado en la catedral palentina en el año $1183^{384}$. En general se disponía que los canónigos pudieran disponer libremente de sus bienes personales, quedando para el abad y cabildo si éstos murieran "ab intestato".

El 13 de enero de 1286 se realizó un concierto entre el obispo de Palencia Juan Alonso y el cabildo de Husillos sobre la forma de nombrar abad ${ }^{385}$. Poco después,

\footnotetext{
${ }^{380}$ DÍAZ MARTÍN, La organización de la iglesia hispana en la Edad Media, 29.

${ }^{381}$ Doc. núm. 40.

382 Doc. núm. 32.

${ }^{383}$ Doc. núm. 47.

${ }^{384}$ REGLERO, La iglesia de Palencia en la Edad Media, 27.

${ }^{385}$ Doc. núm. 80.
} 
el 1 de diciembre de 1290, el abad Sancho González y el cabildo establecían el estatuto de las medias annatas, por el que la mitad de los frutos de los prestimonios del primer año debían entregarse a la catedral ${ }^{386}$. El cabildo de la catedral de Palencia tenía también un estatuto de la media annata, por el que todas las abadías y préstamos que vacaran en la iglesia de Palencia tendrían que pagar al cabildo la mitad de los frutos en el primer año que se cubriera la vacante ${ }^{387}$.

Las rencillas y litigios entre Santa María de Husillos y la catedral palentina por el pago de las medias annatas comenzaron pronto, ya que en 1301 el abad Garci Pérez tuvo que reconocer el derecho del cabildo catedralicio de designar personas para cobrar el impuesto ${ }^{388}$. Los abades de Husillos debieron ser reacios al pago de la media annata, como se extrae de varias noticias relativas a deudas del abad con el cabildo por este concepto ${ }^{389}$, y del pleito que mantuvo el abad Domingo de Carvajal con el cabildo catedralicio, que llegó a la Rota Romana y que se resolvió a favor del primero ${ }^{390}$. Y es que los litigios por la media annata entre ambas instituciones siempre acabaron resolviéndose a favor del cabildo palentino, instándose a los abades al pago de las cantidades adeudadas. Éstos llegarían hasta el final de los días de la abadía, ya que el deán y cabildo palentinos mantuvieron pleito con el abad Diego Messía de Lasarte por el pago de la media annata del abad anterior, Sancho González de Heredia ${ }^{391}$.

No tenemos datos del valor de la media annata que debía pagar Santa María de Husillos al cabildo palentino hasta el siglo XVI. Así, en 1514 era de 25.000 maravedís ${ }^{392}$, de 400 ducados en $1570^{393}$, y de 500 ducados en $1597^{394}$.

La regulación y funciones de las distintas dignidades y servicios litúrgicos se irían conformando con el tiempo, aunque no tengamos testimonios de éstos a

\footnotetext{
${ }^{386}$ Doc. núm. 83.

387 Doc. núm. 95.

388 Doc. num. 95.

389 Así en junio de 1440 el abad de Husillos debía 5000 maravedís al cabildo catedralicio de la media annata (ACP, Actas Capitulares, 25 de junio de 1440).

${ }^{390}$ ACP, Arm. III, leg. 13-8.

${ }^{391}$ ACP, Arm. III, leg. 13-17.

${ }^{392}$ ACP, Actas Capitulares, 6 de abril de 1514.

393 ACP, Actas Capitulares, 11 de febrero de 1570.

${ }^{394}$ ACP, Actas Capitulares, 5 de septiembre de 1597.
} 
excepción del servicio en la sacristía en la iglesia en la época de la confección del libro de las propiedades de Santa María de Husillos, entre 1374 y $1376^{395}$.

\section{Estatutos}

Aunque Santa María de Husillos se iría dotando de estatutos a lo largo del tiempo que reglamentarían variados aspectos como la designación de dignidades y oficios, jurisdicción, repartimiento de bienes y préstamos, etc., la primera aprobación y confirmación de un conjunto de estatutos y disposiciones de los que algunos ya existían, por su aprobación en los cabildos ordinarios y extraordinarios, y por las visitas de los abades, se produjo durante el abadiato de Luis de Carvajal. Así, en 1472 se aprobaron unos estatutos acordados entre dicho abad, el prior y cabildo sobre distintos aspectos como bienes, jurisdicción y prebendas $^{396}$. Dichos estatutos fueron confirmados dos años más tarde, en 1474, por el papa Sixto IV $^{397}$.

Entre otros aspectos, se establecía que el abad pudiese hacer colación en los meses de marzo, junio y septiembre de las canonjías, raciones y medias raciones que vacaran en dichos meses, y que el prior y cabildo pudiesen hacer lo mismo en el mes de diciembre de cada año. El abad podría también en los referidos meses de marzo, junio y septiembre, proveer los préstamos y tesorería; y en caso de que el priorato vacase en dichos meses, el abad podría elegirlo, siendo nombrado por el cabildo en caso de que vacase en diciembre, debiendo ser confirmado en tal caso por el abad.

El abad debía contar con la aprobación del cabildo en las penas a las que se sentenciara a los beneficiados en el uso de su jurisdicción civil y criminal sobre éstos. El prior y cabildo debían poner un obrero en la fábrica de la iglesia y tomarle cuentas, sin que el abad o su provisor se entrometieran en ello. El abad y cabildo podían enviar a realizar estudios a los canónigos y beneficiados que creyeran conveniente. También se establecía que con cada uno de los canónigos pudiese vivir un hombre exento o escusado.

\footnotetext{
395 Doc. núm. 185.

${ }^{396}$ Doc. núm. 233.

${ }^{397}$ Doc. núm. 235.
} 


\section{LA ABADÍA DE SANTA MARÍA DE HUSILLOS: ESTUDIO Y COLECCIÓN \\ DOCUMENTAL $(904-1608)$}

En 1536 se produjo una concordia entre el abad Francisco de Carvajal y el prior y cabildo sobre jurisdicción y otros temas económicos ${ }^{398}$. Esta concordia tenía como precedente las disputas surgidas, a raíz de unos capítulos y estatutos, de la sentencia de avenencia del pleito habido anteriormente entre el abad Francisco Núñez de Herrera y el prior y cabildo. De la inclusión de los capítulos de dicha sentencia que traen disputa y de la concordia en éstos, surgieron nuevas capitulaciones en diversos temas y asuntos: jurisdicción y corrección de las dignidades, canónigos, racioneros y medios racioneros, y encarcelamiento de éstos; provisión y colación de prebendas; visitación de la iglesia y beneficiados; reparación de las ermitas del cabildo; familiares de los beneficiados excusados de hacer sernas al abad; administración de la fábrica de la iglesia; derechos de pasto en la villa y término de Husillos; soto del abad; excesos y privilegios de los beneficiados; casas de los beneficiados; pesca en el río Carrión; número de familiares que el abad podía tener; horas y regimiento del coro.

Así se establecía que el abad o su provisor tenían la jurisdicción civil y criminal sobre todos los beneficiados, teniendo el prior y cabildo jurisdicción sobre los delitos leves y menos graves, y que no conllevasen penas corporales, haciendo relación y detalle de todos los delitos graves y leves. Se establecía también la pena de prisión que se debía aplicar. Así, las dignidades debían ser recluidas en las casas de otras dignidades que vivieran en Husillos. De igual modo, los canónigos, racioneros y medios racioneros, en las casas de otros canónigos, racioneros y medios racioneros respectivamente. Si el crimen era homicidio o mutilación de miembro, se debía encarcelar al beneficiado en la iglesia de Husillos.

A la hora de tratar la colación de las prebendas, se detalla el número de éstas. Así, hay veinte canonjías, dos raciones y ocho medias raciones. El abad podía visitar la abadía sin pedir licencia al prior y cabildo. Podía también tener dos familiares que debían ser beneficiados de la iglesia. Se establece que el provisor que el abad designase debía ser dignidad o canónigo de la iglesia. Los beneficiados podían tener un escusado libre de pechos y de sernas. El prior y cabildo debían administrar la fábrica de la iglesia, nombrando un obrero fabriquero. Se regula el

${ }^{398}$ Doc. núm. 269. 
pasto de ganado en el término de Husillos. Aunque se reconoce la inmunidad judicial de las casas de los canónigos con respecto a los merinos y sayones, se especifica que ésta no afecta al abad o a su provisor, que puede entrar en dichas casas, prender personas y tomar prendas.

A pesar de los acuerdos y concordias entre el abad y el cabildo, no faltaron tensiones entre ambas partes, como muestran dos recursos de fuerza de $1546 \mathrm{y}$ 1547. El primero tenía por objeto un litigio entre el abad Francisco de Carvajal y el cabildo por la jurisdicción ordinaria del segundo ${ }^{399}$. El segundo tenía como origen la adjudicación de una media ración ${ }^{400}$.

En 1554 el obispo de Plasencia Gutierre de Carvajal, tío del abad de Husillos Francisco de Carvajal, realizó una visita a Santa María de Husillos, comprobando el estado de decadencia y crisis económica y moral en el que se encontraba la abadía. Para remediar lo primero mandó trasladar todos los documentos de la abadía y hacer un inventario de sus rentas. Para remediar lo segundo, mandó la redacción de unos estatutos por los que se debía regir la iglesia. Estos estatutos están formados por veintiuna cláusulas en las que se dispone sobre los objetos litúrgicos y las reliquias, el servicio litúrgico, la administración de sacramentos, la sacristía, el coro, las votaciones en el cabildo, el vestido, la prohibición de tratar con mujeres sospechosas y de realizar oficios viles ${ }^{401}$.

Se pone especial atención en la formación religiosa de los feligreses y en la buena prestación del servicio litúrgico hacia éstos. Así, se ordena vigilar la confesión de los feligreses durante la Cuaresma. Se establecen catequesis para la formación religiosa de sus hijos y criados, con pena de un real para los que no los enviasen, estableciendo que se debía decir el Credo en romance. Para asegurar el aprovechamiento de esta formación, no se debía desposar a ningún feligrés que no supiera el Padre Nuestro, el Credo, el Ave María y la Salve Regina.

Establece que no se debían llevar derechos por administrar los sacramentos, excepto la torta $\mathrm{y}$ vela por el bautismo, las velas $\mathrm{u}$ otras ofrendas en las

\footnotetext{
${ }^{399}$ Doc. núm. 286.

${ }^{400}$ Doc. núm. 287.

${ }^{401}$ Doc. núm. 297.
} 
velaciones, y los derechos acostumbrados en la extremaunción, que solía recibir el sacristán. Se fija un mínimo de veinticinco maravedís para cada clérigo por cada misa votiva o funeraria que diga. Se debía elegir un sacristán para el servicio de la iglesia, que debía estar asistido por un muchacho o monaguillo.

Trata de poner orden en el servicio del coro, dada la indisciplina de los beneficiados y la escasa obedencia al prior y al presidente. Se regula la forma de votar en el cabildo, fijándose los viernes como día de votación en cabildo, proponiéndose el negocio por el prior y el beneficiado que lleva el asunto. El secretario debía asentar los votos, aprobándose o no un negocio por mayoría, excepto los asuntos de gracia, que deberían aprobarse con la totalidad de los votos. Se reglamenta también el vestido y calzado que debían utilizar los beneficiados, debiendo ser ropas de color negro o pardo, prohibiéndose las sedas y jubones.

La última aprobación de un conjunto de estatutos se produjo con el abad Francisco de Reinoso en 1588. Se comprueba así que las aprobaciones de un conjunto amplio de estatutos durante el siglo XVI se produjeron a consecuencia de intentos de reforma de la decadente abadía. Reinoso, en su intento de reforma total de la abadía, mandó juntar los estatutos existentes a los que se crearon en este momento, ordenando a todos lo beneficiados que los tuvieran presentes.

"Don Francisco de Reynoso, abad desta nuestra iglesia colegial y villa de Husillos y queriendo cumplir con nuestro oficio y juntamente con los nuestros amados prior y cabildo desta nuestra santa yglesia y con su consentimiento y consejo, hemos hecho juntar los estatutos y constituciones que había y podían seruir para estos tiempos, añadiendo los que nos han parecido ser necesarios para el buen gobierno de la dicha nuestra santa yglesia, ansí en lo tocante al seruicio del altar y coro y oficios de las dignidades y otros preuendados y ministros della, como en lo que toca a la orden que se ha de guardar en hacer los cabildos y gobierno de la yglesia y mesa capitular, para que, estando reducidos a 
un volumen y puestos por orden, todos los beneficiados los tengan en su poder y por ellos sepa cada uno la obligación de su oficio" ${ }^{\text {"402. }}$.

El volumen está formado por veintisiete constituciones, regulando y reglamentando variados aspectos como el número de prebendas, las funciones del prior, tesorero y sacristán, horas canónicas, chantre y coro, reliquias, obrero, hábitos y costumbres de los beneficiados, vestimentas, prohibición de asistir a las corridas de toros, semanero, disposición en el coro, celebración de oficios y cantidades ganadas por éstos, nombramiento de oficiales por el cabildo, confesión y comunión de los beneficiados, residencia obligatoria para ganar la renta de la mesa capitular, beneficiados presos, estudiantes, enfermos, enterramiento de los beneficiados, el cabildo y el voto en éste, oficio de mayordomo de las rentas de la mesa capitular y del procurador general, sede vacante, jurisdicción y encarcelamiento de los beneficiados, romerías, derechos que se entregan a la fábrica y al secretario en la posesión de la dignidad abacial y de los beneficios, derechos por sepulturas en la iglesia, oficio del secretario, etc.

Las constituciones más importantes e interesantes son las relativas al número de prebendas, conformación del cabildo y el voto en éste.

\section{Prebendas:}

Existen veintidós prebendas de las rentas de la mesa capitular, de las que tres son para las dignidades del prior, tesorero y chantre, y quince para igual número de canónigos, una de las cuales pertenece a la Inquisición. Dos prebendas corresponden a dos racioneros que no tienen voto, voz ni asiento en el cabildo. Las dos prebendas restantes se distribuyen en cuatro medias raciones. Todas las dignidades, canónigos, racioneros y medios racioneros, son obligados a residir en las horas canónicas, en los oficios divinos y a ejercer los oficios anexos a cada una de ellas, a excepción de la prebenda de la Inquisición, que está exenta.

Podemos establecer una comparación entre las prebendas existentes en $1183^{403}$ con la aprobación de la canónica, las existentes en 1536 expresadas en una

${ }^{402}$ Doc. núm. 330. 


\section{LA ABADÍA DE SANTA MARÍA DE HUSILLOS: ESTUDIO Y COLECCIÓN \\ DOCUMENTAL $(904-1608)$}

concordia entre el abad Francisco de Carvajal y el prior y cabildo ${ }^{404}$, y las establecidas en el estatuto de Reinoso. Así, en la canónica se establecían dieciséis canónigos y ocho porcioneros ${ }^{405}$, mientras que en la concordia de 1536 existían veinte canonjías, dos raciones y ocho medias raciones. Suponiendo que cada canonjía y ración estuviera dotada con una prebenda o parte de la renta de la mesa capitular, y cada porción y media ración con media prebenda, habría en total 20 prebendas en 1183, mientras que en 1536 habría 26 prebendas, y 22 en 1588.

Las dignidades, beneficiados y racioneros pagaban unas cantidades a la fábrica y secretario al tomar posesión de sus prebendas: el abad pagaba a la fábrica diez mil maravedís; y al secretario, tres escudos. La dignidad dos mil maravedís a la primera y por prebenda, y al segundo uno o dos escudos según fueran una o dos prebendas. El canónigo paga a la fábrica dos mil maravedís; y al secretario, un escudo. Los racioneros, dos mil maravedís a la fábrica y un escudo al secretario. Por último, los medio racioneros pagan a la fábrica mil maravedís y un escudo al secretario. Se observa cómo las cantidades que pagaban en 1588 los beneficiados a la fábrica son idénticas a las que entregaban en noviembre de $1554^{406}$ y en junio de $1561^{407}$, aunque también por el estatuto de Reinoso tenían que pagar al secretario del cabildo.

\section{Cabildo:}

El cabildo ordinario se debía celebrar los viernes, pudiéndose anteponer o posponer si dicho día era fiesta. Aunque en principio no se debían realizar más cabildos, si el prior consideraba que se debía reunir el cabildo para tratar algún tema importante, podía convocarlo celebrándose entonces cabildo extraordinario. El día anterior del cabildo, el prior debía mandar llamar a todos los capitulares, esto es a las dignidades y a los canónigos ordenados de orden sacro, entregándoles una cédula que debía contener los asuntos que se iban a tratar.

\footnotetext{
403 Doc. núm. 40.

${ }^{404}$ Doc. núm. 269.

405 Doc. núm. 40.

${ }^{406}$ Doc. núm. 295.

${ }^{407}$ Doc. núm. 301.
} 
Todos los primeros lunes de cada mes debía celebrarse un cabildo especial en el que se debía tratar el servicio del altar y coro, la disciplina y moralidad de los beneficiados y de otros asuntos espirituales.

Los capitulares debían guardar sus asientos en el cabildo, además de en el coro, y debían dar sus votos con orden y claridad. En las gracias pedidas por los beneficiados u otras personas, se debía votar de forma secreta con habas.

Propuesto y votado un negocio, el prior no lo debía volver a proponer a no ser que fuera de gran necesidad y siempre con la asistencia de los capitulares que votaron la primera vez, que debían proponer por mayoría de dos tercios una nueva votación. Los mismos asuntos de gracia no se podían volver a votar hasta pasados tres meses.

En las votaciones debía haber en cabildo un mínimo de cinco capitulares. En los asuntos administrativos, como las notificaciones e inspección de documentos, bastaba con los capitulares que estuviesen en ese momento en la iglesia.

El cabildo plasmaría todos los asuntos que trataba en las actas capitulares, de las que se conservan, en formato libro, desde el año 1504 hasta el fin de la abadía ${ }^{408}$. Entre éstos destacan la elección de los distintos oficios del cabildo y fábrica, además de los alcaldes, alguaciles y otros oficios de las villas de su dominio, realizada siempre en los primeros días del año. Entre los distintos oficios que se elegían estaban el obrero de la fábrica, el mayordomo de molinos, escritos de las horas, contadores y visitadores, examinadores, portero, médico, barbero, alcaldes y alguaciles, escribano.

De gran interés es el estatuto relativo a los estudiantes. Así, el abad y cabildo podían dar licencia de estudio a los beneficiados que la solicitasen si no eran mayores de treinta años, no pudiéndose prorrogar más de siete años a los estudiantes de Teología y de cinco a los de Cánones, prorrogándose anualmente, previo testimonio de los estudiantes de que están matriculados y de que siguen

\footnotetext{
${ }^{408}$ Los libros de actas del cabildo de Husillos se conservan en el Archivo Parroquial de Ampudia, continuándolos los libros de actas de la colegiata de Ampudia conservados en dicho archivo. Son seis, abarcando sus signaturas desde el Libro 222 hasta el 227, y siendo sus fechas extremas: 1504 $-1606$.
} 
con aprovechamiento sus estudios. Mientras durase su licencia, los estudiantes recibirían la mitad de sus prebendas, no ganando pitanzas, memorias, procesiones, maitines, leña, centeno ni gallinas.

Se reglamentan las romerías y el tiempo que los beneficiados podían emplear en realizarlas, previa solicitud al cabildo y permiso de éste. Así, las romerías que se contemplan son las realizadas a Jerusalén, Roma, Santiago de Compostela, Nuestra Señora de Guadalupe, Santo Toribio de Liébana, el Crucifijo de Burgos y Nuestra Señora de la Peña de Francia. En el tiempo que duraran no percibirían pitanzas, memorias, entierros ni cabos de año.

\section{Visitas}

La visita era un instrumento jurídico por el que se controlaba el normal funcionamiento de las instituciones, sobresaliendo su intensidad en el siglo XVI tanto en las instituciones laicas, desde las reales hasta las concejiles, como eclesiásticas. A través de las visitas, el abad, su provisor, el prior o delegados del cabildo, controlaban el normal funcionamiento y la buena disciplina religiosa y moral de los miembros de su iglesia.

En Santa María de Husillos las visitas generales se realizaban por el abad o su provisor sin necesidad de pedir licencia al prior o al cabildo, según la concordia que se alcanzó entre ambos en $1536^{409}$, y se registraban en las actas del acuerdo capitular, como es el caso de la visita realizada el 3 de diciembre de 1585 por el abad Francisco de Reinoso ${ }^{410}$, teniendo gran importancia al ser una de las fuentes de los estatutos que ordenaban la institución.

En el siglo XVI y a consecuencia del concilio de Trento, los obispos de Palencia intentaron ejercer el derecho de visita sobre la abadía, habiendo litigio a favor del abad por sentencia de $1554^{411}$, aunque la Congregación de cardenales intérpretes del concilio de Trento acordase una solución intermedia en 1575, al establecer

\footnotetext{
${ }^{409}$ Doc. núm. 269.

${ }^{410}$ APA, Actas Capitulares, Libro 225 (1580-1586).

${ }^{411}$ Doc. núm. 294.
} 
que el obispo podría visitar la abadía personalmente y no a través de su vicario o provisor, como había pretendido ${ }^{412}$.

Se conservan nueve visitas a la sacristía y al hospital, que abarcan desde 1569 con el abad Francisco de Vargas Carvajal, hasta 1602 con el prior Baltasar Chaves, debiéndose esta cronología quizá al hecho de que éstas se insertan en los libros de fábrica, que se conservan a partir del año 1569. Dos de éstas fueron realizadas por el abad Francisco de Vargas Carvajal y su provisor en $1569^{413}$ y $1572^{414}$; cuatro por Francisco de Reinoso y su provisor, en $1577^{415}, 1579^{416}$ y $1596^{417}$; y dos por los priores Roque Giraldo y Baltasar Chaves, en $1585^{418}$ y $1598^{419}$ respectivamente.

En las visitas a la sacristía, se inspeccionaba el santísimo sacramento, pila bautismal, reliquias, altares, y bienes de la iglesia: cruces, cálices, ornamentos, capas, sábanas, corporales, aras, camas, tapices, frontales, vinajeras, candeleros, libros y ropas de Nuestra Señora, pidiendo cuenta de su estado y existencia, a través de inventario, al tesorero y al sacristán.

\section{ABADES, DIGNIDADES, CANÓNIGOS Y RACIONEROS DE SANTA MARÍA DE HUSILLOS}

\section{El nombramiento de abades en Santa María de Husillos}

Probablemente hasta la restauración de la abadía por Sancho el Mayor, los abades eran nombrados por los condes de Monzón en calidad de patronos. A partir de dicho rey, y dado que la abadía pasó a depender del obispo de Palencia, el abad sería nombrado por el obispo, como parece expresar el documento fundacional de la abadía ${ }^{420}$, aunque es posible que el cabildo de Husillos interviniera en mayor o menor grado, dada la concordia que se realizó el 13 de enero de 1286 entre éste y

\footnotetext{
412 Doc. núm. 310.

413 Doc. núm. 306.

${ }^{414}$ Doc. núm. 307.

${ }^{415}$ Docs. núm. 311 y 312.

${ }^{416}$ Doc. núm. 320.

${ }^{417}$ Doc. núm. 337.

${ }^{418}$ Doc. núm. 326.

${ }^{419}$ Doc. núm. 341.

${ }^{420}$ Doc. núm. 17. Aunque el documento es falso, algunos datos e informaciones pueden ser ciertos, sobre todo los relativos a las relaciones entre Santa María de Husillos y el obispo de Palencia.
} 
el obispo de Palencia Juan Alonso. Por ésta, el abad tenía que ser dignidad o canónigo de la catedral de Palencia, admitiéndose dos posibilidades en la elección: si el candidato propuesto por el obispo tenía la cuarta parte de votos de los canónigos de Husillos, quedaba elegido y como tal tenían que reconocerle todos los demás. Si no obtenía ese número de sufragios, entonces el obispo tenía que nombrar al que consiguiere las tres cuartas partes y uno más de los votantes $^{421}$.

Vemos así cómo el obispo de Palencia llevaba la iniciativa en la elección del abad, al ejercer el derecho de presentación, aunque tenía que ser votado en mayoría por el cabildo. Además el hecho de que el abad tuviera que ser dignidad o canónigo de la catedral de Palencia aumentaba la dependencia al obispo, máxime cuando muchas de las dignidades y canónigos de Husillos eran a la vez beneficiados en la catedral palentina o aspiraban a serlo.

No obstante, antes y después de dicha concordia, ciertos abades fueron nombrados por el papa merced a su cercanía con éste, lo que les supuso la acumulación de buen número de prebendas eclesiásticas, incluso el cardenalicio. El primer abad documentado de nombramiento pontificio fue el también futuro cardenal Ordoño Álvarez, que fue nombrado abad de Husillos por Gregorio X en $1273^{422}$, aunque posiblemente el abad Esteban fuera nombrado también por el papa $^{423}$.

En el siglo XIV sería constante el nombramiento de los abades por la Santa Sede, merced al centralismo curial de dicho siglo ${ }^{424}$, especialmente en el caso de los abades que desempeñaban algún cargo en la sede vaticana, como Pedro Rodríguez Hispano, Gil Álvarez de Albornoz y Juan de Carvajal, continuando el nombramiento pontificio hasta finales del siglo XVI. Aunque se podía dar el caso de que el obispo de Palencia presentara al papa el nombre del abad, éste tenía que ser confirmado y nombrado por el papa, que debía otorgar letra apostólica de su

\footnotetext{
${ }^{421}$ Doc. núm. 80.

422 Doc. núm. 78.

${ }^{423}$ Fue abad hacia el año 1252.

${ }^{424}$ SAN MARTÍN PAYO, Santa María de Husillos y su colección diplomática, 163.
} 
nombramiento, debiendo presentar el nuevo abad dicha letra en el cabildo catedralicio de Palencia y en el de Husillos.

Sobre el nombramiento pontificio de los abades hay una interesante información en el informe realizado por el licenciado San Román de Tapia, tenientecorregidor de Palencia, el 19 de enero de 1593, realizada en base a una encuesta a los canónigos de la abadía. Según dicho informe, aunque algunos canónigos opinaban que el nombramiento había sido consistorial, en realidad los abades habían sido nombrados por resignación papal ${ }^{425}$.

Santa María de Husillos no escapó a la extensión del derecho de patronazgo sobre las iglesias castellanas propiciada por los reyes en el siglo XVI. Así, el 30 de diciembre de 1596, Felipe II declara de patronazgo real a Santa María de Husillos, ejerciendo desde entonces los reyes el derecho de presentación de los abades $^{426}$, siendo Sancho González de Heredia el primer abad nombrado por presentación regia.

\section{Abadologio de Santa María de Husillos}

- Fernando: 938-05-30 427

Es el primer abad documentado de Santa María de Husillos. Aparece como abad ya existente en la donación de Abo Hamor, su mujer Speciosa y Zalama en el año 938.

\section{- Raimundo:}

Creemos que fue el abad existente cuando Sancho el Mayor de Navarra restauró la abadía hacia el año 1023 ó 1024.

- Poncio Guitardo: $1107-05-28^{428}-1127-11-05^{429}$

\footnotetext{
${ }^{425}$ Doc. núm. 336.

${ }^{426}$ Doc. núm. 339.

${ }^{427}$ Doc. núm. 2.

${ }^{428}$ Doc. núm. 16.

${ }^{429}$ Doc. núm. 20.
} 
Durante su abadiato se produjeron las donaciones de Villaldavín y la pesquera de Ronada $^{430}$, y de Celanova y el arroyo de los Frailes ${ }^{431}$ por Urraca I, y se concedió fuero a Villaudilla ${ }^{432}$.

- Bernardo: 1140-01-25

- Pedro ${ }^{434}$

- Raimundo Giliberti: $1158-05-04^{435}-1173^{436}$

Fue el abad existente en la época dorada de Sancho III el Deseado. Concedió fuero al concejo de San Julián en $1161^{437}$.

- Pedro de Cardona: $1178-08-13^{438}-1181-01-16^{439}$

Coincidió con el reinado de Alfonso VIII, del que parece ser que era familiar ${ }^{440}$. Llegaría a ser también canciller real ${ }^{441}$. Arturo Polanco Pérez habla de un documento apócrifo en el que Pedro de Cardona era canónigo del colegio jacobita de Palencia ${ }^{442}$.

- Gonzalo Pérez de Torquemada: $1183-12-22^{443}$ - 1232-09-22 444

Era nieto del conde Ponce de Minerva, al ser hijo de Pedro García de Lerma y de doña Sancha, hija de dicho conde. En agosto de 1237 hay noticia de que era ya difunto $^{445}$. Aparece documentado por primera vez en la creación de la canónica

${ }^{430}$ Doc. núm. 18.

${ }^{431}$ Doc. núm. 19.

432 Doc. núm. 20.

433 Doc. núm. 21.

${ }^{434}$ AHDP, Ampudia y Abadia de Husillos, Asociaciones, Libro 249. Es posible que se confunda con el obispo de Palencia Pedro II de Agen.

${ }^{435}$ Doc. núm. 28.

${ }^{436}$ ABAJO, Documentación Catedral de Palencia, núm. 73, 148-149.

437 Doc. núm. 31.

${ }^{438}$ Doc. núm. 35.

439 Doc. núm. 38.

${ }^{440}$ Doc. núm. 38.

${ }^{441}$ Docs. núm. 35 y 36.

442 POLANCO PÉREZ, Los capellanes del $n^{\circ} 40$, 138. No da sin embargo signatura de dicho documento.

443 Doc. núm. 40.

${ }^{444}$ Doc. núm. 55.

${ }^{445}$ Doc. núm. 58. 
en $1183^{446}$. Estableció en 1202 el estatuto sobre la forma de realizar testamento por los canónigos ${ }^{447}$, y les donó en 1232 sus aldeas de Hoyales de Roa ${ }^{448}$ y Fuentelisendo $^{449}$, en tierra de Haza, aunque su hermano Pedro González de Marañón intentara tras su muerte, sin éxito, invalidar tales donaciones ${ }^{450}$, reconociendo finalmente el señorío del cabildo sobre dichas aldeas ${ }^{451}$.

Aparece en la venta de una heredad al obispo de Cuenca San Julián ben Tauro, realizada antes de noviembre del año $1201^{452}$.

- Rodrigo Latronis: [1232-09-22 - 1243-04-02]

Durante su abadiato se realizó la permuta entre la mesa abacial y capitular por la que aquella entregaba a ésta Pajares a cambio de las iglesias de San Pedro de Fuentes de Valdepero y de Santa María de Nava, y la mitad de las aldeas de Hoyales de Roa y Fuentelisendo, entre otras heredades y rentas ${ }^{453}$.

- Pedro Martínez: 1243-04-02 $2^{454}$ - 1245-10-30 455

- Esteban: 1252-08-12 $2^{456}$ - 1252-10-18 457

Fue capellán del papa Inocencio IV, del que recibió numerosos beneficios, entre los cuales posiblemente el abadiato de Husillos y una canonjía en Palencia ${ }^{458}$, apareciendo en la documentación con la cualificación de maestro. Gracias a su cercanía al papa, Santa María de Husillos obtuvo privilegios como el concedido en 1252 por el que se eximía a la abadía del pago del subsidio a la Santa Sede ${ }^{459}$, y que no pudiera ser excomulgado ni puesto en entredicho por ningún juez $\operatorname{ordinario}^{460}$.

\footnotetext{
${ }^{446}$ Doc. núm. 40.

${ }^{447}$ Doc. núm. 47.

${ }^{448}$ Doc. núm. 54.

${ }^{449}$ Doc. núm. 55.

${ }^{450}$ Doc. núm. 57.

${ }^{451}$ Doc. núm. 58.

${ }^{452}$ F. J. HERNÁNDEZ, Los cartularios de Toledo, núm. 277, 254-255.

${ }^{453}$ Doc. núm. 59.

${ }^{454}$ Doc. núm. 61.

${ }^{455}$ Doc. núm. 66.

${ }^{456}$ Doc. núm. 68.

${ }^{457}$ Doc. núm. 70.

${ }^{458}$ Doc. núm. 70

${ }^{459}$ Doc. núm. 68.

${ }^{460}$ Doc. núm. 69.
} 
- Fernando: 1256, noviembre ${ }^{461}$

- Ordoño Álvarez: $1273-07-01^{462}$ - 1281-07-13 463

Después de ocupar el abadiato de Husillos, llegó a ser obispo de Salamanca y arzobispo de Braga. Fue además cardenal obispo de Túsculo (Frascati) elegido el 12 de marzo de 1278 , muriendo en $1285^{464}$. Fue nombrado abad de Husillos por el papa Gregorio X el 1 de julio de 1273.

- Sancho González: $1290-12-01^{465}$ - 1294-01-28 466

Acordó con el cabildo el estatuto de las medias annatas. De estirpe noble, el papa Bonifacio VIII le privó en 1295 del arzobispado de Sevilla al haber cometido numerosas irregularidades canónicas ${ }^{467}$.

- Pedro Rodríguez Hispano: 1296, noviembre, $1^{468}$

Canónigo de la catedral de Burgos y referendario de la cámara apostólica de Bonifacio VIII. Fue elegido obispo de Burgos en 1300, teniendo además otros beneficios en lugares como Chartres, Oviedo y Palencia. Poco después, el 3 de febrero de 1301 renunciaba a su canonjía de la catedral de Palencia y a la abadía de Husillos. El 15 de diciembre de 1302, Bonifacio VIII le nombra cardenal y obispo suburvicario de Santa Sabina ${ }^{469}$.

- Garci Pérez: 1301-07-23 ${ }^{470}$

Se documenta en el litigio entre Santa María de Husillos y el cabildo catedralicio de Palencia sobre la designación por el segundo de personas para cobrar la media annata.

\footnotetext{
461 Doc. núm. 73.

462 Doc. núm. 78.

463 Según el episcopologio de Salamanca, en esta fecha es obispo Ordoño Álvarez (ALDEA MARÍN - VIVES, DHEE, 4, 2143. -F. Marcos-).

${ }^{464}$ SAN MARTÍN PAYO, Cardenales abades de Santa María de Husillos, 52.

${ }^{465}$ Doc. núm. 83.

${ }^{466}$ Doc. núm. 86.

${ }^{467}$ DOMÍNGUEZ SÁNCHEZ, Bonifacio VIII, 181-182, núm. 107

${ }^{468}$ Doc. núm. 89.

${ }^{469}$ SAN MARTÍN PAYO, Cardenales abades de Santa María de Husillos, 54.

${ }^{470}$ Doc. núm. 95.
} 
- Tello: circa $1310^{471}$

- García Pérez: 1327, diciembre, $3^{472}$

Aparece en un pleito que se iba a juzgar en la Santa Sede entre de Santa María de Husillos y el obispo y cabildo catedralicio de Palencia.

- Domingo Díaz: circa $1336^{473}$

- Nuño Díaz: 1329 , abril, $13^{474}-1341$, noviembre, $7^{475}$

Durante su abadiato, Santa María de Husillos tuvo que hacer frente a las intromisiones y ataques de los concejos vecinos y de los delegados regios. Así, mantuvo pleitos con los concejos de Fuentes, Vega y Quintanilla de Valdepero ${ }^{476}$, y con los merinos de Campos y Cerrato por el dominio señorial y jurídico sobre varios lugares del señorío de la abadía ${ }^{477}$. Mantuvo pleito también con las iglesias de Santa María, Santa Olalla, San Martín y San Juan, todas en Paredes de Nava, por los diezmos de Villaudilla ${ }^{478}$.

- Pedro Fernández: 1346, febrero, $9^{479}$ - 1353, mayo, $7^{480}$

- Gil Álvarez de Albornoz: 1353, junio, $25^{481}$ - 1355, noviembre, $28^{482}$

Arzobispo de Toledo y canciller real. Nombrado cardenal por el papa Clemente VI el 17 de diciembre de 1350 con el título de San Clemente. En su testamento dejaba como heredero de todos sus bienes al futuro Colegio de San Clemente para

\footnotetext{
${ }^{471}$ AHDP, Ampudia y Abadía de Husillos, Asociaciones, Libro 249.

472 Doc. núm. 109.

${ }^{473}$ AHDP, Ampudia y Abadía de Husillos, Asociaciones, Libro 249.

${ }^{474}$ Doc. núm. 111.

${ }^{475}$ Doc. núm. 130.

${ }^{476}$ Doc. núm. 112.

${ }^{477}$ Doc. núm. 128.

${ }^{478}$ Doc. núm. 127.

${ }^{479}$ CASTRO TOLEDO, Colección diplomática de Tordesillas, núm. 67, 59-60.

${ }^{480}$ Doc. núm. 138.

${ }^{481}$ Doc. núm. 142.

${ }^{482}$ Doc. núm. 146.
} 
los Españoles en Bolonia, que se comenzó a construir antes de su muerte, en el que la diócesis de Palencia tendría derecho de presentación de un colegial ${ }^{483}$. Durante su abadiato, Santa María de Husillos concertó en 1353 con el concejo de Villaumbrales el aprovechamiento de pastos en Villaudilla y sobre los pobladores de dicha villa y de Villaumbrales ${ }^{484}$. Parece que este concierto era el punto final a un largo enfrentamiento acaecido entre el arzobispado de Toledo, titular del señorío de Villaumbrales, y Santa María de Husillos. Si en una primera sentencia se favorecía al arzobispado al ser su titular Gil Álvarez de Albornoz, el hecho de que más tarde fuera abad de Husillos hizo que se llegara al concierto ${ }^{485}$.

- Gutierre Gómez: 1366, abril, $13^{486}$ - 1376, noviembre, $7^{487}$

Hijo de Tel Fernández, alcalde mayor de Toledo, era también sobrino del obispo de Palencia Gutierre I Gómez de Toledo, canciller y capellán mayor de la reina Juana Manuel, canónigo en la catedral de Palencia y racionero en la catedral de Toledo.

- Juan Fernández: 1378, agosto, $26^{488}$

Bachiller en decretos. Durante su abadiato, Enrique II puso en 1378 a la abadía bajo su protección ${ }^{489}$.

- Juan Martínez: [1378, agosto, 27 - 1382, septiembre, 29]

Fue al mismo tiempo que abad de Husillos, nuncio y colector del papa, y futuro obispo de Calahorra ${ }^{490}$.

- Sancho Martínez: 1382, septiembre, $30^{491}$

\footnotetext{
${ }^{483}$ SAN MARTÍN PAYO, Cardenales abades de Santa María de Husillos, 62.

${ }^{484}$ Doc. num. 145.

${ }^{485}$ SAN MARTÍN PAYO, Cardenales abades de Santa María de Husillos, 61.

${ }^{486}$ LEÓN TELLO, Judios de Toledo, II, núm. 548, 153-154.

${ }^{487}$ Doc. num. 186.

${ }^{488}$ Doc. núm. 190.

${ }^{489}$ Doc. núm. 90.

${ }^{490}$ MANSILLA, Catálogo catedral de Burgos, núm. 1636, 411.

${ }^{491}$ Doc. núm. 201.
} 
Es uno de los máximos exponentes de la crisis y relajación moral e institucional al que llegó la abadía durante el siglo XIV. Tuvo tres hijos que ocuparon beneficios eclesiásticos, además de otros familiares ${ }^{492}$.

- Juan González de Illescas: 1384, agosto, $21^{493}$ - $1393^{494}$ : miembro de la audiencia real. Aparece en las actas de cortes de 1393. Durante su abadiato, Juan I en 1388 puso bajo su protección a la hacienda y vasallos de la abadía.

- Fernando Díaz de Aguilar: 1424, junio, $2^{495}$ - 1431, junio, $26^{496}$

Doctor en decretos y canónigo en la catedral de Palencia.

- Juan de Carvajal: 1436, mayo, $2^{497}$ - 1457, junio, $17^{498}$

Nació en Trujillo hacia el año 1399 y muere en Roma en 1469. Además del abadiato de Husillos, en donde inició el linaje de los Carvajal, poseía otros beneficios como archidiácono de Alcaraz, en la diócesis de Toledo, abad de Santa María de Morteruela, en la diócesis de Zamora, y deán de la catedral de Astorga. En 1438 entra en el tribunal de la Rota Romana como Oidor del Palacio Apostólico, y en 1446 es nombrado cardenal ${ }^{499}$.

- Luis de Carvajal: 1470 , julio, $6^{500} 1472$, octubre, $21^{501}$

Concordó con el prior y cabildo en 1472, unos estatutos sobre bienes, jurisdicción y prebendas.

- Francisco de Madrid: 1475, abril, $28^{502}$

- Francisco Martínez: 1478, enero, $16^{503}$

\footnotetext{
492 Doc. núm. 201.

${ }^{493}$ Doc. núm. 206.

${ }^{494}$ ARRANZ GUZMÁN, Abades y monasterios en las Cortes castellanas, 487-504.

495 ACP, Arm. IV, leg. 6-4.

${ }^{496}$ Doc. núm. 225.

${ }^{497}$ SAN MARTÍN PAYO, Cardenales abades de Santa María de Husillos, 63.

${ }^{498}$ Doc. núm. 230.

${ }^{499}$ SAN MARTÍN PAYO, Cardenales abades de Santa María de Husillos, 64.

${ }^{500}$ FRANCIA LORENZO, Actas Capitulares de la catedral de Palencia, núm. 3324.

${ }^{501}$ Doc. núm. 233.

${ }^{502}$ FRANCIA LORENZO, Actas Capitulares de la catedral de Palencia, núm. 3681.
} 
Durante su abadiato se produjo el pleito entre el prior y cabildo con el tesorero Fernando de Corral, sobre los diezmos de Pajares ${ }^{504}$.

- Francisco García: 1481 - $1482^{505}$

- Francisco Núñez de Madrid: 1483, abril, $28^{506}$ - 1500, abril, $28^{507}$

Doctor y oidor de la Real Audiencia y Chancillería de Valladolid, y canónigo de la catedral de Palencia. Pidió y consiguió de los Reyes Católicos que liberaran a la abadía de la encomienda que ejercía sobre ésta el conde de Rivadavia y su alcaide de Fuentes de Valdepero ${ }^{508}$. Durante su abadiato se fundó en 1493 la cofradía de Nuestra Señora de Dehesa Brava ${ }^{509}$ y se llegó a un acuerdo con la abadía de Hérmedes por la que esta última tomaba en censo las heredades de Husillos en San Sebastián de Hérmedes ${ }^{510}$.

Debido al apoyo de la iglesia palentina a la causa de Isabel I en la guerra contra Portugal, se le encargó la misión de recoger toda la plata posible de la diócesis para la causa de la reina ${ }^{511}$.

- Antonio de Acuña: 1501, julio, $10^{512}$

$\mathrm{Su}$ condición de capellán real de los Reyes Católicos fue clave para su nombramiento como abad, ante la oposición que parece existía contra él.

- Pedro González: circa $1514^{513}$

- Jerónimo García Fernández de Bovadilla: 1507, mayo, $26^{514}$ - 1523, febrero, $20^{515}$. Llegó a ser protonotario apostólico. Fue defensor de la obra de Erasmo de

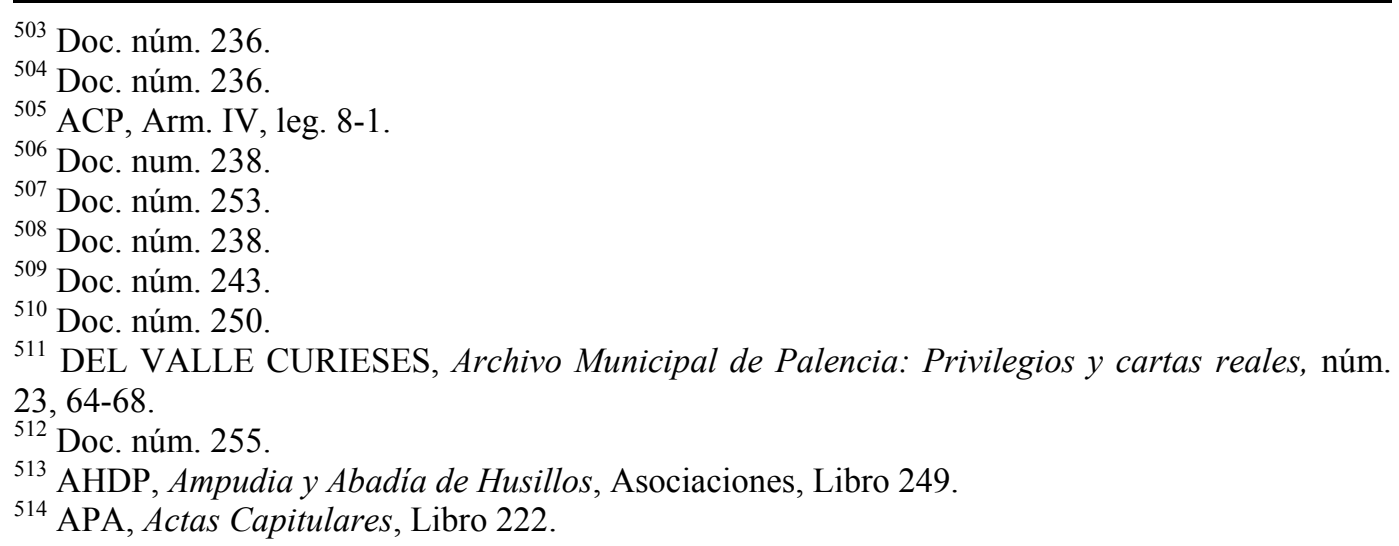


Rotterdam, como se deduce de una carta fechada en Palencia, el 26 de noviembre de 1526, en la que intenta convencer al cardenal Cisneros de que llamase al humanista para la publicación de la Biblia Políglota de Alcalá ${ }^{516}$.

- Bernardino López de Carvajal: 1523 , febrero, $20^{517}$.- 1523 , diciembre, $6^{518}$

Nació en 1456 en Plasencia y murió en Roma en 1523. Era sobrino de Juan de Carvajal. Entre 1488 y 1493 recibe los obispados de Astorga, Badajoz y Cartagena, siendo nombrado cardenal por el papa Alejandro VI en 1493, y obispo de Sigüenza en 1495. En febrero de 1523 es nombrado abad de Husillos, tras la muerte del anterior abad.

- Rodrigo de Carvajal: 1524 , marzo, $4^{519}$.

Se documenta como Patriarca de Jerusalén.

- Francisco de Carvajal: 1533 , noviembre, $6^{520}$ - 1555 , enero, $18^{521}$

Durante su abadiato se realizó el Libro de los Privilegios, como resultado de la visita de su tío, el obispo de Plasencia Gutierre de Carvajal, además de unos estatutos $^{522}$ y del inventario de rentas ${ }^{523}$. Antes, en 1536, había llegado a una concordia con el prior y cabildo sobre jurisdicción y otros temas económicos. Mantuvo pleitos con los concejos de Villaldavín ${ }^{524}$ y Husillos ${ }^{525}$ sobre derechos de pasto, tributos y nombramientos de oficiales de justicia, aunque en el fondo estos concejos trataron de escapar infructuosamente del dominio señorial de la abadía amparándose en el dominio de la corona.

- Domingo de Carvajal: 1561, agosto, $2^{526}$ - 1563, abril, $28^{527}$

\footnotetext{
${ }^{515}$ SAN MARTÍN PAYO, Cardenales abades de Santa María de Husillos, 69.

${ }^{516}$ SAN MARTÍN PAYO, ibid., 69.

${ }^{517}$ SAN MARTÍN PAYO, ibid., 69.

${ }^{518}$ SAN MARTÍN PAYO, ibid., 69.

${ }^{519}$ SAN MARTÍN PAYO, ibid., 70.

${ }^{520}$ Doc. núm. 268.

${ }^{521}$ Doc. núm. 298.

522 Doc. núm. 297.

${ }^{523}$ Doc. núm. 298.

${ }^{524}$ Doc. núm. 275.

${ }^{525}$ Doc. núm. 283.

${ }^{526}$ ACP, Arm. III, leg. 13-8.

${ }^{527}$ Doc. núm. 305.
} 
Mantuvo pleito con el cabildo de la catedral de Palencia por el pago de la media annata, que llegó incluso a la Rota Romana, que acabó determinado a favor del primero $^{528}$.

- Francisco de Vargas Carvajal: 1569 , octubre, $2^{529}$ - 1572, junio, $13^{530}$

- Francisco de Reinoso: 1576, agosto, $23^{531}$ - 1596, octubre, $22^{532}$

Durante su abadiato se produjo una renovación en Santa María de Husillos que afectó a todos los ámbitos de la institución, desde el mismo edificio abacial hasta la hacienda y la regulación interna.

- Sancho González de Heredia: 1597, febrero, $27^{533}$ - 1597, octubre, $13^{534}$

Nombrado por Felipe II, fue el primer abad nombrado en virtud del patronazgo real de la abadía ${ }^{535}$.

- Diego Messia de Lasarte: 1597 , noviembre, $1^{536}$

- Juan de Cortázar: $1601^{537}$ - 1602-08-30 538

Inquisidor en Valladolid.

\section{Dignidades, canónigos y oficiales de Santa María de Husillos:}

Entre las dignidades de Santa María de Husillos, después del abad la más importante era el prior. El primer prior documentado es Pedro, en $1146^{539}$. De gran importancia fue el priorato de Miguel, según se constata en su testamento de

\footnotetext{
${ }^{528}$ ACP, Arm. III, leg. 13-8.

${ }^{529}$ Doc. núm. 306.

${ }^{530}$ Doc. núm. 307.

${ }^{531}$ ACP, Actas Capitulares, f. 37v.

${ }^{532}$ CASTRO SÁNCHEZ, Vida de Francisco de Reinoso, 64.

${ }^{533}$ Doc. núm. 340.

${ }^{534}$ APA, Actas Capitulares, Libro 226.

${ }^{535}$ Doc. núm. 338.

${ }^{536}$ APA, Actas Capitulares, Libro 226. Fue nombrado abad en dicha fecha.

${ }^{537}$ AHDP, Ampudia y Abadía de Husillos, Asociaciones, Libro 249.

${ }^{538}$ APA, Actas Capitulares, Libro 227. Fecha de su muerte.

${ }^{539}$ Doc. núm. 24.
} 
entre 1232 y 1243 , en el que se hace referencia a las obras que mandó realizar en la iglesia, en concreto en el coro y en el altar mayor ${ }^{540}$.

El prior era elegido por el cabildo, pero debía ser confirmado por el abad, según se desprende del nombramiento del prior Juan Fernández en $1370^{541}$. Por otra parte, se valoraba para su nombramiento que estuviera ordenado en órdenes mayores $^{542}$.

A medida que aumentaba el absentismo de los abades por la acumulación de prebendas, especialmente a partir del siglo XIV, en la que el abadiato de Husillos era uno más y no de los más importantes, el protagonismo e importancia del prior aumentaba en paralelo, convirtiéndose en el verdadero rector de la abadía. En este sentido habría que destacar al prior Juan Pérez de Acebes, documentado entre $1330^{543}$ y $1355^{544}$. Solamente en tres ocasiones se le denomina al prior también como presidente del cabildo, en $1472^{545}, 1585^{546}$ y $1588^{547}$.

A partir de la institución de la canónica en 1183, debió desarrollarse y aumentar la estructura y número de dignidades y oficios en la abadía, aunque desde mediados del siglo XII se documenten distintos cargos y oficios. Así el primer sacristán documentado, Andrés, aparece en 1146, al igual que el primer preceptor, llamado también Andrés ${ }^{548}$. El primer capiscol, Andrés, y el primer mayordomo, Gualterio, aparecen en $1151^{549}$. En 1154 se documenta el primer prepósito, Pedro Iohanes $^{550}$. El primer tesorero, Pedro Arnalli, aparece en $1228^{551}$, y el primer cantor, Echnico, en $1202^{552}$.

\footnotetext{
${ }^{540}$ Doc. núm. 60.

${ }^{541}$ Docs. núm. 156 y 157 -

${ }^{542}$ Doc. núm. 153.

${ }^{543}$ Doc. núm. 112.

${ }^{544}$ Doc. núm. 146.

545 Doc. núm. 233.

${ }^{546}$ Doc. núm. 326.

${ }^{547}$ Doc. núm. 329.

548 Doc. núm. 24.

${ }^{549}$ Doc. núm. 25.

${ }^{550}$ Doc. núm. 26.

551 Doc. núm. 52.

${ }^{552}$ Doc. núm. 47.
} 
El primer chantre documentado es Alfonso Rodríguez, en $1301^{553}$. El chantre era una dignidad que se ocupaba del gobierno del canto en el coro, y era el sucesor del capiscol.

En cuanto a los porcioneros o racioneros de Husillos, el último testimonio de porcionero es de $1370^{554}$, mientras que el primer testimonio de racionero es de $1375^{555}$. Vemos así que el cambio en la denominación de este beneficiado se produce en el último cuarto del siglo XIV.

Las iglesias pertenecientes a Santa María de Husillos se gobernaban y regían a través de clérigos, vicarios y capellanes que podían ser al mismo tiempo canónigos o beneficiados en Husillos, actuando en ocasiones como confirmantes en los documentos de la abadía. Es el caso de Juan Abad, capellán de la iglesia de San Julián de Santillán de la Cuesta en $1295^{556}$, o de Juan Martínez, vicario de Grijota y canónigo de Husillos ${ }^{557}$.

Además de las dignidades, canónigos y racioneros, existía un grupo de personas que se encargaban de las labores de mantenimiento y auxilio de la abadía y que en ocasiones podían ser también eclesiásticos, como el criado del abad Martín Gómez en 1324, que era también clérigo ${ }^{558}$, o el criado también del abad Pedro Carrillo en 1500 , que era también familiar suyo ${ }^{559}$, Fernán Pérez, casero del abad en $1306^{560}$, o García Pérez, hombre del prior Juan Pérez de Acebes en $1341^{561}$, y que quizá tendría la connotación de un criado de confianza de dicho prior.

El primer procurador documentado de la abadía es Álvar Curiel en $1324^{562}$, cargo que seguramente naciese y se consolidase al calor del aumento de la litigación en el siglo XIV. El primer provisor que aparece es Diego Ruiz de Camargo en

\footnotetext{
${ }^{553}$ Doc. núm. 95.

${ }^{554}$ Doc. núm. 157.

555 Doc. núm. 177.

${ }^{556}$ Doc. núm. 88.

${ }^{557}$ Doc. núm. 154.

${ }^{558}$ Doc. núm. 106

${ }^{559}$ Doc. núm. 252.

${ }^{560}$ Doc. núm. 98.

${ }^{561}$ Doc. núm. 130.

${ }^{562}$ Doc. núm. 106.
} 
$1457^{563}$, que es además bachiller en decretos. El provisor formaría parte junto al abad del tribunal eclesiástico con jurisdicción sobre los beneficiados de la abadía.

A partir del siglo XIV fue normal la acumulación de prebendas en los beneficiados de Husillos. Así, por ejemplo, en 1486 Sancho Pérez de Calahorra, además de canónigo de Husillos, era clérigo de Palencia y notario apostólico ${ }^{564}$. En 1493, Pedro Ruiz de Villoldo, bachiller en decretos, además de prior en Husillos era también abad de Lebanza, con prebenda en la catedral de Palencia ${ }^{565}$.

El primer secretario del cabildo documentado es Sancho González de Calahorra en $1500^{566}$. Por último, el primer testimonio de contadores es de 1585 , año en que lo eran el canónigo Gaspar de Villadiego y el racionero Juan de la Portilla ${ }^{567}$.

Caso especial y de gran interés lo constituyen los maestros y preceptores documentados en cinco ocasiones en Santa María de Husillos entre 1146 y $1202^{568}$. Así tenemos a los preceptores Andrés ${ }^{569}$ y García ${ }^{570}$, y a los "magister" Poncio $^{571}$, Nicolás ${ }^{572}$ y Odón ${ }^{573}$. Posiblemente fueran todos ellos “magister" en la escuela episcopal existente en Palencia antes de la creación del "Studium generale"en 1208. Así, el maestro Nicolás aparece como "magister scole"574. Al igual que el cabildo catedralicio de Palencia, que estaba representado permanentemente en la universidad por el maestreescuela y varios canónigos con el título de "magister" 575 , el cabildo de Husillos estaría representado de igual modo.

\footnotetext{
${ }^{563}$ Doc. núm. 230.

564 Doc. núm. 241.

${ }^{565}$ Doc. núm. 243.

${ }^{566}$ Doc. núm. 252.

${ }^{567}$ Doc. núm. 326.

${ }^{568}$ Docs. núm. 24, 33, 40,42, 47.

${ }^{569}$ Doc. núm. 24.

${ }^{570}$ Doc. núm. 33.

${ }^{571}$ Doc. núm. 33.

572 Docs. núm. 42 y 47.

${ }^{573}$ Doc. núm. 40.

${ }^{574}$ Doc. núm. 47.

575 SAN MARTÍN PAYO, El cabildo de Palencia, 229-248.
} 


\section{LA ABADÍA DE SANTA MARÍA DE HUSILLOS: ESTUDIO Y COLECCIÓN \\ DOCUMENTAL $(904-1608)$}

En cuanto al origen social de las dignidades, canónigos y beneficiados de Husillos, es de suponer que cuanto más alto era el beneficio, de más alto estatus era la procedencia social del que lo ocupaba. Creemos que la dignidad abacial estuvo siempre ocupada por personas de origen nobiliario o del alto clero. Así, por ejemplo, Pedro de Cardona era probablemente familiar del rey Alfonso VIII $^{576}$, mientras que Gonzalo Pérez de Torquemada era nieto del conde Ponce de Minerva $^{577}$. Este origen nobiliario es más evidente a partir del siglo XIII y sobre todo en los siglos XIV, XV y XVI, en un proceso general en la iglesia castellana, cuando algunos linajes locales ocupen obispados y altas dignidades eclesiásticas, como es el caso de los Carvajal, linaje oriundo de Extremadura, que ocupó obispados extremeños y el abadiato de Husillos entre mediados del siglo XV y el tercer cuarto del siglo XVI, desde Juan de Carvajal hasta Francisco de Vargas Carvajal. Además de los Carvajales hay otros ejemplos como Gutierre Gómez, hijo de Tel Fernández, alcalde mayor de Toledo, y sobrino del obispo de Palencia Gutierre I Gómez de Toledo ${ }^{578}$.

Otro grupo de abades van a ser aquellos pertenecientes al alto clero y que van a ocupar la abadía como una prebenda más, sobre todo en los siglos XIV y XV, en los que es normal la acumulación de prebendas eclesiásticas. Es el caso de los cardenales-abades de Husillos y de aquellos que ocupaban cargos cercanos al papa, como Pedro Rodríguez Hispano ${ }^{579}$, Esteban ${ }^{580}$, Gil Álvarez de Albornoz ${ }^{581}$, Juan de Carvajal $^{582}$ y Bernardino López de Carvajal ${ }^{583}$, o de Antonio de Acuña ${ }^{584}$, capellán real de los Reyes Católicos.

Existiría también un grupo de abades que formarían parte de la administración central o de justicia, en instituciones como la cancillería, las cortes o la audiencia.

\footnotetext{
$5761178-1181$

577 1183-1232.

578 1366-1376.

5791296.

5801252.

${ }^{581} 1353-1355$.

${ }^{582}$ 1436-1457.

5831523

5841501 .
} 
Es el caso de Pedro de Cardona ${ }^{585}$, canciller real, Gutierre Gómez ${ }^{586}$, canciller de la reina, Juan González de Illescas ${ }^{587}$, miembro de la audiencia real y presente en las cortes de Madrid de $1393^{588}$, Francisco Núñez de Madrid ${ }^{589}$, oidor de la Chancillería de Valladolid, y Juan de Cortázar, inquisidor en Valladolid ${ }^{590}$.

En cuanto a los canónigos, su origen social fue también nobiliario, especialmente de la pequeña nobleza, sobre todo en los siglos XIV y XV, en concordancia con el resto de cabildos castellanos ${ }^{591}$, aunque también hay casos de grandes linajes nobiliarios como el canónigo de Husillos Juan Alfonso de Toledo, pariente del obispo de Palencia Gutierre I Gómez de Toledo ${ }^{592}$.

En ocasiones, los canónigos e incluso los abades serían originarios de la pequeña nobleza rural palentina. Los racioneros, clérigos y capellanes de las iglesias de Husillos provendrían de las familias hidalgas y de labradores ricos de la zona.

Todos los miembros de Santa María de Husillos, desde los abades hasta los racioneros, actuarían como testigos y confirmantes en numerosos actos jurídicos sobre todo de instituciones eclesiásticas de la zona, especialmente de la catedral de Palencia y monasterios de la diócesis palentina. Así, por ejemplo, el 15 de diciembre de 1110, Urraca I confirma a la iglesia de Santa María de Valladolid todas las donaciones recibidas, actuando como confirmante el abad Poncio Guitardo $^{593}$. La misma reina hace unas donaciones a San Isidro de Dueñas el 20 de enero de 1116, apareciendo también como confirmante Poncio Guitardo ${ }^{594}$. El 29 de enero de 1163, la sede episcopal palentina premia al clérigo Bucio unos servicios prestados. Entre los confirmantes aparece el abad Raimundo Giliberti $^{595}$. En 1173 el abad Pascual de Santa María de Benevívere hace una

\footnotetext{
${ }^{585} 1178-1181$.

$5861366-1376$.

${ }^{587} 1384-1393$.

${ }^{588}$ ARRANZ GUZMÁN, Abades y monasterios en las Cortes castellanas, 487-504.

589 1483-1500.

$5901601-1602$.

${ }^{591}$ DÍAZ IBÁÑEZ, La incorporación de la nobleza al alto clero, 557-604.

${ }^{592}$ DÍAZ IBÁÑEZ, La incorporación de la nobleza al alto clero, 557-604.

593 ABAJO, Documentación Catedral de Palencia, núm. 22, 57-58.

${ }^{594}$ REGLERO, San Isidro de Dueñas, núm. 40, 378-379.

595 ABAJO, Documentación Catedral de Palencia, núm. 65, 136-137.
} 
permuta con el obispo de Palencia, apareciendo entre los confirmantes también el abad Raimundo Giliberti ${ }^{596}$.

El 10 de septiembre de 1179 Alfonso VIII dona a la sede episcopal palentina y al hospital de San Antolín la villa de Pedraza. El canciller que realiza el documento es el abad Pedro de Cardona ${ }^{597}$.

En 1227 el abad de Husillos Gonzalo Pérez realiza una venta al monasterio de Santa María de Aguilar de Campóo. Entre los confirmantes aparecen el prior Miguel y varios canónigos de Husillos ${ }^{598}$. El 9 de febrero de 1395 el monasterio de San Zoilo hace una cesión de un solar a Pedro Chiquillo. Como notario apostólico aparece el canónigo de Husillos Alfonso Ruiz de Frechilla ${ }^{599}$.

Pero los miembros de Husillos iban a actuar también en los negocios jurídicos de iglesias y monasterios de otras diócesis. Así, el 1 de mayo de 1222 la priora del monasterio de Carrizo hace una reclamación a María Petri, actuando como confirmante el abad Gonzalo Pérez ${ }^{600}$. En agosto de 1240 el maestro Diago vende a Pedro Martínez, para el monasterio de Las Huelgas, una heredad, apareciendo entre los testigos Ferrán García, clérigo de Husillos y de Palencia ${ }^{601}$. Por último, el 12 de julio de 1300 el notario Martín hace pública escritura de la parte del testamento de Juan Álvarez, obispo de Osma, referente al monasterio de Santo Toribio de Liébana. Entre los albaceas de dicho obispo aparece el prior de Husillos Pedro Domínguez ${ }^{602}$.

Los abades, dignidades y tesoreros de Santa María de Husillos actuaron también como jueces y árbitros en tribunales eclesiásticos en las disputas entre distintas instituciones eclesiásticas. Así, por ejemplo, el 13 de agosto de 1341, el abad Nuño Díaz era juez y árbitro en la disputa entre el obispo de Palencia y el abad de Sahagún sobre ciertos derechos en el priorato de Nogal ${ }^{603}$. En 1346 los obispos de

\footnotetext{
${ }^{596}$ L. FERNÁNDEZ, Benevívere, núm. 13, 17.

${ }^{597}$ ABAJO, Documentación Catedral de Palencia, núm.83, 163-165.

${ }^{598}$ RODRÍGUEZ DE DIEGO, Colección diplomática de Santa María de Aguilar, núm. 393, 417418.

${ }^{599}$ PÉREZ CELADA, Documentación de San Zoilo de Carrión, II, 255-257.

${ }^{600}$ CASADO LOBATO, Carrizo, I, núm. 121, 139-140.

${ }^{601}$ LIZOAIN, Las Huelgas de Burgos, núm. 319, 97-98.

${ }^{602}$ SÁNCHEZ BELDA, Santo Toribio de Liébana, núm. 211, 242.

${ }^{603}$ ACP, Arm. II, leg. 2-6.
} 
Palencia y de Zamora daban poder al abad Pedro Fernández y a Miguel Ramírez, arcipreste de Toro, para que averiguasen los límites de sus respectivos obispados $^{604}$. En 1378 el sacristán Fernando Rodríguez actuaba de testigo, junto al obispo de Palencia y el abad de Lebanza, en la concordia entre el monasterio de Santa Clara de Reinoso y el deán y cabildo catedralicio de Palencia, sobre el traslado de dicho monasterio a la ciudad de Palencia ${ }^{605}$. El 5 de abril de 1447, el papa Nicolás V comisionaba al prior de Husillos para que decidiera sobre la donación por Velasco Fernández, clérigo de la diócesis de Zamora, del prestimonio de Esgueva al hospital de Esgueva de Valladolid ${ }^{606}$. Por último, el 4 de junio de 1530 el tesorero Suero González de Benavides dio sentencia contra unos vecinos de Villasirga sobre diezmos ${ }^{607}$.

\footnotetext{
${ }^{604}$ CASTRO TOLEDO, Colección diplomática de Tordesillas, núm. 67, 59-60.

${ }^{605}$ CASTRO Y CASTRO, Santa Clara de Palencia, num. 2, 7-11.

${ }^{606}$ AMV, Pergaminos, Carpeta 1-7.

${ }^{607}$ ACP, Arm. VIII, leg. 2-4.
} 


\subsection{NOTAS SOBRE LA BIBLIOTECA Y EL ARCHIVO DE SANTA MARÍA DE HUSILLOS}

\section{La biblioteca}

Al igual que otras instituciones eclesiásticas, Santa María de Husillos conservaría sus libros litúrgicos en la sacristía y en el coro a cargo del sacristán y tesorero, mientras que el resto de libros los conservaba de forma separada en una librería $^{608}$. Así, los mismos tesoreros de Husillos testimonian en algunas ocasiones que solamente están a su cargo los citados libros litúrgicos ${ }^{609}$.

Tenemos noticia de los libros litúrgicos y del resto de libros de Husillos a través de las visitas realizadas por distintos abades y provisores en la segunda mitad del siglo XVI. Ese el caso de la visita de Pedro de Espinosa, provisor del abad Francisco de Vargas Carvajal, realizada en junio de 1572, en la que se hace inventario de los libros litúrgicos y del resto de libros en base a un inventario anterior del año 1554. Se contabilizan 32 libros litúrgicos, entre misales, breviarios, salterios, y libros de canto; y 52 libros conservados en la librería.

En visita a la sacristía de marzo de 1579 , se hace inventario de los libros litúrgicos conservados en la sacristía y en el coro, que están al cuidado del tesorero Hernando Ruiz Moreno; y de los libros conservados en la librería ${ }^{610}$. De los primeros se contabiliza un total de 25 , mientras que de los segundos contabilizamos alrededor de 50: libros de Cicerón, Plinio, Plutarco, de Derecho Canónico, Geografía, crónicas, libros de gramática latina y hebrea, etc.. Vemos así que se conserva un similar número de libros en las dos citadas visitas.

La biblioteca de Santa María de Husillos sería de un aceptable volumen, ya que estaría en consonancia con el volumen medio de las bibliotecas monásticas, que sería de cincuenta ejemplares aproximadamente ${ }^{611}$.

\section{El archivo}

\footnotetext{
${ }^{608}$ RUIZ ASENCIO, Escribas y bibliotecas altomedievales, 151-174. Observa que en el común de las bibliotecas monásticas los libros litúrgicos se conservan en la sacristía.

${ }^{609}$ En marzo de 1576 el tesorero Hernando Ruiz Moreno da testimonio de que están a su cargo solamente los libros misales (Doc. núm. 319).

${ }^{610}$ Doc. núm. 319.

${ }^{611}$ RUIZ ASENCIO, Escribas y bibliotecas altomedievales, 151-174.
} 
Era el archivo el mayor tesoro de cualquier institución de las edades Media y Moderna, ya que conservaba la documentación que justificaba todas sus propiedades y derechos, amén del resto de documentación producto de su actividad administrativa. La estrecha relación entre el archivo y las rentas y derechos se trasluce claramente en las razones que adujo Gutierre de Carvajal, tío del abad Francisco de Carvajal, quien en visita a la abadía en el año 1554 ordenó sacar traslado de todas las escrituras del archivo, dando lugar así al Libro de los Privilegios de Husillos. Así, adujo a la pérdida progresiva de importancia de la documentación del archivo por el paso del tiempo, debido al descuido y la desidia, y con ello la pérdida de numerosas rentas ${ }^{612}$.

La confección del cartulario de documentos en 1554 supuso la constitución de un archivo de seguridad y de conservación de los originales, ya que se estableció que las consultas que se tendrían que hacer en el futuro se harían a través de los traslados de dicho libro, debiendo estar los originales en una caja que tendría tres llaves, en poder del prior, del canónigo más antiguo y del secretario del cabildo ${ }^{613}$. En el caso de que las gestiones administrativas o judiciales a realizar implicaran la presentación de los documentos originales, se estableció un procedimiento de préstamo y de seguridad. Así, se debía tener conocimiento del secretario o escribano ante quien se presentara, depositándolo en el archivo, estableciendo fuertes penas para quien incumpliera el citado procedimiento o perdiera el documento $^{614}$.

En agosto de 1592, por motivo del expediente para la declaración de patronazgo real de la abadía, Juan Chacón, corregidor de Palencia, informa de que muchas de las escrituras del archivo se quemaron en un incendio que tuvo lugar hacía muchos años ${ }^{615}$, expresando asimismo que el archivo se encontraba en la sacristía. Suponemos que anteriormente se encontraría también en la sacristía, dada la

\footnotetext{
${ }^{612}$ Doc. núm. 296.

613 Doc. núm. 296..

${ }^{614}$ Doc. núm. 296. A pesar del celo por el cuidado de los originales, no se pudo impedir que gran número de originales acabasen en los archivos o dependencias de otras instituciones como la catedral de Palencia o la Real Chancillería de Valladolid. Por otra parte, las notas dorsales que presentaban los documentos originales facilitaban la gestión documental (HERRERO JIMÉNEZ, Sandoval, 27).

${ }^{615}$ Doc. núm. 335. Teniendo en cuenta el número de documentos de la colección trasladados en el Libro de los Privilegios y de los que no se conserva el original, deducimos que alrededor de un tercio de los documentos del archivo desaparecerían en el incendio.
} 
consideración del archivo como uno de los objetos más preciados de la abadía, conservándose junto con las reliquias, los objetos de oro y plata y otros de gran valor $^{616}$. La consideración del archivo como tesoro y elemento de seguridad se refleja también en el hecho de que actuaba como depósito dinerario de la abadía, según se desprende de dos actas capitulares de 17 de octubre de $1586^{617}$, y de 8 de julio de $1588^{618}$.

En cualquier caso, llama la atención el hecho de que en ninguno de los estatutos de la abadía, especialmente en los estatutos otorgados por Francisco de Reinoso en 1588 , no exista ninguna constitución relativa al archivo de la institución ${ }^{619}$.

${ }^{616}$ MARCOS DÍEZ, Los archivos monásticos y sus fondos documentales.

${ }^{617}$ APA, Actas Capitulares, Libro 225.

${ }^{618}$ APA, Actas Capitulares, Libro 226.

${ }^{619}$ Doc. núm. 330. 
DAVID MARCOS DIEZ 


\subsection{CONCLUSIONES}

Santa María de Husillos tuvo una evolución histórica y de su dominio similar al de algunas instituciones eclesiásticas del ámbito palentino. Su larga existencia, desde principios del siglo $\mathrm{X}$ hasta principios del siglo XVII, unos siete siglos, hace que atraviese por varias épocas de apogeo y otras de crisis, generalmente en concordancia con el contexto general. Así el siglo $\mathrm{X}$ fue el siglo en el que se pusieron sus bases y fue uno de los períodos de oro de la abadía, que llegó a ser sede diocesana. Entre finales del siglo X y primer tercio del XI vivió un período de profunda crisis en el que incluso es posible que llegara a desaparecer, al igual que el condado de Monzón, por las campañas de Almanzor. Con Sancho el Mayor de Navarra se ponen los cimientos para una nueva época esplendorosa que habría de llegar hasta finales del siglo XIII, llegando a su máximo apogeo con Alfonso VI, en cuyo reinado se celebra el concilio de Husillos de 1088, y con el rey Sancho III el deseado, que concedió numerosos privilegios y confirmaciones a la abadía y a sus miembros..

A partir de fines del siglo XIII se empiezan a dar los primeros síntomas de la crisis generalizada que abarcaría todo el siglo XIV, aunque en el caso de Husillos, al igual que en el de otras instituciones eclesiásticas, sería mucho más agónico el siglo XV. Las consecuencias de la crisis que llegó a abarcar hasta bien entrados el siglo XVI, fueron una pérdida progresiva del dominio territorial, intromisiones de las autoridades reales intermedias, de los concejos y de otras instituciones eclesiásticas, la gran actividad litigante, la desaparición de la mayor parte de las villas integrantes del dominio territorial y jurisdiccional de la abadía, y la crisis moral y religiosa de sus miembros.

Aunque en el siglo XVI se produjo una ligera mejoría en la institución y en su dominio, marcada por la acción renovadora de algunos abades como Francisco de Carvajal y Francisco de Reinoso, los cimientos sobre los que se basaba la abadía estaban ya muy debilitados, a lo que habría que añadir los ataques exteriores contra su autoridad y dominio, esta vez provenientes de la realeza, con las desamortizaciones de la segunda mitad del siglo XVI y con el patronazgo real de Felipe II, de ahí que a principios del siglo XVII se realizara fácilmente el traslado con el apoyo de los miembros de la iglesia. 
DAVID MARCOS DIEZ 
LA ABADÍA DE SANTA MARÍA DE HUSILLOS: ESTUDIO Y COLECCIÓN DOCUMENTAL (904 - 1608)

2

ESTUDIO DIPLOMÁTICO Y PALEOGRÁFICO 
DAVID MARCOS DIEZ 


\subsection{CRITERIOS DE EDICIÓN}

Se editan los documentos en los que el autor o destinatario es Santa María de Husillos como institución o alguno de sus miembros de forma individualizada, sobre un asunto relativo a la institución o a alguno de sus miembros. También los documentos en los que, siendo el autor y destinatario ajenos a Husillos, el asunto hace relación, de forma total o parcial, a dicha iglesia; y aquellos documentos en que siendo el autor, destinatario y asunto ajenos a Husillos, pertenecen no obstante a dicha institución por acumulación ${ }^{1}$.

Los criterios de edición o regesto de la documentación van a variar según unos períodos cronológicos determinados y del productor por acumulación.

- Hasta 1400:

Se editan los documentos cuyo productor por acumulación sea Santa María de Husillos. Aquellos cuyos productores sean otras instituciones, se editan o regestan según la importancia del documento para la primera.

Caso especial es el de los privilegios de diferentes reyes y papas expedidos a la sede episcopal palentina, donando y confirmando sus posesiones, entre las que se encuentra Santa María de Husillos ${ }^{2}$. Se ha optado por regestar aquellos documentos en los que la citada abadía aparece expresamente en la nómina de villas e iglesias donadas y confirmadas.

- Entre 1400 y 1500 :

En el caso de que el productor por acumulación sea Husillos, se editan o regestan según varios criterios:

\section{Edición completa:}

- Todos los documentos que estén trasladados en el Libro de los Privilegios, se conserven o no en su forma original.

\footnotetext{
${ }^{1}$ En concordancia con la teoría archivística (Normas ISAD-G-), distinguimos entre el productor por acumulación y por creación de un documento. Así el primero sería aquel en cuyo archivo se ha conservado el documento en cuestión, mientras que el segundo sería el autor del documento.

${ }^{2}$ Estos documentos se conservan en el Archivo Capitular de Palencia.
} 
- Los documentos que tengan gran trascendencia, aunque no estén trasladados en el Libro de los Privilegios ${ }^{3}$.

\section{Regesto:}

Los documentos que, no teniendo traslado en el Libro de los Privilegios, informan sobre la evolución del dominio territorial de Husillos y sus relaciones con otras instituciones y particulares (donaciones, testamentos, compraventas, censos, documentos judiciales, etc.).

Al igual que en el período anterior, los documentos cuyo productor son otras instituciones, se editan o regestan en función de su importancia para Santa María de Husillos.

- Entre 1500 y 1608 :

Indistintamente del productor, se editan los documentos de gran trascendencia para Husillos, como por ejemplo las ordenanzas dadas a la abadía por Francisco de Reinoso, los memoriales contra el traslado de la abadía a Tordesillas, la protesta del cabildo catedralicio de Palencia contra el traslado a Ampudia, etc. Igualmente, se regestan indistintamente del productor, los documentos de importancia para establecer la evolución del dominio territorial de Husillos o que informen sobre el funcionamiento interno de la abadía o de sus relaciones con otras instituciones y particulares (donaciones, testamentos, compraventas, censos, visitas, documentación judicial, etc).

\footnotetext{
${ }^{3}$ Docs. núm. 233 y 243.
} 


\section{LA ABADÍA DE SANTA MARÍA DE HUSILLOS: ESTUDIO Y COLECCIÓN \\ DOCUMENTAL $(904-1608)$}

\subsection{FUENTES}

\section{FUENTES MANUSCRITAS}

La colección documental de Santa María de Husillos está formada por 351 documentos editados o regestados, procedentes de varios archivos y bibliotecas, de las que se hace una relación según el orden de importancia en cuanto al volumen documental que conservan sobre Husillos.

\section{Archivo Histórico Diocesano de Palencia:}

Conserva el grueso del archivo de la abadía, ya que dicho archivo, que se llevó a Ampudia con motivo del traslado en 1607, fue trasladado más tarde al Archivo Capitular de Palencia, posiblemente tras la desamortización de la colegiata de San Miguel de Ampudia en 1851. Desde el Archivo Capitular se trasladaría al Archivo Diocesano de Palencia, conservándose en dicho archivo de forma entremezclada con documentación de la citada colegiata de San Miguel ${ }^{4}$. Pertenecen a este archivo 125 documentos originales de la colección ${ }^{5}$ y 72 copias $^{6}$.

\section{Archivo Parroquial de Ampudia:}

Conserva un cartulario o libro becerro de la documentación más importante de Santa María de Husillos en el momento de su realización, entre fines de 1554 y comienzos de 1555, y que en nuestro estudio denominamos como Libro de los Privilegios de Santa María de Husillos (LPH), al ser ésta la denominación que le dio Jesús San Martín Payo, primer autor que abordó el estudio de dicho libro ${ }^{7}, \mathrm{y}$

\footnotetext{
${ }^{4}$ En el inventario analítico de dicho archivo, realizado por el archivero Francisco Herreros Estébanez, la documentación de Husillos se localiza en el grupo documental denominado "Ampudia y abadía de Husillos", organizándose en varias secciones: Libros sacramentales, Fundaciones, Cofradías, Asociaciones, Sueltos, Legajos y Papeles, y Pergaminos, que se conserva en el Archivo Diocesano de Palencia y en el Archivo Parroquial de Ampudia.

${ }^{5}$ Docs. núm. 13, 16, 21, 25, 26, 27, 29, 30, 31, 33, 35, 36, 37, 38, 40, 46, 47, 48, 49, 50, 51, 52, 53, $56,57,58,59,60,61,63,64,65,66,71,72,74,81,82,84,85,86,90,93,97,98,100,102,106$, $112,113,127,128,130,134,135,136,137,138,145,149,155,161,162,163,164,165,166$, $168,169,171,173,174,182,184,186,188,192,194,199,200,203,205,206,207,211,212$, $213,214,215,216,219,220,222,223,226,227,228,231,233,235,236,239,241,242,243$, $252,253,254,256,264,268,269,282,301,308,310,318,322,327,328,330$ у 331.

${ }^{6}$ Docs. núm. 8, 9, 18, 19, 20, 27, 28, 30, 35, 36, 37, 47, 57, 65, 67, 74, 75, 77, 82, 84, 96, 97, 100, $104,110,111,113,114,124,125,126,129,139,140,141,142,143,144,150,151,152,153$, $154,156,157,158,159,160,162,163,167,172,175,176,177,178,180,181,183,188,190$, 191, 193, 195, 196, 197, 198, 204, 210, 212, 218 у 224.

${ }^{7}$ SAN MARTÍN PAYO, El Libro Becerro de Husillos.
} 
para diferenciarlo también del Libro Becerro de las Propiedades de Husillos, que se conserva trasladado en dicho Libro de los Privilegios. Conserva además los libros de actas del cabildo de la citada iglesia ${ }^{8}$, libros de fábrica, de censos y fundaciones, y carpetas y legajos de variado contenido. En total pertenecen al referido archivo 40 documentos originales $^{9}$ y 216 copias, la mayoría de ellas insertas en el Libro de los Privilegios ${ }^{10}$.

\section{Archivo Capitular de Palencia:}

Conserva los fondos documentales del cabildo catedralicio de Palencia, entre los que se localizan documentos relacionados con Santa María de Husillos que se incluyen en la colección. Pertenecen a este archivo 10 documentos originales ${ }^{11}$ y 5 $\operatorname{copias}^{12}$.

\section{Archivo de la Real Chancillería de Valladolid:}

Conserva pleitos, ejecutorias y unidades documentales en pergamino relacionadas con Husillos en los fondos de las Salas de lo Civil, Registro de Ejecutorias y la colección de Pergaminos $^{13}$. A este archivo pertenecen 8 originales $^{14}, 7 \operatorname{copias}^{15} \mathrm{y}$ 11 copias secundarias ${ }^{16}$.

\section{Archivo General de Simancas:}

\footnotetext{
${ }^{8}$ Los libros de actas del Cabildo de Husillos conservados en Ampudia son seis, abarcando sus signaturas desde el Libro 222 hasta el 227, y siendo sus fechas extremas: 1504 - 1606.

${ }^{9}$ Docs. núm. 109, 225, 257, 270, 271, 272, 273, 280, 284, 295, 296, 297, 298, 300, 306, 307, 309, $311,312,313,314,315,316,317,319,320,323,324,325,326,329,332,334,337,341,344$, $345,346,347$ y 350 .

${ }^{10}$ Docs. núm. 2, 3, 4, 5, 6, 7, 8, 9, 10, 12, 16, 17, 18, 19, 20, 21, 25, 26, 27, 28, 29, 30, 31, 33, 34, $35,36,37,38,40,42,43,44,45,46,47,48,49,50,51,52,53,54,56,57,58,61,62,63,64,65$, $66,71,72,73,74,75,76,77,81,82,83,84,85,87,88,90,91,92,93,96,97,98,99,100,101$, $102,103,105,106,107,108,113,114,115,116,117,118,119,120,121,122,123,125,126$, $127,128,131,132,133,134,135,139,140,141,142,143,144,145,146,147,148,149,150$, $151,152,153,154,155,156,157,158,159,160,161,162,163,164,166,167,168,169,170$, $171,172,173,174,175,176,177,178,183,184,185,186,187,188,189,190,191,192,193$, $194,200,201,202,203,204,205,206,208,209,210,211,212,213,214,215,216,217,218$, $219,220,221,223,226,229,230,232,234,236,237,238,242,244,245,246,249,250,252$, $253,254,260,261,262,263,264,266,267,274,275,276,277,278,279,281,283,285,289$, 290, 291, 293, 294, 295, 296, 297, 298 у 343.

${ }^{11}$ Docs. núm. $11,15,22,23,24,32,80,95,292$ y 351.

12 Docs. núm. 11, 15, 22, 23 y 39.

${ }^{13}$ ARRIBAS - FEIJÓO, Guía del Archivo de la Real Chancillería de Valladolid.

${ }^{14}$ Docs. núm. 265, 286, 287, 299, 303, 305, 321 y 342.

${ }^{15}$ Docs. núm. 259, 275, 276, 281, 283, 302 y 304.

${ }^{16}$ Docs. núm. 5, 17, 26, 30, 37, 128, 135, 184, 192, 281 y 298.
} 


\section{LA ABADÍA DE SANTA MARÍA DE HUSILLOS: ESTUDIO Y COLECCIÓN \\ DOCUMENTAL $(904-1608)$}

La documentación relacionada con Husillos se localiza en varias secciones:

Patronato Real, Patronato Eclesiástico, Registro General del Sello y Cámara de Castilla $^{17}$. En total son 3 originales $^{18}, 10 \operatorname{copias}^{19}$ y 62 copias secundarias $^{20}$.

\section{Archivo Secreto Vaticano:}

En los Registros Vaticanos y de Aviñón se conservan seis copias relativas a Santa María de Husillos, fruto de la relación de dependencia de dicha iglesia con la Santa Sede ${ }^{21}$.

\section{Biblioteca Nacional:}

Conserva el manuscrito 705, que es una copia parcial del Libro de los Privilegios de Santa María de Husillos, al cual pertenecen 143 copias secundarias de la colección $^{22}$.

\section{Otros Archivos.}

Algunos documentos de la colección proceden de archivos y bibliotecas variados como el archivo municipal de Palencia (1 original) ${ }^{23}$, archivos capitulares de León $(1 \text { copia })^{24}$, Burgos $(1 \text { copia })^{25}$ y Toledo $(1 \text { copia })^{26}$, Biblioteca de la Real Academia de la Historia en la Colección Salazar (3 copias secundarias) ${ }^{27}$, y Archivo Histórico Nacional, secciones de Consejo Real, Clero regular, y Códices y cartularios ( 1 original $^{28}, 2$ copias $^{29}$ y 2 copias secundarias $^{30}$ ).

\footnotetext{
${ }^{17}$ PLAZA BORES, Guía del Archivo General de Simancas.

${ }^{18}$ Docs. núm. 338, 339 y 340.

${ }^{19}$ Docs. núm. 240, 247, 248, 255, 295, 296, 298, 333, 335 у 336.

${ }^{20}$ Docs. núm. 3, 4, 5, 6, 7, 8, 9, 10, 13, 16, 17, 19, 21, 27, 30, 34, 37, 42, 43, 45, 48, 49, 50, 51, 54, $55,57,62,71,74,75,77,81,85,88,89,101,131,132,134,135,162,163,164,171,184,185$, $188,189,192,193,194,212,213,215,216,218,219,234238$ у 261.

${ }^{21}$ Docs. núm. 68, 69, 70, 78, 89 y 94.

${ }^{22}$ Docs. núm. 2, 3, 4, 5, 6, 7, 8, 9, 10, 13, 16, 17, 18, 19, 20, 21, 25, 26, 27, 28, 29, 30, 31, 33, 34, $35,36,38,40,42,43,44,45,46,47,49,50,51,52,53,54,55,57,58,61,62,63,64,66,71,72$, $73,74,75,76,77,81,82,83,84,85,87,88,90,91,92,93,96,97,100,101,102,103,105,106$, $107,108,113,114,118,119,125,126,127,128,131,132,133,134,135,139,140,141,142$, $143,144,145,146,147,148,149,150,151,152,153,154,155,156,157,158,159,160,161$, $162,163,164,166,167,168,169,170,174,176,177,178,183,186,187,188,192,193,200$, 201, 204, 205, 206, 218 у 219.

${ }^{23}$ Doc. núm. 224.

${ }^{24}$ Doc. núm. 1.

${ }^{25}$ Doc. núm. 14

${ }^{26}$ Doc. núm. 79.

${ }^{27}$ Docs. núm. 11,15 y 79.

${ }^{28}$ Doc. núm. 41.
} 


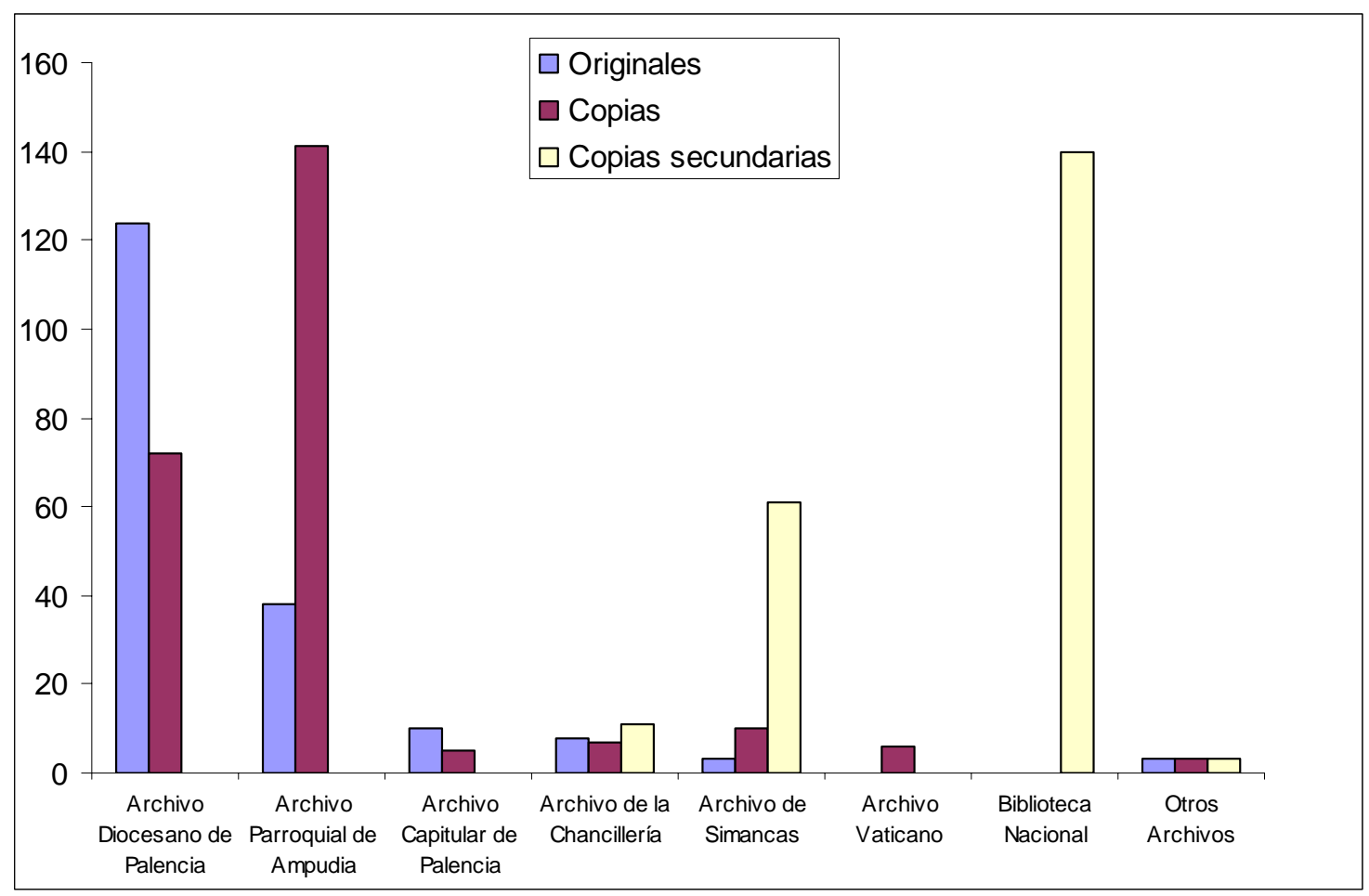

Procedencia de la documentación de Santa María de Husillos

\section{FUENTES IMPRESAS}

En un documento de la colección se ha recurrido a su edición impresa debido a que el original se ha perdido, y aunque se conserva trasladado en el Libro de los Privilegios, hemos optado por la edición que realizó Ramón Menéndez Pidal a partir del original ${ }^{31}$.

\footnotetext{
${ }^{29}$ Docs. núm. 348 y 349.

${ }^{30}$ Docs. núm. 29 y 107.

${ }^{31}$ Doc. núm. 2.
} 


\subsection{ESTUDIO DIPLOMÁTICO}

\section{DOCUMENTOS PÚBLICOS Y PRIVADOS}

El primer aspecto a tratar en un estudio diplomático es distinguir entre documentos públicos o privados en función de la calidad de sus autores. La teoría diplomática no ha fijado de forma clara una sistematización de productores públicos y privados. Para el caso de la diplomática hispana, los diversos estudios se apoyan principalmente en el manual de la UNED de los profesores Tomás Marín y Ruiz Asencio, que fijan un esquema de división de documentación pública y privada según la calidad pública o privada del productor $^{32}$. Para estos autores el problema está en establecer quién es autoridad pública y quién no, agravándose este problema en torno a las autoridades intermedias civiles (nobles y municipios) y eclesiásticas. Consideran que la solución, que es compleja, habrá de determinarse en relación a cada autoridad. Estos autores dan otra pista cuando definen los conceptos de documento público y documento privado. Así establecen que documento público es aquel que procede de una autoridad pública y en forma pública; mientras que documento privado es aquel que está regulado por el derecho privado, siendo posible que documentos producidos por personas públicas pero referentes a asuntos particulares y redactados en la forma correspondiente a éstos sean documentos privados.

Así pues el problema más importante radica en la consideración como autoridad pública o privada de los productores de calidad intermedia como nobles, obispos o abades. Hay autores que han resuelto el problema de manera totalmente opuesta. Así, Manuel Zabalza Duque considera como documentación privada los documentos otorgados por los condes de Castilla ${ }^{33}$. Zabalza dice respetar el tradicional esquema fijado en el manual de la UNED por Tomás Marín y Ruiz Asencio $^{34}$ de la división de documentación pública y privada, aunque ya hemos visto que dichos autores optan por una flexibilización a la hora de considerar como públicos o privados los documentos otorgados por las autoridades intermedias. Por otra parte, José Luis Rodríguez de Diego, en su estudio sobre la

\footnotetext{
${ }^{32}$ MARÍN - RUIZ ASENCIO, Paleografia y Diplomática, 511.

${ }^{33}$ ZABALZA, Colección diplomática de los condes de Castilla, 73.

${ }^{34}$ MARÍN - RUIZ ASENCIO, Paleografia y diplomática, 511.
} 
documentación de Santa María de Aguilar de Campóo, clasifica como documentación pública la producida por la nobleza, los obispos y los abades ${ }^{35}$.

Para el caso de Santa María de Husillos hemos optado por hacer una interpretación diferente a la optada por los citados autores, pero basada, al igual que éstos, en la sistematización dada en el manual de la UNED. Consideramos que un documento es público o privado atendiendo en primer lugar a la calidad pública o privada del productor. Así la monarquía o la Santa Sede son autoridades públicas indiscutibles. También consideramos como documentos públicos a los producidos por la nobleza y las autoridades eclesiásticas intermedias, como obispados, cabildos catedralicios y monasterios, en línea con la interpretación de José Luis Rodríguez de Diego. Pero a diferencia de éste y en línea con lo fijado por los autores del manual de la UNED, el negocio jurídico del documento va a señalar, independientemente del productor, si se trata de un documento público o privado. Así los documentos producidos por autoridades públicas indiscutibles, como la monarquía o la Santa Sede, pueden ser privados si tratan sobre asuntos particulares de dichos productores, de igual modo que los producidos por las autoridades intermedias. El hecho de que estemos ante la colección documental de un monasterio, hace que la mayor parte de las disyuntivas entre documento público o privado las encontremos en productores eclesiásticos de calidad intermedia. El criterio básico que hemos utilizado ha sido considerar si el negocio jurídico se enmarcaba dentro de las facultades de autoridad administrativa y jurisdiccional del productor intermedio, o bien se enmarcaba en aspectos internos particulares de dicho productor, y que entran en el ámbito del derecho privado.

En base a estos criterios, de los 351 documentos de la colección de Husillos, 163 son documentos públicos, es decir, algo menos de la mitad del conjunto documental (46,4\%). De éstos, 64 son reales $^{36}, 6$ nobiliarios $^{37}, 20$ pontificios $^{38}, 13$

\footnotetext{
${ }^{35}$ RODRÍGUEZ DE DIEGO, Colección diplomática de Santa María de Aguilar, 72-78.

${ }^{36}$ Docs. núm. 5, 6, 7, 11, 12, 14, 15, 18, 19, 21, 22, 27, 28, 29, 30, 34, 35, 36, 38, 46, 71, 76, 82, $84,85,92,97,100,101,113,114,129,131,134,135,144,163,164,171,184,190,191,192$, $193,194,210,212,213,214,234,238,240,247,248,255,294,333,334,335,336,338,339,348$ y 349 .

${ }^{37}$ Docs. núm. $3,4,8,9,10$ y 167

${ }^{38}$ Docs. núm. 23, 32, 37, 39, 48, 67, 68, 69, 70, 78, 89, 94, 104, 124, 222, 235, 261, 274, 310 у 350 .
} 


\section{LA ABADÍA DE SANTA MARÍA DE HUSILLOS: ESTUDIO Y COLECCIÓN \\ DOCUMENTAL $(904-1608)$}

monásticos $^{39}, 5$ episcopales ${ }^{40}$ y 55 documentos judiciales de variada tipología diplomática (avenencias, poderes, pleitos, compromisos, sentencias, ejecutorias, recursos de fuerza, etc.) ${ }^{41}$.

Comprobamos de esta manera un predominio de los documentos producidos por la autoridad real, llamando la atención el escaso número de documentos producidos por las instituciones monásticas, máxime cuando estamos ante una colección monástica, si bien es cierto que la mayoría de los documentos judiciales tienen como protagonistas a Santa María de Husillos como institución, y a sus dignidades y canónigos. Los negocios jurídicos más frecuentes en los documentos públicos son los relativos a donaciones territoriales con el poder jurisdiccional asociado, privilegios de inmunidad y de protección, exenciones fiscales, confirmaciones, pleitos y trámites judiciales.

Los documentos privados de la colección son 188 (53,5\%), de los cuales, 1 es real $^{42}, 3$ nobiliarios $^{43}, 79$ monásticos $^{44}, 8$ episcopaless ${ }^{45}, 6$ concejiles $^{46}, 22$ traslados notariales ${ }^{47}$, y 68 de personas particulares ${ }^{48}$. Destacan así los monásticos, relativos la gran mayoría a Santa María de Husillos, y los relativos a personas particulares. Los negocios jurídicos predominantes en los documentos privados son las compraventas, traslados notariales, censos, arrendamientos, donaciones, permutas, testamentos, poderes, estatutos y documentos de regulación de la institución monástica.

\footnotetext{
${ }^{39}$ Docs. núm. 20, 31, 109, 177, 180, 186, 237, 246, 250, 251, 293, 296 у 340.

${ }^{40}$ Docs. núm. 141, 142, 175, 245 y 285.

${ }^{41}$ Docs. núm. 46, 57, 61, 62, 73, 96, 105, 106, 107, 108, 109, 111, 112, 125, 127, 128, 141, 142, $143,144,145,177,178,179,180,181,182,197,198,199,220,224,226,227,232,236,259$, $265,267,275,276,281,283,286,287,288,294,299,302,303,304,305,321,342$ у 343.

${ }^{42}$ Doc. núm. 72

${ }^{43}$ Docs. núm. 51, 58 y 346.

${ }^{44}$ Docs. núm. 17, 26, 41, 47, 59, 64, 65, 66, 74, 75, 80, 83, 95, 103, 110, 139, 146, 150, 151, 152 , $153,154,156,157,158,160,161,176,183,185,196,200,217,229$ 230, 233, 241, 242, 243, 244, 252, 253, 264, 269, 277, 278, 279, 282, 290, 291, 295, 297, 298, 301, 306, 307, 308, 311, 312, $314,315,316,317,318,319,320,322,323,324,325,326,329,330,332,337,341,344,345$ y 347.

${ }^{45}$ Docs. núm. 24, 40, 56, 90, 91, 165, 292 y 351.

${ }^{46}$ Docs. núm. 140, 172, 173, 195, 206 y 249.

${ }^{47}$ Docs. núm. 86, 87, 93, 102, 130, 132, 136, 137, 138, 147, 148, 149, 166, 168, 189, 202, 216, $223,225,239,262$ у 292.

${ }^{48}$ Docs. núm. 1, 2, 12, 16, 25, 42, 43, 44, 45, 49, 52, 53, 54, 55, 63, 77, 79, 88, 99, 116, 117, 118 , $119,120,121,122,123,126,133,155,159,162,169,170,174,201,202,203,204,205,207$, $208,209,211,215,218,219,221,228,231,254,256,258,260,263,266,268,270,271,272$, $273,289,300,309,313,327,328$ y 331 .
} 


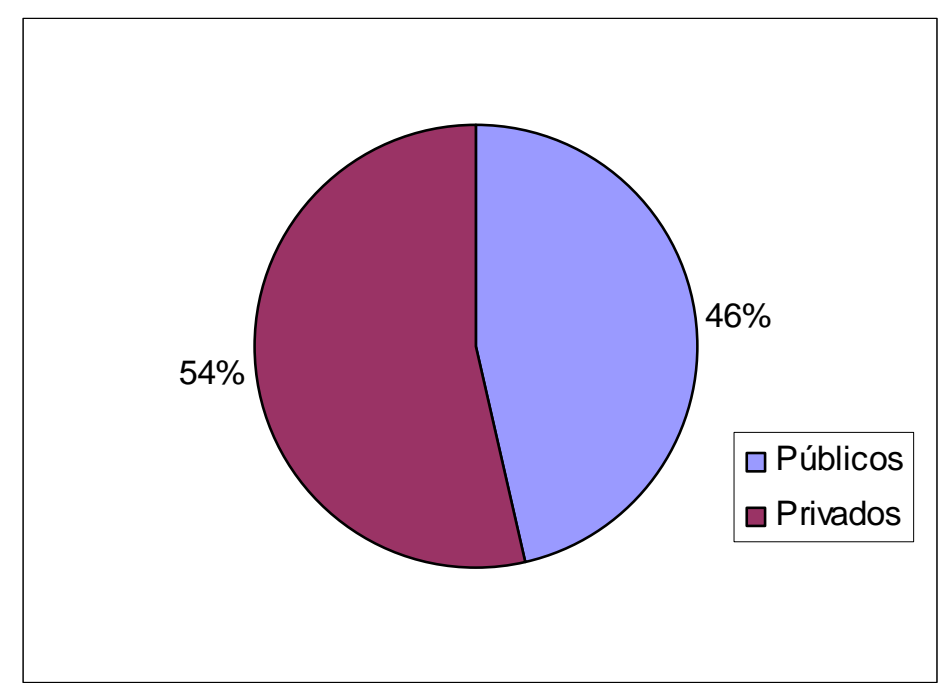

Distribución de la documentación según la calidad de sus autores

\section{VOLUMEN DOCUMENTAL POR SIGLOS}

El establecimiento de la cantidad numérica de documentos producidos por Santa María de Husillos a lo largo de los siglos ayuda al conocimiento de la evolución vital de la institución. Dicha distribución secular es la siguiente:

S. X: $2^{49}$.

S. XI: $5^{50}$.

S. XII: $34^{51}$.

S. XIII: $52^{52}$.

S. XIV: $126^{53}$.

S. XV: $32^{54}$.

S. XVI: $93^{55}$.

S. XVII: $7^{56}$.

\footnotetext{
${ }^{49}$ Docs. núm. 1 y 2.

${ }^{50}$ Docs. núm. 11-15.

${ }^{51}$ Docs. núm. 3-10, 16, y 18-42.

52 Docs. núm. 17, y 43-93.

${ }^{53}$ Docs. núm. 94-219.

${ }^{54}$ Docs. núm. 220-251.

${ }^{55}$ Docs. núm. 252-344.

${ }^{56}$ Docs. núm. 345-351.
} 


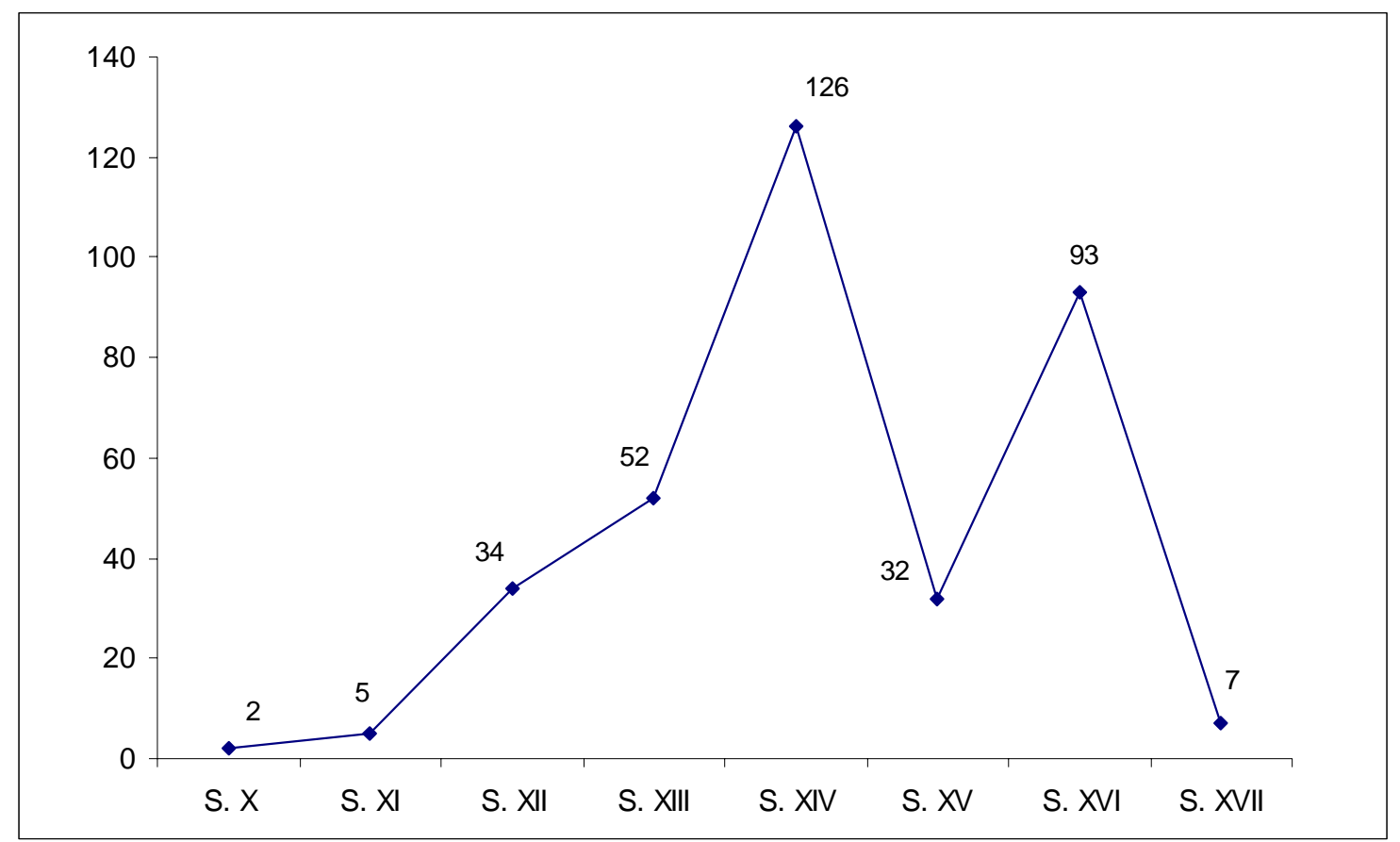

Evolución cuantitativa de la documentación de Santa María de Husillos

A primera vista se observan dos aspectos: el primero es la evolución ascendente del número de documentos hasta el siglo XV, en el que se produce una importante disminución, aunque a partir de dicho siglo comience una nueva ascensión de la producción documental. El segundo aspecto es el gran número de documentos pertenecientes al siglo XIV. En efecto, ante el momento de crisis generalizada del siglo XIV, Husillos, al igual que el resto de instituciones, tuvo que litigar y proteger en gran número de ocasiones sus propiedades y derechos, lo que se traducía en gran cantidad de pleitos, confirmaciones reales de sus términos y derechos, y traslados de los documentos justificativos de éstos. Pero también la institución era beneficiada por el aumento de la religiosidad motivada por la crisis, reflejándose esto en el aumento del número de mandas testamentarias a favor de la abadía y de las compras realizadas por ésta, ya que en momentos de crisis, las instituciones eclesiásticas utilizaban la liquidez monetaria que les proporcionaba las limosnas y mandas testamentarias en la compra de tierras y casas.

\section{TRADICIÓN DOCUMENTAL}


Ciento noventa y dos documentos de Husillos se nos han transmitido en su forma original $(54,7 \%)^{57}$. El resto son copias que se han transmitido en forma de "vidimus", registros, traslados autorizados o copias simples, si bien hay solamente un ejemplar de copia simple ${ }^{58}$.

\section{PUBLICACIONES}

Es relativamente bajo el número de documentos de Santa María de Husillos editados, registrados o citados, siendo el número total de 76 documentos $(21,6 \%)$. En cualquier caso éstos son principalmente los altomedievales, en consonancia con el resto de colecciones documentales de instituciones eclesiásticas y colecciones reales; y también se han editado los que reflejan hechos importantes en la historia de la abadía, como en el caso de los relativos al traslado de la abadía a Ampudia.

Se contabiliza un total de 60 documentos editados (17\%), distribuyéndose por siglos de la siguiente manera:

S. X: $2^{59}$.

S. XI: $4^{60}$.

S. XII: $24^{61}$.

S. XIII: $19^{62}$.

S: XIV: $9^{63}$.

S. XVII: $2^{64}$.

\footnotetext{
${ }^{57}$ Docs. núm. 11, 12, 13, 15, 16, 21, 22, 23, 24, 25, 26, 27, 29, 30, 31, 32, 33, 35, 36, 37, 38, 40, $41,42,43,45,46,47,48,49,50,51,52,53,56,57,58,59,60,61,63,64,65,66,71,72,74,80$, $81,82,84,85,86,90,93,95,97,98,100,102,106,109,112,113,127,128,130,134,135,136$, $137,138,145,149,155,161,162,163,164,165,166,168,169,171,173,174,182,184,186$, $188,192,193,194,199,200,203,205,206,207,211,212,213,214,215,216,219,220,222$, $223,224,225,226,227,228,231,233,235,236,239,241,242,243,252,253,254,256,257$, $264,265,268,269,270,271,272,273,280,282,284,286,287,292,295,296,297,298,299$, $300,301,303,305,306,307,308,309,310,311,312,313,314,315,316,317,318,319,320$, $321,322,323,324,425,326,327,328,329,330,331,332,334,337,338,339,340,341,342$, $344,345,346,347,348,349,350$ y 351 .

${ }^{58}$ Doc. núm. 7 , col. B.

${ }^{59}$ Docs. núm. 1 y 2.

${ }^{60}$ Docs. núm. $11,13,14$ y 15.

${ }^{61}$ Docs. núm. 3, 4, 5, 6, 7, 8, 9, 10, 18, 19, 22, 23, 24, 27, 29, 31, 32, 34, 35, 36, 38, 39, 40 y 41.

${ }^{62}$ Docs. núm. 13, 50, 54, 55, 57, 58, 59, 61, 68, 69, 70, 79, 81, 82, 84, 85, 86, 89 у 90.

${ }^{63}$ Docs. núm. 94, 97, 98, 100, 107, 134, 135, 175 y 184.

${ }^{64}$ Docs. núm. 348 y 349.
} 


\section{LA ABADÍA DE SANTA MARÍA DE HUSILLOS: ESTUDIO Y COLECCIÓN \\ DOCUMENTAL $(904-1608)$}

Los documentos editados se pueden englobar en cuatro bloques: documentos otorgados por los condes de Monzón y por Sancho el Mayor, documentos de la catedral de Palencia, documentos reales y documentos pontificios.

El número de documentos regestados es de 33, de los cuales 24 están editados al mismo tiempo. Los documentos citados en distintas obras son 30, de los que 23 están editados o regestados.

\section{DOCUMENTOS FALSOS}

En la colección de Husillos existen 11 documentos falsos ${ }^{65}$, los cuales, aunque datados entre los años 938 y 1109 , en realidad fueron confeccionados entre el primer tercio del siglo XII y mediados del siglo XIII. Al igual que en otras instituciones eclesiásticas, los documentos falsos de Husillos corresponden a sus donaciones y privilegios más primitivos, que corresponden al siglo $\mathrm{X}, \mathrm{y}$ al relato fundacional de la institución, que aunque datado en el reinado de Alfonso VI, fue escrito a mediados del siglo XIII ${ }^{66}$.

\section{DOCUMENTOS AJENOS A LA INSTITUCIÓN}

Contabilizamos un total de 7 documentos cuyo autor o destinatario es ajeno a Santa María de Husillos ${ }^{67}$. Dichos documentos abarcan desde los años 1056 hasta 1370. Los motivos de la conservación de éstos en el archivo de Husillos, pueden corresponder a dos hechos:

$1^{\circ}$. Que fueran depositados en el archivo de Santa María de Husillos por motivos de seguridad y conservación de los documentos, ya que sobre todo en la Alta Edad Media era frecuente que particulares importantes e incluso reyes depositasen ciertos documentos en instituciones estables como eran los monasterios. En este caso hemos de considerar al tratado de paz entre Sancho III y Fernando II del año $1158^{68}$, la cesión en el año 1228 de Orem Díaz, condesa de Urgel, a su hermano, de su parte en las iglesias de Coca y Tamariz ${ }^{69}$, y la donación en 1255 de Alfonso X a Diego Fernández de Santa Eulalia de León ${ }^{70}$, derechos y propiedades los

\footnotetext{
${ }^{65}$ Docs. núm. 2, 3, 4, 5, 6, 7, 8, 9, 10, 16, 17.

${ }^{66}$ Doc. núm. 17.

${ }^{67}$ Docs. núm. 12, 29, 51, 56, 71, 133 y 155.

${ }^{68}$ Doc. núm. 29.

${ }^{69}$ Doc. núm. 51.

${ }^{70}$ Doc. núm. 71.
} 
anteriores que nunca llegaron a formar parte del patrimonio de Santa María de Husillos.

$2^{\circ}$. Que las propiedades o derechos que justifican terminaran por distintos medios, como donación, testamento, permuta o compraventa, dentro del patrimonio de Santa María de Husillos. Entonces, junto a la propiedad que se transfiere a Husillos, se entrega también el documento original justificativo de la propiedad a modo de escritura de ésta. Este es el caso de la venta de los hermanos Rodrigo y Falcón Álvarez a Anaia de una divisa en la villa de Tejada en el año $1056^{71}$, de la donación de Tello I, obispo de Palencia, a Rodrigo y Juan Cristóbal, de unas aceñas en el año $1234^{72}$; la venta en 1347 de Domingo Gallo a Domingo Fernández de una viña en Santillán de la Cuesta $^{73}$; y la venta en 1370 de Pedro Fernández de Torre a Alonso García de Villada de dos huertas ${ }^{74}$.

\section{CONTRAPRESTACIÓN O “VICISSITUDO”}

La figura jurídica de origen germánico de la "roboratio" o "vicissitudo" aparece en seis documentos de la colección de Husillos, que abarcan desde 1114 hasta $1161^{75}$. Los tipos documentales que la contienen son cuatro donaciones ${ }^{76}$, dos de

ellas falsas, un fuero ${ }^{77} \mathrm{y}$ una permuta ${ }^{78}$. Observamos así que dicha figura alcanza en Husillos hasta mediados del siglo XII y que no se circunscribe exclusivamente al tipo documental de la donación. En cuanto a la nomenclatura que se le da es variada: oferción, roboración, corroboración y confirmación.

La contraprestación es simbólica cuando no hay un fin encubierto de compraventa, como es en el caso del documento de la reina Urraca y de las dos donaciones falsas, en el que el alto valor de la contraprestación hace que se trate en realidad de una venta.

\section{CLASIFICACIÓN DOCUMENTAL}

\footnotetext{
71 Doc. núm. 12.

72 Doc. núm. 56.

${ }^{73}$ Doc. núm. 133.

${ }^{74}$ Doc. núm. 155.

${ }_{76}^{75}$ Docs. núm. 8, 16, 18, 24, 26 y 31.

${ }^{76}$ Docs. núm. 8, 16, 18 y 26.

${ }^{77}$ Doc. núm 31.

${ }^{78}$ Doc. núm. 24.
} 


\section{LA ABADÍA DE SANTA MARÍA DE HUSILLOS: ESTUDIO Y COLECCIÓN \\ DOCUMENTAL $(904-1608)$}

Al tratarse de una colección que abarca períodos cronológicos tan extremos, se puede decir que la colección de Husillos abarca la mayor parte de los tipos documentales conocidos. El criterio básico para realizar la clasificación tipológica de una documentación tan extrema en el tiempo y en la calidad de sus productores, ha sido su contenido jurídico. En efecto, si para el caso de la documentación regia se pude adoptar también una clasificación basada en la tipología diplomática, ya que la documentación altomedieval leonesa y sobre todo desde los siglos XII y XIII, los documentos reales se pueden asignar a tipos diplomáticos bien caracterizados (privilegios reales, cartas plomadas, cartas abiertas, albalás, etc.), para el resto de la documentación, en especial para la documentación privada, es muy difícil realizar una sistematización basándonos solamente en criterios de la tipología diplomática, ya que en ésta dicha tipología no está bien sistematizada. Es por ello por lo que hemos tenido que recurrir a los negocios jurídicos de la documentación para poder sistematizarla, habiendo utilizado para grupos documentales concretos, como en el caso de los documentos otorgados por los condes de Monzón y Sancho el Mayor de Navarra, de la documentación pontificia y judicial, al concurso de ambas sistematizaciones.

Así haremos una sistematización de la documentación de Husillos basándonos en la tipología jurídica de los documentos, haciendo comparaciones entre los distintos tipos en orden a su número con respecto a los demás tipos y en orden a su cuantificación por siglos.

\section{Donaciones ${ }^{79}$}

\subsection{Donaciones propiamente dichas}

El número de donaciones de la colección de Husillos es de 37, lo que representa un $10,5 \%$ del total de la documentación, abarcando sus fechas extremas desde el año 904 hasta $1589^{80}$. A través de las donaciones, y en un proceso similar al resto de instituciones eclesiásticas, Santa María de Husillos iría conformando su patrimonio territorial y jurisdiccional.

\footnotetext{
${ }^{79}$ Para la estructuración de las donaciones, utilizamos el esquema propuesto por Marta Herrero de la Fuente para las donaciones de Sahagún (HERRERO DE LA FUENTE, Sahagún, II).

${ }^{80}$ Docs. num. 1, 2, 3, 4, 8, 9, 10, 16, 18, 19, 21, 25, 26, 33, 34, 42, 49, 51, 54, 55, 56, 71, 74, 77, $81,88,90,91,99,165,174,188,205,215,268,327,328$ у 331 .
} 
El número de donaciones según los siglos es variado y refleja la intensidad evolutiva del proceso de formación del dominio de Husillos. A continuación ofrecemos la cantidad total de donaciones y su porcentaje respecto al total de la documentación por siglos:

S. X: $2^{81}(100 \%)$

S. XI: 0

S. XII: $14^{82}(41,1 \%)$.

S. XIII: $11^{83}(21,1 \%)$.

S. XIV: $6^{84}(4,7 \%)$,

S. XV: 0 .

S. XVI: $4^{85}(4,3 \%)$.

Se observa una evolución descendente desde el siglo X al XV, para iniciar una ligera recuperación en el siglo XVI. El alto porcentaje de donaciones desde los siglos X al XIII coincide con el período de formación del patrimonio territorial de Husillos, contrastando con el escaso porcentaje en los siglos XIV y XV, coincidiendo con un período de crisis general y con el cambio de tendencia en la realeza y nobleza en cuanto a sus relaciones con las instituciones eclesiásticas.

Los autores más frecuentes de las donaciones son la realeza, con 6 donaciones ${ }^{86}, \mathrm{y}$ la nobleza, también con $6^{87}$. El resto de donaciones es de variada procedencia, como personas particulares y diversas instituciones eclesiásticas. Las donaciones de la realeza y la nobleza tienen como denominador común su cronología, ya que ambos donantes actúan hasta mediados del siglo XIII, concretamente hasta 1255. La variedad tipológica de las donaciones es amplia al comprender fechas cronológicas tan extremas: simples o puras $(9)^{88}$, pro remedio anima $(21)^{89}$, post obitum $(2)^{90}$, pro servitio $(2)^{91}$, reservato usufructo $(2)^{92}$. El resto de donaciones

\footnotetext{
${ }^{81}$ Docs. núm. 1 y 2.

${ }^{82}$ Docs. núm. 3, 4, 8, 9, 10, 16, 18, 19, 21, 25, 26, 33, 34 y 42.

${ }^{83}$ Docs. núm. 49, 51, 54, 55, 56, 71, 74, 77, 88, 90 у 91.

${ }^{84}$ Docs. núm. 99, 165, 174, 188, 205 y 215.

${ }^{85}$ Docs. núm. 268, 327, 328 y 331.

${ }^{86}$ Docs. núm. 1, 18, 19, 21, 34 y 71 .

${ }^{87}$ Docs. núm. 3, 4, 8, 9, 1051 .

${ }^{88}$ Docs, núm. 1, 90, 99, 188, 215, 268, 327, 328 y 331.

${ }^{89}$ Docs. núm. 2, 3, 4, 8, 9, 10, 16, 18, 19, 21, 33, 34, 42, 45, 49, 54, 74, 81, 88, 174 у 205.

${ }^{90}$ Docs. núm. 45 y 60.

${ }^{91}$ Docs. núm. 26 y 165.
} 


\section{LA ABADÍA DE SANTA MARÍA DE HUSILLOS: ESTUDIO Y COLECCIÓN \\ DOCUMENTAL $(904-1608)$}

presentan motivaciones variadas: motivos religiosos vagos como el amor a Dios ${ }^{93}$, donaciones para fines concretos como la realización de obras ${ }^{94}$, o con cláusulas condicionales $^{95}$. A veces las donaciones aparecen mezcladas con otros negocios jurídicos ${ }^{96}$. También a través de donaciones se dotan las capellanías ${ }^{97}$.

En general, las donaciones "pro remedio anima" son más frecuentes en los siglos altomedievales, siendo sus autores sobre todo la realeza y la alta nobleza, y suelen corresponder a amplios dominios territoriales. Las donaciones "reservato usufructo" y "pro servitio" comienzan a aparecer a mediados del siglo XII, y las donaciones con cláusulas condicionales, desde el primer tercio del siglo XIII, siendo los autores de todas estas principalmente miembros de la baja nobleza, el clero y particulares, a quienes les sería más difícil desprenderse de forma gratuita de sus posesiones.

En ocasiones, las donaciones llevan consigo la fórmula de la vicissitudo, aunque en alguna de éstas indique, por la alta cuantía de la contraprestación, que en realidad se trata de una venta encubierta ${ }^{98}$.

\subsection{Concesiones}

Clasificamos como concesiones todos aquellos documentos que contienen concesiones de diferente tipo: jurisdiccionales, inmunidades, fueros, exenciones fiscales, privilegios de protección, indulgencias. Así en la colección de Husillos contabilizamos un total de 21 concesiones $(5,6 \%)$, abarcando desde 1127 hasta $1513^{99}$. De éstas, 2 son fueros ${ }^{100}, 14$ son privilegios de inmunidad jurídica que en la mayoría de los casos se asocian a privilegios de exención fiscal y protección real, y en algún caso se asocian también a otros negocios jurídicos como confirmaciones $^{101}$; 3 son indulgencias pontificias a Santa María de Husillos ${ }^{102}$, y 2 son documentos de protección real y pontificia ${ }^{103}$.

\footnotetext{
92 Docs. núm. 25 y 64.

93 Doc. núm. 26.

${ }^{94}$ Doc. núm. 77.

95 Doc. núm. 51.

${ }^{96}$ Doc. núm. 45.

${ }^{97}$ Docs. num. 74, 88 y 90.

98 Docs. núm. 16 y 18.

${ }^{99}$ Docs. núm. 20, 28, 31, 37, 38, 39, 40, 67, 68, 69, 85, 104, 124, 167, 171, 190, 194, 210, 234, 238 y 261.

${ }^{100}$ Docs. núm. 20 y 31.

${ }^{101}$ Docs. núm. 28, 37, 38, 39, 40, 68, 69, 85, 167, 171, 190, 194, 234 y 238.
} 
En cuanto a los autores de las concesiones a Husillos, son variados, al igual que las donaciones. Así la realeza es autora de $9^{104}, 1$ es nobiliaria ${ }^{105}, 8$ pontificias ${ }^{106}$, y 3 son episcopales y monásticas ${ }^{107}$. En cuanto a su cronología tenemos la siguiente distribución:

S. XII: $7^{108}$.

S. XIII: $4^{109}$.

S. XIV: $7^{110}$.

S. XV: $2^{111}$.

S. XVI: $1^{112}$.

Al igual que en el caso de las donaciones, la distribución de las concesiones por siglos informa de la evolución histórica de la abadía, reflejando el alto número en los siglos XII y XIV el culmen de la formación del señorío eclesiástico el primero, y un momento de crisis el segundo, dándose en el siglo XIV sobre todo privilegios de protección y exención físcal del señorío eclesiástico.

\subsubsection{Fueros o contratos agrarios}

En la colección de Husillos se conservan dos fueros y se hace mención de un tercero. Así el 5 de noviembre de 1127, Pedro I Petriz, obispo de Palencia, y Poncio Guitardo, abad de Husillos, conceden fuero al concejo de Villaudilla, lugar de señorío de Husillos, igual que el que disfrutaban los pobladores de Palencia ${ }^{113}$. Asimismo el 21 de septiembre de 1161, Raimundo Giliberti, abad de Husillos, juntamente con el cabildo de dicha iglesia, y con el consentimiento de Raimundo

\footnotetext{
102 Docs. núm. 67, 104 y 124.

${ }^{103}$ Docs. núm. 210 y 261.

${ }^{104}$ Docs. núm. 28, 38, 85, 171, 190, 194, 210, 234 y 238.

${ }^{105}$ Doc. núm. 167.

${ }^{106}$ Docs. núm. 37, 39, 67, 68, 69, 104, 124 y 261.

${ }^{107}$ Docs. núm. 20, 31 y 40.

108 Docs. núm. 20, 28, 31, 37, 38, 39 y 40.

${ }^{109}$ Docs. núm 67, 68, 69 y 85.

${ }^{110}$ Docs. núm. 104, 124, 167, 171, 190,194 y 210.

${ }^{111}$ Docs. núm. 234 y 238.

112 Doc. núm. 261.

113 Doc. núm. 20.
} 


\section{LA ABADÍA DE SANTA MARÍA DE HUSILLOS: ESTUDIO Y COLECCIÓN \\ DOCUMENTAL $(904-1608)$}

II de Minerva, obispo de Palencia, concede fuero en remisión de sus pecados al concejo de San Julián ${ }^{114}$.

Estamos ante dos fueros concedidos por Santa María de Husillos a dos de sus villas en un momento en el que serían palpables las huellas de despoblación y destrucción a consecuencia de la guerra librada entre Urraca I y Alfonso I de Aragón ${ }^{115}$. Vemos también como en ambos fueros el obispo de Palencia interviene como autor o autorizante, lo que refleja la dependencia de Husillos con la sede episcopal palentina. En ambos fueros se regula un conjunto amplio de los aspectos que caracterizan a dicho tipo jurídico: exención e inmunidad, situación de privilegio en conjunto, regulación de las relaciones jurídicas y económicas, contrato agrario colectivo. Por otra parte su cronología se enmarca en el período en el que García Gallo señaló como la época áurea de los fueros realengos, que se inicia a fines del siglo XI.

Por inventario de bienes de la mesa abacial realizado entre el 1 y el 18 de enero de 1555 , tenemos constancia de un fuero no conservado concedido por el abad Gutierre Pérez a los vecinos de Husillos. Si bien no tenemos constancia en el abadologio de ningún abad con dicho nombre, es factible la existencia de dicho fuero $^{116}$.

Los dos fueros existentes en la colección de Husillos se encuentran en latín y no hay constancia, o al menos no se han conservado, ninguna versión romanceada de éstos $^{117}$.

\section{Confirmaciones}

Contabilizamos un total de 39 confirmaciones $(11,1 \%)$, que abarcan desde el falso de Sancho el Mayor de Navarra del año 950 hasta $1474^{118}$. Las confirmaciones son sobre todo reales $(30)^{119}$. También las hay pontificias $(7)^{120}, 1$ monástica $^{121} \mathrm{y}$

\footnotetext{
${ }^{114}$ Doc. núm. 31.

115 Doc. núm. 20.

${ }^{116}$ Doc. núm. 291.

117 Según Carmen Caamaño, las instituciones otorgantes de fueros hicieron trasladar al romance los fueros redactados en latín con el fin de favorecer su acceso a las poblaciones (CAAMAÑO, El fuero romanceado de Palencia, 503-521). Esta tendencia aumentó en los reinados de Fernando III y Alfonso X.

${ }_{118}$ Docs. núm. 5, 6, 7, 11, 12, 15, 22, 23, 27, 30, 32, 35, 36, 37, 48, 70, 82, 84, 89, 92, 97, 100, 101, 113, 114, 134, 135, 157, 163, 164, 184, 191, 192, 193, 212, 213, 214, 215 у 235.

${ }_{119}$ Docs. núm. 5, 6, 7, 11, 12, 15, 22, 27, 30, 35, 36, 82, 84, 92, 97, 100, 101, 113, 114, 134, 135, $163,164,184,191,192,193,212,213$ у 214.
} 
1 de persona particular ${ }^{122}$. Los negocios que se confirman se refieren la inmensa mayoría a donaciones y concesiones anteriores $(37)^{123}$. También hay confirmaciones de nombramientos $(1)^{124}$ y estatutos monásticos $(1)^{125}$.

La distribución por siglos es la siguiente:

S. XI: $3^{126}(60 \%)$.

S. XII: $8^{127}(23,5 \%)$.

S. XIII: $6^{128}(11,5 \%)$.

S. XIV: $17^{129}(13,4 \%)$.

S. XV: $1^{130}(3,1 \%)$.

Se observa una evolución ligeramente descendente desde el siglo XI hasta el XIII, produciéndose un cierto repunte en el siglo XIV, como consecuencia de la necesidad de proteger el patrimonio durante la gran crisis de este siglo, para disminuir de manera importante en el siglo XV.

En ocasiones se alude al motivo de la confirmación, que en los tres casos documentados es "pro remedio anima" o por motivos religiosos. Dichos casos se dan en una confirmación de Sancho III de $1158^{131}$, y en dos de Alfonso VIII de $1178^{132}$. Observamos así que las motivaciones religiosas en las confirmaciones reales aparecen sólo hasta el siglo XII, siendo así un formulismo que tiende a desaparecer con el paso del tiempo.

Vemos también como en ocasiones aparece otro asunto jurídico junto a la confirmación. Es el caso de los documentos 37 y 92 de la colección, en los que además de la confirmación aparecen un privilegio de inmunidad y un mandato respectivamente.

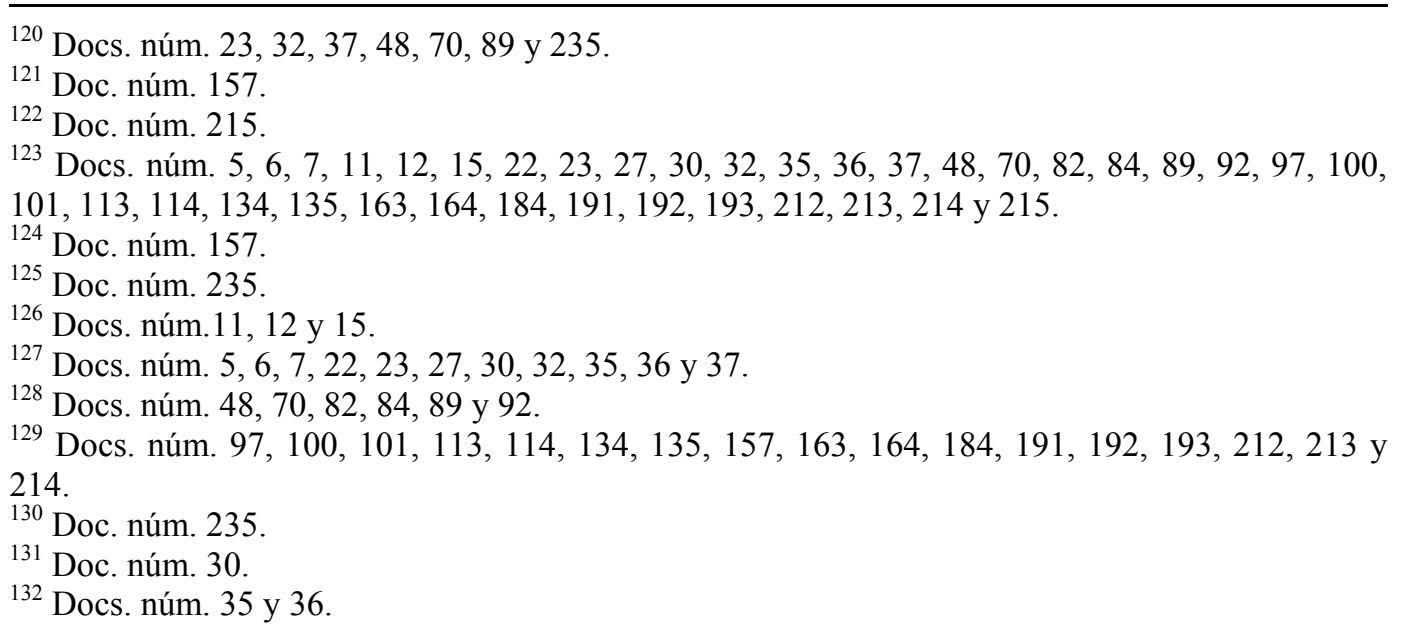




\subsection{Confirmaciones reales}

La importancia cuantitativa y cualitativa de las confirmaciones reales, unida al hecho de que la teoría diplomática haya fijado una evolución en la forma de realización de éstas, hace que dediquemos un apartado a las confirmaciones reales de la colección de Husillos. La teoría diplomática hispana, que se sintetiza en gran medida en el manual de la UNED ${ }^{133}$, establece tres fases en la evolución de las confirmaciones reales: la primera, de suscripciones confirmativas, abarcaría hasta el reinado de Alfonso VII. En el mismo documento a confirmar el rey añadía su suscripción y signo real, confirmando el documento. Durante los siglos XII y XIII se daría la confirmación "in essentia", en la que se produce un nuevo documento con un extracto de los derechos expresados en el documento original que se quieren confirmar, aunque en ocasiones reiteren la validez de derechos preexistentes, sin dar referencia a documentos anteriores que los contengan ${ }^{134}$. Desde mediados del siglo XIII estaría la confirmación “in extenso", en el que el documento a confirmar se inserta en el nuevo.

En la colección de Husillos se aprecia en general dicha evolución, habiendo una excepción en una confirmación "in essentia" de Alfonso VI ${ }^{135}$, y en una suscripción confirmativa de Alfonso VII en un documento falso de Sancho el Mayor, realizada entre 1131 y $1133^{136}$. Hay un total de cinco confirmaciones "in essentia", que comprenden desde el año 1090 (Alfonso VI), hasta 1178 (Alfonso VIII) ${ }^{137}$. Las confirmaciones "in extenso" son un total de 18 , desde el año 1290 hasta $1392^{138}$.

Los tipos diplomáticos de estas confirmaciones presentan sintonía con otras colecciones documentales. Así en las primeras confirmaciones, el tipo diplomático es la carta mixta establecida por Andrés Gambra en la colección documental de Alfonso VI ${ }^{139}$.

\footnotetext{
${ }^{133}$ MARÍN - RUIZ ASENCIO, Paleografia y Diplomática, 599.

${ }^{134}$ En el caso de Husillos, una confirmación de este tipo sería la concedida por Sancho III el 28 de junio de 1158, por la que confirma el coto que él anteriormente había donado.

135 Doc. núm. 15.

136 Doc. núm. 6.

137 Docs. núm. 15, 22, 27, 35 y 36

${ }^{138}$ Docs. núm. 82, 84, 92, 97, 100, 101, 113, 114, 134, 135, 163, 164, 184, 191, 192, 193, 212 y 214.

${ }^{139}$ GAMBRA, Alfonso VI, I, 343-345.
} 
Las confirmaciones de Alfonso VIII llevan por formato el privilegio rodado ${ }^{140}$. Las siguientes confirmaciones a partir de Sancho IV seguirán llevando el formato del privilegio rodado ${ }^{141}$, al que se le unirán también las cartas plomadas y abiertas notificativa $^{142}$.

Se observa, al igual que en otras colecciones documentales, que las confirmaciones reales tienen lugar en los primeros momentos del reinado de los reyes, como reflejo de la importancia que tenía para Santa María de Husillos, al igual que para las diversas instituciones, la confirmación de sus derechos y privilegios. Se aprecia también el alto número de confirmaciones reales en el siglo XIV (15) como síntoma de la crisis generalizada en dicho período. También pudo contribuir a este alto número el hecho de que en las cortes castellanas reunidas en Burgos en el año 1302, se solicitase y se consiguiese del rey la confirmación de los privilegios y cartas que se le presentasen ${ }^{143}$.

\section{Testamentos}

Identificamos en este grupo no sólo a los testamentos en sí mismos, sino también a otros tipos documentales relacionados con éstos, como las ejecuciones, cláusulas, revisiones testamentarias y codicilos. Así en total contabilizamos un total de 22 testamentos o tipos documentales relacionados $(6,2 \%)$, que abarcan desde el año 1232-1243 hasta $1577^{144}$. La razón por la que los testamentos aparezcan tan tarde en la colección de Husillos tiene que ver con el hecho de que en el derecho altomedieval el testamento romano fuera sustituido por las donaciones "mortis causa", que son en su mayoría donaciones "pro anima" y "reservato usufructo". Sólo a partir de Alfonso X, con la recepción del derecho romano, volverá a renacer el testamento como figura jurídica ${ }^{145}$. Algunos testamentos que tienen por beneficiario a Santa María de Husillos fijan la elección

\footnotetext{
140 Docs. núm. 35 y 36.

${ }^{141}$ Docs. núm. 82, 97, 100, 113, 114, 134, 135, 163, 164, 192, 193 у 212.

${ }^{142}$ Docs. núm. 84, 92, 101, 184, 191 y 214. De éstas todas son plomadas, a excepción de la 92, que es abierta.

${ }^{143}$ PARDO RODRÍGUEZ, La confirmación en los documentos señoriales de la Baja Edad Media, 247-276.

${ }^{144}$ Docs. núm. 60, 79, 81, 159, 162, 201, 202, 207, 218, 219, 228, 231, 257, 270, 271, 272, 273, $280,284,300,309$ y 313.

${ }^{145}$ GARCÍA GALLO, Del testamento romano al medieval, 425-498.
} 


\section{LA ABADÍA DE SANTA MARÍA DE HUSILLOS: ESTUDIO Y COLECCIÓN \\ DOCUMENTAL $(904-1608)$}

de sepultura del testador en la iglesia del cenobio, hecho que hacían también anteriormente algunas donaciones "post obitum"146.

La distribución cronológica de los testamentos es la siguiente:

S. XIII: $3^{147}$.

S. XIV: $7^{148}$.

S. XV: $2^{149}$.

S. XVI: $10^{150}$.

Se observa un alto número de testamentos en el siglo XIV, quizá reflejo de una elevada religiosidad producto de un siglo de crisis. También es alto el número de testamentos en el siglo XVI, siendo durante este siglo el principal medio de expansión de la propiedad de Husillos.

\section{Compraventas ${ }^{151}$}

Contabilizamos un total de 35 compraventas $(9,9 \%)^{152}$, aunque existen tres donaciones, entre éstas un falso, cuya vicissitudo es de tal cuantía que las convierte en realidad en ventas encubiertas ${ }^{153}$. Sus fechas extremas abarcan entre 1056 y 1548. La fecha en la que aparecen las compraventas estaría en concordancia con lo afirmado por Barón Faraldo sobre que los primeros casos de compra de propiedades en la Tierra de Campos oriental se dan desde la primera mitad del siglo $\mathrm{XI}^{154}$. La mayoría de las compraventas tienen como autor a uno o varios particulares, y como destinatarios a Santa María de Husillos como institución, o bien al abad, alguna dignidad o canónigo. Es de suponer que las compras realizadas a título personal por las dignidades y canónigos pasaron en algún momento al patrimonio de Santa María de Husillos, y junto a éstas se transferirían también al archivo de la abadía los documentos de compra que

\footnotetext{
${ }^{146}$ ORLANDIS, Sobre la elección de la sepultura en la España medieval, 5-49.

${ }^{147}$ Docs. núm. 60, 79 y 81.

${ }^{148}$ Docs. núm. 159, 162, 201, 202, 207, 218 y 219.

${ }^{149}$ Docs. núm. 228 y 231.

${ }^{150}$ Docs. núm. 257, 270, 271, 272, 273, 280, 284, 300, 309 y 313.

${ }^{151}$ Para el estudio de la compraventa en la Edad Media: ALONSO MARTÍN, La compraventa en los documentos toledanos; y FERNÁNDEZ ESPINAR, La compraventa en el Derecho medieval español.

${ }^{152}$ Docs. núm. 13, 43, 44, 50, 52, 53, 63, 72, 115, 116, 117, 118, 119, 120, 121, 122, 123, 133, 155, 169, 170, 187, 203, 204, 208, 209, 211, 221, 230, 256, 260, 263, 264, 266 у 289.

${ }^{153}$ Docs. núm. 8, 16 y 18.

${ }^{154}$ BARÓN FARALDO, Grupos y dominios aristocráticos, 526-527.
} 
certificaban la propiedad. Solamente tres compraventas tienen como autor y destinatario a personas totalmente ajenas a Santa María de Husillos, suponiendo que pasarían a formar parte de dicha institución en un proceso similar a los anteriores $^{155}$.

La distribución cronológica de las compraventas es la siguiente:

S. XI: $1^{156}$.

S. XII: 0.

S. XIII: $7^{157}$.

S. XIV: $19^{158}$.

S. XV: $2^{159}$.

S. XVI: $6^{160}$.

Se aprecia un gran número de compraventas en el siglo XIV y un escaso número en los siglos XII y XV, observándose así que este tipo documental repunta en los períodos de crisis, como ya observó Alberto Marcos Martín en el caso del hospital de San Antolín de Palencia ${ }^{161}$.

\section{Permutas}

Contabilizamos 7 permutas $(1,9 \%)^{162}$ en la colección de Husillos, abarcando sus fechas desde 1146 hasta 1581, distribuyéndose cronológicamente de la siguiente manera:

S. XII: $1^{163}$.

S. XIII: $3^{164}$.

S. XIV: $1^{165}$.

${ }^{155}$ Docs. núm. 13, 133 y 155.

156 Doc. núm. 13.

157 Docs. núm. 43, 44, 50, 52, 53, 63 y 72.

${ }^{158}$ Docs. núm. 115, 116, 117, 118, 119, 120, 121, 122, 123, 133, 155, 169, 170, 187, 203, 204, 208, 209 y 211.

${ }^{159}$ Docs. núm. 221 y 230.

${ }^{160}$ Docs. núm. 256, 260, 263, 264, 266 y 289.

161 MARCOS MARTÍN, Economía, sociedad, pobreza en Castilla, 179-180. Afirma que el hospital de San Antolín de Palencia y en general las instituciones eclesiásticas, al contar con liquidez dineraria sobre todo por mandas y limosnas, en los momentos de crisis se aprovechan de la coyuntura y compran tierras y casas.

${ }^{162}$ Docs. núm. 24, 45, 59, 65, 186, 282 y 322.

${ }^{163}$ Doc. núm. 24.

${ }^{164}$ Docs. núm. 45,59 y 65.

${ }^{165}$ Doc. núm. 186. 
S. XV: 0.

S. XVI: $2^{166}$.

Las permutas se empiezan a realizar en Husillos en un momento en el que ya era frecuente este tipo jurídico en la zona de la Tierra de Campos Oriental ${ }^{167}$. A través de las permutas territoriales, Santa María de Husillos, al igual que otras instituciones, reestructura su dominio territorial en un momento en que ya está formado su patrimonio territorial, como forma de realizar una mejor gestión de sus propiedades, siendo a este respecto el documento número 186 de la colección el que mejor ilustra el intento de Santa María de Husillos de desprenderse de propiedades alejadas por otras más cercanas y rentables ${ }^{168}$. Las permutas se realizan normalmente con particulares, habiendo un caso en el que se realiza con un alto oficial del rey ${ }^{169}$ y otro en el que se realiza a nivel interno de la institución, entre la mesa abacial y capitular ${ }^{170}$.

No obstante, es escaso el número de permutas en comparación con las realizadas por otras instituciones.

Algunas permutas contienen también elementos de las donaciones y confirmaciones, como es la motivación, en este caso "pro remedio anima" ${ }^{171}$, y la fórmula de la vicissitudo ${ }^{172}$.

\section{Traslados}

Contemplamos al traslado como un tipo documental autónomo, contabilizándose en la colección de Husillos un total de $21(6,2 \%)^{173}$, de los cuales 3 son sacados por notarios apostólicos ${ }^{174}, 15$ lo son por notarios públicos del número de

\footnotetext{
${ }^{166}$ Docs. núm. 282 y 322.

${ }^{167}$ Barón Faraldo afirma que se documentan en esta zona desde el año 1091 (BARÓN FARALDO, Grupos y dominios aristocráticos, 542).

${ }^{168}$ Por este documento, fechado el 7 de noviembre de 1376, la abadía permuta sus propiedades en Hoyales y Fuentelisendo, en tierra de Haza (Burgos), por unas casas en Valladolid.

${ }^{169}$ Doc. núm. 186.

${ }^{170}$ Doc. núm. 62.

171 Doc. núm. 45.

172 Doc. núm. 24.

${ }^{173}$ Docs. núm. 7, 83, 87, 93, 102, 130, 132, 136, 137, 138, 147, 148, 149, 166, 168, 189, 202, 216, $223,225,239,262$ у 292.

${ }^{174}$ Docs. núm. 216, 225 y 262.
} 
Palencia $^{175}$, y en 3 no se especifica el tipo de notario que lo saca. Se contabiliza también una copia simple.

La distribución cronológica de los traslados es la siguiente:

S. XII: Una copia simple falsa de mediados del X que hemos fechado en el primer tercio del siglo XII ${ }^{176}$.

S. XIII: $3^{177}$.

S. XIV: $14^{178}$.

S. XV: $3^{179}$.

S. XVI: $1^{180}$.

Se aprecia cómo los traslados notariales comienzan en el siglo XIII, concretamente en la década de los noventa de dicho siglo, en un momento en el que el notariado ya estaba consolidado por la legislación promovida por Alfonso $\mathrm{X}$ y por los distintos fueros.

Por otra parte destaca el alto número de traslados realizados en el siglo XIV, con un predominio absoluto sobre el resto de siglos, lo cual refleja la necesidad que sintió la abadía de asegurar las escrituras que justificaban sus dominios, derechos y privilegios en un siglo de crisis.

En los motivos esgrimidos para realizar los traslados, suelen relacionarse los habituales, como son los tradicionales peligros para la integridad de los documentos y de los archivos: el fuego, el agua y el hurto. Llama la atención el motivo que se utiliza en el documento número 223 de la colección, en el que a los motivos anteriores se suma también la peligrosidad de los caminos, con lo que se trataba también de salvaguardar el documento original de los imprevistos que pudieran surgir en las salidas del documento del archivo en la resolución de los numerosos pleitos de la abadía.

\section{Arrendamientos}

\footnotetext{
${ }^{175}$ Docs. núm. 93, 102, 130, 132, 136, 137, 138, 147, 148, 149, 166, 168, 189, 202 у 223.

${ }^{176}$ Columna $C$ del doc. núm. 7.

${ }^{177}$ Docs. núm. 86, 87 y 93.

${ }^{178}$ Docs. núm. 102, 130, 132, 136, 137, 138, 147, 148, 149, 166, 168, 189, 202 у 216.

${ }^{179}$ Docs. núm. 223, 225 y 239.

${ }^{180}$ Doc. núm. 262.
} 
Contabilizamos 4 arrendamientos $(1,1 \%)$ en la colección de Husillos ${ }^{181}$, abarcando sus fechas desde 1245 hasta 1486 , de los cuales, 1 es del siglo XIII ${ }^{182}$, 2 del siglo $\mathrm{XIV}^{183}$ y 1 del siglo $\mathrm{XV}^{184}$.

\section{Censos}

Hay un total de 18 censos $(5,1 \%)^{185}$ en la colección de Husillos, que abarcan desde 1244 hasta 1599, presentando la siguiente distribución cronológica:

S. XIII: $1^{186}$.

S. XIV: $1^{187}$.

S. XV: $2^{188}$.

S: XVI: $14^{189}$.

Se constata el gran número de censos en el siglo XVI, ya que en la Edad Moderna el censo es la principal forma de aprovechamiento de los bienes inmuebles por las instituciones eclesiásticas. No obstante su aparición en Husillos es anterior a otras instituciones del ámbito palentino. Así por ejemplo, en San Zoilo los censos empiezan a aparecer a partir de 1378. Aunque se pueden confundir con los arrendamientos, en Husillos se diferencian relativamente bien. Los destinatarios de los censos son particulares a excepción del que se realiza con la abadía de Hérmedes ${ }^{190}$. Los censos se formalizan a una o varias vidas, asociándose siempre a unidades económicas menores, sobre todo casas. El pago puede ser en especie, si se trata de tierras de cultivo, siendo en tal caso el pago realizado en trigo o en cebada o mitad y mitad; o en metálico, si se trata de casas. Se suelen añadir al pago una o varias gallinas.

\footnotetext{
${ }^{181}$ Docs. núm. 66, 161, 173 y 241.

182 Doc. núm. 66.

${ }^{183}$ Docs. núm. 161 y 173.

${ }^{184}$ Doc. núm. 241.

${ }^{185}$ Docs. núm. 64, 200, 242, 250, 252, 253, 278, 279, 290, 291, 314, 315, 316, 317, 323, 324, 325 y 344.

${ }_{186}$ Doc. núm. 64.

${ }^{187}$ Doc. núm. 200.

${ }^{188}$ Docs. núm. 242 y 250.

${ }^{189}$ Docs. núm. 252, 253, 278, 279, 290, 291, 314, 315, 316, 317, 323, 324, 325 y 344.

${ }^{190}$ Doc. núm. 250.
} 


\section{Mandatos ${ }^{191}$}

Los mandatos contabilizados en la colección de Husillos son $11(3,1 \%)^{192}$, que abarcan desde 1268 hasta 1604, siendo su distribución por siglos la siguiente:

S. XIII: $2^{193}$.

S. XIV: $2^{194}$.

S. XV: $3^{195}$.

S. XVI: $3^{196}$.

S. XVII: $1^{197}$.

Comprobamos cómo el número de mandatos es uniforme a lo largo de los siglos.

En lo que se refiere a sus autores, 9 son reales ${ }^{198}, 1$ de un alto oficial real ${ }^{199}$, y 1 monástico de Husillos ${ }^{200}$.

\section{Inventarios de bienes}

A lo largo de la historia de Santa María de Husillos, se hicieron dos grandes inventarios de los bienes raíces e inmuebles que poseía la institución: el primero fue realizado entre 1374 y 1376, y se le denominó Libro Becerro; el segundo, el 18 de enero de 1555. La gran importancia de estos inventarios hace que le dediquemos un estudio individualizado.

\subsection{Libro Becerro}

El 22 de diciembre de 1183 se hizo la separación de las propiedades y rentas de Santa María de Husillos entre el abad y el cabildo. Desde dicho año hasta la realización de este documento tuvieron lugar numerosos cambios en las posesiones de las mesas abacial y capitular. De ahí que se hiciera necesaria la confección de un documento de relación de las propiedades y rentas de ambas

\footnotetext{
191 Identificamos como mandato desde un punto de vista jurídico, siendo conscientes de la existencia del mandato como tipo diplomático que tiene vida hasta el reinado de Alfonso X.

192 Docs. núm. 76, 92, 129, 131, 240, 247, 248, 255, 296, 333 у 348.

193 Docs. núm. 76 y 92.

${ }^{194}$ Docs. núm. 129 y 131.

${ }^{195}$ Docs. núm. 240, 247 y 248.

${ }^{196}$ Docs. núm. 255, 296 y 333.

${ }^{197}$ Doc. núm. 348.

${ }^{198}$ Docs. núm. 76, 129, 131, 240, 247, 248, 255, 333 y 348.

${ }^{199}$ Doc. núm. 129.

${ }^{200}$ Doc. núm. 296.
} 


\section{LA ABADÍA DE SANTA MARÍA DE HUSILLOS: ESTUDIO Y COLECCIÓN \\ DOCUMENTAL $(904-1608)$}

mesas. A esto habría que añadir la orden del papa Benedicto XII (1337-1338) para que las comunidades religiosas regulares realizasen inventarios contables de todos sus bienes ${ }^{201}$.

El documento nos ha sido transmitido por el Libro de los Privilegios de Husillos, en donde se copió desde un traslado. Sin embargo presenta problemas de datación tanto en su forma original como en el traslado, ya que la primera parte del documento, donde debían constar las fechas tanto del original como del traslado, no se conservaba en 1554, cuando se confeccionó el Libro de los Privilegios. Ante este problema hemos de hacer un análisis individualizado:

- Original $^{202}$ :

El mismo documento proporciona algunos datos que delimitan la fecha en el que se realizó. Así ha de ser anterior al 7 de noviembre de 1376, fecha en que Santa María de Husillos permuta las heredades de Hoyales y Fuentelisendo por unas casas en Valladolid. Dicha permuta aún no se refleja en el documento a analizar $^{203}$. Por otro lado comprobamos que en la enumeración de propiedades del cabildo en Fuentes de Valdepero aparecen las dos tierras que el chantre Domingo González donó al prior y cabildo el 4 de diciembre de $1374^{204}$. En conclusión, el documento original debió realizarse entre el 4 de diciembre de 1374 y el 7 de noviembre de 1376. San Martín Payo, en su estudio sobre el Libro Becerro, ya había establecido la fecha máxima de 1376 para la confección del libro apoyándose igualmente en la permuta de las heredades sorianas por las casas de Valladolid, pero establecía como posible fecha inicial el año 1240, fecha en que el abad y cabildo de Husillos permutaban con el obispo de Palencia sus derechos en Hoyales y Fuentelisendo por los derechos del segundo en la villa e iglesia de Pajares $^{205}$.

El documento en su mayor parte es una relación de las propiedades y rentas del abad, prior y cabildo, tanto desde el aspecto territorial como del jurisdiccional, de

\footnotetext{
${ }^{201}$ PÉREZ CELADA, Documentación de San Zoilo de Carrión, II, XLI. En este monasterio existe un inventario de sus cuentas fechado en 1338 .

${ }^{202}$ Doc. núm. 185.

${ }^{203}$ Doc. núm. 186.

${ }^{204}$ Doc. núm. 174.

${ }^{205}$ SAN MARTÍN PAYO, El Libro Becerro de Husillos, 239. No obstante se equivocó tanto en la fecha como en los autores de la permuta, ya que la fecha del documento es cuestión abarca entre 1232 y 1243, y los autores de la permuta son el abad y el cabildo de Husillos, que permutan los derechos del primero sobre San Juan de Pajares por la mitad de Hoyales y Fuentelisendo, propiedad del segundo, junto con otras posesiones.
} 
las propiedades encensadas de aquellos, de las iglesias bajo la jurisdicción de Husillos y de su servicio litúrgico. Las posesiones del abad y prior y cabildo se estructuran a su vez entre los distintos lugares donde tenían posesiones y derechos. Dentro de éstos, se relacionan las heredades, viñas, censos, y un capítulo de "temporalidad" donde se detalla la jurisdicción territorial y jurisdiccional del lugar en concreto.

También se hace relación de los préstamos de la abadía, capellanías, y posesiones para la lámpara de la iglesia y de la cofradía del hospital. Por otro lado, se detalla el servicio en la sacristía de la iglesia.

Por todo, el libro becerro no es simplemente un inventario de propiedades y derechos de la abadía. Es también un libro de control y gestión de su patrimonio territorial, un compendio de la situación jurisdiccional de los lugares de la abadía y del ordenamiento interno de la institución, aunque en este último apartado sólo se refiera a la sacristía.

- Traslado 206 .

Un documento de tanta importancia para los intereses del abad y del cabildo sin duda provocaría el deseo de éstos de realizar un traslado lo antes posible, más aún cuando se trataba de un documento básico para la gestión de la hacienda de ambas partes. De ahí que, como relata el propio documento, se hicieran dos traslados, uno para cada parte. El escribano que realiza el traslado, Juan Fernández de Tablada, aparece en otras dos escrituras de la colección que tienen como data, el 4 de diciembre de 1374 y 25 de agosto de 1375. Por ello la fecha del traslado debe encuadrarse en estas fechas, que coinciden con la del original. Por otra parte, creemos que dicho traslado es el denominado "Becerro" por varios documentos, incluído el propio Libro de los Privilegios, y que aunque es datado en 1415, probablemente no se hizo la conversión de la fecha en dichos documentos desde la era hispánica, siendo la data resultante 1377. El testimonio documental más esclarecedor que apoya nuestra teoría es un listado de documentos presentado en la contaduría episcopal por la colegiata de Ampudia $(1799$, noviembre, 11) en el que se extracta la ejecutoria de un pleito sentenciado por juez apostólico entre el prior y cabildo de Santa María de Husillos con Juan

${ }^{206}$ Doc. núm. 189. 
de Curiel de la Torre, por la posesión de varias propiedades y rentas ${ }^{207}$. En dicho pleito el prior y cabildo presentaron un certificado de propiedad de las posesiones en litigio que se sacó del "libro de becerro, formado el año de 1415". Dicho certificado coincide plenamente con el documento a estudiar.

En el Libro de lo Privilegios se copia el traslado perteneciente al prior y cabildo, deduciéndose que el original no se debía de conservar. Por otra parte, el documento que se traslada debía de estar mal conservado y parte de él roto, ya que no se signó. Probablemente el amplio uso que harían de sus respectivos ejemplares tanto el abad como el prior y cabildo en la gestión y defensa de sus patrimonios, hizo que en 1554 solamente se conservara en el archivo de Santa María de Husillos el ejemplar del prior y cabildo, que es el que se traslada en el Libro de los Privilegios, en no muy buenas condiciones, de ahí que no se validara; lo cual no quiere decir que el original y el traslado del abad no existieran. Probablemente estarían utilizándose en la gestión de algún negocio o como prueba en algún pleito, teniendo en cuenta además el extendido absentismo de los abades que podía provocar fácilmente la pérdida de su ejemplar.

\subsection{Relación de rentas de la abadía ${ }^{208}$}

Entre el 1 y el 18 de enero de 1555, el obispo de Plasencia, Gutierre de Carvajal, de visita en la abadía de Santa María de Husillos por poder del abad Francisco de Carvajal, su sobrino, manda realizar un inventario de las propiedades y derechos de la fábrica, mesa abacial, mesa capitular y hospital de Husillos. En el encabezamiento del documento se explican los motivos que llevaron al obispo a realizar tal mandato, que no eran otros que el grave estado de deterioro y pérdida en que se encontraba el dominio de Santa María de Husillos y la documentación que lo justificaba. Así, habiendo conciencia de la pérdida de muchas heredades, aun existiendo escrituras justificativas de éstas, y de la pérdida y gran deterioro de muchos documentos, se pretende hacer inventario de lo que en ese momento tenía la abadía, y no de su dote inicial.

Se hacen cuatro apartados correspondientes a las rentas de la fábrica, mesa abacial, hospital y mesa capitular. Dentro de éstos se hace relación de todas las

\footnotetext{
${ }^{207}$ APA, Leg. 152, carp 1.

${ }^{208}$ Doc. núm. 298
} 
heredades, tierras, casas, viñas, censos, molinos, diezmos, etc., que formaban las posesiones del apartado correspondiente. También se hace relación de la provisión de préstamos y beneficios. Se indican, en su caso, las dimensiones, linderos, cantidades económicas, escritura o causa de la posesión, y el número del folio del Libro de los Privilegios en el que se traslada el documento justificativo. Cuando se desconoce alguno de los anteriores datos, se deja un espacio en blanco. Aunque hay ocasiones en las que se deja en blanco de forma intencionada o por descuido el número de folio del Libro de los Privilegios donde se encuentra el traslado de un documento, muchas veces tal omisión responde a que el documento en cuestión no se encuentra trasladado en el Libro de los Privilegios, ya sea porque se decidió no trasladarlo o bien porque no se conservaba en el momento de su realización, ya fuera porque se encontraba en los tribunales como probanza o simplemente porque ya no existía ${ }^{209}$.

Por otra parte, el amanuense que realiza el inventario, que sería uno de los que hicieron el Libro de los Privilegios, lo hace valiéndose de éste, de los documentos originales y de información oral.

\section{Nombramientos:}

Se contabilizan cuatro nombramientos en la colección de Husillos, correspondientes a los siglos XIII, XIV y XV respectivamente. Se trata de dos nombramientos pontificios de abad de Husillos ${ }^{210}$, un nombramiento de prior por el abad y cabildo de Husillos ${ }^{211}$, y uno de merino de la villa de Husillos por el $\operatorname{abad}^{212}$.

\section{Documentos de organización, ordenación interna, regulación jurídica y control de la institución}

Se engloba en este grupo a todos los documentos que regulan el ordenamiento y organización interna de Santa María de Husillos como institución y de sus miembros, contabilizándose un total de 16 documentos: creación de la mesa

\footnotetext{
${ }^{209}$ Es el caso del fuero de Husillos otorgado por el abad Gutierre Pérez, según consta en el apartado de la mesa abacial.

${ }^{210}$ Docs. núm. 78 y 94.

${ }^{211}$ Doc. núm. 153.

${ }^{212}$ Doc. núm. 237.
} 


\section{LA ABADÍA DE SANTA MARÍA DE HUSILLOS: ESTUDIO Y COLECCIÓN \\ DOCUMENTAL $(904-1608)$}

abacial y capitular ${ }^{213}$, documentos de regulación del nombramiento del $\operatorname{abad}^{214}$, de la forma de testar de los canónigos $^{215}$, de las medias annatas ${ }^{216}$, estatutos generales $^{217}$ y visitas de los abades o sus procuradores a la sacristía y hospital de la abadía ${ }^{218}$.

En cuanto a la cronología de dicha documentación, se aprecia cómo los actos jurídicos de organización y regulación básica de la institución y sus miembros, como la separación y dotación de las mesas abacial y capitular, y la regulación de la forma de testar de los canónigos, se producen entre fines del siglo XII y principios del XIII; los documentos de regulación de las medias annatas de los nombramientos de dignidades y canónigos, se producen a fines del siglo XIII y comienzos del XIV, quizá como consecuencia de un período de crisis en el que las instituciones tratan de consolidar sus ingresos. Por otra parte, comprobamos cómo los tres estatutos conservados coinciden con el abadiato de tres abades de gran personalidad en la historia de la abadía, como fueron Luis de Carvajal (1472), Francisco de Carvajal (1554), y Francisco de Reinoso (1588). Por último, las visitas conservadas abarcan desde 1569 hasta $1602^{219}$, destacando las realizadas por Francisco de Reinoso.

\section{Acuerdos del cabildo}

El cabildo de Santa María de Husillos, como entidad con personalidad jurídica dentro de la institución monacal, produciría actos jurídicos que se expresarían en documentos individuales o bien en los libros de actas. En la colección de Husillos aparecen dos acuerdos capitulares ${ }^{220}$, uno en un ejemplar documental independiente, el otro en un libro de actas, refiriéndose este último a un acto de gran importancia como es el acuerdo para el traslado de la abadía a Ampudia.

\section{Poderes}

\footnotetext{
${ }^{213}$ Doc. núm. 70.

${ }^{214}$ Doc. núm. 80.

215 Doc. núm. 47.

216 Doc. núm. 83.

${ }^{217}$ Docs. núm. 233, 297 y 330.

${ }^{218}$ Docs. núm. 306, 307, 311, 312, 320, 326, 337, 341 y 345.

${ }^{219}$ Ello se debe a que solamente se conservan los libros de fábrica de Husillos, en los que se insertan las visitas, desde el año 1569.

${ }^{220}$ Docs. núm. 308 y 337.
} 
Se contabilizan un total de 18 poderes en la colección de Husillos $(5,1 \%)^{221}$, en un período cronológico que abarca desde 1323 hasta 1554, siendo su distribución en siglos la siguiente:

S. XIV: $15^{222}$.

S. XV: $1^{223}$.

S. XVI: $2^{224}$.

Once poderes fueron producidos como un trámite más dentro de un proceso judicial o de avenencia, correspondiendo todos ellos al siglo XIV. Con todo se aprecian las siguientes observaciones: que la mayor parte de los poderes corresponden a partes de procesos judiciales, y que éstos corresponden todos al siglo XIV, siendo todo ello reflejo del período de crisis que alentó los litigios entre las instituciones y particulares. El resto de los poderes corresponden a diversos actos jurídicos como la representación del abad o cabildo para el nombramiento de dignidades, oficiales y para la realización de contratos de censo y arrendamiento.

En cuanto a los autores de los poderes, la mayoría corresponden al abad y cabildo de Santa María de Husillos. Pero también aparecen poderes producidos por otras instituciones como diversos monasterios y concejos.

\section{Autorizaciones y licencias}

En la colección de Husillos identificamos un total de diez autorizaciones y licencias $(2,8 \%)^{225}$, correspondiendo tres de ellas a autorizaciones para realizar avenencias con otras instituciones o particulares ${ }^{226}$. Su cronología abarca desde 1353 hasta 1606 . De éstas seis corresponden a la segunda mitad del siglo $\mathrm{XIV}^{227}$, dos a finales del siglo $\mathrm{XV}^{228}$, una a la segunda mitad del $\mathrm{XVI}^{229}$ y una a

\footnotetext{
${ }^{221}$ Docs. núm. 103, 110, 126, 139, 140, 141, 150, 152, 160, 172, 176, 195, 196, 197, 198, 249, 277 y 293.

${ }^{222}$ Docs. núm. 103, 110, 126, 139, 140, 141, 150, 152, 160, 172, 176, 195, 196, 197198.

${ }^{223}$ Doc. núm. 249.

${ }^{224}$ Docs. núm. 277 y 293.

${ }^{225}$ Docs. núm. 142, 143, 144, 151, 183, 206, 245, 246, 308 y 350.

${ }^{226}$ Docs. núm. 142, 143 y 144.

${ }^{227}$ Docs. núm. 142, 143, 144, 151, 183 y 206.

${ }^{228}$ Docs. núm. 245 y 246.

${ }^{229}$ Doc. núm. 308.
} 
comienzos del $\mathrm{XVII}^{230}$. Observamos, al igual que en los poderes, que la mayor parte de las licencias o autorizaciones se producen en el siglo XIV, concretamente en su segunda mitad, correspondiendo tres de las identificadas en este siglo a actos de tramitación dentro de un proceso judicial. El resto tienen como fin autorizar variados actos jurídicos como nombramientos, permutas, explotación de canteras, arrendamientos, compraventas, y por último, la autorización pontificia para el traslado de la abadía a Ampudia.

Los autores de las licencias y autorizaciones son variados: el abad y cabildo de Santa María de Husillos ${ }^{231}$, el obispo de Palencia por sí mismo o a través de algún procurador $^{232}$, delegados regios ${ }^{233}$, $\operatorname{concejos}^{234}$, otros monasterios ${ }^{235}$, y el papa ${ }^{236}$.

\section{Reconocimientos}

Identificamos con este tipo jurídico a tres documentos de la colección de Husillos, cuyas fechas corresponden a $1237^{237}, 1301^{238}$ y $1375^{239}$. Los productores de dos de ellos corresponden a particulares nobles que reconocen el señorío de Husillos sobre los lugares de $\mathrm{Aza}^{240}$ y Villaldavín ${ }^{241}$. El tercero supone el reconocimiento del abad de Husillos del derecho a la media annata sobre los beneficios de Husillos al obispo de Palencia ${ }^{242}$. Se observa, al igual que en el caso de los poderes y de las autorizaciones, que este tipo jurídico coincide con períodos de crisis.

\section{Documentos pontificios}

\footnotetext{
${ }^{230}$ Doc. núm. 350.

${ }^{231}$ Docs. núm. 143, 151, 183 y 308.

${ }^{232}$ Docs. núm. 142 y 245.

${ }^{233}$ Doc. núm. 144.

234 Doc. núm. 206.

${ }^{235}$ Doc. núm. 246.

${ }^{236}$ Doc. núm. 350.

${ }^{237}$ Docs. núm. 58.

${ }^{238}$ Doc. núm. 95.

${ }^{239}$ Doc. núm. 175.

${ }^{240}$ Doc. núm. 58.

${ }^{241}$ Doc. núm. 175.

${ }^{242}$ Doc. núm. 95.
} 
En la colección de Husillos identificamos veinte documentos pontificios $(5,6 \%)$, con una variada tipología tanto documental como jurídica ${ }^{243}$. Así, encontramos privilegios solemnes ${ }^{244}$, litterae gratiae $^{245}$, y litterae solemnes o bulas ${ }^{246}$. Identificamos también tipos más específicos como una conservatoria ${ }^{247}$ o las declaraciones de una institución dependiente de la Santa Sede como era la Congregación del Concilio de Trento ${ }^{248}$.

Los tipos jurídicos son comunes al resto de la documentación: confirmaciones, concesiones de derechos, gracias e indulgencias, nombramientos, autorizaciones.

\section{Documentos judiciales}

La documentación judicial de la colección de Husillos está formada por cuarenta y siete documentos $(13,3 \%)^{249}$, a los que habría que añadir once poderes para trámites judiciales y un reconocimiento de sentencia que han sido identificados como tipos jurídicos propios. La cronología de esta documentación abarca desde 1201 hasta 1598, siendo su distribución por siglos la siguiente:

S. XIII: $5(9,6 \%)^{250}$.

S. XIV: $31(24,6 \%)^{251}$.

S. XV: $6(18,7 \%)^{252}$.

S. XVI: $17(18,2 \%)^{253}$.

Se observa el alto porcentaje de documentos judiciales en el siglo XIV con respecto al resto de siglos, confirmándose así lo observado en otras instituciones eclesiásticas sobre que es el alto número de actos de litigación en el siglo XIV el

\footnotetext{
${ }^{243}$ Para la sistematización diplomática de la documentación pontificia nos basamos en la fijada por la Asociación de Archiveros de la Iglesia (Documentos pontificios), y en la citada por Santiago Domínguez Sánchez (DOMÍNGUEZ SÁNCHEZ, Bonifacio VIII, 41-47).

${ }^{244}$ Docs. núm. 23, 32 y 39.

245 Docs. núm. 48, 67, 68, 69, 70, 78, 89, 94 y 222.

${ }^{246}$ Docs. núm. 103, 124, 235, 274 y 350.

${ }^{247}$ Doc. núm. 61.

248 Doc. núm. 309.

${ }^{249}$ Docs. núm. 46, 57, 61, 62, 73, 96, 98, 195, 106, 107, 108, 111, 112, 125, 127, 128, 145, 146, $177,178,179,180,181,182,199,220,224,226,227,232,236,259,265,299,303,305,321$ у 342.

${ }^{250}$ Docs. núm. 46, 57, 61, 62 y 73 .

${ }^{251}$ Docs. núm. 96, 98, 103, 105, 106, 107, 108, 110, 111, 112, 125, 126, 127, 128, 130, 140, 141, $145,146,176,177,178,179,180,181,182,195,196,197,198$ у 199.

${ }^{252}$ Docs. núm. 220, 224, 226, 227, 232 y 236.

${ }^{253}$ Docs. núm. 259, 265, 267, 275, 276, 281, 283, 286, 287, 294, 299, 302, 303, 304, 305, 321 у 342.
} 


\section{LA ABADÍA DE SANTA MARÍA DE HUSILLOS: ESTUDIO Y COLECCIÓN \\ DOCUMENTAL $(904-1608)$}

mejor reflejo de la gran crisis que se produjo en dicho siglo. Se observa también que el alto porcentaje se mantiene en el siglo $\mathrm{XV}$, habiendo un fuerte descenso en el siglo XVI, por lo que en Santa María de Husillos no se cumpliría la tónica que observó Richard Kagan en su estudio sobre la actividad litigante en Castilla en la Edad Moderna, de un contexto general de aumento de la costumbre de litigar en la sociedad e instituciones castellanas en el siglo $\mathrm{XVI}^{254}$.

Es preciso hacer una clasificación de la documentación judicial en función de variables como las instituciones o personas privadas litigantes, los jueces y árbitros, instituciones productoras, y causas y motivos de los pleitos y conflictos.

\subsection{Litigantes}

En este primer apartado se analiza la tipología de las instituciones que litigan con Santa María de Husillos. Nos encontramos con que la abadía, a lo largo de su historia, litigó con gran variedad de instituciones y particulares. Las instituciones con las que más litigó Santa María de Husillos fueron los concejos, especialmente los de las proximidades, como Monzón de Campos, Fuentes de Valdepero, Becerril de Campos, Palencia y Valdespina, y otros que formaban parte de su señorío territorial y jurisdiccional, como Villaldavín y Villaudilla. A los concejos les sigue la catedral de Palencia como institución o con alguna de sus dignidades, iglesias de localidades como Paredes de Nava o Becerril de Campos, y el monasterio de Santa María de Benavides. A veces los pleitos o avenencias se producen entre las mismas dignidades y canónigos de Santa María de Husillos, siendo entonces juzgados por el abad o alguna de sus dignidades.

\subsection{Jueces y árbitros}

Los jueces y árbitros en los pleitos y avenencias de Santa María de Husillos presentan variada tipología, debiendo hacer una primera clasificación en función del grado o instancia en la que se juzga el asunto. Así, en primera y segunda instancia tendríamos a los "hombres buenos" de los concejos, obispos de Palencia, abades, destacando al de Hérmedes, vicarios episcopales y de los abades, priores, canónigos, clérigos, beneficiados, delegados territoriales de la corona, comisarios

${ }^{254}$ KAGAN, Pleitos y pleiteantes en Castilla, 31-44. 
reales, delegados señoriales, y jueces que podríamos definir como profesionalizados a los que se les da el título de bachiller. La nota común a todos estos sería que en la mayoría de las ocasiones son elegidos por las propias partes litigantes.

En tercera instancia tenemos los pleitos que llegaron a la Real Audiencia y Chancillería de Valladolid por apelación, ya fuera de Santa María de Husillos o de la otra parte litigante, siendo del año 1505 el primer asunto litigado en la Chancillería.

Se observa, al igual que lo que sucede en otras instituciones eclesiásticas como Sahagún ${ }^{255}$, la abundancia de pleitos y avenencias juzgadas por tribunales y jueces exteriores, mientras que escasean los pleitos "infra cauto" en los que los tribunales estarían formados por el abad, dignidades y miembros de la abadía.

\subsection{Asuntos y motivos de los pleitos}

Los motivos de los pleitos y avenencias son similares a los del resto de instituciones eclesiásticas: propiedad, disfrute y límites de pastos y términos, aplicación de privilegios forales, disfrute de diezmos, quebrantamientos $\mathrm{y}$ deshonras, pago de tercias reales, amojonamientos y deslindes de términos, deudas económicas y ejecución de bienes por deudas.

\subsection{Tipología documental}

Es amplio el marco tipológico de la documentación judicial de Santa María de Husillos, reflejo del procedimiento judicial y del grado de complejidad que éste iba alcanzando con el paso del tiempo. Se debe hacer una primera clasificación entre pleitos con instituciones y particulares laicos, y pleitos entre instituciones y particulares eclesiásticos bajo fuero eclesiástico; y entre la documentación judicial producida por los tribunales locales, señoriales y episcopales de primera $\mathrm{y}$ segunda instancia, y la producida por el tribunal superior de justicia del reino de Castilla: la Real Audiencia y Chancillería de Valladolid.

\subsubsection{Documentación de procesos judiciales de primera y segunda instancia}

\footnotetext{
${ }^{255}$ PRIETO PRIETO, Documentos referentes al orden judicial de Sahagún, 489-542.
} 
Normalmente los distintos trámites jurídicos, que corresponden a otros tantos tipos diplomáticos, se insertan en documentos resolutivos como las avenencias, sentencias o las ejecuciones de éstas, especialmente en los siglos XIII, XIV, y $\mathrm{XV}$, en que los procedimientos judiciales y administrativos se están desarrollando, y los documentos originales de los distintos actos jurídicos de trámite no se conservan, a veces porque ni siquiera se reflejan en un documento escrito. Por ello, en el documento final reflejo del trámite resolutivo se insertan todos los trámites a modo de resumen e historia del proceso. Los tipos documentales más frecuentes son los poderes dados a los procuradores por la partes litigantes, demandas, contestaciones a las demandas, citaciones, compromisos, apelaciones, sentencias, ejecuciones de las sentencias.

\subsubsection{Documentación de procesos judiciales de tercera instancia producidos por la Real Audiencia y Chancillería de Valladolid}

La Real Audiencia y Chancillería de Valladolid era el tribunal superior de justicia de la corona de Castilla. En las sentencias de los pleitos civiles que se juzgaban en ésta cabía apelación al consejo real en pleitos de cierta calidad y cuantía, mientras que de sus sentencias de pleitos criminales no cabía apelación.

Como institución eclesiástica, las apelaciones y pleitos de Santa María de Husillos están sujetos a la reglamentación y práctica de la Chancillería sobre los litigios en los que al menos una de las partes era institución eclesiástica o pertenecía a una de éstas. Así, eran dos los tipos de litigios relacionados con la iglesia en los que la Chancillería de Valladolid tenía competencia: los recursos de fuerza eclesiásticos y los pleitos propiamente dichos.

Los recursos de fuerza eran las apelaciones por parte de un litigante laico a la Real Chancillería de sentencias dadas por tribunales eclesiásticos. Si el Acuerdo de la Chancillería consideraba que había abuso de fuerza por parte del tribunal eclesiástico que había sentenciado o negado una apelación, entonces intervenía denegando o aceptando la apelación en la Chancillería, pasando entonces a ser juzgado el caso conforme a su práctica. También podía suceder que se obligara al tribunal eclesiástico a aceptar la apelación anteriormente denegada. La Chancillería no podía conocer de pleitos eclesiásticos cuyos motivos fueran las 
costumbres y reglas de los monasterios ${ }^{256}$, y las visitas de los obispos o sus delegados a los monasterios e iglesias ${ }^{257}$.

Los pleitos eran la principal forma de litigación de las instituciones eclesiásticas en la Chancillería, siendo las instituciones eclesiásticas o sus miembros las que mayor actividad litigante desarrollaron en dicha institución ${ }^{258}$. La entrada en la Chancillería de un litigio en cuestión tenía dos formas: como pleito de nuevo cuño en el que la parte demandante acudía a la Chancillería para dar curso a su demanda, o bien pleito por apelación de uno anterior que había sido sentenciado por un tribunal de primera o segunda instancia ${ }^{259}$.

El procedimiento en la Chancillería se iniciaba con la entrada en la Chancillería de la demanda o apelación a través del procurador o agente de la parte demandante. Éstos podían ser de plantilla de la Chancillería, aunque los monasterios y otras comunidades podían enviar sus agentes para sus negocios ${ }^{260}$. La demanda se entregaba por lo común al repartidor de pleitos de la Chancillería, que encauzaba el pleito en la sala que correspondiera, y dentro de ésta, en el partido correspondiente $^{261}$. Mediante un sistema de cajones e hijuelas, el repartidor encauzaba los pleitos en las escribanías de las salas a que correspondiera el pleito $^{262}$. La mayoría de los pleitos de las instituciones eclesiásticas en la Chancillería eran civiles, siendo seis los partidos por los que se encauzaban dichos pleitos $^{263}$.

\footnotetext{
${ }^{256}$ AULESTIA, Práctica y formulario de la Chancillería de Valladolid, f. 8v.

${ }^{257}$ GARRIGA, Ordenanzas de la Chancillería de Valladolid, Titulo I, De la audiencia y chancillería, f. 11v.

${ }^{258}$ Según Kagan, los clérigos estuvieron implicados en la cuarta parte de los pleitos comenzados en la Chancillería (KAGAN, Pleitos y pleiteantes en Castilla, 114).

${ }^{259}$ Según Kagan, a las instituciones y litigantes poderosos les interesaba llevar el pleito a la Chancillería directamente, ya que la lejanía y lo costoso hacía que la otra parte desistiera (KAGAN, Pleitos y pleiteantes en Castilla).

${ }^{260}$ AULESTIA, Práctica y formulario de la Chancillería de Valladolid, f. $45 \mathrm{r}$.

${ }^{261}$ Los partidos eran divisiones establecidas por los acuerdos de las distintas salas de la Chancillería, por las que el repartidor de pleitos debía encauzar las apelaciones y nuevas demandas. Se configuraban en función de la calidad de los litigantes y de la cuantía de los pleitos.

${ }^{262}$ Según las ordenanzas de la Chancillería, Libro segundo, título cuarto. De los escribanos de la Audiencia, y del crimen y otros jueces, f. 88, en un arca ha de haber seis libros (tantos por partido) y seis cajones. En cada cajón, doce hijuelas, con los nombres de los escribanos. Los pleitos civiles se canalizarán a través de seis partidos.

${ }^{263}$ Los partidos de los pleitos civiles vienen definidos en las ordenanzas de la Chancillería, Libro segundo, título cuarto. De los escribanos de la Audiencia, y del crimen y otros jueces, f. 88:

$1^{\circ}$. Pleitos en los que estén implicados grandes, caballeros y monasterios, sobre mayorazgos, villas, vasallos y asuntos similares, que sean de mucha cantidad y calidad.

$2^{\circ}$. Pleitos en los que estén implicados monasterios, concejos o particulares, sobre términos, jurisdicción, imposiciones, portazgos, o asuntos similares.
} 


\section{LA ABADÍA DE SANTA MARÍA DE HUSILLOS: ESTUDIO Y COLECCIÓN \\ DOCUMENTAL $(904-1608)$}

Encauzada la demanda en una escribanía, era ésta desde entonces la encargada de tramitar el pleito, de reunir toda la documentación necesaria para su resolución, y de dar conocimiento de ésta a otros oficiales como los procuradores, relatores y fiscal. Cuando el pleito estaba listo para ser sentenciado, se le consideraba "concluso". El escribano llevaba entonces el pleito al acuerdo, que asigna un relator, teniendo preferencia los pleitos eclesiásticos ${ }^{264}$. Éste hace relación del pleito, siendo sentenciado en vista por los oidores de la sala correspondiente. Si una parte apela dicha sentencia, entonces el acuerdo de oidores y presidente de la chancillería dan sentencia definitiva. Todavía cabía una tercera apelación al tribunal de las mil quinientas doblas del Consejo de Castilla, si el pleito era de mucha cuantía. Las partes podían entonces solicitar carta ejecutoria de la sentencia definitiva, generalmente la parte vencedora, que era redactada por el escribano y registrada, en su caso, en el Registro de ejecutorias de la Real Chancillería ${ }^{265}$.

Los litigantes eclesiásticos, a diferencia del resto, tenían una serie de privilegios en la tramitación de sus pleitos. Así los escribanos no podían cobrar derechos de vista en los pleitos eclesiásticos ${ }^{266}$. Por otra parte, estaban exentos del pago de registro en las ejecutorias y provisiones.

$3^{\circ}$. Pleitos en los que estén implicados monasterios, concejos o particulares, sobre bienes con valor desde cinco o seis cuentos de maravedís, hasta 500 mil.

$4^{\circ}$. Pleitos en los que estén implicados cualquier parte, sobre bienes de 500 mil maravedís hasta 50 mil. También, los pleitos que entraran por apelación a las salas de hijosdalgo.

$5^{\circ}$. Pleitos sobre bienes de entre 50 mil maravedís hasta 10 mil. También, los pleitos que vinieren por apelación de los notarios, si fuere de cantidad, y si no, estos se deben repartir por el segundo partido.

$6^{\circ}$. Pleitos sobre bienes de 10 mil maravedís abajo. Pleitos de la Villa y su tierra (Valladolid con cinco leguas al derredor), y los de pobres, a no ser que los pleitos antedichos convendrían canalizarlos por otro partido.

264 AULESTIA, Práctica y formulario de la Chancillería de Valladolid, f. 31v: "Los pleitos eclesiásticos, después que los entregan, los llevan en el primer acuerdo a encomendar a relator, sin que las partes hagan otra diligencia".

${ }^{265}$ Debido al alto precio de las ejecutorias, no siempre las partes solicitaban la confección de carta ejecutoria de la sentencia, conformándose con una provisión signada de la sentencia, que se registraba en el registro de provisiones de la Chancillería. No obstante, generalmente las instituciones eclesiásticas, gracias a su mayor potencial económico y por la calidad de los pleitos que litigaban, sí solicitaban ejecutoria de la sentencia de los pleitos que ganaban. También se podía dar la posibilidad de que la parte solicitase carta ejecutoria de la sentencia pero no mandara registrarla en el Registro de ejecutorias (GARRIGA, Ordenanzas de la Chancillería de Valladolid, Libro primero, título noveno. Del registrador y de los registros, f. 71r).

${ }^{266}$ GARRIGA, Ordenanzas de la Chancillería de Valladolid, Libro cuarto, titulo tercero. De los pleitos, procesos y pleitos remitidos, f. 153v. 
El procedimiento de los litigios en la Chancillería se traduciría en los distintos tipos documentales existentes en su archivo y registro, y también en el fondo de Husillos: pleitos fenecidos, olvidados, depositados, registro de ejecutorias y registro de provisiones, organización documental que se mantendría con la formación del archivo histórico a mediados del siglo XIX. En la década de los sesenta del siglo $\mathrm{XX}$, se conformaría una sección factícia por motivos de conservación de pergaminos y planos y dibujos, con la documentación en pergamino aportada como prueba por los litigantes que, por varios motivos, se había quedado en los fondos de las escribanías ${ }^{267}$.

A grandes rasgos, los pleitos fenecidos son aquellos que tienen sentencia definitiva, ya sea de vista o de vista y revista ${ }^{268}$. Los pleitos olvidados son aquellos que o bien no cuentan con ninguna sentencia, o bien cuentan con sentencia de vista, pero siendo apelado, no se llegó a dar sentencia de revista. Los pleitos depositados se definieron en el último tercio del siglo XVIII con el archivero Manuel de Barradas, y eran todos aquellos pleitos en los que hubieran pasado más de diez años entre que se dio su sentencia de vista, y habiéndose apelado ésta, no se hubieran continuado ${ }^{269}$.

\subsection{Pleitos de Santa María de Husillos en la Real Chancillería de Valladolid}

Como la mayoría de las instituciones eclesiásticas de la edad Moderna, Santa María de Husillos llegó a litigar en la Chancillería de Valladolid, ya fuera como parte demandante o demandada, por apelación de un pleito con una parte seglar o bien por recurso de fuerza a la sentencia de un tribunal eclesiástico por una causa

\footnotetext{
267 Las partes litigantes o sus procuradores, en apoyo a sus demandas o a sus contestaciones, presentaban escrituras que el escribano debía trasladar, devolviendo el original a la parte en cuestión, como estipulaban las reales ordenanzas en su Libro segundo, título IV, "De los escribanos de la Audiencia, del Crimen y otros jueces", f. 85r. Aunque los escribanos solían inventariar todas las escrituras que se le presentaban para constancia y un mayor control, en ocasiones no realizaban traslado de dichas escrituras, adjuntando los originales en el mismo pleito. También a veces por la falta de interés de las partes en recuperar sus documentos o por la desorganización de las escribanías, la documentación acababa por quedarse en los archivos de las escribanías o en los mismos pleitos.

${ }^{268}$ La bibliografía tradicional los ha definido como los pleitos de los que se había expedido carta ejecutoria, debido a la definición que hace en este sentido obras como la de Fernández de Ayala Aulestia.

${ }^{269}$ Sobre los procedimientos en los distintos tipos de pleitos en relación con el Archivo de la Chancillería: MARCOS DIEZ, El Archivo de la Real chancillería de Valladolid.
} 


\section{LA ABADÍA DE SANTA MARÍA DE HUSILLOS: ESTUDIO Y COLECCIÓN \\ DOCUMENTAL $(904-1608)$}

eclesiástica. A diferencia de otras instituciones eclesiásticas como las catedrales o los grandes monasterios como Sahagún, el volumen documental de Husillos en la Chancillería es pequeño. La documentación localizada tanto en el propio archivo de la Real Chancillería como en el fondo de Husillos se refiere a pleitos fenecidos, olvidados y ejecutorias de las sentencias ${ }^{270}$.

\subsubsection{Pleitos fenecidos}

Son dos los pleitos fenecidos relativos a Santa María de Husillos conservados en el Archivo de la Real Chancillería de Valladolid, de los años $1562^{271}$ y $1598^{272}$ respectivamente. Del primero se conserva su respectiva carta ejecutoria en el registro de ejecutorias del Archivo de la Real Chancillería ${ }^{273}$. Del segundo no se conserva, lo cual indica que Husillos pudo mandar sacar una provisión signada de la sentencia.

\subsubsection{Pleitos olvidados}

Se conservan cuatro pleitos olvidados de Husillos en la Chancillería, abarcando su cronología entre 1522 y $1579^{274}$.

\subsubsection{Ejecutorias}

Se conservan 8 ejecutorias relativas a Santa María de Husillos, que abarcan entre 1505 y $1593^{275}$. De éstas, ninguna se conserva en forma original en el fondo de Husillos, siendo su constancia los traslados realizados en el Registro de ejecutorias de la Real Chancillería de Valladolid y en el Libro de los Privilegios de Husillos. Esto se debe a que quizá dichas ejecutorias se presentasen en pleitos posteriores como documentos de prueba, adjuntándose entonces en los $\operatorname{procesos}^{276}$. De tres ejecutorias de los años $1505^{277}$ y $1562^{278}$ conservadas en el

\footnotetext{
${ }^{270}$ No obstante los trabajos de descripción que se vienen realizando en el Archivo de la Real Chancillería de Valladolid hace que dicho elenco documental sea ampliable, en especial en lo que se refiere al Registro de provisiones.

${ }^{271}$ Doc. núm. 303.

272 Doc. núm. 342.

273 Doc. núm. 304.

${ }^{274}$ Docs. núm. 265, 299, 305 y 321.

275 Docs. núm. 259, 275, 276, 281, 283, 294, 302 y 304.

${ }^{276}$ Estos pleitos serían sobre todo los realizados por la colegiata de San Miguel de Ampudia.

277 Doc. núm. 259.

${ }^{278}$ Docs. núm. 302 y 304.
} 
Registro de la Chancillería, no existe su traslado en el Libro de los Privilegios. Dos de ellas, del año 1562, se explicarían por el hecho de que dicho Libro ya estaba confeccionado y que ya no se redactaba en él nuevos traslados, aunque sí nuevos originales, como se verá en el capítulo específico de dicho libro. Existe una ejecutoria inserta en un testimonio notarial de 1533 en el Libro de los Privilegios que no está registrada en el Registro de la Chancillería ${ }^{279}$. Esto puede deberse a que Santa María de Husillos optó por no registrar la ejecutoria que solicitó para no pagar la tasa del registro, posibilidad existente como se ha indicado anteriormente, lo cual evidenciaría además que no siempre las instituciones eclesiásticas estaban exentas de pagar derechos de registro en la Real Chancillería. Por último son cuatro las ejecutorias conservadas en el Registro de la Chancillería y en el Libro de los Privilegios de Husillos.

En cualquier caso, el número de ejecutorias conservadas relativas a Husillos no refleja de forma exacta la intensidad de la actividad litigante de dicha institución, ya que solamente mandaría sacar ejecutoria de las sentencias que le serían favorables, teniendo en cuenta además que las partes vencedoras no siempre sacarían ejecutoria por los gastos de registro que éstas conllevaban.

\subsubsection{Motivos y causas de los pleitos}

Los motivos y causas por los que Santa María de Husillos litigó en la Chancillería de Valladolid son los comunes al resto de instituciones eclesiásticas que litigaron en dicho tribunal: deudas económicas por arrendamientos y censos de casas y tierras, derechos de riego, pastos y tránsito de ganados, jurisdicción de lugares, propiedad de heredades y términos, ejecución de bienes.

\subsubsection{Recursos de fuerza}

Son dos los recursos de fuerza relativos a Husillos conservados en el Archivo de la Real Chancillería de Valladolid, ambos de $1547^{280}$, siendo uno admitido y otro rechazado por la Chancillería. En ambos los litigantes que hacen el recurso de fuerza a la Chancillería son dignidades de Husillos. Del examen de ambos recursos de fuerza se desprende que la apelación a la Chancillería suponía un

\footnotetext{
${ }^{279}$ Doc. núm. 267.

${ }^{280}$ Docs. núm. 286 y 287.
} 


\section{LA ABADÍA DE SANTA MARÍA DE HUSILLOS: ESTUDIO Y COLECCIÓN \\ DOCUMENTAL $(904-1608)$}

último intento por la parte recurrente de seguir la tramitación del pleito y conseguir una sentencia a favor. En ambos casos la primera instancia es el tribunal del abad; la segunda, el tribunal del obispo o diocesano; y la tercera, en su caso, la Real Chancillería de Valladolid.

\subsubsection{Conclusiones}

Se observa que la actividad pleiteadora de Husillos en la Chancillería de Valladolid se concentró exclusivamente en el siglo XVI. Este dato concordaría con las afirmaciones de Richard Kagan sobre la gran actividad litigante de las instituciones castellanas en el siglo XVI y el descenso espectacular en el siglo siguiente $^{281}$.

Por otra parte se observa también que la Real Chancillería de Valladolid actuó, al menos en el caso de Husillos, como tribunal de última instancia tanto en sus pleitos civiles como eclesiásticos, sustituyendo así al tribunal del arzobispado y Santa Sede en el caso de estos últimos.

\section{Otros tipos documentales}

Clasificamos en este apartado aquellos tipos jurídicos de escasa presencia, pero cuya existencia contribuye a la amplitud y diversidad de la colección documental de Husillos: acta conciliar del concilio legatino celebrado en Husillos en el año $1088^{282}$, concordia entre el abad de Husillos y el prior y cabildo de dicha iglesia $^{283}$, capitulación sobre el servicio en una capellanía de Santa María de Husillos $^{284}$, expediente sobre la declaración de patronazgo real de Santa María de Husillos $^{285}$, informe del corregidor de Palencia sobre dicho patronazgo ${ }^{286}$, declaraciones de la Congregación del Concilio de Trento a favor de Santa María

\footnotetext{
281 Según Kagan, además del carácter pleiteador de la sociedad castellana del siglo XVI, la inflación fomentó dicha actividad al dar cabida en la Chancillería a pleitos cuya cuantía fijada por las ordenanzas se había quedado desfasada en dicha centuria. Kagan va más allá al afirmar que la litigación es una de las causas por las que a partir del siglo XVI los archivos de Castilla se conservan más completos, afirmación que aunque exagerada, tiene su parte de razón (KAGAN, Pleitos y pleiteantes en Castilla, 38).

282 Doc. núm. 14.

${ }^{283}$ Doc. núm. 268.

${ }^{284}$ Doc. núm. 75.

285 Doc. núm. 328.

${ }^{286}$ Doc. núm. 326.
} 
de Husillos y contra el obispo de Palencia ${ }^{287}$, y de Felipe II sobre el patronazgo real de Husillos ${ }^{288}$; protesta realizada por el cabildo catedralicio de Palencia por el traslado de la abadía a Ampudia ${ }^{289}$; acatamiento de una sentencia ${ }^{290}$ y de una cédula real ${ }^{291}$; información "ad perpetuam rei memoriam" sobre ciertas posesiones de la fábrica de Santa María de Husillos ${ }^{292}$; requerimiento del prior de Husillos al vicario general de la diócesis de Palencia en relación al monte de la Reyerta $^{293}$.

\section{Evolución de los tipos documentales: conclusiones}

La evolución en el tiempo de los distintos tipos documentales de la colección de Husillos es similar a lo observado en las colecciones documentales de otras instituciones eclesiásticas. Así se observa que los distintos tipos se adaptan más intensamente a épocas variadas de crecimiento o crisis: las donaciones son más importantes en los siglos altomedievales y en los momentos de crecimiento generalizado, en los que los donantes se pueden permitir el desprendimiento de parte de sus posesiones. Por el contrario, en los momentos de crisis, principalmente en el siglo XIV, destacan los pleitos, privilegios de protección del patrimonio monástico, traslados, testamentos y compraventas, reflejos todos ellos del aumento de la conflictividad, de las intromisiones externas en el patrimonio de Husillos y del aumento de la religiosidad derivado de la crisis socioeconómica.

\footnotetext{
${ }^{287}$ Doc. núm. 301.

288 Doc. núm. 329.

289 Doc. núm. 341.

${ }^{290}$ Doc. núm. 108.

${ }^{291}$ Doc. núm. 330.

292 Doc. núm. 288.

${ }^{293}$ Doc. núm. 146.
} 


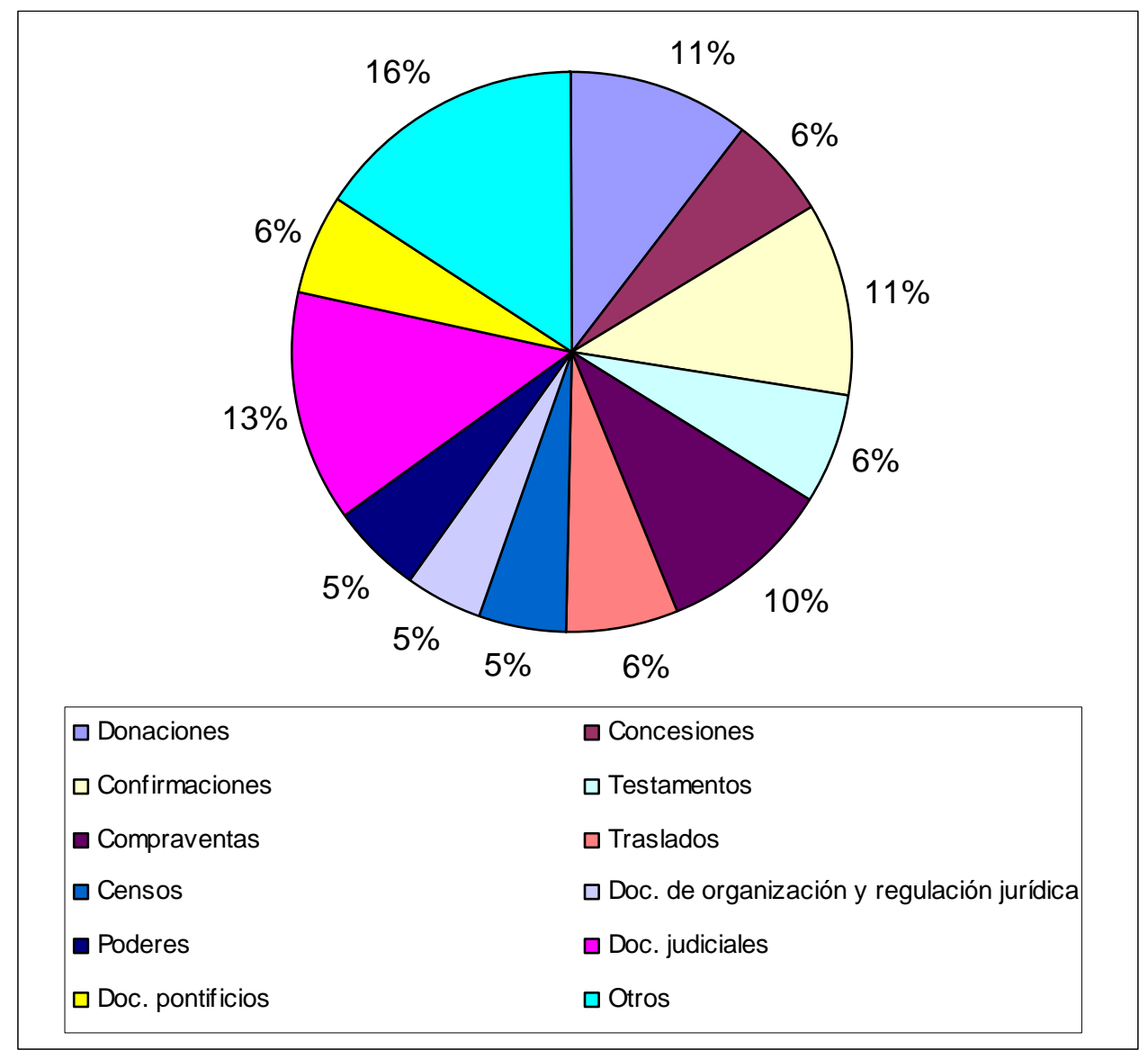

\section{FECHA CRONOLÓGICA}

Solamente ocho documentos de la colección de Husillos se encuentran sin la mención del año ${ }^{294}$, siendo cuatro de éstos tipos documentales judiciales caracterizados por no llevar la fecha, como las demandas, contestaciones a las demandas, y requerimientos. En dos casos no se ha conservado la parte del documento en el que se expresaba la fecha ${ }^{295}$.

\section{Eras y estilos cronológicos}

En la colección de Husillos nos encontramos con todas las eras y estilos cronológicos utilizados en los reinos de León y Castilla a lo largo de la Edad Media y Edad Moderna: era hispánica (1 de enero), era cristiana, y est ilos de la Encarnación del Señor (25 de marzo), Natividad del Señor (25 de diciembre) y

\footnotetext{
${ }^{294}$ Docs. núm. 17, 87, 146, 177, 180, 181 y 185.
}

295 Docs. núm. 17 y 185. 
Circuncisión del Señor o estilo moderno ( 1 de enero), todos ellos correspondientes a la era cristiana.

Son un total de 154 los documentos que utilizan la era hispánica como forma de datación $(43,8 \%)^{296}$, desde el año 904 hasta $1383^{297}$. El estilo de la Encarnación lo encontramos en 6 documentos, desde el año 1088 hasta $1474^{298}$, siendo en todos los casos producidos por instituciones eclesiásticas como la Santa Sede y Santa María de Husillos. Los documentos fechados por el estilo de la Natividad son un total de $39(11,1 \%)^{299}$, desde 1286 hasta 1554, apareciendo así dicho estilo de forma temprana en la colección de Husillos, ya que el siguiente documento fechado por este estilo tiene por fecha el año 1370. El estilo de la Circuncisión del Señor aparece en 36 documentos (10,2\%), abarcando sus fechas extremas desde 1232 hasta 1604, siendo así el estilo más longevo, aunque sea minoritario en el conjunto de la colección.

Llama la atención las fechas tan tempranas en los que aparecen los estilos cristianos en contradicción con lo expuesto por el manual de la UNED, sobre que la era cristiana no aparece en los reinos peninsulares hasta fines del siglo $\mathrm{XIV}^{300}$. Y si bien por el estilo de la Natividad sólo hay un documento fechado fuera del marco considerado como normal en la aparición de la era cristiana, en el caso del estilo de la Circuncisión del Señor son 14 los documentos fechados hasta 1334, siendo cuatro los documentos entre 1232 y 1234 fechados conjuntamente por el estilo de la Natividad y por el año del Señor.

Por el estilo del año del pontificado se fechan 17 documentos $(4,8 \%)$, fechados entre 1143 y $1483^{301}$. A excepción de $\operatorname{dos}^{302}$, todos fueron creados por la

\footnotetext{
${ }^{296}$ Docs. núm. 1, 2, 3, 4, 5, 6, 7, 8, 9, 10, 11, 12, 13, 14, 15, 16, 18, 19, 20, 21, 22, 24, 25, 26, 27 , $28,29,30,31,32,34,35,36,38,40,41,42,43,44,45,46,47,49,50,51,52,53,54,55,56,57$, $58,61,62,63,64,65,66,71,72,73,76,77,81,82,84,85,88,90,91,92,93,97,98,99,100$, $101,105,106,107,108,110,111,113,114,115,116,117,118,119,120,121,122,123,125$, $126,127,128,129,130,131,132,133,134,135,136,137,138,139,140,141,142,143,144$, $145,147,148,149,150,155,156,159,160,161,162,163,164,165,167,169,170,171,172$, $173,174,175,176,179,182,183,184,186,187,188,190,191,192,193,194,195,196,197$, $198,199,200,201$ y 202 .

${ }^{297}$ La era hispánica existió oficialmente hasta el año 1383, año en que Juan I ordenó, en las Cortes de Segovia, que se dejara de usar dicho estilo cronológico por el de la Navitidad del Señor.

${ }^{298}$ Docs. núm. 14, 37, 47, 74, 103 y 235.

${ }^{299}$ Docs. núm. 80, 152, 204, 205, 206, 207, 208, 209, 210, 211, 212, 214, 215, 216, 218, 219, 220, $221,223,226,230,232,234,236,238,239,242,243,245,246,249,250,251,252,253,254$, 269,295 y 296.

${ }^{300}$ MARÍN - RUIZ ASENCIO, Paleografia y Diplomática, 553.

${ }^{301}$ Docs. núm. 23, 32, 37, 39, 48, 67, 68, 69, 70, 78, 89, 94, 104, 222, 229, 235 у 239.

302 Docs. núm. 229 y 239.
} 


\section{LA ABADÍA DE SANTA MARÍA DE HUSILLOS: ESTUDIO Y COLECCIÓN \\ DOCUMENTAL $(904-1608)$}

cancillería pontificia. Un documento se fecha al mismo tiempo por los estilos de la Natividad y del año de pontificado ${ }^{303}$, y dos por los estilos de la encarnación y del pontificado al mismo tiempo ${ }^{304}$.

Fue costumbre en la datación de los documentos medievales acompañar a la fecha crónica de la mención del reinado del rey del momento, del año concreto de reinado, mención de un hecho histórico de trascendencia, o bien la mención del año de pontificado de un obispo concreto. En la colección documental de Husillos nos encontramos con 10 documentos que mencionan el año de reinado del rey, abarcando sus fechas entre los años 938 y $1290^{305}$. La mención a un reinado concreto se observa en 29 documentos, entre el primer tercio del siglo XII, período de confección de los falsos otorgados por Sancho el Mayor de Navarra, y $1331^{306}$. En un documento aparece una doble mención del reinado y del año concreto de reinado del rey ${ }^{307}$. La mención a un obispo aparece en 8 documentos, en todos casos apareciendo también la mención del reinado ${ }^{308}$. Por último, en dos documentos se utiliza para acompañar la datación, la mención a un acontecimiento histórico ${ }^{309}$.

Como conclusión, observamos que las menciones en los documentos a reinados, años de reyes, obispos y acontecimientos históricos, se producen hasta principios del siglo XIV, siendo menor su frecuencia cuanto más se avanza en el tiempo. Esto indica que era un formulismo característico de cancillerías en fase de formación y consolidación.

\section{Fecha del mes y del día}

Solamente en tres documentos no aparece la mención del mes ni del día: el primero de la colección del año 904, y dos documentos de Juan I del año $1379^{310}$.

\footnotetext{
303 Doc. núm. 239.

${ }^{304}$ Docs. núm. 37 y 235.

${ }^{305}$ Docs. núm. 2, 12, 14, 21, 31, 33, 35, 36, 57 y 82.

${ }^{306}$ Docs. núm. 6, 7, 20, 21, 24, 25, 26, 27, 28, 30, 40, 41, 42, 43, 44, 45, 46, 47, 53, 54, 55, 63, 65, $71,73,97,100,113$ у 114 .

${ }^{307}$ Doc. núm. 21, fechado en 1140

${ }^{308}$ Docs. núm. 40, 41, 42, 43, 44, 45, 46 y 47. Estos documentos se fechan entre finales del siglo XII y principios del XIII.

${ }^{309}$ Docs. núm. 50 y 71. Se fechan en los años centrales del siglo XIII.

${ }^{310}$ Doc. núm. 1, 192 y 193.
} 
En cinco documentos no aparece la mención del día, estando comprendidos entre los años 904 y $1379^{311}$.

Para la expresión del mes y el día del mes se utilizaba en la Edad Media el sistema romano y varios sistemas surgidos a lo largo de la Edad Media. En la colección de Husillos se datan por el sistema romano 54 documentos fechados entre los años 938 y 1420. De éstos, 1 corresponde al siglo $\mathrm{X}^{312}, 1$ al siglo $\mathrm{XI}^{313}, 30$ al siglo $\mathrm{XII}^{314}, 20$ al siglo $\mathrm{XIII}^{315}, 1$ al siglo $\mathrm{XIV}^{316}$ y 1 al siglo $\mathrm{XV}^{317}$. Observamos así que son los siglos XII y XIII el período en el que más se usa el sistema romano, siendo prácticamente inexistente en los siglos XIV y XV. Por ello no se cumple en Husillos la afirmación que hace el manual de la UNED sobre que dicho sistema fue el preferido hasta fines de la Edad Media ${ }^{318}$.

En cuanto a los sistemas propiamente medievales, nos encontramos con el sistema de "días por andar" en tres documentos fechados entre 1228 y $1245^{319}$. El sistema paralelo de "días andados" lo encontramos en 6 ocasiones, entre los años 1243 y $1351^{320}$. Observamos en primer lugar que dichos sistemas no son muy usados en la colección de Husillos, y en segundo lugar que su uso acontece entre mediados del siglo XIII y mediados del XIV, es decir, en la parte central de la Edad Media. Los documentos que a partir del año 1234 cuentan en su data con el día del mes lo hacen con el sistema actual de contar los días del mes por orden correlativo de sucesión o en cardinales. Se observa así que es en los años centrales del siglo XIII cuando comienza la mención del día del mes por el sistema actual.

\section{Día de la semana}

Encontramos el día de la semana en 67 documentos de la colección de Husillos, fechados entre 1161 y 1599. De éstos, 66 lo hacen con la nomenclatura actual,

\footnotetext{
${ }^{311}$ Docs. núm. 1, 44, 49, 192 y 193.

312 Doc. núm. 2.

313 Doc. núm. 12.

${ }^{314}$ Docs. núm. 3, 4, 5, 6, 7, 8, 9, 10, 16, 18, 19, 20, 21, 24, 25, 26, 27, 28, 29, 30, 31, 33, 34, 35, $36,37,38,40,41$ y 42

${ }_{315}$ Docs. núm. 43, 45,46, 47, 48, 50, 52, 54, 55. 67, 68, 69, 70, 74, 75, 77, 78, 80, 86 у 89.

316 Doc. núm. 94.

${ }^{317}$ Doc. núm. 222.

${ }^{318}$ MARÍN - RUIZ ASENCIO, Paleografia y Diplomática, 557.

${ }^{319}$ Docs. núm. 51, 65 y 66.

${ }^{320}$ Docs. núm. 63, 64, 71, 81, 100 y 135.
} 
comenzándose a usar ésta en el año 1243, mientras que sólo uno lo hace por la nomenclatura litúrgica de ferias ${ }^{321}$. La distribución por siglos es la siguiente:

S. XII: $1^{322}$

S. XIII: $6^{323}$

S. XIV: $50^{324}$

S. XV: $7^{325}$

S. XVI: $3^{326}$

Observamos así cómo es excepcional en Husillos el empleo de la feria para expresar el día de la semana, y que la misma mención es casi excepcional en los siglos XV y XVI, siendo por otra parte muy frecuente en el siglo XIV, donde de los 125 documentos contabilizados en total de dicho siglo, 50 expresan el día de la semana.

\section{Calendario litúrgico}

En cuatro documentos de Husillos se expresa el día mediante el nombre de una fiesta litúrgica. Dichos documentos se suceden en un breve período de tiempo, entre 1243 y 1256, observándose que esta modalidad de expresar la fiesta litúrgica se emplea en Husillos exclusivamente a mediados del siglo XIII ${ }^{327}$.

\section{Otras formas cronológicas}

Observamos la existencia de otras formas cronológicas siquiera de forma testimonial. Es el caso de la indicción, empleada en un documento pontificio del año $1322^{328}$, y de la mención de la hora, que se produce en dos documentos de los años 1329 y $1402^{329}$.

\footnotetext{
${ }^{321}$ Doc. núm. 31.

322 Doc. núm. 31 ..

${ }^{323}$ Docs. núm. 63. 66. 82, 88, 91 y 93.

${ }^{324}$ Docs. núm. 95, 96, 97, 98, 99, 102, 105, 106, 107, 108, 109, 110, 111, 112, 125, 126, 127, 128, $130,132,133,136,139,143,145,147,148,149,153,156,157,162,168,170,173,174,176$, 179, 182, 183, 186, 202, 203, 204, 205, 206, 207, 209, 216 у 217.

${ }^{325}$ Docs. núm. 221, 223, 224, 226, 229, 239 y 243.

${ }^{326}$ Docs. núm. 268, 301 y 343.

${ }^{327}$ Docs. núm. 63, 64, 66 y 72.

${ }^{328}$ Doc. núm. 103.

${ }^{329}$ Docs. núm. 110 y 220.
} 


\section{Errores cronológicos}

En ocasiones se aprecian errores de coincidencia del año cuando un documento concreto se fecha por dos estilos diferentes. Esta anomalía se observa en cinco ocasiones a partir del año 1232, cuando es normal que los documentos se fechen, además de por la era hispánica, por otros estilos como el año del Señor ${ }^{330}$.

Por otra parte también se observan errores en el día de la semana en el que se expidió el documento con respecto al día del mes, dándose dichos errores en 12 documentos entre los años 1268 y $1599^{331}$. Algunos de estos documentos fueron escritos un día más tarde del que en realidad corresponde al día del mes ${ }^{332}$. Esto se explicaría por el uso del calendario litúrgico, en el que el día comenzaba al anochecer, y que a veces se aplicaba al día de la semana. Así en estos casos posiblemente los documentos fueran escritos por las noches de los respectivos días del mes ${ }^{333}$. En otros la diferencia es de varios días o en un día de la semana posterior al que expresa el documento. En estos casos los errores de pueden deber a descuidos del escriba.

\section{FECHA TÓPICA}

En 68 documentos de la colección de Husillos (19,3\%) no aparece la fecha tópica, es decir, el lugar donde se expidió el documento. A continuación se hace relación de dichos documentos por siglos y en proporción al total de documentos por siglo:

S. X: $2^{334}(100 \%)$.

S. XI: $4^{335}(80 \%)$

S. XII: $19^{336}(55,8 \%)$

S. XIII: $18^{337}(34,6 \%)$.

S. XIV: $23^{338}(18,2 \%)$

S. XV: $1^{339} \cdot(3,1 \%)$

${ }^{330}$ Docs. núm. 54, 55, 56, 57 y 156.

${ }^{331}$ Docs. núm. 76, 98, 99, 102, 108, 128, 133, 136, 145, 217, 243 y 343. Dichos errores se comprueban a través de las tablas de cronología de GIRY (GIRY, Manuel de Diplomatique), tomadas del Art de vérifier les dates (París 1750).

${ }^{332}$ Docs. núm. 76, 102, 145 y 243.

${ }^{333}$ RUIZ ASENCIO, La medida del tiempo en la España cristiana, 93-116.

334 Docs. núm. 1 y 2.

335 Docs. núm. 11, 12, 13 y 15.

${ }^{336}$ Docs. núm. 3, 4, 5, 6, 7, 8, 9, 10, 16, 18, 19, 20, 24, 25, 26, 33, 39, 40 y 42.

${ }^{337}$ Docs. núm. 43, 44, 45, 46, 47, 49, 50, 51, 52, 56, 59, 60, 65, 72, 73, 87, 88 y 91.

${ }^{338}$ Docs. núm. 98, 99, 115, 116, 117, 118, 119, 120, 121, 122, 123, 129, 130, 132, 146, 147, 151, $160,177,180,181,185$ y 208. 
S. XVI: $1^{340}(1 \%)$.

Se observa claramente como el porcentaje de documentos en los que no aparece la data tópica es menor según avanzan los siglos, siendo mayoritarios en los siglos altomedievales, la mitad aproximadamente en los siglos XII y XIII ${ }^{341}$, y testimoniales en los siglos XV y XVI. Por otra parte comprobamos cómo a partir del año 1338 la data tópica en mayoritaria en los documentos, habiendo solamente dos documentos hasta 1607 en los que no aparece. Esto indica que a partir del siglo XV se hace imprescindible la mención del lugar donde se expiden los documentos.

En diez documentos aparece, además de la población de expedición, el lugar exacto o específico dentro de la población. De éstos, cinco corresponden al siglo $\mathrm{XIV}^{342}$, cuatro al siglo $\mathrm{XV}^{343}$, y uno al $\mathrm{XVI}^{344}$.

\section{ESCRIBANOS Y NOTARIOS DE SANTA MARÍA DE HUSILLOS}

Santa María de Husillos, como institución eclesiástica de tipo intermedio, contó, al menos en ciertos momentos de su historia, con una escribanía configurada en el seno de la institución formada por un escribano o notario que era además beneficiado de la iglesia. Esta afirmación la apoyamos por testimonios documentales expresos como el ofrecido por un documento de 28 de junio de 1202 por el que Gonzalo, abad de Husillos, y a instancias del cabildo, establece un estatuto sobre la forma de testar de los canónigos. En la parte final del documento aparece: "Petrus Martini, notarius domini iam dicti abbatis"345. De esta manera Santa María de Husillos estaría en la tónica general de aparición de escribanos propios en los cenobios en el siglo XIII, como en el caso del monasterio de San Millán de la Cogolla ${ }^{346}$. En tiempos modernos la escribanía estaría plenamente asentada, como parece demostrar un documento de 27 de febrero de 1597 por el

\footnotetext{
${ }^{339}$ Doc. núm. 227.

${ }^{340}$ Doc. núm. 348.

${ }^{341}$ Según Floriano Cumbreño, la data tópica comienza a hacerse regular a partir del reinado de Alfonso VII (FLORIANO, Paleografía y diplomática, 463).

${ }^{342}$ Docs. núm. 106, 136, 137, 138 y 142.

${ }^{343}$ Docs. núm. 220, 226, 232 y 236.

${ }^{344}$ Doc. núm. 269.

345 Doc. núm. 47.

${ }^{346}$ GARCÍA TURZA, Diplomática monástica de San Millán, 345-361.
} 
que el prior jura los estatutos otorgados por el abad Francisco de Reinoso. En dicho documento aparece Antonio López como escribano de la abadía ${ }^{347}$.

Hay casos en los que suponemos que el escribano que realiza el documento forma parte de la escribanía de Husillos. Estos testimonios de escribanos se encuentran en documentos cuyo autor es la propia abadía:

- El 21 de septiembre de 1161, el abad de Husillos Raimundo Giliberti, juntamente con el cabildo, concede fuero al concejo de San Julián. En parte final del escatocolo: "Petrus Iohannis hanc cartam scripsit"348.

- El 23 de agosto de 1244, el abad Pedro Martínez realiza un convenio con Fernando, arcipreste de Torre de Astudillo. Su escribano: “Juan Martín, clérigo del abbat, que escriuió la carta"349.

- El 19 de abril de 1396, el prior Pedro Fernández exige al adelantado mayor de Castilla que respete las libertades de los vecinos de Husillos. Su autor material: "Alfonsus García, canónigo y notario público de Husillos"350.

- El 31 de julio de 1493 se constituye la cofradía de Nuestra Señora de Dehesa Brava. El escribano de los estatutos: "Juan Gutiérrez, escribano y canónigo"351.

Así, aunque en ningún caso aparece expresamente que el escribano en cuestión lo es de Santa María de Husillos, la relación directa del amanuense con la iglesia en la mayor parte de los casos, ya que aparecen como clérigos o canónigos de ésta, hace que pensemos que forman parte de la escribanía de la institución.

En ciertos documentos de autoría ajena a la institución pero que tienen como destinatario ésta misma, suponemos que los escribanos que las realizan pertenecen a la escribanía de la institución. Se trata de documentos en los que personas particulares hacen donaciones y ventas a Husillos o fundan capellanías en su iglesia $^{352}$, y que acudirían a la misma escribanía de la institución para formalizar el documento ante la escasez de profesionales independientes. Las fechas de estos documentos abarcan hasta 1267. A partir de mediados del siglo XIII, con la formación y consolidación del notariado, los documentos de particulares cuyo

\footnotetext{
${ }^{347}$ AHDP, Ampudia y Abadía de Husillos, Asociaciones, Libro 249, f. $21 \mathrm{v}$.

348 Doc. núm. 31.

349 Doc. núm. 64.

350 Doc. núm. 217.

351 Doc. núm. 243.

352 Docs. núm. 25, 52, 63, 74 y 75.
} 
destinatario es Husillos van a estar realizados por notarios públicos o apostólicos independientes.

\section{VALIDACIÓN DE LOS DOCUMENTOS: CARTAS PARTIDAS POR ABC Y SELLOS}

\section{Cartas partidas por $\mathrm{ABC}$ o por alfabeto}

Uno de los principales sistemas de validación de los documentos en los siglos centrales de la Edad Media principalmente, es la carta partida por a, b, c, o por alfabeto. En la colección de Husillos se contabilizan 18 documentos validados a través de este sistema, cuyas fechas abarcan desde 1146 hasta 1380. Su distribución por siglos es la siguiente:

S. XII: $4^{353}$.

S. XIII: $12^{354}$.

S. XIV: $2^{355}$.

Se observa claramente que el período de mayor utilización de este sistema es la segunda mitad del siglo XII y el siglo XIII, siendo escasa su presencia en el siglo $\mathrm{XIV}$, en el que desaparecería. Así, las fechas de los dos ejemplares de este siglo corresponden a 1306 y 1380. Todos los ejemplares conservados corresponden a cartas de tipo rectilíneo.

\section{Sellos}

Entre los elementos de validación de los documentos, además de los signos o rúbricas del notario, confirmantes y testigos, se encontraban los sellos pendientes o de placa, de cera o plomo, según fuera la calidad del autor del documento, y según el tipo diplomático. En la colección de Husillos nos encontramos con 79 documentos $(22,5 \%)$ que conservan algún tipo de sello o bien lo llevaron, abarcando sus fechas desde 1158 hasta $1493^{356}$.

\footnotetext{
${ }^{353}$ Docs. núm. 24, 29, 31 y 41.

${ }^{354}$ Docs. núm. 46, 49, 57, 59, 64, 65, 66, 74, 75, 77, 80, 88, 98 y 199.

355 Docs. núm. 98 y 199.

${ }^{356}$ Docs. núm. 18, 27, 28, 30, 35, 36, 37, 40, 47, 48, 49, 51, 56, 57, 58, 59, 60, 61, 63, 64, 65, 66, $67,71,72,74,80,81,82,84,85,86,90,95,97,100,102,104,113,114,124,125,126,127,134$,
} 
Tanto el abad como el cabildo de Santa María de Husillos dispusieron de sello propio con el que validaban los documentos en los que intervenían. Los primeros testimonios documentales de éstos se producen en 1202 para el sello del abad ${ }^{357}, \mathrm{y}$ en 1226 para el sello del cabildo ${ }^{358}$. Estas fechas concordarían con las existentes en otros cenobios como San Millán de la Cogolla, en el que se documentan los sellos del abad y cabildo desde $1240^{359}$.

\section{DIPLOMÁTICA MONÁSTICA DE SANTA MARÍA DE HUSILLOS}

Al igual que en el caso del monasterio de San Millán de la Cogolla, a partir de mediados del siglo XIII se configura una diplomática específica monástica en Husillos, diferenciándose del resto de la documentación privada. Esta especificación diplomática está directamente relacionada con la existencia de una escribanía en el cenobio y por elementos de validación documental propios como son los sellos del abad y cabildo. Entre los documentos monásticos más característicos están los documentos de relación con otras instituciones, los estatutos, compraventas e inventarios de propiedades ${ }^{360}$.

$135,139,140,141,142,143,144,145,163,164,165,171,175,180,181,182,183,184,186$, 190, 191, 192, 193, 194, 210, 212, 213, 214, 222, 224, 233, 235, 239 у 243.

357 Doc. núm. 47.

${ }^{358}$ Doc. núm. 49.

359 GARCÍA TURZA, Diplomática monástica de San Millán, 345-361.

${ }^{360}$ GARCÍA TURZA, Diplomática monástica de San Millán, 345-361. 


\subsection{ESTUDIO PALEOGRÁFICO:}

\section{LENGUA DE LOS DOCUMENTOS}

Las lenguas usadas en la colección de Husillos van a ser el latín y el romance castellano. Se contabilizan un total de 85 documentos en latín $(24,2 \%)$, que abarcan desde los años $904^{361}$ hasta $1606^{362}$, si bien el último documento en latín expedido por un particular o institución no eclesiástica es del año $1269^{363}$. El primer documento en romance castellano lleva por fecha el año $1228^{364}$, y el último el año $1608^{365}$, último de la colección de Husillos.

A continuación se muestra el número y su proporción respecto al total por siglos, de los documentos latinos:
S. X: $2^{366} \quad(100 \%)$.
S. XI: $5^{367}$. (100\%).
S. XII: $34^{368} \quad(100 \%)$.
S. XIII: $27^{369} \quad(51,9 \%)$.
S. XIV: $8^{370}(6,3 \%)$.
S: XV: $4^{371} \quad(12,5 \%)$.
S. XVI: $3^{372} \quad(3,2 \%)$
S. XVII: $1^{373} \quad(14,2 \%)$

Se observa cómo a partir del siglo XIII el porcentaje de documentación latina baja bruscamente, hasta alcanzar un número meramente anecdótico en el siglo XVI, ya que en el siglo XVII la documentación llega solamente hasta el año 1608. No obstante hay que tener en cuenta de que al estar ante una institución eclesiástica que utiliza la lengua latina más frecuentemente tanto en la documentación que

\footnotetext{
${ }^{361}$ Doc. núm. 1.

362 Doc. núm. 350.

${ }^{363}$ Doc. núm. 77.

364 Doc. núm. 51.

${ }^{365}$ Doc. núm. 351.

366 Docs. núm. 1 y 2.

${ }^{367}$ Docs. núm. $11,12,13,14$ y 15.

${ }^{368}$ Docs. núm. 3, 4, 5, 6, 7, 8, 9, 10, 16, 18, 19, 20, 21, 22, 23, 24, 25, 26, 27, 28, 29, 30, 31, 32, $33,34,35,36,37,38,39,40,41$ y 42 .

${ }^{369}$ Docs. núm. 43, 44, 45, 46, 47, 48, 49, 50, 52, 53, 54, 55, 56, 59, 67, 68, 69, 70, 74, 75, 77, 78, $80,83,86,87$ y 89.

${ }^{370}$ Docs. núm. 94, 104, 109, 151, 152, 153, 157 y 158.

${ }^{371}$ Docs. núm. 222, 229, 235 y 239.

372 Docs. núm. 261, 274 y 310.

${ }^{373}$ Doc. núm. 350.
} 
expide como en la que recibe principalmente de otras instituciones eclesiásticas, en especial de la Santa Sede, estos porcentajes no corresponderían exactamente con la evolución general del uso de dicha lengua. En cualquier caso, se puede concluir diciendo que es en el siglo XIII cuando se produce el cambio definitivo en el empleo de la lengua latina por la romance.

\section{SISTEMAS DE ESCRITURA}

Los sistemas de escritura utilizados en la documentación de Husillos son análogos a los utilizados en las colecciones de otras instituciones eclesiásticas ya estudiadas. No obstante en la colección de Husillos se puede apreciar una evolución de todos los sistemas de escritura desde el siglo X hasta el siglo XVII que no ofrecen otras colecciones documentales del ámbito palentino estudiadas hasta el momento, ya sea porque se centran en un período de tiempo más breve, o bien porque la mayor parte de sus documentos se editan a partir de cartularios al no conservarse los originales ${ }^{374}$.

Por todo, pensamos que existen varias razones por las que la colección de Husillos puede servir de modelo para el estudio de la evolución de los sistemas de escritura en el ámbito palentino: en primer lugar, un volumen documental asequible y conservado de modo importante en forma original ${ }^{375}$, y al mismo tiempo suficientemente representativo como para que las conclusiones obtenidas puedan ser válidas. En segundo lugar, un período cronológico amplio y natural, es decir, fijado por la vida de la institución y no por criterios metodológicos o personales.

\footnotetext{
${ }^{374}$ Es el caso de San Isidro de Dueñas, Santa María de Aguilar, San Zoilo de Carrión y catedral de San Antolín.

${ }^{375}$ Son 192 los documentos de Husillos (54,7\%) que se han transmitido en su forma original.
} 


\section{LA ABADÍA DE SANTA MARÍA DE HUSILLOS: ESTUDIO Y COLECCIÓN \\ DOCUMENTAL $(904-1608)$}

\section{Escritura visigótica}

Se contabiliza un total de 8 documentos escritos en visigótica redonda $(4,3 \%)$, que abarcan desde el año 1034 hasta el primer tercio del siglo XII, momento de realización de los falsos de las donaciones de los condes Ansúrez de Monzón ${ }^{376}$.

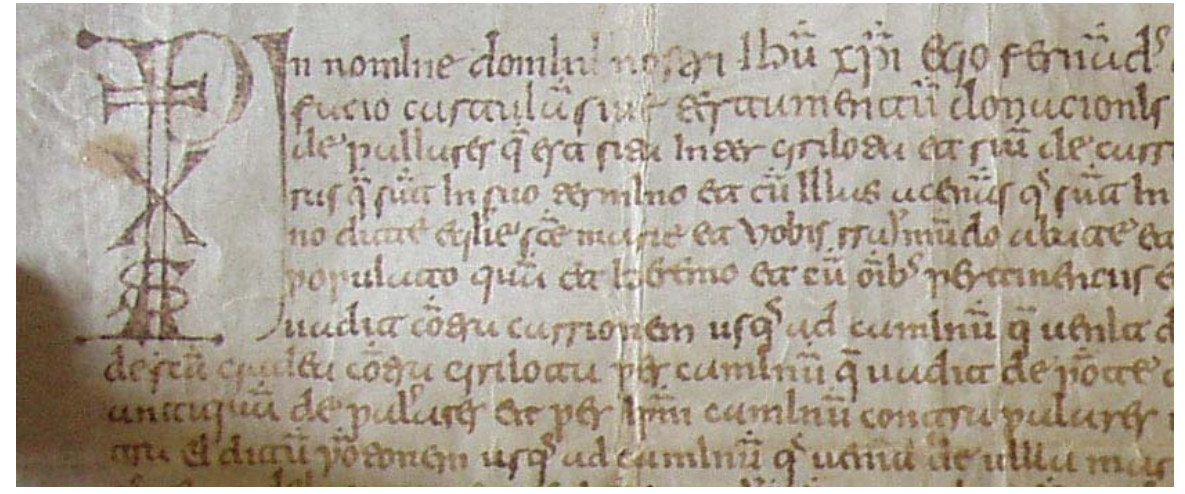

Ejemplo de escritura visigótica

\section{Escritura carolina}

Hay un total de 22 documentos escritos en carolina (6,2\%), desde un documento otorgado por Alfonso VII en 1140, hasta el año $1202^{377}$. Identificamos también 4 documentos escritos en carolina avanzada, desde el año 1227 hasta $1229^{378}$.

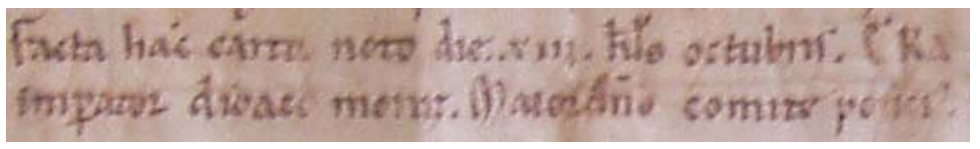

Ejemplo de escritura carolina

\section{Escritura gótica documental}

Identificamos tres documentos escritos en pregótica documental, desde el año 1226 hasta $1243^{379}$. El primer documento en gótica documental pura tiene por fecha 1234, y el último 1298 , siendo un total de 13 documentos $(3,7 \%)^{380}$.

\footnotetext{
${ }^{376}$ Docs. núm. 9, 11, 12, 13, 15, 16, 18 y 19.

${ }^{377}$ Docs. núm. 21, 22, 23, 25, 26, 27, 29, 30, 31 32, 33, 35, 36, 37, 38, 40, 41, 42, 43, 45, 46 y 47.

${ }^{378}$ Docs. núm. 50, 51, 52 y 53.

${ }^{379}$ Docs. núm. 49, 56 y 59.

${ }^{380}$ Docs. núm. 57, 58, 61, 63, 64, 65, 66, 72, 74, 80, 81, 90 y 93.
} 


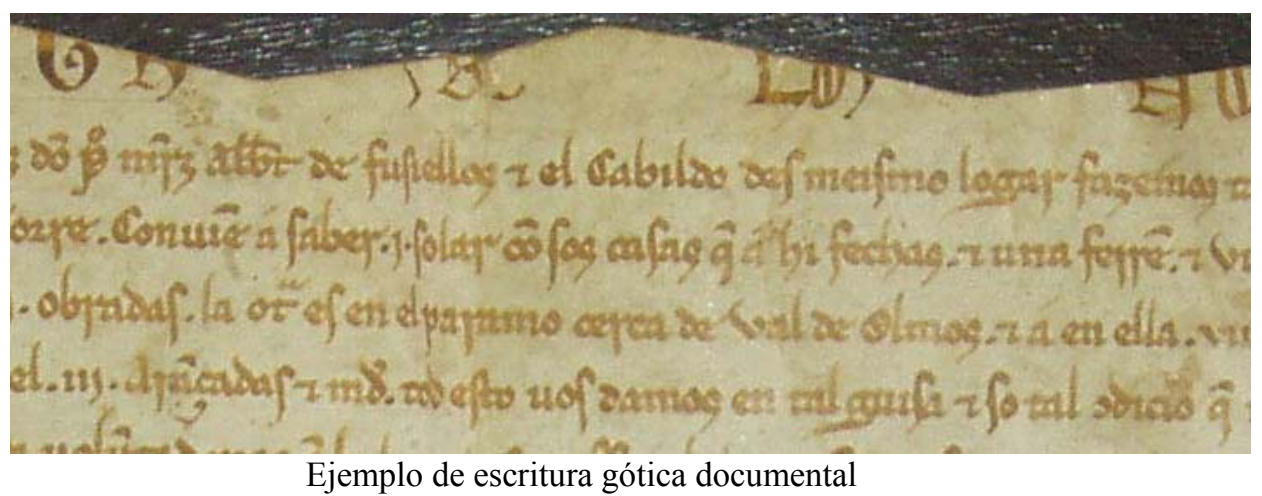

\section{Escritura de albalaes}

Se contabilizan siete documentos (1,9\%), desde el año 1301 hasta $1336^{381}$.

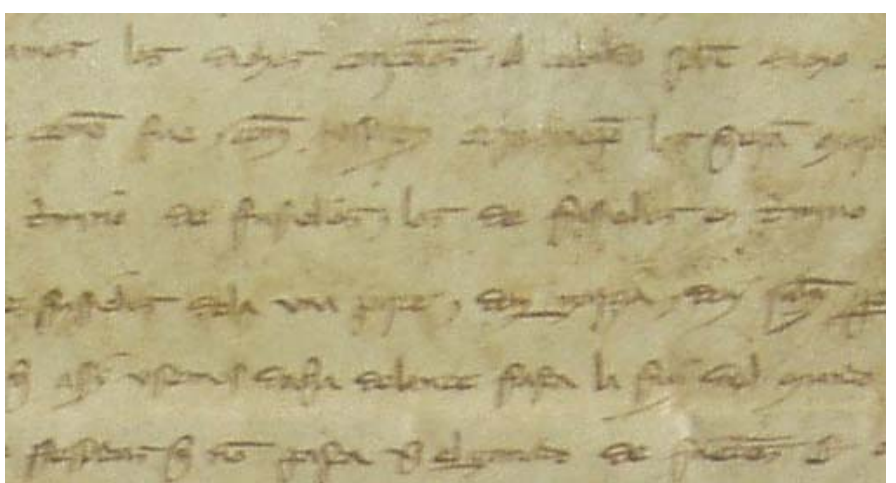

Ejemplo de escritura de albalaes

\section{Escritura gótica de privilegios}

Veintiséis documentos (14\%), desde 1255 hasta $1493^{382}$.

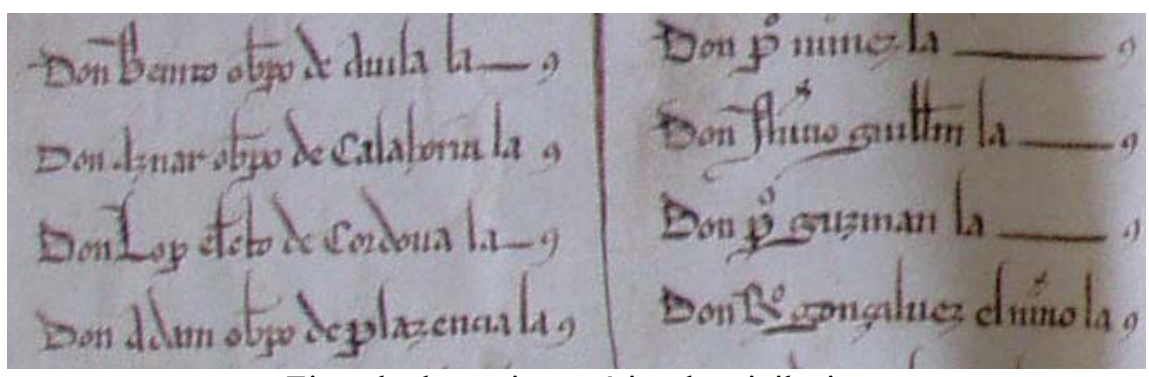

Ejemplo de escritura gótica de privilegios

\footnotetext{
${ }^{381}$ Docs. núm. 95, 98, 102, 112, 125, 126 y 127.

382 Docs. núm. 71, 82, 84, 85, 86, 97, 100, 113, 134, 135, 145, 163, 164, 190, 191, 192, 193, 194, $212,213,214,224,233,239,242$ y 243.
} 


\section{Escritura precortesana}

Treinta y dos documentos (17,2\%), desde1324 hasta $1402^{383}$.

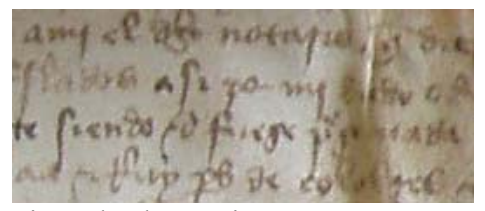

Ejemplo de escritura precortesana

\section{Escritura cortesana}

Dieciséis documentos $(8,6 \%)$, desde1422 hasta $1501^{384}$.

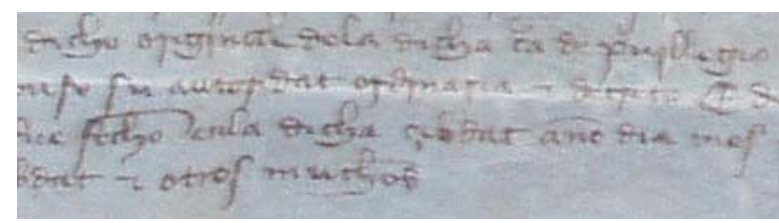

Ejemplo de escritura cortesana

\section{Escritura procesal}

Cincuenta y seis documentos (30,2\%), desde1502 hasta $1604^{385}$.

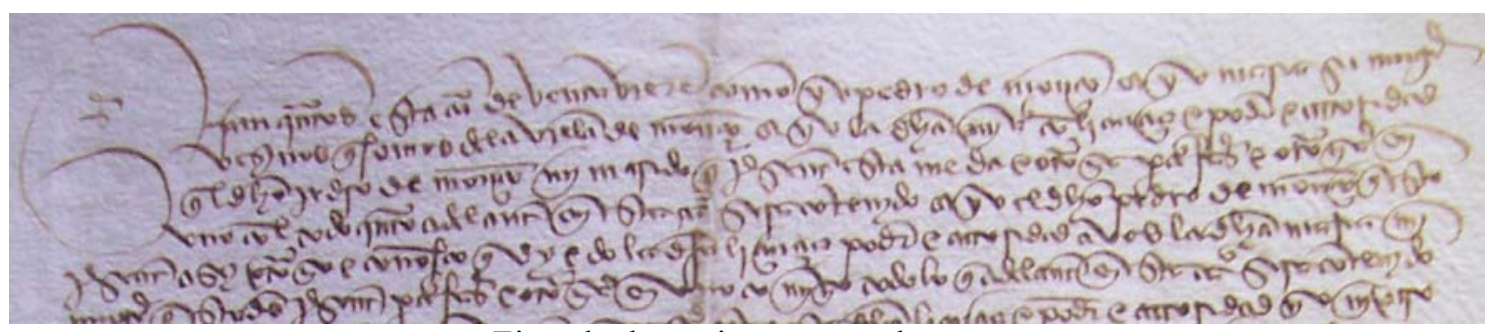

Ejemplo de escritura procesal

\section{Escritura gótica de cancillería pontificia}

Tres documentos $(3,2 \%)$, desde 1210 hasta $1474^{386}$.

\footnotetext{
${ }^{383}$ Docs. núm. 106, 109, 128, 130, 136, 137, 138, 149, 155, 161, 162, 165, 166, 168, 169, 171, 173, 174, 182, 186, 188, 199, 200, 203, 205, 206, 207, 211, 215, 216, 219 у 220.

${ }^{384}$ Docs. núm. 223, 225, 226, 227, 228, 231, 233, 236, 240, 241, 247, 248, 252, 253, 254 у 255.

${ }^{385}$ Docs. núm. 256, 257, 264, 265, 268, 270, 271, 272, 273, 275, 280, 281, 282, 284, 286, 287 , $299,300,301,303,305,306,307,308,309,311,312,313,314,315,316,317,318,319,320$, $321,322,323,324,325,326,327,328,329,331,332,337,338,339,340,341,342,344,345,346$ y 347 .

${ }^{386}$ Docs. núm. 48, 222 y 235.
} 


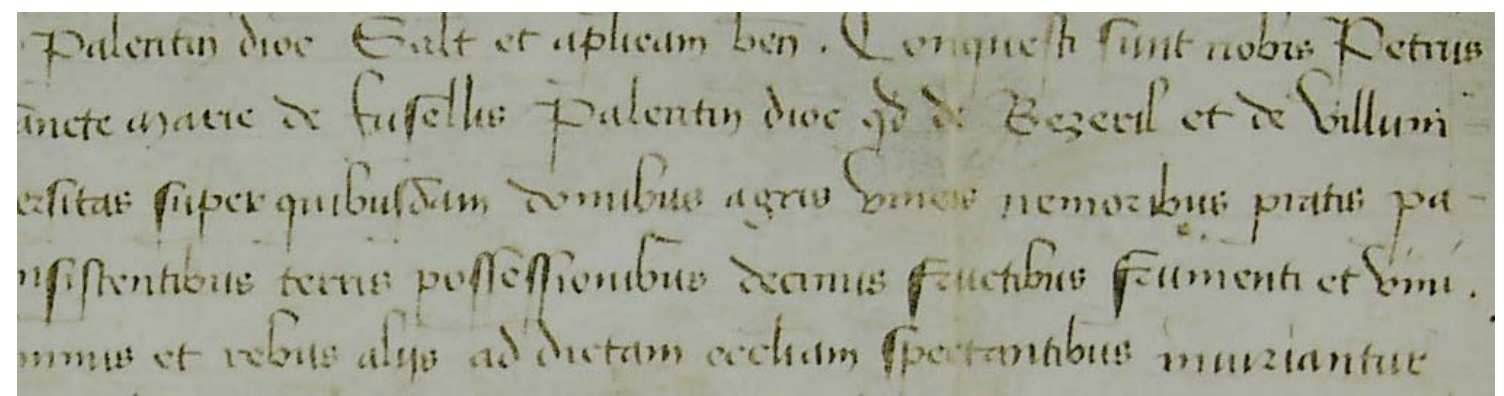

Ejemplo de escritura gótica de cancillería pontificia

\section{Escritura humanística}

Diez documentos (5,4\%), desde 1575 hasta $1608^{387}$.

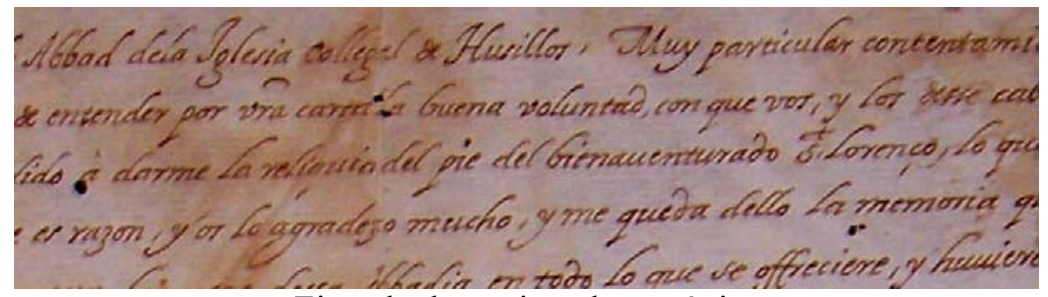

Ejemplo de escritura humanística

\section{Escritura gótica de juros o de ejecutorias}

Cinco documentos $(2,7 \%)$, desde 1554 hasta $1588^{388}$.

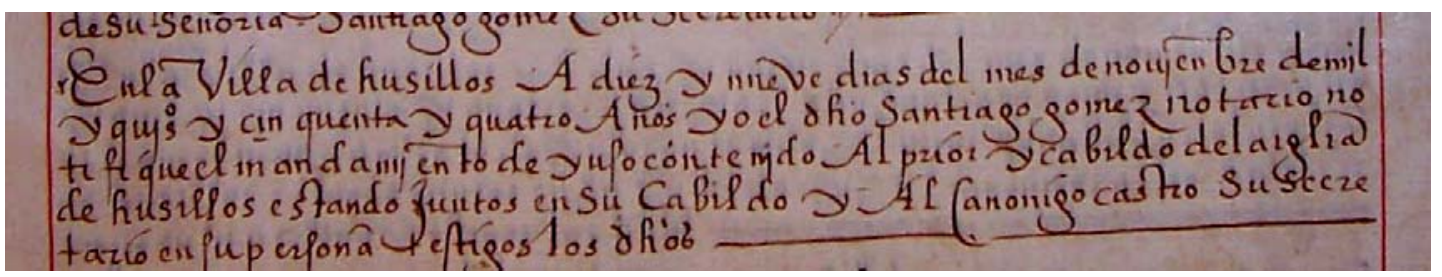

Ejemplo de escritura gótica de juros o de ejecutorias

\section{Conclusiones}

Se observa que la duración y cambio de los ciclos de escrituras son análogos a los generales para el ámbito castellano, siendo quizá en el tránsito de la escritura carolina a la gótica donde se observa cierta divergencia con respecto a la evolución general. Así el primer documento escrito en pregótica documental es del año 1226, cuando la escritura gótica ya es habitual a principios del siglo XIII.

\footnotetext{
${ }^{387}$ Docs. núm. 310, 333, 334, 337, 341, 344, 345, 346, 347 y 351.

${ }^{388}$ Docs. núm. 295, 296, 297, 298 y 330.
} 


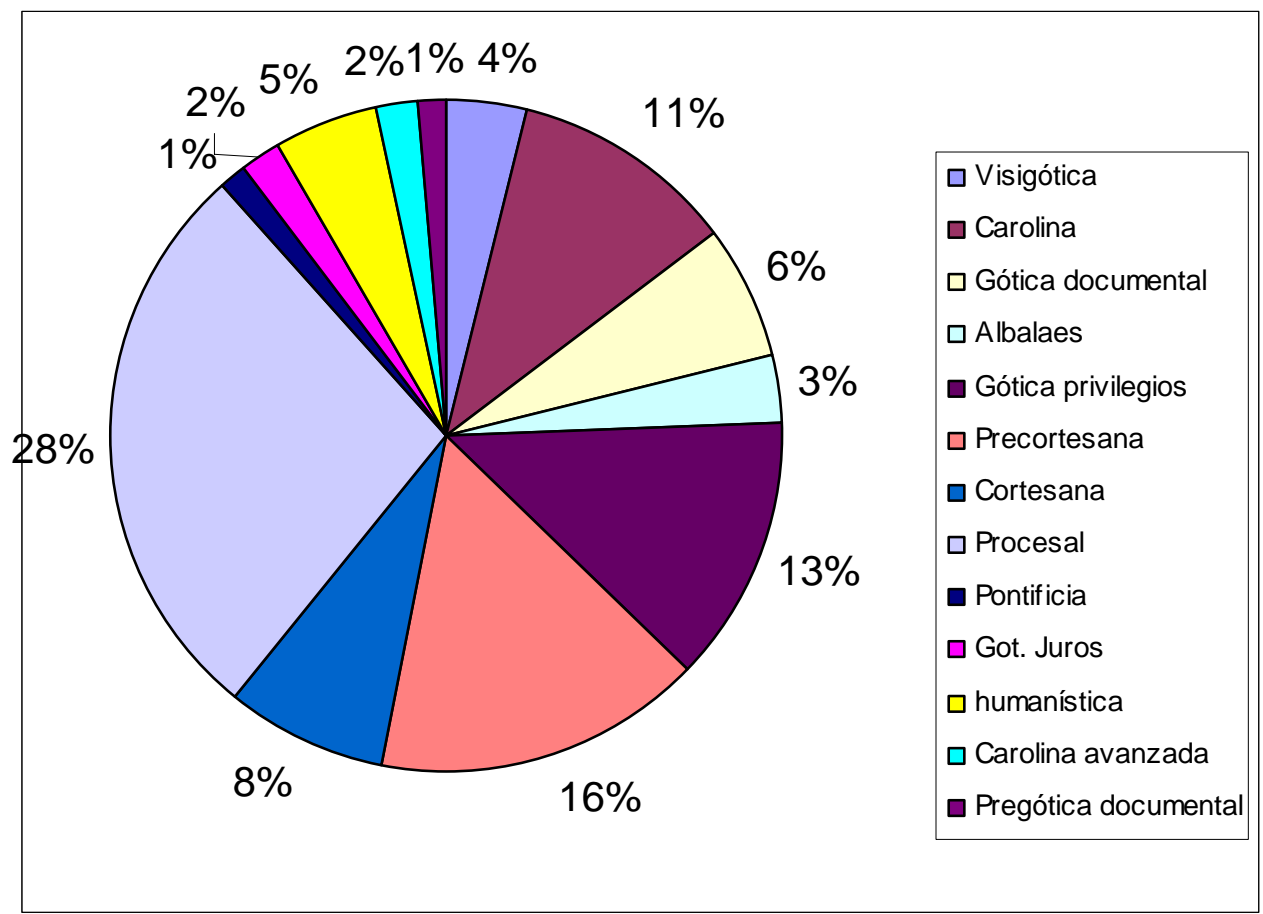

Distribución de la documentación según los tipos de escritura 
DAVID MARCOS DIEZ 


\subsection{EL LIBRO DE LOS PRIVILEGIOS DE SANTA MARÍA DE HUSILLOS:}

De 351 documentos de la colección, 218 están insertos en el Libro de los Privilegios de Husillos $(62,1 \%)^{389}$. De éstos, $69(19,6 \%)$ no se conservan en su forma original, siendo transmitidos por primera vez en el Libro de los Privilegios $^{390}$. Cuatro documentos se conservan en el libro en su forma original ${ }^{391}$. De estas cifras y porcentajes se puede deducir fácilmente la gran importancia cuantitativa y cualitativa que tiene el Libro de los Privilegios de Santa María de Husillos para la colección documental de dicha iglesia.

En cuanto a su descripción física, estamos ante un libro de grandes proporciones, siendo sus medidas de 310 por $440 \mathrm{~mm}$., habiendo un total de 274 folios numerados. Hay un error en la numeración final, pues desde el folio 272 salta al 278. No obstante, los traslados llegan hasta el folio 245, ya que en el resto, aunque está marcada la caja de escritura con líneas rojas, no hay documentos. La caja de escritura en cada folio se delimita por cuatro márgenes que fijan unas líneas rojas que se entrecruzan, siendo las medidas de la caja de escritura, de 210 por $355 \mathrm{~mm}$. El libro está protegido por un cantoral latino de pergamino. La encuadernación es de cuero, cerrada con hebilla.

El proceso por el que se escribió el Libro nos es conocido a través de un testimonio notarial escrito entre el 15 de junio de 1554 y el 30 de noviembre de 1554 por Santiago Gómez, escribano público de Husillos, por el que Gutierre de

\footnotetext{
${ }^{389}$ Docs. núm. 2, 3, 4, 5, 6, 7, 8, 9, 10, 12, 16, 17, 18, 19, 20, 21, 25, 26, 27, 28, 29, 30, 31, 33, 34, $35,36,37,38,40,42,43,44,45,46,47,48,49,50,51,52,53,54,56,57,58,61,62,63,64,65$, $66,71,72,73,74,75,76,77,81,82,83,84,85,87,88,90,91,92,93,96,97,98,99,100,101$, $102,103,105,106,107,108,113,114,115,116,117,118,119,120,121,122,123,125,126$, $127,128,131,132,133,134,135,139,140,141,142,143,144,145,146,147,148,149,150$, $151,152,153,154,155,156,157,158,159,160,161,162,163,164,166,167,168,169,170$, $171,172,173,174,175,176,177,178,183,184,185,186,187,188,189,190,191,192,193$, 194, 200, 201, 202, 203, 204, 205, 206, 208, 209, 210, 211, 212, 213, 214, 215, 216, 217, 218 , $219,220,221,223,226,229,230,232,234,236,237,238,242,244,245,246,249,250,252$, $253,254,260,261,262,263,264,266,267,274,275,276,277,278,279,281,283,285,289$, 290, 291, 293, 294, 295, 296, 297, 298 у 343.

390 Docs. núm. 2, 3, 4, 5, 6, 7, 10, 17, 34, 44, 54, 62, 73, 76, 83, 87, 88, 91, 92, 99, 101, 103, 105, $107,108,115,116,117,118,119,120,121,122,123,131,132,133,146,147,148,170,185$, $187,179,201,202,208,209,217,221,229,230,232,237,238,244,245,246,249,250,260$, $261,262,263,267,279,293,294$ у 343.

391 Docs. núm. 295, 295, 297 y 298.
} 
Carvajal, obispo de Plasencia y tío de Francisco de Carvajal, abad de Husillos, por poder otorgado por este último en Valladolid el 15 de junio de 1554, visitó la abadía de Husillos y ordenó sacar traslado notarial de las escrituras de la abadía, aduciendo a su pérdida progresiva de importancia por el paso del tiempo debido al descuido y desidia, y con ello la pérdida de numerosas rentas con que fue $\operatorname{dotada}^{392}$.

Da cuenta de cómo el obispo nombró como procurador fiscal del abad a Juan de la Torre, que se presentó ante Pedro Ruiz de Villoldo, alcalde mayor de Husillos, al que entregó un escrito en el que le instaba a autorizar y estar presente en los traslados de las escrituras de la abadía, y que mandara dar edictos en los lugares de la abadía que creyera conveniente para hacerlo constar a los posibles perjudicados. El alcalde mayor publica el edicto con el memorial de las escrituras a trasladar en la puerta de la iglesia de Santa María de Husillos y de Villaldavín. Al no haber alegaciones de ningún perjudicado, se procede al traslado de las escrituras por Santiago Gómez, en presencia de Pedro Ruiz de Villoldo y a requerimiento de Juan de la Torre.

Vemos así cómo el protagonista de la realización del Libro de los Privilegios fue el obispo de Plasencia, Gutierre de Carvajal. Causa asombro el hecho de que fuera un personaje ajeno a Santa María de Husillos el que, siendo consciente del antiguo esplendor de la institución, del estado de abandono y crisis del momento en el que la visitó, y de la pérdida de numerosos documentos justificativos de sus propiedades y rentas, tratara de buscar remedios a la situación con la realización de un cartulario con la mayor parte de la documentación de la abadía ${ }^{393}$. La gran labor del obispo de Plasencia proseguiría poco más tarde. Así, el 8 de diciembre de 1554 mandaba realizar unos estatutos por los que se debían regir las dignidades y beneficiados de Husillos ${ }^{394}$. También entre el 1 y el 18 de enero de 1555, mandó realizar un inventario de las propiedades y derechos de la fábrica,

\footnotetext{
392 Doc. núm. 295.

${ }^{393}$ En el testimonio notarial se dice que el alcalde mayor de Husillos mandó dar memorial de los documentos que se iban a trasladar, pudiendo deducirse que se produjo anteriormente una selección de dichos documentos, como así parece demostrar también el hecho de que ciertos documentos de la relación de rentas de principios de 1555 no aparezcan trasladados en el Libro de los Privilegios.

${ }^{394}$ Doc. núm. 297.
} 
mesa abacial, mesa capitular y hospital de Husillos ${ }^{395}$. Los motivos aducidos fueron, al igual que en el caso del Libro de los Privilegios, el grave estado de deterioro en el que se encontraba la abadía.

La realización del Libro se enmarca en un momento histórico de confección por gran número de monasterios y cabildos catedralicios de cartularios y libros becerros como archivo de seguridad para defensa de sus privilegios y derechos en un momento de debilidad de las instituciones eclesiásticas ante la desamortización realizada por Felipe II, los continuos ataques de la nobleza y los concejos, y la crisis generalizada de dichas instituciones, como es el caso de Santa María de Husillos, aunque en el caso de Husillos, la realización del libro sea anterior a la generalización de la realización de éstos, que se produce a principios del siglo XVII como respuesta a la crisis generalizada ${ }^{396}$. Por otra parte, ya desde el siglo XII se empezaron a confeccionar dichos cartularios y libros becerros por algunos cenobios, sobre todo los más importantes y ricos. Los libros becerros actúan, además de como archivos de conservación, como archivos administrativos-patrimoniales de las instituciones. A partir de su realización, los archiveros y notarios no acudirán ya más a los documentos originales a la hora de sacar traslados para presentarlos como probanzas en litigios o para fines administrativos, sino que acudirán al traslado del becerro, cumpliendo así una función de conservación y seguridad del original y con ello de la propiedad o derecho que justifica, y una función de eficacia administrativa. En el caso del Libro de Husillos, como en todos los cartularios en general, va a tener como función la justificación de las propiedades y derechos del monasterio y fijar la situación del momento para proceder a una mejor explotación de aquellos. Para su realización se procede primero a una revisión de toda la documentación, sistematización de la documentación y su ordenación mediante criterios alfabéticos, topográficos o cronológicos, como es el caso de Husillos ${ }^{397}$.

\footnotetext{
395 Doc. núm. 298.

${ }^{396}$ RODRÍGUEZ DE DIEGO, El tumbo del monasterio de La Espina, 25.

${ }^{397}$ RODRÍGUEZ DE DIEGO, El tumbo del monasterio de La Espina, 25.
} 
El libro comienza con una tabla o índice de los documentos que lo componen ${ }^{398}$. En dicho índice se ofrece una descripción somera del documento y el número del folio en el que comienza en número arábigo. En el margen derecho, se hace relación del número de folio en número romano. Sigue con el testimonio notarial analizado anteriormente, y el documento fundacional. A continuación se traslada por un orden cronológico aproximado los documentos que se seleccionaron para su traslado.

Los traslados comienzan el día 18 de noviembre de $1554^{399}$ y terminan el día 28 de enero de $1555^{400}$. Vemos así que el tiempo empleado por el escribano público de Husillos Santiago Gómez en trasladar los 155 ejemplares independientes que forman el Libro de los Privilegios fue de 71 días, siendo de poco más de dos la media diaria de documentos trasladados.

Son cuatro los documentos que aparecen en el Libro en forma original, todos ellos derivados de la acción reformadora del obispo Gutierre de Carvajal y realizados al mismo tiempo que se realizaban los traslados ${ }^{401}$. Solamente hay un documento trasladado en el Libro más tardíamente ${ }^{402}$.

Los testigos de los traslados de los documentos son los clérigos Juan Ruiz Cabeza de Vaca y Gaspar de Vedoya, este último además notario público apostólico ${ }^{403}$, y Pedro Manuel, todos ellos estantes en la villa de Husillos. Solamente hay seis traslados en los que los testigos son diferentes. Así, en el primer traslado del libro sacado el 18 de noviembre de 1554, los testigos son Antonio Mogollón y Pedro Manuel $^{404}$. En cinco traslados los testigos son Luis López y Alonso Torres, clérigos y criados del obispo Juan de Carvajal ${ }^{405}$.

\footnotetext{
398 "Tabla de las escrituras que están en este libro, que perteneçen a la fábrica y mesa abaceal y capitular de la yglesia colegial de la villa de Husillos, que es de la dióçesi de Palençia". Dicho índice ocupa las tres primeras hojas del libro.

${ }^{399}$ El primer documento en el que aparece la fecha del traslado es el tercero del Libro (doc. núm. 12), ya que el segundo, que se corresponde con el documento fundacional (doc. núm. 17), no expresa la fecha ya que no se signó por su mal estado de conservación.

${ }^{400}$ Doc. núm. 279.

401 Docs. núm. 295, 296. 297, 298.

${ }^{402}$ Doc. núm. 343. La fecha del documento trasladado es 15 de septiembre de 1599.

403 Doc. núm. 293.

404 Doc. núm. 3.

405 Docs. núm. 274, 277, 278, 279, 291.
} 


\section{LA ABADÍA DE SANTA MARÍA DE HUSILLOS: ESTUDIO Y COLECCIÓN \\ DOCUMENTAL (904 - 1608)}

La mayor parte de los traslados fueron sacados por el escribano público de Husillos, Santiago Gómez. En algunas ocasiones los traslados fueron mandados sacar por dicho escribano, identificándose en tales ocasiones a un único amanuense.

Normalmente, cuando el documento a trasladar está mal conservado y no se puede leer fácilmente o se hace con muchas omisiones, no se signa, expresándose esto con expresiones del tipo: "Esta scriptura, por estar rota en algunas partes que no se pudo leer, no se signó" 406 .

\section{ALGUNAS NOTAS PALEOGRÁFICAS Y DIPLOMÁTICAS DEL LIBRO DE LOS PRIVILEGIOS}

La escritura empleada en la redacción del libro es la humanística bastarda, inclinada hacia la derecha, y la gótica de juros o de ejecutorias contaminada de elementos humanísticos, en general de trazo firme y claro.

Solamente aparece una ilustración en el libro, situándose dentro de la primera letra por la que comienza el libro, tratándose de una figura zoomorfa representada por un grupo de aves. En gran número de traslados aparece en los márgenes notas marginales en las que se describe brevemente el documento que se traslada, se dan palabras clave de dicho traslado, o bien se hacen algunas aclaraciones $y$ correcciones.

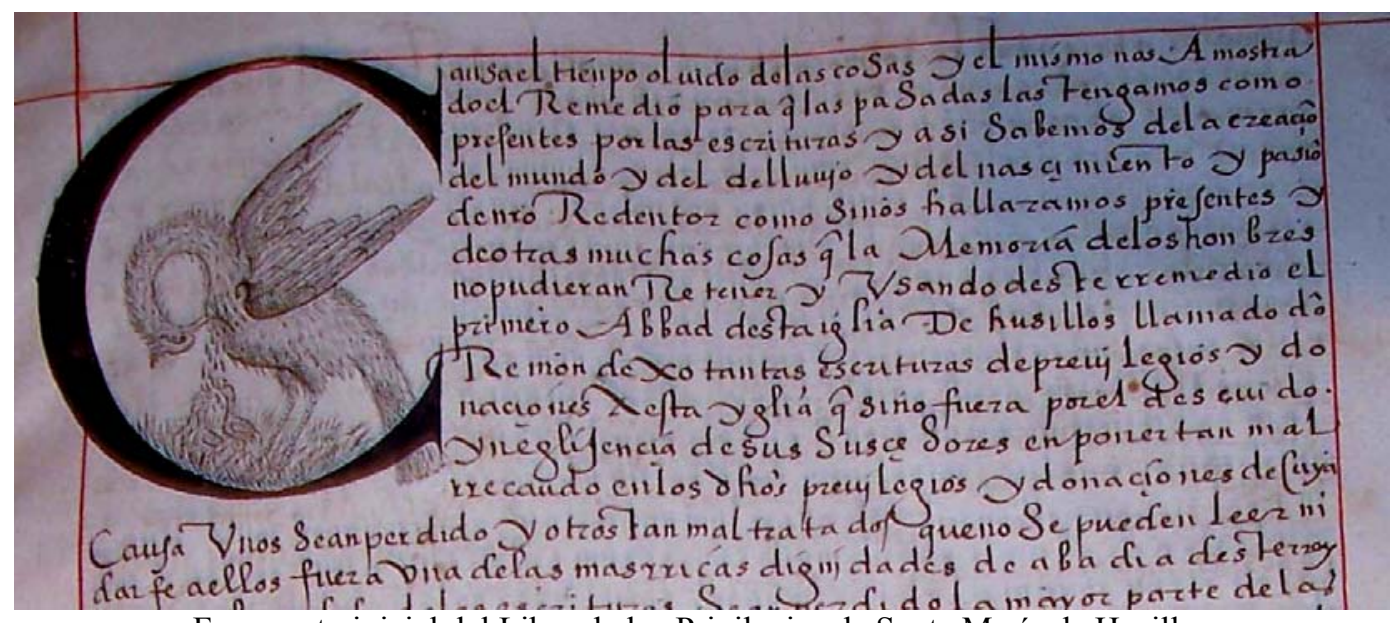

Fragmento inicial del Libro de los Privilegios de Santa María de Husillos

${ }^{406}$ APA, $L P H .$, f. 20 r. 
DAVID MARCOS DIEZ 


\section{LA ABADÍA DE SANTA MARÍA DE HUSILLOS: ESTUDIO Y COLECCIÓN \\ DOCUMENTAL $(904-1608)$}

\subsection{EL MANUSCRITO 705 DE LA BIBLIOTECA NACIONAL}

En la Biblioteca Nacional de Madrid se conserva un libro manuscrito que es una copia simple de parte del Libro de los Privilegios de Santa María de Husillos. Está formado por 264 hojas, con unas medidas de 215 x $303 \mathrm{~mm}$. La encuadernación es de pergamino. En el tejuelo se expresa: "Donación y preuilegios de la iglesia de Usillos".

El libro comienza siguiendo el orden del Libro de los Privilegios, aunque al final varía dicho orden, ya que acaba con el documento núm. 91 de la colección. Son 136 los documentos de la colección que están trasladados en el manuscrito $705^{407}$. Vemos así que en el manuscrito 705 se copiaron algo más de la mitad de los documentos del Libro de los Privilegios, aunque es posible que el resto de documentos se copiaran en un volumen hoy perdido. En las copias del manuscrito 705 se omiten los formulismos notariales que daban validez a los documentos trasladados en el Libro de los privilegios.

Se desconoce el momento y las circunstancias de realización del manuscrito 705 . Posiblemente se realizaría poco más tarde que el Libro de los Privilegios de Husillos, y sería conservado por el abad que lo mandó realizar y posiblemente también por algunos de sus sucesores, justificándose por el gran absentismo de éstos y porque el original se depositaría en el archivo de la abadía. Así en el expediente sobre el patronazgo real de Santa María de Husillos, el abad Francisco de Reinoso da cuenta de que tiene en su casa un libro becerro con todas las escrituras autorizadas, mostrando además el Libro de los Privilegios de Husillos $^{408}$. Así es posible que el libro becerro que Reinoso custodiaba en su casa fuese el manuscrito 705, y que debido a su posterior custodia por los abades de Husillos hasta el traslado a Ampudia de la institución en 1607, muchos de ellos ausentes de la abadía, hizo que finalmente no se conservara en el archivo monástico de San Miguel de Ampudia, como el resto de la documentación de Husillos, y que acabara en el Biblioteca Nacional de Madrid.

\footnotetext{
${ }^{407}$ Docs. núm. 3, 4, 5, 6, 7, 8, 9. 10, 12, 16, 17, 18, 19, 20, 21, 25, 26, 27, 28, 29, 30, 31, 33, 35, $36,38,40,42,43,44,45,46,47,49,50,51,52,53,54,55,57,58,61,62,63,64,66,71,72,73$, $74,75,76,77,81,82,83,84,85,87,88,90,91,92,93,96,97,100,101,102,103,105,106,107$, $108,113,114,118,119,125,126,127,128,131,132,133,134,135,139,140,141,142,143$, $144,145,146,147,148,149,150,151,152,153,154,155,156,157,158,159,160,161,162$, $163,164,166,167,168,169,170,174,176,177,178,183,186,187,188,192,193,200,201$, $204,205,206,218$ y 219.

408 Doc. núm. 335.
} 
DAVID MARCOS DIEZ 
DAVID MARCOS DIEZ 


\section{LA ABADÍA DE SANTA MARÍA DE HUSILLOS: ESTUDIO Y COLECCIÓN \\ DOCUMENTAL $(904-1608)$}

\section{INTRODUCCIÓN}

En este capítulo abordamos el estudio de los nueve diplomas fundacionales otorgados y confirmados por los condes de Monzón y por Sancho el Mayor de Navarra a la abadía de Santa María de Husillos. Se trata de los diplomas que más suspicacias han provocado entre los historiadores que se han centrado en la abadía de Santa María de Husillos en concreto, y en el ámbito de las relaciones entre los condados de Castilla y de Monzón, en general, y entre los que se cuentan desde Ambrosio de Morales hasta Gonzalo Martínez Díez.

El objeto de análisis son los documentos 3, 4, 5, 6, 7, 7', 8, 9 y 10 de la colección documental de Santa María de Husillos ${ }^{1}$. El denominador común de éstos es la presencia de uno, dos o tres hermanos Ansúrez, condes de Monzón durante el siglo X. La destinataria es en todos la abadía de Santa María de Husillos.

Los documentos objeto de nuestro estudio se localizan en el Libro becerro o Libro tumbo de la abadía de Husillos, al cual denominamos Libro de los Privilegios de Husillos $^{2}$, nombre que le asignó Jesús San Martín Payo. Es un traslado notarial de todas las escrituras que se conservaban en el archivo del cenobio en el momento de su realización.

Del Libro de los Privilegios de Husillos se confeccionó una copia abreviada. Se trata del manuscrito 705 de la Biblioteca Nacional de Madrid ${ }^{3}$.

De las nueve escrituras propuestas para ser estudiadas, solamente una, el documento 9, se nos ha transmitido como ejemplar independiente. Se conserva en el Archivo Histórico Diocesano de Palencia, con la signatura: “Ampudia, Serie G, Pergaminos. Donaciones, número 207, documento 2". Se trata de un pergamino de 289 x 416 mm., extraordinariamente fino. Su forma es rectangular, estando los dos lados más cortos, a un milímetro del borde, salpicado, en toda su longitud, de diminutos agujeros espaciados regularmente para el pautado del pergamino.

\footnotetext{
${ }^{1}$ Identificamos en este estudio como documentos 7 y $7^{\prime}$, a las columnas $B$ y $C$ del documento núm. 7 de la Colección.

${ }^{2}$ APA, Ampudia, Serie G, Pergaminos, Becerro, $n^{\circ}$ 214. Existe fotocopia en el Archivo Histórico Diocesano de Palencia.

${ }^{3} \mathrm{BN}, \mathrm{ms} 705$.
} 
Su estado de conservación es bueno. Su escritura es la redonda visigótica, pero con muchas influencias de la carolina, gruesa y de trazado firme.

Del anterior diploma y del número 8 fueron sacados sendos traslados el 7 de mayo de 1353, antes de ser trasladados en el Libro de Privilegios de Husillos. Son los documentos 138 y 139 respectivamente de la presente colección documental. Esto indica que también del documento 8 existió un ejemplar independiente que hoy no se conserva.

El documento 6, de la que no existe ejemplar independiente, fue trasladado al Libro de Privilegios de Husillos con la suscripción confirmativa realizada por Alfonso VII.

Los diplomas 7 y 8 son prácticamente iguales, exceptuando pequeñas diferencias, algunas erradas. Ambos fueron trasladados al Libro de Privilegios de Husillos. Todos los documentos están en latín.

Los nueve documentos se fechan por la era hispánica, entre el 26 de abril de 947 (doc. 3) y el 18 de septiembre de 957 (doc. 10).

\section{ESTADO DE LA CUESTIÓN}

El primer autor que trató sobre el tema fue Ambrosio de Morales (1513-1591), cronista del rey Felipe II. En su obra El Viaje Santo ${ }^{4}$, relata la fundación de la abadía según el testimonio de los canónigos, pues en ese momento la escritura de fundación no se encontraba en el archivo, ya que había sido presentada para la resolución de un pleito. En su obra la Crónica General de España ${ }^{5}$, también menciona la fundación de la abadía de Santa María de Husillos, ampliando y, sobre todo, corrigiendo algunas conclusiones anteriores.

Justo Pérez de Úrbel regestó los documentos objeto de estudio en el tercer volumen de su Historia del Condado de Castilla ${ }^{6}$.

\footnotetext{
${ }^{4}$ MORALES, Viaje a los reinos de León y Galicia y Principiado de Asturias.

${ }^{5}$ MORALES, Crónica general de España

${ }^{6}$ PÉREZ DE ÚRBEL, Historia del Condado de Castilla
} 


\section{LA ABADÍA DE SANTA MARÍA DE HUSILLOS: ESTUDIO Y COLECCIÓN \\ DOCUMENTAL $(904-1608)$}

Jesús San Martín Payo ha sido el que, hasta el momento, ha realizado un estudio más profundo de la abadía de Husillos, abordando también los diplomas fundacionales en uno de sus artículos ${ }^{7}$. Sus conclusiones siguen totalmente las planteadas por Ambrosio de Morales.

Tomás Teresa León, en su estudio sobre Paredes de Nava, se ocupó de la donación a Santa María de Husillos de Sahagún el Viejo (doc. 3) ${ }^{8}$, aunque aborde de forma desafortunada la datación de la escritura.

Gonzalo Martínez Diez, en Los condados de Carrión y Monzón: sus fronteras ${ }^{9}$, cita varias de las escrituras que nos ocupan, apuntando ya a noticias llegadas a través de falsos del XI. Estas afirmaciones las ha mantenido en su obra $\mathrm{El}$ condado de Castilla, la historia frente a la leyenda ${ }^{10}$, observándose en ésta la gran importancia que los documentos que pretendemos analizar tienen para la historia de los condados de Castilla y de Monzón. Así, a través de numerosas referencias a éstos, traza una evolución de los avatares sucedidos en dichos condados durante la segunda mitad del siglo X hasta Sancho el Mayor de Navarra.

Nicolás Villa Calvo, en su estudio sobre la historia del Condado de Monzón, hace mención de los documentos a estudiar, si bien no los empleó como fuente directa al ser consciente de la falsedad de éstos y de la gran dificultad que encerraba su estudio $^{11}$.

Julián Aparicio, en su obra sobre Grijota, transcribe el documento sobre la donación de Pajares por los condes de Monzón a Santa María de Husillos, exponiendo que es en dicho documento donde aparece por primera vez el nombre de Grijota, sin cuestionar la originalidad del documento ${ }^{12}$.

\section{ANÁLISIS DIPLOMÁTICO}

\footnotetext{
${ }^{7}$ SAN MARTÍN PAYO, Santa María de Husillos y su Colección Diplomática.

${ }^{8}$ TERESA LEÓN, Paredes de Nava, 30.

${ }^{9}$ MARTÍNEZ DIEZ, Los condados de Carrión y Monzón, sus fronteras.

${ }^{10}$ MARTÍNEZ DÍEZ, El condado de Castilla.

${ }^{11}$ VILLA CALVO, Historia del condado de Monzón, 236-242.

${ }^{12}$ GUTIÉRREZ APARICIO, Grijota: Pueblo con Historia, 26.
} 
Ninguno de los documentos a estudiar se ha transmitido en forma original, a excepción de la escritura por la que el conde Fernando Ansúrez de Monzón dona Pajares (doc. 9), que es un ejemplar independiente en escritura visigótica redonda. Los otros ocho documentos son traslados notariales realizados en 1554-1555 en el Libro de los Privilegios de Husillos, por lo que nada se puede decir de ellos en aras a una crítica paleográfica.

Somos conscientes de lo incierto que pueden resultar las conclusiones en un estudio diplomático al trabajar con documentos procedentes de traslados. Afortunadamente, el ejemplar independiente nos muestra, en comparación con los traslados, que las fórmulas empleadas, en algunos de ellos, son bastante similares, por lo que intuimos que los supuestos originales, de los que se sacaron los traslados, no hubieron de diferenciarse mucho en el aspecto diplomático.

\section{Análisis de las partes formales de los documentos}

Con el objetivo de aclarar ciertos problemas existentes en los documentos a estudiar, algunos sobre su autenticidad y otros históricos, vamos a realizar un examen diplomático de las escrituras, agrupándolas según las similitudes que presenten.

\subsection{Invocación simbólica o monogramática}

El crismón solamente aparece en el documento 9, el único ejemplar independiente que existe. En él aparece, encabezando la escritura, un anagrama caligráfico con una " $P$ " muy alta, cuyo astil consiste en un estrecho rectángulo al que, sobre la mitad, se le ha superpuesto una " $X$ ” y, en la parte baja, una " $S$ ". Este símbolo es muy similar a los dos crismones contenidos en los documentos de la reina doña Urraca existentes en esta misma colección ${ }^{13}$.

El supuesto original del diploma 3, también parece que contenía la invocación monogramática, pues el traslado realizado en el Libro de los Privilegios de Husillos, nos ha transmitido en su encabezamiento, la palabra "Christus". Es de suponer que el resto de supuestos originales también contaran con invocación

\footnotetext{
${ }^{13}$ Docs. núm. 18 y 19.
} 


\section{LA ABADÍA DE SANTA MARÍA DE HUSILLOS: ESTUDIO Y COLECCIÓN \\ DOCUMENTAL $(904-1608)$}

simbólica, y que el escriba del libro becerro, como era normal en estos casos, no mencionara dicha invocación.

\subsection{Invocación verbal}

Todas las escrituras incluyen invocación verbal ${ }^{14}$, consistente, en las escrituras 3 , 4, 6 y 9, en un ablativo precedido de la preposición "in", seguido de una referencia al nombre de nuestro Señor Jesucristo: "In nomine Domini nostri Ihesu Christi". El documento 8 usa la preposición "sub" y después la misma fórmula anterior pero abreviada: "Sub Christi nomine". El resto, documentos 5, 7 y 7', aunque en la misma línea usan una forma bastante más ampulosa, haciendo referencia a Dios creador en el misterio de la Trinidad, rey y señor de cielos y tierra:

"In nomine omnium opificis rerum creantis et regentis, transcendentis et circumplectentis et circumscripti atque inuisibilis Dei, Patris et Filii et Spiritus Sancti in eternum et vltra, cuius regnum in sempiternum non corrumpetur neque auferetu, cuius nutu principes regnant et tempora mutantur temporibus, per quem cuncta subsistunt elementa, cui famulantur vniversa, celestia pariter et terrestria, atque mare continentia; illius iubante clementia, igitur in nomine Domini nostri Ihesu Christi"; el documento 10 usa la misma fórmula pero abreviada: "In nomine omnium opificis rerum creantis et regentis".

De esta manera, se representan los tres tipos de invocaciones verbales por la extensión del contenido que Andrés Gambra concluyó para los documentos de Alfonso $\mathrm{VI}^{15}$.

\subsection{Intitulación}

En los casos en que aparece colocada inmediatamente después de la invocación verbal (docs. 3, 4, 8, 9 y 10), contiene los siguientes elementos y en este mismo

\footnotetext{
${ }^{14}$ Según Andrés Gambra, antes del siglo XII la invocación verbal es un elemento imprescindible (GAMBRA, Alfonso VI, I, 185).

${ }^{15}$ GAMBRA, Alfonso VI, I, 186-191. Hay tres clases de fórmulas según su extensión: muy breves (3-8 palabras). De extensión reducida (12-20 palabras). Media (28-40) y extensas, con vacuas formulaciones de contenido teológico (60-120).
} 
orden: pronombre personal en primera persona, "ego"; nombre personal seguido del patronímico "Ansurez"; condición nobiliaria; preposición “in”; lugar donde se ejerce dicha condición: "Monteson".

Existe sólo un caso de intitulación triple (doc. 8) que se resuelve poniendo tres veces sucesivas los dos primeros elementos de la intitulación unidos por la conjunción "et" y después de la condición nobiliaria en plural: "comites" y por último, los otros dos elementos: "in Monteson”. En el documento 10 sólo existen los dos primeros elementos.

Son los documentos 5, 6, 7 y $7^{\prime}$ los que presentan una intitulación y en general un tenor diplomático más complejo. Se trata de confirmaciones de hechos pasados que se relatan en forma de "notitia" y que son expuestos por testigos locales. La complejidad estriba en que la nómina de otorgantes: Sancho el Mayor de Navarra, su madre doña Jimena, la condesa doña Urraca, madre del joven García Sánchez, y el dicho García Sánchez, cuñado de Sancho el Mayor, se insertan en la parte final de la "notitia", antes de la mención a que lo relatado fue dicho por testigos. Dichos otorgantes aparecen tambien en la lista de confirmantes, a excepción de Sancho el Mayor. En el caso del documento 5, los otorgantes solamente aparecen en la lista de confirmantes.

\subsection{Dirección}

En todos los casos, la destinataria de la magnanimidad de los condes de Monzón y de Sancho el Mayor es Santa María de Husillos: según los diplomas 3, 4 y 9: "dicte eglesie Sancte Marie et vobis, Raymundus, abate, et sucesoribus vestris". La escritura 8 utiliza una fórmula muy similar: "ecclesie Sancte Marie de Fusillos et vobis dominus Reymundus, abbas dicte ecclesie, et omnes sucessores vestros"; en el número 10 es algo diferente la dirección: "ecclesie Sancte Marie de Dehesa Brava et vobis Raymundo, cardinali Sancte Crucis, abbati dictae ecclesiae, et vestris successoribus et fratribus, tam presentibus quam futuris, in perpetuum substituendis". De todos estos documentos, únicamente el 8 cita una sola vez la dirección, dos lo hace el 10 y hasta tres veces la reiteran las escrituras 3, 4 y 9.

En los documentos 5, 6, 7 y 7' la dirección inserta en la "notitia" de las donaciones de los condes de Monzón es de tipo "ad honoris" de la tipología 
establecida por Andrés Gambra: "in honore Sancte Marie Virginia et matris Domini nostri Ihesu Christi, et Sancti Machaeli Archangeli, et a sanctorum apostolorum Petri et Pauli, et Sancti Iohannis apostoli et euangelisti et Sancti Iohani Batiste et Sancti Martini episcopi et confesoris Christi; sanctorum Fructuosi episcopi et Aguri diaconorum et martirum et Sancti Pelagii, ${ }^{16}$.

\subsection{Salutación}

Esta fórmula está ausente en los diplomas analizados.

\subsection{Preámbulo}

No se detecta preámbulo en ninguna de las escrituras analizadas. En realidad, es un elemento que solamente era frecuente en los privilegios, de ahí esa ausencia ${ }^{17}$.

\subsection{Notificación}

En los documentos 5, 6, 7 y $7^{\prime}$ se sitúa, esta cláusula, inmediatamente después de la invocación verbal; en los cuatro, únicos que la incluyen, se comienza con la locución "Hoc est" o "Hec est" y a continuación se da a conocer el contenido de la carta: "cartula testamenti atque memoria de illos comites". La fórmula utilizada por el diploma 6 es algo más escueta: "memoria de illos comites".

\subsection{Exposición}

La estructura de la exposición en es todos los documentos muy similar, al tratarse de donaciones y confirmaciones "pro anima". Documentos 3, 4, 9 y 10 "pro redempcione anime mee et parentum meorum"; el diploma 8 , al ser la intitulación triple, dice "pro redempcione animarum nostrarum et parentum nostrorum"; y los documentos 5, 6, 7 y 7' "pro suas animas".

\section{9. “Narrationes" de contenido histórico}

\footnotetext{
${ }^{16}$ GAMBRA, íbid., 200-201. Se comprueba que los tipos de fórmulas usadas en las direcciones en que los destinatarios son eclesiásticos, que Andrés Gambra fija en la documentación de Alfonso VI, se observan también en los documentos otorgados por los condes de Monzón, incluida la fórmula "ad honores".

${ }^{17}$ GAMBRA, ibíd., 203.
} 
Se trata de explicaciones sobre los precedentes o hechos que motivaron la confección del acto jurídico $^{18}$. Las encontramos en las confirmaciones (docs. 5, 6, 7 y $\left.7^{\prime}\right)$.

\subsection{Disposición}

El dispositivo se anuncia o prepara con la fórmula "facio cartulam siue testamentum donacionis ... istam antea dictam villam cum omnia supranominata", en los documentos 3, 4 y 9, manifestándose mediante el verbo "dono". En los documentos 9 y 10 el dispositivo se anuncia y constituye con la expresión "facimus cartulam siue testamentum donacionis" en el primero, por ser tres los donantes, y "facio cartulam siue testamentum donnationis" en el segundo, en todos ellos como expresión del hecho jurídico contenido en los documentos: la donación de una serie de villas pertenecientes a los condes de Monzón.

En los documentos 5, 6, 7 y 7', en los que se confirman donaciones anteriores, los verbos dispositivos aparecen de forma distinta. En el documento 5 no se aprecia ningún verbo dispositivo, debiéndose deducir el dispositivo de la naturaleza jurídica de la carta mencionada en la datación. En el documento 6, el verbo dispositivo aparece al final de la "notitia", cuando se da cuenta de que Sancho el Mayor de Navarra, su madre Jimena, doña Urraca de Castilla y García Sánchez confirmaron las donaciones ya relatadas, por el alma de Sancho García de Castilla. En el documento 7 el dispositivo empleado es: "corroborarunt", y en el documento 8: "corroborauerunt et confirmauerunt".

Como los anteriores verbos dispositivos, que por incluirse en la "notitia" se encuentran en pretérito perfecto, los demás verbos de los documentos 5, 6, 7 y 7 también lo están, en consonancia con el carácter narrativo de los diplomas: "qui aedificarunt monasterium in Dehesa Braua" en el número 5; "qui dederunt" en el 6; "qui aedificarunt monasterium" en el 7; y "qui confirmarunt monasterium" en el documento $7^{\prime}$. En los escritos 6, 7 y $7^{\prime}$ no se expresa el lugar donde fue construido el monasterio.

\footnotetext{
${ }^{18}$ MARÍN-RUIZ ASENCIO, Paleografia y Diplomática, 530. La consideración de estas “notitias" interesa más a la crítica histórica que a la diplomática.
} 


\section{LA ABADÍA DE SANTA MARÍA DE HUSILLOS: ESTUDIO Y COLECCIÓN \\ DOCUMENTAL (904 - 1608)}

A las cinco villas donadas por los condes de Monzón se les nombra y ubica perfectamente. Además, en las tres últimas se especifica el título de propiedad: “Villa Sancti Facundi, circa Parietes de Naua" (doc. 3); "Villagutierrez Aluarez, que est sita inter Montem del Rey et Villaximenam" (doc. 4); "de loco nostro de Paliareios, circa Bezerril" (doc. 8); "de illa mea villa de Paiares, qui est sita inter Griiota et rium de Carrione" (doc. 9); "de illa villa mea Sancti Iuliani, que est sita inter Vilumbrales et Fuent Quinana" (doc. 10). En todas estas donaciones se hacen otras muchas precisiones tratando de limitar su territorio: "cum suos terminos", sus propiedades: "et cum domibus, soliis, vineis, terris, pratis, pastis" y en algunos casos "et sua defesa", "et cum helbegeras", "et cum illas acennas"; reiterándolo y precisándolo una vez más: “ut habeatis perpetuo cum introitus et exitus et cum omnibus terminis suis, tam populato quam et heremo et cum omnibus pertinentiis et directuris".

También todos, excepto los documentos 9 y 10 deslindan, con toda minuciosidad, las susodichas villas, precediendo a la tal delimitación la fórmula: “cuius terminus vadit", o bien: "qui quidem terminus vadit".

En el grupo de las escrituras confirmatorias, la estructura documental es muy variada; así el número 5, después de la dirección, porta una especie de intitulación del hecho relatado sin el pronombre personal en primera persona "ego", diciendo: "Hoc est Fernandus et Gundisaluus Anxurez, comites". Después utilizando el nexo: "et vadit terminus eius", delimita con exquisita meticulosidad el marco territorial de la abadía de Santa María de Husillos. En el documento 6 también tras la dirección se ejecutan una serie de transmisiones patrimoniales y donaciones "pro anima" en forma narrativa. Todos los hechos relatados están separados por muchos años. Por último, se establece la finalidad: "pro remedio animae suae" y se reitera la dirección: "a Sanctae Marie”.

Las escrituras 7 y $7^{\prime}$, que son casi idénticas, parecen una suma de las dos anteriores escrituras; efectivamente, comienzan de forma muy similar al documento 5: "Hoc est Fernando Anxurez, comes, et Gonsaluo Anxurez, comes", continuando exactamente igual, pero haciendo un acotamiento menos preciso. En 
un segundo apartado, que no contiene el documento 5, se deslinda, con toda precisión, el monasterio de San Sebastián de Hérmedes. Por último, al igual que el doc. 6, relata las donaciones "pro anima" a Santa María de Husillos, tras la muerte de un buen número de personajes.

Los cuatro documentos terminan la extensa narración con una fórmula que, aunque con distinta extensión y precisión, viene a expresar lo mismo, y que da fe de que estamos ante hechos jurídicos pasados que se confirman a través de lo relatado por los testigos y relatores presentes:

Doc. 5: "Et hoc de consilio et consensu rectorum et confabulatorum"

Doc. 6: "et fuerunt ibi rex, testes et fabulatores qui dixerunt veritatem".

Doc. 7 y 7': "et fuerunt ibi rectores et fabulatores plurimi qui dixerunt veritatem"

Finalizado el deslinde, en las escrituras 3 y 4 se reitera alguna de las fórmulas anteriores como el anuncio del dispositivo, el verbo que establece el propio dispositivo, la dirección y la finalidad, añadiéndose otra nueva como es la situación jurídica de la villa: "Istam antea dictam villam, cum omni iurisdictione et mixto et mero imperio, dono dicte ecclesie et vobis Raimundo, abbati, et successoribus vestris, ut seruiatis domino nostro Ihesu Christo, redemptori nostro, et beate Marie, matri eius".

El documento 8 muestra la finalidad de la donación: "tali conuentione ut habeatis omnibus diebus seculi, vos et succesores vestros, ad seruiendum Dominum nostrum saluatorem mundi et beate Marie, mater eius". Después recuerda, haciéndolo en plural al ser triple la intitulación, otra de las finalidades: "hoc facimus pro remissione pecatorum nostrorum et parentum meorum", añadiendo la única cláusula de vicisitudo existente en los nueve diplomas: "et ad confirmandam hanc cartulam, dedistis nobis XL marchas argenti purissimi".

El diploma 10 primero expresa la situación jurídica: “et cum omni mero et mixto imperio et iurisdictione", después reitera la dirección y la finalidad: "Hoc facio ut vos, supradictus Raymundus et successores et fratres vestris seruiatis Domino Iesu Christo, redemptori nostro, et beatae Mariae, matri suae". 


\subsection{Sanción}

Las sanciones que se encuentran son de tipo prohibitivo o negativo. Estas últimas comportan una formulación de penalizaciones. Estas penas pueden ser espirituales o materiales y pueden formularse conjunta o alternativamente.

- Donaciones:

En las donaciones (doc. 3, 4, 8, 9 y 10) las materiales consisten en la restitución del doble de lo infringido a Santa María de Husillos y en una multa de cien libras de oro puro para el fisco real, destinatario que solamente es determinado de forma clara en el documento 10 .

Únicamente el número 9, al estipular las penas materiales, se aparta de las cien libras de oro purísimo que todos estipulan, reduciéndolas a veinte.

Al ser en todos los documentos la formulación muy similar, ofrecemos como ejemplo la del único ejemplar independiente que subsiste:

"Quod si aliquis aduersus, hanc legitimam cartam ad infringendum insurgere temptauerit, inprimis yram Dei et indignacionem habeat et cum Iuda traditore Domini pares penas in eterna dampnacione lugeat atque cum Datam et Abiron, quos terra obsorbuit, sit dimersus in profundum inferni, et pro ausu temeritatis quantum infringere uoluerit duplicatum rrestauret eglesie uestre et uobis, antea dicto Reymundo, et sucesoribus uestris, et insuper pecet centum libras purissimi auri, et semper hec scriptura plenum obtineat firmitatis roborem equo pereni in secula seculorum".

\section{- Confirmaciones:}

En las escrituras 5, 7 y $7^{\prime}$ (pues la 6 no contiene cláusulas) la sanción es muy parecida y ha sido colocada después de la data, lugar un tanto extraño, pues se trata de un complemento del dispositivo. Advierte la escritura 5: "et quisquis hanc cartulam rumperit vel contravenerit, sexaginta denarios auri componat". Muy similar a lo que dispone la 7 y 7": "et quisquis hec cartula ad disrrumpendum venerit, sexaginta ciclos auri opponat". 


\subsection{Cláusula preceptiva final}

En todos los instrumentos se sitúa inmediatamente después de la sanción. Los documentos 3, 4, 8, 9 y 10 son los únicos que contienen esta cláusula. Al ser todas ellas muy similares, ofrecemos el texto del ejemplar independiente: "et senper hec scriptura plenum obtineat firmitatis roborem euo pereni in secula seculorum".

\subsection{Data}

Los nueve diplomas comienzan esta cláusula con la palabra "facta", para continuar con la expresión "carta" o "cartula", no apareciendo ninguna otra variedad ortográfica. A continuación va el término en genitivo "donacionis", expresivo del contenido jurídico del documento, que algunas veces aparece con alguna variante como “donationis" o “donnationis". Los documentos 5, 7 y 7' añaden "et confirmationis".

Sin ninguna excepción contienen la data crónica, constituida por el día del mes por el sistema romano, y el año, expresado, como ya dijimos, por la era hispánica.

Al día del mes, expresado por la palabra "die", se antepone, en algunos casos, la partícula "noto" o la variante ortográfica "nocto". En los documentos 5, 6, 7 y 7" no existe la expresión formada por estas dos palabras. El cardinal del día viene indicado por un número escrito en cifras romanas o bien por un ordinal desarrollado en escritura. También, sin excepción, su datación se realiza por las calendas, encontrándose la variante ortográfica "kalendas". Después de tal expresión, aparece el nombre del mes enunciado en genitivo.

La era la encontramos, en todos ellos, enunciada con letras numerales, precedidas de la locución "in era".

Al ser todas ellas muy similares, mostraremos la data que contiene el ejemplar independiente que se ha conservado (doc. 9): "Facta cartula donacionis, nocto die VIII kalendas may, in era DCCCCLXXXXIII". En el documento 10 se expresa “in era $D C C C C X C V$ '. Seguramente al ser trasladado el supuesto original en el Libro 


\section{LA ABADÍA DE SANTA MARÍA DE HUSILLOS: ESTUDIO Y COLECCIÓN \\ DOCUMENTAL $(904-1608)$}

de los Privilegios, la fecha se abrevió, al igual que sucedió en el traslado del documento 9 .

Los diplomas 6, 7 y 7' presentan como complemento una fecha histórica. Dice el instrumento 6: "Regnante rex Santius in Castella et in Pampilona et in Monteson”. En los números 7 y 7' es más personal y algo diferente: "Regnante ego rex Santius memet ipso in Castella et in Pampilona et in Monteson".

\subsection{Corroboración}

Se localiza solamente en las donaciones (docs. 3, 4, 8, 9 y 10). En algunos comienza, como si se tratara de una intitulación, con el pronombre personal "ego", excepto en la escritura 8, que al ser tres los donantes dice "nos", sin nombrar personalmente a ninguno. Hay casos en que antepone la conjunción "et". Continúa colocando el nombre personal seguido del patronímico, para finalizar con la expresión: "qui hanc cartam fieri iussi, confirmo" para los documentos 3, 4 y 10. El ejemplar independiente añade, después del patronímico, la condición nobiliaria "comite", para continuar con la frase "que hanc cartam fieri iussi tota mentis intencione, confirmo". En el diploma 8 la suscripción es muy similar al 9.

\subsection{Suscripciones}

La suscripción de los confirmantes y testigos, que en todos aquellos documentos que aparecen son prácticamente los mismos personajes, debieron estar en un principio colocados en tres columnas, según muestra el único ejemplar independiente que subsiste:

$\begin{array}{lll}\text { Gloriosissima regina, confirmat. } & \text { Nunno Garsias, confirmat. } & \text { Comes Gunsalus Sanchez, confirmat. } \\ \text { Gunsalus Diaz, confirmat. } & \text { Rodericus Gunsalui, confirmat. } & \text { Comitissa domina Uraca, confirmat. } \\ \text { Bellid Nunez, confirmat. } & \text { Pelagius Garsia, confirmat. } & \text { Domina Ximena, confirmat. } \\ \text { Anxur Nunez, confirmat. } & \text { Frola Diez, confirmat. } & \text { Sancius Uermudez, confirmat. } \\ \text { Petro Cidez de Facinas, testis. } & \text { Guter Perez de Avia, testis. } & \text { Feran Garsias de Fita, testis. }\end{array}$

Todos estos personajes, o parte de ellos, aparecen confirmando la gran mayoría de los nueve documentos. Casi nunca guardan el mismo orden. Otras veces los nombres se han tergiversado, mezclándose con el patronímico de otros, o se usan 
distintas variantes ortográficas e, incluso, hay evidentes confusiones que debieron cometerse al transcribir los supuestos originales en el Libro de Privilegios de Husillos.

Existen, dentro de la nómina de confirmantes, tres categorías diferenciadas de personajes. Cada uno realiza la suscripción de acuerdo con su condición. Al contrario que en otros diplomas, las columnas no son indicativas de la posición social de los suscriptores. Tal vez en los supuestos originales sí lo fueron, pero en esta copia se les encuentra mezclados unos con otros, hecho extraño ya que en las copias se solía mantener la estructura de las columnas de confirmantes.

En la fórmula de suscripción se expresa la condición nobiliaria de aquellos que la poseen, el nombre personal, el patronímico y el verbo "confirmat" o "testis" en el caso de los testigos.

Aparece en las suscripciones de las confirmaciones (en los docs. 5, 7 y $7^{\prime}$ ) la fórmula visigótica de constatación de testigos: Pelagius, Cid, Bellit. En cambio, en las donaciones ya no aparece. Esto se debe a que ya en la época de Alfonso VII los notarios ya no utilizan esta fórmula, aunque se copie la lista de suscriptores.

De la primera confirmante de la primera columna, "gloriosissima regina", deducimos que se trata de la reina Jimena de Navarra. No debe de resultar extraño que un personaje femenino ocupe el primer puesto entre los suscriptores, pues se trata de un miembro de la familia real.

En el documento 8 se muestra una lista de suscriptores totalmente diferente, tratándose de personajes de las primeras décadas del siglo XIII.

Todos los documentos presentan la suscripción de la persona que los realizó, y los agrupamos según sus notarios:

Documento 3: "Ioannes de Auila, notarius regis, quod scripsit, signauit". 
Documento 4: "Ego, Lopez de Manquillos, notarius regis, quod scripsit, signauit".

Documento 9: "Petro Lopez de Manquillos, notarius regis, quod scripsit, signauit".

Documento 5: “Lucino, preste, scripsit et signauit".

Documento 6: "Licino, presbitero, scripsit".

Documento 7: “Licino, presbitero, scripsit".

Documento 7': "Lucinio, presbitero, scripsit".

Documento 8: “Et ego, Dominico Moro, quod scripsi, signaui commo scriba regis de meo signo".

Documento 10: "Garsia Nunnez, quod scripsi, signaui”.

Es posible que el notario real Juan de Ávila fuese el notario real Iohannis que escribe dos documentos datados el 29 de mayo de 1117 y el 9 de diciembre del mismo año ${ }^{19}$.

El notario real Pedro López de Manquillos es el mismo que confirma la donación de Urraca I a Santa María de Husillos de Celanova y el Arroyo de Frades, el 28 de mayo de 1114, redactada por Martín de Palencia ${ }^{20}$. De esta manera, este personaje, que se habría formado en la escuela episcopal palentina, pudo haber sido notario real en tiempos de Alfonso $\mathrm{VII}^{21}$. Los propios nombres de estos notarios nos indican en la misma dirección, pues la adicción, al nombre y el patronímico, del cognomen toponímico, no empezó a ser frecuente hasta después del siglo XII.

Juan de Ávila y Pedro López de Manquillos, que son titulados como notarios reales, pudieron ser requeridos por Santa María de Husillos para la confección de

\footnotetext{
${ }^{19}$ REILLY, Chancery of Alfonso VII of León-Castilla, 245.

${ }^{20}$ Doc. núm. 19.

${ }^{21}$ Ruiz Albi afirma que dicho notario se formó en la escuela episcopal de Palencia (RUIZ ALBI, Cancillería y colección diplomática de la reina Urraca, 175).
} 
los instrumentos que suscriben, ya que en ocasiones las instituciones destinatarias de privilegios y confirmaciones podían recurrir a notarios o escribas reales para la confección de sus documentos.

En cuanto al presbítero Lucino o Lucinio, pudo tratarse de un escriba dependiente de Santa María de Husillos en tiempos de Sancho el Mayor de Navarra, al igual que García Núñez, al que circunscribimos en la época de los notarios reales de Alfonso VII.

En cuanto al artífice del diploma 8, Domingo Moro, se trata de un notario de comienzos del siglo XIII al servicio del obispo de Palencia Tello Téllez de Meneses.

Un elemento común a todos estos notarios es que ellos mismos escriben y signan los documentos. Esto es sintomático de la época precancilleresca, en la que no existe organización ni estratificación en las escribanías regias, dándose una acumulación de funciones por parte de los notarios o escribas regios.

\subsection{Signos}

Al conservarse únicamente un documento independiente, no podemos afirmar, de forma rotunda, que no existieran signos personales acompañando a las suscripciones. Desde luego, si les hubo, no fueron transcritos al Libro de Privilegios de Husillos.

Este no es el caso de los notarios, algunos de los cuales sí dejaron su signo personal al lado de la suscripción. El documento 9 nos permite conocer el signo personal del notario Pedro López de Manquillos. Se trata de un signo monogramático formado con el emblema cruciforme, al que se le ha añadido, en cada uno de los cuatro extremos, un pequeño círculo y todo ello encerrado en la tetrapétala. En los espacios de las conjunciones de las curvas, se sitúan unos ángulos con el vértice apuntando hacia fuera y rellenos con tinta, sobre los cuales se sobreponen otros cuatro, de cuyos vértices parten unas líneas rectas. En la parte izquierda de la tetrapétala, se encuentra la sílaba " $P$ " y en la parte derecha, la 
sílaba "tro", el nombre del notario. En cada lado del nombre hay un par de rúbricas en forma de ocho.

Los documentos 5 y 8, conocidos gracias al Libro de Privilegios de Husillos, parece ser que también sus respectivos ejemplares independientes llevaron el signo personal del notario, tal como parecen mostrar sus traslados en dicho libro.

\section{Definición y génesis de los documentos}

\subsection{Clasificación en cuanto a los otorgantes}

Ante la problemática sobre si la documentación condal se debe considerar documentación pública o privada, hay que detenerse en primer lugar en el criterio adoptado por Manuel Zabalza Duque para con los documentos otorgados por los condes de Castilla ${ }^{22}$, a los que considera dentro de la documentación privada.

Zabalza dice respetar el tradicional esquema fijado en el manual de la UNED por los profesores Tomás Marín y Ruiz Asencio ${ }^{23}$ de la división de documentación pública y privada. No obstante, se comprueba que éstos consideran que el problema de la división entre documento público y privado se plantea a la hora de establecer quién es autoridad pública y quién no, agravándose este problema en torno a las autoridades intermedias, civiles (nobles, municipios, etc) y eclesiásticas. Consideran que la solución, que es compleja, habrá de determinarse en relación a cada autoridad.

A pesar de la dificultad de diferenciar documentación pública y privada en la Alta Edad Media, nosotros, siguiendo la sugerencia que hacen los autores del manual de la UNED, consideramos como documentación pública la documentación otorgada por los condes de Monzón y por Sancho el Mayor de Navarra.

En efecto, a pesar de que en la Alta Edad Media la diferencia entre documentación pública (léase la documentación emitida por la escribanía y cancillería regia) y privada es muy tenue debido a que las características formales y de contenido de

${ }^{22}$ ZABALZA, Colección diplomática de los condes de Castilla, 73.

${ }^{23}$ MARÍN - RUIZ ASENCIO, Paleografía y diplomática, 511. 
ambos tipos de documentación son muy similares, consideramos que los condes de Monzón, al igual que los de Castilla, representaban en el siglo X un poder "de facto" con gran autonomía con respecto a la capital regia leonesa, de la que Monzón se encontraba a una considerable distancia, considerando además la débil representación del poder regio en el territorio castellano y leonés hasta Alfonso VI. Prueba de esta gran autonomía, que de hecho suponía que los condes de Monzón casi actuaran como gobernantes independientes, son las embajadas propias enviadas a los califas de Córdoba durante los años centrales del siglo X.

A esto hemos de añadir que la documentación otorgada por Sancho el Mayor de Navarra, actuando en un momento en que el condado de Monzón ha caído bajo su área de influencia, indudablemente se ha de considerar como documentación pública.

\subsection{Génesis de los documentos}

Para el análisis de la génesis de los documentos a estudiar, haremos una división previa entre las donaciones y las confirmaciones, por las peculiaridades que presentan estas últimas.

\subsubsection{Donaciones}

Como afirma Ruiz Albi ${ }^{24}$, en la época en que la cancillería están sin organizar, en las que las escribanías, tanto públicas como privadas, carecen de libros de fórmulas conservados, tiene gran importancia los datos dispersos que aparecen en los documentos y que señalan las distintas fases de la génesis documental. En las donaciones de los condes de Monzón, se hace referencia a la naturaleza jurídica de la "actio" (donationis). Se observan también varias fases de la conscriptio en la fórmula: "Ego... qui hanc cartam fieri iussi, confirmo" y en las fórmulas de suscripción de los notarios y escribas (notuit, scripsit) ${ }^{25}$. Dichas fases son: iussio, confectio del mundum (scripsit, notuit), recognitio, validación (corroboratio). La conscriptio termina con la suscripción del notario o escriba.

\footnotetext{
${ }^{24}$ RUIZ ALBI, Cancillería y colección diplomática de la reina Urraca, 243.

${ }^{25}$ Se observa a través de la suscripción de los notarios la inexistencia de organización en las escribanías que realizaron los diplomas ya que, indistintamente, utilizan los verbos "scripsit", "notuit" o los dos juntos.
} 


\section{LA ABADÍA DE SANTA MARÍA DE HUSILLOS: ESTUDIO Y COLECCIÓN \\ DOCUMENTAL $(904-1608)$}

Es tradicional en Diplomática la problemática sobre si la fecha se refiere a la actio o a la conscriptio. Según Bouard, en su Manuel de diplomatique ${ }^{26}$, el término "factum" se refiere a la actio; y "datum" a la conscriptio. Pero normalmente, los testigos, que lo son de la fase final de la conscriptio, suelen concordar con la fecha. Igualmente, los rogatarios de las donaciones otorgadas por los condes de Monzón trataron de hacer coincidir, aunque sin fortuna, la fecha de los documentos, que introdujeron con "factum", con los testigos y confirmantes.

\subsubsection{Confirmaciones}

La actio de estos diplomas se manifiesta en la confirmación de las anteriores donaciones por Sancho el Mayor de Navarra y su séquito en los documentos 6, 7 y 8 (aunque en el 5 se presupone) y en la naturaleza jurídica del diploma expresada en la data en los documentos 5, 7 y 7' como "donationis et confirmationis" e inexplicablemente como "donationis" en el 6. Posiblemente, al ser trasladado en el Libro de los Privilegios, se omitiera "confirmationis".

Dentro de la conscriptio, a diferencia de las donaciones no se refleja la iussio ni la corroboratio. Sí aparece la confectio del mundum (scripsit, notuit), y la validación de los diplomas a través de los confirmantes y testigos.

Se observa, al igual que Andrés Gambra para los documentos de Alfonso VI, que los intervenientes y consentientes se han convertido igualmente en confirmantes ${ }^{27}$, entremezclándose de esta manera dos fases de la actio y conscriptio como son la interventio y consentio por una parte y la validatio por otra.

El documento 6 inserta una suscripción confirmativa de Alfonso VII. Dentro de la actio, refleja la naturaleza jurídica de ésta ("confirmo"), la interventio y consentio. También se refleja varias fases de la conscriptio: el mundum y la validatio.

\footnotetext{
${ }^{26}$ BOUARD, Manuel de Diplomatique.

${ }^{27}$ GAMBRA, Alfonso VI, I, 291-293. Considera que en la diplomática alfonsina se da el tránsito de lo que en diplomática se considera tránsito del consentimiento al testimonio, de modo que los intervenientes y consentientes se han convertido en testigos y confirmantes.
} 
La gran controversia de estos diplomas, que afecta directamente a la génesis, es que la data de estos documentos (17 de septiembre de 950) no se corresponde con los otorgantes de los diplomas ni con los confirmantes de éstos. La explicación de este problema se aborda en el capítulo de la crítica diplomática e histórica.

\section{Tipos diplomáticos según características formales}

Fue el manual de la UNED de los profesores Tomás Marín y Ruiz Asencio los que, en evolución con los estudios de Barrau-Dihigo, propusieron una tipificación de los documentos altomedievales que se ha seguido por los autores que se han centrado en una época o documentación determinada, como son Pilar Blanco ${ }^{28}$, Andrés Gambra, Manuel Zabalza Duque o Irene Ruiz Albi. Esta tipificación se concreta en privilegios, carta leonesa, precepto o mandato, y documentos judiciales o plácitos. No obstante, estos últimos autores, aun manteniendo la tipificación del manual de la UNED, matizan sus planteamientos y hacen observar que en ocasiones es muy difícil distinguir entre privilegios o cartas. Andrés Gambra va más allá y habla de la necesidad de introducir subdivisiones dentro de estos tipos documentales principales.

Irene Ruiz Albi observa que en el período de Urraca I terminan las distinciones tipológicas establecidas anteriormente y que, por otra parte, no hay argumentos sólidos que permitan diferenciar claramente entre privilegio y carta.

Siguiendo las sugerencias de los autores citados y tras el análisis de los documentos, consideramos que los nueve documentos otorgados por los condes de Monzón y Sancho el Mayor de Navarra se engloban en la categoría de mixtos entre privilegios y cartas que propone Andrés Gambra, y según los documentos, unos se acercan más a las características de los privilegios y otros a las de las $\operatorname{cartas}^{29}$.

\footnotetext{
${ }^{28}$ PILAR BLANCO, Colección diplomática de Fernando I.

${ }^{29}$ GAMBRA, Alfonso VI, I, 364-366. Afirma que el 75 por ciento de las donaciones graciosas del último tercio del siglo XI otorgadas a instituciones eclesiásticas responden al tipo de cartas. Los documentos de Husillos siguen esta pauta y se pueden clasificar como cartas, pero contienen elementos característicos de los privilegios. De ahí que estemos ante documentos mixtos o cartasprivilegios 364-366)
} 


\section{LA ABADÍA DE SANTA MARÍA DE HUSILLOS: ESTUDIO Y COLECCIÓN \\ DOCUMENTAL $(904-1608)$}

Así en primer lugar hay que resaltar que ningún documento contiene preámbulo, seña de identidad de los privilegios, pero vemos que algunos documentos tienen una invocación verbal excesivamente larga y con alusiones teológicas propias de los privilegios.

Por otra parte vemos que ningún documento, en especial las donaciones, contiene una fórmula típica de las cartas como es la expresión: "placuit nobis" o "euenit nobis". Pero también es de destacar la estructura concisa y breve que presentan todos los documentos, especialmente las donaciones, y la escasa lista de confirmantes, lo que les aleja de los privilegios.

En fin, vemos cómo en las confirmaciones aparecen insertan notitias o narraciones de contenido histórico características de los privilegios.

\section{Tipos diplomáticos según la naturaza jurídica}

Es a partir del contenido jurídico de los diplomas donde podemos trazar una clasificación de los documentos más lógica ${ }^{30}$. De este modo podemos hacer una tipificación entre donaciones y confirmaciones.

\subsection{Donaciones}

Corresponden a esta categoría los documentos 3, 4, 8, 9 y 10. Todos ellos reciben la denominación de "cartulam" o "testamentum donationis" tras el verbo dispositivo. Introduciendo la data, todos ellos son denominados como "carta donationis".

En cuanto a la motivación, todos ellos corresponden a la categoría de donaciones "pro anima". La naturaleza de lo donado corresponde a villas y lugares del ámbito sur palentino.

El documento 8 es el único que presenta vicissitudo, algo anormal en donaciones "pro anima" a instituciones religiosas.

\subsection{Confirmaciones}

\footnotetext{
${ }^{30}$ Esta observación es similar a la que hacen Pilar Blanco, Andrés Gambra e Irene Ruiz en sus respectivos estudios.
} 
Corresponden a esta categoría los documentos 5, 6, 7 y $7^{\prime}$. Utilizan en el dispositivo, que se inserta en el relato, el verbo "confirmauerunt" en el documento 6; “corroborarunt" en el 7; y "confirmauerunt et corroborarunt" en el 7'. El documento 5 no presenta denominación de su naturaleza jurídica en el relato.

En cuanto a la denominación en la fórmula precedente a la data, en los documentos 5, 7 y 7' es idéntica: “donationis et confirmationis". El documento 6 presenta la denominación "donationis". Dicho quedó anteriormente como los sucesivos traslados del que fue objeto el supuesto original tuvo como consecuencia que finalmente se omitiera "confirmationis".

En cuanto a la naturaleza de las confirmaciones, el documento 5 se trata de la confirmación de un privilegio por el que se determina el marco territorial de Santa María de Husillos. El documento 6 corresponde a una confirmación de las donaciones recibidas anteriormente por Santa María de Husillos. El documento 7 es una confirmación de las propiedades primitivas y de las donaciones recibidas.

Del documento $7^{\prime}$ nada diremos al tratarse de una copia simple del 7.

\subsubsection{Suscripción confirmativa}

Fue práctica común entre las instituciones eclesiásticas, que en la Alta Edad Media acapararon la mayor parte de las donaciones de reyes y señores, presentar a cada nuevo rey los privilegios otorgados por reyes anteriores para que, suscribiéndolos, renovaran su fuerza y validez legal. Así la donación original se convertía, tras la suscripción, en una modalidad de privilegio de confirmación.

La forma en que se realizaron estas confirmaciones reales fue sufriendo cambios a través del tiempo. A las confirmaciones realizadas entre los siglos VIII y fines del XII, se las puede denominar suscripciones confirmativas ${ }^{31}$. En el documento 6 se inserta una suscripción confirmativa que fue introducida, en el supuesto original, por el rey Alfonso VII “El Emperador”:

\footnotetext{
${ }^{31}$ MARÍN-RUIZ ASENCIO, Paleografia y diplomática, 599. La etapa de las suscripciones confirmativas abarca hasta Alfonso VII.- FLORIANO CUMBREÑO, Paleografia y diplomática, 236 y 237. Establece como primera etapa en la evolución de la confirmación, la de la suscripción confirmativa, que abarcaría desde el siglo VIII al XII. Similares conclusiones se observan en SÁNCHEZ BELDA, La confirmación de documentos, 6-9.
} 
"Ego, Alfonsus, Dei gratia Hispaniae rex, confirmo una cum coniuge mea, regina domina Berengaria, illos testamentos hereditatibus que supra nominati sunt, quas dederunt comites et reges et regine ad Sanctam Mariam de Fusellis et hereditatibus que sunt nominate in hoc testamento nostra carta siue voluntate, abbatis et clericorum ibidem morantium. Petrus Lopez, comes, confirmat. Gundisaluus comes, conf. Gutierre Fernandez, conf. Didaci Munniz, conf. Lopo Lopez, confirmo. Martinus, regis capellanus, per manus domini Bernardi, regis cancellario, scripsit".

Reilly afirma que según el manuscrito 705 de la Biblioteca Nacional, está datada en el 27 de septiembre de 1149, aunque claramente se observa que no hay ninguna data que haga referencia a dicha suscripción ${ }^{32}$.

Así aunque no presenta data, una serie de elementos ayudan a definirla. El hecho de que Alfonso VII casara con Berenguela de Barcelona en enero de 1128 y fuera coronado emperador el 2 de junio de 1135, nos lleva a pensar que dicha confirmación fue realizada entre 1128 y 1135.

Por otra parte, la suscripción del escriba Martín y la mención del canciller Bernardo, nos ayuda a afinar en este aspecto. Según Reilly ${ }^{33}$, Bernardo aparece en los diplomas de Alfonso VII que él analizó entre 1127 y 1133 . Además afirma que un gran número de documentos certifican que el futuro obispo Martín de Orense fue capellán de Alfonso VII entre 1131 y $1133^{34}$.

De esta manera podemos concluir que la confirmación otorgada por Sancho el Mayor de Navarra escrita por el presbítero Lucino, fue confirmada a su vez por Alfonso VII entre 1131 y 1133.

Respecto a los confirmantes, todos aparecen como tales en numerosos documentos del emperador. Es el caso del conde Petrus Lopez, quien aparece en varios documentos de los primeros años del reinado de Alfonso VII, al igual que el conde Gundisaluus Peláez. De Gutierre Fernández de Castro, señor de Monzón

\footnotetext{
${ }^{32}$ REILLY, Chancery of Alfonso VII of León-Castilla, 243-261.

${ }^{33}$ REILLY, ibid., 254 y 255.

${ }^{34}$ REYLLY, íbid., 254 y 255.
} 
y Castrojeriz, diremos que aún no ostenta el puesto de mayordomo real, indicio que señala los primeros años del nuevo rey. Diego Muñoz será con posterioridad merino en Carrión y mayordomo real, al contrario que Lopo López, quien había sido mayordomo de la reina doña Urraca.

\section{ANÁLISIS PALEOGRÁFICO}

El hecho de que sólo sea un documento el que se ha conservado como ejemplar independiente hace que de su estudio paleográfico no se puedan sacar conclusiones importantes que afecten a la generalidad de los documentos, pero sí que nos pueden ayudar a respaldar las conclusiones derivadas del estudio diplomático e histórico.

El documento a analizar paleográficamente se conserva en el Archivo Histórico Diocesano de Palencia. Tiene unas dimensiones de 289 por 416 milímetros y presenta una buena conservación. El documento fue trasladado el 7 de mayo de 1353. Igualmente fue trasladado al Libro de los Privilegios de Husillos, de donde se trasladó al manuscrito 705 de la Biblioteca Nacional. También se conserva un traslado en la sección de Patronato Eclesiástico del Archivo General de Simancas. Ha sido editado por Jesús San Martín Payo y Julián Gutiérrez Aparicio, y regestado por Justo Pérez de Úrbel.

El documento fue redactado por el notario real Pedro López de Manquillos, que redacta también el documento 4.

Dicho ha quedado cómo este notario pertenecería a la escuela episcopal palentina en la que probablemente uno de sus maestros sería Martín de Palencia. Por ello no es de extrañar que la escritura y el tenor diplomático de este documento presente características similares a las que fueron definidas para los escritos de Martín de Palencia y de los otros notarios de escuela episcopal palentina: Fernando Pérez y Pedro Vicéntez ${ }^{35}$.

\footnotetext{
${ }^{35}$ RUIZ ALBI, Cancillería y colección diplomática de la reina Urraca, 336-337.
} 


\section{LA ABADÍA DE SANTA MARÍA DE HUSILLOS: ESTUDIO Y COLECCIÓN \\ DOCUMENTAL $(904-1608)$}

Respecto a las características de estilo coincidentes, habría que señalar: la construcción de las sanciones: "Quod si aliquis aduersus ... insurgere" y construcción similar de la data con la partícula "noto". A diferencia de Martín de Palencia, no utiliza la fórmula visigótica de inclusión de testigos simbólicos (Citi, Velliti, Anaya, Pelagius). Por otra parte el crismón es muy similar al de los dos documentos otorgados por la reina Urraca redactados por Martín de Palencia.

En relación con las características paleográficas, la escritura visigótica redonda en la que está redactada la escritura, presenta escasas y ocasionales influencias carolinas, algo que no es lógico en un escrito de ya entrado el siglo XII. Entre los rasgos carolinos podemos destacar las letras sobrepuestas para abreviar (en Manquillos), las abreviaciones de uri, nri (con $r$ en vez de $s$ ) y pro con rabo de cerdo. Aparecen ingerencias de la cursiva visigótica como $t$ en foma de beta invertida, rasgo que se prolongó hasta época avanzada en el ámbito portugués y leonés ${ }^{36}$, y utiliza de forma sistemática la $s$ volada visigótica para las terminaciones en -ue y también en -us.

En conclusión, vemos cómo apenas se observan influencias carolinas, lo cual es extraño en un documento de tan avanzado el siglo XII, especialmente el escaso uso de la fórmula de letras sobrepuestas.

Igualmente, observamos que la escritura presenta unas características estilísticas y sobre todo paleográficas acordes a la época y formación del notario que la redactó y que pertenecería a la citada escuela episcopal palentina.

\section{CRÍTICA DIPLOMÁTICA}

Abordaremos la crítica diplomática de forma separada para las donaciones y las confirmaciones.

\section{Donaciones}

${ }^{36}$ AZEVEDO SANTOS, $O$ "beta invertido" em cartas de escrita francesa, 13-15 
Establecemos dos grupos: los números 3, 4 y 9 por una parte; y por otra, los números 8 y 10, que aunque similares al primer grupo, tienen unas características particulares como puede ser la ausencia de deslinde en las villas donadas.

Comenzaremos el análisis del primer grupo, documentos 3, 4 y 9, usando como prototipo el último de ellos, al tratarse del único ejemplar independiente que subsiste. No descartamos que el posible original del diploma 4 también llevara la invocación monogramática, lo mismo que los números 3 y 9 , ya que fue realizado por el notario Pedro López de Manquillos, al igual que el documento 9.

Como ya se dijo anteriormente, el crismón conservado en el documento 9 es el propio de los documentos carolinos en general, y de la primera época de Alfonso VII en particular. La invocación verbal también es idéntica en las tres escrituras, hecho que aboga a favor de la existencia en el trío del crismón.

De la intitulación lo único que cambia es el nombre del otorgante, y en los números 4 y 9 ni eso, pues se trata del mismo otorgante. Sí existe una pequeña variación ortográfica en la condición nobiliaria.

Todas las donaciones son "pro anima" y están realizadas a favor de la abadía de Santa María de Husillos y del abad Raimundo. El formulismo de la dirección varía según los grupos, mas en los documentos 3, 4 y 9 es como si estuvieran copiados entre sí, observándose sólo pequeñas variaciones ortográficas. También la exposición es idéntica en los tres.

En la disposición, como es lógico, el nombre de las villas donadas y sus respectivos deslindes son diferentes, pero la fórmula con la que se anuncia el dispositivo, la forma de especificar con todo detalle la situación de las villas, el vocablo que precede al deslinde y prácticamente todas las variadas apreciaciones que se realizan en las tres escrituras, y en el mismo orden, son iguales en los tres diplomas. Existe un detalle, anterior al acotamiento, que sólo contiene el documento 9: es el título de propiedad. 


\section{LA ABADÍA DE SANTA MARÍA DE HUSILLOS: ESTUDIO Y COLECCIÓN \\ DOCUMENTAL $(904-1608)$}

Continúa la semejanza, o mejor dicho, la igualdad, entre las escrituras 3 y 4 después de terminado el deslinde. Se reiteran formalidades anteriores y se introduce, creemos que con posterioridad, una cláusula como es la situación jurídica de las villas: "cum omni iurisdictione et mixto et mero imperio", fórmula que no aparece en el ejemplar independiente, aunque sí todo lo demás.

La sanción no solamente es prácticamente idéntica en los documentos 3,4 y 9, sino también en los números 8 y 10, que como ya dijimos, forma otro grupo de características muy similares al que en estos momentos estudiamos. Lo mismo sucede con la corroboración, con la forma en que se expresa la data y con la suscripción del donante. Únicamente el documento 8 contiene distintas suscripciones, tanto de confirmantes como de testigos, diferentes a los otros ocho diplomas aquí estudiados. La causa de esta diferencia será razonada en su momento.

En realidad, la diferencia más importante entre los dos grupos estriba en que una vez realizadas las donaciones, en los diplomas 8 y 10 , no se realiza el acotamiento de las villas, deslinde que se realiza con toda meticulosidad en las escrituras 3, 4 y 9. Existen, además, otros pequeños detalles, la mayoría de ellos nimios, como por ejemplo, en el documento 8, al ser tres los otorgantes, en muchas ocasiones se habla en plural. También algunas precisiones un tanto extrañas, que parecen introducidas con posterioridad, como la coletilla expresada únicamente en el número 10, en que se titula al abad Raimundo "cardinali Sancte Crucis", o la rebaja de las penas materiales que la escritura 9 hace en la sanción, pasando de las consabidas cien libras de oro purísimo a veinte, razón, ésta última, que tiene su explicación y que apuntaremos en su momento.

\section{Confirmaciones}

Del grupo formado por los documentos 5, 6, 7 y $7^{\prime}$ diremos, en primer lugar, que la similitud entre los documentos 7 y $7^{\prime}$ puede llevar a confusión. La diferencia, en principio, parece estar en pequeñas confusiones cometidas siempre en el número 7'. Así por ejemplo se dice de Raimundo: “abbas et episcopus”, mientras en el resto de documentos solamente se le nombra como abad. Estamos seguros 
que la abreviatura del pronombre "ipsum", que en el diploma 7 va inmediatamente después de "abbas", se trascribió como "episcopus". Otra diferencia, esta apreciable, es que dice del rey Sancho El Mayor de Navarra: “venit rex Santius de Pampilona cum sua mulier, illa regina donna Ximena". La reina doña Jimera era madre, y no esposa, de Sancho el Mayor, y así se recoge en el documento 7. Estos ejemplos son ilustrativos, aunque existen otros de menor importancia, de que siempre la equivocación se comete en el número $7^{\prime}$. Quizá la mayor diferencia entre ambos estriba en que el verbo usado en el dispositivo: del documento 7 utiliza "qui aedificauerunt monasterium", mientras que el 7' emplea "qui confirmarunt monasterium".

Por todo ello, llegamos a la conclusión de que el documento $7^{\prime}$ es una copia simple del 7, tal vez coetánea, y que, como en otros casos, se trasladó también al Libro de los Privilegios de Husillos.

Por todo lo anterior, la crítica la realizaremos sobre los documentos 5, 6 y 7. Ya se comentó anteriormente la estructura del tenor extremadamente compleja que presentan estos documentos. Dos de ellos, el 5 y el 7, tienen idéntica y ampulosa invocación trinitaria de tipo deprecativo, y los tres, una extensa dirección.

En este grupo de escrituras el acto central del texto consiste en un relato de acontecimientos que, supuestamente, habían sucedido. Decimos supuestamente porque en la fecha señalada por los tres documentos, 17 de septiembre de 950, nada de lo narrado había pasado. Su verdadera función consiste en dar justificación a un acto jurídico. En dos de ellos se trata de dejar perfectamente claro una relación directa de sucesión entre los condes de Monzón y el rey Sancho III el Mayor de Navarra. En el otro, el número 5, se quiere dejar constancia de cómo, desde muy antiguo, los límites de las propiedades de Santa María de Husillos estaban perfectamente definidos, aunque un deslinde tan meticuloso y extenso no es propio de mediados del siglo $\mathrm{X}$.

No faltan las contradicciones con el grupo de las donaciones, pues en estos tres, que ahora son objeto de crítica y que llevan como fecha 17 de septiembre de 950, 
aparecen dentro del patrimonio de Santa María de Husillos las villas de Pajarejos y Pajares, propiedades que en realidad no fueron donadas, según se atestigua en sus datas, hasta el 24 de abril de 951 la primera (doc. 8), y el 24 de abril de 955 la segunda (doc. 9).

El otorgante de estas confirmaciones es Sancho el Mayor de Navarra, cuya suscripción sanciona el acto, manifestándose con toda su fuerza en el documento 7 al usar el rey el pronombre personal "ego", reiterado con la locución "memet ipso", según podemos comprobar: "Regnante ego, rex Santius, memet ipso, in Castella et in Pampilona et in Monteson". Pero, obviamente, la suscripción de Sancho el Mayor estaría en clara contradicción con la data de los tres diplomas.

Más extraña resulta la similitud que todos los documentos ofrecen en el protocolo final o escatocolo, ya que están separados por más de diez años el primero del último. Sus datas, según la era hispánica, son respectivamente:

Documento 3: "Facta carta donacionis, noto die sexto calendas mai, in era D CCCC LXXX V' (26 de abril de 947).

Documento 4: "Facta carta donationis, noto die VI calendas mai, in era "D CCCC LXXX VIII” (26 de abril de 952).

Documento 5: "Facta cartula donationis et confirmationis, decimo quinto calendas octobris, in era D CCCC LXXX VIII” (17 de septiembre de 950).

Documento 6: "Facta carta donationis, decimo quinto calendas octobris, in era D CCCC LXXX VIII" (17 de septiembre de 950).

Documentos 7 y 7': "Facta cartula donnationis et confirmationis, decimo quinto calendas octobris, in era D CCCC LXXX VIII” (17 de septiembre de 950).

Documento 8: "Facta cartula donacionis, noto die VIII calendas may, era D CCCC LXXX VIIII" (24 de abril de 951).

Documento 9: "Facta cartula donacionis, nocto die VIII kalendas may, in era D CCCC LXXXX III" (24 de abril de 955).

Documento 10: "Facta carta donnationis, noto die XIIII calendas octobris, in era D CCCC LXXXX V', (18 de septiembre de 957). 
El estudio paleográfico demuestra, sin ningún género de dudas, la incompatibilidad de la data con el tipo de escritura que se desarrolla en el único documento independiente que se conserva. El análisis diplomático respalda dicha incompatibilidad, al igual que el análisis histórico, como se verá más adelante. Pero antes de considerar estas donaciones y confirmaciones como apócrifas, trataremos de comprobar si, tal vez, lo único equivocado es la fecha, pudiendo, así, salvar de la falsedad el acto jurídico contenido en cada una de las escrituras.

Ambrosio de Morales, hace más de cuatro siglos, y Jesús San Martín, mucho más recientemente, pero siguiendo al primero, creyeron resolver el problema aduciendo que los documentos estaban fechados por los años de Cristo, cosa por otro lado incierta, pues se lee, claramente, tanto en el ejemplar independiente como en las copias del Libro de Privilegios, la palabra "era", lo cual quiere decir que se trata de la era hispánica. Además fue la forma oficial de datar en los reinos de Castilla y León hasta el año 1383.

Gracias al estudio paleográfico y de los notarios, podemos deducir con aproximación la data en la que este documento fue redactado. Dicho quedó como Pedro López de Manquillos fue un notario real de la época de Alfonso VII al que debemos situar en el período comprendido entre la fecha en el que aparece confirmando una donación de la reina Urraca a Santa María de Husillos el 28 de mayo de 1114, y la conformación de la cancillería de Alfonso VII con la llegada de Hugo y Giraldo en 1135. Afinando más, esta redacción se debió realizar después de que Alfonso VII confirmara el documento 6, que según se ha expuesto, se produjo entre 1131 y 1133 , pues de otro modo también se habría llevado a confirmar por el rey. Por ello deducimos que el escrito 10 fue realizado entre 1133 y 1135.

Otro de los problemas lo constituye el hecho de que en documentos separados por más de diez años, existan las mismas suscripciones de confirmantes y testigos, perteneciendo, además a notarios diferentes. Además algunos de los confirmantes y testigos aún no habían nacido o contaban muy poca edad. 


\section{LA ABADÍA DE SANTA MARÍA DE HUSILLOS: ESTUDIO Y COLECCIÓN \\ DOCUMENTAL $(904-1608)$}

Precisamente, en las suscripciones de confirmantes, testigos y notarios, podemos hallar la clave para esclarecer parte de los enigmas de estos documentos, observando la diferencia entre las confirmaciones y las donaciones.

En el grupo de las confirmaciones exponemos los confirmantes y testigos dados por el documento 5, al ser la lista más completa:

"Gloriosissima regina domna Ximena conf. Comitissa domna Vrraca conf. Comes Garsias Sanchez conf. Bellit testis. Gunsaluus Diaz conf. Bellid Nunnez conf. Nunno Garsia conf. Rodiricus Gundisalui conf. Anxur Nunnez conf. Pelagius conf. Cid testis."

Respecto a las donaciones, exponemos los confirmantes suministrados por el ejemplar independiente (doc. 9):

$\begin{array}{lll}\text { Gloriosissima regina, confirmat. } & \text { Nunno Garsias, confirmat. } & \text { Comes Gunsalus Sanchez, confirmat } \\ \text { Gunsalus Diaz, confirmat. } & \text { Rodericus Gunsalui, confirmat. } & \text { Comitissa domina Uraca, confirmat. } \\ \text { Bellid Nunez, confirmat. } & \text { Pelagius Garsia, confirmat. } & \text { Domina Ximena, confirmat. } \\ \text { Anxur Nunez, confirmat. } & \text { Frola Diez, confirmat. } & \text { Sancius Uermudez, confirmat. } \\ \text { Petro Cidez de Facinas, testis. } & \text { Guter Perez de Avia, testis. } & \text { Feran Garsias de Fita, testis. }\end{array}$

Así, observamos cómo entre las suscripciones de los confirmantes se hallan los nombres de los personajes citados por el documento 5 .

Algunos de estos mismos actores han sido, a su vez, también hallados suscribiendo como confirmantes en varias escrituras del monasterio de San Pedro de Cardeña:

- 1019, julio, 27. El obispo Pedro dona al monasterio de Cardeña su casa de Burgos con todas las heredades. Entre las suscripciones de los confirmantes aparecen, entre otros: Munnio Guterriz conf. Gundissalbo Didaz conf. Uellite Munnioz conf. Assur Nuniz conf. ${ }^{37}$

${ }^{37}$ Bec. Gót., fol 19r, col. B 
- 1024, abril, 4. El conde de Castilla, García Sánchez, ofrece a su presbítero Julián toda la heredad de San Julián. Entre los testigos aparecen, junto a otros más: Urraca, Christi ancilla, testis. Gundissalbo Didaz testis. Assur Nuniz testis ${ }^{38}$.

- 1028, septiembre, 29. Rexenda se entrega en cuerpo y alma al monasterio de San

Pedro de Cardeña. Entre los testigos que roboran el acto: Rodrico Gundisalbiz testis. Nunno Assuriz testis ${ }^{39}$.

También las escrituras del monasterio de San Salvador de Oña nos proporcionan suscripciones confirmativas de alguno de los citados personajes entre los años 1011 y 1014, en algunas donaciones y compras realizadas por el conde Sancho de Castilla y su mujer Urraca.

Este hallazgo nos permite considerar como históricamente factible la excursión narrada en las confirmaciones:

"Venit rex Santius de Pampilona cum sua matre, illa regina domina Ximena, et illa comitisa domina Euraca et comite Garsia Sanchez; confirmauerunt illas villas pro sua anima de illo comite Sanctius Garciannez a Sanctae Marie”.

Ya fray Justo Pérez de Úrbel en su monografía sobre Sancho III el Mayor de Navarra $^{40}$, y recientemente Gonzalo Martínez Díez ${ }^{41}$, habían apuntado la verosimilitud de tal viaje y la posibilidad de que la corte condal castellana se hubiera trasladado hasta Santa María de Husillos. El cortejo estaría encabezado por el rey Sancho III de Navarra y su esposa doña Mayor; la madre del primero, la reina doña Jimena; la condesa Urraca, madre del joven conde de Castilla García Sánchez, quien también se sumó a la comitiva; además de los caballeros, ya nombrados, Gonzalo Díaz, Bellido Núñez, Ansur Núñez, tal vez hermano del anterior; Nuño García y Rodrigo González, juntamente con el séquito de rigor.

\footnotetext{
${ }^{38}$ Bec. Gót., fol. 31r, col. A

${ }^{39}$ Bec. Gót., fol. $74 \mathrm{v}$, col. A

${ }^{40}$ PÉREZ DE ÚRBEL, Sancho el Mayor de Navarra.

${ }^{41}$ MARTÍNEZ DIEZ, El condado de Castilla, 665.
} 


\section{LA ABADÍA DE SANTA MARÍA DE HUSILLOS: ESTUDIO Y COLECCIÓN \\ DOCUMENTAL (904 - 1608)}

Estos ilustres personajes también confirman las escrituras que se confeccionan durante su visita.

\footnotetext{
Gloriosissima regina, confirmat. Nunno Garsias, confirmat. Comes Gunsalus Sanchez, confirmat

Gunsalus Diaz, confirmat. Rodericus Gunsalui, confirmat. Comitissa domina Uraca, confirmat.

Bellid Nunez, confirmat. Pelagius Garsia, confirmat. Domina Ximena, confirmat.

Anxur Nunez, confirmat.. Frola Diez, confirmat. Sancius Uermudez, confirmat.

Petro Cidez de Facinas, testis. Guter Perez de Avia, testis. $\quad$ Feran Garsias de Fita, testis.
}

Los otorgantes expresan a través del dispositivo que "confirmarunt" y “confirmauerunt" las villas y donaciones por el alma del conde Sancho García.

Si consideramos correcta la narración de los documentos 6 y 7, al menos desde el punto de vista histórico, al primer confirmante de la tercera columna se le habría equivocado el nombre, tratándose en realidad del conde García Sánchez, el joven conde castellano que en el año 1029 fue asesinado en León por los Velas; y con este nombre aparece en los documentos 5, 6 y 7. Pero en el documento 9, único ejemplar independiente que se conserva, dice: “Comes Gunsalus Sanchez", lo que se debe achacar a un descuido o equivocación del notario.

De igual modo, la "gloriosissima regina" es en realidad, según el documento 6, la reina Jimena de Navarra, y no dos personas diferentes, como constata el documento 9 .

Hemos de volver a insistir no obstante en que todos estos personajes son incompatibles con las fechas aportadas por los documentos, que oscilan entre el 26 de abril de 947 y el 18 de septiembre de 957.

Del resto de personajes que aparecen suscribiendo como confirmantes y testigos en las donaciones, y que aún no han sido identificados, estamos en condiciones de hacer algunas matizaciones:

\footnotetext{
Gloriosissima regina, confirmat. Nunno Garsias, confirmat. Comes Gunsalus Sanchez, confirmat Gunsalus Diaz, confirmat. Rodericus Gunsalui, confirmat. Comitissa domina Uraca, confirmat. Bellid Nunez, confirmat. Pelagius Garsia, confirmat. Domina Ximena, confirmat. Anxur Nunez, confirmat.. Frola Diez, confirmat. Sancius Uermudez, confirmat. Petro Cidez de Facinas, testis. Guter Perez de Avia, testis. Feran Garsias de Fita, testis.
} 
Los que aparecen suscribiendo como testigos son, los tres, sin la menor duda, personajes que vivieron entre fines del siglo XI y comienzos del XII, y estuvieron relacionados con la reina doña Urraca. Así lo demuestran dos documentos de esta misma colección documental, en que la mencionada reina hace sendas donaciones a Santa María de Husillos, el día 28 de mayo de $1114^{42}$. Hecho que se repite en otras tres escrituras del monasterio de San Isidro de Dueñas fechadas el 18 de enero de $1114^{43}$, el 22 de mayo de $1115^{44}$ y el 20 de enero de $1116^{45}$, que son también donaciones realizadas por dicha reina.También la catedral palentina conserva una donación de la reina Urraca realizada el 9 de febrero de 1116, en que confirman dos de los consabidos personajes ${ }^{46}$.

Frola Diez podría ser el conde del mismo nombre que, en algunos escritos de la reina Urraca Alfónsez, aparece como conde de Aguilar y conde de León. "Sancius Uermudez" también aparece en las dos donaciones realizadas por la reina doña Urraca a Santa María de Husillos, aunque en una aparece como "Suarius Uermudez"; un conde con este nombre aparece con asiduidad en la documentación de la reina doña Urraca. A "Pelagius Garsias" no hemos conseguido identificarlo; las otras formas con que aparece en los documentos 3, 4 y 7: "Pelagius de Lara", "Pelagius Garsias de Lara" o simplemente "Pelagius", parecen indicar que puede tratarse de un personaje de la época de la reina Urraca y Alfonso VII o tal vez uno anterior al cual se le tergiversó el nombre al ser transcrito. Un Pelayo García aparece en la documentación de la reina Urraca, aunque siempre actúe en ámbito gallego ${ }^{47}$.

Al comprobar la coexistencia de personajes de las dos centurias, se nos plantean algunas lógicas dudas. Ahora, confirmantes que habíamos calificado como pertenecientes al tiempo de Sancho el Mayor, pueden ser personajes de comienzo del XII. Así la insegura confirmación del conde "Gunsalus Sanchez”, podría ser la suscripción de un personaje que durante el reinado de doña Urraca aparece

\footnotetext{
${ }^{42}$ Docs. núm. 18 y 19.

${ }^{43}$ RUIZ ALBI, Cancillería y colección diplomática de la reina Urraca, núm. 55, 443-444.

${ }^{44}$ RUIZ ALBI, ibid., núm. 65, 457-459.

${ }^{45}$ RUIZ ALBI, ibid., núm. 69, 463-464.

${ }^{46}$ RUIZ ALBI, íbid., núm. 71, 465-467.

${ }^{47}$ RUIZ ALBI, ibid., núm. 86, 488-490; y núm. 115, 539-542.
} 


\section{LA ABADÍA DE SANTA MARÍA DE HUSILLOS: ESTUDIO Y COLECCIÓN \\ DOCUMENTAL $(904-1608)$}

algunas veces como dominante en Carrión y otras como dominante en Tariego. Pudiera ser también que "Rodericus Gunsalui" fuera el conde Rodrigo González de Lara, hermano del conde Pedro González de Lara, el valido de la reina Urraca.

Sea como fuere, nos ha resultado imposible reducir todos los personajes a comienzos del siglo XII. Demostrado queda así como en el grupo de las donaciones, entre las suscripciones de confirmantes y testigos existen personajes de inicios del siglo XI y también de principios del XII.

La explicación más probable a estas observaciones es que fue el documento 6 escrito por Lucino, que presenta unas características en el tenor documental propias de la época de Sancho el Mayor de Navarra, incluyendo la fórmula visigótica de testigos simbólicos que ya no ofrecen las donaciones, el que sirvió de modelo y base para la redacción de las demás confirmaciones y de las donaciones. Este fue el único documento que Alfonso VII confirmó, de lo que se desprende que solamente existía éste en el momento de la confirmación. Por ello consideramos que es un privilegio de confirmación otorgado por Sancho el Mayor a su paso por el condado de Monzón entre los años 1023 y $1024^{48}$, con el fin de revitalizar el monasterio de Santa María de Husillos, realizado a partir de las informaciones de los testigos locales sobre los derechos y propiedades otorgadas por los condes Ansúrez de Monzón. Su procedimiento de realización sería similar al utilizado por los francos en la elaboración de los reescritos, y que según Floriano Cumbreño también se dio en la Hispania visigoda, de ahí que no es extraño que también hubiera arraigado en la cancillería real pamplonesa. Así en el documento 6, al final del relato se dice: "et fuerunt ibi rex, testes et fabuladores, qui dixerunt veritatem" 49 . En el intento por contextualizar el relato con los condes de Monzón, se dató el 17 de septiembre de 950.

\footnotetext{
${ }^{48}$ MARTÍNEZ DÍEZ, Sancho III el Mayor, 119.

${ }^{49}$ Por este procedimiento, la persona que había perdido un privilegio, sobre todo si éste le garantizaba una posesión, se presentaba ante una especie de junta formada por los importantes del lugar y presentaba una reclamación en tal sentido. En la audiencia eran consultados testigos y conocedores de la existencia de tales derechos, y si los testimonios ratificaban la versión del solicitante, tras una serie de requisitos, el señor extendía un nuevo documento para sustituir el desaparecido. Esta costumbre tuvo influencia en la Hispania visigoda, y fue recogida en la Ley de Partidas (FLORIANO CUMBREÑO, Paleografía y diplomática, 245-246).
} 
Efectivamente, las donaciones presentan unas características en el tenor diplomático propias de comienzos del siglo XII. Por otra parte, el análisis paleográfico del documento 9 indica claramente que se redactó a principios del siglo XII. A todo ello hay que añadir las conclusiones extraídas del estudio de los notarios que realizaron los documentos. Dicho quedó cómo dos de los notarios de las donaciones se enmarcaban dentro del período inicial del reinado de Alfonso VII, aunque varios de los confirmantes que aparecen en éstos puedan enmarcarse en el de Urraca I. El hecho de que la suscripción confirmativa del documento 6 corresponda a Alfonso VII, y de que Ruiz Albi no haya identificado a ninguno de estos notarios como actuantes en la época de doña Urraca, refuerza la hipótesis de que corresponden a la primera época de Alfonso VII.

Probablemente, sintiendo la necesidad de poseer más documentos justificativos de sus propiedades y derechos, Santa María de Husillos procedería a realizar dichas confirmaciones y donaciones falsas con el concurso de los notarios reales, dándolas una data aproximada a la del documento 6 , aunque no tendrían en cuenta el detalle comentado en relación a Pajares y Pajarejos. A las suscripciones de los confirmantes y testigos se les sumaron las de los personajes de comienzos del siglo XII.

Ya hemos apuntado que de los nueve instrumentos, el único que tiene distintas suscripciones de confirmantes y testigos es el número 8. Fray Justo Pérez de Úrbel advirtió que en él aparecen como visores una serie de personajes que se muestran también, como confirmantes, en una donación original del reinado de Alfonso VI, fechada el 28 de mayo de 1107, perteneciente a este mismo monasterio de Santa María de Husillos (doc. 16). Nosotros vamos más allá: el documento en que Fernando, Gonzalo y Nuño Ansúrez, condes de Monzón, donan Pajarejos, cerca de Becerril, a Santa María de Husillos (doc. 8) está copiado de la escritura en que Roi Gutiérrez y su mujer, doña Andrequina, donan el lugar de Pozuelos de Amianos a Santa María de Husillos y a su abad Poncio Guitardo (doc. 16). Solamente cambia, como es lógico, el nombre de los otorgantes, el del destinatario, lo donado y la data. Hasta parte de los visores que se han colocado 


\section{LA ABADÍA DE SANTA MARÍA DE HUSILLOS: ESTUDIO Y COLECCIÓN \\ DOCUMENTAL $(904-1608)$}

son los mismos, y la forma en que se expresa el escriba, algo poco habitual, es idéntica.

Sería lógico pensar que fue el documento 16 el que se realizó usando como matriz el documento 8, pero algunos indicios nos sugieren que fue a la inversa. En primer lugar está la lista de visores, término, este último, usado en el documento 16, pues en ninguna de las donaciones de los condes de Monzón aparece tal expresión; el cargo de uno de ellos, "merino maiore", indica que tal nómina no está desarrollada a principios del siglo XII.

Otro detalle a tener en cuenta son las penas económicas estipuladas por la sanción. Todos los documentos del grupo (docs. 3, 4, 8, 9 y 10) utilizan idéntica fórmula para la sanción y contemplan exactas penas en metálico: “centum libras purissimi auri”; solamente el diploma nueve se aparta de tal cantidad, sustituyéndose por "libras XX purissimi auri"; la misma sanción recogida por la escritura $16 \mathrm{y}$ expresada, también, anteponiendo el sustantivo al cardinal.

Algo parecido ocurre con la contraprestación económica recibida por la donación o vicissitudo. Ninguno de los otros ocho documentos la contiene; únicamente en el 8 es precisada, curiosamente, en la misma cantidad que en el documento 16: "XL marchas argenti purissimi",50.

En un principio consideramos que tal vez en el documento 8 los visores fueran añadidos años después, en un copia realizada con posterioridad a la mitad del siglo XIII y con anterioridad al 7 de mayo de 1353, mas todas las razones apuntadas anteriormente, a las que hemos de añadir las propias de todos los documentos de los condes de Monzón, nos hace considerar al documento 8 como una burda copia del 16 .

Utilizamos el apelativo burda porque mal eligieron el documento que les sirvió de matriz para realizar la falsificación. Efectivamente, el documento 16 expresa en su data:

${ }^{50}$ En realidad se trata de una venta encubierta con la estructura de una donación. 
"Facta carta donacionis noto die. $V$. kalendas iunii, era $M C X L V$, et nos, auanditos Roy Guterez et dona Andrequina, qui hanc cartam fieri iussimus totamentis intencione. Reinante rex Adefonsus cum uxore sua dona Constancia in Toleto et in Castella".

Aunque la escritura está desgastada en ambos márgenes, esta parte no presenta problemas para su lectura. Del nombre de la reina se lee "Cos", lo cual indica que se trata de la reina Constanza. Por ello existe una evidente contradicción, ya que en el 28 de mayo de 1107, la reina Costanza de Chalon, hija de Roberto de Borgoña y nieta de Roberto II el Piadoso de Francia, que contrajo matrimonio con Alfonso VI en el año 1080, hacía más de una década que había fallecido (1093).

Hemos tratado, apurando todas las posibilidades, de reducir la data a la era $\mathrm{M}$ CXIV, imaginando que la "L" de la data sea en realidad una "I", cosa por otra parte casi imposible, pues los notarios para poner "IV" hubieran puesto "IIII", obteniendo así la fecha 1076; pero por entonces, Alfonso VI estaba casado con su primera esposa Inés, con quien contrajo matrimonio en 1074 y de la que se divorció en 1077.

De los otorgantes de la donación, Roy Gutiérrez y su esposa, doña Andrequina, poco podemos decir, salvo que en una de las anotaciones que hay en el dorso se dice de él que era conde.

El abad Poncio Guitardo, destinatario juntamente con Santa María de Husillos de la donación, aparece con la misma dignidad en las dos escrituras otorgadas por la reina doña Urraca en 1114 (docs. 16 y 17).

El resto de personajes que aparecen suscribiendo la donación después del rey, nos pueden indicar la posible fecha del documento:

"Alvar Nunnez alferez. Gonsaluo Royz mayordomo regis. Garcia Roiz merino maiore. [...] ]ez electus in Palencia". 


\section{LA ABADÍA DE SANTA MARÍA DE HUSILLOS: ESTUDIO Y COLECCIÓN \\ DOCUMENTAL $(904-1608)$}

Del último personaje solamente podemos leer las dos últimas letras. En el momento de redacción del Libro de Privilegios de Husillos, finalizado en 1555, el documento debía de hallarse en mejor estado, ya que fue transcrito como Tello Téllez. El documento 9, copia de esta donación de 1107, también pone como electo al obispo Tello Téllez; y el traslado original del documento 9, que fue sacado el 7 de mayo de 1353, insiste que se trata del obispo Tello Téllez. Por ello deducimos fácilmente que dicho obispo es el que aparece en el documento 16.

Tello Téllez (1208-1247) fue elegido obispo de Palencia en 1208 y consagrado en 1212. Entre estos años podríamos fijar el "electus in Palencia" y buscar los cargos reales.

Éstos aparecen en varios documentos de la catedral de Palencia; en uno, dado el 6 de mayo de $1209^{51}$, después de la familia real, se dice:

"Domno Tellio, Palentine ecclesie electo. Aluaro Nunez, alfieret domini regis. Gondissaluo Roderici, mayordomo. Garsia Roderici Bartu, merino maiore”.

El mayordomo real Gonzalo Royz o Roderici, es el mismo personaje que a finales del siglo XII y comienzos del XIII aparece, con inusitada frecuencia, en la documentación de Santa María de Benevívere ${ }^{52}$ y de la catedral de Palencia como mayordomo real y tenente de Monzón.

El resto de personajes pertenecen a la abadía de Santa María de Husillos, y como no disponemos de más documentos de la época, poco podemos decir de ellos:

"A lo qual fuerunt visores: Petro Martinez capiscol de Fusellis. Petro Royz [...]ez. Petro Petrez. Don Florente el freyre. Don Uidal el abate. Dominico Moro".

\footnotetext{
${ }^{51}$ ABAJO MARTíN, Documentación de la Catedral de Palencia, 247-249, núm. 125. Rodrigo González y su esposa, María Peláez, donan a la sede episcopal palentina los derechos que poseían en las iglesias de Villaverde y Belmonte.

${ }^{52}$ L. FERNÁNDEZ, Colección Diplomática de la abadía de Santa María de Benevivere, 34-39. Aparece como tenente de Monzón. Diversas personas venden ciertas horas o partes del día en varios molinos al monasterio de Benevívere. Suscribe como tenente de Monzón..
} 
Solamente hallamos un escollo a la hora de valorar este documento como redactado entre 1208 y 1212, en concordancia con el obispo Tello Téllez. Se trata del hecho de que el tipo de escritura es visigótica redonda con influencia carolina, siendo muy similar a la del diploma 9. Obviamente, no es posible que un documento de esta época esté redactado en visigótica redonda, ya que en esta época la carolina está en su máximo apogeo. La explicación a este hecho está posiblemente en que el falsario, siendo consciente que la data del documento no se correspondía con el tipo de escritura del momento, utilizó como modelo de escritura un ejemplar de las donaciones de los condes de Mozón, posiblemente el documento 9 .

Con todo, creemos haber demostrado la falsedad de los documentos 8 y 16 . La primera de ellas, que es en este momento la que nos interesa, creemos que se gestó en alguna reclamación, desarrollando como escritura independiente la mención que se hace de tal donación en el documento 6 .

\section{CONCLUSIONES}

A raíz de la estancia de Sancho el Mayor de Navarra en el condado de Monzón, y con el fin de revitalizar el monasterio, se expidió un diploma que confirmaba las antiguas posesiones de Santa María de Husillos otorgadas por los condes de Monzón y la reina Teresa Ansúrez de León, enumeradas en forma de relato. Además nn éste último se trataba de vincular a la familia de los Banû-Ansur, constructores de la abadía y señores del condado de Monzón, con la casa condal castellana, cuyos intereses eran en ese momento los del rey Sancho III. En un intento por contextualizar las donaciones relatadas con los condes de Monzón, se dató el documento el 17 de septiembre de 950, fecha que no concuerda con los condes otorgantes de dichas donaciones.

Este diploma fue confirmado por Alfonso VII entre 1131 y 1133, y a partir de éste fueron realizadas las falsas donaciones de los condes de Monzón y las falsas confirmaciones de Sancho el Mayor de dichas donaciones, además del coto concedido por dichos condes; las donaciones probablemente entre 1133 y 1135 , año este último en el que se consolida la cancillería de Alfonso VII con los 


\section{LA ABADÍA DE SANTA MARÍA DE HUSILLOS: ESTUDIO Y COLECCIÓN \\ DOCUMENTAL $(904-1608)$}

maestros Hugo y Giraldo; las confirmaciones, bien entre estos años o bien más tarde, ya que no aparece ninguno de los notarios reales de la primera época de Alfonso VII. No obstante el documento 5 se redactaría más tardíamente que el 7 , ya que los límites del coto son más amplios que los establecidos en el documento 7. En concordancia con la data del diploma a partir del cual se redactaron los falsos, éstos se dataron entre los años 947 y 957.

Los documentos estudiados habría que contextualizarlos con lo que se ha definido como época dorada de falsificaciones e interpolaciones de documentos, auspiciada por el movimiento cluniacense ${ }^{53}$. Así si tenemos en cuenta el verdadero significado de la palabra auténtico, cuando se aplica a un documento, no será calificativo aplicable a ninguno de los nueve documentos, ya que en ninguno el otorgante puede haber redactado el documento en la fecha que se expresa en el mismo. Por lo tanto, todos ellos son falsos.

Otra gran cantidad de pruebas e indicios corroboran lo expresado, como puede ser el deslinde que se hace de algunas villas donadas. Tan extensa y minuciosa descripción de límites, caminos y poblados, no concuerda con la escasez de población existente en la zona a mediados del siglo $\mathrm{X}^{54}$.

Además, en el caso de las donaciones, algunas coletillas demuestran que han sido interpolados, como sería el caso del documento 11, que llama al abad Raimundo cardenal de la Santa Cruz; o la ya apuntada, cuando al hacer referencia a la jurisdicción de las villas, se dice "et mixto et mero imperio" (doc. 4); o la muy curiosa, pues es cierta, cuando en el documento 7, al referirse a la condición nobiliaria de Fernando Ansúrez, expresa: "qui erat comes in Monteson qui in Pennafiele". Estas adicciones, nunca malintencionadas, junto con ciertas expresiones romanceadas, se realizaron muy posiblemente al ser trasladados al

\footnotetext{
${ }^{53}$ Así lo afirma Ruiz Asencio en el prólogo de la Colección diplomática de los condes de Castilla de Manuel Zabalza Duque (ZABALZA, Colección diplomática de los condes de Castilla, 9-10).

${ }^{54}$ RUIZ ASENCIO, Documentos y códices altomedievales de San Román de Entrepeñas, 21-22. Afirma que la interpolación de límites aparece frecuentemente en las copias realizadas en los siglos XII e inicios del XIII de documentos más antiguos (X y XI), en los que generalmente suele mencionarse solamente el nombre de la villa donada o vendida sin expresar los linderos con las fincas vecinas.
} 
Libro de los Privilegios de Husillos. Por todo lo expuesto, además de ser falsos, sufren interpolaciones.

A pesar de tratarse de documentos falsos, no se adivina en ninguno de ellos una clara intención de mentir. Es más, lo narrado en alguno de ellos, con matizaciones, es cierto históricamente.

Existe controversia entre los diplomatistas clásicos sobre los documentos falsos. Floriano Cumbreño reconoce dos tipos de falsos: los diplomáticamente falsos, y los totalmente falsos (en lo diplomático y en lo histórico). Paoli, siguiendo a Mabillon y Muratori, distingue tres categorías de falsos: "ex caducitate", cuando se hace un falso con la intención de sustituir al original por deterioro o pérdida; "ex iactura", cuando el documento se rehace teniendo como fuente el recuerdo de otro perdido, cuyo contenido global se trata de reproducir con más o menos exactitud; y "ex dolo malo", cuando el documento es inventado en su totalidad, aunque finalmente afirme que todos los falsos, independientemente de la voluntad que hubo en su redacción, se pueden considerar como "ex dolo malo".

Por todo ello podemos considerar todos los documentos analizados dentro de la categoría de falsos diplomáticamente de Floriano, y de falsos "ex iactura" de Mabillon. 
LA ABADÍA DE SANTA MARÍA DE HUSILLOS: ESTUDIO Y COLECCIÓN DOCUMENTAL (904 - 1608)

4

COLECCIÓN DOCUMENTAL 
DAVID MARCOS DIEZ 
DAVID MARCOS DIEZ 
Utilizamos como modelo las elaboradas por José María Fernández Catón y José Manuel Ruiz Asencio, y publicadas en la Colección documental del Archivo de la Catedral de León (775-1230), III (986-1031), León 1987, XX-XXXIV.

\section{Normas de Edición}

\section{Número}

Los documentos se inician con un número correlativo en negrita en el centro, utilizando para su ordenación un criterio cronológico.

\section{Fecha}

En línea aparte al regesto se indica la fecha, compuesta por año, mes, día del mes, día de la semana y data tópica, siempre y cuando aparezcan en el documento. Si el documento no lleva fecha explícita, se reconstruye a partir de los datos que puedan aparecer en el diploma. La fecha reconstruida se expresa entre corchetes. Si aparece sólo el año, se sitúa al final de los documentos de dicho año. Si se ofrece una horquilla de dos fechas, se sitúa en la última. Si la fecha se ha tenido que reconstruir o se han presentado problemas como la falta de coincidencia entre el día del mes y de la semana, sincronismos erróneos, etc., se indican tras el apartado de las citas bibliográficas.

\section{Regesto}

Se ha tratado de hacer un regesto amplio de los documentos, incluyéndose siempre el autor, destinatario, y acto jurídico central. Todos los topónimos que aparecen en los regestos se identifican con el nombre actual.

\section{Tradición documental}

Se indica si el documento es original (A) o copia (B, C, D, ...). Las copias se ordenan cronológicamente. A continuación se indica el archivo o biblioteca de procedencia y su signatura.

En los documentos sueltos se indica el soporte y sus dimensiones si se trata de pergamino. Si los documentos se insertan en un códice, no se hace referencia al 
soporte ni dimensiones, ya que se trata sobre ellos en el capítulo del estudio diplomático y paleográfico. Se indica también el tipo de escritura.

Por último se hace relación de los elementos externos de los documentos, como el estado general de conservación, manchas o agujeros que puedan tener, exisncia de sellos e hilos, etc.

No se incluyen las notas archivísticas dorsales.

\section{Referencias bibliográficas}

Se dividen en tres apartados: ediciones, regestos y citas; las obras que aparecen se ordenan por fecha de edición.

\section{Observaciones}

Se pueden incluir comentarios o explicaciones sobre cuestiones varias en torno a datos diplomáticos, paleográficos e históricos.

Texto

Se transcribe el original en caso de que se conserve. Si se publica una copia, se opta siempre por la más antigua. Solamente en un caso hemos preferido una edición de calidad a la copia del documento (Doc. núm. 2). En el documento número 7, y debido a las peculiaridades del documento, se ha optado por ofrecer dos versiones del mismo correspondientes a dos copias del Libro de los Privilegios de Husillos.

El texto latino en los documentos en romance se indica entre comillas.

\section{Aparato crítico}

Separadas del texto por una raya, se incluyen las anotaciones del aparato crítico, correspondiendo a las que hacen referencia a elementos del texto, como tachaduras, correcciones, notas marginales, etc.

\section{Normas de Transcripción}

2.1 Normas sobre la disposición y presentación externa del texto 


\section{Numeración de líneas}

Se indica mediante barra oblícua (/) el salto de línea en los documentos sueltos en pergamino, numerándose de tres en tres.

\section{Numeración de folios}

En los documentos sacados de códices, se indica el salto de folio con barra oblícua (/)

\section{Indicación de las suscripciones en las columnas}

En el caso de que haya varias columnas, se numeran de izquierda a derecha, en una misma altura, y de arriba abajo: $\left(2^{a} \mathrm{col}\right.$. $),\left(3^{a} \mathrm{col}\right.$. $)$, etc. Los saltos de línea dentro de una columna se señalan con punto y guión (.-).

\section{Mención de elementos figurados}

Se señalan entre paréntesis y en cursiva en el lugar exacto donde figuren: (Christus), (Signum). En el caso de los monogramas, se añade además el texto que contenga: (monogramma: VRRACA).

\section{Indicación de lagunas}

Las lagunas en el texto causadas por el deterioro del soporte documental y de las tinta, roturas, etc., se indican mediante corchetes y con puntos suspensivos [...]. Si se conoce el texto perdido, se reconstruye también entre corchetes. Si se dejó intencionadamente un espacio en blanco, se señala: (en blanco).

\section{Interlineado}

Se inserta entre paréntesis angulares $(<>)$ el texto que va entre líneas o en los márgenes.

2.2. Normas sobre elementos ortográficos del texto

\section{Principio general}

Se respeta la grafía original del texto. En el caso de que presente errores claros, se indica mediante un (sic). Las lecturas dudosas van seguidas de un signo de 
interrogación (?). Las cancelaciones, tachaduras, correcciones, etc., se señalan a nota.

\section{Abreviaturas}

Se resuelven todas las abreviaturas, salvo conf. y ts. Cuando solamente aparece la letra inicial de un nombre propio, el resto del nombre se reconstruye entre corchetes.

Empleo de mayúsculas o minúsculas, separación de palabras, acentuación y puntuación

Se siguen los usos modernos, sin tener en cuenta el sistema utilizado por el escriba. 
LA ABADÍA DE SANTA MARÍA DE HUSILLOS: ESTUDIO Y COLECCIÓN DOCUMENTAL (904 - 1608)

\section{II COLECCIÓN DIPLOMÁTICA}


DAVID MARCOS DIEZ 
904, 4-6.

El presbitero Gratón dona a su señor, el [infante] y diácono Gonzalo, hijo del rey Alfonso III, todos los bienes que tiene y los que pueda ganar en el suburbio del castro de Monzón, esto es:

La iglesia llamada Santa María [de Husillos], que fue destruida por los infieles y él había restaurado; unas casas que construyó, una viña que plantó con sus manos y sernas en los lugares de Santa María, en Carejas, en Campo, en Quintana Mediana y en Cisneros, además de diversas cabezas de ganado y ropas.

B. ACL, Libro Tumbo, ff. 347v-348.

ED. SÁEZ, Colección documental de la catedral de León, 28-29, núm. 17.

CIT.- SÁNCHEZ ALBORNOZ, Documentos de Asturias, 348-349.- FLORIANO, Diplomática Astur, II, 338-339.- YÁÑEZ CIFUENTES, El monasterio de Santiago de León, 135, núm. 1.- J. GONZÁLEZ, Siglos de Reconquista, 171.

KARTULAM DONACIONIS QUAM FECIT GRATON DE SUA HEREDITATE ET DE SUO AVERE AD GUNDISALVO DIACHONO.

In Dei nomine. Ego, Graton, presbiter vobis nostro domnitillo domno Gundisalvo diachono, in Domino Deo eterna salutem. Amen. Placuit michi atque convenit, nullus quoquegentis imperio neque suadentis articulo, set sanus et sanamente, integroque consilio, propria et spontanea michi evenit voluntas, ut facerem vobis, meo domnicillo, kartula donationis de omnia quicquid abere, de quantum ganatum abeo in suburbio de kastro quod dicitur Monteson, id est: ecclesia vocabulo Sancte Marie, quod fuit dirupta a paganis et ego, cum Dei iuvamine, restauravi eam, sive et kasas quas ibidem construxi, et vinea quod ibidem manibus meis plantavi, et sernas in locos predictos: ibidem a Sancta Maria, in Karelias; in Campo, ad Quintana Mediana, ad illas fontes, ad illo archo; in Cenisarios, ad illum kastrum; sive res, equas, kavallos, vacas, boves, oves, porcos, vestitum, quantum abeo vel de hodie, cum Dei iubamine, proficare potuero, omnia vobis sit 
concessum, perpetualiter abiturum, tam de hodie quam et post discessum quidem meum. Siquis karta ista donationis vel concesionis mee ad disrumpendum venire conaverit, quod ego vel pars mea non valverimus vindicare, tunc inferat vel inferam, de parte mea partique vestre, adprehendere omnia quod superius resonat duplatum, vobis perhenniter abiturum, et donadio ista in omni robore plenissimam obtineat firmitatem.

Facta kartula donationis nostre II nonas, era $\mathrm{DCCCC}^{\mathrm{a}} \mathrm{XL}^{\mathrm{a}} \mathrm{II}^{\mathrm{a}}$.

Graton presbiter, in hanc kartula donationis quem fieri volvi, manu mea (signum).

( $1^{a}$ col.) Radulfus, abba, ts. Facinus, presbiter, ts. Frankila presbiter ts. David, presbiter, ts. Aurelius, presbiter, ts.

( $2^{a}$ col.) Savaricus diachonus. Petrus diachonus. Ascaricus diaconus. Ranosindus diachonus. Ordonius diachonus.

Severus, diachonus, notuit (signum).

938, mayo, 30. Falso.

Abo Hamor, su mujer Speciosa y Zalama, presbitero y hermano del primero, donan a Santa María de Husillos y a su abad Fernando, en remedio de sus almas y de las de sus padres, su iglesia de Santa María, sita entre Castrillo y Ampudia.

B. APA, $L P H$, f. $7 \mathrm{r}-\mathrm{v}$.

C. AGS, Patronato eclesiástico. Inconexos, leg.159, ff. 15-16. Papel; escr. procesal; buena conservación.

$D$. BN, $m s 705$, ff. $14 \mathrm{v}-15$.

ED. MENÉNDEZ PIDAL, Los orígenes del Español, 29-30, núm. IV. Edita la escritura original, en la actualidad desaparecida. Establece como procedencia: Archivo Capitular de Palencia. Perg., 


\section{LA ABADÍA DE SANTA MARÍA DE HUSILLOS: ESTUDIO Y COLECCIÓN \\ DOCUMENTAL $(904-1608)$}

16-42. (letra visigótica).- SAN MARTÍN PAYO, Las primeras donaciones de los condes de Monzón, 333-334. Duda de la fecha creyendo que se ha corregido, y la data en 936 ó 933, pero ninguna de las dos se corresponde con la que transcribe; pues la era DCCCCLXXVI (976) corresponde al año 938.- IZQUIERDO MISIEGO, La villa de Ampudia, 188, núm. 1 (la data el 30 de mayo de 938).

REG. PÉREZ DE ÚRBEL, Historia del condado de Castilla, III, 1116, núm. 153.

CIT. VIELVA, La antigua abadía de Husillos, 19.- SANCHO PRADILLA, La abadía de Husillos, 293.- GARCÍA GUINEA, El arte románico en Palencia, 296-297.- ALDEA-MARÍNVIVES, DHEE, III, 1578.- J. GONZÁLEZ, Siglos de Reconquista, 171.

Se sigue la transcripción que realizó Menédez Pidal. En las partes del documento que éste no pudo transcribir, se sigue el Libro de los Privilegios de Husillos, transcribiéndose entre corchetes.

La estructura diplomática del documento, similar a la de las donaciones de los condes de Monzón, denotan que fue redactado a principios del siglo XII, en consonancia con los apócrifos de los condes de Monzón. En efecto, estamos ante una carta cuyo asunto jurídico es una donación "pro anima", que presenta una estructura simple que comienza por una invocación de reducida extensión, seguida de una fórmula de notificación similar a la que se muestra en las citadas escrituras (Hoc est memoria). El hecho de que no presente características típicas de las cartas altomedievales como es la expresión: "placuit nobis" o "euenit nobis", indica al igual que en los documentos apócrifos de los condes de Monzón, que a inicios del siglo XII esta fórmula se va omitiendo.

Por otra parte, su contenido denota también la imposibilidad de que el documento se redactase en la data que presenta. Así, consigna una serie de lugares (Ampudia, Pedraza, Castrillo, etc) y un nivel de minuciosidad en los deslindes que implica un volumen demográfico impropio del primer tercio del siglo $\mathrm{X}$, cuando la repoblación estaría arrancando en una zona abierta y llana, teniendo en cuenta que Palencia, sede diocesana, estaba semidespoblada; a lo que hay que sumar el hecho de que se le denomine Santa María de Fusillos, y no de Dehesa Brava, acepción que tendría en su época más primitiva. Por otra parte, la cláusula "sine rauso" es sospechosa de interpolación. Al menos, no es factible su uso en un documento del primer tercio del siglo X. También es de destacar la alusión al término "foro", siendo una forma contractual no desarrollada en esta época, y el tono romanceado que adquiere la escritura en ocasiones.

Con todo, consideramos que estamos ante un apócrifo de la época de las donaciones de los Ansúrez (inicios del siglo XII), cuando abundan las acciones falsarias en las escribanías de los monasterios. No obstante, una serie de datos nos hace pensar que estamos ante una rehecho: el dato de Menéndez Pidal sobre el tipo de escritura (visigótica); los nombres propios de los donantes y confirmantes, que denotan un origen mozárabe y cuyo protagonismo en la repoblación de la zona en el siglo X está demostrada; el hecho de que, efectivamente, el 30 de mayo de 938 reinara 
en el reino de León Ramiro II, dato que un escriba del siglo XII tendría ya problemas para consignar.

Así pues, el presente documento es un traslado notarial de mediados del siglo XVI de un rehecho de principios del siglo XII de un documento de 30 de mayo de 938. Quizá en el traslado al Libro de los Privilegios se le añadirían algunas interpolaciones.

A pesar de presentar una datación y una estructura diplomática similar, el presente documento se diferencia de los apócrifos de los condes de Monzón fundamentalmente en cuanto a su génesis.

In nomine Domini [nostri Ihesu Christi, Patris et Filii et Spiritus Sancti]. Hec est memoria qui facimus ego, Abo Hamor, una pariter cum uxor mea, nomine Speciosa, et iermano / meo Zalama, presbiter. Facimus karta sibe testacione spontanea nostra volumtas, pro remedio anime nostre sibe parentorum nostrorum que migrati sunt de hoc seculo a Sancta Maria de Fuselensis $\beta$ et quorum reliquie que ibi recondite sunt et a uobis domnus Fredenandus abba [siue a vobis quomodo post obitum tuum quas ibidem dignus fuerit possideat], nostra ecclesia uocabulo Sancta Maria, que est sita in nostro / termino uel censui nostro, inter Castrello et Fonte Pudeda [cum omnis suis dextris. Damus ea ad possidendum et ad populandum et ad per hauendum] cum sernas pernominatas: una serna que est sub / kareira que uadi de Kastrelo a Fonte Pudeda cum suo pozo et suo prado et fiet se in illa lacona et in illo aroio que discurit de Fonte de Castrello. Et alia terra que est intrata de illo prado, et ipsa $/{ }^{6}$ serna fiet se in kareira que ueni de illas eiras que discurrit ad illo prado. Alia serna que est super illa karreira et ualles et illas costas, que est nominata Boca. Alia terra que est inter illa kareira / que discurrit ad illo poz, et fiet se in kareira que uadi a Petraza [et Auacin. Alia terra sub Petraza quem vadit Fonte Pudeda] et alia super ipsa via, fiet se in illa Boca, [siue alias pro vbi eas poteritis inuenire de nostra parte siue illas que vos poteritis ganare et amplicare terras cultas uel incultas, vineas, pastis, pradis, petras mobiles uel immobiles, aquas aquarorum cum eductibus earum; vna fonte in castello] $/ \rho^{9}$ et una uinea, $\mathrm{II}^{\mathrm{as}}$ ferregines una de una parte et alia de altera, uno orto cum duos pozos, et abet ic una kasa / $\mathrm{II}^{\text {as }}$ ferregines ab ea iazencia tras illo orto, exito per Kastrello, exito per akampo, exito kareira que uadit per illo vale et fiet se in ipsa kareira que uenit de Fonte Pudeda, alio exito que uadi / kareira que discurrit a monte de (...). [Damus et concedimus ea per tale foro quomodo habuerunt nostri abii et bisauii siue parentes nostros, sine rauso, sine homicidio, sine fosaterra, sine parricidio, 
cum exitus, cum monte, cum tantum quantum prestatum est a dominis, habeatis illa ecclesia in temporibus seculorum, ita vt de hodie die et tempore sit de iure nostro abrasa et in iure de Sancta Maria de Fusellensis tradita ad confirmada temporibus seculorum]. Si quis tamen, [que fieri non credo, aliquis homo] contra hunc factum nostrum ad inrumpendum uenerit, [inprimis sedeat excomunicatus et a fide Christi separatus et] $/{ }^{15}$ cum Iuda traditore abea pena in eterna damnatione et insuper redat in kauto aparte de Sancta Maria de Fusellos, II $^{\text {as }}$ libras / aureas [ditrinas? et illa ecclesia dublata in simile tale loco et domnus de case Sancta Maria de Fusellos perpetum habitura per infinita $<$ secula $>$ seculorum, amen]. Facta karta [testamenti ecclesie noto die infra III $^{\circ}$ kalendas iunii, in era DCCCC LXX UI, regnante rex Ranemiro in Legione et in Obedo. Saracino iudice et confirma (signum?). Ego, Abo Hamor, et dulcisima mea Speciosa et iermano meo Zalama, presbiter, in hanc cartam [et tertiam coram? legere audiuimus et de manus / (f.7r) nostras roborauimus].

Abo Abdella conf. Habibi conf. Habhanez conf. Abdeket? conf. Lubla conf. Obeco abba (signum). Adeltarius conf. Luba conf. Scipio conf. Sape Pelaio testis. Ueldi testis. Tuldusi presbiter.

947, abril, 26. Falso.

Gonzalo Ansúrez, conde de Monzón, dona a Santa María de Husillos y a su abad Raimundo, en remedio de su alma y de las de sus padres, la villa de Sahagún el Viejo, cerca de Paredes de Nava, haciendo una detallada delimitación del término.

$B$. APA, $L P H$, ff. $4 \mathrm{v}-5 \mathrm{r}$.

C. AGS, Patronato eclesiástico, Inconexos, leg.159, ff. 11v-12v. Papel; escr. procesal; buena conservación.

D. BN, ms. 705 , ff. $7 \mathrm{v}-8 \mathrm{r}$. 
ED. SAN MARTÍN PAYO, Las primeras donaciones de los condes de Monzón, 319-320.

REG. PÉREZ DE ÚRBEL, Historia del condado de Castilla, III, 1143-1144, núm. 216.- TERESA LEÓN, Paredes de Nava, 30. En una primera cita le data en 985. A continuación le data el 6 de mayo de 947.

CIT. BARÓN FARALDO, Grupos y dominios aristocráticos, 39.

Fecho y sacado fue este dicho traslado de la dicha escritura de donaçion original que de suso va encorporada en la villa de Husillos, a diez y ocho días del mes de nouiembre, año del nasçimiento de nuestro Saluador Ihesu Christo de mil y quinientos y çinquenta y quatro años. Y fueron presentes por testigos a lo ver leer, corregir y conçertar con el original Antonio Mogollón y Pero Manuel, estantes en la dicha villa.

E yo, Santiago Gómez, escriuano público en la dicha villa de Husillos, presente fui con los dichos testigos al corregir y conçertar este dicho traslado con la escritura original donde se sacó. Y del dicho pedimiento y mandamiento del dicho señor alcalde mayor, que aquí firmó su nonbre, lo fize escrevir y escreví y fize aquí mi signo (signo) en testimonio de verdad.

Pero Ruiz de Billoldo (rúbrica). Santiago Gómez (rúbrica).

Christus. In nomine Domini nostri Iesu Christi. Ego, Gundisaluus Ansurez, comite in Montesson, pro redemptione animę meę et parentum meorum, facio cartulam siue testamentum < donationis $>$ ecclesię Sanctę Marię de Fusellis, quam gubernat et regit domnus Raimundus, abbas, de villa Sancti Facundi, circa Parietes de Naua, cum suos terminos et cum domibus, soliis, vineis, terris, pratis, pastis. Istam ante dictam villam cum omnibus supra nominatis dono dictę ecclesie Sancte Marię et vobis Raimundo abbati et sucessoribus vestris, ut habeatis perpetuo cum introitus et exitus et cum omnibus terminis suis, tam populato, quam et heremo, et cum omnibus pertinentiis et directuris, cuius terminus vadit de illo camino qui vadit de Sanct Fayum ad Parietes, incipit in vinea que vocatur de Sancta Maria et per ipsa vineam usque ad agus? de Duio linde la serna sombria de Paredes, et per ipsum valladarum usque ad caminum de Carre Uitrera et per ipsum caminum contra Sanctum Facundum usque ad areas Sancti Facundi, et per inde ad manum dexteram usque ad caminum de la Cruz, et per ipsum caminum ayuso contra Hauum et reberte per unum sendero contra viam que venit de Mazariegos ad Sanctum Facundum, et antea quam accedatur ad dictam carreram que descendit iste sendero contra Nauam et postea reuertitur ad dictam carreram que venit de Mazariegos ad Sanctum Facundum, et per ipsum caminum ayuso contra Mazariegos usque accedatur ad sernam nominatam et per inde sursum in linde la 
antea dicta serna in circuitu eius usque accedere ad sendero del Arlar, et de ipso sendero per arroyum de Pospinom, sursum usque circa fontem de Pospinom et deinde ad manum dexteram per unum sendero per iunctum cum termino del Arlar et per ipsum lindero usque accedere ad caminum de Carre Uitrera et per ipsum caminum contra Sanctum Facundum usque ad sendero de Pospinom et deinde reuertitur per vnum lindero inter Quintanas et terminum de Sancto Facundo usque ad arroyum de las Quintanas et per ipsum arroyum usque ad finem arroyo et deinde ad manum dexteram linde las Quintanas in circuitu usque ad sendero qui venit de Annillo ad Sanctum Facundum et per ipsum lindero usque ad senderuelo quod segregatur a camino qui venit de Paredes ad Sanctum Facundum et per ipsum senderuelo usque ad ante dictum caminum.

Istam antea dictam villam cum omni iurisdictione et mixto et mero imperio, dono dicte ecclesie et vobis Raimundo abbati et successoribus vestris, ut seruiatis domno nostro Ihesu Christo redemptori nostro et beatę Marię matri eius.

Quod si aliquis aduersus hanc cartam ad infringendum temptauerit, indignationem et iram Dei habeat et cum Iuda traditore domini pares penas in eterna damnatione lugeat atque cum Datan et Abiron, quos terra obsoruuit, sit dimersus in profundum inferni et pro ausu temeritatis quantum infringere uoluerit restauret ecclesię uestre et uobis antea dicto Raimundo et successoribus uestris et insuper pecet centum libras purissimi auri, et $(f .4 v)$ semper hec scriptura plenum firmitatis roborem in secula seculorum.

Facta carta donationis noto die sexto kalendas maii, in era DCCCC LXXX' $\mathrm{V}$. Ego, Gunsaluus Ansurez, qui hanc cartam fieri iussi, confirmo. Bellii Nunnez confirmat. Anxur Nunnez confirmat. Nunno Guz confirmat. Pelagius de Lara confirmat. Gloriosissima regina confirmat. Gunsaluus Sanchez comes confirmat. Gunsaluus Diaz confirmat. Petrus Garsias de Fita testis. Comitisa donna Vrraca confirmat. Donna Ximena confirmat. Sancia Bermudez confirmat. Frola Diez de Avila testis. Iohannes de Avila, notarius regis, quod scripsit, signauit. 
950, abril, 26. Falso.

Fernando Ansúrez, conde de Monzón, dona a Santa María de Husillos y a su abad Raimundo, en remedio de su alma y de las de sus padres, la villa de Gutiérrez Álvarez, sita entre Villajimena y el Monte del Rey.

B. APA, $L P H$, f. 5 r-v.

C. AGS, Patronato eclesiástico, Inconexos, leg.159, ff. 12v-13v. Papel; escr. procesal; buena conservación.

D. BN, $m s .705$, f. 8r-v.

E. APA, Caja 152, carp. 1. Papel;2 hojas. (Copia del Libro de los Privilegios de Husillos. $1^{\text {a }}$ mitad siglo XVIII)

ED. SAN MARTÍN PAYO, Las primeras donaciones de los condes de Monzón, 323-324.

REG. PÉREZ DE ÚRBEL, Historia del condado de Castilla, III, 1156-1157, núm. 252.

CIT. BARÓN FARALDO, Grupos y dominios aristocráticos en la Tierra de Campos oriental, 37.

Fecho y sacado fue este dicho traslado de la dicha escritura original de suso encorporada en la villa de Husillos, a diez y nuebe días del mes de nouiembre de mil y quinientos y çinquenta y quatro años. Y fueron presentes por testigos a lo ver, leer, corregir y conçertar con el original, Joán Ruiz Cabeça de Vaca y Gaspar de Vedoya, clérigos, y Pero Manuel, estantes en la dicha villa.

E yo, Santiago Gómez, escriuano público en la dicha villa de Husillos, presente fui a corregir y conçertar el dicho traslado con el original en vno con los dichos testigos. Y del dicho pedimento y mandamiento del dicho señor alcalde mayor, que aquí firmó su nombre, lo fize escreuir y fize aquí mi signo (signo) en testimonio de verdad.

Pero Ruiz de Billoldo (rúbrica). Santiago Gómez (rúbrica).

In nomine Domini nostri Iesu Christi. Ego, Fernandus Ansurez, comite in Monteson, pro redemptione anime meę et parentum meorum, facio cartulam siue testamentum donationis ecclesię Sancte Marie de Fusellis, quam gubernat et regit dominus Raimundus, abbas, de villa Gutierrez Aluarez, que est sita inter montem del Rey et Villa Ximenam, cum suos terminos et cum domos, solios, vineas, terras, pratos, pastos, et cum sua defesa.

Istam antea dictam villam cum omnia supra nominata, dono dictę ecclesię Sancte Marię et vobis Raymundo abbati et successoribus vestris, ut habeat perpetuo cum 
introitus et exitus et cum omnes terminos suos, tam populato quam heremo, et cum omnibus pertinentiis et directuris suis, cuius terminos vadit de Valdeperal supra colem sicud vertuntur aquae usque ad corbam et de recorba supra colem sicud vertuntur aquae usque ad caminum quod vadit de Valdeolmillos a Çarçadillo, et per ipsum caminum inter montem del Rey et montem de villa ante dictam de Guterre Aluarez vsque ad caminum de los Pannos, quod vadit de Astudillo ad ante dictam villam, et transato isto camino de los Pannos, per ipsum ante dictum caminum de Çarçadillo vsque ad caminum quod vadit $(f .5 r)$ de Palentia ad Palacios et Astudillo infra Coronam del abbad et ascendit ad colem, et per ipsum colem sicud vertuntur aquae vsque supra fontem Leh et deinde per ipsum Valde vsque ad caminum quod venit de Villaximena a Hermosilla, deinde per planum ad colem solanum directo de Prado Moral, et de cole solana descendit a prado moral et deinde ascendit directo per colem sombrium usque ad planum et per ipsum planum directo usque ad bocam de supra de Valdeperal.

Istam antea dictam villam cum omni iurisditione et mixtu et mero imperio, dono dicte ecclesie et vobis Raymundo abbati et succesoribus vestris, ut seruiatis domno nostro Iesu Christo redemtori nostro et beate Marię matri eius.

Quod si aliquis aduersus hanc cartam ad infringendum temptauerit, indignationem et iram Dei habeat et cum Iuda traditore Domini pares penas in eterna damnatione lugeat, atque cum Datam et Abiron, quos terra obsoruuit, sit dimersus in profundum inferni, et pro ausu temeritatis quantum infringere voluerit duplicatum restauret ecclesie vestre et vobis ante dicto Raymundo et successoribus vestris et insuper pecet centum libras purissimi auri, et semper haec scriptura plenum obtineat firmitatis roborem ęuo perenni in secula seculorum.

Facta carta donationis noto die VI calendas mai in era DCCCC LXXX $^{0}$ VIII $^{\mathrm{a}}$. Ego, Fernandus Ansurez, qui hanc cartam fieri iussi, confirmo. Gloriosissima rregina confirmat. Comes Gunsaluus Sanchez confirmat. Gunsaluus Diaz confirmat. Petrus Garsias de Fita testis. Comitissa domna Vrraca confirmat. Domna Ximena confirmat. Sancia Bermudez confirmat. Frola Diez de Auila confirmat. Pelagius Garsias de Lara testis.

Ego, Lopez de Manquillos, notarius regis quod scripsit signauit. 
950, septiembre, 17. Falso.

[Sancho III el Mayor de Navarra], junto con la condesa Urraca de Castilla, su madre, la reina Jimena de Navarra, y su cuñado, el conde García Sánchez de Castilla, confirma el coto de Santa María de Husillos, otorgado por Fernando y Gonzalo Ansúrez, condes de Monzón.

$B$. APA, $L P H$, ff. $5 \mathrm{v}-6$ r. En el f. 6 r, en el margen der.: <en el original se pone la data en la era DCCCCXXXVIII en cuyo tiempo reynaba Don Alfonso el Magno, cuya muger era Doña Ximena y en cuyo tiempo vivía Fernán Ansúrez y no en esta era, pues fue degollado antes por Ordoño 2, vease el f. 425 de la executoria de 1777 en la nota>.

C. AGS, Patronato eclesiástico, Inconexos, leg.159, ff. 13v-14r. Papel; escr. procesal; buena conservación.

D. BN, $m s .705$, ff. $8 \mathrm{v}-9 \mathrm{v}$.

E. ARCHV, Salas de lo Civil. Masas (F), Caja 2787-1, ff. 40r-41v. Traslado desde B, aportado como prueba en un pleito fenecido (1774) de la colegiata de Ampudia con el concejo de Husillos por la posesión de ciertas heredades.

ED. SAN MARTÍN PAYO, Las primeras donaciones de los condes de Monzón, 328-329.

REG. PÉREZ DE ÚRBEL, Historia del condado de Castilla, III, 1160-1161, núm. 261.

Fecho y sacado fue este traslado de la dicha escritura original en la villa de Husillos, a diez y nueue días del mes de nouiembre de mil y quinientos y çinquenta y quatro años. Testigos que la vieron corregir, Joán Ruiz Cabeça de Vaca, clérigo, y Gaspar de Vedoya, clérigo notario, y Pero Manuel, estantes en la dicha villa.

E yo, Santiago Gómez, escriuano público en la dicha villa de Husillos, fui presente con los dichos testigos al corregir y conçertar este traslado con el original. Y del dicho pedimento y mandamiento del dicho señor alcalde mayor, que aquí firmó su nombre, lo fize escreuir y fize aquí mi signo (signo) en testimonio de verdad.

Pero Ruiz de Billoldo (rúbrica). Santiago Gómez (rúbrica).

In nomine omnium opificis rerum, creantis et regentis, transcendentis et circumplectentis et circumscripti atque inuisibilis Dei, Patris et Filii et Spiritus Sancti in eternum et vltra cuius regnum in sempiternum corrumpetur neque 
auferetus, cuius nutu principes regnant et tempora mutantur temporibus, per quem cuncta subsis $(f .5 v)$ tunt elementa, cui famulantur vniuersa celestia pariter et terrestria atque mare continentia illius iubante clementia. Igitur in nomine Domini nostri Iesu Christi. Hec est cartula testamenti atque memoria de illos comites qui edificarunt monasterium in Dehesa Braua pro suas animas in honore Sancte Marię virginis et matris Domini nostri Iesu Christi et Sancti Micaelis arcangeli et sanctorum apostolorum Petri et Pauli et sancti Ioannis apostoli et euangelistę et sancti Ioannis Batistę et sancti Martini episcopi et confessoris Christi et sanctorum Fructuosi episcopi et Aguri diaconorum et martirum et sancti Pelagii. Hoc est Fernandus et Gundisaluus Anxurez comites, et vadit terminus eius ex vna parte de illa carrera que venit de Monçon ad Donnas contra Fontes, et per illum montem super de Ronadas super villam Zalama et per planum illum et viam que vadit ad illum oterum quod dicitur Miranda contra Palentiam, et vadit apud Sanctum Facundum ad illum pontonem angustum circa vadum de Quintanilla et deinde per flumen de Carrione, et per illam viam que vadit de Palentia contra Carrionem usque ad viam que vadit de Bezerril contra Monçonem, et per eamdem viam de Bezerril usque ad caminum que venit de Bezerrileios ad Fusellos, et deinde descendit ad caminum que venit de Villaumbrales ad Monçon, et postea venit ad caminum que venit de Ribas contra Fusellos via recta ad Foyum de Andrinos et deinde ad vineam Colubreram et postea ad cotarrum iunctum cum flumine de Carrione. Et hoc de consilio et consensu rectorum et confabulatorum. Facta cartula donationis et confirmationis decimo quinto calendas octobris in era DCCCC $^{\mathrm{e}}$ LXXX $^{\circ}$ VIII $^{\circ}$.

Et quisquis hanc cartulam rumperit uel contravenerit, sexaginta denarios auri componat. Gloriosissima regina domna Ximena conf. Comitissa domna Vrraca conf. Comes Garsias Sanchez conf. Bellit testis. Gunsaluus Diaz conf. Bellid Nunnez conf. Nunno Garsia conf. Rodiricus Gundisalui conf. Anxur Nunnez conf. Pelagius conf. Cid testis. Lucino preste scripsit et signauit Lucina. 


\section{DAVID MARCOS DIEZ}

950, septiembre, 17. Falso.

Sancho III el Mayor de Navarra, junto con la condesa Urraca de Castilla, su madre, la reina Jimena de Navarra, y su cuñado, el conde García Sánchez de Castilla, confirma las donaciones realizadas por los condes de Monzón, la reina Teresa Ansúrez de León, y el rey Ramiro III de León, a Santa María de Husillos, a partir de las noticias dadas por testigos locales. Estas donaciones son: Pajares, Gutiérrez Álvarez, Pajarejos, San Julián y Villaudilla.

Contiene suscripción confirmativa de Alfonso VII y su esposa doña Berenguela.

$B$. APA, $L P H$, f. $6 \mathrm{v}$. En el margen izq.: $<\mathrm{Ojo}$ : adviértase que esta señora doña Teresa es hermana de los condes Ançures, reyna de Leon, casada con el rey don Sancho el Gordo y madre del rey don Ramyro y no muger como diçe la carta de la fundacion de la iglesia, que es falsa. Véase al arzobispo don Rodrigo y los demas cronistas $>$; <confirmacion de estos lugares de el rey don Alonso, año 950>.

C. AGS, Patronato eclesiástico, Inconexos, leg.159, ff. 14v-15r. Papel; escr. procesal; buena conservación.

$D$. BN., ms. 705 , ff. $13 \mathrm{v}-14 \mathrm{v}$.

E. APA, caja 152, carp. 1. Papel;2 hojas. (Copia del Libro de los Privilegios de Husillos. Primera mitad del siglo XVIII).

ED. SAN MARTÍN PAYO, Las primeras donaciones de los condes de Monzón, 330-331.

REG. PÉREZ DE ÚRBEL, Historia del condado de Castilla, III, 1161-1162, núm. 262.

CIT. PÉREZ DE ÚRBEL, Sancho el Mayor, 106-107.- VILLA CALVO, Historia del condado de Monzón, 203.- MARTÍNEZ DÍEZ, El condado de Castilla, 542, 543, 636, 665 y 690. Sitúa el Libro de privilegios de Husillos en el Archivo de la Catedral de Palencia.- MARTÍNEZ DÍEZ, Sancho III el Mayor, 119.

Fecho y sacado fue este traslado de la dicha escritura original en la villa de Husillos, a diez y nueue días del mes de nouiembre de mil y quinientos y cinquenta y quatro años. Testigos que la vieron corregir, Joán Ruiz Cabeça de Vaca, clérigo, y Gaspar de Vedoya, clérigo notario, y Pero Manuel, estantes en la dicha villa. E yo, Santiago Gómez, escrivano público en la dicha villa, fui presente con los dichos testigos a lo corregir y conçertar. Y del dicho pedimento y mandamiento del dicho señor alcalde mayor, que aquí firmó su nombre, lo fize escreuir y fize aquí mi signo (signo) en testimonio de verdad.

Pero Ruiz de Billoldo (rúbrica). Santiago Gómez (rúbrica). 


\section{LA ABADÍA DE SANTA MARÍA DE HUSILLOS: ESTUDIO Y COLECCIÓN \\ DOCUMENTAL $(904-1608)$}

In nomine Domini nostri Iesu Christi. Hec est memoria de illos comites qui dederunt por suas animas a Sancte Marie, matris Domini nostri Iesu Christi, et Sancti Machaeli archangeli et a sanctorum apostolorum Petri et Pauli et Sancti Ioannis apostoli et euangelisti et Sancti Ioani Batiste et Sancti Martini episcopi et confesoris Christi, Sanctorum Fructuosi episcopi, diaconorum et martirum et Sancti Pelagii. Anrricus et Nunio Ansurez dedit suo germano Ferdinando Ansurez, qui erat comite in Monteson, villam de Paiares, cum suas hereditates et suos terminos, et por sua anima dedit villam de Guterre Aluarez dedit Ferdinando Anxures cum sua dehesa et cum suas hereditetes; transitus est Gundisalvo Ansurez, dedit villam de Paiareros cum sua dehesa et suas hereditates; transitus est illo comite Ferdinando Ansurez. Venit sua germana domina Tarasia regina et rex Ramiro, qui erat in Legione, venit a Montesone, dederunt por sua anima villa de Sancti Iuliani et villam de Abaudella, cum suas hereditates et suos terminos pro illo comite Ferdinando Anxuret. Possedit comite Santio Gartianez Castella et Monteson, transitus est. Venit rex Santius de Pampilona cum sua matre, illa regina domina Ximena, et illa comitiva, domina Euraca et comite Garsia Sanchez confirmauerunt illas villas por sua anima de illo comite Sanctius Garciannez a Sanctae Mariae.

Et fuerunt ibi rex, testes et fabulatores qui dixerunt veritatem. Gonsalus Didaz, Bellid Munnoz, Nunius Guterrius, Rodirico Gonsaluez, Ansur Munnoz, confirmarunt ipsas villas et ipsas hereditates pro anima de illo comite Sanctio Garciannez por remedio animae suae a Sanctae Marie.

Facta carta donationis decimo quinto calendas octobris, in era DCCCC LXXX VIII. Regnante rex Santius in Castela et in Pampilona et in Monteson. Licinio prebitero scripsit.

Ego, Alfonsus, Dei gratia Hispaniae rex, confirmo una cum coniuge mea regina domina Berengaria, illos testamentos hereditatibus que supra nominati sunt, quas dederunt comites et reges et regine ad Sanctam Mariam de Fusellis et hereditatibus que sunt nominate in hoc testamento nostra carta sive voluntate abbatis et clericorum ibidem morantium. Petrus Lopez, comes, confirmat. Gundisaluus, comes, conf. Gutierre Fernandez conf. Didaci Munniz conf. Lopo Lopez confirmo. Martines, regis capellanes, per manus domini Bernardi, regis cancellario, scripsit. 


\section{DAVID MARCOS DIEZ}

950, septiembre, 17. Falso.

Sancho III el Mayor de Navarra, junto con la condesa Urraca de Castilla, su madre, la reina Jimena de Navarra, y su cuñado, el conde García Sánchez de Castilla, confirma las donaciones realizadas por los condes de Monzón, la reina Teresa Ansúrez de León, y el rey Ramiro III de León, a Santa María de Husillos, a partir de las noticias dadas por testigos locales. Estas donaciones son: el coto de Santa María de Husillos, el monasterio de San Sebastián de Hérmedes con su coto, Pajares, Corrales, Gutiérrez Álvarez, Pajarejos, San Julián y Villaudilla.

$B$. APA, $L P H$, ff. $7 \mathrm{v}-8 \mathrm{r}$.

$C$. APA, $L P H$, ff. $8 \mathrm{r}-9 \mathrm{r}$.

D. AGS, Patronato eclesiásico, Inconexos, leg.159, ff. 16-17v. Papel; escr. procesal; buena conservación.

E. AGS, Patronato eclesiástico, Inconexos, leg.159, ff. 17v-18v. Papel; escr. procesal; buena conservación.

F. BN, ms. 705, ff. 15r-16r.

G. BN, ms. 705, f. 16r-v.

ED. SAN MARTÍN PAYO, Las primeras donaciones de los condes de Mónzón, 336-337.

CIT. MARTÍNEZ DÍEZ, Sancho III el Mayor, 119.

Fecho y sacado fue este traslado de la dicha escritura original en la villa de Husillos, a diez y nueue días del mes de nouienbre, año del señor de mil y quinientos y çinquenta y quatro años. Testigos que fueron presentes a lo ver, leer, corregir y concertar con el original, Gaspar de Vedoya, clérigo notario, y Joán Ruiz Cabeça de Vaca y Pero Manuel, estantes en la dicha villa.

E yo, Santiago Gómez, escriuano público en la dicha villa, fui presente con los dichos testigos. Y del dicho pedimento y mandamiento del dicho señor alcalde mayor, que aquí firmo su nombre, lo fize escreuir y fize aquí mi signo (signo) en testimonio de verdad.

Pero Ruiz de Billoldo (rúbrica). Santiago Gómez (rúbrica). 


\section{LA ABADÍA DE SANTA MARÍA DE HUSILLOS: ESTUDIO Y COLECCIÓN \\ DOCUMENTAL $(904-1608)$}

La gran importancia del grupo de documentos en el que se contextualiza este documento, hace que se editen las copias $B$ y $C$ a partir del Libro de los Privilegios de Husillos, a pesar de ser casi idénticas.

Fecho y sacado fue este traslado de la dicha escritura original en la villa de Husillos, a diez y nueve días del mes de nouienbre de mil y quinientos y çinquenta y quatro años. Testigos que fueron presentes a lo uer, corregir y conçertar, Joán Ruiz Cabeça de Vaca, clérigo, y Gaspar de Vedoya, clérigo notario, y Pero Manuel, estantes en la dicha villa de Husillos.

E yo, Santiago Gómez, escriuano público en la dicha villa de Husillos, presente fui al ver, leer, corregir y conçertar este dicho traslado en vno con los dichos testigos. Y del dicho pedimento y mandamiento del dicho señor alcalde mayor, que aquí firmó su nombre, lo fiz escreuir y fize aquí mi signo (signo) en testimonio de verdad.

Pero Ruiz de Billoldo (rúbrica). Santiago Gómez (rúbrica).

\section{Columna B}

In nomine omnium opificis, creantis et regentis, transcendentes, circumplectentis et circumscripti atque imbisibilis Dei, Patris silicet, et Filii et Spiritus Sancti regnanti in eternum et ultra, cuius regnum sempiternum que non corrumpetur neque auferetur, cuius nutu principes regnant et tempora mutantur temporibus, per quem cuncta subsistunt elementa, cui famulantur vniuersa, cęlestia pariter et terrestria ac mari continentia illius iuuante clementia. Igitur in nomine Domini nostri Iesu Christi. Hec est cartula testamenti atque memoria de illos comites qui edificauerunt monasterium pro suas animas in honore Sancte Mari virginia, matris Domini nostri Iesu

\section{Columna C}

In nomine omnium opificis rerum, creantis et regentis, transcendentis et circumplectentis et circunscripti atque inuisibilis Dei, Patris, scilicet, et Filii et Spiritu Sancti regnanti in eternam et ultra, cuius regnum regnum (sic) sempiternum non corrumpetur neque auferetur, cuius nutu principes regnant et tempora mutantur temporibus, per quem cuncta sub testum elementa, $(f .8 v)$ cui famulantur vniversa, celestia pariter et terrestria ac mari continentia illius iubante clementia. Igitur in nomine Domini nostri Iesu Christi est cartula testamenti atque memoria de illos comites qui confirmarunt monasterium pro suas animas in honore Sanctę Marię virginis, matris Domini 


\begin{tabular}{|c|c|}
\hline $\begin{array}{l}\text { Christi, et Sancti Michaeli archangeli et } \\
\text { sanctorum anostolorum Petri et Pauli et }\end{array}$ & $\begin{array}{l}\text { nostri Ihesu Christi et Sancti Micaelis } \\
\text { archangeli cum sanctorum apostolorum } \\
\text { Petri et Pauli et Sancti Ioannis apostoli } \\
\text { et evangeliste et Sancti Ioannis Baptiste } \\
\text { et Sancti Martini episcopi et } \\
\text { confessoris Christi, sanctorum Frutuosi } \\
\text { episcopi, diaconorum et martirum et } \\
\text { Sancti Pelagii, hoc est Fredinando } \\
\text { Ansurez comes et Gonsalvo Ansurez } \\
\text { comes. Et vadit terminus eius ex qua } \\
\text { parte usque ad carrera qui venit de } \\
\text { Sancta Maria pro ad Donas, et sic in } \\
\text { illo flumine Carrioni, et sic per eius } \\
\text { monte usque quo descendit ad illa } \\
\text { carrera qui venit de Montson, et sic per } \\
\text { eius via vsque descendit ad ipso } \\
\text { flumine iam dicto et venit ad illa } \\
\text { carrera de Carrione. Iterum construxit } \\
\text { et edificauit Nunno Ansurez, comes, et } \\
\text { Reymanus, abbas et episcopus, } \\
\text { monasterium in } \text { honore } \\
\text { Sabastiani martiris Christi; et vadit eius } \\
\text { terminum usque ad carrera de Canellas } \\
\text { saliario et per ipso pozolo et sic ad illa } \\
\text { et Valdepetroso et ad illo Spino et ad } \\
\text { Valde de Palatios usque ad otero de } \\
\text { Fortunno, et descendit ad illo quadrone } \\
\text { et ad illa carrera de Mesa Mediana et } \\
\text { per valeio de Latrone et pro val de }\end{array}$ \\
\hline
\end{tabular}




\begin{tabular}{|c|c|}
\hline Iaria de Fusellos pro sua anima cum & $\begin{array}{l}\text { terio Sancti Sabastiani ad Sancta Maria } \\
\text { de Fusellos pro sua anima, cum suis } \\
\text { antiquis terminis et cum ipsa villa de } \\
\text { Corrales, cum suis antiquis terminis, et } \\
\text { villa de Paliares, cum suos terminis } \\
\text { antiguos, et villa de Gutierre Aluarez, } \\
\text { cum suas defesas et cum suis antiquis } \\
\text { terminis. Transitus est Gonsaluo } \\
\text { Ansurez. Dedit villam de Paliareios ad } \\
\text { Sanctam Mariam, cum suis antiquis } \\
\text { terminis, pro sus anima. Transitus est } \\
\text { illo comite Ferdinando Ansurez. Venit } \\
\text { sua germana donna Tarasia, regina, et } \\
\text { rex Randimiro, qui erat in Legione, } \\
\text { venit ad Montson. Dederunt por sua } \\
\text { anima villam de Sancti Iuliani et } \\
\text { Villam de Abdella cum suis antiquis } \\
\text { terminis ad Sancta Maria pro illo } \\
\text { comite Ferdenando Ansurez. Possedit } \\
\text { comite Santio Garciannez Castella et } \\
\text { Montson, et transitus est. Venit rex } \\
\text { Santius de Pampilona cum sua mulier, } \\
\text { illa regina donna Ximena, et illa } \\
\text { comitissa donna Eurraca et comite } \\
\text { Garsia Sanchez corroborauerunt et } \\
\text { confirmauerunt illo monasterio Sancti } \\
\text { Sabastiani et illas villas pro sua anima } \\
\text { de illo comite Santius Garciannez a } \\
\text { Sancta Maria, et fuerunt ibi rectores et }\end{array}$ \\
\hline
\end{tabular}




\begin{tabular}{|c|c|}
\hline $\begin{array}{l}\text { Facta cartula donationis et } \\
\text { confirmationis, decimo quinto calendas } \\
\text { octobris in era DCCCCe LXXX }{ }^{\mathrm{o}} \mathrm{VIII}^{\mathrm{a}} \text {, } \\
\text { regnante ego, rex Santius memet ipso, } \\
\text { in Castella et in Pampilona et in } \\
\text { Monteson. } \\
\text { Et quisquis hanc cartulam ad } \\
\text { dirumpendum venerit sexaginta ciclos } \\
\text { auri componat. Bellid Munniz conf. } \\
\text { Nunno Gutierrez conf. Rodrigo } \\
\text { Gonsaluez conf. Ansur Nunnez conf. } \\
\text { Gloriosissima regina domna Ximena } \\
\text { conf. Comitisa domna Vrraca conf. }\end{array}$ & $\begin{array}{l}\text { octobris, in era DCCCC LXXX VIII. } \\
\text { Regnante ego rex Santius memet ipso } \\
\text { in Castella et in Pampilona et in } \\
\text { Montson. } \\
\text { Et quisquis hec cartula ad } \\
\text { disrrumpendum venerit, sexaginta } \\
\text { siclos auri opponat. Gloriosissima } \\
\text { regina donna Ximena confirmat. } \\
\text { Comitisa donna Urraca confirmat. } \\
\text { Comes Garsias Sanchez confirmat. } \\
\text { Gonsalvo Diaz confirmat. Belid } \\
\text { Nunnez confirmat. Nunno Gutierrez } \\
\text { confirmat. Rodrigo (f. 9r) Gonçalez } \\
\text { confirmat. Ansur Nunnez confirmat. } \\
\text { Pelagius, hic testis. Belit hic testis. Cid } \\
\text { hic testis. Licinio, presbitero, scripsit. }\end{array}$ \\
\hline
\end{tabular}

951, abril, 24. Falso.

Fernando, Gonzalo y Nuño Ansúrez, condes de Monzón, donan a Santa María de Husillos y a su abad Raimundo, en remedio de sus almas y de las de sus padres, la villa de Pajarejos, cerca de Becerril. Reciben en confirmación cuarenta marcas de plata pura. conservación. Inserto en traslado sacado en Palencia, a 7 de mayo de 1353. Véase doc. núm. 137. $C$. APA, $L P H$, f. 9r-v. 
D. AGS, Patronato eclesiástico, Inconexos, leg.159, ff.18v-19r. Papel; escr. procesal; buena conservación.

E. BN, ms. 705, ff. 16v-17r.

ED. SAN MARTÍN PAYO, Las primeras donaciones de los condes de Monzón, 342-343.

REG. PÉREZ DE ÚRBEL, Historia del condado de Castilla, III, 164-1165, núm. 270; y 13291330, núm. 670 (traslado de 1391).

CIT. BARÓN FARALDO, Grupos y dominios aristocráticos, 39.

Sub Christi nomine. Ego Fernandus Anxurez et ego Gonsaluus Anxurez et ego Nunius Anxurez, comites de Monteson, pro redempçione animarum nostrarum et parentum nostrorum, facimus cartulam siue testamentum donacionis ecclesie / Sancte Marie de Fusillos et vobis donnus Raymundo, abbas dicte ecclesie, et omnes sucessores vestros, de loco nostro de Paliareios, circa Bezerril, cum monte et defesa et cum domos et soliis, vineys, terris, pratis, ecclesias et introytus et exitus et cum omnes terminos suos, tam popula/to quam et heremo, tali conuentione: ut habeatis omnibus diebus seculi vos et sucessores vestros, ad seruiendum Dominum nostrum saluatorem mundi et beate Maria, mater eius. Hoc facimus pro remissione pecatorum nostrorum. Et ad confirmandam hanc cartulam, dedistis / nobis XL marchas argenti purissimi.

Quod si aliquis aduersus hanc legitimam cartam ad infringendum insurgere tentauerit, inprimis iram Dei et indignacionem habeat, et cum Iuda traditore Domini pares penas in eterna dampnacione lugeat, atque cum Datan $\rho^{9}$ et Abiron, quos terra obsorboyt, sit dimersus in profundum inferni, et pro ausu temerario duplicatum restauret quantum infringere voluerit ecclesie vestre et vobis uel sucesoribus vestris, et pecet libras XX purissimi auri, et in super hac escriptura / plenum obtineat firmitatis roborem euo pereni et secula cuncta.

Facta cartula donaçionis noto die VIII kalendas mai, era DCCCC ${ }^{\mathrm{a}} \mathrm{LXXX}^{\mathrm{a}}$ VIIII ${ }^{\mathrm{a}}$. Et nos, anteadicti comites, hanc cartam fieri iusimus tota mentis intencione. Fueronn visores: Aluar Pérez, ma/yordomo regis. Petrus Nunnez, alferez regis. Garsia Royz, merino maiore. Tello Tellez, electus in Palencia. Petrus Martinez, 
capiscol de Fusellos. Don Florente el abbad. Et ego, Dominico Moro, quod scripsi, signaui commo escriba regis de meo / signo. Dominico Moro.

955, abril, 24. Falso.

Fernando Ansúrez, conde de Monzón, dona a Santa María de Husillos y a su abad Raimundo, en remedio de su alma y de las de sus padres, la villa de Pajares, sita entre Grijota y el río Carrión.

B. AHDP, Ampudia y Abadía de Husillos, Pergaminos, carp. 207-2. Perg., 289 x 416 mm; escr. visigótica redonda; buena conservación.

C. AHDP, Ampudia y Abadía de Husillos, 207-22. Perg., 240 x 480 mm.; escr. precortesana; regular conservación con dos pequeñas roturas, varias manchas de humedad y con la tinta en algunas partes desvaída. Inserto en traslado sacado en Palencia, a 7 de mayo de 1353. Véase doc. núm. 138.

$D$. APA, $L P H$, ff. 9v-10r.

E. AGS, Patronato eclesiástico, Inconexos, leg.159, ff. 19r-20r. Papel; escr. procesal; buena conservación.

$F$. BN, $m s .705$, ff. $17 \mathrm{r}-18 \mathrm{r}$.

ED. SAN MARTÍN PAYO, Las primeras donaciones de los condes de Monzón, 326-327 y 344345.- GUTIÉRREZ APARICIO, Grijota: Pueblo con Historia, 26.

REG. PÉREZ DE ÚRBEL, Historia del condado de Castilla, III, núm. 277, 1168-1169 y núm. 671, 1330-1331 (traslado que no se conserva. Le cataloga como una copia del siglo XII. ACP. Cajón de Husillos).

CIT. BARÓN FARALDO, Grupos y dominios aristocráticos, 38.

(Christus). In nomine Domini nostri Ihesu Christi. Ego, Fernandus Ansurez, comite in Monteson, pro redempcione anime mee et parentum meorum, / facio cartulam siue testamentum donacionis eclessie Sancte Marie de Fusellos, 
quam gubernat et regit domnus Raimundus, abas, de illa mea villa / de Pallares qui est sita inter Griiota et rium de Carrione, cum suos terminos et cum domos, sollos, vineas, terras, pratos, pastos et cum suas helbege $/ 3$ ras, qui sunt in suo termino, et cum illas acennas, quas sunt in dicto termino in rio de Carrione. Istam antedictam villam cum omnia supranominata do/no dicte eclessie Sancte Marie et vobis Raimundo abate, et sucesoribus vestris, ut habeatis perpetuo, cum introitus et exitus et cum omnes terminos suos tam $/^{5}$ populato quam et heremo, et cum omnibus pertenenciis et directuris suis. Qui quidem terminus vadit de illo ponte de domno Guarino per caminum qui / uadit contra Carrionem usque ad caminum qui uenit de Sancta Gadea ad molinos de Uiruiescar, et per ipsum caminum usque ad Sanctam Gadeam, et / de Sancta Gadea contra Griiota per caminum qui uadit de ponte de dono Guarino ad Griiotam usque ad alium caminum qui uenit de Griiota ad portam / antiquam de Paiares, et per ipsum caminum contra Paiares usque ad caminum qui uenit de pontone de Griiota ad Palenciam, et per ipsum caminum con ${ }^{9}$ tra el dictum pontonem usque ad caminum qui uenit de Uilla Martin ad uillam de Paliares, et per ipsum caminum contra Uilla Martín usque ad arroium / qui uenit de la Naua, et per ipsum arroium contra Palenciam usque ad alium caminum qui uenit de Uilla Martin ad acennas de Paliares, et per ipsum caminum usque / ad helbegueram de Pallares et de ipsam helbeguera per caminum qui uadit ad Sanctum Romanum usque ad eglesiam de Sancto Romano, et de ipsa eglesia ad rrium de $\mathrm{Ca} /{ }^{12}$ rrione et per ipsum rrium usque ad acennas de Pallares, et de ipsas acennas per ipsum rrium usque ad pontem de dono Guarrino. Hoc facio pro rremisione meo/rum pecatorum et ut uos antea dictus Raimundus abas et sucesores vestros seruiatis domino Ihesu Christo redemptore nostro et beate Marie matre eius.

Quod / si aliquis aduersus hanc legitimam cartam ad infringendum insurgere temtauerit, inprimis iram Dei et indignacionem habeat et cum Iuda tradi $/{ }^{15}$ tore domini pares penas in eterna dapnacione lugeat atque cum Datam et Abiron, quos terra obsorbuit, sit dimersus in profundum inferni, et pro au/su temeritatis quantum infringere uoluerit duplicatum restauret eglesie uestre et uobis antea dicto Raimundo et sucesoribus uestris, et insuper pe/ctet centum libras purissimi auri, et senper hec scriptura plenum obtineat firmitatis roborem ęuo pereni in secula seculorum. 
Facta cartula $/{ }^{18}$ donacionis noto die VIII kalendas maii, in era DCCCC LXXXX III. Ego Fernandus Ansurez, comide, qui hanc cartam fieri iussi, tota mentis intencione con/firmo.

( $1^{a}$ col.) Gloriosissima regina confirmat.- Gunsaluus Diaz confirmat.- Bellid Nunez confirmat.- Anxur Nunez confirmat.- Petro Cidez de Facinas testis.

( $2^{a}$ col.) Nunno Garsia confirmat.- Rodericus Gunsalui- confirmat.- Pelagius Garsia confirmat.- Frola Diez confirmat.- Guter Perez de Auia testis.

( $3^{a}$ col. $)$ Comes Gunsaluus Sanchez confirmat.- Comitissa domna Vrraca confirmat.- Domna Ximena confirmat.- Santius Uermudez confirmat.- Fernan Garsias de Fita testis.

Petro Lopez de Manquillos, notarius regis, quod scripsit signauit.

(rúbrica) Pe(signo)tro (rúbrica).

957, septiembre, 18. Falso.

Nuño Ansúrez, conde de Monzón, dona a Santa María de Husillos y a su abad Raimundo, en remedio de su alma y de las de sus padres, la villa de San Julián con su jurisdicción, sita entre Villaumbrales y Fuente Quintana.

B. APA, $L P H$, f. $10 \mathrm{r}-\mathrm{v}$.

C. AGS, Patronato eclesiástico, Inconexos, leg.159, ff. 20r-v. Papel; escr. procesal; buena conservación.

D. BN, ms. 705 , f. $18 \mathrm{r}$

ED. SAN MARTÍN PAYO, Las primeras donaciones de los condes de Monzón, 346-347. 


\section{LA ABADÍA DE SANTA MARÍA DE HUSILLOS: ESTUDIO Y COLECCIÓN \\ DOCUMENTAL $(904-1608)$}

REG. PÉREZ DE ÚRBEL, Historia del condado de Castilla, III, 1177-1178, núm. 301.

CIT. BARÓN FARALDO, Grupos y dominios aristocráticos, 39.

Fecho y sacado fue este traslado de la dicha escritura original en la villa de Husillos, a diez y nuebe días del mes de nouiembre, de mil y quinientos y çinquenta y quatro años. Testigos que fueron presentes a lo ver, leer, corregir y conçertar con el original Joán Ruiz Cabeça de Vaca y Gaspar de Vedoya, clérigos, y Pero Manuel, estantes en la dicha villa. Y yo, Santiago Gómez, escriuano público en la dicha villa, fui presente con los dichos testigos a lo susodicho. Y del dicho pedimento y mandamiento del dicho señor alcalde mayor, que aquí firmó su nombre, fize escreuir y fize aquí mi signo (signo) en testimonio de verdad.

Pero Ruyz de Billoldo (rúbrica). Santiago Gómez (rúbrica).

In nomine omnium opificis rerum, creantis et regentis. Ego, Nunius Ansurez, pro redemptione anime meę et parentum meorum, facio cartulam siue testamentum donationis ecclesię Sancte Marię de Dehesa Braua et vobis, Raymundo, cardinali Sancte Crucis, abbati dictę ecclesię et vestris successoribus et fratribus tam presentibus quam futuris in perpetuum substituendis, de illa villa mea Sancti Iuliani, que est sita inter Uilumbrales et Fuent Quintana, ut habeatis perpetuo cum domibus soliis, vineis, terris, pratis, pascuis, cum introitus et exitus et cum omnibus terminis suis, tam populato quam et heremo, et cum omni mero et mixto imperio et iurisdicione et cum omnibus directuris et pertinentiis suis. Hoc facio ut vos, supra dictus Raymundus, et successores et fratres vestri seruiatis domno Iesu Christo redemptori nostro et beatę Marię, matri suę.

Et si aliquis aduersus hanc legitimam cartam insurgere temptauerit, in primis iram Dei et indignationem habeat et cum Iuda traditore Domini pares penas in eterna dampnatione lugeat, atque cum (f.10r) Datam et Abiron, quos terra obsoruuit, sit dimersus in profundum inferni, et pro ausu temeritatis quantum infringerit dupplicatum restauret dicte ecclesię vestre et vobis supra dicto Raymundo abbati et successoribus uestris, et insuper pecet centum libras purissimi auri regi, et semper hec carta plenum obtineat firmitatis roborem euo perenni et secula cuncta. Facta carta donationis, noto die $\mathrm{XIIII}^{\mathrm{o}}$ calendas octobris in era $\mathrm{DCCCC}^{\mathrm{e}} \mathrm{XCV}$. Et ego, Nunius Ansurez, qui hanc cartam fieri iussi, confirmo. Comes Gunsalus Sanchez confirmat. Comitisa domna Vrraca confirmat. Gutierre Perez confirmat. Ansur Nunnez confirmat. Domina domna Ximena confirmat. Rodiricus Gunsalui 
confirmat. Pelagius Bermudez confirmat. Guter Garsia confirmat. Santius Perez confirmat. Nunius Nunnez confirmat. Garsia Nunnez, quod scripsi, signaui.

1034, diciembre, 21.

Sancho III el Mayor de Navarra ratifica los derechos originarios de la sede palentina y le otorga nuevas capacidades territoriales y jurisdiccionales, entre ellas Santa María de Husillos con sus villas, decanías y términos antiguos, al tiempo que determina sus límites.

A. ACP, Arm. III, leg. 1, doc. 2. Perg., 630 x 483 mm.; escr. visigótica redonda; buena conservación.

B. ACP, Arm. III, leg. 1, doc. 2. Copia coetánea de fines del siglo XII.

C. ACP, Arm. III, leg. 1, doc. 27 (en traslado sin fecha, pero datable entre 1240 y 1246).

D. ACP, Arm. III, leg. 3, doc. 20. En confirmación de Pedro I (1351, octubre 18. Valladolid).

E. ACP, Arm. III, leg. 3, doc. 24. En confirmación de Enrique II (1367, febrero 15. Cortes de Burgos).

F. ACP, Arm. III, leg. 3, doc. 27. En confirmación de Juan I (1379, agosto, 12. Cortes de Burgos).

G. ACP, Arm. III, leg. 10, doc. 1, Libro de Escrituras, Bulas y Privilegios (siglo XVI), foliación en Papel;ff. 65-67

H. BRAH, Col. Salazar y Castro, sign. 9/1098 (olim O-17), ff. 195-199 y 199-202v)

ED. FERNÁNDEZ DE MADRID, Silva Palentina, t. I, lámina 11; y versión romanceada en ff. 100-104.- FERNÁNDEZ DEL PULGAR, Historia Secular y Eclesiática de Palencia, II, 40-43; y versión romanceada en 44-47.- ABAJO, Documentación catedral de Palencia, 5-9, núm. 2.ZABALZA - DE LA CRUZ, Sancho III el Mayor, 242-247, núm. 47 (versión en castellano)MARTÍNEZ LLORENTE, Sancho III El Mayor y Palencia, 10; versión en castellano en 11.

REG. SAN MARTÍN PAYO, Catálogo Catedral de Palencia, 73.

CIT. BERGANZA, Antigüedades, I, 320.- GARRACHÓN BENGOA, Palencia y su provincia, 36.- J. GONZÁLEZ, Siglos de Reconquista, 176 y 183 (lo data en 1034).- MANSILLA, Iglesia castellano-leonesa, 127.- MORET, Anales, XII, 234-236, núm. 104-106.- PÉREZ DE ÚRBEL, 


\section{LA ABADÍA DE SANTA MARÍA DE HUSILLOS: ESTUDIO Y COLECCIÓN \\ DOCUMENTAL $(904-1608)$}

Sancho El Mayor, 217.- AGAPITO REVILLA, La catedral de Palencia, 13-14.- SÁNCHEZ HERRERO, Las diócesis del reino de León, 49 y 83.- SERRANO, Obispado de Burgos, I, 229231.- MARTÍNEZ DÍEZ, Cinco diplomas relativos a la restauración de la diócesis de Palencia.

En la nómina de los lugares, villas y abadías donadas, Santa María de Husillos aparece en primer lugar.

[1056], julio, 31 .

Los hermanos Rodrigo y Falcón Álvarez venden a Anaia y a su mujer, Momaduena, la divisa que tienen en la villa de Tejada, en término de Monzón, con todas sus propiedades, en precio de ciento veinte sueldos.

A. AHDP, Ampudia y Abadía de Husillos, Pergaminos, carp. 207-5. Perg., 106 x 415 mm.; escr. visigótica redonda; buena conservación. Rotura que afecta a la data.

B. APA, $L P H$, ff. 3v-4r. En el f. 4, en el margen der., al lado de Tejata aparece: $<$ Santa Ana de Monçón>, lo cual indica que el despoblado de Tejada estaría próximo a la antigua ermita de Santa Ana, próxima a Monzón de Campos.

C. AGS, Patronato eclesiástico, Inconexos, leg.159, ff. 10v-11v. Papel; escr. procesal; buena conservación.

D. BN, $m s .705$, ff. $6 \mathrm{v}-7 \mathrm{v}$.

Las menciones del rey Fernando I (1035 / 27-12-1065), del obispo San Alvito de León (1057 / 1063) ${ }^{1}$; del obispo Miro de Palencia (primera mención documental: 26-09-1044 / ultima mención: 17-01-1060), y de su sucesor, Bernardo II (primera meción: 20-04-1062) ${ }^{2}$, nos hacen colocar el documento entre 1057 y el 20 de abril de 1063, años en los cuales los tres coincidieron en sus respectivos mandatos. Las cifras romanas que faltan que se pueden suponer para establecer esta fecha, son. "XXXX", siendo la fecha resultante de 1056, siendo admisible que el escriba se equivocara en la fecha en un año.

(Figura zoomorfa) In Dei nomine ineffabilis, patris homnipotentis et miseratoris, hunigenite Ihesu Christo filii Dei, Spiriti Sancti, unita Trinitas,

${ }_{1}^{1}$ ALDEA - QUINTÍN - VIVES, DHEE, II, 1284-1285 (voz "León").

${ }^{2}$ REGLERO, La iglesia de Palencia en la Edad Media. 
sempiterna maiestas, cuius laus et imperio permanet iugis adque sapientia extat mirabiles adque circumplexa unitas, Deus uiuus / et uerus, qui super homnia regnat, equalis per numquam finienda senper secula seculorum, amen.

Sub ipsius nomine et imperio, ego, Rodrico Albarez, ego, Falcon Albarez, in Domino Deo eterno et superanixo senpiterno et uera sospitate etiam, amen. / Placuit mici predicto toto animo et expontanea mea uoluntas ut facimus kartula uenditionis de illa diuisa qui abuimus in uilla qui uocitant Tegata, qui est in termino de Monteson, id est: terras et uinias et molinos et pumares et casas, $\beta$ cum suos exitus in montes, in fontes, in aquis aquarum, cum aquis ductilibus earum ab integro, cum tale foro quomodo abuerunt nostros abolos et parentes nostros sicut et nos que abuerunt in ipsa billa qui bendimus a tibi, Anaia, et ad uxor tua, / Momaduena. Et ego, Rodrico Albarez, et ego, Falcone Albarez, in precio qui accepimus de tibi, Anaia, et uxor tua, Momaduena, pro ipsa diuisa con terras et uinias et suas casas et suos pumares et tota ipsa ereditate sic dictum / pertinet in ipsa uilla, id est, CXX solidos de argento, nostro precio complitum qui inter nos bene complacuit, ita ut de odie die uel tempore de nostro iuro abraso tuo qui domineo sit tradito adque confirmatum per secula cuncta, amen.

Et si aliquis homo $/ 6$ contra hunc factum nostrum ad disrumpendum uenerit, propinquos uel extraneas subditus uel prelatus, tam regia, quam potestas populorum, quisque fuerit qui talia conmiserit, inprimis ambobus harescat lucestus de fronte sua, non / uideat qui bona sunt in Iherusalem nec pax in Israel set con Iudas traditore luceat penas in eterna damnatione, amen, et a parte regis auri libras quinques aut uinas, et a tibi Anaia et uxor tua, ipsa diuisa duplata uel / triplicata in simile tale locum con quale lauore abuerit, vt hec series in comparatione in cunctis abeat robore ad que plenissima obtineat firmitate usque in finem. Et ego, Rodrico Albarez et ego, Falcon Albarez, uel progenia nostra ${ }^{9}$ balentes non fuerimus in concilio bindicare uel auctoritare ipsa ereditate quomodo in ista scriptura resonat quomodo pariemus ego, Rodrico Albarez, et ego, Falcone Albarez.

Facta kartula notu die II kalendas augustus / era T [...]XIIII. Regnante rex Fredinando in Legione et in Kastella.

Et ego, Rodrico Albarez, et ego, Falcon Albarez, in hanc kartula qui fecimus a tibi, Anaia, et ad uxor tua, Momaduena, legente audiuimus et de manus nostras 


\section{LA ABADÍA DE SANTA MARÍA DE HUSILLOS: ESTUDIO Y COLECCIÓN \\ DOCUMENTAL $(904-1608)$}

signus fecimus / (signa) et roboramus coram testes: Nina, Beliter, Iacobu et Obteo Bermudez et Auriolo hic testes. $/^{12}$

Virtus Christi protectus Aluitus, Legiones sedis capituli. Mirus, capituli Palentine sedis, episcopi.

Stefanus scripsit.

1059, diciembre, 29.

Fernando I fija los límites de las diócesis de León, Castilla y Palencia. Al mismo tiempo, confirma la donación que hizo Sancho III el Mayor, su padre, a la sede palentina y a su obispo Miro. Entre las iglesias y monasterios confirmados, se encuentra Santa María de Husillos con sus villas, decanías o términos antiguos.

A. ACP, Arm. III, leg. 1, doc. 5. Perg., 664 x 493 mm.; escr. visigótica redonda; buena conservación.

B. ACP, Arm. III, leg. 1, doc. 27, copia del siglo XIII.

C. ACP, Arm. III, leg. 3, doc. 20, en confirmación de Pedro I (1351, octubre, 18)

D. ACP, Arm. III, leg. 3, doc. 27, en confirmación de Juan I (1379, agosto, 10).

E. ACP, Arm. III, leg. 10, doc. 1, Libro de privilegios, ff. 68-70v.

ED. FERNÁNDEZ DE MADRID, Silva Palentina, I, lámina 12, y versión romanceada en págs. 104-109.- FERNÁNDEZ DEL PULGAR, Historia Secular y Eclesiástica de Palencia, II, 66-70, y versión romanceada en págs. 70-73.- ABAJO, Documentación catedral de Palencia, 23-28, núm. 9.

REG. CASTRO TOLEDO, Colección diplomática de Tordesillas, 5, núm. 6.- PÉREZ DE ÚRBEL, Sancho el Mayor, apédice III, núm. CCXIII, 453.- SAN MARTÍN PAYO, Catálogo Catedral de Palencia, 74, núm. 50.

En la nómina de los lugares, villas y abadías donadas, Santa María de Husillos aparece en primer lugar. 


\section{DAVID MARCOS DIEZ}

1088. Husillos.

El concilio de Husillos, presidido por el legado pontificio, cardenal Ricardo [Milhaud], con la presencia del rey Alfonso VI y de los magnates, prelados y abades de sus reinos, fija los límites entre las diócesis de Burgos y Osma, recién restaurada, resolviéndose así el conflicto existente entre el obispo de Burgos, Gómez, y el arzobispo de Toledo, Bernardo.

B. Archivo de la Catedral de Burgos, Vol. 48, f. 1.

ED. LOAISA, Collectio, 144.- LABBE, Collectio, VI, 566.- SÁENZ DE AGUIRRE, Collectio, V, 26-27.- MANSI, Collectio, XX, 718.- LA FUENTE, Historia Eclesiástica de España, 4, 554-555.LLORENTE, Disertación, núm. 41, 170-171.- FÉROTIN, Recueil de Silos, núm. 29 bis, 62.FITA, Texto completo del concilio de Husillos, 410-413- SERRANO, Obispado de Burgos, III, núm. 31, 76-78.- GARRIDO, Documentación Catedral de Burgos, núm. 46, 99-101.- C. SÁEZ, Colección de Sepúlveda, núm. 2.- GAMBRA, Alfonso VI, II, núm. 97, 256.

REG. MANSILLA, Catálogo catedral de Burgos, núm. 42, 30.

CIT. CAMPELO Y SUÁREZ, Historia Compostellana, ES, XX, 17.- SANDOVAL, Cinco reyes, 46r-79r.- FERNÁNDEZ DEL PULGAR, Historia secular y eclesiástica de Palencia, 148-149.SOTA, Crónica, 539.- MILLARES, La cancillería real, 242, na. 93.- MALDONADO, Las relaciones, 257-258.- SERRANO, Obispado de Burgos, I, 334. Cree que el concilio se celebró entre fines de abril y comienzos de mayo.- J. GONZÁLEZ, La Extremadura Castellana, 285-286.VONES, Historia Compostellana, 109-110.- PROCTER, Curia y cortes, 38.- GARCÍA Y GARCÍA, Concilios y sínodos, 393-395.- REYLLY, El reino de León, 221-223 y 229.CARRIEDO, Concilio de Husillos, 29-31.

Según Andrés Gambra, "la celebración del concilio fue anterior al 30 de abril, fecha a partir de la cual figura en los diplomas reales el obispo Pedro de Iria, cuyo nombramiento tuvo lugar en esta asamblea". 


\section{LA ABADÍA DE SANTA MARÍA DE HUSILLOS: ESTUDIO Y COLECCIÓN \\ DOCUMENTAL $(904-1608)$}

Dicho autor cree igualmente que el pergamino de la catedral de Burgos que se edita no es el original, sino una copia de la primera mitad del siglo XII. ${ }^{3}$

Anno ab incarnatione Domini $\mathrm{M}$. octogesimo VIII, era $\mathrm{T}$ C XXVI, regnante gloriosisimo Adefonso imperatore in Toleto, Legione, Galletia, Castella et Nagara, facta est sinodus in ecclesia Sancte Marie de Fusellis, apud castrum Montsoy, presidente domno / Ricardo, vicario Sancte Dei Romane Ecclesie, presente cum eo domno Bernardo, archiepiscopo toletano, et archiepiscopo domno Petro Aquense, residentibus cunctis episcopis regni ipsius gloriosisimi regis, videlicet: Dumiensi episcopo Gundisalvo, Arderico Teudensi episcopo, Ariano, Ovetense episcopo, Osmundo Asturicensi episcopo, / Raimundo Palentino episcopo, Petro Legionense episcopo, necnon electis in ministerium episcopii: Petro in ecclesia beati Iacobi, Martino in ecclesia Conimbriensi, Sigefredo in ecclesia Nagerensi, Petro in ecclesia Oriense; presentibus ibidem abbatibus Fortunio in monasterio Exiliensi, Vincentio in monasterio Sancti Petri $\beta$ Asilance, Didaco in monasterio Sancti Facundi, Petro in cenobio Sancti Petri Caradigne.

Cum consilio et consensu supradicti catholici regis sed et episcoporum, abbatum, principum et procerum ipsius regni necnon tocius concilii, facta es divisio / inter Hoxomensem et Aucensem episcopatum, qui noviter Burgis translatus est; et quia Hoxomensis episcopatus prius a sarracenis invasus cotidie per misericordiam Dei redintegratur, quoniam confinia eorum et termini incerti habebantur, et quia iugis contemptio erat inter Bernardum, Toletanum archiepiscopum, ad quem Hoxomensis ecclesia metropolitano / iure pertinet, et Gomizonem, Aucensem seu Burgensem episcopum, assenciente, videlicet, utraque parte, visum est saniori consilio sic determinare parrochias eorum: ut a fine Canatanazore et de Murello et Argança et castri qui dicitur Mesella et castri quod dicitur Spega, et a villis que dicuntur Congosto et Buezo $/{ }^{6}$ et sicut aqua ipsa currit et labitur in Arandam, aqua que discurrit per Cluniam et pertransit ipsam Cluniam usque ad Pennam de Aranda donec labitur in fluvium Dorium, et omnes ville ex hac parte fluminis Aranda in quibus currit saio de Clunia, necnon trans fluvium Dorium castrum Materiolum et Vocikellas / et usque ad civitatem Septem publicensem . Et

\footnotetext{
${ }^{3}$ GAMBRA, Alfonso VI, II, núm. 97, 256.
} 
quicquid ultra continetur, decerneretur esse Hoxomensis ecclesie. Illa vero que citra sunt a terminis prenotatis versus septemtrionalem plagam, Aucensis ecclesia iure perpetuo possideat.

Sane, si quis archiepiscopus, episcopus, rex, comes, princeps aut aliqua potestas seu / quelibet ecclesiastica secularisue persona, definitionis huius paginam pertinaci audatia violare vel in aliquo infirmare temptaverit, rerum se de perpetrata iniquitate cognoscat, et a sacratissimo corpore et sanguine Dei et Domini Redemptoris nostri Ihesu Christi aliena fiat, atque in extremo examine cum $/{ }^{9}$ sinistris deputatus districte ultioni subiaceat.

Ego, Adefonsus, divina preordinante gratia Hispaniarum rex, supra nonatam divisionem fieri volui, manuque propria firmavi.

Ego, Ricardus, Sancte Dei Romane Ecclesie vicarius, huic concilio presidens, laudo manuque propria confirmo.

Ego, Bernardus, Toletanus archiepiscopus, finium Hoxomensis ecclesie defensor et investigator, suprascriptam divisionem laudo manuque propria corroboro.

( $1^{a}$ col.) Ego, Petrus, Aquensis archiepiscopus, conf.- Ego, Gomessanus, Burgensis episcopus, conf.- Ego, Gundisalvus, Dumiensis episcopus, conf.- Ego, Adericus, Tudensis episcopus, conf.- Ego, Arianus, Ovetensis episcopus, conf.- Osmundus, Asturicensis episcopus, conf.

( ${ }^{\circ}$ col.) Ego, Raimundus, palentinus episcopus, conf.- Ego, Petrus, Leionensis episcopus, conf.- Ego, Petrus, in ecclesia beati Iacobi electus, conf.- Ego, Martinus, in ecclesia Conimbriensi electus episcopus, conf.- Ego, Sigefredus, in ecclesia Nagarensi electus episcopus, conf.- Ego, Petrus, in ecclesia Oriense electus episcopus, conf.

( $3^{a}$ col.) Ego, Fortunio, Exiliensis abbas, conf.- Ego, Vicentius, Sancti Petri Arelicensis abbas, conf.- Ego, Didaco, monasterii Sancti Facundi abbas, conf.- 


\section{LA ABADÍA DE SANTA MARÍA DE HUSILLOS: ESTUDIO Y COLECCIÓN \\ DOCUMENTAL $(904-1608)$}

Ego, Iohannes, in monasterio Oniensi electus, conf.- Ego, Petrus, in monasterio Sancti Petri Caradigne electus, conf.

( $4^{a}$ col.) Ego, Garsias, Nagarensis comes, conf.- Ego, Petrus, comes de Carrion, conf.- Ego, Fredinandus, comes, conf.- Ego, Martines, comes, conf.- Ego, Rudericus Ordoniz, princeps, conf. Ego, Gundisalvus Nuniz, princeps, conf.- Ego, Rudericus Gunsalvez, princeps, conf.- Ego, Albari Didaz, princeps, conf.- Ego, Lop Sangez, princeps, conf.- Ego, Didac Sangez, princeps, conf.- Ego Bermudo Rodriz, princeps, conf.- Ego, Petro Alvarez, princeps, conf.

1090, marzo, 31 .

Alfonso VI confirma las donaciones y privilegios otorgados a la sede episcopal palentina por su abuelo, Sancho III el Mayor de Navarra, y su padre, Fernando I de Castilla. Entre éstas se encuentra Santa María de Husillos con sus villas, decanías y términos antiguos.

A. ACP, Arm. III, leg.1, doc.9. Perg., 675 x 498 mm.; escr. visigótica redonda; buena conservacion.

$A^{\prime}$. ACP, Arm. III, leg. 1, doc. 9'.

B. ACP, Arm. III, leg.1, doc. 27, copia del siglo XIII.

C. ACP, Arm. III, leg. 3, doc. 19, en confirmación de Pedro I (1351, octubre, 18).

D. ACP, Arm. III, leg. 3, doc. 20, en confirmación de Pedro I (1351, octubre, 18).

E. ACP, Arm. III, leg. 3, doc. 27, en confirmación de Juan I (1379, agosto, 1).

F. BRAH, Colección Salazar, O-17, ff. 211-217; O-15, ff. 247-249v; O-17, ff. 250-252; O-17, ff. 252-254.

ED. FERNÁNDEZ DEL PULGAR, Historia Secular y Eclesiástica de Palencia, II, 120-125; y versión romanceada en págs. 126-129.- ABAJO, Documentación Catedral de Palencia, 37-43, núm. 15. 
REG. SAN MARTÍN PAYO, Catálogo Catedral de Palencia, 75.

CIT. FERNÁNDEZ DE MADRID, Silva Palentina, I, 82.- J. GONZÁLEZ, Siglos de Reconquista, 185, 197, nota 6, 209 y 51.- SAN MARTíN PAYO, El cabildo de Palencia, 23.- SERRANO, Obispado de Burgos, 343.

En la nómina de los lugares confirmados, aparece en primer lugar Santa María de Husillos.

1107, mayo, 28. Falso.

Roi Gutiérrez y Andrequina, su esposa, donan a Santa María de Husillos y a su abad Poncio Guitardo, en remedio de su alma y las de sus padres, la villa de Pozuelos de Amianos. Reciben en corroboración cuarenta marcas de plata pura.

A. AHDP, Ampudia y Abadía de Husillos, Pergaminos, carp. 207-3. Perg.; 255 x 307 mm.; escr. visigótica redonda; regular conservación

B. APA, $L P H$, ff. $10 \mathrm{v}-11 \mathrm{r}$.

C. AGS, Patronato eclesiástico, Inconexos, leg.159, ff. 20v-21v. Papel; escr. procesal; buena conservación.

D. BN, ms. 705 , ff. $18 \mathrm{v}-19$.

CIT. PÉREZ DE ÚRBEL, Historia del condado de Castilla, III, 1165.- J. GONZÁLEZ, Siglos de Reconquista, 197.

Sub Christi nomine. Ego, Roi Guterez, et vxor mea, dona Andrequina, pro redempcione animarum nostrarum et parentum nostrorum, facimus cartulam [siue tes]/tamentum donacionis eglesię Sanctę Marię de Fusellis et vobis dopnus Poncius Guitardus, abas dicte eglesię, et omnes suces[ores] / uestros, de loco nostro de Pozolos Damianos cum domos et solis, vineis, terris, pratis, eglesias et exitus et cum omnibus $\beta^{3}[\ldots]$ uos, tam populato quam et heremo, tali conuencione: ut habeatis omnibus diebus seculi uos et sucesoribus uestris ad seruiendum Domino / redemptoris mundi et beate Marie, matris sue. Hoc facimus pro 
remissione pecatorum nostrorum et parentum nostrorum. Et ad confirman[dum / hanc] cartulam dedistis nobis XL marcas argenti purissimi.

Quod si aliquis aduersus hanc legitimam cartam ad infringen[dum $/{ }^{6}$ insur]gere tentauerit, inprimis iram Dei et indignacionem habeat et cum Iuda traditore Domini pares penas in [eterna / da]mpnacione lugeat atque cum Datam et Abiron, quos terra obsorboit, sit dimersus in profundum inferni, et pro ausu $\mathrm{t}[\mathrm{eme} / \mathrm{rar}] \mathrm{io}$ duplicatum restauret quantum infringere uoluerit eglesię uestrę et uobis uel sucesoribus uestris, et pecet libras $\mathrm{X}\left[\mathrm{L}\right.$ purissi $\left./^{9}\right] \mathrm{mi}$ auri, et insuper hanc scripturam plenum obtineat firmitatis roborem euo perheni et secula cuncta.

Fact[a / cart]a donacionis noto die V kalendas iunii, era $\mathrm{M}^{\mathrm{a}} \mathrm{C}^{\mathrm{a}} \mathrm{XL} \mathrm{V}^{\mathrm{a}}$. Et nos antea dictos, Roi Guterez et dona Andrequi[na, / qui han]c cartam fieri iussimus, tota mentis intencione. Regnante rex Adefonsus c $[\mathrm{u}] \mathrm{m}$ uxore sua, dona Cos[rancia, $/{ }^{12}$ in] Toleto et in Castella. Aluar Nunnez, alferez. Gonsaluo Roiz, maiordomo regis. Garcia Roiz, merino maiore. [Tello / Tell]ez, electus in Palencia. Et nos antea dictos Roi Guterez et dona Andrequina, hanc cartam mandauimus scribere a uobis, [Gutier / Perez], scriba regis in concilio de Pozolos, a lo qual fuerunt visores: Petro Martinez, capiscol de Fusellis. Petro Roiz $\left[\ldots /{ }^{15} \ldots\right]$. Petro Petrez. Don Florente el freire. Don Uidal el abate. Dominico Moro. Et concilio de Pozolos Damianos. /

[Et ego), Goter Perez, qui scrisi, signam commo scriba regis de meo sig(signum: G. P.)no.

[1072-1109]. Falso.

Relato resumen de la fundación de Santa María de Husillos, teniendo lugar durante las cortes de Carrión, hallándose presentes Alfonso VI, la infanta Urraca Fernández, Pedro Ansúrez y otros magnates.

Las donaciones fundacionales fueron realizadas por Gonzalo y Fernando Ansúrez, hermanos del dicho Pedro Ansúrez, y los tres, hijos de Assur Díaz; 
Urraca Fernández, la cual es titulada reina y en nota marginal equivocadamente se dice que tal vez sea la hija de Alfonso VI, después que casara con Alfonso "El Batallador", y la condesa Justa Fernández.

Relata también los pleitos habidos entre la sede palentina y la abadía de Husillos y los fueros que tenía ésta y Monzón.

\section{$B$. APA, $L P H$, ff. $2 \mathrm{v}-3 \mathrm{v}$.}

C. AGS, Patronato eclesiástico, Inconexos, leg.159, ff. 8r-10v. Papel; escr. procesal; buena conservación.

D. BN, ms. 705, ff. 2-6v.

E. ARCHV, Salas de lo Civil. Pérez Alonso (OLV). Caja 136-1. Traslado sacado del Libro de los Privilegios de Husillos, aportado como prueba en un pleito olvidado (1735-1736) del concejo de Husillos con Marcelo Antonio de Tovar, canónigo y cura mayor de la colegiata de Ampudia, gobernador de la iglesia de Husillos y procurador de la colegiata de Ampudia, sobre la nulidad de las elecciones de los oficios de justicia en la villa de Husillos.

ED. SAN MARTÍN PAYO, Las primeras donaciones de los Condes de Monzón, 314-318.

CIT. MORALES, Crónica General de España, $3^{\mathrm{a}}$ parte, lib. XVI, cap. XLIII, ff. 258v-259.GARRACHÓN BENGOA, Palencia. Guía del turista, 354-355 (da noticia de que Regino Inclán Inclán había encontrado en el Archivo Diocesano de Palencia varios documentos, uno de los cuales era éste, del que transcribe parte).

Por la sintaxis y el vocabulario, se puede datar entre fines del siglo XIII y principios del XIV.

Esta escritura lo que va en blanco della no se puede leer por estar roto; ni se pudieron leer tres rrenglones de los postreros della, y por eso no se signa.

Estando el rey don Alonso, fijo del rey don Fernando, el primer emperador, en Carrión en sus cortes allegadas e con todos los ombres de [su reino], llegó y vn ome bono que venía de Roma y era muy rreverendo, que por ser cardenal en Roma mucho mal auía pasado, y era de (en blanco) provincia, y avíanle echado de Roma, y era fijo de vn conde que era mucho onrrado, y pedía merced al rey que le fiziese al (en blanco). Catose entonces el rey contra la reina y contra los fijosdalgo y dixo que quál daría que non tenía auer que le dar ni echaría por él pecho en la tierra. Dixo entonces el conde Per Ansúrez: “yo vos mostraré que le dedes y con que él sea pagado: mi padre, el conde don Ansúrez, ouo poblada vna iglesia en Dehesa Braua, cabo de Monçón, su condado, y vos pedilda 
a mis germanos que yo dáuosla de grado para él y vos darles desmás y faredes y una dignidad muy buena".

Demandó entonces el rey por los condes que viniesen y luego. Y el rey dixo a la reyna que ge la demandase y que la darían a ella más ayna. Ella demandógela luego y ellos diérongela muy de buenamiente. Y dixo el conde Gonçalo Ansúrez: "Dónosla yo, señora, muy de grado e donos Sancta Enfimia". Fernán Ansúrez, mi hermano, dixo Fernán Ansúrez: "Señora, dónosla yo de grado". Y Goncalo Ansúrez dixo: "Pues dole yo desde la Puente Vieja de Monçón y toda la vega del llano fasta do llaman la Huerta del Otero, Quintaniella del obispo de Palencia”. Y Fernán Ansúrez dixo: "Dole yo Sancta Eufimia con todos sus heredamientos y pertenencias por alma de mi padre que nos la ouo dexado". Y dixeron al Rey que lo confirmase. Y él dixo que lo haría muy de grado. Otrosí dixo la reyna doña Vrraca: "Fernando, dole yo dos iglesias que e en Frechiella, que me dexó mi padre, el rey don Fernando, y dole más a San Fagún el Viejo, como lo tengo aforado con XXIIII yugos de buey con LX solariegos que yo y e poblado. Y dole Pajares, y dole Sant Sebastián de Hérmidas. Y esto todo le doy muy de grado. Y vos, señor rey don Alfonso, confirmaldo luego".

Y entonces el rey confirmógelo y diole preuilegios firmados con su mano.

Sópolo el obispo de Palencia y fue por ello mucho yrado. Y defendió al abad que no entrase en la dignidad. [E mandose] fuese librado por derecho. Y el abad apeló para corte de Roma, y ouieron muy gran pleyto sobre ello, y duró el pleito siete años (en blanco) dieron avenir. Y en cabo venció el obispo al abad y echole en grandes costas. Y defendió que no labrasen los eredamientos. Y a cabo (en blanco) años quando pudo ganar el abad que lo confirmase el obispo, touo que auía mucho acabado e ouo de confirmar el obispo don Alfonso Núñez. (en blanco) E por esto conosció señorío el abad de Dehesa Braua al obispo de Palencia. Y otrosí sobre las libertades ouieron otra vez muy gran [pleito, y] no les pudieron auenir el rey ni ningún otro ome. $\mathrm{Y}$ en cabo ouo de vencer el obispo al abad, y ganó en corte de Roma que no ouiese otro abad en Dehesa Braua, y dixéronle don Remón.

E ansí a de hazer el obispo de Palencia abad en Dehesa Braua sin rey e sin corte de Roma y sin otro ome ninguno, y auía y el obispo de Palencia procuración. 
De mientra esquieron los condes no gela querían dar el abad. Y el obispo citó al abad para la corte de Roma e ouo de ganar el abbad que diese su procuración al obispo. Y traxo dello tal preuilegio firmado del papa, en tal manera que biéspera de Santa María de agosto mediado, vaya el obispo de Palencia cenar a Dehesa Braua y él diga las biésperas; y a la noche dele el dicho abad candelas (en blanco); y en otro día, en el día de Santa María, diga el obispo la misa; y denle y dé yantar. Y después que ouiese comido, duerma y la siesta; y después que ouiere dormido, denle del vino y salga el obispo de la villa, que no esté y más. Y si el obispo y aluergare por fuerça del abad, pierda la cura dende por siempre, que nunca más faga abad ni aya que ver en la dignidad. Y si el obispo y aluergare por autoridad del abad o por conuite del cabildo, e porque touiese la posesión de la dignidad, que se torne la dignidad libre al obispo, que nunca y aya más abad en quanto el mundo dure, que sea del obispo.

E Palencia era poblada de muy malos fueros, que los non podían endurar los que y morauan. Y por eso tenían más las jentes con el abad que no con el obispo. Y por eso ouieron de ermar la villa de Palencia, que lo non podían sufrir. Y dioles el abad dos pueblos que poblasen: la vna, Santa Eufemia; la otra Santillán de la Cuesta. Sobre esto dio una dueña al abad otra puebla que poblase, qual dizen San Pero de Val Rozado. Y después le cambiaron el nombre, quando el emperador por ay pasó, y dixéronle Val de Emperador, porque abría por y el camino, que no quiso entrar por Palencia porque era cotado, y por esta rrazón le llaman Val de Emperador.

E por aquellos malos fueros que auían en Palencia, ermose que más rrica era el abadía que no el obispado. Y aquel obispo don Alfonso Martínez murió camino de Roma e soterráronlo en San Dionis de Francia. Y estuvo de quatro años que no ouo y obispo. E fiziesen obispo a un abad de tierra que dixeron don Remón. E quando este don Remón vio que auía en la villa tan malos fueros y las malas costumbres de sí, tornose para Carrión a las cortes. Y él allí estando, vino el abad de Santa María de Dehesa Braua a él y pidiole por merced que diese fueros, que aún no los auía, que le franquease la abadía.

Dixo el rey don Alfonso: "Que muy de grado e yo vos la franqueo con mío previlegio firmado, con entradas y con salidas y con pastos y con ganados, e que 
vos la vayan a apear como vos la dieron los condes fijosdalgo, el conde Goncalo Ansúrez y Fernán Ansúrez su hermano”.

Dixéronle los condes: "Señor, plácenos de grado". Tomó el abad fieles de Carrión y fieles de Palencia del prelado, y mío Cid que vino y por rruego del rey don Alfonso.

Apeole el conde Fernán Ansúrez a Sancta Eufimia de la frontera de Palencia, desde el pontón angosto, y es agora el vado por do pasan a la Huerta del Otero qual dizen Quintaniella; y mudaron el frontón deste vado y fiziéronle un pontón más ayuso, llámanle la puente de Don Guarí. Y comiença deste vado por los (en blanco) viejos y sale derecho a los otros a más agudos, que están sobre Palencia por del camino que va para Monçón e viene adelante como viene fasta Sancta María de Dehesa Brava. Esto le apeó el conde Fernán Ansúrez.

E apeole el conde Gonçalo Ansúrez, desde la Puente Vieja de Monçón como atraviesa la vega y sale a la fuente que está sobre el camino que va de Palencia a Carrión, e de la fuente como sale al llano entre San Felices y Santillán; y sale a las eras de Villaumbrales, y viene entre la lonja de Grijota y de Santillán, e biene a la vega que está sobre la Huerta del Obispo, en derecho de Sancta Eufemia, y viene adelante como va fasta Sancta María de Dehesa Brava.

Y después que ge lo ouieron apeado, fuese el abad con este donadío para el rey Alfonso a Carrión. E preguntó al rey don Alfonso a los condes qué fueros les fazían los solariegos y las jentes que y morauan. E porque era condado nunca pechauan a Rey. Y mostraron los condes las sernas que les fazían, ca non pagauan otro pecho: el que auía bueyes, un día a senbrar y otro día a trillar, otro día a baruechar; el que no auía bueyes, un día a cauar en las viñas, otro día a segar en los panes, otro día a limpiar el pan de la era. E todo esto y an de hazer a Monçón. E por ome o muger, desque era de edad, yva fazer sendos días en el castillo de Monçón, e non se escusaua el padre por el fijo ni la madre por la fija, que cada uno labraua su día o su obrero por él. Y todo conde de Monçón auía en cada lugar fazendero y montábala fazer quatro marauedises.

Dixo el rey don Alfonso: "Quitos son ellos desde hoy más en labrar en el castillo". Y mandó a los que bueyes ouieren que den las huebras sobredichas al abad, mas otro pobre labrador ni muger no, ca sería pecado por clérigo tenerlas en tal premio. 
Y mandó que den a cada abad nuevo que viniese entre todos una yantar y unas huesas de cinco marauedís. Y el que labrare con bueyes que le de una emina de trigo. Y el que ouiere tierras y las traxere a labrar a rrenta, de media emina de ceuada.

Y porque sea más amparada la dignidad, que la non pueda entrar conde ni ricosome ni otro ome ninguno, mandó que el ganado que paciere en este término desta dignidad, sin grado del abad y del cabildo, si fueren ouejas pechen al abad de cinco vna; y si fueren de ciento a yuso, peche de quatro cabecas un dinero; y de bueyes, de cada cabeza vn dinero; bestias asnales, un dinero; yegua o bestia caballar, dos dineros.

Todo esto vos franqueo yo con mío preuilegio firmado. E todo aquel que vos este fuero quebrantase, conde ni ricoome ni otro ninguno, peche cien marauedís de los buenos, la meatad al rey, la metad al abad, y sea maldito y dexcomulgado.

Estos previlegios dio el rey don Alfonso en Carrión a Sancta María de Dehesa Braua.

1114, mayo, 28.

La reina Urraca, juntamente con su hijo Alfonso, dona a Santa María de Husillos, gobernada por Poncio Guitardo, en remedio de su alma y de las de sus padres, la villa de Villaldavín y la pesquera de Deronnada. En confirmación reciben cuarenta y cinco marcas de plata.

B. AHDP, Ampudia y Abadía de Husillos, Pergaminos, carp. 197-2. Copia coetánea. Perg. 467 x $333 \mathrm{~mm}$.; escr. visigótica redonda de gran calidad; algunos rotos en el pergamino, dos en el margen izquierdo afectan a las líneas 4 y 5 y a la primera columna.

C. AHDP, Ampudia y Abadía de Husillos, Pergaminos, carp. 198-15. Perg., 736 x 679 mm.; escr. gótica redonda de privilegios; regular conservación, presentando varias manchas de humedad que a veces impiden la lectura y una rotura en la línea 25 . Conserva los agujeros y cinta del sello, que 


\section{LA ABADÍA DE SANTA MARÍA DE HUSILLOS: ESTUDIO Y COLECCIÓN \\ DOCUMENTAL $(904-1608)$}

no se conserva. Inserto en confirmación de Sancho IV, dada a 31 de julio de 1290. Véase doc. núm. 82.

D. AHDP, Ampudia y Abadía de Husillos, Pergaminos, carp. 199-19. Perg. 684 x 631 mm.; escr. gótica redonda de privilegios y de albalaes; buena conservación; sello pendiente de plomo. Inserto en confirmación de Fernando IV, dada en Medina del Campo, el 10 de mayo de 1305. Véase doc. núm. 97.

E. AHDP, Ampudia y Abadía de Husillos, Pergaminos, carp. 200-21. Perg., 784 x 638 mm.; escr. gótica redonda de privilegios y precortesana; regular conservación. Sello de plomo pendiente. Inserto en confirmación de Pedro I del privilegio de Alfonso XI, dada en Valladolid, a 28 de noviembre de 1351. Véase doc. núm. 135.

F. AHDP, Ampudia y Abadia de Husillos, Pergaminos, carp. 201-23. Perg. 714 x 608 mms.; escr. gótica de privilegios y precortesana; regular conservación, aunque las roturas y manchas no impiden su completa lectura. Inserto en confirmación de Enrique II del privilegio de Alfonso XI, dada en Valladolid, a 20 de mayo de 1371. Véase doc. núm. 163.

G. AHDP, Ampudia y Abadia de Husillos, Pergaminos, carp. 201-27. Perg., 784 x 685 mm.; escr. gótica de privilegios y precortesana. Muy deteriorado, ha desaparecido, prácticamente, toda su parte izquierda. No conserva sello ni cinta. Inserto en confirmación de Juan I del privilegio de Enrique II, dada en Burgos, a 22 de agosto de 1379. Véase doc. núm. 192.

$H$. APA, $L P H$, ff. $11 \mathrm{v}-12$ r. En el f. $11 \mathrm{v}$, en el margen izq.: $<\mathrm{Ojo}$, esta pesquera es las Islas que comiencan desde la pesquera del Soto del Abad, como salimos del soto, hasta el molino>. Traslado de $B$.

I. APA, $L P H$, ff. 43r-46r. Traslado de $C$.

$J$. APA, $L P H$, ff. $74 \mathrm{v}-78$ r. Traslado de $E$.

$K$. APA, $L P H$, ff. $88 \mathrm{v}-92$ r. Traslado de $F$.

$L$. APA, $L P H$, ff. 104r-108v. Traslado de $G$.

M. ARCHV, Salas de lo Civil. Zarandona y Balboa (OLV). Caja. 697.1. Traslado sacado del original, aportado como prueba en un pleito olvidado (1560) del concejo de Villaldavín con Santa María de Husillos, sobre la jurisdicción en primera y segunda instancia en Villaldavín, alegando el concejo pertenecer a la jurisdicción real (véase doc. núm. 286).

N. AGS, Patronato eclesiástico, Inconexos, leg.159, ff. 22r-23r. Papel; escr. procesal; buena conservación.

$\tilde{N}$. BN, $m s .705$, f. 19r-v. Traslado de $H$.

$O$. BN, $m s .705$, ff. 70v-76v. Villa Zuleiman se ha transformado en "vineam Çalenia". Traslado de la confirmación de Sancho IV. Traslado de $I$.

$P$. BN, $m s .705$, ff. 155 r-166r. Traslado de la confirmación de Pedro I. Traslado de $J$.

$Q$. BN, $m s .705$, ff. 196v-201r. Comete numerosos errores Traslado de $K$.

$R$. BN, $m s$. 705, ff. 231v-238r. Transcribe el documento muy resumido. Traslado de la confirmación de Juan I. Traslado de $L$. 
ED. SAN MARTÍN PAYO, Villaldavín, 117-118. Data el documento en 22 de mayo.MONTERDE ALBIAC, Diplomatario, núm. 72, 121-123.- RUIZ ALBI, Cancillería y colección diplomática de la reina Urraca, núm. 57, 445-447.

REG. FELBER, The marriage, núm. 61, 227-228.- LOBATO YANES, Urraca I, núm. 47, 152.

CIT. SERRANO, Obispado de Burgos, I, 387.- REILLY, Queen Urraca, 98.- CALLEJA, El conde Suero Vermúdez, 562, nota 39.- J. GONZÁLEZ, Siglos de Reconquista, 197.

(Christus). Sub Christi nomine. Ego, Urraca, Domini disposicione tocius Ispanie, regina nobilisimi regis dompni Adeffonsi, Constancieque regi/ne filia, una cum filio meo dompno Adefonso rege, pro redencione anime mee, et parentum meorum, facio cartulam / siue testamentu donacionis eglesię Sanctę Marię de Fusellis, quam siquidem eglesiam gubernat et regit dompnus / Poncius Guitardus, abbas michi in omnibus et per omnia fidelissimus, de uilla quę dicitur Uilla de Don Daui, cum domibus et soliis, uinais $\beta$ et terris, pratis, cultus et exitus et cum omnes terminos suos tam populato quomodo et heremo. Dono etiam ego iam dicta regina domna / Urraca una cum predicto filio meo domno Adefonso rege, predictę eglesię Sancte Marię de Fusellis et uobis iam dicto Poncio Guitardo ${ }^{6}$ abbati, illam pescariam de Deronnada, tali conuencione ut abeatis omnibus diebus seculi uos et successoribus uestris, predictam / uillam de Don Daui et predictam pescariam de Deronnada ad seruiendum domini nostri saluatoris mundi et beate Marię, matris / suę. Hoc enim facio pro remissione peccatorum meorum et pro redemcione anime patris mei; et ad confirmandam huius cartulam $/^{9}$ dedistis michi XL et V marcas argenti purissimi.

Quod si aliquis aduersus hanc legitimam cartam ad infringendum insurgere / temtauerit, in primis iram Dei et indignacionem habeat et cum Iuda traditore domini pares penas in eterna damnacione / lugeat, atque cum Datan et Abiron, quos terra obsorbuit sit, dimersus in profundum inferni, et pro ausu temeritatis quantum $/{ }^{12}$ infringere uoluerit duplatum restauret eglesię uestrę et uobis uel successoribus uestris et pariet libras XX purissimi auri et in super / hanc scripturam plenum obtineat firmitatis roborem euo perhenni et secula cuncta. 
Facta cartula donacionis noto die V kalendas iunii, / era $\mathrm{M}^{\mathrm{a}} \mathrm{C}^{\mathrm{a}} \mathrm{L}^{\mathrm{a}} \mathrm{II}^{\mathrm{a}}$. Ego Urraca regina qui hanc cartam fieri iussi tota mentis intencione signaui (monogramma: VRRACA).

( ${ }^{a}$ col.) Bernaldo Toletano, archiepiscopo, conf.- Sancia, soror supradicte regine (signum), conf.- Petrus Assurez, Carrionensium comes, conf.- Petrus Gunsaluez, Larensium comes, conf.- Santius Uermundiz, Legionensium comes, conf.- Frola Didaz, Astorrensium comes, conf.- Rodricus, Asturiensium comes, conf.

( $2^{a}$ col.) Pascasius, Burgensis eglesie presul, conf.- Ferran Garciaz de Fita conf.Ferran Garciaz Pellica conf.- Petro Lopez de Uillaplan Uisaia conf.- Petro Didaz de Manrrellos conf.- Gonsaluo Sangez de Mante Tarilo conf.- Rodricus Didaz Surdi conf.

( $3^{a}$ col.) Didacus, Legionensis eglesię presul, conf.- De escola regine, Garcia Enneqez conf.- Petro Cidez de Facinas conf.- Tello Ferrandiz de Mante Cea conf.Goter Pedrez de Auia conf.- Don Geruas de Palenza conf.- Petro Paschalez de Palenza conf.

Martinus notarius regine quod scripsit signauit (monogramma: MARTINUS)

Cid, Bellit, conf.

1114, mayo, 28.

La reina Urraca, juntamente con su hijo Alfonso, dona a Santa María de Husillos, gobernada por Poncio Guitardo, en remedio de su alma y de las de sus padres, la villa de Celanova y el arroyo de los Frailes. 
B. AHDP, Ampudia y Abadía de Husillos, Pergaminos, carp. 197-1. Perg., 599 x 187 mm.; escr. visigótica redonda; buena conservación.

$C$. APA, $L P H$, f. $12 \mathrm{r}-\mathrm{v}$.

D. AGS, Patronato eclesiástico, Inconexos, Leg. 159, ff. 23r-24r. Papel; escr. procesal; buena conservación.

E. BN, ms. 705, ff. 19v-20r.

ED. SAN MARTÍN PAYO, Villaldavin, 118-120.- MONTERDE ALBIAC, Diplomatario, 123124, núm. 73.- RECUERO, Documentos de Galicia: Doña Urraca, 77-78, núm. 35.- RUIZ ALBI, Cancillería y colección diplomática de la reina Urraca, 447-449, núm. 58.

REG. FELBER, The marriage, 228, núm. 62.- LOBATO YANES, Urraca I, 152-153, núm. 48.

CIT. SERRANO, Obispado de Burgos, I, 387.- REILLY, Queen Urraca, 98.- FRANCIA LORENZO, Notas de Archivo 3, 219-220. Afirma que la Urraca del documento es la hija natural de Alfonso VII, y que se realiza, la donación, en el año 1152. Lo cierto es que se dice claramente que se trata de la hija de Alfonso VI y de la reina Constanza. La data también es clara: era 1152 (año 1114).- J. GONZÁLEZ, Siglos de Reconquista, 197.

(Christus) Sub Christi nomine. Ego, Urraca, Domini disposicione tocius Ispanie / regina, nobilissimi regis dopni Adeffonsi, Constancieque regine fil/ia, una cum filio meo dopno Adeffonso rege, pro redemcione $\mathrm{a} /{ }^{\beta}$ nime mee et paremtum meorum, facio cartulam sive testamen/tum donacionis eglesie Sancte Marie de Fusellis, quam siquidem eglesi/am gubernat et regit dopnus Poncius Guitardus, abbas mihi in $/ 6$ omnibus et per omnia fidelissimis, de villa que vocatur Cellanova, cum do/mibus, soliis, vinas, terris, pratis, exitus et directuris et cum omnibus termi/nis suis, tam populato quam et heremo. Dono eciam, predicte eglesie $/ 9$ Sancte Marie de Fusellis et vobis iam dicto Poncio Guitardo, abbati, / Arroyum de Frades, cum aqua currente ut habeatis perpetuo omnibus / diebus seculi, vos et sucessores vestri ad rrigando terminos, pretos, $1 \mathrm{i} /{ }^{12}$ nares, ortos et alia necesaria dicte eglesie Sante Marie de Fusellis, / et serviatis domino Ihesu Christo rredemtori nostro et beate Marie, matri sue. / Hoc enim facio pro rremissione peccatorum meorum et pro rredemcione anime $/{ }^{15}$ patris mei.

Quod si aliquis adversus hanc legitimam cartam ad in $/{ }^{15}$ fringendum insurgere temtaverit, in primis yram Dei et indig/nacionem habeat et cum Iuda traditore domini parres penas in eter/na damnacione lugeat, atque cum Datam et Abiron, 
quos terra $\mathrm{ob} /{ }^{18}$ sorbuit, sit dimersus in profundum inferni, et pro ausu temeritatis quam/tum infringere volverit duplicatum rrestauret eglesie vestre et vobis / vel sucessoribus vestris et in super pecet libras quinquaginta purissimi ${ }^{21}$ auri, et semper hec scriptura plenum obtineat firmitatis roborem / evo pereni in secula seculorum.

Facta cartula donacionis noto die $\mathrm{V} /$ kalendas iunii, era $\mathrm{M}^{\mathrm{a}} \mathrm{C}^{\mathrm{a}} \mathrm{L}^{\mathrm{a}} \mathrm{II}^{\mathrm{a}}$. Ego, urraca regina, que hanc cartam $\mathrm{fi} /{ }^{24}$ eri iussi tota mentis intencione signavi. (monogramma: VRRACA)

( $l^{a} \mathrm{col}$.) Bernardo, Toletano archiepiscoppu, confirmat. Sancia, soror supradicte regine, confirmat.- Petrus Assures, Carrionis comes, confirmat.- Petrus Gunsalvez, Larensium comes, confirmat.- Sancius Bermúdez, Legionis comes, confirmat.- Frola Didaz, Astorensium comes, confirmat.- Rodricus, Asturiensium comes, confirmat.- Ferran Garciaz de Fita confirmat.- Ferran Gaciaz Pellica confirmat.- Petro Lopez de Villa Flavista confirmat.- Petro Lopez de Mankellos confirmat.

( ${ }^{a} \mathrm{col}$. .) Pascasius, Burgensis eglesie presul, confirmat.- Didacus, Legionensis eglesie presul, confirmat.- Gonsalvo Sangez de Mante Torileo confirmat.Rodricus Didaz Surdi confirmat.- De scola regine, Garcia Eneqez confirmat.Petro Cidez de Facinas confirmat.- Tello Fernandiz de Mante Cea confirmat.Goter Pedrez de Avia confirmat.- Don Gervas de Palencia confirmat.- Petro Pascalez de Palencia cf.

Martinus notarius regine quod scripsit signauit (monogramma: MARTINUS).

Bellit.

1127, noviembre, 5 . 
Pedro I Pérez, obispo de Palencia, y Poncio Guitardo, abad de Santa María de Husillos, conceden el fuero de Palencia a los pobladores de Villaudilla, que había sido destruida por las sucesivas guerras y quemada por Martín Bernaldi. Reciben por ello sesenta morabetinos que emplearán en las necesidades de Santa María de Husillos y de la catedral de Palencia.

B. AHDP, Ampudia y Abadía de Husillos, Pergaminos, carp. 198-11. Inserto en sentencia de pleito entre Santa María de Husillos y el concejo de Villaudilla, dada el 2 de abril de 1243. Véase doc. núm. 61.

$C$. APA, $L P H$, f. 68v-69r. Inserto en traslado del doc. núm. 61.

$D$. BN, ms. 705, ff. 9v-10r y 137r-139r. Inserto en traslado del doc. núm. 61.

CIT. J. GONZÁLEZ, Siglos de Reconquista, 197.

In nomine sempiterne Trinitatis et indiuidue unitatis, Patris / et Filii et Spiriti Sancti. Ego, Petrus, gratia diuina sede Palentine episcopus, et ego, Poncius Guitardi, Fusellensis ecclesie abbas, cupientis populare et reedi/ficare villas de Sancta Maria de Fusiellos, quas longi temporis guerra destruxit et in desolacionem redegit, satisfacimus uoluntati et $/^{6}$ ad qui oferimus petitioni omnium hominum qui volunt populare Villabdella, tam presencium quam futurorum, dextruxit enim illam adque cremauit / Martinus Bernaldi in guerram. Nos ergo utili consilio prudentes, cum fauore clericorum totius capituli Sancte Marie, donamus forum de / Palencia omnibus ominibus que populauerint Villabdellam et in illa morauerint. Et concedimus in perpetuum ut nullum aliut seruicium faciant $\rho^{9}$ de isto diem antea in qualem facere solent homines de Palencia seniori sue, vnde accepimus de uobis sexaginta morabetinos, quos in necessi/tatibus Sancte Marie et Sancti Antonini expedimus. Huic autem nostre donationi et roborationi hanc adibemus firmitatem, ut si quis ultra alias / leges vel aliut forum uobis hominibus de Villabdella inponere uoluerit in qualem faciunt homines de Palencia hodie domno episcopo.

Qui $/{ }^{12}$ autem hoc testamentum infringere conatus fuerit, a sinu matris ecclesie sit depulsus, in perpetuo excomunicatus, inresipuerit post / mortem cum Iuda, qui Saluatorem nostrum inpiis iudeis tradidit, et cum Datan et Abiron, quos terra 


\section{LA ABADÍA DE SANTA MARÍA DE HUSILLOS: ESTUDIO Y COLECCIÓN \\ DOCUMENTAL $(904-1608)$}

terribiliter uiuos absorbuit, in inferno pe/nas lugeat sine fine, et insuper parti qui uocem uestram tenuerit in toto pariet mille morabetinos. Et hoc meum factum firmum et inuiolabi $/{ }^{15}$ le maneat semper.

Facta carta nonas nouembre, era M C LX quinta. Regnante rege Aldefonso in Hyspania. Petrus episcopus in / Palencia. Petro comite tenente Monçon et La Tor. Ego, pietate diuina, Petrus episcopus, et ego, Poncius abbas, qui hanc cartam scri/bere mandauimus et in capitulo Sancti Antonini et Sancte Marie legem coram testibus audiuimus et roborauimus. Guter Ferrandiz test. Rodrigo $/{ }^{18}$ Ferrandiz test. Gutier Gutierrez test. Martin Donez test. Ioannes Cipriani test. Cite Dotent test. Nunno Tellez test. Cid conf. Bellit / conf. Annaya conf. Et totum capitulum Sancti Antonini et Sancte Marie auditores et confirmatores. Petrus Bernaldi archidiaconus conf. / Miro archidiaconus test.

Ioannes, pontificias notarius, scripsit et hoc signo signauit. (signum)

1140, enero, 25. Palencia

Alfonso VII, “imperator Hispanie”, juntamente con su esposa, la emperatriz Berenguela, dona a Santa María de Husillos, a su abad Bernardo y a sus sucesores, en remisión de sus pecados y por su salvación y la de sus padres, la iglesia de San Boal con sus heredades, sita junto a la muralla de Villagarcía de Campos.

A. AHDP, Ampudia y Abadía de Husillos, Pergaminos, carp. 197-3. Perg., 307 x 552 mm.; escr. carolina; buena conservación.

B. APA, $L P H$, f. $13 \mathrm{v}-14$ r. En el margen izquierdo: $<$ Ojo. Este conde don Rodrigo Gómez es el fundador de la casa de la mesma".

C. AGS, Patronato eclesiástico. Inconexos, leg.159, ff. 25v-26v. Papel; escr. procesal; buena conservación.

D. BN, ms. 705, f. 20r-v. 


\section{DAVID MARCOS DIEZ}

CIT. J. GONZÁLEZ, Siglos de Reconquista, 197.

En el mismo día y lugar, Alfonso VII donó a Santa María de Husillos la iglesia de San Boal de Villagarcía de Campos (Valladolid) y confirmó a la sede episcopal palentina todos sus privilegios. Esta iglesia de San Boal sería con el tiempo objeto de litigio con el monasterio de Sahagún, como ilustran varios documentos de la colección documental de Sahagún:

Así por un documento de 11 de marzo de 1225, otorgado en Letrán por Honorio $\mathrm{III}^{4}$, éste manda al abad de Sandoval y al deán de Zamora que restituyan al monasterio de Sahagún la plena posesión de ciertas iglesias objeto de litigio, entre otras, San Boal de Villagarcía. Que la disputa era con el abad y cabildo de Santa María de Husillos lo muestra otro documento con la misma data y otorgante ${ }^{5}$, por el que el dicho Honorio III confía a los abades de Valparaíso y Sacramenta y al arcediano de Sigüenza, el examen de la causa que se ventila entre el obispo de Palencia y el monasterio de Sahagún sobre los derechos de ciertas iglesias, entre éstas, San Boal de Villagarcía. En este documento se cita a Santa María de Husillos como la litigante con Sahagún por San Boal.

Así pues, la posesión de San Boal por Santa María de Husillos duró desde 1140 hasta 1225. Aunque la iglesia de San Boal no aparece en las dos confirmaciones reales a Husillos de todas sus donaciones anteriores, la primera por Sancho III el 4 de mayo de 1158; y la segunda por Alfonso VIII el 13 de agosto de 1178, en la realizada por Alejandro III en 1179 sí que aparece.

Con todo, la información dada por el Diccionario de Historia Eclesiástica sobre que la iglesia de San Boal era señalada ya a fines del siglo XI por un monasterio de San Boal o Baudilio, que dotó copiosamente Nepociano Bermúdez y agregó al de Sahagún en clase de priorato, apareciendo en la época de esta donación (1097) bajo la advocación de San Salvador, es errónea, ya que como ilustra el documento $n^{\circ} 1002$ de la colección de Sahagún de Marta Herrero ${ }^{6}$, el monasterio de San Salvador es independiente de la iglesia de San Boal.

(Chistus, alfa et omega). Cum omnes et si non equaliter a Deo bona suscipiamus plurima equum est ut nos qui ceteris largius suscepisse uidemur de commissis bonis ęcclesiis et ueris Dei Christi colis largiter pro nostra et parentum nostrorum salute largiamur et huius rei / gratia, ego, Adefonsus Hispanie imperator una cum uxore mea Berengaria, grato animo uoluntate spontanea, nemine cogente, pro mea parentumque meorum salute, pro peccatorum nostrorum remissione, dono Deo et ęcclesię Sanctę Marię de Fusellis et / domno Bernardo, eiusdem ecclesię abbati suisque successoribus, ecclesiam Sancti Bauduli que sita est prope murum Uille Garsię, cum omnibus hereditatibus ad eandem ęcclesiam

\footnotetext{
${ }^{4}$ FERNÁNDEZ FLÓREZ, Sahagún, IV, 145-146, núm. 1633.

${ }^{5}$ FERNÁNDEZ FLÓREZ, Sahagún, IV, 146-148, núm. 1634.

${ }^{6}$ HERRERO DE LA FUENTE, Sahagún III, núm. 1002.
} 
pertinentibus cum terris, scilicet: et uineis cum intratibus et exitibus, $\beta^{\beta}$ montibus et uallibus, ortis et casis et solaribus et cum ceteris suis pertinentiis, ubicumque sint et poterint inueniri, supra memoratam ęcclesiam Sancti Bauduli, cum omnibus suis pertinentiis, tali modo, tali tenore, dono ęcclesię Sancte Marię de / Fusellis et domno Bernardo, ipsius loci abbati, eiusque successoribus ut eam, in perpetuum libere et absolute iure hereditario possideant.

Si quis uero, cuiuscumque generis sit, huius meę donationis confirmationem infregerit uel diminuerit, / anatemate feriatur et cum Datam et Abiron et Iuda proditore apud inferos nisi resipuerit tormentetur, insuper peccet ecclesie Sancte Marie de Fusellis mille morabitinos et hereditatem duplatam eidem restituat. $/^{6}$ Facta carta Palentię, VIII ${ }^{\circ}$ kalendas februarii, era $\mathrm{M}^{\mathrm{a}} \mathrm{C}^{\mathrm{a}} \mathrm{LXXVIII}^{\mathrm{a}}$. Adefonso imperatore imperante in Toleto, Legione, Cesaraugusta, Naiara, Castella, Galecia. Ego, Adefonsus, imperator hanc cartam quam iussi fieri, anno quinto quo coronam imperii primum in Legione, suscepi, confirmo et manu mea roboro. (signum: SIGNUM IMPERATORIS).

( $l^{a}$ col.) Petrus, Palentini episcopus sedis, confirmat.- Petrus, Secobiensis episcopus, confirmat.- Berengarius, Salamantinus episcopus, confirmat.- Petrus, Burgensis electus, confirmat.

$\left(\begin{array}{ll}2^{a} & \text { col. }\end{array}\right)$ Comes Rodericus Gomez confirmat.- Comes Osorius Martinez confirmat.- Comes Ferrandus confirmat.- Guterrus Ferrandez confirmat.Rodericus Ferrandez confirmat.

( ${ }^{a}$ col.) Didacus Munioz, maiordomus imperatoris, confirmat.- Iohannes Rana, tenens Uillam Garsiam, confirmat.- Didacus Frolez, alferiz, confirmat.- Lop Lopez confirmat.- Guterrus Pedrez Orco confirmat.

( $4^{a}$ col.) Michael Feliz, maiorinus in Burgis, confirmat.- Martinus Nozaniz, maiorinus in Campis, confirmat.

Geraldus scripsit iussu magistri Hugonis, cancellarii imperatoris. 
1140, enero, 25. Palencia

Alfonso VII confirma la totalidad de los bienes y derechos de la sede episcopal palentina, entre ellos, Santa María de Husillos con sus villas, decanías $y$ términos antiguos.

A. ACP, Arm. III, leg. 1, doc. 15. Perg., 460 x 520 mm.; escr. carolina; buena conservación.

B. ACP, Arm. III, leg. 3, doc. 19, en confirmación de Pedro I (1351, octubre, 18).

C. ACP, Arm. III, leg. 3, doc. 20, en confirmación de Pedro I (1351, octubre, 18).

D. ACP, Arm. III, leg. 3, doc. 27, en confirmación de Juan I (1379, agosto, 1).

E. ACP, Arm. III, leg. 10, doc. 1, Libro de privilegios, ff. 41v-42-v.

ED. FERNÁNDEZ DEL PULGAR, Historia secular y eclesiástica de Palencia, 182-184.ABAJO, Documentación catedral de Palencia, 80-82, núm. 35.

REG. SAN MARTÍN PAYO, Catálogo Catedral de Palencia, 76.

CIT. SÁNCHEZ HERRERO, Las diócesis del reino de León, 136.

En la nómina de lugares confirmados, después de Palencia con sus términos antiguos, se encuentra Santa María de Husillos.

1143, abril, 24. Letrán.

Inocencio II ratifica las donaciones efectuadas a la sede episcopal palentina. Enumera las más destacadas, entre ellas Santa María de Husillos con 
sus términos, villas, decanías y todas sus pertenencias, y relaciona los principales territorios que la integran.

A. ACP, Arm. III, leg. 8, doc. 3. Perg., 763 x 585 mm.; escr. carolina; buena conservación.

B. ACP, Arm. III, leg. 8, doc. 4, copia de 1155.

C. ACP, Arm. III, leg. 14, doc. 3, copia del siglo XII.

D. ACP, Arm. III, leg. 10, doc. 1, Libro de privilegios, ff. 19-20v.

ED. ABAJO, Documentación catedral de Palencia, 90-93, núm. 41.

REG. CASTRO TOLEDO, Colección diplomática de Tordesillas, núm. 14, 8, con fecha 26 de abril de 1143.- SAN MARTÍN PAYO, Catálogo Catedral de Palencia, 128.

CIT. CASTRO ALONSO, Episcopologio vallisoletano, 39.- FERNÁNDEZ DE MADRID, Silva Palentina, I, 120, con fecha 1118; II, 13, 85, con fecha 1103.- SERRANO, Obispado de Burgos, II, 35 .

En la nómina de lugares confirmados, Santa María de Husillos aparece en primer lugar.

1146, abril, 16 .

Pedro II de Agen, obispo de Palencia, con el consenso de los canónigos de San Antolín de Palencia y de Santa María de Husillos, permuta con Palea y María Andrés, su mujer, los siguientes bienes pertenecientes al obispado: una azeña sobre el río Carrión; cuatro tiendas en la ciudad de Palencia; una viña cercana a la viña de San Julián; la parte de viñedo perteneciente al obispo de la viña que posee Palea con Pedro Memez en San Román; la parte de viñedo que le corresponde de la viña que plantó Miguel Martínez en Grijota; las heredades que pertenecieron al obispo antecesor Pedro I Petriz; un huerto y varias tierras sitas en el Otero del Obispo, Grijota y el Hospital de Fuentes; y dos tierras pertenecientes a Santa María de Husillos próximas al Hospital de Fuentes y que 
fueron de Ethavida de Ribas . Permuta estas heredades por unas tierras y viñas sitas en Villamuriel y parte del monte de dicho lugar, pertenecientes a dicho Palea y su mujer.

En corroboración dio Palea a los señores de San Antolín, un ezebro y dos gallos, y a los señores de Santa María de Husillos, un maravedí.

A. ACP, Arm. II, leg. 1, doc. 7. Carta partida por ABC de tipo rectilíneo. Perg., 385 x 315 (+76) mm.; escr. carolina; buena conservación.

ED. ABAJO, Documentación Catedral de Palencia, 95-97, núm. 43.

REG. SAN MARTÍN PAYO, Catálogo Catedral de Palencia, 39.

CIT. SERRANO, Obispado de Burgos, II, 31; y Cartulario de Arlanza, 194.

(alfa, beta, omega...) In Christi nomine et indiuidue Trinitatis, Patris et Filii et Spiritus Sancti, amen. Ego, Petrus, Dei gracia Palentine minister aecclesiae, cum assensu et uoluntate canonicorum eiusdem aecclesiae, facio cartam tibi, Paleae, et uxori tue, / Marie Andree, de camiacione quam fecimus inter nos.

Dono, enim, tibi unam azeniam, sitam super flumen Carrionis, inter duas alias azenias, prope ortum qui fuit Osberti. Preterea, dono tibi in eadem / uilla quatuor tendas, que sunt in calle, et habent quatuor affrontaciones: in prima parte, carniceriam; de secunda, palacium episcopi, cum $\mathrm{I}^{\mathrm{a}}$ passada de corrali, quam dat ei; de tercia, tendam Guilelmi $\beta$ Ermegodi; de IIII ${ }^{\mathrm{a}}$, uero, parte, callem qui discurrit per mediam uillam. Insuper, do tibi uineam que est inter duas aquas, prope uinea Sancti Iuliani, derechexo que est episcopi in alia parte fluminis, et affrontat: / de I ${ }^{\mathrm{a}}$ partem, uineam que fuit Poncii Raimundi; de $\mathrm{II}^{\mathrm{a}}$, uineam Martín Pedriz Gordo; de III ${ }^{a}$, terra Migael Pedrez. Addo, etiam, huic donacioni illam meam partem de uineas, quas posuisti tu, / Palea, cum Petro Memez, in Sancto Romano et affrontat: de $\mathrm{I}^{\mathrm{a}}$ parte, uineam Pelagii Belidez de Magaz; de $\mathrm{II}^{\mathrm{a}}$, uineam Pelagii de Ponte; de III ${ }^{\mathrm{a}}$, uineam Migael Romanez. Et prope, in eodem $/{ }^{6}$ loco, do tibi meam racionem quam habeo in uineam quam plantauit Migael Martinez, in alia parte me, que pergit ad Ecclesia Auta, prope uineam de Didago Fernandez, et 


\section{LA ABADÍA DE SANTA MARÍA DE HUSILLOS: ESTUDIO Y COLECCIÓN \\ DOCUMENTAL $(904-1608)$}

affrontat: uineam / de Arnaldo, et in alia parte, uineam Martini Pedriz Grandis. Insuper, do tibi omnes terras que fuerunt Petri, Palentini aepiscopi, antecessoris mei, quas habuit de hereditate sua in Palencia, et aream, / similiter, quam habuit ad portam de Monzon. Dono, etiam, tibi illum ortum quem habuit in prestimonio Iohanem Radmirez, inter ortum quem tenet episcopus de Zamora et ortum quem tenet Albertinus $/{ }^{9}$, prope ortum quem habet Arsenius, germanus episcopi; et unam terram ad Otero de Episcopo; et duas terras ad Ecclesia Auta, ad Ospitale de Fontibus; necnon et alias duas terras ad illas Fontes, que fuerunt de / Ethauida de Ribas et sunt de pertinencia Sancte Marie de Fusellis, quorum una habet affrontaciones: de I ${ }^{\mathrm{a}}$ parte, Fernand Romanez; de alia, uia publica; de III ${ }^{\mathrm{a}}$, Migael Cidez; / alia, uero, habet affrontaciones: de $\mathrm{I}^{\mathrm{a}}$ parte, Berenguer Bernard; de alia, Fernandus Romanez; aliam, quoque, terram iuxta illos de pertinencia Sancti Iacobi de Quintanella.

Pro his omnibus $/^{12}$, accipio a te omnem illam hereditatem quam habebas in Uilla Morel, uidelicet, unam azeniam et XII arenzadas uinearum et VIII collazos et terras quantas possunt laborare duo / iuga bouum in anno et racionem, quam habebas in monte supredicte uille, cum suis ingressibus et regressibus; et in de susanga, unas luas. Hoc testamentum quare ratum et firmum / esse uolo.

Quod si, in posterum, aliquis, quicumque sit, hoc testamentum uiolenter infringere temptauerit, non id ualeat edificere sed potestati, cui predictus Palea uocem suam comiserit, $/{ }^{15}$ pectet in coto $\mathrm{M}$ morabitos et talem hereditatem duplatam ei restituat.

Facta carta ista XVI kalendas mai, era $\mathrm{M}^{\mathrm{a}} \mathrm{C}^{\mathrm{a}} \mathrm{LXXX}^{\mathrm{a}}$ IIII ${ }^{\mathrm{a}}$, regnante Aldefonso imperatore / in Ispania et rege Garsia tenente Monzon; Guter Fernandez, princeps in terra nostra; comes Ermengaudus, maiordomus imperatoris; Petro secundo, episcopo in Palencia; Iohannes / Andres, merino.

Ego, Petrus Palentinus episcopus, una cum consenso canonicorum ecclesie Sancti Antonini et Sancte Marie de Fusellis, qui hanc cartam scribere mandaui coram subscriptis $/^{18}$ testibus, clericis et laicis, in capitulo Sancti Antonini et Sancte Marie de Fusellis legere audiui et propria manu roboraui et testamentum, quod ei imperator in Uilla Morel de supradicta hereditate / fecerat, mandato eidem imperatoris et assensu ab eo accepi. 
( $1^{a}$ col.) Herbertus, prior, testis. Nicholaus, archidiaconus, testis. Raimundus, archidiaconus, testis. Bernardus, archidiaconus, testis. Item de laicis: Petrus Diaz testis. Domnus Arsenius testis. Ennego Petriz testis.

( $2^{a}$ col.) Guilelmus, sacricustos, testis. Petrus Otoni, prepositus, testis. Petrus Suprinus testis. Et omnis canonici eiusdem ecclesie: Fernand Annaiat testis. Martin Petriz testis. Roderico Arnaldi testis. Berengel Bernald testis.

$\left(3^{a}\right.$ col. $)$ De canonicis Sancte Marie de Fusellis: Petrus, comes, prior, testis. Andreas, precentor, testis. Andreas, sacricustos, testis. Et omnes canonici eiusdem ecclesie: don Miro, testis. Pexon de Socouia testis. Richard de Olea testis.

( $\left.4^{a} \mathrm{col}.\right)$ Cid conf. Bellid conf. Anaia conf.

Et in corroboramentum istius cartule dedi ego, Palea, senioribus Sancti Antonini uno enebro et duos gallos et senioribus Sancte Marie de Fusellis dedi I morabetino.

Petrus scripsit et hoc signum fecit (signum).

1151, junio, 12.

Pedro Arnaldo dona a Santa María de Husillos, en remedio de su alma, las de sus parientes, las de sus padres y la de su esposa, Juliana, una viña perfectamente delimitada, en el pago llamado Arroyo, para que se hagan cuatro aniversarios anuales, entregando en cada aniversario cincuenta panes, un carnero, un tocino, cuatro gallinas y seis terrazas de vino. Para después de su muerte, deja la viña en usufructo a su criado Juan, que debe cumplir lo 
estipulado con Santa María de Husillos. En caso de que no lo cumpliera, dicha iglesia elegiría al usufructuario.

A. AHDP, Ampudia y Abadía de Husillos, Pergaminos, carp. 207-6. Perg., 214 x 345 mm.; escr. carolina; buena conservación.

$B$. APA, $L P H$, f. $14 \mathrm{r}-\mathrm{v}$.

C. BN, ms. 705, ff. 20v-21r.

CIT. J. GONZÁLEZ, Siglos de Reconquista, 197.

Raimundo II de Minerva, obispo de Palencia y tío materno de Sancho III de Castilla y Fernando II de León, aparece como "senior" en Santa María de Husillos. Es posible que en la fecha de este documento la dignidad abacial estuviera vacante, ya que solamente se dice que Pedro es prior y “comes” en Santa María.

In Dei nomine. Ego, Petro Arnaldo, placuit michi bono pacis, bono animo, bone uoluntas et caro consilio, nullius quoque gentis imperio nec suadentis / articulo, sed propria michi accessit uoluntas, ut facerem cartam de mea hereditate pro remedium anime mee uel parentorum meorum, patri et matri mee / et uxor mea, Iuliana. Inprimis dono in anniuersarium, una uinea que fuit de Dominico Uermudez, in pago que uocitant Arroyo, et affrontat de ${ }^{\beta} \mathrm{I}^{\mathrm{a}}$ pars, illo Arroyo; de II ${ }^{\mathrm{a}}$ pars, uinea de filios de Dominico Iaguez et illo maiolo de La Uega que fuit de Annaya, circa uinea de Petro Iulianez / et alio maiolo en uinea Larigo, circa uinea de Petro Tellez; de alia pars, uinea de Petro Diaz; de III ${ }^{\mathrm{a}}$ pars, semdero que uenit a la peschera et la / cuba que fuit de don Berencher; et IIII ${ }^{\mathrm{a}}$ pars, del molino de Angulo de Caput de Ca Uinea et el medio pumar que plantauit don Arnaldo de $/^{6}$ Caput de Uinea. Et hanc hereditatem que supra diximus faciant inde IIII $^{\text {or }}$ anniuersarii unusquisque anni. Et unumquemque anniuersarium / faciant temporibus suis et dent LL ( $\mathrm{sic}$ ) panes et singulos carneros et singulos tocinos et IIII $^{\text {or }}$ IIII $^{\text {or }}$ (sic) gallinas et sex sex (sic) terrazas de uineo. / Et post obitum Petrus Arnaldus teneat Iohannes, criado, et adimpleat hoc quod superius resonat. Et si non adimpleuerit, dent illa hereditate $\rho^{9}$ los canonici Sancte Marie ad uno de alios criados qui hoc adimpleat, et si non adimpleuerint, remaneat, a canonici Sancte Marie et faciant et adimpleant / istos anniuersarios unumquemque annum. Et hoc testamentum firmum permaneat omni tempore. 
Et siquis tamen uenerit ad disrumpendum, / anatematizatus et excommunicatus sit et cum Iuda traditore et Datan et Abiron habeat penas in inferni, amen. Et in coto pectet ubi uult qui uox uestra ${ }^{12}$ pulsauerit, $\mathrm{C}$ morabetis et ipsam hereditatem duplatam in talis similis locis.

Facta karta noto die pridie idus iunii, / era $\mathrm{M}^{\mathrm{a}} \mathrm{C}^{\mathrm{a}} \mathrm{LXXX}^{\mathrm{a}}$ VIIII'. Imperator Ildefonso in Leon et in Gallecia et in Castella et in Toleto atque in Almaria. Maiordomo comite / Poncius. Merino Diago Moniuz. Raimundus, episcopus sedens in Palentina sedis et senior in Sancta Maria. Gualterius maiordomo. Petrus, prior, $/^{15}$ comes in Sancta Maria. Et ego, Petrus Arnardus, qui hanc cartam mandaui scribere et coram testes firmabi. Diago Petriz testis. Martin Iaguez testis. ./ Moniu Alfonso testis.

Andreas, sacricustus, confirma. Andrea, capiscol, confirma. Berengarius confirma. Et concilium Sancte Marie uisores et auditores. Cid, Bellid, Annaya testes.

Petrus notuit.

1154, septiembre, 19.

El abad Raimundo [Giliberti] y los canónigos de Santa María de Husillos, por amor a Dios y por los servicios recibidos, donan al concejo de Husillos el soto de Las Mimbreras, sito en la Serna de Congosto y que se extiende hasta el arroyo de Viña Alarigo. Reciben en roboración tres maravedís.

A. AHDP, Ampudia y Abadía de Husillos, Pergaminos, carp. 207-4. Perg., 92 x 425 mm.; escr. carolina.; buena conservación.

$B$. APA, $L P H$, ff. $14 \mathrm{v}-15 \mathrm{r}$.

C. BN, $m s .705$, f. $21 \mathrm{r}-\mathrm{v}$.

D. APA, caja 152, carp. 1. Papel; 1 hoja; buena conservación. Traslada erróneamente la fecha al escribir: MCLXXXII. Escritura humanística; primera mitad del siglo XVII. 
E. ARCHV. Salas de lo Civil. Masas (F), caja 2787-1, f. 62r-v. Al igual que el anterior, traslada erróneamente la fecha al escribir: MCLXXXII. Traslado desde $A$, aportado como prueba en un pleito fenecido (1774) de la colegiata de Ampudia con el concejo de Husillos por la posesión de ciertas heredades.

CIT. J. GONZÁLEZ, Siglos de Reconquista, 197.

El patronímico del abad Raimundo aparece en la inscripción conmemorativa de Sancho III que se conserva en la iglesia de Santa María de Husillos.

In nomine Domini nostri Ihesu Christi. Notum sit omnibus quod ego, abbas Raimundus Sanctę Marię de Fusellis, uobis concilium de Sancta Maria, facio uobis carta, una cum canonici mei, de uno soto de Uimueras, pro amore Dei et propter seruicium quod mi/chi facitis. Et est ipsum sotum in locum predictum de illa Serna de Congosto usque ad uadum riuuli de Uinea Alarigo, ambas illas riberas del riuulo. Et accepi de uos in roboratione III morabitinos.

Et siquis tamen contra / hanc cartam uenerit ad disrumpendum, sit maledictus. Facta hanc carta noto die XIII kalendas octubris, era $\mathrm{M}^{\mathrm{a}} \mathrm{C}^{\mathrm{a}} \mathrm{LXXXX}$ II. Regnante imperator Adefonsus cum imperatrice donna Rika in Ispania. Episcopus Raymundus II in Palentina sedis. $\beta$ Guter Fernandez et don Nunno in Monzon. Maiorino de imperator, Didaco Moniz. Maiordomo comite, Poncius. In Sancta Maria, maiorino Michael Martinez. Saion, Iohannes Dominguez. Et ego, abbas Raimundus, una cum conuentum / Sanctę Marie, in hanc karta que fieri iussimus manus nostras roboramus coram testis. Richardus, sacricustos, testis. Lupus, capiscol, testis. Berengarius, presbiter, testis. Petrus Iohanes, prepositus, testis. Et capitulum Sanctę Marię una cum / concilio, auditores et confirmatores. Cid confirmat. Belid confirmat. Anaia confirmat.

(monogramma: L.M.)

1158, mayo, 4. Carrión de los Condes. 
Sancho III confirma las posesiones que Santa María de Husillos recibió de Urraca I, su abuela, los condes de Monzón y otros particulares: Justa Coxa, que donó San Pedro de Valdepero; Martín Sánchez, que donó San Jacobo de Calabazanos; Fagin Pelaiz, que donó las iglesias de San Mamés, San Román y San Martín, todas en Frechilla; María Gudesteiz, que donó la iglesia de San Miguel de Pozuelos y una heredad en Torre de Astudillo; la mujer de Ermildo Rodríguez, que donó San Miguel de Fuentes de don Bermudo; y Santa María de Castrillo.

A. AHDP, Ampudia y Abadía de Husillos, Pergaminos, carp. 197-4 b. Perg., 401 x 648 mm.; escr. carolina.; buena conservación, aunque con manchas en los márgenes.

B. AHDP, Ampudia y Abadía de Husillos, Pergaminos, carp. 198-15. Perg., 736 x 679 mm.; escr. gótica redonda de privilegios; regular conservación, con varias manchas de humedad que a veces impiden la lectura y una rotura en la línea 25. Mantiene los orificios y la cinta pero no el sello.

Sobre la primera línea del texto: <está éste a f. 43>. También en el dorso aparece escrito que este documento se corresponde con el que aparece escrito en el f. 43 del Libro de los Privilegios de Husillos; esto no es cierto, pues entre los ff. 43r y 46r se contiene el privilegio rodado concedido por Fernando IV, en el cual, al ser posterior, sí se contiene el de Sancho IV. Inserto en confirmación de Sancho IV, dada a 31 de julio de 1290. Véase doc. núm. 82.

C. AHDP, Ampudia y Abadía de Husillos, Pergaminos, carp. 199-19. Perg. 684 x 631 mm.; escr. gótica redonda de privilegios y de albalaes; buena conservación; sello pendiente de plomo. Al final de la primera línea, la F y la E del nombre FERNANDO, están delimitadas pero sin miniar. Inserto en confirmación de Fernando IV, dada en Medina del Campo, el 10 de mayo de 1305. Véase doc. núm. 97.

D. AHDP, Ampudia y Abadía de Husillos, Pergaminos, carp. 200-21. Perg., 784 x 638 mm.; escr. gótica redonda de privilegios y precortesana. Su conservación no es muy buena, pero se puede leer perfectamente. Se conserva el sello de plomo pendiente de una cuerda. Inserto en confirmación de Pedro I del privilegio de Alfonso XI, dada en Valladolid, a 28 de noviembre de 1351. Véase doc. núm. 135.

E. AHDP, Ampudia y Abadía de Husillos, Pergaminos, carp. 201-23. Perg. 714 x 608 mms.; escr. gótica de privilegios y precortesana; regular conservación, aunque las roturas y manchas permiten su perfecta lectura. Inserto en confirmación de Enrique II del privilegio de Alfonso XI, dada en Valladolid, a 20 de mayo de 1371. Véase doc. 163.

F. AHDP, Ampudia y Abadía de Husillos, Pergaminos, carp. 201-27. Perg., 784 x 685 mm.; escr. gótica de privilegios y precortesana. Muy deteriorado, ha desaparecido, prácticamente, toda su parte izquierda. No conserva sello ni cuerda. Inserto en confirmación de Juan I del privilegio de Enrique II, dada en Burgos, a 22 de agosto de 1379. Véase doc. núm. 193. 
$G$. APA; $L P H$, f. $16 \mathrm{r}-\mathrm{v}$. Traslado de $A$.

$H$. APA, $L P H$, ff. 43r-46r. Traslado de $B$.

I. APA, $L P H$, ff. $74 \mathrm{v}-78$ r. Traslado de $D$.

$J$ APA, $L P H$, ff. $88 \mathrm{v}-92$ r. Traslado de $E$.

$K$. APA, $L P H$, ff. $104 \mathrm{r}-108 \mathrm{v}$. Traslado de $F$.

L. AGS, Patronato eclesiástico. Inconexos, leg.159, ff. 26v-28r. Papel; escr. procesal; buena conservación.

M. BN; $m s .705$, f. 23r-v. Traslado de $G$.

$N$. BN, $m s .705$, ff. 70v-76v. Traslado de $H$.

N. BN, $m s .705$, ff. 155r-166r. Traslado de $I$.

$O$. BN, $m s .705$, ff. 196v-201r. Comete numerosos errores. Traslado de $J$.

$P$. BN, $m s .705$, ff. $231 \mathrm{v}-238$ r. Traslado de $K$.

ED. J. GONZÁLEZ, Alfonso VIII, II, núm. 43, 77-90.- SAN MARTÍN PAYO, Villaldavín, 121123.

CIT. IZQUIERDO MISIEGO, Historia de Ampudia, 116.

(Christus, alfa et omega). In nomine Sancte et individue Trinitatis que a fidelibus in unitate colitur et adoratur decet inter ceteros homines regiam precipue maiestatem ecclesias Dei diligere ecclesiasticas personas honorare et eis grata sufragia verbo et opere conferre. /

Ea propter, ego, rex Sancius Dei gratia, domni Adefonsi bone memorie illustris Hispaniarum imperatoris filius, facio cartam firmitatis et textum scripture in perpetuum ualiturum Deo et ecclesie Sancte Marie de Fuselus. Per presens scriptum confirmans et corroborans cunctas / uillas et hereditates quas regina domina Urraca, aua mea, prefate ecclesię et Federnandus Assuriz, comes, et Gunzaluus Assuriz, comes, et Nunus Assuriz, qui eandem ecclesiam construerunt et edificauerunt, pro remedio animarum suarum et pecatorum suorum remissione, dederunt, scilicet: $\beta$ Uillam Dumdaui, quam eidem ecclesie regina domina Urraca, cum suis terminis et directuris et cum illa pisqueira de Derunada, que est subtus pontem ecclesię Sancte Marie, dedit. Et alias uillas et monasteria que ei dederunt prefati comites, scilicet: Sanctum Sebas/tianum de Hermidas cum suis terminis et directuris; Uillam Abdela; Paigares; Sanctum Adrianum; Uillam de Guterre Aluariz; Sanctam Eugeniam de Pinia; Sanctum Iulianum; Sanctum Facundum de Paredes; Sanctam Mariam de Celeirolum et Sanctam Mariam de 
Fonte Pudia et Cellam Nouam cum / Arroiu de Frades; Paigaregus cum sua defesa et terminis et directuris; Sanctum Sebastianum de Bezerril; Sanctam Eufemiam de Beruesca; Sanctum Petrum de Ualdeperu, quod dedit Iusta Coxa; Sanctum Iacobum de Calabazanus, quod dedit Martinus Sanctus; in Frechela, Sanctum

Mametem; / 6 Sanctum Romanum; Sanctum Martinum, que dedit Fagin Pelaiz; Sanctum Michaelem de Puzolus et hereditatem de Turre de Studelu, que dedit Maria Gudesteiz; Sanctum Michaelem de Fontes de dun Uermudo, quod dedit uxor de Ermildo Rudriguiz; Sanctam Mariam de / Castrelu.

Confirmo et corroboro has predictas uillas, hereditates, monasteria, quecumque habet uel deinceps adipisci poterit et diuisas, similiter sic in diebus patris mei imperatoris predicta ecclesia habuit et possedit.

Cauto etiam et contestor ganatum domini Raimundi, / prefate ecclesię ministrantis abbatis, et omnium successorum suorum et canonicorum eiusdem ecclesie, tam presencium quam futurorum, tali modo et tenore ut si quis predictum ganatum pignorauerit uel per uim abstulerit, pectet abbatis eiusdem ecclesie pro suo ganato quingentos $/^{9}$ solidos et canonicis similiter pro suo, et ipsum ganatum duplicatum reddat.

Si quis hoc meum factum ex meo genere uel alieno, ausu temerario irrumpere presumpserit, sit maledictus et excomunicatus, et cum Iuda proditore Domini in inferno dampnatus, / et pectet regie maiestati mille morabetinos. Et hoc meum factum imperpetuum maneat firmum.

Facta carta in Carrione, sub era $\mathrm{M}^{\mathrm{a}} \mathrm{C}^{\mathrm{a}} \mathrm{LXXXXVI}^{\mathrm{a}}$ et quartas nonas madii, anno quo domnus Adefonsus, famosissimus Hispaniarum imperator, obiit. /

Raimundo, comite Barchinone, et Sancio rege Nauarre, existentibus uassallis domni regis. Ego, rex Sanctus, hanc cartam quam fieri iussi meo propio robore confirmo.

( $1^{a} \mathrm{col}$.) Comes Almanrricus conf.- Comes Poncius conf.- Comes Lupus, signifer regis, conf.- Comes Uela de Nauarra conf.- Guter Fernandiz, potestas in Castella, conf.- Garsia Garsiaz de Aza conf.- Nunus Petriz conf.

( $2^{a}$ col.) Gumez Gunzaluiz, maiordomus regis, conf.- Fernandus Ruderiguiz conf.Gundisaluus de Maranon conf.- Aluarus Petriz conf.- Domnus Boso, maiorinus in 


\section{LA ABADÍA DE SANTA MARÍA DE HUSILLOS: ESTUDIO Y COLECCIÓN \\ DOCUMENTAL $(904-1608)$}

Saldania, conf.- Gunxaluus Rudriguiz conf.- Didacus Fernandiz, maiorinus Burges, conf.

(Signum: SIGNVM REGIS SANCII)

$\left(\begin{array}{ll}3^{a} & c o l\end{array}\right)$ Iohannes, Toletanus archiepiscopus et primas Hispanie, conf.Raimundus, Palentinus episcopus, conf.- Vilielmus, Secobiensis episcopus, conf.Petrus, Burgensis episcopus, conf.- Iohannes, Oxomensis episcopus, conf.Cerebrunus, Segontinus episcopus, conf.- Rudericus, Calagurritanus episcopus, conf.- Ordonius, prior hospitales, regis capellanus, conf.

Martines, domni regis notarius. Bernaldo, Palentino archidiacono, existente cancellario, scripsit.

1158, mayo, 4. Carrión de los Condes.

Sancho III, en remedio de las almas de sus padres y de su propia salvación, concede a Raimundo, abad de Santa María de Husillos, y a los canónigos de dicha iglesia, el privilegio de los infanzones, exentándolos asimismo de todo servicio real.

B. AHDP, Ampudia y Abadia de Husillos, Pergaminos, carp. 198-13. Perg., 406 x 375 mm.; escr. gótica redonda de privilegios y gótica documental; buena conservación. Tiene cinta pero no sello. Inserto en confirmación de Sancho IV, dada en Valladolid, a 16 de agosto de 1291. Véase doc. núm. 84 .

C. AHDP, Ampudia y Abadía de Husillos, Pergaminos, carp. 199-17. Perg., 696 x 586 mm.; escr. gótica redonda de privilegios y de albalaes; muy buena conservación. Sello de plomo pendiente. Inserto en confirmación de Fernando IV, dada en Valladolid, a 7 de marzo de 1312. Véase doc. núm. 100 .

D. AHDP, Ampudia y Abadía de Husillos, Pergaminos, carp. 199-18. Perg., 742 x 574 mm.; escr. gótica redonda de privilegios y gótica documental; buena conservación. Sello de plomo. Inserto en confirmación de Alfonso XI, dada en Valladolid, a 16 de diciembre de 1331. Véase doc. núm. 113. 


\section{DAVID MARCOS DIEZ}

E. AHDP, Ampudia y Abadia de Husillos, Privilegios Reales, carp. 200-20. Inserto en confirmación de Pedro I, dada en Valladolid, a 12 de noviembre de 1351. Véase doc. núm. 134. F. AHDP, Ampudia y Abadia de Husillos, Privilegios Reales, carp. 201-24. Inserto en confirmación de Enrique II del privilegio de Alfonso XI, dada en Valladolid, a 20 de mayo de 1371. Véase doc. núm. 164.

G. AHDP, Ampudia y Abadia de Husillos, Privilegios Reales, carp. 201-26. Perg., 719 x 573 mm.; escr. gótica de privilegios; buena conservación. Mantiene parte de la cinta pero no el sello. Inserto en confirmación de Juan I del privilegio de Enrique II, dada en Burgos, a 22 de agosto de 1379. Véase doc. núm. 194.

H. AHDP, Ampudia y Abadía de Husillos, Pergaminos, carp. 202-29. Perg., 717 x 517 mm.; escr. gótica redonda de privilegios y precortesana; buena conservación. Todos los elementos decorativos están dibujados pero sin miniar. No conserva la cinta pero sí el sello de plomo, que está suelto. Inserto en confirmación de Enrique III del privilegio de Juan I, dada en Burgos, a 20 de febrero de 1392. Véase doc. núm. 213.

I. APA, $L P H$, ff. 40v-41r. Traslado de $B$.

$J$. APA, $L P H$, f. 48r-49v. Traslado de $C$.

$K$. APA, $L P H$, ff. 60r-61v. Traslado de $D$.

$L$. APA, $L P H$, ff. 72r-74r. Traslado de $E$.

$M$. APA, $L P H$, ff. 92r-94v. Traslado de $F$.

$N$. APA, $L P H$, ff. $108 \mathrm{v}-111 \mathrm{r}$. Traslado de $G$.

$\tilde{N}$. APA, $L P H$, ff. $124 \mathrm{r}-127 \mathrm{v}$. Traslado de $H$.

$O$. BN, ms. 705, ff. 64r-66r. Traslado de I.

$P$. BN, $m s .705$, ff. 79r-83v. Traslado de $J$.

$Q$. BN, $m s .705$, ff. $118 \mathrm{v}-124$ r. Traslado de $K$.

$R$. BN, $m s .705$, ff. $147 \mathrm{v}-154 \mathrm{v}$. Traslado de $L$.

$S$. BN, $m s .705$, ff. 201r-208r. Traslado de $M$.

T. BN, $m s .705$, ff. 238r-242r. Traslado de $N$.

U. ARCHV. Salas de lo Civil. Masas (F). Caja. 2787-1, ff. 49v-50r. Traslada la parte de los confirmantes y testigos, al expresar que ya se ha trasladado el asunto. Traslado desde $B$, aportado como prueba en un pleito fenecido (1774) de la colegiata de Ampudia con el concejo de Husillos por la posesión de ciertas heredades. El receptor no transforma la data desde la era hispánica.

ED. J. GONZÁLEZ, Alfonso VIII, II, núm. 42, 75-77.

In nomine Sancte et indiuidue Trinitatis, que a fidelibus in unitate colitur et adoratur. Quoniam ratio exigit ut ea que a regibus $\beta$ fuit scripto firmentur, ne temporum diuturnitate ea que gesta sunt obliuioni tradantur, decet et inter ceteros homines regiam precipue magestatem ecclesias diluyere, ecclesiasticas personas 
hono/rare et eis grata suffragia uerbo et opere conferre. Ea propter, ego, rex dompnus Sancius, Dey gratia dompni Alffonsi, bone recordationis, illustris Yspaniarum imperatoris filius, consilio et auc/toritate comitum et principum regni mei, libenti animo et uoluntate spontanea, pro animabus parentum meorum et salute propria, dono et concedo uobis, dompno Raymundo, abbati ecclesie Sancte Marie $/{ }^{6}$ de Fusellis, et omnibus successoribus uestris et canonicis eiusdem ecclesie, tam presentibus quam futuris, in omnibus et per omnia, forum et calumniam de infancon, ut quicumque uobis iniuriam fecerit / in dicto uel in facto dehonestando, impellando, percutiendo uel res uestras auferendo, sicut est de infancon, pectet uobis quingentos solidos. Et etiam facio uos liberos et absolutos ad omni ser/uicio regio, ut nec michi unquam aut posteritati mee aliquod seruicium faciatis coacti. Set semper ecclesie Sancte Marie de Fusellis seruite et Deum pro nobis et pro antecessoribus $\rho^{9}$ et posteris nostris rogate, vt ipse per gratiam suam et oraciones uestras, ceptrum regni nostri coroboret et confirmet per longa seccula et in fucturo, tam preteritis quam presentibus et futuris de / genere nostro, uitam eternam concedat.

Si quis hoc meum factum ex meo genere uel alieno ausu temerario irrumpere presumpserit, sit maledictus et excomunicatus et cum Iuda proditore in in/ferno dampnatus, et pectet regie magestati mille morabetinos, et hoc meum factum imperpetuum maneat firmum.

Facta carta in Carrione, sub era $\mathrm{M}^{\mathrm{a}} \mathrm{C}^{\mathrm{a}} \mathrm{LXXXX}^{\mathrm{a}} \mathrm{VI}^{\mathrm{a}}$, quarto nonas $/{ }^{12}$ madii, anno quo dompnus Alfonsus, famosissimus Yspaniarum imperator, obiit. Raymundo, comite Barchinione, et Sancio, rege Nauarre, existentibus uasallus domini regis.

Ego, rex Sancius, / hanc cartam, quam fieri iussi, meo propio robore confirmo. Comes Almanrricus conf. Comes Poncius conf. Comes Lupus, signifer regis, conf. Comes Vela de Nauarra conf. Gutier Fer/nandez, potestas in Castiella, conf. Garcia Garciaz de Aça conf. Nunno Peret conf. Gomez Gonzalvez, maiordomus regis, conf. Fernandus Rodriguez conf. Gundisaluus de Maranon $/{ }^{15}$ conf. Aluarus Perit conf. Domnus Bosus, maiorinus in Saldanna, conf. Gundisaluus Rodriguez, maiorinus Burgis, conf. Iohannes, Toletanus archiepiscopus et primas Yspanie, conf. Raymundus, Palentinus / episcopus, conf. Guillelmus, Segobiensis episcopus, conf. Petrus, Burgensis episcopus, conf. Iohannes, Oxomensis 
episcopus, conf. Cerebrunus, Segontinus episcopus, conf. Rodericus, Calagurritanus episcopus, conf. Ordonius, prior Ospitalis, / regis capellanus, conf. Martines, domini regis notarius, Bernaldus, Palentinus archidiaconus existens cancellarius, scripsit.

1158, mayo, 23. Sahagún.

Sancho III de Castilla suscribe un pacto de paz y amistad con su hermano Fernando II de León, tras el fallecimiento del padre de ambos, Alfonso VII.

Se comprometen a ayudarse mutuamente si alguien atacara a uno de ellos, excluido el conde de Barcelona, tío de ambos. Ninguno pactará con el rey de Portugal o con otro que pudiera dañar a uno de los dos. Se declaran entre sí herederos mutuos si uno muriera sin hijo varón legítimo; si dejaran heredero, éste mantendrá el presente pacto.

El rey Sancho devuelve al rey Fernando las tierras que ocupó en su reino, con la condición de que la tengan los condes Poncio, Osorio y Poncio de Minerba, y le ayuden con ella en caso de no cumplir lo pactado; si no llegaran a un acuerdo en un año, toda la tierra le será entregada a Sancho. Al conde Osorio le concede por heredad la tierra que ocupa. El rey de León mantendrá a los citados condes y a sus herederos en posesión de la tierra y con ella deben servirlo lealmente.

El rey Fernando entrega a su hermano los condes Ramiro, Pedro y Poncio de Minerba y Abril, para que si no se cumple lo pactado, sirvan con sus personas y bienes al rey de Castilla.

Acuerdan que lo que conquisten en Portugal se dividirá entre ambos y una vez conquistado todo el rey Fernando II dividirá el reino en dos partes y Sancho eligirá la que él se queda.

La tierra en mano de los musulmanes se dividirá de la siguiente forma: Fernando tendrá Niebla hasta Lisboa, a saber, Niebla, Mentanches, Mérida, Badajoz, Évora, Mértola, Medina de Silves, Silves y Caztaila, y Sancho el resto. 


\section{LA ABADÍA DE SANTA MARÍA DE HUSILLOS: ESTUDIO Y COLECCIÓN DOCUMENTAL $(904-1608)$}

\section{La ciudad de Sevilla junto con las ciudades y fortalezas desde dicha ciudad hasta la desembocadura del Guadalquivir serían igualmente repartidas por mitad.}

A. AHDP, Ampudia y Abadía de Husillos, Privilegios Reales, carp. 197-4. Original múltiple. Carta partida por IN NOMINE SANCTE ET INDIVIDUE TRINITATIS QUE A FIDELIBUS IN UNITATE COLITUR ET ADORATUR, pudiendo observarse menos de la mitad inferior de dicho texto. Perg. 284 x 622 mm.; escr. carolina; buena conservación, con dos pequeñas roturas que afectan a la invocación verbal. Se halla enmarcada en un cuadro depositado en el Museo Diocesano del Palacio Episcopal de Palencia.

Las diferencias entre este manuscrito y el del monasterio de Sahagún son mínimas y existen, sobre todo, en los nombres propios.

$A^{\prime}$. AHN, Clero, Sahagún, carp. 899-13. Original múltiple, partido por IN NOMINE SANCTE ET INDIVIDUE TRINITATIS QUE A FIDELIBUS IN UNITATE COLITUR ET ADORATUR, pudiendo observarse más de la mitad superior de dicho texto. Perg. 599 x 303 mm.; escr. carolina; buena conservación.

$B$. APA, $L P H$, ff. 15 r-16r.

C. BN, $m s .705$, ff. $21 \mathrm{v}-22 \mathrm{v}$.

ED. FERNÁNDEZ DE MADRID, Silva Palentina, 690-691.- ESCALONA, Historia del Real Monasterio de Sahagún, III, 540-541, núm. CLXXIV.- J. GONZÁLEZ, Fernando II, 241-243, núm. 1; y Alfonso VIII, II, 79-82, núm. 44.- FERNÁNDEZ FLÓREZ, Colección Diplomática del monasterio de Sahagún, IV, 275-277, núm. 1332.

REG. VIGNAU, Índice de los documentos del monasterio de Sahagún, 34, núm. 128.

CIT. J. GONZÁLEZ, Siglos de Reconquista, 177. No incluye este documento como perteneciente a la colección de Husillos: "Es lógico que una copia del tratado se conserve en la catedral palentina, pues afectaba a sus tierras".

La causa por la que este documento se encuentra en el fondo de Santa María de Husillos es, además de la devoción que profesaba Sancho III por esta abadía, como aparece escrito en el Libro de los Privilegios de Husillos, porque al igual que Fernando II de León, que depositó su original en el monasterio más importante de su reino, San Facundo y Primitivo de Sahagún, Sancho III depositó el suyo en la iglesia más, de alguna manera, al alza de su reino: la abadía de Santa María de Husillos, que había sido objeto de la piedad de dicho rey con importantes donaciones y confirmaciones.

Posiblemente, el hecho de que el tío materno del rey y también de Fernando II de León, Raimundo II de Minerva, era obispo de Palencia, influyó en la predisposición de Sancho III a otorgar privilegios y confirmaciones a la catedral de Palencia y a Santa María de Husillos, iglesia esta última de la que Raimundo II era "senior" según el documento número 25 de la colección. Tal generosidad derivaría en la confianza del rey para depositar aquí tan importante documento. 


\section{IN NOMINE SANCTE ET INDIVIDUE TRINITATIS QUE A} FIDELIBUS IN UNITATE COLITUR ET ADORATUR. / Ex confederatione et amicicia regum et eorum qui pre ceteris in mundo principatum tenent, quanta regno et ecclesie Dei comoda proveniant, frequens exemplorum multitudo docet et demonstrat. Hinc est quod ego, rex Sancius de Toleto et de Castella, et frater meus, rex Fernandus de Legione et de Gallecia, facimus / pacem et veram amiciciam, per bonam fidem et sine malo ingenio, ut boni fratres et boni amici deinceps in perpetuum. Et hanc facimus firmam et veram sicut filii unius patris et unius matris, tali pacto et convenientia: ut fideliter iuvemus nos contra omnes qui iniuriam nobis facere volverint; excepto contra comitem Barchinonie, qui avunculus $\beta$ nostre est et vinculum amicicie nostre, et nullus nostrum aliquam compositionem vel amiciciam cum rege Portugalis vel cum aliquo alio faciat que alteri nocere possit, absque consensu, consilio et volumtatem alterius. Et si aliquis nostrum absque filio legitimo obierit, alter habeat totum regnum eius cum hominibus; et si filios vel nepotes legitimos dimiserit, / hanc eandem amiciciam et convenientiam teneat eis. Similiter, filii nostri legitimi et nepotes hanc eandem amiciciam et convenientiam, quam modo facimus, inter se habeant, teneant et conservent. Et ego, rex Sancius, do vobis fratri meo, regi Fernando, illam terram vestram quam ego cepi, pro magno amore et amicicia et do vobis eam hoc modo: ut / comes Poncius et comes Osorius et Poncius de Minerba teneant eam in fidelitate, ut si de hac amicicia et convenientia mihi mentitus fueritis, ipsi cum ea iuvent me donec inde mihi directum faciatis; ut si usque ad unum annum mihi directum facere nolveritis, ipsi mihi totam terram illam sine ulla occasione mihi deliberent. Comiti, vero, Osorio concedimus $/{ }^{6}$ hereditatem suam pro hereditate, et non serviat de ea nisi sicut de hereditate sua et teneat eam in predicta fidelitate. Similiter, si ego de convenientia ista et amicicia vobis mentitus fuero, et usque ad unum annum vobis directum non fecero, terram illam, cum hominibus, liberam habeatis sine ullo inpedimento. Nobis, vero, tenentibus hanc amiciciam et convenientiam, ipsi sic / teneant terram illam ut vos nullo modo aufferatis eam illis, et ipsi serviant vobis cum ea fideliter, cum havere et hominibus, sicut fideles vassalli domino suo. Quod siquis istorum obierit, nulli detis eam nisi alicui istorum qui fedelitatem et honorem tenere sciat, scilicet: comiti R[a]miro et filiis 
eius; comiti Poncio et filiis eius; comiti Petro et filiis eius; / comiti Osorio et filiis eius; Poncio de Minerba et filiis eius; Aprili et filiis eius; Fernando Goterriz, sobrino comitis Ponci; Nuno Melendiz, filio Melendi Nuniz; Fernando Roderiguiz, filio Roderici Didaci et fratri suo Alvaro Roderici; et filiis Iohanis Petri de Astorica, sobrinis comitis Petri; Petro Munniz, filio comitis Munionis; $\rho^{9}$ Petro Balzan; Pelagio Captivo et soprinis eius. Et quibuscumque istorum vos volveritis, date eam; et isti teneant eam, eo pacto quo comes Poncius et comes Osorius et Poncius de Minerva tenent. Et ego, rex Fernandus, pro amore isto quem mihi facitis et pro dilectione quam vobis habere volo semper, iuro vobis et do vobis ad hominum comitem Ramirum et comitem / Petrum et Poncium de Minerba et Aprilem. Ut si ego de ista amicicia et convenientia vobis mentitus fuero, ipsi, cum suis corporibus et honoribus quos de me tenent, serviant vobis et iuvent vos fideliter, donec inde vobis directum faciam. Et siquis istorum honorem suum de vita vel de morte perdiderit, ille cui ego dedero idem hominum vobis fideliter faciat; / et preter istos quos vobis do ad hominum, iuro vobis, cum hominibus meis, ut si ego mentitus fuero vobis de ista amicicia et convenientia, ipsi, cum corporibus et honoribus adiuvent vos, usque dum vobis directum faciam. Et ego, rex Sancius, iuro vobis cum hominibus meis, quod si de amicicia et convenientia ista vobis mentitus fuero, $/{ }^{12}$ ipsi adiuvent vos, cum corporibus et honoribus, donec inde vobis directum faciam. Quantum, vero, adquisierimus de Portugal, teneamus per medium. Postquam, vero, totum adquisierimus, vos, frater meus rex Fernandus, dividite eum; et ego rex Sancius eligam contra partem meam. De terra, vero, sarracenorum hanc facimus divisionem, scilicet: quod vos / frater meus, rex Fernandus, habeatis de Nebla usque ad Lixbonam: Neblam, cum omnibus directuris suis; Mentanges, cum directuris suis; Emeritam, cum toto regno suo; Badailoz, cum toto regno suo; Evoram, cum toto regno suo; Mertula, Medina de Silve et Silve et Caztaila, cum toto regno suo, usque ad Lixbonam; cum mari, cum / insulis, cum montibus, terris et aquis. Et ego, rex Sancius, abhinc superius habeam totam aliam terram.

Facta convenientia et amicicia ista in Sancto Facundo, in era M C LXXXX VI, decimo kalendarum iunii, anno quo domnus Adefonsus, pater noster, famosissimus Hispaniarum imperator, obiit. $/{ }^{15}$ Concedo, quoque, ego rex Sancius vobis fratri meo regi Fernando, ut habeatis medietatem corporis ville de Sibilia et 
medietatem de reditibus eiudem ville et omnia illa castella que sunt a flumine Gadalquivir usque Nebla, que pertinent ad ipsam villam; et ego habeam omnia alia que sunt a flumine Guadalquivir / usque ad Granada.

1158, junio, 28. Cuéllar.

Sancho III confirma, en remisión de sus pecados y por amor a Dios, el coto de Santa María de Husillos que él mismo había donado. Dicho coto tiene la siguiente delimitación: del Puente de Monzón hasta Cabo de Viña, y de Villa Zalama, por San Cristóbal, hacia Deronada, hasta dicho puente de Monzón. Asimismo establece que no se puedan sacar prendas de dicho coto y que ningún hombre pueda ser perseguido ni asesinado dentro de éste. El que infringiere lo establecido debía pechar al rey dos mil sueldos, y a Santa María de Husillos el doble del daño causado.

A. AHDP, Ampudia y Abadía de Husillos, Privilegios Reales, carp. 197-5. Perg., 467 x 723 mm.; escr. carolina; buena conservación. Sello de cera pendiente, conservándose solamente la mitad.

B. AHDP, Ampudia y Abadía de Husillos, Privilegios Reales, carp. 198-15. Perg., 736 x 679 mm.; escr. gótica redonda de privilegios; regular conservación, tiene varias manchas de humedad que a veces impiden la lectura y una rotura en la línea 25. Mantiene los orificios y la cinta, pero no el sello. Sobre la primera línea del texto: <está éste a f. 43>. También en el dorso aparece escrito que este documento se corresponde con el que aparece escrito en el f. 43 del Libro de los Privilegios de Husillos; esto no es cierto, pues entre los ff. 43r y 46r se contiene el privilegio rodado concedido por Fernando IV, en el cual, al ser posterior, sí se contiene el de Sancho IV.

Inserto en confirmación de Sancho IV, dada el 31 de julio de 1290. Véase doc. núm. 82.

C. AHDP, Ampudia y Abadía de Husillos, Pergaminos, carp. 199-19. Perg. 684 x 631 mm.; escr. gótica redonda de privilegios y de albalaes; buena conservación; sello pendiente de plomo. Al final de la primera línea, la F y la E del nombre FERNANDO, están dibujadas pero sin miniar. Inserto en confirmación de Fernando IV, dada en Medina del Campo, el 10 de mayo de 1305. Véase doc. núm. 97.

D. AHDP, Ampudia y Abadía de Husillos, Pergaminos, carp. 200-21. Perg., 784 x 638 mm.; escr. gótica redonda de privilegios y precortesana. Su conservación no es muy buena, pero se puede leer 


\section{LA ABADÍA DE SANTA MARÍA DE HUSILLOS: ESTUDIO Y COLECCIÓN \\ DOCUMENTAL $(904-1608)$}

perfectamente. Se conserva el sello de plomo pendiente de una cuerda. Inserto en confirmación de Pedro I del privilegio de Alfonso XI, dada en Valladolid, a 28 de noviembre de 1351. Véase doc. núm. 135.

E. AHDP, Ampudia y Abadía de Husillos, Pergaminos, carp. 201-23. Perg. 714 x 608 mms.; escr. gótica de privilegios y precortesana; regular conservación, aunque las roturas y manchas permiten su perfecta lectura. Inserto en confirmación de Enrique II del privilegio de Alfonso XI, dada en Valladolid, a 20 de mayo de 1371. Véase doc. 163.

F. AHDP, Ampudia y Abadía de Husillos, Pergaminos, carp. 201-27. Perg., 784 x 685 mm.; escr. gótica de privilegios y precortesana. Muy deteriorado, ha desaparecido, prácticamente, toda su parte izquierda. No conserva sello ni cuerda. Inserto en confirmación de Juan I del privilegio de Enrique II, dada en Burgos, a 22 de agosto de 1379. Véase doc. núm. 193.

G. APA, $L P H$, ff. $16 \mathrm{v}-17 \mathrm{r}$. Traslado de $A$.

$H$. APA, $L P H$, ff. 43r-46r. Traslado de $B$.

I. APA, $L P H$, ff. $74 \mathrm{v}-78 \mathrm{r}$. Traslado de $C$.

$J$. APA, $L P H$, ff. $88 \mathrm{v}-92$ r. Traslado de $D$.

$K$. APA, $L P H$, ff. $104 \mathrm{r}-108 \mathrm{v}$. Traslado de $E$.

L. AGS, Patronato eclesiástico. Inconexos, leg.159, ff. 28r-29v. Papel; escr. procesal; buena conservación.

M. BN, ms. 705, ff. 23v-24v. Traslado de $G$.

$N$. BN, ms. 705, ff. 70v-76v. Traslado de $H$.

N. BN, $m s$. 705, ff. 155r-166r. Traslado de $I$.

$O$. BN, ms. 705, ff. 196v-201r. Comete numerosos errores. Traslado de $J$.

P. BN, $m s .705$, ff. 231v-238r. Traslado de $K$

Q. ARCHV. Salas de lo Civil. Masas (F). Caja 2787.1, ff. 49v-50r. Traslada solamente los confirmantes. Traslado desde $A$, aportado como prueba en un pleito fenecido (1774) de la colegiata de Ampudia con el concejo de Husillos por la posesión de ciertas heredades.

ED. J. GONZÁLEZ, Alfonso VIII, II, núm. 47, 85-86.

(Christus, alfa et omega). In nomine Sancte et indiuidue Trinitatis, que a fidelibus in unitate colitur et adoratur. Quoniam racio exigit ut ea que a regibus fiunt scripto firmentur ne temporum diuturnitate ea que gesta sunt obliuioni trandantur. Eapropter, ego rex / domnus Sancius, domni Adefonsi bone recordacionis illustris Hispaniarum imperatoris filius, consilio et auctoritate comitum et principum regni mei, presenti scripto roboro et confirmo totos illos cautos quos ego dedi ecclesie Sancte Marie de / Fuseliis, scilicet: a ponte de Munzum usque ab Cab de Uinea et inde ad Uillam Zaleimam et per Sanctum 
Christoforum usque ad Derronadam et inde ad predictum pontem. Et testor et ratum perhenniter aberi uolo ut nullus sit ausus de infra cautos istos aliquam pignoram $\beta$ extrahere uel aliquem hominem intra persequi uel interficere. Et quicumque hos cautos istis de causis uiolare presumpserit, pectet duos mille solidos regi, et abbati predicte ecclesie quicumque fuerit pignora duplicata restituatur. Liceat autem abbati cuicumque / merinorum regis uoluerit uocem huius calumnie dare. Et istos cautos dono et concedo prefate ecclesie Sancte Marie de Fuseliis amore Dei et remissione pecatorum meorum.

Si uero aliquis ex meo genere uel alieno hoc meum factum rumpere temptauerit, sit / a Deo maledictus et excomunicatus et cum Iuda proditore domini in inferno dampnatus, et hoc meum factum semper maneat firmum.

Facta carta in Colar, IIII ${ }^{\circ}$ kalendas iulii, sub era $\mathrm{M}^{\mathrm{a}} \mathrm{C}^{\mathrm{a}} \mathrm{LXXXXVI}^{\mathrm{a}}$, anno quo domnus Adefonsus famosissimus Hispaniarum $/ 6$ imperator obiit. Raimundo comite Barchinonie et Sancio rege Nauarre existentibus uasallis domni regis. Ego rex domnus Sancius hanc cartam quam fieri iussi meo proprio robore confirmo.

( $1^{a}$ col.) Comes Almanrricus conf.- Comes Lupus, signifer regis, conf.- Comes Uela de Nauarra conf.- Guter Fernandiz, potestas in Castella, conf.- Garcia Garciaz de Aza conf.- Gunzaluus de Maranum conf.- Didacus Fernandi, maiorinus Burgi, conf.

( $2^{a} \mathrm{col}$.) Gumez Gunzaluiz, maiordomus regis, conf.- Nunus Petriz conf.- Aluarus Petriz conf.- Fernandus Ruderigiz conf.- Guter Petriz de Rignoso conf.- Didacus Muninz Masedo conf.- Domnus Boso, maiorinus in Carrione, conf.

(Signum: SIGNUM REGIS SANCII)

$\left(\begin{array}{ll}3^{a} & c o l .\end{array}\right)$ Iohannes, Toletanus archiepiscopus et primas Hispanie, conf.Raimundus, Palentinus episcopus, conf.- Vilielmus, Secobiensis episcopus, conf.Petrus, Burgensis episcopus, conf.- Iohannes, Oxomensis episcopus, conf.Cerebrunus, Segontinus episcopus, conf.- Cunigus, Auilensis episcopus, conf. 
Martines, domni regis notarius, Bernardo, Palentino archidiacono, existente cancellario, scripsit.

1161, septiembre, 21. Husillos.

Raimundo [Giliberti], abad de Santa María de Husillos, juntamente con el cabildo de dicha iglesia, y con el consentimiento de Raimundo II de Minerva, obispo de Palencia, concede fuero, en remisión de sus pecados, al concejo de San Julián. Deben recibir, en oferción, cuatro maravedis anuales por el día de Navidad.

Las condiciones del fuero son: cada hombre de San Julián ha de hacer dieciocho sernas al monasterio, doce de ellas desde San Juan hasta Navidad y seis desde Navidad a San Juan.

El que no prestara el servicio de serna, pagará de multa un carnero. Las sernas se harán en San Julián y en Husillos y no en otros lugares. El trabajo en las viñas computará por dos sernas. Recibirá cada hombre en su trabajo dos panes según la medida de Palencia, uno de trigo y otro de cebada, de un total de dieciséis panes, de lo que se deduce que eran ocho los habitantes de San Julián Los hombres de San Julián no harán sernas los sábados ni lunes, y los días que trabajen recibirán un queso y una terraza de vino para cuatro, los cuales no recibirá si trabajan en las viñas. Les exime del pago de huesas por fallecimiento. Que ni señor, merino o sayón, teniendo alguna potestad en la villa, no haga fuerza a sus moradores, sino que demande su caloña. El señor tendrá derecho a la mitad de la caloña y del homicidio. Si en pleito el morador perdiera, pagará la multa completa. Las muertes accidentales no pagarán homicidio. Si alguien fuera muerto por perro o animal de tiro, éste se entregará al señor. Que nadie sea apresado en la villa si diera fiadores para satisfacer la caloña. Si un vecino desea abandonar la villa, tiene nueve días para vender todo lo suyo, siendo para el 
señor lo que quedara a partir del décimo día; el vecino no puede derribar las paredes de las casas ni arrancar árboles.

A. AHDP, Ampudia y Abadía de Husillos, Pergaminos, carp. 208-1. Carta partida por ABC...PQR. Perg., 219 x 448 mm.; escr. carolina; buena conservación.

$B$. APA, $L P H$, ff. $17 \mathrm{v}-18 \mathrm{r}$.

C. BN, $m s .705$, ff. 24v-26v.

D. BN, ms. Q- 91 (siglo XVIII), f. 72. (traslado incompleto).

ED. HINOJOSA, Documentos para las instituciones de León y Castilla, 68-69, núm. XLII. Utiliza la versión del manuscrito Q-91 de la Biblioteca Nacional.- SÁEZ, E., Fueros de San Julián y Villamuriel, 557-561. Estudia el original, que lo situa en el Archivo Catedralicio de Palencia.RODRÍGUEZ FERNÁNDEZ, Palencia: Panorámica Foral, 112-114, núm. 17.

$(A B C \ldots P Q R)$ In nomine Domini nostri Ihesu Christi, Patris et Filii et Spiriti Sancti. Ego, Raimundus, Dei gratia abbas Sancte Marie de Fusellis, amore Dei et remissione pecatorum meorum, cum consilio et assensu tocius capituli Sancte Marie, facio cartam firmitatis et textum scripture in per/petuum ualiturum concilio de Sancto Iuliano et omnibus hominibus, tam presentibus quam futuris in eadem uilla morantibus, per presentem scripturam, donans et concedens eis forum: ut uno quoque anno decem et octo sernas faciant canonicis Sancte Marie pre/sentibus et futuris, duodecima festiuitate Sancti Iohannis usque ad Natiuitatem Domini; sex autem a Natiuitate Domini usque ad festiuitatem predictam Sancti Iohannis, hoc uidelicet modo: ut quicumque in predicta uilla fuerit et facta amonitione sayonis ad sernam cum hora no $\beta$ uenerit, altera die pectet unum carnerum; et ille serne fiant in termino Sancti Iuliani et in termino Fusellis et non alibi; et serna uindemiarum computetor pro duabus. Et cum homines Sancti Iuliani ad sernam fuerint faciendam, canonici faciant fieri [de] / quarta Palencie XVI panes, et dent unicuique duos panes, unum de tritico et alium de ordeo, ita quod molatur sine maquila. Absoluo etiam eis osas. Preterea mando et concedo ut nullus deinceps dominus uel merinus aut sayo aut aliquis alius, in predicta / uilla de Sancto Iuliano potestatem aliquam habens, iniuriam inferat uel uim faciat alicui in predicta uilla moranti, set calumpniam suam iuste requirat et secumdum forum terre. Et de tota calumpnia manifesta et de homicidio manifesto, non habeat dominus $/{ }^{6}$ nisi medietatem. Si autem reus negauerit et conuictus fuerit, totam 
calumpniam siue homicidium pectet. Concedo etiam uobis ut pro illis qui in igne, uel aqua, uel puteo, uel terrero, uel silo, uel sub pariete mortui fuerint, homicidium a uobis <nullatenus $>$ exigatur. / Verumptamen pro illo quem canis uel bestia interfecerit domino uille dampnatorem tradatis. Nullus preterea in eadem predicta uilla capiatur si fideiussores dare potuerit idoneos et rectos ad persoluendam calumpnia que habeo requiretur. / Concedo etiam, ut quicumque de predicta uilla exire uoluerit ut alibi moretur, exeat libere et habeat spatium nouem dierum in quibus leuet uel uendat omnia sua, set parietes non destruat nec arbores eradicet. Post nouem dies si quis intra $/^{9}$ uillam remanserit domini sit. Concedo insuper ut non currat pesquisa inter dominum predicte uille, quicumque fuerit, et uassallos eius sed iudicium.

Si quis autem cuiuscumque generis sit uel ordinis huius mee donationis et huius carte confirmationem in/fregerit uel diminuerit, anathemate feriatur et cum Datan et Abiron et Iuda proditore, nisi resipuerit, in inferno dampnetur.

Facta carta in Fusellis, undecima kalendas octobris, feria prima, era $\mathrm{M}^{\mathrm{a}} \mathrm{C}^{\mathrm{a}}$ LXXXX $^{\text {a VIIII }}$. Ildefoso / rege, filio regis Sancii, regnante in Toleto et in Nagera et in Castela. Regnante Ferdinando in Legione et in Gallicia. Dompnus Raimundus secundus, episcopus in Palencia, cuius mandato et uoluntate carta hec facta est. Preterea sciendum quod nullam sernam $/{ }^{12}$ faciant homines de Sancto Iuliano die sabbati neque die lune, et cum fecerint sernam, detur unicuique obolata casei et quatuor una terracia uini, preter in serna uindemiarum ubi non debent habere nisi panem tantum.

( $1^{a}$ col.) Petrus Cidez testis. Magister Ricardus, sacrista, testis. Laurentius, cantor, testis. Nicholaus, operarius ecclesie, testis. Magister Poncius testis. Et totum capitulum Sancte Marie confirmat. Petrus Petri de Palentia testis. Sancius Aznar testis. Petrus Pascalez testis. Petrus Captiuus, merinus episcopi, testis.

( $2^{a}$ col. $)$ Comes Almaricus dominans in Toleto. Gutterius Fernandez potestas in Castella. Nunius Petri potestas in Auia et in Ferraria. Dompnus Boso potestas in Saldania et in Carrione. 
( $3^{a}$ col.) Abbas Iohannes testis. Petrus Raimundi de Ecclesia Ota testis. Petrus Martinet testis. Iohannes Abbas testis.

( $4^{a} \mathrm{col}$.) Gomez Petri de Fontes testis. Pelagius Petri testis. Petrus Iohannis testis. Petrus Dominici de Monzon testis. Alardus testis.

Ego, Raimundus, abbas Sancte Marie de Fusellis, hanc cartam corroboro et hoc signo crucis (signo) propria manu confirmo.

Petrus Iohannis hanc cartam scripsit.

Preterea concilium Sancti Iuliani det unoquoque anno canonicis Fusellensibus in Nathali Domini quatuor morabetinos pro offercione.

1162, agosto, 18. Clermont.

Alejandro III, a petición de Raimundo II de Minerva, obispo de Palencia, confirma los bienes, derechos y lugares de la sede palentina, entre ellos, Santa María de Husillos con sus términos, villas, decanías y todas sus pertenencias.

A. ACP, Arm. III, leg. 8, doc. 6. Perg., 618 x 475 mm.; escr. carolina; buena conservación.

ED. ABAJO, Documentación catedral de Palencia, 129-132, núm. 62.

REG. CASTRO TOLEDO, Colección diplomática de Tordesillas, 11, núm. 22.- SAN MARTÍN PAYO, Catálogo Catedral de Palencia, 127-128.

CIT. FERNÁNDEZ DE MADRID, Silva Palentina, I, 93; y III, 88. 
1171, septiembre, 9 .

Gonzalo, en remedio de su alma y las de sus padres, dona en ocasión de su aniversario la villa de Villálvarez, sita entre Villa Gudiel y Quintanilla, a los canónigos de Santa María de Husillos, en remedio de su alma, las de sus padres y las de aquellos que donaron la villa a sus antepasados y a él mismo. Como condición establece que él mismo y Pedro dispondrán de la villa durante el resto de sus días.

A. AHDP, Ampudia y Abadía de Husillos, Pergaminos, carp. 207-7. Perg., 217 x 308 mm., escr. carolina; regular conservación.

B. $A P A, L P H$, f. $18 \mathrm{r}-\mathrm{v}$.

C. BN, ms. 705 , ff. 26v-27r.

In Dei nomine. Notum sit omnibus hominibus, tam presentibus quam futuris, quod ego, Gondisaluus, nullo cogente imperio nec suadente articulo, sed propria uoluntate, dimito / in meo anniuersario canonicis Sancte Marie de Fusellis, Uillam Albarrez, pro remedio animę meę parentumque meorum et eorum, scilicet, qui predictam uillam / parentibus meis michique dederunt, que scilicet uilla adiacet inter Uillam Godel et Quintanellam. Et ego ut supradictum est dimitto eam predictis canonicis $\beta$ cum omni sua hereditate, terris, uineis, pratis, fontibus, pascuis, molendinis, cum egressibus et regressibus suis; sub tali uero conditione dimitto / predictam uillam assignatis canonicis ut ego et Petrus habeamus eam canonice cunctis diebus uite nostrę nisi nos relinquerimus eam propria uoluntate. /

Si quis de progenie mea uel de extranea, hoc meum factum infringere temptauerit, pectet in coto $\mathrm{C}$ libras purissimi auri, nec non et ipsam $/^{6}$ uillam cum predictis pertinenciis in con simili loco penitus restituat.

Facta carta $\mathrm{V}$ idus septembris, era $\mathrm{M}^{\mathrm{a}} \mathrm{CC}^{\mathrm{a}} \mathrm{IX}^{\mathrm{a}}$. Regnante rege / Aldefonso in Toleto et Castella cum regina Elionor. Domno Raimundo II $^{\circ}$ episcopo in Palencia. Raimundo Giliberti abbate in Sancta Maria / de Fusellis. Roderico Guterii et eius fratres dominantibus in Montson. 
Et ego, Gondisaluus, qui hanc cartam scribere mandaui, $\rho^{9}$ coram testibus roboro et confirmo.

( $1^{a}$ col.) Garnerius, decanus beati Antonini, conf.- Bernardus Simonis, archidiaconus, conf.- Bernardus Iohannis, archidiaconus, conf.- Martinus Ermegaudi, archidiaconus, conf.

$\left(2^{a}\right.$ col.) Petrus sobrini, sacrista, conf.- Fredinandus, real precentor, conf.- Petrus Iohannis de ultra flumen conf.- Garsia de Fornellis conf.

$\left(3^{a}\right.$ col.) Magister Pon[ci]us, prior Sancte Marie de Fusellis, conf.- Berengarius, sacrista, conf.- Garsia, precentor, conf.- Petrus Cidez conf.

1171, septiembre, 9. Montealegre.

Alfonso VIII, "rex hispanorum”, juntamente con su esposa Leonor, ampara una alberguería fundada por Miguel Cidez, sita en el campo de Pajares.

$B$. APA, $L P H$, ff. $18 \mathrm{v}-19 \mathrm{r}$. Contiene errores en el traslado.

C. AGS, Patronato eclesiástico. Inconexos, leg.159, ff. 29v-30r. Papel; escr. procesal; buena conservación.

D. BN, $m s .705$, ff. 27r-28r.

ED. J. GONZÁLEZ, Alfonso VIII, II, 274-275, núm. 161.

Fecho y sacado fue este dicho traslado de la dicha escritura original, que de suso va encorporada, en la villa de Husillos, a veynte y vn días del mes de nouienbre de mil y quinientos y çinquenta y quatro años. Testigos que fueron presentes a lo uer, leer, corregir y conçertar $(f .19 r)$ con el original, Joán Ruiz Cabeça de Vaca y Gaspar de Vedoya, clérigos, y Pero Manuel, estantes en la dicha villa. 
E yo, Santiago Gomez, escriuano público en la dicha villa, fui presente con los dichos testigos a lo que dicho es. Y del dicho pedimiento y mandamiento del dicho señor alcalde mayor, que aquí firmó su nombre, lo fize escreuir y fize aquí mi signo (signo) en testimonio de verdad.

Pero Ruyz de Billoldo (rúbrica). Santiago Gómez (rúbrica).

In nomine Domini, amen. Tam presentibus quam futuris notum hanc manifestatum esse volo quod ego, Aldefonsus, Dei gratia Hispanorum rex, vna cum vxore mea Alienor, regina, amore Dei et pro salute animę meę, illam elbengueriam quam uos, Michael Cidez, in campo de Paiares, in vestra hereditate, fecistis in perpetuum liberam, facio ut nemini nisi Deo et vobis et cui vobis placuerit vnque seruiat, omnino mando totam ex integro cum omnibus que hodie possidet abba a modo acquirere poterit cauto hic et contestor illam ut deinceps nullus ex ea aliquid extrahere per vim nullum que hominem qualibet ex causa fugientem ab vno lapides iactum in antea in sequi sit ausus nec suos homines nec suos homines (sic) ganados pignorare nisi proprio debito audeat.

$\mathrm{Si}$ quis vero hanc cartam in aliquo frangere voluerit iram Dei omnipotentis incurrat et regie parti mille aureos in coto persoluat.

Facta carta Monte Alacri, era MCCIX quinto idus septembris. Et ego, rex Ildefonsus, hanc cartam manu propria roboro et confirmo. Celebrinus, Toletanus archiepiscopus et Hispaniarum primas, conf. Reymundus, Palentinus episcopus, conf. Guilielmus, Segouiensis episcopus, conf. Santius, Abilensis episcopus, conf. Comes Nunio conf. Comes Petrus conf. Comes Gomez conf. Comes Pontius conf. Petrus Rodirici, filius comitis, conf. Rodiricus Gutterrez conf. Petrus Guterrez conf. Lup Gordo conf. Tell Petriz conf. Lop Diaz, merinus regis, conf. Rodiricus Gundisalui, alferez regis, conf. Petrus Garsie, maiordomus curiem regis, conf. Petrus, regis notarius. Reymundo, existente cancellario, scripsit.

1178, agosto, 13. Carrión de los Condes. 


\section{DAVID MARCOS DIEZ}

Alfonso VIII y su esposa Leonor, confirman a Santa María de Husillos y a su abad Pedro de Cardona, canciller real, por las almas de sus padres y por su propia salvación, las villas, heredades y monasterios donados por Urraca I, Sancho III, Fernando Ansúrez, Gonzalo Ansúrez y Nuño Ansúrez, condes de Monzón, y otros donantes.

A. AHDP, Ampudia y Abadía de Husillos, Pergaminos, carp. 197-6. Perg., 535 x 464 mm.; escr. Carolina; regular conservación, solamente se ve afectada la última línea de la escritura. Falta el sello de plomo pero mantiene las cuerdas de cuero.

B. AHDP, Ampudia y Abadía de Husillos, Pergaminos, carp. 198-15. Perg., 736 x 679 mm.; escr. gótica redonda de privilegios; regular conservación, tiene varias manchas de humedad que a veces impiden la lectura y una rotura en la línea 25. Mantiene los orificios y la cinta pero no el sello.

Sobre la primera línea del texto: <está éste a f. 43>. También en el dorso aparece escrito que este documento se corresponde con el que aparece escrito en el f. 43 del Libro de los Privilegios de Husillos; esto no es cierto, pues entre los ff. 43r y $46 \mathrm{r}$ se contiene el privilegio rodado concedido por Fernando IV, en el cual, al ser posterior, si se contiene el de Sancho IV.

Inserto en confirmación de Sancho IV, dada el 31 de julio de 1290. Véase doc. núm. 82.

C. AHDP, Ampudia y Abadía de Husillos, Pergaminos, carp. 199-19. Perg., 684 x 631 mm.; escr. gótica redonda de privilegios y de albalaes; buena conservación; sello pendiente de plomo. Al final de la primera línea, la $\mathrm{F}$ y la $\mathrm{E}$ del nombre FERNANDO, están marcadas pero sin miniar. Inserto en confirmación de Fernando IV del privilegio de Sancho IV, dada en Medina del Campo, el 10 de mayo de 1305. Véase doc. núm. 97.

D. AHDP, Ampudia y Abadía de Husillos, Pergaminos, carp. 200-21. Perg., 784 x 638 mm.; escr. gótica redonda de privilegios y precortesana. Su conservación no es muy buena pero se puede leer perfectamente. Se conserva el sello de plomo pendiente de una cuerda. Inserto en confirmación de Pedro I del privilegio de Alfonso XI, dada en Valladolid, a 28 de noviembre de 1351. Véase doc. núm. 135.

E. AHDP, Ampudia y Abadía de Husillos, Pergaminos, carp. 201-23. Perg., 714 x 608 mms.; escr. gótica de privilegios y precortesana; regular conservación, aunque las roturas y manchas permiten su perfecta lectura. Inserto en confirmación de Enrique II del privilegio de Alfonso XI, dada en Valladolid, a 20 de mayo de 1371. Véase doc. 163.

F. AHDP, Ampudia y Abadía de Husillos, Pergaminos, carp. 201-27. Perg., 784 x 685 mm.; escr. gótica de privilegios y precortesana. Muy deteriorado, ha desaparecido, prácticamente, toda su parte izquierda. No conserva sello ni cuerda. Inserto en confirmación de Juan I del privilegio de Enrique II, dada en Burgos, a 22 de agosto de 1379. Véase doc. núm. 193.

$G$. APA, $L P H ;$ f. 19r-v. Traslado de $A$.

$H$. APA, $L P H$, ff. 43r-46r. Traslado de $B$.

I. APA, $L P H$, ff. $74 \mathrm{v}-78$ r. Traslado de $D$. 
$J$. APA, $L P H$, ff. $88 \mathrm{v}-92$ r. Traslado de $E$.

$K$. APA, $L P H$, ff. $104 \mathrm{r}-108 \mathrm{v}$. Traslado de $F$.

L. AGS, Patronato eclesiástico. Inconexos, leg.159, ff. 30r-31v. Papel; escr. procesal; buena conservación.

M. BN, $m s .705$, ff. 28r-29v. Traslado de G.

$N$. BN, ms. 705, ff. 70v-76v. Traslado de $H$.

N. BN, $m s .705$, ff. 155r-166r. Traslado de $I$.

$O$. BN, $m s .705$, ff. 196v-201r. Comete numerosos errores. Traslado de $J$.

$P$. BN, $m s .705$, ff. $231 \mathrm{v}-238$ r. Transcribe el documento muy resumido. Traslado de $K$.

Q. ARCHV, Salas de lo Civil. Masas (F). Caja 2787.1, ff. 50r-51v. Traslado desde A, aportado como prueba en un pleito fenecido (1774) de la colegiata de Ampudia con el concejo de Husillos por la posesión de ciertas heredades.

ED. J. GONZÁLEZ, Alfonso VIII, II, 498-500, núm. 304.

CIT. SERRANO, Obispado de Burgos, II, 96.- BARÓN FARALDO, Grupos y dominios aristocrático, 37.

(Christus, alfa et omega). In nomine Sancte et indiuidue Trinitatis que a fidelibus in unitate colitur et adoratur, decet inter ceteros homines regiam precipue maiestatem ecclesias diligere / ecclesiasticas personas honorare et eis grata suffragia uerbo et hopere confferre. Ea propter, ego Aldefonsus, Dei gratia rex Castelle, una cum uxore mea / Alienor, regina, pro animabus parentum meorum et salute propria, facio cartam firmitatis et textum scripture, in perpetuum ualiturum Deo et ecclesie Sancte $\mathrm{Ma} /{ }^{3}$ rie de Fusellis et uobis, domno Petro de Cardona, eiusdem abbati uestrisque successoribus omnibus, per presens scriptum confirmans et corroborans, cunctas uillas et here/ditates quas regina domna Urraca, aua regis Sanctii, patris mei, uiri illustris et pie recordationis, prefate ecclesie et Federnandus Assuriz comes et Gunzaluus Assuriz comes / et Nunus Assuriz, qui eandem ecclesiam construxerunt et edificauerunt pro remedio animarum suarum et peccatorum suorum remissione, dederunt scilicet: Sanctum Sebastianum $/{ }^{6}$ de Hermidas cum suis terminis et directuris, Uillam Don Daui, quam prefata regina Urraca, cum suis terminis et directuris et cum illa pesquera de Runada que est subtus / pontem ecclesie Sancte Marie, eidem ecclesie dedit et alias uillas et monasteria que dederunt ei prefati comites, scilicet: Uillam Abdala, Paiares, Sanctum Adrianum, Uillam de Guterrio / Aluariz, Sanctam Eugeniam de 
Pinia, Sanctum Iulianum, Sanctum Facundum de Paredes, Sanctam Mariam de Cellerolo et Sanctam Mariam de Fonte Pudia et Cellam Nouam cum Arroio de Frades, Paiaregos cum sua $/^{9}$ deffesa et terminis et directuris, Sanctum Sebastianum de Bezerril, Sanctam Eufemiam de Beruesca, Sanctum Petrum de Ualdepero, quod dedit Iusta coxa, Sanctum Iacobum de Calabazanos que dedit / Martinus Sanctii. In Frechela Sanctum Mametem, Sanctum Romanum, Sanctum Martinum, que dedit Facundus Pelaiz, Sanctum Micahelem de Puzolos et hereditatem de Turre de Astudello, que dedit / Maria Godesteiz, Sanctum Micahelem de Fontes de don Uermudo, quod dedit uxor de Ermildo Roderici, Sanctam Mariam de Castrello.

Confirmo hic et corroboro has predictas uillas, hereditates, $/^{12}$ monasteria quecumque habet et deinceps adipisci poterit, et diuisas similiter sicud in diebus patris mei, regis Sanctii, prenominata ecclesia habuit et possedit. Cauto est et contestor ga/natum domni Petri de Cardona, cancellarii mei et prefate ecclesie instantis abbatis et omnium successorum suorum et canonicorum eiusdem ecclesie, tam presentium quam futurorum, tali modo et tenore ut / si quis predictum ganadum pignorauerit uel per uim abstulerit pectet, abbati eiusdem ecclesie, pro suo ganato mille solidos et canonicis similiter pro suo, et ipsum ganatum duplicatum reddat. $/^{15}$

Si quis uero ex meo uel alieno genere hoc factum męę donationis et concessionis temerario ausu rumpere uel in aliquo diminuere presumpserit, sit maledictus et excommunicatus et cum Iuda domini / proditore in inferno dampnatus et pectet, regie parti, mille aureos in cauto, et hoc meum factum imperpetuum maneat firmum et ratum.

Facta carta in Carrione, era $\mathrm{M}^{\mathrm{a}} \mathrm{CC}^{\mathrm{a}} \mathrm{XVI}^{\mathrm{a}}$, idus augusti, / anno secundo quo serenissimus rex prefatus Aldefonsus Concam cepit. Et ego rex Aldefonsus, regnans in Castella et Toleto, hanc cartam manu propria roboro et confirmo et ad maiorem eius firmitudinem eam proprio sigillo munire $/{ }^{18}$ mando.

Cerebrunus, Toletanus archiepiscopus et Yspaniarum primas, confirmat.

( $1^{a}$ col.) Raimundus, Palentinus episcopus, conf.- Petrus, Burgensis episcopus, conf.- Sanctius, Auilensis episcopus, conf.- Gundisaluus, Secobiensis episcopus, conf.- Michael, Oxomensis episcopus, conf.- Iocelmus, Segontinis episcopus, 
conf.- Magister Iohannes, scolaris, electus in Conca, conf.- Rodericus, Calagurritanus episcopus, conf.- Comes Petrus de Lara conf.- Comes Gomez conf.- Comes Ferrandus conf.

\section{(Signo rodado)}

Primer círculo concéntrico: SIGNVM REGIS ALDEFONSI.

Segundo círculo concéntrico: (Signum: cruz).

Rodericus Guterrez, maiordomus curie regis, conf. Comes Guterre de Marannone, alferiz regis, conf.

( $2^{a}$ col.) Petrus, Roderici filius comitis, conf.- Petrus Roderici de Azagua conf.Petrus de Arazuri conf.- Gomez Garsie conf.- Diago Semeniz conf.- Ordonius Garsie conf.- Petrus Guterrez conf.- Tel Petriz conf.- Albarus Roderici de Guzman conf.- Petrus Roderici, frater eius, conf.- Lupus Diaz, merinus regis in Castella, conf.

Petrus de La Cruce, regis notarius, [domno Petr]o de Cardona, iam pre scripto existente cancellario, scripsit.

1178, agosto, 13. Carrión de los Condes.

Alfonso VIII, juntamente con su esposa, Leonor, confirma, en remedio de las almas de sus padres y por su propia salvación, a Santa María de Husillos y a su abad Pedro de Cardona, canciller real, la donación que hizo Sancho III, su padre, a dicha iglesia, del coto con la siguiente delimitación: del Puente de Monzón, hasta Cabo de Viña, y de Villa Zalama por San Cristóbal, hasta Derronada, y hacia dicho puente. 


\section{DAVID MARCOS DIEZ}

A. AHDP, Ampudia y Abadía de Husillos, Pergaminos, carp. 197-7. Perg., 436 x 479 mm.; escr. carolina; buena conservación. Tiene las cuerdas de cuero pero le falta el sello.

B. AHDP, Ampudia y Abadia de Husillos, Pergaminos, carp. 198-15. Perg., 736 x 679 mm.; escr. gótica redonda de privilegios; regular conservación, tiene varias manchas de humedad que a veces impiden la lectura y una rotura en la línea 25. Mantiene los orificios y la cinta pero no el sello.

Sobre la primera línea del texto: <está éste a f. 43>. También en el dorso aparece escrito que este documento se corresponde con el que aparece escrito en el f. 43 del Libro de los Privilegios de Husillos; esto no es cierto, pues entre los ff. 43r y 46r se contiene el privilegio rodado concedido por Fernando IV, en el cual, al ser posterior, si se contiene el de Sancho IV.

Inserto en confirmación de Sancho IV, dada el 31 de juliode 1290. Véase doc. núm. 82.

C. AHDP, Ampudia y Abadía de Husillos, Pergaminos, carp. 199-19. Perg. 684 x 631 mm.; escr. gótica redonda de privilegios y de albalaes; buena conservación; sello pendiente de plomo. Al final de la primera línea, la $\mathrm{F}$ y la $\mathrm{E}$ del nombre FERNANDO, están marcadas pero sin miniar. Inserto en confirmación de Fernando IV, dada en Medina del Campo, el 10 de mayo de 1305. Véase doc. núm. 97.

D. AHDP, Ampudia y Abadia de Husillos, Pergaminos, carp. 200-21. Perg., 784 x 638 mm.; escr. gótica redonda de privilegios y precortesana. Su conservación no es muy buena, pero se puede leer perfectamente. Se conserva el sello de plomo pendiente de una cuerda. Inserto en confirmación de Pedro I del privilegio de Alfonso XI, dada en Valladolid, a 28 de noviembre de 1351. Véase doc. núm. 135 .

E. AHDP, Ampudia y Abadía de Husillos, Pergaminos, carp. 201-23. Perg., 714 x 608 mms.; escr. gótica de privilegios y precortesana; regular conservación, aunque las roturas y manchas permiten su perfecta lectura. Inserto en confirmación de Enrique II del privilegio de Alfonso XI, dada en Valladolid, a 20 de mayo de 1371. Véase doc. 163.

F. AHDP, Ampudia, Serie G, Pergaminos. Privilegios Reales, carp. 201-27. Perg., 784 x 685 mm.; escr. gótica de privilegios y precortesana. Muy deteriorado, ha desaparecido, prácticamente, toda su parte izquierda. No conserva sello ni cuerda. Inserto en confirmación de Juan I del privilegio de Enrique II, dada en Burgos, a 22 de agosto de 1379. Véase doc. núm. 193.

$G$. APA, $L P H$, ff. 43r-46r. Traslado de $A$.

$H$. APA, $L P H$, ff. $74 \mathrm{v}-78 \mathrm{r}$. Traslado de $D$.

I. APA, $L P H$, ff. $88 \mathrm{v}-92$ r. Traslado de $E$.

$J$. APA, $L P H$, ff. $104 \mathrm{r}-108 \mathrm{v}$. Traslado de $F$.

$K$. BN, $m s .705$, ff. 70v-76v. Traslado de $G$.

L. BN, $m s .705$, ff. 155r-166r. Traslado de $H$.

$M$. BN, $m s .705$, ff. 196v-201r. Comete numerosos errores. Traslado de $I$.

$N$. BN, $m s .705$, ff. 231v-238r. Traslado de $J$.

ED. J. GONZÁLEZ, Alfonso VIII, II, 500-502, núm. 305. 


\section{LA ABADÍA DE SANTA MARÍA DE HUSILLOS: ESTUDIO Y COLECCIÓN \\ DOCUMENTAL $(904-1608)$}

(Christus, alfa et omega). In nomine Sancte et indiuidue Trinitatis que a fidelibus in unitate colitur et adoratur, quoniam racio exigit ut eaque a regibus fiunt scripto firmentur ne temporum diuturnitate tradantur / obliuioni. Ea propter, ego Adefonsus, Dei gratia rex Castelle, una cum uxore mea Alienor regina, libenti animo et uoluntate spontanea, pro animabus parentum meorum et salute propria, consilio et auctorita/te comitum et principum regni nostri, presenti scripto roboro et confirmo totos illos cautos quos patris mei rex Sanctius, dedit ecclesie Sancte Marie de Fusellis, scilicet: a Ponte de Monzon usque ad $\mathrm{Cab} / \beta$ de Uinea et inde ad Uillam Zalemam et per Sanctum Christoforum usque ad Derronadam et inde ad predictum pontem. Et testor et ratum perhenniter aberi uolo ut nullus sit ausus de infra cautos istos aliqua pigno/ra extrahere uel aliquem hominem infra persequi uel interficere. Et quicumque hos cautos istis de causis uiolare presumpserit pectet duos mille solidos regi et abbati predicte ecclesie quicumque fuerit pignora duplata / restituat. Liceat aut abbati cuicumque merinorum regis uoluerit uocem huius calumpnie dare. Dono enim et concedo hos cautos prefate ecclesie Sancte Marie de Fusellis et uobis domno Petro de Cardona $/{ }^{6}$ et omnibus successoribus uestris imperpetuum ualituros.

Si quis uero ex meo uel alieno genere huius męę concessionis et donationis paginam in aliquo rumpere uel diminuere temptauerit; iram Dei omnipotentis ple/narie incurrat et regie in supliciis infernalibus Iude Domini proditoris consors fiat et regie parti et abbati predictum cautum ut dictum in cauto persoluat et hoc meum factum semper ratum / maneat.

Facta carta apud Carrion, era $\mathrm{M}^{\mathrm{a}} \mathrm{CC}^{\mathrm{a}} \mathrm{XVI}^{\mathrm{a}}$, idus augusti, anno $\mathrm{II}^{\mathrm{o}}$ quo serenessimus prefatus rex Adefonsus Concam cepit. Et ego, rex iam dictus rex Adefonsus, regnans in Castella et $\rho^{9}$ Toleto hanc cartam manu propria robo et confirmo et ad maiorem eius firmitudinem eam proprio sigillo munire mando. Cenebrunius Toletanus archiepiscopus et Yspaniarum primas confirmat.

( $1^{a}$ col.) Raimundus, Palentinus episcopus, conf.- Petrus, Burgensis episcopus, conf.- Sanctius, Auilensis episcopus, conf.- Gundisaluus, Secobiensis episcopus, conf.- Michael, Oxomensis episcopus, conf.- Ioscelmus, Segontinus episcopus, conf.- Magister Iohannes, scolaris electus de Conca, conf.- Rodericus, Calagurris 
episcopus, conf.- Comes Petrus de Lara conf.- Comes Gomez conf.- Comes Ferrandus conf.

(Signo rodado)

Primer círculo concéntrico:

SIGNVM REGIS ALDEFONSI.

Segundo círculo concéntrico:

(signum: cruz).

Rodericus Guterrez, maiordomus curie regis, conf. Comes G[undisaluus] de Marannone, alferiz regis, conf.

( ${ }^{a}$ col.) Petrus Roderici, filius comitis, conf.- Petrus Roderici de Azagra conf.Petrus de Arazuri conf.- Comes Garsie conf.- Diago Semenez conf.- Ordonius Garsie conf.- Petrus Guterrez conf.- Tel Petriz conf.- Albarus Roderici de Guzman conf.- Lupus Diaz, merinus regis in Castella, conf.

Petrus de La Cruce, regis notarius. Domno Petro de Cardona, iam pre scripto existente cancellario, scripsit.

1179, noviembre, 18. Agnani.

Alejandro III exenta a Santa María de Husillos de la jurisdicción del obispo de Palencia y la hace dependiente de la Santa Sede. Asimismo confirma todas sus posesiones y bienes, privilegia las sepulturas en dicha iglesia y defiende sus posesiones y pertenencias de todo infractor.

A. AHDP, Ampudia y Abadía de Husillos, Pergaminos, carp. 203-1. Perg., 517 x 567 mm., escr. carolina de cancillería pontificia; buena conservación. Sello pendiente de plomo. 
B. AHDP, Ampudia y Abadía de Husillos, Pergaminos, carp. 203-2. Perg., 619 x 363 mm.; escr. precortesana. Muy deteriorado. Inserto en traslado sacado en Palencia, a 7 de abril de 1353. Véase doc. núm. 136.

C. AHDP, Ampudia y Abadía de Husillos, Pergaminos, carp. 203-4. Perg., 587 x 323 mm.; escr. cortesana; regular conservación, con algunas roturas longitudinales, debidas a las dobleces, que dificultan su lectura. Inserto en traslado sacado en Palencia, a 22 de abril de 1422. Véase doc. núm. 223.

D. APA, $L P H$, ff. $12 \mathrm{v}-13 \mathrm{v}$.

E. AGS, Patronato eclesiástico. Inconexos, leg.159, ff. 24r-26v. Papel; escr. procesal; buena conservación.

F. ARCHV. Salas de lo Civil. Masas (F). Caja 2787.1, ff. 59r-62r. Traslado desde A, aportado como prueba en un pleito fenecido (1774) de la colegiata de Ampudia con el concejo de Husillos por la posesión de ciertas heredades.

CIT. SAN MARTÍN PAYO, Santa María de Husillos y su colección diplomática, 164-165.

Alexander, episcopus, seruus seruorum Dei. Dilectis filiis Petro, abbati Sancte Marie de Fusellis eiusque fratribus, tam presentibus quam futuris, / canonice substituendis in perpetuum quotiens a nobis petitur quod religioni et honestati conuenire dinoscitur. Animo nos decet libenti concedere et petentum desideriis con/gritum impetiri consensum ea propter dilecti in Christo, filii uestris iustis postulationibus clementer annuimus et prefatam ecclesiam in qua diuino $\mathrm{man} /{ }^{3}$ cipati estis obsequio sub beati Petri et nostra proctetione in proprios et speciales subiectos romane ecclesie suscipimus et presentis scripti priuilegio / conmunimus statuentes ut quascumque possessiones, quecumque bona eadem ecclesia in presentiarum iuste et canonice possidet aut in futurum concessione / pontificum largitione, regum uel principum, oblacione fidelium seu aliis iustis modis prestante domino poterit adipisci firma uobis uestris $/{ }^{6}$ sucessoribus et illibata permaneant in quibus hec propriis duximus exprimenda uocabulis, vidilicet: villam ipsam de Fusellis, cum omnibus / decimus, rusticis et ceteris pertinentiis suis; ecclesiam de Vilabdela, cum tota villa et ominibus decimis et pertinenciis ipsius; ecclesias de / Paliares, de Vilagoterre, de Vilandavid et Sancti Iuliani et Sancte Marie de Cellerolo et ipsas villas omnes in quibus ecclesie site $\rho^{9}$ sunt, cum omnibus decimis et pertinentiis earum; ecclesiam Sancte Euphemie, cum omnibus decimis et pertinenciis eius; ecclesiam Sanc/ti Sabastiani de Ermides, cum omnibus decimis, possessionibus ac pertinenciis eius; in Fontibus 
de Don Bermudo, ecclesiam Sancti Machaelis, cum / omnibus decimis, rusticis, possessionibus atque pertinenciis suis; in Fontibus de Vallepero, ecclesiam Sancti Petri, cum omnibus decimis, solaribus, terris, $/^{12}$ vineis et omnibus pertinenciis suis; ecclesiam Sancti Iacobi, in Calabazanos, cum omnibus decimis, rusticis, possessionibus ac pertinenciis eius; ecclesiam Sancte Ma/rie, prope Monzon, cum omnibus decimis, possessionibus ac pertinenciis eius; ecclesiam Sancti Adriani et totam villam, cum omnibus decimis ac pertinenciis suis; ecclesiam / Sancti Facundi de Paredes, cum omnibus decimis et pertinenciis suis; ecclesiam Sancte Marie de Castrello, cum omnibus decimis et pertinenciis suis; ecclesiam Sancte $/^{15}$ Eugenie de Pinna, cum omnibus pertinenciis suis; quicquid, etiam, iuris habetis in ecclesia de Fontepudia et eius pertinenciis; ad hec, Villan Alberez, cum omnibus per/tinentiis; Celamnouam, cum omnibus suis pertinentiis; in Turre de Astudelo, unum palacium, solares, terras, vineas et prata preterea; quicquid habetis in Palen/cia, in Bezerrileios, in Populacione, in Ripis, in Mazaregos, in Ecclesiota, in Quintanella, in Berbesca, in Celata, in Villacastin, in Motera, in Sancto Martino, in Sancto $/{ }^{18}$ Ouio, in Cellata, in Fonte Quinana, in Villa Vnbrales, in Castro Viridi, in Villa Garcia Sancti Basilio, in Palacio, in Villa Ximena, cum autem generale inter/dictum terre fuerit liceat uobis, clausis ianuis exclusis excomunicatis et interdictis suppressa uoce non pulsatis canpanis diuina officia cele/brare sepulturam quoque ipsius loci, liberam esse descernimus ut eorum deuocioni et extreme uoluntati qui se illic sepeliri deliberauerint nisi forte excomunicati ${ }^{21}$ uel interdicti sint. Nullus obsistat salua tamen iusticia illarum ecclesiarum a quibus mortuorum corpora assumuntur, porro sub interminacione anathematis / prohibemus ne ullus umquam laicos in laicali ordine, remanentes canonicos, de cetero ecclesie ipsius instituat uel aliis quam canonicis nisi tamtum pi/etatis et paupertatis intuitu ipsius ecclesie possessiones uel redditus conferat in prebendas, ceterum antiquas et racionabiles consuetudines iam dicte ecclesie ${ }^{24}$ ac tenus obseruatas, ratas habemus et auc tornate apostolica; confirmamus immunitates, preterea et libertates eidem ecclesie a regibus et principibus / iuste indultas, sicut in eorum scriptis autenticis continetur illibatas. Sanctimus futuris temporibus permansura decernimus ergo ut nulli / omnino hominum liceat prefatam ecclesiam temere perturbare aut eius possessiones auferre uel ablatas retinere, minuere aut aliquibus uexacionibus $\mathrm{fa} /{ }^{27}$ tigare, sed omnia integra 
conseruentur eorum pro quorum gubernacione ac sustentacione concessa sunt usibus omnimodis pro futura salua sedis / apostolice auctoritate et eius legatorum canonica justicia. Si qua igitur in futurum eclesiastica, secularis ne persona hanc nostre constitucionis / paginam sciens contra eam temere uenire temptauerit. Secundo tertio ne canonica nisi reatum suum digna satisfactione correxerit potestatis honoris que sui $\mathrm{di} /{ }^{30}$ gnitate careat ream que se divino iudicio existere de perpetrata iniquitate conoscat et a sacratissimo corpore ac sanguine Dei et domini redemptoris nostri Ihesu Christi / aliena fiat aut in extremo examine diuine ulcioni subiaceat cunctis autem eidem loco sua iura seruantibus sit pax domini nostri Ihesu Christi, qua tenus / et hic fructum bone actionis percipiant et apud districtum iudicem premia eterne pacis inueniant, amen, amen.

(Signo rodado cuarteado y en los cuarteles: SANCTUS PETRUS. SANCTUS PAULUS. ALEXANDER PAPA III. Alrededor: VIAS TUAS, DOMINE, DEMONSTRA MICHI)

(Monogramma: BENE VALETE).

Ego Alexander, Catholice Ecclesie episcopus.

( $1^{a}$ col.) (Signum: cruz) Et ego, Iohannes, Sanctorum Iohannis et Pauli presbiter cardenalis, testis.- Pamachi conf.- (Signum: cruz) Ego, Cimilius, presbiter cardenalis, testis.- Sanctem Cerilie conf.- (Signum: cruz) Ego, Matheus, presbiter cardenalis, testis.- Sancti Marçeli conf.- (Signum: cruz) Ego, Ardicius, diaconus cardenalis Sancti Theodori, conf.

( $2^{a}$ col.) (Signum: cruz) Ego, Enrricus Albanensis episcopus, conf.- (Signum: cruz) Ego, Theodinus Portuensis episcopus, conf.- (Signum: cruz) Ego, Bernered, Prenestinus episcopus, conf.

( $3^{a}$ col.) (Signum: cruz) Ego, Bamerius, diaconus cardenalis Sancti Georgii ad Vellum Aurum, conf.- (Signum: cruz) Ego, Gratianus, diaconus cardenalis Sanctorum Cosme et Damian, conf.- (Signum: cruz) Ego, Iohannes, diaconus, 
cardenalis Sancti Angeli, conf.- (Signum: cruz) Ego, Ramerius, diaconus, cardenalis Sancti Adriani, conf.

Datum Anagnie, per manum Alberti, Sancte Romane Ecclesie presbiteri, cardenalis cancelaris. XIIII kalendas decembris, indictione XIII, incarnationis Dominice anno M C LXX VIIII, pontificatus uero domini ALEXANDRI Pape III, anno XXI.

1181, enero, 16. Toledo.

Alfonso VIII ordena que nadie de su reino embargue bienes de los hombres de su pariente don Pedro de Cardona, a saber, los hombres de Cilleruelo y San Julián, salvo por deudas propias, fianzas por ellos dadas o a causa del mayordomo de Santa María de Husillos puesto por Pedro de Cardona o sus sucesores.

A. AHDP, Ampudia y Abadía de Husillos, Pergaminos, carp.197-9. Perg., 164 x 131 mm.; escr. carolina; buena conservación, aunque existe una rotura que afecta a las líneas 11 y 12 .

$B$. APA, $L P H$, ff. $19 \mathrm{v}-20 \mathrm{r}$. Al final: $<$ Esta scriptura, por estar rota en algunas partes que no se pudo leer, no se signó>.

C. BN, ms. 705, ff. 29v-30r. Tanto el Libro de los Privilegios de Husillos como el manuscrito 705 trasladan erróneamente el año.

ED. J. GONZÁLEZ, Alfonso VIII, II, 606-607.

Aldefonsus, Dei gratia rex Castelle, omnibus regni sui fidelibus et uillarum / conciliis ad que litere iste peruenerint, salutem et gratiam. Notum sit omnibus hanc / cartam regali sigillo signatam uidentibus quod ego, Aldefonsus, rex prefatus, mando et fir $/ 3$ miter defendo quod nullus homo tocius regni mei aliqua occasione pignorare au/deat homines de honore dilectissimi consanguinei mei, 
Petri de Cardona, scilicet: / homines Sancte Marie de Celeruelo, nec homines de Sancto Iuliano, nisi solum modo propter sua $/{ }^{6}$ propria debita aut propter fiaduras $\mathrm{ab}$ ipsis factas aut propter maiorem domus Sancte $\mathrm{Ma} /$ rie de Fusellis qui canonicam Sancte Marie de manu prefati Petri de Cardona / aut sucessorum suorum tenebit.

Siquis uero contra hoc meum mandatum in ali $/{ }^{9}$ quo fecerit aut prefatarum uillarum homines propter canonicos aut propter aliam / ocasionem nisi propter prefatam [...] regie parti centum aureos in coto / pectabit et predictarum uillar[um...] dampnum quod intulerit duplatum pec $/{ }^{12}$ tet.

Facta carta apud Toletum, era $\mathrm{M}^{\mathrm{a}} \mathrm{CC}^{\mathrm{a}} \mathrm{XVIIII}^{\mathrm{a}}$, XVII ${ }^{\circ}$ kalendas febre/arii. Magister Geraldus, regis notarius. Petro de Cardona, existente can/cellario, scripsit. $/^{15}$

1182, agosto, 6 .

Lucio III pone bajo la protección del pontificado a los bienes y derechos de la sede episcopal palentina, en especial a los que se enumera, entre los que se encuentra Santa María de Husillos con sus términos, villas, decanías y todas sus pertenencias.

B. ACP, Arm. III, leg. 2, doc. 26, copia del siglo XIII.

C. ACP, Arm. III, leg. 10, doc. 1, Libro de privilegios, ff. 39v-41r.

ED. ABAJO, Documentación Catedral de Palencia, 191-194, núm. 93.

REG. SAN MARTÍN PAYO, Catálogo Catedral de Palencia, 92.

En la nómina de iglesias que se confirman, Santa María de Husillos aparece en primer lugar. 


\section{DAVID MARCOS DIEZ}

1183, diciembre, 22.

Raimundo II, obispo de Palencia, con el consenso del abad de Santa María de Husillos, Gonzalo Pérez, y de los canónigos de dicha iglesia, establece que estos últimos tengan sus propios réditos por separado del abad y de la fábrica, a saber, los diezmos de Husillos, dos terceras partes de las oblaciones a su iglesia, y las limosnas que se entregaran por los difuntos; dos molinos en la casa mayor y la tercera parte de la pesquera situada encima de aquella; en Cabo de Viña, cinco molinos y medio y los diezmos de dicho lugar; Sahagún el Viejo de Paredes con sus heredades y pertenencias; el monasterio de San Pedro de Fuentes; la tercera parte de la marzadga de Villaudilla; la villa de San Julián con todas sus pertenencias y con los diezmos y obladas de su iglesia; la villa de Santa María de Cilleruelo con su iglesia; el río Carrión desde el puente de Monzón hasta el vado que está debajo de los molinos de Palacios; y todas las heredades que en el futuro puedan ganar.

Podrán nombrar de entre sus miembros, un administrador de sus bienes y un canónigo obrero o fabriquero. Se les concede las mismas libertades que disfrutan los canónigos de la catedral de Palencia, entre éstas que ningún merino o sayón pueda entrar en las casas de los dichos canónigos. Cada canónigo tendrá un escusado y una casa de la misma condición, y todo el cabildo tendrá siempre como escusado a su hortelano. Fija su número en dieciséis canónigos, incluido el prior; y ocho porcioneros.

A. AHDP, Ampudia y Abadía de Husillos, carp. 207-8. Perg., 294 x 494 mm.; escr. carolina; regular conservación,con algunas manchas y roturas.

$A^{\prime}$. ACP, Arm. III, leg. 13, doc. 1. Perg., 425 x 500 mm.; escr. carolina; buena conservación. Falta el sello pendiente.

$B$. APA, $L P H$, ff. 20r-21r.

C. BN, ms. 705, ff. 30r-32v. 
ED.- SAN MARTÍN PAYO, Santa María de Husillos y su colección diplomática, 151-171.ABAJO, Documentación Catedral de Palencia, 197-200, núm. 95.

REG.- SAN MARTÍN PAYO, Catálogo Catedral de Palencia, 149-150.

CIT.- J. GONZÁLEZ, Siglos de Reconquista, 198.

In nomine Domini nostri Ihesu Christi, amen. Ex officii nostri debito constringimur omnibus ecclesiis regimini nostro comissis paterna sollicitudine inminere, precipue tam dilecte filie nostre Fusellensi ecclesie, que quanto amplius nostro indiget ad miniculo et auxilio vel consilio, eo magis / nos oportet eius necessitatibus pro disiderio condescendere et circa libertatem atque utilitatem omnimodis in vigilare. Ea propter, ego R[aimundus], Dei gratia Palentine ecclesie episcopus licet indignus, una cum consilio et voluntate Gundissalvi Petri, Fusellensis ecclesie abbatis, / et eiusdem loci canonicorum, statuo, dono et concedo, ut canonica prenominate ecclesie habeat propios redditus per se, partitos et divisos a cetero honore abbatie et palacii. Hos scilicet: decimas tocius laboris domus Fusellensis, tam panis quam vini, ovi $/{ }^{3}$ um et ceterorum animalium et omnium fructuum ortorum et arborum. Similiter de linaribus et cannamariis et de leguminibus duas quoque partes oblationis quas ad ecclesiam attulerint, nam tercia sacricustodis erit. Et omnes elemosinas et lectos qui cum mortuis ad ecclesiam / allati fuerint. Et duos molendinos in maiori domo, et terciam partem in piscaria de supra de illa, et in Capite Vinee $\mathrm{V}$ molendinos et medium et decimas omnes eiusdem ville, panis et vini et ortorum, arborum et animalium, similiter de linaribus et cannamariis, / et de leguminibus; et Sanctum Facundum de Paredis, cum hereditate et pertinenciis suis; et monasterium Sancti Petri de Fontibus; et ex solidis marcii de Villa Abdela terciam partem; et villam Sancti Iuliani cum omnibus pertinenciis suis in integrum et ecclesiam cum decimis $/{ }^{6}$ et oblationibus suis; et villam Sancte Marie de Celleroso cum ecclesia et pertinenciis suis; et totum rivum a ponte de Monzon usque ad vadum quod est sub molendinis Palacii; et omnes vineas et terras et pratos et saltus et omnem hereditatem et omnia quecumque iuri eiusdem / canonice sunt in presenti vel in futuro fuerint deputata. Hos itaque honores Fusellensi canonice et eiusdem ecclesie canonicis tali libertate donamus et concedimos, ne episcopus Palentinus vel abbas de 
Fusellis possit ex eis aliquid diminuere vel sibi usurpare, nec / offitium vel ammistrationem ipsius prepositure, sibi liceat vendicare vel quocumque modo habere, sed habeat conventus Fusellensis liberam potestatem eligendi et constituendi sibi in canonica sua prepositum vel prepositos de canonicis suis, cum consilio tamen $/^{9}$ et assensu Palentini episcopi vel abbatis sui et etiam removendi, si forte quod absit res canonice, male tractaverint vel conductum refectorii diminuerint in aliquo, vel abstulerint. Si vero res ipsius canonice supra habundaverit ita quod redditus ei provenientes eiusdem / expensas excedant, quod superfuerit in utilitates convertatur canonice prout prior et capitulum sanius et consulcius fore providerint. Volumus quoque et concedimus ut prior et capitulum habeant ius et potestatem constituendi operarium in opera ipsius ecclesie, absque / tamen havito consilio et consensu Palentini episcopi vel abbatis de Fusellis, ita dumtaxat quod dictus episcopus vel abbas ipsam operam sibi non possit aliquatenus retinere, sed neque res ipsius in presenti habitas vel in futuro habendas diminuere vel propriis usibus ap $/{ }^{12}$ plicare.

Item bonum bono addentes, donamus et constituimus predictis canonicis eandem libertatem in domibus suis et in villa de Fusellis in omnibus et per omnia, quam habent palentini canonici in Palentia, scilicet: quod nec maiorinus, nec sagio, nec concilium, pro ali/qua causa domos eorum violenter intrare presumat. Siquis autem de saepe dictis canonicis querimoniam habuerit, querela priori et capitulo exposita, eorum iudicio emendationem accipiat. Adhuc autem concedimus quod unusquisque canonicorum excusare possit unum / collatium qui non sit de hereditariis vel postariis eiusdem ville et tali modo unusquisque eorum singulas tantum domos et non amplius excuset. Ortolanum quoque canonicorum ab omnibus semper excusatum fore statuimus. Quicumque autem sive miles vel cuiuscumque conditionis $/^{15}$ homo domos predictorum canonicorum violenter intraverit vel disruperit vel hominibus eorum violentiam aliquam seu dampnum aliquod facere presumpserit, aut ganatum suum intus vel exterius pignoraverit, eo modo quo et palentinis canonicis de iniuria seu dampno illa/to eis satisfaciat et penam eandem paciantur.

Deinde certum numerum canonicorum in eadem ecclesia firmiter statuentes decernimus, ut sint ibi XVI canonici tantum, annumerato priore, et VIII porcionarii ibidem Deo iugiter servientes, nec possint ibi de cetero / aliquis fieri 
canonici seu portonarii donec hii socii qui nunc supersunt ad numerum determinatum descenderint, qui postea numerus nullatenus augeatur, sed quot de prelibato numero desciderint, tot portionarii numerum prefatum iterum supleant, quorum etiam loco alii $/^{18}$ admittantur, ita quod taxatus numerus in utrisque ex tunc, non excedat aut minoretur. Portionarii vero nullam prosus in ecclesia vel capitulo vocem habeant, nec aliqua laicalis persona in eadem ecclesia canonicari possit, vel portione seu prestimonia habere, sed neque aliquis / non legitime procreatus nisi forte probate opinionis vita claruerit.

Omnia itaque que supradiximus volumus rata et firma stare in perpetuum ac illibata permanere.

Siquis autem ausu temerario huic privilegio obviaverit vel hanc libertatem a nobis donatam ani/chilare vel delere temptaverit, deleatur nomem eius de libro viventium, et cum iustis non scribatur, et quicquid atemptatum contra fuerit, in irritum deducatur, nec habeat vires.

Facta carta XI kalendas ianuarii, era M CC XXI. Regnante rege ${ }^{21}$ Aldefonso cum uxore sua regina Alienor, in Castella et in Toleto et in Extrematura. Raimundo, episcopo in Palentia. Gundisalvo, archiepiscopo in Tholeto. Gundisalvo Petri, abbate in Fusellis. Priore eidem loci, Dominico. Garsia, sacricustode. Magistro Odone, / precentore. Iohane, maiordomus de Fusellis. Et de domo regia, maiordomus Rodericus Guterrii. Lupus Diez, maiorinus Domini regis. Senior in Monzon, Rodericus Guterrii.

Et ego, Raimundus, Palentini ecclesie episcopus qui hanc cartam fieri feci, manu propia / corroboro et confirmo coram his testibus: Petrus Guterrii, Palentinus archidiaconus, testes. Gundisalvus Monuz, Palentinus canonicus, testes. Raimundus, scriba maiordomus Palentie, testes. Gregorius, canonicus, testes. Petrus Poncii, cancellarius episcopi, testes.

Raimundus, notarius episcopi, scripsit et hoc signum (signum) fecit.

1197, enero, 13. Sandoval. 
Gonzalo, abad de Santa María de Husillos, recibe del monasterio de Santa María de Sandoval y de su abad, Juan, seiscientos maravedís de buen oro en concepto de préstamo. Los recibe sobre el aval de las heredades que aquel tenía de su madre en Villarroañe. Establece el abad Gonzalo la condición de que, en remedio de las almas de sus padres, los frutos obtenidos sean destinados a pobres y peregrinos. Transcurrido un año, que finalizará en enero de mil ciento noventa y ocho, será devuelta la cantidad recibida en préstamo.

A. AHN, Clero, carp. 993-6. Carta partida por ABC...FGH invertidas. Perg., 258 x 265 mm.; escr. carolina; buena conservación.

ED. CASTÁN, Documentos de Sandoval, 76-77, núm. 30.- ÍD., El dominio del monasterio de Sandoval, 313-314, núm. 6.- HERRERO JIMÉNEZ, Sandoval, 95-96, núm. 34.

Se incluye el presente documento ante la posibilidad de que el préstamo se destinara a Santa María de Husillos a nombre de su abad Gonzalo, con la posible existencia en su momento en el archivo de Husillos del otro ejemplar de carta partida por ABC.

Edición tomada de Mauricio Herrero Jiménez.

In Dei nomine et eius gratia. Ego, Gondisaluus, gratia Dei abbas Fusellensis, rogaui abbatem Iohannem Saltus Noualis et conuentum eius / et acomodauerunt mihi DC morabitinos boni auri et obtime monete super Uilla Roan, quantum ibi habuit uel habere debuit mater mea, / sub tali conditione: quod fructuum prouentus in Saltu Nouali pauperibus, pro animabus matris et fratris mei, concedatur et peregrines. Accepi ergo aureos $\beta$ predictos quos cum reddidero a ianuario usque ad ianuarium, secundum morem terre hereditatem recipiam predictam. Ita tamen placuit mihi pro / remissione peccatorum meorum et pro animabus parentum meorum, nec uendere nec sub pignore alicui obligare per bonam fidem sine malo / ingenio si fraters predicti illam recipere uoluerint, eodem modo quo alter uoluerit eam habere causa uendicionis uel sub pignora/tionis sub maioris precii quantitate.

Facta carta apud Saltum Noualem, sub era $\mathrm{M}^{\mathrm{a}} \mathrm{CC}^{\mathrm{a}} \mathrm{XXX}^{\mathrm{a}} \mathrm{V}^{\mathrm{a}}$, die idus ianuarii. $/^{6}$ Regnante rege Adefonso in Legione, Gallecia, Asturiis et Stremadura. Episcopo Manrico, presidente in Legione. Maior/domus regis, Petro Fernandi. 


\section{LA ABADÍA DE SANTA MARÍA DE HUSILLOS: ESTUDIO Y COLECCIÓN \\ DOCUMENTAL $(904-1608)$}

Qui presentes fuerunt, uiderunt et audierunt: abbas de Spina, conf. I Gundissaluum (sic) Martin conf. Pelagius Gallego conf. Gondissaluus Pelaez de Raneros conf. $/{ }^{9}$ Dominicus Michaeli conf. Nicholaus Iohanni conf. Petrus Petri conf. Gutier Didaz conf. / Petrus Pelagii conf. Don Lope conf. Don Loppe de Aulinus conf. Don Bartolot conf. / Martin Monte Roso. Domnus Andreas conf. Vasal, fiel, conf. Pelagius Michola.

1198, abril, 18.

Mayor, viuda de García Anaiz, con el consentimiento de sus hijos Rodrigo y Elvira García, en remedio de su alma y de las de sus padres, dona a Santa María de Husillos su heredad en Villatoquite, para que se haga un aniversario por su esposo y por ella cuando muera.

A. AHDP, Ampudia y Abadía de Husillos, Pergaminos, carp. 197-8. Perg., 112 x 179 mm.; escr. carolina; buena conservación.

B. APA, $L P H$, f. $21 \mathrm{v}$.

C. AGS, Patronato eclesiástico. Inconexos, leg.159, ff. 31v-32r. Papel; escr. procesal; buena conservación.

D. BN, $m s .705$, ff. 33v-34r.

(Christus). In Dei nomine. Ego, Maior, uxor quondam domni Garsie Annaiz, pro anima eius et mea parentumque / nostrum una cum uoluntate et asensu filii mei Roderici ac filie mee Eluire Garsie, dono et concedo Deo / et ecclesie Sancte Marie de Fusellis totam hereditatem quam habeo uel habere debeo in Uilla Toquit, uide $/{ }^{\beta}$ licet: terras, uineas, cultas et incultas, solares, collacios cum introitibus et exitibus eorum, cum toto quod ibi / ad dominium meum meum (sic) pertinet ad anniuersarium predicti uiri mei Garsie Annaiz et meum cum finiero uitam./ 
Siquis autem ex proienie mea siue ab extranea hoc scriptum infringere temptauerit, sit maledictus et excommuni $/{ }^{6}$ catus, et cum Iuda Domini traditore damnatus et in super quantum inquietauerit duplet, et regie potestati centum / morabetinos persoluat et careat uoce. Et hoc scriptum donationis quod ego et filii mei fieri iussimus in perpetuum maneat / ualiturum.

Facta carta sub era $\mathrm{M}^{\mathrm{a}} \mathrm{CC}^{\mathrm{a}} \mathrm{XXX}^{\mathrm{a}} \mathrm{VI}^{\mathrm{a}}$, die XIIII kalendas mai. Regnante rege Adefonso $/{ }^{9}$ cum regina Allionor in Toleto et in Castella. Martino archiepiscopo existente in sede Toletana. Alderico episcopo / in Palencia. Domno Gondissaluo Petri, abbate in Fusellis. Maiordomo regis Gondisaluo Roiz. Maiorino Roderico / Petri de Mala Uilla.

Ego, iam dicta Mayor, et filii mei, hanc cartam quam fieri iussimus propriis manibus roboramus et con $/{ }^{12}$ firmamus et signum facimus (Signum).

( $1^{a}$ col.) Petrus, prior de Fusellis, conf.- Martinus de Orella, sacrista, conf.Reimundus Catalanus, cantor, conf.

( ${ }^{a}$ col.) Magister Nycholaus, canonicus, conf.- Iohannes de Uezella, canonicus, conf.- Donnus Alexander, canonicus, conf.

1200, mayo, 21.

Fernando Ponce y su mujer, María Gutiérrez, juntamente con los hijos de Salomón: Esteban Salomón, Sancha Salomón y Sancha Verengaria, venden a Martino, sacristán de Santa María de Husillos, unas tierras ubicadas entre Santa María de Cilleruelo y Cilleruelo, en precio de cien áureos.

A. AHDP, Ampudia y Abadia de Husillos, Pergaminos, carp. 208-3. Perg., 215 x 192 mm.; escr. carolina; buena conservación con pequeñas roturas en varias líneas que no impiden su lectura. B. APA, $L P H$, f. $22 \mathrm{r}-\mathrm{v}$. 
C. AGS, Patronato eclesiástico. Inconexos, leg.159, ff. 32r-33r. Papel; escr. procesal; buena conservación.

D. BN, $m s .705$, f. 35r-v.

Notum sit omnibus hominibus, quod ego, Ferrandus Poncii et uxor mea Maria Guterri / simul cumque filiis dompni Salomonis, scilicet: Stefanus Salomonis, Sancia Salomonis et Sancia / Berengarii, uenditores sumus uobis, dompno Martino, sacristae Fusellensi, quasdam terras $\beta$ quas habemus inter uillam Sancte Marie de Cillerolo et ipsam uillam de Cillerolo. Prima terra, que dicitur /de Manicis, abet affrontationes: de duabus partibus terram canonicorum Fusellensium, de tercia terram fratrum / de Ucles, de IIII $^{\mathrm{a}}[\ldots]$ parte illa carrera que uadit ad Cillerolum; alia terra abet affrontationes: de / prima parte terra dompni Iusti, de II ${ }^{\mathrm{a}}$ terram domni Aznarii, de III $^{\mathrm{a}}$ el aroyo, de IIII ${ }^{\mathrm{a}}$ uero parte $/{ }^{6} \mathrm{La}$ Carera; alia terra est iusta pratum de Cillerolo que abet affrontationes: de duabus partibus illum pratum / de Cillerolo, de III ${ }^{\mathrm{a}}$ terram fi[li]orum Gondisalui Martini, de IIII ${ }^{\text {a }}$ uero parte terram domni Berengarii; alia terra que / dicitur Ferrem abet affrontationes: de prima parte terram Dominici Paiares, de secunda terram filiorum Petri $/{ }^{9}$ Dominici, de III $^{\text {a }}$ et de IIII ${ }^{\mathrm{a}}$ las Carreras; ad huc uendimus uobis aliam terram que est inter Cillerolum et Uillam Mar/tim, que dicitur Friera, que abet affrontationes: de duabus partibus terreas fratrum de Ucles, de III ${ }^{\mathrm{a}}$ terram de / Solbella, de IIII ${ }^{\mathrm{a}}$ la Carrera; alias terras habemus in ipso termino de Sancta Maria de Cillerolo quas uen $/{ }^{12}$ dimus uobis $<$ cum terra que $>$ est iusta uineas de La Coua, que abet affrontationes: de prima parte terram domni / Iusti, de II $^{\mathrm{a}}$ terram que dicitur de Comitissa, de III $^{\text {a }}$ terram filiorum domni Cristoforum, de IIII $^{\text {a }}$ La Carcaua; alia ter/ra est Carera de Uilla Ramiro que abet affrontationes: de prima parte terram Iohanis de Sancta Marta, de $\mathrm{II}^{\mathrm{a}} /{ }^{15}$ uineam domni Petri, de III ${ }^{\mathrm{a}}$ terram filiorum domni Sabastiani, de IIII ${ }^{\mathrm{a}}$ terram canonicorum Fusellenssium.

Omnes istas / terras quas nominauimus uendimus uobis domno Martino, supradicto sacriste, pro centum aureos et suo al/baroc, de quibus aureis sumus bene pacati et sumus manifesti de repetitione uero de proienie nostra $/{ }^{18}$ uel de extranea. 
Qui hanc uenditionem nostram infringere uoluerint, pectet in coto CCC morauetinos $^{7}$ et ipsas / terras duplatas uel melioratas in talibus locis < uobis $>$ restituant.

Facta carta XII kalendas iunii, sub era / M CC XXX VIII. Regna[nte re]ge Aldefonso $<$ cum $>$ regina Alionore in Toleto et in Castella. Alderico, episcopus $<$ existens $>$ in $~^{21}$ Palentia. Gondisaluo P[e]tri, abbate in Fusellis. Isti sunt testes: Gondisalvus de Sancta Maria de Cillerolo. Dominicus / Paiares. Domnus Iustus. Berengarius de Otella. Dominicus Lupi. Iohanes, filii dompnus April. Iohanes Puchero. De Villa Mar/tino: Petrus Petri. Dominicus Lozano. Martinus Gondisalui. Et Sancta Maria de Cillerolo est merinus domnus Petri, et ho/ $/ 24$ mines ipsius uille sunt uisitores, auditores et confirmatores. Cid, Bellid, Anaia confirmant.

Rodericus scripsit.

1200, diciembre.

Isabel y Gonzalo Pérez, su hijo, venden a Pedro de Becerril, prior de Santa María de Husillos, unas casas en el barrio de San Antolín de Palencia, en precio de ciento diez maravedís.

B. APA, $L P H$, ff. $21 \mathrm{v}-22 \mathrm{r}$

C. BN, ms. 705, ff. 34r-35r.

Fecho y sacado fue este dicho traslado de la dicha escritura que de suso va incorporada al original en la villa de Husillos, a veynte e un dias del mes de noviembre de mil e quinientos e cinquenta y quatro años. Testigos que fueron presentes a lo ver, leer, corregir y concertar con el original, Joán Ruiz Cabeça de Vaca y Gaspar de Vedoya, clérigos, e Pero Manuel estantes en la dicha villa.

\footnotetext{
${ }^{7}$ morauetinos] Se tachó "aureos" y se escribió "morauetinos".
} 
Y yo, Santiago Gómez, escriuano público en la dicha villa, fui presente a lo que dicho es con los dichos testigos. E del dicho pedimiento e mandamiento lo fize escrevir e fize aquí mi signo (signo) en testimonio de verdad.

Pero Ruyz de Billoldo (rúbrica). Santiago Gómez (rúbrica).

Notum sit omnibus hominibus quod ego, domna Elisabet et filius meus, Gundisaluus Petri, vendimus vobis domno Petro de Bezerril, priori Fusillensis ecclesie, vnas casas que sunt in barrio Sancti Antonini et habent quator afrontaciones: de vna parte case Palentini episcopi et murus ciuitatis. De II $^{\mathrm{a}}$ parte sunt case Palentini episcopi quas domnus Didacus precentor debet tenere in vita sua. De III ${ }^{\mathrm{a}}$ parte sunt case Ferdinandi Santii et sunt case domne Marte et sunt case Ioannis Laurentii. De IIII ${ }^{\mathrm{a}}$ vero parte, calle qui vadit ad flumem. Quamtum infra predictas afrontationes includitur totum vendimus vobis pro centum et decem morabetinos inter pretium et alborot, et de isto pretio non remansit super vos vllum debitum pro dare nec nos in predictis casis aliquod ius possidendum.

Quicumque hanc cartam infringere voluerit, pectet in coto ducentos uiginti morabetinos cui vocem vestram dedistis et vobis tales casas con semilibus locis duplet.

Facta carta ista mense decembrio sub era MCCXXXVIII $^{\mathrm{a}}$, regnante rege Aldefonso cum regina Alionore in Toleto et in Castella. Alderico, episcopo in Palentia. Petro Quintana, merino. Micaela, sagione. Vnde sunt presentes testes: Petrus Armegot et Gundisaluus Sisamon et Terrin Alfaat; Aldefonsus Simonius et Mauricius et Guilielmus Robet, et Ioannes Armegot et Petrus Cutral et filii Petro Pagom, scilicet, Stephanus et Antonius; Dominicus Arnaldi et Martinus Alfaat et Petrus Raymundi, et Ioannes, Sancti Antonini capellanus. Et concilium Sanct Antonini sunt visores, auditores et confirmatores.

Ioannes scripsit et hoc signum fecit.

1201, julio, 7 . 
Elvira, hija de Pedro Gutiérrez de Frechilla, permuta con los canónigos de Santa María de Husillos, en remedio de su alma y por un aniversario por el alma de su hijo, Martín Fernández, la cuarta parte de la iglesia de Pozuelos de Damián, recibiendo a cambio un solar que don Gueraldo y su mujer Andrequina donaron a Santa María de Husillos para después de su muerte.

A. AHDP, Ampudia y Abadía de Husillos, Pergaminos, carp. 207-9. Perg., 195 x 157 mm.; escr. carolina; buena conservación.

B. APA, $L P H$, f. $22 \mathrm{v}$.

C. AGS, Patronato eclesiástico. Inconexos, leg.159, f. 33r-v. Papel; escr. procesal; buena conservación.

D. BN, ms. 705, ff. 35v-36v.

CIT. BARÓN FARALDO, Grupos y dominios aristocráticos, 503.

In Dei nomine. Notum sit omnibus hoc scriptum audientibus quod ego, domna / Elbira, filia Petri Guterii de Frechella, pro remedio anime męe et anniuersario filii / meii Martini Ferdinandi, do in perpetuum uobis, canonicis Sancte Marie de Fusellis $\beta$ et comuni uestro, quartam partem ęcclesie Sancte Marie de Pozuelos de Amianos cum omni iure / suo ad me pertinente. Et recipio a uobis in con cambio huius donacionis illud solar quod uos / datis mei amoris intuitu domno Gueraldo et uxori sue Andrequine in omni uita sua $/{ }^{6}$ possidendum in Sancta Maria de Cellerolo tali condicione ut post obitum eorum ad uos ut / prius habebatis redeat.

Siquis uero hoc scriptum infringere uoluerit, pectet in coto / quingentos morabetinos et predictam ęcclesiam in con simili loco restituat.

Facta carta nonas $/^{9}$ iulii, sub era $\mathrm{M}^{\mathrm{a}} \mathrm{CC}^{\mathrm{a}} \mathrm{XXX}^{\mathrm{a}}$ VIIII. Regnante rege Aldefonso cum uxore sua, / Alionore, in Toleto et in Castella. Maiordomus eius, Gondisaluus Roderici. Maior merinus / eius, Guterrius Didaci. Domno Arderico, in sede palentina episcopo existente. Gondissaluo Petri, $/^{12}$ abbate in Fusellis. Dominantibus in Pozuelos, Goterriio Didaci et Roderico Martini. Huius rex sunt / testes: el prior don Remond. Don Alfonso Guterrii. Garcia Martinez. Rodericus Fernandiz. Ro/dericus Gondisaluus. Don Gil, preste. Don Iones, ${ }^{15}$ preste. 
Sancius, preste. De laicis: don Laguo. Iohan Iohannes. Gonzaluo / Fortęs. Petro Iohannes. Don Gil. Martinus Lozano.

1201, noviembre.

Carta de avenencia con apeamiento sobre los términos de Santa Eufemia, cerca de San Cristóbal, por mandato de Alfonso VIII, realizado entre Arderico, obispo de Palencia, con consentimiento del cabildo catedralicio, y Gonzalo Pérez de Torquemada, abad de Santa María de Husillos, juntamente con su cabildo. Se establece que el ganado de Palencia no pueda pastar en término de Santa María de Husillos sin licencia de su cabildo.

A. AHDP Ampudia y Abadia de Husillos, Pergaminos, carp. 210-1. Carta partida por ABC. Perg., 193 x 309 mm.; escr. carolina; regular conservación, aunque se puede leer perfectamente.

B. APA, $L P H$, f. 23 r.

C. BN, $m s .705$, ff. $36 \mathrm{v}-37 \mathrm{v}$.

In nomine Domini. Notum sit presentibus et futuris qui hanc cartam audierint, quod ego, Aldericus, Palentinus episcopus, de consensu nostri capituli / ecclesie Palentine, et ego, Gundisaluus Petri de Ture Cremata, de mandato domni regis Allefonssi, fecimus abenenciam super controuersiam / que erat inter concilium Palentinum et ecclesiam de Fusellis super terminus Sancte Eufemie qui est prope Sanctum Chistoforum; et fuit facta ista concordia et abenen/ $/ 3$ tia secundum dispositionem antiquorum uirorum in festo Sancti Laurentii, cum beneplacito et uoluntate predictorum capituli et concilii Palentini et abatis / et capituli ecclesie Fusellensi et deberet perpetuo perdurare sicut diuisa est per terminos. Primus moion, contra Palentiam fuit po/situs prope flumem de Carrione ubi [so]lebat stare el Ponton Angosto et uocatur modo El Vado per quem transitur ad Ortam Topi que dicitur Quinta $/{ }^{6}$ nilla, et uadit per uiam illam apud Sanctum Facundum. Secundo moion fuit posita apud los Linderos Uieios inde et uadit uia 
recta per uiam / qui uadit et transit apud illos oteros qui sunt contra Palentiam per illam uiam que uadit a Monçon, de inde per Derronandas que sunt ibi prope et inde / per uiam illam que uadit contra planum usque ad dictam ecclesiam de Fusellis. Et intra istos moiones contra Fusellis non debet intrare ad pascen/ $/ 9$ dum ganatum de Palentia sine licencia capituli ecclesie Fusellensis. Huius conuentione et limitatione sunt testes: Martinus abbas Sancti Pelagii / de Cerrato. Iordanus archidiaconus Palentinus. Iohannes de Metina, canonicus palentinus. Martinus Mathei de Carrione, capellanus episcopi.

Facta carta mense nouembris, era M CC XXX IX. Regnante rege Aldefonsso cum coniuge sua, Alleonor, et cum filio suo, Fernando, / in Toleto et in Estremadura et in Castella et in toto regno suo. Gundissaluus Dominici, maiordomus regis. Guterrio Didaci, [merino] $/{ }^{12}$ domini regis, sub eo Gundissalus Giles, in Campis. Si quis hanc cartam infringere temptauerit, sit maledictus et excomunicatus et pectet in coto mil/le morabitinos, medietatem domno regis, et aliam medietatem, cui iniuriam fecerint. De hoc facto sunt due carte diuise per alphabetum / sub eodem tenore coram predictis domno episcopo et Gundissaluo. Et de eorum mandato sub era supra scripta.

1202, junio, 28.

Gonzalo, abad de Santa María de Husillos, a instancias del cabildo de dicha iglesia, establece el siguiente estatuto:

Si algún canónigo o socio de Santa María de Husillos muriera sin testamento desde el día de Navidad en adelante, los frutos de las rentas que tiene asignadas quedarán a libre disposición del abad y del cabildo. Si tuviera deudas, se pagará a los acreedores y lo restante se entregue para el alma del difunto.

Si algún canónigo o socio quisiera disponer en testamento de los frutos de sus prestimonios del año en curso, el testamento tendrá validez si hay testigos, al menos dos canónigos o socios. De sus bienes personales puede disponer 


\section{LA ABADÍA DE SANTA MARÍA DE HUSILLOS: ESTUDIO Y COLECCIÓN \\ DOCUMENTAL $(904-1608)$}

libremente. Si estuviera enfermo fuera de Husillos y quisiera redactar testamento, bastará el testimonio de unos hombres buenos, pero el testamento deberá ser aprobado por unos canónigos que eligiera el cabildo, a cuyo arbitrio se dispondrá de los bienes para el alma del difunto y utilidad de la iglesia de Husillos.

Si el abad no quisiera cumplir con disposiciones precedentes, el prior y el cabildo tienen autoridad para hacerlo desde el segundo día del fallecimiento.

La casa de la iglesia en que viviera el difunto permanecerá nueve días sin disponer de ella hasta que se saquen los muebles y se entreguen a los herederos señalados en el testamento o al cabildo si muriera "ab intestato".

A. AHDP, Ampudia y Abadía de Husillos, Pergaminos, carp. 212-1. Perg., 205 x 481 mm.; escr. carolina; buena conservación. Conserva la cuerda de cuero que sostuvo el sello.

B. AHDP, Ampudia y Abadía de Husillos, Pergaminos, carp. 209-21. Perg., 266 x 324 mm.; escr. precortesana; buena conservación con algunas manchas de humedad que no impiden su perfecta lectura. Inserto en traslado sacado en Palencia, a 1 de abril de 1367. Véase doc. núm. 149.

C. APA, $L P H$, ff. $23 \mathrm{v}-24 \mathrm{v}$.

D. BN, ms. 705 , ff. $37 \mathrm{v}-40 \mathrm{v}$.

(Christus, alfa et omega) In nomine Sancte et Indiuidue Trinitatis, Patris, uidelicet et Filii et Spiriti Sancti, amen. Quoniam canonica iura iustas et racionabiles petitiones et maxime a prelatis eclesiarum precipiunt / exaudiri. Ego, Gondissaluus, Dei gracia abbas Fusellensis ecclesie, ad preces et instanciam tocius capituli eiusdem ecclesie, presenti scripto statuo et confirmo in perpetuum: ut siquis canonicorum uel sociorum Fusellensis eclesie a die Natalis Domini in antea, uel eciam in ipsa die Natalis decesserit intestatus, fructus omnium prestimoniorum eius in ipso / sequenti anno prouenturi sint in prouidencia abbatis et capituli Fusellensis; ita tamen ut, si debita habuerit, primo persoluantur et creditoribus satisfaciat et residua dentur pro anima defuncti; prout uisum fuerit, eius consulcius anime defuncti. Si uero de fructibus omnium prestimoniorum suorum qui possunt prouenire ex ipsis prestimoniis in ipso anno ad $/ 3$ plenum, quilibet socius vel canonicus Fusellensis eclesie, condere volverit testamentum, convocatis testibus uel ad minus duobus canonicis uel sociis eiusdem eclesie, illud testamentum quod de pretaxatis fructibus in eorum presencia condiderit, ratum et 
inuiolabile permaneat. Si vero habuerit propria uel patrimonii bona, de eis pro uoluntate sua disponat. Quod si / extra uillam Fusellensis uel infra quilibet canonicorum uel sociorum iam dicte eclesie infirmus fuerit et ibi non poterit habere canonicos uel socios ipsius eclesie, testamentum quod condiderit de fructibus prestimoniorum suorum sub testimonio bonorum uirorum, ualeat et inuiolabile permaneat. Ita tamen quod illud testamentum quod canonicis uel sociis / suis absentibus condiderit, referatur ad aprobandum testibus canonicis supradicte eclesie, pro eorum arbitrio ad salutem anime defuncti et Fusellensis eclesie utilitatem, quos Fusellensis capitulum elegerit. Preterea testamenta de predictis fructibus condita sicut superius dictum est ualeant; si illi a quibus fuerint condita a die Natalis Domini in antea uel in $/{ }^{6}$ ipsa die Natalis decesserint. Verum si abbas his ordinandis interesse nequiuerit, priori et capitulo ipsius eclesie secundum diem nichilominus liceat ordinare. Adicitur eciam ut si aliquis canonicorum uel sociorum ipsorum domos de sepe dicta eclesia habuerit in prestimonium quandocumque decesserit ipse domus sint libere sicut eo uiuente erant, donec infra nouem dies conputatos a die / qua decesserit, mobilia deducantur defuncti ab his quibus sub testamento fuerint disponenda uel a Fusellensis capitulo si decesserit intestatus. Sane mobilia tunc ipsa tenebitur capitulum pro anima defuncti largiri, ubicumque secundum diem fuerint largienda.

Siquis igitur de successoribus meis de aliis quibuslibet personis hec statuta uiolare uolverit, omnipotentis Dei / terribilem incurrat sentenciam, et cum Datan et Abiron penas inferos nisi resipuerit tomentetur, et hoc factum semper firmum permanent.

Facta carta huius institutionis, sub era M CC XL, anno Incarnatione Domini M CC II, inditione X, die IIII kalendas iulii. Regnante rege Adefonso in Toleto et in Castella. Arderico, episcopo existente in Palencia. $/^{9}$ Maiordomo regis, Gondissaluo Roderici. Maiorino regis, Guterio Didaci. Ego, Gondissalvus, iam dictus abbas Fusellensis ecclesie, hoc scriptum quod fieri iussi in comuni capitulo roboro et confirmo et presenti meo sigillo conmunio.

( $1^{a}$ col.) Petrus, prior Fusellensis, conf. Petrus, sacrista Fusellensis, confir. Echnicus, cantor Fusellensis, conf. 
$\left(2^{a} \mathrm{col}\right.$.) Nycholaus, magister scole et canonicus Fusellensis, conf. Petrus Arnaldi, prepositus canonie Fusellensis, conf.

Petrus Martini, notarius domini iam dicti abbatis, per scripsit.

1210, agosto, 4. Letrán.

Inocencio III confirma al cabildo de Santa María de Husillos sus derechos $y$ heredades en la villas e iglesias de Santa María de Cillerolo, San Julián, Villa Alarigo, San Facundo de Paredes, Santa María de Nava, San Pedro de Fuentes de Valdepero y Torre de Astudillo, más los diezmos de pan, vino y menudos de Husillos.

A. AHDP, Ampudia y Abadía de Husillos, Pergaminos, carp. 203-3. Perg., 251 x 221 mm.; escr. gótica de cancillería pontificia; buena conservación. Sello de plomo pendiente.

B. APA, $L P H$, f. $11 \mathrm{r}-\mathrm{v}$.

C. AGS, Patronato eclesiástico. Inconexos, leg.159, ff. 21v-22r. Papel; escr. procesal; buena conservación.

Innocentius, episcopus, seruus seruorum Dei, dilectis filiis capitulo Fusellensi, salute et apostolicam benedictione. Cum / a nobis petitur quod iustum est et honestatum tam uigor equitatii quam ordo exigit rationes / ut id per sollicitudinem officii nostri ad debitum perducatur effectum ea propter dilecti in dominio $\beta$ filii uestris iustis postulationibus inclinarii: villas Sancte Marie de Cellerol et Sancti Iuliani, cum / pertinetiis earumdem, sernam de Villa Alarigo, cum uinea quam plantastis; ibidem ecclesias Sancti / Facundi de Paredes et Sancte Marie de Naua et Sancti Petri de Fontibus de Valle Pero, cum hiis que pertinent, $/^{6}$ ad easdem quicquid habetis in Turri de Astudello et decimas pannis et uini, ortorum et minutorum ville / Sancte Marie de Fusellis, libertates quoque ac alias possessiones et bona uobis tam ab eo qui nunc ecclesie uestre, pre / est quam ab 
aliis qui eidem ecclesie per tempora pre fuere concesa, sicut ea omnia iuste ac pacifice possidetis, et $/^{9}$ in eorum autenticis continent auctoritate uobis aplicam confirmamus et presentis scripti patrocinio communimus. / Nulli ergo omnia hominum liceat hanc paginam nostre confirmationis infringere ut ei ausu temerario contraire, / siquis aut hoc attemptare presumpserit indignationem omnipotentis Dei et beatorum Petri et Pauli apostolorum eius se noue $/{ }^{12}$ rit incursurum.

Datis Laterant, II nonas augusti, pontificatum nostri anno tertio decimum.

1226, mayo.

Rodrigo Álvarez transfiere a Santa María de Husillos, en remedio de su alma y de la de sus padres, todas sus heredades en Becerril, entre las que se encuentran todo el término de Pajares y varias posesiones en San Sebastián y El Arnal, junto con cuatro viñas en este último lugar, además de unos solares junto a la iglesia de Santa Eugenia.

A. AHDP, Ampudia y Abadía de Husillos, Pergaminos, carp. 208-4. Carta partida por ABC. Perg., 179 x $288 \mathrm{~mm}$.; escr. pregótica documental; buena conservación con algunas manchas que no impiden su lectura. Conserva restos de un sello de cera, con la figura de un águila, las cuerdas de un segundo sello y la perforación donde debió pender un tercero. Estos sellos correspondían al obispo de Palencia, al abad y al cabildo de Santa María de Husillos.

$B$. APA, $L P H$, f. $27 \mathrm{r}$-v.

C. AGS, Patronato eclesiástico. Inconexos, leg.159, ff. 33v-34v. Papel; escr. procesal; buena conservación.

D. BN, $m s .705$, ff. 40v-41v.

$(A B C D E F G I)$. Notum sit omnibus presentem paginam inspecturis quod ego, Rodericus Aluari, dimitto liberas et solutas terras, uineas, ecclesie beate Marie de Fusellis quas retinebam in / Bezerril, uidelicet: totum terminum de 
Paiares, que habet affrontationes, in prima parte, uiam Carrionis, in secunda, el fito del monte de Paredes, in tertia el monte de Santa Maria, / in quarta Valle Longo et totam hereditatem Sancti Sebastiam, que habet affrontationes: in prima parte, terra de Mari Aluaret, in secunda, el arroio, in tertia, terra de Domingo Romant et $\beta$ el Campo, in quarta parte, las uinnas. El Arnal habet affrontationes: in prima parte, la carrera de Mercaderos, in secunda, terra de Mari Aluaret, in tertia, terra de Domin/go Uicentet. Et quator uineas in eodem termino que habent affrontationes: uineas de Mari Aluaret et la carrera del Campo et la carrera de Sant Sebastian. Que omnia re/cognosco ad ius et ad proprietatem eiusdem ecclesie pertinere, unde ipsas totas hereditates eidem ecclesie libere dimitto et possessionem ei trado etiam corporalem, nichil iuris proprietatis pos $/{ }^{6}$ sessionis seu detentionis mihi retinendo; et si aliquid iuris habeo uel habere debeo in ipsis hereditatibus do ipsi ecclesie pleno iure; et si quid iuris habet ipsa ecclesia in monte de Bezerril seu / in aliis locis, ecclesie dimitto libere et quiete. Preter hec autem pro remedio anime mee et parentum meorum do supradicte ecclesie quodam solare quod habeo in Bezerril iuxta ecclesi/am Sancte Eugenie et proprietatem et possessionem ipsius solaris quam habeo et habere debeo, transfero in ecclesiam supradictam. Nos, uero abbas et conuentus Fusellensis, attendentes deuo/ ${ }^{9}$ tionem prefati R[odericus] Aluari quam guerit erga ecclesiam nostram de consensu et uoluntate domini et T[ellus], episcopi Palentini, tradimus R[odericus] Aluari eidem predictas hereditates, scilicet: ter/ras et uineas et quod habemus et habere debemus in predicto monte et in aliis locis de Bezerril, preter dictum solare, quod nobis retinemus, ut ipsas dum uixerit retineat sub / annuo censu, uidelicet: pro septem morabetinis, quod soluere debet quo libet anno nobis in natiuitate Domini, eo uero defuncto, predicte hereditates et omnia iura alia predicta sine con $/{ }^{12}$ tradictione aliqua redeant ad ecclesiam Sancte Marie de Fusellis, cuius est possessio et proprietas eorundem. Et ego, dictus R[odericus] Aluari obligome uobis conuentus Fusellensis ad / dandos duos fideiussores et debitores idoneos in Bezerril qui dictos septem morabetinos quam diu ego uixero uobis persoluant annuatim et si unus eorum moriatur, teneor / alium substituere qui persoluat cum reliquo, quod si non fecero hereditates et omnia alia predicta uobis remaneant pacifice et quiete. 
Facte sunt autem secumdum hoc tres cartes diuise ${ }^{15}$ per alfabetum quarum una remanet in ecclesia Sancti Antonini, aliam ego R[odericus] Aluari retineo, tercia remanet in ecclesia Fusellensi. Et ut hoc factum Maius robur obtineat firmitatis, nos abbas et conuentus Fu/sellenses. Et ego, R[odericus] Aluari, predictas cartas sigillo domini Palentini episcopi et abbatis et conuentus Fusellensis fecimus comuniri.

Actum est hoc mense madii, era $\mathrm{M}^{\mathrm{a}} \mathrm{CC}^{\mathrm{a}} \mathrm{LX}$ IIII ${ }^{\mathrm{a}}$. Unde sunt testes. $(A B C D E F G N)$.

1227, abril, 29.

Sol de Villaldavín, juntamente con su marido, Pascasio de Mazariegos, vende a Miguel, prior de Santa María de Husillos, a Rodrigo Sánchez, cantor, y a los canónigos de dicha iglesia, varias tierras y viñas en Villaldavín, perfectamente delimitadas, en precio de sesenta maravedis.

A. AHDP, Ampudia y Abadía de Husillos, Pergaminos, carp. 208-5. Perg., 221 x 250 mm.; escr. carolina avanzada; buena conservación.

$B$. APA, $L P H$, f. $28 \mathrm{r}-\mathrm{v}$.

C. AGS, Patronato eclesiástico. Inconexos, leg.159, ff. 34v-36r. Papel; escr. procesal; buena conservación.

D. BN, $m s .705$, ff. $41 \mathrm{v}-42 \mathrm{v}$.

ED. SAN MARTÍN PAYO, Villaldavín, 124-125.

In Dei nomine. Ego, donna Sol de Uilla Dauid, una cum marito meo, Pascasio de Mazaregos, uenditores sumus uobis, / Michaeli, priori, et Roderico Santii, cantori, canonicis Fusellensis ecclesie, terrarum et uinearum in Uilla Dauid. Prima terra habet / affrontaciones: in prima parte, carreram de Uilla Godiel, que uadit ad montem; in secunda parte, terram Marie Petri, uxoris de $\beta^{3}$ 
Iacob. Alia terra en la Uega habet affrontaciones: el Arroio de Sancta Maria et terram Iohanis Dominici; la tercera afrontacion: terra de / Taresa Fernandi. In pago de Sola Uilla, unam uineam et habet affrontaciones: uineam de donna Maior et uineam Marie Iohanis / et terra Dominici Iohanis. Alia uinea habet affrontaciones: carreram de La Calera et uineam filiorum Garsie Ferdinandi. Alia uinea $/ 6$ habet affrontaciones: uineam Bartolomei et uineam de donna Taresa et uineam filiorum Fernandi Iohanis. Quarta uinea habet / affrontaciones: uineam donni Mathei et uineam filiorum Petri Michaelis. Alia terra est in Ual de don Padre, habet affrontaciones: / terram Iohanis de Manquiellos et terram filiorum del Caluo et terram Iohanis Dominici. Alia terra de Ual de Thau habet affrontaciones: ter ${ }^{9}$ ram Marie Petri et terram de Garsie Porrado. Un pedazo in eodem termino habet affrontaciones: terram de Sancia Fernandi et terram / Iohanis Dominici. Alia terra in ipso termino habet affrontaciones: terram donna Eluira et terram Iohanis Dominici et terram de donna Taresa. / Alia terra carrera de Paredes habet affrontaciones: terram donni Mathei et terram Iohanis Dominici. Alia uinea est en los Maiuelos $/{ }^{12}$ de Monte, habet affrontaciones: uineam Marie Petri et la Maiada. Alia uinea in ipso pago habet affrontaciones: uineam / Marie Petri et uineam Iohanis Dominici. Alia terra del Melgar habet affrontaciones: terra Marie Petri et terram filiorum Dominici / Iohanis. Alia uinea est in Uineis de Pozo, habet affrontaciones: uineam Marie Petri et uineam de donna Taresa. Alia $/{ }^{15}$ uinea de Plano habet affrontaciones: uineam Didaci Fernandi et uineam filie Dominici Ramiri. Alia uinea Carera Sancti / Felicis habet affrontaciones: uineam Dominici Pelagii et uineam de donna Maior. Alia uinea en Plano habet affrontaciones: / uineam donni Didaci del Otero et uineam de Aparicio et uineam de donna Maior. Alia uinea est circa ipsam et par $/{ }^{18}$ tela el sendero, habet affrontaciones: uineam donni Didaci del Otero et uineam filiorum Dominici Ramiri. Otro pedazue/lo hi luego habet affrontaciones: uineam Marie Petri.

Omnes predictas terras et predictas uineas, sicut presens pagi/na testatur, uendimus uobis Michaeli priori et predicto Roderico cantori pro sexaginta morabetinis inter precium et alba $/{ }^{21}$ roch; et de istis morabetinis sumus integre pagati.

Facta carta III kalendas may, in era $\mathrm{M}^{\mathrm{a}} \mathrm{CC}^{\mathrm{a}} \mathrm{LX}^{\mathrm{a}} \mathrm{V}^{\mathrm{a}}$. / Ego, Michael priori, et Rodericus Santii cantor, facimus hanc comparacionem ecclesie, matris nostre, 
Sancte Marie de Fuselis. / Regnante rege Fernando in Toleto et in Castella, cum regina sua Beatrice. Donno Tellio, existente episcopo in Palentia. ${ }^{24}$ Gundisalvo Petri, abbate in Fusellis. Huius rey (sic) sunt testes.

1228, mayo, 29.

Orem Díaz, condesa de Urgel, dona a Fernando Álvarez, su hermano, hijo del conde Álvaro, su parte en las iglesias de Coca y Tamariz, que heredó de la condesa Elvira, su madre. Establece varias cláusulas: si Fernando Álvarez fallece antes que ella, dichas iglesias deben retornar a su propiedad; y si a su muerte deja descendencia, dichas iglesias debian heredarlas sus hijos a la muerte de su hermano.

A. AHDP, Ampudia y Abadía de Husillos, Pergaminos, carp. 207-10. Perg., 205 x 196 mm.; escr. carolina avanzada. Muy deteriorado. No conserva el sello que llevaba pendiente.

B. APA, $L P H$, f. $29 \mathrm{r}-\mathrm{v}$.

C. AGS, Patronato eclesiástico. Inconexos, leg.159, f. 36r-v. Papel; escr. procesal; buena conservación.

D. BN, ms. 705 , ff. $43 \mathrm{v}-44 \mathrm{r}$.

No nos consta que las iglesias de Coca y de Tamariz [de Campos] llegaran a formar alguna vez parte del dominio de Santa María de Husillos. Al menos no se reflejan estas posesiones en ninguna escritura ni en el libro becerro de sus propiedades realizado entre finales de 1374 y finales de 1376. Dos son las posibilidades que pueden explicar la presencia de este documento en la colección de Husillos.

La primera apunta a que la parte de estas iglesias que Orem Díaz donaba a Fernando Álvarez, acabaron formando parte del dominio de Husillos, por donación del mismo Fernando Álvarez, de sus descendientes o de los descendientes de la misma Orem Díaz. Con la donación de las iglesias se entregaría también el documento jurídico que avalaba la propiedad. El derecho de Husillos sobre dichas iglesias se daría entre el 29 de mayo de 1228 y finales de 1376, fecha de formación del libro becerro de las propiedades de Husillos, en el que no constan dichas iglesias. 


\section{LA ABADÍA DE SANTA MARÍA DE HUSILLOS: ESTUDIO Y COLECCIÓN \\ DOCUMENTAL $(904-1608)$}

Posiblemente la lejanía del lugar de Husillos, hiciera que la abadía no pudiera controlar de forma idónea sus derechos, por lo que éstos acabarían transfiriéndose o permutándose.

La segunda posibilidad es que Fernando Álvarez, sus descendientes, o los descendientes de Orem Díaz, pudieron depositar la carta de donación en Husillos para su seguridad y buena conservación, ya que en numerosas ocasiones en la Edad Media, los particulares depositaban sus escrituras más importantes en el archivo de un cenobio como medio de seguridad para la conservación de su documentación.

In Dei nomine. Notum sit omnibus hominibus, [tam presenti]bus quam futuris, quod ego, don Orem Diay, / per la gratia de Dios condessa de $\operatorname{Vr}$ [gel, de buen au]er e de bona uoluntat, do a uos, / don Ferrando Áluarez, [ mío cormano, filio del conde ] don Áluaro, toda la part que y[o he en] $\beta$ las eglesias de [Coca] e de [Tamariz, que] yo heredo de parte de mi madre, la / condessa donna Eluira. E deuo heredar, [e ansí u]os las do estas [eglesias; que las a]/yades liures e quitas por en todos ues[tros días sin] entredicho ninguno. E si uos, don $/{ }^{6}$ Ferrán Áluarez, fináredes antes que yo, que [estas] eglesias que uos yo do que se tornen [en mí]; / e si yo finare antes de uos e dexare [fiio o] fiia, que después de uestros días que [estas] / eglesias sobredichas que las hereden [míos fiios. E] si por auentura yo o fiio o fiia non fincare $/^{9}$ de mí después de uestros días, estas eglesias [finquen en] que lo uestro deuiere heredar o en que uos man/dáredes. E porque uos más firme ayades [estas eglesias], esta carta fiz seelar de mío seelo.

E nenguno / que esto que yo do quisiera contrariar, aya la [ira] de Dios e de Santa María, e [sea] maldicto $/{ }^{12}$ e descomungado, e con Iudas trahydor en [infierno] dannado, e peche en coto al rrey D marauedís.

Facta / carta in mense mayo, II días por andar, [sub] era $\mathrm{M}^{\mathrm{a}} \mathrm{CC}^{\mathrm{a}} \mathrm{LX}^{\mathrm{a}} \mathrm{VI}^{\mathrm{a}}$. Desto son pesquisas: / el maestro don Pero Gómez de Vclés e don Pero Pérez, comendador de Cuenca. Don Gil Gómez, comen $/{ }^{15}$ dador de Olamo. Don Pero Martín de Sant Oyo. Don Nunno Pérez, fiio del conde don Pero. / Don Lope Pérez, freyre de Vclés. Juan Velásquez, bestiario de Vclés. Rodrigo Rodríguez de Lu/zio. 
1228, agosto, 30 .

Fernando Gutiérrez, nieto de Diego de Fuente Quintana, vende al cabildo de Santa María de Husillos la heredad que sus padres le dejaron en Fuente Quintana y en San Julián, en precio de ciento diez áureos.

A. AHDP, Ampudia y Abadía de Husillos, Pergaminos, carp. 208-6. Perg., 229 x 196 mm.; escr. carolina avanzada; buena conservación.

B. APA, $L P H$, ff. $28 \mathrm{v}-29 \mathrm{r}$.

C. BN, ms. 705, ff. 42v-43v.

Fuente Quintana y San Julián se localizan en el término de Fuentes de Nava (según documento de rentas de la mesa abacial cuya data es: 1554, noviembre, 22. Husillos / 1555, enero, 18. Husillos; el cual indica que el abad tiene un término en Fuentes de Nava en el que se encuentran estos nombres, lo cual trasluce que en esos momentos los lugares primitivos están despoblados).

In nomine Sancte et indiuidue Trinitatis, Patris et Filii et Spiritus Sancti, amen. Notum sit omnibus tam presentibus / quam futuris presentem paginam inspecturis, quod ego, Ferdinandus Guterii, nieto donni Didaci de Fonte / Quinana, vendo meo ultro uobis, Fusellensi capitulo, quicquid in Fonte Quinana et in termino Sancti Iuliani $\beta$ heredito nec non hereditare debeo ex parte patris mei et matris mee, scilicet: domos cum suis ap/paratibus et atria, tam populata quam non populata, ortos, terras, vineas, arcas, montes et / ualles, fontes et aquas, exitus, uille cum pascuis et ingressus. Hoc quidem totum uobis uendo, dicto $\mathrm{ca} /{ }^{6}$ pitulo, pro centum aureis et decem et concedo de cetero iure hereditario possidendum et istud precium / et aluaroc est michi integre iam solutum.

Facta carta tercio kalendas mensis semptembris, in era $\mathrm{M}^{\mathrm{a}} / \mathrm{CC}^{\mathrm{a}} \mathrm{LX}^{\mathrm{a}} \mathrm{VI}^{\mathrm{a}}$.

Si quis enim uer sucia aliqua presentem paginam calumniari presumpserit, pectet in coto uobis, $/^{9}$ dicto capitulo, uel cui uocem uestram comiseritis, CC aureos et dictam hereditatem in locis con simi/libus in duplum restituere teneatur. Regnante rege Ferdinando cum regina Beatrice, uxore sua, / in Toleto et in Castella. Tello, Palentine ecclesie presidente. Gondisaluo Petri, Fusellensi ecclesie domi/ ${ }^{12}$ nante. Micael, priore existenti. Roderico de Fiterio percinente. Petro Arnalli tesaurante. Domi/nis in Fonte Quinana eodem capitulo Sancte Marie de Fusellis. Petro Didaci 
et suis sororibus. Garsia Ro/derici et Didaco Allefonsi et Ordonio Munoz, scilicet, maritis earumdem, et filiis Gondisalui $/{ }^{15}$ Petri de Ribas, uidelicet, Roderico Gondisalui et Sancio, fratre eius. Huic autem uendicioni multi tam / senes quam iueues astiterunt, scilicet de Monzon: Iohanes Petri Bacon. Iohanes Martini. Iohanis Cipriani de Ualle / Espina. Dominicus Martini. Petrus, filii Petrus Ouieco de Glisota. Donnus Iohanes. Ferdinandus Iohanis. ${ }^{18}$ Donnus Nicholaus El Alfaiat. Dominicus Martini. Martinus Dominici de Otiela. Donnus Micael. Petrus / Iohanis de Sant Felizes. Dominus Michaelis. Petrus Iohanis de Sancto Iuliano. Filius Iohanis Meto. Marti/nus Iohanis, frater eius. Dominicus Iohanis, filius Uraze Martini. Petrus Guterii, suus frater. Donnus Dominicus, ${ }^{21}$ filius Fabri, et donnus Michael Rubio de Otella. Et de Fonte Quinana: Petrus Didaci et donnus Dominicus, / frater Petri Cari de Sancto Facundo. De Fusellis: donnus Aprilis, uillicus. Iohanes Comes et frater eius. / Petrus Comes et Ferdinandus Comes et donnus Gondisalvus, filius Petri Soleri. Petrus Iohanis, filius ${ }^{24}$ Iohanis Bernalli. Gondisaluus Romazo. Dominicus Andree. Ferdinando Alumpuus. Michaelis prioris. / De Carrione: Petrus Iohanis, nepos predicti prioris, scriba qui hanc scripturam feci et sign(signum)aui.

1229 , octubre.

Teresa Díaz, hija de Diego de Fuente Quintana, juntamente con su marido García Rodríguez, vende al cabildo de Santa María de Husillos toda su heredad en Fuente Quintana y en San Julián, en precio de ciento quince maravedís.

A. AHDP, Ampudia y Abadía de Husillos, Pergaminos, carp. 208-7. Perg., 150 x 195 mm.; escr. carolina avanzada; buena conservación.

B. APA, $L P H$, ff. $29 \mathrm{v}-30 \mathrm{r}$.

C. BN, ms. 705, ff. 44r-45r. 
Notum sit omnibus hanc cartam uidentibus, quod ego, domna Teresa Didaci, filia domni Didaci de Fonte Quinana et maritus / meus, domnus Garsias Roderici, uendimus uobis, capitulo Fusellensi, quicquid habemus uel habere debemus in Fonte Quinana et in / suo termino et in termino Sancti Iuliani, scilicet: domos, solaria populata et non populata, portas et uzos, ortos, areas, fontes et $\beta^{3}$ aquas, uocem et diuisam et omnes terras et omnes uineas, quas in predictis terminis habemus uel habere debemus et quicquid iuri / uestro spectat in ecclesia de Fonte Quinana et exitus et regressus et omnia ista predicta, sicut presens scriptum declarat uendi/mus uobis, predicto capitulo, et concedimus pro centum et quinque morabetinis, inter precium et alvaroch; et de istis morabetinis $/^{6}$ sumus bene pacatti.

Et si quis homo uel femina, de nostra proienie uel de aliena, hanc cartam infringere, uoluerit, / pectet in coto ducentos et decem morapetinos et tales possessiones, uobis, predicto capitulo, in duplum restituere te/neatur.

Facta carta in mense octobris, sub era $\mathrm{M}^{\mathrm{a}} \mathrm{CC}^{\mathrm{a}} \mathrm{LX}^{\mathrm{a}} \mathrm{VII}^{\mathrm{a}}$. Regnante rege Ferdinando, cum uxo $/ 9$ re sua domna Beatrice, in Toleto et in Castella. Domno Tello existente episcopo in Palentia. Gundisaluo Petri abbate in / Fusellis. Lupo Didaci alfierez domni regis. Gundisaluo Roderici maiordomo regis. Garsia Gundisalui de Ferrera me/rino regis. Roderico Gundisalui tenente Monzon. Vnde sunt testes: Ferdinandus Petri, milles de Uilla Izan. Domnus $/{ }^{12}$ Sanchius, armiger de Villa de Rey. Ordonius Munioz. Domnus Rodericus de Arneleias, qui erat tunc capellanus de Fon/te Quinana. Dominicus Petro. Guterrius Egidii. Domnus Andreas et frater eius, Dominicus Antholini. Domnus Aprilis et frater eius, Dominicus. / Domnus Alvarus, clericus de Sancto Felice, et frater eius, Petrus Iohanis. Domnus Ferdinandus, comes de Fusellis. Iohanes Petri, ge $/{ }^{15}$ ner Iohanis Castellani. Dominicus Andree. Dominicus Bezerril. Iohanes Arnaldi. Guilelmus Iohanis. Petrus Iohanis de / Sancto Iuliano. Domnus Romeus. Ferdinandus Zapatero. Petrus et Dominicus, filii domni Aprilis de Fonte Quinana. 


\section{LA ABADÍA DE SANTA MARÍA DE HUSILLOS: ESTUDIO Y COLECCIÓN \\ DOCUMENTAL $(904-1608)$}

1232, abril, 18. Haza.

Gonzalo Pérez, abad de Santa María de Husillos, concede a los canónigos de su abadía la aldea de Hoyales de Roa, de la villa de Haza, con todas sus posesiones, para la dotación de una capellanía para decir misa diaria de difuntos por su alma y por las de sus padres.

B. APA, $L P H$, ff. 30v-31r.

C. AGS, Patronato eclesiástico. Inconexos, leg.159, ff. 37r-38v. Papel; escr. procesal; buena conservación.

D. BN, ms. 705, ff. 46r-47r.

ED. SAN MARTÍN PAYO, Apasionante historia de cinco casas, 199-200.

La data por era hispánica corresponde al año 1233. Por el año del Señor corresponde a 1232.

Fecho y sacado fue este traslado de la dicha escritura en la villa de Husillos, a veynte e dos días del mes de novienbre de mill e quinientos e çinquenta y quatro años. Testigos que fueron presentes a lo ver, leer, corregir y conçertar, Gaspar de Vedoya e Joán Ruiz Cabeça de Vaca, clérigos, y Pero Manuel, estantes en la dicha villa.

E yo, Santiago Gómez, escriuano público en la dicha villa, fui presente con los dichos testigos. E del dicho pedimiento e mandamiento, lo fize escrevir e fize aquí mi signo (signo) en testimonio de verdad.

Pero Ruiz de Villoldo (rúbrica). Santiago Gómez (rúbrica).

In Dei nomine. Nouerint vniversi presentes pariter et futuri, quod ego, Gundisaluus Petri, Dei gratia abbas Fusellensis, mea bona voluntate et in mente sana positus ad honorem Dei et beate Virginis Marie, donno et concedo vobis, capitulo Fusellensis, quandam aldeam meam de Aça que dicitur Foiales, cum omnibus possessionibus suis, scilicet: pratis et terris, vineis et hortis, molendinis et pascuis, montibus et vallibus, ribis et fontibus, eggressibus et regresibus et cum omnibus pertinentiis suis, que habet et habere debet, tali pacto et tenore quod eam vos possideatis et in perpetuum iure hereditario habeatis et totius vel directum quod ibi habeo, vobis donno et concedo et nullam potestatem uel iurisdictionem in ea mihi retineo nec retinere volo si ab hac die in antea sit abstracta a domineo 
meo et vos in ea plenum dominium habeatis facientes de ipsa sicut de aliis rebus vestris vos autem pro dicta donnatione providebitis in perpetuum, quod vnus capellanus celebrata prima in choro cantet quotidie missam defunctorum in altare beatem Virginis, pro anima mea et pro animabus parentum meorum et dicta missa cum orationibus super meam exeat sepulturam.

Si quis vero contra hanc dictam donnationem venire presumpserit vel eam infringere temptauerit, pectet regi mille marcos auri et vobis, dictam aldeam duplet, in tale loco vel meliori.

Actum est hoc apud Açam, XIIII calendas madii, anno Domini M CC XXX II, sub era M CC LXX I. Regnante rege Ferdinando cum uxore sua donna Beatrice, regina, in Castella et Toleto, Legione et Galletia. Rodirico Simoni, archiepiscopo in Toleto. Domno Ioanne, cancellario domini regis et episcopo in Osona. Alferat domno Lupo Didaci. Maiordomo Garsia Fernandi. Merino maiore Aluaro Roderici. Huius donnationis testes sunt: Ferdinandus Petri, archidiaconus de Aça et Rodiricus, cantor, et Fernandus Aluari et Gundisaluus Facundi. Donus Martinus et Garsias Fernandi, sotii Fusillensi, et domnus Egidius Petri de Marannon et Rodericus Petri, frater domini abbatis. Ferdinandus Fernandi et Petrus Fernandi et Gundisalus Fernandi de Ribiella, milites, et donus Ramirus, milles. Domini abbatis et domnus Rodiricus de Penam Fidele et donus Cobus et domnus Garsias et domnus Stephanus et domnus Ioannes, clerici de Aça, et domnus Santius et domnus Enuxus Petri et Garsia Gundisalui et Garsia Ordonnez, filius Ordonum Martinez, et Fernandus Armili et domnus Ioannes et Gundisaluus Petri de Valrrodrigo et Rodiricus Garsie de $(f .31 v)$ Torreziella et Gundisalvus Didaci de Castro et Alvarus Rodirici et domnus Bernaldus de Palençia. De Aça: Petrus Martin et Petrus Mengarde et Dominicus Ioannis. Iapel et Petrus Gundisalui El Alfaiat et donus Petrus et Benitus Ioannes de Foiales et domnus Gundisaluus et Petrus, cognatus eius, et domnus Maurus et Dominicus Arnaldi et Martinus, filius eius. Totum concilium de Aça. 


\section{LA ABADÍA DE SANTA MARÍA DE HUSILLOS: ESTUDIO Y COLECCIÓN \\ DOCUMENTAL $(904-1608)$}

1232, septiembre, 22. Fuentelisendo.

Gonzalo Pérez, abad de Santa María de Husillos, concede a los canónigos de su abadía la aldea de Fuentelisendo, de la villa de Haza, con la condición de que sus habitantes vivan en las mismas condiciones que con sus padres y en su tiempo.

$B$. APA, $L P H$, f. $30 \mathrm{r}-\mathrm{v}$.

C. AGS, Patronato eclesiástico. Inconexos, leg.159, ff. 34v-36r. Papel; escr. procesal; buena conservación.

D. BN, ms. 705, f. 36v-37r.

ED. SAN MARTÍN PAYO, Apasionante historia de cinco casas, 197-198.

La data por era hispánica corresponde al año 1233. Por el año del Señor corresponde a 1232.

Fecho y sacado fue este traslado en la villa de Husillos, a veynte e dos días del mes de novienbre de mil e quinientos y çinquenta y quatro años. Testigos que fueron presentes a lo ver, leer, corregir y conçertar, Gaspar de Vedoya e Joán Ruiz Cabeça de Vaca, clérigos, y Pero Manuel, estantes en la dicha villa.

E yo, Santiago Gómez, escriuano público en la dicha villa, presente fui a lo que dicho es, en uno con los dichos testigos. E del dicho pedimiento y mandamiento del dicho señor Pero Ruiz de Villoldo, lo fize escrevir e fize aquí mi signo (signo) en testimonio de verdad.

Pero Ruyz de Villoldo (rúbrica). Santiago Gómez (rúbrica).

Nouerint vniuersi presentes pariter et quod ego, Gundisaluus, per Dei gratia abbas Fuselensis, mea voluntate et in mente sana positus ad amorem Dei et Beate Virginis Marie, dono et concedo vobis, canonicis Fuselensis presentibus et futuris, quamdam aldeam de Aça que dicitur Fon Aldesendo cum omnibus possessionibus, scilicet: pratis et terris, vineis et hortis, molendinis et pascuis, montibus et vallibus, ribis et fontibus, agressibus et regressibus et cum omnibus pertinentiis suis que habet et habere debet; tali pacto et tenore quod vos eam possideatis et in perpetuum iure hereditario habeatis et totum ius vel directum quod ibi habeo vobis dono et concedo et nullam potestatem vel iurisdictionem in ea mihi retineo nec retinere volo sed ab hac die in antea sit abstrata a domineo 
meo et vos in ea plenum domineum habeatis, fatientes de ipsa tota voluntatem vestram sicud de aliis rebus vestris. Volo in super quod homines predicte aldeę viuant cum vicinis suis tam de villa quam de aldeis in eamdem consuetudinem et modum quo tempore patris mei et nostro tempore vixerunt.

Si quis vero contra hanc dictam condonationem venire presumpserit vel eam infringere temptauerit pecet regi duo millia aureorum et vobis dictam aldeam duplet in tali loco vel meliori.

Acta sunt hec apud Fontem Aldesendo, decimo calendas octobris, anno Domini MCCXXXII, sub era MCCLXXI, regnante rege Ferdinando cum vxore sua domna Beatrice regina in Castella et Toleto, Legione et Galletia. Domno Rodirico Ximenez, archiepiscopo in Toleto. Domno Iuanem, cancellario domini regis et episcopo in Osma. Alfired domno Lupo Didaci. Maiordomo Garsias Ferdinandi. Merino maior domno Aluaro Rodirici. Huius rei testes sunt: Petrus abbas et Michael sub prior et frater Guilelmus de Sacramenia. Domnus Ferdinandus Petri, archidiaconus de Aça, et Rodiricus Petri, frater domini abbatis. Ferdinandus Garsia et Ordonius Garsie de Villacisla et domnus Ramirus et Martinus Pelagii, frater Vclensis. De Armigeris: Fernandus Armilli et Gutterrius Gundisalui. Domnus Santius et Rodiricus Antonini de Cobas et Reymundus de Cauriz, et Albarus Eunici de Penna Fideli. Domnus Rodiricus clericus et Rodiricus Andree et domnus Garsias de Aça et domnus Garsias, clericus, et Petrus Martini et Dominicus Ioannes El Alfaiad, et Petro de Megarda, et domnus Petrus, filius Arnaldi. Ioannis Subtor et domnus Ioannes, filius domne Marte, filius de Valdecapf. Domnus Ioannes, clericus, et domnus Velascus de Foiales. Benitus Ioannes (f.30r)

1234, marzo, 1.

Tello I, obispo de Palencia, con el consentimiento del cabildo capitular, dona a Rodrigo y Juan Cristóbal, hijos de Juan Cristóbal, la mitad de una aceña 
$y$ de las que pudieran conseguir en Hérmedes, y la mitad de dos aceñas en Barguilla, estipulando ciertas condiciones.

A. AHDP, Ampudia y Abadia de Husillos, Pergaminos, carp. 207-11. Perg., 230 x 265 mm.; escr. pregótica documental; bastante deteriorado, sobre todo el margen izquierdo además de algunas manchas y una rotura en la línea 15. Lleva pendiente una correa de cuero sin sello, conservando los orificios para sujetar otras dos.

B. APA, $L P H$, f. 38r-v. Al final del texto: $<\mathrm{Y}$ esta escritura por estar algunas partes della que no se pudieron leer, que es a donde va una rraya de tinta en blanco, no se signó>.

La data por la era hispánica corresponde al año 1235. Por el año del Señor corresponde a 1234.

In Dei nomine, amen. Connoscida cosa sea a todos los ombres que esta carta uieren que nos, don Tello, por la gracia de Dios obispo de Palencia / [...] con consentimiento del cabildo de Sant Antolín de Palencia e con uoluntad de maestre Lope, que era prestamero / en el logar a la ora, damos e otorgamos a uos, Rodrigo, e a uos, Domingo Iohannes, fiios de Iohán Christóual, la meetad de la azenna $\beta$ [...] en Hérmidas, e la meetad de II azennas en Barguiella. E otrosí, uos otorgamos la meetad de las azennas / [...] que fizierdes en término de Hérmidas. E esta meetad destas azennas e destos molinos por nonbrados e de las que fi/[zierdes tanto] bien de molinos como de azennas, uos otorgamos e uos damos por heredad a uos e a uestros herederos que uernán depos de $/^{6}$ uos, por tal pleito que uos e los uestros herederos que uinieren depos de uos que a uestra costa e a uestra missión fagades quanto mester ouie/re en las azennas de fazer fora ende picar e pinar e las cosas que ouiere de fazer el molinero. E nos e uos deuemos pagar el / molinero de común, e nos non uos auemos a fazer nenguna missión en las azennas nin en los molinos, fora ende adozir las molas $\rho^{9}$ e la madera onde la conpráredes. E si acaeziere que alguno de uos quisiere uender o enpeñar la sue ración, otorgamos que / la poda uender a los herederos que deuen heredar con ellos por razón de la maestría. E queriendo la uos uender o enpeñar en otro / logar o enagenar, que non seades poderosos de uender nin de enajenar si non a nos, dando uos tanto como otro diere. $\mathrm{E} \mathrm{si} \mathrm{al} /{ }^{12}$ guna azenna o molino estudiere por uestra culpa que non mola o por maestría o por otras cosas que uos aiades de fazer del / día que uiéredes nostro mensaje o del cabildo, a VIII días que lo uengades fazer. E si non 
quisierdes o non pudiéredes, nos que lo faga/mos lealmiente. E si fasta un anno nos entregardes daquel auer que nos hi metiéremos como es foro de azen[na...] $/^{15}$ [...] en nostra heredad, e si non aquella azenna de que fore alante que finque en cosimente del sennor del anno adelante. /

Esta donación sobrescripto firmamos que sea estable por todo tiempo, e nos otorgamos uos que non dedes en pecho nin / en [...]s en fonsado e nos recevimos uos en nostro defendimiento e en nostro mamparamiento.

Facta carta $/^{18}[\ldots]$ [era MCC]LXX ${ }^{\mathrm{a}} \mathrm{III}^{\mathrm{a}}$, anno Domini $\mathrm{M}^{\mathrm{o}} \mathrm{CC}^{\mathrm{o}} \mathrm{XXX}^{\mathrm{o}} \mathrm{IIII}^{\mathrm{o}}$, primo die marcii. Ego, Tello Palentini episcopus, conf. Petrus Martin, ar/chidiaconus, conf. [Don Garçia], archidiaconus, conf. Martinu Pelagii, archidiaconus, conf. Alfonsus Garsie, archidiaconus, conf. Magistro de Tesauiatio conf. Gundisaluus, can/tor, conf. Rodericus Fusellensi conf. Et totum capitulum ecclesie Sancti Antonini conf.

Dominicus Petri, scriptor domini Palentine, scripsit et conf.

1234. Haza.

Sentencia confirmada por Fernando III del pleito litigado por el abad y el cabildo de Santa María de Husillos, con Pedro González de Marañón, por la que se reconoce el derecho de los primeros sobre Hoyales de Roa y Fuentelisendo, aldeas de Haza, que habían sido donadas por Gonzalo Pérez, abad de Santa María de Husillos.

A. AHDP, Ampudia y Abadía de Husillos, Pergaminos, carp. 198-10. Carta partida por ABC. Perg., 280 x 365 mm.; escr. gótica documental. Regular conservación, tiene varias manchas y una pequeña rotura en la línea 20, que no impiden su completa lectura. Conserva la cuerda pero no el sello.

B. AHDP, Ampudia y Abadía de Husillos, Pergaminos, carp. 211-13; escr. gótica documental; regular conservación. Inserto en traslado sacado en Palencia, a 19 de marzo de 1298. Véase doc. núm. 93. 
C. APA, $L P H$, ff. $31 \mathrm{v}-32 \mathrm{v}$.

D. AGS, Patronato eclesiástico. Inconexos, leg.159, ff. 38v-40v. Papel; escr. procesal; buena conservación.

E. BN, ms. 705 , ff. $48 \mathrm{v}-50 \mathrm{v}$.

ED. SAN MARTÍN PAYO, Apasionante historia de cinco casas, 201-203.

CIT. J. GONZÁLEZ, Siglos de Reconquista, 198.

La data por la era hispánica corresponde al año 1235. Por el año del Señor corresponde a 1234.

(alfa, beta, omega,...) Connoçuda cosa sea que sobrel pleito que era entre el abad e el cabillo de Fusiellos, e don Pero Gonçáluez de Marannón, porque don Pero Gonzáluez les enbargaua e les fazíe destor/uo en Foyales e en Fuent Aldesendo, [aldeas de Aça], que les diera don Gonzaluo Pedret, abad de Fusiellos, en su uida e en su sanidad e sobre sietecientos menos dos morabetinos, e sobre los tuertos e los / dannos que les fizo en las aldeas que dichas son, que juzgó el chanceler que diesse e emendasse a la eglesia de Fusiellos, por las despesas que fizieron en el pleito, e por los tuertos e los dannos que les fiziera $\beta$ don Pero en las aldeas, porquel descomulgó el chançeler obispo de Osma, fata que lo emendasse; e sobrel pleito del quinto de quanto heredaua don Pero de lo que fuera del abad don Gonzaluo en Aza, e en / sos términos; fazen tal abenentia que don Pero, con consentimiento de su muger, dona María, e de sos fiios, don Gil e don Gonzaluo, e de sus fiias, doña Ignés e doña Vrraca, reconoce e otorga que / aquellas aldeas que dichas son, son de la eglesia de Fusiellos, libres e quitas, e que él nengún derecho no a en ellas ni deue auer. E conócelas por quitas e por libres, de quanta derechura él deman $/{ }^{6}$ da ni podríe demandar en las aldeas; e conócelas por quitas e por libres de todo fuero e de toda premia e de todo señor de Aça e de todo señorío, e de toda fazendera de Aça, que ni él ni / nenguno de los que so heredaren ni señor nenguno otro de los de Aza ni conceio de Aça, ni nengún ombre por ellos non sea poderoso daquí adelant de les fazer premia, ni destoruo, ni enbar/go, ni sus lauores, ni en sos términos, ni en sus heredades, o quier que las an e las deuen auer, porque ellos no puedan labrar e pacer e cortar o solíen e cuemo solíen quando el $/{ }^{9}$ abad don Gonzaluo Pérez ge las dio. E adozir lenna de los montes de Aza por al abad de Fusiellos quando fore y o pora los canónigos de 
Fusiellos quando foren; y quanto les fuere menester / daquellos montes e daquellos logares dond lo solíen adozir el abad don Gonzaluo Pérez. E en las defesas no puedan cortar sino quando cortaren y cuemo cortaren los otros señores / de Aça. E pártesse destas aldeas daquí adelant e otorgágelas entegramientre assí cuemo ge las dio el abad don Gonzaluo Pérez con todas sus pertenentias e con todas sus derechuras e con $/^{12}$ todas sus heredades, o que quier que las an e las deuen auer, conuiene a saber: con prados e tierras e uinnas e ortos e molinos e pastos e montes e ualles e ríos e fuentes e con casas / e con solares, e con uoz e con demanda, e con entradas e con exidas, e con quanto derecho el abad don Gonzaluo Pérez les dio, e con quanto derecho y auíe e deuíe auer quando ge las dio. E otorgógelas con / todos sos derechos assí cuemo es dicho pora dar e pora uender e pora enpennar e pora fazer dellas cuemo de su cosa e de su heredad quita. E el abad e el cabillo de Fusiellos quie/ ${ }^{15}$ ran a don Pero Gonzáluez aquellos DCC morabetinos menos dos de las despesas e los tuertos e los dannos que les fizo en las aldeas. E pártense de quanto derecho auíen e deuíen auer en el quinto que le de/mandauan de lo que heredaua don Pero Gonzáluez en Aza e en sos términos, del abad don Gonzaluo Pérez, que daquí adelant ni ellos ni otro por ellos, no ayan poder de lo demandar. E si don Pero / Gonzáluez o alguno de sos herederos uiniesse contra lo que esta carta diz, sea maleito de Dios, e peche en coto mil maravedís al rey e la heredad doblada a la eglesia de Fusiellos. E don $/^{18}$ Pero Gonzáluez mete así, e a tod ombre que lo so heredare, en poder del obispo que fuere en Osma, así que le faga esta abenencia atener, él pueda costreñir por deuiedo e por desco/mulgamiento e por todo poder que obispo a e deue auer.

E este pleito fo fecho en Aça, anno Domini $\mathrm{M}^{\mathrm{o}} \mathrm{CC}^{\mathrm{o}} \mathrm{XXX}^{\mathrm{o}} \mathrm{IIII}^{\mathrm{o}}$, sub era $\mathrm{M}^{\mathrm{a}} \mathrm{CC}^{\mathrm{a}}$ LXX $^{\mathrm{a}}$ III $^{\mathrm{a}}$, rregnant el rrey don Fernando con / su muger, la reyna dona Beatriz, en Castiella e en Toledo, en León e en Gallizia. Alfiérez del rrey, don Lop Diaz de Faro. Mayordomo, don Garci Fernández. Merino mayor no / era entonz ninguno. Don Rodrigo, arzobispo en Toledo. Don Iohán, obispo en Osma e chanceler del rrey.

Deste fecho foron pesquisas: Gonzaluo Pérez, fiio de don Pero Gonzáluez, $/^{21} \mathrm{e}$ maestro Pero de Burgos, e Martín Peláez, fradre de la orden de Vélez, e fray Domingo de Aça la Uieia, e Domingo Martín de Ualdenebro, e don Áluaro, capellán de don / Pero, e Alfonso Martínez de Loreda, e Pero Gómez, e Gutier 
Pérez de Uillodrigo, e Alfonso García de Ualera, e Fernand Gutiérrez de Guzmán, e Martín García, e Pero Gar/cía, yerno de don Nunnio de Correziella de Escudo. Roy Gonzáluez de Luzio, e Pero Iuannez de Ualladolit, e Enigo Pérez de Gamarra, e Xemen Iuannez, e Gonzaluo Pérez de Uilla $/^{24}[\mathrm{R}]$ odrigo, e Pero Gil de Tordoseles, e Roy García de Uilla Fuertes, e Roy García de Torreziella, e Gil Pérez de Peniella, e Gómez Uelasco de Fuente Duenna, e don / Iuannez de Zorita, e Lope de Aranda. Don Adam de Fesiella, e don Migale, e don Antolín, e don Gil, e don Domingo El Ferrero. De Uilla Alua: Migal Martín, e don / Antolín, e Domingo Esteuan, e Domingo Migael de Uillielas. Pero Gonzáluez, fi de Gonzaluo Pérez, e Iuan Domínguez, fi de Pero Guerra. De Aça, de uassallos de la orden: don Iuan ${ }^{27}$ el Catalán, Martín Nafarro, Pero Sancho de la Sombría, e Domingo Iuan de la Puerta. De uassallos de fiios de don Nunio: don Aparitio, ermano del arcipreste, e don Velasco / de Ualdezat, e Domingo Arnaldo, e don Iuan, so hermano. De uassallos de don Pero: Pero Martín de Rica Posada.

E todas estas pesquisas se mandaron escreuir en esta carta. /

Et ego, Ferrandus, Dei gratia rex Castelle et Toleti, Legione et Gallecie, ad instanciam utriusque partis, presentem cartam feci segilli mei munimine roborari.

1237, agosto. Haza.

Pedro González de Marañón, hermano de Gonzalo Pérez, difunto, abad que había sido de Santa María de Husillos, reconoce el señorío que dicha iglesia tiene sobre Haza.

A. AHDP, Ampudia y Abadía de Husillos, Pergaminos, carp. 208-2. Perg., 128 x 226 mm., escr. gótica documental. Regular conservación, tiene una rotura que afecta a la $8^{\text {a }}$ línea. Mantiene los orificios en que se sujetaban las cuerdas del sello.

B. APA, $L P H$, f.21r.

C. BN, ms. 705, ff. 32v-33v. 
ED. SAN MARTÍN PAYO, Apasionante historia de cinco casas, 204.

CIT. J. GONZÁLEZ, Siglos de Reconquista, 198. Da como fecha del documento el año 1239.

Conoçuda cosa sea que yo, don Pero Gonzálvez de Marañón, otorgo e cognosco a la ecclesia de Fusiellos que ha señorío y derecho / en Aça e en todos sos montes, e en defesas, e en fuentes, e en ríos, e en uales, e en pastos, e en prados, e en entradas, e en exidas, e en / términos e en todo el otro señorío de Aça para servirse e fazer so pro de todo esto la ecclesia. Cuemo todo otro senor de Aça $\beta^{\beta}$ sa a servir e a fazer so pro dello, e conosco que sos uassallos de las aldeas han a beuir con los de la uilla, e de las otras aldeas, en aquel / uso e en aquela uezindat que uisquieron en tiempo de don Pero Garcíez so padre del abbad don Gonçaluo. E esto cognosco e otor/go por las aldeas e por el heredamiento de Aça quel dio mío cormano, el abbad don Gonçaluo Pedrez. E porque este otorgamiento / 6 sea mais firme e pongo en la carta mío seello.

E desto son pesquisas, los caualleros don Tello de Quintanuela. Martín García de Pra/dielo. Iohán Pérez de Palencia. Don Bernaldo de Palencia. De escuderos, Roy Díaz de Cane[...] y [...]z de Gamarra. Diac Díaz de Fore/la. Ferrand Ferrández de Tañer. Gonçaluo Royz de Fontorida. Gutier Fernández de Cabannas. Ordon Pérez Ribiela. Gonçaluo Garcíez Dara $/{ }^{9}$ da. Pero Martínez de Aça. Don Migael Zapatón de Aça. Don Gil de Uiliegas.

Este fecho fue fecho en Aça, en el mes de agosto, en la era de $/$ Mil $C^{\text {tos }}$ e LXX V annos.

[1232-09-22 - 1243-04-02]

El abad y el cabildo de Santa María de Husillos realizan permuta de varias propiedades que cada uno tenía después del reparto realizado el 22 de diciembre de 1183. El abad entrega San Juan de Pajares y su término y recibe a cambio las siguientes villas, iglesias y heredades: las iglesias de San Pedro de 


\section{LA ABADÍA DE SANTA MARÍA DE HUSILLOS: ESTUDIO Y COLECCIÓN \\ DOCUMENTAL $(904-1608)$}

Fuentes de Valdepero y de Santa María de Nava; ocho maravedís sobre la marzadga en Villaudilla; la mitad de Hoyales de Roa y Fuentelisendo, aldeas de Haza; sus heredades en Torre de Astudillo; varias viñas y tierras sitas en los pagos de Opera y Falaf y próximas a los molinos de Casa y Cabo de Viña; seiscientos maravedís debidos al abad previamente y treinta maravedís de la capellanía en aniversario del abad Gonzalo; la villa de Villagutierre Álvarez y parte de las viñas llamadas Majuelos de la Serna.

A. AHDP, Ampudia y Abadía de Husillos, Pergaminos, carp. 212-3. Carta partida por ABC. Perg., 186 x 293 mm.; escr. pregótica documental; buena conservación. Mantiene tres cuerdas de las que debieron pender tres sellos.

A'. AHDP, Ampudia y Abadía de Husillos, Pergaminos, carp. 212-2. Carta partida por ABC. Perg., 135 x 285 mm.; escr. pregótica documental; buena conservación aunque con dos grandes manchas de humedad que no impiden su lectura.

ED. SAN MARTÍN PAYO, Apasionante historia de cinco casas, 205.

La data propuesta se ajusta a los datos que nos aportan los documentos. Tello Téllez de Meneses presidió la sede palentina entre 1208 y 1246. Según el abadologio de Husillos, el abad Rodrigo Latronis lo fue entre el 22 de septiembre de 1232 y el 2 de abril de 1243. Por otro lado, el tipo de escritura, pregótica documental, corresponde con la data propuesta.

Se opta por la edición de la escritura que contiene los sellos pendientes, que debieron pertenecer al obispo de Palencia, al abad y al cabildo de Santa María de Husillos.

De la permuta se desprende el valor que debía tener Pajares y su término, ya que fue permutado por un gran elenco de heredades y derechos.

(alfa, beta, omega...) Quam longinquitate sepe sit temporis ut origo non pateat inutatis, id circo nos, capitulum Fusellensi per presens scriptum notum fieri uolumus uniuersi que super quibusdam / querelis inferius ad nectendis quas venerabilis R[oderiocus] Latronis, abbas Fusellensis, contra nos se proponebat habere inter nos et ipsum pro bono pacis et concordie, talis conpositio siue / transactio sponte ac amicabiliter, intercessit. Donat itaque, nobis et successoribus nostris, idem abbas: uillam de Paiares, cum omni iure quod habet in ea et habere debet et ecclesiam $\beta$ eiusdem, cum terris, uineis et uassallis, populatis et non populatis, aceniis, riuis et piscaria, cum montibus, fontibus, ortis, pratis, pascuis, ingressibus et egressibus et cum terminis omnibus et / pertinentiis suis, stabilitate 
perpetua possidenda. Et nos, capitulum Fusellensis, damus et concedimus, dicto venerabili abbati et successoribus suis, pro iure quod concedit nobis in ecclesia / de Paiares, ecclesiam Sancti Petri de Fontibus de Val de Pero, cum omnibus pertinentiis suis et rebus aliis, cum palatio, cum solaribus populatis et populandi, cum terris, uineis, montibus, $/{ }^{6}$ fontibus, pratis, pascuis, ingressibus et egressibus et cum diuisa et cum omni iure quod habemus et habere debemus in eis. Nec non damus ei ecclesiam Sancte Marie de Naua, cum terris, uineis et / cum omnibus pertinentiis suis et cum omni iure quod ibi habemus et habere debemos, et damus ei octo morabetinos quos habemus in Uillaudela, del março; ita quod nichil iuris nobis in Uil/laudela de cetero retinemus preter possessiones que nobis pro anniuersariis relicte erant; pro ceteris uero supra dictis temporalibus que ab, ipso abbate, recepimus concedimus, sibi et successoribus $\rho^{9}$ suis, medietatem de Foyales et de Fuent Aldesendo, aldeis de Aza, cum terris, uineis, ortis, molendinis, montibus, pascuis, terminis, pratis, riuis, fontibus, ingressibus et / egressibus, portatico et cum omni iure quod ibi habemus et habere debemus. Et totum quicquid habemus et habere debemus in Turre de Astudielo, cum palatio, cum solaribus populatis et populandi / et cum diuisa, cum terris, uineis, ortis, molendinis, montibus, pascuis, terminis, pratis, riuis, fontibus, ingressibus et egressibus. Damus insuper ei malleolum quod est iuxta molen $/{ }^{12}$ dina de Casa et aliam uineam que erat de Opera et malleolum de Falaf et unam terram de Opera que est iuxta uineas, ac quicquid habemus uel habere debemus nos et Opera / quod est inter molendina de Cab de Uinna et molendina de Casa; preter hec remittimus domno abbati, sexcentos morabetinos in quibus nobis tenebatur, honera etiam triginta morabetinorum capella/nie et anniuersarii domni Gundissalui, abbatis astringimus nos subire, querele autem quas domni abbas contra nos se contendebat habere sunt hee. Petebat, enim a nobis, Uillam Guter $/{ }^{15}$ rii, cum terris, uineis, palatio et diuisa, cum uassallis populatis et populandi, aceniis, riuis, cum montibus, fontibus, ortis, pascuis, pratis, ingressibus et egressibus et cum omnibus / terminis et pertinentiis suis. Petebat etiam partem uinearum que dicuntur Maiolos de la Serna, super quibus omnibus idem abbas libere cessit et capitulum memoratum absoluit. Pre/missam itaque opositionem siue transactionem super dictis querelis initam; nos, R[oderico] Latronis, abbas, totumque capitulum Fusellensis, unanimiter approbamus et eam sigillorum, $/^{18}$ 


\section{LA ABADÍA DE SANTA MARÍA DE HUSILLOS: ESTUDIO Y COLECCIÓN \\ DOCUMENTAL $(904-1608)$}

nostrorum patrocinio comunimus, ad maiorem etiam firmitatem rogavimus et suplicavimus venerabili domno T[ellus], Dei gratia palentino episcopo, quod sigillum suum, dicte scripture / apponere dignaretur. Et nos, T[ellus], Dei gratia Palentinus episcopus, ad supplicationem dictorum abbatis et capituli, quod ab ipsius abbate et capitulo, factum est approbamus et transactionem / siue compositionem supradictam, sigilli nostri munimine confirmamus.

[1232-09-22 - 1243-04-02]

Testamento de Miguel, prior de Santa María de Husillos. Manda dinero, tierras y viñas a la fábrica de dicha iglesia, a sus beneficiados y a varios de sus criados. Hace referencia a las obras que mandó realizar en la iglesia, al decir que deja cubiertos el coro, el altar de Santa María y el portal por donde solían salir en procesión.

A. AHDP, Ampudia y Abadía de Husillos, Pergaminos, carp. 209-20. Perg., 333 x 237 mm.; escr. gótica documental; buena conservación, con dos raspaduras en que se ha borrado lo escrito y alguna pequeña mancha de humedad que no impide su perfecta lectura. Tiene tres orificios de los que pendían los sellos. Los de los extremos conservan las tiras de cuero.

CIT. J. GONZÁLEZ, Siglos de Reconquista, 198.

Las fechas propuestas corresponden al abadiato de Rodrigo Latronis (1232-09-22 / 1243-04-02). Por otra parte, la fecha se corresponde con el tipo de escritura empleado.

Connoszuda cosa sea a todos los qui esta carta uieren que hio, don Migael, dicho prior de Fusiellos [...] / de Fusiellos, fago mío testamiento de las cosas que Dios et Santa María me dieron por su misericordia. Quito al abad don Rodrigo XXX morabitinos que deuía auer / de enpresto, que fit a mío sennor, el abad don Gonzaluo, onde tenía fiadores; et IV morabetinos menos quinta que presté a él. E mando a mi fin, a él o al abad qui aquí fue $/ 3$ re, la mula si sana fuere; si no, .XX. 
morabetinos et el mío uaso de plata. Dexo en la eglesia I missal nueuo et vestimienta festiual complida et I estola de más / et I túnica et un dalmatiga et III capas de pórpora pora oficiar. Et di LX morabetinos a los canónigos, ond aian VI morabetinos cada anno pora su matinada. Et dexo la nau / del coro et del altar de Santa María et el portal por o salen a la procesión, cubiertos cumo están. Et di pora fazer el sagrario, XL morabetinos; et pora fazer el ca/ $/ 6$ billo, L morabetinos. Di II cubas a la bodega del cabillo. Et dexo a míos compañeros [...] cada anno pora mío anniuersario en esta uilla, el mío majuelo de La Serna, la / vinna de La Penna et otras II vinnas hi luego en arroio. Et déxoles el majuelo maior, carrera de Fuente Quinana, et el majuelo maior que he en Población. Et / la mi terra de Las Eras et II terras, otras que he carrera de Sant Illán et la terra maior que he carrera de Fuentequinana et otra que he en linde del majuelo mayor, et $\rho^{9}$ otra a Sant Iarre, et otra en linde del arroio so carrera de Judíos. Et déxoles en Sant Illán, la vinna maior de Val Sonera et la uinna de Barrial, toda así cumo iaz. / Et déxoles la uinna que fue de don Romío, que es carrera de Bezerril, con todo lo al que hio hi compré, et la uinna del Ual et la uinna de Touistlo. Et déxoles las mis / casas con todas sus pertenencias enteramient, así cumo las hio he. Et que den, cada anno,.I solido del portal, por anniuersario de Gonzaluo Roit.

Et esto lexo todo a míos $/{ }^{12}$ compañeros por tal condición: que lo aian et que lo contengan don Fernando et Simón et Domingo Pérez, míos criados, en toda su uida. Et que den a uos VI morabetinos por mío anniuersa/rio, cada anno, en toda su uida; et den I morabetino por anniuersario de Pero Martín, mío sobrino; et otro morabetino por anniuersario de mi ermana, madre que fue / de Pero Martín. Et mando que don Fernando aia cada anno la meatad de la renda que saliere desta heredad o del fruito. Et Simón et Domingo Pérez $/{ }^{15}$ la otra meatad. Et depués que finaren don Fernando et Simón et Domingo Pérez, asigno en esta dicha heredad, sennos morabetino por anniuersario de cada / uno dellos. Et assí cumo finare cada uno destos, que finque luego la su part al cabillo; et quando el potrimero destos míos criados finare, que finquen estonz / IIII cubas et II carreles, que les dexo a la bodega del cabillo. Et si pora uentura alguno destos míos criados o todos quisieren prender orden, mando que $/^{18}$ aia su part del fruito desta heredad, asi cumo la abrí si fuese al sieglo. Et retengo mío poder, mientre uiuo fuere, pora minguar o pora / acrecer si quisiere en est mío testamiento. 


\section{LA ABADÍA DE SANTA MARÍA DE HUSILLOS: ESTUDIO Y COLECCIÓN \\ DOCUMENTAL $(904-1608)$}

Et nos, Roi Ladrón, abbad, et el cabillo de Fusiellos, otorgamos este testamiento. Et porque sea más / firme, mandamos hi poner nuestros sellos. E yo, don Migueles, mismo prior, cresco en mío testamento aquestas cosas. Conuiene a saber: do la mi ${ }^{21}$ terra de Entramas Aguas a la uebra por L morabetinos de C quel deuía, de LXXX morabetinos que me deue al cabillo, menos $\mathrm{X}$ solidos, denle los / otros L morabetinos. E mando el mío majolo de la Serna pora la lámpada del crucifixo, e quel tengan míos criados en su uida e que arda la lámpada de no/che e de día, a las oras; e depués de uida de míos criados, tome el cabillo el majolo e cumpla la lámpara. Mando a Saluador Medea alançada de uinna $/^{24}$ so La Cabanna, en su uida, depués la uinna sea del cabillo. Mando a Domingo, mío criado, el majuelo que pus cabe la uinna de Migal Díaz, en su uida, / depués la uinna sea del cabillo. Mando a los monaziellos, XX morabetinos por anniuersario cada anno, e dégelos el cabillo de los LXXX morabetinos de que me / deuíe sobre los L que mande dar a la obra. Mando a Juan, mío criado, en su uida, el mío majolo que es en linde de uinna de don Juan, fiio de Pero ${ }^{27}$ Uerzerlejo, e de uinna de Domingo Pérez, fiio de Pero Pardo. Depués de su uida, la uinna sea del cabillo.

1243, abril, 2. Valladolid.

Sentencia pronunciada por Fernando III del pleito litigado por Pedro Martínez, abad de Santa María de Husillos, y su cabildo, con el concejo de Villaudilla, sobre el derecho de fuero como el que disfrutan los pobladores de Palencia, negado por los primeros. El concejo de Villaudilla presenta un privilegio otorgado por Poncio Guitardo, abad de Santa María de Husillos, y Pedro, obispo de Palencia (1127, noviembre, 5), inserto, por el cual los pobladores de Villaudilla debian tener el mismo fuero que los de Palencia. La sentencia es favorable al concejo de Villaudilla. 
A. AHDP, Ampudia y Abadía de Husillos, Pergaminos, carp. 198-11. Perg., 278 x 245 mm.; escr. gótica documental; buena conservación, aunque presenta una rotura que afecta a la línea 22. Conserva la cuerda pero no el sello de plomo.

$B$. APA, $L P H$, ff. $68 \mathrm{v}-69 \mathrm{r}$.

C. BN, $m s .705$, ff. 9v-10r y 137r-139r.

D. BAH, ms. 9/6448. Copia del siglo XIX.

ED. J. GONZÁLEZ, Fernando III, III, 258-259, núm. 707. Da como signatura del documento: “A. Diocesano de Palencia, no 36".

Ferrandus, Dei gratia rex Castelle et Toletus, Legionis, Gallecie et Corduba, omnibus hominibus hanc cartam uidentibus, salutem et gratiam. Sobre pleyto que era entre / el abbat Pero Martíniz et el cabildo de Fusiellos del una parte, et el conceio de Villabdella del otra, sobrel fuero que dizien los de Villabdella / que deuíen auer tal qual le han oy los omes de Palencia, et el abbat et el cabildo dizíen que non. La una parte et la otra uinieron ante mí $\beta$ et el conceio de Villabdella mostró tal carta ante mí et ante míos alcaldes:

(Sigue doc. núm. 20)

Sobre tod aquesto razonaron los de Villabdella cosas $/^{21}$ que usaran [del] fuero que agora Palencia en tiempo del rey don Alfonso, nuestro auuelo, et en tiempo del rey don Anric et en el mío. A esto / respondió el abbat, por sí et por so cabildo, que pues que ellos carta de fuero mostraran et a fuero se lamaran, non podíen razonar costun/bre nin uso contra el que era sennor, et la carta del fuero non se deue entender si non daquel fuero que auíe Palencia a qual día et a qual ora que $2^{24}$ la carta les fuera dada del fuero. Et yo, rey don Ferrando, uista la carta que mostraron los de Villabdella et oydas las razones de / la una parte et de la otra, mando por yudizio que los de Villabdella ayan aquel fuero que auíen los de Palencia aquel día et aquel tiempo / que la carta del fuero les dieron el obispo de Palencia et el abbat de Fusiellos, et otro non fueras si se abinieren con el abbat et ${ }^{27}$ con el cabildo de Fusiellos. Et porque este mío yudizio sea más firme, mando poner el mío seello en esta carta.

Facta carta apud / Vallisoletanum, rege expedito, II die aprilis, era M CC LXXX prima. 
1243, junio, 7. Palencia.

Avenencia entre Santa María de Husillos y el concejo de Villaudilla, ordenada por Fernando III, con motivo del litigio entre ambas partes sobre el fuero que tenía dicho concejo desde el año 1127, estableciéndose un nuevo fuero en el que se regulan las compensaciones por accidentes y homicidios, fijando para Santa María de Husillos el yantar, sernas, marzadga, huesas, regulando la explotación y compra de solares y la jurisdicción del abad a través de sus alcaldes.

B. APA, $L P H$, ff. $32 \mathrm{v}-33 \mathrm{r}$.

C. AGS, Patronato eclesiástico. Inconexos, leg.159, ff. 40v-42r. Papel; escr. procesal; buena conservación.

D. BN, ms. 705, ff. 50v-52r.

El lugar de Villaudilla presenta diferentes variantes terminológicas en la colección: Villaudela, Villa Abdala o Villabdela.

Fecho y sacado fue este traslado de la dicha escritura original en la villa de Husillos, a veynte y tres días del mes de novienbre de mil y quinientos y çinquenta y quatro años. Testigos que fueron presentes a lo uer, leer, corregir y conçertar con el original, Joán Ruiz Cabeça de Vaca y Gaspar de Vedoya, clérigos, y Pero Manuel, estantes en la dicha villa.

E yo, Santiago Gómez, escriuano público en la dicha villa, presente fui a lo que dicho es en vno con los dichos testigos. Y del dicho pedimiento y mandamiento del dicho alcalde mayor que aquí firmó su nombre, lo escreví y fize aquí mi signo (signo) en testimonio de verdad.

Pero Ruyz de Billoldo (rúbrica). Santiago Gómez (rúbrica).

Conosçida cosa sea a todos aquellos que esta carta vieren que sobre contienda que era entre el abad don Pero Martínez y el cabilldo de Fusillos de vna parte, y el concejo de Villaudela de la otra, sobre que dize el concejo de Villaudela que los desaforaua el abad. La vna partida y la otra vinieron delante 
mí, don Fernando, por la graçia de Dios rrey de Castilla, de Toledo, de León y de Galizia, y de Córdoua, y los de Villaudela mostraron su carta de so fuero antiguo que auían, y los vnos y los otros touieron sus bozes. Y yo, auendicho rrey don Fernando, vista la carta de los de Villaudela y oídas las rrazones de vna parte y de la otra y o de mío consejo y de voluntad de anbas las partidas, pus tal auenençia entre ellos que si en Villaudela o en so término fuere ome muerto en pozo o en rrío o lo matare pared o árbol o qualquier cosa que muerta sea seyendo el ome de Villaudela, de tal omezillo, el abad ni so término ni canónigo ni ome por él no pueda nada demandar. Et si cauallo o buey o otra bestia o qualquier otra cosa biua no seyendo ome matare algún ome, que sea en voluntad del señor del dañador de dar el omezillo todo entero o el dañador. Y si vn onbre matare a otro o uiniere malfiesto, dé las tres partes del omezillo, e la quarta sea quita. Y si lo parare en niego o en contienda y el abad y su ome si lo pudiere vençer por derecho, dé todo su omezillo entero, de lançada o de espadada o de cuchillada, que no pasare de parte a parte, peche çinco sueldos, y si pasare peche diez sueldos, de ferido onde huesos salieren, sesenta sueldos por cada hueso que se la descubrieren y ansí facta trezientos sueldos y no más, y en todas las otras cosas como desjudgamiento de ome o de muger o enterramiento o mienbro podrido o ojo cortado o en diente perdido o crebantado, o en liuor o en tumor o en qualquier otra cosa doquier que el señor deua auer calunia, lleue el abbad sus calunias según fueron de la $(f .32 v)$ tierra, saluas aquellas cosas de que el abad es en tenençia cuemo de xantar y de sernas y del sueldo del março que se las aya como se las a y ninguno no rresponda sin querelloso si non fuere por muerte de ome; y después que metiere la querella, no se pueda dende rretraer y lléuenla adelante. Y si muger viuda casare ante de año, dé quatro maravedís al abad por huesas. Y si después de anno casare, no dé nada. Y si solar estoviere yermo vn año y el dueño del solar no mostrare y provare rrazón derecha cuemo de hanbre o de hueste o de enemistad o de otra rrazón derecha, de año adelante, tómese el abad el solar. Y un casado no aya más de vn solar, sino aquellos que compraron después de muerte de mi abuelo, a la que los aya cada vno y fagan fuero por ellos. Y los que compraron antes de muerte de mi abuelo, áyanlos ansí commo los auían entonçes, y de aquí adelante ninguno pueda comprar ni auer dos suelos si no se le vinieren de eredamiento de sus parientes y éstos que los tengan poblados y fagan fuero por ellos. Y quien no ouiere suelo 


\section{LA ABADÍA DE SANTA MARÍA DE HUSILLOS: ESTUDIO Y COLECCIÓN \\ DOCUMENTAL $(904-1608)$}

pueda comprar vn suelo, no más. Y faga alcaldes en Villaudela que juzguen las cosas que y acaesçieren. Y quien no se pagare de su judiçio, álçese al mío adelantado. Y quien no se pagare de su judiçio, álçese a mí.

Y esta misma avenencia que yo, auen dicho rrey don Fernando, puse entre el abad y los de Villaudela, déngela por fuero el obispo de Palençia y el abad y el cabilldo de Fusiellos al concejo de Villaudela. Con mío otorgamiento, denles ende buenas cartas firmes para siempre, selladas con sus sellos. Y desto son fechas dos cartas partidas por A, B, C. E lo que a en la vna esso mismo a en la otra; la vna dellas tiene el abad y el cabildo de Fusiellos, y la otra los de Villaudela.

Y porque esta auenençia que yo, rrey don Fernando fiz, sea más firme, mandé poner mío sello de plomo en cada vna destas cartas.

Facta carta apud Palenciam, rege expedito, siete die iuni, era MCC LXXXI'.

1243, julio, 16, jueves. San Cebrián de Meneses.

Sancha Pérez, esposa de Pedro Rodríguez, vende a Pedro Martínez, abad de Santa María de Husillos, dos molinos que tiene en Villagudiel y que llaman del Final, en precio de quinientos maravedis. Estipula ciertas condiciones relativas al juicio que mantiene con Pedro Ponz por la mitad de dichos molinos.

A. AHDP, Ampudia y Abadía de Husillos, Pergaminos, carp. 208-9. Perg., 204 x 398 mm.; escr. gótica documental. Muy buena conservación. Lleva pendientes tres cintas pero no sus correspondientes sellos.

B. APA, $L P H$, f. $31 \mathrm{r}-\mathrm{v}$.

C. BN, $m s .705$, ff. $47 \mathrm{r}-48 \mathrm{v}$.

Conoscida cosa sea a todos aquellos que esta carta uiren cuemo yo, donna Sancha Pérez, mugier de don Peidro Rodríguez, vendo a uos, don Peidro Martínez, abbat de Fusiellos por nombre de la eglesia de Fusiellos, aquellos dos molinos / que he en Villa Godiel, que dizen del Final, con exidas et con entradas 
et con cespederas et con aguas et con presas et con quanta derechuría hi he et auer deuo. Et estos molinos uos uiendo por quinientos morauedís, a VII florines et medio el morauedí, entre pre/cio y aluaroch, onde so bien pagada, assí que ninguna cosa non finca a uos por pagar, nin a mí por recebir, et doy más en adelante que sean salidos de mío yur et entrados en el uestro, assí que uos podades dellos fazer cuemo de uestra propria ${ }^{\beta}$ heredat, dando, uendiendo et cambiando a toda uestra uoluntat. Et yo, donna Sancha, nin heredero que yo aya, non deuemos fazer molinos en aquel arroyo de Fradres, nin en aquel que ua a los molinos del Fenal, nin sobre los molinos nin so / ellos, nin sacar el agua en otra part porque los molinos pierdan moleo, nin el agua dexe de uenir a Fusiellos cuemo deue. Et yo, dauandicha donna Sancha, so tenida et so fiador sobre mí et sobre quanto he, pora agora et pora siem/pre, de redrar tod omme qui estos molinos demandar quisiesse, a uos o a la eglesia de Sancta María de Fusiellos, de tanto en fuera, que si don Pero Ponz uenciesse por judizio derecho, a mí donna Sancha, en míos días, de la meitat de aquellos $/{ }^{6}$ molinos, que me demanda con otras heredades, que yo sea tenida de tornar, a uos et a la eglesia, dozientos et cinquenta morabedís daquestos quinientos, et uos, dexarle la meatad daquestos molinos. Et si don Pero Ponz, en los míos días non uenciesse / por derecho juyzio, la demanda que a contra mí, destos molinos, qualesquiere qui lo mío heredaden, sean tenidos de redrar, también a don Pero Ponz cuemo a todo otro omme qui demandasse estos molinos o parte en ellos, a Sancta María / de Fusiellos. Et pora cumplir todo esto quanto escripto es en esta carta, obligo yo a mí et todo lo mío por oquier que sea et a míos herederos, por agora et pora siempre. Et porque esta carta sea maes firme, yo, dauandicha donna Sancha, rue $/{ }^{9}$ go a don Tello, por la gracia de Dios obispo de Palentia et al deán don Martín Peláez et al cabildo de Palentia, que pongan en ella sos seellos. Et nos dauandichos don Tello, por la gracia de Dios obispo de Palencia et yo deán don Martín / Peláez et nos cabildo de Palentia, por ruego de donna Sancha, ponemos en esta carta nuestros seellos. Si algun omme del linaje de mí, donna Sancha o de otro, uenir quisiesse contra esta carta et contra esta uendición que yo donna / Sancha fago al abbat et a la eglesia de Fusiellos, sea maldicto et descomulgado con Juda traydor en infierno dampnado et aya la hira de Dios et peche en coto mil morauedís a la eglesia de Fusiellos et al abbat o a qui so uoz dieren et el $/{ }^{12}$ daño duplado. 
Fecha la carta en Sant Cibrián de Meneses, en el mes de julio, ioues, viéspera de sancta Justa et Rufina, XVI días andados del mes, en era M CC LXXX I. Regnante el rey don Fernando con so madre, / la reyna doña Beringuela et con so mugiere, la reyna doña Juana, et con so fiio, el yfante don Alfonso, en Toledo et en Castiella et en León et en Gallizia et en Córdoua. Alfiéraz del rrei, don Diago López de Faro. Mayordomo, / don Rodrigo Gonçáluez. Merino mayor, don Sancho Sánchez de Velasco. Obispo en Palentia, don Tello. Desta cosa son pesquisas: el obispo don Tello de Palentia. Maestro Tiburcio, electo de Colimbria. Don Marciel, abbat $/{ }^{15}$ de Matallana. Don García, celerero de Matallana. Don Symón, frayre. Maestre Diago, arcidiano de Campos et canonge de Fusiellos. Don Tello, chantre de Palentia. Roy Gonçáluez, canonge de Palentia et de Fusiellos. Juan Suárez, / canonge de Palentia. Don Alfonso de Salamanca et maestro Domingo et Fernant Áluarez, compañeros de la eglesia de Palentia. Pero Pérez, canonge de Fusiellos. Maestre Gonçaluo et don Veuián et Pero, abbat de Oter de Siellas, clérigos del obispo. / Gonçalo Pérez, canonge de Trianos. Juan Martín, Pero Áluarez, Pero Peláez, clérigos del electo. Juan Martín, Domingo Abril, clérigos del abbat de Fusiellos. Pero Díaz, clérigo del camarllengo. Don Gonçalo de Córdoua. Don Alfonso Pérez Girón. Guter Gonçáluez Quexada. ${ }^{18}$ Tel Pérez de Ualuerde. Guter Díaz. Juan Suárez, pintor. Domingo Martínez de Meneses. Peidro Carandia de Sant Cibrián.

Iohanes Martín, scripsit.

1244, agosto, 23. Palencia.

Pedro Martínez, abad de Santa María de Husillos, juntamente con el cabildo de dicha iglesia, realiza un convenio con Fernando, arcipreste de Torre de Astudillo, por el que éste puede aprovecharse durante el resto de su vida de una heredad que la abadia posee en dicho lugar. A cambio debe entregar a dicho abad y a sus sucesores quince maravedís en censo, desde el día de San Martín 
hasta Navidad. También entrega al abad y al cabildo una viña que hace cinco cuartas, reservándose su usufructo durante el resto de su vida.

A. AHDP, Ampudia y Abadía de Husillos, Pergaminos, carp. 207-12. Carta partida por ABC. Perg., 160 x 325 mm.; escr. gótica documental; buena conservación. Mantiene casi intacto el sello del obispo don Tello, otros dos de los que apenas quedan restos y los orificios para un cuarto sin cinta. Posiblemente pertenecieran al abad y cabildo de Husillos, y al arcipreste de Torre de Astudillo.

B. APA, $L P H$, ff. 33r-34r.

C. BN, ms. 705, ff. 52r-54r.

( $A B C \ldots S T U)$ Connoscida cosa sea a todos aquellos que esta carta uieren, cuemo nos, don Pero Martínez, abbat de Fusiellos e el cabildo del meismo logar, fazemos tal pleto con uusco, F[ernant], abbat arcipreste de Torre de Astudiello. Damos uos que tengades en / uestros días quanta heredat la eglesia de Sancta María de Fusiellos a en Torre. Conuiene a saber: I solar con sos casas que a hi fechas, e una ferrén e vuerto e era e prado e III tierras, de las quales la una es en linde de los Prados, e a en ella / X obradas. La otra es en linde del Era del Obispo, e a en ella XIIII obradas. La otra es en el páramo, cerca de Val de olmos, e a en ella VIII obradas. E damos uos III pedaços de uinnas, los dos son carrera de las Sarças, e a en $/ 3$ ellos II arançadas. El otro pedaço es en Fondón de los Prados, e a en él III arançadas e media. Todo esto uos damos en tal guisa e so tal condición que non ayades poder de uender, nin de enpennar, nin de dar, nin de enagenar, nin de canbiar, / nin de arrendar ninguna cosa destas dauandichas, menos de nostra uoluntad, mas que lo lauredes e desfruchedes e que uos siruades dello en todos uestros días, e que dedes cada anno a nos, don Pero Martínez, abbat dauandicho, o a nostros suc/cessores, XV marauedís por encens, desde la fiesta de Sanct Martín fasta la fiesta de nabidat, so pena del doble. E si alguna cosa en estas dauandichas heredades meioraredes o en las casas, o ganaredes quier de uestros parientes, $/^{6}$ quier de otra parte, pora la ecclesia de Fusiellos, que lo tengades todo en uestros días, so aquel cens que es dicho, e después de uestros días tanbien lo que nos uos damos cuemo lo que uos meioráredes o ganáredes, assí cuemo es dicho. Que todo finque / libre e quito a la ecclesia de Fusiellos en ningún entredicho e sen ninguno otro porcionero, e si por auentura nos don Pero Martínez, abbat, e el cabildo de 


\section{LA ABADÍA DE SANTA MARÍA DE HUSILLOS: ESTUDIO Y COLECCIÓN \\ DOCUMENTAL $(904-1608)$}

Fusiellos o nostros successores, quisiéremos uender o canbiar esto que nos damos a uos Fernant, abbat / arcipreste, con el obispo o con otro ombre alguno, que sea en uoluntad daquel a quien lo uendieremos o con quien lo canbiáremos si quisier estar en el pleto, assí cuemo es dicho, uos que lo atengades si non alçado el fruto daquel anno e pagada $/{ }^{9}$ la renta; que finque todo lo que nos a uos damos a aquel a quien lo uendiéremos o con quien lo canbiáremos, e lo uestro a uos.

E yo, Fernant, abbat arcipreste dauandicho, otorgo tod este pleto assí cuemo diz en esta carta; e por esta merced que uos / don Pero Martínez, abbat, e el cabildo de Fusiellos me fazedes, do uos yo I uinna en que a V quartas, la qual es a las Sarças, en linde de la uestra. E esta uinna que uos yo do e yo de tener en todos míos días, e que la laure e desfruche e que / me sirua della, assí cuemo de lo al que me uos dades. E después de míos días, tanbién esta uinna, cuemo lo al que me uos dades e todo lo que yo meiorar o ganar, assí cuemo es dicho de suso, que todo finque libre e quitamientre a la $/{ }^{12}$ eglesia de Sancta María de Fusiellos sen ningún entredicho e sen ninguno otro porcionero; e que lo uos podades entrar por uestra autoridat, sen calonnia ninguna. E pora tod esto cunplir assí cuemo es dicho, yo meismo, Fernant, abbad / arcipreste sobredicho, so fiador e recabdo por uida e por muert, e obligo a mí e a tod ombre que lo mío heredar pora cumplir tod esto.

E deste pleto son fechas tres cartas partidas por A, B, C, e lo que a en la una, esso a en cada una / de las otras. E porque este pleto sea más firme, nos don Pero Martínez, abbat, e el cabildo de Fusiellos e Fernant, abbat arcipreste dauandichos, rrogamos e pedimos merced a nostro sennor don Tello, por la gracia de Dios obispo de Palencia, que man $/{ }^{15}$ dé poner so seello en cada una destas cartas, e nos otrosí mandamos hi poner los nostros. E destas cartas, la una tienne el abbat e el cabildo de Fusiellos, e la otra Fernant, abbat arcipreste de Torre. La otra es en el sagrario de Sanct / Antolín. E nos, don Tello, obispo dauandicho, por ruego de ambas las partidas, mandamos poner nostro seello en cada una destas cartas.

Fecha la carta en Palencia, en el mes de augusto, uiéspera de Sanct Barcholomeo, XXIII / días andados del mes, en era $\mathrm{M}^{\mathrm{a}} \mathrm{CC}^{\mathrm{a}} \mathrm{LXXX}{ }^{\mathrm{a}} \mathrm{II}^{\mathrm{a}}$. Desta cosa son pesquisas: el prior don Martino de Fusiellos. El capiscol don Rodrigo Fitero. El sacristano don Pero Domínguez. De canónigos de Palencia: el arcidiano Nicolás Marchos. ${ }^{18}$ Don Iuan de Palencia. De canónigos de Fusiellos: don Rodrigo, capellán de la rreyna. Rodrigo Rodríguez. Garci Uannez. Iuan Pérez. Garci 
Fernández. Don Sancho. De conpanneros de la eglesia: Iuan Martín, clérigo del / abbat que escriuió la carta, e don Arnalt. Maestro Steuano. Don Adam.

1245, mayo, 25.

Pedro Martínez, abad de Santa María de Husillos, con el consentimiento del cabildo de dicha iglesia, permuta con Domingo, vecino de Fuentes de Valdepero e hijo de Pedro Ruiz de Quintanilla, una tierra que llaman La Laguna por otra sita en Val Mayor, debajo de una pedrera propiedad de Santa María de Husillos.

A. AHDP, Ampudia y Abadía de Husillos, Pergaminos, carp. 208-8. Carta partida por ABC. Perg., 148 x 167 mm.; escr. gótica documental; buena conservación. Mantiene pendiente dos cintas sin sus sellos, que petenecían al abad y al cabildo de Husillos.

B. AHDP, Ampudia y Abadía de Husillos, Pergaminos, carp. 207-19. Perg., 405 x 266 mm; escr. precortesana. Aunque el texto está perfectamente conservado, tiene dos roturas que suplimos con el Libro de los Privilegios de Husillos. Traslado sacado en Fuentes de Valdepero, el 21 de agosto de 1384, con motivo de la autorización del concejo de Fuentes de Valdepero a Santa María de Husillos para sacar piedra de unas canteras. Da como data crónica, el 26 de mayo de 1245. Véase doc. núm. 206.

$C$. APA, $L P H$, ff. $34 \mathrm{v}-35 \mathrm{v}$. Al final del documento: $<\mathrm{Y}$ esta escritura por estar rota en algunas partes no se signó>. Traslado de $B$.

$(A B C \ldots)$ Conoscida cosa sea a todos aquelos qui esta carta uiren, cuemo yo, don Pero Martínez, abbat de Fusiellos, con otorgamiento / del cabillo del mismo logar, fago cambio con don Domingo de Fuentes de Ual de Pero, fiio de Pero Royz de Quintaniella, de / una terra que he en Fuentes, quel do por otra terra que ha él en Ual Mayor, so la pedrera por o echan la piedra, en tal guisa / que él faga de la terra quel yo do daquí adelante como suya propria, et yo de la que me él da, que faga dela como de heredad propia $\beta$ de la ecclesia. Et la terra quel yo do es en La Laguna, et a estas affrontaciones: la primera de don Pérez, fiio de Pero 
Hañez. La segun/da el mío majuelo. La tercera de Juan Pérez, yerno de Martín Velasco. La quarta affrontación de doña Urraca, fiia de Juan Rava/uello. Et la terra que me él da en Ual Mayor, a estas affrontaciones: la primera affrontación la pedrera de los canónigos de Fusi ${ }^{6}$ ellos. La segunda de don Martín, fiio de Cid Juannes. La tercera de dos sobrinos, fiios de Juan Pérez, so ermano. La quarta affrontación, / heredad de Fusiellos.

E por este cambio que fizo comigo, dol en dessusanga una saszuela que es en la Laguna cerca aquella / terra, et a affrontaciones: la primera de Pero Domínguez, fiio de Pero Criador. La segunda el mío majuelo.

Et porque este cambio sea más fir $/{ }^{9}$ me, dol por fiador de saneamiento don Romón de Fuentes et don Domingo. Otrosí a mí da por fiador de saneamiento Juan Pérez, so suegro.

Et desto son fechas dos cartas partidas por A, B, C, et lo que ha en la una esso mismo a en la otra, et la / una dellas tiene don Domingo et la otra es en el sagrario de Fusiellos. Et porque sean más firmes yo, don Pero Martínez, abbat de Fusi/ellos et el cabillo del mismo logar, mandamos poner en cada una de las nuestros seellos.

Fecha la carta en mes de $/^{12}$ mayo, VII días por andar del mes, sus era $\mathrm{M}^{\mathrm{a}} \mathrm{CC}^{\mathrm{a}}$ LXXX $^{\mathrm{a}}$ III $^{\mathrm{a}}$. Regnante el rey don F[ernando] con su mugier la reyna doña / Juana et con su madre la reyna dona Berenguela en Castiella et en Toledo et en León et en Galizia et en Córdoua et en / Murcia. Desto son pesquisas: don Pérez, fiio de Pero Fañez. Don Domingo, so fiio. Don Diago. Don Rodrigo, fiio de Pero Calzas. $/{ }^{15}$ De Fusiellos: don Abril. Migal Díaz.

66

1245, octubre, 30, lunes. Palencia.

Pedro Martínez, abad de Santa María de Husillos, arrienda por cuatro años a Pedro Ibáñez, clérigo de Fuentes de Valdepero, a Martín Velasco y a Miguel, la heredad de San Adrián, en precio de ciento veinticinco maravedis; de 
los cuales, diecicho han de pagar el día de San Martín; y de los restantes, la mitad por el día de Navidad y la otra mitad por la cuaresma. Estipula ciertas condiciones.

A. AHDP, Ampudia y Abadía de Husillos, Pergaminos, carp. 208-10. Carta partida por ABC. Perg., 273 x 159 mm.; escr. gótica documental; buena conservación con algunas manchas sin importancia. Tiene cinta pero falta el sello de cera.

$B$. APA, $L P H$, f. $34 \mathrm{r}-\mathrm{v}$.

C. BN, $m$ s. 705 , ff. $54 \mathrm{r}-55 \mathrm{v}$.

$(A B C \ldots K L M)$. Conoszuda cosa sea a todos aquellos que esta carta uieren, cuemo yo, don Pero Martínez, abbat de Fusiellos, arrendo / a uos, Pedryuanes, clérigo de Fuentes de Ual de Pero, et a Martín Uelasco et a don Miguel, Sant Adrián, con / quantas derechurías yo hi he, terras et vinnas et prados et casas et el orto et el azeña et el pecho, et la yantar, $\beta$ et las enffurciones et las sernas et las calonnas, daquí IIII annos; cada anno, por C et XXV morabetinos, sacada / calonna, de LV sueldos a arriba, et esta que sea mía. E destos morabetinos, me auedes a pagar por Sant Martín, / XVIII morabetinos. Et de los otros que fincan, la meatad por la Nabidad et la otra meatad por la Cinquesma. Et $/ 6$ si estos morabetinos a estos deuandichos plazos non fossen pagados assí como es dicho, que quantos días / passassen, dent adelante, que me diessedes cada día, I morabetino en pena. Et si cuesta omissión, yo ouies / a fazer a merino o a portero o a rey, por auer de uos los morabetinos, que sea sobre uos, et destos morabetinos et de la $/^{9}$ pena fazer dar. Son fiadores: Don Romero et Martín Fernández, et fiadores et debdores de mancomún / con estos, et cada uno por todo, los mismos arrendadores que de ssuso son dichos. E deuedes labrar las / vinnas de IIII lauores, et cada una a so tiempo, porque las uinnas ualan más; et si alguna destas la/uores menguássedes, que perdades la vua daquel anno, et que me pechedes de más I morabetino. Et a qual sazón entrá ${ }^{12}$ redes, que salades dello a tal. Et por quantos fructos leuáredes, deuedes a pagar tantas rendas, a los / plazos que de ssuso son dichos. E las cosas que son de la azeña son preciadas: la rueda, V morabetinos et la uiga, / III morabetinos et tercia et la entruesga, VI morabetinos et IX dineros et la muela de yuso, VI morabetinos, et es tan gruesa cuemo $/{ }^{15}$ esta carta es en ancho, et la muela de suso, II morabetinos et medio et es tan ancha 


\section{LA ABADÍA DE SANTA MARÍA DE HUSILLOS: ESTUDIO Y COLECCIÓN \\ DOCUMENTAL $(904-1608)$}

como la carta fastal pera/grafio. Summa destos morabetinos del preciamiento, XXIII morabetinos menos VI dineros. Et el palo et el anadiza, sano / et calzado de nueuo et el carriello bien calzado e bien sano, et II picos et un cabo martiello, sanos et $/{ }^{18}$ calzados de nueuo. Et esto todo deuedes adobar et mantener, que por uestra culpa non quiebre nin se danne. / Et quando dello salíderes, complidos los IIII annos, deuédesme esto todo dexar apreciado, et si menos / ualiere que agora, quando uos lo yo da, devédesme complir por quanto vos lo yo do, et si más valiere $f^{21}$ que agora, quando uos lo yo do, lo demás que uos lo torne yo, et si quebrar las rueda o la viga o la entruesga, / de guisa que se non pueda adobar, mando que lo metades nueuo et que lo contedes sobre mi renda, a uista de / mío ome. Et deuédesme dexar tantos baruechos et de tantas rejas como uos yo do: L et VI obradas de $/^{24}$ tres rejas. Et deuédesme dexar I casa leña de buen feno, fasta las uigas, et otra de paja menuda, / fasta las uigas; esto porque uos lo do prestado. Et deuédesme contener las casas et dexármelas bien / techadas, et si casa me cayere por uestra culpa, que me la fagades, et si por uestra culpa non cayere, que me la ${ }^{27}$ faga yo. Et yo que non pierda mi renda, nin por piedra, nin por elada, nin por otra tempestad. Et con tal / pleto uos lo arrendo, que me non defforedes míos omes, que se me yermen por uestra malfetria, et deuen uos / fazer el fuero que me fazíen a mí, et uos fazerles sos derechos, como les yo fazía. Et préstouos dos bues que son $\beta^{30}$ preciados IX morabetinos, et quando los II annos foren complidos, que me dedes dos bues que ualan tantos morabetinos o si non / los IX morabetinos, quanto los bues que uos yo presto son preciados. E nos, deuandichos arrendadores, otorgamos todo quanto / en esta carta dize.

Et desto, son fechas dues cartas, partidas por ABC., e lo que ha en la una, esso mismo $/^{33}$ ha en la otra, e la una dellas tengo yo, don Pero Martínez, abbat de Fusiellos, et la otra los mismos arren/dadores. E porque esta cosa sea más firme, mando poner mío seello, en cada una destas cartas.

Este pleyto / fue fecho en Palentia, lunes, tercer día ante de la fiesta de Todos Sanctos, dos días por andar del mes de ochubre, ${ }^{36}$ sub era M CC LXXX III. Desto son pesquisas: don Symón. Pero Fernández, criado de maestre Andrés. / Fernand Papon. G[onzalo] Talauera. G[onzalo] Tarugon. Don Guiielmo, criado de Fernando de Casa. Don Fernando, / el Padellano. Don Pero Bermúdez, el alfayat. Don Gil, so fiio. Don Lorent, el selero. Don Ordoño, el alfa $/{ }^{39}$ yat. 
1250, marzo, 31. Lyon.

Inocencio IV concede bula de indulgencias a Santa María de Husillos.

B. AHDP, Ampudia y Abadia de Husillos, Pergaminos, carp. 204-11. Perg., 665 x 547 mm.; escr. gótica de cancillería pontificia; regular conservación con algunas manchas y una rotura que afecta a las líneas 40, 41, 42, 43 y 44. No tiene sello, pero sí parte de la cinta. Inserta en traslado sacado en Husillos, el 31 de julio de 1483. Véase doc. núm. 239.

En la datación utiliza el sistema de nonas por el más lógico de kalendas en este caso.

Innocentius quartus, $/{ }^{12}$ episcopus, seruus seruorum Dei, dilectis filiis abbati et capitulo secularis ecclesie Fusellensis, Palentine diocesis, salutem et apostolicam benedictionem. Licet is decimis munere venit ut sibi a fidelibus digne ac laudabili seruiatur de / habundantia pietatis sue que merita suplicum preces et vota bene sermentibus multo maiora retribuant quam valeant pro mereri. Nichilominus tamen cupientes reddere domino populum acceptabilem Christi fideles ad com/placenbam ei quasi quibusdam electius numeribus indulgenciis scilicet et remissionibus immittamus ut exiude reddantur diuine gracie optiores. Cupientes igitur ut ecclesia vestra in honore beate Virginis dedicata con $/{ }^{15}$ gruis honoribus frequentetur, omnibus vere penitentibus et confessis qui ecclesiam ipsam in festiuitatibus ipsius virginis venerabiliter visita[...] obsequium ipsius ecclesie manus porrexerint ad iuctrices de omnipoten/tis Dei misericordia et beatorum Petri et Pauli apostolorum eius, auctem confissi mille quadringentos annos de inmunitis sibi penitenciis misericorditer relaxamus.

Datum Lugdim, VI nonas aprilis, pontificatus nostri anno octauo. 
1252, agosto, 12. Perusa.

Inocencio IV exime al maestro Esteban, abad de Santa María de Husillos y capellán del papa, del subsidio a la Santa Sede, y absuelte a éste y a todos sus familiares, procuradores, vicarios, y a todos los clérigos y laicos dependientes de Santa María de Husillos, en caso de que incurran en excomunión, suspensión o entredicho por causa de dicho subsidio.

B. AHV, Reg. Vat. 22, f. 203r, núm. 65.

ED. QUINTANA PRIETO, Inocencio IV, I, 694, núm. 784.

Magistro Stephano ut supra.

Tuis inclinati precibus, te ab omni prestatione subsidii, hactenus impositi, occasione Romane Ecclesie seu Imperii eximimus, necnon te ac clericos, familiares, <procuradores $>$ et vicarios tuos, clericos et laicos, ecclesie Fussellensis et aliorum locorum, ab excomunicationis, suspensionis et interdicti sententiis, si quas tu, pretextu dictorum subsidiorum, vel ipsi occasione tui, propter hoc, incorruistis, auctoritate presentium absoluentes, dispensamus tecum ac cum eisdem clericis super irregularitate, si quam tu uel ipsi occasione subsidiorum huiusmodi contraxistis.

Datum Perusii, II idus augusti, anno $\mathrm{x}^{\mathrm{o}}$.

1252, agosto, 13. Perusa. 
Inocencio IV concede al maestro Esteban, abad de Santa María de Husillos y capellán del papa, que no pueda ser excomulgado, suspendido ni puesto en entredicho por ningún juez ordinario.

B. AHV, Reg. Vat. 22, f. 203r, núm. 61.

ED. QUINTANA PRIETO, Inocencio IV, I, 695, núm. 786.

REG. BERGER, Inoccent IV, III, 100, núm. 5920.

Eidem.

Tuis grauaminibus occurrere cupientes remedio gratie specialis, auctoritate tibi presentium indulgemus ut nullus iudex ordinarius tuus, auctoritate propria, possit in personam tuam, absque manifesta et rationabili causa et monitione canonica non premissa, excomunicationis, suspensiones vel interdicti sententias promulgare.

Nulli ergo nostre concessiones etc.

Datum ut supra.

1252, octubre, 18. Lyon.

Inocencio IV confirma al maestro Esteban, abad de Santa María de Husillos y capellán del papa, todos los beneficios y préstamos que disfrutaba en diversas iglesias de España y Francia, entre éstos: la abadía de Santa María de Husillos y una canongía en la catedral de Palencia.

B. AHV, Reg. Vat. 22, f. 231v, núm 187.

ED. BERGER, Inoccent IV, III, 122, núm. 6044 (edición parcial).- QUINTANA PRIETO, Inocencio $I V$, I, 713, núm. 809. 


\section{LA ABADÍA DE SANTA MARÍA DE HUSILLOS: ESTUDIO Y COLECCIÓN \\ DOCUMENTAL $(904-1608)$}

Magistro Stephano, subdiacono, capellano nostro, abbati secularis ecclesie Fussellense.

Grata devotionis obsequia etc. usque gratiam specialem. Hinc esto quos nos, tuis supplicationibus inclinati, abbatiam secularis ecclesie Fussellense, archidiaconatum et canoniam Zamorenem cum pertinentiis eorumdem, canoniam Septimanam et prestimonia que in Compostelana ecclesia es adeptus, ecclesie Palentine canoniam et prestimonia, canoniam ecclesie Ovetense de Saxo Albo et de Corcibarbas, prestimonia que ab Aurien. et Salamantinis ecclesiis dihisceris obtinere, prestimonia que in Toleran et Abulen diocesis es adeptus, prestimonia que a Calagurritana ecclesia te asseris assecutum, canonicatus et prebendas quos in Carnoten., Catalaunen. Verdunen. Pragen. et Lucen Atrebaten diocesis ecclesiis es adeptus, tibi auctoritate apostolica confirmamus et cetera usque communimus. Non obstante, si prestimoniorum ipsorum aliquid noscatur ad mensam alicuius episcopi pertinere.

Nulli ergo nostre confirmationis et cetera.

Datum Lugduni XV kalendas novembris, anno $\mathrm{X}^{\mathrm{o}}$.

1255, febrero, 25. Burgos.

Alfonso X, juntamente con su esposa, Yolant, y sus hijas, Berenguela y Beatriz, dona, en juro de heredad, al duque Diego Fernández y a su esposa, Juana, Santa Eulalia de León.

A. AHDP, Ampudia y Abadía de Husillos, Pergaminos, carp. 198-12. Perg., 524 x 538 mm.; escr. gótica privilegios; buena conservación, tanto del documento como del sello de plomo.

B. APA, $L P H$, ff. $35 \mathrm{v}-36 \mathrm{v}$.

C. AGS, Patronato eclesiástico. Inconexos, leg.159, ff. 43r-44r. Papel; escr. procesal; buena conservación.

D. BN, $m s .705$, ff. $55 \mathrm{v}-57 \mathrm{v}$. 


\section{DAVID MARCOS DIEZ}

En la documentación de Husillos no existe constancia de que una villa llamada Santa Eulalia formara parte del dominio de la abadía. De ahí que, al igual que en el documento núm. 51, sean dos las posibilidades que pueden explicar su presencia en la colección de Husillos.

La primera posibilidad supondría que el mismo duque Diego Fernández o sus descendientes hasta la confección del libro becerro de las propiedades de Husillos (entre finales de 1374 y finales de 1376), donarían la villa a Husillos y con ella, el documento jurídico que sustentaba su propiedad.

Existen en la actualidad dos localidades con el nombre de Santa Eulalia situadas en el territorio histórico del reino de León: Santa Eulalia de Cabrera y Santa Eulalia de Tábara. Por cercanía a Husillos, la población que dona Alfonso X podría ser la segunda. En conclusión, podemos admitir que después del 25 de febrero de 1255 y antes de finales de 1376, un poblado llamado Santa Eulalia, que de no ser un despoblado podría tratarse de Santa Eulalia de Tábara, formó parte del dominio de Santa María de Husillos por donación del duque Diego Fernández y su mujer, o de algún descendiente, pero que en poco tiempo dejó de pertenecer a dicho dominio, ya que no existe ninguna contancia documental aparte de este documento. Es lógico pensar que la lejanía del lugar con Husillos, ya que en cualquier caso se hallaría en el territorio del reino de León, supondría que la abadía no pudiera tener un control directo sobre su propiedad, circunstancia que sería aprovechada por algún poderoso vecino para apropiarse de dicho lugar.

La segunda posibilidad es que el duque Diego Fernández o sus descendientes, depositaran la donación real en Husillos para su seguridad y buena conservación.

(Christus, alfa et omega). Connosçuda cosa sea a todos los ombres que esta carta uieren cuemo yo, don Alfonso, por la graçia de Dios rrey de Castiella, de Toledo, de León, de Gallizia, de Seuillia, de Córdoua, / de Murcia, et de Iahén, en uno con la rreyna donna Yolant, mi mugier, et con mis ffijas la inffante donna Berenguella et la inffante donna Beatriz, do et otorgo a Diago / Ferrández, duc, et a su mugier donna Iohanna, Sant Ellalia de León, con todos los derechos que yo hy he, con montes, con ffuentes, con rríos, con pastos, con entradas et con sallidas $\beta$ et con todas sus pertenencias. Que la ayan libre et quita por juro de heredad pora siempre jamás, pora ellos et pora sus ffijos et pora sus nietos, et pora todos aquellos que lo suyo ovieren de here/dar para dar, pora uender, pora empennar, pora canmiar, pora ennagenar, et pora ffazer della todo lo que ellos quisieren como de lo suyo mismo.

Et mando et deffiendo ffirmemientre que ninguno non sea osado de yr contra / este priuilegio deste mío donadío, nin de crebantarlo, nin de minguarlo en ninguna cosas; ca qual quiere que lo ffiziesse, auríe mi yra e pecharmie, en coto, mille 
maravedís, et a ellos todo el danno doblado. Et porque este mío $/{ }^{6}$ donadío sea firme et estable, mandé seellar este priuilegio con mío seello de plomo.

Fecha la carta en Burgos por mandado del rrey, XXV días andados del mes de ffebrero en era de mille et dozientos et no/uaenta et tres annos, en el anno que don Edoart, ffijo primero et heredero del rrey Henrric de Anglatierra, rrecibió cauallería en Burgos del rrey don Alfonso el sobredicho. Et yo, sobredicho rrey don / Alfonso, rregnant en uno con la rreyna donna Yolant, mi mugier, et con mis ffijas la inffante donna Berenguella et la inffante donna Beatriz en Castiella, en Toledo, en León, en Gallizia, en Seuillia, en $/{ }^{9}$ Córdoua, en Murcia, en Iahén, en Baeça, en Badalloz, et en el Algarue, otorgo este priuilegio e confírmolo.

Don Alffonsso de Molina, la conf. Don Frederic, la conf. Don Henrric, la conf. Don Manuel, la conf. Don Ferrando / la conf. / Don Ffelipp, electo de Seuillia, la conf. Don Sancho, electo de Toledo e chançeler del rrey, la conf., ${ }^{12}$ Don Iohán, arçobispo de Sanctyago, la conf. / Don Aboabdille Abennazar, rrey de Granada, uassallo del rrey, la conf. Don Mahomat Abenmahomat Abenhut, rrey de Murcia, uassallo del rrey, la conf. Don Abenmalisot, rrey de Niebla, uassallo del rrey, la conf. /

( $1^{a}$ col.) Don Apparitio, obispo de Burgos, la conf.- Don Pero, obispo de Palencia, la conf.- Don Remondo, obispo de Segouia, la conf.- Don Pero, obispo de Siguença, la conf.- Don Gil, obispo de Osma, la conf.- Don Mathe, obispo de Cuenca, la conf.- Don Benito, obispo de Áuila, la conf.- Don Aznar, obispo de Calahorra, la conf.- Don Lop, electo de Córdoua, la conf.- Don Adam, obispo de Plazencia, la conf.- Don Paschual, obispo de Iahén, la conf.- Don ffrey Pero, obispo de Carthagenia, la conf.- Don Pedryuánnez, maestre de la orden de Calatraua, la conf.

( $2^{a} \mathrm{col}$.) Don Nunno Gonçáluez la conf.- Don Alffonsillo López la conf.- Don Remón Gonçáluez la conf.- Don Symón Royz la conf.- Don Alffonsso Théllez la conf.- Don Ferrand Royz de Castro la conf.- Don Pero Núnnez la conf.- Don Nunno Guillém la conf.- Don Pero Guzmán la conf.- Don Remón Gonçáluez, el ninno, la conf.- Don Rodrig Áluarez la conf.- Don Ferrand García la conf.- Don Alffonsso García la conf.- Don Diago Gómez la conf.- Don Romez Royz la conf. 
( $3^{a}$ col.) Don Gastón, vizcomde de Beart, uassallo del rrey, la conf.- Don Rui, vizcomde de Limoges, uassallo del rrey, la conf.

\section{(signo rodado)}

- Primer círculo concéntrico:

EL ALFÉREZ DEL RREY LA CONFIRMA. DON ILÁN GARCÍA, MAYORDOMO DE LA CORTE DEL RREY, LA CONFIRMA.

- Segundo círculo concéntrico:

SIGNO DEL RREY DON ALFONSO.

- Tercer círculo concéntrico:

(cruz)

( $4^{a} \mathrm{col}$.) Don Martín Fernández, electo de León, la confirma. Don Pero, obispo de Ouiedo, la confirma. Don Suero Pérez, electo de Çamora, confirma. Don Pero, obispo de Salamanca, la confirma. Don Pero, obispo de Astorga, la confirma. Don Leonart, obispo de Cipdat, la confirma. Don Migael, obispo de Lugo, la confirma. Don Iohán, obispo de Orens, la confirma. Don Gil, obispo de Tuy, la confirma. Don Iohán, obispo de Mendonnedo, la confirma. Don Pero, obispo de Coria, la confirma. Don ffrey Roberto, obispo de Silue, la confirma. Don Pelay Pérez, maestre de la orden de Sanctyago, la confirma.

( $5^{a}$ col.) Don Rodrig Alffonsso la confirma. Don Martín Alffonsso la confirma. Don Rodrigo Gómez la confirma. Don Rodrigo Frólaz la confirma. Don Iohán Pérez la confirma. Don Ferrand Yuánnez la confirma. Don Martín Gil la confirma. Don Andreo, perteguero de Sanctyago, la confirma. Don Gonçaluo Ramírez la confirma. Don Rodrigo Rodríguez la confirma. Don Aluar Díaz la confirma. Don Pelay Pérez la confirma.

( $6^{a}$ col.) Diago López de Salzedo, merino mayor de Castiella, la conf.- Garci Suárez, merino mayor del rregno de Murcia, la conf.- Maestre Ferrando, notario del rrey en Castiella, la conf. 
( $7^{a}$ col.) Roy López de Mendoça, almirage de la mar, la conf.- Sancho Martínez de Xodar, adelantado de la ffrontera, la conf.- Garci Pérez de Toledo, notario del rrey en Andaluzía, la conf.

( $8^{a} \mathrm{col}$.) Gonçaluo Morant, merino mayor de León, la conf.- Roy Suárez, merino mayor de Gallizia, la conf.- Don Suero Pérez, electo de Çamora et notario del rrey en León, la conf.

Iohán Pérez de Cuenca la escriuió el anno tercero que el rrey don Alffonsso rregnó.

1256, febrero, 3 .

La reina Mencía vende al cabildo de Santa María de Husillos la heredad que compró a Lope Jiménez y a Juan López, su cuñado: Boadilla del Camino y todo lo que tenía en Becerrilejos y en Poblacioncilla, además de dos huertos, uno que fue de Diego Románez y el otro de Mate, en precio de doscientos maravedís.

A. AHDP, Ampudia y Abadía de Husillos, Pergaminos, carp. 208-11. Perg., 235 x 187 mm.; escr. gótica documental; buena conservación; conserva la cinta pero no el sello.

B. APA, $L P H$, ff. $36 \mathrm{v}-37 \mathrm{r}$.

C. BN, ms. 705, ff. 10r-v. y $57 \mathrm{v}-58 \mathrm{r}$.

Conoçuda cosa seya a todos los omes qui esta carta uieren et ouieren, cumo yo, / reyna dona Mençía, uendo a uos, cabillo de Fusiellos, quanta heredat yo compré de / Lope Xeménez et de Iohán López, so cunado. Conuiene a saber: en Bouadiella del Camino $\beta$ et en todos sus terminos, en Bezerrileyos et Poblacionciela et en todos sos términos, con dos / huertos; el uno fue de don Románez et el otro de Mathe. Esto uos uendo yo, con uoz et con / razón, con todo sennorío que deuo hi auer et lo e oy día; con tierras et uinas, casas et solares, $/^{6}$ 
molinos et paradas, palomares, ortos, prados, montes, fuentes, labrado et por labrar, poblado / et por poblar, todo uolo uendo et uolo otorgo por doçientos morabetinos alfonsís que io e recibido / de vos por precio et por roboramiento, et so bien pagada et a uos non finco nada por dar ny /a my por recebir. Et de oy día en adelantre en todas estas heredades yo non e ningun derecho que $/^{9}$ demandar. Et todas estas heredades uos lexo yo libres et quitas pora dar, pora cambiar, / pora fazer delas pro del cabillo de Fusiellos, por secula cunta.

Si algun ome de míos / o de estranos quisiere este mi fecho contraliar aya la ira de Dios et peche en coto quinientos $/{ }^{12}$ morabetinos al rey et a uos, cabillo de Fusiellos, otros quinientos morabetinos et duple estas heredades / todas en tales logares o en meiores. Et porque este nuestro fecho seia firme et non / pueda venir en dubda, yo reyna dona Mencía mandé esta carta seellar con el my $/{ }^{15}$ seello. Facta carta otro día de Purificatio Sante Marie, era M CC LXXXX IIII.

1256, noviembre.

Sentencia pronunciada por los jueces Jaime de Garzón y Gómez de Monzón del pleito litigado por Pedro Payán y Aznar, su hermano, con el cabildo de Santa María de Husillos, por la propiedad de unas viñas en Santillán de la Cuesta que, según los demandantes, fueron de su tío-abuelo, el sacristán Pedro Arnaldo. La sentencia establece que el cabildo debe pagar cincuenta maravedís a los primeros, a cambio de la propiedad de dichas viñas.
$B$. APA, $L P H$, f. $37 \mathrm{r}-\mathrm{v}$.
C. BN, ms. 705, ff. 58r-59r.

Fecho y sacado fue este traslado de la dicha escritura en la villa de Husillos, a veinte y tres días del mes de nouiembre de mil y quinientos y çinquenta y quatro años. Testigos que fueron presentes a lo uer, leer, corregir y conçertar, Joán Ruiz Cabeça de Vaca y Gaspar de Vedoya, clérigos, y Pero Manuel, estantes en la dicha villa. 
Y yo, Santiago Gómez, escriuano público en la dicha villa de Husillos, presente fui a lo que dicho es en vno con los dichos testigos. Y del dicho pedimiento y mandamiento del dicho señor alcalde mayor, que aquí firmó su nombre, lo escreuí y fize escreuir y fize aquí mi signo (signo) en testimonio de verdad. Pero Ruyz de Billoldo (rúbrica). Santiago Gómez (rúbrica).

Conosçida cosa sea a quantos esta carta vieren que cuemo yo, Pero Payán, demandase al cabilldo de Fusiellos por mí e por mi hermano, don Aça, vnas vinnas en Sant Illám de la Cuesta que fueran de mío tio el sacristán Pero Arnaldo, que fue hermano de mío abuelo Joán Arnaldo. El sobredicho cabildo touiese que las auía con derecho y que non me deuían a rresponder dellas. Fue así que fuímos avenidos yo y el cabildo de meter este pleyto en mano de amigos, y aquellos amigos en cuya mano lo metiésemos que oysen las rrazones y sobresen la uerdad de la vna parte y de la otra, y que quier que nos mandasen por juizio o por abenençia, que ésta diésemos por ello, y la partida que non quisiese estar por ello que pechase a la otra partida dozientos maravedís y que todavía, que ésta diese por quanto aquellos amigos mandasen. Y los amigos en cuya mano lo metiésemos fue don Jaymes de Garzón y don Gómez de Monçón, ellos rreçibiéronlo, y yo, Pero Payán, die al cabildo por fiador de cumplir quanto ellos amos mandasen por juizio o por avenençia, Joán Remón, mío cormano, y si non que pechase los dozientos maravedís sobredichos, y Garçía Nicolás, y Martín Fagúndez, dieron a mi fiador por el cabildo el sobredicho don Gómez; et nos, don Jaymes y don Gómez, por rruego del cabildo de Husillos y de Pero Payán, rreçebimos este pleyto en nostra mano para juzgarlo o auenirlo a voluntad de anbas las partes, y nos oydas ya las rrazones y sabida la uerdad de amas las partes, mandamos por juizio y por avenençia que dé el cabildo a Pero Payán, çinquenta maravedís. Y mandamos a Pero Payán que por estos sobredichos çinquenta maravedís, que sea pagado, por sí y por su hermano don Aznar, de aquellas vinnas que demandaua al cabildo y de quantas demandas se auía contra cabilldo fasta el día de oy, y que arriedre a todo omne que de parte de Joán Arnaldo viniese en esta demanda sobre dicha al cabildo; y dezimos que el cabildo aya pagado a Pero Payán çinquenta maravedís, y conplido quanto nos mandamos. Y don Gómez, escrito de la fiadura, y yo, Pero Payán, otorgo que so bien pagado de los çinquenta maravedís, y otorgo todo quanto en esta carta dize, y rruego al conçejo de Palençia y a don Jaymes, y a don Gómez, que manden poner sos sellos en esta carta por testimonio. Y nos, 
conçejo de Palençia, por rruego de Pero Payán, mandamos poner nostro sello en esta carta. Y nos, don Gómez y don Jaymes, por rruego de Pero Payán, mandemos poner nostros sellos en esta carta. Y yo, sobredicho Pero Payán, digo que si alguno de mío linaje o de otro esta carta quisiere quebrantar o contra este mío fecho venir, que sea maldito y descomulgado, y peche en coto trezientos maravedís, la mitad por al rrey, y la otra meitad por al sobredicho cabildo.

Facta carta en el mes de nouiembre, era $\mathrm{MCCXCIIII}^{\circ}$, regnando el rrey don Alfonso con su muger, la rreyna domna Violante, y con su fijo, el ynfante don Fernán Gonçáluez de Rojas, obispo en Palençia. Don Fernando, abad en Fusiellos. Maestre Esteuan. (f.37r) Pesquisas de Palencia: don Domingo Escudero, y don Joán y Joán Remón, y don Gil, fijo de don Rendol, y don Jaymes de Catuxo, y don Sadermín, capellán de San Miguel, y Domingo Estébanez, y don Gonçaluo el Corredor, y Don Gonçaluo, el de María Quintaniella, y don Fernando, criado de maestre Andrés, y don Joannes, el Gallego, y don Joannes, el merino de Villamuriel, y otros muchos.

1267, abril, 20. Husillos.

Gómez de Monzón y María, su esposa, dotan una capellanía en la capilla de Santiago de la iglesia de Santa María de Husillos, donde tienen su enterramiento, constituyendo la porción de dicha capellanía: pan, vino, denarios de los aniversarios, pitanzas y matutinas. Asimismo donan al prior Gonzalo Facundo y al cabildo, mil maravedís.

A. AHDP, Ampudia y Abadía de Husillos, Pergaminos, carp. 212-4. Carta partida por ABC. Perg., 197 x 274 mm.; escr. gótica documental; buena conservación. Tiene dos cuerdas pendientes, en la de la izquierda se observan restos de un sello de cera en que aparece Santa María con el niño en brazos y, debajo, tres personas en posición orante. 
A'. AHDP, Ampudia y Abadía de Husillos, Pergaminos, carp. 212-5. 5. Carta partida por ABC. Perg., 212 x 266 mm.; escr. gótica documental; buena conservación. Conserva una cuerda de uno de los dos sellos que llevó.

B. AHDP, Ampudia y Abadía de Husillos, Pergaminos, carp. 198-16. Perg., 518 x 395 mm.; escr. gótica redonda de privilegios; buena conservación. Inserto en traslado sacado en Palencia, a 28 de enero de 1294. Véase doc. núm. 86.

$C$. APA, $L P H$, f. 39 r. Traslado de $A$.

$D$. APA, $L P H$, ff. 41v-42r. Traslado del doc. núm. 87.

E. AGS, Patronato eclesiástico. Inconexos, leg.159, ff. 44v-45v. Papel; escr. procesal; buena conservación. Traslado de $C$.

$F$. BN, $m s .705$, ff. 61v-62r. Traslado de $C$.

G. BN, $m s .705$, ff. 67r-68r. Traslado de $D$.

CIT. BARÓN FARALDO, Grupos y dominios aristocráticos, 505.

$(A B C \ldots)$ In Dei nomine, amen. Anno eiusdem Incarnationis, millesimo ducentessimo sexagesimo septimo. Nouerint vniuersi presentem literam / inspecturi quod nos, Gundisaluus Facumdi, prior, et capitulum Fusellensi, intuitu pie deuotionis et precordialis dilectionis quam uos, do/minus Gomeci de Monçon et vxor uestra, dopna Maria, erga nos et ecclesiam nostram, semper habuistis et habetis nec non $\beta^{\beta}$ ob uestrorum multi modam exigenciam meritorum, concedimus ac promittimus, in perpetuum, dare liberaliter et benigne capellano / uestro qui pro tempore fuerit institutus in capella beati Iacobi, quam uos ad sepulturam propriam construxistis, destributiones cotidianas / unius integre portionis, silicet: panis et vini et denariorum anniuersariis et pitanciis ac matutinata, dumtaxat exceptis, eo modo pro $/{ }^{6}$ ut habuerint canonici qui pro tempore fuerint in eclesia Fusellensi.

Et ego, donus Gomecius et uxor mea, dopna Maria, libenti animo et sponta/nea uoluntate, offerimus seu damus per donationem inter uiuos, uobis priori et capitulo memoratis, mille morabitinos, usualis monete, ad hono/re suportandum pie ac liberalis gracie nobis facte. Et ne hoc possit in dubium euocari, nos dicti prior et capitulum et dominus Gomecius, fecimus pre $/{ }^{9}$ sentem literam sigillorum nostrorum pendencium munimine roborari.

Et de hoc sunt due carte eiusdem tenoris facte et diuise per alphabetum, qua/rum una remanet penes capitulum et alia penes dictum domnum Gomecium. 
Actum est hoc Fusellis, duodecimo kalendas mayi, in capella Sancte Brigide. / Presentibus et consencientibus:

( ${ }^{a}$ col. $)$ / Dopno Gundis[al]uo Facundi, priore Fusellensi.- Petro Iohanis, cantore Fusellensi.- Roderico Roderici, archidiaconus in Campis.- Roderico Petri, cantore Palentino.- Dopno Saluatore.- Dopno Ennico.

( $2^{a}$ col.) Dominico Aprilis.- Iohane Martini.- Dopno Marcho.- Petro Pelagii.Dominico Martini.- Dominico Aprilis, canonicis.

( $3^{a} \mathrm{col}$.) Dompno Petro.- Dopno Marco, portionariis.- Stephano Ferrandi.- Iohane Martini.- Ferdinand[o] Egidii, semis portionariis.

Dominicus Aprilis Palentinus, ex mandato prioris et capituli, scripsit.

1267, abril, 20. Husillos.

Gonzalo Facundo, prior de Santa María de Husillos, y el cabildo de dicha iglesia, juntamente con Gómez de Monzón y María, su esposa, estipulan cómo ha de realizarse el servicio en la capellanía de Santiago.

B. AHDP, Ampudia y Abadía de Husillos, Pergaminos, carp. 198-16. Perg., 518 x 395 mm.; escr. gótica redonda de privilegios; buena conservación. Inserto en traslado sacado en Palencia, a 28 de enero de 1294. Véase doc. núm. 86.

C. APA, $L P H$, ff. 39v-40r.

D. AGS, Patronato eclesiástico. Inconexos, leg.159, ff. 46v-47v. Papel; escr. procesal; buena conservación.

E. BN, ms. 705, ff. 63r-64r. 


\section{LA ABADÍA DE SANTA MARÍA DE HUSILLOS: ESTUDIO Y COLECCIÓN \\ DOCUMENTAL $(904-1608)$}

Notum sit omnibus hominibus, tam presentibus quam ffuturis, quod nos, Gundisaluus Facundi, prior, et capitulum Fusellensi, intuitu pie deuotionis generi semper habistis et habituri estis ad ecclesiam Fusellensi et ob/ $/{ }^{12}$ vestrorum exigenciam meritorum, concedimus uobis, domno Gomeçio de Monçón et vxori uestre, dopne Marie, nec non toti generi uestro, imperpetuum capellam quam uos Fusellis, iusta ecclesiam nostram, ad hono/rem Dei et beati Iacobi, construsistis ad propriam sepulturam verum tamen ut uos, domine Gomeçi, et vxor uestra, dopna Maria, dumtaxat uiuentes in dicta capella capellanum, iuxta uestre uoluntatis / arbitrium presentetium ita tamen, ut ipse capellanus, seruiat coro in diuinis, cum capa uel super pelliceo temporis conpetenti post mortem vero vestram, tam institutio quam presentatio, dicti capellani in predicta capella, $/{ }^{15}$ libere pertineat ad capitulum memoratum. Concedimus in super uobis ut de oblationibus in dicta capella, ob uestri uel uestrorum causas factis in festo beati Iacobi uel quandocumque aliter capellanus uester, dicte ca/pelle, habeat terciam partem et capitulum duas partes. Volumus etiam ut de omnibus pie oblatis seu causa mortis legatis, capellano sepe dicte capelle, a uobis uel ab aliquo uestrorum idem ca/pellanus, terciam partem habeat, capitulum uero duas, ad hec etiam et si aciderit in die, sepulture corporis uestri uel alicuius uestrorum, corpore existente in coro uel ecclesia ut ad maiorem honorem ad $/{ }^{18}$ altare celebratur misa de omnibus, ibidem oblatis, capellanus uester, habeat libere quartam partem et si fforte quod ab sit aliquis impediret ne capellanus, se peditus, illam quartam partem perciperet tan / tam (sic) qualitatem de nostro solueremus eidem et predicta, promittimus nos, imperpetuum seruaturos.

Et ego, dominus Gomeçius, et vxor mea, dopna María, ut supra scriptum est, gratantur accipi/mus et libenti animo volumus obseruare, et ne hoc posit in $\mathrm{d}<\mathrm{u}>$ ibium euocari, nos predicti prior et capitulum, et dominus Gomeçius, presentem literam, sigillorum nostrorum feçimus muni ${ }^{21}$ mine roborari.

Et de hoc sunt due carte eiusdem tenoris facte et diuise per alphabetum, quarum vna remanet penes capitulum, alia, uero penes dominum Gomeçium.

Actum est hoc / Fusellis, XII ${ }^{\circ}$ kalendas mayi, in capella Sancte Brigide, anno Domini millesimo duocentesimo sexagesimo septimo. Presentibus et consencientibus: Gundisaluo Facundi, priore. Petro Iohannis, cantore. Roderi/çi, archidiacono in Canpis. Roderico Petri, cantore Palentini. Dopno Saluatore. 
Dopno Ennico. Dominico Aprilis. Iohanne Martini. Dopno Marco. Petro Pelagii. Dominico Martini. Dominico Aprilis, canoniçis. ${ }^{24}$ Dopno Petro. Dopno Marco, portonariis. Stephano Ferrandi. Iohanne Martini. Ferdinando Egidii, semis portonariis.

Dominicus Aprilis Palentinus, ex mandato prioris et capituli, scripsit. /

1268, marzo, 8, viernes. Jerez de la Frontera.

Alfonso X ordena a los habitantes de Pajares y San Adrián, que habian emigrado a otros lugares, vuelvan a sus lugares de origen, bajo pena de perder sus posesiones en favor de Santa María de Husillos.

$B$. APA, $L P H$, ff. $47 \mathrm{v}-48$ r. Inserto en traslado de la confirmación de Alfonso XI, dado en Valladolid, a 24 de enero de 1318. Véase doc. núm. 101.

C. BN, ms. 705, ff. 76v-79r.

El día 8 de marzo de 1268 fue jueves y no viernes. Véase A. GIRY, Manuel de Diplomatique. La letra dominical correspondiente a 1268 es la G, y la Pascua cayó el 8 de abril.

Don Alfonso, por la graçia de Dios rrey de Castilla y de Toledo y de León, de Galizia, de Seuilla, de Córdoua, de Murçia, de Jaén y del Algarbe, a todos los merinos de Castilla, salud y graçia. Sepades que el abad y el cabildo de Fusiellos me ynbiaron mostrar que Pajares y Sant Adrián, sus aldeas, eran yermas a fumo muerto, y de las otras sus aldeas, que se fueron muchos omes morar a behetrías y a otros sennoríos. Y esto no tengo yo por bien ni por derecho, ca pierdo yo por ende los míos derechos y ellos los suyos. Onde vos mando que cada vno de uos en su meridad entredes las eredades de aquellos que fueron morar a befetrías o a sennoríos de solariegos y que los entreguedes a la iglesia de Fusiellos y aquellos que fueron morar a abadengo o a rrealengo que los fagades copiar y tornar a los lugares onde se fueron a ellos o a sus erederos o que fagan a la iglesia de Fusiellos 
aquellos fueros y aquellos derechos que suelen y que deuen fazer por las eredades que an en su sennorío. Y si no quisieren tornar a los sus lugares onde se fueron ni fazer a la iglesia aquellos fueros y aquellos derechos que suelen y deven fazer, que les entredes las eredades y las entreguedes a la iglesia sobredicha. Y si algunos se fueren de aquí adelante a otros sennoríos así como es dicho de suso, mando vos que les fagades otrosí como es de susodicho y non fagades ende al si no a vos me tornaría por ello.

Dada en Xerez, el rrey lo mandó viernes, ocho días de março, era de mil y trezientos y seis annos. Garçi Ferrández la fizo escreuir.

1269, abril, 30. Husillos.

Gómez de Monzón y María, su esposa, donan a Gonzalo Facundo, prior de Santa María de Husillos, y al cabildo de dicha iglesia, cuatrocientos maravedis para que mejoren las aceñas y los molinos que poseen en la pesquera de Pajares. Asimismo se establece el modo en el que ha de realizarse el servicio en la capilla de Santiago.

B. AHDP, Ampudia y Abadía de Husillos, Pergaminos, carp. 198-16. Perg., 518 x 395 mm.; escr. gótica redonda de privilegios; buena conservación. Inserto en traslado sacado en Palencia, a 28 de enero de 1294. Véase doc. núm. 86.

C. APA, $L P H$, f. 39r-v.

D. AGS, Patronato eclesiástico. Inconexos, leg.159, ff. 65v-66v. Papel; escr. procesal; buena conservación.

E. BN, ms. 705, ff. 62r-63r.

Nouerint vniuersi presentem literum inspecturi quod ego, dominus Gomecius, et uxor mea, dopna Maria, libenti animo et per donaçionem inter uiuos, damus uobis, Gonsaluo Facundi, / priori, et capitulo Fusellensi, quatuorcentos morabitinos ad reparandum seu meliorandum acennas seu 
molendina, piscarie nostra de Paiares et alia nostre comunis mense que reparatione seu $/^{27}$ melioracione indiguerint facienda uideliçet tali modo: vt in uno quoque die veneris post primam celebretur misa defuntorum et fiat comemoratio pro animabus nostris, nec / non parentum nostrorum et si ob onorem alicuius festiuitatis hoc in die veneris iuxta Fusellensi ecclesie, consuetudinem fierit, non contingat dicta comemoracionem seu missa in die alia ce/lebretur et ex prouentibus ex diçtis quatuorçentis morabitinos, provenientibus caritatiue inter soçios et capellanum nostrum, qui mise seu dicte comoraçioni inter fuerint $\beta^{30}$ quatuor solidi diuidantur. Et si forte capitulum seu soçii, qui pro tempore fuerint ut dictum est, ad implere neglexerint ad petiçionem uel instanciam cuiuscumque uiri / uel mulieris nostri generis uel alterius per abbatem Fusellem uel per episcopum Palentinum, qui pro tempore fuerint ad id facte conpellantur. Et nos, dicti prior et capitulum ut supra dictum / est, concedimus et promitimus in perpetuum obseruare et confitemur nos predictos quatuorcentos morabitinos a uobis integre recipise nobis traditos ac numeratos, fuisse et assignamus, dictos $\beta^{33}$ quatuor solidos, ad opus comemoraçionis faciende in die vnius cuiusque veneris in reditibus prouenientibus ex villa nostra Sancti Iuliani. Et nec hoc possit in dubium / euocari nos, dicti dominus Gomeçius et prior et capitulum Fusellense presentem literam, sigillorum nostrorum feçimus munimine roborari.

Et de hoc, sunt due carte eiusdem tenoris facte, diui/se per alphabetum, quarum vna remanet penes dictum Gomeçium, alia penes capitulum memoratum.

Actum est hoc, pridie kalendas mayi, era millesima $\mathrm{CCC}^{\mathrm{a}}$ septima, in capi ${ }^{36}$ tulo ecclesie Fusellensi. Presentibus et consencientibus: Gonsaluo Facundi, priore. Petro Belleti, sacrista. Petro Iohannis, cantore. Dopno Saluatore. Dopno Marco. Petro Pelagii. Dominico / Aprilis et Dominico Aprilis (sic). Iohanne Martín. Dopno Enico, canoniçis. Dopno Marco, porçionario. Franco Petri. Stephano Ferdinandi. Ferdinando Egidii et / Iohanne Martini, semis porçionariis Fusellensi.

1273, julio, 1. Florencia 
Gregorio X nombra a Ordoño Álvarez abad de Santa María de Husillos.

B. AHV, Reg. Vat. 37, f. 93r, núm. 55.

Ordonio Aluari, abbati secularis ecclesie Fusellense, Palentine diocesis. Inducunt nos tue deuotionis merita ut te persequamur beniuolentia gratiosa cum igitur abbatiam secularis ecclesie Fusellense, Palentine diocesis, uacantem apud sedem apostolicam tibi obtinenti archidiaconatum et canonicatum in ecclesia Palentine duximus auctoritate apostolica conferendam ut abbatiam predictam et prestimonia quem in eadem ecclesia Palentine te obtinere asseris in simul licite retinere ualeas tibi tuis inclinati percibi auctoritate presentium, indulgemus dummodo non sint annexa predicto archidiaconatui qui uacare debet postquam eiusdem abbatie fueris? pacificam possessionem adeptus. Non obstante, qui in eadem ecclesie Palentine [...esse) statutum qui abbates suis abbatiis et quilibet canonicus ipsius ecclesie extimaticem, centum marabotinorum debeant esse contenti siue quolibet alio ipsius ecclesie Palentine statuto [...] iuramento confirmatione sede apostolice siue quacumque firmitate alia roborato. Nulli ergo nostre concessionis et [...]. Datum Florentie, kalendas iulii, anno secundo.

1285, junio, 15. Zamora.

Cláusula del testamento de Martín Alfonso Téllez de Alburquerque en el que manda a Santa María de Husillos sus posesiones en Amayuelas y en Castellanos, cercanas a dicha iglesia, a condición de que haga anualmente un aniversario en el día de su muerte.

B. ACT, AC, Tumbo, f. $67-69 \mathrm{v}-$ n. $^{\circ} 103-108$.

B' BRAH, Col. Salazar, núm. 35, 82-83. 
REG. CALVO, Gradefes, 393.

CIT. GUTIÉRREZ CUÑADO, Un rincón de Castilla, 43.- F. ANTÓN, Monasterios medievales, 122.- YÁÑEZ NEIRA, El monasterio de La Espina y sus abades, 96-97.- BARÓN FARALDO, Grupos y dominios aristocráticos, 506.

Aunque en la cláusula no se especifica que las posesiones se donen a Husillos, en la ejecución testamentaria de 20 de julio de 1287 se especifica claramente.

“... He mando quanto he en Amayuelas e en Castellas, que es cerca de Santa María de Fosiellos, porque fagan cada anno aniversario por mi alma en el día que ...".

1286, enero, 13. Husillos.

El obispo de Palencia, don Juan Alonso, y el cabildo de Santa María de Husillos, conciertan el modo de nombrar abad. Éste tenía que ser dignidad o canónigo de la catedral de Palencia. Se admiten dos casos: si el candidato propuesto por el obispo tenía la cuarta parte de votos de los canónigos de Husillos, quedaba elegido y como tal tenían que reconocerle todos los demás. Si no obtenía ese número de sufragios, entonces el obispo tenía que nombrar al que consiguiere las tres cuartas partes y uno más de los votantes.

A. ACP, Arm. III, leg. 13, doc. 2. Carta partida por ABC de tipo rectilíneo. Perg., 450 x 330 (+ 90) mm.; escr. gótica documental. Tres sellos de cera pendientes, del obispo de Palencia, cabildo de Santa María de Husillos y cabildo de la catedral de Palencia; buena conservación.

CIT. SAN MARTÍN PAYO, Santa María de Husillos y su colección diplomática, 163.

$(a, b, c, a, b, c, a, b, c)$ In Dei nomine, amen. Anno natiuitatis eiusdem $\mathrm{M}^{\mathrm{o}}$ $\mathrm{CC}^{\mathrm{o}}$ octuagesimo sexto, decimo $<$ nono $>$ kalendas ffebruarii. Pulssata campana ad 
capitulum in ecclesia Ffusellense ut est moris presente priore et omnibus perssonis, canoni/cis et ssociis ecclesie Ffusellense qui uoluerunt et potuerunt capitulo interesse presente quoque reuerendo patre domino Iohanne, episcopo Palentine, in presentia nostri, Petri Roderici et Didaci Iohannis, publicorum notariorum ciui/tatis Palentini, et testium subscriptorum ad hoc uocatorum specialiter et rogatorum, in eodem capitulo Ffusellense lecta fuit quedam littera conpositionis de mandato dicti episcopi et capituli Ffusellense, cuius littere tenor talem est: nouerint / vniuersi quod orta contentione inter rreuerendum patrem dominum Iohannem, episcopum Palentinum, nomine eiusdem ecclesie, ex parte vna, et capitulum Ffusellense, nomine ecclesie Ffusellense, ex alia, super iure prouidendi seu eligendi abbatem in ecclesia / Ffusellense tandem inter eos de consensu capituli Palentini tali amicabiliter conpositio interuenit saluo iure in posterum utriusque ecclesie ad $<$ que quantum $>$ presentem uicem videlicet cum primo contigerit abbatiam Ffusellense vacare per consecrationem / domini Iohannis Aluari electi confirmari in ecclesia Oxomense uel mortem uel renunciationem uel quecumque alium modum quod dominus episcopus dat ad capitulum Ffusellensem die per ipsum episcopum et capitulum Ffusellensem ad prouidendum / seu eligendum asignata. Et si episcopus habuerit quartam partem canonicorum existencium in capitulo qui debuerint interesse quod omnes alii canonici Ffusellenses teneantur consentire in eum quem episcopus duxerit nominandum / de perssonis seu canonicis ecclesie Palentine et eum absque contraditione qualibet recipere in abbatem quod si forte dominus episcopus quartam partem non habuerit teneatur pronunciare de eo quem tres partes et apostolici cano/'nicorum Ffusellense in capitulo existencium duxerint eligendum de personis seu canonicis ecclesie Palentine, ita tamen quod in omni casu pronunciet episcopus supradictus quod si forte tempore quo uacauerit abba/cia predicta ut supradictam est episcopum abbatem contigerit teneatur capitulum Ffusellense denunçiare infra mensem vacationem eandem episcopo supradicto, vt infra reliquos duos mensses si voluerit perssonaliter / veniat uel procuratorem mittat qui eius nomine predicta cum capitulo Ffusellense peragat et pertraeret. Item dominus episcopus obligauit se et bona fide promisit presentem conpositionem seruare et in nullo contrauenire similiter / capitulum Ffusellense obligauerunt se et bona fide promiserunt et iurauerunt presentem conpositionem 
seruare et in nulla contrauenire. Et si aliquis per dictum episcopum uel capitulum Ffusellense uel aliquem / de ipso capitulo contra predicta actum fuerit seu etiam atentatum, sit nullum et irritum ipso iure et quod dominus episcopus et capitulum predictum sint vnanimes et concordes in ista conpositione / seruanda. Item quod si aliquis de facta cum de iure non possit contra istam conpositionem prouiderit uel eregerit quod capitulum Ffusellense talem electum uel illum de / quo sic fuerit prouisum non habeant pro abbate, ymo quod appellent contra eum et vna cum episcopo prosequantur negocium contra eum taliter quod de malicia sua non consequare / effectum presente conpositione post prouisionem seu electionem qui primo ocurrerit facienda minime ualitura. Et ut presens conpositio maiorem habeat firmitatem, / nos, episcopo et capitulum predicti presentem conpositionem sigillis nostris et capituli Palentini fecimus sigillari et mandauimus et rrogauimus Petrum Roderici et / Didacum Iohannis, publicos notarios ciuitatis Palentine, quod ex inde conficiant duo publica instrumenta per abecedarium sub eodem tenore quorum vnum te/neat episcopus predictus, aliud uero capitulum Ffusellense. Quibus omnibus nos, predicti notarii, presentes fuimus, vidimus, audiuimus.

Presentibus domino Iohanne Aluari, / electo Oxomensi. Dompno Simone, archidiachono del Alcor. Dompno Sancio Roderici, archidiachono de Çerrato. Iohanne Ferrandi, Petro Martini, Alffonsso Petri, Rroderico / Gundisalui, Petro Martini, canonicis palentinis. Didaco Petri, Iohanne Dominici, scriptoribus.

Et ego, Petrus Roderici, predictus notarius, hoc presens publicum instrumentum manu propria conscripsi et publicaui dicto Didaco Iohannis michi asistente. / Et nos, ambo predicti notarii signa nostra consueta apposuimus in testimonium geste rey. Acta sunt hec apud Ffusellos, anno, loco et die superius nominatis et emenda/ui in prima linea de super ubi dicitur nono et inter lineaui in quinta linea ubi dicitur que quantum (signa).

1287, julio, 20. San Pedro de la Espina. 


\section{LA ABADÍA DE SANTA MARÍA DE HUSILLOS: ESTUDIO Y COLECCIÓN \\ DOCUMENTAL $(904-1608)$}

Fernando y Pedro, abad y prior de San Pedro de La Espina, y Paulo, abad del monasterio de Santa María de Valdeiglesias, albaceas del testamento de Martín Alfonso, hijo de Alfonso Téllez de Alburquerque, dan cumplimiento a su voluntad, entregando al prior y cabildo de Santa Maria de Husillos lo que había dispuesto: sus heredades en Amayuelas y Castellanos, cerca de Lerones, a cambio de un aniversario.

A. AHDP, Ampudia y Abadía de Husillos, Pergaminos, carp. 207-13. Perg., 211 x 224 mm.; escr. gótica documental; buena conservación. Lleva pendiente dos cintas; en la de la derecha se observan restos de un sello de cera.

B. APA, $L P H$, f. $38 \mathrm{v}$.

C. AGS, Patronato eclesiástico. Inconexos, leg.159, ff. 44r-v. Papel; escr. procesal; buena conservación.

D. BN, $m s .705$, ff. $60 \mathrm{v}-61 \mathrm{r}$.

ED. CORIA COLINA - FRANCIA LORENZO, Reinado de Sancho IV, 85, núm. 13.

Seguramente se trate de Amayuelas de Abajo, ya que según el Libro becerro de las propiedades es esta villa donde el cabildo tiene posesiones (véase doc. núm. 185). Localizamos la villa de Lerones en Cantabria, en las cercanías de Potes.

Sepan quantos esta carta vieren commo nos, ffrey Ferrando, abbad de Sant Pero del Espinna, et yo, don ffrrey Pau/lus, abbad de Val de Yglesias, et ffrey Pero, prior del Espinna, massessores del testamento de don Martín Alffonso, / ffijo de don Alffonso Téllez, otorgamos et conosçemos que don Martín Alffonso mandó en ssu testamento al cabillo de Sancta Ma/ría de Fusiellos, por ssu aniverssario, estos heredamientos que aquí sserán dichos. Todo quanto quel avía et devía aver $\beta$ de derecho en Amayuellas et en Castellanos, cabo Lerrones; et diógello por heredad pora ssienpre, con entradas / et con ssalidas et con vassallos et con todas ssus pertenençias, assí como lo él avía. Et nos, los massessores / ssobredichos, por el poderío que nos avemos pora conplir el testamento de don Martín Alffonso, damos et entregamos $/{ }^{6}$ todo esto que ssobredicho es, a vos, el prior et el cabillo de Sancta María de Fusiellos. Et del día que esta carta es / ffecha en adelante, vos damos el iuro et la possessión et la propriadad, que lo 
ayades et lo entredes ssin cal/lonna ninguna et que ffagades dello et en ello assí commo de la cossa más libre et más quita que avedes o podríe/des aver. Et todo el derecho que nos y avemos por rraçón que ssomos manssessores del testamento sobre $/{ }^{9}$ dicho o en otra manna qualquier, rrenunçiámoslo et partímosnos dello et entregámosvoslo por esta / carta.

Et porque esto ssea ffirme et non venga en dubda nos, los manssessores ssobredichos, pusiemos / en esta carta nuestros sseellos colgados en testimonio de verdad. Et porque yo, ffrey Pero, el prior ssobredicho, $/^{12}$ non e sseello proprio, otorgo los sseellos dellos abbades pu[e]stos en esta carta.

Fecha la carta en ele Espina, XX / días andados de iulio, era de mille et CCC et XXV annos.

1290, julio, 31, lunes. Valladolid.

Sancho IV, juntamente con María, su esposa, y los infantes Fernando, Alfonso y Enrique, sus hijos, confirma a Santa María de Husillos los siguientes privilegios:

- Privilegio de Urraca I (1114, mayo, 28), inserto, por el que concede a Santa María de Husillos, Villaldavín y la pesquera de Deronnada.

- Privilegio de Sancho III (1158, mayo, 4. Carrión de los Condes), inserto, por el que confirma las posesiones que Santa María de Husillos recibió de Urraca I, los condes de Monzón y otros particulares.

- Privilegio de Sancho III (1158, junio, 28, Cuéllar), inserto, por el que confirma el coto de Santa María de Husillos que él mismo había donado.

- Privilegio de Alfonso VIII (1178, agosto, 13. Carrión de los Condes), inserto, por el que confirma a Santa María de Husillos, las villas, heredades y monasterios donadas por Urraca I, Sancho III, Fernando Ansúrez, Gonzalo Ansúrez y Nuño Ansúrez, condes de Monzón, y otros donantes. 


\section{LA ABADÍA DE SANTA MARÍA DE HUSILLOS: ESTUDIO Y COLECCIÓN \\ DOCUMENTAL $(904-1608)$}

- Privilegio de Alfonso VIII (1178, agosto, 13. Carrión de los Condes), inserto, por el que confirma a Santa María de Husillos el coto que donó Sancho III, su padre.

A. AHDP, Ampudia y Abadía de Husillos, Pergaminos, carp. 198-15. Perg., 736 x 679 mm.; escr. gótica redonda de privilegios; regular conservación, tiene varias manchas de humedad que a veces impiden la lectura y una rotura en la línea 25. Mantiene los orificios y la cinta pero no el sello.

Sobre la primera línea del texto: <está éste a f. 43>. También en el dorso aparece escrito que este documento se corresponde con el que aparece escrito en el f. 43 del Libro de los Privilegios de Husillos; esto no es cierto, pues entre los ff. 43r y 46r se contiene el privilegio rodado concedido por Fernando IV, en el cual, al ser posterior, si se contiene el de Sancho IV.

B. AHDP, Ampudia y Abadia de Husillos, Pergaminos, carp. 199-19. Perg., 684 x 631 mm.; escr. gótica redonda de privilegios y de albalaes; buena conservación; sello pendiente de plomo. Al final de la primera línea, la $\mathrm{F}$ y la $\mathrm{E}$ del nombre FERNANDO, están marcadas pero sin miniar. Inserto en confirmación de Fernando IV, dada en Medina del Campo, el 10 de mayo de 1305. Véase doc. núm. 97.

C. AHDP, Ampudia y Abadía de Husillos, Pergaminos, carp. 200-21. Perg., 784 x 638 mm.; escr. gótica redonda de privilegios y precortesana. Su conservación no es muy buena, pero se puede leer perfectamente. Se conserva el sello de plomo pendiente de una cuerda. Inserto en confirmación de Pedro I del privilegio de Alfonso XI, dada en Valladolid, a 28 de noviembre de 1351. Véase doc. núm. 135

D. AHDP, Ampudia y Abadía de Husillos, Pergaminos, carp. 201-23. Perg., 714 x 608 mms.; escr. gótica de privilegios y precortesana; regular conservación, aunque las roturas y manchas permiten su perfecta lectura. Inserto en confirmación de Enrique II del privilegio de Alfonso XI, dada en Valladolid, a 20 de mayo de 1371. Véase doc. 163.

E. AHDP, Ampudia y Abadía de Husillos, Pergaminos, carp. 201-27. Perg., 784 x 685 mm.; escr. gótica de privilegios y precortesana. Muy deteriorado, ha desaparecido, prácticamente, toda su parte izquierda. No conserva sello ni cuerda. Inserto en confirmación de Juan I del privilegio de Enrique II, dada en Burgos, a 22 de agosto de 1379. Véase doc. núm. 193.

$F$. APA, $L P H$, ff. 43r-46r. Traslado de $A$.

$G$. APA, $L P H$, ff. $74 \mathrm{v}-78 \mathrm{r}$. Traslado de $C$.

$H$. APA, $L P H$, ff. $88 \mathrm{v}-92$ r. Traslado de $D$.

I. APA, $L P H$, ff. $104 \mathrm{r}-108 \mathrm{v}$. Traslado de $E$.

$J$. BN, $m s .705$, ff. 70v-76v. Traslado de $F$.

$K$. BN, ms. 705, ff. 155r-166r. Traslado de $G$.

$L$. BN, ms. 705, ff. 196v-201r. Este manuscrito comete numerosos errores. Traslado de $H$.

M. BN, $m s .705$, ff. 231v-238r. Transcribe el documento muy resumido. Traslado de $I$. 
N. ARCHV. Salas de lo Civil. Masas (F). Caja 2787-1, ff. 41v-49v. Traslado de A, aportado como prueba en un pleito fenecido (1774) de la colegiata de Ampudia con el concejo de Husillos por la posesión de ciertas heredades.

$\tilde{N}$. APA, Caja 152, Carpeta 1. Papel; 4 hojas. Primera mitad s. XVIII. Traslado de $F$.

ED. CORIA COLINA - FRANCIA LORENZO, Reinado de Sancho IV, 101-110, núm. 20.

(Christus, alfa et omega). En el nombre de Dios, Padre, e Fiio e Spiritu Santo, que son tres personas e vn Dios, e a onrra e a seruiçio de Santa María, su madre su madre (sic) que nos tenemos por sennora e por auogada en todos nostros fechos. Porque es natural cosa que todo ombre que bien faze quiere que ge lo lieuen adelante, e que se non oluide ni se pierda, que commo quier que cansse e mingue el / cursso de la uida deste mundo aquello es lo que finca en remenbrança por él al mundo e éste bien es guiador de la su alma ante Dios, e por non caer en oluido lo mandaron los rreys poner en escripto en sus priuilegios, porque los otros que regnassen después dellos e touiessen el so logar, fuessen tenudos de guardar aquello e de lo leuar adelantre, / confirmándolo por sus priuilegios. Por ende, nos, catando esto, queremos que sepan por este nostro priuilegio los que agora son e serán, daquí adelantre, como nos, don Sancho, por la graçia de Dios rrey de Castiella, de Toledo, de León, de Gallizia, de Seuilla, de Córdoua, de Murcia, de Jahén, e del Algarbe, viemos vn priuilegio $\beta$ del rrey, don Sancho fijo del emperador don Alfonsso de Espanna, fecho en esta guisa:

(Sigue doc. núm. 21)

Otrossí viemos otro priuilegio del rrey don Sancho el sobredicho, fecho en esta guisa:

(Sigue doc. núm. 23)

Viemos otrossí otro priuilegio del rrey don Alfonso, nostro tresauuelo, fecho en esta guisa.

(Sigue doc. núm. 28) 
Viemos otrossí otro priuilegio del rrey don Alfonsso el sobredicho, fecho en esta guisa:

(Sigue doc. núm. 27)

Otrossí viemos otro carta de la rreyna donna Vrraca de Espanna fecha en esta guisa.

(Sigue doc. núm. 16)

E nos, sobredicho rrey don Sancho, rregnante en uno con la rreyna doña María, mi mugier, et con nostros fijos, el inffante don Fernan/do, primero et heredero, et con don Alfonsso et con don Henrrique, en Castiella, en Toledo, en León, en Gallizia, en Seuilla, en Córdoua, en Murcia, en Jahén, en Baeça, en Badalloz, et en el Algarbe, otorgamos estos priuilegios et esta carta, et confirmámoslos et mandamos que ualan assí commo ualieron fata aquí. E porque esto sea firme e estable, mandamos seellar esta priuilegio con nostro seello de plomo.

Fecho en Valladolit, $1 \mathrm{lu} /{ }^{33}$ nes postrimero día de iulio, era de mille e CCC e veynt e ocho annos, en el anno que el sobredicho rrey don Sancho se uio en la cibdat de Bayona con el rrey don Felipe de Francia, so primo cormano, et pusieron su amor en uno e sacaron todas las estrañezas que eran entrellos, e partiose la casa de Francia de todas las demandas que auíe contra la casa de Castiella. /

Don Mahomat Aboabdille, rrey de Granada e vassallo del rrey, conf. Don Gonçaluo, arçobispo de Toledo, primado de las Espannas e chanceller de Castiella e de León e del Andaluzía, conf. Don García, obispo de Seuilla, conf. Don frey Rodrigo, arçobispo de Santiago, conf.

( $1^{a}$ col.) Don Iohán Alfonsso, obispo de Palençia, conf.- Don frey Fernando, obispo de Burgos, conf.- Don Iohán, obispo de Osma, conf.- Don Garçía, obispo de Siguença, conf.- Don Velasco, obispo de Segouia, conf.- Don Fernando, obispo de Áuila, conf.- La eglesia de Cuenca vaga. Don Domingo, obispo de Plazencia, conf.- Don Diago, obispo de Cartagena, conf.- La eglesia de Jahén 
vaga. Don Pascual, obispo de Córdoua, conf.- Don frey Suero, obispo de Cádiz, conf.- Don Aparicio, obispo de Aluarrazín, conf.- Don Roy Pérez, maestre de Calatraua, conf.- Don Fernant Pérez, grand comendador del Hospital, conf.- Don Gonçalo Yuánnez, maestre del temple, conf.

( $2^{a}$ col.) Don Nuño Gonçález conf.- Don Iohán Alfonsso conf.- Don Diago López de Salzedo conf.- Don Diago García conf.- Don Vela conf.- Don Diago Martínez de Finojosa conf.- Don Rodrigo Rodríguez Malrrique conf.- Don Diago Froyat conf.- Don G[onçalo] Yuánnez de Aguilar conf.- Don Per Anrrique de Harana conf.- Don Sancho Martínez de Leyua, merino mayor en Castiella, conf.- Don Iohán, fidel inffante don Manuel, adelantado mayor en el rregno de Murcia, conf.

\section{(Signo rodado)}

- Primer círculo concéntrico:

(Cruz) DON IOHÁN FERNÁNDEZ, MAYORDOMO MAYOR DEL REY, CONFIRMA. DON ALFONSO, ALFÉREZ DEL REY, CONFIRMA.

- Segundo círculo concéntrico:

(Cruz) SIGNO DEL REY DON SANCHO.

- Acuartelado con los escudos de Castilla y León.

( $3^{a} \mathrm{col}$.) Don Fernando, obispo de León, conf.- Don Miguel, obispo de Ouiedo, conf.- Don Pero, obispo de Çamora, conf.- Don frey Pero Fechor, obispo de Salamanca, conf.- Don Antón, obispo de Cibdat, conf.- Don Alfonsso, obispo de Coria, conf.- don Gil, obispo de Badaioz, conf.- Don frey Bartolomé, obispo de Silues, conf.- Don Áluaro, obispo de Mondoñedo, conf.- Don Iohán, obispo de Tuy e chanceller de la rreyna, conf.- La eglesia de Lugo vaga. Don Pero, obispo de Orens, conf.- Don Pero Ferrández, maestre de la cauallería de Santiago, conf.Don Ferrant Páez, maestre de Alcántara, conf.

( $4^{a}$ col.) Don Sancho, fiio del inffante don Pero, conf.- Don Esteuan Ferrández, pertiguero mayor en tierra de Santiago, conf.- Don Ferrant Pérez Ponz conf.- Don Iohán Ferrández de Limia conf.- Don Ferrand Ferrández, so hermano, conf.- Don Arias Díaz conf.- Don Per Áluarez conf.- Don Rodrig Áluarez, so hermano, conf.- 
Don Diago Ramírez conf.- Don Iohán Alfonsso de Alburquerque, adelantado mayor en el rregno de Gallizia, conf.- Ferrand Gonçález, merino mayor en tierra de León, conf.

( $5^{a}$ col.) Don Martín, obispo de Astorga e notario de Castiella e de León e del Andaluzía, conf.- Don Pero Díaz e don Nuño Díaz de Castanneda, almirantes de la mar, conf.- Tel Gutiérrez, justicia mayor de casa del rrey, conf.

Yo, maestre Gonçalo, abbat de Alffaro, llo fiz escreuir por mandado del rrey en el año sseteno que el rrey ssobredicho rregnó.

(rúbrica) Per Alboriten (rúbrica).

1290, diciembre, 1. Husillos

Sancho González, abad de Santa María de Husillos, juntamente con el cabildo de dicha iglesia, estipula el estatuto de las medias annatas.

$B$. APA, $L P H$, ff. $37 \mathrm{v}-38 \mathrm{r}$. Inserto en traslado sacado en Palencia, a 1 de abril de 1367 . Véase doc. núm. 148.

C. BN, ms. 705 , ff. $59 \mathrm{v}-60 \mathrm{v}$.

Nouerint vniuersi ad quos perneuerint presens scriptum quod cum in Fusellensi ecclesia quotidiana portio ad diminutionem non modicam a Deo deuerissent quod eadem ecclesia in diuinis offitiis obseruitorum defectum detrimentum non modicum pateretur volentes huic morbo tam pestifero occurere cum medella tam necessaria quam salubri. Ideo nos, Santius Gundisalui, abbas, prior, totum quam capitulum Fusellensis de communi consensu et expontanea voluntate, decernimus, constituimus et ordinamus et dicto presenti nunc et in perpetuum valiturum, quod omnium fructuum, reddituum et prouentuum 
prestimoniorum quorumcumque in ecclesia vel abbatia Fusellensi de çetero vacare contigerit et per nos vel successores nostros vel qua uis auctoritate alia qualicumque confferri seu et agssinari medietatem primo anno quo illi quatenus predicta prestimonia collata fuerint fructus percipiant eorumdem reddat ex integro capitulo Fusillensi immo potuis ipsum capitulum primo anno secundum, quod predictum est, per se medietatem percipiant supradictum in supplementun quotidianem portionis ipsius ecclesiem compertendum super hoc tamen descendentium canonicorum et sotiorum totaliter iure saluo ut si quicumque ipsorum a die natalis Domini descedere forte contigerit suorum prestimoniorum in illo anno totaliter fructus percipiant iuxta Fusellensi ecclesiem consuetudinem diutuis approbatam quam omnino nos abbas prior totumque capitulum Fusellenses, pro nobis nostris quam sucessoribus promittimus in perpetuum fideliter obseruare, et in testimonium predictorum, presens statutum in presenti abscriptum, pagina sigillorum nostrorum muni $(f .37 v)$ mine duximus muniendum. Actum est hoc Fusellensi, prima die decembris, anno Domini M CC XC.

1291, agosto, 16. Valladolid.

Sancho IV confirma un privilegio de Sancho III (1158, mayo, 4. Carrión de los Condes), inserto, por el que concede a Raimundo, abad de Santa María de Husillos, y a todos sus canónigos, el privilegio de los infanzones, exentándolos asimismo de todo servicio real.

A. AHDP, Ampudia y Abadía de Husillos, Pergaminos, carp. 198-13. Perg., 406 x 375 mm.; escr. gótica redonda de privilegios y gótica documental; buena conservación. Tiene cinta pero no sello. B. AHDP, Ampudia y Abadía de Husillos, Pergaminos, carp. 199-17. Perg., 696 x 586 mm.; privilegio rodado; escr. gótica redonda de privilegios y de albalaes; muy buena conservación. Sello de plomo pendiente. Inserto en confirmación de Fernando IV, dada en Valladolid, a 7 de marzo de 1312. Véase doc. núm. 100. 


\section{LA ABADÍA DE SANTA MARÍA DE HUSILLOS: ESTUDIO Y COLECCIÓN \\ DOCUMENTAL $(904-1608)$}

C. AHDP, Ampudia y Abadía de Husillos, Pergaminos, carp. 199-18. Perg., 742 x 574 mm.; escr. gótica redonda de privilegios y gótica documental; buena conservación. Sello de plomo. Inserto en confirmación de Alfonso XI, dada en Valladolid, a 16 de diciembre de 1331. Véase doc. núm. 113. D. AHDP, Ampudia, Serie G, Pergaminos. Privilegios Reales, carp. 200-20. Inserto en confirmación de Pedro I, dada en Valladolid, a 12 de noviembre de 1351. Véase doc. núm. 134.

E. AHDP, Ampudia, Serie G, Pergaminos. Privilegios Reales, carp. 201-24. Inserto en confirmación de Enrique II del privilegio de Alfonso XI, dada en Valladolid, a 20 de mayo de 1371. Véase doc. núm. 164.

F. ADHP., Ampudia, Serie G, Pergaminos. Privilegios Reales, carp. 201-26. Perg., 719 х 573 mm.; escr. gótica de privilegios; buena conservación. Mantiene parte de la cinta Pero no el sello. Inserto en confirmación de Juan I del privilegio de Enrique II, dada en Burgos, a 22 de agosto de 1379. Véase doc. núm. 194.

G. AHDP, Ampudia, Serie G, Pergaminos. Privilegios Reales, carp. 202-29. Perg., 717 x 517 mm.; privilegio rodado; escr. gótica redonda de privilegios y precortesana; buena conservación. todos los elementos decorativos están dibujados Pero sin miniar. No conserva la cinta Pero si el sello de plomo, que está suelto. Inserto en confirmación de Enrique III del privilegio de Juan I, dada en Burgos, a 20 de febrero de 1392. Véase doc. núm. 213.

$H$. APA, $L P H$, ff. $40 \mathrm{v}-41$ r. Traslado de $A$.

I. APA, $L P H$, ff. $48 \mathrm{r}-49 \mathrm{v}$. Traslado de la confirmación de $B$

$J$. APA, $L P H$, ff. 60r-61v. Traslado de $C$.

$K$. APA, $L P H$, ff. 72 r-74r. Traslado de $D$.

$L$. APA, $L P H$, ff. 92r-94v. Traslado de $E$.

$M$ APA, $L P H$, ff. $108 \mathrm{v}-111$ r. Traslado de $F$.

$N$. APA, $L P H$, ff. $124 \mathrm{r}-127 \mathrm{v}$. Traslado de $G$.

N. AGS, Patronato eclesiástico. Inconexos, leg.159, ff. 47v-49v. Papel; escr. procesal; buena conservación. Traslado de $H$.

$O$. BN, $m s .705$, ff. 64r-66r. Traslado de $H$.

P. BN, ms. 705, ff. 79r-83v. Traslado de $I$.

$Q$. BN, $m s .705$, ff. $118 \mathrm{v}-124 \mathrm{r}$. Traslado de $J$.

$R$. BN, ms. 705, ff. $147 \mathrm{v}-154 \mathrm{v}$. Traslado de $K$.

$S$. BN, $m s .705$, ff. 201r-208r. Traslado de $L$.

T. BN, $m s .705$, ff. 238r-242r. Traslado de $M$.

ED. GAIBROIS, Sancho IV, III, 231, núm. 364. No edita el documento que se confirma.- CORIA COLINA - FRANCIA LORENZO, Reinado de Sancho IV, 115-117, núm. 23.

Sepan quantos esta carta vieren, commo nos, don Sancho, por la graçia de Dios rrey de Castiella, de Toledo, de León, de Gallizia, de Seuilla, de Córdoua, / de Murçia, de Iahén, et del Algarbe, viemos una carta del rrey don Sancho de 
Castiella fijo del emperador, que nos mostraron el prior et el cabildo de la eglesia de Sancta / María de Fusiellos, ffecha en esta guisa:

(Sigue doc. núm. 28)

Agora, el prior et el cabildo de la eglesia sobredicha, pidieron nos merçed que les con/18firmásemos esta carta. Et nos, sobredicho rrey don Sancho, por les fazer bien et merçed, otorgámosles et confirmámosles esta carta, et mandamos que les uala et les sea guarda/da bien et complidamiente en todo para siempre iamás, assí commo en ella dize.

Et defendemos firmemiente, que ninguno non sea osado de les yr nin de les passar contra ella en ningún tiempo por / ninguna manera, sinon qualquier o qualesquier que lo fiziesen, pecharnos y an en pena mille marauedís de la moneda nueua, et al prior et al cabildo de la eglesia sobredicha o a quien esta carta mos $/{ }^{21}$ trare por ellos, todos los daños et los menoscabos que por ende rrecibieren, doblados. Sobresto, mandamos a todos los concejos, alcaldes, iurados, iuezes, iusticias, alguaziles, et a don Sancho / Martínez de Leyua, nuestro merino mayor en Castiella, o a qualquier que sea merino mayor daquí adelante en Castiella et a todos los otros merinos que hy andudieren, tambien a los / que agora y son commo a los que serán daquí adelante que, si pora auentura, alguno o algunos les quisieren passar contra esto que sobredicho es en alguna cosa, que ge lo non consientan et que les peyndren $/^{24}$ por la pena sobredicha, et que la guarden para fazer della lo que nos mandaremos. Et non fagan ende al nin se escusen de lo complir los vnos por los otros, más que lo cumplan luego el prime/ro o los primeros dellos a quien esta nostra carta fuere mostrada, si non a ellos et a quanto ouiessen nos tornaríemos por ello. Et desto les mandamos dar esta nuestra carta seellada con / nostro seello colgado.

Dada en Valladolit, diez et seys días de agosto, era de mille et trezientos et veynte et nueue annos. Don Roy Díaz, abbat de Valladolid, la mandó fazer ${ }^{27}$ por mandado del rrey. Yo, Fernand Royz, la escreuí. Roy Díaz. Alfons Royz. Iohán Pérez. (rúbricas) 
1292, abril, 1. Carrión de los Condes.

Sancho IV pone bajo su amparo la iglesia y las posesiones de Santa María de Husillos, a causa de que el abad, prior y cabildo le habían denunciado que ciertos hombres ricos, caballeros y otros hombres habian entrado en sus posesiones violentamente, robando a dicha abadía y a sus vasallos. Prohíbe que en adelante ninguna persona entre en los términos de Husillos y tome prendas, a no ser que sea a causa de deudas o fiaduras.

A. AHDP, Ampudia y Abadía de Husillos, Pergaminos, carp. 198-14. Perg., 266 x 264 mm.; escr. gótica redonda de privilegios; regular conservación con una rotura vertical que va desde la línea 8 hasta la 12. Lleva pendiente una cinta con hilos de diferentes colores, pero no el sello.

$B$. APA, $L P H$, f. $41 \mathrm{r}-\mathrm{v}$.

C. AGS, Patronato eclesiástico. Inconexos, leg.159, ff. 49v-50v. Papel; escr. procesal; buena conservación.

D. BN, ms. 705, ff. 66r-67r.

ED. GAIBROIS, Sancho IV, III, 276, núm. 410.

Sepan quantos esta carta uieren como nos, don Sancho, por la graçia de Dios rrey de Castiella, de Toledo, de León, de Gallizia, de Se/uilla, de Córdoua, de Murçia, de Iahén, et del Algarbe. Porque el abbat et el prior et el cabildo de la eglesia de Fusiellos nos dixieron que / algunos rricos ombres et caualleros et otros ombres que posan en los sus logares, et que les tomauan a ellos et a los sus uassallos lo que les ffallan, et que les $\beta$ fazen y otras muchas mal ferias como non deuen, tenemos por bien de tomar a ellos et a los sus uassallos et a todo lo que la eglesia sobredicha / a en nostra guarda et en nostro deffendimiento. Ende mandamos et deffendemos firmemiente que daquí adelante ningún rric ombre, nin infançón, / nin rrica fembra, nin cauallero, nin otro ombre ninguno, non sea osado de posar en los sus logares nin de les tomar nin de les peyndrar a los $/{ }^{6}$ sus uassallos, nin a ningunas de sus cosas ninguna cosa de lo suyo como non deuen, 
nin de les fazer y mal fetrias ningunas, saluo ende / si los peyndraren por su debda connosçuda o por fiadura que ellos mismos ayan fecha. Si non, qualquie[r o] qualesquier que lo fiziessen, pechar / nos y en pena mille maravedís de la moneda nueua, et a ellos todos los dannos et menoscabos que por esta [r]azón reçibier[en] con el doblo. Et $/^{9}$ mandamos a los alcalldes et a los merinos e a todos los aportellados de las villas et de los logares [que] esta nostra carta uieren, que si alguno / o algunos contra esta merçed que les nos fazemos les passaren en alguna cosa, que les peyndren por [la] pena sobredicha, et que la guarden / pora fazer della lo que nos mandáremos, et que fagan emendar a abbat et al prior et al cabildo de la eglesia [so]bredicha e a los sus uassallos $/{ }^{12}$ o a quien esta nostra carta mostrare por ellos, t $[0]$ dos los daños e los menoscabos que por esta razón reçibiere con el doblo. Otrossí, mandamos / et deffendemos firmemiente, que ninguno de los nostros merinos non sea osado de tomar, a ellos nin a los sus uassallos, ninguna cosa / por fuerça nin de fazer mal feria ninguna en los sus logares. Et non fagan ende al so la pena sobredicha. Et desto les manda $/{ }^{15}$ mos dar esta nostra carta seellada con nostro seello colgado.

Dada en Carrión, primero día de abril era de mille et CCC et treynta annos. / Don Roy Díaz, abbad de Valladolid, la mandó fazer por mandado del rrey. Yo, Fernand Royz, la fiz escreuir.

Alfonso Pérez. Iohán Pérez. (rúbrica)

1294, enero, 28. Palencia.

Traslado de tres documentos solicitado por Rodrigo Gómez y García Gómez, canónigos de la catedral de Palencia, a Sancho González, abad de Santa María de Husillos:

$1^{\circ}$ - (1267, abril, 20. Husillos) Gómez de Monzón y María, su esposa, dotan una capellanía en la capilla de Santiago de Santa María de Husillos. 
$2^{\circ}$ - (1267, abril, 20. Husillos) Gómez de Monzón y María, su esposa, junto con el prior y el cabildo de Santa María de Husillos, estipulan cómo ha de realizarse el servicio en la capellanía fundada.

3- (1269, mayo, 1. Husillos) Gómez de Monzón y María, su esposa, donan a Santa María de Husillos cuatrocientos maravedís para mejorar las aceñas y los molinos de la pesquera de Pajares.

A. AHDP, Ampudia y Abadía de Husillos, Pergaminos, carp. 198-16. Perg., 518 x 395 mm.; escr. gótica redonda de privilegios; buena conservación.

ED. CORIA COLINA - FRANCIA LORENZO, Reinado de Sancho IV, 124-128, núm. 30.

Rodrigo Gómez y García Gómez, canónigos de Palencia son, seguramente, hijos de Gómez de Monzón.

Nouerint vniuersi quod Roderico Gomecii et Garsias Gomecii, canonici Palentini, ostenderunt coram me, Sancio Gundisalui, abbate Fusellensi, tria paria literarum, qui erant sigillare sigillo capituli Fusellensis et sigillo, bone memorie, quondam / dopni Gomecii de Monçóm, quarum tenores sunt isti qui secuntur:

(Sigue doc. núm. 74)

(Sigue doc. núm. 75)

(Sigue doc. núm. 77)

Et predicti Rodericus Gomecii et Garsias Gomeçii pecierunt a me, abbate supradicto, cum instançia suplicantes ${ }^{\beta 9}$ quatinus iam dictis literis meum asensum et autoritatem in pertirer. Ego, vero abbas pre nominatus, ex afectione et deuoçione quam dictus dopnus Gomeçius et / dopna Maria, vxor sua, erga Fusellensi ecclesiam habuerunt petiçionem eorumdem Roderiçi Gomecii et Garsie Gomeçii considerans / ese vistam per dictus literis $/^{42}$ meam autoritatem per beo et asensum. Et ut perpetuam habeant firmitatem presentem literam feci mei sigilli munimine conmuniri. 
Date Palencie, V kalendas fe/bruarii, anno Domini $\mathrm{M}^{\circ} \mathrm{CC}^{\circ}$ nonagesimo quarto.

Circa 1294, enero, 28.

Traslado de una carta (1267, abril, 20. Husillos), presentada por Rodrigo Gómez y García Gómez, canónigos de la catedral de Palencia, a Sancho González, abad de Santa María de Husillos, por la que Gómez de Monzón y María, su esposa, dotan una capellanía en la capilla de Santiago de la iglesia de Santa María de Husillos, donde tienen su enterramiento, constituyendo la porción de dicha capellanía: pan, vino, denarios de los aniversarios, pitanzas y matutinas. Asimismo donan al prior Gonzalo Facundo y al cabildo, mil maravedis.

B. APA, $L P H$, ff. $41 \mathrm{v}-42 \mathrm{r}$.

C. BN, ms. 705, ff. 67r-68r.

Aunque se omite la fecha, el hecho de que sean los canónigos de la catedral palentina Rodrigo Gómez y García Gómez los que presentan el documento a trasladar al abad de Husillos Sancho González, en un acto jurídico similar al representado por el anterior documento, hace que lo datemos en una fecha cercana.

Es muy posible que esta escritura se hallara bastante deteriorada en el momento de ser transcrita al Libro Tumbo, pues como sucede en estos casos no se signa.

No se traslada en el becerro las tres columnas de confirmantes ni el nombre del escribano.

Nouerint vniuersi quod Rodiricus Gometii et Garsias Gometii, canonici palentini, ostenderunt coram me, Santio Gundisaluo, abbati Fusellensi, tria paria literarum que erant sigillata sigillo capituli Fusillensi et sigillo, bone memorie, quomdam doni Gometii de Moncon, quarum tenores sunt isti qui sequuntur:

(Sigue doc. núm.74) 
1295, mayo, 31, martes.

Los herederos de Urraca "La Soriega" conceden a Bebian Martínez, prior de Santa María de Husillos, y al cabildo, un corral con una casa en Santillán de la Cuesta, y tres viñas, dos en Solajera de Santillán y una en Val, para que se dote una capellanía por el alma de la difunta en la iglesia de San Julián de Santillán de la Cuesta. Joán de Santillán y María, su esposa, donan, en ayuda de dicha capellanía y en remisión de sus almas, dos viñas, una en Las Quintanas y la otra en Val.

B. APA, $L P H$, f. 42 r-v.

C. AGS, Patronato eclesiástico. Inconexos, leg.159, ff. 50v-52r. Papel; escr. procesal; buena conservación.

D. BN, ms. 705 , ff. $68 \mathrm{r}-69 \mathrm{v}$.

Nos inclinamos por la data expresada en el Libro de los Privilegios de Husillos.

Fecho y sacado fue este traslado de la dicha escritura original en la villa de Husillos, a veynte y quatro días del mes de nouienbre de mil y quinientos y çinquenta y quatro años. Testigos que fueron presentes a lo ver leer, corregir y conçertar, Ioán Ruiz Cabeça de Vaca y Gaspar de Vedoya, clérigos, y Pero Manuel, estantes en la dicha villa. E yo, Santiago Gómez, escrivano público en la dicha villa, presente fui a lo que dicho es en vno con los dichos testigos; y del dicho pedimiento y mandamiento del dicho señor alcalde mayor que aquí firmó su nombre, lo escreví y fize aquí mi signo (signo) en testimonio de verdad. Pero Ruyz de Billoldo (rúbrica). Santiago Gómez (rúbrica).

In nomine Domini nostri Ihesu Christi, amen. Sepan quantos esta carta vieren como yo, Pero Pérez Yiosa, y yo, Joán Yiesosa, su hermano, vezinos y moradores de Villumbrales, y yo don Joán de Sanctillán de la Cuesta, fijo de Martín Yáñes, en boz y en rrazón de mi muger, doña María, y yo, Domingo Mínguez, fijo de doña Urraca, y yo, don Adán, fiio de Domingo Rodríguez, en boz y en rrazón de mi muger, doña Urraca, vecinos y moradores en Grijota, 
erederos más propincos de doña Urraca "la Soriega" de Santillán, que Dios perdona, por nos y por todos los otros erederos, de la dicha doña Vrraca, a serviçio de Dios y por consejo de omes buenos y aprobechamiento del ánima de la dicha doña Vrraca, damos a vos, Bebian Martínez, prior, y al cabildo de Fusiellos, por agora y por siempre jamás, un corral con una casa y tres viñas, que dexó doña Vrraca la Soriega, que Dios perdone, de que nos eramos tenedores fasta el día de oy que esta carta es fecha. El qual corral con su casa es en Santillán de la Cuesta, en linde de casas de don Pascual, hiio de Joán Pérez, y en linde de casas de Domingo Pérez, el sobrino. Y las dos viñas son en Solajeras de Santillán, y la vna es en linde de viña de Joán Yáguez y en linde de viña de Per Alfonso de Villunbrales; y la otra viña es en linde de viña de don Rebel y en linde de viña de don Ioán, el dicho fijo de don Martín Yáñes; y la otra viña es en Val, en linde del prado de Val y en linde de viña de Yañez Domingo de Villumbrales. Este eredamiento vos damos en tal manera nos, que pongades un capellán para siempre jamás, que cante en la iglesia de San Julián de Santillán, al altar de Sancta Brígida, por el ánima de la dicha doña Vrraca la Soriega y por todos quantos dieren sus ayudas a esta dicha capellanía, en guisa que vos non seades tenudos de poner y ninguna cosa de lo vuestro y vos, el prior y el cabildo, que ayades poder de dar esta capellanía. Y si algún clérigo y ouiere que venga del linaje de la dicha dona Vrraca, fasta en tanto grado, que la dedes al que si fueren dos o tres, que la dedes a quien más quisiéredes. Y nos, el prior y cabildo sobredichos, lo reçebimos en esta manera que dicho es por nos y por nosotros que ende an de venir y damos luego esta capellanía a Pero Abad, hijo de don Joán de Santillán, visnieto de la dicha doña Vrraca, para en toda su vida y él, que sea tenudo de la cantar personalmente, el dicho capellán que fuere por tiempo, que dé cada año al cabildo de Fusiellos, seis maravedís de los dineros de la guerra por aniversario de la dicha doña Vrraca. Y yo, don Joán de Santillán, fijo de Martín Yáñes, y yo, doña María, su muger, damos en ayuda a esta dicha capellanía, en rremisión de nuestras almas, dos viñas que son en lugares pernonbrados, la vna, en las Quintanas, linde de viña de la yglesia y en linde de viña de doña Mayor, fija de la Malua, y la otra viña es en Val, en linde de viña de Tello y en linde de viña de Domingo Macho. Y porque esto seya más firme y no venga en duda nos, el prior y el cabildo e nos los omes sobredichos, rogamos a Domingo Abril, escriuano del concejo de Villumbrales, 
que fiziese ende dos cartas partidas por A, B, C, en vn tenor y que pusiese en ellas su signo en testimonio. Y yo, Domingo Abril, el dicho escriuano por amas las dichas partes sobredichas, fize desto dos cartas partidas por A, B, C, en vn tenor. Martes, postrimero día de mayo, era de mil y trezientos y treynta y tres años. Pesquisas que estauan presentes e que lo vieron, rogados de amas las partes: don Fernando, fijo de Fernán Pérez, merino de Fusillos, y don Domingo, fijo de Martín Yáñez de Fuentes, y Martín Yáñes, capellán (f.42r) del obispo de Osma, y Joán Abad, capellán de Santillán de la Cuesta; y pusen cada una dellas mi signo en testimonio de verdad. Otrosí nos, el prior y cabildo sobredichos de Fusiellos, posimos en cada vna destas cartas nuestros sellos pendientes en testimonio de verdad.

1296, noviembre, 1. Roma.

Litterae gratiosae de Bonifacio VIII facultando al maestro Pedro Rodríguez Hispano, clérigo de la Cámara apostólica y abad de Husillos en la iglesia de Palencia, para seguir recibiendo sus rentas correspondientes de la citada abadía de Husillos y los beneficios que tiene en Chartres (Francia), Oviedo y otras iglesias, mientras resida en la Sede Apostólica.

B. AHV, Reg. Vat. 48, f. 129, núm. 546.

ED. DOMÍNGUEZ SÁNCHEZ, Bonifacio VIII, 350-351, núm. 293.

REG. DIGARD-FAUCON - THOMAS, Boniface VIII, I, cols. 522-523, núm. 1437.

Pedro Rodríguez Hispano fue abad de Husillos al menos a partir del 13 de julio de 1295, fecha de una litterae executoriae de Bonifacio VIII en la que confirma la elección como arzobispo de Sevilla del anterior abad, Sancho González ${ }^{8}$

${ }^{8}$ DOMÍNGUEZ SÁNCHEZ, Bonifacio VIII, 181-182, núm. 107. 
[Bonifatius episcopus, seruus seruorum Dei], dilecto filio magistro Petro Roderici, Camere nostre clerico, abbati Fusellensi in ecclesia Palentina, [salutem et apostolicam benedictionem].

Attendentes grata et accepta seruitia que nobis ab olim ante nostre promotionis auspitia familiariter inpendisti et inpendere studiose non cessas, considerantes etiam tue multiplicis probitatis merita que nobis experientia nota fecit, et propterea uolemptes te prosequi speciali gratia et fauore, tibi, auctoritate presentium, indulgemus ut, existens apud Sedem Apostolicam uel alibi ubicumque, fructus, redditus et prouentus abbatie Fusellensis quam in Palentina et prebendarum tuarum quas in ea et Carnotensi ac Ouetensi ecclesiis, et aliorum benefitiorum tuorum ecclesiasticorum que in quibuscumque ecclesiis obtines teque obtinere contigerit in futurum, cum ea integritate percipere ualeas, cotidianis distributionibus que in horis canonicis exhibentur dumtaxat exceptis, cum qua illos perciperes si in eisdem ecclesiis personaliter resideres, nec ad faciendum in eis personalem residentiam tenearis, neque ad id a quoquam meritus ualeas cantari; non obstantibus sit $\mathrm{u}$ in ipsis ecclesiis primam consuetam personalem residentiam non fecisti, aut quibuscumque contrariis statutes et consuetudinibus ipsarum ecclesiarum, iuramento, confirmatione Sedis Apostolice uel alia quauis firmate uallatis, etiam si de illis seruandis et non impetrandis licteris apostolicis contra ea, et ipsis licteris non utendo, per te uel per procuratorem tuum, prestitisti forsitan iuramentum; seu si locorum diocesano ab eadem sit Sede concessum ut canonicos et personas ecclesiarum suarum ciuitatum et diocesium in dignitatibus constitutas possint compellere ad fatiendum personalem residentiam in eisdem; siue si dilectis filiis capitulis ecclesiarum predictarum a prefata sit Sede indultum quod canonicis et personis eisdem fructus, redditus et prouentus prebendarum, dignitatum et benefitiorum suorum ministrare in absentia minime teneantur, quodque ad id compelli non possint per licteras apostolicas non fatientes plenam et expressam, ac de uerbo ad uerbum, de indulto huiusmodi mentionem; seu quibuscumque priuilegiis, indulgentiis et licteris apostolicis, generalibus uel specialibus, cuiuscumque tenoris existent, per que presentibus non expressa uel totaliter non inserta effectus huiusmodi gratie impediri ualeat uel differri, et de quibus quorumue totis tenoribus oporteat plenam 
et expressam, ac de uerbo ad uerbum, fieri in nostris licteris mentionem; prouiso de abbatial ipsa debitis non fraudentur obsequiis, et animarum cura, si qua eis imminet, nullatenus negligatur. Nulli ergo [omnino hominum liceat hanc paginam] nostre concessionis [infringere, uel ei ausu temerario contraire. Si quis autem hoc attemptare presumpserit, indignationem omnipotentis Dei et beatorum Petri et Pauli, apostolorum Eius, se nouerit incursurum].

Datum Rome, apud Sanctum Petrum, kalendis novembris, [pontificatus nostril] anno secundo.

1296, noviembre, 6. Valladolid.

Juan Álvarez, obispo de Osma, dona por juro de heredad al cabildo de Santa María de Husillos, sus heredades en Fuentes de Valdepero y Quintanilla de Valdepero. Además, con los beneficios que les produciera las posesiones que les dio en Torquemada y Hornillos de Cerrato, pide que se dote una capellanía con uno o dos capellanes, para rogar por él y por sus familiares.

A. AHDP, Ampudia y Abadía de Husillos, Pergaminos, carp. 207-14. Perg., 127 x 207 mm.; escr. gótica documental; regular conservación Tiene pendiente las cuerdas, aunque no conserva el sello. B. APA, $L P H$, ff. $42 \mathrm{v}-43 \mathrm{r}$.

C. BN, $m s .705$, ff. $69 \mathrm{v}-70 \mathrm{v}$.

ED. CORIA COLINO - FRANCIA LORENZO, Reinado de Fernando IV, 107-108, núm. 13.

Sepan quantos esta carta vieren commo nos, don Iohán, por la graçia de Dios obispo de Osma, entendiendo quantos bienes et quantas graçias nos fizo Sancta María de / Fusiellos et por quantas merçedes della attendemos, tan bien en el espiritual commo en lo temporal, tenemos por bien de fazer algo al cabillo de la eglesia de / Fusiellos sobredicha, et fazémosgelo en esta manera, segund aquí será dicho. Todo quanto nos heredamos et auemos et auer deuemos en Fuentes et en 
Quintaniella de $\beta$ Valdepero et en su término, nombradamente: tierras, vinnas, casas pobladas et por poblar, vuertas, prados, fuentes, vassallos, con deuisas et con todos quantos derechos et pe/chos nos hy auemos et auer deuemos en estos logares sobredichos, con entradas et con salidas et con todas sus pertenençias. Todo uos lo damos al dicho cabillo del día / que esta carta es fecha adelantre, que lo ayades por iuro de heredat para siempre iamás. Et daquí uos damos la possessión de todas las cosas sobredichas, et que fagades dello et $/{ }^{6}$ en ello assí commo de uestro propio heredamiento. Et qualquier ombre o mugier de nostros herederos o de estrannos que contra esta merçed que nos fazemos a uos el dicho cabillo quisiere / uenir para desfazerlo, nin para embargarlo, nin para contrallarlo en ninguna manera en todo nin en parte, en ningún tiempo del mundo, que aya la yra de Dios omnipotente et peche / a uos, el cabillo sobredicho o a quien esta carta por uos mostrare, dos mille maravedís de la bona moneda, et otra tan bon heredamiento et tanto et en tan bon logar doblado, et en $/^{9}$ cabo que vala e sea firme todo esto que a uos damos commo dicho es. Et porque esto sea firme et más estable para en todo tiempo, vos el dicho cabillo que fagades de to/dos los fructos que Dios y diere; et otrossí de los fructos que Dios diere en la heredat que nos uos diemos en Torquemada et en Forniellos, poner dos capellanes si sse $/^{12}$ ende podieren mantener, o vn capellán si dos se y non podiessen mantener que canten perpetuo por nostra alma et por las almas de nostro padre et de nostra madre, que Dios perdone. / Et que uos todos et los otros que serán benefiçiados, o non benefiçiados en la dicha eglesia, que roguedes a Dios por nos et por nostra vida. Et porque esto sea firme, nos, / don Iohán, obispo sobredicho, mandamos seellar esta carta con nostro seello colgado en testimonio.

Pesquisas que fueron presentes quando esta donaçión fue fecha: Fernand / Yuánnez de Frómesta. Fernand Núnnez de Aréualo, físico. Pero Domínguez, sacristán de Fusiellos et mayordomo del dicho sennor, et Rodrigo Rodríguez, et Domingo $/{ }^{15}$ Abbad, camareros del dicho sennor, et Garçi Pérez de Fusiellos, çeuadero, et Alfonsso Pérez, portero. Fecha la carta en Valladolit, seys días de nouiembre era / de mille et trezientos et treynta et quatro annos /. 


\section{LA ABADÍA DE SANTA MARÍA DE HUSILLOS: ESTUDIO Y COLECCIÓN \\ DOCUMENTAL $(904-1608)$}

1296, noviembre, 14, miércoles.

Testamento de Juan Álvarez, obispo de Osma, por el que manda a Santa María de Husillos todas sus heredades en Torquemada, en Hornillos de Cerrato, en Fuentes de Valdepero, con Quintanilla de Valdepero y Vega de Valdepero, y en el Cerrato, para dotar una capellanía por su alma. Manda también a dicha iglesia, mil maravedís para cantar misas y rezar salterios antes de su entierro.

B. APA, $L P H$, ff. $24 \mathrm{v}-27 \mathrm{r}$.

C. BN, ms. 705, ff. 255v-264r. Con este documento termina el manuscrito 705 de la Biblioteca Nacional. Posiblemente el resto de documentos del Libro de los Privilegios de Husillos se trasladarían en otro volumen.

El hecho de que fueran Pedro Domínguez, sacristán de Husillos, y Juan Martínez, arcediano de Campos, los albaceas testamentarios del obispo de Osma, hizo que el original del testamento finalmente se conservase en el archivo de Santa María de Husillos. Por otra parte, con anterioridad a la redacción de su testamento, el obispo de Osma había empezado a poner sus cosas terrenales en orden; así es, ocho días antes de la fecha de su testamento, el 6 de noviembre de 1296, es emitida en Valladolid, una escritura que recoje, resumidamente, lo que el obispo don Juan dejó al cabildo de Husillos (véase doc. núm. 90). Según el episcopologio de Osma, Juan Álvarez lo fue entre el 24 de mayo de 1286 y el 20 de octubre de 1296, por lo que es de suponer que las dos escrituras se realizaran en base a un codicilo anterior.

Fecho y sacado fue este dicho traslado de la dicha escritura original en la villa de Husillos, veinte y vn días del mes de nouienbre de mil y quinientos y çinquenta y quatro annos. Testigos que fueron presentes a lo ver, leer, corregir y conçertar con el original, Joán Ruiz Cabeça de Vaca y Gaspar de Vedoya, clérigos, y Pero Manuel, estantes en la dicha villa.

Y yo, Santiago Gómez, escriuano público en la dicha villa, presente fui a lo que dicho es en uno con los dichos testigos. Y del dicho pedimiento y mandamiento del dicho señor alcalde mayor, que aquí firmó su nombre, lo escreuí y fize aquí mi signo (signo) en testimonio de verdad.

Pero Ruyz de Billodo (rúbrica). Santiago Gómez (rúbrica).

En el nombre de Dios, Padre, Hijo, Espiritu Sancto, que son tres personas y vn solo Dios, que fizo ome a su semejança y le dio entendimiento sobre todas 
las criaturas que crió en la terra y le rredimió por su sangre preçiosa del pecado en que cayera por su culpa. El dio ley y manera porque se saluase si después del baptismo cayese por alguna razón en su yra. Y por esto nos, don Joán, por la su merced ca non por los nuestros meresçimientos, obispo de Osma, conosçiendo nuestras culpas y nuestras menguas qual erramos en muchas maneras y temiendo la su saña y la su yra, pues que nos Él redimió, que otra cosa ninguna non avemos ante nos que nos aprouecho, saluo la su merced, y penitençia que Él establesçió porque pudiesen por ella los pecadores ser saluos. Querrendo enmendar algunas cosas de las en quel erramos, estando en nuestro sano entendimiento, en nuestra sana memoria de los bienes que nos Él dio en este mundo y de la merçed que del ouiéremos; ordenamos nuestro testamento en esta manera y hazemos testamentarios al muy noble ynfante don Enrrique, fijo del muy noble rrey don Fernando, y a Pero Domínguez, sacristán de Fusiellos, nuestro mayordomo, y a Joán Martínez, arçipreste del Canpo, nuestro clérigo, en tal manera: que los dichos Pero Domínguez y Joán Martínez sean $(f .24 v)$ apoderados. Luego, quando acaesciere de nuestro finamiento en todos nuestros bienes, tan bien muebles como rraízes, do cumplan amos todo lo que nos mandamos en este dicho testamento y rrogamos, al dicho don Enrrique, que los defienda y los ayude por su buena mesura si los, por aventura, alguno quisiere enbargar. $\mathrm{Y}$ pedimos merçed a nuestro señor el rey, cuya merçed y cuya fechura somos, que así como nos fizo mucho bien y mucha merçed en vida, que tenga por bien de fazer cumplir después de nuestra muerte lo que mandamos, a Dios por nuestra alma. Lo primero, damos el alma a Ihesu Christo, que nos lo metió en la carne y encomendámosla a la bienaventurada virgen Sancta María, su madre, a qui él estableció por abogada de los pecadores, que sea la su merçed de rogar y pedir merçed, por ella, a su bendito hijo. Y damos el cuerpo a la iglesia de Osma, a cuya merçed nos bibíamos, y mandamos que nos entierren ante la capilla del altar de San Pero, el cuerpo sancto vna laude, a par de tierra, y sean estas las letras escritas en ella: "Ora pro me, miserimo pecatore, Sanctissime confesor Petri tituli et memoriam indignos sed de tue pretati confidimus animam pecatuzen ad miserimam".

Recomendo et ordenamos vna capellanía en esta manera, que se cante para siempre jamás en la iglesia de Osma, al altar de San Pero, mi confesor, y mandamos para ella todo nuestro eredamiento de Fuente Fierro, con los nuestros 
molinos que nos conpramos y con las casas que nos y fezimos, quatro bueyes y con alimento para ellos y con todo lo al que nos y auemos; y el nuestro heredamiento de Fuente Mariella con todo su aparejamiento, así como deve estar y con las viñas y con todo lo que nos avemos en Valera, aldea de Roa, con todo su apareiamiento, así como lo deue auer y si bueyes o çeuo o semiença o alguna otra cosa fiziere menester para alimento de alguno destos lugares, mandamos que lo compren de lo nuestro, en guisa que sea todo bien adereçado. Y esta nuestra capellanía damos a Pero Garçía, nuestro capellán, con todas las cosas que ouier y deue aver en los lugares susodichos y con las rrentas della y que la cante por nuestra alma en nuestra vida y después que la dé el obispo de Osma, a capellán bueno ydóneo. Y mandamos, que el día de nuestro enterramiento, que piensen del prior y del cabildo y de los capellanes y que den a las personas veynte maravedís y los canónigos diez maravedís y a los capellanes y a los clérigos del coro çinquenta maravedís, eso mismo que piensen dellos el día de los quarenta días, según el día del enterramiento. Y mandamos que den, el día que nos soterrasen, tres mil maravedis por Dios por aves y por cosas algunas que cuidamos que ouiemos de no bien ganado. Y mandamos, para dos aniuersarios perpetuos cada año, la eredad que compramos en Villa Nueua de Caraço, al cabildo de nuestra iglesia. Y mandamos que den quinientos maravedís para cumplir el testamento de doña María, nuestra madre que Dios perdone, que ouiemos de dos bestias que tomamos della. Otrosí, que paguen luego trezientos maravedís por su ánima, eso mismo que paguen quanto con derecho saben que tomamos y no es pagado por doquier que sean y generalmente quantas deudas pareçieren y fallaren por buena verdad que las nos deuemos, que las paguen luego, antes que manda ninguna, saluo aquello que fuese menester para nuestro enterramiento. Otrosí, que paguen en Fusiellos trezientos maravedís de conducho, que tomaron los caseros que fueron y por tiempo y lo non pagaron. A los erederos de don Christobal, sacristán que fue de Palençia, çien maravedis. A los erederos que son de don Gómez de Gil de Fuentes, canónigo que fue de Palençia, çien maravedís. A Domingo Velasco, canónigo de Fusiellos, dozientos maravedís. Y si éstos no ouieren erederos que los den por sus almas. Den por el alma de Nuño Pérez, canónigo que fue de Palençia, çiento y treinta maravedís que valía vna mula que tomamos a sus mansesores. Y a los erederos de Gonçalo Núñez de Monçón, quinientos 
maravedís, y si no hallaren erederos que los den por Dios. Y den a maestre Gonçalo, abbad de Aruas, mil torneses gruesos de plata que le deuemos, que nos enprestó para nuestra pro; déngelos de la plata que troxiéremos con vusco y páguenlos ante que manda ninguna. Y mandamos la nuestra blibia mayor al conuento de los frailes predicadores de Palençia y ellos que fagan $(f .25 r)$ cantar tres mil sacrifiçios por nuestra alma, de más de quantos cantarían por vn su fraile. Esto dezimos porque esperamos la merçed de Ihesu Christo de finar en el ábito de santo Domingo y en la su sancta orden que el establesçió. Y mandamos al cabildo de Fusiellos todo quanto nos avemos en Torquemada y en Forniellos y en Fuentes de Valdepero, con Quintanilla y con Vega, y toda la nuestra parte que nos cayó en Çerrato, de nuestra madre y de nuestra hermana el abadesa, y ellos que pongan vn capellán perpetuo que cante, cada día, por nuestra alma y los mansesores entendiesen que para dos pareçiese y auer, que lo fagan ansí cumplir. Otrosí, mandamos que den mil maravedís para cantar misas y rrezar salterios, ante que nos seamos enterrado, del mueble que traxéremos con vusco. Y mandamos lo que nos auemos en Melgar de Fernán Armentales y lo de la Villiella y lo de Requexo, que sea vendido, de que compren eredamientos para vna capellanía perpetua de Sancta Catherina y la canten por nuestra alma, a la dicha capiella, en la iglesia de Osma. Y si por esto no ouiere cumplimiento, que tomen tantos de los nuestros dineros, porque se pueda, bien y cumplidamente cantar la capellanía. Otrosí, quitamos a las personas y a los canónigos, del cabildo de la iglesia de Osma, la metad de lo que ouiere a su finamiento y la otra meitad que lo aya el obispo y desto les mandamos dar nuestra carta sellada con nuestro sello. Y por esta graçia y por otro algún serviçio, si lo fiziésemos, a la iglesia de Osma, rogámosles que salgan cada día, sobre nuestra huesa, a dezir vn rresponso y el Pater Noster y un salmo con su oraçión. Y mandamos la nuestra yuguería de Yntrago, con la eredad de Soto, a Gomez Garçía, nuestro sobrino, según pareçe por vna carta que él de nos tiene, en como ge lo dimos. Y si él, desto, carta non a, que ge la den. Y mandamos a Gonçalo, su hermano, la casería de Moyas. E mandamos a Aluar Gómez, nuestro sobrino, quanto nos auemos en Santi Vañeo, dola e en Villa Verde y en Sotros, que entendemos que val, de doze hasta quinze mil maravedís. $\mathrm{Y}$ tenemos por bien que le de i más, dos mil maravedis. Y mandamos a Sancta María de Cauadoga, quanto avemos en toda Cangas y en Ovis, salvo lo que 


\section{LA ABADÍA DE SANTA MARÍA DE HUSILLOS: ESTUDIO Y COLECCIÓN \\ DOCUMENTAL $(904-1608)$}

mandamos a Aluar Gómez y a Gómez Garçía y a Gonçalo, su hermano, y ellos que pongan dos capellanes perpetuos, y en el monesterio, que canten, cada día, sendos sacrifiçios, por nuestra alma y de aquellos que nos lo dexaron. Otrosí, mandamos quanto avemos, en Leges y en Colunga y en los Duesos y quanto y auer deuemos, al monasterio de Val de Dios, y ellos que pongan dos capellanes perpetuos que canten, cada día, por nuestra alma. Otrosí, mandamos quanto auemos en Corrales, saluo lo de Sotros que diéremos a Aluar Gómez, al monesterio de Sancta María de Villa Nueua, y ellos que pongan dos capellanes perpetuos que canten, cada día, por nuestra alma. Y mandamos, que las dos yuntas que auemos en Ledesma, que tenemos de la iglesia de San Pero de Soria, que ge las den y más mil maravedís que echen en heredamiento, y que hagan dos aniversarios por nuestra alma cada año. Y mandamos, a la obra de la nuestra iglesia de Osma, mil maravedís. Y mandamos, a Sancta María de la Vid, mil maravedís. Y mandamos otros mil maravedís, a Sancto Domingo de Caleruega. Y mandamos a San Pero de Arlança, mil maravedís. Y mandamos, a Santo Domingo de Silos, mil maravedís. E mandamos al convento de los Descalços de Soria, trezientos maravedís, y ellos que fagan cantar quinientos sacrifiçios más de quantos cantan por vn su fraile. Y al conuento de Sant Esteuan de Gormaz, dozientos maravedís, y ellos que fagan cantar trezientos sacrifiçios, por nos, más de quantos cantan por vn su fraile. $\mathrm{Y}$ al conuento de Fuen Caliente, mil maravedís, y ellos que fagan dos aniversarios, cada año, por nuestra alma. Y al convento de las dueñas de Braçacorta, quinientos maravedís, y que fagan, cada año, dos aniversarios por nuestra alma. Al cabildo de los clérigos de Soria, dozientos maravedís, y que fagan, cada año, vn aniversario por nuestra alma. Al cabildo de Sant Estevan, dozientos maravedís, y que fagan un aniversario, cada año, por nuestra alma. Y al conuento de las Dueñas de Fresniello, dozientos maravedís, y que fagan vn aniuersario, cada año, por nuestra alma. Y a las dueñas de Santa Rosia, dozientos maravedís, y que fagan vn aniuersario cada año por nuestra alma. Y a los malatos por Dios, çinquenta maravedís, y que den, dellos, a los de Soria y de Cañatamaçor y de Sant Esteuan de Gormaz. Quinientos maravedis a San Pero de Gomel, con esta condiçión o con otra mejor, si pudiere hazer con todos los mansesores, $\mathrm{y}$ en aquellos logares do non quisieren $(f .25 v)$ fazer condiçiones, estas que dichas son mandamos a los mansesores, que lo 
vendan y que lo den por nuestra alma. Y mandamos, para sacar cautiuos de terra de moros, dozientos maravedís. Y mandamos, a la yglesia de Sancto Toribio, quanto eredamiento avemos en Colio y en Penbes, y en Frama Las Abejas, y en Valverique y todo quanto nos avemos en Liébana, y el abad y el convento pongan dos capellanes perpetuos que canten por nuestra alma. Y mandamos, el nuestro decreto y los nuestros decretales y las más leyendas y el nuestro libro de "Propietatis rerum" y la crónica que conpuso el arçobispo don Rodrigo, al cabildo de la iglesia de Osma con tal condiçión, que los non puedan vender, ni enajenar, ni dar, más que sean sienpre para serviçio de los criados de la iglesia, en que puedan leer y aprender y aprouecharse dellos, y dando siempre muy buen rrecaudo, que los tornen a la iglesia. Y mandamos al sacristán y al arçipreste, nuestros mansesores, mil maravedís, que coman y que vayan, por nos, a San Saluador de Ouiedo y a Santiago, y que vendan toda la eredad que nos auemos en Galizia y le den por nuestra alma, y la que vender no pudiesen, que la den en aquellos lugares o ellos entendiesen que la mejor enpleasen, a seruiçio de Dios, por nuestra alma y o mejores condiçiones fiziesen por nuestra alma. Y mandamos, a los nuestros criados, su bestia y su auer a cada uno, así como la traen, salvo, ende, el nuestro falcón onrra barua, que tenemos por bien que le den a don Enrrique, y una sortija de oro; y el que lo traxere, que le den otro falcón o buen pecho por él. Y las otras aues que las vendan y que las mejoren en pro de nuestra alma, según que nos mandamos, y a todos los otros, que ayan sus bestias, cada vno, así como la tienen. Y mandamos a Fernán Ruiz, nuestro sobrino, vn cauallo y vn açor, el que guarda Alfón Pérez, y un falcón de los neblis, que estan en la muda, o a el que le den de otro, o pecho por él. Y a Fernán y Gonzalo, nuestro sobrino, un cavallo y un açor y mil maravedís, y de más a los que están desposados, que den a cada vno seis çientos maravedís, para ayuda de sus casamientos. Otrosí, mandamos que den quatro çientos maravedís por las yeguas que ouiemos de Joán Sánchez y si erederos no gallaren, que lo den por Dios, por su alma. Y mandamos a Pero Diez, sacristán de Fusiellos, tres mil maravedís; y al arçipreste de Canpo tres mil maravedís; y a Joán Rodríguez, nuestro sobrino, dos mil maravedís; y a Pero Hernández Haçeves dos mil maravedís; y a Diego Pérez y Alfón Pérez, su hermano, dos mil maravedís a cada uno; y a Riano Patiño dos mil maravedís; y a Garçía Fernández dos mil maravedís; y a Joán Sánchez dos mil 


\section{LA ABADÍA DE SANTA MARÍA DE HUSILLOS: ESTUDIO Y COLECCIÓN \\ DOCUMENTAL $(904-1608)$}

maravedís; y a Pero Garçía, nuestro capellán, dos mil maravedís; y a Pero Ruiz mil maravedís; y a Pero Cornero mil maravedís; y a Domingo Abad mil maravedís; y a Roy Gutiérrez mil maravedís; y a Fernán Rodríguez, nuestro sobrino, quinientos maravedís; y a Simón Pérez y a Pero Pérez y Nicolás Pérez y Garçía Gómez y a Benito y a Diego Martín y a Joán de Santo Domingo y a Miguel, a cada vno, çien maravedís; y Alfon Pérez, portero, mil maravedís; y a Garçía Pérez Çeuada mil maravedís; y a Garçía López mil maravedís; y a Gonçalo mil maravedís; y a Pero Pérez, casero de Roa, mil maravedís; y a Ruy Martinez, casero de Cruña, mil maravedís; y a Diego Gómez mil maravedís; y su açor y su bestia. A don Gonçalo Falcon mil maravedis. A Diego Pérez, casero de Santa María de Duero, quinientos maravedís. A Diego Pérez Alfanguen quinientos maravedís. A Martín Toçino dozientos maravedís. A Pero de Hayuelas dozientos maravedís. A Joán Martínez, su hermano, çinquenta maravedís. A Álvaro trezientos maravedís. A Joán, hermano de Diego Pérez, çient maravedís. A Lorigo dozientos maravedís. A Martín de Roa dozientos maravedís. A Alfón de Palençia çien maravedís. A Rui Pardo dozientos maravedís. A Rui Pelas dozientos maravedís. A Fernán Tolas çien maravedís. A Joán, hermano de García Pérez, çien maravedís. A Antón çien maravedís. A Joán Gallego quinientos maravedís. A Martín Garçía trezientos maravedís. A Sancha Ruiz trezientos maravedís. A doña Sancha, nuestra hermana tres mil maravedís, en lo que ella se más pagaren, en pan o en heredamientos, y que haga cantar una capellanía perpetua por nuestra alma. Otrosí, tenemos por bien, que aquellos a quien nos mandamos algo, por non bien que les non den mal y lo al que fincare, que lo den a los otros criados que nos siruen, a cada vno segun su mereçimiento y a pobres por nuestra alma. Otrosí, mandamos (f.26r) que tomen quenta de los nuestros mayordomos y de los nuestros caseros y a los que hallaren que siruieron bien, que les den galardón, quinientos maravedís, o según su mereçimiento, y a los otros que alcançaren algo, que ge lo fagan dar, y que les den carta de quitamiento desde el día que algo ouieron de uer por nos, fasta la postrimera quenta, y lo que finca sobre cada vno por la quenta, que lo pague. Y las armas que las vendan y las den para cumplir aquellos que nos mandamos, y los tres lorigones que tomaron prestados que los den a sus dueños. Otrosí, mandamos, que la nuestra instituta y la nuestra suma del ditar, que la den a Romer Garçía y que se aproueche della en su vida, después que 
las torne a la iglesia de Osma, con aquella condiçión que dexamos los otros nuestros libros. Otrosí, mandamos que los libros que tiene de nos Fernán Áluarez, nuestro hermano, en guarda, que los demanden a doña Elvira, su muger, y los den a la iglesia de Santo Antolín de Palençia. Otrosí, mandamos, que todas las vestimentas que nos compramos o que nos dieron para la nuestra capiella, que las den a las nuestras capellanías, que dexamos en la yglesia de Osma, y si no ouiere abondo, que les conpren todo lo que ouieren menester, y dos cáliçes de plata, el vno para la capiella de San Pero y el otro, para la capiella de Sancta Catalina. Los libros y las vestimentas que nos fallamos de la iglesia, que finque todo al nuestro susçesor o al que sea dado, allí do nos mandamos. Otrosí, mandamos la nuestra cama al ospital de la iglesia de Osma, saluo la nuestra colcha de seda, que dexan para las espaldas del altar de San Pero. Y todos los paños de nuestro cuerpo que los den a clérigos pobres vergonçosos o que entendieren que mejor se emplearan y que fagan que ellos canten, las misas que pudieren, por nuestra alma. Y mandamos que vendan todo el nuestro pan y vino y ganado y bestias y sortijas de oro y donas y armas y aues y todo lo al que nos auemos, para cumplir todo lo que nos mandamos en este testamento y lo que fincare, que lo den a los pobres por Dios. Y mandamos a Joán Díaz, arçipreste de Coruña, nuestro capellán, mil maravedís y a Fernán Núnez, físico, nuestro amigo, dos mil maravedís. A Pablos, çien maravedís y a Domingo Yáñez, nuestro cozinero, çinquenta maravedis y a Antón Cleymente, nuestro carniçero, çinquenta maravedís. Otrosí, tenemos por bien y mandamos, que Domingo Pérez, sacristán de la yglesia de Osma, que sea testamentario con los dichos Pero Díaz y Joán Núñez, nuestros testamentarios, y que todos en vno o los dos, con otorgamiento del terçero, fagan y cumplan todo lo que nos mandamos en este testamento, y mandámosle, mil maravedís. Y mandamos, al monesterio de Avia, lo que nos auemos en Rebiella y en Payo y en Bastones, y ellos que hagan carta de cantar una capellanía perpetua por nuestra alma. Y mandamos la nuestra casa de Villagonçalo, con todo quanto derecho en ella auemos, y con quanto auemos en Villa Soña muy bien, viñas, eredamientos y vasallos, guertas, y lo de San Mamés, y todo lo que auemos en terra de Aguilar, a la yglesia de Osma en tal manera, que lo aya el obispo que fuere, por tiempo, y después de nuestra muerte, que lo non den a ninguno aquellos que lo ouieren, fasta que, en la iglesia de Osma aya electo confirmado, que ge lo entreguen. Y 


\section{LA ABADÍA DE SANTA MARÍA DE HUSILLOS: ESTUDIO Y COLECCIÓN \\ DOCUMENTAL $(904-1608)$}

mandamos que den dos açores al abad de Aruas, badarra y el torçuelo mudado, y el cauallo que fue de Fernán Áluarez que lo ynbíen a doña Eluira y que le den dozientos maravedís para dar por su ánima. De eso que ouiere en Villagonçalo, a Garçía Pérez Çeuadon, denle una bestia que y ouiere, de siella o azémila de las mejores, y las mías mulas, amas, que las vendan para dar por nuestra alma. Y den el açor que fue de Joán Fernández de Rojas, a Fernán Tiváñez y el otro açor, que fue de Gonçalo Ruiz de Toledo que lo den a Alfón Pérez, portero, por el suyo, que mandamos dar a Fernán Ruiz de Saldaña, y den más al dicho Fernán Ruiz, vn cauallo y mil maravedís y a Pero Padiella dozientos maravedís. Al ynfante dozientos maravedís. A Pero de Enzinas çinquenta maravedís. A Ferrandillo el Chiquillo çien maravedís (f.26v). A Gonçalo Falcon, nuestro criado, dozientos maravedís. A Pero Martínez Enzinas Falcon dozientos maravedís. A Andrés Pérez, nuestro criado, dozientos maravedís. Den a doña Vellida, judía de Valladolid, mil maravedís que nos prestó.

Y porque esto sea firme y no venga en duda, mandamos sellar este testamento con nuestro sello de çera, colgado en testimonio de verdad. Y rrogamos a Fernán Alfonso, escriuano público del conçejo de Valladolid, que pusiese en este testamento su signo. Testigos que estavan presentes, llamados señaladamente para esto: Pero Domínguez, sacristán de Fusiellos. Ferrán Núnez, físico. Pero Garçía, capellán. Rodrigo Rojas, Pero Tornero, Domingo Abbad, clérigos del obispo. Garçía Pérez Çevadero. Alfón Pérez, fijo de Ruy Pérez. Alfonso Núnez, fi de don Miguel.

Fecho este testamento y otorgado miércoles, catorze días de novienbre, era de mil y trezientos y treynta y quatro anos; y está escrito entre los rrenglones do dize: “en Roma y no le enbargue”. Yo Fernán Alfón, el dicho escrivano, fize fazer este testamento por mandado del dicho señor, y fui presente quando otorgó todo aquello que se en él contiene y fize en el este mío signo en testimonio. Fernán Martínez. Yo, Pero Garçía, capellán, so testigo. Yo, Alfón Pérez, so testigo. Yo, Alfón Martínez, so testigo. 
1297, septiembre, 12. Alcañices

Fernando IV confirma un mandato de Alfonso X (1268, marzo, 8), inserto, por el que ordena a los habitantes de Pajares y San Adrián, que habian emigrado a otros lugares, vuelvan a sus lugares de origen, bajo pena de perder sus posesiones en favor de Santa María de Husillos. Hace extensible este mandato a los habitantes de Cilleruelo.

B. APA, $L P H$, ff. $47 \mathrm{v}-48$ r. Inserto en traslado de la confirmación de Alfonso XI, dada en Valladolid a 24 de enero de 1318. Véase doc. núm. 101.

C. BN, ms. 705, ff. 76v-79r.

Sepan quantos esa carta vieren commo yo, don Fernando, por la graçia de Dios rrey de Castilla y de Toledo y de León y de Galizia de Seuilla, de Córdoua, de Murçia, de Jaén, del Algarbe, y sennor de Molina, vi vna carta del rrey don Alfonso, mi abuelo, que Dios perdone, fecha en esta guisa:

(Sigue doc. núm. 76)

Y yo, el sobredicho rrey don Fernando, con consejo y con otorgamiento de la rreyna donna María mi madre y del infante don Enrrique, mío tío y mío tutor, confirmo esta carta y mando que vala en todo tiempo ansí como en ella dize, y defiendo firmemente que ninguno non sea osado de yr ni de pasar contra ella en ninguna cosa, ca qualquier que lo fiziese pecharme y a en pena çien maravedís de la moneda nueva, y al abad y al cabildo y a quien su boz toviese todo el danno que por ende rreçibiesen doblado

Y porque el cabildo de Fusiellos enbiaron dezir que Çilleruelo es suyo, que es yerma esta aldea, por esta rrazón mando que ayan esta franqueza que an estos otros lugares sobredichos. Y desto les mando dar esta mi carta sellada con mío sello colgado.

Dada en Alcañizes, doze días de setienbre era de mil y trezientos y treynta y çinco annos. Yo, Gil Gonçález, la fize escreuir por mandado del rrey y del ynfante don 
Enrrique, su tutor. Gutierre Pérez. Gonçalo Pérez. Rui Pérez. Joán Garçía. Garçi Pérez.

1298, marzo, 19, miércoles. Palencia

Traslado sacado por Martín Ruiz, notario público de Palencia, a petición de Domingo Pérez, canónigo de Santa María de Husillos, de una sentencia confirmada por Fernando III (1234. Haza) del pleito habido entre, de una parte, el abad y el cabildo de Santa María de Husillos, y de la otra, Pedro González de Marañón, por la que se reconoce el derecho de los primeros sobre Hoyales de Roa y Fuentelisendo, aldeas de Haza, que habian sido donadas por Gonzalo Pérez, abad de Husillos.

A. AHDP, Ampudia y Abadía de Husillos, Pergaminos, carp. 211-13. Perg., 393 x 206 mm.; escr. gótica documental; regular conservación.

Comete algunos errores sin importancia en el traslado de los confirmantes.

Sepan quantos esta carta vieren, commo miércoles, diez et nueue días de março, era de mille e CCC e XXXVI annos. Ante / mí, Martín Royz, público notario de la çipdat de Palençia, et ante las pesquisas de yuso escriptas, rrogadas para esas a[...]çio / vna carta escripta en pargamino et sseellada con sseello de çera colgado et en el qual sseello auía, del un cabo, figura del $\beta^{\beta}$ rrey que estaua en sso cauallo, el cuerpo et el cauallo armado. Et las sseñales de las armas eran a castiellos et a leones, et las / letras de derredor dizíen: "Ferrandus Deii gratia rrex Castelle et Toleti". Et del otro cabo auía quatro figuras, las dos de / castiellos et las dos de leones, et las letras de derredor dizíen: "ssigillum Ferrandus rrex Legionis et Galleçie". Et el te/ $/ 6$ nor de la qual carta era ffecho en esta manera:

(Sigue doc. núm. 57) 
Este traslado ffue fecho en el día / et en la era de ssuso escriptos. Pesquisas: Diego Pérez et Fernando Díez, escriuanos; don Gómez de Uillalobón; don / Gonçalo, torreonero; don Yánnez, yerno de Iohán Díaz de Potes, uezinos de Palençia.

Et yo, Martín Royz, nota $/{ }^{54}$ rio sobredicho, a rruego de Domingo Pérez, canónigo de Fusiellos, fiz este traslado de la dicha carta de nostro ssennor / el rrey don Fernando, que Dios perdone, et pus en él mío sig(signo)no en testimonio.

1301, febrero, 3. Letrán.

Litterae gratiosae de Bonifacio VIII, concediendo a García Pérez el beneficio prebendado de abad de Husillos en la iglesia de Palencia, vacante por haberlo dejado libre su antiguo titular, Pedro Rodríguez Hispano, al ser nombrado obispo de Burgos. Se especifica que el nuevo abad de Husillos podrá mantener otros beneficios que ya tenía: capellán de San Acisclo de Pontuelles, en la diócesis de Oviedo, canónigo de Salamanca, canónigo de Oviedo, beneficiado de Palencia, y con rentas en la diócesis de Sevilla y el priorato agustino de Bénévent-l'Abbaye, en la diócesis de Limoges (Francia); aunque deberá renunciar a una "porción" que ya tenía en la propia catedral palentina.

B. AHV, Reg. Vat. 50, f. 11v, núm. 40.

ED. DOMÍNGUEZ SÁNCHEZ, Bonifacio VIII, 783-783, núm. 778.

REG. DIGARD - FAUCON - THOMAS, Boniface VIII, III, cols. 27-28, núm. 3965, editando unas pocas líneas.

CIT. MANSILLA, El cardenal, 247. 


\section{LA ABADÍA DE SANTA MARÍA DE HUSILLOS: ESTUDIO Y COLECCIÓN \\ DOCUMENTAL $(904-1608)$}

[Bonifatius episcopus, seruus seruorum Dei, dilecto filio] Carsie (sic) Petri, canonico ecclesie palentine ac abbati secularis ecclesie Fussellensis in ipsa ecclesia palentina, [salutem et apostolicam benedictionem].

Apostolice Sedis benignitas personis benemeritis libenter dexteram sue prouisionis extendit, ut per hoc nedum persone ipse, set etiam alie ipsarum exemplo ad uirtutum studia fortius animentur. Cum igitur in ecclesia palentina canonicatus et prebenda necnon abbatia secularis ecclesie Fussellensis, quos venerabilis frater noster Petrus, burgensis episcopus, olim canonicus palentinis eet abbas Fussellensis in ipsa palentina ecclesia, promotionis sue tempore, obtinebat, per promotionem huiusmodi post consecrationis munus apud Sedem Apostolicam de mandato nostro impensum eidem, uacauisse noscantur, et nullus preter nos canonicatum, pre/bendam et abbatiam eosdem conferre potuerit, constitutione felicis recordationis Clementis, Pape IIII ${ }^{\mathrm{ti}}$, super dignitatibus et personatibus, canonicatibus et prebendis et aliis beneficiis eclesiasticis apud Sedem ipsam uacantibus per Romanum dumtaxat Pontificem conferendis edita obsistente, pro eo quod nos canonicatum et prebendam et abbatiam predictos, ante lapsum temporis statutum per moderationem pie memorie Gregorii, Pape X, predecessoris nostril, super hoc adhibitam in Generali Concilio Lugdunensi, collationi nostre et Sedis eiusdem duximus reseruandos, et decreuimus irritum et inane si super hiis secus a quoquam, scienter uel ignoranter, contingeret attemptari; nos, uolentes tibi, quid apud nos de honestate morum, conuersatione uite laudabilis et aliarum probitatum meritis fidedignorum testimonio comendaris, huiusmodi tuis exigentibus meritis, gratiam facere specialem, canonicatum, prebendam et abbatiam eosdem sic uacantes, cum plenitudine Iuris canonici et omnibus iuribus et pertinentiis suis, apostolica tibi auctoritate conferimus, et de illis etiam prouidemus, decernentes prout est irritum et inane si super hiis secus a quoquam, scienter uel ignoranter, attemptatum est hactenus uel attemptari contigerit in futurum; non obstantibus quibuslibet ipsarum ecclesiarum contraries consuetudinibus uel statutes, iuramento, confirmatione apostolica uel quacumque alia firmitate uallatis; seu si aliqui nostra uel predecessorum nostrorum Romanorum Pontificum, uel alia quauis auctoritate, in ipsa palentina ecclesia in canonicos sint recepti, uel ut recipiantur insistant; uel si super prouisionibus sibi faciendis de personatibus, dignitatibus, canonicatibus et prebendis, uel aliis 
beneficiis eclesiasticis in ipsis ecclesiis specialiter, uel in illis partibus generaliter, prefate Sedis, uel legatorum eius, litteras impetrarunt, etiam si ad inhibitionem, reseruationem et decretum uel alias quomodolibet sit earum auctoritate processum, quibus omnibus in assecutione predictorum canonicatus, prebende et abbatie te uolumus anteferri; seu si venerabili fratri nostro episcopo Palentino et dilectis filiis capitulis predictarum Palentine et Fussellensis ecclesiarum, uel aliquibus aliis, communiter uel diuisim, ab eadem sit Sede indultum quod ad receptionem uel prouisionem alicuius minime teneantur, et ad id compelli non possint, et quod de dignitatibus, personatibus, canonicatibus et prebendis uel beneficiis ad eorum collationem, electionem uel quamcumque dispositionem spectantibus nulli ualeat prouideri per litteras apostolicas non facientes plenam et expressam, ac de uerbo ad uerbum, de indulto huiusmodi mentionem; et qualibet alia ipsius Sedis indulgentia, generali uel speciali, cuiuscumque tenoris existat, per quam effectus presentium impediri ualeat uel differri, et de qua cuiusque toto tenore de uerbo ad uerbum in nostris litteris habenda sit mention specialis; aut si presens non fueris ad prestandum [de obseruandis statutis et consuetudinibus ipsarum Palentine et Fussellensis ecclesiarum solitum iuramentum, dummodo in absentia tua per procuratorem ydoneum, et cum ad easdem ecclesias accesseris corporaliter] illud prestes; siue quod parocialem ecclesiam Sancti Aciscli de Pontuebles, Ouetensis dioceses, cuius curam geris perpetuus capellanus qui pro tempore instituitur in eadem, et in Salamantina ac Ouetensi canonicatus et prebendas cum prestimoniis, necnon in ipsa Palentina, cuius portionarius existis, quamdam portionem, ecclesiis, et in diocesi Ispalensi quandam aliam portionem ecclesiasticorum prouentuum, nosceris obtinere, et in prioratu de Benauento, Ordinis sancti Augustini, Lemouicensis diocesis, quandam percipis annuam pensionem. Tecum insuper, ex uberioris dono gratie, dispensamus ut abbatiam predictam licite supradictis retinere libere ualeas, constitution Generalis Concilii et qualibet contraria non obstante; prouiso quod abbatial et ecclesia Sancti Aciscli, canonicatus, prebende, prestimonia et portiones huiusmodi debitis non fraudentur obsequiis, et animarum cura in eis, quibus illa imminet, nullatenus negligatur. Volumus autem quod postquam eosdem canonicatum, prebendam et abbatiam, cum iuribus et in ipsa Palentina ecclesia obtines, et quam ex tunc uacare decernimus, omnino dimittere tenearis. Nulli ergo [omnino hominum liceat hanc 
paginam] nostre collationis, prouisionis, constitutionis, dispensationis, uoluntati et decreti [infringere, uel ei ausu temerario contraire. Si quis autem hoc attemptare presumpserit, indignationem omnipotentis Dei et beatorum Petri et Pauli, apostolorum Eius, se nouerit incursurum].

Datum Laterani, III nonas februarii, [pontificatus nostril] anno septimo.

1301, julio, 23, domingo. Palencia.

El abad de Husillos, Garci Pérez, reconoce el derecho del cabildo de la catedral de Palencia de designar personas para cobrar las medias annatas de la citada abadía, esto es, la mitad de los frutos del primer año de la dignidad abacial y de los prestameros, según estatuto establecido anteriormente y que era general para toda la diócesis palentina; y autoriza para que designe persona que las cobre, como el estatuto establecía y anteriormente se había hecho.

A. ACP, Arm. III, leg. 13, doc. 3. Perg., 395 x 255 mm; escr. de albalaes; buena conservación.

Sepan quantos esta carta vieren, commo sobre contienda que era entrel cabildo de la eglesia de Palencia de la vna parte, e de mí, Garçi Pé/rez, abbat de Fusiellos de la otra, por rraçón que el dicho cabildo quería poner ombres en la dicha abbadía de Fusiellos para recabdar / la meatad de los ffructos de la dicha abbadía. La qual meatad deue auer el cabildo de la dicha abbadía por tiempo del statuto iu/rado que es en la eglesia de Palençia, en que dize que el cabildo deue auer e rreçebir por sí, la meatad de todos los préstamos e de todas / las abbadías que vacaren en la eglesia de Palençia el primero anno que les recibiere aquel a quien fueren dados los préstamos e las abadías. Que / porque yo dizía que no deuíe y poner el ombre para recabdar la dicha meatad porque me fizieron entender que nunca quel y pusieran en meatad / de los míos antecessores que fueron abbades antes que yo, yo, el dicho abbat, porque fallé en bona uerdat que el dicho 
cabildo pusieron siempre / ombres después que fue fecho el statuto en la dicha abbadía para recabdar la meatad sobredicha, assí como dize el estatuto, otorgo que los / deuen y poner agora en el mío tiempo e adelante quando se acaesçiere para recabdar la dicha meatad.

Et porque esto sea firme e non venga / en dubda, yo, dicho abbat, pongo conuusco el dicho cabildo de seellar esta carta con mío seello pendente quando lo uiere de la dicha / abbadía. Et esto fue fecho en el cabildo de la eglesia de Palençia, tocada la campana a cabildo, assí como es vso e costumbre, estando / presentes las personas e los canónigos e los companneros de la dicha eglesia, aquellos que pudieron y quisieron y seer.

Otrosí fueron presentes / a esto que sobredicho es en el dicho cabildo, Pero Diaz? [...] sacristán, e Alffonsso Rodríguez, chantre, e los otros canónigos / companneros que están presentes en la eglesia de Fusiellos.

Que ffue fecho e sabido en bona uerdat en el dicho cabildo, sábbado, veynte e / dos días de iulio, anno Domini millesimo treçentesimo primero.

Esta carta sobredicha fue oyda en el cabildo de la eglesia de Palen/çia, domingo, XXIII días de iulio, anno Domini millesimo $\mathrm{CCC}^{\mathrm{o}}$ primero, seyendo y ayuntados sobresta rraçón sobredicha, personas e canónigos / rraçioneros, e en presençia de mí, Iohán Domínguez, público notario de la cibdat de Palençia, con los canónigos e rraçioneros e / todos racioneros de Palençia e de Fusiellos que y seyen presentes.

Don Garçi Pérez, abbat de Fusiellos, otorgó todo quanto en es/ta carta dize e dixo. Mas que él non auíe aún el su seello de la abbadía de Fusiellos e que a la fago que le ouiesse que la seellaría commo / dicho es, e que degara a mí, Iohán Domínguez, dicho notario, que escriuesse esto que dizíe.

Testigos presentes beneficiados en la eglesia / de Palençia e de Fusiellos: don Loppe Garçía de Torquemada, sacristán de Palençia e rraçionero de Fusiellos. E Ruy Gómez, / canónigo de Palençia e de Fusiellos. Ruy Pérez, sacristán de Fusiellos e canónigo de Palencia. E Bruno Díaz, canónigo de / Palençia e medio raçionero de Fusiellos. E Domingo Bartolomé, canónigo de Palençia e medio raçionero de Fusiellos.

Et yo, Iohán / Domínguez, notario sobredicho, fu present, e rrogado del dicho abbat, escreuí este estrumento e pus aquí mío $\operatorname{sig}($ signo $)$ no en testimonio / de 
verdat.

\section{6}

1302, mayo, 7, lunes. Palencia.

Sentencia pronunciada por García Ruiz, canónigo y vicario del obispo Álvaro Carrillo de Palencia, del pleito litigado por el cabildo de Santa María de Husillos con la iglesia de Santa Olalla de Paredes de Nava, por el derecho a los diezmos de Sahagún el Viejo, cerca de Paredes de Nava, y que se resolvió a favor del primero.

B. AHDP, Ampudia y Abadía de Husillos, Pergaminos, carp. 210-3. Perg., 336 x 242 mm.; escr. de albalaes; buena conservación con alguna mancha. Tiene cinta pendiente y restos de un sello de cera. Inserto en traslado sacado en Palencia, a 22 de febrero de 1321. Véase doc. núm. 102. C. APA, $L P H$, ff. 57r-58r. Traslado del traslado sacado en Palencia, a 22 de febrero de 1321. D. BN, ms. 705 , ff. 109r-111v.

In Dei nomine, amen. Sepan quantos esta carta vieren, como en el pleito de los diezmos de Sant Fagunt el Vieio, que es / cerca Paredes de Nava, entre el cabillo de la eglesia de Santa María de Fusiellos, de la una parte, et los clérigos et los terçeros de la eglesia de Santa Ola/ ${ }^{6} 11 a$, de Paredes de Naua; ante mí, Garçía Ruyz, canónigo et vicario general en los pleitos por el onrrado padre et ssennor don Áluaro, por la graçia de / [Dios] obispo de Palençia, ssobre que dize, el cabillo de la eglesia de Santa María de Fusiellos, que los diezmos de los heredamientos de Sant Fagunt el Viejo, que es cer/ca de Paredes de Nava, perteneçen a la eglesia de Fusiellos, de los quales diezmos, el cabillo desta dicha eglesia, fue en tenençia et es de muy gran $/{ }^{9}$ des tiempos a acá, que los dichos clérigos et terçeros les enbargan los diezmos, diziendo a los dezmeros et a los labradores que an a dar el diezmo, que ge lo non / den, el diezmo, al cabillo de Fusiellos. Et Martín Garçía, conpannero et procurador del dicho cabillo de Fusiellos, demandó a mí, vicario ssobredicho, que los manda/se por ssentençia, a 
los dichos terçeros, que non enbarguen los diezmos al dicho cabillo de Fusiellos et que ssi alguna cosa ende an leuado, que lo tornen con aque $/{ }^{12}$ lla pena que manda el derecho. Et Garçía, abbat procurador de los clérigos de la eglesia de Santa Olalla de Paredes de Naua, contestado el pleito, rrespondió et dixo: / "nego narrata pro ut narratur et dico presentata fieri non debere". Et Martín Garçía, ssobredicho procurador, dixo que lo quere prouar sso de iuramiento, assí como lo / pussiera en su demanda, por nombre del cabillo de Fusiellos. Et rreçebidas las pesquisas, que aduxo el dicho Martín Garçía, a prouar su entençión et publicadas et $\mathrm{pu} /{ }^{15}$ esto plazo a los dichos procuradores, que dixiesen todo lo que quissiesen dezir et rrazonar en este pleito. Et los procuradores del / cabillo de Fusiellos et de los clérigos de Santa Olalla, contruxieron tal pleito et demandaron a mí, muy affincadamiente, que diesse la / ssentençia en este pleito, ssegunt ffallasse de derecho. Ende yo, Garçía Ruyz, vicario sobredicho, vista la demanda et las partes, que adu $/{ }^{18}$ xo el dicho Martín García, procurador, a prouar ssu entençión et las rrazones de la una parte et de la otra parte, ençerradas, auido conssejo de / ssabios, definiendo, pronunçio que el dicho Martín Garçía, procurador, prouó su entençión, ende, por diffinitiua sentençia, iuzgo los diezmos / de los heredamientos de Sant Fagunt el Viejo, cerca de Paredes de Naua, que pertenecen a la eglesia de Santa María de Fusie/ ${ }^{21} 1$ los, también por tenençia como por possesión. Et deffiendo a los clérigos et a los terçeros de Santa Olalla de Paredes de Naua, et mán/doles, que daquí adelantre, non enbarguen los dichos diezmos de los heredamientos de Sant Fagunt el Viejo, al cabillo et a la eglesia / de Santa María de Fusiellos. Et si alguna cosa ende al leuado ffasta aquí, que ge lo den al cabillo sobredicho. Et las despesios $/^{24}$ taxadas por mí et iuradas por el dicho Martín Garçía, procurador, condepno los clérigos de la eglesia de Santa Ollalla de Paredes de Nava et / a ssus procuradores en dozientos et cinquenta marauedís, et mando que den estos dozientos et cinquenta marauedís al cabillo de Fusiellos et a / ssus procuradores, ffasta el día de Sant Iohán de los Arcos, primera fiesta que viene.

Et porque esto ssea firme et non venga en dubda, $/^{27}$ ffize poner el sseello de la vicaría en esta carta desta ssentençia, en testimonio de verdat.

Fecha en Palençia, en las cassas de / nuestro sseñor el obispo, lunes, ssiete días de mayo, por nos, Iohán Garçía et Fernand Ruiz, escrivanos de los autos en la corte 
de nuestro / ssennor el obispo de Palençia, anno Domini millesimo CCC secundo. Pesquissas que estauan presentes a esto: Iohán Guillén, canónigo de Palençia, et Aluar ${ }^{30}$ Pérez, canónigo de Valladolit, et Guillén Pérez, auogado, Gonçalo Ruyz, capellán de Sant Yllán, et Pasqual Pérez, ome de Fernand Ruyz, mo/radores en Palençia. Et yo, Iohán Garçía, sobredicho escriuano, que ffui pressente a todo et lo escriuí con mi mano. Iohán Garçía scripsit.

1305, mayo, 10, lunes. Medina del Campo.

Fernando IV confirma un privilegio de Sancho IV (1290, julio, 31. Valladolid), inserto, que a su vez confirma los siguientes privilegios.

- Privilegio de Urraca I (1114, mayo, 28), inserto, por el que concede a Santa María de Husillos, Villaldavín y la pesquera de Deronnada.

- Privilegio de Sancho III (1158, mayo, 4. Carrión de los Condes), inserto, por el que confirma las posesiones que Santa María de Husillos recibió de Urraca I, los condes de Monzón y otros particulares.

- Privilegio de Sancho III (1158, junio, 28, Cuéllar), inserto, por el que confirma el coto de Santa María de Husillos, que él mismo había donado.

- Privilegio de Alfonso VIII (1178, agosto, 15. Carrión de los Condes), inserto, por el que confirma a Santa María de Husillos, las villas, heredades y monasterios donadas por Urraca I, Sancho III, Fernando Ansúrez, Gonzalo Ansúrez y Nuño Ansúrez, condes de Monzón, y otros donantes.

- Privilegio de Alfonso VIII (1178, agosto, 15. Carrión de los Condes), inserto, por el que confirma a Santa María de Husillos el coto que donó Sancho III, su padre.

En esta confirmación, de privilegios anteriores, podemos observar algunas variaciones importantes respecto a los primitivos originales: 


\section{DAVID MARCOS DIEZ}

En el primer documento, las cuartas nonas se han convertido en quintas. En el segundo, el mes de "iunii" se ha cambiado por "iulii". En el cuarto, al abad Pero de Cardona se le apellida de Córdova.

A. AHDP, Ampudia y Abadía de Husillos, Pergaminos, carp. 199-19. Perg., 684 x 631 mm.; escr. gótica redonda de privilegios y de albalaes; buena conservación; sello pendiente de plomo. Al final de la primera línea, la $\mathrm{F}$ y la $\mathrm{E}$ del nombre FERNANDO, están marcadas pero sin miniar.

B. AHDP, Ampudia y Abadía de Husillos, Pergaminos, carp. 200-21. Perg., 784 x 638 mm.; escr. gótica redonda de privilegios y precortesana. Su conservación no es muy buena, pero se puede leer perfectamente. Se conserva el sello de plomo pendiente de una cuerda. Inserto en confirmación de Pedro I del privilegio de Alfonso XI, dada en Valladolid, a 28 de noviembre de 1351. Véase doc. núm. 135.

C. AHDP, Ampudia y Abadía de Husillos, Pergaminos, carp. 201-23. Perg., 714 x 608 mm.; escr. gótica de privilegios y precortesana; regular conservación, aunque las roturas y manchas permiten su perfecta lectura. Inserto en confirmación de Enrique II del privilegio de Alfonso XI, dada en Valladolid, a 20 de mayo de 1371. Véase doc. 163.

D. AHDP, Ampudia y Abadía de Husillos, Pergaminos, carp. 201-27. Perg., 784 x 685 mm.; escr. gótica de privilegios y precortesana. Muy deteriorado, ha desaparecido, prácticamente, toda su parte izquierda. No conserva sello ni cuerda. Inserto en confirmación de Juan I del privilegio de Enrique II, dada en Burgos, a 22 de agosto de 1379. Véase doc. núm. 193.

$E$. APA, $L P H$, ff. 43r-46r. Traslado de $A$.

$F$. APA, $L P H$, ff. $74 \mathrm{v}-78 \mathrm{r}$. Traslado de $B$.

$G$. APA, $L P H$, ff. 88v-92r. Traslado de $C$.

$H$. APA, $L P H$, ff. $104 \mathrm{r}-108 \mathrm{v}$. Traslado de $D$.

I. AGS, Patronato eclesiástico. Inconexos, leg.159, ff. 52r-58v. Papel; escr. procesal; buena conservación. Traslado de $E$.

$J$. BN, $m s .705$, ff. 70v-76v. Traslado de $E$.

$K$. BN, $m s .705$, ff. 155r-166r. Traslado de $F$.

$L$. BN, $m s .705$, ff. 196v-201r. Comete numerosos errores. Traslado de $G$.

M. BN, $m s .705$, ff. 231v-238r. Traslado de $H$.

$N$. APA, Caja 152, Carpeta 1. Papel; 5 hojas; primera mitad siglo XVIII. Traslado de $E$.

Ñ. ARCHV. Salas de lo Civil. Masas (F). Caja 2787.1, ff. 51r-54r. Solamente se traslada el protocolo inicial, dispositivo, cláusulas y protocolo final. Traslado de $A$, aportado como prueba en un pleito fenecido (1774) de la colegiata de Ampudia con el concejo de Husillos por la posesión de ciertas heredades.

ED. CORIA COLINO - FRANCIA LORENZO, Reinado de Fernando IV, 171-182, núm. 27.

(Christus, alfa et omega). En el nonbre del Padre et del Fiio et del Espiritu Sancto, que son tres personas et vn Dios; et de la bien auenturada Uirgen gloriosa 
sancta María su madre; et a onrra et a seruicio de todos los sanctos de la corte çelestial. Queremos que sepan por este nostro priuillegio los ombres que agora son et serán daquí adelante, commo nos, don / Fernando, por la graçia de Dios, rrey de Castiella, de Toledo, de León, de Galizia, de Seuilla, de Córdoua, de Murçia, de Iahén, del Algarbe, et sennor de Molina, viemos un priuillegio del rey don Sancho, nostro padre, que Dios perdone, fecho en esta guisa.

\section{(Sigue doc. núm.82)}

Et nos, el sobredicho rrey don Fernando, por fazer bien et merçet a Garçía Pérez, abbat de Fusiellos, nostro clérigo, et a la su yglesia, otorgamos este priuillegio et confirmámoslo. Et mandamos que uala / et le sea guardado en todo segunt que lo mejor et más conplidamientre fue en tiempo de los otros rreyes onde nos uenimos, et en el nostro, fasta aquí.

Et defendemos firmemientre que ninguno non sea osado de passar contra él. Ca qualquier que lo fiziesse, auería nostra yra et pecharnos y a en coto, diez mille marauedís de la moneda nueua, et al abbat et a su ${ }^{42}$ yglesia todo el danno et menoscabo que por ende rreçibiessen doblado.

Et porque esto sea firme et estable, mandamos seellar este priuillegio con nostro seello de plomo. Fecho en Medina del Canpo, lunes, diez días de mayo, era de mille et trezientos et quarenta et tres annos.

Et nos, el sobredicho rrey don Fernando, rregnan/te en uno con la rreyna doña Costanca, mi muger, en Castiella, en Toledo, en León, en Galizia, en Seuilla, en Córdoua, en Murçia, en Iahén, en Baeça, en Badaioz, et en el Algarbe, et en Molina, otorgamos este priuillegio et confirmámosle./

Don Mahomat Abenaçar, rrey de Granada, vasallo del rrey, conf. Don Iohán, tío del rrey, conf. El infante don Pero, hermano del rrey, conf. El infante don Felipe, hermano del rrey, conf. El infante don Alfonso de Portogal, vasallo del rrey, conf. ${ }^{45}$

Don Gonçalo, arçobispo de Toledo, primado de las Espannas et chanceler mayor del rrey, conf. La eglesia de Santiago, vaga. Don Fernando, arçobispo de Seuilla, conf. / 
( $1^{a}$ col.) Don Pero, obispo de Burgos, conf.- Don Áluaro, obispo de Palençia, conf.- Don Iohán, obispo de Osma, conf.- Don Rodrigo, obispo de Calahorra, conf.- Don Simón, obispo de Siguença, conf.- Don Pasqual, obispo de Cuenca, conf.- Don Fernando, obispo de Segouia, conf.- Don Pero, obispo de Áuilla, conf.- Don Domingo, obispo de Plazençia, conf.- Don Martino, obispo de Cartagena, conf.- Don Antón, obispo de Aluarrazín, conf.- Don Garçía, obispo de Iahén, conf.- Don Fernando, obispo de Córdoua, conf.- Don frey Pero, obispo de Cádiz, conf.- Don Garçi López, maestre de Calatraua, conf.- Don Garçi Pérez, prior del Hospital, conf.

( $2^{a}$ col.) Don Fernando, fiio del infante don Fernando, conf.- Don Iohán, fiio del infante don Manuel, conf.- Don Alfonso, fiio del infante de Molina, conf.- Don Iohán Núnnez, adelantado mayor de la frontera, conf.- Don Iohán Alfonso de Haro conf.- Don Fernán Royz de Saldaña conf.- Don Arias Gómez de Çisneros conf.- Don Garçi Ferrández de Uilla Mayor conf.- Don Diego Gómez de Casteñada conf.- Don Pero Núnnez de Guzmán conf.- Don Iohán Ramírez, sso hermano, conf.- Don Alfonso Pérez Guzmán conf.- Don Roy Gómez Maçanedo conf.- Don Garçi Fernández Marrique conf.- Don Lope de Mendoça conf.- Don Rodrig Áluarez de Aça conf.- Don Gonçal Iuanez de Aguillar conf.- Don Per Anrríquez de Harana conf.- Sancho Sánchez de Uelasco, adelantado mayor de Castiella, conf.

\section{(Signo rodado)}

- Primer círculo concéntrico:

(cruz). DON DIAGO, SENNOR DE VIZCAYA, ALFIÉREZ DEL RREY, CONFIRMA. DON PERO PONZ, MAYORDOMO DEL REY, CONFIRMA.

- Segundo círculo concéntrico:

(cruz). SIGNO DEL REY DON FERNANDO.

- Acuartelado con los escudos de Castilla y León.

( $3^{a} \mathrm{col}$.) Don Gonçalo, obispo de León, conf.- Don Fernando, obispo de Ouiedo, conf.- Don Alfonso, obispo de Astorga et notario mayor del rregno de León, conf.- Don Gonçalo, obispo de Çamora, conf.- Don frey Pero, obispo de 
Salamanca, conf.- Don Alfonso, obispo de Çibdad, conf.- Don Alfonso, obispo de Coria, conf.- Don Bernaldo, obispo de Badajoz, conf.- Don Pero, obispo de Orens, conf.- Don Rodrigo, obispo de Mendunnedo, conf.- Don Iohán, obispo de Tuy, conf.- Don Rodrigo, obispo de Lugo, conf.- Don Iohán Osórez, maestre de la cauallería de la Orden de Santiago, conf.- Don Gonçalo Pérez, maestre de la Orden de Alcántara, conf.

( $4^{a} \mathrm{col}$.) Don Sancho, fiio del infante don Pero, conf.- Don Pero Ferrández, fiio de don Fernán Rodríguez, conf.- Don Fernán Pérez Ponz conf.- Don Lope Rodríguez de Uilla Lobos conf.- Don Roy Gil, sso hermano, conf.- Don Iohán Ferrández, fiio de don Iohán Ferrández, conf.- Don Alfonso Ferrández, sso hermano, conf.- Don Fernán Ferrández de Limia conf.- Don Arias Díaz conf.- Don Rodrig Áluarez conf.- Don Diego Ramírez conf.- Bernar Gutiérrez Quexada, adelantado mayor en tierra de León et en Asturias, conf.

Fernán Gómez, notario mayor del rregno de Toledo, conf.

( $5^{a}$ col.) Don Tel Gutiérrez, justiçia mayor en casa del rrey, conf. Diego Gutiérrez de Çauallos, almirante mayor de la mar, conf. Pero López, notario mayor de Castiella, conf.

Alfonso Díaz, notario mayor del Andaluzía, conf.

Maestre Gonçalo, abbat de Aruas, lo mandó fazer por mandado del rrey. Yo, Per Alffonsso lo ffiz escriuir en el anno onzeno que el rrey don Fernando rregnó.

Maestre Gonçalo, conf. Gil (...)? (rúbrica). Pero Gómez. (rúbrica) Fernán Pérez (rúbrica). (rúbrica) Alffonso Royz (rúbrica).

En esquina inferior izquierda: de Fussiellos. 
1306, mayo, 10, jueves.

Avenencia entre, de una parte, Santa María de Husillos y el concejo de Husillos, y de otra parte, el concejo de Fuentes de Valdepero, sobre términos, pastos y otras cuestiones.

A. AHDP, Ampudia y Abadía de Husillos, Pergaminos, carp. 210-2. Carta partida por A,B,C. Perg., 282 x $294 \mathrm{~mm}$; escr. de albalaes. Regular conservación con una rotura que afecta a las líneas 27 y 28, además de varias manchas que impiden parcialmente su lectura.

$B$. APA, $L P H$, f. $46 \mathrm{r}-\mathrm{v}$. Al finalizar el documento: $<$ Esta escritura por estar rota y muchas partes della que no se pudieron leer, no se signó>.

ED. CORIA COLINO - FRANCIA LORENZO, Reinado de Fernando IV, 184-187, núm. 29.

CIT. FRANCIA LORENZO, Pleito entre Husillos y Fuentes de Valdepero, 2.

El día 10 de mayo de 1306 fue martes y no jueves. Véase A. GIRY, Manuel de Diplomatique. La letra dominical correspondiente a 1396 es la B, y la Pascua cayó el 3 de abril.

In Dei nomine, amen. Sepan quantos esta carta uieren e oyeren, commo yo, Fernán Pérez, cassero dell abad de Fusellos, por nombre del sseñorío e del abad et / del cauillo de la yglesia de Santa María de Fussellos e el concejo deste mismo logar, todos llamados a cabildo e a conçejo, de la una parte. Et de uos, / Garçía, fijo de Iohán González, don Iohán de Palacio, e Pero Ferrández, merino de Lope Garçía, veçinos de Fuentes de Valle Pero, perssoneros del conçejo ssobre dicho de Fuentes, por $\beta$ nombre del dicho conçejo de Fuentes, cuyo poder nos tememos, de la otra parte. Otorgamos, amas las partes sobredichas, cada uno en la su rraçón, e conosçemos [...] / dicha sin condiçión ninguna que sobre rraçón de la contienda que era entre amos los dichos conçeios sobre rraçón de las pastos de los términos en que el cabildo e el conçejo sobredicho / de Fusiellos sobredicho diçía que auía en los términos e apartados en que los del dicho conçeio de Fuentes non auían de paçer. E otrosí que el conçejo de Fuentes que auían $/{ }^{6}$ término y apartado en que non auían de paçer los de Fussiellos. E por esta rraçón auiemos amos los 


\section{LA ABADÍA DE SANTA MARÍA DE HUSILLOS: ESTUDIO Y COLECCIÓN \\ DOCUMENTAL $(904-1608)$}

dichos conçeios e el cabildo sobredicho contienda en uno. Et por quitar / contienda e ssaber uerdad preguntamos e ssepamos en buena uerdad de ombres buenos antiguos de commo fue e commo ussaron otro tiempo los que eran moradores en los dichos conçejos e sson e / viéremos e ffallamos en verdad que siempre usaron de paçer el ganado de Fuentes en el término de Fusiellos e los de Fusiellos en término de Fuentes sin contienda ninguna $/ 9$ en los logares deffesados o coteados. Et pues nos, Fernán Pérez, e el cabildo e el conçejo de Fusiellos de la una parte e don Garçía e don Iohán e Pero Ferrández por nombre del dicho conçejo de / Fuentes de la otra parte fallamos esto que dicho es en verdad. Confirmamos e otorgamos que assy ussemos en ha delante fasta la fin del mundo por siempre iamás, e pazca el ganado / de Fuentes en todo el término de Fusiellos saluo en los sotos e en los uinbreros que sean deffessadas que non pasta e el ganado de Fuentes. E otrossy e pazça el ganado de Fusiellos $/^{12}$ en el término de Fuentes saluo ssy ouiere y prado coteado que ffue siempre usado e sin contienda ninguna. E otrosy que al tiempo que los de Fussiellos cotearen las uiñas que non entre el ganado / en ellas e eso mismo los de Fuentes e que al tiempo que qualquier cortejo de las dicha cortaren sus uiñas que lo ffagan saber all otro conçejo que lo serán que es corchado. E otrossí otorgamos e / ponemos postura que quando el ganado del un conçejo entrare en lo deffessado dell otro o en las uiñas de que ffueren coteadas que los querellosos que puedan de día degollar de la manada de que $/{ }^{15}$ el ganado que fuera o tomar una cabeça e ssi ffuere de noche que deguelle o tome çinco cabeças e que la otra parte non aya poder de lo demandar. E otrossí al tiempo que el ganado de Fussiellos / anduuiere en el término de Fuentes paçiendo e ffiçieren daño en panes o en uiñas o en otra cossa, que pechen el daño a qual qual (sic) rreçibo e que peche por cada manada de ganado merino un quintal de / uino, e por cada cabeça de ganado mayor dos nouenas a los del conçejo de Fuentes. E esto mismo sea quando el ganado de Fuentes andudiere en término de Fusiellos que estos derechos todos $/{ }^{18}$ ayan en ello los de Fussiellos. E otrossí otorgamos que quando el ganado de Fussiellos anduuiere en el término de Fuentes o lo de Fuentes en término de Fusiellos que ande seguro. Et / ssy algunos de los sseñores de esos logares o otros por ellos o el conçejo por rraçón que anda en ssu término el ganado dell otro conçejo alguna cossa les tomaren quier ganado quier otra cossa que / qual sea que el conçejo del 
término en que fuer tomado o del señorío que lo fiçiese que lo faga desatar o que lo peche todo al otro conçejo que rresoluiere al duenno sin entredicho ninguno. $\mathrm{E}$ más que al tiempo $/^{21}$ que el ganado dell un conçejo andudiere en el término del otro conçejo e los ueladores fueren por los tomar el pena por daño en quales falle fecho que el pasçer que non minguare el penno e / si le manparare que el otro non varage con ello mas que vaya a los alcalles o a los yurados o al merino do fuere el dañador que lo entregue a el coto sobredicho doblado. E si a qual a quien lo mostrare no / quisiere luego fazer derecho que el velador que se torne a so logar e prente sin coto e sin calunia por diez marauedís [...] e otrosí [...] ${ }^{24}$ otorgamos que ninguno que non ouiere o non touiere casa poblada o non fiçiere veçindad en qualquier / de los dichos lugares [...] que fueren sea suyo o lo touiere a medias o a rraçión derecha que sea conuenible a los omes. E todo esto otorgamos amas las dichas partes susodichas que seamos / en vno para agora e para siempre iamás.

E qualquier o qualesquier que contra esta carta (roto) contiene en este escrito quesiere pasar o lo envargar o non quisiere estar por ello en $/^{27}$ qualquier manera que sea que peche en coto e en pena e postura que ponemos mill marauedís [dados desta manera la mitad al señor] a quien fuer dada la querella la otra mitad / a la parte que fiziere et cumpliere commo dicho es et todauía esto que susodicho es que sea ffirme et estable para en tido tiempo.

Et otrossy, / otorgamos que qualquier de las dichas partes que ante si quisiere ponernos a rrazón quier por sí o por otro quier sin escrito o por escrito en qualquier manera que sea por lo que sobredicho $/^{30}$ es menguar o enbargar todo o parte de ello que nos no vala ni seamos de ello oydos ante iuez ni iuezes ni otro sseñor ni ante perlado ni ante otro ome ninguno ni muger que en el / mundo sean clérigo ni seglar et todauía estar et cumplir por quanto sobredicho es sola dicha pena et para todo esto cumplir et atener commo ssobredicho es, amas las dichas partes obligamos a vos / et a todos vestros bienes, ansí muebles commo raíces, ganados et por ganar.

Et porque esto sea firme et non venga en duda, amas $/^{33}$ las partes ssobredichas mandamos a Miguel Pérez, escriuano público de Monçón, que fiziese dos letras deste pleyto sobredicho, amas de un tenor, partidas por A, B, C. La una que tengamos nos el cabillo et $/^{36}$ el conçejo de Fusiellos, et la otra que tengan el 
conçejo dicho de Fuentes et que ponga y su signo en testimonio de verdad. Et rrogamos a estos omes buenos que ay so escritos que sean dello pesquisas. $/^{39}$ Fecha la carta iueues, diez días de mayo era de mill et treszientos et quarenta et quatro años. Pesquisas rrogadas espeçialmiente para esto que se mandaron escreuir, / don Garçía, alcalle de Monçón, fijo de don Sancho, et don Francisco de Fuentes et don Áluaro de [...], fijo de Iohán Pérez, et Domingo Iohán de Palaçios, fijo de Toribio / Sebastián del Postigo, et Iohán Pérez de Becerril, fijos de doña María, mugier que fue de $[\ldots]$

[...] público de Monçón que estuue a todo esto llamado et presente. Et por mandado de las $/^{42}$ sobredichas partes fize esta carta et puse aquí mi signo en testimonio de verdad.

1310, agosto, 10, domingo.

Gómez Ruiz de Sandoval y Mayor Sánchez, su esposa, donan al cabildo de Santa María de Husillos diez obradas de tierra y nueve cuartas y media de viñedo que poseían en Amayuelas.

B. APA, $L P H$, ff. $46 \mathrm{v}-47 \mathrm{r}$.

C. AGS, Patronato eclesiástico. Inconexos, leg.159, ff. 58v-60r. Papel; escr. procesal; buena conservación.

El día 10 de agosto de 1310 fue lunes y no domingo. Véase A. GIRY, Manuel de Diplomatique. La letra dominical correspondiente a 1396 es la D, y la Pascua cayó el 19 de abril.

Sepan quantos esta carta vieren commo nos, Gómez Ruiz de Sandoval, fijo de Ruy Gómez, y su muger, Mayor Sánchez, por muchas ayudas que nos oviemos y esperamos auer de vos, el cabildo de la iglesia de Sancta María de Fusiellos, damos vos y otorgamos vos en propiedad y en donadío diez obradas de tierras y nueve quartas y media de vinnas de lo que nos auemos en Amayuelas $(f .46 v)$ y en 
sus términos, que fue de Pero Alfonso. Conviene a saber: quales obradas y media de tierra en Melgares en linde de tierra de Toribio y de Sancha, fija de María Corneja, y vna obrada carrera Matiella en linde de tierra de Ioán Benito y la carrera. Otra obrada en Fuente Sanctillán, linde de la Segadora y de la carrera, y obrada y media so los majuelos en linde de tierra de la iglesia y de Martín Fidel Yzquierdo, y otra obrada en Prado, en linde de tierras de María Martín, de la cofradía de Sancto Antolín, y dos obradas en los valles Soarennos, en linde de tierras de Diego Pérez, fijo de Joán Sánchez, y de donna Teresa, muger de don Sevastián, y dos obradas en Verçanna, en linde de tierras de Joán Velasco y la Segadera. Y vinnas, vna alançada de carrera de Poblaçión, en dos lugares, linde de Martín Fidel Yzquierdo y de Joán Benito, y quarta y media en los Arnales, en linde de Joán de Paz y de Joán Pérez "El Amo", y tres quartas en Arroyales, en linde de la carrera de los Prados, y vna quarta en los majuelos en linde de Joán Velasco y de la cofradía de sancta María.

$\mathrm{Y}$ este eredamiento sobredicho, tierras y vinnas, con entradas y con salidas y con todas sus pertenençias, damos y otorgamos según sobredicho es, nos, los dichos Gómez Ruiz y Mayor Sánchez, a vos, el sobredicho cabilldo, que lo ayades por vestro propio aver, libre y quito, por juro de eredamiento para dar, donar, vender y enpeñar, camiar, para fazer dello y en ello como de lo vestro propio que vos más libre y quito avedes y podríades aver de vestro patrimonio o de vestra compra de limosna o de donadío. Y corporalmente desapoderamos a nos de todo el sennorío y la tenençia que auemos y podríamos aver fasta este día desta carta fasta fecha que el dicho eredamiento o en alguna cosa dellos. Y corporalmente con esta carta deste día de oy en adelante apoderamos en ello en todo a vos el sobredicho cabildo y rrenunçiamos y partimos de nos toda boz y rrazón y a todas ferias de pan y vino cojer y a toda hueste carta de cruzada y afonsado y afonsadera y a toda carta y merçed de rrey y de rreyna y de ynfante y de otro sennor qualquier ganada ni por ganar y todo derecho escrito y no escrito, eclesiástico nin seglar que si por este dicho donadío todo o parte del menguar o enbargar en qualquier manera que sea, nos o otro por nos o ante nos lo posiemos y otorgamos que nos non vala ni seamos dello oydos ante juez ni ante sennor ni ante ome qualquier que sea eclesiástico ni seglar qualquier que contra este dicho donadío fuere por le enbargar todo o parte del en qualquier manera que sea, que peche en coto y en 
pena çien maravedís de los buenos, y otro tanto eredamiento en tan buen lugar o mejor doblado, a vos, el dicho cabildo o a quien esta carta mostrare en vestra boz. Y nos, los dichos Gómez Ruiz y Mayor Sánchez, partimos demanda común, vno de nos, por todos otorgamos que somos fiadores de saneamiento para en todo tienpo pechar a quien quier que vos, este dicho eredamiento, contrallase, so obligaçión de nos y nostros bienes, rraízes y muebles, conprados, ganados o por ganar.

Y porque esto sea firme y no venga en duda, mandamos a Miguel Pérez, escriuano público de Monçón, que fiziese esta carta y pusiese y su signo en testimonio de verdad. Y por más firme yo, Gómez Ruiz, puse y mío sello pendiente y rrogamos a estos omes bonos que y son escritos que sean dello pesquisas.

Fecha la carta domingo, diez días de agosto, era de mil y trezientos y quarenta y ocho annos. Pesquisas, Joán Gómez, clérigo de Pinna, y don Sancho, fijo de Pero Martín, y don Sancho, fijo de Joán Pérez, y Joán Marcos, fijo de Diego Rodríguez de Pinna, y Rodrigo de Ronada, vezino de Pinna.

Y Sebastián Pérez, escriuano público de Monçón que fui a esto presente por mandado de los sobredichos Gómez Ruiz y Mayor Sánchez, fize esta carta y puse mío signo en testimonio de verdad.

Y so los veynte y ocho rrenglones, entre línea que está entre dos rrenglones dize Mayor Sánchez, vala y non enpezca a la carta ni a cosa della. Yo, Miguel Pérez $(f .47 r)$

1312, marzo, 7. Valladolid.

Fernando IV confirma un privilegio de Sancho IV (1291, agosto, 16. Valladolid), inserto, confirmatorio a su vez de otra de Sancho III (1158, abril, 28. Carrión de los Condes), inserto, por el que concede a Raimundo, abad de Santa 


\section{DAVID MARCOS DIEZ}

María de Husillos, y a los canónigos de dicha iglesia, el privilegio de los infanzones, exentándolos asimismo de todo servicio real.

A. AHDP, Ampudia y Abadía de Husillos, Pergaminos, carp. 199-17. Perg., 696 x 586 mm.; escr. gótica redonda de privilegios y de albalaes; muy buena conservación. Sello de plomo pendiente.

B. AHDP, Ampudia y Abadía de Husillos, Pergaminos, carp. 199-18. Perg., 742 x 574 mm.; escr. gótica redonda de privilegios y gótica documental; buena conservación. Sello de plomo. Inserto en confirmación de Alfonso XI, dada en Valladolid, a 16 de diciembre de 1331. Véase doc. núm. 113. C. AHDP, Ampudia y Abadía de Husillos, Pergaminos, carp. 200-20. Inserto en confirmación de Pedro I, dada en Valladolid, a 12 de noviembre de 1351. Véase doc. núm. 134.

D. AHDP, Ampudia y Abadía de Husillos, Pergaminos, carp. 201-24. Inserto en confirmación de Enrique II del privilegio de Alfonso XI, dada en Valladolid, a 20 de mayo de 1371. Véase doc. núm. 164.

E. ADHP., Ampudia y Abadía de Husillos, Pergaminos, carp. 201-26. Perg., 719 x 573 mm.; escr. gótica de privilegios; buena conservación. Mantiene parte de la cinta pero no el sello. Inserto en confirmación de Juan I del privilegio de Enrique II, dada en Burgos, a 22 de agosto de 1379. Véase doc. núm. 194.

F. AHDP, Ampudia y Abadía de Husillos, Pergaminos, carp. 202-29. Perg., 717 x 517 mm.; escr. gótica redonda de privilegios y precortesana; buena conservación. Todos los elementos decorativos están dibujados pero sin miniar. No conserva la cinta pero sí el sello de plomo, que está suelto. Inserto en confirmación de Enrique III del privilegio de Juan I, dada en Burgos, a 20 de febrero de 1392. Véase doc. núm. 213.

$G$. APA, $L P H$, ff. 48r-49v. Traslado de $A$.

$H$. APA, $L P H$, ff. 60r-61v. Traslado de $B$.

I. APA, $L P H$, ff. 72r-74r. Traslado de $C$.

$J$. APA, $L P H$, ff. 92r-94v. Traslado de $D$.

$K$. APA, $L P H$, ff. $108 \mathrm{v}-111 \mathrm{r}$. Traslado de $E$.

$L$. APA, $L P H$, ff. $124 \mathrm{r}-127 \mathrm{v}$. Traslado de $F$.

M. AGS, Patronato eclesiástico. Inconexos, leg.159, ff. 62r-65v. Papel; escr. procesal; buena conservación. Traslado de $G$.

$N$. BN, $m s .705$, ff. 79r-83v. Traslado de $G$.

$\tilde{N}$. BN, $m s .705$, ff. $118 \mathrm{v}-124$ r. Traslado de $H$.

$O$. BN, $m s .705$, ff. $147 \mathrm{v}-154 \mathrm{v}$. Traslado de $I$.

$P$. BN, $m s .705$, ff. 201r-208r. Traslado de $J$.

$Q$. BN, $m s .705$, ff. 238r-242r. Traslado de $K$.

ED. CORIA COLINO - FRANCIA LORENZO, Reinado de Fernando IV, 193-199, núm. 33. 


\section{LA ABADÍA DE SANTA MARÍA DE HUSILLOS: ESTUDIO Y COLECCIÓN \\ DOCUMENTAL $(904-1608)$}

(Christus, alfa et omega) En el nombre del Padre, et del Fiio, et del Spirito Sancto, que son tres perssonas et un Dios, et de la bienauenturada Virgen gloriosa sancta María su madre; et a onrra et a sseruiçio de todos los sanctos de la corte çelestial, porque entre las creaturas que Dios, fizo sennaló el ombre, él dio / entendimiento pora conosçer bien et mal; el bien porque obrasse por ello, et el mal por sabersse dello guardar. Por ende, todo grand sennor es tenudo a aquel que obrare por el bien del fazer bien et del dar buen gualardón por ello, et non tan solamientre por lo de aquel sennero, / más porque todos los otros tomen ende enxiemplo que con bien fazer uençe ombre todas las cosas del mundo et las torna assí. Et por ende, queremos que sepan por este nostro priuilegio, los que agora son et serán daquí adelante, commo nos, don Fernando, por la graçia $\beta$ de Dios, rrey de Castiella, de Toledo, de León, de Gallizia, de Seuilla, de Córdoua, de Murçia, de Iahén, del Algarbe et sennor de Molina, viemos una carta del rrey don Sancho, nostro padre, que Dios perdone, fecha en esta guysa:

(Sigue doc. núm. 84)

Agora Gaçía Pérez, abbat de Fusiellos, et el prior et el cabildo de la eglesia sobredicha, pidiéronnos merçed que les confirmássemos esta carta et gela mandás/semos tornar en priuilegio seellado con nostro seello de plomo et signado de nostro signo. Et nos, sobredicho rrey don Fernando, por les fazer bien et merçed, otorgámosles et confirmámosles esta carta, et mandamos que les vala et les sea guardada en todo bien et conplidamientre segunt que en ella dize.

Et deffendemos / firmemente que ninguno non sea osado de yr contra este priuilegio para quebrantarlo nin para minguarlo en ninguna cosa. Ca qualquier que lo fiziesse, auríe nostra yra et demás pechar nos y en coto dos mille marauedís de la moneda nueua. Et al abbat de Fusiellos et al prior et al cabildo de la eglesia sobredicha, o a quien su boz touiesse, todo $/^{21}$ el danno doblado. Et porque esto sea firme et estable, mandamos seellar este priuilegio con nostro seello de plomo. Fecho en Valladolit, siete días andados del mes de março, era de mille et trezientos et çinquaenta annos. Et nos, el sobredicho rrey don Fernando, rregnant en vno con la rreyna donna / Costança, mi mugier, et con nostro fiio, el inffante don Alfonso, primo et heredero, et con nostra fiia, la inffante donna Leonor, en 
Castiella, en Toledo, en León, en Gallizia, en Seuilla, en Córdoua, en Murçia, en Iahén, en Baeça, en Badaioz, en el Algarbe et en Molina, otorgamos / este priuilegio et confirmámoslo.

Don Riaçar Abotasi, rrey de Granada, vassallo del rrey, conf. El inffante don Iohán, tío del rrey, adelantado mayor de la frontera et señor de Vizcaya, conf. El inffante don Pero, hermano del rrey, conf. El inffante don Felippe, señor de Cabrera et de Ribera et pertiguero de Santiago, conf. $/^{24}$ Don Gutierre, arçobispo de Toledo, primado de las Españas et chanceller mayor de Castiella, conf. Don Rodrigo, arçobispo de Santiago, chanceller et notario mayor del rregno de León, conf. Don Ferrando, arçobispo de Seuilla, conf. / Don Alffonso, fiio del inffante de Molina, conf. Don Ferrando, fiio del inffante don Ferrando, conf. Don Gonçalo, obispo de León, conf. Don [Gonçalo], fiio del inffante don Pero, conf.

( $1^{a}$ col.) Don Pero, obispo de Burgos, conf.- Don Giraldo, obispo de Palençia, conf.- don Ferrando, obispo de Segouia, conf.- Don Iohán, obispo de Osma, conf.La eglesia de Calahorra vaga.- Don Symón, obispo de Syguença, conf.- Don Pasqual, obispo de Cuenca, conf.- Don Pero, obispo de Áuila, conf.- Don Domingo, obispo de Plazençia, conf.- Don Ferrando, obispo de Córdoua, conf.Don Garçía, obispo de Iahén, conf.- Don frey Pero, obispo de Cádiz, conf.- Don Garçía López, maestre de Calatraua, conf.- Don Roy Ferrández, prior del Hospital, conf.

( $2^{a}$ col.) Don Iohán Núnnez conf.- Don Iohán Alffonso de Haro, señor de los Cameros, conf.- Don Ferrando, fiio de don Diago, conf.- Don Roy Gil de Villa Lobos conf.- Don Ferrant Royz de Saldanna, adelantado mayor de Castiella, conf.- Don Loppe de Mendoça conf.- Don Pero Martínez de Guzmán conf.- Don Iohán Ramírez, so hermano, conf.- Don Iohán Alffonso, fiio de don Alffonso Pérez de Guzmán, conf.- Don Gonçalyz de Aguilar conf.- Don Per Anrríquez de Harana conf.- Don Lope Royz de Baeça conf.

(Signo rodado)

Primer círculo concéntrico: 
(Cruz). DON IOHÁN ALFONSO DE HARO, ALFÉREZ DEL RREY, CONFIRMA. DON IOHÁN, FIIO DEL INFANTE DON MANUEL, MAYORDOMO DEL RREY, CONFIRMA.

Segundo círculo concéntrico:

SIGNO DEL REY DON FERNANDO (Signo).

Acuartelado con los escudos de Castilla y León.

( $3^{a} \mathrm{col}$.) Don Gonçalo, obispo de León, conf.- Don Diago, obispo de Çamora, conf.- Don Alffonso, obispo de Astorga, conf.- Don Ferrando, obispo de Ouiedo, conf.- Don Pero, obispo de Salamanca, conf.- Don Alffonso, obispo de Çiudad, conf.- Don Alffonso, obispo de Coria, conf.- Don frey Symón, obispo de Badajoz, conf.- Don Gonçalo, obispo de Orens, conf.- Don Rodrigo, obispo de Mendonnedo, conf.- Don Iohán, obispo de Thuy, conf.- Don frey Iohán, obispo de Lugo, conf.- Don Diago Muñiz, maestre de la Orden de la cauallería de Santiago, conf.- Don Gonçalo Pérez, maestre de Alcántara, conf.

( $4^{a} \mathrm{col}$.) Don Alfonsso, fiio del inffante do Iohán, conf.- Don Iohán, so hermano, conf.- Don Pero Ferrández de Castro conf.- Don Pero Ponz conf.- Don Ferrant Pérez Ponz conf.- Don Diago Gómez de Castanneda conf.- Don Ferrant Ferrández de Limia conf.- Don Rodrigo Áluarez conf.- Don Diago Ramírez conf.- Don Rodrigal Gonçález Mançanedo conf.- Martín Ferrández Portocarrero, adelantado mayor en el rregno de León et en Asturias, conf.- Alffonso Suárez de Deça, adelantado mayor en el rregno de Gallizia, conf.

Ferrant Gómez, notario mayor del rregno de Toledo, conf.

( $5^{a} \mathrm{col}$.) Don Gonçalo Royz de Toledo, notario mayor del rreyno de Castiella et mayordomo del rrey, conf.- Pero López de Padiella, iustiçia mayor en casa del rrey, conf.- Garçía Suárez, chançeller del rrey, conf.- Don Guysberte, bizconde de Castel Nouo, almirante mayor de la mar, conf.- 
Maestre Gonçalo, abbat de Aruas et notario mayor del Andaluzía, conf.

Yo, Alffonsso Royz, lo ffiz escriuir por mandado del rrey en el diez et sseteno anno que el rrey ssobredicho rregnó.

Gonçalo Ferrández (rúbrica)

1318, enero, 24. Valladolid.

Alfonso XI confirma una carta de Fernando IV (1297, septiembre, 12. Alcañizes), inserta, confirmatoria a su vez de un mandato de Alfonso X (1268, marzo, 8), inserto, por el que ordena a los habitantes de Pajares y San Adrián que habian emigrado a otros lugares, vuelvan a sus lugares de origen, bajo pena de perder sus posesiones en favor de Santa María de Husillos. Fernando IV hace extensible este mandato a los habitantes de Cilleruelo.

B. APA, $L P H$, ff. $47 \mathrm{v}-48 \mathrm{r}$.

C. AGS, Patronato eclesiástico. Inconexos, leg.159, ff. 60r-62r. Papel; escr. procesal; buena conservación.

D. BN, ms. 705, ff. 76v-79r.

Fecho y sacado fue este dicho traslado de la dicha escritura en la villa de Husillos, a veynte y çinco días del mes de novienbre de mil y quinientos y çinquenta y quatro anos. Testigos que fueron presentes a lo uer, leer, corregir y conçertar con el original, Joán Rruiz Cabeça de Vaca y Gaspar de Vedoya, clérigos, y Pero Manuel, estantes en la dicha villa.

E yo, Santiago Gómez, escriuano público en la dicha villa, presente fui a lo que dicho es en vno con los dichos testigos. Y del dicho pedimento e mandamiento del dicho señor alcalde mayor, que aquí firmó su nombre, lo escreuí y fize aquí mi signo (signo) en testimonio de verdad. Pero Ruyz de Billoldo (rúbrica). Santiago Gómez (rúbrica). 


\section{LA ABADÍA DE SANTA MARÍA DE HUSILLOS: ESTUDIO Y COLECCIÓN \\ DOCUMENTAL $(904-1608)$}

Sepan quantos esta carta [vieren] como yo, don Alfonso, por la graçia de Dios rrey de Castilla, de Toledo, de León, de Galizia, de Seuilla, de Córdoua y de Murçia y de Jaén y del Algarbe y sennor de Molina, yo y la rreyna doña María, mi abuela, y los ynfantes don Joán y don Pero nostros tíos y míos hermanos, viemos vna carta del rrey don Fernando mío padre, que Dios perdone, escrita en pargamino de cuero y sellada con su sello de çera colgado, fecha en esta guisa:

(Sigue doc. núm. 92)

Y yo, el sobredicho rrey don Alfonso, con consejo y con otorgamiento de los dichos míos tutores, confirmógela y mando que les vala y les sea guardada en todo según que mejor y más cumplidamente les valió y les fue guardada fasta aquí, y defiendo firmemente que ninguno no sea osado de les yr ni de les pasar contra ella en ninguna manera; ca qualquier o qualesquier que los fiziesen o contra ella les pasasen contra alguna cosa della, pecharme y a la pena sobredicha cada vno y al abad y al cabildo sobredichos o a quien su boz ouiese o que esta mi carta mostrare por ellos, todo el danno y el menoscabo que por esta rrazón rresçibieren doblado. Y sobre esto mando a todos los $(f .47 v)$ conçejos, alcaldes, iurados, iuezes, iusticias, merinos, alguaziles, comendadores, y a los merinos que andovieren por mí o por los míos merinos mayores en las merindades de Castilla $\mathrm{y}$ todos los otros aportellados que esta mi carta vieren, que anparen y defiendan a los dichos abad y cabildo en todo esto que dicho es, que lo cumplan luego así que no consientan a ninguno que les pase contra ello. Y si alguno o algunos y ouiere que lo ansí faze y no quisieren todo el danno y el menoscabo que por esta rrazón rreçibiere doblado y non fagan ende al por ninguna manera ni se escusen los vnos por los otros de lo ansí cumplir, más cúmplanlo luego qualquier o qualesquier dellos que esta mi carta vieren, sino por qualquier o qualesquier dellos que fincasen que lo ansí no cumpliesen, mando a los dichos abad y cabildo o a quien esta mi carta mostrare por ellos que los enplaze que parezcan ante mí doquier que yo sea del día que los enplazare a nueve días, so pena de çien maravedís de la moneda nueva a cada vno y como lo cumplieren y del enplazamiento si por esta rrazón les fuere fecho, mando a qualquier escriuano público de qualquier lugar que para esto fuere llamado que les dé testimonio signado con su signo y no faga 
ende al so la pena suso dicha. Y desto les mando dar esta mi carta sellada con mío sello de plomo.

Dada en Valladolid, a veynte y quatro días de enero, era de mil y trezientos y çinquenta y seis annos. La fize escrevir por mandado del rrey y de los sus tutores.

1321, febrero, 22, lunes. Palencia.

Traslado sacado por Juan Fernández, notario público de Palencia, a petición de Juan, abad de Santa María de Husillos, de la sentencia (1302, mayo, 7, lunes. Palencia) del pleito litigado por el cabildo de Santa María de Husillos con la iglesia de Santa Olalla de Paredes de Nava, por el derecho a los diezmos de Sahagún el Viejo, cerca de Paredes de Nava, y que se resolvió a favor del primero.

A. AHDP, Ampudia y Abadia de Husillos, Pergaminos, carp. 210-3. Perg., 336 x 242 mm.; escr. de albalaes; buena conservación con alguna mancha. Tiene cinta pendiente y restos de un sello de cera.

$B$. APA, $L P H$, ff. $57 \mathrm{r}-58 \mathrm{r}$.

C. BN, $m s .705$, ff. 109r-111v.

El día 22 de febrero de 1321 fue domingo y no lunes. Véase A. GIRY, Manuel de Diplomatique. La letra dominical correspondiente a 1396 es la D, y la Pascua cayó el 19 de abril.

Sepan quantos este público instrumento vieren, como lunes, XXII días de febrero, anno Domini millesimo CCC XXI, en pressençia de mí, Iohán Fernández, notario públi[co de] / Palençia et de las partes que aquí sson escriptas, rrogadas et llamadas, speçialmiente, para esto, Iohán, abbat canónigo en la eglesia de Santa María de Fusiellos, apareció / [ante el] onrrado varón et ssabio, M[arco] Díaz, canónigo et vicario del onrrado padre et sseñor don Iohán, por la graçia de Dios obispo de Palençia, et apresen/3 tó et ffizo leer, antel dicho vicario, Marco Díaz, 
una carta de ssentençia, escripta en papel vieio, ssellada con el ssello de la vicaría del dicho ssennor obispo, el / tenor de la qual, es este que sse sigue:

(Sigue doc. núm. 96)

La qual, leyda antel dicho vicario, el dicho Iohán, abbat, pidió al dicho vicario Marco Díaz, que por rrazón que la dicha ssentencia era escripta en /papel et era ya muy vieja et que sse molíe toda et que auíe miedo que se perdiere, que sse non podríe leer, que mandasse et diesse ssu auto/ridad a mí, Iohán Ferrández, notario público ssobredicho, que ssacasse esta dicha carta de ssentencia en pergamino et la tornasse en pública for ${ }^{34} \mathrm{ma}$ et la ssignase con mío ssigno et que la mandasse sseellar con el sseello de la vicaría del dicho sseñor obispo don Iohán, porque podi/ese ffazer fe a también, como el original de la dicha sentencia. Et el dicho vicario, Marco Díaz, a pedimiento del dicho Iohán, abbat, mandó / a mí, Iohán Ferrández, dicho notario, et diome autoridat que la ssacase en pública f[orma] et que la signase con mío ssigno. Et por mayor ffirmedu $/{ }^{37}$ ra, mandola sseellar con el sseello de la vicaría de nuestro sseñor el obispo. Testigos que estauan pressentes a esto: Iohán Pérez de Façeves, arçipreste /de Bezerril, et Alffón Pérez de Logrono et Iohán López, ome del abbat de Fusiellos, et Diego Abbat, et Gonçalo Garçía y Gonçalo Pérez, omes del dicho vicario, todos moradores / en Palençia. Et yo, Iohán Ferrández, notario público sobredicho, fuy present, et por mandamiento et de autoridat del dicho vicario ssaqué de $/^{40}$ [la dicha sentençia] este traslado. Et en testimonio de verdat, ffize aquí este mío sig(signo)no. Marco Díaz.

1322, marzo, 22. Aviñón.

Bula de indulgencias concedida por Juan XXII a Santa María de Husillos. 
B. AHDP, Ampudia y Abadía de Husillos, Pergaminos, carp. 204-11. Perg., 665 x 547 mm; escr. gótica de privilegios; regular conservación con algunas manchas y una rotura que afecta a las líneas: 40, 41, 42, 43 y 44. No tiene sello pero sí parte de la cinta morada y verde que lo sujetó. Inserto en traslado sacado en Husillos, a 31 de julio de 1483. Véase doc. núm. 239.

El año del Señor no concuerda con el año del pontificado, ya que Juan XXII fue elegido papa en 1216 y el año del pontificado es el quinto, correspondiendo al año 1320. En cualquier caso optamos por el año del Señor.

UNIVERSIS Christi fidelibus presentes literas inspecturis nos fratres miseratione diuina: Ualeriamis colocensis. Matheus duracensis, archiepiscopi, et Stephanus Luvocensis. Sacharias suationensis. Franciscus ceretimensis. $/^{18}$ Egidius ardinapolitanensis. Guillermus Sancte Iuste. Petrus taracenensis. Guillermus ad partes tartariorum. Guillermus putenensis episcopi salutem in domino qui est omnium vera salus et bonis operibus in perpetuum / habundare pia mater ecclesia de animarum salute solicita deuotionem fidelium per quedam munera spiritualia remissiones videlicet et indulgencias inuitare consuerit ad debiti famulatus honorem Deo scilicet et fatris edibus / impedendam ut quanto celebrius et deuoctius illuc confluitur populus christianus assiduis saluatoris gratiam precibus implorando omnium delictoris suorum veniam et gloriam regni celesti consequi mereantur eternam. $/^{21}$ Cupientes igitur ut ecclesie Sancte Marie de Fusellis, palentine diocesis, congruis honoribus frequentetur et a Christi fidelibus iugiter veneretur, omnibus vere penitentibus et confessis qui ad ipsam ecclesiam in quo libet fes/to eiusdem ecclesie necnon festiuitatibus infrascriptis, videlicet: Natiuitatis domini nostri Ihesu Christi, Circuncisionis et Eppiphanie, Parasceues Resurrectionis, Ascensionis, Penthecostes, Trinitatis et Eucharistie et in omnibus / et singularis festiuitatibus ipsius beate virginis gloriose et beatorum Petri et Pauli apostolorum cum ceteris apostolis et euangelistis inuentionis et exaltationis Sancte Crucis, Iohannes Baptiste, Sancti Iacobi, Michaelis Archangeli, ${ }^{24}$ Laurentii, Christofori, Dionisii, sociorumque eius Cosme et Damiani, Martini, Nicolay, Gregorii ac Sanctarum Marie Magdalene, Brigide, Katherine, Cecilie, Agnetis, Ane, Lucie, Margarite, Agathe, Barbare, / Marthe et Eufemie. In conmemoratione omnium Sanctorum et dedicatione ipsius ecclesie aut qui cum deuotione per octabas dictarum festivitat, dictam ecclesiam 
visitauerint et in omnibus et singulis primis / diebus Dominicis mensium necnon in singulis diebus Sabbati ad missam que ibidem solenniter celebratur in honore ipsius beate Marie virginis causa peregrinationis deuotionis uel orationis accesserint aut ${ }^{27}$ qui corpus Christi et oleum Sancto cum portantur infirmis secuti fuerint seu qui predicationibus missis et diuinis officiis exequis et sepulturis mortuorum in dicta ecclesia uel eius cimiterio interfuerint aut qui / in serotina pulsatione campane flexis genibus ter aue Maria deuote dixerint uel qui in extremis laborantes dicte ecclesie quicquam suarum erogauerint necnon qui ad facienda luminaria ornamenta et alia di/cte ecclesie neccessaria manus porrexerint adintrices quotiens cumque premissa uel premissorum aliquod fecerint de omnipotentis Dei misericordia et beatorum Petri et Pauli, apostolorum eius, auctem confissi singuli vestrum $\sin /{ }^{30}$ gulas dierum quadragenas de immunitis sibi penitenciis misericorditer in domino relaxamus, dum modo diocesani voluntas ad id accesserit et consensus. In quorum omnium et singulorum testimonium et certitudine / pleniorem presentes literas sigillorum nostrorum iussimus appensione muniri.

Datum Auinion, anno Domini millessimo tricentessimo vicessimo secundo, inditione quarta, die vicessima tercia, mensis marcii, pon/tificatus Sanctissimi patris et domini nostri domini Iohannis, diuina prouidencia Pape vicessimi secundi, anno quinto.

Domino Iohanni, episcopo Palentine, placuit et predictis benefactoribus vere penitentibus et confessis, qua/ ${ }^{33}$ draginta dies indulgentie concessit.

1323, febrero, 24. Husillos.

Carta de poder del prior y cabildo de Santa María de Husillos a Bernal del Pumar, sacristán, Juan Abad, Juan Pérez, y Fernán Martínez, canónigos en dicha iglesia, para que representen a la abadía en los pleitos que esperaban tener con el monasterio de Santa María de Benavides. 
$B$. APA, $L P H$, ff. 58r-60r. Inserto en traslado del reconocimiento de la sentencia por las partes pleiteantes. Véase doc. núm. 108.

C. BN, $m s .705$, ff. $111 \mathrm{v}-118 \mathrm{v}$.

Sepan quantos esta carta vieren como nos, Nuño Pérez y Joán Abad, y el cabildo de la yglesia de Sancta María de Fusiellos aplicados en nostro cabildo a canpana tañida como auemos por vso y por costumbre, fazemos y establesçemos más personas generales y nostros çiertos speciales procuradores a Bernal del Pumar, sacristán, y a Joán Abbad, y a Joán Pérez, y a Fernand Martínez, canónigos en la dicha yglesia y nostros companneros procuradores desta presente carta a todos en vno que del otro más lo que el vno començare el otro o los otros lo puedan seguir y fenecer. Specialmente les damos cumplido y libre poderío a todos en vno y a cada vno por sí que puedan por nos y en nostro nombre comprometer en qualesquier personas eclesiásticas o seglares de qualquier condiçión o estado que sean por rrazón del pleyto o pleytos que nos auemos o esperamos aver (f.58r) contra el abad y conuento del monesterio de Benebiuas o los dichos abad y conuento del sobredicho monesterio entienden auer contra nos en todo conprometimiento, que los dichos nostros procuradores o qualesquier dellos fizieren toda pena o penas, postura o posturas que ellos o qualquier dellos pusieren, nos prometemos de lo auer por firme y por estable para en todo tiempo ansí commo si fuese fecho y puesto por nos mismos si presentes fuésemos so obligamiento de todos los bienes spirituales y temporales que petenesçen y deuen pertenesçer al comunal de nostro cabildo.

Y porque esto sea firme y no pueda venir en duda por rrazón que no auemos escriuano público, mandamos fazer esta carta y fezímosla sellar con nostro sello en las spaldas, que fue fecha y dada en el dicho cabildo, veynte y quatro días del mes de febrero, anno ab incarnationi Domini $\mathrm{M} \mathrm{CCC}^{\circ} \mathrm{XX}^{\mathrm{o}} \mathrm{II}$. 
1323, febrero, 24, sábado. Palencia

Compromiso por motivo del pleito entre Santa María de Husillos y el monasterio de Santa María de Benavides por los diezmos de la iglesia de San Mamés de Villacid, por la que se declara que los procuradores de Husillos eligen como juez árbitro a Fernán Fernández, clérigo de Villalón; y Fernando, prior de Benavides y procurador del abad y cabildo de dicha iglesia, elige como juez árbitro a Sancho Pérez de Villalón; y ambas partes eligen como juez árbitro a Gonzalo Fernández, clérigo, cura de la iglesia parroquial de San Miguel de Villalón.

$B$. APA, $L P H$, ff. 58r-60r. Inserto en traslado del reconocimiento de la sentencia por las partes pleiteantes. Véase doc. núm. 108.

C. BN, $m s .705$, ff. $111 \mathrm{v}-118 \mathrm{v}$.

In Dei nomine, amen. Sepan quantos esta carta de conpromiso vieren y oyeren como en presençia de mí, Alfhonso Ruiz, público notario de la çiudad de Palençia, y ante los vezinos de suso escriptos llamados y rrogados speçialmente para esto sobre todos quantos pleytos y querellas y demandas que el prior y la iglesia de Sancta María de Fusiellos deuían de auer y podrían auer contra el abad y el conuento del monesterio de Benebiuas, sobre rrazón de los benefiçios de la yglesia de San Mamés de Villaçis, que es en el obispado de León, y sobre la iglesia sobredicha fazer y sobre el capellán poner y sobre todas las dichas demandas que aurían y ally podrían auer contra los dichos prior y cabildo de la iglesia de Sancta María de Fusiellos sobre esa misma rrazón de los diezmos de la dicha yglesia de Villacís, y de la fazer y de poner capellán y sobre todas las otras demandas que auían y an y podrían auer contra los dichos prior y cabildo fasta oy día que esta carta es fecha, en qualquier manera y por qualquier razón, Bernal del Pumar Sant Esteuan, Joán Abad, Joán Pérez, canónigos de la dicha iglesia de Fusiellos por nombre de los dichos prior y cabildo cuyos procuradores son de la vna parte por el poderío de la procuraçión que los dichos prior y cabildo les dieron, el tenor de la qual es este que se sigue:

(Sigue doc. núm. 104) 
Y frai Fernando, prior del dicho monesterio de Benebiuas, procurador que se dezía de los dichos abad y conuento, por nombre de los dichos abad y conuento del dicho monesterio de la otra parte anbas las partes por su propia voluntad, fizieron por su amigo y juez árbitro y conuinieron de lo poner todo sinplemente de llano, en mano de amigos. Y los dichos sancristán y Joán Abad y Joán Pérez, por nombre de los dichos prior y cabildo de Fusiellos, nonbraron e posieron por su amigo y juez árbitro amigable componedor a Fernánd Fernández, clérigo de Villalón. Y el dicho fray Fernando prior, por nombre de los dichos abad y conuento del dicho monesterio de Benebiuas nombraron y tomaron por su amigo y juez árbitro y amigable componedor a Sancho Pérez de Villalón, criado que fue de doña Joana, madre de doña María, y amas las partes nombraron y tomaron por su amigo y juez árbitro y amigable componedor a Gonçalo Fernández, clérigo y cura de la yglesia de San Miguel de Villalón, y amas las partes dieron cumplido y libre poderío a los dichos amigos que lo libren en manera que por todo quanto los dichos amigos todos tasen, vno o los dos qualesquier dellos mandaren, juzgando o aueniendo o conponiendo o sentençiando o amigablemente conponiendo, sabida verdad o no sabida, guardada la orden del derecho o no guardada, las partes presentes o no presentes, o qualquier de las partes presente llamadas o no llamadas, quier en día feriado o no feriado, quier por escrito, quier por palabra, quier seyendo, quier se estando o en otra manera qualquier que los dichos amigos, todos tres en vno o los dos qualesquier dellos, lo mandaren o juzgaren o auenieren o conpusieren o sentençiaren, que amas las partes que queden y estén por ello y lo ayan por firme para en todo tiempo. Y la parte que no quisiere estar ni quedar y lo non quisiere auer por firme en la manera que dicho es y quisiere venir contraello, por sí y por otra, para lo quebrantar o menguar en todo o en parte, que peche por cada vegada mil maravedís de los buenos, la meatad para los dichos amigos y la otra meatad para la parte que estouiere y todauía que estar auer por firme, para en todo tiempo, todo quanto los dichos amigos juezes árbitros, y amigables componedores, todos tres o los dos dellos mandaren, holgaren o auinieren, compusieren, sentençiaren en la manera que sobre dicho es.

Y para estar y quedar y auer por firme para todo tiempo todo quanto sobre dicho es, los dichos sancristán y Joán Abad, y Joán Pérez de la vna parte, prometieron 


\section{LA ABADÍA DE SANTA MARÍA DE HUSILLOS: ESTUDIO Y COLECCIÓN \\ DOCUMENTAL $(904-1608)$}

de lo fazer auer por firme a los dichos prior y cabilldo de Fusiellos, so la dicha pena de mil maravedís de los buenos por cada vegada que contra ello quisieren venir, so la dicha obligación que se contiene en la dicha procuraçión. Y el dicho fray Fernando de la otra parte dio por fiador a fray Pero, prior de Herruz, de la orden de Sancta María de Monte Sión, y el dicho fray Pero, prior, con el dicho fray Fernando, amos de mancomún, y cada vno dellos por todo obligaron todos sus bienes muebles y rraízes, espirituales y temporales, ganados y por ganar para fazer ésta y quedar y auer por firme para en todo tiempo los sobredichos abad y conuento del dicho monesterio de Benebiuas todo quanto los dichos amigos y juezes, árbitros, amigables, conponedores todos tres o los dos qualesquier dellos mandaren o juzgaren, auinieren o conpusieren o sentençiaren en la manera que sobredicho es, y so la dicha pena de los mil maravedís de los buenos por cada vegada que contra ello quisiesen venir y todavía estar, que están y por lo que dicho es.

Y amas las partes dieron poderío a los dichos amigos a todos en vno o a los dos dellos que los plazos que los asignaren que aparezcan ante ellos. Y la parte que no apareçiere por sí o por sus procuradores o procurador, sufiçientes o sufiçiente, que peche por cada plazo diez maravedís de los buenos, la meatad para los amigos y la otra meatad para la parte que apareçiere. Y amas las partes pusieron de apareçer ante los dichos amigos en Villa Tello, lunes, otro día de la dominica de quasi modom, primero que viene, por el primero plazo y que presenten este compromiso. Y la parte que no apareçiere al dicho plazo que peche çien maravedís, la meatad para los amigos y la meatad para la parte que aparesçiere so las dichas obligaciones, y venieron por auenidos que ninguno no se pueda agrauiar de lo que los dichos amigos mandaren en la manera que dicho es ni tomar alçada ni suplicaçión para ante papa ni para ante otros perlados ni para ante rrey ni otros señores eclesiásticos ni seglares. Y si no qualquier de las partes que se agraviase o tomase alçada o suplicaçión por esta rrazón por sí o por otra que non vala y que peche la pena de los mil maravedís y todavía estar, que estar por lo que los dichos amigos todos tres en vno o los dos dellos mandaren como sobre dicho es y cumplan todo quanto mandaren o juzgaren o auinieren y conpusieren o sentençiaren en qualquier manera según que sobredicho es. 
Y amas las partes rrequirieron y rrogaron a mí, Alphonso Ruiz, sobredicho notario, que escriuiese esta carta de compromiso y la signase con mío signo.

Que fue fecha en Palençia, en las casas de nostro señor el obispo, sábado, veynte y seis días de febrero era de mil y trezientos y sesenta y vn años. Testigos: Aluar Pérez, rraçionero, chançiller. Domingo Pérez, capellán, y Gonçalo Martínez, escriuano del dicho señor obispo. Y Bernal Viçe[in]se.

Y yo, Alfonso Ruiz, notario sobredicho, fui presente con los dichos testigos a esto y ví y ley la dicha carta de procuraçión abierta y sellada en las espaldas con el sello del cabildo de la iglesia de Sancta María de Fusiellos. Y rrogado de las partes o a su requerimiento, escreuí esta carta deste compromiso, y la signé con mío signo en testimonio de verdad.

1324, noviembre, 5, lunes. Palencia.

Sentencia pronunciada por Mateo Díaz, abad de Hérmedes, y Juan Díaz, canónigo de la catedral de Palencia, y escrita por Juan Fernández, notario público de Palencia, del pleito litigado por Domingo Bartolomé, deán de la Catedral de Palencia, con el prior y cabildo de Santa María de Husillos, por el derecho al préstamo de la cuarta parte de los diezmos de la iglesia de Santa María de Pozuelos de Amianos, favorable a los segundos.

A. AHDP, Ampudia y Abadía de Husillos, Pergaminos, carp. 211-8. Perg., 409 x 274 mm.; escr. precortesana.; buena conservación aunque con la tinta algo desvaída.

B. APA, $L P H$, ff. $78 \mathrm{v}-79 \mathrm{r}$.

C. BN, $m s .705$, ff. $167 \mathrm{r}-169 \mathrm{v}$.

In Dei nomine, amen. Sepan quantos esta ssentençia vieren commo en el pleito et demanda que es entre el onrrado varón et ssabio Domingo Bar/tholomé, deán de Palençia de la vna parte, et Aluar Curiel, vezino de Palençia et procurador de los onrrados varones et ssabios / el prior et el cabillo de Fusiellos de la otra, 
ante nos, Mateo Díaz, abbat de Hérmidas et Iohán Díaz, canónigo de Palençia, juezes, a/ ${ }^{3}$ migos, árbitros, arbitradores, amigables, verdaderos conpronedores dados et escogidos et rresçebidos a pedimiento et a consentimiento de amos estas / partes. Vista la demanda et petiçión que fizo ante nos el dicho Aluar Curiel por ssí et en nonbre de los dichos prior et cabillo de Fusiellos cuyo / procurador él es, al dicho deán en que sse contiene que el dicho prior et cabillo de Fusiellos que ffueran et estudieran en possesión de derecho et que leuaron et que / ${ }^{6}$ auían de leuar la quarta parte de todos los diezmos que leuaran et auían de leuar los préstamos que ffueran por tienpo de la eglesia de Palençia [et] / de la eglesia de Sancta María de Pozuel Damiannos por cartas et priuilegios de donación que les ffuera ffecho al dicho prior et cabilldo de Fusi/ellos. Et que el dicho deán que auíe grand tienpo que auíe el préstamo del pontifical que auíe la eglesia de Palençia en la dicha $/{ }^{9}$ eglesia de Pozuel Damianos, et que lo leuaua todo el dicho deán, et que non queríe dar dende ninguna cossa nin daua al dicho prior et / cabilldo de Fusiellos de la su quarta parte que ellos y auíen de auer de derecho por la dicha donaçión, et que nos pidíen que por ssentençia ge lo man/dássemos dar.

Et vista la rrespuesta del dicho deán en que dixo lite contestando que él que non ssabíe nin creíe que los dichos prior et cabilldo $/{ }^{12}$ de Fusiellos que ffuesen en possesión de leuar nin que leuaran nin auíen de leuar la quarta parte de los diezmos del préstamo que él auíe / et teníe del pontiffical de la eglesia de Palençia que auíe en la dicha eglesia de Sancta María de Pozuel Damianos. Et visto el con/promisso que ffue fecho entre amas estas dichas partes del poder que nos dieron, que nos que viéssemos esta dicha demanda et que ssupiésse $/{ }^{15}$ mos verdat por cartas o por preuilegios o por testimonios o por quantas partes lo nos podiéssemos ssaber, et que lo librássemos en aquella / manera que nos touiéssemos por bien, et que amas las partes que estaríen por todo quanto nos mandássemos en qualquier manera que lo nos / mandássemos. Et vistas las cartas de la donaçión que an los dichos prior et cabilldo de Fussiellos que les ffue ffecha et dada de los dichos diez $/{ }^{18}$ mos, et los dichos que dixieron los testigos que nos auissenos el dicho Aluar Curiel, procurador de los dichos prior et cabilldo para prouar su intençión. Et / examinado esto todo diligentemiente, et visto en commo nos mandamos dar al dicho deán el traslado de las dichas cartas et testimonios / et en commo le preguntamos ssi queríe dezir alguna cossa contra ellos et en commo 
él dixo que non queríe dezir ninguna cossa contra ellos. Et $/^{21}$ vistas todas las otras rrazones que amas las partes quissieron dezir et rrazonar ante nos, nos Mateo Díaz, abbat de Hérmidas, et Iohán / Díaz, canónigo, iuezes amigos, árbitros arbitradores, amigables, conponedores ssobredichos, auido consejo con ombres bonos ssabios et leydos en / derecho ssentençiado, pronunçiamos que el dicho Aluar Curiel que prouó muy bien ssu entençión, et dámosla por bien prouada por las cartas $2^{24}$ que an el dicho prior et cabilldo de Fusiellos de la donaçión que les ffue fecha de los dichos diezmos et por los dichos de los testimonios que / ay presentó ante nos. Ende iuzgando, abeniendo, conponiendo, ssentençiando, arbitrando, mandando por diffinitiua ssentençia, iuzgamos que el dicho prior / et el cabilldo de Fusiellos que deuen auer et leuar la quarta parte de todos los diezmos que pertenesçen all dicho deán del préstamo del pontifical ${ }^{27}$ que él a por la eglesia de Palençia en la dicha eglesia de Pozuel Damianos. Et mandamos al dicho deán que ge lo dexe et dessenbargue et dexe / leuar a los dichos prior et cabilldo de Fusiellos o a los que lo ouieren de rrecabdar por ellos a tanbién de este pan de ogano que y está commo de / todo lo al que y ouieren por toda ssu vida del dicho deán de mientras que lo ouieren de ver. Et esto todo mandamos que sse cunpla et que sse [faga] $/^{30}$ sso la pena del compromisso que ffue fecho por esta rrazón. Et desto mandamos dar a los dichos prior et cabilldo de Fusiellos esta carta de esta / ssentençia que ffue fecha por mano de Iohán Ferrández, notario público de Palençia, et mandámosle que la ssigne con ssu ssigno en testimonio [de verdat.

Esta] / ssentençia ffue dada en Palençia por los dichos árbitros en la claustra de la Eglesia de Sant Antolín, lunes, çinco días de nouienbre, [era] ${ }^{33}$ de mille et treszientos et ssesenta et dos annos. Pérez Alffons, yerno de Iohán Domíguez, et Martín Gómez, clérigo et criado del abbat de Fusiellos, / et Gonçalo Garçía, ome de Mateo Díaz, et Domingo Pérez, capellán de los dos capellanes, et Iohán Domínguez, capellán, et Alffons Pérez de Logronno, vezinos de Palençia./

[Et] yo, Iohán Ferrández, notario público ssobredicho, ffuy presente, et por mandamiento de los dichos Mateo Díaz, abbat, et Iohán Díaz, canónigo, escreuí ${ }^{36}$ esta ssentençia et en testimonio de verdat ffiz aquí este mío sig(signo)no. 
1325, mayo, 16, jueves. Villalón de Campos.

Sentencia pronunciada por Fernán Fernández, clérigo, Sancho Pérez, lego, y Gonzalo Fernández, clérigo, vecinos de Villalón, jueces árbitros, y escrita por Domingo Alfonso, escribano, teniente de Fernán Pérez, notario público de Villalón, del pleito litigado por Juan Abad, canónigo de Santa María de Husillos, como procurador de Nuño Pérez, prior de dicha iglesia, y su cabildo, con Pedro Miguélez, abad de Santa María de Benavides y su convento, por el disfrute de los diezmos de la iglesia de San Mamés de Villacid, en la diócesis de León, y sobre el derecho a designar capellán para dicha iglesia. La sentencia establece que las tres cuartas partes del diezmo sean disfrutadas por Santa María de Benavides, y la cuarta parte por Santa María de Husillos.

$B$. APA, $L P H$, ff. 58r-60r. Inserto en traslado del reconocimiento de la sentencia por las partes pleiteantes. Véase doc. núm. 108.

C. BN, ms. 705, ff. 111v-118v.

D. AHN, Clero, Benavides, Leg. 5379-1. Copia del siglo XVI. Comienza desde: "Mandamos que el abad de Benavivas...".

ED. L. FERNÁNDEZ, Benavides, 178-180.

In Dei nomine, amen. Sepan quantos esta carta vieren commo ante Fernán Fernández, clérigo, y Sancho Pérez, lego, y Gonçalo Fernández, clérigo, todos tres de Villalón, juezes, árbitros, arbitradores, amigables, componedores de los pleytos y querellas y demandas que eran o esperauan seer entre el señor Nuño Pérez y el cabildo de la yglesia de Sancta María de Fusiellos, por sí de la vna parte, y don frey Pero Miguélez, abad del monesterio de Benebiuas y el convento deste mismo lugar por sí, de la otra parte, sobre rrazón de los diezmos de la yglesia de San Mamés de Villaçid, que es en el obispado de León, y sobre la yglesia sobredicha fazer y sobre el capellán poner y sobre todas las otras 
demandas que auían y podrían auer anbas las partes vnos contra otros segund se contenía en vn compromiso fecho en esta manera:

(Sigue doc. núm. 105)

En presençia de mí, Domingo Alfonso, escreuano, teniente las vezes de Fernán Pérez, notario público de Villalón, de los testigos de yuso escritos, los dichos Fernán Fernández y Sancho Pérez y Gonçalo Fernández, juezes sobredichos, libraron estos pleytos y demandas que el dicho don frey Pero Miguélez, abad del dicho monesterio de benebiuas por sí y por su conuento fizo contra el prior y cabildo de la iglesia de Sancta María de Fusiellos y contra Joán Abad, su procurador por nombre dellos; y visto las demandas que el dicho Joán Abad, fizo por nombre del dicho prior y cabildo de Sancta María de Fusiellos, cuyo procurador es, contra el dicho abad y conuento, y visto los testigos que fueron traydos sobre estos pleytos sobredichos, y visto y oydo los dichos dellos, y vista la verdad por quantas partes podiemos lo más cumplidamente que lo nos podiemos saber, y visto y oído quanto anbas partes quisieron dezir y rrazonar y en como nos pidieron que sobre la verdad que auíamos sabido que les librásemos lo que fallásemos por derecho de quien se contenía en el dicho conpromiso. Y auido consejo con ombres buenos sobre ello juzgando por sentençia, $(f .59 r)$ mandamos que el abad de Benebiuas y el conuento ansí los que son agora como los que fueren de aquí adelante para siempre jamás, que pongan vn ombre en Villaçís, cada anno, de aquí adelante para siempre jamás, que coja todo el terçio del pan y del vino de la yglesia de San Mamés de Villaçís y todas las otras cosas que a este terçio pertenesçieren y pertenesçer deuan en qualquier manera; y el ome que lo cogiere, que luego dé todo el terçio del pan, el medio diezmo. Y luego que fuere cogido cada anno que vengan y el prior y cabildo de Fusiellos o su procurador o el que la su quarta parte ouiere de rrecaudar por ellos. Y mandamos que de todo este dicho terçio y de las cosas que le pertenesçen o pertenesçer deuen antes que se partan, que se tomen cada anno el abad y conuento de Benebiuas o el que lo y ouiere a rrecaudar por ellos tanta quantía fasta cumplimiento de pagar el rrefazimiento de la dicha yglesia de San Mamés cada que menester fuere y para pagar todos los pechos y derechos que la dicha yglesia o ellos, por ella an a dar al 


\section{LA ABADÍA DE SANTA MARÍA DE HUSILLOS: ESTUDIO Y COLECCIÓN \\ DOCUMENTAL $(904-1608)$}

obispo de León y al arçediano y al arçipreste y otros pechos y derechos si fueren echados por el papa y en la provisión o mantenimiento que oviere en cada anno, a dar al capellán que cantar y siruier la dicha yglesia. Y que éste y que el prior y cabillo de Fusiellos o so mandado si quisieren y que lo pongan en fieldad en omes buenos de Villaçís, porque se paguen y se cumplan todas estas cosas sobredichas cada anno por el tiempo que se ouieren a pagar. Y lo al que fincare de todo el dicho terçio y de las cosas que le pertenesçen, mandamos que tomen el dicho cabildo y convento para sí las tres partes y que tomen el prior y cabildo de Sancta María de Husillos la otra quarta parte ansí los que son agora como los que serán de aquí adelante cada año, para siempre jamás, o aquel que ouiere de rrecaudar por ellos.

Y otrosí, mandamos que si alguna cosa rremanesçiere deste pan que tomaren el abad y convento para pagar los dichos derechos y el rrefazimiento de la iglesia y el mantenimiento del capellán y ésto pagado, lo que rremaneçiere que lo partan en la manera sobredicha. Y otrosí, si alguna cosa menguare que lo que y menguare para lo pagar y cumplir que lo pague el dicho abad y conuento y que se entreguen de lo que pagaren al nueuo primero que viniere, cada anno, del pan del dicho terçio. Y esto todo mandamos que se pague y se cumpla y se vse ansí en todo como dicho es para siempre jamás, so la pena de los mil maravedís de los buenos que se contiene en el dicho conpromiso a cada vna de las partes sobredichas que contraello o contra alguna cosa dello vinieren o quisieren venir, por sí o por otrie y por cada vegada que contra ello viniere el dicho abad, por sí y por su convento y el dicho Joán Abad, por nombre del prior y cabildo sobredicho, que fiziese desto que de susodicho es dos cartas anbas fechas en vn tenor y las signase con mío signo. La vna que tengan el abad y conuento del monesterio de Benebiuas, y la otra que tengan el prior y cabildo de Sancta María de Fusiellos. Y por más firmedunbre, el dicho abad del dicho monesterio de Benabiuas fizo sellar estas cartas anbas con su sello de çera colgado. Y otrosí el dicho prior y cabildo de Fusiellos fizieron sellar estas dichas cartas con sus sellos de çera colgados.

Fecha la carta en Villalón, jueues, diez y seis días del mes de mayo, era de mil y trezientos y sesenta y tres años. Testigos que fueron presentes rrogados y llamados para esto: frey Pero, prior de Ferri. Joán Llorente y su yerno, don Andrés, $(f .59 v)$ y su hijo, Joán Llorente, clérigo. Fagún Pérez, alfajeme. Domingo 
Pérez, carretero, vezinos de Villalón. Joán Domínguez de Santillán, capellán del abad. Don Gonçalo de Sancta María de Fusiellos. Alfonso Sánchez, fijo de Sancho Fernández de Toledo.

Y yo, Domingo Alfonso, escrivano sobredicho, fue desto presente, y por ruego de las dichas partes fize esta carta y otra tal y puse en cada vna dellas mío signo en testimonio de verdad.

1325, agosto, 1 , lunes.

Reconocimiento y acatamiento por Pedro Miguélez, abad de Santa María de Benavides, y Juan Abad, procurador del prior y cabildo de Santa María de Husillos, de la sentencia del pleito habido entre ambas abadías por el disfrute del diezmo de la iglesia de San Mamés de Villacid.
B. APA, $L P H$, ff. 58r-60r.
C. BN, $m s .705$, ff. $111 \mathrm{v}-118 \mathrm{v}$.

El día 1 de agosto de 1325 fue jueves y no lunes. Véase A. GIRY, Manuel de Diplomatique. La letra dominical correspondiente a 1325 es la F, y la Pascua cayó el 7 de abril.

Aunque este documento forma parte de la sentencia y está escrito sobre el mismo soporte que ésta, el hecho de que los fedatarios sean diferentes, que constituya en sí mismo un acto jurídico propio aunque relacionado con la sentencia, y que ambos estén escritos con muchos días de diferencia, hace que lo editemos de manera independiente.

Fecho y sacado fue este dicho traslado en la villa de Husillos, a veinte y quatro días del mes de noviembre de mil y quinientos y çinquenta y quatro años. Y fueron testigos a lo ver, leer, corregir y conçertar, Joán Ruiz Cabeça de Vaca y Gaspar de Vedoya, clérigos, y Pero Manuel, estantes en la dicha villa.

E yo, Santiago Gómez, escriuano público en la dicha villa, presente fui a lo que dicho es en vno con los dichos testigos. Y del dicho pedimiento y mandamiento, lo escreví y fize aquí mi signo (signo) en testimonio de verdad.

Pero Ruyz de Billoldo (rúbrica). Santiago Gómez (rúbrica). 
(Precede doc. núm. 107)

Lunes, primero día de agosto en la era sobredicha, en presençia de mí, Martín Pérez, notario público de Villalón, y de los testigos de yuso escritos, apareçieron don fray Pero Miguélez, abad del sobredicho monesterio de Benebiuas, y Joán Abad, canónigo y procurador del prior y cabildo de Sancta María de Fusiellos. Los sobredichos y conoçieron que esta sentençia sobredicha fuera dada en la manera que sobredicho es, y que ellos la rreçibieron y consintieron en ella y que pasaron por todo assí como en estas cartas sobredichas se contenía y pidieron a mí, Martín Pérez, notario sobredicho, que escriviese mío nombre y fiziese mío signo en cada vna destas cartas en testimonio de verdad.

Testigos que fueron a esto presentes: Joán Pérez, hijo de don Pero, prior de Ferrin. Joán Rodríguez, capellán de la yglesia de Fusiellos.

Y porque yo, Martín Pérez, notario sobredicho, fue a esto presente, fizla escrevir y puse aquí mío nombre y mío signo en testimonio. (f.60r)

1327, diciembre, 3, jueves. Husillos.

Alfonso Gutiérrez, notario público de Palencia, da fe de cómo Pedro Martínez Nepote, hombre de García Pérez, abad de Santa María de Husillos, y procurador del prior y cabildo de dicha iglesia, inicia su viaje a la Santa Sede desde Husillos para representar a Santa María de Husillos en el pleito que mantiene con Juan II Fernández de Limia, obispo de Palencia, y el cabildo de la catedral de Palencia. En el acto de despedida se encuentran el prior y cabildo de Santa María de Husillos y algunos habitantes de Husillos en calidad de testigos.

A. APA (Se encuentra dentro del Libro de los Privilegios de Husillos). Perg., 105 x 354 mm.; escr. precortesana; buena conservación con dos pequeñas roturas que no afectan al texto. 
Nouerint vniuerssi presens publicum instrumentum inspecturi, etiam anno Domini millesimo $\mathrm{CCC}^{\mathrm{o}} \mathrm{XX}^{\mathrm{o}}$ septimo, tercia die, menssis decembris, scilicet die iouis, in Fusellis, Palentine diocesis, in presen/cia mei, notarius, testium super svscriptorum ad hoc vocatorum specialiter rogatorum, et venabiles et discreti viri prior et capitulum ecclesie Fusellensis, dicte Palentine diocesis, congregati apud portas dicti loci / de Fusellis, campana pulssata, exierint ommes extra villam, dicti loci de Fusellis, scilicet, prior et capitulum nominati. Et dictus prior, nomine suo et capituli memorati, dixit que super causis quas $\beta$ ipsi prior et capitulum Fusellensis habent seu habituris sunt in curia romana contra reuerendum in Christo Patrem et Domini domini Iohanem, miseracione diuina episcopum, ac capitulum $\mathrm{Pa} /$ lentine, mitebant et eciam miserunt suum ligitimum procuratorem ac nuncium salen et ad prosequndum dictas causas, discretum virum Petrum Martini Nepotem domini Garssie Petri, / quondam abbatis de Fusellis, tunc presentem et mandatum spotem suscipierem paratum cum omnibus actis et monumentis suis ac eciam cum expenssis. Et statim dictes procura $/{ }^{6}$ tor dixit que nomine dictorum prioris et capituli et de ipsorum mandato, iturus erat ad dictam curiam romanam eum dictis actis et monumentis ac eciam cum suficiencia expenssa/rum et statim dictos procurator exivit per portas dicti loci de Fusellis et arripuit iter in continenti ut predicitor ad dictam curiam romanam. Et statim dictis prior, nomine suo et /capituli memorati, requisivit me, notarium infra scriptum, ut de predictas sibi darem publicum instrumentum.

Acte est hoc dicto loco de Fusellis, anno, mensse et die predictis. Testibus $\rho^{9}$ presentibus: discretis viris Iohane Roderici, capellano Sancte Marie de Fusellis. Petro Ferrandi de Carrione, conmorante in villa que dicitur Sancta Cruz de Monçon, Palentine diócesis. Turibio, /filio dompni Guterrii. Paschasio Petri et Dominico Ferrandi de Castrello, in dicto loco de Fusellis conmorantibus.

Et ego, Alfonssus Guterrii, publicus notarius civitatis Palentine, vo/catus et rrogatus, una cum dictis testibus omnibus et singulis, supradictas presens inter fui et rrequisitus, hoc presens publicum instrumentum propria manu scripssi, meo que solito sig(signum)no $/{ }^{12}$ signavi in testimonium promissorum. 
1329, abril, 12, miércoles. Husillos.

Nuño Pérez, prior de Santa María de Husillos, y el cabildo de dicha iglesia, nombran como procuradores a Pedro Ferrández, sacristán, Pedro Pérez, chantre, Juan Pérez, Ferrán Alfonso, Ferrán Martínez y a Martín Fernández, canónigos en dicha iglesia de Husillos, en los pleitos que pudieran tratarse, especialmente en el que se trata con Diego López de Torquemada.

B. AHDP, Ampudia y Abadía de Husillos, carp. 210-7. Perg., 878 x 513 mm.; escr. de albalaes; mala conservación, la tinta está muy desvaída, dando fe de ello el Libro de los Privilegios de Husillos: "No se pudo ler y por eso no se sacó". Inserto en ejecución de la sentencia, dada en Palencia, a 3 de junio de 1330. Véase doc. núm. 112.

Sepan quantos esta carta de procuraçión vieren commo nos, el prior et el cabillo de la eglesia de Fussiellos, llamados por campana tañida, ajuntados a cabillo en el logar acostumbrado, aquellos que pudimos y ssomos, ssegunt auemos de vsso et de $/ 6$ costumbre. Façemos et estableçemos et ordenamos nuestros çiertos, generales, espeçiales procuradores a Pero Ferrández, ssacristán, et a Pero Pérez, chantre, et a Iohán Perez et a Ferrant Alffonsso et a Ferrant Martínez et a Martín Ferrández, canónigos en la dicha eglesia de Fussiellos, a todos en unno et a cada unno dellos /por ssu cabo, assí que non ssea maior la condiçión del que primero encomenzare el pleito o los pleitos, que la del otro que después vaia más en aquel missmo punto et logar, lo pueda, el unno dellos, tomar do el otro lo dexar et yr por el primero adelante et ffenesçer, en todos / los pleitos et demandas que nos auemos contra qualquier o qualesquier personas, eclessiásticas o sseglares, de qualquier cobdiçión, dignidad o estado que ssean, o ellos an o esperan auer contra nos, por qualquier rraçón et manera que ssean. Et espeçialmiente en el pleito que nos aue $/{ }^{9} \mathrm{mos}$ e esperamos aueer contra Diego López et ssus compannas et contra los canónigos de Fuentes et de Vega et de Quintaniella de Valdepero, o ellos an o esperan auer contra nos, para ante nuestro señor el rey o para ante ssus alcalles o para ante qualquier dellos o para ante 
nuestro sse/ñor el obispo de Palençia o para ante ssus vicarios o ante ssus iuezes o para ante qualquier dellos o para ante otro o otros iuez o iuezes qualesquier que ssean, ordinarios o dellegados o subdelegados, árbitros eclessiásticos o sseglares, que el pleito o los pleitos ayan poder de oyr / et de iudgar. Et damos todo nuestro cumplido et llanero poder a estos dichos nuestros procuradores et a cada unno dellos por ssu cabo, para demandar, rresponder et conosçer et negar et deffender, abenir et componer et comprometer et componer rraçones et axempçiones et deffenssiones et para iurar $/{ }^{12}$ en nuestras almas, iura o iuras de qualquier manera que al pleito o a los pleitos conuenga. Et espeçialmiente iuramientos de calumpnia et dezir verdat. Et para rrecebir iura o iuras de la otra parte o partes et mester ffueren. Et para perssonar testigos et prueuas et cartas et todas otras / cossas que mester ffueren et nos aprouecharen. Et veer iurar las que la otra parte presentaren et dezir contra ellas en dichos et en perssonas. Et para oyr ssentençia o ssentençias et conssentie en ellas et para apellar della o dellas, que ffuerde dada o dadas contra nos, ssegunt la apellaçión / o apellaçiones o dar quien la ssigna para ante aquel que mester ffuere. Et para ganar carta o cartas, previllego o preuillegos et demandar et rreçebir iuramentos et para demandar et iurar costas et para las rreçebir. Et pedir et rreçebir beniffiçio de rrestituçión in integrum. Et para dar carta o cartas de pagamiento $/{ }^{15}$ et de quitamiento et rreçebir paga o pagas, entrega o entregas, assentamiento o assentamientos. Et para ffaçer sustituyr otro o otros procurador o procuradores por nos et en nuestro nombre, quantos et quando quessieren et para los rreuocar quando por bien touieran et tomar en ssí el offiçio de la procuraçión. Et / para ffazer et dezir todas aquellas cosas et cada una dellas qual tales legítimos ssuffiçientes et procuradores pueden et deuen ffaçer et dezir et rraçonar et que nos mismos ffaríamos et deríamos si pressentes ffuéssemos, aunque ssean tales que rrequiran sspeçial mandado. Et obliga/mos todos nuestros bienes del nuestro comunal para esstar et auer por ffirme por todo quanto ffuere ffecho et dicho et rraçonado por los dichos nuestros procuradores o por qualquier dellos o por los ssos ssobstitutos o por qualquier dellos. Et para pagar et complir todo quanto contra nos ffuere iudga $/{ }^{18}$ do rrelevando, los dichos nuestros procuradores o los ssustitutos de toda carga de ssetisdaçión con ssus costas. 


\section{LA ABADÍA DE SANTA MARÍA DE HUSILLOS: ESTUDIO Y COLECCIÓN \\ DOCUMENTAL $(904-1608)$}

Et porque essto ssea ffirme et non venga en dubda, rrogamos a Alffonso Gutiérrez, notario público de Palençia, que estaua pressente, que esscriuiesse essta carta de procuraçión et que la ssignasse / con ssu ssigno en tesstimonio.

Que ffue ffecha en nuestro cabillo, desspués de primera ante de terçia, miércolles, doçe días de abril, era de mille et treçientos et ssessenta et ssiete annos. Testigos que estauan pressentes: Yuán Abat et Iohán Iohánez, capellanes. Alffonso Pérez, clérigo del coro de la / dicha eglesia de Fussiellos. Don Santiago, carpentero, morador en Piña.

Et yo, Alffonso Gutiérrez, público notario ssobredicho de la çipdat de Palençia, ffuy pressente a esto que dicho es con los dichos pesquisas en el dicho cabillo. Et por rruego de los dichos prior et cabillo esscriuí essta carta de procuración, ${ }^{21}$ et ffiz aquí esste mío ssigno en testimonio de verdat.

1329, abril, 13, jueves. Palencia

Carta de compromiso entre los procuradores de Santa María de Husillos y Diego López de Torquemada, por sí y como procurador de los concejos de Fuentes de Valdepero, Vega de Valdepero y Quintanilla de Valdepero, por la que eligen como juez árbitro a Juan II Fernández de Limia, obispo de Palencia, en el pleito que mantienen.

B. AHDP, Ampudia y Abadía de Husillos, carp. 210-7. Perg., 878 x 513 mm.; escr. de albalaes; mala conservación, la tinta está muy desvaída, dando fe de ello el Libro de los Privilegios de Husillos: "No se pudo ler y por eso no se sacó". Inserto en ejecución de la sentencia, dada en Palencia, a 3 de junio de 1330. Véase doc. núm. 112.

Sepan quantos esta carta deste compromisso vieren, commo ssobre pleitos et $\mathrm{de} /{ }^{\beta}$ mandas et contiendas et querellas et otrossí, de injurias que sson o entienden sseer contra el onrrado varón et ssabio don Nuño Díaz, abat de Fussiellos, et Nuño Pérez, prior, por sí, et otrossí, Pero Ferrández, ssacristán, et 
Pero Pérez, chantre, et Ferrand Alffonsso, canónigo, por ssí et / por el cabillo de la eglesia de Fussiellos, cuyos procuradores son, diçen, por el poder de una procuraçión que mostraron, sscripta en paper, ssignada, ssegund por ella aparesçía, de mano de Alffonsso Gutiérrez, escriuano público de la çipdat de Palençia, el tenor de la qual / es este que sse sigue:

(Sigue doc. núm. 110)

Esstos ssobredichos, de la una parte, et Diego López de Torquemada, por ssí et por ssus compannas et por los conçeios de Fuentes et de Vega et Quintaniella de Val de Pero, de la otra parte, ssobre rraçón de quebrantamientos et de injurias que / los dichos abat et prior et procuradores deçían que auíen rreçebido en el ssu logar et la eglesia de Santa María de Fussiellos. Et todos quantos pleitos et demandas et querellas et contiendas ha la una parte contra la otra, ffassta el día de oy que este compromisso ess ffecho, amas estas dichas par/tes venieren por abenidas de comprometer estas dichas injurias, quebrantamientos et todas quantas demandas et querellas et contiendas ha la una parte contra la otra, ffassta el día de oy. Et luego, amas estas dichas partes, nombraron por juez et amigo, árbitro arbitrador $/^{24}$ et amigable componedor al onrrado padre et sseñor don Iohán, por la graçia de Dios, obispo de Palençia, que estaua pressente. Et diéronle todo ssu llanero, complido poder a este dicho señor obispo, assí commo amigo, árbitro arbitrador et amigable componedor en essta manera: que por / quanto el dicho señor mandare, abeniere, compussiere, ssentençiare, indagare, ordenare, en día fferiado o non fferiado, las partes pressentes o non pressentes, ssabida la verdat o non ssabida, llamadas las partes o non llamadas, sseyendo o esstando en pie o esstando guardada la orden del derecho / o non guardada, en qualquier manera que ssea, que los dichos abat et prior et procuradores et cabillo et Diego López et cada unno dellos esstén et queden por ello et lo ayan por ffirme, para agora et para todo tiempo et lo cumplan, paguen et atengan. Et que nunqua, ninguna de las dichas partes, que sse non pueda querellar ${ }^{27}$ nin apellar nin alçar nin ssuplicar, a rrey nin a rreyna nin a inffante nin a rrico omme nin al papa nin arçobispo nin a obispo nin a sseñor nin a otro omme que en el mundo ssea nin pueda auer rrecusso a aluedrío de buen varón. Et qualquier o qualesquier de los dichos abat et 


\section{LA ABADÍA DE SANTA MARÍA DE HUSILLOS: ESTUDIO Y COLECCIÓN \\ DOCUMENTAL $(904-1608)$}

prior et procuradores et Diego / López que sse agrauiaren o sse alçaren o querellaren o ssuplicaren o apellaren et non cumplieren et pagaren et touieren lo que el dicho señor obispo, amigo árbitro, mandare, abeniere, arbitrare, senteziare, ordenare en qualquier manera, ssegund dicho ess, que de et pague et peche diez mille maravedís de los / buenos, la meatad para el dicho señor obispo, la otra meatad para la parte que esstudiere, quedare et touiere et pagare et compliere lo que el dicho señor obispo, amigo arbitro, mandare, ssenteziare, abeniere, ordenare. Et pagada la pena de los dichos diez mille maravedís o non pagada, que todavía que esté et $\rho^{30}$ queden et paguen et cumplan et atengan, todo lo que el dicho señor obispo, amigo árbitro, mandare o ssentençiare, abeniere, arbitrare o iudgare, ordenare, seggunt dicho ess et en qualquier manera que ssea. Et cada vez que el dicho señor obispo, amigo árbitro, assignare, mandare o diere plaço / a las dichas partes, que ante paressca la que non viniere por ssí, ssi pudiere, ssi non por ssu procurador ssuffiziente, que dé et pague et peche doçientos maravedís de los bonos, la meytad para el dicho señor obispo et la otra meatad para las partes que venieren al plaço.

Et amas esstas / dichas partes, rrenunçiaron et partieron de ssí a todas leyes et ffueros et derechos, ussos et cosstumbres, sscriptas et non sscriptas et a todas boçes et a toda rraçón et a toda deffenssión et a todas lass otras rraçones et cossas, que cada unno dellos por ssí, podiere poner, que les non vala en esta rraçón nin ssea, sobre $\beta^{\beta 3}$ ello, oydos nin oydo, en iuyçio nin ffuera de iuyçio, ante ningun juez, eclessiásstico nin seglar. Et otrossí, amas estas dichas partes, venieron por auenidas que lass ssentençias intredichas, que por el dicho señor, estauan puesstas en los logares et en las eglesias de Fuentes et de / Vega et de Quintaniella de Val de Pero, que esstudiessen en la manera que agora esstauan, ffassta que el dicho señor obispo, assí commo amigo, árbitro arbitrador, amigable componedor, ssenteziasse, iudgasse, mandasse, abeniesse, compussiesse, ordenasse en qualquier manera, commo dicho ess. Et la / ssentençia, mandamiento, ordenamiento, abenimiento componiendo, ffuesse complido et pagado en todo et por todo, ssegunt que lo el dicho señor obispo mandasse, abeniesse, componiesse, iudgasse, ssentençiasse, ordenasse.

Et para todas esstas cossas et cada una dellas, que en essta carta desste compromisso sse contiene, complir $/^{36}$ et atener et pagar, ssegunt que lo el dicho 
señor obispo, madare, ssentençiare o iudgaren, ordenaren, abenieren los dichos abat, prior, obligaron a ssí et a todos ssus bienes, muebles et rrayzes, sspirituales et tenporales, ganados et por ganar. Et otrossí, los dichos Pero Ferrández, ssacristán, et Pero Petrez, chantre, et Ferrant / Alffonso, canónigo, por ssí et por el cabillo de la eglesia de Fussiellos, cuyos procuradores sson, obligaron a todos los ssus bienes et del dicho cabillo, muebles et rrayzes, sspirituales et tenporales, quantos oy día han et aurán de aquí adelante. Et otrosí, el dicho Diego López de Torquemada, por ssí et por ssus compannas / et por los dichos conçeios de Fuentes, de Vega et de Quintaniella, obligó a ssí et a ssus bienes, muebles et rrayzes, ganados et por ganar, quantos oy día ha et aurá daquí adelante. Et dessto, los dichos abat et prior et procuradores et Diego López, rrogaron a nos, Alffonsso Ruyz et Iohán Sánchez ${ }^{\beta 9}$ de Saia, notarios públicos de la çipdat de Palençia, que ffeziéssemos, desto, una carta de compromisso o dos o más, quantas compliessen et messter oviessen, ssignadas con nuestros ssignos.

Et luego, el dicho señor obispo, rreçebió en ssí esste dicho compromissso ssin periuyçio de ssí et de ssu eglesia / et de todas ssus rrentas et derechos et bienes que él ha. Et pusso plaço a las dichas partes, que aparessçiessen antel et traxiessen por sscripto todas quantas querellas et demandas la vna auía contra la otra, para el iueves primero, sseguiente, del día que esta carta desste compromisso ess ffecha, a la / ora de la terçia, so la dicha pena que en esste compromisso sse contiene.

Fecho ffue essto en Palençia, en la cámara del dicho señor obispo, yueues, XIII días de abril, era de mille et treçientos et ssesenta et ssiete annos. Tesstigos que esstauan pressentes, iamados et rrogados $/^{42}$ sspeçialmiente para essto: Pero Ruyz de Villamediana, don Alffonso de Quintaniella, caualleros, don Toribio, veçino de Palençia, Iohán Pérez, camarero del dicho señor obispo.

Et yo, Iohán Sánchez de Saia, notario público de la çipdat de Palençia sobredicho, que ffuy presente a esto que dicho / es, con el dicho Alffonso Ruyz, notario, et con los otros tesstigos que ssobredichos, por rruego de los dichos abat, prior et procuradores et Diego López, esscriuí essta carta de compromisso et ffiz, en ella, esste mío ssigno, acosstumbrado, en tesstimonio de verdat.

Et yo, Alffonsso Ruyz, notario público / de la çipdat de Palençia, ffuy pressente a lo que dicho es con el dicho Iohán Sánchez, notario, et con los dichos tesstigos et rrogado et rrequerido de los ssobredichos abat et prior et procuradores et Diego 


\section{LA ABADÍA DE SANTA MARÍA DE HUSILLOS: ESTUDIO Y COLECCIÓN \\ DOCUMENTAL $(904-1608)$}

López, pus essta ssubcripçión en esste compromisso et ffiz, aquí, esste mío signo en tesstimonio de ${ }^{45}$ verdat.

1330, junio, 1, viernes - 1330, junio, 3, domingo. Palencia

Sentencia y testimonio notarial de ejecución de ésta, pronunciada por Juan Fernández de Limia, obispo de Palencia, juez árbitro en el pleito litigado por Nuño Díaz, abad de Santa María de Husillos, y el prior y cabildo de dicha iglesia, con Diego López de Torquemada, en su nombre y en el de los concejos de Fuentes, Vega y Quintanilla de Valdepero, por los quebrantamientos y deshonrras que los segundos hicieron a la iglesia de Santa María y al lugar de Husillos, ordenando que el dicho Diego López de Torquemada y su hijo, Lope García, entren en Husillos, una vez atravesado el río Carrión, en sayas, descalzos y con cintas en la garganta; y los hidalgos y compañias que fuesen con él, en camisas y en paños menores. Y que cien hombres de los dichos concejos entren en paños menores y con sogas de esparto en la garganta. Todos debían pedir perdón al abad, prior y cabildo de Santa María de Husillos. Además debían pagar a dicha iglesia veinte mil maravedís y poner una lámpara con cinco marcos de plata en el altar mayor de dicha iglesia. Para el suminitro de aceite de dicha lámpara, debían dar quinientos maravedís para que la iglesia comprara posesiones con las que poder sacar renta para dicho aceite.

A. AHDP, Ampudia y Abadía de Husillos, Pergaminos, carp. 210-7. Perg., 878 x 513 mm.; escr. de albalaes; mala conservación, la tinta está muy desvaída, dando fe de ello el Libro de los Privilegios de Husillos: "No se pudo ler y por eso no se sacó".

Aunque el nombramiento de procuradores y de juez tuvo lugar los días 12 y 13 de abril del año 1329, la sentencia no fue dictada hasta más de un año después, el 1 de junio de 1330. 
In Dei nomine. Sepan quantos esta carta dessta ssentençia vieren, commo ssobre pleitos et demandas et contiendas que eran et entienden sseer contra el onrrado varón et ssabio don Nuño Díaz, abat de Fussiellos, et el prior et el cabillo dessa misma eglesia, de la una parte. Et Diego López / de Tor[quema]da, por ssí et por ssos compañas et por los conçejos de Fuentes et de Vega et de Quintaniella, de la otra parte. Ante nos, don Iohán, por la graçia de Dios obispo de Palençia, iuez et amigo arbitro et arbitrador et amigable componedor en el dicho pleito, ssegunt sse contiene / en una carta de compromisso, ffecha et ssignada por mano de Iohán Sánchez de Saia et de Alfonso Ruyz, notarios públicos de la nuestra çipdat de Palençia, el tenor de la qual es este que sse ssigue:

(Sigue doc. núm.111)

Et nos, dicho obispo, iuez ssobredicho, vistas lass querellas et demandas et rraçones et cada una dellas que, los dichos abat et prior et cabillo, pussieron et rraçonaron et dexieron ante noss, contra el dicho Diego Lopez et contra sus compañas et contra los que con el ffueron; et vistos los / quebrantamientos de la eglesia et del logar de Fussiellos. Et vissto lo que el dicho Diego Lopez rraçonó et dixo et allegó et pusso, por ssí et por los que con el sse acaesçieron en el dicho quebrantamiento. Et otrossí, vistos los previllegos et libertades de la eglesia de Fussiellos, que los dichos abat et prior et cabi/ello mosstraron, ante nos, ssobre essta rraçón et ssobre esstas querellas. Et vistas todas las otras cossas et cada una dellas, que las dichas partes quissieron dezir et rraçonar ante noss, auido nuestro conssejo et examinado todo lo que ante noss passó ssobre este ffecho, por el poder que las dichas pa $/{ }^{48}$ rtes nos dieron por el dicho compromisso, sseteçiando, ordenado, arbitrando, abeniendo, componiendo, iudgando por ssentençia deffenitiua, mandamos que, por rraçón que el dicho Diego López et las ssus compañas et los otros que con el sse acaessçieron, entraron por ffuerça et que/brantaron et dessonrraron los beniffiziados de la dicha eglesia et logar de Fussiellos et prendraron et tomaron las cossas que y ffallaron por ssu propia obturidat, ssin rraçón et ssin derecho que el dicho Diego López, por su perssona et las ssus compañas et los otros que sse y acaesçieron et çient / omes bonos, de los dichos conçejos, vengan de dos en dos ffazer essta emienda, este domingo de la 


\section{LA ABADÍA DE SANTA MARÍA DE HUSILLOS: ESTUDIO Y COLECCIÓN \\ DOCUMENTAL $(904-1608)$}

Trenidat, primero que viene, que sserá tres días deste mes de iunio, este primero que viene, por el quebrantamiento et dessonrra que ffeçieron a los dichos abat et prior et cabi $/{ }^{51} 1$ lo de la dicha eglesia et al dicho logar de Fussiellos, desde la Assomada de Fuentes que pareçe Fussiellos, ffassta la eglesia de Santa María de Fussiellos et entre por la dicha eglesia et anden la claustra toda en derredor et ssalgan por la otra puerta que ess contra / la plaça et leguen otra vez a la puerta mayor de la eglesia, en esta manera: El dicho Diego López et Lope Garçía, ssu ffijo, et los fijosdalgo que y venieren, desque passaren el rrío de Carrión, en ssayas et descalços, et lass ssus compañas et los que sse y acaessçie/ron con él en el dicho quebrantamiento, que vengan tan ssolamiente en camissas et en paños menores et çintas a las gargantas, desdel dicho logar que assomaren a la dicha eglesia de Fussiellos, desde asse missmo logar de la Assomada. Et los dichos

çient omes bonos $/^{54}$ de los dichos conçejos que vengan todos dessnudos, tan ssolamiente en paños menores et et sseñas ssogas de esparto a las gargantas. Et en legando a la dicha puerta, andando la dicha clausstra, que ffinquen todos los ynoios, que rruegen et pidan perdón a los dichos abat et prior et cabillo, mucho / omillossamiente, que por amor de Dios et por lo nuestro et por rruego de los otros omes bonos que y esstudieren en deredor, a la dicha emienda, que los perdonen de tanto yerro et de tanta desonrra et quebrantamientos que les ffeçieron a los dichos abat et prior et cabillo et que digan de que sson mucho / arrepentidos. Et otrossí, porque el dicho Diego López entró por ffuerça et quebranto la dicha eglesia de Santa María de Fussiellos, non temiendo a Dios nin ssu alma nin catando rreuerenzia a los santos nin a las rreliquias nin a las libertades et priuillegos que an, la dicha eglesia et logar de Fusiellos, de los $/^{57}$ reyes que ffueron por tiempo en Castiella. Et assí que, por essta rraçón, cayó, el dicho Diego López et los otros que sse y acaessçieron, con él, en el dicho quebrantamiento, cayeron en pena de veynte mille maravedís, desta moneda, que ffallamos que sse contiene en los dichos priuillegos. Et mandamos, que por essta missma ssentençia, que / el dicho Diego López et ssus compañas et los otros que con el sse acaessçieron, en el dicho quebrantamiento, den et paguen, ffassta el día de Sant Iohán Bautista, esste primero que viene que cae en el mess de iunio, a los dichos abat et prior et cabillo, los dichos veynte mille maravedís de la dicha pena en / que cayeron, ssegunt ess tenido en los dichos priuillegos et libertades. Et mandamos más, que el dicho 
Diego López et ssus compañas et los otros que sse acaesçieron, con él, en el dicho quebrantamiento, porque ssea escarmentado et exienplo de los que lo vieren et lo oyeren, et que ffinque en memo $/{ }^{60}$ ria et en rremembrança, para los que sson et sserán de aquí adelante para ssienpre iamás, que ponga luego, este dicho domingo de la hemienda, ante el altar mayor de la dicha eglesia de Santa María, una lánpara en que aya çinco marcos de plata et que den quinien/tos maravedís en dineros, en el dicho plaço de Sant Iohán, para comprar possessiones que rrenda para azeite para alumbrar para ssienpre jamás la dicha lánpara et para las otras cossas que sson messter, para mantenimiento et rreffaçemiento de la dicha lánpara. Et otrossí, mandamos que el dicho Die/go López et el dicho ssu ffijo et ssus compañas et los dichos çient omes bonos, por ssí, en nombre de los dichos conçejos, iuren sobre ssos euangelios, tomándolos corporalmiente, que nunca sserán, por ssí nin por otre, maniffiesstamiente nin encobiertamiente, contra lass yglesias de Palençia $/{ }^{63}$ nin de Fussiellos nin contra ssus libertades nin contra ssus derechos nin contra nos nin contra nuestros antezessores nin contra los dichos abat et prior et cabiello de Fussiellos nin contra ssus vassallos nin contra ninguno dellos nin contra ninguno nin ninguno de los beniffiziados de la dicha eglesia de / Fussiellos. Et essto todo ffecho, ssegunt dicho es, que rressponda el dicho abat, por ssí et por ssu eglesia, et el dicho prior, por ssí et por el dicho cabiello, que por el amor de Dios et por nos et por los omes bonos que y esstudieren a la dicha emienda, que perdona et perdonan al dicho Diego / López et al dicho ssu ffijo et a las dichas ssus compañas et a los dichos conçejos, para agora et para ssienpre iamás, por rraçón del dicho quebrantamiento et dessonrra.

Et essta dicha emienda primeramiente ffecha, ssegund dicho es, damos por libres et por quitos, para agora et para ssienpre iamás, $/{ }^{66}$ a los dichos Diego López et ssu ffiio et ssus compannas et conçeios, del dicho quebrantamiento et dessonrra et ffuerça, que ffizieron a los dichos abat et prior et cabiello de la dicha eglesia et al dicho logar de Fussiellos. Et essto ffecho, mandamos que todas quantas querellas, los dichos abat, prior, cabi/ello o otre por ellos, dieron a qualquier o a qualesquier perssona o perssonas, eclessiássticas o sseglares, de qualquier dignidat o estado o condiçión que ssean, del dicho Diego López et el dicho ssu ffiio o otro o otros amigos et parientes, por ellos o por qualquier dellos o qualquier o qualesquier que y acaessçieron con / el dicho Diego López et de los dichos abat et prior et 
cabiello, que todo ssea ninguno et que non valan et que todas ssean rrotas et ssacadas del regisstro. Et que por essta rraçón, de aquí adelante, que el dicho abat, prior et cabillo non ayan ninguna demanda contra el dicho Diego López nin contra el dicho $/{ }^{69}$ ssu ffiio nin contra ninguno nin ningunos de los que con el dicho Diego López sse acaeesçieron en el dicho quebrantamiento. Et otrossí, que el dicho Diego López nin el dicho ssu ffiio nin ninguno de ssus parientes nin de ssus amigos nin ninguno nin ningunos de aquellos que sse acaessçieron, con el dicho Diego López, / que non aya, ninguno, querella nin ninguna demanda contra los dichos abat et prior et cabiello. Et essto todo mandamos que sse cumpla et sse page et atenga, en todo et por todo, para agora et para ssienpre iamás. Et aquel o aquellos que lo quebrantaren et contra esta ssentenzia ffueren, en todo o en / parte, et lo non cumplieren et pagaren et atouieren, que den et pechen et paguen, ssin ninguna cobdiçión, la quantía de los maravedís, de la pena que sse contiene en el dicho compromisso, et todavía esstar, que esstar por lo que nos mandamos por essta nuestra ssentenzia.

Et dessto, mandamos et $/^{72}$ rrequerimos a Alffonsso Ruyz et a Iohán Sánchez, nuestros notarios públicos de la nuestra çipdat de Palençia, que esscriuan, dessto, cartas et ssentençias et den una al abat et al cabillo de la yglesia de Fussiellos et otra al dicho Diego López et aquellos que las quessieren et les perteneze, todas en un / tenor, sscriptas et ssignadas con ssus ssignos.

Essta ssentenzia ffue dada en Palençia por el dicho sseñor obispo en el palaçio de las ssus cassas, do él mora, esstando pressentes, de la una parte: Don Nuño Díaz, abat, et Iohán Pérez, prior, et Pero Ferrández de Castriello de Villa / Vega, ssacrisstán, et Martín Ferrández, canónigo en la yglesia de Fussiellos et procuradores del cabiello de la dicha eglesia; et de la otra parte: el dicho Diego López de Torquemada. Viernes, primero día de iunio, era de mille et treçientos et ssessenta et ocho años, anno Domini $/{ }^{75}$ millesimo $\mathrm{CCC}^{\mathrm{o}} \mathrm{XXX}^{\mathrm{o}}$. Pessquissas rrogados que esstauan pressentes: Don Alffonso Rodríguez, arçediano de Carrión; don Lope Garçía de Torquemada, sacristán; maestre Françisco, maestre escuella; Garçía Yuánez, canónigo; don Per Esteuan, arçediano de Nágera et canónigo de Palençia; Per Ferrández, / ffijo de Ferrant Pérez de Piña, abat de Sant Saluador de Seuilla et canónigo de Palençia; et Bartolomé Pérez, canónigo; et Garçía Pérez et Pero Ferrández de Castro, rraçioneros en la eglesia de Palençia; Alffonso Moriel 
de Rojas, Dig Alffonso de Quintaniella de Valdolmiellos, caballeros; Françico Garçía, / capellán del hospital de Sant Antolín; Pero Ruyz de Vallarna, Saluador Pérez, Iohán Domínguez, Diego Ferrández, capellanes; liçençiado Martínez, clérigo del coro en la dicha eglesia de Palençia; ffray Iohán de Mazariegos, ffrayre del monesterio de Sant Françisco de Palençia; don Toribio de Vega; $7^{78}$ Françisco Martínez de Puerta del Sol, carniçero; Aluar Ferrández, ffijo de Yuán Yuánnez; Alffonso Pérez de Logroño; Iohán Gonçález, alffagem; Iohán Ferrández de Seguenza; Iohán Pérez, portero; Áluaro, ffijo de Diego Pérez, cabrero; Garçía Ferrández, criado de don Lope Garçía, sacristán; Domingo Martínez, hermano de Martín Pérez de Tablada, /avogado; Diego de Corral, ffijo de Iohán Esteuan, moradores en Palençia, Iohán Ferrández, tegero, vezino de Palençia; Essteuan Pérez, clérigo de Fonpudia; don Gonçalo, ffijo de Françico Gordo de Paredes de Naua; don Alffonso, ssu ffijo; Diego Abat, vicario del dicho logar de Paredes.

Item, desspués dessto, do/mingo, ffiessta de la Trinidat, tres días del mes de iunio, era de mille et treçientos et ssessenta et ocho años, en pressençia de noss, Alffonsso Ruyz et Iohán Sánchez, notarios públicos de la çipdat de Palençia, et delante lass partes de yusso scriptas, rrogadas et llamadas sspeçialmiente $/{ }^{81}$ para essto, vino el dicho Diego López et Lope Garçía, ssu ffijo, et Diego Alffonso, cauallero de Quintaniella de Valdolmiellos, et otros esscuderos et compañas del dicho Diego López, et çient omes desspués, en paños menores, de los conçejos de Fuentes et de Vega et de Quinta/niella de Valdepero, dessde la dicha Assomada de Fuentes et ssetençia et enmienda complidamiente, en todo et por todo, en la manera que el dicho señor obispo mandó por la dicha ssu ssetenzia et ssegund lo él mandó et touo por bien. Et andudieron la / dicha clausstra toda en derredor et llegaron cabe la puerta de la dicha eglesia de Santa María de Fussiellos et ffincaron, todos los inoios ante el dicho ssennor obispo et ante el abat et el prior et los otros omes bonos del cabillo de la yglesia de Fussiellos, $/^{84}$ que y esstauan. Et dexieron et rrogaron et pidieron perdón a los dichos abat et prior et cabillo, por las palabras ssobredichas que el dicho ssennor obispo mandó por la dicha ssu ssetenzia. Et luego, el dicho sseñor obispo, propusso et dixo ssu ssermón, et entre tantomientre ssu ssermón / dixo, el dicho Diego López et todos los otros ssobredichos los ynoios ffincados, et el ssermón acabado, el dicho sennor obispo dixo, que veyendo la emienda que auíen ffecha et el ssu rrepentemiento et la ssu 


\section{LA ABADÍA DE SANTA MARÍA DE HUSILLOS: ESTUDIO Y COLECCIÓN \\ DOCUMENTAL $(904-1608)$}

umildanza, que él, por ssí et por la ssu eglesia / de Palençia, que les perdonava el mal et yerro et la dessonrra et quebrantamiento que ffezieran a la dicha yglesia de Fussiellos. Et rroguó, a los dichos abat et prior et cabiello, que los quissiessen

perdonar et los dichos abat et prior et cabillo dexieron $/^{87}$ que perdonauan et perdonaron al dicho Diego López et a todos los otros ssobredichos por esta rraçón. Et pedieron todas las querellas et pleitos et demandas, que los dichos abat et prior et cabillo, auíen contra el dicho Diego López et ssus compañas et contra todos los otros / ssobredichos et los dichos Diego López et ssus compañas et los otros ssobredichos, auíen contra los dichos abat et prior et cabillo et compliéronlo assí todo, en todas las ssobredichas cossas et en cada una dellas, ssegund sse contiene en la dicha ssentençia / que el dicho sseñor dio et lo él mandó. Et los dichos abat et prior et cabillo ouieron, en todo et por todo, complida la dicha emienda, ssegunt el dicho sseñor obispo lo mandó. Et luego, los dichos Diego López et Lope Garçía, ssu ffijo, et Diga Alffonso, caua $/{ }^{90} 11$ ero, et otros ssus compañas del dicho Diego López et omes bonos a mano, por nombre de los dichos conçejos, ffeçieron iura ssobre santos euangelos, tomándolos corporalmiente que ssus manos et teniéndolos los avangelos el dicho sseñor obispo en ssus manos, iurando et / deçiendo las cossas ssobredichas et cada una dellas, que el dicho sseñor obispo mandó por ssu ssentençia. Et el dicho ssennor obispo et abat et prior et cabillo, auiendo et ouieron por complido la dicha emienda et ffechas las dichas cossas et cada una dellas, ssegunt el / dicho sseñor obispo lo mandó por ssu ssentençia. Et dessta enmienda, en commo nos, los dichos notarios, lo vimos ffazer et en commo sse ffiço et en qual manera passó, el dicho sseñor obispo mandó a nos, los dichos notarios, que ffeçiéssemos ende sse et esste público insstro $/{ }^{93}$ mento et signado por nuestras manos.

Pessquissas rrogados pressentes para essto: don Alffonso Rodríguez, arçediano de Carrión. Gonçalo Sánchez, abat de Haro. Gonçalo Yuánnez. Aluar Pérez, Ruy Martínez de Piña, canónigos. Garçía Pérez et Diego Garçía, rraçioneros en la yglesia de Palen/çia. Ffray Iohán de Mazariegos, ffreyre de Sant Françisco. Iohán del Pumar. Pero Ruyz. Alffonso Martínez, ffi de Alffonso Martínez. Martín Sánchez de Villaudella. Ruy Martínez, ffijo de Ruy Pérez de Villaudela. Diego de Corral, ffi de Iohán Estevan. Fraçisco Alffonso, ssobrino de Iohán de Pumar. Alffonso Sánchez, sserragero. Garçía / Gutiérrez de Siguenza. Aluar Ferrández. 
Don Toribio de Vega. Ferrnant Martínez, carniçero. Ruy Pérez de Bouar. Esteuan Ferrández, ballestero del rrey, moradores en Palençia. Françisco Garçía, capellán del hosspital de Sant Antolín, et Salvador Pérez, capellán de los veynte et quatro capellanes en $/{ }^{96}$ la yglesia de Palençia et otros muchos clérigos et legos que sse y acaessçieron.

Et yo, Alffonso Ruyz, notario público sobredicho de la çipdat de Palençia, ffuy presente a todo lo que sobredicho es con el dicho Iohán Sánchez, notario. Et con los dichos / pesquissas et por mandado del dicho sseñor obispo et a ssu rrequirimiento, ffiz escriuir esta carta et sentençia desto todo sobredicho, en commo passó, et ffiz aquí mío ssig(signo)no en testimonio de uerdat.

Et yo, Iohán Sánchez de Saia, notario público ssobredicho, ffui pressente a todo esto, que ssobredicho es, con el dicho Alffonso Ruyz, notario. Et con los dichos testigos et por mandado de los dichos et rrogado et requirido de las dichas partes, sso escriuí aquí con mi propria mano, et ffiz / aquí este mío $\operatorname{sig}($ signo)no acostumbrado en testimonio de uerdat.

\section{3}

1331, diciembre, 16. Valladolid.

Alfonso XI confirma un privilegio de Fernando IV (1312, marzo, 7. Valladolid), inserto, confirmatorio de otro de Sancho IV (1291, agosto, 16. Valladolid), inserto, confirmatorio a su vez de otro de Sancho III (1158, abril, 28. Carrión de los Condes), inserto, por el que concede a Raimundo, abad de Santa María de Husillos, y a todos sus canónigos, el privilegio de los infanzones, exentándolos asimismo de todo servicio real.

A. AHDP, Ampudia y Abadía de Husillos, Pergaminos, carp. 199-18. Perg., 742 x 574 mm.; escr. gótica redonda de privilegios; buena conservación. Sello de plomo.

B. AHDP, Ampudia y Abadía de Husillos, Pergaminos, carp. 200-20. Inserto en confirmación de Pedro I, dada en Valladolid, a 12 de noviembre de 1351. Véase doc. núm. 134. 


\section{LA ABADÍA DE SANTA MARÍA DE HUSILLOS: ESTUDIO Y COLECCIÓN \\ DOCUMENTAL $(904-1608)$}

C. AHDP, Ampudia y Abadía de Husillos, Pergaminos, carp. 201-24. Inserto en confirmación de Enrique II del privilegio de Alfonso XI, dada en Valladolid, a 20 de mayo de 1371. Véase doc. núm. 164.

D. ADHP, Ampudia y Abadía de Husillos, Pergaminos, carp. 201-26. Perg., 719 x 573 mm.; escr. gótica de privilegios; buena conservación. Mantiene parte de la cinta, pero no el sello. Inserto en confirmación de Juan I del privilegio de Enrique II, dada en Burgos, a 22 de agosto de 1379. Véase doc. núm. 194.

E. AHDP, Ampudia y Abadia de Husillos, Pergaminos, carp. 202-29. Perg., 717 x 517 mm.; escr. gótica redonda de privilegios y precortesana; buena conservación. Todos los elementos decorativos están dibujados pero sin miniar. No conserva la cinta pero sí el sello de plomo, que está suelto. Inserto en confirmación de Enrique III del privilegio de Juan I, dada en Burgos, a 20 de febrero de 1392. Véase doc. núm. 213.

$F$. APA, $L P H$, ff. 60r-61v. Traslado de $A$.

$G$. APA, $L P H$, ff. 72 r-74r. Traslado de $B$.

$H$. APA, $L P H$, ff. 92r-94v. Traslado de $C$.

I. APA, $L P H$, ff. $108 \mathrm{v}-111$ r. Traslado de $D$.

$J$. APA, $L P H$, ff. $124 \mathrm{r}-127 \mathrm{v}$. Traslado de $E$.

$K$. BN, $m s .705$, ff. $118 \mathrm{v}-124$ r. Traslado de $F$.

$L$. BN, $m s .705$, ff. $147 \mathrm{v}-154 \mathrm{v}$. Traslado de $G$.

M. BN, $m s .705$, ff. 201r-208r. Traslado de $H$.

$N$. BN, $m s .705$, ff. 238r-242r. Traslado de $I$.

(Christus, alfa et omega) En el nonbre de Dios, Padre et Fiio et Spiritu Sancto, que son tres personas et un Dios uerdadero que biue et rregna por sienpre iamás, et de la bien auenturada Uirgen gloriosa sancta María, su madre, a quien nos tenemos por senñora et por abogada en todos nostros fechos; / et a onrra et a seruiçio de todos los sanctos de la corte celestial. Queremos que sepan por este nostro priuillegio todos los ombres que agora son et serán daquy adelante, commo nos, don Alfonso, por la graçia de Dios rrey de Castiella, de Toledo, de / León, de Gallizia, de Seuilla, de Córdoua, de Murçia, de Jahén, del Algarbe, et senñor de Uizcaya et de Molina, en uno con la rreyna doña María mi mugier, uiemos vn priuillegio del rrey don Ferrando nostro padre que Dios per ${ }^{3}$ done, rodado et seellado con su seello de plomo, fecho en esta guisa.

(Sigue doc. núm. 100) 
Et agora el prior et el cabildo de la eglesia sobredicha enbiaron pedir mercet que touiésemos por bien de les confirmar este priuillegio, et de ge lo mandar guardar. Et nos el sobredicho rrey don Alfonso, por les fazer bien et / merced, tenémoslo por bien et confirmámosgelo, et mandamos que les uala et les sea guardado en todo segunt que les ualió et les fue guardado en tienpo del rrey don Alfonso, nostro bisauuelo, et del rrey don Sancho, nostro auuelo, et del rrey ${ }^{\beta 3}$ don Ferrando, nostro padre, que Dios perdone.

Et defendemos firmemente que ningunos non sea osados de yr nin de pasar contra él por lo quebrantar nin menguar en ninguna cosa, ca qualesquier que lo fiziesen, auríen nostra yra et demás pechar nos yan / la pena que en ell dicho priuillegio se contiene. Et al prior et al cabildo de la eglesia sobredicha de Fusiellos o a quien su boz touiese, todos los cabos et los menoscabos que por ende rresçibiesen doblados. Et porque esto sea firme et estable, / mandámosles ende dar este nostro priuillegio rrodado et seellado con nostro seello de plomo.

Fecho el priuillegio en Ualladolit, diez et seys días de dezienbre, en era de mille et trezientos et sesenta et nueue años. Et nos, el sobredicho ${ }^{\beta 6}$ rrey don Alfonso, rreynante en vno con la rreyna doña María mi muger, en Castiella, en Toledo, en León, en Gallizia, en Seuilla, en Córdoua, en Murçia, en Jahén, en Baeca, en Badajoz, en ell Algarbe, en Vizcaya et en Moli/na, otorgamus este priuillegio et confirmámoslo. /

Don Abdalla, fiio de Auin Amus Lemmi, rrey de Granada, vasallo del rrey, conf. ${ }^{39}$ Don Alfonso, fiio del infante don Fernando, uasallo del rrey, conf. Don Iohán, fiio del infante don Manuel, adelantado mayor por el rrei en la frontera et en ell rregno de Murçia, conf. / Don Ximeno, arcobispo de Toledo, primado de las Espannas et chançeller mayor de Castiella, conf. Don Iohán, arcobispo de Santiago et capellán mayor del rrey et chançeller del rregno de León, conf.

( $1^{a}$ col.) Don Garçía, obispo de Burgos, conf.- Don Iohán, obispo de Palençia, conf.- Don Iohán, obispo de Calahorra, conf.- Don Bernabé, obispo de Osma, conf.- Don frey Alfonso, obispo de Siguença, conf.- Don Pero, obispo de Segouia, conf.- Don Sancho, obispo de Áuila, conf.- Don Pero, obispo de Cuenca, conf.Don Pero, obispo de Cartagena, conf.- Don Gutierre, obispo de Córdoua, conf.- 
Don Iohán, obispo de Plazençia, conf.- Don Fernando, obispo de Jahén, conf.Don Bartolomé, obispo de Cádiz, conf.- Don Iohán Nunnez, maestre de la orden de la cauallería de Calatraua, conf.- Don frey Ferrant Rodríguez de Valbuena, conf. (sic) prior de la orden del Ospital de conf.(sic) Sanct Iohán, et mayordomo mayor del conf.(sic) rrey, conf.

( ${ }^{a} \mathrm{col}$.) Don Iohán Núñez de Lara conf.- Don Ferrando, fiio de don Diego, conf.Don Diego López, su fiio, conf.- Don Iohán Alfonso de Haro, sennor de los Cameros, conf.- Don Aluar Díaz de Haro conf.- Don Alfonso Téllez de Haro conf.- Don Lope de Mendoça conf.- Don Beltrán Yuánnez de Mendoça conf.Don Iohán Alfonso de Guzmán conf.- Don Gonçalo Yuánnez de Aguilar conf.Don Ruy Gonçález Mancanedo conf.- Don Lope Ruyz de Baeca conf.- Don Ruy Gonçález de Saldanna conf. Don Iohán Garçía Malrrique conf.- Don Garçía Ferrández Malrrique conf.- Don Gonçalo Ruyz Girón conf.- Don Nuño Núñez de Aça conf.- Don Iohán Rodríguez de Cisneros conf.

(Signo rodado)

- Primer círculo concéntrico:

(cruz). DON FREY FERNAND RODRÍGUEZ DE VALBUENA, MAYORDOMO MAYOR DEL RREY, CONFIRMA (signum). DON IOHÁN NÚNNEZ DE LARA, ALFÉREZ MAYOR (signum) DEL REY, CONFIRMA.

- Segundo círculo concéntrico:

(cruz). SIGNO DEL REY DON ALFONSO.

- Acuartelado con los escudos de León y Castilla.

( $3^{a} \mathrm{col}$.) Don Garçía, obispo de León, conf.- Don Iohán, obispo de Ouiedo, conf.La eglesia de Astorga uaga. Don Llorencio, obispo de Salamanca, conf.- Don Rodrigo, obispo de Camora, conf.- Don Iohán, obispo de Cibdat Rodrigo, conf.Don Alfonso, obispo de Coria, conf.- Don Joán, obispo de Badajoz, conf.- Don Gonçalo, obispo de Orens, conf.- Don Áluaro, obispo de Mendoñedo, conf. Don Rodrigo, obispo de Tuy, conf.- Don Iohán, obispo de Lugo, conf.- Don Uasco 
Rodríguez, maestre de la Orden conf. (sic) de la cauallería de Santiago, conf.Don Suero Pérez, maestre de conf.(sic) Alcántara, conf.

( $4^{a}$ col.) Don Iohán, arcobispo de Seuilla, conf.- Don Pero Ferrández de Castro, pertiguero mayor conf.(sic) de tierra de Santiago, conf.- Don Iohán Alfonso de Alborquerque, mayordomo conf.(sic) mayor de la rreyna, conf.- Don Rodrigo Áluarez de Asturias, merino conf.(sic) mayor de tierra de León et de Asturias, conf.- Don Ruy Pérez Ponçe conf.- Don Pero Ponçe conf.- Don Iohán Díaz de Çifuentes conf.- Don Rodrigo Pérez de Uillalobos conf.- Don Pero Núnnez de Guzmán conf.

( $5^{a} \mathrm{col}$.) Garcilaso de la Uega, iusticia mayor de casa del rrey, conf.- Alfonso Iufre de Teneyto, almirante mayor de la mar et guarda mayor del rrey, conf.- Garçía Ferrández de Toledo, notario mayor de Castiella, conf.

Iohán Pérez, tesurero de la eglesia de Iahén, teniente logar por Ferrant Rodríguez, camarero del rrey, lo mandó fazer por mandado del dicho señor, mille ueynteno año que el sobredicho rrey don Alfonso rregnó.

Yo, Iohán Sánchez, lo escriuí (rúbrica). Iohán Sánchez.

1331, diciembre, 18. Valladolid.

Alfonso XI confirma un privilegio de Fernando IV (1305, mayo, 10. Medina del Campo), inserto, confirmatorio de otro de Sancho IV (1290, julio, 31. Valladolid), inserto, que a su vez confirma los siguientes privilegios:

- Privilegio de Urraca I (1114, mayo, 28), inserto, por el que concede a Santa María de Husillos, Villaldavín y la pesquera de Deronnada. 


\section{LA ABADÍA DE SANTA MARÍA DE HUSILLOS: ESTUDIO Y COLECCIÓN \\ DOCUMENTAL $(904-1608)$}

- Privilegio de Sancho III (1158, mayo, 4. Carrión de los Condes), inserto, por el que confirma las posesiones que Santa María de Husillos recibió de Urraca I, los condes de Monzón y otros particulares.

- Privilegio de Sancho III (1158, junio, 28, Cuéllar), inserto, por el que confirma el coto de Santa María de Husillos que él mismo había donado.

- Privilegio de Alfonso VIII (1178, agosto, 15. Carrión de los Condes), inserto, por el que confirma a Santa María de Husillos, las villas, heredades y monasterios donadas por Urraca I, Sancho III, Fernando Ansúrez, Gonzalo Ansúrez y Nuño Ansúrez, condes de Monzón, y otros donantes.

- Privilegio de Alfonso VIII (1178, agosto, 15. Carrión de los Condes), inserto, por el que confirma a Santa María de Husillos el coto que donó Sancho III, su padre.

B. AHDP, Ampudia y Abadía de Husillos, Pergaminos, carp. 200-21. Perg., 784 x 638 mm.; escr. gótica redonda de privilegios y precortesana. Su conservación no es muy buena pero se puede leer perfectamente. Se conserva el sello de plomo pendiente de una cuerda. Inserto en confirmación de Pedro I, dada en Valladolid, a 28 de noviembre de 1351. Véase doc. núm. 135.

C. AHDP, Ampudia y Abadía de Husillos, Pergaminos, carp. 201-23. Perg., 714 x 608 mms.; escr. gótica de privilegios y precortesana; regular conservación, aunque las roturas y manchas permiten su perfecta lectura. Inserto en confirmación de Enrique II del privilegio de Alfonso XI, dada en Valladolid, a 20 de mayo de 1371. Véase doc. 163.

D. AHDP, Ampudia y Abadía de Husillos, Pergaminos, carp. 201-27. Perg., 784 x 685 mm.; escr. gótica de privilegios y precortesana. Muy deteriorado, ha desaparecido, prácticamente, toda su parte izquierda. No conserva sello ni cuerda. Inserto en confirmación de Juan I del privilegio de Enrique II, dada en Burgos, a 22 de agosto de 1379. Véase doc. núm. 193.

E. APA, $L P H$, ff. $74 \mathrm{v}-78 \mathrm{r}$. Traslado de $B$.

$F$ APA, $L P H$, ff. $88 \mathrm{v}-92$ r. Traslado de $C$.

$G$. APA, $L P H$, ff. 104r-108v. Traslado de $D$.

$H$. BN, $m s .705$, ff. 155r-166r. Traslado de $E$.

I. BN, $m s .705$, ff. 196v-201r. Comete numerosos errores. Traslado de $F$.

$J$. BN, ms. 705, ff. 231v - 238r. Traslado de $G$.

En el nombre de Dios, $\beta$ Padre et Fiio et Spiritu Sancto, que sson tres personas et vn Dios verdadero que viue et rregna por siempre iamás, et de la bien auenturada Uirgen gloriosa sancta María su madre, a quien nos tenemos por señora et por auogada en todos nostros fechos. Et a onrra et a seruicio de todos los 
sanctos de la corte celestial, / queremos que sepan por este nostro priuillegio todos los ombres que agora son et serán daquí adelante, commo nos, don Alfonso, por la graçia de Dios rrey de Castiella, de Toledo, de León, de Gallizia, de Seuilla, de Córdoua, de Murçia, de Iahén, del Algarbe, et señor de Vizcaya et de Molina, en / vno con la rreyna doña María mi muger, viemos un priuillegio del rrey don Fernando nostro padre, que Dios perdone, rrodado et escripto en pargamino et sseellado con su seello de plomo, fecho en esta guisa:

(Sigue doc. núm. 97)

Et nos, el sobredicho rrey don Alfonso, por les fazer bien et merçed, et porque ellos sean tenudos de rrogar a Dios por las ánimas de los / rreyes onde nos venimos, et por la nostra uida et por la nostra salut, que nos lexe vivir et rregnar al su seruiçio, touiémoslo por bien et confirmámosgelo, et mandamos que les uala et les sea guardado en todo ssegunt que les valió et les fue aguardado en tiempo del rrey don Alfonso, nostro uisauue, $/{ }^{57}$ lo et del rrey don Sancho nostro auuelo, et del rrey don Fernando, nostro padre, que Dios perdone.

Et defendemos firmemente que ningunos non sean osados deles yr nin deles passar contra él por lo quebrantar nin minguar en ninguna cosa. Ca qualesquier que lo fiziessen aurían nostra yra et / demás pechar nos yan la pena que en el dicho priuillegio se contiene. Et al abbat et a los canónigos de la dicha eglesia de Sancta María de Fusiellos, o a quien su boz touiesse, todos los daños et menoscabos que por ende rreçibiessen doblados. Et porque esto sea firme et estable, mandámosles ende / dar este nostro priuillegio rrodado et seellado con nostro seello de plomo.

Fecho el priuillegio en Valladolit, diez et ocho días de deziembre, en era de mill et trezientos et ssessenta et nueue años. Et nos, el sobredicho rrey don Alfonso, rregnante en vno con la rreyna doña María mi mu $/{ }^{60}$ ger en Castiella, en Toledo, en León, en Gallizia, en Seuilla, en Córdoua, en Murçia, en Iahén, en Baeça, en Badajoz, et en el Algarbe, et en Vizcaya, et en Molina, otorgamos este priuillegio et confirmámoslo. 
1333, febrero, 27.

Domingo Pérez, hijo de Pedro Rojo, juntamente con Urraca, su esposa, vecinos de Grijota, venden a Domingo Ruiz de Porras, canónigo de Santa María de Husillos, una tierra en Husillos, en el pago que llaman La Rallosa, en precio de seis maravedís.

B. APA, $L P H$, f. $65 \mathrm{r}-\mathrm{v}$.

Fecho y sacado fue este dicho traslado en la villa de Husillos, a veynte y quatro días del mes de noviembre de mil quinientos y çinquenta y quatro años. Y fueron testigos a lo uer, corregir y conçertar con el original, Joán Ruiz Cabeça de Vaca y Gaspar de Vedoya, clérigos, y Pero Manuel, estantes en la dicha villa.

Y yo, Santiago Gómez, escriuano público en la dicha villa, fui presente con los dichos testigos a lo que dicho es. Y del dicho pedimiento y mandamiento, lo escreuí y fize aquí mi signo (signo) en testimonio de verdad.

Pero Ruyz de Billoldo (rúbrica). Santiago Gómez (rúbrica).

Sepan quantos esta carta vieren, como yo, Domingo Pérez, fijo de Pero Roxo, y yo donna Vrraca, su muger, vezinos de Grijota, vendemos a vos, Domingo Ruiz de Porras, canónigo de Fusiellos, vna tierra que es en término de Fusiellos, en La Rallosa, que a por afrontaçiones: de la vna parte, tierra de Toribio Miguel; de la otra parte, tierra de vos, el dicho comprador. Esta dicha tierra, quanto estas dichas afrontaçiones ençierran, vos vendemos y nos otorgamos, los dichos Domingo Pérez y donna Vrraca a uos, el dicho Domingo Ruiz, por seis maravedís desta moneda vsual que fazen diez dineros vn marauedí, que nos rresçebimos de vos, en buenos dineros, entre preçio y alboroque, de que nos otorgamos por bien pagados a todas nuestras voluntades. Y deste dicho preçio no finca ningún deudo por pagar sobre vos, el dicho comprador, ni nos, los dichos vendedores, ni otro por nos en la dicha tierra ni en parte della, de oy adelante ningún derecho que demandar. Y renunçiamos la ley e derecho en que dize que las pesquisas de la carta deuen ver fazer la paga de los maravedís o de la valía 
dellos y la otra ley en que dize, que fasta dos años es ome tenudo de prouar la paga que fiziere, saluo si la rrenunçia el que a de rreçebir la paga y se partiere dellas, y nos renunçiámoslas y partímosnos dellas, que si las ante nos pusiéremos, que no nos valan. E nos, los dichos vendedores, obligámosnos y a todos nuestros (f.65r) bienes, muebles y rraízes, ganados y por ganar, anbos de mancomún y cada vno de nos por todo, para vos fazer sana la dicha tierra, a todo tiempo de quien quier que vos la contrallase o vos la enbargase, toda o parte della, por qualquier razón. Si no, que vos pechemos los dichos maravedís, doblados, o otra tal tierra en tan buen lugar o en mejor, doblada.

Fecha esta carta, veinte y siete días de febrero, era de mil y trezientos y setenta y un años. Pesquisas rrogadas para ello: Pero Yváñez Viçente y Pero Monse, fijo de don Miguel, y Joán Maçías, vezinos de Griiota.

Y yo, Diego Pérez, escrivano público en Grijota, fui presente, con las dichas pesquisas, a lo que dicho es y rrogado escreuí esta carta y fize aquí este mi signo en testimonio.

\section{6}

1333, marzo, 1.

Domingo, hijo de Juan García de Grijota, y Juan, hijo del primero y de María, venden a Domingo Ruiz de Porras, canónigo de Santa María de Husillos, una viña en Val Bermudo y una tierra en Aterada, lugares sitos en el término de Husillos, en precio de cuarenta maravedis.

\section{B. APA, $L P H$, f. $64 \mathrm{v}$.}

Fecho y sacado fue este dicho traslado en la villa de Husillos, a veynte y quatro días del mes de novienbre de mil quinientos y çinquenta y quatro años. Testigos que lo vieron leer, corregir y conçertar con el original, Joán Ruiz Cabeça de Vaca y Gaspar de Vedoya, clérigos, y Pero Manuel, estantes en la dicha villa. 


\section{LA ABADÍA DE SANTA MARÍA DE HUSILLOS: ESTUDIO Y COLECCIÓN \\ DOCUMENTAL $(904-1608)$}

Y yo, Santiago Gómez, escriuano público en la dicha villa, fui presente con los dichos testigos a lo que dicho es. Y del dicho pedimiento y mandamiento, lo escreví y fize aquí mi signo (signo) en testimonio de verdad.

Pero Ruyz de Villoldo (rúbrica). Santiago Gómez (rúbrica).

Sepan quantos esta carta vieren, como yo, don Domingo, fijo de Joán Garçía de Grijota, y yo Joán, su hijo, del dicho Domingo, y fijo de donna María, fija que fue de Domingo Yenego de Fusiellos, vendemos a vos, Domingo Ruiz de Porras, canónigo de Fusiellos, vna viña y vna tierra que es en término de Fusiellos, en lugares per nombrados; e la dicha viña es do dizen a Val de Bermudo, que a por afrontaçiones: de la vna parte, viña que fue de Bernal de Pumea y otrosí que fue de don Pérez; de la otra parte, viña de Briz de Sanctillán de la Cuesta; de la otra parte, viña de don Antolín; de la otra parte, viña del cabildo de la iglesia de Fusiellos; de la otra parte, tierra del dicho cabildo; de la otra parte, viña de la sacristanía; de la otra parte, viña de Fernando el molinero. Y la dicha tierra es do dizen Aterada, que a por afrontaçiones: de la vna parte, la carrera que dizen de Mercaderes; de la otra parte, tierra de Rodrigo, nieto de Carofuso; de la otra parte, tierra de la capellanía de Joán Abad. Esta dicha viña y esta dicha tierra, quanto estas dichas afrontaçiones ençierran, vos vendemos por quarenta maravedís desta moneda vsual que fazen diez dineros el marauedí, que nos reçebimos de vos ante las pesquisas dichas en esta carta, entre preçio y alboroque, de que nos otorgamos por bien pagados a todas nuestras voluntades. Y deste dicho preçio, no finca ningún deudo por pagar sobre vos, el dicho comprador, ni nos, los dichos vendedores, ni otrie por nos en la dicha viña y en la dicha tierra, ni en parte, de ay adelante ningún derecho que demandar. Y nos, los dichos vendedores, obligamos a nos y a todos nuestros bienes, muebles y raízes, pagados y por pagar, por doquier que los nos ayamos, de mancomún y cada uno de nos por todo, por vos fazer sana la dicha viña y la dicha tierra, en todo tiempo de quien quier que vos la contrallase o vos las enbargase, todas o parte dellas, por qualquier rrazón a vos el dicho comprador o a quien esta carta mostrare. Si no, que vos nos pechemos los maravedís susodichos, doblados, y otras tales viña y tierra en tan buenos lugares o mejores, doblados. Y yo, el dicho Joán, por quanto soy menor de aquella edad que la ley del fuero manda, juro a Dios y a Santa María y a estos sanctos evangelios, teniéndolos corporalmente con las manos, que 
esta dicha venta que yo la aya por firme para en todo tiempo, que yo, ni otre por mí, en ningún tiempo, no pueda venir contra esta dicha venta, maguer que yo o otro por mí diga que yo, en esta sazón que agora fago esta venta, que era menor de edad, ni porque yo o otre por mí, diga que la dicha tierra y la dicha viña valió menos de aquella quantía que debía valer, ni auvnque diga que el preçio sobredicho, que no entró en mí pro, ni por otra rrazón ninguna. Y si por ventura, contra esta dicha venta, yo o otre por mí, viniere en algún tiempo, en qualquier manera, que me non vala y que seré perjuro por ello.

Fecha esta carta, primero día de março, [era de] de mil y trezientos y setenta y vn años. Pesquisas que fueron rrogados, vezinos de Grijota: Diego Yváñez, fijo de Joán de Fuentes, vezino de Fusiellos. Toribio Abad, clérigo.

Y yo, Diego Pérez, escrivano público en Grijota, fui presente, con las dichas pesquisas a lo que dicho es y rrogado escreuí esta carta, fize aquí este mío signo en testimonio.

1333, marzo, 17.

Pedro Pérez, hijo de Pedro Mamaduenna, y María, su esposa, vecinos de Grijota, venden a Domingo Ruiz de Porras, canónigo de Santa María de Husillos, una tierra en Husillos, en el término de La Rallosa, donde llaman El Hedero, en precio de trece maravedis.

B. APA, $L P H$, f. 63 r.

Fecho y sacado fue este dicho traslado en la villa de Husillos, a veynte y quatro días del mes de noviembre de mil quinientos y çinquenta y quatro años. Testigos que fueron presentes a lo ver sacar, corregir y conçertar, Joán Ruiz Cabeça de Vaca y Gaspar de Vedoya, clérigos, y Pero Manuel, estantes en la dicha villa. 
Y yo, Santiago Gómez, escriuano público en la dicha villa, fui presente con los dichos testigos. Y del dicho pedimiento y mandamiento, lo escriví e fize aquí mi signo (signo) en testimonio de verdad.

Pero Ruyz de Villoldo (rúbrica). Santiago Gómez (rúbrica)

Sepan quantos esta carta vieren commo yo, Pero Pérez, fijo de Pero Mamaduenna, y yo, María Joana, su muger, vezinos de Grijota, vendemos a vos, Domingo Ruiz de Porros, canónigo de Fusiellos, vna tierra que era en término de Fusiellos, La Rallosa, do dizen El Hedero, que a por afrontaçiones: de la vna parte, tierra de Pero Gómez Viçente, vezino de Grijota; y de la otra parte, tierra de Joán Izquierdo, hijo de Juán Yzquierdo, vezino del dicho lugar; de la vna parte, tierra que fue de donna María, muger que fue de Pero Fernández Portogal, vezina que fue del dicho lugar de Grijota; de la otra parte, tierra de don Briz de Santillán de la Cuesta. Esta dicha tierra, quanto estas dichas afrontaçiones ençierran, vos vendemos y vos otorgamos por treze marauedís desta moneda vsual que fazen diez dineros vn marauedí, que nos rreçebimos de vos, de que nos otorgamos por bien pagados en todas nostras voluntades, por preçio y alboroco. Y deste dicho preçio no finca ningún deudo por pagar sobre vos, el dicho comprador, $(f .63 r) \mathrm{ni}$ yo el dicho vendedor ni otro por mí en la dicha tierra ni en parte della, de oy adelante ningún derecho que demandar. Y rrenunçio la ley del derecho que dize que las pesquisas de la carta deuen ver fazer la paga de los marauedís o de la valía dellos, y la otra ley en que dize que fasta don años es ome tenudo de provar la paga que fiziere, saluo si la rrenunçiare el que a de rreçebir la paga. Y yo rrenúnçiolas y pártome dellas, que si las ante mí pusieren o otro por mí que no me valan en ningún tiempo. Y yo, el dicho vendedor, obligo a mí y a todos mis bienes muebles y rraízes ganados y por ganar, por doquier que los ayamos anbos a do[s o d]e mancomún y cada uno de nos por todo, para nos fazer sana la dicha tierra, a todo tiempo de quien quier que vos la contrallase o enbargase toda o parte della por qualquier rrazón a vos, el dicho comprador, o a quien esta carta mostrare si no yo que vos peche los dichos marauedís doblados o otra tal tierra en tan buen lugar o en mejor doblado.

Fecha esta carta, diez y siete días de março, era de mil y treszientos y setenta y vn años. Pesquisas: Antón Patalla, fijo de Yañez, y Pero Fernández, fijo de don Esteuan, Y Martín Ximeno, amos todos clérigos, vezinos de Grijota. 
Y yo, Diego Pérez, escriuano público en Grijota, fui presente con las dichas partes a lo que dicho es. Y rrogado de las partes escreuí esta carta y fize aquí este mío signo en testimonio.

1333, marzo, 21.

Juan, hijo de Juan Izquierdo, vecino de Grijota, vende a Domingo Ruiz de Porras, canónigo de Santa María de Husillos, una tierra en Husillos, sita en el pago de El Sendero, en precio de siete maravedis.

$B$. APA, $L P H$, f. 62r-v. El índice del Libro de los Privilegios de Husillos recoge éste y el siguiente documento juntos.

C. BN, $m s .705$, ff. $124 \mathrm{r}-125 \mathrm{r}$.

Fecho y sacado fue este traslado de la dicha escritura en la villa de Husillos, a veinte y quatro días del mes de noviembre de mil quinientos y çinquenta y quatro años. Testigos que fueron presentes a lo ver, leer, corregir y conçertar, Joán Ruiz Cabeça de Vaca y Gaspar de Vedoya, clérigos, y Pero Manuel, estantes en la dicha villa.

E yo, Santiago Gómez, escriuano público en la dicha villa, presente fui con los dichos testigos. E del dicho pedimiento e mandamiento, lo escreví y fize aquí mi signo (signo) en testimonio de verdad.

Pero Ruyz de Villoldo (rúbrica). Santiago Gómez (rúbrica).

Sepan quantos esta carta vieren como yo, don Joán, fijo de Joán Yzquierdo, vezino de Grijota, vendo a vos, Domingo Ruiz de Porras, canónigo de Fusiellos, vna tierra que yo e en término de Fusiellos, do dizen El Sendero, que a por afrontaçiones: de las dos partes tierra de vos el dicho comprador; de la otra parte tierra de Diego Pérez, hijo de Pero Arroyo, vezino de Grijota. Esta dicha tierra, quanto estas dichas afrontaçiones ençierran, vos vendo y vos otorgo, por siete marauedís desta moneda vsual que fazen diez dineros el marauedí que yo rreçebí de vos, en buenos dineros entre preçio y alboroque, de que me otorgo por 
bien pagado a toda mi voluntad. Y deste dicho preçio no finca ninguna deuda por pagar sobre vos el dicho comprador ni yo el dicho vendedor ni otro por mí en la dicha tierra ni en parte della, de oy adelante ningún derecho que demandar. Y rrenunçio la ley del derecho en que dize que las pesquisas de la carta deuen ver fazer la paga de los marauedís o de la valía dellos, y la otra ley que dize que fasta dos años es ome tenudo de prouar la paga que fiziere saluo si lo rrenunçiare el que a de rreçebir la paga, y yo rrenúnçiolas y apártome dellas, que si las ante mí pusiere que non me valan. Y yo el dicho vendedor obligo a mí y a todos mis bienes muebles y rraízes, ganados y por ganar, para vos fazer sanna la dicha tierra en todo tiempo y de qualquier que vos la contrallase o vos la enbargase por qualquier rrazón a uos o aquí en esta carta mostrase. Y yo, que vos peche los dichos marauedís doblados o otra tal tierra en tan buen lugar o en mejor doblada. Fecha esta carta, veynte y vn días de março era de mil y trezientos y setenta y vn años.

Pesquisas: Pero Pérez, fijo de Pero Duena, y Diego Fernández, fijo deste testigo, y Pero Ximénez. Viçeynte y Diego Patallo, y Diego Ximénez, fijo de Fernán Lego, vezinos de Grijota.

Y yo, Diego Pérez, escriuano público $(f .62 v)$ en Grijota, fui presente con las dichas pesquisas a lo que dicho es y rrogado de las partes escreuí esta carta y fize aquí este mío signo en testimonio.

1333, marzo, 21.

Domingo Peralejo, vecino de Grijota, vende a Domingo Ruiz de Porras, canónigo de Santa María de Husillos, una tierra en Husillos, próxima al arroyo del Oteruelo, en precio de seis maravedís.

B. APA, $L P H$, f. $62 \mathrm{v}$.

C. BN, ms. 705, ff. 125r-126r. 
Fecho y sacado fue este traslado en la villa de Husillos, a veynte y quatro días del mes de noviembre de mil quinientos y çinquenta y quatro años. Testigos que lo vieron corregir y conçertar, Joán Ruiz Cabeça de Vaca y Gaspar de Vedoya, clérigos, y Pero Manuel, estantes en la dicha villa.

E yo, Santiago Gómez, escriuano público en la dicha villa, fui presente a lo que dicho es con los dichos testigos. Y del dicho pedimiento y mandamiento, lo escreví y fize aquí mi signo (signo) en testimonio de verdad.

Pero Ruyz de Villoldo (rúbrica). Santiago Gómez (rúbrica).

Sepan quantos esta carta vieren commo yo, Domingo Peralejo, vezino de Domingo Peralejo, vezino de Grijota, vendo a uos, Domingo Ruiz de Porras, canónigo de Fusiellos, vna tierra que yo en en término de Fusiellos, al arroyo que dizen del Oteruelo, que a por afrontaçiones: de la vna parte tierra, que fue de Aluar Ruiz de Cardeñosa; y de la otra parte, el dicho arroyo; de la otra parte, la carrera que viene de Sanctillán a los molinos de Cabo Vinna; de la otra parte, tierra de Toribio Abad, clérigo de Grijota, fijo de don Lázaro. Esta dicha tierra quanto estas dichas afrontaçiones ençierran vos vendo y vos otorgo por seis marauedís desta moneda vsual que fazen diez dineros vn marauedí, que yo rreçebí de vos en buenos dineros entre preçio y alboroque, de que me otorgo por bien pagado a toda mi voluntad y deste dicho preçio no finca ninguna deuda por pagar sobre vos el dicho comprador ni yo el dicho vendedor ni otro por mí en la tierra ni en parte dello de oy adelante ningún derecho que demandar. Y rrenunçio la ley del derecho en que dizen que las pesquisas de la carta deven ver fazer la paga de los marauedís o de la valía dellos, y la otra ley que dize que fasta dos años es ome tenudo de provar la paga que fiziere saluo si la rrenunçiare el que a de rreçebir la paga. Y yo rrenúnçiolas y pártome dellas; y si las ante mí pusieren, que me non valan. Y yo, el dicho vendedor, obligo a mí y a todos mis bienes muebles y rraízes, ganados y por ganar, para vos fazer sanna la dicha tierra a todo tiempo de quienquier que vos la contrallase o vos la enbargase por qualquier rrazón si no yo que vos peche los dichos marauedís doblados o otra tal tierra en tan buen lugar o en mejor doblada.

Fecha esta carta, veynte y vn días de março, era de mil y trezientos y setenta y vn años. Pesquisas: Pero Pérez, hijo de Pero Duenna. Diego Fernández, fijo de don 
Toribio. Y Pero Ximénez, Viçente y don Antonio, fijo de Fernán lego, vezinos de Grijota.

Y yo, Diego Pérez, escriuano público en Grijota, fui presente con las dichas pesquisas a lo que dicho es. Rrogado de las partes escreuí esta carta, fize aquí este mío signo en testimonio.

1333, marzo, 21.

Pedro Ibáñez, hijo de Diego Ibáñez, vecino de Grijota, vende a Domingo Ruiz de Porras, canónigo de Santa María de Husillos, una tierra en Husillos, situada en La Rallosa, donde llaman Hedero, en precio de diez maravedís.

B. APA, $L P H$, f. $63 \mathrm{r}-\mathrm{v}$.

Fecho y sacado fue este traslado en la villa de Husillos, a veynte y quatro días del mes de noviembre de mil quinientos y çinquenta y quatro años. Testigos que le vieron sacar, corregir y conçertar, Joán Ruiz Cabeça de Vaca y Gaspar de Vedoya, clérigos, y Pero Manuel, estantes en la dicha villa.

Y yo, Santiago Gómez, escriuano público en la dicha villa, fui presente con los dichos testigos. Y del dicho pedimiento y mandamiento, lo escreví y fize aquí mi signo (signo) en testimonio de verdad.

Pero Ruyz de Villoldo (rúbrica). Santiago Gómez (rúbrica).

Sepan quantos esta carta vieren, como yo, Pero Yváñez, fijo de Diego Yváñez, vezino de Griiota, vendo a vos, Domingo Ruiz de Porras, canónigo de Fusiellos, vna tierra que yo e en término de Fusiellos, en La Rallosa, do dizen Hedero, que a por afrontaçiones: de la vna parte, tierra del abad de Fusiellos; y de la otra parte, tierra de Joán Yzquierdo, fijo de Joán Yzquierdo, vezino de Grijota; de la otra parte, tierra de vos el dicho comprador; de la otra parte, tierra de vos el dicho comprador, que comprastes de Diego Yváñez, fijo de Fernán Legon. Esta dicha tierra, quanto estas dichas afrontaçiones ençierran, vos vendo y vos otorgo, 
por diez maravedís desta moneda vsual que fazen diez dineros el maravedí, que yo rreçebí de vos, en buenos dineros, entre preçio y alboroque, de que me otorgo por bien pagado a toda mi voluntad. Y deste dicho preçio, no finca ningún deudo por pagar sobre vos, el dicho comprador, $(f .63 v)$ ni yo, el dicho vendedor, ni otro por mí en la dicha tierra ni en parte della, de oy adelante ningún derecho que demandar. Renunçio la ley del derecho que dize que las pesquisas de la carta deuen ver fazer la paga de los maravedís o de la valía dellos y la otra ley en que dize que fasta dos años es ome tenudo de provar la paga que fiziere, saluo si la rrenunçiare el que a de rreçebir la paga, y yo rrenunçiolas y pártome dellas, que si las ante mí pusieren o otre por mí, que no me valan en ningun tiempo. Y yo, el dicho vendedor, obligo a mí y a todos mis bienes, muebles y rraízes, ganados y por ganar, por doquier que los yo aya, para vos fazer firme la dicha tierra, a todo tiempo de quien quier que vos la contrallase o enbargase, toda o parte della, por qualquier rrazón, a vos, el dicho comprador, o a quien esta carta mostrare. Si no, yo, que vos peche los dichos maravedís, doblados, o otra tal tierra en tan buen lugar o en mejor, doblada.

Fecha esta carta, veinte y un días de março, era de mil y trezientos y setenta y un años. Pesquisas que fueron rogados: Pero Pérez, fijo de Pero Mamaduenno. Diego Yváñez Legon. Diego Fernández, fijo de don Toribio, vezinos de Griiota.

Y yo, Diego Pérez, escriuano público en Grijota, fui presente, con las dichas pesquisas a lo que dicho es. Rogado de las partes escreuí esta carta y fize aquí este signo en testimonio.

1333, marzo, 21.

Domingo Fernández, hijo de Toribio, vecino de Grijota, vende a Domingo Ruiz de Porras, canónigo de Santa María de Husillos, una tierra en Husillos, situada en La Rallosa, y que llaman de La Mula, en precio de dieciocho maravedis. 
$B$. APA, $L P H$, ff. $63 \mathrm{v}-64 \mathrm{r}$.

Fecho y sacado fue este dicho traslado en la villa de Husillos, a veynte y quatro días del mes de noviembre de mil quinientos y çinquenta y quatro años. Testigos que lo vieron sacar, corregir y conçertar, Joán Ruiz Cabeça de Vaca y Gaspar de Vedoya, clérigos, y Pero Manuel, estantes en la dicha villa.

Y yo, Santiago Gómez, escriuano público en la dicha villa, fui presente a lo que dicho es con los dichos testigos. Y del dicho pedimiento y mandamiento, lo escreví y fize aquí mi signo (signo) en testimonio de verdad.

Pero Ruyz de Villoldo (rúbrica). Santiago Gómez (rúbrica)

Sepan quantos esta carta vieren commo yo, Domingo Fernández, fijo de don Toribio, vezino de Grijota, vendo a vos, Domingo Ruiz de Porras, canónigo de Fusiellos, vna tierra que yo e en término de Fusiellos en La Rellosa, en la tierra que dizen de La Mula, que a por afrontaçiones: de la vna parte, tierra de don Juán, fijo de don Joán; y de la otra parte, tierra del abad de Fusiellos; de la otra parte, tierra de don Toribio, mío padre; de la otra parte, tierra de Pero Ferrández, mío hermano. Esta dicha tierra quanto estas dichas afrontaçiones ençierran, vos vendo y vos otorgo con el quinto del pan que Dios y diere de la simiença que en ella y aze por diez y ocho marauedís desta moneda vsual que fazen diez dineros el marauedí, que yo rreçebí de vos en buenos dineros entre preçio y alboroque. Y deste dicho preçio no finca ningún deudo por pagar sobre vos, el dicho comprador, ni yo, el dicho vendedor, ni otro por mí en la dicha tierra ni en dicho quinto del dicho pan ningún derecho que demandar. Y rrenunçio la ley del derecho que dize que las pesquisas de la carta deuen ver hazer la paga de los marauedís o de la valía de ellos, y la otra ley en que dize que fasta dos años es ome tenudo de prouar la paga que fiziere saluo si la rrenunçiare el que a de rreçebir la paga, y yo rrenúnçiolas estas dichas leyes y pártome dellas que si las ante mí pusiere yo o otre por mí que me non valan en ningún tiempo. Y yo el dicho vendedor obligo a mí y a todos mis bienes muebles y rraízes, ganados y por ganar por doquier que los yo aya para vos fazer sana la dicha tierra a todo tiempo de quien quier que vos la contrallase, o vos la enbargase toda o parte della, por qualquier rrazón a uos, el dicho comprador, o a quien esta carta mostrare. Si no 
yo, que vos peche los dichos marauedís doblados o otra tal tierra en tan buen lugar o en mejor, doblada.

Fecha esta carta, veynte y vn días de março, era de mil y trezientos y setenta y vn años. Pesquisas rrogados que estavan presentes: Pero Pérez, fijo de Pero Mamaduenno, y Pero Ibáñez, Viçeynte y Diego (f.63v) Yváñez, fijo de Fernán Legon, y Diego Procallo, vezinos de Grijota.

Y yo, Diego Pérez, notario público en Grijota, fui presente a lo que dicho es y rrogado de las partes, escreuí esta carta y fize aquí este mío signo en testimonio.

1333, marzo, 21.

Diego Ibáñez, hijo de Fernán Legón, vecino de Grijota, vende a Domingo Ruiz de Porras, canónigo de Santa María de Husillos, dos tierras en Husillos, situadas en La Rallosa; una en El Hedero y la otra en el camino de Santillán de la Cuesta, en precio de doce maravedís y medio.

\section{B. APA, $L P H$, f. 64 r.}

Desconocemos en qué orden se hicieron estas cinco compras por el canónigo de Husillos Domingo Ruiz de Porras, fechadas todas el 21 de marzo de 1333; por lo que las hemos colocado respetando el que llevan en el Libro de los Privilegios de Husillos.

Fecho y sacado fue este traslado en la villa de Husillos, a veynte y quatro días del mes de noviembre de mil quinientos y çinquenta y quatro años. Testigos que lo vieron leer y corregir Joán Ruiz Cabeça de Vaca y Gaspar de Vedoya, clérigos, y Pero Manuel, estantes en la dicha villa.

Y yo, Santiago Gómez, escriuano público en la dicha villa, fui presente con los dichos testigos. Y del dicho pedimiento y mandamiento, lo escreuí y fize aquí mi signo (signo) en testimonio de verdad.

Pero Ruyz de Villoldo (rúbrica). Santiago Gómez (rúbrica). 


\section{LA ABADÍA DE SANTA MARÍA DE HUSILLOS: ESTUDIO Y COLECCIÓN DOCUMENTAL $(904-1608)$}

Sepan quantos esta carta vieren, como yo, Diego Yváñez, fijo de Fernán Legón, vezino de Grijota, vendo a vos, Domingo Ruiz de Porras, canónigo de Fusiellos, dos tierras que yo e en término de Fusiellos, en La Rellosa, y la vna tierra es do dizen Hedero, que a por afrontaçiones: de la vna parte, tierra de vos el dicho comprador; de la otra parte, tierra de Martín Pérez, merino de Husillos; de la otra parte, tierra del abad de Fusiellos. Y la otra tierra es carrera de Sanctillán de la Cuesta, que a por afrontaçiones: de la vna parte, tierra de don Briz de Santillán; de la otra parte, tierra que fue de Aluar Ruiz de Cardeñosa; y de la otra parte, la dicha carrera de Santillán. Y estas dichas dos tierras, quanto estas dichas afrontaçiones ençierran, vos vendo y vos otorgo, por doze marauedís y medio desta moneda vsual que hazen diez dineros un marauedí, que yo rreçebí de uos en buenos dineros, en preçio y alboroque, que me otorgo por bien pagado a toda mi voluntad. Y deste dicho preçio, no finca ningún deudo por pagar sobre vos, el dicho comprador, ni yo, el dicho vendedor o otro por mí, en las dichas tierras ni en parte dellas, de oy adelante ningún derecho que demandar. Y rrenunçio la ley del derecho que dize que las pesquisas de la carta deuen ver hazer la paga de los maravedís o de la valía dellos y la otra ley en que dize, que fasta dos años es ome tenudo de prouar la paga que fiziere, saluo si la rrenunçiare el que a de reçebir la paga y se partiere dellas, y yo, renunçiolas y pártome dellas, que si las ante mi pusiese yo o otre por mí, que me non valan. Y yo, el dicho vendedor, obligo a mí y a todos mis bienes, muebles y rraízes, ganados y por ganar, por doquier que los yo aya, para vos fazer sanas las dichas dos tierras, a todo tiempo de quien quier que vos las contrallase o vos las enbargase, todas o parte dellas, por qualquier rrazón, a uos, el dicho comprador, o a quien esta carta mostraren. Si no, yo que vos peche los dichos marauedís, doblados, o otras tales tierras en tan buenos lugares o mejores, doblados.

Fecha esta carta, veynte y un días de março, era de mil y trezientos y setenta y un años. Pesquisas rrogadas que estauan presentes a esto: Pero Pérez, hijo de Pero Mamaduenna, y Toribio Procallo y Pero Fernández, fijo de Diego Yváñez, y Diego Fernández, fijo de don Mileno, y Joán Yzquierdo, fijo de Joán Yzquierdo, vezinos de Grijota.

Y yo, dicho Diego Pérez, escriuano público en Grijota, fui presente, con las dichas pesquisas a lo que dicho es, y rogado de las partes escreví esta carta y so 
los quinze rrenglones de suso, otro viene entre rrenglón, do dize: "dellas" non, le enpezca. Y fize aquí este signo en testimonio.

1333, mayo, 17.

Domingo Fernández, hijo de Toribio, vecino de Grijota, vende a Domingo Ruiz de Porras, canónigo de Santa María de Husillos, una tierra en Husillos, situada en La Rallosa, en la tierra de La Mula, en precio de doce maravedís.

\section{$B$. APA, $L P H$, ff. $64 \mathrm{v}-65 \mathrm{r}$.}

Fecho y sacado fue este traslado en la villa de Husillos, a veynte y quatro días del mes de novienbre de mil quinientos y çinquenta y quatro años. Testigos que lo vieron sacar, corregir y conçertar, Joán Ruiz Cabeça de Vaca y Gaspar de Vedoya, clérigos, y Pero Manuel, estantes en la dicha villa.

Y yo, Santiago Gómez, escriuano público en la dicha villa, fui presente con los dichos testigos. Y del dicho pedimiento y mandamiento, lo escreví e fize aquí mi signo (signo) en testimonio de verdad.

Pero Ruyz de Villoldo (rúbrica). Santiago Gómez (rúbrica).

Sepan quantos esta carta vieren, como yo, Domingo Fernández, fijo de don Toribio, vezino de Grijota, vendo a uos, Domingo Ruiz de Porras, canónigo de Fusiellos, vna tierra que es en término de Fusiellos, en La Rellosa, en la tierra que dizen de La Mula (f.65r) que es, esta dicha tierra que vos vendo contra Grijota, que a por afrontaçiones: de la vna parte, tierra de Pero Fernández, mi hermano; y de la otra parte, tierra de don Toribio, mi padre, que es contra Santillán de la Cuesta; de la otra parte, tierra de los nietos de Joán Legón, fijos de don Joán; de la otra parte, la serna del abad de Fusiellos. Esta dicha tierra, quanto estas dichas afrontaçiones ençierran, vos vendo y vos otorgo, yo, el dicho Domingo Fernández a vos, el dicho Domingo Ruiz, canónigo, por doze marauedís desta moneda vsual que fazen diez dineros el marauedí, que yo rreçebí de vos, en buenos dineros, 


\section{LA ABADÍA DE SANTA MARÍA DE HUSILLOS: ESTUDIO Y COLECCIÓN \\ DOCUMENTAL $(904-1608)$}

entre preçio y alboroque, de que me otorgo por bien pagado a toda mi voluntad. Y deste dicho preçio, no finca ningun deudo por pagar sobre vos, el dicho comprador, ni yo, el dicho vendedor, ni otro por mí en la dicha tierra ni en parte della, de oy adelante ningún derecho que demandar. Y renunçio la ley del derecho en que dize que las pesquisas de la carta deuen ver fazer la paga de los marauedís o de la valía dellos y la otra ley en que dize, que fasta dos años es ome tenudo de provar la paga que fiziere, saluo si lo rrenunçiare el que a de rreçebir la paga y se partiere dellas. Y yo renúnçiolas y pártome dellas, e si las ante mí pusiere, yo o otro por mí, que me non valan. Y yo, el dicho vendedor, obligo a mí y a todos mis bienes, muebles y rraízes, ganados y por ganar, para vos fazer sana la dicha tierra, a todo tiempo de quien quier que vos la contrallase o vos la enbargase, toda o parte della, por qualquier razón. Si no, yo, que vos peche los dichos marauedís, doblados, o otra tal tierra en tan buen lugar o en mejor, doblada. Esta dicha tierra vos vendo con el quinto del pan que Dios y diere de lo que y haze.

Esta carta fecha, diez y seis días de mayo, era de mil y trezientos y setenta y un años. Pesquisas: Pero Viçeynte y Pero Pérez, fijo del escrivano, y don Diego, fijo de Pero Pérez, y Pero Briz, clérigo, vezinos de Grijota.

Y yo, Diego Pérez, escrivano público en Grijota, fui presente con las dichas pesquisas a lo que dicho es. Rogado de las partes escreuí esta carta y so el primero renglón, sol rreescreuí do dize: "carta” no le enpezca. Y fize aquí este mío signo en testimonio.

1334, abril, 13. Aviñón.

Juan XXII concede bula de indulgencias a Santa María de Husillos.

B. AHDP, Ampudia y Abadía de Husillos, Pergaminos, carp. 204-11. Perg., 665 x 547 mm; escr. gótica de privilegios; regular conservación con algunas manchas y una rotura que afecta a las líneas: 40, 41, 42, 43 y 44. No tiene sello, pero sí parte de la cinta morada y verde que lo sujetó. Inserto en traslado sacado en Husillos, a 31 de julio de 1483. Véase doc. núm. 239. 
El año del Señor no concuerda con el año de pontificado, ya que Juan XXII fue elegido en 1316, correspondiendo al año 1333. En cualquier caso optamos por el año del Señor.

UNIUERSIS Sancte matris ecclesie filiis ad quos presentes litere peruenerint nos miseratione diuina: Almamus suciuenensis episcopus. Iohannes terealensis episcopus. Nocolaus s/carpatensis episcopus. Iohannes colonensis episcopus. Andreas coronensis episcopus. Bonifacius corlumensis episcopus. Uincentius maranensis episcopus. Franciscus cernenensis episcopus. Petrus montismaranensis episcopus. / Thomas iteranensis episcopus. Galganus alerienensis episcopus et Guillermus taurisiensis episcopus, salutem in domino sempiternam pia mater ecclesia de animarum salute solicita deuotionem fidelium per quedam $\mathrm{mu} /{ }^{36}$ nera spiritualia remissiones videlicet et indulgencias remittere consuerit ad debitum firmitatis honorem Deo et fatris edibus impendendum ut quanto crebrius et deuotius illuc confluit populus christiani / assiduis salutaris gratiam implorando tanto delictorum suorum veniam et gloriam regni celestis consequi mereatur eternam. Cupientes igitur ut ecclesia fundata in honore Sancte Marie virginis in loco Fuse/llense, Palentine diocesis, dignis aludibus atque congruis honoribus frequentetur et Christi fidelibus iugiter veneretur. Omnibus vere penitentibus et confessis qui ad dictam ecclesiam in omnibus festis sancto/ ${ }^{39}$ rum quorum nomina altaria habentur in eadem ecclesia et in dedicatione eiusdem ac in aliis festis infrascriptis, videlicet: Natiuitatis Domini, Circuncisionis, Eppiphanie, Parasceues Pasche, Ascensionis, Penthe/costes, Trinitatis, Corporis Christi, inuentionis et exaltationis Sancte Crucis in omnibus et singulis festis beate Marie virginis, Sancti Mi[chaelis] archangeli, natiuitas et decollationis Sancti Iohannis Baptis/te, beatorum Petri et Pauli apostolorum et omnium apostolorum et euangelistorum, Sanctorum Stephani, Laurentii, Uincentii, Martin, Martin, Nicol[ay, Gr]egorii, Augustini, Ambrosii, Ieromini confesorum, Sanctarum $\mathrm{Ma} /{ }^{42}$ rie Magdalene, Katherine, Margarite, Cecilie, Lucie, Agathe, Agnetis, Brigide et undecim millium virginum in comemoratione om[nium] sanctorum et animarum. Et per octabas dictarum festiuitatum octabas / habentium singulisque diebus dominicis causa deuotionis, orationis, peregrinationis accesserint seu qui missis predicationibus matutini [...]pis aut aliis quibuscumque diuinis officiis ibidem interfuerint / aut corpus Christi uel oleum 


\section{LA ABADÍA DE SANTA MARÍA DE HUSILLOS: ESTUDIO Y COLECCIÓN \\ DOCUMENTAL $(904-1608)$}

Sanctum cum infirmis portentur secuti fuerint seu in serotina pulsatione campane secundum modum curie romane flexis genibus ter aue Maria dixerint necnon $/{ }^{45}$ qui ad fabricam luminaria et ornamenta aut quauis alia dicte ecclesie neccessaria manus porrexerint adintrices uel qui in eorum testamentis aut extra aurum, argentum, vestimentum aut aliud aliquos / caritatiuum subsidium dicte ecclesie donauerit uel legauerit aut donari uel legari procurauerit aut ad separationem ipsius ecclesie uel eius poutis suas pias helemosinas aut grata pietatis subsidia / begnine erogauerint aut lignum seu lapides in subsidium eiusdem poutis detulerint quotienscumque quandocumque et qualicumque premissa uel aliquod premissorum detulerint de omnipotentis Dei misericor ${ }^{48}$ dia et beatorum Petri et Pauli apostolorum eius auctem confissi singuli uestrum quadraginta dies indulgentiarum de immunitatis eis penitenciis misericorditer in domino relaxamus dum modo diocesani voluntas ad id acces/serit et consensus in cuius rei testimonium presentes literas sigillorum nostrorum iussimus appensione muniri.

Datum Auinion, decimo tercio, mensis aprilis, anno Domini millessimo tricentessimo tricessimo quarto et / pontificatus domini Iohannis, diuina prouidentia Pape vicessimi secundi, anno decimo octauo.

1335, agosto, 30, miércoles. Palencia.

Carta de compromiso entre Nuño Díaz, abad de Santa María de Husillos, con Garci Abad, clérigo de Santa María, y Alfonso Pérez, clérigo de San Juan, ambas iglesias de Paredes de Nava, por sí y en nombre de los clérigos de las iglesias de Paredes, por la que nombran como juez árbitro en el pleito que mantienen por los diezmos de Villaudilla, a Pedro Martínez, abad de Hérmedes.

B. AHDP, Ampudia y Abadía de Husillos, Pergaminos, carp. 210-4. Perg., 747 x 673 mm.; escr. de albalaes; buena conservación con alguna mancha de humedad y una pequeña rotura entre las líneas 51-52, que no impiden su lectura. Lleva pendiente una cinta sin sello y se observan los orificios de otro sello. Inserto en sentencia del pleito. Véase doc. núm. 127. 
C. APA, $L P H$, ff. $65 \mathrm{v}-68 \mathrm{v}$. Traslado de la sentencia del pleito.

D. BN, $m s .705$, ff. 126r-137r.

La carta de compromiso tiene una data anterior a la carta de procuración, que está inserta, y que por lógica debía ser anterior, por lo cual hay un posible error en la data.

Sepan quantos esta carta de compromisso vieren, commo sobre pleitos et contiendas et demandas que eran et sson o esperan seer entre el onrrado uarón et sabio don Nunno Díaz, abbat de Fusiellos, de la una parte, et los clérigos de las yglesias de Santa María et de Santa Olalla et de Sant Martín / et de Sant Iohán de Paredes de Naua, deffendedores de los diezmos de sos feligreses, de la otra. Sobre rrazón de diezmos de pan et de vino et de ganados, que el dicho abbat demandaua o entiende demandar, a todos aquellos et aquellas, varones et mugeres, ansí clérigos como legos, del pan et del vino que Dios les / diere et ovieren de los heredamientos, tierras et viñas, que labraron et labran et labrarán, de aquí adelante, en término de Uillaudilla, aldea del dicho abbat de Fusiellos, et de los ganados que traxieren et paçieren en el dicho término a también sobre los pleitos que auían ante don Diego, abbat de Sant Fagunt, juez delegado $/ 6$ de nuestro sseñor el papa, commo ante los vicarios de nuestro sseñor el obispo de Palençia, sobre esta rrazón, commo ante otros qualesquier juezes o vicarios o alcalles o merinos; a tanbién de los diezmos passados commo de los por venir a tanbién en los pleitos mouidos commo en los por mouer, sobre esta rrazón de los dichos diezmos, / el dicho abbat de Fusiellos por ssy et García Abbat, clérigo de la yglesia de Santa María, ffijo de Gonçalo Briz, et Alffonso Pérez, clérigo de la yglesia de Sant Iohán, ffijo de Domingo Mínguez, del dicho logar de Paredes, por ssy et por nombre de los clérigos de las dichas yglesias del dicho logar de Paredes, cuyos procuradores / sson por el poder de una personería, que los dichos clérigos les dieron, ssignada de escriuano público que mostraron et presentaron, el tenor de la qual es este que se ssuige:

(Sigue doc. núm. 126)

Et el dicho don Nunno Díaz, abbat de Fusiellos por ssy, de la una parte. Et los dichos Garçi Abbat et Alffonso Pérez, por ssy et por / nombre de los clérigos de 


\section{LA ABADÍA DE SANTA MARÍA DE HUSILLOS: ESTUDIO Y COLECCIÓN \\ DOCUMENTAL $(904-1608)$}

las dichas yglesias de Paredes de Naua, cuyos procuradores sson por el poder de la dicha personería, de la otra parte, vinieron por abenidos de poner et comprometer todos los dichos pleitos et contiendas et demandas de los dichos diezmos a también de lo passado commo de lo [pre]/sente, commo de lo que es por venir, en mano del onrrado varón et ssabio don Pero Martínez, abbat de Hérmidas en la yglesia de Palençia, assí commo en amigo, juez árbitro, amigable conponedor, en tal manera: que quanto el dicho amigo mandare o juzgare o sentençiare o ordenare o abiniere o compusiere o arbitrare, en día fera $/{ }^{33}$ do o non ferado, las partes presentes o non presentes, llamadas o non llamadas, en escripto o ssin escripto, seyendo estando en pie o levantado, guardada la orden del derecho o non guardada, sabida bona verdad o non sabida, que las dichas partes que estén et que den por ello et lo cunplan et guarden et atengan et paguen por su / todo tiempo. Et que se non puedan alçar nin agraviar nin querellar nin apellar nin suplicar, a nuestro señor el papa nin a nuestro señor el rrey nin a nuestra señora la rreyna nin a inffante nin a arçobispo nin a otro sseñor nin vicario nin juez nin alcalle nin merino nin justiçia, eclesiástico nin seglar, nin a omme que en el mundo / ssea, de la sentençia o juzgamiento o mandamiento o ordenamiento o abinimiento o componimiento, que el dicho amigo diere o mandare o ordenare o abiniere o arbitrare o compusiere. Et si se alçaren o querellaren o apellaren o agraviaren o suplicaren, que lo non vala nin sean ende oydos. Et la parte que lo assí non conpliere ${ }^{36}$ et non atoviere et contra ellos viniere, en qualquier manera, que peche diez mille marauedís desta moneda busual que ffazen diez dineros buenos cada maravedí, la meatad para el dicho amigo et la otra meatad para la parte que lo cumpliere et pagare et atouiere et non viniere contra ello. Et la pena pagada o non pagada, su alçada / nin querella nin agrauança nin apellaçión nin suplicaçión non vala. Et quando el dicho amigo pusiere plazo a las partes, la parte que non viniere al plazo, por ssy o por su procurador, peche çinquenta marauedís de la dicha moneda, la meatad paral dicho amigo et la otra meatad para la parte que viniere al plazo. Et / otrossy, el dicho abbat de Fusiellos, por ssy, et los dichos Garçía Abbat et Alffonso Pérez, por ssy et por nombre de los dichos clérigos, rrenunçiaron que non puedan traer nin allegar nin rrazonar, aluedrío de bon varón, nin auer rrecurso a él, sobre lo que el dicho amigo juzgare o sentençiare o auiniere o arbitra $/{ }^{39}$ re o mandare, en estos dichos pleitos et querellas et demandas, más que 
vala et ssea ffirme, para agora et para en todo tiempo, et que non pueda pedir benefiçio de rrestituçión "in integrut" nin se puedan allegar a engaño nin puedan dezir que no saben derecho en su rrazonar nin puedan allegar priuilegio que ayan por rrazón / de sus personas. Et sobresto, el dicho abbat de Fusiellos, et los dichos Garçía Abbat et Alffonso Pérez, por ssy et por nombre de los dichos clérigos del dicho logar de Paredes, cuyos procuradores sson, rrenunçiaron et partieron, de ssy, que non puedan poner, ante ssy, ley nin derecho, eclesiástico nin seglar, nin usso nin costumbre nin exempçión nin / deffensión nin allegaçión nin boz nin rrazón nin cartas nin priuilegios nin libertades nin ffranquezas de rrey nin de rreyna nin de inffante nin de arçobispo nin de obispo nin de otro sseñor que contra esta carta de compromisso vaya o contra parte della o contra lo que, el dicho amigo, mandare o juzgare o sentençiare, nin contra parte dello $/^{42}$ en qualquier manera, que los non vala nin les ssea oydo nin rreçibido en juyzio nin fuera de juyzio, ante iuez eclesiástico nin sseglar, nin ante otro omme del mundo. Et otrossí, las dichas partes dixieron que por cosa que el dicho abbat de Hérmidas, juez amigo, árbitro sobredicho, mandare o juzgare o sentençiare, que non / puedan poner demanda nin querella nin fforma nin action, contra el dicho abat de Hérmidas nin contra ssus bienes, agora nin en algun tiempo. Et si lo demandaren, que lo non vala. Et otrossí, le dieron poder que sobre lo que el dicho amigo mandare o iuzgare o ssentençiare, que pueda declarar et emendar quantas vegadas, sobrello o en ello, / algunas dubdas acaeçieren entre las dichas partes, sobre la sentençia que diere el dicho amigo o sobre las cosas que en ella se contenieren. Et para estar et quedar et auer por ffirme todo lo que ssobredicho es et en este conpromisso se contiene, et complir et pagar et atener, todo lo que el dicho amigo mandare o $/ 45$ juzgare o sentençiare o ordenare, el dicho don Nunno Díaz, abbat de Fusiellos, obligó a todos ssus bienes, muebles et rrayzes, esprituales et tenporales, ganados et por ganar, por doquier que los aya. Et los dichos Garçía Abbat et Alffonso Pérez, obligaron a todos sus bienes et a todos los bienes de los dichos clérigos, de las / dichas eglesias de Paredes, cuyos procuradores sson por el poder de la dicha personería, muebles et rrayzes, esprituales et tenporales, ganados et por ganar. 


\section{LA ABADÍA DE SANTA MARÍA DE HUSILLOS: ESTUDIO Y COLECCIÓN \\ DOCUMENTAL $(904-1608)$}

Et porque esto sea ffirme et non venga en dubda rrogaron, amas las dichas partes a mí, Alffonso Ruyz, notario público de la çipdat de Palençia, que escriuiese / esta carta de compromisso et la ssignase con mío ssigno.

Fecho en Palençia, miércoles, treynta días de agosto, era de mille et trezientos et ssetenta et tres años. Testigos rrogados que estauan presentes: don Guillén. Iohán, abbat de Lauança. Iohán Ferrández de Támara, su omme. Iohán Sánchez de Soria, notario público de la çipdat de ${ }^{48}$ Palençia. Nicolás Martínez de Valladolit.

Et yo, Alffonso Ruyz, notario público sobredicho, ffuy presente a lo que dicho es con los dichos testigos. Et a rruego del dicho Nunno Díaz, abbat de Fusiellos, et de los dichos Garçi Abbat et Alffonso Pérez, escriuí esta carta de conpromisso, en estas dos piezas de papel, et ffiz aquí mío ssigno en / testimonio.

1335, septiembre, 3, domingo. Paredes de Nava.

Carta de procuración por la que los clérigos de las iglesias de Santa María, Santa Olalla, San Martín y San Juan, todas en Paredes de Nava, nombran como procuradores en el pleito que mantienen con Santa María de Husillos por los diezmos de Villaudilla, a Garci Abad, clérigo de la iglesia de Santa María, y Alfonso Pérez, clérigo de la iglesia de San Juan.

B. AHDP, Ampudia y Abadía de Husillos, Pergaminos, carp. 210-4. Perg., 747 x 673 mm.; escr. de albalaes; buena conservación con alguna mancha de humedad y una pequeña rotura entre las líneas 51-52, que no impiden su lectura. Lleva pendiente una cinta sin sello y se observan los orificios de otro sello. Inserto en sentencia del pleito. Véase doc. núm. 127.

$C$. APA, $L P H$, ff. $65 \mathrm{v}-68 \mathrm{v}$. Traslado de la sentencia del pleito.

D. BN, ms. 705, ff. 126r-137r.

Sepan quantos esta carta desta personería vieren, commo nos, Pero Díaz et Iohán Mathe et Alfonso Garçía Turri et Iohán Fernández, ffijo de Domingo Alvar, et Pero Pérez $/^{9}$ et Iohán Fernández, ffijo de don Miguel, et Garci Yváñez et 
Antolín Abbat et Fernán Gonçález et Alffonso Pérez et Blas Abbat et Benito Abbat et Pero Fernández, fijo de don Diego, et Domingo Abbat Chaperete et García Pérez, ffijo de Martín Pérez, et Alffonso García "El Moço", et Alffonso Pérez, ffijo de Pero Iohán, et Pero Fernández, ffijo de don Iohán, et Fernand García, et / Domingo Pérez Carriço, et Martín Sánchez, fijo de Iohán Sánchez, et Lope Díaz, et Ma[...]nete García, et García Pérez Peláiz, et García alfonso, et Martín Sánchez Chaperete, et García Martínez Gasco, et Pasqual Pérez, et Domingo Martínez Cabezudo, et Martín Ibáñez, et Gonçalo Martínez, et Alffonso Pérez, et Iohán Alffonso, todos clérigos presentes. Et diáconos, Alffonso Martínez et Benito Martínez. [Et de la yglesia] / de Santa Olalla de Paredes de Naua, Benito Pérez Cura, et Garçía Ibáñez, et Domingo Martínez, et Esteuan López, et Alfonso Pérez, ffijo de Diego Assensio, et Pero Fernández, ffijo de Fernando Pérez, et Domingo Díaz Lobote, et Alfonso García, ffijo de don Alffonso, et Garçi Gonçález, ffijo de Diego Yváñez, et Domingo Fernández, ffijo de don Andrés, et Garçi Pérez, ffijo de Pero $/{ }^{12}$ Rey, et Iohán Alffonso, ffijo de Fernand Domínguez, Fernand Díez, ffijo de Domingo Díez, todos clérigos pressentes. Diácono Toribio Pérez, ffijo de Domingo Pérez, de la yglesia de Santa María. Pero Abbat Cura, et Benito Pérez, et Diego Abbat "El Moço", et Domingo Abbat de Villa Opdio, et Pero Gonçález, ffijo de don Antolín, et Per Antolínez et Yuán López, / ffijo de Martín López, et Pero Fernández, ffijo de Diego Yváñez et Alffonso Fernández, ffijo de don Apariçio, et Gonçalo Alffonso, ffijo de Pero Alffonso, et Durant Martínez et Iohán Pérez Lorito, Domingo Abbat Calagranno, todos clérigos presentes. Diácono Domingo Pérez, de la yglesia de Sant Martín. Benito Abbat, et Iohán Abbat, ffijo de Martín Áluarez, et Diego / Abbat Cura, Domingo Abbat, su hermano, et Alffonso Pérez, et Domingo Fernández, ffijos de Domingo Mínguez, et Domingo Pérez Lloreynte et Iohán Abbat, ffijo de don Áluaro, et Diego Pérez, ffijo de Domingo Santos, et Yuán Abbat, ffijo de don Fernando, et Domingo Pérez, ffijo de Pero Gil, et Diego Pérez, ffijo de Pero Fernández, Diego Abbat, ffijo de $/{ }^{15}$ Iohán Pérez, et Pero Fernández, ffijo de Diego Yváñez, et Toribio Fernández, todos clérigos pressentes. Diacon, Iohán Fernández, de la yglesia de Sant Iohán, todos clérigos de las dichas yglesias de Paredes de Naua. Estando ayuntados a campana tanida en las casas de Diego Abbat, vicario, segund que auemos usso et costunbre de nos ayuntar a nuestro / comunal, por nos mismos et 


\section{LA ABADÍA DE SANTA MARÍA DE HUSILLOS: ESTUDIO Y COLECCIÓN \\ DOCUMENTAL $(904-1608)$}

por los nuestros clérigos de las dichas yglesias que oy día sson et serán de aquí adelante. Otorgamos et conosçemos que ffacemos nuestros personeros çiertos, speçiales procuradores, conuiene a saber: a Garçi Abbat, clérigo de la dicha yglesia de Sancta María, ffijo de Gonçalo Vriz, et / Alffonso Pérez, clérigo de la dicha yglesia de Sant Iohán, nuestros conpanneros, que sson presentes et rreçibientes desta dicha carta de personería et desta procuraçión, a amos en vno et a cada uno dellos por ssy, espeçialmiente en los pleitos et demandas et contiendas que don Nunno Díaz, abbat de Fusiellos, mouió $/{ }^{18}$ o entiende mouer contra todos aquellos varones o mugeres, clérigos et legos, moradores en la dicha Paredes, que labraron o labran o entienden labrar, de aquí adelante, en los términos de Uillaudilla, sobre rrazón de diezmos, que el dicho abbat de Fusiellos, demandaua o entendía demandar, / de aquí adelante, a los sobredichos varones et mugieres, clérigos et legos, commo sobredicho es. Et por quanto el dicho abbat dizía, que lo deuía auer, pues labravan en el dicho término et que le pertenesçía a él, assí commo abbat de Fusiellos. Et por quanto los clérigos, del dicho logar de Paredes, dizían et rrazonavan que lo / deuían ellos auer todo, por quanto ffue usso et costumbre que todos los que cogiessen pan et vino, en el dicho término de Uillaudilla, que lo dezmasen a ellos, assí de ganados commo de otras cosas qualesquier. Et por esta rrazón, en este ffecho, dámosles poder a los dichos nuestros personeros, a amos en uno et cada $/^{21}$ uno dellos por ssy, que lo puedan poner et comprometer con el dicho abbat de Fusiellos, en mano et en poder de don Pero Martínez, abbat de Hérmidas, vicario de nuestro sennor don Iohán, obispo de Palençia, que los dichos nuestros procuradores puedan ffazer iuez et amigo árbitro, en el dicho pleito. Et que él, que lo libre assí, / commo iuez ordinario et árbitro, en qualquier manera que él quisiere et por bien touiere, en todas aquellas cosas que los dichos nuestros procuradores ffezieren o compusieren $\mathrm{o}$ comprometieren o convenieren, en este dicho pleito, ante el dicho abbat de Hérmidas, con el dicho abbat de Fusiellos, como dicho es. Et / nos, nos obligamos de estar por ello et lo auer por ffirme, para agora et por en todo tiempo, so obligaçión de nos et de todos nuestros bienes sprituales et temporales. Et damos poder a los dichos nuestros procuradores, que ellos por nos et en nuestro nombre, que puedan oyr ssentençia o ssentençias, que el dicho a[bbat] $/^{24}$ de Hérmidas diere en este dicho pleito. Et obligamos a todos nuestros bienes, sprituales et 
temporales, commo dichos sson, de estar et quedar et auer por ffirme por todo quanto el dicho abbat de Hérmidas iuzgare o ssentençiare o librare, en qualquier manera contra nos, et en este dicho pleito, o contra los dichos / nuestros procuradores o contra los dichos labradores que labran et labraran, en el dicho término de Villaudilla. Et otrosí, obligamos a nos et a todos nuestros bienes, sprituales et temporales, de estar et auer por ffirme, para en todo tiempo, por todo quanto los dichos nuestros procuradores, o qualquier dellos, dixieren o ffizieren o [iuzga]/ren o componieren o comprometieren o abinieren, en qualquier manera, ante el dicho abbat de Hérmidas, so obligaçión de nos et de todos nuestros bienes, commo dichos sson. Et de sacar dende, a los dichos nuestros procuradores, en ssalvo, rrelevánd[oles] de todas ssatisfaçión con sus cláusulas. Et si alguna cosa menguaren, $/^{27}$ esta personería, de aquellas que son scriptas en el derecho que deven seer escriptas en carta de personería et procuraçión general et çierta, que aquí non sson scriptas, nos las otorgamos et las auemos por ffirmes, agora et en todo tiempo, assí como ssi aquí fuesen scriptas, magner que espeçial mandado rrequería, so obligaçión de nos / et de todos nuestros bienes, commo dichos sson. Et porque esto sea ffirme et non venga en dubda, nos, los ssobredichos clérigos, rrogamos a Alffonso Fernández, escriuano público del conçeio de Paredes de Naua, que ffiziese escriuir esta carta, desta personería, et que ssignase con su ssigno.

Fecha esta carta, Paredes, domingo, tres días de setienbre, era de mille et trezientos et ssetenta et tres annos. Desta desta personería, / en la dicha sson pesquisas rrogados, que ffueron presentes a esto: don Diego, ffijo de Martín Pérez, et Per Yváñez, ffijo de Diego Yváñez, et Domingo Ferrández, personero, et Fernand Gutiérrez, ffijo don Gutierre, et Domingo Santos et otros.

Et yo, ${ }^{30}$ Alffonso Ferrández, escriuano público sobredicho, ffui presente et rrogado, con las dichas pesquisas, et ffiz escriuir esta carta, desta personería, et pus en ella mío ssigno en testimonio. 


\section{LA ABADÍA DE SANTA MARÍA DE HUSILLOS: ESTUDIO Y COLECCIÓN \\ DOCUMENTAL $(904-1608)$}

1336, enero, 31, miércoles. Palencia.

Sentencia pronunciada por Pedro Martínez, abad de Hérmedes, del pleito litigado por Santa María de Husillos con Garci Abad y Alfonso Pérez, como procuradores de los clérigos de las iglesias de Santa María, Santa Olalla, San Martín y San Juan, todas en Paredes de Nava, sobre los diezmos de Villaudilla. La sentencia reconoce que Villaudilla pertenece a Santa María de Husillos, pero que por atender los clérigos de Paredes las necesidades sacramentales de los pobladores de Villaudilla, la mitad del diezmo de dicho lugar sea para Santa María de Husillos, y la otra para los clérigos de Paredes. Establece también que estos últimos entreguen diez cargas de pan, mitad trigo y mitad cebada, a Santa María de Husillos.

A. AHDP, Ampudia y Abadía de Husillos, Pergaminos, carp. 210-4. Perg., 747 x 673 mm.; escr. de albalaes; buena conservación con alguna mancha de humedad y una pequeña rotura entre las líneas 51-52, que no impiden su lectura. Lleva pendiente una cinta sin sello y se observan los orificios de otro sello.

$B$. APA, $L P H$, ff. $65 \mathrm{v}-68 \mathrm{v}$.

C. BN, $m s .705$, ff. 126r-137r.

In Dei nomine, amen. Sepan quantos esta carta desta ssentençia vieren, commo en los pleitos et demandas et contiendas, que sson entre el onrrado maestro et sabio don Nunno Díaz, abbat de Fusiellos, de la vna parte, et los clérigos de las yglesias de Santa María et de Santa Olalla et de Sant / Martín et de Sant Iohán de Paredes de Naua, deffendedores de los diezmos de sus ffelygresses, de la otra. Sobre diezmos de pan et de vino et de ganados, que el dicho abbat de Fusiellos, demanda a los moradores et vezinos de Paredes de Nava, de los ffrutos que cogíen en los heredamientos que labrauan en / la tierra en término de Villaudilla, aldea del dicho abbat de Fusiellos. Ante mí, Pero Martínez, abbat de Hérmidas en la yglesia de Palençia, juez amigo, árbitro arbitrador, amigable componedor, tomado et nombrado por las dichas partes, según el poder que me dieron por una carta de compromisso, escripta et ssignada de notario público, el $/ 3$ tenor de la qual es este que se ssuige: 
(Sigue doc. núm. 125)

Et yo, el dicho Pero Martínez, abbat de Hérmidas, juez amigo, arbitro ssobredicho, visto el poder que las dichas partes me dieron por el dicho conpromisso, et vista la demanda que Martín Díaz, clérigo, criado et procurador del dicho Nunno Díaz, abbat de Fusiellos, ffizo ante el onrrado varón et sab[io], don Diego, abbat de Sant / Fagunt, juez delegado de nuestro señor el papa, en este dicho pleito de los $\mathrm{d}[\mathrm{ic}]$ hos diezmos contra don Fernando, ffijo de don Decienbre, et contra Iohán Ferrández, su ffijo, et contra Garçi Peláez et Fernand Martí Yváñez et don Sanctos Ollero et Garçi Lasso et Martín Ferrández, legos, vezinos et moradores en el dicho logar de $/^{51}$ Paredes de Naua, parrochianos de la eglesia de Santa Olalla dese mismo logar, en que se contiene en la dicha demanda que estos sobredichos labradores, legos, que labraron et labran heredamientos et tierras que sson en el término et so la canpana et vela de Villaudilla, aldea que es del dicho abbat de Fusiellos, assy / commo a abbat de Fusiellos, que non quisieron nin quieren dar et pagar el diezmo de lo que y cogieron, en los dichos heredamientos, que dizíen que lo avíe de aver el dicho abbat de derecho et de costunbre aprovada, assí commo abbat de Fusiellos, et que non quisieron nin quieren pagar el diezmo de lo que y cogieron. Et / que le pidíe, al dicho abbat de Sant Fagunt, juez ssobredicho, por nombre del dicho abbat de Fusiellos, que por ssentençia costriniesen, a los ssobredichos labradores, legos, que lo diesen et pagasen, al dicho abbat de Fusiellos o al dicho Martín Díaz, su procurador en su nombre, los diezmos del pan que cogieron de quatro años $/^{54}$ a acá, en los dichos heredamientos et tierras; los quales diezmos, estimaua en ssesenta cargas de pan, meatad trigo et meatad çeuada, a quatro ffanegas la carga.

Et otrosy, vista otra demanda que Per Ordónez, clérigo et procurador del dicho abbat de Fusiellos, presentó ante Guillén Iohán, abbat de Lauança, et / ante mí, dicho Pero Martínez, abbat de Hérmidas, assí como ante vicarios generales del onrrado padre et sseñor don Iohán, por la gracia de Dios obispo de Palençia, chanceller mayor del inffante don Peydro, contra donna Taresa, muger que ffue de Garçía Calbo, et Alvar Garçía, su ffijo, et Iohán Garçía, yerno del / portero, et Iohán Gonçález, ballestero, et Iohán Alffonso, escriuano, vezinos moradores en el dicho logar de Paredes de Naua, sobre diezmo que les demandaua de pan que 
cogieron este año en que estáuamos, que passó de la era mille et trezientos et setenta et tres años, en los heredamientos del dicho término de Villau ${ }^{57}$ dilla, que estimaua en çinquenta cargas de pan, medio trigo, medio çeuada, a quatro ffanegas la carga. Et visto lo que ffue pedido et demandado, ante mí, por la parte del dicho abbat de Fusiellos. Et otrossy, lo que ffue dicho et pedido, por la parte de los dichos clérigos de Paredes de Naua, deffendedores / de los diezmos de los dichos sus ffeligreses, et de los otros vezinos del dicho logar, que labraron et labran heredamientos en el dicho término de Villaudilla, en que dizen que el dicho abbat de Fusiellos, que lo non deue auer por rrazón que dizen, que es usso et costunbre de quarenta años a acá / et más, que todos los que cogen pan et vino en el término de Villaudilla, que sson moradores en el dicho logar de Paredes et lo traen a coger a las eras de Paredes, que dan el diezmo en Paredes et non en Villaudilla.

Et visto en commo, el dicho abbat de Fusiellos, dixo que este usso et costunbre ${ }^{60}$ et prescripçión, que ellos allegauan eran interrutas, por rrazón que la yglesia de Fusiellos vacara en este tiempo que los ssobredichos de Paredes allegauan, por muchas uegadas, et que los abbades que fueron de Fusiellos, que ffueron absentes et moraron ffuera del sseñorío de nuestro señor, el rrey de Castiella. Et vistos / todas las otras rrazones, que amas las dichas partes et sus procuradores en su nombre, quisieron dezir et rrazonar; et ssabido uerdat por quantas partes yo meior lo pude saber, auido mío conseio con ommes buenos et sabios et examinado todo diligentemiente, ffallo: que el dicho logar de Villau/dilla, que perteneçe a la eglesia de Fusiellos, que ha término apartado sobre ssy. Et que los heredamientos, que sson en término del dicho logar de Villaudilla, de que el dicho abbat de Fusiellos, demanda diezmo a los sobredichos labradores, legos, nombrados de ssuso et a los otros que aquí ${ }^{63}$ non sson nombrados, assy clérigos como legos, varones et mugieres, vezinos et moradores, en el dicho logar de Paredes de Naua, que fueron dezmeros de la dicha eglesia de Villaudilla. Et fallo que la prescripçión et usso et costumbre, que los sobredichos clérigos de Paredes allegan, en rrazón de los dichos diezmos que / ffueron intorruptos, por las rrazones que el dicho abbat de Fusiellos allegó. Pero porque el dicho logar de Villaudilla es yermo et los dichos clérigos de Paredes de Naua ffazen sus offiçios et dan los eclesiásticos sacramentos a sus feligreses et parrochianos, moradores en 
el dicho logar de Paredes, / que labran los dichos heredamientos en el dicho término de Villaudilla, porque ellos et sus eglesias ayan prouecho de los sus parrochianos que labran et labraren, de aquí adelante, los dichos heredamientos. Et por parar las dichas partes de daños et de costas et de tributos et porque sea paz et concordia, para $/{ }^{66}$ agora et para sienpre iamás, entre las dichas partes. Por ende abiniendo, componiendo, ordenando, mandando, laudando, assí commo amigo, amigable componedor, juez, arbitro arbitrador, en aquella manera que más et meior pueda ualer, iuzgando por ssentençia, mando: que de oy día que esta sentençia es dada en adelantre, / que todos los vezinos, moradores, clérigos et legos, varones et mugeres, de qualquier condiçión o estado que sean, moradores en el dicho logar de Paredes de Naua, que labran et labraren de aquí adelante, por ssy o por otrie, en rrenta o en fialdat, o en otra qualquier manera, tierras et vinnas, en término del dicho logar de Villaudi/lla, que del fructo del pan et del vino que y cogieren et Dios les diere, que den la meatad, ssin condiçión et ssin contienda ninguna, a la eglesia de Villaudilla et al abbat de Fusiellos, que es agora, et a los abbades de Fusiellos que ffueren por tiempo. Et esso mismo que den a la dicha eglesia de Villaudilla et al dicho $/{ }^{69}$ abbat de Fusiellos que agora es et a los abbades de la dicha eglesia de Fusiellos que fueren por tiempo, a quien perteneçe del diezmo de los ganados que traxieren et criaren en término de Villaudilla, la meatad. Et la otra meatad de los diezmos de pan et de vino, que se cogieren en los dichos heredamientos de / Villaudilla, et de los ganados que se y troxieren et criaren, que lo den ssin condiçión ninguna, a las eglesias et clérigos de Paredes de Naua. Et otrosí, por quitar toda contienda que era entre el dicho abbat de Fusiellos et entre los dichos clérigos, sobre rrazón de los diezmos del tiempo et año passados, sobre que anda/van en pleito iuzgando, mando por ssentençia, a los dichos clérigos de Paredes de Naua et a sus procuradores en su nombre, que den al dicho Nunno Díaz, abbat de Fusiellos, diez cargas de pan, meatad trigo et meatad çeuada, a quatro ffanegas cada carga, medido a la medida derecha del dicho logar de Paredes, por $/^{72}$ todas las demandas que los demandaua et auía contra ellos, sobre rrazón de los dichos diezmos, ffasta el día de oy. Et mándoles et assignoles plazo a que ge las den et paguen, en el dicho logar de Paredes, ffasta el primero Domingo de Quaresma, primero que viene. Et mando que çessen et 
queden todos los / pleitos et demandas que eran ffasta el día de oy, entre las dichas partes, sobre rrazón de los dichos diezmos.

Et todas las sobredichas cosas et cada vna dellas, mando que sean atenidas et complidas et guardadas, et non vengan contra ellas, agora nin en ningun tiempo, so la dicha pena de los / dichos diez mille marauedís, que se contiene en el dicho conpromisso; en la qual pena, quiero que caya et encorra qualquier de las dichas partes que lo assí non compliere et atouiere et contra ello fuere. Et desto mando dar, a cada vna de las dichas partes, ssendas sentençias escriptas et ssignadas por mano de Alffonso $/^{75}$ Royz, notario público de la cipdat de Palençia, el qual ffue presente por mi rruego et rrequirimiento, a escriuir esta sentençia, et sseelladas con seellos pendientes, con mío seello et con el seello de la vicaría et audiençia del dicho sseñor obispo.

Esta sentençia ffue dada en Palençia, çerca de la proçessión de la eglesia / de Sant Antolín, estando presentes de la vna parte, el dicho don Nunno Díaz, abbat de Fusiellos, et de la otra, los dichos Garçi Abbat et Alffonso Pérez, clérigos procuradores de los dichos clérigos de Paredes de Naua, miércoles, treynta et vn día de enero, era de mille et trezientos et ssetenta et quatro años. Estando / presentes por testigos, rrogados et llamados para esto: Per Ordónnez de Hornellos, capellán de los veynte et quatro capellanes. Diego Garçía, escriuano, ffijo de Garçía Pérez, criado del electo. Don Fernand Pérez Sarmiento. Ruy Pérez de Colonbres. Yenego López, criado de don Lope Garçía, sacristán. Fernand Pérez, ${ }^{78}$ ffijo de Fernand Pérez de Torre Cubero. Ruy Pérez de Binia. Martín Pérez de Villa Eriaz, todos moradores en Palençia.

Et yo, Alffonso Ruyz, notario público sobredicho, ffuy presente [a 1]o que dicho es, con los dichos testigos. Et a rruego et a rrequirimiento del dicho abbat de Hérmidas, juez, / amigo árbitro sobredicho, escriuí esta ssentençia et otra tal, amas en un tenor, et ffiz aquí mío ssig(signo)no en testimonio de verdat.

Petrus Martini, abbas de Hermidas. 
1338, abril, 23, miércoles. Palenzuela - 1338, junio, 15. Villamediana.

Testimonio notarial de Rui Pérez, notario público del rey, del pleito y sentencia dictada por Rodrigo Álvarez de Carrión, alcalde del adelantamiento de Castilla, en cesión de Ferrán Pérez Portocarrero, merino mayor de Castilla. Las partes del pleito eran por un lado, el abad, prior y cabildo de Santa María de Husillos, y por el otro, Juan Fernández de Porto, merino de Campos, y Juan Pérez de Palenzuela, merino de Cerrato, por el derecho a impartir justicia, cobrar yantar y martiniega, en los lugares de Husillos, Villaudilla, Villaldavín, Santillán de la Cuesta, Pajares y San Sebastián de Hérmedes; y para que los segundos devolvieran ciertas prendas que habian tomado en los dichos lugares.

La sentencia establece que Santa María de Husillos estaba exenta de ciertos tributos, estableciendo y cuantificando los que debía pagar. Por otra parte establece el pleno dominio jurídico de Santa María de Husillos en los lugares en litigio, salvo en los caminos reales y sobre vecinos que no fueran de dichos lugares.

A. AHDP, Ampudia y Abadia de Husillos, Pergaminos, carp. 210-5. Perg., 450 x 336 mm.; escr. precortesana; regular conservación. En algunos sitios se ha raspado y borrado el texto.

$B$. APA, $L P H$, ff. $69 \mathrm{v}-70 \mathrm{v}$.

C. ARCHV, Salas de lo Civil. Zarandona y Balboa (OLV). Caja 697.1. Traslado sacado del original, aportado como prueba en un pleito olvidado (1560) del concejo de Villaldavín con Santa María de Husillos, sobre la jurisdicción en primera y segunda instancia en Villaldavín, alegando el concejo pertenecer a la jurisdicción real (véase doc. núm. 292).

D. BN, $m s .705$, ff. 139r-143v.

El día 23 de abril de 1338 fue jueves y no miércoles. Véase A. GIRY, Manuel de Diplomatique. La letra dominical correspondiente a 1338 es la D, y la Pascua cayó el 12 de abril.

En la uilla de Palençuela, miércoles, beynte et trres días del mes de abril, era de mille et treszientos et setenta et seys annos, estando el liçençiado señor Ferrant Pérez Puertocarrero, / merino mayor de Castilla por el rrey dentro en vnas posadas a donde posaua asentado en vn poyo en presençia de mí, Ruy Pérez, escriuano de nostro señor el rey et su notario público / en todos los sus rregnos et dichos términos de yusso scriptos, pareçió presente Juan Pérez de Haçeues, prior 
de la eglesia de Fusillos por sy asy quanto prior eso mesmo asy commo $\beta$ procurador que se mostró ser de don Nunno Díaz, abbat, et del cabilldo de Santa María del dicho logar de Fusillos, segunt paresçió por vna carta de procuraçión que ante el dicho Ferrant Pérez, / merino, et ante mí et los dichos testigos mostró. Et dixo el dicho prior al dicho Ferrant Pérez, merino, en que le daua et dio por querella en que Juan Ferrández de Porto, merino de Canpos, et Juan Pérez de / Palençuela, merino de la merindat de Çerrato, merinos que eran en las dichas merindades por el que estauan ally presentes, en que façían muchos agrauios a los lugares de la $/{ }^{6}$ dicha eglesia et abbadía de Fusillos, espeçialmiente que eran merindear, el dicho Juan Ferrández, merino de Canpos en la billa de [Fusillos y en] los lugares de Villandilla et / de Villandauín, lugares de la dicha abadía de Fusillos, et en Santillán de la Cuesta et en Pajares, lugares del dicho cabilldo. Et el dicho Juan Pérez, merino de Çerrato en el lugar / de Sant Sabastián, çerca de Hérmidas, logar otrosy que era de la dicha Abadía de Fusillos

Et que cada vno dellos querían leuar las penas [o calumnias] que eran fechas en $/^{9}$ los dichos logares et sus términos, lo qual era contra derecho, pues el señorío de los dichos logares et el [mero y misto imperio y toda la iurisdiçión] era de los sobredichos / conçeio et cabilldo. Et eso mesmo les [querían fazer pagar yantares y quarto de martiniega] más que las avían de uso et de costunbre de [pagar] a los otros merinos sus / predeçessores. Et que le pidía et pidió por merçed en que los mandase que lo non quisiesen fazer de aquí adelante; otrosy los mandare que toruasen a los dichos conçeios çiertas $/ /^{12}$ prendas que sobre esta rrazón les avían tomadas, en espeçial çiertas prendas que tomaran el dicho Juan Ferrández en el dicho lugar de Fusillos por çiertos marauedís de yantar / que él dizía que pertenesçían al dicho Ferrant Pérez asy commo a merino mayor; la qual el dicho lugar de Fusillos nunca abía pagado de rato tienpo a esta parte que memo/ria de onbres fuere en contrario. Et los sobredichos Juan Ferrández, merino de Canpos, et Juan Pérez, merino de Cerrato, rrespondieron et dixeron que le negauan al dicho prior to $/{ }^{15}$ do lo que dezía. Et que sy penas et calonnias et yantaron leuauan del os dichos lugares, que las leuauan porque siempre obieran de uso et de constunbre de los leuar sus / predeçessores. Et non commo el dicho prior dezía. Et que sy prendata por la yantar que el dicho Ferránt Pérez que mandase fazer pesquisa et saber verdat et que el ffablaría que el dicho / lugar de Fusillos nin los 
dichos señores abbat et cabilldo non eran obligados a pagar la dicha yantar nin las otras cosas, et que era el contrario que lo que los dichos Juan Ferrández $/{ }^{18}$ e Juan Pérez dezían.

Et luego el dicho Ferránt Pérez Portocarrero dixo que mandaua et mandó a Rodrig Áluarez de Carrión, alcalde del rrey en el dicho adelantamiento que / estaua presente, que a costa de amas las dichas partes fiziere pesquisa et sopiese uerdat sy el dicho lugar et abadía de Fusillos avían pagado la dicha yantar en los / tienpos pasados. Et de que manera avían usado los otros merinos pasados en los dichos lugares de quarenta annos a esta parte. Et fecha la dicha pesquisa librase $/^{21}$ entrellos aquello que fablare por fuero et por derecho. Et el dicho Rodrig Áluarez, alcalde, dixo que estaua presto para fazer [la dicha pesquisa] et librar aquello que / fablare por derecho.

Testigos que fueron presentes: Juan Sánchez Barahona, et Ruy Martínez de Cuéllar, et Rodrigo de Arco, et Martín Sánchez de Burgos, escuderos del / dicho Ferrant Pérez Portocarrero, presente.

Et después desto, lunes, dos días del mes de junio del anno susodicho, estando el dicho Rodrig Áluarez, alcalle, en Billa ${ }^{24}$ Mediana en vna posada de Domingo Ferrández, alcalle dicho lugar a donde posaua asentado en vn poyo, paresçieron ay presentes los sobre dichos Juan Pérez, prior et Juan Ferrández, me/rino de Canpos, et Juan Pérez, merino de Çerrato, et Alfons Bázquez, scudero et procurador que se mostró ser del dicho señor Ferrant Pérez Portocarrero, en presençia de mí, el dicho / notario, et de los testigos de yuso scriptos. Luego el dicho prior dixo al dicho alcallde que bien sabía en commo quedara que fiziere pesquisa que eran los derechos et cosas que ${ }^{27}$ solían lleuar el merino mayor de Castilla del lugar de Fusillos et los otros merinos pasados de Canpos et de Çerrato et commo [solían] usar en los lugares / de Fusillos et de Villaudilla et de Villandauín et de Santillán de la Cuesta et de Sant Sabastián de Çerrato et de Pajares, çerca de Grigota. Et que pues por mandado / del dicho Ferrant Pérez avía fecho la dicha pesquisa que su merçed fuere de mandarla abrir et verla et librare aquello que ffallare por derecho. Et el dicho alcalde $/^{30}$ preguntó a las sobredichas partes sy querían estar por aquello que fuere fallado por la dicha pesquisa; et cada una dellas rrespondió et dixo que sy. Et luego el dicho / alcalde mandó a mí, el dicho notario, que leyere et publicare la dicha pesquisa. La qual dicha pesquisa, 


\section{LA ABADÍA DE SANTA MARÍA DE HUSILLOS: ESTUDIO Y COLECCIÓN \\ DOCUMENTAL $(904-1608)$}

asy leyda et publicada ante el dicho alcallde en presençia de las di/chas partes; et el dicho alcalde preguntó a cada vna de las dichas partes en que sy quería más decir; et cada vna dellas rrespondió et dixo que non, saluo que dixeron que $\operatorname{con} /{ }^{33}$ cluyan et concluyeron et que pidían et pidieron sentençia. Et luego el dicho allcalde dixo que concluya et concluyó con ellos et que les asignaua et asignó término perentorio para otro día, martes, para oyr sentençia. Testigos que fueron presentes a esto que dicho es: Ruy Martínez, et Juan Sánchez, et Fernando, omes del dicho alcallde, et Juan Martínez, et Esteuan Ferrández, / vezinos del dicho lugar de Villa Mediana, et otros.

Et después desto, martes, quinçe, a la hora de las viesptas, estando el dicho Rodrigo Áluarez, alcallde, en el dicho lo/gar de Villa Mediana, dentro en su posada, asentado en el portal della en el dicho poyo, en presençia de mí, el dicho notario, et testigos de yuso scriptos, leyó vn scripto $/^{36}$ de sentençia que tenía en su mano el tenor del qual es este que se sigue:

Yo, Rodrig Áluarez de Carrión, alcalde que so por nostro señor el rrey en todo el ade/lantamiento de Castilla, visto vna pesquisa por mí fecha sobre rrazón de vna querella que fue dada por Juan Pérez de Haçeues, prior de la eclesia de Fusillos, / presentada que se mostró ser de don Nunno Díaz, abad, et del Cabilldo de la dicha eglesia de Fusillos, al honrrado varón Ferrant Pérez Puerto Carrero, merino mayor ${ }^{39}$ por nostro señor el rrey en el dicho adelantamiento de Castilla, contra Juan Ferrández de Porto, merino de Canpos, et Juan Pérez de Palençuela, merino de Çerrato, / sobre rrazón de çiertos agrauios que los sobredichos merinos fazían a los lugares de Fusillos et de Villaudilla et de Villandauín et de Santillán de la Cuesta / et de Pajares et de Sant Sabastián de Çerrato, çerca de Hérmides, lugares que son de la abbadía et cabilldo de Fusillos, segunt más largamiente se contiene en la $/^{42}$ querella por el dicho prior al dicho señor Ferrant Pérez, merino, dada. Et visto lo que amas las dichas partes quisieron dezir et rrazonar fasta que concluyeron et ençerraron rra/zones et me pidyeron sentençia. Ffallo que el lugar et abadía de Fusillos que non ha de pagar yantar al Merino Mayor de Castilla por quanto mostraron priuilegio / et exençión de ella, Pero an de pagar al merino de Canpos de entrada seys marauedíes et que le non han de pagar yantar nin quinto de martiniega, et el lugar de $/^{45}$ Santillán ha de pagar de quinto de martiniega nouenta marauedís et que non ha de pagar yantar nin entrada de [merino]. Et el 
lugar de Villandauín ha de pagar / al merino, de martiniega nouenta marauedís. Et que non ha de pagar yantar nin entrada de [merino. Et a] pagar el lugar de Villandilla al merino de martiniega / [nueve maravedís. E que no a de pagar yantar] nin entrada de merino. Et que han de pagar el lugar de Pajares quatro marauedís de entrada et non $/^{48}$ yantar [ni] martiniega. Et el lugar de Sant Sabastián ha de pagar de yantar doze marauedís al merino de Çerrato, et que non ha de pagar entrada de / merino nin quinto de martiniega. [Ítem] que los sobredichos merinos nin han de [merindear en los dichos lugares ni an de llevar las penas] et calomnias fechas [en los] / dichos lugares et términos [dellos, salvo el dicho abad de Fusillos] en los dichos sus lugares et el prior et cabilldo en los suyos, saluo sy fueren fechas en los caminos $/^{51}$ rreales por ombres viandantes que non sean vezinos de los dichos lugares. Et que el dicho señor Ferrant Pérez, meryno mayor de Castilla, nin los sobre dichos Juan Ferrández et Juan Pérez, / merinos que agora son de las dichas merindades de Canpos et de Çerrato, et los otros merinos mayores de Castilla que agora son o de aquí adelante de las dichas / merindades serán que non deuen auer más derechos nin de leuar otras penas et [calonnias de merindear] en los dichos lugares de la dicha abadía et cabilldo de $/^{54}$ Fusillos de los suso en esta mi sentençia contenido. Et pongo a los dichos merinos et sus suçessores perpetuo seruiçio a que non increten a los dichos lugares nin uezinos / de ellos por vsar en ellos nin leuar por rrazón de las dichas merindades ssaluo en aquellas cosas en esta mi sentençia contenidas. Et por esta mi sentençia definitiua, iuz/gando sentençia de ello declaro et pronunçio todo asy.

Dada fue esta sentençia anno, mes et día susodicho, testigos que a esto fueron presentes llamados et rrogados: ${ }^{57}$ Juan Pérez et Martín Ferrández, clérigos, et Domingo Martínez et Juan Rodríguez, uezinos del dicho lugar de Villa Mediana. Et otrosy et yo, Rui Pérez, escriuano de nostro señor el / rrey et su notario público en todos los sus rregnos, fuy presente a todo lo sobre dicho et en esta carta de [sentencia contenido con los quales] dichos testigos et a / rruego et pidimiento del dicho Juan Pérez, prior, et por mandado del dicho Rodrig Áluarez, alcalle, escreuí esta carta de sentençia, et puse aquí en ella este mío sig(signo)no en testimonio de verdat. (rúbrica) Ruy Pérez (rúbrica). 
[1339], abril, 27.

Ferrán Pérez Portocarrero, merino mayor de Castilla, ordena a Juan Fernández de Porto, merino de Campos, y a Juan Pérez de Palenzuela, merino de Cerrato, que respeten y cumplan los derechos que Santa María de Husillos tiene en sus lugares, apercibiéndoles que de lo contrario pueden ser privados de sus cargos.

B. AHDP, Ampudia y Abadía de Husillos, Pergaminos, carp. 210-6. Perg., 300 x 158 mm.; escr. precortesana; regular conservación pues la tinta se ha difuminado y hace difícil su lectura. Inserto en traslado sacado en Palencia, a 7 de noviembre de 1341. Véase doc. núm. 130.

Dado que la sentencia dada por Juan Fernández de Carrión, alcalde del adelantamiento de Castilla, tiene por fecha el 15 de junio de 1338, no es posible que el mandamiento ejecutorio sea anterior, debiendo suponer que fue realizado al año siguiente, en 1339.

De mí, Ferrant Pérez Perto Carrero, merino mayor por el rrey / en Castiella, a uos Iohán Ferrández de Perto, merino por mí en la merindad de Campos, a uos Iohán Pérez de Palençuela, mío merino en la merindad de Çerrato o a otros merinos qualesquier que por mí o por / uos andudieren en las dichas merindades, ssalud [...] de aquellos de quien ffío. Fago uos ssaber que Iohán Pérez de Haçeues, prior de Fussiellos, paressçió ante mí et díxome que uosotros, los meri $/ 3$ nos et los que an coger por mí martiniegas et los $\mathrm{d}[\ldots]$ as de las martiniegas, que demandades a la abbadía de Fussiellos et a los sus logares entradas et yantares et matiniegas et otras cosas / que de [...] non auemos por qué demandar. Et pediome, por el offiçio que tenía, que yo que mandasse ssaber verdat, deste fecho; et la verdat sabida, que ffeziesen, sobrello, lo que sse deviesse por / ende. Et yo mandé ssaber verdat deste fecho a Rodrigo Álvarez de Carrión, alcalle del rrey que anda comigo. Él, el dicho Rodrigo Áluarez, díxome que ssopieran por çierto que la dicha abbadía $/{ }^{6}$ de Fussiellos, en ssos los lugares, que nunca pagaron más dessto que aquí sse ssigue: Por el día de año nueuo ha de pagar el abadía de 
Fusiellos de yantar [...] [...] / que nunca pagó el abbadía de Fussiellos quarto de martiniega. Et den de entrada al merino, en Fussiellos, sseis maravedís desta moneda. Et en Santillán de la Cuesta, que han de pagar, / de quarto de martiniega noventa maravedís. Et an de pagar, en Villandavín, nueve maravedís de martiniega. Et en Villaudella an de pagar, de quarto de martiniega, treynta maravedís. Et $\rho^{9}$ en Sant Sabastián de Hérmidas an de pagar doze maravedís. Et el dicho Iohán Pérez, prior, pediome, pues auían sabido verdat deste ffecho, de lo que auía a pagar la dicha abbadía / et sus logares, que mandasse dar una mi carta para uosotros, que possiere todo lo que dicho an en esta carta, de cada año, que non ffússedes contra la dicha abbadía nin contra / los dichos ssus logares nin los prendássedes nin los tomássedes ningunos de ssus bienes, ssaluo por lo que dicho es en esta carta. Porque uos mando [...] cada $/{ }^{12}$ vno de uos en uestra merindat, que pagando la dicha abbadía de Fussiellos et los ssus logares a aquel a quien de derecho lo an de pagar, lo que dicho es en esta / carta, de cada unno, que los non tomedes nin prendedes ningunos de sus bienes por otros derechos ningunos que los demandedes, ssi non por estos que en esta / carta sse contienen et non ffagades ende al, sso pena de los offiçios de las merindades et de çient maravedís de los buenos a cada unno.

Et desto mandé dar esta mi carta abier/ ${ }^{15}$ ta et seellada con mío sseello del dicho Iohán Pérez. La carta leyda dádgela.

Fecha veynte et siete días de abril, era de mille et trezientos et setenta / et sseis años.

Yo, Alffonso Martínez la ffiz esscriuir por mandado de Rodrigo Áluarez, alcalle del rrey. Rodrigo Áluarez.

1341, noviembre, 7, miércoles. Palencia.

Traslado sacado por Martín Pérez, notario público de Palencia, de un mandato (1339, abril, 27) por el que el merino mayor de Castilla, Ferrán Pérez 
Portocarrero, ordena a Juan Fernández de Porto, merino de Campos, y a Juan Pérez de Palenzuela, merino de Cerrato, que respeten y cumplan los derechos que Santa María de Husillos tiene en sus lugares, apercibiéndoles que de lo contrario pueden ser privados de sus cargos.

A. AHDP, Ampudia y Abadía de Husillos, Pergaminos, carp. 210-6. Perg., 300 x 158 mm.; escr. precortesana; regular conservación pues la tinta se ha difuminado y hace difícil su lectura.

El traslado del mandamiento ejecutorio de Ferrán Pérez Portocarrero, confeccionado al poco tiempo de realizarse el original, evidencia que la abadía siguió sufriendo las intrusiones de los merinos territoriales, a las que tuvo que poner freno el mismo rey Alfonso XI, según se comprueba por el posterior documento.

Este es traslaudo de vna carta de Ferrant Perez Porto Carrero, escripta en paper et sseellada en las espaldas, ffecha en esta guissa:

(Sigue doc. núm. 129)

Testigos que estauan pressentes et vieron la dicha / carta del dicho Ferrant Pérez, ende ffue sacado este trasluado: Pero Vidones, capellán del número de los veyntequatro capellanes en la eglesia de Palençia, et Rodrigo Pérez $/^{18}$ de Colonbes et Santiago, ommes de Nunno Díaz, abbat de Fussiellos, et Garçía Pérez, omme de Iohan Pérez, prior de Fussiellos.

Fecho este traslaudo en Palençia, miércoles, ssi/ete días de nouiembre, era de mille et trezientos et setenta et nueue annos. Et yo, Martín Pérez, notario público de la çipdat de Palençia, ffuy presente / a esto con los dichos testigos, et vy et ley la dicha carta ante los dichos testigos, onde ffue sacado traslado et conçertel con la dicha carta et ffiz aquí este $/^{21}$ mío ssig(signo)no en testimonio de uerdad.

1347, junio, 11. Segovia. 
Alfonso XI ordena a Ferrán Pérez Portocarrero, merino mayor de Castilla, y a los merinos territoriales, que respeten y hagan cumplir los privilegios que posee Santa María de Husillos, ante los atropellos denunciados por el abad y prior, a saber, que el dicho merino mayor cada vez que va a Husillos cobra yantares y entradas, debiendo cobrar estos impuestos solamente una vez al año; que los merinos se hospedan en las casas de los canónigos en vez de en las casas de los labradores, tomándoles ropas y agraviándoles; que los merinos le toman al abad la potestad jurisdiccional sobre los vecinos de Husillos, derivándose de todos estos agravios el hecho de que Husillos se esté despoblando.

B. APA, $L P H$, f. 71r-72r. Inserto en traslado sacado en Palencia, a 17 de julio de 1347. Véase doc. núm. 132.

C. BN, ms. 705 , ff. $144 \mathrm{v}-147 \mathrm{v}$.

Don Alfonso, por la graçia de Dios rrey de Castilla, de Toledo, de León, de Galizia, de Sevilla, de Córdova, de Murçia, de Jaén, del Algarbe, de Algezira, y señor de Molina, a vos, Fernán Pérez Portocarrero, nostro merino maior en Castilla, y a los merinos que por nos y por vos andovieren agora y de aquí adelante en las dichas merindades, y a qualquier o qualesquier de vos a quien esta nostra carta fuere mostrada o el traslado della signado de escrivano público, salud y graçia. Sepades que el abad y el prior de la nostra yglesia de Sancta María de Fusiellos se nos ynbiaron a querellar y dizen que cada que venides al dicho su lugar de Fusillos que les demandades y tomades yantares y entradas no aviendo ellos ni (f.71r) los sus vasallos por qué las dar más de vna vez en el año; y otrosí que aviendo, en el dicho lugar, casas de los labradores do podrían bien posar los vestros merinos, quando y acaecen, que lo no quieren fazer más que van posar a casa de los dichos canónigos benefiçiados, les toman las rropas y les fazen muchos agravios. Y otrosí que por les fazer mal y daño y desaguisado que por qualquier querella o demanda que les fagan o les den dellos que les enplazan y ynbían a enplazar que parezcan y vayan ante ellos a doquier que fueren que les constrinnen que rrespondan y cumplan de derecho, no seyendo los pleytos y 


\section{LA ABADÍA DE SANTA MARÍA DE HUSILLOS: ESTUDIO Y COLECCIÓN \\ DOCUMENTAL (904 - 1608)}

querellas criminales ni vestras ni de vestros merinos ni de librar sino por el su abad y por el obispo de Palençia y por sus vicarios. Y desto que se lo hazedes por fuerça y sin rrazón y sin derecho prendándoles y tomándoles lo que les fallades con poder de los oficios que tenedes, no les queriendo guardar las cartas de previlegios que an de nos y de los rreyes donde nos venimos y confirmadas de nos que vos muestran esta razón. Y por estos agravios y males que les fazedes de cada día que an perdido y menoscabado mucho de lo suyo ellos y los dichos sus vasallos, y que se yerman el dicho lugar de Fusiellos. Por ende ynbiaron nos a pedir merçed que mandásemos lo que la nostra merçed fuese. Porque vos mandamos que vista esta nostra carta que veades las dichas cartas y previlegios que los dichos abad y prior y cabildo y qualquier dellos vos mostraren que dizen que ay en esta rrazón, y guardádgelas y cumplídgelas todo bien y cumplidamente según que en ella se dize, y no les pasedes contra ello en ninguna cosa.

Otrosí, no les demandedes ni tomedes cada año a los lugares de los dichos abad y prior y cabilldo más de vn ayantar, vos el dicho merino maior y los merinos quando vieren por vos en las dichas merindades vna entrada quando fuere puesto merino nuevamente fasta vn año cumplido, según que se contiene en el nostro ordenamiento que nos mandamos fazer en esta razón. Y que no posen los vestros merinos en las casas de su morada de los canónigos y benefiçiados ni les tomedes rropa ni otra cosa de lo suyo contra su voluntad, pues que dizen que ay casas de labradores a do pueden posar; ni les enplazen que parezcan y vayan ante vos fuera por las merindades con demanda o querella ay de los dichos canónigos y clérigos del dicho lugar de Fusillos demande a los antel obispo de Palençia o ante el su abad o ante sus juezces y vicarios de cuya jurisdiçión son, e cúmplales de derecho.

Y los vnos ni los otros non fagades ende al, so pena de la nostra merçed y de çien maravedís de la moneda nueva a cada vno. Y si no se lo ansí fazer y cumplir, non quisierdes y contraello les pasardes en alguna cosa por quanto los dichos abad y prior y cabildo querellan de suerte que ge lo fazedes con poder de los ofiçios que anden de acá allá y non pueden aver otro maior juez que les cumpliese de derecho y tales fechos commo estos son nostros de oyr y de librar, mandámosles que vos enplazen que parezcais ante nos personalmente del día que vos enplazaren en quinze días a dezir por qual rrazón non quiéredes cumplir nostro mandado y de 


\section{DAVID MARCOS DIEZ}

cómo esta nostra carta vos fuere mostrada, y los vnos y los otros la cumplierdes, mandamos, a qualquier escriuano público que para esto fuere llamado que de ende al ome que vos la mostrare testimonio signado con su sygno porque nos sepamos como cumplides nostro mandado y del enplazamiento si vos fuere fecho, para qual día es y non faga ende al so la pena dicha. La carta leyda dádgela.

Dada en Segovia, onze días de junio, era de mil y trezientos y ochenta y çinco años. Fernán Sánchez, notario mayor de Castilla, la mandó dar de parte del rrey. Yo, Sancho Mudarra, escriuano del dicho señor, la fize escrevir. Io, Esteuanos.

1347, julio, 17, martes.

Traslado sacado por Juan Fernández, notario público de Palencia, a petición de Juan Pérez de Aceves, prior de Santa María de Husillos, de un mandato de Alfonso XI (1347, junio, 11. Segovia), por el que ordena al merino mayor de Castilla, Ferrán Pérez Portocarrero, y a los merinos territoriales, que respeten y hagan cumplir los privilegios que posee Santa María de Husillos.

\section{B. APA, $L P H$, ff. $71 \mathrm{r}-72 \mathrm{r}$.}

C. AGS, Patronato eclesiástico. Inconexos, leg.159, ff. 34v-36r. Papel; escr. procesal; buena conservación.

D. BN, $m s .705$, ff. $65 \mathrm{v}-67 \mathrm{v}$.

El corto espacio de tiempo trascurrido entre la emisión del original y del traslado, poco más de un año, indica la importancia del documento a trasladar para Santa María de Husillos, que quiso garantizar la conservación del mandato de Alfonso XI mediante un traslado.

Fecho y sacado fue este dicho traslado en la villa de Husillos, a veynte y çinco días del mes de noviembre de mil y quinientos y çinquenta y quatro años. Testigos que fueron presentes a lo ver, leer, corregir y conçertar, Joán Ruiz Cabeça de Vaca y Gaspar de Vedoya, clérigos, e Pero Manuel, estantes en la dicha villa. 
Y yo, Santiago Gómez, escriuano público en la dicha villa, presente fui a lo que dicho es en vno con los dichos testigos. Y del dicho pedimiento y mandamiento, lo escreví e fize aquí mi signo (signo) en testimonio de verdad.

Pero Ruyz de Villoldo (rúbrica). Santiago Gómez (rúbrica).

Martes, diez y siete días de julio, era de mil y trezientos y ochenta y çinco años. Ante Diego Pérez de la Flor, alcalde de Palençia, en presençia de mí, Juán Ferrández, notario público de la çibdad de Palençia y de las pesquisas de yuso escritas, apareçió Joán Pérez de Açeues, prior de la yglesia de Fusiellos e mostró y fizo leer por mí, el dicho notario, vna carta de nostro señor el rrey escrita en papel y sellada con su sello de çera en las espaldas fecha en esta manera.

(Sigue doc. núm. 131)

La qual carta leyda el dicho prior $(f .71 v)$ dixo quel que avía menester de ynbiar la dicha carta a otras partes, y que avía rreçelo de la perder en el camino de la tomar o decaer en fuego o el agua, que pedía y pidió, al dicho alcalde, que mandase diese avtoridad a mí, Joán Fernández, dicho notario, que sacase el traslado de la dicha carta, vno o dos o más, o quantos menester ouiese, y los signase con mío signo. Y el dicho alcalde, de pedimiento del dicho prior, mandó y dio avtoridad a mí, Joán Fernández, dicho notario, que fiziese sacar el traslado de la dicha carta por vno, dos o más quantos menester oviese, y los signase con mío signo. Y dio avtoridad que valiesen los dichos traslados o traslado de la dicha carta doquier que pareçiesen así commo la dicha carta. Pesquisas questavan presentes: Bernal Pérez. Rui Martínez. Alfonso Fernández y Martín Fernández, yerno de Gonçalo Rodríguez. Y Garçía Estéuanez Pérez, fijo de Garçía Pérez.

Y yo, Joán Fernández, notario público sobresdicho por mandado y autoridad del dicho alcalde, fize escrevir este traslado de la dicha carta y conçerté con la dicha carta y fize este mío signo en testimonio de verdad. 
1347, diciembre, 16, sábado. Villaumbrales.

Domingo Gallo y Urraca, su esposa, vecinos de Villaumbrales, venden a Domingo Fernández, maestro, vecino del dicho lugar, una viña en término de Santillán de la Cuesta, en Gamonal, en precio de dieciséis ovejas y cinco maravedis.

B. APA, $L P H$, ff. $70 \mathrm{v}-71 \mathrm{r}$.

C. BN, $m s .705$, ff. $143 \mathrm{v}-144 \mathrm{v}$.

El día 16 de diciembre de 1347 fue domingo y no sábado. Véase A. GIRY, Manuel de Diplomatique. La letra dominical correspondiente a 1347 es la G, y la Pascua cayó el 1 de abril.

Fecho y sacado fue este traslado en la villa de Husillos, a veynte y quatro días del mes de noviembre de mil y quinientos y cinquenta y quatro annos. E fueron testigos a los veer, corregir y conçertar, Joán Ruiz Cabeça de Vaca y Gaspar de Vedoya, clérigos, e Pero Manuel, estantes en la dicha villa.

Y yo, Santiago Gómez, escriuano público en la dicha villa, presente fui a lo que dicho es con los dichos testigos. Y del dicho pedimiento y mandamiento lo escreví e fize aquí mi signo (signo) en testimonio de verdad.

Pero Ruyz de Villoldo (rúbrica). Santiago Gómez (rúbrica)

Sepan quantos esta carta vieren commo yo, Domingo Gallo, y yo, doña Vrraca, su muger, vezinos de Villunbrales, otorgamos y conosçemos que trocamos y vendemos a vos, Domingo Fernández, maestro, vezino de Villunbrales, vna viña que nos avemos en término de Santillán, que es en Gamonal, que es en linde de viña de don Martín de la Cueva, y en linde de de (sic) viña de Alfonso merino, en linde (f.70r) la carrera de Valle Ermundo. Esta dicha viña que estos dichos linderos y afrontaçiones ençierra, y otras más si las y, a vos la trocamos y vendemos por diez y seis cabeças de ovejas y çinco marauedís desta moneda vsual que agora corre, que fazen diez dineros el maravedí. De las quales dichas ovejas y maravedís nos otorgamos por bien pagados. En rrazón de la paga rrenunçiamos las leyes del derecho, la vna ley en que dize que los testigos de la carta deven ver hazer la paga, y la otra ley en que dize que fasta dos años es el ome tenudo de provar la paga que faze saluo si aquel que a de rreçebir la paga 
rrenunçia estas leyes y se parte dellas, y de todas las otras leyes y defensiones que por nos podríamos poner o otro por nos. Que si las dixiéremos o alegáremos que nos non vala ni seyamos sobre ello oydos ante alcalde ni ante ome del mundo. Otrosí obligamos a nos e a todos nostros bienes muebles e rraízes, ganados y por ganar, para vos la fazer sana e desenbargada todavía y todo tiempo del mundo esta dicha viña, so pena de dos maravedís por quantos días estodiere, con querellas e demás pechar vos costas y daños y menos cabos que fizieren y rreçibieren por esta rrazón doblados.

Fecha esta carta en Villunbrales, sábado, diez y seis días del mes de diciembre, era del nasçimiento de nostro Saluador Ihesu Christo de mil y trezientos y ochenta y çinco años.

Testigos que estavan presentes a esto: Juán Avinnar y Pero Pastor, vezinos de Villunbrales.

Y yo, Joán Martínez, escriuano público de Villunbrales por nostro señor el arçobispo de Toledo, fui presente a esto que dicho es con los dichos testigos. Por rruego de las dichas partes, escreuí esta carta y fize aquí este mío signo en testimonio de verdad. Joán Martínez.

1351, noviembre, 12. Valladolid.

Pedro I confirma un privilegio de Alfonso XI (1331, diciembre, 16. Valladolid), inserto, confirmatorio de otro de Fernando IV (1312, marzo, 7. Valladolid), inserto, confirmatorio a su vez de otro de Sancho IV (1291, agosto, 16. Valladolid), inserto, confirmatorio asimismo de otro de Sancho III (1158, abril, 28. Carrión de los Condes), inserto, por el que concede a Raimundo, abad de Santa María de Husillos, y a todos los canónigos de dicha iglesia, el privilegio de los infanzones, exentándolos asimismo de todo servicio real. 
A. AHDP, Ampudia y Abadía de Husillos, Pergaminos, carp. 200-20. Perg., 790 x 623 mm.; escr. gótica redonda de privilegios y precortesana.; buena conservación. Sello pendiente de plomo.

$B$. APA, $L P H$, ff. $72 \mathrm{r}-74 \mathrm{r}$.

C. AGS, Patronato eclesiástico. Inconexos, leg.159, ff. 68r-73r. Papel; escr. procesal; buena conservación.

D. BN, ms. 705 , ff. $147 \mathrm{v}-154 \mathrm{v}$.

REG. DÍAZ MARTÍN, Pedro I, II, 300, núm. 569. Equivoca la signatura en el pergamino original y el número de folio en el ms. 705 .

(Christus, alfa et omega) En el nonbre de Dios Padre, et Fijo et spiritu sancto, que son tres personas et vn Dios uerdadero que biue et rregna por sienpre jamás, et de la bien auenturada uirgen gloriosa sancta María su madre, a quien yo tengo por señora et por auogada en todos mis fechos. Et a onrra et a ser/uiçio de todos los sanctos de la corte çelestial, quiero que sepan por este mi priuillegio todos los ombres que agora son et serán de aquí adelante commo yo, don Pero, por la graçia de Dios rrey de Castiella, de Toledo, de León, de Gallizia, / de Seuilla, de Córdoua, de Murçia, de Iahén, del Algarbe, de Algezira et señor de Molina, ví vn priuillegio del rrey don Alfonso, mío padre, que Dios perdone, escripto en pargamino de cuero et rrodado et sellado con su sello de plomo, fecho en esta guysa: $/^{3}$

(Sigue doc. núm. 113)

Et agora el abad et el cabildo de la eglesia sobredicha, enbiaronme pedir merçed que les confirmase este dicho priuillegio et ge lo mandase ${ }^{\beta 6}$ guardar. Et yo, el sobredicho rrey don Pero, por les fazer bien et merçed et porque ellos sean tenudos de rrogar a Dios por las almas de los rreyes onde yo uengo, et por la mi vida et por la mi salud, tóuelo por bien et confirmógelo et mando que les uala et les sea guardado / en todo bien et conplidamente segunt que en él se contiene.

Et defiendo firmemente que alguno nin algunos non sean osados de les yr nin de les pasar contra este dicho priuillegio para ge lo quebrantar nin menguar en alguna cosa, ca qualquier que lo fiziesen auríen la mi yra / et demás pecharme y an la pena que en el dicho priuillegio se contiene, et al abad et cabildo de la 
eglesia sobredicha, o a quien su boz touiese, todos los daños et menoscabos que por esta rrazón rreçibieren doblados.

Et porque ésto sea firme et estable para sienpre, mandeles ende dar este mi $/^{39}$ priuillegio rrodado et sellado con mi sello de plomo. Fecho el priuillegio en Valladolit, doze días de nouienbre, era de mille et trezientos et ochenta en nueue años. Et yo, el sobredicho rrey don Pero, rregnant en Castiella, en Toledo, en León, en Gallizia, en Seuilla, / en Córdoua, en Murçia, en Iahén, en Baesça, en Badaioz, en el Algarbe, en Algezira, et en Molina, otorgo este priuillegio et confírmolo.

( $1^{a}$ col.) Don Gonçalo, arçobispo de Toledo, primado de las Espannas, confirma.Don Uasco, obispo de Palençia, notario mayor del rreyno de León et chançeller mayor de la rreyna, conf.- La yglesia de Burgos uaga- don Gonçalo, obispo de Calahorra, conf.- Don Garçía, obispo de Cuenca, conf.- Don Pero, obispo de Siguença, conf.- Don Gonçalo, obispo de Osma, conf.- Don Uasco, obispo de Segouia, conf.- Don Sancho, obispo de Áuila, conf.- Don Sancho, obispo de Plazençia, conf.- Don Martín, obispo de Córdoua, conf.- Don Alfonso, obispo de Cartagena, conf.- Don Iohán, obispo de Iahén, conf.- Don Sancho, obispo de Cádiz, conf.- Don Iohán Núñez, maestre de la Orden de Calatraua et notario mayor de Castiella, conf.- Don Ferrant Pérez de Deça, prior de Sanct Iohán, conf.

( $2^{a}$ col. $)$ El infante don Fernando, fijo del rrey de Aragón, primo del rrey et su uasallo, adelantado mayor de la frontera, conf.- El infante don Iohán, su hermano, uasallo del rrey, conf.- Don Nuño, señor de Vizcaya, alférez mayor del rrey, conf.- Don Tello, señor de Aguilar, conf.- Don Sancho, su hermano, conf.- Don Pero, su hermano, conf.- Don Pero, fijo de don Diego, conf.- Don Alfonso Téllez de Haro, conf.- Don Aluar Díaz de Haro conf.- Don Alfonso López de Haro conf.Don Iohán Alfonso, su fijo, conf.- Don Iohán Garçía Manrrique, adelantado mayor de Castiella, conf.- Don Garçía Ferrández Manrrique conf.- Don Pero Núnnez de Guzmán, adelantado mayor de Gallizia, conf.- Don Iohán Rodríguez de Cisneros, adelantado mayor de tierra de León et de Asturias, conf.- Don Roy Gonçález de Castañeda conf.- Don Nuño Núñez de Aça conf.- Don Iohán 
Remírez de Guzmán conf.- Don Beltrán de Gueuara conf.- Don Alfonso Téllez Girón conf.- Don Ferrant Royz, su hermano, conf.-

( $3^{a}$ col.) Don Nuño, arçobispo de Seuilla, confirma.

\section{(signo rodado)}

- Primer círculo concéntrico:

(cruz). DON NUNNO, SEÑOR DE UIZCAYA, ALFÉREZ MAYOR DEL RREY, CONFIRMA. DON FERNANDO DE CASTRO, MAYORDOMO MAYOR DEL RREY, CONFIRMA.

- Segundo círculo concéntrico:

(cruz). SIGNO DEL RREY DON PERO

- Acuartelado con los escudos de Castilla y León.

( $4^{a}$ col.) Don Gómez, arçobispo de Santiago, confirma.- Don Diego, obispo de León, conf.- Don Sancho, obispo de Ouiedo, conf.- Don Rodrigo, obispo de Astorga, conf.- Don Iohán, obispo de Salamanca, conf.- Don Pero, obispo de Çamora, conf.- Don Alfonso, obispo de Çibdat, conf.- Don Pero, obispo de Coria, conf.- Don Iohán, obispo de Badaioz, conf.- Don Iohán, obispo de Orens, conf.Don Alfonso, obispo de Mendoñedo, conf.- Don Iohán, obispo de Tuy, conf. Don Pero, obispo de Lugo, conf.- Don Fradrique, maestre de Santiago, conf.- Don Ferrant Pérez Ponçe, maestre de Álcántara, conf.

( $5^{a}$ col.) Don Iohán Alfonso de Alborquerque, chançeller mayor del rrey et mayordomo mayor de la rreyna, conf.- Don Martín Gil, su fijo, adelantado mayor del rreyno de Murçia, conf.- Don Ferrando de Castro, mayordomo mayor del rrey, conf.- Don Enrrique Conde conf.- Don Iohán, su hermano, conf.- Don Pero Ponçe de León conf.- Don Rodrigo Pérez Ponçe de León conf.- Don Alfonso Pérez de Guzmán conf.- Don Anrric Anrríquez conf.- Don Ferrant Anrríquez, su fijo, conf.- Don Aluar Pérez de Guzmán conf.- Don Pero Núñez, su fijo, conf.- Don 
Lop Díaz de Cisneros conf.- Don Ferrant Rodríguez de Villalobos conf.- Don Iohán Royz de Baesça conf.

( $6^{a}$ col.) Iohán Alfonso de Benauides, iustiçia mayor de casa del rrey, conf.- Don Egidiolo Bocanegra de Gueuara, almirante mayor de la mar, conf.- Diego Gómez, notario mayor del rregno de Toledo, conf.- Martín Ferrández de Toledo, ayo del rrey, notario mayor del Andaluzía et chançeller mayor del sello de la poridat, conf.

Ferrant Martínez de Ágreda, teniente logar de notario de los priuillegios rrodados por Iohán Martínez, de la cámara del rrey, lo mandó ffazer por mandado del rrey en el año ssegundo que el ssobredicho rrey don Pero rreynó.

Pero Martínez; [...]; Pero [...] Pero de Corral; Iohán Martínez.

1351, noviembre, 28. Valladolid.

Pedro I confirma un privilegio de Alfonso XI (1331, diciembre, 18. Valladolid), inserto, que confirma otro de Fernando IV (1305, mayo, 10. Medina del Campo), inserto, confirmatorio a su vez de otro de Sancho IV (1290, julio, 31. Valladolid), inserto, que a su vez confirma los siguientes privilegios:

- Privilegio de Urraca I (1114, mayo, 28), inserto, por el que concede a Santa María de Husillos, Villaldavín y la pesquera de Deronnada.

- Privilegio de Sancho III (1158, mayo, 4. Carrión de los Condes), inserto, por el que confirma las posesiones que Santa María de Husillos recibió de Urraca I, los condes de Monzón y otros particulares.

- Privilegio de Sancho III (1158, junio, 28, Cuéllar), inserto, por el que confirma el coto de Santa María de Husillos que él mismo había donado. 
- Privilegio de Alfonso VIII (1178, agosto, 15. Carrión de los Condes), inserto, por el que confirma a Santa María de Husillos, las villas, heredades y monasterios donadas por Urraca I, Sancho III, Fernando Ansúrez, Gonzalo Ansúrez y Nuño Ansúrez, condes de Monzón, y otros donantes.

- Privilegio de Alfonso VIII (1178, agosto, 15. Carrión de los Condes), inserto, por el que confirma a Santa María de Husillos el coto que donó Sancho III, su padre.

El documento confirmatorio de Alfonso XI no se conserva, ni el original ni el traslado del Libro de los privilegios de Husillos.

En el segundo documento del rey don Alfonso comete el mismo error que en confirmaciones anteriores, llamando al abad de Husillos don Pero de Córdoba, cuando en realidad es de Cardona.

A. AHDP, Ampudia y Abadía de Husillos, Pergaminos, carp. 200-21. Perg., 784 x 638 mm.; escr. gótica redonda de privilegios y precortesana. Su conservación no es muy buena pero se puede leer perfectamente. Se conserva el sello de plomo pendiente de una cuerda.

$B$. APA, $L P H$, ff. $74 \mathrm{v}-78 \mathrm{r}$.

C. AGS, Patronato eclesiástico. Inconexos, leg.159, ff. 73r-81v. Papel; escr. procesal; buena conservación.

D. BN, $m s .705$, ff. 155r-166r.

E. ARCHV, Salas de lo Civil. Masas (F). Caja. 2787-1, ff.. 40r-59v. Traslado de parte del documento desde $A$. Omite los documentos confirmados. Aportado como prueba en un pleito fenecido (1774) de la colegiata de Ampudia con el concejo de Husillos por la posesión de ciertas heredades.

REG. DÍAZ MARTÍN, Pedro I, II, 347, núm. 615. Equivoca la signatura del pergamino original y el número de folio del ms. 705.

(Christus, alfa et omega). En el nombre de Dios Padre, et Fijo, et Spiritu Sancto, que sson tres perssonas et vn Dios verdadero que biue et rregna por siempre jamás, et de la bien auenturada Uirgen gloriosa sancta María su madre, a quien yo tengo por señora et por auogada en todos míos fechos. Et a onrra et / a seruicio de todos los sanctos de la corte celestial, quiero que sepan por este mío priuillegio todos los ombres que agora son et serán daquí adelante commo yo, don Pero, por la graçia de Dios rrey de Castiella, de Toledo, de León, de Gallizia, de Seuilla, de / Córdoua, de Murçia, de Jahén, del Algarbe, de Algezira, et señor de 
Molina, uí un priuillegio del rrey don Alfonso nostro padre, que Dios perdone, escripto en pargamino de cuero et rrodado et seellado con su seello de plomo, fecho en esta guisa.

(Sigue doc. núm. 114)

Et yo, el ssobredicho rrey don Pero, por les fazer bien et merçed, touelo por bien et confirmógelo, et mando que les vala et les ssea guardado en todo bien et complidamente segunt que en él se confiene.

Et / defiendo firmemente que alguno nin algunos non ssean osados de les yr nin de les passar contra este dicho priuillegio para ge lo quebrantar nin minguar en alguna cosa; ca qualquier o quales quier que lo fiziessen avrían la my yra et demás pecharme y an la pena que en el dicho priuillegio $/{ }^{63}$ se contiene. Et al abbat et a los canónigos de la dicha eglesia de Sancta María de Fusiellos o a quien su boz touiesse, todos los dannos et los menoscabos que por ende rreçibiessen doblados. Et porque esto ssea firme et estable, mandeles ende dar este mío priuillegio rrodado et seellado con mío / seello de plomo.

Fecho el priuillegio en las cortes de Valladolit, veynte et ocho días andados del mes de nouiembre, en era de mille et trezientos et ochenta et nueue años. Et yo el ssobredicho rrey don Pero, rregnante en Castiella, en Toledo, en León, en Gallizia, / en Seuilla, en Córdoua, en Murçia, en Iahén, en Baeça, en Badaioz, en el Algarbe, en Algezira, et en Molina, otorgo este priuillegio et confírmolo.

Don Gonçalo, arçobispo de Toledo, primado de las Espannas, confirma. Don Nunno, arçobispo de Seuilla, confirma. Don Gómez, arçobispo de Santiago, confirma.

( $1^{a}$ col.) Don Vasco, obispo de Palençia, notario mayor del rregno de León et chanceller mayor de la rreyna, conf.- La eglesia de Burgos, vagat.- Don Goncalo, obispo de Calahorra, conf.- Don Garçía, obispo de Cuenca, conf.- Don Pero, obispo de Siguença, conf.- Don Gonçalo, obispo de Osma, conf.- Don Vasco, obispo de de Segouia, conf.- Don Sancho, obispo de Áuila, conf.- Don Sancho, obispo de Plazençia, conf.- Don Martín, obispo de Córdoua, conf.- Don Alfonso, obispo de Cartagena, conf.- Don Iohán, obispo de Jahén, conf.- Don Sancho, 
obispo de Cádiz, conf.- Don Iohán Núñez, maestre de la orden de Calatraua, notario mayor de Castiella, conf.- Don Ferrnant Pérez de Deça, prior de Ssanct Iohán, conf.

( $2^{a}$ col.) El infante don Fernando, fijo del rrey de Aragón, primo del rrey et su uassallo, adelantado mayor de la frontera, conf.- El infante don Iohán, su hermano, vasallo del rrey, conf.- Don Nunno, sseñor de Vizcaya, alférez mayor del rrey, conf.- Don Tello, señor de Aguilar, conf.- Don Sancho, ssu hermano, [conf.]- Don Pero, su hermano, [conf.]- Don Iohán, fijo de don Loys, conf.- Don Pero, fijo de don Diego, conf.- Don Alfonso Téllez de Haro conf.- Don Aluar Díaz de Haro conf.- Don Alfonso López de Haro conf.- Don Iohán Alfonso, su fijo, conf.- Don Iohán Garçía Malrrique, adelantado mayor de Castiella, conf.Don Garçía Ferrández Malrrique conf.- Don Pero Nunnez de Guzmán, adelantado mayor de Gallizia, conf.- Don Iohán Rodríguez de Cisneros, adelantado mayor de tierra de León et de Asturias, conf.- Don Ruy Gonçález de Castañeda conf.- Don Nunno Núñez de Aça conf.- Don Iohán Ramírez de Guzmán conf.- Don Beltrán de Gueuarra conf.- Don Alfonso Téllez Girón conf.- Don Ferrnán Ruyz, su hermano, conf.

\section{(Signo rodado)}

- Primer círculo concéntrico:

(cruz). DON NUÑO, SEÑOR DE UIZCAYA, ALFÉREZ MAYOR DEL RREY, CONFIRMA. DON FERNANDO DE CASTRO, MAYORDOMO MAYOR DEL RREY, CONFIRMA.

- Segundo círculo concéntrico:

(signo). SIGNO DEL RREY DON PERO.

Acuartelado con los escudos de Castilla y León.

( $3^{a}$ col.) Don Diego, obispo de León, conf.- Don Sancho, obispo de Ouiedo, conf.Don Rodrigo, obispo de Astorga, conf.- Don Iohán, obispo de Salamanca, conf.Don Pero, obispo de Çamora, conf.- Don Alfonso, obispo de Çibdat, conf.- Don 
Pero, obispo de Coria, conf.- Don Iohán, obispo de Badaioz, conf.- Don Iohán, obispo de Orens, conf.- Don Alfonso, obispo de Mendoñedo, conf.- Don Iohán, obispo de Tui, conf.- Don Pero, obispo de Lugo, conf.- Don Fradrique, maestre de Santiago, conf.- Don Ferrnant Pérez Ponçe, maestre de Alcántara, conf.

( $4^{a}$ col.) Don Iohán Alfonso de Alborquerque, chançeller mayor del rrey et mayordomo mayor de la rreyna, conf.- Don Martín Gil, su fijo, adelantado mayor del rregno de Murçia, conf.- Don Ferrnando de Castro, mayordomo mayor del rrey, conf.- Don Enrrique conde conf.- Don Iohán, ssu hermano, conf.- Don Pero Ponçe de León conf.- Don Rodrigo Pérez Ponçe de León conf.- Don Alfonso Pérez de Guzmán conf.- Don Enrrique Anrríquez conf.- Don Ferrnant Enrríquez, su fijo, conf.- Don Aluar Pérez de Guzmán conf.- Don Pero Núnnez, su fijo, conf.- Don Lop Díaz de Cifuentes conf.- Don Ferrnant Rodríguez de Uillalobos conf.- Don Iohán Royz de Baeça conf.

( $5^{a}$ col.) Iohán Alfonso de Benauides, iustiçia mayor de casa del rrey, conf. Don Egidiolo Bocanegra de Gueuara, almirante mayor de la mar, conf.- Diego Gómez, notario mayor del rregno de Toledo, conf.- [Iohán] Fernández de Toledo, ayo del rrey, notario mayor del Andaluzía et chançeller del seello de la poridat, conf.

Ferrnand Martínez de Ágreda, teniento logar de notario de los priuillegios dados por Iohán Martín, de la cámara del rrey, lo mandó ffazer por mandado del rrey el año ssegundo que el ssobredicho rrey don Pero rreynó.

Pero de Corral. Ferrnant Martínez. [...]

1353, abril, 7, jueves. Palencia. 
Traslado sacado por Francisco Fernández, notario público de Palencia, a petición de Juan Pérez de Aceves, prior de Santa María de Husillos, de una bula (1179, noviembre, 18. Agnani) por la que Alejandro III exenta a Santa María de Husillos de la juriscicción del obispo de Palencia y la hace dependiente de la Santa Sede. Asimismo confirma todas sus posesiones y bienes, privilegia las sepulturas en dicha iglesia y defiende sus posesiones y pertenencias de todo infractor.

A. AHDP, Ampudia y Abadía de Husillos, Pergaminos, carp. 203-2. Perg., 619 x 363 mm.; escr. precortesana. Muy deteriorado.

El día 7 de abril de 1353 fue domingo y no jueves. Véase A. GIRY, Manuel de Diplomatique. La letra dominical correspondiente a 1353 es la F, y la Pascua cayó el 24 de marzo.

Sepan quantos este público intrumento vieren commo jueues, siete días del mes de abril, era de mill et trezientos et nouenta et un años. Dentro de la eglesia cathedral de Sant Antolín de Palençia, estando assentado en [el consistorio] donde se acostumbra librar los pleitos, el onrrado et discreto et sabio / uarón don Domingo Ferrández, deán de Palençia, prouisor et vicario general en lo spiritual et temporal en todo el obispado de Palençia por el onrrado "in Christo" padre et señor don Vasco, por la gracia de Dios et de la santa eglesia de Roma, obispo de Palençia et notario mayor del reyno de León et chançiller mayor de la / reyna. En presençia de mí, Françisco Ferrández, notario público de la çibda de Palençia, et de los testigos de yuso escriptos, paresçió y presente Juan Pérez de Haçeues, prior de la eglesia de Fusillos et procurador, que se mostró ser del prior et cabiello de la dicha eglesia. Et estando presente Juan Sánchez de Saia, notario de Palencia, procurador $\beta$ del dicho señor obispo. Et luego, el dicho prior de Fusillos presentó et fizo leer, por mí el dicho notario, ante el dicho señor vicario et prouisor, un priuilegio del papa Alexandro terçio, escripto en pergamino de cuero et sellado de su sello de plomo, pendiente en filos de seda amarilla. Et en el dicho sello / estauan, de la una parte, dos cabeças figuradas et sobre ellas escriptas vnas letras abreuiadas en las quales dezia: sant Pablo et sant Pero; et de la otra parte, era escripto a do dezía: Alexander papa Tercius. El tenor del qual dicho priuilegio, "uerbo ad uerbum", es este que se sigue: 
(Sigue doc. núm. 37)

$2^{21}$ El qual dicho priuilegio, leydo por mí, el dicho notario, en presencia del sobredicho sennor deán, prouisor. Et estando ende presente el dicho Juan Sánchez, procurador del dicho señor obispo. Luego, el dicho Juan Pérez, prior, dixo al dicho señor deán, en que por quanto él et el dicho / cabiello de la dicha eglesia de Fusillos, su parte era necessario de enbiar el dicho priuilegio a diverssas partes et que auía rreçelo que se podría perder por rrobo o por fuego o por agua o por otra ocasión alguna, ende que le pedía que mandasse a a mí, el dicho notario, que le diesse un traslado, dos o / tres o más, los que menester ouiesse él o el dicho cabiello et que quisiesse interponer su decreto et auctoridat al traslado o traslados, que así, por mí, le fuesse dado o dados, para que feziessen fe en iuizio o fuer[a de iuizio, doquier que paresc]iessen asy commo faría el mesmo original seyen $/{ }^{24}$ do presentado. Et luego, el dicho señor, deán et prouisor, preguntó al dicho Juan Sánchez de Saia, procurador del dicho sennor obispo, que sy querían dezir alguna cosa contra el dicho priuilegio o contra aquello que el dicho pri[or pedía. Et luego, el dicho Juan] Sánchez, procurador del dicho sennor obispo, rrespondió et di/xo que él non vidía cosa en el dicho priuilegio porque él le [deviese] inpugnar nin vedía que el dicho Juan Pérez de Haceues, prior, dixiesse cosa que fuesse en perjuyzio del dicho señor obispo. Et esto así dicho, el [dicho señor deán et prouisor, tomó en] sus manos el dicho priuilegio et diligentemente / por él visto et examinado, dixo que por quanto el a[vía visto et diligentemente examinado] el dicho privilegio et fablaua que non estava rraso nin cancellado nin en alguna parte del sospechoso. Et que la petiç[ión, al dicho Juan Pérez, por esto, justa et rrazona]ble. Dixo que mandaua et mandó a mí, el dicho notario, ${ }^{27}$ que diesse, al dicho prior et cabiello, vn traslado, dos o t[res o más, del] dicho priu[ilegio, los] que menester ouiesse el dicho [prior et cabiello de la] dicha eglesia de Fusillos, signados con m[i signo; a los quales dichos traslado o tras]lados, asy por mí dado o dados, dixo que interponía et in/terpuso su decreto et auctoridat et que mandaua et man[dó que fiziesse] et fiziessen fe en iuyzio o fuera de iuyzio, a d[o quier que paresciesse asy como] el dicho priuilegio original faría 
presente s[eyendo presentado. De lo qual todo, el dicho prio]r, pedió a mí, el dicho notario, testimonio.

Fecho día et mes / et año sobredichos. T[esti]gos que a esto fueron presentes: Ruy G[ómez], arçipreste de la Cueza, et Juan Guillén, físic[o, compañeros en la eglesia de Palen]çia, et Ruy Pérez de Celobres, et Pero Ferrández de C[astrillo] [...] et Dom]ingo Alffonso et Juan Martínez, criados del dicho prior, vezinos de $\mathrm{Pa} /{ }^{30}$ lençia, a lo sobredicho llamados espeçialmente et rrogados.

[Et] yo, Françisco Ferrández, notario público s[obredicho de la çiudad d]e Palençia, fuy presente a esto que dicho es con los dichos [testigos por] rruego et mandado del dicho Iohán Pérez, por ser ocupado de / otros negoçios por otro, fiz escriuir este público inst[rumento] en que ba encorporado el dicho pri[vilegio "de verbo ad verbum”, et fiz aquí este mío] sig(signo)no en testimonio de verdat.

1353, mayo, 7. Palencia.

Traslado sacado por Francisco Fernández de Palencia, notario público de Palencia, a petición de Juan Pérez de Aceves, prior de Santa María de Husillos, de la donación realizada por los condes de Monzón, Fernando, Gonzalo y Nuño Ansúrez a Santa María de Husillos, de su lugar de Pajarejos, cerca de Becerril (951, abril, 24).

A. AHDP, Ampudia y Abadía de Husillos, Pergaminos, carp. 207-1. Perg., 204 x 511 mm; escr. precortesana; buena conservación.

Sepan quantos este público instrumento vieren, commo a siete días del mes de mayo, era de mille e trezientos e nouenta e vn años, dentro de la iglesia catredal de Sanct Antolín de Palençia, estando asentado en el consistorio donde se acostumbran librar los pleitos / el honrrado, discreto, e sabio varón don Domingo Ferrández, deán de Palençia, prouisor e vicario general en lo spiritual e temporal 
en todo el obispado de Palençia por el honrrado "in Christo" padre e señor don Vasco, por la graçia de Dios e de la sancta iglesia de Roma, obispo de Palençia / e notario mayor del rreyno de León e chançeller mayor de la rreyna. En presençia de mí, Françisco Ferrández de Palençia, notario público de la dicha çibdat e de los testigos de yuso escriptos, paresçió y Juan Pérez de Açeues, prior de la iglesia de Fusillos e procurador que se mostró $\beta$ ser del cabilldo de la dicha iglesia de Fusillos, e estando presente Juan Gonçález de Zaia, procurador del dicho señor obispo, e otros vezinos de la dicha çibdat e de otros logares del dicho obispado; e luego el dicho prior presentó e fizo leer por mí el dicho notario ante el dicho señor proui/sor, vna carta de donaçión que don Fernand Anxúrez e Gonçalo Anxúrez e Nuño Anxúrez, condes de Monçón, fizieron a la iglesia de Fusillos del su logar de Paiareios, çerca de Bezerril de Campos, escripta en pargamino de letra antigua, signada de escriuano público, el tenor / de la qual, de "uerbo ad uerbum", es este que se sigue:

(Sigue doc. núm. 8)

La qual dicha carta de donaçión leyda por mí, el dicho notario, en presençia del dicho señor deán e prouisor; luego el dicho Juan Pérez, prior de Fusillos, dixo al dicho señor deán et prouisor que por quanto él e el dicho cabilldo de la dicha iglesia de / Fusillos, su parte era neçesario de sacar e mostrar la dicha carta de donaçión, e que auía reçelo que se podría perder por fuego o por agua o por otra ocasión; por ende que le pedía que mandase a mí, el dicho notario, que le diese vn traslado, dos, o tres, / o más, los que menester ouiese, e que quisiese interponer su decreto e autoridat al traslado o traslados que así por mí le fueren dados para que fiziesen fe en iuyzio e fuera de iuyzio doquier que paresciesen, así commo faría el mesmo $/{ }^{15}$ original siendo presentado. E luego, el dicho señor deán e prouisor preguntó al dicho Juan Gonçález de Zaia, procurador del dicho señor obispo et a todos los otros que ende estauan, que si querían dezir alguna cosa contra la dicha carta de donaçión o contra aquello / que el dicho prior pedía. E luego el dicho Juan Gonçález de Zaia e los otros ca ende estauan, rrespondieron e dixieron que ellos non vidian cosa alguna en la dicha su carta de donaçión porque la deuiesen inpunar nin vedar, nin vidían que el dicho Juan Pérez, / prior, dezía cosa que fuese 
en perjuyzio del dicho señor obispo nin de la dicha çibdat, ni de otro logar alguno, nin de persona alguna. E esto así dicho, el dicho señor deán e prouisor tomó en sus manos la dicha carta de donaçión, e diligentemente por $/^{18}$ él vista e examinada, dixo que por quanto él auía visto e diligentemente examinado la dicha carta de donaçión, e fallaua que non estaua rrasa nin acçelada nin en alguna parte della sospechosa, e que la petiçión del dicho Juan Pérez, prior, era justa / e rrazonable; por ende que mandaua e mandó a mí, el dicho notario, que diese al dicho prior e cabilldo vn traslado, dos, tres o más de la dicha carta de donaçión, los que menester ouiesen los dichos prior e cabilldo de la dicha iglesia de Fusillos, signa/dos con mi signo. A los quales dichos traslado o traslados así por mí dado o dados, dixo que interponía e interpuso su decreto e autoridat, e que mandauan e mandó que fiziese e fiziesen fe en juyzio o fuera de juyzio, a doquier que paresciesen, así com $/{ }^{21}$ mo la carta de donaçión original faria presente, siendo e fuese presentada. De lo qual todo el dicho prior pidió a mí, el dicho notario, testimonio.

Fecho día e mes e anno sobredichos. Testigos que a esto fueron presentes: Ruy Gonçález, arçipreste de La Cueça, e Juan / Guillén, físico, compañeros en la iglesia de Palençia, e Ruy Pérez de Cololres, e Pero Ferrández de Castrillo, e Domingo Alfonso, e Juan Martínez, vezinos de Palençia, a lo sobredicho llamados specialmente e rrogados.

E yo, Françisco Ferrández, notario público sobredicho / que fuy presente a todo lo sobredicho en vno con los dichos testigos por rruego e rrequeremiento del dicho prior e mandado del dicho prouisor, fiz e escreuí este público instrumento en que va encorporada la dicha donaçión de "verbo ad verbum", $2^{24}$ e fiz aquí este mío $\operatorname{sig}($ signo $)$ no en testimonio de verdat (rúbrica).

1353, mayo, 7. Palencia. 


\section{LA ABADÍA DE SANTA MARÍA DE HUSILLOS: ESTUDIO Y COLECCIÓN \\ DOCUMENTAL $(904-1608)$}

Traslado sacado por Francisco Fernández, notario público de Palencia, a petición de Juan Pérez de Aceves, prior de Santa María de Husillos, de la donación realizada por Fernando Ansúrez, conde de Monzón, a Santa María de Husillos, de su lugar de Pajares (955, abril, 24).

A. AHDP, Ampudia y Abadía de Husillos, Pergaminos, carp. 207-22. Perg., 240 x 480 mm.; escr. precortesana; regular conservación con dos pequeñas roturas, varias manchas de humedad y con la tinta en algunas partes desvaída.

Es notorio como en los meses de abril y mayo de 1353, fueron sacados traslados de tres de las principales escrituras de la abadía de Husillos. El motivo parece obvio, si tenemos en cuenta que dos meses después se realiza el concierto con el concejo de Villaumbrales.

Sepan quantos este público instrumento vieren, commo a siete días del mes de mayo, era de mille e trezientos e nouenta e vn años, dentro de la eglesia catredal de Sanct Antolín de Palençia, estando asentado en el cosistorio donde se acostumbran librar los / pleitos el honrrado e discreto e sabio varón don Domingo, deán de Palençia, prouisor e vicario general en lo spiritual e temporal en todo el obispado de Palençia, por el honrrado "in Christo" padre e señor don Vasco, por la graçia de Dios e de la santa eglesia de Roma, obispo de Palençia e notario / mayor del rreyno de León e chançeller mayor de la rreyna. En presençia de mí, Françisco Ferrández, notario público de la çibdat de Palençia, e de los testigos de yuso escriptos, paresçió y presente Juan Pérez de Haçeues, prior de la eglesia de Fusillos e procurador que se mostró ser del prior e ca $/ 3$ billdo de la dicha eglesia de Fusillos, e estando presente Juan Sánchez de Saia, notario de Palençia, procurador del dicho señor obispo, e otros vezinos de la dicha çibdat. Luego, el dicho Juan Pérez, prior, presentó e fizo leer por mí, el dicho notario, antel dicho señor vicario e prouisor, / vna carta de donaçión que don Fernand Anxúrez, conde de Monçón, fizo a la eglesia de Fusillos de la villa de Pajares, escripta en pargamino e signada de escriuano público, el tenor de la qual "de uerbo ad uerbum", es este que se sigue:

(Sigue doc. núm. 9) 
La qual dicha carta de donaçión leyda por mí, el dicho notario, ${ }^{18}$ en presencia del sobredicho señor deán e prouisor, estando [su] merçed presente, el dicho Juan Sánchez de Saia, procurador del dicho señor obispo, e otros vezinos de la dicha çibdat, luego el dicho Juan Pérez, prior, dixo al dicho señor deán e prouisor, que por quanto él e el / dicho cabilldo de la dicha eglesia de Fusillos su parte era nes[çesa]rio de sacar e mostrar la dicha carta de donaçión, e que auía rreçelo que se podría perder por fuego o por agua o por otra ocasión, por ende, que le pedía que mandase a mí, el dicho notario, que le diese vn traslado, / o dos, o tres, o más, los que menester ouiese, con el e el dicho [escrip]to, le demandasen, e que quisiese interponer su decreto e actoridat al traslado o traslados que así, por mí, le fuesen dado o dados para que fiziere fe en iuyzio o fuera de iuyzio, doquier que paresçiesen así commo lo $/^{21}$ faría el mesmo oreginal seyendo presentado. E [luego, el] dicho e luego el dicho (sic) señor deán e prouisor, preguntó al dicho Juan Sánchez de Saia, procurador del dicho señor obispo, e a todos los otros que ende estauan, que si querían dezir alguna cosa contra la dicha carta de donación / o contra aquello que el dicho prior pedía. E luego, el dicho Juan Sánchez, procurador del dicho señor obispo, e los otros que ende estauan, rrespondieron e dixieron que ellos non vidían cosa alguna en la dicha carta de donación porque la deuiesen inpunar nin vedar, nin vidían que el dicho Juan Pérez / de Haçeues, prior, dezía cosa que fuese en periuzio del dicho señor obispo nin de la dicha çibdat. E esto así dicho, el dicho señor deán e prouisor, tomó en sus manos la dicha carta de donaçión e diligentemente por él vista e esaminada, dixo que quanto él auía $/^{24}$ visto e diligentemente esaminado, la dicha carta de donaçión, e fallaua que non estaua rrasa nin cançelada nin en alguna parte della sospechosa. E que la petiçión, al dicho Juan Pérez, prior, era iusta e rrazonable. Por ende que mandaua e mandó a mí, el dicho notario, que diese / [al dicho prior] e cabilldo, vn traslado, dos, tres, o más, de la dicha carta de donaçión, los que me[nester ouiesen los dichos prior e] cabilldo de la dicha iglesia de Fusillos, signados con mi signo. A los quales dichos traslado o traslados, así por mí dado o dados, dixo que [inter/ponía] e interpuso su decreto e actoridat, e que mandaua e mandó que fiziese e fiziesen fe en iuyzio o fuera de iuyzio, doquier que paresçiesen así commo la dicha carta de donaçión original faría presente, seyendo e fuese 


\section{LA ABADÍA DE SANTA MARÍA DE HUSILLOS: ESTUDIO Y COLECCIÓN \\ DOCUMENTAL $(904-1608)$}

presentada. De lo qual todo, el $/^{27}$ [dicho prior] pidió a mí, el dicho notario, otro testimonio.

Fecho día e mes e año sobredichos. Testigos que a esto fueron presentes: Ruy Gómez, arçipreste de La Cuesta, e Juan Guillén, físico, compañeros en la eglesia de Palençia, e Ruy Pérez de Colobriz, e Pero Ferrández de Castrillo / [clérigos...] de Pero Ferrández, abbad de Fusillos, e canónigos Alfonso e Juan Martínez, vezinos de [Palençia, a lo sobredicho] llamados espeçialmente e rrogados.

E yo, Françisco Ferrández, notario público sobredicho de la dicha çibdat de Palençia, fuy / presente a esto que dicho es con los dichos testigos. E por rruego e mandado del dicho Iohán Pérez, prior, ocupado de otros negoçios por otro, fiz escreuir este público instrumento en que va encorporada la dicha $/^{30}$ donaçión. E ffiz aquí este mío sig(signo)no en testimonio de verdat. (rúbrica).

1353, junio, 4, martes. Husillos.

Carta de procuración dada por Juan Pérez de Aceves, prior de Santa María de Husillos, junto con el cabildo de dicha iglesia, a favor del mismo Juan Pérez de Aceves, para representar a Santa María de Husillos en el concierto y avenencia que se espera realizar con el concejo e iglesias de Villaumbrales, sobre aprovechamiento de pastos, poblamiento y diezmos en los términos de Villaumbrales y de Santillán de la Cuesta.

B. AHDP, Ampudia y Abadía de Husillos, Pergaminos, carp. 200-22. Perg., 355 x 250 mm.; escr. gótica de privilegios. Relativa buena conservación a excepción de los dos últimos folios, en el que el penúltimo está bastante deteriorado y del último falta prácticamente la mitad. Conserva la cinta, que cose el canto del cuadernillo y lleva pendiente el sello de cera, el cual está bastante deteriorado aunque todavía se distinguen dos figuras antropomorfas. Consta de cinco hojas de pergamino dobladas al medio y cosidas, lo que hace un total de diez folios; en el 1r, que es la portada: "Escritura de CLIII años en tiempo del rey don Pero por donde parece desde entonçes la temporalidad que los abades de Husillos tovieron en la villa de Husillos. Item, para que el conçejo 
de los veçinos y seglares que se llaman de Husillos no es parte para ninguna cosa que toque a la villa de Husillos en común, salvo el prior y cabildo de la villa al antiguo representan el concejo de la villa. Y ellos, sin el concejo de los seglares, determinaron y compusieron lo que a ellos y al dicho concejo tocó en lo temporal con qualesquier personas que tovieron los unos y otros diferençias de consuno>.

Todos los folios van rubricados en el folio vuelto en la parte inferior y en el folio recto en la parte superior. El f. 9v está en blanco; el f. 10r es una copia del 1v y está al revés; el f. 10v es la contraportada: "Las ordenancas antiguos entre los pueblos de Villumbrales y Santillán de la Cuesta con Villumbrales, año de 1358; siendo abbad el cardenal Gil de Albornoz y reynado el rey don Pero".

Dos veces se da una nómina de vecinos de Villaumbrales, habiendo tres que no coincide el nombre o el apellido, pudiendo deberse a un descuido del notario.

Inserto en avenencia entre Santa María de Husillos y el concejo de Villaumbrales. Véase doc. núm. 145.

C. APA, $L P H$, ff. $49 \mathrm{v}-57 \mathrm{r}$.

D. BN, $m s .705$, ff. 83v-109r.

Sepan / quantos esta carta de poder et procuraçión vieren commo nos, Iohán Pérez de Haçeues, prior, / et el cabilldo de la eglesia colegiada de Fusiellos, estando ayuntados a cabilldo en el logar / do nos solemos ayuntar que es junto al cuerpo de la dicha eglesia de Fusiellos do nos /solemos ayuntar a nostro cabilldo llamados et ayuntados por nostra canpana segund que auemos / de vso et de costunbre de nos ayuntar, estando presentes yo, el dicho Iohán Pérez, prior, et Iohán / Pérez, chantre, et todos los otros canónigos et benefiçiados que eran rresidentes en el dicho logar / de Fusiellos, todos de vna voluntad et vn consentemiento, entendiendo que era seruiçio de Dios / (f.lv) et de la dicha nostra iglesia, et onrra et guarda de nos et de cada vno de nos, auiendo muchos tratados / sobre esto que se sigue. Entendiendo por nos et por la dicha nostra eglesia, et por todos los morado/res que ffueron o son o serán de aquí adelante en el nostro logar de Santillán de la Cuesta, et en el / dicho logar de Fusiellos fazer abenençia con el conçejo et con los ombres buenos de Villavnbra/les et clérigos de todas las eglesias del dicho logar de Villavnbrales sobre muchos da/ños et menoscabos et ffuerças et pleitos que ellos et su mandado et los moradores que ffueron o / son en el dicho logar de Villavnbrales a uos o a qualquier o qualesquier de nos et en / nostros bienes en qualquier manera et por qualquier rrazón. Et nos a ellos fasta el día de / oy et de las quales cosas ffueron dadas querellas sobre algunas dellas a la 
eglesia de Palençia / et adelantados et a merynos por la vna parte et por la otra, et fechas pesquisas, et ffueron dadas sentençias / por los vicarios de la dicha eglesia de Palençia contra algunos vezinos de Villavnbrales que aue/mos aquí por nonbrados et fue apellado dellas et fueron rreuocadas las sentençias por los jue/zes del arçobispo de Toledo de la qual fue apellado por nos, et porque estas cosas todas na/çieren sobre los pastos de los términos de los dichos logares de Villavnbrales et de Santillán de / que auemos vso et costunbre de vsar nos con ellos et ellos connusco; et sobre rrazón que algunos / vezinos de Santillán se pasauan morar a Villavnbrales et de Villavnbrales a Santillán, porque des/techauan las casas et trayan la teja et la madera segund fuera de vn logar a otro, et auían / manera commo despoblamientos de los logares, et otrosí sobre los diezmos de las heredades que son en el / término de Villavnbrales et en el término de Villavnbrales et en el término de Santillán, los quales / nos demandamos porque eran sobre nostra vela; et la otra parte se defendía por vso et costumbre./ Et otrosí por la costituçión que fizo nostro señor el obispo de Palençia sobre los diezmos do era / tal vso et costunbre et fue apellado por los clérigos de Villavnbrales et contendimos ante los / juezes del papa et ante los ordinarios por do naçieron muchas discordias et males et pleitos, / queriendo ffazer abenençia amas las partes en vno tan bien en común commo en singular sobre / coda cosa que fue tomada a qualquier de nos o dellos la vna parte a la otra o daño o injuria fecha; / otorgamos et conosçemos que nos, el dicho prior et cabilldo de Fusiellos, damos todo nostro conplido poder / a uos, el dicho Iohán Pérez, prior, para que tratedes et vos abengades et fagades postuar et abenençia / et obligaçión con el dicho conçejo et ombres buenos de Villavnbrales et con los clérigos et eglesias del / dicho logar et con aquel o aquellos que ouieren poderío dellos para lo fazer sobre todas las dichas / cosas et cada vna dellas et sobre las que se siguen o podrían seguir de todas et qualquier de las / sobredichas; et sobre que pazcamos et rroçemos con ellos en el término de Villavnbrales et pongamos / vmanderos et cabañas en el dicho término et en el de Santillán, et ellos en lo nostro en la manera que vi/erdes que cunple. Et que podades rreçebir et rreçibades quantía çierta de marauedís o otra cosa dellos, et conpen/sar daños en todo o en parte segund que vierdes que cunple, et para poner pena de quantía quantía (sic) / vos quisierdes sobre nos et obligar a nos et a los bienes de la nostra mesa de nos el dicho prior / 
et cabilldo et de cada vno de nos et para atener et conplir et jurar en nostras ánimas de nos / et de los que moraron fasta aquí en el dicho logar de Santillán et en el de Fusiellos et morarán de aquí / adelante así que en vestra persona de nos el dicho nostro procurador sienpre fecimos tenudos de / (f.2r) atener et conplir et guardar para sienpre todo quanto tratáredes et abeniéredes et posiéredes con el dicho / conçejo et ombres buenos et clérigos de Villavnbrales, et con aquel o aquellos que ouieren poderío / dellos, et para que vos podades parar et dexar et rrenunçiar de las querellas et pleitos moui/dos et por mouer contra el dicho conçejo et ombres buenos et clérigos de Villavnbrales o contra / qualquier dellos et sobre las que ellos an mouido o espera mouer contra nos, et sobre to/das las otras cosas mayores o menores por qualesquier rrazones et manera que sean que tangan / o puedan tañer a nos el dicho prior et cabilldo de Fusiellos o a qualquier de los vezinos et morado/res que fueron o son en el dicho logar de Fusiellos et en el dicho logar de Santillán, et rrenunçiar/las o que tangan o puedan tañer al dicho conçejo et ombres buenos et clérigos de Villavnbrales o a qual/quier dellos así commo si spiçialmiente et singularmiente se nonbrasen aquí, et que poda/des vos, el dicho nostro procurador, declarar et espaçeficar los nonbres de los querellosos de aquellos, / ssingularmiente de aquellos con quien eran las prendias et tomas et pleitos et contiendas et / fuerças et injurias et do non las espaçeficardes singularmiente que en generalmiente se en/tiendan todas las personas et canónigos et benefiçiados de la dicha eglesia de Fusiellos, et todos / los vezinos et moradores que ffueron et son o serán en el dicho logar de Santillán et en el dicho logar de / Fusiellos, et eso mesmo se entiendan los del conçejo de Villavnbrales et clérigos del dicho logar / commo dicho es, et a los que ffueron con ellos o conuusco, o a qualesquier de nos o dellos en las pren/dias et tomas et fechos o en qualquier dellos así commo si ffuesen personalmiente nonbrados. Et / que nos, los dichos prior et cabilldo de Fusiellos, seamos tenudos a satidfazer et dar todos los / daños et menoscabos que nos rreçebimos o qualquier de nos et los vezinos que ffueron o son en el / dicho logar de Santillán et de Fusiellos, rreçebieron del dicho conçejo de Villavnbrales o de qual/quier o qualesquier que moran o moraron en el dicho logar. E eso mesmo los del conçejo de Vi/llavnbrales sean tenudos a satidfazer a sise de todos los daños e menoscabos que ellos / e los moradores que fueron o son en el dicho logar de Villavnbrales rreçebieron o de qualquier / o 
qualesquier de nos o de qualquier de los de los (sic) dichos lugares de Santillán e de Fusiellos, e pa/rar a saluo a la nostra parte de nos los dichos prior e cabilldo e de los que moran o moraron en los di/chos lugares de Santillán e de Fusiellos, e nos a ellos o a qualquier o qualesquier dellos de / la dicha otra parte de todas las querellas e demandas que fasta el día de oy auremos o / podríemos auer nos e los vezinos e moradores que ffueron e son en el dicho logar de San/tillán e de Fusiellos contra ellos o contra qualquier o qualesquier de la dicha otra parte, saluo / de conpras o de deudas de enpréstido o donadíos o de guarda o herençias o penas o posturas / o semejables destas spaçeficadas que alguno o algunos de nos el dicho prior e cabilldo aya de / dar a otro o a otros o ellos o qualquier dellos a nos o a qualquier de nos, e eso mesmo / el dicho conçejo de Villavnbrales sean tenudos a satidfazer a sise o a qualesquier / dellos o de los moradores que fueron e son en el dicho logar de Villavnbrales, de todas / querellas e demandas e injurias e prendias e tomas e desonrras que nos o qual/quier de nos ffezimos o ffezieron a ellos o a qualquier o a qualesquier dellos, / e les ffagan sin querella. E de parar nos a saluo, e para rrenunçiar todas casas $(f 2 v$. $)$ e preuilleios e merçedes que auemos de señores e señoras escriptos e non escriptos, eclisiásti/cos e seglares, huestes e cruzadas, e ferias e todas las otras cosas que auemos aquí / por espaçeficadas. E para jurar en nostras ánimas de todos e de cada vnos de nos para estas / cosas e otras qualesquier que sean puestas por el dicho nostro procurador para las atener e con/plir e nunca venir contra ellas, e para todo lo sobredicho de lo que se sigue o puede se/gir dello, le damos conplido poder al dicho nostro procurador; e otrosí le damos conplido / poder al dicho Iohán Pérez, nostro prior, que se auenga e pueda avenir e con las eglesias e clérigos / e prestameros de Villavnbrales sobre los pleitos e contiendas que auiemos e auemos en / vn sobre los diezmos de los términos de Santillán e de Villavnbrales por nos e por / la nostra eglesia del dicho logar de Santillán, e sobre la limitaçión de la perrocha de la di/cha eglesia, e sobre la costituçión que fizo el dicho señor don Vasco, obispo de Palençia / e rrenunçiar los pleitos e partirse dellos, e ponerlo en mano de amigos árbi/tros arbitradores de muchos o de vno, e poner pena sobre sí e sobre nos, e iurar / en almas de cada vnos de nos, e obligar a nos el dicho cabilldo e a los bienos nostros / e de la nostra mesa e de cada vno de nos en general e en special para estar e quedar e / conplir por toda postura e abenençia e trasaçión que 
el dicho prior feziere en qualquier manera / a tienpo o perpetuo para sienpre iamás; e para demandar abtoridat sobre ello e firmeza al / obispo e a los perlados o a sus vicarios, e sobre todo le damos conplido poder, e obli/gamos a nos e a todos los bienes de la nostra mesa, de auer por firme e por gradeçido / todo lo que el dicho prior abeniere e posiere, feziere e diere o prometiere sobre esto que / dicho es, e de lo conplir e atener e nunca venir contra ello en tienpo del mundo. E / porque esto sea firme e non venga en dubda, mandamos e rrogamos a Gonçalo $\mathrm{Al} /$ fonso, notario público de la çipdat de Palençia, que escriuiese esta carta e la signase con / su signo.

Fecha la carta en el dicho logar de Fusiellos, martes, quatro días del mes de / iunio, era de mille e trezientos e nouenta e vn años. Testigos que ffueron presentes a / esto todo que dicho es: Iohán Garçía, astoriano, familiar de la dicha eglesia, e Iohán Martínez, ombre / del dicho prior, e Martín Pérez, alcallde de Fusiellos. E yo, Gonçalo Alfonso, notario público so/bredicho de la dicha çipdat de Palençia, ffui presente a esto todo que dicho es con los di/chos testigos. E por mandado de los dichos prior e cabilldo de Fusiellos, escreuí esta carta e / ffiz aquí este mío signo en testimonio de uerdat. (rúbrica).

1353, junio, 17. Villaumbrales.

Carta de procuración dada por el concejo de Villaumbrales a favor de Domingo Díez, merino, y Martín Fernández, escribano, para representar al dicho concejo en el concierto y avenencia que se espera realizar con la abadía de Santa María de Husillos, sobre aprovechamiento de pastos, poblamiento y diezmos en los términos de Villaumbrales y de Santillán de la Cuesta.

B. AHDP, Ampudia y Abadía de Husillos, Pergaminos, carp. 200-22. Perg., 355 x 250 mm.; escr. gótica de privilegios. Relativa buena conservación a excepción de los dos últimos folios, en el que el penúltimo está bastante deteriorado y del último falta prácticamente la mitad. Conserva la cinta, que cose el canto del cuadernillo y lleva pendiente el sello de cera, el cual está bastante 


\section{LA ABADÍA DE SANTA MARÍA DE HUSILLOS: ESTUDIO Y COLECCIÓN \\ DOCUMENTAL $(904-1608)$}

deteriorado aunque todavía se distinguen dos figuras antropomorfas. Consta de cinco hojas de pergamino dobladas al medio y cosidas, lo que hace un total de diez folios; en el 1r, que es la portada: "Escritura de CLIII años en tiempo del rey don Pero por donde parece desde entonçes la temporalidad que los abades de Husillos tovieron en la villa de Husillos. Item, para que el conçejo de los veçinos y seglares que se llaman de Husillos no es parte para ninguna cosa que toque a la villa de Husillos en común, salvo el prior y cabildo de la villa al antiguo representan el concejo de la villa. Y ellos, sin el concejo de los seglares, determinaron y compusieron lo que a ellos y al dicho concejo tocó en lo temporal con qualesquier personas que tovieron los unos y otros diferençias de consuno>.

Todos los folios van rubricados, en el folio vuelto en la parte inferior y en el folio recto en la parte superior. El f. 9v está en blanco; el f. 10r es una copia del $1 \mathrm{v}$ y está al revés; el f. 10v es la contraportada: "Las ordenancas antiguos entre los pueblos de Villumbrales y Santillán de la Cuesta con Villumbrales, año de 1358; siendo abbad el cardenal Gil de Albornoz y reynado el rey don Pero".

Dos veces se da una nómina de vecinos de Villaumbrales, habiendo tres que no coincide el nombre o el apellido, pudiendo deberse a un descuido del notario.

Inserto en avenencia entre Santa María de Husillos y el concejo de Villaumbrales. Véase doc. núm. 145.

C. APA, $L P H$, ff. $49 \mathrm{v}-57 \mathrm{r}$.

D. BN, $m s .705$, ff. 83v-109r.

Sepan quantos esta carta de poder e / procuraçión vieren, commo nos el conçejo de Villavnbrales, estando ayuntados a nostro / conçejo en el portal de la eglesia de Sanct Pelayo deste dicho logar, a canpana rrepica/da segund que lo auemos de vso e de costunbre de nos ayuntar, estando presentes Iohán / Domíngez e Diego Ferrández e Pero Nicolás, alcalldes, e Domingo Diez, merino, e todos los / otros ombres deste dicho logar presentes todos de vna voluntad e de vn otorgamiento, / auiendo muchos tratado sobre esto que se sigue, entendiendo por nos e por todos / los moradores e vezinos que fueron o son en Villavnbrales fazer abenençia con / (f.3r) el prior e con el cabilldo de la eglesia colegiada de Sancta María de Fusiellos, sobre muchos daños e me/noscabos e fuerças que ellos e su mandado e los moradores que fueron e son en Santillán / de la Cuesta e en Fusiellos, ffezieron a nos o a qualquier de nos e en nostros bienes, e nos e / los moradores que son e fueron en Villavnbrales fezieron a ellos o a qualquier dellos e en / sus bienes en qualquier manera e por qualquier rrazón fasta el día de oy, de las quales cosas / ffueron dadas querellas sobre algunas dellas a la eglesia de 
Palençia, e adelantados e a merynos por / la vna parte, e por la otra, e fechas partes, e fueron dadas sentençias por los vicarios de la dicha / eglesia de Palençia contra algunos nostros vezinos que auemos aquí por nonbrados, e fue apellado / e fueron rreuocadas las sentençias por los juezes del arçobispo de Toledo. E otrosí, sobre que / fue querellado al adelantado e alcalldes, merinos por el conçejo e moradores que ffueron en $\mathrm{Vi} /$ llavnbrales de los dichos prior e cabilldo de personas çiertas que auiemos aquí por nonbrados, a / Rodrigo Alfonso, fijo de Alfonso Pérez; e a Bartolomé Sánchez, fijo de Domingo Martínez; e a Felipe, fijo de / Yuán Pastor; e Alfonso Martín, fijo de Martín Çidon; e a Sancho "el Ferrero"; e a Domingo Martín, fijo de Santos Lu/çián; e a Domingo Ferrández, fijo de Ferrand Lobo; e a Iohán Martínez, fijo de Martín Çidón; e a Iohán Dominges, / fijo de don Apariçio; e a Iohán Martín, fijo de Iohán Ferrero; e Alfonso, fijo de Cidón Pérez; e a Iohán Ferrández, / fijo de Iohán Ferrero; e a Domingo Rallo e Miguel Rallo, fijos de Bartolomé Rallo; e a Pascual, / fijo de Yuán Pastor; e a Garçía Ferrández, fijo de Iohán Garçía; e Alfonso Gonçález; e a Martín Ferrández, fijo de Martín Çidón; / e a Mathe, fijo de Rodrigo Corbato; e a Iohán Ximón, fijo de don Ximón; e a Diego Ferrández e Do/mingo Ferrnández, escriuanos; e a Ferrnand Martín, fijo de Domingo Martín; e a Martín Deleyto, fijo de Martín Deleyto; / e a Pero Castriellejo, fijo de Iohán Castriellejo; e a Domingo Moro, fijo de Nicolás Moro; e a Ferrnand / Sánchez, fijo de Domingo Sánchez; e a Benito Uascón; e a Iohán Domíngez Cortés, fijo de Domingo / Calagueno; e Alfonso Ferrnández, fijo de doña Marina.

E de los dichos concejos e moradores que fue/ron o son en los dichos logares de Santillán o de Fusiellos así commo si todos fuesen aquí por/nonbrados de querellas e males e injurias e calopnias e tomas e rrobos fasta el día de / oy; e porque estas cosas naçieron sobre los pastos de los términos de los dichos lugares de / Villavnbrales e de Santillán de que auiemos de vso e costunbre de vsar nos con ellos e ellos / connusco; e por rrazón que algunos vezinos de Santillán se pasauan morar a Villavnbrales / e de Villavnbrales a Santillán, e porque destechauan las casas e trayan la teja e / la madera segund ffuero de vn logar a otro e auía manera commo despoblamiento de los lo/gares por do naçieron muchas discordias e males e prendias e contiendas e querellas en/tre la vna parte e la otra. 


\section{LA ABADÍA DE SANTA MARÍA DE HUSILLOS: ESTUDIO Y COLECCIÓN DOCUMENTAL $(904-1608)$}

Por ende, de consentemiento de los perlados de la eglesia e / de los alcalldes que oyen los pleitos, queriendo fazer abenençia amas las partes en vno / tanbién en común commo en singular sobre cada cosa que fues tomada a qualquier de / nos o dellos la vna parte a la otra o daño o iniuria fecha, otorgamos e conosçemos / que nos, el dicho conçejo de Villavnbrales, que damos todo nostro conplido poder a uos, Domin/go Diez, merino, fijo de Pero Diez, e a Martín Ferrnández, escriuano, fijo de Martín Çidon, nostros vezi/nos amos a dos en vno e a cada vno de uos por si así que non sea mejor la condi/çión del que primero lo esconpeçare que del otro para que traytedes e vos auengades e faga/des postura e abenençia e obligaçión con el prior e con el cabilldo de la dicha eglesia o (f.3v.)

con aquel o aquellos que ouieren poderío dellos para lo fazer sobre todas las dichas cosas e cada vna / dellas o sobre las que se sigiesen o podrían segir de todas e qualquier de las sobredichas, e / sobre que pazcamos e rroçemos en el término de Santillán de la Cuesta, e pongamos vmanderos / e cabañas en el término de Santillán e ellos en lo nostro en la manera que vierdes que cunple, e po/dades darles quantía çierta de marauedís por qualesquier cosas que vierdes o entendierdes que cunple / e rreçebir quantías de marauedís dellos, e consensar daños en todo o en parte segund que vierdes que / cunple. E para poner pena a quantos a quantos (sic) vos quisierdes sobre nos, e obligar a uos el dicho con/çejo a todos e a cada vnos de las personas ssingulares que somos e seremos en el dicho logar / de Villavnbrales, e a todos nostros bienes e a cada vnos de nos para atener e conplir e / jurar en nostras ánimas de nos e de los que moraron fasta aquí en el dicho logar de Villa/vnbrales e moraran de aquí adelante así que en vestra persona de uos los dichos nostros procura/dores sienpre seamos tenudos de atener e conplir e guardar para sienpre todo quanto trate/rdes e abenierdes e posierdes con los dichos prior e cabilldo o con aquel o aquellos que ouie/ren poderío dellos; e para que vos podades partir e dexar e dexar (sic) de las querellas e pleitos / mouidos e por mouer contra los dichos prior e cabilldo o contra qualquier dellos, e contra / el conçejo e moradores que fueron en el dicho logar de Santillán e en el dicho logar de Fusi/ellos, e sobre las que ellos an mouido o esperan mouer contra nos, e sobre todas las / otras cosas mayores o menores por qualesquier rrazones e manera que sea que tanga o pueda / tañer a nos el dicho conçejo de Villavnbrales o a qualquier de los vezinos e moradores / que fueron o son en el dicho logar de 
Villavnbrales o que tangan o puedan tañer a los dichos / prior e cabilldo e a cada vno dellos o que tangan o puedan tañer al conçejo e moradores / que fueron o son en el dicho logar de Santillán, e en el dicho logar de Fusiellos, así commo si / spiçialmiente e signularmiente se nonbrasen aquí; e que podades vos, los dichos nostros / procuradores, declarar e espaçeficar los nonbres de los querellosos de aquellos singular/miente de aquellos con quien eran las prendias e tomas e contiendas e fuerças e inju/rias, e do non los espaçeficardes singularmiente que en generalmiente se entien/dan todos los vezinos que fueron o son moradores en el dicho logar de Villavnbrales, e / todos los que fueron e son de los dichos prior e cabilldo de Fusiellos e de los conçejos de / Santillán e de Fusiellos, e a los que fueron con ellos o connusco o con qualquier de nos / o dellos en las prendias e tomas e fechos o en qualquier dellos; e que nos, el dicho / conçejo de Villavnbrales, seamos tenudos a sastidfazer e dar todos los daños e / menoscabos que rreçebieron los dichos nostros vezinos de los dichos prior e cabilldo e mora/dores en los dichos logares de Santillán e de Fusiellos e de qualesquier dellos. E paren / en saluo a la parte de los dichos prior e cabilldo e a cada vno de los moradores que fueron / o son en los dichos logares de Santillán e de Fusiellos de todas las querellas e deman/das que fasta el día de oy auían o podrían auer nos o los vezinos que ffueron o son / en el dicho logar de Villavnbrales contra ellos o contra qualquier o qualesquier dellos de / la dicha otra parte, saluo de conpras o de deudas de enpréstido o de guarda o de herençias / o postura o semejables destas espaçeficadas o daños o penas que alguno o algunos de nos, el / dicho conçejo, aya de dar a otro o a otros de la otra parte o ellos o qualquier dellos a nos / (f.4r) o a qualquier de nos. E eso mesmo los dichos prior e cabilldo sean tenudos a sastidfazer a sise / o a qualesquier dellos o a los moradores que ffueron o son en el dicho logar de Santillán e de Fuse/llos de todas querellas e demandas e iniurias e prendias e tomas e desonrras que nos o / qualesquier de nos ffezimos o fezieron a ellos o a qualquier dellos o de qualquier o qualesquier de/llos e les fagan sin querella e depararnos a saluo; e para rrenunçiar todas cartas e / priuilleios, merçedes, que auemos de señores e de señoras, escriptos e non escriptos, eclisiásticos / e seglares, huestes e cruzadas, e ferias e todas las otras cosas que auemos aquí por es/paçeficadas, e para iurar en nostras ánimas de todos e do cada vnos de nos para estas cosas / e otras qualesquier que sean puestas por los dichos 
nostros procuradores e por qualquier dellos para / las atener e conplir e nunca venir contra ellas, et para todo lo sobredicho que se sigue de/llo, les damos conplido poder e obligamos a nos, el dicho conçejo, e a las personas singulares / que son e serán en el dicho logar de Villavnbrales e a todos nostros bienes e de cada vnos de nos / singularmiente para estar e quedar e auer por ffirme e a tener e conplir todo lo que ffuere fecho / e dicho e rrazonado e traytado por los dichos nostros procuradores e por qualquier dellos e de les / sacar a saluo.

E porque esto sea ffirme e non venga en dubda, nos, el dicho conçejo de / Villavnbrales, rrogamos e mandamos a Diego Ferrández, notario público en el dicho logar de Villa/vnbrales, que escriuiese esta carta de poder e la signase con su signo.

Ffecha esta carta en / Villavnbrales, diez e siete días de junio, era de mille e trezientos e nouenta e vn / años. Testigos que estauan presentes: Iohán Garçía e Gonçalo Ferrnández, fijos de Iohán Garçía, e Iohán Domíngez / Cortés, e Iohán Domíngez, ffijo de don Apariçio, e Domingo Díez, meryno, vezinos de Villa/vnbrales.

E yo, Diego Ferrández, notario público sobredicho, ffuy presente a esto con los dichos testigos, / e rreçebí la obligaçión dellos en la manera que dicha es, e escriuí esta carta de poder en / quaderno de papel en que ay quatro ffojas, e escriuí mi nonbre en cada plana, e fiz aquí este / mío signo en testimonio de verdat (signo).

1353, junio, 21. Valladolid.

El obispo de Palencia, Vasco Fernández de Toledo, da poder a Domingo Fernández, deán de la catedral de Palencia, para juzgar una avenencia que se iba a efectuar entre Husillos y Villaumbrales sobre aprovechamiento de pastos, poblamiento y diezmos en los términos de Villaumbrales y de Santillán de la Cuesta. 


\section{DAVID MARCOS DIEZ}

B. AHDP, Ampudia y Abadía de Husillos, Pergaminos, carp. 200-22. Perg., 355 x 250 mm.; escr. gótica de privilegios. Relativa buena conservación a excepción de los dos últimos folios, en el que el penúltimo está bastante deteriorado y del último falta prácticamente la mitad. Conserva la cinta, que cose el canto del cuadernillo y lleva pendiente el sello de cera, el cual está bastante deteriorado aunque todavía se distinguen dos figuras antropomorfas. Consta de cinco hojas de pergamino dobladas al medio y cosidas, lo que hace un total de diez folios; en el 1r, que es la portada: "Escritura de CLIII años en tiempo del rey don Pero por donde parece desde entonçes la temporalidad que los abades de Husillos tovieron en la villa de Husillos. Item, para que el conçejo de los veçinos y seglares que se llaman de Husillos no es parte para ninguna cosa que toque a la villa de Husillos en común, salvo el prior y cabildo de la villa al antiguo representan el concejo de la villa. Y ellos, sin el concejo de los seglares, determinaron y compusieron lo que a ellos y al dicho concejo tocó en lo temporal con qualesquier personas que tovieron los unos y otros diferençias de consuno>.

Todos los folios van rubricados, en el folio vuelto en la parte inferior y en el folio recto en la parte superior. El f. 9v está en blanco; el f. 10r es una copia del $1 \mathrm{v}$ y está al revés; el f. 10v es la contraportada: "Las ordenancas antiguos entre los pueblos de Villumbrales y Santillán de la Cuesta con Villumbrales, año de 1358; siendo abbad el cardenal Gil de Albornoz y reynado el rey don Pero".

Dos veces se da una nómina de vecinos de Villaumbrales, habiendo tres que no coincide el nombre o el apellido, pudiendo deberse a un descuido del notario.

Inserto en avenencia entre Santa María de Husillos y el concejo de Villaumbrales. Véase doc. núm. 145.

C. APA, $L P H$, ff. $49 \mathrm{v}-57 \mathrm{r}$.

D. BN, ms. 705, ff. 83v-109r.

Don Vasco, por la graçia de Dios e de la sancta eglesia de / Roma obispo de Palençia e notario mayor del rrey en el rreyno de León e chançeller mayor de / la rreyna, a uos, Domingo Ferrández, deán de la nostra eglesia de Palençia, salut e bendiçión. Sepades que el / prior e el cabilldo de la eglesia de Fusiellos nos enbiaron dezir que por escusar muchas costas / e daños que rreçebían de cada día por rrazón del pleito que auían con el conçejo de Villavnbra/les por rrazón del su lugar de Santillán de la Cuesta e de su término, que auían tratado de / ffazer abenençia e conpusiçion con el dicho conçejo de Villavnbrales sobre la dicha razón. E / enbiáronnos pedir merçed que les diésemos nostra liçençia e abtoridat para fazer la dicha conpu/siçión e abenençia. E nos, por quanto somos enbargado de otros muchos negoçios de nostros se/ñores el rrey e la rreyna, e non podemos entender este fecho fiando de la vestra discreçión, en/comendamos e dámosvos 


\section{LA ABADÍA DE SANTA MARÍA DE HUSILLOS: ESTUDIO Y COLECCIÓN \\ DOCUMENTAL $(904-1608)$}

poder por esta nostra carta para que veyades e examinedes la dicha con/pusiçión e abenençia. E si vierdes que non es en permysio de la dicha eglesia e del cabilldo de / Fusiellos que dedes consentemiento e liçençia por nostra abtoridat para que se faga. E en testi/monio desto mandamos dar esta nostra carta abierta e sellada con nostro sello.

Dada en / Valladolid, veynte vn días de junio, era de mille e trezientos e nouenta e vn años. Yo, / Alfonso Fernández, la fiz escriuir por mandado del obispo (rúbrica) Petrus Pétrez (signo).

1353, junio, 25. Palencia.

Domingo Fernández, deán de la catedral de Palencia, por poder del obispo de Palencia, Vasco Fernández de Toledo, da licencia a Santa María de Husillos para efectuar una avenencia con el concejo de Villaumbrales sobre aprovechamiento de pastos, poblamiento y diezmos en los términos de Villaumbrales y de Santillán de la Cuesta.

B. AHDP, Ampudia y Abadía de Husillos, Pergaminos, carp. 200-22. Perg., 355 x 250 mm.; escr. gótica de privilegios. Relativa buena conservación a excepción de los dos últimos folios, en el que el penúltimo está bastante deteriorado y del último falta prácticamente la mitad. Conserva la cinta, que cose el canto del cuadernillo y lleva pendiente el sello de cera, el cual está bastante deteriorado aunque todavía se distinguen dos figuras antropomorfas. Consta de cinco hojas de pergamino dobladas al medio y cosidas, lo que hace un total de diez folios; en el 1r, que es la portada: "Escritura de CLIII años en tiempo del rey don Pero por donde parece desde entonçes la temporalidad que los abades de Husillos tovieron en la villa de Husillos. Item, para que el conçejo de los veçinos y seglares que se llaman de Husillos no es parte para ninguna cosa que toque a la villa de Husillos en común, salvo el prior y cabildo de la villa al antiguo representan el concejo de la villa. Y ellos, sin el concejo de los seglares, determinaron y compusieron lo que a ellos y al dicho concejo tocó en lo temporal con qualesquier personas que tovieron los unos y otros diferençias de consuno>. 
Todos los folios van rubricados, en el folio vuelto en la parte inferior y en el folio recto en la parte superior. El f. 9v está en blanco; el f. 10r es una copia del 1v y está al revés; el f. 10v es la contraportada: "Las ordenancas antiguos entre los pueblos de Villumbrales y Santillán de la Cuesta con Villumbrales, año de 1358; siendo abbad el cardenal Gil de Albornoz y reynado el rey don Pero".

Dos veces se da una nómina de vecinos de Villaumbrales, habiendo tres que no coincide el nombre o el apellido, pudiendo deberse a un descuido del notario.

Inserto en avenencia entre Santa María de Husillos y el concejo de Villaumbrales. Véase doc. núm. 145.

C. APA, $L P H$, ff. $49 \mathrm{v}-57 \mathrm{r}$.

D. BN, $m s .705$, ff. 83v-109r.

Según el episcopologio palentino de Carlos Reglero ${ }^{9}$, Vasco Fernández de Toledo fue promovido el 12 de septiembre de 1343 y trasladado a Toledo el 17 de junio de 1353, siendo su sucesor Reginaldo de Maubernand, que fue promovido el 17 de junio de 1353. De ahí que tanto en este documento como en el anterior no se ajuste la fecha del documento con la del pontificado del obispo de Palencia.

Sepan / quantos esta carta vieren commo yo, Domingo Ferrández, deán de Palençia, prouisor e vicario general / en lo spiritual e en lo tenporal en todo el obispado por el onrrado padre e señor don Vasco, por / la graçia de Dios e de la sancta eglesia de Roma obispo de Palençia e notario mayor del rrey en el / rreyno de León, e chançeller mayor de la rreyna, por el poder que yo he por vna carta del / dicho sseñor obispo, que es escripta en papel e sellada con su sello de çera en las espalldas, el / tenor de la qual es este que se sigue.

(Sigue doc. núm. 141)

E otrosí, vista la dicha / conpusiçión que el dicho prior e cabilldo de Fusiellos an de ffazer con el dicho conçejo e ombres bu/enos de Villavnbrales, el tenor de la qual es este que se sigue:

Lo primero que auemos de / ffazer por bien de paz entre el prior e el cabilldo de la eglesia de Fusiellos e el conçe/jo de Villavnbrales, e porque pazen e rroçen con sus ganados los moradores en Villa/vnbrales en término de Santillán en todo

\footnotetext{
${ }^{9}$ Historia de las diócesis españolas. Iglesias de Palencia, Valladolid y Segovia.
} 


\section{LA ABADÍA DE SANTA MARÍA DE HUSILLOS: ESTUDIO Y COLECCIÓN \\ DOCUMENTAL $(904-1608)$}

tienpo, e los moradores de Santillán en término de Vi/llavnbrales, guardando pan e vino; e otrosí por todas las contiendas e querellas e da/ños e demandas que el dicho prior e cabilldo an o podrían auer en qualquier manera fasta el día / de oy contra el dicho conçejo de Villavnbrales o contra qualquier vezino o vezina del / dicho logar; e otrosí porque los moradores que fueren en el dicho logar de Santillán paz/can e rroçen en término de Villavnbrales esto todo guardando pan e vino; e otrosí por / todas las contiendas e querellas e demandas que el dicho conçejo de Villavnbrales e / (f.5r) los moradores o vezinos del dicho logar an o podrían auer en qualquier manera contra los dichos prior e / e (sic) cabilldo o contra qualquier dellos o de los de Santillán lo segundo, que si postura fezieron el dicho / conçejo de Villavnbrales en que los que veniesen morar de Santillán a Villavnbrales que sea desfecha, / e que si los de Villavnbrales quissieren venir morar de Villavnbrales a Santillán, e él de Santillán a / Villavnbrales, que vayan ssin premia e ssin pena alguna. E lo terçero, que el prior e el cabilldo de $\mathrm{Fu} / \mathrm{ssiellos}$, que pongan mesqueros e vmanderos sobre pan e vino en su término de mientra que ouiere diez la/bradores moradores en Santillán o los dichos labradores. E de mientra que non ouiere los dichos diez / labradores moradores en el dicho logar de Santillán, que sean los dichos mesqueros e vmanderos de los mora/dores del dicho logar de Villavnbrales quales el dicho conçejo diere. E el prior o su mandado que los / ponga o enbíen poner todavía seyendo de los moradores del dicho conçejo de Villavnbrales e non otros / ningunos. E los mesqueros que sean puestos en el mes de março, e los vmanderos mediado el mes de / julio o después. E lo cuarto, que las heredades que son del dicho prior e cabilldo de la eglesia de Sanct Ju/llián e de la capellanía de Sancta Brígida, que si los moradores de Villavnbrales las arrendaren o / las labraren por mandado del dicho prior e cabilldo, que den enteramiente todo el diezmo de pan e / de vino destas dichas heredades a los dichos prior e cabilldo o a su mandado, e ellos que enbíen por ello / al dicho logar de Villavnbrales o al tanto quanto montare el diezmo que los dichos clérigos e eglesias / o otros que los ouiesen de auer leuasen de las dichas heredades por su derecho. E lo quinto, que si ga/nados se criaren en término de Santillán acogiéndose a maner dentro en el dicho logar de Santillana / la meatad del año, que den la meatad del diezmo del fruto de los dichos ganados a los dichos / prior e cabilldo o al tanto quanto montare del diezmo que leuaren los 
clérigos e eglesias de Villavn/brales o otros algunos que de derecho lo ouiesen de leuar. E esto todo que atengan e cunplan amas / las partes e que non vayan contra ello nin contra parte dello en tienpo del mundo, so pena de veynte / mille marauedís.

E vista e examinada bien e diligentemiente la dicha conpusiçión e auido mi con/sejo con el cabilldo de la eglesia de Palençia e con ombres buenos sabidores en derecho, porque fallé que / la dicha conpusiçión e abenençia era prouechosa al prior e al cabilldo, que puedan ffazer e fagan / la dicha conpusiçión e abenençia con el dicho conçejo e ombres de Villavnbrales. E porque esto sea / ffirme e non venga en dubda, mandé a Gonçalo Alfonso, notario público de la çipdat de Palençia / que escriuiese esta carta e la signase con su signo.

Ffecha en el coro de la eglesia cathedral de / Ssancto Antolín de Palençia, veynte çinco días del mes de junio, era de mille e trezientos e no/uenta e vn años. Testigos que ffueron presentes llamados e rrogados spiçialmiente para esto todo que di/cho es firmar, los onrrados varones Alfonso López, abad de Lavanza, e Jacobo Iohán, e Este/uan Domíngez, canónigos en la eglesia de Palençia, e Ferrnand Alfonso, e Pero Sánchez, connpanneros otro/sí en la dicha eglesia.

E yo, Gonçalo Alfonso, notario público sobredicho de la dicha çipdat de / Palençia, ffuy presente a esto todo que sobredicho es con los dichos testigos; e por mandado del di/cho Domingo Ferrández, deán de Palençia, escreuí esta carta e fiz aquí este mío signo en testimonio de verdat. /

1353, junio, 27, jueves. Husillos.

Juan Pérez de Aceves, prior de Santa María de Husillos y su procurador, juntamente con el cabildo, obtienen licencia de Juan Fernández de Meneses, clérigo de la catedral de Palencia y procurador de Gil de Albornoz, abad de Husillos y cardenal en la Santa Sede, para efectuar una avenencia con el concejo 


\section{LA ABADÍA DE SANTA MARÍA DE HUSILLOS: ESTUDIO Y COLECCIÓN \\ DOCUMENTAL $(904-1608)$}

de Villaumbrales sobre aprovechamiento de pastos, poblamiento y diezmos en los términos de Villaumbrales y de Santillán de la Cuesta.

B. AHDP, Ampudia y Abadia de Husillos, Pergaminos, carp. 200-22. Perg., 355 x 250 mm.; escr. gótica de privilegios. Relativa buena conservación a excepción de los dos últimos folios, en el que el penúltimo está bastante deteriorado y del último falta prácticamente la mitad. Conserva la cinta, que cose el canto del cuadernillo y lleva pendiente el sello de cera, el cual está bastante deteriorado aunque todavía se distinguen dos figuras antropomorfas. Consta de cinco hojas de pergamino dobladas al medio y cosidas, lo que hace un total de diez folios; en el 1r, que es la portada: "Escritura de CLIII años en tiempo del rey don Pero por donde parece desde entonçes la temporalidad que los abades de Husillos tovieron en la villa de Husillos. Item, para que el conçejo de los veçinos y seglares que se llaman de Husillos no es parte para ninguna cosa que toque a la villa de Husillos en común, salvo el prior y cabildo de la villa al antiguo representan el concejo de la villa. Y ellos, sin el concejo de los seglares, determinaron y compusieron lo que a ellos y al dicho concejo tocó en lo temporal con qualesquier personas que tovieron los unos y otros diferençias de consuno>.

Todos los folios van rubricados, en el folio vuelto en la parte inferior y en el folio recto en la parte superior. El f. 9v está en blanco; el f. 10r es una copia del $1 \mathrm{v}$ y está al revés; el f. 10v es la contraportada: "Las ordenancas antiguos entre los pueblos de Villumbrales y Santillán de la Cuesta con Villumbrales, año de 1358; siendo abbad el cardenal Gil de Albornoz y reynado el rey don Pero".

Dos veces se da una nómina de vecinos de Villaumbrales, habiendo tres que no coincide el nombre o el apellido, pudiendo deberse a un descuido del notario.

Inserto en avenencia entre Santa María de Husillos y el concejo de Villaumbrales. Véase doc. núm. 145.

C. APA, $L P H$, ff. $49 \mathrm{v}-57 \mathrm{r}$.

D. BN, ms. 705 , ff. 83v-109r.

Yueues, veynte siete días de junio, era de mille e trezien/tos e nouenta e vn años. Estando en el cabilldo de la eglesia de Fusiellos, logar del obispado de / Palençia, estando y presentes Iohán Pérez de Haçeues, prior de Fusiellos, e otras personas canónigos / e benefiçiados de la dicha eglesia de Fusiellos que estauan ayuntados a su cabilldo por canpana ta/ñida segund que lo an de vso e de costunbre, e estando y presente Iohán Ferrández de Mexeses, / clérigo de la eglesia de Palençia, procurador del onrrado padre e señor don Gil, por la graçia de / Dios cardenal en la sancta eglesia de Roma e abad de la dicha eglesia de Fusiellos; e en / presençia de mí, Diego López, notario público de la çipdat de 
Palençia e de los testigos de yuso escriptos. E / luego, los dichos prior e cabilldo dexieron al dicho Iohán Ferrández así commo a procurador del di/cho abad de Fusiellos, que sobre rrazón de pleitos e contiendas que eran entre ellos e el con/çejo e ombres çiertos de Villavnbrales sobre el su logar de Santillán de la Cuesta e sobre su / término, que auían tratado abenençia e conpusiçión; e que porque la dicha abenençia e conpusiçión / fuese firme e valedera, que pedía e pedieron al dicho Iohán Ferrández así commo a procurador del / dicho abad de Fusiellos, que les diese liçencia e abtoridat para poder fazer la dicha abanençia / e conpusiçión. E luego, el dicho Iohán Ferrández, procurador sobredicho del dicho abad de Fusiellos, / dixo que él en nonbre del dicho abad, que daua e dio liçençia e abtoridat a los dichos prior / e cabilldo para que podiesen fazer e feziesen abenençia e conpusiçión sobre la dicha rrazón $(f .4 r)$ con los sobredichos conçejo e ombres çiertos del dicho logar de Villavnbrales. E desto todo en commo / pasó, los dichos prior e cabilldo pedieron e rrequerieron a mí, el dicho Diego López, notario, que les diese / vn público instrumento, o más, los que mester ouiese. Testigos que estauan presentes llamados e rrogados / spiçialmiente para esto, Gil Ferrández, capellán del número de los Quarenta Capellanes en la eglesia de Palençia, / e Alfonso Ferrández de Carrión, yrmano de don Pero Ferrández, abad que ffue de Fusiellos, e Diego Ferrández de Torre /, moradores en Fusiellos. E yo, el dicho Diego López, notario público de la dicha çipdat de Palen/çia, ffuy presente a esto que dicho es con los dichos testigos. E por rruego e rrequerimiento de los dichos / prior e cabilldo, ffiz escriuir este público instrumento e fiz aquí este mío signo en testimonio (signo).

1353, julio, 11. Palencia.

Alfonso Martínez, alcalde del rey en las merindades de Castilla, autoriza al prior y cabildo de Santa María de Husillos, y al concejo de Villaumbrales, a efectuar una avenencia que esperan hacer entre ellos sobre aprovechamiento de 
pastos, poblamiento y diezmos en los términos de Villaumbrales y de Santillán de la Cuesta.

B. AHDP, Ampudia y Abadía de Husillos, Pergaminos, carp. 200-22. Perg., 355 x 250 mm.; escr. gótica de privilegios. Relativa buena conservación a excepción de los dos últimos folios, en el que el penúltimo está bastante deteriorado y del último falta prácticamente la mitad. Conserva la cinta, que cose el canto del cuadernillo y lleva pendiente el sello de cera, el cual está bastante deteriorado aunque todavía se distinguen dos figuras antropomorfas. Consta de cinco hojas de pergamino dobladas al medio y cosidas, lo que hace un total de diez folios; en el 1r, que es la portada: "Escritura de CLIII años en tiempo del rey don Pero por donde parece desde entonçes la temporalidad que los abades de Husillos tovieron en la villa de Husillos. Item, para que el conçejo de los veçinos y seglares que se llaman de Husillos no es parte para ninguna cosa que toque a la villa de Husillos en común, salvo el prior y cabildo de la villa al antiguo representan el concejo de la villa. Y ellos, sin el concejo de los seglares, determinaron y compusieron lo que a ellos y al dicho concejo tocó en lo temporal con qualesquier personas que tovieron los unos y otros diferençias de consuno>.

Todos los folios van rubricados, en el folio vuelto en la parte inferior y en el folio recto en la parte superior. El f. 9v está en blanco; el f. 10r es una copia del 1v y está al revés; el f. 10v es la contraportada: "Las ordenancas antiguos entre los pueblos de Villumbrales y Santillán de la Cuesta con Villumbrales, año de 1358; siendo abbad el cardenal Gil de Albornoz y reynado el rey don Pero". Dos veces se da una nómina de vecinos de Villaumbrales, habiendo tres que no coincide el nombre o el apellido, pudiendo deberse a un descuido del notario.

Inserto en avenencia entre Santa María de Husillos y el concejo de Villaumbrales. Véase doc. núm. 145 .

C. APA, $L P H$, ff. $49 \mathrm{v}-57 \mathrm{r}$.

D. BN, ms. 705 , ff. 83v-109r.

De mí, Alfonso Martínez, alcallde del rrey en las meryndades de Castiella, al prior e al cabilldo de la eglesia co/legiada de Sancta María de Fusiellos, e a cada vnos de uos; e al conçejo de Villavnbrales e a los / que ffuestes enplazados nonbradamiente sobre las querellas e pesquisas que fueron fechas a querella / de los dichos prior e cabilldo e eglesia de Fusiellos, sobre prendias e tomas e quebrantamientos del / logar de Santillán de la Cuesta que es de los dichos prior e cabilldo, sabet ví las cartas que me $(f .5 r)$ enbiastes amas las partes que a vos queríedes abenir en este pleito si a mí plagiese que era alcallde dello e di/ese mi consentemiento a ello; e yo, veyendo que todos estos fechos naçieron sobre los pastos de los térmi/nos que auedes juntos en vno e prendias e tomas e 
quebrantamientos de los lugares que vos fezísteis, / la vna parte a la otra; e porque cada vno lieua sus cosas pasándose morar del vn logar al otro / ssegund ffuero de los dichos lugares, e non ouo y muertes entre vos nin otros peligros; por ende / a mí, dicho Alfonso Martínez, alcallde, plázeme e do a uos, las dichas partes, mi consentemiento porque las / partes uos auengades e ayades paz e non contendades más en esta rrazón. E toda abenençia que fe/zierdes yo lo otorgo e he por firme. E si en algo fuere menguado o se menguar, yo lo / cunplo que sea valedero e ffirme en todo tienpo. E porque esto sea firme e non venga en / dubda, rroge e mandé a Gonçalo Alfonso, notario público de la çipdat de Palençia, que escriuiese esta carta / e la signase con su signo.

Ffecha la carta en Palençia, onze días de jullio, era de mille e / trezientos e nouenta e vn años. Testigos que fueron presentes a esto todo que dicho es, Pero Sánchez, fijo / de doña Luca; e Alfonso Gómez, maestro de las feridas, e Iohán Caluo, ombres del dicho Alfonso Martínez, ve/zinos de Palençia, e Domingo Díez, meryno de Villavnbrales, e Martín Ferrnández, escriuano, moradores en el / dicho logar de Villavnbrales.

E yo, Gonçalo Alfonso, notario público sobredicho de la dicha çip/dat de Palençia, ffuy presente a esto todo que dicho es con los dichos testigos. E por rruego e mandado del / dicho Alfonso Martínez, escreuí esta carta e fiz aquí este mío signo en testimonio de uerdat (signo).

1353, julio, 14, lunes. Palencia.

Concierto y avenencia entre Santa María de Husillos y el concejo de Villaumbrales sobre el aprovechamiento de pastos en los lugares de Santillán de la Cuesta, perteneciente al prior y cabildo de Santa María de Husillos, y de Villaumbrales, y sobre que los vecinos de Villaumbrales pasaban a morar a Santillán de la Cuesta y viceversa, llevando consigo los componentes materiales de sus casas. Sobre estas cuestiones había pleitos anteriores, en los que se había 


\section{LA ABADÍA DE SANTA MARÍA DE HUSILLOS: ESTUDIO Y COLECCIÓN \\ DOCUMENTAL $(904-1608)$}

condenado por los vicarios de la diócesis de Palencia a varios vecinos de Villaumbrales. Los acuerdos alcanzados en la avenencia fueron los siguientes: los ganados de Villaumbrales pueden pacer libremente en Santillán de la Cuesta, y viceversa; los habitantes de Villaumbrales pueden ir a vivir a Santillán de la Cuesta y viceversa, sin poder llevar los materiales de construcción de sus casas; el concejo de Villaumbrales y el cabildo de Husillos se comprometen a comprar en justo precio las casas que se deshabiten; se renuncia a todos los pleitos y querellas anteriores, especialmente los habidos contra ciertos vecinos de Villaumbrales; el prior y cabildo de Husillos deben situar mesqueros y humanderos en Santillán de la Cuesta para guarda de cereal y viñedo, aunque mientras en dicho lugar no habiten diez labradores, dichos mesqueros y humanderos serán colocados por el concejo de Villaumbrales; las posesiones de las capillas de Santa Brígida y San Julián, y del prior y cabildo de Husillos, sitas en el término de Santillán de la Cuesta, en caso de que sean alquiladas a labradores de Villaumbrales, éstos deben pagar el diezmo a los dichos prior y cabildo de Husillos; en caso de que los ganados de Villaumbrales se crien en término de Villaumbrales, deben dar el diezmo del fruto al prior y cabildo de Husillos.

A. AHDP, Ampudia y Abadía de Husillos, Pergaminos, carp. 200-22. Perg., 355 x 250 mm.; escr. gótica de privilegios. Relativa buena conservación a excepción de los dos últimos folios, en el que el penúltimo está bastante deteriorado y del último falta prácticamente la mitad. Conserva la cinta, que cose el canto del cuadernillo y lleva pendiente el sello de cera, el cual está bastante deteriorado aunque todavía se distinguen dos figuras antropomorfas. Consta de cinco hojas de pergamino dobladas al medio y cosidas, lo que hace un total de diez folios; en el 1r, que es la portada: "Escritura de CLIII años en tiempo del rey don Pero por donde parece desde entonçes la temporalidad que los abades de Husillos tovieron en la villa de Husillos. Item, para que el conçejo de los veçinos y seglares que se llaman de Husillos no es parte para ninguna cosa que toque a la villa de Husillos en común, salvo el prior y cabildo de la villa al antiguo representan el concejo de la villa. Y ellos, sin el concejo de los seglares, determinaron y compusieron lo que a ellos y al dicho concejo tocó en lo temporal con qualesquier personas que tovieron los unos y otros diferençias de consuno>.

Todos los folios van rubricados, en el folio vuelto en la parte inferior y en el folio recto en la parte superior. El f. 9v está en blanco; el f. 10r es una copia del 1v y está al revés; el f. 10v es la contraportada: "Las ordenancas antiguos entre los pueblos de Villumbrales y Santillán de la 
Cuesta con Villumbrales, año de 1358; siendo abbad el cardenal Gil de Albornoz y reynado el rey don Pero".

Dos veces se da una nómina de vecinos de Villaumbrales, habiendo tres que no coincide el nombre o el apellido, pudiendo deberse a un descuido del notario.

B. APA, $L P H$, ff. $49 \mathrm{v}-57 \mathrm{r}$.

C. BN, ms. 705 , ff. $83 \mathrm{v}-109$ r.

El día 14 de julio de 1353 fue domingo y no lunes. Véase A. GIRY, Manuel de Diplomatique. La letra dominical correspondiente a 1353 es la F, y la Pascua cayó el 24 de marzo.

Como en los documentos insertos, este documento presenta el problema ya referido de la mención del obispo de Palencia Vasco Fernández de Toledo.

Sepan quantos esta carta de abenençia vieren commo nos, Iohán Pérez de Haceues, prior de la / eglesia colegiada de Sancta María de Fusiellos, et canónigo en la eglesia de Palençia, por nonbre / del cabilldo de la dicha eglesia de Fusiellos cuyo procurador so, et por nonbre de los que fueron o son / moradores en los logares de Santillán et de Fusiellos, et a quien tañe o podría tañer este fe/cho de todos et de cada vnos de los del cabildo de Fusiellos, et de cada vnos de los pueblos / et de los moradores que fueron o son en los dichos logares de Santillán et de Fusiellos, commo / si ffuesen aquí por nonbrados de la vna parte. Et nos, Domingo Díez, merino, fijo de Pero Díez, / et Martín Ferrández, escriuano, fijo de Martín Çidón, vezinos et moradores en Villavnbrales, en nonbre / del conçejo de Villavnbrales et de los que fueron çitados et llamados ante los señores de / la eglesia de Palençia por los dichos prior et cabilldo de Fusiellos, et sobre querellas dadas / et pesquisas fechas sobre tomas et quebrantamientos que dezía la otra parte que fuera fecho en el / dicho logar de Santillán et de Fusiellos et de sus términos, los quales nonbramos aquí dos / o tres por auer por nonbrados todos los otros. Conuiene a saber: a Rodrigo Alfonso, fijo de / Alfonso Pérez; et a Bartolomé Sánchez, fijo de Domingo Martínez; et a Felipe, fijo de Yuán Pastor; / et por los que ffueron llamados por ante los alcalldes que andauan con Garçi Ferrández Manrrique, a/delantado de Castiella por nostro señor el rrey de la otra parte; et por todos aquellos que son et / ffueron moradores en Villavnbrales, et a quien tañe o podría tañer estos fechos las / dichas querellas et pesquisas et pleitos et demandas et contiendas de la otra parte, et pen/dientes apellaçiones amas las partes de vn consentemiento. Et nos, los dichos procu/radores por nonbre de las 
dichas partes, entendiendo fazer abenençia rrealmiente para / sienpre jamás entre los dichos prior et cabilldo de Fusiellos et los moradores et querellosos / que fueron o son en Santillán et en Fusiellos de la vna parte, et entre el conçejo et los ombres / buenos de buenos de Villavnbrales et querellosos et moradores que fueron $\mathrm{o}$ son en el dicho logar de Villa/vnbrales de la otra parte, de consentemiento de los vicarios et procuradores en lo spiritual et / tenporal del onrrado padre et señor don Gil de España, cardenal en la sancta eglesia de Roma et abad / de Fusiellos, et por abtoridat del onrrado padre et señor don Vasco, por la graçia de Dios et / de la sancta eglesia de Roma, obispo de Palençia et chançeller mayor de la rreyna, et de don Do/mingo Ferrández, deán de Palençia et vicario del dicho señor obispo, et pues speçialmiente da/do del dicho señor obispo sobre esta abenençia, et otrosí de consentemiento et liçençia de / los alcalldes de nostro señor el rrey que andan con don Garçía Ferrández Manrrique, adelantrado de / Castiella por nostro señor el rrey don Pero, que Dios mantenga por el poder de las procuraçio/nes et consentemientos et liçençia et abtoridat de las partes de los sobredichos señores, / el tenor de los quales poderes et consentemiento et abtoridat son estos que se siguen:

(Sigue doc. núm. 139)

(Sigue doc. núm. 140)

(Sigue doc. núm. 143)

(Sigue doc. núm. 142)

(Sigue doc. núm. 144)

Yo, el dicho / Iohán Pérez de Haçeues, prior de Fusiellos, por nonbre de mí e del dicho cabilldo de Fusiellos cuyo procura/dor so, e por el poder que me es dado dellos en esta rrazón; e nos, Domingo Díez, meryno, fijo de Pero Díez, / e Martín Ferrnández, escriuano, fijo de Martín Çidón, vezinos de Villavnbrales, en nonbre del conçejo de Villavnbra/les cuyos procuradores somos; e por el poder que nos 
es dado nos, los dichos prior e Domingo Díez / e Martín Ferrnández, procuradores sobredichos, entendiendo ffazer abenençia e conpusiçión rrealmiente para sien/pre jamás entre las dichas partes prinçipales e entre el dicho cabilldo de Fusiellos e cada vnas personas / ssingulares e canónigos del dicho cabilldo, e entre los moradores que ffueron e son en Fusiellos e en el / dicho logar de Santillán de la vna parte, e entre el dicho conçejo de Villavnbrales e moradores que / ffueron e son en el dicho logar de la otra parte, ssobre todas querellas, acusaçiones, injurias, ffuerças, to/mas, rrobos, demandas, que cada vna de las personas singulares an fecho, la vna parte a la otra, e / en los dichos logares que auemos aquí todos por nonbrados e por espaçeficados, nos los dichos procu /-radores, entendiendo sacar muchas peleas e a montar muchas discordias e escándalos que eran / entre los dichos conçejos e el dicho cabilldo e personas singulares, e entendiendo que todas estas / discordias naçieron por el paçer e rroçar e pasar morar de vn logar a otro con todo lo suyo / de que sienpre ouieron vso e costunbre los de Santillán de paçer e rroçar en término de Villavn/brales, e so la su vela e los de Villavnbrales en término de Santillán e so su vela, e de pasar/se morar los vnos del vn logar al otro con lo suyo segund que lo vsaron e lo auían acostun/brado los vnos con los otros de luengo tienpo acá, e por nueuos ombres que pasauan la manera / del vso, naçieron muchas contiendas entre ellos. E nos, queriéndolas todas a matar, primera/miente abenimos e ponemos postura entre nos valedera para sienpre, e ordenamos que el conçejo / e los moradores de Villavnbrales que pazcan e rroçen por sí e con los sus ganados en todas las he/redades e téminos de Santillán, segund que el dicho logar de Santillán lo vsa e lo tiene por suyo e / so la su vela por sus términos. E el conçejo e moradores de Santillán que pazcan e rroçen en términos / de Villavnbrales así commo el conçejo de Villavnbrales lo tiene e lo vsa por sus términos e so sus / velas, a qualesquier partes que los vnos e los otros lo ayan, e que vsen todos e cada vnos dellos / (f.6r) de los dichos términos commo de vn término de todos e cosa comunal en paçer e en rroçar consigo e con sus ga/nados commo de susodicho es, guardando sienpre panes e vinos. E que cada vno de los moradores en Villa/vnbrales se puedan pasar a morar si quisieren libremiente al logar de Santillán sin pena de conçejo; / e eso mesmo los moradores en Santillán se puedan pasar libremiente a morar a Villavnbrales. / E si sobre los edifiçios e casas desfazer para leuar teja e madera consigo segund fuero e vso fu/ere fecho 
defendemiento por alguno de los señores del logar donde se quisiere yr el morador, non ge lo con/ssentiere que el conçejo de Villavnbrales por los que moraren en Villavnbrales sean tenidos de conprar las / casas por justo preçio tasado por buenos ombres dados por el que se quisiere pasar a morar a Santillán o por el / dicho cabilldo. E eso mesmo, si el morador en Santillán se quisiere pasar a morar a Villavnbrales e / ouiere defendemiento e enbargo, que non pueda desatar las casas nin leuar la teja e madera, que / el cabilldo de la dicha eglesia de Fusiellos sea tenudo a conprar las dichas casas e pagar el ju/sto preçio dellas al labrador que se pasare a morar a Villavnbrales segund que fueren apreçiadas por ombres / buenos dados por el labrador o por el conçejo del dicho logar de Villavnbrales; e estos tales apreçia/dores que sean jurados sobre sanctos euangiellos que lo apreçiaran bien e uerdaderamiente a mí que la parte / contraria non esté presente, e lo que apreçiare cada vna de las partes en lo suyo que lo page o faga / pagar al dicho labrador que se pasare así a morar del vn logar al otro del día que lo apreçiare / fasta treynta días primeros segientes. E esto que se cunpla, so pena de veynte marauedís por cada vn / día que estodiere el labrador querelloso. E si otra toma o daño feziere el señor o otro por él al / labrador porque se pasa a morar al otro logar, que el dicho cabilldo de Fusiellos sea tenudo de / pagar el daño al labrador que se pasare de Santillán morar a Villavnbrales. E eso mesmo / el dicho conçejo de Villavnbrales sea tenudo a sastidfazer e pagar el daño al labrador / que se pasare morar de Villavnbrales a Santillán. E commo quier que esto fue ordenado por / los señores de los logares e vsado de tanto tienpo acá, que non es memoria de ombres en contrario / en paçer e rroçar los vnos con los otros guardando panes e vinos e pasándose morar los vnos / del vn logar al otro sin pena. Pero porque se confirme este ordenamiento e se confirme esta cos/tunbre antigua e nos partamos de contienda sobre ello por mejoría de la dicha eglesia, ordena/mos que el conçejo de Villavnbrales dé al dicho cabilldo para rrefazemiento de sus posesiones, / tres mille marauedís. E nos, los dichos Domingo Domingo (sic) Díez, e Martín Ferrández, procuradores del dicho conçe/jo de Villavnbrales, por el poder que nos es dado obligamos el dicho conçejo de Villavnbrales / a que dé e page los dichos tres mille marauedís al dicho cabilldo de Fusiellos o a uos, el dicho prior su procu/rador, en su nonbre. E para esto obligámosnos de fazer carta aparte a uos, el dicho prior, en qual/quier manera 
que uos querades de debdo por rrazón de los dichos marauedís en nonbre del dicho conçejo, so pena çierta / al plazo que en la dicha carta se conternán los mille marauedís fasta el día de sancta María de a/gosto mediado. E los dos mille marauedís al día de Todos Santos primeros que vienen, so pena de veynte / marauedís por cada vn día de quantos días pasaren de cada vno de los dichos plazos en adelante. E / obligámosnos de uos fazer tal carta por el poder que nos es dado por el dicho conçejo de / Villavnbrales. E ponemos amas las dichas partes que los dichos términos de Santillán e / de Villavnbrales segund que se vsaua de paçer e rroçar en vno sea vn término comunal / para paçer e rroçar segund dicho es guardando panes e vinos, e firmamos la dicha costunbre / para sienpre jamás. E si algunos vezinos e moradores en Santillán o en Villavnbrales o sus (f.6r.) ganados ffezieren daño en los dichos panes e vinos, que lo peche a vista de los veladores o de ombres buenos / ssin sospecha, dados de la parte que rreçebiere el daño que lo apreçien; e que lo pagen fasta diez días, so / pena de veynte marauedís por cada día. E que el dicho prior e cabilldo sea tenudo por la su parte e el dicho / conçejo de Villavnbrales por lo suyo, e qualquier parte que enbargare o contrallare a la otra en / qualquier manera sobre el paçer e rroçar e vsare de los dichos términos comunalados en vno o parare/bos en juyçio sobre ello o querellare o tornare a aquerellar o a demandar sobre lo pasado a qualquier ombre, / que peche a la otra parte veynte mille marauedís e todavía pagar la pena o non estar que estar e conplir la / dicha postura para sienpre jamás. E lo sacado ordenamos de nos quitar e quitámosnos e partímosnos / de todos los pleitos e contiendas e querellas e demandas mouidos e por mouer fasta el día de oy. / E rrenunçiamos todas las querellas e pesquisas, acusaçiones, demandas e pleitos mouidos e por mo/uer, e damos las por minguas tanbién las por parte del dicho cabilldo de Fusiellos o por los / de Santillán o de Fusiellos, o por los moradores que ffueron e son en los dichos lugares de Fusiellos / e de Santillán que ffuesen dadas e mouidas contra el conçejo de Villavnbrales e contra personas / çiertas que ffueron o son en el dicho logar de Villavnbrales, conuiene a saber: contra Rodrigo Al/ffonso, fijo de Alfonso Pérez; e Bartolomé Sánchez, fijo de Domingo Martínez; e Felipe, fijo de Yuán Pastor; / e Alfonso Martín, fijo de Martín Çidón; e Sancho el Ferrero; e Domingo Martín, fijo de Santos Luçía; e Domingo / Ferrández, fijo de Ferrnand Lobo; e a Sancho Martín, fijo de Martín Çidón; e 
Iohán Martín, fijo de don Apariçio; e Iohán / Martín, fijo de Iohán Ferrero; e Alfonso, fijo de Adán Pérez; e Iohán Ferrández, fijo de Iohán Ferrero; e Domin/go Rallo e Migel Rallo, fijos de Bartolomé Rallo; e Felipe, fijo de Yuán Pastor; e Garçía Ferrández, / fijo de Iohán Garçía; e Alfonso Gonçález; e Martín Ferrández, fijo de Martín Çidón; e Martín, fijo de Rodrigo Corbato; / e Iohán Ximón, fijo de don Ximón; e Diego Ferrández e Domingo Ferrández, escrIuanos; e Ferrnand Martín, fijo / de Domingo Martín; e Martín de Leyto, fijo de Martín de Leyto; e Pero Castriello, fijo de Iohán Castriello; e / Domingo Moro, fijo de Nicolás Moro; e Ferrnand Sánchez, fijo de Domingo Fernández; e Benito Cas/cón; e Iohán Domíngez Cortés, fijo de Domingo Calagruno; e Alfonso Ferrández, fijo de domna Marina, / e generalmiente contra otros muchos singulares personas e conçejo de Villavn[brales], aue/mos a que por nonbrados tanbién las que ffueron mouidas ante los vicarios de la eglesia de / Palençia, de los quales fue apellado e su juyzio rreuocado commo las que fueron mouidas / ante el adelantado e dadas querellas ante otros merynos commo todas las querellas e de/mandas e pleitos que fueron dadas o mouidas o por mouer por el dicho conçejo de Villavnbra/les e por los moradores que fueron e son en el dicho logar de Villavnbrales contra el dicho / cabilldo e contra mí el dicho prior, e contra las personas singulares e contra el dicho conçejo / de Santillán, e contra el conçejo de Fusiellos, e contra las singulares personas e mora/dores que ffueron o son en los dichos lugares de Santillán e de Fusiellos, sobre qualesquier cosas / e fechos, o por qualesquier rrazones o cosas que fuesen o podrían ser o naçer dellas en qualquier / manera fasta el día de oy. E dámoslas todas por menguas, en tal manera que los dichos / prior e cabilldo e personas singulares de Fusiellos e de Santillán e conçejo de Villavnbra/les e moradores que ffueron e son en los dichos lugares de Villavnbrales e Santillán / e Fusiellos del día de oy en adelante, ninguna de las partes nunca sea oyda ni ninguna de / las partes de onbres moraron e moran en los dichos lugares de Villavnbrales e Santillán / e Fusiellos, nunca sea oyda sobre querellas e tomas e daños e cosas e calopnias que / ffuesen fechos de que fuese querelloso e se podiese querellar fasta el día de oy, e conpen/(f.7r)sando los daños e injurias e deshonras, si algunas fezieron el conçejo e los moradores en Villavnbrales / al cabilldo e personas e canónigos e benefiçiados e clérigos de la eglesia de Fusiellos o a los moradores / del dicho conçejo de Fusiellos e de 
Santillán o en los dichos lugares, conpensando todos estos daños / o otros qualesquier fechos que se podrían demandar por querella o por calopnia o por desonrra en qualquier ma/nera e por qualquier rrazón, conpensándolo con los daños e injurias, desonrras, tomas e fuerças e / quebrantamientos que los dichos prior e cabilldo e personas e canónigos e benefiçiados e clérigos e los di/chos conçejos de Fusiellos e de Santillán e los moradores en los dichos lugares, fezieron en qualquier / manera e por qualquier rrazón al dicho conçejo de Villavnbrales o a los moradores que ffueron o son en $\mathrm{Vi} / 1$ lavnbrales e en el dicho logar de Villavnbrales fasta el día de oy, que todas se conpiesen / e vayan vnas por otras, e sean quietas en tal manera que los del dicho logar de Villavnbrales sean tenu/dos de sastidfazer e fazer enmienda a los moradores que ffueron o son en Villavnbrales de todos los da/ños e calopnias e tomas e pesquisas e desonrras que los dichos prior e cabilldo e personas e / canónigos e benefiçiados e clérigos e los dichos conçejos de Fusiellos e de Santillán e moradores / que ffueron o son en los dichos logares de Fusiellos e de Santillán, fezieron al conçejo e moradores / en Villavnbrales fasta el día de oy en todo tienpo desdel día que ffueren rrequeridos por el dicho / cabilldo de Fusiellos o por qualquier de los moradores que ffueron o son en Fusiellos e en Santillán, fas/ta treynta días primeros segientes, so pena de mille marauedís por cada querelloso a quien non fezieren enmien/da el dicho conçejo de Villavnbrales e matase la querella. E otrosí, que eso mesmo sea tenido / el dicho cabilldo de Fusiellos por lo suyo de su parte a que sean tenidos a sastidfazer e enmendar / a los suyos personas canónigos benefiçiados en la dicha eglesia de Fusiellos, e conçejos e morado/res que ffueron e son en los dichos lugares de Fusiellos e de Santillán, e sastidfazerlos de / todos los daños, injurias, desonrras, que rreçebieron en sus cuerpos e en sus bienes e en sus luga/res del dicho conçejo de Villavnbrales, e de los moradores que ffueron e son en el dicho logar de / Villavnbrales o de [qualquier] dellos, desdel día que ffueren rrequeridos por el dicho conçejo de Villa/[vnbrales] por qualquier de los moradores que ffueron e son en el dicho logar de Villavnbrales fasta / treynta días primeros segientes, so la dicha pena de los dichos mille marauedís por cada vn ombre que/relloso a quien nos sastidfazieren en qualquier tienpo que ffueren rrequeridos fasta el dicho plazo / de los dichos treynta días. E pedimos merçed a nostro señor el rrey e al arçobispo de Toledo / e al obispo de Palençia e a todos los otros 


\section{LA ABADÍA DE SANTA MARÍA DE HUSILLOS: ESTUDIO Y COLECCIÓN \\ DOCUMENTAL $(904-1608)$}

señores e a todos merynos, alcalldes, vicarios, e juezes / que sea la su merçed de lo auer por ffirme e bueno e que non quiera oyr a ninguna de las partes que/rellarse sobre ello de cosa que sea pasada segund dicho es fasta el día de oy que esta carta / es fecha. E todavía que el dicho conçejo de Villavnbrales sea tenido a sastidfazer / a qualquier de la su parte del daño e injuria que rreçebieron de la parte del dicho cabilldo de Fusiellos / e de los moradores que ffueron o son en los dichos lugares de Fusiellos e de Santillán, e eso / mesmo los dichos prior e cabilldo de Fusiellos sean tenudos de sastidfazer a sise e a quales/quier de la su parte personas singulares e conçejos, e moradores que ffueron e son en los dichos lo/gares de Fusiellos e Santillán del daño e injuria que rreçebieron de los vezinos e mora/dores en el dicho logar de Villavnbrales segund dicho es.

Otrosí, lo terçero ponemos e orde/namos que el prior e el cabilldo de Fusiellos pungan mesqueros e vmanderos que guarden $\mathrm{pa} /$ nes e vinos en el dicho término de Santillán en esta manera, que mientra que non ouiere diez labra/dores que moren en el dicho logar de Santillán, que los mesqueros e vmanderos que sean del dicho logar $(f .7 r)$ de Villavnbrales quales el dicho conçejo de Villavnbrales asinare e nonbrare. E do el conçejo non / los diere para guardar los panes a ocho días del mes de março. E para guardar los vinos a quin/ze días del mes de mayo, que entonçes que el dicho prior e cabilldo que pongan mensqueros e vman/deros donde quisieren e las cabañas que estén do solían estar por parte e término de Santillán, / la vna vela en Melgarejo e la otra a Toyslo, e la otra vela a Val de Santillán, e / la otra vela en Oteruelo, e la otra en Valdesona. E quando ouiere diez ombres buenos mo/radores en Santillán, que ponga el prior e el cabilldo o por su mandado, mesqueros e vmanderos / donde quisieren. E el conçejo de Villavnbrales que ge lo non enbarge nin contralle nin el prior / nin el cabilldo non venga contra ello, so pena de los dichos veynte mille marauedís.

E otrosí, lo quarto / ponemos e ordenamos que las heredades que son de la cappellanía de Sancta Brígida e de Sanct / Jullián del dicho logar de Santillán e de los dichos prior e cabilldo, que si los moradores de Villa/vnbrales lo arrendaren e lo labraren lo de la dicha capellanía e de los dichos prior e cabill/do, que den enteramiente los diezmos de las dichas heredades a los dichos prior e cabilldo, / e ellos que vayan por ello al dicho logar de Villavnbrales. E si los clérigos de Villa/vnbrales o otro rreçebiere el dicho diezmo, que los dichos labradores de 
Villavnbrales den al tan/to pan e vino a los dichos prior e cabilldo quanto montare el diezmo de los frutos de las / dichas heredades que ellos labraren desdel día que fuere cogido e ge lo demandare fasta tres dí/as, so pena del doblo. E el dicho conçejo de Villavnbrales que sea tenido de lo fazer conplir o / conplirlo por los labradores.

E lo quinto, ponemos e ordenamos e fazemos abenençia que si ga/nados se criaren de Villavnbrales en término de Santillán acogiéndose a maner dentro en el / dicho logar de Santillán la meatad del año continuadamiente, que den la meatad del di/ezmo del fruto de los dichos ganados a los dichos prior e cabilldo de Fusiellos. E si y an/dodieren todo el año, que ge lo den enteramiente. E si el diezmo de los f[rutos de los] dichos / ganados leuaren los dichos clérigos e pres[tameros] de Villavnbrales, que los dichos [labradores] / den al tanto diezmo entero al dicho prior [e] cabilldo quanto montare por el dicho tienpo que los gana/dos se criaren e se acogieren en el dicho logar de Santillán segund dicho es. E esto que sea a/sí atenido el conçejo de Villavnbrales de lo fazer así a tener e conplir a los labradores / de Villavnbrales que labraren las dichas heredades segund dicho es. E a los que criaren / los dichos ganados en el dicho término de Santillán e se acogieren y sin pleito e sin otra / contienda de juez seyendo cogido el pan e vino e pasado el día de Sanct Pero de los Ar/cos a que estreman el ganado seyendo rrequeridos a quinze días so pena del doblo, e si sobre / estos diezmos de la dicha heredat de ganados pasaren algunos contienda e contrario de boz / en juyzio sobre ello deziendo, sin rrazón derecha, que el dicho prior e cabilldo non lo abrán de / auer e el conçejo de Villavnbrales fuere requerido, e del día que ffuere rrequerido a treynta días / sobre ello non lo ffezieren desatar o non lo pagaren, que por ese mesmo fecho caya el conçejo en / pena de los dichos veynte mille marauedís, e sean tenidos de lo pagar segund que lo ponemos e ordenamos. /

E nos, los dichos prior, por nonbre del [ca]billdo de la dicha eglesia de Fusiellos e por las perso/nas singulares e conçejos e moradores [que fue]ron e son en los dichos lugares de Fusiellos e / (f.8r) de Santillán de la vna parte; e nos, Domingo Díez e Martín Ferrández, por nonbre del dicho conçejo de Villavn/brales e por los moradores que ffueron e son en el logar de Villavnbrales de la otra parte e / por el poder que nos es dado, ponemos e firmamos todas estas cosas sobredichas e ca/da vna dellas, e ffirmámmoslas que sean valederas para agora e para sienpre jamás, 
so las di/chas penas. E yo, el dicho Iohán Pérez, prior de Fusiellos, así commo prior e por el poder e ab/toridat que el dicho cabilldo de Fusiellos me dio, obligo a mí e al dicho cabilldo e a cada vnas / de las personas e canónigos e benefiçiados en la dicha eglesia de Fusiellos e a sus bienes para ate/ner e conplir todas las cosas sobredichas e cada vna dellas en quanto tañe al dicho ca/billdo de fazer e conplir e a los moradores que ffueron e son en Fusiellos e en Santillán, / e so las dichas penas e de pagar las do cayéremos en ellas segund dicho es. E nos, / los dichos Domingo Díez e Martín Ferrández, procuradores sobredichos, por el poder que nos es dado, obli/gamos al dicho conçejo de Villavnbrales e a todos los moradores que son o serán en el dicho / logar de Villavnbrales e a sus bienes en todo lo que tañe al dicho conçejo e moradores / que ffueron e son en Villavnbrales, de fazer e atener e conplir todo lo sobredicho e de / non venir contra ello, so las dichas penas. E de las pagar do en cayéremos, segund / dicho es. E yo, el dicho Iohán Pérez, prior de Fusiellos, por mí e en nonbre del dicho cabilldo / de la dicha eglesia de Fusiellos e por los que son e serán moradores en el dicho logar de / Santillán; e nos, los dichos Domingo Díez e Martín Ferrández, por el dicho conçejo de Villavnbrales / o por los que son o serán moradores en el dicho logar de Villavnbrales, e por por (sic) el poder que / nos es dado, ponemos a buena fe de todo esto guardar e conplir. E por más seguro de / las partes, juramos verdat a Dios e a Sancta María e a esta cruz e a estos sanctos euangellos que / tenemos [corporalmiente] con nostras manos en nostras almas e en las almas de las sin/gula[res personas, del dicho ca]billdo e del dicho conçejo de Villavnbrales e de cada vno de los / [que son o serán] atener e conplir e de non [venir] contra ello ni contra parte dello en tienpo del / [mundo.

E] sobre esto todo que dicho es, yo el dicho [Iohán] Pérez, prior de Fusiellos, por mí e en nonbre / del dicho cabilldo, e por todas las personas, [canónigos] e benefiçiados que son o serán e fueron / en la dicha eglesia de Fusiellos, e por todos los vezinos e moradores que son o serán e / ffueron en el dicho logar de Santillán e de Fusiellos; e nos los dichos Domingo Díez e / Martín Ferrández, por nonbre del dicho conçejo de Villavnbrales, e por todos los vezinos e mo/radores que son e ffueron o serán en el dicho logar, e por los poderes que nos, amas las / dichas partes, auemos, rrenunçiamos e partimos de nos todas leys e todos fueros, derechos, / vsus, custunbres, casos e merçedes, hueste e cruzada, rromería e 
fonsado de rrey e de / rreyna, e de infante e de rrico ombre, e de rrica fenbra e de arço]bispo, e / de todos los otros señores eclesiásticos e segl[ares, e todas exençiones de] engaño e rres/tituçiones "in integrum"; e todas las otras cosas, buenas rraçones, defensiones, exepçiones / e allegaçiones, que nos, los dichos prior, en nonbre [del] dicho cabilldo e de las personas, canónigos / e benefiçiados en la dicha eglesia de Fusi[ellos, e conçejos] de Santillán e de Fusiellos. / E nos, los dichos Domingo Díez e Martín [Ferrández], en nonbre del dicho conçejo e de los vezinos $(f .8 r)$ e moradores que ffueron o son o serán en el dicho logar de Villavnbrales, podriemos poner o dezir / o allegar para esto todo sobredicho o para parte dello contradezir e enbargar que si lo ante nos / posiéremos, nos o qualquier de los dichos conçejos de Villavnbrales e del dicho cabilldo e conçejos / de Santillán e de Fusiellos o ellos mesmos o otro qualquier por nos o por ellos que nos / non valan nin seamos nin sean sobre ello oydos nin creydo en juyzio nin fuera de juyzio / ante rrey nin ante rreyna nin ante infante nin ante rrico ombre nin rrica fenbra nin arço/bispo nin obispo nin ante otro señor nin juez que en el mundo sea eclisiástico nin seglar. E abenençia / se entendemos que es paz e pro de las partes e en guardarlo para sienpre jamás. E / estendemos la jura a todas las cosas sobredichas que nunca sea oyda alguna de las / partes sobre ello para lo contradezir nin venir en manera del mundo contra todo nin contra parte / dello. E porque esto ssea ffirme e non venga en dubda, nos, los dichos Iohán Pérez, / prior procurador del dicho cabilldo, e nos, los dichos Domingo Díez e Martín Ferrández, procuradores / del dicho conçejo de Villavnbrales, rrogamos e mandamos a Gonçalo Alfonso, notario públi/co de la çipdat de Palençia, que escriuiese desto todo que dicho es dos cartas en vn tenor tal / la vna commo la otra parte por parte, e palabra por palabra, la vna para mí el dicho / prior e el cabilldo de la dicha eglesia de Fusiellos, e la otra para el dicho conçejo de Vi/llavnbrales. E por más firmedunbre mandamos sellar las dichas cartas con los se/ellos de mí, el dicho prior e cabilldo de la dicha eglesia de Fusiellos, e del dicho conçejo / de Villavnbrales.

Ffecha esta carta en Palençia, lunes, catorze días del mes de jullio, / era de mille e trezientos e nouenta e vn años. Testigos que ffueron presentes rrogados / e llamados [speçial]miente para esto todo que dicho es [firmar, Iohán Martínez, canónigo de Pa]/lençia, e Lope Ferrández, su ombre, e Alfonso Ferrández, clérigo 


\section{LA ABADÍA DE SANTA MARÍA DE HUSILLOS: ESTUDIO Y COLECCIÓN \\ DOCUMENTAL $(904-1608)$}

[de Frechilla, e Iohán Al]fonso, fijo / de Felipe Pérez, e Alfonso Martín, fijo de [don Martín,] clérigos de Amayuelas, [Iohán] / [Garçía,] fijo de Pero Nieto, clérigo de [Rebenga], e Gil Ferrández, capellán del [número de los] / Quarenta Capellanes, e Sanctos Pérez, [e Iohán Martínez], de Sanct Saluador de Cantamuda, ombres / del dicho Iohán Pérez, prior.

E yo, Gonçalo [Alfo]nso, notario público sobredicho de la dicha çip/dat de Palençia, ffuy presente a esto todo que dicho es con los dichos testigos. E por mandado / e rruego del dicho Iohán Pérez, prior de Fusiellos, procurador del dicho cabilldo, e otrosí, / por mandado e rruego de los dichos Domingo Díez e Martín Ferrández, procuradores sobredichos del / dicho conçejo de Villa[vnbrales, escriuí esta] carta en siete fojas e dos planas de pargami/no de cuero, [que va cosido con filo de li]no. E va escripto sobre rroydo desdel comien/ço de la dicha [carta, que es la primera] plana [e] dende fasta las dos fojas primeras, / e de las dichas dos [fojas primeras, de la o]tra plana primera a siete rrenglones contados / dençima do dize: "de [quanta e non le en]pezca", que se ffizo por yerro, en cada / foja de la dicha carta va [escripto mi nombre. E] fiz aquí este mío sig(signo)no en / testimonio de uerdat (rúbrica).

[1353, julio, 14 - 1355, noviembre, 28]

Requerimiento de Juan Pérez de Aceves, prior de Santa María de Husillos, a Domingo Fernández, deán de la catedral de Palencia y vicario general de la diócesis de Palencia por su obispo Reginaldo de Maubernand, para que haga guardar el derecho de propiedad de Santa María de Husillos sobre el monte de La Reyerta, sito entre Paredes de Nava y Becerril, que ambos concejos se disputaban y que había sido descepado por vecinos de Paredes de Nava.

B. APA, $L P H$, f. 78r-v. Inserto en traslado sacado en Palencia, a 28 de noviembre de 1355 . Véase doc. núm. 147.

C. BN, $m s .705$, ff. 166r-167r. 
Las fechas propuestas corresponden la primera, a la fecha del documento anterior, ya que en él se cita al obispo Vasco Fernández de Toledo, aunque en el episcopologio palentino de Carlos Reglero ${ }^{10}$ se diga que Reginaldo de Maubernand fue promovido en la diócesis de Palencia el 17 de junio de 1353; y la segunda, a la fecha del traslado de este documento.

Deán señor provisor por nostro señor don Reginaldo, obispo de Palencia. Yo, Joán Pérez de Açeues, prior de Fusiellos, vos pido que pues vos y yo fecha fee por conosçimiento de los omes buenos de Paredes y por su dicho que el monte y el eredamiento sobre que contienden el conçejo de Paredes de Nava y el conçejo de Bezerril que es de la yglesia de Fusiellos; y otrosí vos y fecha fee de commo los del dicho conçejo de Paredes le costaron y desçeparon por fuerça y contra voluntad mía y de la dicha yglesia por omes buenos dignos de las vezindades, que querades hazer justiçia y derecho y cumplimiento a mí y a la dicha yglesia, y que mandedes guardar las constituçiones que fizo nostro señor el cardenal legado y las provinçiales y signodales, fasta que yo y la dicha yglesia ayamos conplimiento de derecho. Y en esto fazedes bien y lo que devedes sino protestando me querellar de vos a don Gil, cardenal en la sancta yglesia de Roma y abad de Fusiellos, y a este legado de nostro señor el papa. Y deste rrequerimiento y pedimiento que vos fago, pido a este notario que me dé vn público ynstrumento, o dos, o más, quantos menester oviere. $\mathrm{Y}$ a estos omes buenos que están presentes, que sean dello testigos, porque el derecho de la dicha yglesia y mío no se pierda por tiempo.

1355, noviembre, 28, sábado.

Traslado sacado por Diego López, notario público de Palencia, a petición de Juan Pérez de Aceves, prior de Santa María de Husillos, ante Domingo Fernández, deán de la catedral de Palencia y vicario general de la diócesis de Palencia por su obispo Reginaldo de Maubernand, de un requerimiento, sin

\footnotetext{
${ }^{10}$ Historia de las diócesis españolas. Iglesias de Palencia, Valladolid y Segovia.
} 
fecha, que hizo el dicho Juan Pérez de Aceves ante el dicho Domingo Fernández, sobre el monte de La Reyerta, entre Paredes de Nava y Becerril, que pertenecía a Santa María de Husillos y que se disputaban ambos concejos.

B. APA, $L P H$, f. $78 \mathrm{r}-\mathrm{v}$.

C. BN, ms. 705 , ff. 166r-167r.

Fecho y sacado fue este traslado en la villa de Husillos, a veynte y çinco días del mes de noviembre de mil y quinientos y çinquenta y quatro años. Testigos que fueron presentes a lo ver, leer, corregir y conçertar, Joán Ruiz Cabeça de Vaca y Gaspar de Vedoya, clérigos, e Pero Manuel, estantes en la dicha villa.

E yo, Santiago Gómez, escriuano público en la dicha villa, fui presente con los dichos testigos. E del dicho pedimiento e mandamiento lo escreví y fize aquí mi signo (signo) en testimonio de verdad.

Pero Ruyz de Villoldo (rúbrica). Santiago Gómez (rúbrica)

Sábado, veynte y ocho días del mes de novienbre, era de mil y trezientos y noventa y tres años. Estando en Palençia antel onrrado varón y sabio don Domingo Fernández, deán de Palençia y provisor y vicario general en lo espiritual y tenporal en todo el obispado por el onrrado padre y señor don Reginaldo, por la graçia de Dios y de la santa yglesia de Roma, obispo de Palençia, thesorero de nostro señor el papa; y en presençia de mí, Diego López, notario público de la çibdad de Palençia y de los testigos de yuso escriptos, pareçió Joán Pérez de Açeves, prior de Husyllos, y presentó y fizo leer por mí, el dicho notario, vn escrito en papel del tenor del qual es este que se sigue:

(Sigue doc. núm. 146)

El qual escrito leydo, luego el dicho deán pidió traslados para ver su consejo, y dixo que lo vería y faría sobre ello lo que fallase por derecho.

Testigos que estavan presentes: Fernán Martínez y Mudarro Pérez, y Pero Fernández, canónigos de Palençia. Y Françisco Ferrández, notario público de Palençia.

Y yo, el dicho Diego López, notario público de la dicha çiudad de Palençia, fuy (f.78r) presente a esto que dicho es con los dichos testigos. $\mathrm{Y}$ por rruego $\mathrm{y}$ 
rrequerimiento del dicho Joán Pérez, prior, escreví este público ynstrumento y fize aquí este mío signo en testimonio. ( $f .78 v)$

1367, abril, 1, jueves. Palencia.

Traslado sacado por Diego López, notario público en Palencia, a petición de Juan Fernández de Meneses, sacristán de Santa María de Husillos, de un documento (1290, diciembre, 1. Husillos) por el que Sancho González, abad de Santa María de Husillos, juntamente con el cabildo, estipulan el estatuto de las medias annatas.

B. APA, $L P H$, ff. $37 \mathrm{v}-38$ r. Cuando comienza el texto del original, escribe la mano que dio comienzo al Libro de los Privilegios de Husillos.

C. BN, $m s .705$, ff. $59 \mathrm{v}-60 \mathrm{v}$.

Fecho y sacado fue este traslado de la dicha escritura en la villa de Husillos, a veynte y quatro días del mes de novienbre de mil y quinientos y çinquenta y quatro años. Testigos que fueron presentes a lo uer, leer, corregir y conçertar, Joán Ruiz Cabeça de Vaca y Gaspar de Vedoya, clérigos, y Pero Manuel, estantes en la dicha villa.

Y yo, Santiago Gómez, escriuano público en la dicha villa, presente fui a lo que dicho es en vno con los dichos testigos. Y del pedimiento y mandamiento de dicho señor alcalde mayor, que aquí firmó su nombre, lo escreuí y fize escreuir y fize aquí mi signo (signo) en testimonio de verdad. Pero Ruyz de Billoldo (rúbrica). Santiago Gómez (rúbrica).

Jueues, primero día de abril era de mil y quatroçientos y çinco años. Estando en Palençia ante el onrrado varón y sabio don Alfonso López, abad de Lavanza en la iglesia de Palençia, vicario por el onrrado padre y señor don Gutierre, por la graçia de Dios y de la sancta iglesia de Roma, obispo de Palençia y notario mayor del Andaluzía; y en presençia de mí, Diego López, notario público de la dicha çiudad de Palençia y de los testigos de yuso escritos, pareçió Joán Fernández de Mixeses, sacristán de la dicha yglesia colegiada de Sancta 
María de Fusiellos del obispado de Palençia, y presentó y fizo leer por mí el dicho notario vna carta escrita en pargamino de cuero, en la qual estauan dos cuerdas y en la vna cuerda dellas vn pedaço de vn sello, en el qual dicho pedaço estauan figuras que paresçían de la imagen de sancta María y de la imagen de Ihesu Christo en braços, y de ome que estaua como rrogando a las dichas ymágines a sus pies dellas, y vnas pocas de letras que estauan en derredor que no se podían bien leer. Y en la otra cuerda no estaua sello alguno, según que por la dicha carta paresçía, el tenor de la qual es este que se sigue:

(Sigue doc. núm. 83)

La qual carta presentada y leyda, luego el dicho Joán Fernández, sacristán, dixo que el cabildo de la dicha yglesia de Fusiellos, y él en su nombre, que avía menester de ynbiar mostrar la dicha carta a muchas partes y en muchos lugares, y que avían rreçelo de la perder por agua o por fuego o por furto o por rrobo o por otros muchos peligros que podrán acaesçer, y por ende que pedía y pidió, al dicho abad, que mandase e diese auctoridad a mí, el dicho Diego López, notario, para que trasladase o fiziese trasladar la dicha carta, y que diese traslado o traslados della signados con mío signo al dicho cabildo de la dicha iglesia de Sancta María de Fusiellos o al dicho sacristán en su nonbre los que menester oviese. Y otrosí mandó y dio autoridad para que el traslado o traslados que les yo diese de la dicha carta signados de mío signo como dicho es que valiesen y fiziesen fee doquier que paresçiesen ansí commo el original.

Testigos que estavan presentes: Alfonso Martínez, abogado, y Toribio Martín de Fuente Pudia, y Alfonso Pérez, notarios públicos de Palençia, y Martín Fernández de Paredes, vezinos de Palençia

Y yo, el dicho Diego López, notario público de la dicha çiudad de Palençia, fui presente a esto que dicho es con los dichos testigos; y vi y ley la dicha carta onde este traslado fue sacado; y por mandado y autoridad del dicho don Alfonso López, abad y vicario sobredicho, y porque está ocupado de otros negoçios, fize escrevir este traslado de la dicha carta y fize aquí este mío signo en testimonio. 
1367, abril, 1, jueves. Palencia.

Traslado sacado por Diego López, notario público en Palencia, a petición de Juan Fernández de Meneses, sacristán de Santa María de Husillos, de un documento (1202, junio, 28. Husillos) por el que Gonzalo, abad de Santa María de Husillos, estipula cómo deben hacer testamento los canónigos de dicha iglesia y cómo han de gozar de los frutos de sus préstamos.

A. AHDP, Ampudia y Abadía de Husillos, Pergaminos, carp. 209-21. Perg., 266 x 324 mm.; escr. precortesana; buena conservación con algunas manchas de humedad que no impiden su perfecta lectura. En el catálogo del Archivo Diocesano de Palencia se describe erróneamente como el testamento del beneficiado Juan Fernández de Meneses.

B. APA, $L P H$, ff. $23 \mathrm{v}-24 \mathrm{v}$.

C. BN, ms. 705, ff. 37v-40v.

Jueues, primero día de abril, era de mille et quatroçientos et cinco años. Estando en Palençia ante el onrrado varón et sabio don Alfonso López, abbad de Lavanza en la eglesia de Palençia, < vicario> por el onrrado padre / et señor don Gutierre, por la graçia de Dios et de la santa eglesia de Roma, obispo de Palençia et notario mayor del Andalozía, et en presençia de mí, Diego López, notario público de la dicha çibdat / de Palençia, et de los testigos de yuso escriptos, paresció Iohán Ferrández de Mixeses, sacristán de la eglesia colligiada de Santa María de Fusiellos, del obispado de Palençia, et presentó et fizo leer por mí, el dicho $/^{\beta}$ Diego López, notario, una carta escripta en pargamino de cuero et sellada con un sello pendiente, redondo, de çera amariella en vna correa de cuero, en el qual dicho sello estaua figura de vna / águila et las letras de en derredor non se podían bien leer por vegez; et en comienço de la dicha carta estaua un signo de los tiempos antiguos, segund que por la dicha carta parescía, el / tenor de la qual es este que se sigue:

(Sigue doc. núm. 47) 
La qual carta presentada et leyda, luego el dicho Iohán Ferrández, sacristán, / dixo que el cabiello de la dicha eglesia de Fusiellos et él, en su nombre, que auían mester de enbiar mostrar la dicha carta a muchas partes et en muchos lugares et que auían rreçelo de la perder por agua o / por fuego o por furto o por robo o por otros muchos peligros que podrían acaecer. Et por ende, que pedía et pedió, al dicho abbad, que mandase et diese autoridat a mí, el dicho Diego López, notario, para que tras $/{ }^{24}$ laudase o feziese traslaudar la dicha carta et que diese traslaudo o traslaudos della signados con mío signo, al dicho cabiello de la dicha eglesia de Fusiellos o a él en su nombre, los que mester / ouiesen. Et otrosí, que mandase et diese autoridat que el traslaudo o traslaudos que les yo diese, de la dicha carta, signados con mío signo, como dicho es, que valiesen et feziesen fe, doquier que pare/sciesen, así commo el original. Et luego, el dicho don Alfonso López, abbad de Lavanza et vicario sobredicho, dixo que vista la dicha carta, non rrota nin rayda ni emendada nin cançellada $/^{27}$ nin en alguna otra cosa sospechosa. Et otrosí, visto el pedimiento del dicho Iohán Ferrández, sacristán, que mandaua et mandó et dio autoridat a mí, el dicho Diego López, notario, para que traslaudase o fezie/se traslaudar la dicha carta et que diese traslaudo o traslaudos della, signados con mío signo, al dicho cabiello de la dicha eglesia de Fusiellos o al dicho sacristán en su nombre, los que mester / ouiesen. Et otrosí, mandó et dio autoridat que el traslaudo o traslaudos que les yo diese de la dicha carta, signados con mío signo, commo dicho es, que valiesen et feziesen fe, doquier que paresçiesen $/^{30}$ así commo el original. Testigos que estauan presentes: Alfón Martínez, abogado, et Toribio Martínez de Fuent Pudia et Alfón Pérez, notarios públicos de Palençia, et Martín Ferrández de Paredes, vezinos de Palençia. /

Et yo, el dicho Diego López, notario público de la dicha çipdat de Palençia, fuy presente a esto que dicho es con los dichos testigos, et ví et ley la dicha carta / onde este traslado fue sacado. Et por mandado et auctoridat del dicho don Alfón López, abbad de Labanza, vicario sobredicho, et porque era ocupado de otros negoçios, fiz escriuir este traslado de la dicha carta et fiz aquí este mi sig(signo)no en testimonio (rúbrica). 
[1370], enero, 16. Valladolid.

Gutierre Gómez, abad de Santa María de Husillos, nombra como procurador para la elección de prior a Fernando Rodriguez, canónigo en dicha iglesia. Se excusa del asunto aduciendo su servicio a la reina y al infante, y por ser canciller de la reina.

B. AHDP, Ampudia y Abadia de Husillos, Pergaminos, carp. 212-6. Perg., 541 x 665 mm.; escr. precortesana; buena conservación. Inserto en traslado sacado en Palencia, a 7 de julio de 1371, de un testimonio notarial por el que Juan Fernández es elegido prior de Santa María de Husillos. Véase doc. núm. 166.

$C$. APA, $L P H$, ff. $80 \mathrm{r}-84 \mathrm{v}$.

D. BN, $m s .705$, ff. 170v-184r.

La era de la fecha está equivocada, ya que todos los documentos de este asunto, fechados por el año del Señor y por la Natividad, indican el año 1370.

Sepan quantos esta carta de procuraçión vieren, commo yo, Gutierrre Gómez, ${ }^{\beta 0}$ abbat de Fusiellos, otorgo et connosco que por rrazón que Fernant Rodríguez et Iohán Martínez et Iohán Gutiérrez, canónigos de la mi eglesia de Fusiellos, venieron a mí a Valladolid et me dexieron en commo Iohán Pérez de Haçeues, prior que fue de la dicha mi eglesia, en commo era finado et que me lo fazían saber et que touiesse por bien dellegar, a la mi eglesia, a la eleçión del prioradgo. Et que por quanto yo esto aquí, / en Valladolid, en seruiçio de mi sennora la reyna et de mi sennor el infante et de mi sennor el obispo et se an, agora, de fazer las rrentas de la dicha sennora reyna. Et yo, por rrazón del ofiçio de chançillería de la dicha sennora que tengo, he de estar aquí presente et non puedo, personalmiente, yr a la dicha eglesia, a me a terciar a la dicha eleçión; por ende, yo fago mío çierto speçial / procurador a Fernand Rodríguez, canónigo de la dicha eglesia, al qual conmeto para la dicha eleçión et negoçio, complidamiente todas mis vezes et dole todo mío libre general et poderío poder para nombrar et 
elegir, por mi boz et en mío nombre, ydónea persona para prior de la dicha eglesia de Fusiellos et para iurar en mi ánima, sy menester fuere, segund forma de concilio general et fazer $/^{33}$ et dezir todas aquellas cosas et cada una dellas, que yo mismo faría presente seyendo. Et porque esto sea firme, rrogué et mandé a Iohán Fernández, notario público de la çipdat de Palençia, que escriuiese esta carta de procuraçión et la signase con su signo.

Fecha en Valladolid, diziseys días de enero, era de mille et quatroçientos et nueue annos. Testigos que a esto fueron presentes: Roy Gómez, / Iohán Fernández, sacristán de Fusiellos, et Iohán Martínez, vicario de Griiota, et Gonçalo Gómez, criado del dicho abbat, vezinos de Palençia. Et yo, Iohán Fernández de Tablada, notario público de la çipdat de Palençia, fuy presente a esto que dicho es con los dichos testigos. Et por mandado del dicho sennor abbat, escriuí esta carta de procuraçión et fiz aquí este mío signo en testimonio.

1370, enero, 17.

Gutierre Gómez, abad de Santa María de Husillos, autoriza al cabildo de dicha iglesia a realizar elección de prior.

B. AHDP, Ampudia y Abadía de Husillos, Pergaminos, carp. 212-6. Perg. 541 x 665 mm.; escr. precortesana; buena conservación. Inserto en traslado sacado en Palencia, a 7 de julio de 1371, de un testimonio notarial por el que Juan Fernández es elegido prior de Santa María de Husillos. Véase doc. núm. 166.

C. APA, $L P H$, ff. $80 \mathrm{r}-84 \mathrm{v}$.

D. BN, $m s .705$, ff. $170 \mathrm{v}-184 \mathrm{r}$.

In nomine Domini, amen. Nouerint vniuersi presentes literas inspecturi quod nos, Guterrius Gometii, abbas secularis ecclesie Sante Marie de Fusellis et capitulum eiusdem ecclesie Palentine diocesis, dilectis in Christo Dominis, domno Fernando Martini, abbati de Hermidas et Dominico Fernandi de Castriello 
et Iohanne Andree, archipresbitero de Baltanas, et Iohanne Fernandi de Hamusco et Fernand Rodericii, canonico palentino, / et Iohanne Guterrii, portionario eiusdem ecclesie Palentine diocesis, dilectis in Christo dominis, domno Fernando, canoniciis, salutem. Auctoritate cum recolende memorie dominus Iohannes Petri de Haceues, quodam prior Fusellensis, die mercurii, decima quinta die, mensis ianuarii, quod non sine grandis mentis amaritudinis rreferimus nominate soluens sperui suo redidit creatori. Nos ipsius corpore tradicto reuerenter ecclesiastice sepolture, volentes quod nostre ${ }^{27}$ ecclesia prioris existat solatio diutius instituta $\mathrm{XX}^{\circ} \mathrm{III}^{\mathrm{o}}$ die, mensis ianuarii cum continuatione omnium dierum sequentium conceditur prefiximus ad electionem futuri prioris in nostro capitulo celebrandam et ad alia omnia per agenda que ipsius corpore tradicto rreuerenter electionem negotium contingere dignoscitur ut igitur ignorançia precederet neque retis vobis prefixionem huius modi duximus intimandam mandantes quotiens dicta die mane ora capituli quam / diem et oram cum omnibus diebus sequentibus quod usu ipsius eleçtionis negotium fuerit expeditum uobis tenorem presentium asignamos, ad Fusellensis capitulum veniatis ad facti prioris electionem tratare et in eodem electionis negotio debito processuri alio qui volumus non expectatis vt vtilius etiam sy predictus terminus prorogatus fuerit conuocatis in huius $[\mathrm{mo}]<\mathrm{di}>$ electionis negotio, procedemus vestri absentio non obstant ad istas autem literas presentandas latorem Petri Fernan/di, presentia specialiter dicimus eis deputandum.

Datis XVII die, mensis ianuarii, anno Domini millesimo trecentesimo LXX, G[uterrio] abbas Fussillensis.

1370, enero, 23. Husillos.

El cabildo de Santa María de Husillos nombra como procurador a Juan Martínez, canónigo de dicha iglesia, para tratar con el abad la confirmación del prior elegido. 
B. AHDP, Ampudia y Abadía de Husillos, Pergaminos, carp. 212-6. Perg., 541 x 665 mm.; escr. precortesana; buena conservación. Inserto en traslado sacado en Palencia, a 7 de julio de 1371, de un testimonio notarial por el que Juan Fernández es elegido prior de Santa María de Husillos. Véase doc. núm. 166.

C. APA, $L P H$, ff. $80 \mathrm{r}-84 \mathrm{v}$.

D. BN, $m s .705$, ff. 170v-184r.

In nomine Domini. Nouerint uniuersi et singuli presentis procuratori seu publici instrumenti sententie inspecturi quod anno a Natiuitate eiusdem Domini, millesimo trecentisimo septuagesimo, in mei notarii publici testium que infra scriptorum ad hoc specialiter vocatorum et rrogatorum, presencia venit et discreti viri Dominicus Gundisalui, cantor, $/^{6}$ Fernandus Rodericii, Iohannes Andree, Iohannes Guterrii, Iohannes Martini, Iohannes Fernandi de Famusco, Dominicus Fernandi de Castriello, Didacus Didaci et Iohannes Alfonsi, canonici Fusellensis, congregati ad capitulum ante noctem, vocati maneque pulsato cinbalo, ut moris est, fecerunt, constituerunt ac ectiam ordinauerunt suum verum legitimum que iudubicatum procuratorem, actores, factorem ac negocii infra scripti gestorem venerabilem / et discretum uirum dictum Iohanne Martini, canonicum, dantes et concedentes, eidem procuratorii suo plenam generalem specialem, que liberam potestatem ad comparendum et se rrepresentandum coram rreuerendo patre et domino suo domno Guterrio, abbas Fussellensis, et ad petendum ipsorum nomine ab eodem domino abbatem uel con quibuscumque aliis iudicibus seu auditoribus deputatis seu deputandis, ab eo confirmationem electionis celebrate ab eis de venerabili priore Fusellensis, / prout in inscritum serie dicte eletionis plenius continetur, et ad omnia alia et singula faciendi que in predictis ut ante predicta notaria fuerint uel ecclesie oportuna promitentes michi, notario publico infra scripto, nomine omnia ipsorum intercesit uel intercesorum in futurum sollepniter stipulantum se factum et firmum perpetuo habituris quique per domini procuratorem suum actum siue gestum fuerit in premissis et que libet premissorum. Datum et actum in eclesia Fusellensis, $/{ }^{9}$ XXIII die, mensis ianuarii, anno, die, loco, mense, predictis. Presentibus discretis viris: Iohanne Garsie Treçetilla, Alfonso Fernandi de Estrada, Martino Petri, vicinis hauitantibus in dicto loco, Fusellensis testibus ad premisa vocatis specialiter et rrogatis. 
Et ego, Rodericus Martin de Tapia, diocesis Burgensis publicus auctoritate episcopali, notaris palentinem predictis omnibus et singulis, dum sicut premititur, agerentur et fierent una cum prenominatis testibus, / presens fuy eaque omnia et singula propria manu scripssi signo que meo solito signaui, rrogatus et rrequisitus in testimonio premissorum uno instromento procurationis per me, dictum notarium, loco predictus.

1370, enero, 23, jueves. Husillos.

Fernando Rodríguez, procurador del abad Gutierre Gómez, y el cabildo de Santa María de Husillos, eligen como prior a Juan Fernández, sacristán, por muerte del anterior, Juan Pérez de Aceves, enterrado en dicha iglesia. Se tienen en cuenta para su elección sus buenas costumbres y su ordenación en órdenes mayores.

B. AHDP, Ampudia y Abadía de Husillos, Pergaminos, carp. 212-6. Perg., 541 x 665 mm.; escr. precortesana; buena conservación. Inserto en traslado sacado en Palencia, a 7 de julio de 1371, de un testimonio notarial por el que Juan Fernández es elegido prior de Santa María de Husillos. Véase doc. núm. 166.

C. APA, $L P H$, ff. $80 \mathrm{r}-84 \mathrm{v}$.

D. BN, ms. 705 , ff. 170v-184r.

In Dei nomine, amen. Reuerendo patri in domino nostro domno Guterrio, abbati Fusellensis: Fernandus Rodericii, canonicus, procurator vestre, et capitulum nostre, colligiatis ecclesie Sancte Marie de Fusellis, cum rreconmendatione se ipsos ad omnia beneplacita et mandata defunto igitur de presenti Iohanne Petri, priore uestre predicte ecclesie Fusellensis et ipsius corpore tradicto ecclesiastice sepolture ne ipsa eclesia $/{ }^{12}$ prioris sui incomoda divtius deploraret fuit a presentibus die iouis, XXIII, istius menssis ianuarii, concorditer asignatum ad electione futuri prioris celebrandam citatis autem interim absentibus 


\section{LA ABADÍA DE SANTA MARÍA DE HUSILLOS: ESTUDIO Y COLECCIÓN \\ DOCUMENTAL $(904-1608)$}

et conuenientibus in termino supradicto ad capitulum Fusellensis omnibus qui voluerunt, debuerunt et potuerunt comode interese tandem cum vellemus cartam exquirire formam per quam esset in electionis negocio procedendum ipso. Placuit facto nobis omnibus et / singulis per formam Sancti Spiritus eiusdem ecclesie prouidere statutum interuenientem subito et repente Spiritus Sancti gratia inuocatum ut firmiter credimus inspirati omnis nullo penitus, discrepante direximus in venerabilem virum Iohanne Fernandi, sacristam ecclesie Fusellensis, uoca nostra, virum utique, prouidum et discretum, honore, ciencia, vita et moribus comendamdum in maioribus ordinibus et etate legitima constitutum ac de legitimo matrimonio procre/atum et cum vna uoce ac vno spiritu in nostram ecclesiam Fusellensis, elegimus priorem et te Deum laudamus, ut est moris, sollepniter, decantando dictum Iohanne Fernandi, electum in priorati cathedra intonui. Sauimus et electione huius, modi dicto electo infra tempus debitum per nos presentata, et petito ab eo ut suum preberet eidem assensum. Ipse tamem nolens diuine resistere voluntati. Infra tempus a iure statutum anuit vocis $/{ }^{15}$ nostris electioni consentiens de se fructe qua propter donationes, vestre voto vnamini suplicamus gratis electionem eamdem, si sollepniter, comuniter celebratam digne $<\mathrm{m}>$ confirmare, ut Deo actorem nobis et predicte ecclesie valeat vtiliter prodese nosque et alii in dicta ecclesia beneficiati sub ipsius rregimine prout ad ipsum spectad, posimus coram Deo salubriter, militare ceterum ut donatio vestra [...] / in predictis omnibus et singulis concordase ut in petitionem huius modi existere hunamines et concordes. Presens electionis nostre decretum uobis, stamus nostro quidem sigillo sigillari fecimus. Et ad maiorem cautelam per infra scriptum notarium in publica redidegi forma mandauimus.

[Datum et] actum in capitulo nostre ecclesie Fusellensis, sub anno Dominus millesimo trecentesimo septuagesimo, XXIII die, mensis ianuarii. Presentibus discretis viris Iohanne Garsie / Treçetilla, Alfonso Fernandi de Estrada et Martino Petri, vicinis havitantibus in dicto loco Ffusellensi, testibus ad premissa uocatis specialiter et rogatis.

Et ego, Rodericus Martini de Tapia, diocesis Burgensis, publicus auctoritate episcopali notarius Palentini, premissis omnibus et singulares dum sic uero omnia supra scripta sunt, agerentur ducerentur et fierent una cum prenominatis testibus, presens fui aliis occupatus negociis usque ad uerbum rogatis per alium scribi, feci 
ac inhibuit $/{ }^{18}$ publica forma redegi signo que solito signaui rogatus et rrequisitus in testimonio.

1370, enero, 27. Valladolid.

Gutierre Gómez, abad de Santa María de Husillos, se da por enterado de la elección de Juan Fernández como prior por muerte del anterior, Juan Pérez de Aceves, en dicho mes de enero, por el cabildo de dicha iglesia. La escritura de la elección por el cabildo de Husillos, realizada el 23 de enero de 1370, fue presentada para su confirmación por el abad por el dicho Juan Fernández, prior de Husillos, y Juan Martínez, vicario de Grijota y canónigo de Husillos, por sí mismos y en nombre del cabildo de dicha iglesia, para su confirmación por el abad.

El abad da un plazo de seis días desde su publicación en la iglesia de Husillos para posibles alegaciones en contra, que deberían ser hechas ante él en Valladolid.

B. AHDP, Ampudia y Abadia de Husillos, Pergaminos, carp. 212-6. Perg., 541 x 665 mm.; escr. precortesana; buena conservación. Inserto en traslado sacado en Palencia, a 7 de julio de 1371, de un testimonio notarial por el que Juan Fernández es elegido prior de Santa María de Husillos. Véase doc. núm. 166.

C. APA, $L P H$, ff. $80 \mathrm{r}-84 \mathrm{v}$.

D. BN, $m s .705$, ff. 170v-184r.

De mí, don $/{ }^{45}$ Gutierre Gómez, abbat de Fusiellos, a todos los vezinos et moradores en Fusiellos et en todos los logares del abadía de Fusiellos, asy clérigos commo legos, barones et mugeres, de qualquier ley, estado o condiçión que sea. Et a todos los otros de qualesquier logares, aquí en el negoçio de yuso escripto, tanne o tanner puede, en qualquier manera et qualquier o qualesquier de uos que esta mi carta viéredes o della sopiéredes, salud en Ihesu Christo. Sepades 


\section{LA ABADÍA DE SANTA MARÍA DE HUSILLOS: ESTUDIO Y COLECCIÓN \\ DOCUMENTAL $(904-1608)$}

que pa/resçieron ante mí, Iohán Ferrández, electo por prior de la dicha eglesia de Fusiellos, et Iohán Martínez, vicario de Griiota et canónigo de Fusiellos, por sy et en nombre del cabiello de la eglesia de Fusiellos. Et presentáronme un escripto, escripto en pargamino de cuero et signado de notario público et seellado del seello pendiente del dicho cabiello, en que se contenía que por rrazón que la dicha eglesia de Fusiellos estaua vacada de prior / por muerte de Iohán Pérez de Haçeues, prior postrimero de la dicha eglesia, el qual finara en este mes de enero en que estamos, de anno domini millesimo CCC LXX, que se aiuntaran a su cabiello, en la dicha eglesia de Fusiellos, el dicho Iohán Fernández, electo, et los canónigos et todos los que deuían et quisieron et podieron y seer ayuntados, yueues, veynte tres días del dicho mes de enero, en que estamos, para entrar en la dicha exleción $/^{48}$ et exlecir prior de la dicha eglesia. Et que todos en concordia, por forma de Spiritu Santo, que tomaran et exleyeran por prior de la dicha eglesia, al dicho Iohán Ferrández et que lo estalaran, al dicho electo, en la siella del dicho prioradgo en el coro de la dicha eglesia, et que fezieran publicar la dicha exleción, en el término devido, ante el dicho electo et al pueblo, por el dicho Iohán Martínez et por todos los otros canónigos / et cada uno dellos que ay estavan. Et que fuera rrequerido, el dicho electo, por ellos que quisiese consentir en la dicha exleción et la quisiese rresçebir. Et que el dicho Iohán Fernández, electo, que consentía en la dicha exleción et la rresçebiera et avierla por firme. Et que me pedían et pedieron, asy commo abbat et sennor a quien pertennesçía et pertennesçe la confirmaçión del electo de la dicha eglesia, en prior, que quisiese / confirmar la dicha exleçión. Et eso mismo me fue pedido por el dicho electo et por el dicho Iohán Martínez, por sy et en nombre del dicho cabiello, que quisiese confirmar la dicha exleçión. Et yo, queriendo proçeder en este negoçio, en aquella manera que el derecho quiere et manda, mandé dar et di esta mi carta en esta rrazón, porque vos mando et vos amonesto, primo, secundo, terçio, a todos et a cada vno de uos $/^{51}$ a quien este negoçio tanne et tanner puede en qualquier manera; que del día que esta mi carta ffuere leyda et publicada publicamientre en la dicha eglesia de Santa María de Fusiellos o della sopiéredes, fasta seys días primeros seguientes, el qual plazo vos asigno por término perentorio, parezcades ante mí en Valladolid, a dezir, de vestro derecho, lo que quisiéredes dezir contra la dicha exleción o contra el dicho electo, / porque la dicha conffirmaçión non se 
deua fazer. Et yo, ouir vos he et librarlo he, en aquella manera que fallare por derecho; en otra manera sabed que del dicho plazo en adelante, non enbargando vestra absençia et rrebeldía, yo proçedere, en este negoçio, en aquella manera que fallare por derecho. La carta leyda, dátgela.

Dada en Valladolid, veynte siete días de enero, anno Domini millesimo CCC LXX. G[uterrio] / abbas Ffusellensis.

1370, enero, 28. Palencia.

Pedro Fernández de Torre, hortelano, vecino de Palencia, vende a Alonso García de Villada, vecino de dicha ciudad, dos huertas que fueron de Pedro Fernández de Ordejón, cerca de la aceña que llaman del Buen Consejo, en precio de mil maravedis.

A. AHDP, Ampudia y Abadía de Husillos, Pergaminos, carp. 208-14. Perg., 164 x 266 mm.; escr. precortesana; buena conservación.

B. APA, $L P H$, ff. $84 \mathrm{v}-85 \mathrm{r}$.

C. BN, $m s .705$, ff. $184 \mathrm{r}-185 \mathrm{v}$.

Sepan quantos esta carta vieren, commo yo, Pero Ferrández de Torre, ortolano, vezino de la çiudat de Palençia, otorgo et connosco que vendo a uos, Alonso / Garçía de Villoldo, vasallo de nuestro señor el rey, vezino, otrosy, de la dicha çiudat, dos huertas que yo he aquí, en término de la dicha çiu/dat, las quales fueron de Pero Ferrández Ordejón, vezino que fue de la dicha çiudat, las quales sson çerca de la açeña que dizen de Buen Consejo, $\beta$ que han por afrontaçiones: de la una parte, el rrío de Carrión et la dicha açeña que dizen de Buen Consejo; et de la otra parte, huerta del cabiello de la / eglesia de Palençia, et otrosy, huerta de nuestro señor el obispo de Palençia et de la otra parte, huerta que fue de Iohán Pérez, fijo de Garçía Pérez et es agora de / los Quarenta Capellanes. Et estas dichas dos huertas, que estas dichas afrontaçiones ençierran, con entradas et con 


\section{LA ABADÍA DE SANTA MARÍA DE HUSILLOS: ESTUDIO Y COLECCIÓN \\ DOCUMENTAL $(904-1608)$}

salidas et con todas sus pertenen $/{ }^{6}$ çias quantas le pertenesçen, asy de fecho commo de derecho, vos vendo; vendida buena, leal et uerdadera, sin contrario et sin contradiçión alguna, por / mille maravedís desta moneda vsual que fazen diez dineros nuevos el maravedí, los quales yo tomé et reçebí de uos en buenos dineros contados ante el notario et testi/gos desta carta. Et por esta carta apodero, corporalmiente, a uos, el dicho comprador, en las dichas huertas et en cada una dellas, que de oy $\rho^{9}$ día, que esta carta es fecha, en adelante, que sea todo vuestro libre et quito et desenbargado, para vender et enpeñar, trocar et cambiar et mandar et dar et / donar et enajenar et fazer dellas et en ellas, todo lo que vos quisierdes et por bien touierdes, assy commo de vuestro propio juro heredamiento. Et / yo, el dicho Pero Ferrández, vendedor, sso ffiador et pongo con uusco. Et obligo todos míos bienes, muebles et rayzes, auidos et por auer, de uos $/{ }^{12}$ fazer ssanas las dichas huertas et de uos rredrar et anparar et deffender et parar a saluo et sin daño de qualquier omme o mugier que vos / enbargaren o contrariaren las dichas huertas o parte dellas, en todo tiempo del mundo, so pena que yo que vos peche et pague, sin ninguna con/diçión, dos mille maravedís desta dicha moneda o otras tan buenas huertas en tan buen logar o mejor et todauía rredraruos et pararuos a / ${ }^{15}$ saluo et ffazer ssanas las dichas huertas, commo dicho es.

Et porque esto ssea firme, rrogué et rrequerí a Esteuan Ferrández, notario público de la çiu/dat de Palençia, que escriuesse esta carta et la signasse con su signo.

Ffecha en la çiudat de Palençia, veynte et ocho días de / enero, era de mille et quatroçientos et ocho años. Testigos que estauan presentes, llamados et rrogados espeçialmente para esto: Alffonso $/{ }^{18}$ Ferrández, tendero de pannos de color, ffijo de Alfón Pérez; et Martín Prieto, ortolano; et Domingo Ferrández de Medina de Río Seco, criado que fue del / dicho Pero Ferrández et otros vezinos de la dicha çiudat.

Et yo, Esteuan Ferrández, notario público sobredicho, de la dicha çiudat, fuy presente a to/do lo que dicho ess, con los dichos testigos. Et por ruego et requerimiento del dicho Pero Ferrández, vendedor, escriuí esta carta et fiz aquí este $/^{21}$ mío sig(signo)no en testimonio. (rúbrica) 
1370, enero, 23, jueves. Husillos - 1370, enero, 30, jueves. Husillos.

Testimonio notarial de Rui Martínez de Tapia, notario público de Palencia, del proceso de elección de Juan Fernández como prior de Santa María de Husillos: Fernando Rodriguez, procurador de Gutierre Gómez, abad de Husillos, por un poder otorgado por dicho abad en Valladolid, el 16 de enero de 1370, inserto, juntamente con el cabildo de dicha iglesia, teniendo en cuenta la autorización dada por dicho abad para la elección de nuevo prior por muerte del anterior, Juan Pérez de Aceves, el 17 de enero de 1370, inserto, nombran como nuevo prior a Juan Fernández, sacristán de Husillos, que recibe la dignidad sin renunciar a la sacristanía.

Asimismo da cuenta de que el abad Gutierre Gómez se da por enterado por escritura dada en Valladolid, el 27 de enero de 1370, inserta, de la elección del nuevo abad, y da un plazo de seis días para alegar, si es el caso, contra dicha elección.

B. AHDP, Ampudia y Abadía de Husillos, Pergaminos, carp. 212-6. Perg., 541 x 665 mm.; escr. precortesana; buena conservación. Inserto en traslado sacado en Palencia, a 7 de julio de 1371, de un testimonio notarial por el que Juan Fernández es elegido prior de Santa María de Husillos. Véase doc. núm. 166.

C. APA, $L P H$, ff. $80 \mathrm{r}-84 \mathrm{v}$.

D. BN, $m s .705$, ff. $170 \mathrm{v}-184 \mathrm{r}$.

El año por la era no coincide con el año del Señor, decantándonos por el segundo.

In Dei nomine, amen. Sepan quantos este / público instrumento vieren, como yueves, veynte tres días de enero, era de mille et quatroçientos et nueue annos. Estando en el cabiello de la eglesia coligial de Santa María de Fusiellos, del obispado de Palençia, estando ay presentes Ferrand Rodríguez, vicario et procurador, speçial para este fecho de xuso escripto, del onrrado varón et sabio don Gutierre Gómez, abbat de Fusiellos et en su nombre, Iohán Ferrández, sacristán, et Domingo Gonçález, chantoris, et Iohán Andrés, et Iohán / Martínez, 
et Iohán Gutiérrez, et Iohán Ferrández de Hamusco, et Domingo Ferrández de Castriello, et Diego Díaz, et Iohán Alfonso de Griiota, canónigos de la dicha eglesia de Fusiellos, que dexieron et conosçieron que fueron llamados de ante anoche et este día por campana tannida et estando ayuntados a cabiello en el logar acostumbrado, asy commo lo an de huso et de costumbre de se ayuntar a su cabiello, speçialmente para esto que se sigue. Et en presençia de mí, ${ }^{24}$ Ruy Martínez de Tapia, notario público de la çipdat de Palençia, et de los testigos de yuso escriptos. Et luego los dichos Ferrand Rodríguez et sacristán et cabiello fezieron leer ante sy, por mí, dicho notario, una carta escripta en papel et seellada en las espaldas con dos seellos de çera, de los quales paresçía seer, vno, del onrrado varón et sabio don Gutierre Gómez, abbat, et el otro del cabiello de la dicha eglesia de Fusiellos, el tenor / de la qual es este que se sigue:

(Sigue doc. núm. 151)

La qual carta leyda, luego el dicho Ferrand Rodríguez, canónigo et procurador, presentó et fizo leer por mí, dicho notario, una carta de procuraçión escripta en paper et signada de notario público, segund que por ella paresçía, fecha en esta guisa:

(Sigue doc. núm. 150)

La / qual carta de procuraçión leyda, luego los dichos Fernant Rodríguez, procurador, et el sacristán et el cabiello, dixieron que sabían et eran çiertos que Iohán Pérez de Haçeues, prior que fuera de la dicha eglesia, que era finado. Et porque podría pasar el término de la eleçión al mayor, que acordauan et acordaron de eslecir prior, porque la dicha eglesia non estodiese vacada sin prior et que asignara término ${ }^{36}$ para tractar et eslecí prior, como dicho es, para oy dicho día yueues et que fiçieran çitar et saber este fecho a todos los contenidos en la dicha carta çitatoria, para que veniesen conçertar el negoçio de la dicha esleçión et para eslecí prior de la dicha eglesia oy yueues. Et por ende, que querían proçeder a la dicha esleçión a seruiçio de Dios et de Santa María et a pro de la dicha eglesia et auiendo este dicha ora / celebrada, en la dicha eglesia, missa de Santi Spiritus, 
cantada. Et otrosy, auiendo cantando el igno de Beni Creator Spiritus et auiendo, otrosy, tratardo, entrosí en su cabiello, por qual de las tres formas que el derecho manda proçedería en este fecho; que sobre el dicho tratamiento que acordaran et escogieran de proçeder, en este fecho, por forma de Santi Spiritus et proçediendo por la dicha forma todos los dichos, Fernant Rodríguez, / vicario en nombre del dicho sennor abbat, et Iohán Fernández, sacristán, et Domingo González, chantoris, et Iohán Andrés, et Iohán Martínez, et Iohán Gutiérrez, et Iohán Ferrández de Hamusco, et Domingo Fernández de Castriello, et Diego Díaz, et Iohán Alfonso, canónigos, estando ayuntados a su cabiello, commo dicho es, acordadamiente en uno, dixieron que elexían et tomauan et exleexieron et tomaron por electo en prior de la dicha eglesia de ${ }^{39}$ Fusiellos et suyo, al dicho Iohán Fernández, sacristán, el qual dixieron que era omme bueno et complía para prior de la dicha eglesia, a seruiçio de Dios et de Santa María et a pro de la dicha eglesia. Et luego, el dicho Domingo González, chantoris, leuantó él et todos los otros dichos canónigos, cantaron "Te Deum laudamus" et fueronsé en proçesión al altar mayor de Sancta María, de la dicha eglesia, con el dicho electo. Et luego, / el dicho cabiello, stalaron, al dicho Iohán Fernández, electo, en una siella que es en el coro de la dicha eglesia, de parte del altar de Santa María. Et esto asy fecho, tornronsé a su cabiello todos en uno et dixieron, al dicho Iohán Fernández, electo, que touiese por bien de consentir en la dicha exleçión, que ellos del fixieron, agora, del dicho prioradgo et de la resçebir et auerla por firme. Et luego, / el dicho Iohán Fernández, electo, dixo que él que tenía en merçed al dicho cabiello la dicha exleçión que del fezieran en prior de la dicha eglesia et de consentir en la dicha exleçión et suyo et que consentía et consentió en la dicha exleçión que del fuera fecha del dicho prioradgo et que la auía et rresçebía et ouo et rresçebió por firme, con protestaçión do le fuese deuida de derecho o en otra qualquier ${ }^{42}$ manera, sin preiuizyo de ssí et de la dicha su sacristanía. Et do non que non entendía dexar nin dexaua la dicha sacristanía. Et desto todo, en commo pasó los dichos cabiello et electo, pedieron et requerieron a mí, el dicho Ruy Martínez, notario, que les diese sendos públicos instrumentos o más, los que menester ouiesen, signados con mío signo. Testigos rrogados speçialmiente llamados que fueron / presentes a todo esto: Iohán Garçía Treçetilla, et Alfonso Fernández de Estrada, et Martín Pérez, vezinos et moradores en el dicho logar de Fusiellos. 
Después desto, en la dicha eglesia de Santa María de Fusiellos, yueues, treynta días de el dicho mes de ennero, de la era de mille et quatroçientos et nueue annos, quod est anno domini, millesimo $\mathrm{CCC}^{\mathrm{o}} \mathrm{LXX}^{\mathrm{o}}$, a la ora de la prima, Iohán Martínez, canónigo de la dicha iglesia, en presençia de mí, Ruy Martínez de Tapia, notario / público de la çipdat de Palençia et de los testigos que aquí son escriptos, presentó et fizo leer por mí, dicho notario, publicamiente, alta et intelligible voz una carta del onrrado varón et sabio don Gutierre Gómez, abbat de Fusiellos, escripta en paper et seellada en las espaldas con un seello de çera colorada et firmada del nombre del dicho abbat, segund que por ella paresçía, fecha en esta guisa:

(Sigue doc. núm. 154)

La qual carta leyda, el dicho Iohán Martínez dixo, que le diesse, ende, un público instromento o más, los que menester ouiesse, signados con mío signo, et que rrogaua, a los ommes buenos que estauan presentes, que fuesen, ende, testigos, fecho ut supra. Testigos que estauan presentes: Domingo Gonçález, chantor, et Domingo Fernández de Castriello, canónigos, et Pero Fernández, rraçionero, et Martín Sánchez, medio rraçionero en la $/^{54}$ dicha eglesia et otros ommes buenos. Et yo, Ruy Martínez de Tapia, notario público de la çipdat de Palençia, fuy presente a todo esto que dicho es con los dichos testigos et cada uno dellos, et por rruego et rrequirimiento de los dichos cabiello et electo et Iohán Martínez, escriuí este instromento et va escripto en un pliego de paper et en este pedaço et mi nombre puesto en la yuntura del pliego et del pedazo, et fiz / aquí este mío signo en testimonio de uerdat.

1370, febrero, 5. Valladolid. 
Gutierre Gómez, abad de Santa María de Husillos, confirma la elección de Juan Fernández como prior de dicha iglesia.

B. AHDP, Ampudia y Abadía de Husillos, Pergaminos, carp. 212-6. Perg., 541 x 665 mm.; escr. precortesana; buena conservación. Inserto en traslado sacado en Palencia, a 7 de julio de 1371, de un testimonio notarial por el que Juan Fernández es elegido prior de Santa María de Husillos. Véase doc. núm. 166.

C. APA, $L P H$, ff. $80 \mathrm{r}-84 \mathrm{v}$.

D. BN, $m s .705$, ff. $170 \mathrm{v}-184 \mathrm{r}$.

Ego, Guterrius Gometii de Toleto, abbas Fusellensis, cum ad me pertinet et pertineat domni [...]ratus confirmatio compatiens dicta ecclesie Fusellensis ne quod abssit grauiores quod actenus utinam $/{ }^{60}$ irreparabilis ex de vtinam uacationem incurrat lessionis post deliberationem diligenter super hiis [cunc]tis per actis habitam presentatam michi electionem rricte et canonice per meum vicarium et procuratorem nomine meo et capituli dicte ecclesie celebratum de predicto Iohanne Fernandi, sacrista Fusellensis, viro utique prouido et discreto, ac sciente suficiente de legitimo matrimonio nacto et etate legitima constituto precedente conmitione / plenaria in ipsius electi presentia solum Deum procelis Zeus. Confirmo electionem factebam de eodem electo curam et administrationem ipsius capituli Fusellensis sibi, conmito firma spe fidutium que teneo quod eidem ecclesie Fusellensis dextera domini sibi absistente propitia per sue diligentie. Studium rreseruabitur ano Christi et aduerssis grata que actore domno suscipi et incrementa, mando eis capitulo dicte ecclesie, ne non omnibus clerigis / ac vasallis, dicti capituli Sancte Marie de Fusiellos et omnibus aliis, quibus interest uel interese potest ut dictum Iohannem Fernandi in suum priorem recipiant ne non cum iuribus et rredditibus et prouentibus et pertinentiis omnibus integre respondeant et ab aliis quod in eis fuerint faciant rresponderi. Et statim, dictus Iohannes Fernandi, prior, confirmatus consentiens et acceptans predictam confirmationem factam per dictum $/{ }^{63}$ dominum abbatem obedientiam et rreuerentiam, dicto domno abbati Fusellensis, et qui pro ipse fuerit ac de obseruando statuta et consuetudines et iura et honores ecclesie Fusellensis corporaliter prestitit iuramentum et statim, dictus domnus abbas per suum viretum in quam possesionem inuestium quibus sit actis superdicti abbas et prior petierunt 


\section{LA ABADÍA DE SANTA MARÍA DE HUSILLOS: ESTUDIO Y COLECCIÓN \\ DOCUMENTAL $(904-1608)$}

a me, notario publico infra scripto, de hiis fieri publicum instrumentum, seu publica / instrumenta uel plura quotiens fuerit oportunum.

Actis et a datis apud Vallem Oletti, dicte diocesis Palentine, quinta die, mensis februarii, anno Domini millesimo CCC septuagesimo. Presentibus vezinos et discretis viris, Iohanne Alfonssy de Toleto, canonico dicte ecclesie Fusellensis, et Micaeli Fernandi, portionario dicte ecclesie Fusellensis, et Fernando Roderici, filio Fernando Roderici, et Dominico Fernandi, clerico Sante / Marie de la Antigua, et Alfonso Garsie, sutori, et Iohanne Fernandi et Gundisaluo Petri de Villa Nubla, vicinis dicte ville Vallis Oletti, et pluribus aliis clericis et laicis, testibus ad premissa vocatis specialiter et rogatis.

1370, enero, 27. Valladolid - 1370, febrero, 5. Valladolid

Testimonio notarial dado por Juan Fernández de Tablada, notario público de Palencia, y otorgado por Gutierre Gómez, abad de Husillos y canciller de la casa de la reina, por el que Juan Fernández, sin renunciar a la sacristanía, es elegido prior de Santa María de Husillos, tras la muerte del anterior, Juan Pérez de Aceves, en el mes de enero de 1370.

B. AHDP, Ampudia y Abadía de Husillos, Pergaminos, carp. 212-6. Perg. 541 x 665 mm.; escr. precortesana; buena conservación. Inserto en traslado sacado en Palencia, a 7 de julio de 1371, de un testimonio notarial por el que Juan Fernández es elegido prior de Santa María de Husillos. Véase doc. núm. 166.

C. APA, $L P H$, ff. $80 \mathrm{r}-84 \mathrm{v}$.

D. BN, $m s .705$, ff. $170 \mathrm{v}-184 \mathrm{r}$.

- 1370, enero, 27. Valladolid.

Juan Martínez, procurador del cabildo de Santa María de Husillos por poder otorgado en Husillos, el 23 de enero de 1370, inserto, y canónigo de dicha iglesia, presenta a Gutierre Gómez, abad de Husillos, estante en Valladolid, la 
escritura de elección de Juan Fernández como prior, otorgada en Husillos, el 23 de enero de 1370, inserta.

- 1370, febrero, 4. Martes.

El prior y sacristán de Husillos, Juan Fernández, se presenta ante el abad para darle a conocer su proceso de elección como prior, presentando un testimonio notarial de Rui Martínez de Tapia, notario público de Palencia, (1370, enero, 23. Jueves. Husillos. / 1370, enero, 30.Jueves. Husillos), inserto, de elección de Juan Fernández como prior de Santa María de Husillos. Asimismo da cuenta de una carta del abad Gutierre Gómez, dada el 27 de enero de 1370, inserta, por la que se da por enterado de la elección de Juan Fernández como prior de Husillos, y da un plazo de seis días para alegar, si es el caso, contra dicha elección

- 1370, febrero, 5. Valladolid.

Fernando Rodríguez, prior electo por el cabildo de Husillos, suplica al abad la confirmación de su dignidad, respondiendo dicho abad con escritura de confirmación dada la misma fecha, inserta.

In Dei nomine, amen. Nouerint vniuersi presentes publici instrumenti sententie inspecturi quod anno Domini millesimo trecentissimo septuagesimo, vigesima septima die, mensis ianuarii, / coram rreuerendo patre et domino domno Guterrio Gomeçii de Toledo, abbate ecclesie colligiatis Sancte Marie de Fusiellos, Palentine diocesis, in presentia mei, notari publici et testium subscriptorum ad hoc specialiter vocatorum et rrogatorum, comparuit discretus vir Iohannes Martini, canonicus eiusdem ecclesie Fusellensis, nomine suo ac procuractionis nomine capituli dicte ecclesie Fusellensis, prout aparebat per quodam publicum instrumentum procuractionis signa/tum manu Roderici Martini de Tapia, notarii publici civitatis Palentine, cuius tenor dignosçitur esse talis:

(Sigue doc. núm. 152)

Iohannes Martini, procurador, presentauit coram dicto domno abbatem, detratum electionis celebrate in dicta ecclesia Fusellensis, de venerabili, discreto viro, 
domno Iohanne Fernandi, sacrista in eadem ecclesia, electo in forma publica, sigillo dicti / capituli pendenti rroboratum cuius tenor dignoscitur ese talis:

(Sigue doc. núm. 153)

Premissis infra me, dictum notarium, per literas dictus procurator petiuit procuratore nomine quo siquis ut electionem de prefacto Iohanne Fernandi per uiam inspirationis canonice celebratam confirmaret vt abbas Fusellensis ad quem confirmatio dicte electionis pertinebat eidem electo curam instrutionem ipsius capituli Ffusellensis comitendo supradictus uerbo dominus abbas, / rrespondit quod ipse videbat illud instrumentum et intendebat in dicto negocio procedere prout ordo iuris rrequireret et preciperet fieri per suas horas publice vocationem in ecclesia Fusellensis in qua dicta election exiit celebrata et competentem perentorium terminum in eisdem hiis asignauit vt siquis predicte electionis electo uel electoribus se opponere vellet coram ipso infra ipsum terminum seu in termino compareret.

Et dictus procuractor petiit / a me, notario publico infra scripto, de hiis fieri publicum instrumentum seu publica instructio presentibus: Iohanne Alfonsi, canonico eiusdem ecclesie, et Didaco Gometii de Santoyo et Gundisaluo Gometii, notario, alupnis dicti dominus abatis, testibus ad premissa vocatis specialiter et rogatis

Post hec vero die, martis, quarta die mensis februarii, anno supra scripto, coram reuerendo patre et domino abbate supradicto et in presentia mei, notarii et testium $p^{21}$ infra scriptorum, comparuit discretus vir Iohannes Fernandi, sacrista ac electus in priorem ecclesie colligiatis ecclesie Sancte Marie Fusellensis, et presentauit coram eo vestrum publicum instrumentum manu publica scriptum in quo continebatur procesum electionis celebrate in dicta ecclesia de supradicto Iohanne Fernandi, electo et consensus dicti electi et quamdam lecentiam dicti domini abbatis, cuius tenor instrumenti dignoscitur ese talis:

(Sigue doc. núm. 156) 
Quo per me, dictum notarium lecto, dictus Iohannes Fernandi, electus, instanter suplicando petit a dicto domno abbate quod ad confirmationem dicte electionis procederet et cum confirmaret ut abbas Fusellensis ad quem confirmation dicte eletionis pertinebat et eidem omnia et administrationem ipsius capituli comitendo. Supradictus uero domnus abbas, respondit die quinta, / mensis februarii, se rrespunsurum dicte petitionis confirmationis pro ut ius et iustitia sibi dictarent et dictus Iohannes Fernandi petiit a me, notario publico infra escripto, de hiis fieri publicum instrumentum seu publico instrumento presentibus dictus Iohanne Alfonsi, canonico eiusdem ecclesie, et Gundisaluo Gomecii, notario, et Didaco Fernandi, filio Fernandi Iohannes de Çigales, testibus ad premisa vocatis speçialiter rogatis. Quinta uero $/^{57}$ die mensis februarii, eiusdem anni in quo se rresponsurum predixerat, dictus Iohannes Fernandi, electus, instater suplicando, pectit a dicto domno abbate, pro ad confirmationem dicte electionis procederet.

Et ipse supradictus abbas rrespondit coram me, dicto notario, et aliis personis ecclegiasticis et secularibus asistentibus quod tunc ipse formam iuris in dicta confirmatione electionis obseruaret pro ut per supradicta instrumenti publice / aparebat et videntis quod contra personas eligentium uel electi aut formam electionis nichil fuerint, apponitur ac processu dicte electionis et decrecto diligenter examinatis ad aeque inter personas eorum ingerenda fuerant ex oficio suo duxerat procedendum et facta diligendi inquisitione cum nichil inuenisse ese oppositum neque probatum contra personas dictarum elegentium uel electi propter quod debeat dicta electio / vitiari quod ut iudici constabat ei dictam electionem fuis erite et canonice celebratam dictus domnus abbas pronunciruit et produxit coram me, dicto notario, quodam cedulam inscriptis cuius tenor sequi in hec uerba:

(Sigue doc. núm. 157)

Et ego, Iohannes Fernandi de Tabulata, notarius publicus ciuitatis Palentine, una cum dictis testibus omnibus et singulis supradictis, presens inter sui. Et ad rrequesitione tam supradicti $/{ }^{66}$ domni Guterrii Gometii, abatis, quam dicti Iohannes Fernandi, prioris, hoc instrumentum publicum scripssi et signum meum apposui in tetimonium premissorum. G[uterrio], abbas Fusellensis. 
1370, febrero, 24. Torrelobatón.

Testamento de Juan Núñez de Ferrera, vecino de San Esteban de Gormaz, hijo de Díaz Gómez y nieto de Gómez de Monzón, fundador este último de la capilla de Santiago en Santa María de Husillos. Pide ser enterrado en la capilla que edificó su abuelo en Santa María de Husillos, y entre otras mandas, dota una capellanía perpetua cantada en dicha capilla, con una huerta que llaman de Villaverde, en término de Monzón; la heredad que posee en el arroyo de Frades, en dicho término de Monzón, y una tierra denominada de La Huelga. Para la cera de dicha capilla deja una tierra en Vega.

En caso de que no sea aceptado su enterramiento en Santa María de Husillos, pide ser enterrado en el monasterio de Santa Cruz de Monzón.

B. AHDP, Ampudia y Abadía de Husillos, Pergaminos, carp. 209-22. Perg., 697 x 513 mm.; escr. precortesana; regular conservación. Inserto en testimonio notarial escrito entre el 13 de abril de 1370 y el 18 de junio de dicho año. Véase doc. núm. 162.

C. AHDP, Ampudia y Abadía de Husillos, Pergaminos, carp. 209-23. Perg., 853 x 335 mm., escr. precortesana; buena conservación, pues es un pergamino de extraordinario grosor y dureza. Inserto en testimonio notarial escrito entre el 13 de abril de 1370 y el 18 de junio de dicho año.

D. APA, $L P H$, ff. $85 \mathrm{r}-87 \mathrm{v}$. Traslado de $C$.

E. BN, ms. 705, ff. 185v-193v.

En el nombre de Dios, Padre et Fijo et Espiritu et Santo, que es uerdadero et Santa Trenidad, que ffizo el çielo et la tierra et tyene todo el mundo et / poder et es uerdadero Dios. Sepan quantos esta carta deste testamento vieren, commo yo, Iohán Núñez de Ferrera, fijo de Dya Gómez, estando en mi ssano ssesso et entendemiento et en mi ssana memorya, qual Dios me quiso dar, otorgo et connosco que ffago et ordeno myo / çierto testamento valedero, en esta manera: mando el my cuerpo a la tierra et la my alma a Dios uerdadero que la fizo et a la 
[virgen] gloriosa santa María, ssu madre, que la quiera perdonar et a sseñor san Miguel, ángel, que la lieue a buen logar. Mando a la orden de $/ 6$ Santa Olalla, Barzylona, XXX maravedís. Et mando a la Trenidat treynta maravedís. Et mando a la Cruzada treynta maravedís. Et mando a la cofradría de San Iohán de aquí, de Torre, ssy aquí ffynare, porque me ffagan honrra, XX maravedís.

Mando a Santa María del Rybero, de Sant Esteuan / de Gormaz, et al cabiello della, treyta maravedís. Et mando a Gonçalo Alfonso de Villa Franca, ffijo de Bernabé Martínez, por sseruiçio que me ffizo otro tiempo que tenía del carga et por el sserviçio et affán que me ha ffecho en mi dolençia, trezientos maravedís, quel den luego quel mi / cuerpo ffuese enterrado. Mándole más, el mi rroçín castaño que yo tengo aquí, en Torre, ensellado et enffrenado, que ssy yo ffynase, que lo tome et lo aya libremientre por ssuyo. Et que vaya, con el mío cuerpo, a do lo mando enterrar. Et mando a Sancho Ruyz, mi criado, $\rho^{9}$ dozientos maravedís. Et que le non demanden nin tomen quenta alguna, de ningunas cosas que por mi procuro o aministro en qualquier manera, que yo le do, de todo, por libre et por quito. Et mando a Diagillo, mi criado, dozientos maravedís. Et mando a su hermana dozientos maravedís. / Et mando a Yssabel, mi cryada, toda la mi heredat, casas et viñas et tierras et huertas, prados et pastos et toda la otra heredat que yo he en Váscones et en Pyquera et en sus términos, para que sseya todo ssuyo, libremient.

Mando que el mi cuerpo que sseya leua/do a la eglesia de Santa María de Fussiellos, sseya enterrado en la capiella do está enterrado don Gómez, mi auuelo. Et que ssea puesto çerca del, en logar non más alto. Et el mi cuerpo que sseya metido en una ataud copierta de paño de yaple, gu $/{ }^{12}$ arnida de clauos et çintas doradas. Et que sseya comprado çera a basto, de lo que los mis mansesores entendiesen que cumple. Et que den de comer a todos los que ffueren a ber mi cuerpo et sse y llegaren ffasta que ssea enterrado.

Mando a Iohán Fernández, escriuano de Torre / de Lobatón, por ssu ssalario de ssu ofiçio, deste mi testamento, et porque rruegue a Dios por mi alma, dozientos maravedís. Et para que se cumpla et pague luego mi mortuorio et myo enterramento et mi honrra et paguen luego, aquí yo mando, al dicho Gonçalo / Alfonso et Iohán Ferrández, escriuano, et a las dichas órdenes, mando que se venda luego la mi mula murziella que yo tengo aquí, en Torre, ensellada et 


\section{LA ABADÍA DE SANTA MARÍA DE HUSILLOS: ESTUDIO Y COLECCIÓN \\ DOCUMENTAL $(904-1608)$}

enffrenada. Et que sea entregada a don Iohán Pérez Bastardo, arçediano de Campos en la eglesia de Palençia, myo manse $/{ }^{15}$ sor, porque la él uenda, porque se cumpla della, todo esto que yo mando. Et lo demás, ssy rremanesçiere, que sea para pagar las otras mandas que yo mando. Et establesco et dexo et ordeno vna capellanía perpetua que sea cantada por ssiempre jamás, en la / dicha capiella do me mando enterrar, por mi ánima et por las ánimas daquellos onde yo vengo. Et doy et dexo para esta capilla cantar perpetuamiente, la mi huerta que yo he en Monçón, que llaman de Villa Verde, çerca del Calçe, con todos sus / entradas et ssalidas et con todos sus derechos et pertenençias. Et do et dexo más para esta dicha capella, toda la mi heredat que yo he al arroyo de Frades, en término de Monçón, con la mi tierra de la Huelga de Villa Anadino, que es y çerca de la huerta. $/^{18}$ Et do más. Et dexo para çera de cada año que arda en la dicha capiella, la mi terra de la Vega. Et pido por mercet, al abat et al cabiello de la dicha eglesia de Santa María de Fussiellos, que rresçiba estos bienes et otorguen et fagan dezir, para en ssiempre, / esta dicha capellanía, et rresçiba el mi cuerpo en la dicha capiella. Et esta dicha capellanía dexo en carga et en vissitaçión, del dicho abat et arçediano de Campos, que agora sson o ffueren por tiempo, que ffagan cantar bien et coplidamient la dicha / capellanía. Et pongan, ssobrello, aquel rremedio que de derecho deue sser puesto. Ca yo les do et otorgo, amos a dos et a cada uno dellos, todo myo poder conplido, para ello. Otrosy, mando et quiero que estas dichas posesiones, que yo do et dexo $/^{21}$ para la dicha capellanía et çera, nin alguna dellas, que nunca pueda ser uendidas ni empeñadas nin agenadas nin las cossietan vender nin empeñar, los dichos abat et arçidiano, mas que ssiempre sean labradas et aministradas en manera que se non pier/dan ni destruyan, porque de los frutos et rrentas, dellas, sseya cantada et proueyda et mantenida commo deue la dicha capellanía. Et ssy por auentura el dicho abat et cabillio non quisieren resçebir el mi cuerpo en la dicha capilla, nin cantar nin otorgar / esta dicha capellanía, nin rresçibir para ello estas dichas possessiones et bienes, mando que enterren el mi cuerpo en Santa Cruz de Monçón, en logar conuenient, et que el dicho arçediano que dote y la dicha capellanía perpetua con todas las possesiones suso/ ${ }^{24}$ declaradas et con las condeçiones que dichas son, que yo le dexo et otorgo todo myo poder coplido para ello. Et esta capellanía, sy asy fuese dotada, déxola en carga et aminstraçión del arçediano de Campos et de la que fuese, por tiempo. 
La mi / heredat que yo he en Villa Aluín et en Villa Çopeque et Valle Luengo, vale muchos dineros. Et rruego et pido mercet, al dicho Iohán Pérez, arçediano, que lo vea et ponga et dote, dello, vna capellanía perpetua, que se cante por mi alma et de aquellos / onde yo vengo, en Santa María de Villa Aluín et segund su conçiençia, dé et dexe, para la dicha capellanía, tantos et aquellos bienes heredades que de los frutos dellos se pueda cantar et sseya proueyda commo deue la dicha capellanía. Et las otras $/^{27}$ heredades, terras et viñas que ffincase demás, que sseya para rreparar la dicha eglesia de Villa Alvín, porque el capellán que fuese y puesto pueda dezir missa. Et otrosy, que sseya para çera, para cantar la dicha capellanía. Et para esto, que lo ordene / et dote el dicho arçediano, en manera que mi volutat sea complida, yo le do et otorgo et dexo libre aminstraçión et decreto et poderío con toda la ssoldenidat, mejor que puedo et deuo en tal caso. Et un solar que yo he en Sant Testevan de / Gormaz, cabe Santa María del Ribero, mandógelo a la dicha eglesia de Santa María del Ribero.

Mando por mi alma mille maravedís, que den luego, porque cante dellos mill misas, las quinietas do el mi cuerpo fuese enterrado et las otras quinientas $\beta^{30}$ misas, que las canten en Santa María del Ribero et en Sant Miguel de Santa Testevan de Gormaz. Et para esto, mando que vendan luego la mi açeña que está cabe la puent de San Testevan de Gormaz.

Et otrossy, el pan que me deue la / orden de Moral, que lo presté, ssepan en uerdat quanto me deuen et denlo a mis manssesores et mis mansesores cabienlo et denlo luego por mi alma, ally do etendiesen que es más sseruiçio de Dios.

Et para todo esto fazer et complir et pagar / et fazerlo pagar et complir, fago et ordeno et establesco, por myo mansesor et testamentario, al dicho don Iohán Pérez, arçidiano de Campos. Et pídole por merçet que quiera tomar esta carga. Et porque él, por ssy, todo non lo podrya ${ }^{\beta 3}$ auer nin ver nin cumplir, dole poder complido, que tome conssigo et escoja otro omme buenno qual el quissiese et viese que cumple para ello, para que lo aiude a fazer et complir et husar desto que yo mando. Et al que él tomase et escogiese, yo le do et otorgo / poderío coplido para ello, assy commo ssí le yo tomase et espaçifficase. Et porque todos bienes et heredades que yo he allende Duero, non podrya auer nin saber, el dicho arçediano ni el que él possiese ni escogiese et para esto dole / et déxole por su compañero mansesor a Ferrand Sánchez de Peña Aranda, fijo de Garçía Ferrández. Et rruego 
al dicho Ferrand Sánchez, que por vezes que le darán por mis açeñas, que escoja el derecho et lo myo non lo dexe ni lo ageno non lo tome. ${ }^{\beta 6}$ Et otrossy, lo que allá es de fazer et ver et complir, que lo ffaga et cumpla. Et mando al dicho arçidiano por ssu afán et trabajo que en esto ha de tomar, mill maravedís, et mando al omme bueno que él tomase et escogiese conssigo, quinientos maravedís. Et mando al dicho Ferrand / Sánchez, por ssu trabajo, otros quinientos maravedís. Et a estos dichos mis testamentarios et a cada uno dellos, yo los apodero en todos mis bienes, assy muebles commo rrayzes, en qualesquier logares que los yo aya et en todas las cartas de deudas et compras et rrentas / et enpréstidos que yo tengo et a mí pertenesçen. Et dolos poder complido, que ussen dellos et cobren todo lo que a mí deuen et a mí pertenesçe en qualquier manera et para que entren et tomen et vendan todos mis bienes, muebles et rrayzes, para pagar et complir todo esto ${ }^{39}$ que yo mando. Et rreuoco todos los otros testamento o testamentos, codeçillo o codeçillos, que yo, fasta oy, aya ffechos en qualquier manera et mando que non valan, ssaluo éste, que mando que vala por mi testamento o codeçillo o mi postrymera vo/luntad.

Et porque esto sseya firme et non venga en duda, rruego al dicho Iohán Ferrández, escriuano público de Torre de Lobatón, que ffeziese este testamento, ca yo le otorgo todo commo et segund que en él dize et lo ssignase con ssu ssigno. Testigos rrogados que a esto / fueron presentes: Diego Sánchez, clérigo de San Pero, et Iohán Rodriguez, fijo de Ruy Diez, et Antón Ferrández Ferrero, et Iohán Rodríguez, fijo de Martín Ferrández, et Per Alfonso, ffijo de Iohán Alfonso, et Alfonso Ferrández, fijo de Pero Ferrández, vezinos de Torre de Lobatón, et Gonçalo Alfonso et Sancho Ruyz, criados del $/^{42}$ dicho Iohán Núñez.

Fecho et otorgado fue este testamento en el dicho logar de Torre, veynt quatro días de febrero, era de mille et quatroçientos et ocho annos. Et yo, Iohán Ferrández, escriuano público sobredicho, a esto que dicho es, fuy present con los dichos testigos. Et a rruego et otorgamiento del / dicho Iohán Núñez, fize este testamento et fize aqui este myo ssigno en testimonio de uerdat. 
1370, junio, 8.

Juan Pérez de Aceves, prior de Santa María de Husillos, nombra como procurador suyo a Martín Gil, canónigo de dicha iglesia.

B. AHDP, Ampudia y Abadía de Husillos, Pergaminos, carp. 208-13. Perg., 260 x 382 mm.; escr. precortesana; regular conservación con tres roturas de regular tamaño y otras más pequeñas que impiden en parte la lectura. Inserto en carta de arrendamiento, dada en Husillos, a 15 de junio de 1370. Véase doc. núm. 161.

C. APA, $L P H$, f. $88 \mathrm{r}-\mathrm{v}$.

D. BN, ms. 705 , ff. 193v-196v.

Sepan quantos esta carta vieren, commo yo, Iohán Pérez < de Haçeues>, prior de Fusiellos, / por esta carta fago juez et vicario, en mi nombre, a Martín Gil, canónigo en la dicha eglesia y en el dicho lugar de Fusiellos y en los otros que pertenesçen al cabildo de la dicha eglesia. Et dol poder / que pueda çitar, ante sy, a todos et a ca uno del dicho lugar de Fusiellos et de los otros que pertenesçen a mí en juridiçión. Et oyr los pleitos et liblarlos et dar en ellos sentençias, et las sentençias que diere leuar $/{ }^{6}$ las a esecuçión, contriniedo a los rrebeldes por toda sentençia de esta eglesia, commo deuiere de derecho. Et otrosy, le do poder que pueda llamar a cabildo et estar en él quando menester ffuere et dar benefiçio o / benefiçios, asy commo yo mesmo faría sy presente ffuese. Et rreuoco todos los otros vicarios que yo fize ffasta el día de oy. Et mando que non usen de la dicha vicaría de aquí adelante por mí, / saluo el dicho Martín Gil, que yo agora pongo por mí. Et en testimonio de esto, dí él esta mi carta, abierta et seellada con mi sello, en que escriuí mío nombre.

Fecha ocho días del mes de junnio, era de mille $/^{9}$ et quatroçientos et ocho años. 
El prior y el cabildo de Santa María de Husillos, con licencia del abad Gutierre Gómez, arriendan a Fernán Martínez de Cantoral las aldeas de Santillán de la Cuesta y Fuente Quintana, en precio de un carnero y una cántara de vino anuales, a entregar el día de Santa María de agosto. Si en el plazo de dos años no puebla el lugar de Santillán, que lo deberá comenzar con cinco labradores y cinco pares de bueyes, la renta se invalidará. Inserta carta por la que el prior Juan Pérez de Aceves hace juez y vicario suyo al canónigo Martín Gil (1370, junio, 8).

A. AHDP, Ampudia y Abadía de Husillos, Pergaminos, carp. 208-13. Perg., 260 x 382 mm.; escr. precortesana; regular conservación con tres roturas de regular tamaño y otras más pequeñas que impiden en parte la lectura.

B. APA, $L P H$, f. 88 r-v.

C. BN, ms. 705, ff. 193v-196v.

Sepan quantos esta carta vieren, commo nos, el prior et el cabildo de la eglesia de Santa María de Fusiellos, estando ayuntados a cabildo a campana tañida, segunt que lo auemos de uso et de costumbre / de nos ayuntar, et con liçencia et autoridat de don Gutierre Gómez, abbat de Fusiellos, nuestro señor, que nos dio estando presente, conuusco, en cabildo. Et yo, el dicho Gutierre Gómez, abbat, estando / presente, vos do et vos otorgo liçençia et abtoridat para esto. Et estando presente conuusco, Martín Gil, canónigo en la dicha eglesia, tenient lugar de prior por Iohán Pérez de Haçeues, prior de Fusiellos, $\beta$ segunt se contiene en una carta seellada con su seello, del dicho prior puesto su nombre, el tenor de la qual es este que se sigue:

(Sigue doc. núm. 160)

Iohanis Petri, prior Fusillensis, otorgamos et conosçemos que arrendamos a vos, Ferrant Martínez de Cantoral, para vos, para vestros fijos legítimos naturales, la nuestra aldea de San Yllán et de Fuent / Quinana, todo lo temporal, tierras et viñas et términos et prados et pastos et rríos et ffuentes et infurçiones et calopnias et omeçiellos et sernas, para toda vestra vida et de vestros fijos, <legítimos> 
naturales, et para vestros nietos, legí/timos naturales, veniendo los vestros nietos después de vestros días et de vestros fijos, a fazer contrabto nueuo, con el cabildo, sobre la dicha rrenta. Et que ge la den para ellos, en su vida, con las condiçiones que la teníades vos, $/^{12}$ el dicho Ferrant Martínez, su auuelo. Et que dedes vos, el dicho Ferrant Martínez, en rrenta cada año, al dicho cabildo, un carnero et vna cántara de vinno el día de santa María de agosto, mediado cada año, vos et / los vestros fijos et los vestros netos, segunt dicho es et en esta carta se contiene. Et otrosy, que pobledes el dicho lugar de San Yllán, desde el día de sant Iohán de junnio, primero que uiene, fasta dos años primeros / seguientes. Et sy non poblardes el dicho lugar en el dicho tiempo de los dichos dos años, que la rrenta que sea ninguna et non vala. Et que desde el día que vos, el dicho Ferrant Martínez, poblardes el dicho lugar, con çinco $/{ }^{15}$ labradores et con çinco pares de bues, que el dicho cabildo, que vos dé et dexe, desembarg[ada]mient, toda la eredat et viñas et términos et todas las otras cosas sobredichas, saluo la martiniega et los diezmos / et las primecias et las visitaçiones de las eglesias, que rretenemos en nos para el dicho c[abil]do. Et todas las mejorías que vos, el dicho Ferrant Martínez, ffezierdes en el dicho lugar, que sean vestras et de vestros ere[deros, defendi]/endo et pagando los que de vos lo eredaren et deçendieren, todo fuero et derecho que usa[ron] pagar et fazer, todos los moradores labradores que en el dicho lugar moraron. Et saluamos lo que ffezierdes en la çerca de [la ffortaleça] ${ }^{18}$ et en la çerca del dicho lugar o otra ffortaleça alguna, se y feziere, que sea et finque para el dicho cabildo. Et para lo cumplir et atener et dar las dichas eredades et términos, segunt dicho es et en esta c[arta se con]/tienne, obligamos los bienes de la mesa del cabildo. Et yo, el dicho Ferrant Martínez, otorgo et conosco que arriendo et tomo a rrenta de vos, los dichos prior et cabildo de la dicha eglesia de Santa María de Fusi[ellos, la] / dicha vestra aldea de Santillán et de Fuent Quinana, por la dicha rrenta et por toda mi uida et de mis fijos et nietos, segunt dicho es et con las condiçiones que dichas son et en esta carta se contiene. Et pongo con uusco, los $/^{21}$ dichos prior et cabildo, de poblar el dicho lugar de Santillán, en el dicho tiempo de los dichos dos años. Et demandar et ordenar en mi testamento, Dios dándome lugar de lo ffazer, que al tiempo pasado, de los mis nietos, / que vos finque libre et quito, el vestro lugar de Santillán et de Fuent Quinana. Et para lo cumplir et atener, obligo todos mis bienes, muebles et rrayzes, 
quantos oy día he et auré de aquí adelante. Et por más cumplimiento desto, /para vos poblar el dicho lugar en el dicho tiempo, lo más ayna que podiere et voslo guardar et deffender et pagar la dicha rrenta cada año et la mandar pagar et mandar dexar el dicho lugar, segunt dicho es et en esta $/^{24}$ carta se contiene, juro verdat a Dios et a santa María et a estos santos avangelios que tengo corporalmient con mi mano, de cumplir et atener et guardar et mantener todo lo que sobredicho es et en esta carta se contiene, si lo yo feziere / que Dios me ayude et si non que Dios me lo demande, en este mundo, al cuerpo et en el otro, al alma, do más he de durar, amén.

Et porque esto sea firme et non venga en duda, nos, amas las partes, rrogamos et / mandamos a Ferrant Áluarez, notario público de la cibdat de Palençia, que feziese dos cartas en un tenor para cada una de las partes.

La suya, que ffue ffecha en el cabildo de la eglesia de Santa María de Fusiellos, quinze días de ${ }^{27}$ junnio, era de mille et quatroçientos et ocho años. Testigos que estauan presentes, para esto espeçialmient rogados: Sancho Ferrández et Ruy Ferrández, su hermano, fijos de Lorenço Ferrández de Cantoral, et Gómez, fijo de Ferrant Pérez de Vlas, / et Pero Ferrández, compañero en la dicha eglesia de Fusiellos, et Gunzallo Gómez, criado del dicho abbat.

Et yo, Ferrant Áluarez, notario público sobredicho de la çipdat de Palençia, fuy presente a todo lo que sobredicho / es con los dichos testigos, et rresçibí las dichas obligaçiones del dicho cabiello et del dicho Ferrant Martínez et la jura del dicho Ferrant Martínez. Et a su rruego et mandado et fiz escriuir $\beta^{\beta 0}$ dos cartas, amas en un tenor, para cada una de las partes la suya. Et está escrito entrelinado en un logar a los quatro rrenglones, a do dize "de Haçeues", et en otro logar / a los onze rrenglones, a do dize "legítimo", et non enpezca. Et fiz aquí este mío sig(signo)no en testimonio de uerdat. Ferrant Áluarez. (rúbrica)

1370, abril, 13, sábado. Palencia - 1370, junio, 18, martes. Palencia. 
Testimonio notarial de Fernando Álvarez, notario público de Palencia, de varios actos:

- 1370, abril, 13. Sábado. Palencia

Juan Pérez Bastardo, arcediano de Campos, albacea del testamento de Juan Núñez de Ferrera, da su poder para actuar en dicha condición a Domingo González, chantre de Santa María de Husillos.

- 1370, junio, 15. Sábado. Husillos.

Domingo González informa a Gutierre Gómez, abad, Martín Gil, procurador de Juan Pérez, prior, y a otros canónigos, de una manda del testamento de Juan Núñez de Ferrera, por la que otorga a Santa María de Husillos una huerta en término de Monzón, a condición de que cantasen por su alma veinticuatro aniversarios al año.

Acto seguido, Juan Pérez, canónigo y mayordomo del cabildo, toma posesión de dicha huerta.

- 1370, junio, 18. Martes. Palencia

Traslado sacado por el dicho notario Fernando Álvarez, a petición de Juan Pérez Bastardo, arcediano de Campos, del testamento de Juan Núñez de Ferrera (1370, febrero, 24. Torrelobatón).

A. AHDP, Ampudia y Abadía de Husillos, Pergaminos, carp. 209-22. Perg., 697 x 513 mm.; escr. precortesana; regular conservación.

B. AHDP, Ampudia y Abadía de Husillos, Pergaminos, carp. 209-23. Perg., 853 x 335 mm.; escr. precortesana; buena conservación pues es un pergamino de extraordinario grosor y dureza.

$C$. APA, $L P H$, ff. $85 \mathrm{r}-87 \mathrm{v}$. Traslado de $B$

D. AGS, Patronato eclesiástico, Inconexos, leg.159, ff. 84r-90v. Papel; escr. procesal; buena conservación.

E. BN, $m s .705$, ff. $185 \mathrm{v}-193 \mathrm{v}$.

En la eglesia cathedral de Sant Antolyn de Palençia, delante la puerta del coro, entre el coro et el altar mayor de la dicha eglesia, sábado, treze días de abryl, era de mille et quatroçientos et ocho años, en presençia de mí, Ferrand Áluarez, 
notario públyco de la çibdat / de Palençia et de los testigos de yuso escriptos, paresçió don Iohán Pérez Bastardo, arçediano de Campos en la dicha eglesia, et dixo que Iohán Núñez de Ferera, vezyno que ffue de Sant Esteuan de Gormaz, que al tiempo que ffynara, que le ffezyera et ffizo ssu manssesor para que complyese ssus mandas et pagase / su testamento et que le diera poder, en el dicho su testamento, que ssy él non podiesse complyr el dicho testamento, que podiese tomar vn omme buenno para que vssasse del dicho testamento, al qual daua y dyo, el dicho Iohán Núnnez, ssu poder complido en el dicho ssu testamento, para que complese $\beta^{3}$ et pagase todo lo que en el sse contenya, ssegún que por el dicho testamento paresçía, el tenor del qual es este que sse sigue:

(Sigue doc. núm. 159)

Et luego, el dicho don Iohán Pérez, arçidiano de Campos, dixo que, por quanto él era ocupado de otros negoçios, que él assy como mansesor del dicho Iohán Núñez et por el poder que él / auía por el dicho testamento, para ello, que tomaua et tomó, por omme bueno, para que compliese et pagase el dicho testamento, del [dicho Iohán Núñez, et fezie]se todo segund que en el dicho testamento sse contenía, a Domingo Gonçález, chantre de Fussiellos, al qual dixo que daua et dyo todo ssu po ${ }^{45}$ der para ello, segund que mejor et más complidamient se contiene en el dicho testamento. Et de commo lo dezía et daua et dyo, [el dicho poderío; dixo que rrequería et] rrogaua a mí, dicho notario, que lo diese todo signado con mío signo, al dicho Domingo Gonçález, chantre, encorporado en el dicho testa/mento. Testigos que estauan presentes: don Remón, arçediano de Çerrato en la eglesia de Palençia, et Ferrand Núñez, abat de Hérmidas, [...] dicha eglesia.

Et yo, Ferrand Áluarez, notario público de la çibdat de Palençia, sobredicho, fuy present a todo lo que sobredicho / es con los dichos testigos, et a pedemiento et rrequeremiento del dicho don Iohán Pérez, arçidiano de Campos, mansesor [del ...] este testimonio encorporado en el testamento del dicho Iohán Núnez.

Et después desto, sábado, quinze días $/^{48}$ del mes de junio, era sobredicha, en el cabellio de la eglesia de Santa María de Fussiellos, en presençia de mí, Ferrand Áluarez, notario público sobredicho, estando y present don Gutierre Gómez, abat 
de Fusiellos, et Martín Gil, canónigos tenient logar de prior, por Iohán Pérez, / prior de Fussiellos, segund mostró por una carta suya et otros canónigos et benefeçiados et en la dicha eglesia de Fussiellos et estando aiuntados a cabello a campana tannida, segund que lo an de uso et de costumbre de se aiuntar, Domingo Gonçález, chantre e la dicha eglesia, / dixo et rrequeryó, a los dichos prior et cabellio, que bien ssabían en commo Iohán Núñez de Ferrera, al tiempo de su fynamiento, sse mandara enterrar en la dicha eglesia et estaua y enterrado. Et que mandó, al dicho cabelio, vna huerta que él auía en término de Monçón et toda $/^{51}$ la otra heredat que el auía en Monçón et en ssus términos, para que el dicho cabelio cantase et feziese cantar en la dicha eglessia una capellanía, segund que él mandara en ssu testamento. Et pedía al dicho abat que los mandase yr tomar la posessión dello et el poder / que auía de don Iohán Pérez Bastardo, arçediano de Campos, su mansesor, que le dyo por poderío del dicho testamento, que los yría poner en possesión dello, porquellos fuesen tenudos de fazer cantar la dicha capellanía et rrogar a Dios por ssu alma. Et de commo / ge lo dezía et rrequería, que me pedía et pedió a mí, dicho notario, testimonio ssignado con mío ssigno, vno o más, quantos mester ouiese. Et luego, el dicho abbat, dixo que los mandaua et mandó que ffuesen a tomar la posesión de la dicha huerta et heredat et que can $/{ }^{54}$ tase et feziese cantar deste mes de junio, en que agora estamos, adelant, para ssiempre jamás, dos aniuerssarios cada mes, que eran veynt et quatro aniuersarios cada año, para ssiempre. Et luego, el dicho prior et capello, dexieron que ellos que tomarían et toma/uan la dicha huerta et heredat del dicho Iohán Núñez para la mesa del cabillo, et que tomauan et tomaron, en carga, de cantar et fazer cantar los dichos dos aniuerssarios cada mes. Et el uno, la primera ssemana del mes, et el otro, la postrymera semana del / mes, en cada año por ssiempre jamás, assy que sean, cada año, los dichos veynt quatro aniuersarios. Et que contaría la rrenta, que la dicha huerta et heredat, rrendiese en cada año. Et que pagarían, los dichos aniuersarios, a los que ffuesen en cantarlos, de lo de la $/{ }^{57}$ mesa del cabillo, porque tomarían las rrentas para la dicha messa. Et desto todo, en commo pasó, el dicho abat, mandó et rrequerió a mí, dicho notario, que lo tornase, todo, en pública forma et que encorporase y el testamento del dicho Iohán Núñez et diese uno / al dicho cabillo, para que lo touiese con la posessión de que tomase la dicha huerta et heredat, porque estodiese en la dicha eglesia para ssiempre jamás. Testigos que 
estauan et presentes: Pero Ferrández, compañero en la eglesia de Fussiellos, et Martín Pérez de la Carua, et Iohán, fijo de Per / Antolínez de Grijota, vezinos de Fussiellos.

Et después desto, este dicho día, en término de Monçón, en la huerta que ffue del dicho Iohán Núnez, en presençia de mí, dicho notario, et de los testigos de yuso escriptos, el dicho Domingo Gonçález, chantre, fizo leer ${ }^{60}$ por mí, dicho notario, el testamento del dicho Iohán Núñez et el poderío que el dicho arçediano le auía dado. Et luego, tomó a Alfón Capellán, hortolano de la dicha huerta, et echolo fuera della et tomó vna açada et començó a cauar et dixo que / él entraua et entró, la dicha huerta del dicho Iohán Núnez, por el poderío, a él dado, por el dicho testamento et por el dicho arçediano et en toda la otra eredat, en nobre de la dicha huerta. Et de commo etraua la dicha hu/erta et eredad, en qual día pedió a mí, dicho notario, testimonio ssignado con ssigno. Et dixo que commo la etraua la dicha huerta et heredad del dicho Iohán Núnez, que asy lo daua et dyo et etregó, a Iohán Pérez, canónigo de Fussiellos et ma ${ }^{63}$ yordomo del cabillo, et para el dicho cabillo, para quellos copliesen todo el sseruiçio que era ordenado de fazer en la dicha eglesia, por rrogar a Dios por el alma del dicho Iohán Núnez. Et de commo ge lo daua et dio et entregó, pedió tes/timonio. Et luego, el dicho mayordomo del dicho cabillo, dixo que él, que tomaua et tommó, la possessión de la dicha huerta et heredat, del dicho Iohán Núñez, por el dicho cabillo et para el dicho cabillo, con aquella carga que era ordenada, / para rogar a Dios por el alma del dicho Iohán Núñez. Et de todo esto, commo pasó, Iohán Pérez, pedió a mí, dicho notario, en nombre del dicho cabillo, testimonio ssignado con mío ssigno, vno o más, quantos mester ouiese, para guarda del derecho del ${ }^{66}$ dicho cabillo de Fussiellos et suyo en ssu nombre.

Testigos que estaua presentes: Ferrand Garçía, fijo de Garçía Martínez de Villa Anavín, et Iohán Ferrández, ffijo de Iohán de Melgar, et Iohán Ferrández, fijo de don Alfonso, et Iohán Martínez, fijo de don Pero de Santo / Felizes, vezinos de Monçón.

Et luego, el dicho Iohán Pérez deffendió al dicho ortolano, que non vsase ni labrase más la dicha huerta, sy non por el cabillo et tornole en nobre del dicho cabillo a la dicha huerta. Et él dixo que la / quería tener et labrar en nombre del 
dicho cabillo et se quería abenir con ellos. Et el dicho Iohán Pérez demandó testimonio. Testigos los sobredichos.

Et después desto, martes $\mathrm{XVIII}^{\circ}$ días de junio, era de mill et quatroçietas et VIII ${ }^{\circ}$ años, $/^{69}$ en el coro de la eglesia cathedral de Sant Antolín de Palençia, en presençia de mí, dicho notario, ante don Alfonso López, deán de Palençia, prouisor et vicario general por nuestro señor el obispo, paresció don Iohán Pérez Bastardo, arcediano de Campos en la eglesia de Palençia, masesor de / Iohán Núñez de Ferrera, vezino que ffue de Sand Testeuan, et mostró antel dicho Alfón López, deán, prouisor et vicario de nuestro señor el obispo, un testamento del dicho Iohán Núñez, escripto en paper et ssignado del signo de Iohán Ferrández, escriuano público de Torre de Lobatón, / ssegund que por él paresçía, el tenor del qual es este que sse ssigue.

Luego, el dicho arçediano, dixo et pedió al dicho deán et prouisor, que por rrazón que el dicho testamento estaua escrito en paper et era aténtico de estar en el ssagrario de la eglesia de Fussiellos $/^{72}$ et lo auía de enbiar a otras partes, que rresçelaua que se podría perder, que le pedía que diese liçençia et abtoridat et ssu decreto a mí, dicho notario, para que lo podiese traslaudar et tornar en pública fforma, et el traslado o traslados que yo feziese, conçertados con el oregynal, / que valyessen et ffeziesen ffe. Et luego, el dicho don Alfón López, deán et prouisor et vicario general, dixo que dava et dyo et liçençia et autoridat et que etreponga ssu decrepto a mí, dicho notario, para que traslaudase el dicho testamento et el traslado o traslados que / yo ffeziese et los conçertase con el oregynal, que valiesen et ffeziesen ffe. Testigos: Ruy Gómez de Tapia et Esteuan Sánchez, canónigo en la eglesia de Palençia.

Et yo, Ferrand Áluarez, notario público de la çipdat de Palençia sobredicho, fuy ${ }^{75}$ presente a todo esto que sobredicho es con los dichos testigos, et por la autoridat a mí del dicho deán, Alfonso López, deán, prouisor et vicario general, et a pedimiento et rrequerimiento de dicho deán / Iohán Pérez, arçediano de Campos, mansesor del dicho Iohán Núnez, et a rrequerimiento et pedimiento del dicho don Gutierre Gómez, abat de Fusiellos, et a pedimiento et rrequerimiento del dicho Domingo / Gonçález, chantre de Fusiellos, omme buenno tomado et escogido por el dicho don Iohán Pérez, arçidiano de Campos, mansesor del dicho Iohán Núnez, et a pedimiento et rrequerimiento de los dichos $/^{78}$ prior et cabiello 
de la eglesia de Santa María de Fusiellos, et de Iohán Pérez de Haçeues, mayordomo del prior et cabiello de Fusiellos, fiz escriuir estos testamentos en esta piel de pergamino. / Et encorporado el testamento del dicho Iohán Núnez et conçertado con el oreginal, bien et lealmientre, et fiz aquí este mío sig(signo)no en testimonio de uerdat. Ferrand Áluarez.

1371, mayo, 20. Valladolid.

Enrique II confirma un privilegio de Alfonso XI (1331, diciembre, 18. Valladolid), inserto, confirmatorio a su vez de otro de Fernando IV (1305, mayo, 10. Medina del Campo), inserto, confirmatorio asimismo de otro de de Sancho IV (1290, julio, 31. Valladolid), inserto, que a su vez confirma los siguientes privilegios:

- Privilegio de Urraca I (1114, mayo, 28), inserto, por el que concede a Santa María de Husillos, Villaldavín y la pesquera de Deronnada.

- Privilegio de Sancho III (1158, mayo, 4. Carrión de los Condes), inserto, por el que confirma las posesiones que Santa María de Husillos recibió de Urraca I, los condes de Monzón y otros particulares.

- Privilegio de Sancho III (1158, junio, 28, Cuéllar), inserto, por el que confirma el coto de Santa María de Husillos que él mismo había donado.

- Privilegio de Alfonso VIII (1178, agosto, 15. Carrión de los Condes), inserto, por el que confirma a Santa María de Husillos, las villas, heredades y monasterios donadas por Urraca I, Sancho III, los condes de Monzón: Fernando Ansúrez, Gonzalo Ansúrez y Nuño Ansúrez, y otros donantes.

- Privilegio de Alfonso VIII (1178, agosto, 15. Carrión de los Condes), inserto, por el que confirma a Santa María de Husillos el coto que donó Sancho III, su padre. 
A. AHDP, Ampudia y Abadía de Husillos, Pergaminos, carp. 201-23. Perg., 714 x 608 mms.; escr. gótica de privilegios y precortesana; regular conservación, aunque las roturas y manchas permiten su perfecta lectura. Sello pendiente de plomo.

B. AHDP, Ampudia y Abadía de Husillos, Pergaminos, carp. 201-27. Perg., 784 x 685 mm.; escr. gótica de privilegios y precortesana. Muy deteriorado, ha desaparecido, prácticamente, toda su parte izquierda. No conserva sello ni cuerda. Inserto en confirmación de Juan I, dada en Burgos, a 22 de agosto de 1379. Véase doc. núm. 193.

$C$. APA, $L P H$, ff. 88v-92r. Traslado de $A$.

$D$. APA, $L P H$, ff. $104 \mathrm{r}-108 \mathrm{v}$. Traslado de $B$.

E. AGS, Patronato eclesiástico, Inconexos, leg.159, ff. 90v-98v. Papel; escr. procesal; buena conservación. Traslado de $C$.

$F$. BN, $m s .705$, ff. 196v-201r. Traslado de $C$.

G. BN, $m s .705$, ff. 231v-238r. Traslado de $D$.

Santa María de Husillos lleva a confirmar a la cancillería regia el privilegio de Alfonso XI y no el de Pedro I.

(Christus, alfa et omega) En el nonbre de Dios Padre et Fijo et Spiritu Santo, que son tres personas et vn Dios verdadero que biue et rregna por sienpre jamás, et de la bien aventurada virgen gloriosa santa María su madre, a quien nos tenemos por señora et por abogada / en todos nostros fechos, et a onrra et a seruiçio de todos los santos de la corte çelestial, queremos que sepan por este nostro priuillegio todos los onbres que agora son o serán daquí adelante commo nos, don Enrrique, por / la graçia de Dios rrey de Castiella, de Toledo, de León, de Gallizia, de Seuilla, de Córdoua, de Murçia, de Iahén, del Algarbe, de Algezira, et señor de Molina, vimos vn priuillegio del rrey don Alfonso, nostro padre, que Dios perdone, escripto en par ${ }^{\beta}$ gameno de cuero et rrodado et sellado con su sello de plomo, fecho en esta guisa:

(Sigue doc. núm. 114)

Et agora el abbat et los canónigos de la eglesia de Santa María de Fusi/ellos, enbiáronnos pedir merçed que les confirmásemos este priuillegio et ge lo mandásemos guardar. Et nos, el sobredicho rrey don Enrryque, por les fazer bien et merçed, touiémoslo por bien et confirmámosgelo et mandamos que les vala et les sea guardado $/{ }^{63}$ en todo bien et cunplidamiente segunt que en él se contien. Et 


\section{LA ABADÍA DE SANTA MARÍA DE HUSILLOS: ESTUDIO Y COLECCIÓN \\ DOCUMENTAL $(904-1608)$}

defendemos firmemiente que alguno nin algunos non sean osados de les yr nin de les pasar contra este dicho priuillegio para ge lo quebrantar nin mengoar en alguna cosa. Ca qualquier o qualesquier que lo fiziesen, a/berían la nostra yra et demás pechar y an la pena que en el dicho priuillegio se contiene, et al abbat et a los canónigos de la dicha iglesia de Santa María de Fusiellos o a quien su boz touiese, todos los daños et menoscabos que por ende rresçebiesen doblados. Et porque esto sea firme et estable, (signum) / mandámosles ende dar este nostro priuillegio rrodado et sellado con nostro sello de plomo.

Ffecho el priuillegio en la villa de Valladolit, veynte días de mayo, era de mille et quatroçientos et nueue años. Et nos, el sobredicho rrey don Enrrique, rregnante en

vno con la rreyna $/{ }^{66}$ doña Juana, mi muger, et con el infante don Juan, mi fijo primero, heredero en los rregnos de Castiella, et de León, et en Toledo, et en Gallizia, et en Seuilla, et en Córdoua, en Murçia, en Iahén, en Baeça, en Badajoz, en Algarbe, et en (signo) / Molina, otorgamos este priuillegio et confirmámoslo.

( $\left.1^{a} \mathrm{col}.\right)$ El infante don Juan, fijo del muy alto et muy noble rrey don Enrique primero, heredero, conf.- Don Alfonso, fijo del infante don Pero de Aragón, marqués de Villena, conde de Ribacorça et de Denia, conf.- Don Alfonso Enríquez, fijo del muy noble rrey don Enrrique, señor de Lorenna, conf.- Don Diego, obispo de Burgos, conf.- Don Gutierre, obispo de Palençia, conf.- Don Ruberico, obispo de Calahorra, conf.- La iglesia de Osma vaga. Don Iohán, obispo de Siguença, conf.- Don Iohán, obispo de Segouia, conf.- Don Bernal Çason, obispo de Cuenca, conf. Don Alfonso, obispo de Áuila, conf.- Don Ióhán, obispo de Plazençia, conf.- Don Nicolás, obispo de Cartagena, conf.- Don Iohán, obispo de Iahén, conf.- Don Iohán, obispo de Córdoua, conf.- Don frey Gonçalo, obispo de Cádiz et de Algezira, conf.- Don Pero Fernández de Velasco, camarero mayor del rrey, conf.- Don frey Iohán Gutiérrez Mesia, prior de la orden de San Juan, conf.- Don Pero Manrique, adelantado mayor de Castiella, conf.

( $2^{a} \mathrm{col}$.) Don Sancho, hermano del rrey, conde de Albuquerque, señor de Haro et de Ledesma, alfiérez mayor del rrey, conf.- Don Beltrán de Claquin, duc de Molina, conde de Longa Villa et de Boria, conf.- Don Iohán Sánchez Manuel, conde de Carrión, conf.- Don Filipe de Castro, vasallo del rrey, conf.- Don Iohán 
Martínez de Luna, vasallo del rrey, conf.- Don Pero Buyl, vasallo del rrey, conf.Don Iohán Ramírez de Arellano, señor de Los Cameros, vasallo del rrey, conf.Don Beltrán de Guerarra, vasallo del rrey, conf.- Don Iohán Alfonso de Haro, conf.- Don Garçía Fernández Manrique, conf.- Don Iohán Rodríguez de Villalobos, conf.- Don Fernán Ruyz de Villalobos, conf.- Don Fernant Sánchez de Touar, guarda mayor del rrey, conf.- Don Alfonso Fernández de Montemayor, adelantado mayor del Andaluzía, conf.

( $3^{a}$ col.) Don Gómez Manrique, arçobispo de Toledo, primado de las Espanias, chançeller mayor del rrey, conf.

(Signo rodado)

- Primer círculo concéntrico:

DON SANCIUS, CONDE DE ALBURQUEQUE, ALFÉREZ MAYOR DEL RREY, CONF. DON ÁlUARO GARCÍA DE ALBORNOZ, MAIORDOMO MAYOR DEL RREY, CONF.

- Segundo círculo concéntrico:

SIGNO DEL RREY DON ENRIQUE

- Acuartelado con los escudos de Castilla y León.

Iohán Núnez de Villazán, iustiça mayor de cas del rrey, conf.- Ariçer Anbrosio Bocanegra, almirante mayor de la mar, conf.- Iohán Rodríguez de Torquemada, notario mayor de Castiella, conf.- Diego Gómez de Toledo, notario mayor del rregno de Toledo, conf.

( $4^{a} \mathrm{col}$.) Don Rodrigo, arçobispo de Santiago, capellán mayor del rrey, chançeller et notario mayor del rregno de León, conf.- Don frey Gonçalo, obispo de León, conf.- Don (en blanco), obispo de Ouiedo, conf.- Don Martín, obispo de Çamora, conf.- Don Alfonso, obispo de Salamanca, notario mayor del rregno del Andaluzía, conf.- Don Alfonso, obispo de Çibdat Rodrigo, conf.- Don frey Diego, 
obispo de Coria, conf.- Don Iohán, obispo de Badajoz, conf.- Don Françisco, obispo de Mondoñedo, conf.- Don Iohán, obispo de Tuy, conf.- Don Andrés, obispo de Orense, conf.- Don frey Pero López, obispo de Lugo, conf.- Don Fernando, obispo de Astorga, conf.- Don Fernand Osórez, maestre de la orden de la cauallería de Santiago, conf.- Don Melen Suárez, maestre de la orden de Alcántara, conf.- Don Pero Suárez de Quinones, adelantado mayor de tierra de León, conf.

( $5^{a} \mathrm{col}$.) Don Pero, arçobispo de Seuilla, conf.- Don Pero, fijo de maestre don Fradrique, hermano del rrey, conde de Trastamar, señor de Lemos et de Saria, conf.- Don Iohán Alfonso de Guzmán, conde de Niebla, conf.- Don Alfonso Pérez de Guzmán conf.- Don Pero Ponçe de León, señor de Marchena, conf.- Don Ramir Núnez de Guzmán conf.- Don Martín Fernández de Guzmán conf. Don Pero Munniz, maestre de la cauallería de Calatraua, conf.- Don Iohán Sánchez Manuel, conde de Carrión, adelantado mayor del rregno de Murçia, conf.

Don Pero Fernández, arçediano del Alcor, notario mayor por el rrey de los priuillegios rrodados, lo mandó fazer por mandado del rrey en el sesto año que el sobredicho rrey don Enrrique rregnó. Et yo, Diego Ferrández, escriuano del rrey, lo ffiz escriuir.

(rúbrica) Pero Gonçález (rúbrica).

(rúbrica) [...] (rúbrica).

(rúbrica) Iohán Ferrández (rúbrica).

1371, mayo, 20. Valladolid.

Enrique II confirma un privilegio de Alfonso XI (1331, diciembre, 16. Valladolid), inserto, confirmatorio de otro de Fernando IV (1312, marzo, 7. 


\section{DAVID MARCOS DIEZ}

Valladolid), inserto, confirmatorio a su vez de otro de Sancho IV (1291, agosto, 16. Valladolid), inserto, confirmatorio asimismo de otro de Sancho III (1158, abril, 28. Carrión de los Condes), inserto, por la que concede a Raimundo, abad de Santa María de Husillos, y a los canónigos de dicha iglesia, el privilegio de los infanzones, exentándolos asimismo de todo servicio real.

A. AHDP, Ampudia y Abadía de Husillos, Pergaminos, carp. 201-24. Perg., 607 x 601 mm.; escr. gótica de privilegios y precortesana; buena conservación. Sello de plomo pendiente.

B. ADHP., Ampudia y Abadía de Husillos, Pergaminos, carp. 201-26. Perg., 719 x 573 mm.; escr. gótica de privilegios; buena conservación. Mantiene parte de la cinta pero no el sello. Inserto en confirmación de Juan I del privilegio de Enrique II, dada en Burgos, a 22 de agosto de 1379. Véase doc. núm. 194.

C. AHDP, Ampudia, Serie G, Pergaminos. Privilegios Reales, carp. 202-29. Perg., 717 x 517 mm.; privilegio rodado; escr. gótica redonda de privilegios y precortesana; buena conservación. todos los elementos decorativos están dibujados pero sin miniar. No conserva la cinta pero sí el sello de plomo, que está suelto. Inserto en confirmación de Enrique III del privilegio de Juan I, dada en Burgos, a 20 de febrero de 1392. Véase doc. núm. 213.

$D$. APA, $L P H$, ff. 92r-94v. Traslado de $A$.

$E$. APA, $L P H$, ff. $108 \mathrm{v}-111 \mathrm{r}$. Traslado de $B$.

$F$. APA, $L P H$, ff. $124 \mathrm{r}-127 \mathrm{v}$. Traslado de $C$.

G. AGS, Patronato eclesiástico, Inconexos, leg.159, ff. 98v-104r. Papel; escr. procesal; buena conservación. Traslado de $D$.

$H$. BN, ms. 705, ff. 201r-208r. Traslado de $D$.

I. BN, $m s .705$, ff. 238r-242r. Traslado de $E$.

Al igual que en el documento anterior, no se presentó en la cancillería regia el privilegio rodado confirmatorio de Pedro I, sino el de Alfonso XI.

(Christus, alfa et omega) En el nonbre de Dios, Padre, et Fijo, et Spiritu Santo, que son tres personas et vn Dios verdadero que biue et rregna por sienpre jamás, et de la bien auenturada Virgen gloriosa santa María su madre, a quien nos tenemos por señora et por abogada / en todos nostros fechos, et a onrra et a seruiçio de todos los santos de la corte çelestial, queremos que sepan por este nostro priuillegio todos los ombres que agora son o serán daquí adelante, commo nos, don Enrryque, por la graçia / de Dios rrey de Castiella, de Toledo, de León, de Gallizia, de Seuilla, de Córdoua, de Murçia, de Iahén, del Algarbe, de Algezira, et señor de Molina, vimos vn priuillegio del rrey don Alfonso nostro 
padre, que Dios perdone, escrito en pargamino de $\beta$ cuero et rrodado et sellado con su sello de plomo, fecho en esta guisa:

(Sigue doc. núm. 113)

Et agora el abbat et el cabildo de la iglesia sobredicha, enviáronnos pedir merçed que les confirmásemos este dicho priuillegio et ge lo mandásemos guardar. Et nos, el sobredicho $\beta^{30}$ rrey don Enrryque, por les fazer bien et merçed et porque ellos sean tenudos de rrogar a Dios por las almas de los rreys onde nos venimos et por la nostra vida et por la nostra salud, touiémoslo por bien et confirmámoslo et mandamos que les vala et les sea / guardado en todo bien et cumplidamiente segunt que en él se contien.

Et defendemos firmemiente que alguno nin algunos non sean osados de les yr nin de les pasar contra este dicho priuillegio para ge lo quebrantar nin mengoar en alguna cosa. Ca qualquier o qualesquier que lo fiziesen, abrían la / nostra yra et demás pechar nos y an la pena que en el dicho priuillegio se contiene. Et al abbat et cabilldo de la iglesia sobre dicha o a quien su boz tosiese, todos los dampnos et menoscabos que por esta rrazón rresçebieren doblados. Et porque esto sea firme et estable ${ }^{\beta 3}$ para sienpre, mandámosles ende dar este nostro priuillegio rrodado et sellado con nostro sello de plomo.

Fecho el priuillegio en Valladolit, veynte días de mayo, era de mill et quatroçientos et nueue años. Et nos, el sobredicho rrey don Enrryque, rregnante en vno con la / rreyna doña Juana, mi muger, et con el infante don Juan, mi fijo primero, heredero en los rregnos de Castiella, de León, de Toledo, de Gallizia, de Seuilla, de Córdoua, de Murçia, de Iahén, del Algarbe, de Algezira et en Badajoz et en / Molina, otorgamos este priuillegio et confirmámoslo.

$\left(l^{a} \mathrm{col}\right.$.) El infante don Juan, fijo del muy alto et muy noble rrey don Enrrique primero, heredero, conf.- Don Alfonso, fijo del infante don Pero de Aragón, marqués de Villena, conde de Ribacorça et de demás, conf.- Don Alfonso Enrríquez, fijo del muy noble rrey don Enrrique, señor de Lorena, conf.- Don Diego, obispo de Burgos, conf.- Don Gutierre, obispo de Palençia, conf.- Don Rubiarte, obispo de Calahorra, conf.- La eglesia de Osma conf.- Don Iohán, 
obispo de Siguença, conf.- Don Iohán, obispo de Segouia, conf.- Don Bernal Cason, obispo de Cuenca, conf.- Don Alfonso, obispo de Áuila, conf.- Don Iohán, obispo de Plazençia, conf.- Don Nicolás, obispo de Cartagena, conf.- Don Iohán, obispo de Iahén, conf.- Don Iohán, obispo de Córdoua, conf.- Don Frey Gonçalo, obispo de Cádiz, conf.- Don Pero Fernández de Velasco, camarero mayor del rrey, conf.- Don Iohán Gonçáluez Mesía, prior de la orden de San Iohán, conf.Don Pero Manrrique, adelantado mayor de Castiella, conf.

( $2^{a}$ col. $)$ [D]on Sancho, hermano del rrey, conde de Albuquerque, señor de Haro et de Ledesma, alfiérez mayor del rrey, conf.- Don Beltrán de Claquin, duc de Molina, conde de Longa Villa et de Borja, conf.- Don Iohán Sánchez Manuel, conde de Carrión, conf.- Don Philipe de Castro, vasallo del rrey, conf.- Don Iohán Martínez de Luna, vasallo del rrey, conf.- Don Pero Buyl, uasallo del rrey, conf.Don Iohán Ramírez de Arellano, señor de Los Cameros, vasallo del rrey, conf.Don Iohán Alfonso de Haro conf.- Don Garçía Fernández Manrique conf.- Don Iohán Rodríguez de Castañeda conf.- Don Iohán Rodríguez de Villalobos conf.Don Fernán Ruyz de Villalobos conf.- Don Fernán Sánchez de Touar, guarda mayor del rrey, conf.- Don Alfonso Fernández de Montemayor, adelantado mayor del Andaluzía, conf.

$\left(3^{a} \mathrm{col}\right.$.) [D]on Gómez Manrique, arçobispo de Toledo, primado de las Espannas, chançiller mayor del rrey, conf.

(Signo rodado)

- Primer círculo concéntrico:

(Cruz) DON SANCHO CONDE ALBURQUEQUE, ALFÉREZ DEL RREY, CONF.; DON ÁLVARO GARÇYA DE ALBORNOZ, MAYORDOMO DEL RREY, CONF.

- Segundo círculo concéntrico:

SYGNO DEL RREY DON ENRIQUE 
- Tercer círculo concéntrico:

Acuartelado con los escudos de Castilla y León.

Iohán Martínez de Villazán, justiçia mayor de casa del rrey, conf.- Miçer Anbrosio Bocanegra, almirante mayor de la mar, conf.- Iohán Rodríguez de Torquemada, notario mayor del rreyno de Toledo, conf.

( $4^{a}$ col.) [D]on Rodrigo, arçobispo de Santiago, capellán mayor del rrey, chançeller et notario mayor del rregno de León, conf.- Don frey Gonzalo, obispo de León, conf.- Don Sancho, obispo de Ouiedo, conf.- Don Martín, obispo de Çamora, conf.- Don Alfonso, obispo de Salamanca, notario mayor del rreyno del Andaluzía, conf.- Don Alfonso, obispo de Çibdat Rodrigo, conf.- Don frey Diego, obispo de Coria, conf.- Don Iohán, obispo de Badajoz, conf.- Don Françisco, obispo de Mendoñedo, conf.- Don Andrés, obispo de Orenes, conf.- Don frey Pero López, obispo de Lugo, conf.- Don Fernando, obispo de Astorga, conf.- Don Fernant Osórez, maestre de la orden de la cauallería de Santiago, conf.- Don Melen Suárez, maestre de la cauallería de Alcántara, conf.- Don Pero Suárez de Quinones, adelantado mayor de tierra de León, conf.

( $5^{a}$ col. $)$ [D]on Pero, arçobispo de Seuilla, conf.- Don Pero, fijo del maestre don Fradrique, hermano del rrey, conde de Trastamar, senñor de Lemos et de Sarria, conf.- Don Iohán Alfonso de Guzmán, conde de Niebla, conf.- Don Alfonso Pérez de Guzmán conf.- Don Pero Ponçe de León, señor de Marchena, conf.- Don Ramir Núnez de Guzmán conf.- Don Martín Fernández de Guzmán conf.

Don Pero Ferrández, arçediano de Alcor, notario mayor por el rrey de priuillegios rrodados, lo mandó fazer por mandado del rrey en el sesto año que el sobredicho rrey don Enrrique rregnó. Yo, Diego Ferrández, escriuano del rrey, lo ffiz escriuir.

Firmas: Pero Rodríguez. Iohán Ferrández. 
1371, junio, 17. Palencia.

Alfonso López, deán de la catedral de Palencia, juntamente con el cabildo de dicha iglesia, concede a Gutierre Gómez, abad de Santa María de Husillos, una casa detrás del cabildo donde se reunían los contadores, para que pueda construir una capilla para su enterramiento y el de sus familiares, y una librería sobre dicha capilla.

A. AHDP, Ampudia y Abadía de Husillos, Pergaminos, carp. 207-16. Perg., 245 x 304 mm.; escr. precortesana. Muy buena conservación. Mantiene los tres orificios de donde pendía el sello, pero no éste ni la cuerda de la que pendía.

Sepan quantos esta carta vieren, commo nos, don Alfonso López, deán, et el cabilldo de la eglesia de Palençia, seyendo llamados antenoche por nostro portero / et este día por campana tannida, estando ayuntados a nostro cabilldo en el lugar acostumbrado assí commo lo auemos de vso e de costumbre de nos ayuntar, es/peçialmiente para esto que sse sigue. Por fazer bien e ondía a uos, don Gutier Gómez, abbat de Fusiellos, canónigo en la dicha eglesia, porque sodes ombre $\beta$ bono e onrrado e lo meresçedes, et por muchos bonos seruiçios que a la dicha eglesia e a nos auedes fecho e fazedes de cada día e faredes de / aquí adelante, dámosuos e assignámosuos la casa de la nostra tabla, do sse fazen agora las nostras cuentas por los nostros contadores, que está tras / el nostro cabillo, para que podades fazer della e en ella vna capiella; la qual capiella uos damos para enterramiento de uos e de los de uestro linage et $/{ }^{6}$ de todos los otros que uos quisierdes. Et que podades fazer sobre la dicha capiella vna casa para librería, para en que estén uestros libros después de uestros / días et los otros que y quisieren poner. Et dámosuos liçençia e abtoridat por esta nostra carta, para que podades fazer e derronper e derronpades la / pared e paredes que fueren mester, para ffazer la dicha capiella. Et prometemos e ponemos conuusco de non venir contra esto nin contra parte dello, $\rho^{9}$ agora nin en algund tiempo, por ninguna manera, et de lo guardar e complir todo, segund dicho es. 
Et en testimonio desto mandamos uos dar esta nostra / carta, seellada con nostro sseello pendiente e rrobrada del nombre de mí, el dicho deán.

Dada en Palençia, diez e siete días de junio, era de / mille e quatroçientos e nueue años.

(rúbrica) Scolasticus Palentinus (rúbrica). Abbas de Hérmides.

(rúbrica) Alfonsus, decanus Palentinus (rúbrica). (rúbrica). G[utierre], archidiaconus de Alcor (rúbrica).

1371, julio, 7, lunes. Palencia.

Traslado sacado por Pedro Sánchez, notario público de Palencia, ante Alfonso López, deán de la catedral de Palencia y vicario general del obispo de Palencia, Gutierre I Gómez de Toledo, a petición de Juan Fernández, prior de Santa María de Husillos, de un testimonio notarial (1370, enero, 23. Husillos / 1370, febrero, 5. Valladolid) dado por Juan Fernández de Tablada, notario público de Palencia, y otorgado por Gutierre Gómez, abad de Husillos y canciller de la casa de la reina, por el que Juan Fernández, sin renunciar a la sacristanía, es elegido prior de Santa María de Husillos, tras la muerte del anterior, Juan Pérez de Aceves.

A. AHDP, Ampudia y Abadía de Husillos, Pergaminos, carp. 212-6. Perg., 541 x 665 mm.; escr. precortesana; buena conservación.

$B$. APA, $L P H$, ff. $80 \mathrm{r}-84 \mathrm{v}$.

C. BN, $m s .705$, ff. $170 \mathrm{v}-184 \mathrm{r}$.

Lunes, siete días de el mes de iulio, anno Domini millesimo trecentesimo LXX I. Estando en la çipdat de Palençia, en la eglesia cathedral de sennor Santo Antolín, ante el onrrado varón et sabio don Alfonso López, deán de Palençia, prouisor et vicario general en lo spiritual et temporal, en todo el obispado, por el onrrado padre et sennor don Gutierre, por la graçia de Dios e de la Santa eglesia 
de Roma, obispo de Palençia, chançiller mayor / de la reyna. En presençia de mí, Pero Sánchez, notario público de la çipdat de Palençia, et de los testigos de yuso escriptos, paresçió don Iohán Ferrández, prior en la eglesia de Fusiellos, et en presentó una carta, escripta en pergamino de cuero et firmada del nombre de don Gutierre Gómez, abbad de Fusiellos et seellada con su seello, pendiente en cuerda de lino et signada del signo de Iohán Ferrández de Tablada, notario público de la çipdat de Palençia, / segund que por ella paresçía, et dixo que por quanto se rreçelaua de perder la dicha carta, por fuego o por agua o por rrobo o por furto o por otra cosa alguna que podríe acaesçer en qualquier manera o por qualquier rrazón, que pedía et pidió, al dicho sennor deán et prouisor et vicario sobredicho, que diese liçençia et apitoridat a mí, dicho notario, para que sacase un traslavdo de la dicha carta de confirmaçión, del cuerpo ori ${ }^{\beta}$ ginal, conçertado parte por parte, et que mandase a mí, dicho notario, que lo signase para que fiziese fe doquier que aparesçiese asy commo el cuerpo original de la dicha carta, para guarda de su derecho, el tenor de la qual carta es este que se sigue:

(Sigue doc. núm.158)

La qual carta de confirmaçión pressentada et leyda, luego, el dicho sennor deán et prouisor et vicario sobredicho, dixo que daua et dio liçençia et apctoridat a mí, dicho notario, para que traslaudasse la dicha carta / de confirmación, parte por parte, et el traslaudo que, dende sacase, que lo signase con mío signo et que feziese fe doquier que aparesçiese, asy commo el cuerpo original de la dicha carta, et que interponía et interpuso, en él, su decreto. Et luego, el dicho don Iohán Fernández, prior, dixo que pedía et pidió a mí, dicho notario, que le diese, ende, testimonio para guarda de su derecho. Testigos que estauan presentes a esto / que dicho es: don Esteuan Ferrández, maestre escuela en la eglesia de Palençia, et don Garçi Martínez, arçediano del Alcor, vezinos de Palençia.

Et yo, Pero Sánchez, notario público de la çipdat de Palençia, sobredicho, fuy presente, a esto que dicho es, con los dichos testigos. Et por rruego et rrequirimiento del dicho prior, escriuí este traslaudo de liçençia, que saqué de la dicha carta de confirmaçión, $/{ }^{69}$ que fue fecho día et mes et anno et era ut supra. Et ffiz aquí este mío sig(signo)no en testimonio. (rúbrica) 
1371, julio, 22. Paredes de Nava.

Don Sancho, hijo de Alfonso XI y hermano de Enrique II, conde de Alburquerque, señor de Haro y Ledesma y conde de Paredes merced a la donación de su hermana Juana, desembarga la parte de su propiedad del monte de La Reyerta, lindante con la villa de Pajares, que pertenecía a Santa María de Husillos por donación de Fernando, Gonzalo y Nuño Ansúrez, condes de Monzón, y que era ilegalmente utilizado por los concejos limitrofes de Paredes de Nava y Becerril de Campos.

B. AHDP, Ampudia y Abadía de Husillos, Pergaminos, carp. 207-15. Perg., 314 x 313; escritura precortesana; buena conservación. Inserto en traslado sacado en Palencia, a 24 de julio de 1371. Véase doc. núm. 168.

C. APA, $L P H$, ff. $94 \mathrm{v}-95 \mathrm{v}$.

D. BN, $m s .705$, ff. 208r-211r.

Sepan quantos esta carta vieren, commo yo, don Sancho, fijo del muy noble et alto rrey don Alfonso, conde de Alborquerque et señor de Haro et de Ledesma, conosco que por quanto que por parte del / abbad et prior et cabilldo de la eglesia de Sancta María de Fusiellos, vino a mí el dicho prior de la dicha eglesia, sobre rrazón de vn monte que dizen de La Refierta, el qual dicho monte era contienda grand tiempo $/{ }^{9}$ pasado, entre el conçejo de Paredes de Naua et el conçejo de Bezerril, rrazonándolo por suyo los vnos et los otros, et poseyéndolo et teniéndolo por suyo, el qual dicho monte es en linde de las here/dades que dizen de Pajares, que son de la dicha eglesia, et en linde otro monte que dizen de Paredes et en linde de los términos de Villa Fruela et de Villa Dondauin et de Sanct Yliçes et de Bezerril; et es / contenido en la donaçión que doña Iohanna, mi hermana, me fizo de la dicha villa de Paredes con sus términos et montes et con todas las otras cosas a ella pertenesçientes, de fecho et de derecho. Et por/ ${ }^{12}$ que 
vos, el dicho prior, en nombre del dicho abbat et cabilldo, me fezistes entender que commo quier que los dichos conçejos poseyen el dicho monte husando del grande tiempo, sin rrazón et sin derecho, a mengua et va/camiento del non demandar nin rrequerir fasta aquí por se partir de auer contienda con los señores pasados que fueron de los dichos logares et con los dichos conçejos que agora, pues Dios me auía dado señorío, que me / enbiauan pedir merçed el dicho abbat et cabilldo que fuese la mi merçed de veer algunos priuilleios et donaciones et cartas que la dicha eglesia auía en rrazón del senñorío del dicho monte et derecho que en él auía. ${ }^{15}$ Et otrosy que sopiese uerdat en ombres bonos, ydóneos et dignos de creer, porque yo ouiese enformaçión uerdadera del fecho, porque sabida la uerdat, yo guardase el derecho de la dicha iglesia. / sobre lo qual, para auer enformaçión deste fecho, me fue mostrado et fecho fe, por cartas de donaçiones et priuilleios et otros rrecabdos en que se contiene que los condes Fernand Ansúrez et Gonçalo Ansúrez et Nuño / Ansúrez, con bona conuersaçión, por fazer merçed a la dicha eglesia, le dieron et fezieron donaçión de la heredat et término de Pajares con su defesa, la qual defesa sope por enformaçión et dichos de bonos ombres $/{ }^{18}$ dignos de fe et por bonas et çiertas presunçiones dellos et dichos et de ouidas et de fama, que el dicho monte que es la dicha defesa nombrada de suso, que fue donada por los dichos condes / con la dicha heredat de Pajares. Et yo, el dicho conde, por esta rrazón sabida la uerdat, et por fazer bien e merçed a la dicha eglesia et cabilldo, a la qual so tenudo de obedesçer et guardar; / et por tirar toda la dubda et carga deste fecho, otorgo et conosco que por esta mi carta o por el traslaudo della signado de escriuano público, dexo et desenbargo libremientre a la dicha $/^{21}$ eglesia, el dicho monte con todas sus pertenençias, segund que a mí pertenesçía et era fecha donaçión çierta lo sobredicho et auía el señorío et posesión del; la qual posesión auía tomada / por notarios públicos et vasallos de mío señor el rrey et en quanto a mí pertenesçe et deuía pertenesçer, en el dicho monte, por rrazón de la dicha donaçión et posesión et huso que los del dicho / logar de Paredes ouieron en la parte que del poseyeron en todo el tiempo que le ouieron et auían posesión en él. Et yo oue después, por título de la dicha donaçión et posesión, tomada todo, lo ${ }^{24}$ rrenunçio et lo he por rrenunçiado de lo non demandar nin contrallar en ningún tiempo, et lo dexo libremientre desenbargado a la dicha eglesia et cabilldo para 
que lo ayan et lo tengan et posean et /fagan dello et en ello commo de su propia heredat.

Et por esta mi carta mando, de parte del rrey, mío hermano et mío señor, et de la mía, a qualesquier alcalldes et merynos que andan por él en las / sus meryndades, o a otros ofiçiales qualesquier que esta mi carta vieren, o el traslaudo della signado commo dicho es, que vos pongan en tenençia et en posesión de la dicha parte que los del dicho logar $/^{27}$ de Paredes poseyan en el dicho monte et vos defeiendan et anparen en la dicha posesión, de manera que la dicha eglesia et cabilldo puedan dello husar asy commo de su heredat propia, / et non fagan ende al por ninguna manera, so pena de la merçed del dicho señor rrey et de la mía.

Et porque esto sea firme et valedero et non venga en dubda, mandevos dar esta mi carta, / seellada con mío seello de çera, en que escreuí mío nombre.

Dada en la dicha mi villa de Paredes de Naua, veynt dos días de julio, era de mille et quatroçientos et nueue ${ }^{30}$ años. Yo el conde.

1371, julio, 24, jueves. Palencia

Traslado sacado por Pedro Sánchez, notario público de Palencia, de un documento (1371, julio, 22. Paredes de Nava) por el que don Sancho, hijo de Alfonso XI y hermano de Enrique II, conde de Alburquerque, señor de Haro y Ledesma y también conde de Paredes gracias a la donación de su hermana Juana, desembarga la parte del Monte de la Reyerta lindante con la villa de Pajares, que pertenecía a Santa María de Husillos y era ilegalmente utilizado por otros concejos limitrofes.

A. AHDP, Ampudia y Abadía de Husillos, Pergaminos, carp. 207-15. Perg., 314 x 313; escritura precortesana; buena conservación.

B. APA, $L P H$, ff. $94 \mathrm{v}-95 \mathrm{v}$.

C. BN, $m s .705$, ff. 208r-211r. 
Yueues, veynte quatro días de julio, anno Domini millesimo $\mathrm{CCC}^{\circ} \mathrm{LXXI}^{\circ}$. Estando en la çipdat de Palençia, en la eglesia cathedral de señor Sanct Antolín ante el onrrado varón et sabio don Alfonso Lóppez, / deán de Palençia, prouisor et vicario general en lo spiritual et temporal en todo el obispado, por el onrrado padre et señor don Gutierre, por la graçia de Dios et de la sancta eglesia de Roma, obispo de Palençia et chançiller / mayor de la rreyna. En presençia de mí, Pero Sánchez, notario público de la çipdat de Palençia, et de los testigos de yuso escriptos, paresçió don Iohán Ferrández, prior en la eglesia de Fusiellos, et en presentó vna carta escripta en paper $\beta$ et firmada del nombre del conde et seellada en las espaldas con su seello de çera bermeja, que auía figuras de castiello et de leones, segund que por ella paresçía, et dixo que por quanto el abbat / et él et el dicho cabilldo de la dicha eglesia se rreçelauan perder la dicha carta por fuego o por agua o por rrobo o por furto o por otra cosa alguna que podíe acaesçer en qualquier manera o por qual/quier rrazón, que pedía et pedió al dicho señor deán et prouisor et vicario sobredicho, que diese liçençia et aptoridat a mí, dicho notario, para que sacase vn traslaudo o dos de la dicha carta del cuerpo original, $/^{6}$ conçertado parte por parte, et que mandase a mí, dicho notario, que lo signase para que feziese fe doquier que paresçiese, asy commo el cuerpo original, para guarda del dicho cabilldo, el tenor de la qual carta es este / que se sigue:

(Sigue doc. núm. 167)

La qual carta, en presentada et leyda por mí dicho notario; luego, el dicho señor deán et prouisor et vicario sobredicho, dixo que daua et dio liçençia et aptoridat a mí, dicho / notario, para que trasladase la dicha carta, parte por parte, et el traslavdo o traslavdos que dende sacase que los signase con mío signo, para que feziesen fe doquier que aparesçiesen, asy commo el / cuerpo original de la dicha carta, et que enterponía et enterpuso en él o en ellos su decreto. Et luego, el dicho Iohán Ferrández, prior sobredicho, dixo que pedía et pedió a mí, dicho notario, que le die ${ }^{33}$ se ende testimonio para guarda del dicho cabilldo, de la dicha eglesia et suyo, en su nombre.

Testigos que estauan presentes, llamados et rrogados spiçialmientre a esto que dicho es: Alfonso Garçía / de Çiguenza, criado de Ruy Galuán, canónigo; et 
Gonçalo Alfonso de Valdespina, ombre de Sancho Royz de Torre, et Alfonso Martínez, fijo de Iohán Martínez de Sanct Çibrián, vezinos de Palençia. /

Et yo, Pero Sánchez, notario público sobredicho, fuy presente a esto que dicho es con los dichos testigos, et por rruego et rrequirimiento del dicho señor prior, escriuí este público instromento, que ${ }^{36}$ fue fecho día et mes et año et era sobredicha. Et fiz aquí este mío sig(signo)no en testimonio (rúbrica).

1372, enero, 29. Palencia.

Fernán Rodríguez, sacristán de Santa María de Husillos, vende a Domingo González, chantre en dicha iglesia, dos tierras en Fuentes de Valdepero, en precio de cuatrocientos maravedis.

A. AHDP, Ampudia y Abadía de Husillos, Pergaminos, carp. 208-15. Perg., 260 x 186 mm.; escr. precortesana; regular conservación, pues la tinta está algo desvaída y tiene una pequeña rotura.

B. APA, $L P H$, ff. $95 \mathrm{v}-96 \mathrm{r}$.

C. BN, $m s .705$, ff. $211 \mathrm{r}-212 \mathrm{r}$.

Sepan quantos esta carta vieren, como yo, Fernant Rodríguez, sacristán en la eglesia de Fussiellos e / canónigo en la eglesia de Palençia, otorgo et connosco que vendo a uos, Domingo Gonçález, chantre en la dicha eglesia de / Fussiellos, dos tierras que yo he en término de Fuentes de Valdepero, que yo compré de Iohán Fernández, fijo de Llorente Fernández, mi primo. $\beta$ Vendóuoslas, vendida buena et sana sin carga alguna, con los derechos et açiones que las yo compré de el dicho Iohán / Ferrández, que es quien me las vendió con toda la açción que el dicho Iohán Ferrández las auía de diez años acá, de los tenedores que las / touieron en rrazón de los fructos et esquilmos de las dichas tierras; las quales vos uendo por quatroçientos maravedís, desta mo $/{ }^{6}$ neda vsual que fazen tres cruzados el maravedí et vn rreal un maravedí, de los quales me otorgo por bien pagado a toda mi volun/tad et renunçio las leys del derecho, la una que dize que los testigos 
de la carta deuen ueer fazer la paga de / los maravedís o de otra cosa que los vala et la otra ley, que dize que fasta dos años es omme tenudo de prouar la paga $/{ }^{9}$ que faze, saluo ssi aquel que resçibe la paga renunçiare estas dichas leys. Et yo renúnçiolas et pártome dellas. / Et por esta carta uos pongo en la tenençia et possesión et poderío et açión et derecho, que yo he o podría auer, contra / las dichas tierras et traspásolo todo en uso, el dicho chantor, de oy día que esta carta es fecha en ade $/{ }^{12}$ lante, para que sean vestras, libres et quitas, para vender, enpeñar, trocar, cambiar et fazer dellas et en ellas, / assí commo de vestro proprio. Et oblígome con todos mis bienes, muebles et rrayzes, spirituales et temporales, de / uos fazer sanas las dichas tierras, de todo omme o muger que uos las contrallare o enbargare, agora $/{ }^{15}$ et en todo tiempo, si non, que uos de otras tales tierras commo éstas et en tan buen logar o en mejor o los / maravedís doblados, qual uos más quisierdes.

Fecha fue esta carta en la çipdat de Palençia, veynte et / nueue días de enero, era de mille et quatroc[ien]tos et diez años. Testigos que estauan presentes $/{ }^{18}$ a esto que dicho es: Ruy Fernández, fijo de Marcos Pérez, et Iohán Fernández del Pozo, et Iohán de Castro, criado del / Hospital de Santo Antolín, vezinos de Palençia.

Et yo, Iohán Alfonso de Pedraza, / notario público de la çipdat de Palençia, fuy presente a esto que dicho es $/^{21}$ con los dichos testigos. Et rrogado de las partes, fiz escreuir esta carta et ffiz aquí este mío sig(signo)no en testimonio de / verdat.

1372, mayo, 12, miércoles. Palencia.

Martín Pérez de la Carva de Millanés, vecino de Husillos, vende a Domingo González, chantre de Santa María de Husillos, una tierra en dicho lugar, en el pago que llaman Tras El Soto, en precio de media carga de trigo.

B. APA, $L P H$, f. $96 \mathrm{r}-\mathrm{v}$.

C. BN, $m s .705$, ff. $212 \mathrm{r}-213 \mathrm{v}$. 
Fecho y sacado fue este traslado en la villa de Husillos, a veinte y seis días del mes de novienbre de mil y quinientos y çinquenta y quatro annos. Testigos que fueron presentes a lo ver corregir y conçertar Joán Ruiz Cabeça de Vaca y Gaspar de Vedoya, clérigos, y Pero Manuel, estantes en la dicha villa. E yo Santiago Gómez, escriuano público en la dicha villa, fui presente con los dichos testigos, a lo que dicho es. Y del dicho pedimento e mandamiento, lo escreví e fize aquí mi signo (signo) en testimonio de verdad.

Pero Ruyz de Villoldo (rúbrica). Santiago Gómez (rúbrica).

Sepan quantos esta carta vieren, como yo, Martín Pérez de la Carva de Millanés, vezino et morador en Fusiellos, otorgo et conozco que vendo a vos, Domingo González, chantre de la yglesia de Fusiellos, vna tierra que fue viña mía, que es en término de Fusiellos, do dizen Tras Soto; que a por linderos en derredor: tierra del cabildo de la yglesia de Fusiellos, de la mayor parte, y de la otra parte, viña erial de Diego Fernández de Piña, notario de Palençia. Y esta dicha tierra vos vendo por media carga de trigo, que de vos rreçebí. E me otorgo por bien pagado della et en razón de la dicha paga, rrenunçio las leyes del derecho, la vna en que dize que los testigos de la carta deben ver fazer la paga de aquello sobre que es fecha la carta o de cosa que lo vala, y la otra ley en que dize que el que faze la paga la deve provar fasta dos años, saluo si aquel que la reçibe no renunçia estas leyes expresamente.

Y por ésto, yo rrenúnçiolas et pártome dellas, et rrenunçio la exençión del dicho trigo, no ser visto, yo auerlo rreçebido de vos, ni vos auerlo dado a mí. Et desde el día de oy, que esta carta es fecha, me desapodero de la tenençia y posesión y señorío que en la dicha tierra auía, et con esta carta doy et entrego a vos, el dicho chantre, la tenençia et posesión et señorío que en la dicha tierra avía, para que sea vuestra y fagades, della, así commo de cosa vuestra propia, para vender y enpeñar y dar y trocar y canbiar y enajenar. Et pongo, con vusco, de vos la hazer sana en todo tiempo, de quien quier que vos la contrallare o enbargare et si vos, la non fizier sana, que vos de otra tamaña tierra y tan buena y en tan buen lugar o en mejor, en el dicho término. E para lo así fazer et cumplir, obligo a mí et a todos mis bienes, muebles y rraízes, avidos $(f .96 v)$ y por aver, et do vos, por fiador, a Pero Fernández, mi yerno que está presente, fijo de Antolín Pérez, vezino del dicho lugar de Fusiellos, al qual ruego que me fíe; e me obligo de le sacar a saluo 
et sin daño, de esta fiadura, e si pérdida o daño, por ende rreçibiera, que se peche doblado. Et yo, el dicho Pero Fernández, otorgo et conozco que so tal fiador et que si el dicho Martín Pérez, mi suegro, no vos fiziere sana la dicha tierra, yo que vos la faga sana o vos de otra tamaña et tan buena o mejor, e para lo ansí fazer et conplir, obligo a mí et a todos mis bienes, muebles et rraízes, auidos e por aver. E porque esto sea firme et non venga en duda, yo, el dicho Pero Fernández y el dicho Martín Pérez, rogamos e requerimos a Ruy Martínez de Tapia, notario público de la çibdad de Palencia, que escriviese o fiziese escrevir esta carta et la signase con su signo et vos la diese.

Fecha en la çibdad de Palençia, miércoles, doze días de mayo, era de mil et quatroçientos y diez años. Testigos que estavan presentes rrogados: Diego Fernández de Astudillo, carpintero, et Domingo Fernández, fijo de Joán, covezinos de Palençia, et Joán Garçía, clérigo de Torre, çerca de Castroverde, et Fernando de Bezerril, fijo de Gonçalo Martínez.

E yo, Ruy Martínez de Tapia, notario público de la çibdad de Palençia, fui presente, a lo que dicho es con los dichos testigos. Et por ruego de los dichos Martín Pérez et Pero Fernández, e rrequerimiento del dicho chantre fasta la suscreçión, fize escrevir esta carta et fize aquí este mi signo en testimonio de verdad.

1372, agosto, 22. Burgos.

Enrique II, a petición de Gutierre Gómez de Toledo, abad de Santa María de Husillos, canciller y capellán mayor de la reina Juana, exenta a diez vecinos de Villaudilla, que pertenecía a dicha abadía y se encontraba despoblada, de toda contribución durante un periodo de diez años, a condición de que los canónigos y beneficiados rogasen a Dios por él. 
A. AHDP, Ampudia y Abadía de Husillos, Pergaminos, carp. 207-17. Perg., 333 x 382 mm.; escr. precortesana; buena conservación, aunque el punto desde donde pendía el sello de plomo ha sido cortado en semicírculo.

$B$. APA, $L P H$, ff. 96v-97r. En la línea del original se confunde y salta a la de abajo. A partir de aquí está muy resumido y se aparta bastante del original.

C. AGS, Patronato eclesiástico, Inconexos, leg.159, ff. 104r-105r. Papel; escr. procesal; buena conservación.

La mención de que varios lugares de Santa María de Husillos estaban destruídos y despoblados por las guerras pasadas, hay que contextualizarla en los efectos de la guerra civil entre Enrique II y Pedro I.

[S]epan quantos esta carta vieren commo nos, don Enrrique, por la graçia de Dios rrey de Castiella, de Toledo, de León, de Gallizia, de Ssevilla, de Córdoua, de Murçia, de Iahén, del / Algarbe, de Algezira, sseñor de Molina. Porque a los rreyes es dado de guardar et onrrar las eglesias do sse consagra el cuerpo de nostro ssennor Ihesu Christo et sse ffazen otros sacramentos a/catar, por quantas maneras podieren por las rreparar et ssostener, ffaziendo limosnas et ayudas para ello. Et porque nos ffue ffecho entender en commo los lugares de la eglesia de ${ }^{\beta}$ Santa María de Ffusiellos ha grant tiempo que ffueron destruydos et que están mal rreparados por los grandes destronamientos et guerras pasados, et en commo ffue otrossí despoblado el ssu lugar de / Villaudilla, en lo qual es a nos dado de poner rremedio entendiendo el grant prouecho que dende sse nos sigue por las muchas ayudas que ffasta aquí auemos rresçebido de la virgen Sancta María, a la / qual tenemos por sseñora et por abogada en todos nostros ffechos, et esperamos della rresçebir cabo adelante. Et porque los canónigos et benefiçiados que en ella ffueren, ssean tenudos de rrogar a Dios por $/ 6$ nos, et por les fazer limosna, et por quanto otrossí nos lo pedió por merçed don Gutierre Gómez de Toledo, abbat que es agora de la dicha eglesia de Ffusiellos, et chançeller et capellán mayor de la rreyna / donna Iohanna, mi muger, tenemos por bien de quitar et ffazer essentos et quitos diez ombres labradores que ssean moradores en el dicho lugar de Villaudilla, de todo pecho et pedido et seruiçio et / monedas et seruiçios et yantares et martiniegas, et de todos otros pechos et pedidos que en qualquier manera nos derramemos o nos ayan a dar o pechar los de la nostra tierra del día de la data $/^{9}$ desta nostra carta que les esta merçed ffazemos, ffasta diez 


\section{DAVID MARCOS DIEZ}

años cumplidos primeros sseguientes que vienen en tal manera; que alguno nin algunos de los nostros cogedores o arrendadores o pesquisidores o / rrecobdadores que ffueren de aquí adelante en estos dichos diez años et en qualquier dellos, de los dichos pechos et rrentas et tributos que dichos sson, o de qualquier dellos, non los ayan nin cog/gan nin rrecabden nin demanden en estos dichos diez años nin en qualquier dellos a los dichos diez labradores et moradores en el dicho lugar, nin a alguno dellos. Et ssobresto mandamos a qual ${ }^{12}$ quier o a qualesquier de los dichos arrendadores et pesquisidores et cogedores et rrecabdadores ssobredichos, que ayan de auer et de coger et rrecabdar en rrenta o en ffialdat o en otra manera qualquier / en estos dichos diez años o en qualquier dellos, los dichos pechos et pedidos et monedas et seruiçios et martiniegas et yantares et tributos ssobredichos et a qualquier o a qualesquier dellos que esta nostra / carta ffuere mostrada o el traslado della signado de escriuano público, que non coggan nin rrecabden nin demanden a los dichos labradores nin a nenguno dellos, en todo este dicho tiempo, alguno $/{ }^{15}$ nin algunos de los dichos pechos et tributos que dichos sson; nin los prenden nin tomen nin enbarguen alguna cosa de lo ssuyo nin los ffagan premia nin afincamiento alguno ssobrello. Ca nos ge lo / quitamos et dexamos et los ffranquiamos en todo este dicho tienpo. Et non ffagan ende al por nenguna manera, so pena de la nostra merçed. Si non, mandamos a Pero Manrrique, nostro adelantado mayor en / las merindades de Castiella et al merino o merinos que por nos o por él ffueron agora et daquí adelante en las dichas merindades et en qualquier dellas, et a todos los otros alcalldes et merinos et $/^{18}$ jurados et juezes et justiçias e otros ofiçiales qualesquier de todas las çibdades et villas et lugares de nostros rregnos et a qualquier o a qualesquier dellos que esta nostra carta vieren o el traslado della / signado, commo dicho es, que ge lo non consientan et que anparen et defiendan en todo este dicho tienpo a los dichos diez labradores con estas merçedes que les nos ffazemos. Et que non consientan a los / dichos arrendadores et cogedores et rrecabdadores nin a alguno dellos, que les vayan nin pasen contra ellas, en todo este dicho tiempo, por alguna manera, et más quier que muestren nostras cartas o $/^{21}$ alualás que ssean dadas en contrario de lo que dicho es; porque nostra entençión et nostra merçed es que ssean guardadas estas dichas merçedes a los del dicho lugar, en todo este di/cho tiempo, commo dicho es. Et los vnos et los otros non ffagades ende al por nenguna manera, so pena de la 
nostra merçed et de mille marauedís a cada vno, para la nostra cámara. Et demás te/nemos por bien, que los del dicho lugar que anparen las prendias que por rrazón de los dichos pechos et tributos los dichos cogedores o qualquier dellos lo quisieren ffazer, et que les non $/^{24}$ rrecudan con ellos en todo este dicho tiempo, ssi non por qualquier o qualesquier dellos por quien ffincare de lo assí ffazer et conplir, mandamos al ombre que esta nostra carta mostrare o el / traslado della signado commo dicho es, que los enplazen, que parescan ante nos del día que los enplazaren a quinze días, so la dicha pena a cada vno, a dezir por qual rrazón non cunple / nostro mandado, et de commo esta nostra carta les ffuere mostrada, et los vnos et los otros la cunplieren. Mandamos so la dicha pena a qualquier escriuano público que para esto ffuere llamado, ${ }^{27}$ que de ende, al que lo mostrare, testimonio signado con su signo, porque nos sepamos commo conplides nostro mandado. Et desto les mandamos dar esta nostra carta, escripta en pargamino de / cuero et ssellada con nostro ssello de plomo colgado.

Dada en la muy noble çibdat de Burgos, veynte dos días de agosto, era de mille quatroçientos et diez años (rúbrica) Yo, / Pero Bernabé, la fiz escriuir por mandado del rrey (rúbrica).

(rúbrica) Iohán Fferrández (rúbrica).

(rúbrica) Pérez Ferrández (rúbrica).

1373, noviembre, 18. Becerril de Campos.

Carta de procuración otorgada por los clérigos y el común de Becerril de Campos a favor de Salvador Pérez, clérigo de dicho lugar, para que pueda arrendar a Santa María de Husillos sus heredades de Pajares y San Sebastián, sitas en el término de Becerril. 
B. AHDP, Ampudia y Abadía de Husillos, Pergaminos, carp. 208-19. Perg., 318 x 283 mm.; escr. precortesana; regular conservación con varias pequeñas roturas. Inserto en carta de arrendamiento, dada en Palencia, a 19 de noviembre de 1373 (Véase doc. núm. 173).

C. APA, $L P H$, f. 97v. Si bien en el anverso del documento original se dice: "No está en el Becerro", no es cierto pues fue trasladado hasta "pueda arrendar". Después dice: "No se sacó más desta escritura porque no se pudo leer".

Aunque en un primer momento el nombre del procurador es Diego Martínez, el hecho de que posteriormente y en el siguiente documento se nombre a éste como Salvador Pérez, hace que nos inclinemos por este segundo nombre.

Sepan quantos esta carta de procuraçión vieren, commo nos, los clérigos et común de Bezerril, estando ayuntados a cabiello en la eglesia $\beta$ de Santa Eugenia, del dicho logar, a campana tañida, segund que lo auemos de huso et de costumbre de nos ayuntar, otorgamos et connoscemos que fazemos et establesçemos nuestro / perssonero et procurador a Diego Martínez [...], para que por nos et en nuestro nombre, pueda arrendar todas las heredades que la eglesia de Fusiellos ha en término de Bezerril, / también tierras commo viñas, con sus [...]las que las dichas heredades et viñas [...] en Pajares et en Sante Sauastián [...] del dicho logar de Bezerril et para que pueda trocar $/{ }^{6}$ et abenir con el prior o cabiello de la dicha eglesia de Fusiellos, por nos et en nuestro nombre, todas aquellas cosas et cada vna dellas que nos en suos [...] et rra/zonaríamos presentes siendo, et tratar abenençias et rrentas et composiciones que el dicho Saluador Pérez, nuestro personero, feziere en esta rrazón, del dicho prior et cabiello, nos lo auemos / por firme et por baledero, para agora et para en todo tiempo et le otorgamos so obligaçión, amos et de todos nuestros logares de auer por firme et por baledero de todo lo quel dicho $/^{9}$ Saluador Pérez, nuestro personero, feziere et dexiere et rrazonare. Et otrosy, de aueer por firme et por baledero, todas cartas o carta de rrenta que en esta rrazón fiziere o otorgare, por / nos et en nuestro nombre por nos. Et porque esto sea firme, rrogamos a Iohán Martínez, escriuano público en Bezerril por nuestro señor el rey, que feziese esta carta de perssonería et la signasse / con su signo.

Fecha en Bezerril, a dieziocho días de noviembre, era de mille et quatroçientos et honze años. Testigos rrogados que estauan presentes: Diego Martínez, fijo de 
Pero Roxo, et Sancho / ${ }^{12}$ Ferrández, fijo de Pasqual Abbad, Pero Martínez Reçio, vezinos de Bezerril.

Et yo, Iohán Martínez, escriuano público sobredicho, fuy presente con los dichos testigos, et por rruego del dicho canónigo, escriuí esta carta / de personería et fiz aquí este myo signo en testimonio.

1373, noviembre, 19, sábado. Palencia.

Salvador Pérez, clérigo de Becerril de Campos, en su nombre, en el de los otros clérigos y en el del común de dicho lugar, arrienda a Juan Fernández de Meneses, prior de Santa María de Husillos, los lugares de Pajares y San Sebastián, sitos en el término de Becerril de Campos, en precio anual de varias cargas de pan según la medida toledana. Estas mismas heredades fueron donadas a Santa María de Husillos por Rodrigo Álvarez en mayo de 1226 (véase doc. núm. 49).

A. AHDP, Ampudia y Abadía de Husillos, Pergaminos, carp. 208-19. Perg., 318 x 283 mm.; escr. precortesana; regular conservación con varias pequeñas roturas.

$B$. APA, $L P H$, f. $97 \mathrm{v}$. Si bien en el anverso del documento original se dice: "No está en el Becerro", no es cierto pues fue trasladado hasta "pueda arrendar". Después dice: "No se sacó más desta escritura porque no se pudo leer".

Sepan quantos esta carta vieren commo yo, Saluador Pérez, clérigo de Bezerril, por mí et en nombre de los clérigos et común del dicho logar de Bezerril; por el poder que yo he por / vna carta de procuraçión, escripta en paper et signada del signo de Iohán Martínez, escriuano público del rey del dicho logar de Bezerril, segund que por la dicha carta paresçía, el tenor de la / qual dicha carta de procuraçión es este que se sigue:

(Sigue doc. núm. 172) 
Otorgo et connosco que arrendo a vos, don Iohán Ferrández [de Mixe]zes, [prior] de Fusiellos, a toda mi bentura et de los dichos / clérigos et común del dicho logar, et aventura de Dios et de los otros et de todo fo[...] que se ay podía [...]es[...] a, la heredat de Pajares, asy tierras commo viñas $/{ }^{15}$ con sus diezmos, la qual heredat ha por afrontaçiones: de la vna parte, carrera de Carrión que es en término de Becerril; de la otra parte, el rito del monte de Paredes; et / de la otra parte, el monte de Santa María de Fusiellos; et de la otra parte el Balle Luengo. Et otrosy, vos arrendamos la heredat de Sante Sauastián con los diezmos; que han por linderos: / de la vna parte, tierra que fue de María Áluarez et de la otra parte, el arroyo de Sante Sauastián; et de la otra parte, [...] et la carrera de Sante Sauastián. Et las viñas han por afrontaçiones: la $/^{18}$ carrera de María Áluarez, et de la otra parte, el arroyo et la carrera de Mercaderos et tierra que fue de María Áluarez [...] et de viña de [...]ales et [...] viñas de Pero Diez Corbo / et en linde viña de los clérigos et común de Bezerril et en linde tierra de Domingo Martínez, fijo de Pero [...], qual dicha heredat [...] suos son et pertenescen a la eglesia / de Santa María de Fusiellos más el dicho prior, asy commo a prestamero de la dicha heredat et diezmos lo auedes de auer. Et la dicha heredat arriendo a vos, del día $/^{21}$ de oy que esta carta es fecha, por toda la buestra vida, et pongo con vusco de vos dar en rrenta cada año por la dicha heredat, [...] años dichos $[\ldots]$ cargas de pan, medido a la / medida derecha toledana, a quatro fanegas la carga, plazo que pongo con vusco de vos dar et pagar este año por cada día de Sant Antón este primero que viene puesto / en Bezerril et dende oy adelantre en cada [...] s[...]de media carga de pan, por quantos días pasaren del dicho plazo en adelantre, en pena et en postura $/^{24}$ et en paramiento, que con vusco pongo contado por nombre de in[...] convencional. Et rrenunçio et parto de mí todas las leyes, fechos et derechos, escriptos et non escriptos, ecle/giásticos o seglares et todas ferias de pan et vino, coger hueste et cruzada et voto et rromería et fonsado et todas las sos leys et buenas rrazones et esepçiones, / que sy las ante mi allegare por mí et en nombre de los dichos clérigos et común, que me non valan nin sea sobre ello oydo en juyzio nin fuera de juyzio, ante juez $/^{27}$ nin ante alcalle que en el mundo sea. Et para lo asy avenir et complir, obligo todos los míos bienes, spirituales et temporales, por doquier que los yo he o abre cabo adelantre. / Et otrosy, obligo 


\section{LA ABADÍA DE SANTA MARÍA DE HUSILLOS: ESTUDIO Y COLECCIÓN \\ DOCUMENTAL $(904-1608)$}

todos los bienes spirituales et temporales de los dichos clérigos et común, por doquier que los ellos han o abrán cabo adelante. Et por esta carta / de poder a qualquier alcalle o meryno o juez de qualquier çipdat o villa o logar que a la [...] sinple querella fago o fagan o manden o puedan fazer esempción et $/^{30}$ en carga en mí et en todos mis bienes et de los dichos clérigos et común et las prendas o prenda que a mí et a los dichos clérigos fueren tomada o tomadas, que las vendan luego, / a buena barata o a mala $\operatorname{an}[\ldots] \operatorname{rr}[\ldots]$ et a[... [...]ion et los marauedís que valieren que vos entreguen luego en quantía del dicho pan, con las penas cresçidas que fueren fechas pora / esta rrazón, asy commo sy yo et los dichos clérigos et común lo auiésemos tomado et rrescibido por iuyzio et por $\mathrm{s}[\ldots]$ et posessión, cosa iudgada et notoria et magni $/{ }^{33}$ fiesta. Et yo, el dicho Iohán Sánchez, otorgo et connosco que vos arriendo la dicha heredat et viñas et diezmos por el di[...] et por la valía del dicho, para que me / auedes a dar en cada año et con las cargas et condepnas que dichas son et en esta carta se contienen. Et pongo con vusco, el dicho Saluador Pérez, et prior et con los dichos clérigos et común / del dicho logar abs[...] de[...] [...] [...] la dicha heredat et viñas et diezmos, en el dicho tiempo, por más nin por me[nos] por el tanto que otro me de por $[\ldots]^{36}$ s quanto que vos de otro tal et en tan buena heredat et viñas, commo lo sobredicho. Et de vos lo fazer sano de qualquier omme o muger que vos lo enbargare o contrallare, en qualquier manera / o por qualquier rrazón, por mi deb[...] [...] commo [...]do. Et para lo asy auer et complir, obligo a todos míos bienes, spirituales et temporales, por doquier que los yo he o auere / cabo adelantre. Et por esta carta de poder a qualquier alcalle o iuez de qualquiera çibdat o billa o logar, que me lo fagan asy atener et complir, segund dicho $/^{39}$ es et en esta carta se contiene.

Et porque esto sea firme et non venga en dubda, rrogué et requerí a Pero Sánchez, notario público de la çipdat de Palençia, que escriuie/se o feziese escriuir desto que sobredicho es, dos cartas, amas en un tenor, [et las s]ignase con su signo.

Que fue fecha en la çipdat de Palençia, / sábado, diez et nueue días del mes de nouiembre, era de mille et quatroçientos et honze años. Testigos que estauan presentes, llamados et rrogados speçial ${ }^{42}$ mientre a esto que dicho es: Martín Nicolás de Monte Alegre et Toribio Ferrández, fiio de Toribio Ferrández, vezino del dicho logar de Bezerril, Benito Ferrández, notario, vezino / de Palençia. 
Et yo, Pero Sánchez, escriuano público de la çipdat de Palençia, fuy presente a esto que dicho es con los dichos testigos. Et por rruego et rrequirimiento / del dicho Iohán Ferrández, prior, escriuí esta carta et fiz aquí este mío sig(signo)no en testimonio.

1374, diciembre, 4, lunes. Husillos.

Domingo González, chantre de Santa María de Husillos, dona al prior y cabildo de dicha iglesia, una serie de tierras en Fuentes de Valdepero y en Husillos, para que se doten dos aniversarios perpetuos: uno por el alma de su tio Pedro Fernández, abad que había sido de Husillos; el otro, por el alma de su padre.

A. AHDP, Ampudia y Abadía de Husillos, Pergaminos, carp. 207-20. Perg., 475 x 271 mm.; escr. precortesana; buena conservación.

B. APA, $L P H$, ff. $97 \mathrm{v}-98 \mathrm{r}$.

C. BN, $m s .705$, ff. $213 \mathrm{v}-216 \mathrm{r}$.

Lunes, quatro días del mes de dezienbre, era de mille e quatroçientos e doze años, estando en Fussiellos, en la eglesia / de Santa María, dende e estando el prior e el cabillo de la dicha eglesia, ayuntados e llamados a su cabillo por canpana / tannida segunt que dixieron que lo auían de vso e de costunbre de se ayuntar. Et en presençia de mí, Iohán Fernández de $\beta^{\beta}$ Tablada, notario público de la çipdat de Palençia, e ante los testigos que aquí se conternan, estando presente Domingo / Gonçález, chantre en la dicha eglesia, este día el dicho chantre dixo que daua e donaua e dio e donó en donaçión / de su propria voluntad e sin premia alguna al dicho prior e cabillo de la dicha eglesia, que agora allí estauan presentes e non $/^{6}$ estauan presentes, e a los que viniessen de aquí adelante, para sienpre jamás, vnas tierras que él a en el término del dicho lo/gar e en término de Fuentes de Valdepero, las quales tierras dixo que él tenía e possedía por acto de conpra, 
que él con/prara de algunas personas segunt que se contenía en tres cartas scriptas en pergamino; la vna signada del signo de $/^{9}$ mí, dicho notario, e la otra signada del signo de Ruy Martínez, otrossí notario de Palençia; e la otra signada del signo de / Iohán Alffonso de Pedraza, notario otrossí de la dicha çipdat. E otrossí, que les daua en donaçión otra tierra que non se conte $/^{11}$ nía en las dichas cartas, que estaua çerca de la tierra que se contenía en la vna carta que yo, el dicho notario, signé, que fabla que a / vna obrada, que a por linderos: tierra de Diego Fernández de Piña, alcallde de Palençia, la qual tierra dixo que conprara de vn ${ }^{13}$ procurador de la Cruzada.

Et estas dichas tierras dixo que daua e fazía donaçión, segunt suso, al dicho prior e cabillo, / por rrazón que dixiessen ellos e los que después dellos viniessem, agora e para sienpre jamás, vn enauessario a quinze / días deste dicho mes de dezienbre en cada año, speçialmiente por el ánima de don Pero Fernández, que Dios perdone, abat que ${ }^{16}$ fue en la dicha eglesia, su tío e su señor, que dixo que fuera e speçialmiente para este enauesario, que le daua las dichas tierras / que se contenían en las dos cartas, las quales eran en término de Fussiellos con la dicha tierra que non se contenía en ninguna / de las dichas cartas. Et otrossí, dixo que les daua e donaua e dio e donó las dos tierras que él a en término del dicho 1o $/{ }^{19}$ gar de Fuentes, que él conpró de Fernant Rodríguez, sacristán que es de la dicha eglesia, segunt que se contiene en la una de las / dichas cartas, signada del signo del dicho Iohán Alfonso de Pedraza, por razón que ellos et los que después dellos vinie ${ }^{21}$ ssem, dixiessen en cada año, a diez et seys días deste dicho mes de dezienbre susodicho, agora et para siempre jamás, otro / enaverssario por el ánima de su padre, del dicho chantre, speçialmientre.

Et el dicho prior et cabilldo, estando presentes segunt su/so ayuntados por ssí e por los que non eran presentes e por los que auían de venir después dellos, dixieron que rresçibían las $/^{24}$ dichas tierras aquí contenidas del dicho chantre, con esta carga de fazer e fazer fazer (sic) los dichos enauessarios en cada año agora e / para sienpre jamás por las ánimas de los dichos abat e padre del dicho chantre, al dicho tiempo e tiempos e días aquí contenidos e / en la manera que aquí se contiene. Et el dicho Domingo Gonçález, chantre, apoderó a los dichos prior e cabillo en las dichas tierras ${ }^{27}$ por las dichas cartas de la dicha compra, que les dio luego, e despoderose dellas, et todo el señorío que en ellas auía, para que / 
fagan dellas e en ellas así commo fazen de las otras possesiones que an e deuen fazer de derecho.

Et desto, en commo pasó e com/mo e en qué manera fazía la dicha donaçión e commo el dicho prior e cabillo e chantre sobredichos pidieron a mí, dicho notario, ${ }^{\beta 0}$ que lo diesse signado para el dicho cabillo, vn scripto, o dos, o los que ouiesem mester, e para do los ouiesem mester, e rrogaron / a los ombres buenos que estauan presentes, que fuessem, dello, testigos.

Fecho fue este scripto desta dicha donaçión en el / dicho logar de Fussiellos, día e año e mes e era sobredicha. Testigos que fueron presentes rrogados, llamados speçial $/{ }^{33}$ miente a esto: Gonçalo Ferrández, clérigo de Vellossiello, capellán de los Quarenta Capellanes en la eglesia de Palençia, e Toribio / Ferrández, fijo de Egidio Pérez, e Fernant Gonçález, fijo de Garçi Gonçález, e Iohán, criado del dicho chantre, vezinos de Fussiellos.

Et / yo, Iohán Ferrández de Tablada, notario público sobredicho, fuy pressente a esto que dicho es con los dichos, e ví en commo se fi ${ }^{36}$ zo esta dicha donaçión. $\mathrm{E}$ por rruego del dicho cabillo e prior e chantre, scriuí este scripto de donaçión segunt que pasó e aquí / se contiene, et fiz aquí este my sig(signo)no en testimonio (rúbrica).

1375, febrero, 12. Alcalá de Henares.

Juan Manrique, obispo de Orense y canciller mayor de Enrique II, juntamente con su hermana, Teresa Manrique, reconoce el señorio que Santa María de Husillos tiene sobre Villaldavín, lugar que tenían ocupado, después de haber visto los privilegios de la reina Urraca, de reyes posteriores y del papa, presentados por Gutierre Gómez, abad de dicha iglesia y capellán mayor de la reina. Además instan al concejo y hombres buenos de Villaldavín que reconozcan al abad de Husillos como su señor. 
B. AHDP, Ampudia y Abadía de Husillos, Pergaminos, carp. 201-25. Perg., 341 x 265 mm.; escr. precortesana; buena conservación en cuanto al texto, ya que el lugar de donde colgó el sello de plomo y la correspondiente cinta está rasgado. Inserto en confirmación de Enrique II, dada en Valladolid, a 25 de octubre de 1376. Véase doc. núm. 184.

$C$. APA, $L P H$, ff. 98r-99r.

D. AGS, Patronato eclesiástico, Inconexos, leg.159, ff. 105v-107v. Papel; escr. procesal; buena conservación.

E. ARCHV, Salas de lo Civil. Zarandona y Balboa (OLV). Caja 697.1. Traslado sacado del original, aportado como prueba en un pleito olvidado (1560) del concejo de Villaldavín con Santa María de Husillos, sobre la jurisdicción en primera y segunda instancia en Villaldavín, alegando el concejo pertenecer a la jurisdicción real (véase doc. núm. 286).

ED. SAN MARTÍN PAYO, Villaldavín, 125-127. En este documento, que transcribió del original y no del Libro de los Privilegios de Husillos, como otros, comete algunos errores de transcripción, el más llamativo de los cuales consiste en datar la carta en Ávila, cuando en realidad es Alcalá.

Nos, don Iohán, por la graçia de Dios obispo de Orense, chançeller del $/ 3$ rrey, e yo donna Teresa Manrrique, fazemos saber a uos el conçejo e ombres buenos de Villandouín, que don Gutierre Gómez, abbad de Fusiellos, capellán mayor de la rreyna, vino / aquí a nos e mostronos por priuilleios del papa e de la rreyna donna Hurraca e de los rreyes pasados en commo ese dicho logar es de la dicha eglesia de Fosiellos por quanto fuera fecha / donaçión del dicho logar por la dicha rreyna doña Hurraca a la dicha eglesia, e que nos que teniemos el dicho logar por lo qual que nos pidía quisiésemos dexar e desenbargar $/^{6}$ ese dicho logar a la dicha eglesia, pues es suyo e le pertenesçe por los dichos priuilleios e donaçión sobredicha.

E por quanto el arçobispo nostro tío e nos vimos los / dichos priuilleios e la dicha donaçión, e fablamos por ellos que el dicho logar de Villandouín que es de la dicha eglesia e del señorío della, nos por esto por seruiçio de / Dios e en rremisión de las ánimas de aquellos onde nos venimos, e por seruiçio de la dicha eglesia, touimos por bien de dexar e desenparar ese dicho logar para la dicha $/{ }^{9}$ eglesia de Fusiellos con el señorío e rrentas e derechos que al dicho señorío pertenesçe e pertenesçer deuen daquí adelante fincando nos sienpre a saluo a uos las nostras rrentas / de las nostras heredades que a nos pertenesçen de auer en el dicho logar fuera del dicho señorío. 
Porque vos dizemos e mandamos que de aquí adelante que ayades e obedesçedes / por vestro señor dese dicho logar al dicho abbad que agora y es e a todos los otros abades que fueren por tienpo daquí adelante en la dicha eglesia, e cunplades su $/^{12}$ mandado segund deuedes e sodes tenudos así commo de vestro señor, e le rrecudades e fagades rrecudir daquí adelante con todas las rrentas e derechos que le pertenesçen / e pertenesçer deuen por rrazón del dicho señorío, sacando ende las dichas nostras rrentas de las nostras heredades que nos pertenesçen auer y en el dicho logar e en su / término fuera del dicho señorío commo dicho es, e non fagades ende al por ninguna manera.

E porque entendades que es nostra volontad, dimos esta nostra carta al dicho $/{ }^{15}$ abbad en que escriuimos nostros nonbres e mandámosla seellar con nostros seellos.

Ffecha en Alcalá, doze días de febrero, era de mille e quatroçientos e treze / años. Episcopus Aurien. Doña Teresa Manrrique.

1375, abril, 29, domingo. Husillos

El prior y el cabildo de Santa María de Husillos nombran como procuradores en todos sus pleitos a Fernán Rodríguez, sacristán en dicha iglesia; Alfonso Martínez, abogado; Bernal de Barras, capellán en la catedral de Palencia; Toribio Fernández de la Rúa, y Alfonso, criado del susodicho sacristán, todos ellos vecinos de Palencia.

B. AHDP, Ampudia y Abadía de Husillos, Pergaminos, carp. 211-10. Perg., 482 x 422 mms.; escr. precortesana; buena conservación. Inserto en la sentencia del pleito dada en Palencia, el 25 de agosto de 1375, entre el prior y el cabildo de Santa María de Husillos y Pascual Fernández, por el diezmo de una tierra. Véase doc. núm. 179.

C. APA, $L P H$, ff. 99r-100r.

D. BN, $m s .705$, ff. 216r-220r. 


\section{LA ABADÍA DE SANTA MARÍA DE HUSILLOS: ESTUDIO Y COLECCIÓN DOCUMENTAL $(904-1608)$}

Sepan quantos esta carta de procuraçión vieren, commo nos, el prior et cabillo de la eglesia de Fussiellos, estando ayuntados a nuestro cabillo, llamados por campana tañida, segunt que lo auemos de uso et de co/stumbre de nos ayuntar, speçialmiente para esto que se sigue, otorgamos et connosçemos que fazemos nuestros procuradores generales et speçiales al onrrado varón et sabio Fernant Rodríguez, sacristán en la dicha eglesia, et a / ${ }^{12}$ Alffón Martínez, abogado, et a Bernal de Barras, capellán en la eglesia de Palençia, et a Toribio Fernández de la Ruua et Alfonso, criado del dicho sacristán, vezinos et moradores en la dicha çipdat de Palençia, que esta carta de pro/curaçión mostraran, a todos çinco en vno et a cada uno dellos por su cabo, assí que non sea la condiçión del vno mejor que la del otro, más lo que él uno començare, que el otro o los otros lo pueda tomar et seguir et fenesçer, / para en todos los pleitos, negoçios, questiones et demandas que nos auemos o entendemos auer o mouer contra qualquier o qualesquier personas, eclesiásticas et seglares, de qualquier condiçión, dignidad o estado que sean o $/^{15}$ ellos an o entienden auer et mouer contra nos, en qualquier manera et por qualquier rrazón que sea, para ante qualesquier juezes o alcalles ordinarios o delegados o subdelegados, árbitros eclesiásticos et seglares, que / el pleito o los pleitos ayan poder de oyr et de judgar en qualquier manera. Et damos todo nuestro conplido poder a estos dichos nuestros procuradores et a cada uno dellos, para demandar et responder et defender, connosçer / et negar et poner razones et exepçiones, defensiones, libellos, presentar et responder, contradezir los presentados contra nos, pleito o pleitos, contestar et jurar en nuestras almas toda jura o juras que al pleito o a los $/{ }^{18}$ pleitos conuengan, speçialmiente juramento de calupnia et de verdad dezir, possiçiones, artículos poner et rresponder a los presentados por las partes aduersas et presentar testigos, proeuas et causas et todas las otras cossas que sean master. / Et veer presentar et jurar los de las otras partes et contradezirlos, assí en dichos commo en personas, o poner pleito o pleitos, contestar, concludir et rrenunçiar et oyr sentençia o sentençias, interlocutorias o difinitiuas et consentir et apellar / et alçar et suplicar appellaçiones, alçadas, suplicaçiones, seguir et presentarlas en juyzio o fuera de juyzio et pedir et rresçebir apelos, cartas et instrumentos. Et pedir et jurar et rresçebir costas et despensas, daños et menosca/ ${ }^{21}$ bos et benefiçio de restituçión "et intregrum" et absoluçión a cautela o en otra manera qualquier que sea mester, beneffiçio de 
absoluçión et jurar en nuestras almas de estar a derecho a los mandamientos de santa iglesia, et pedir et rresçebir / carta o cartas de absoluçión et demandar et procurar, en juyzio o fuera de juyzio, todas debdas, bienes et rrentas et derechos, sacrillegios et penas et todas las otras cossas que a nos et al dicho nuestro cabillo pertenesçem / et deuen pertenesçer, en qualquier manera, et pedir et resçebir paga o pagas, entrega o entregas, asentamiento o assentamientos, dar carta o cartas de pago et de quitamiento de todo lo que por nos rresçibieren et fazer et susti/ ${ }^{24}$ tuyr en iuyzio o fuera de iuyzio, antes de los pleitos contestados o después, otro o otros procurador o procuradores, quantos et quando quissieren et rrevocarlos cada que quissieren et tomar en ssí de cabo el offiçio de la procu/raçión et fazer et dezir et procurar, en juyzio o fuera de juyzio, todas aquellas cossas et cada vna dellas, que verdaderos, legítimos et suffiçientes procuradores, pueden et deuen fazer et dezir, et que nos mismos faría/mos, diríamos si presentes fuéssemos, aunque sean tales que mandado speçial requirán. Et obligamos todos lo bienes, del dicho nuestro cabillo, para auer por firme todo quanto fuere fecho, dicho et razonado, quitado et ${ }^{27}$ procurado por los dichos nuestros procuradores et por cada uno dellos o por los sustitutos dellos o de qualquier dellos et de estar et quedar por ello et conplir et pagar todo lo que fuere judgado contra nos, rreleuándolos / de toda carga de satisdaçión, con sus cláussulas.

Et porque esto sea firme et çierto nos, el dicho prior et cabillo, rogamos a Iohán Fernández, notario público de la çipdat de Palençia, que scriuiesse esta carta de procuraçión et la si/gnase con su signo.

Fecha en el dicho cabillo de la dicha eglesia de Fussiellos, domingo, veynte et nueue días del mes de abril, era de mille et quatroçientos et treze años.

Testigos que fueron presentes, llamados et ${ }^{30}$ rrogados a esto: Martín Pérez de La Carua, et Fernando Diez, et Iohan Heruás et Iohán, yerno del familiar, vezinos del dicho logar de Fussiellos.

Et yo, Iohán Fernández de Tablada, notario público de la çipdat de Palençia, fuy presente / a esto que dicho es, con los dichos testigos, et rrogado de los dichos prior et cabillo, scriuí esta carta de procuraçión en la manera que aquí se contiene et la otorgaron. Et fiz aquí este mi signo en testimonio. 
[1375, abril, 29 - 1375, agosto, 22]

Demanda de Fernán Rodríguez, canónigo de Santa María de Husillos, por sí mismo y en nombre del prior y cabildo de dicha iglesia, cuyo procurador es, contra Pascual Fernández, hijo de Domingo Martínez, vecino de Fuentes de Valdepero, por el diezmo de una tierra sita en Husillos, en el término de El sotillo, estimado en tres cargas de trigo, y que según el demandado pertenecía a los clérigos de Fuentes de Valdepero.

B. AHDP, Ampudia y Abadía de Husillos, Pergaminos, carp. 211-10. Perg., 482 x 422 mms.; escr. precortesana; buena conservación. Inserto en la sentencia del pleito dada en Palencia, el 25 de agosto de 1375, entre el prior y el cabildo de Santa María de Husillos y Pascual Fernández, por el diezmo de una tierra. Véase doc. núm. 179.

C. APA, $L P H$, ff. 99r-100r.

D. BN, $m s .705$, ff. 216r-220r.

Ante vos, Iohán Gutiérrez, vicario en toda el abadía de Fussiellos por el onrrado varón et sabio don Gutierre Gómez, / abat de Fussiellos, capellán mayor de la reyna, yo, Fernant Rodríguez, canónigo en la eglesia de Palençia, en nombre de la eglesia de Santa María de Fussiellos et del prior et cabillo, de la dicha eglesia, cuyo procurador so, / ésto es lo que demando a Pascual Fernández, fiio de Domingo Martín, vezino de Fuentes de Valdepero. Et digo que en este año en que estamos, de la era de mille et quatroçientos et treze años, el dicho Pascual Ferrández $\beta^{36}$ cogió trigo en vna tierra que es en término de Fussiellos, a do dizen El Sotillo, que a por linderos, de la una parte tierra de la sacristanía de Fussiellos et de la otra parte La Cuesta et de la otra parte dos caminos que van de / Fussiellos a Fuentes, et non quiso dar el diezmo del dicho pan a la dicha eglesia de Fussiellos. Porque vos pido, dicho vicario, en nombre de los dichos eglesia, prior et cabillo, cuyo procurador so, que por vuestra sentençia difinitiua, / judgándolo assí, mandedes et costringades al dicho Pascual Fernández, que dé cuenta con paga a la dicha mi parte et a mí en su nombre del dicho diezmo del trigo que 
cogió en la dicha tierra este dicho año, segunt dixe, el ${ }^{39}$ qual dicho diezmo, estimo en tres cargas de trigo. Et pídouos, que le mandedes que dé et pague el dicho trigo a la dicha mi parte, do la dicha cuenta con paga non quissiere dar. Et si la otra parte lo sobresdicho me quisiere / negar, pido sseer resçebido a la proeua que yo quiero prouar, todo o parte dello, lo que cumpla a la mi parte et a mí en su nombre et a más non me obligo et querello las costas et pido abogado en este pleito. /

[1375], agosto, 22. Palencia

Carta de citación de Juan Gutiérrez, racionero en la catedral de Palencia y vicario de Gutierre Gómez, abad de Santa María de Husillos, a Pascual Fernández, presentada por Fernán Rodríguez, procurador de Santa María de Husillos, en relación a un pleito litigado por el prior y cabildo de Santa María de Husillos con el dicho Pascual Fernández, por el diezmo de una tierra.

B. AHDP, Ampudia y Abadía de Husillos, Pergaminos, carp. 211-10. Perg., 482 x 422 mms.; escr. precortesana; buena conservación. Inserto en la sentencia del pleito dada en Palencia, el 25 de agosto de 1375, entre el prior y el cabildo de Santa María de Husillos y Pascual Fernández, por el diezmo de una tierra. Véase doc. núm. 179.

C. APA, $L P H$, ff. 99r-100r.

D. BN, $m s .705$, ff. 216r-220r.

La fecha de este documento de este documento debe ser 1375 y no 1376 como aparece en el texto. Aunque en principio es más fiable la data por el sistema del año del Señor que por la era hispánica, el hecho de que el resto de documentos pertenecientes a este pleito se daten en 1375 por la era hispánica, hace que nos inclinemos por dicho año.

De mí, Iohán Gutiérrez, rraçionero en la eglesia de Palençia et vicario en toda el abadía por el onrrado varón et sabio don Gutierre Gómez, abat de Fussiellos, capellam mayor de la rreyna, a uos, Pasqual Ferrández, ${ }^{6}$ fijo de 


\section{LA ABADÍA DE SANTA MARÍA DE HUSILLOS: ESTUDIO Y COLECCIÓN \\ DOCUMENTAL $(904-1608)$}

Domingo Martínez, vezino de Fuentes de Valdepero, salud. Sepades que Fernant Rodríguez, sacristán et procurador del cabillo de la eglesia de Fussiellos, se me querelló et dize que vos, que le deuedes pan et dineros et otras cosas / et que non ge lo queredes dar. Porque uos mando que ge lo dedes o que uos abengades con él, Pero ssi contra esto algo queredes dezir, amonéstovos primero, secundo et terçio, que parescades, ante mí, este sábado primero que viene, a la terçia, a rrespon/der a derecho. Sin non, yo proçedere contra vos quanto fallare por derecho. La carta leyda dátgela.

Dada en Palençia, veynte et dos días de agosto, anno Domini millesimo $\mathrm{CCC}^{\circ}$ $\mathrm{LXX}^{\mathrm{o}} \mathrm{VI}^{\mathrm{o}}$.

1375, agosto, 25, sábado. Palencia.

Sentencia pronunciada por Juan Gutiérrez, vicario de Gutierre Gómez, abad de Santa María de Husillos, del pleito entre el prior y cabildo de Santa María de Husillos y Fernán Rodríguez, su procurador en su nombre, sacristán de dicha iglesia y canónigo en la catedral de Palencia, con Pascual Fernández, hijo de Domingo Martínez, vecino de Fuentes de Valdepero, por el diezmo de una tierra sita en Husillos, en el término de El Sotillo, estimado en tres cargas de trigo, y que según el demandado pertenecía a los clérigos de Fuentes de Valdepero. Establece que el diezmo pertenece al prior y cabildo de Husillos.

A. AHDP, Ampudia y Abadía de Husillos, Pergaminos, carp. 211-10. Perg., 482 x 422 mms.; escr. precortesana; buena conservación.

$B$. APA, $L P H$, ff. 99r-100r.

C. BN, ms. 705, ff. 216r-220r.

Sábado, veynte et çinco días del mes de agosto, era de mille et quatroçientos et treze años. Estando en Palençia, en las cassas do mora el onrrado varón et sabio don Gutierre Gómez, abbat de Fussiellos, capellam mayor de la / 
reyna, estando presente Iohán Gutiérrez, rraçionero en la eglesia de Palençia, vicario por el dicho señor abbat en todos los logares de la dicha su abbadía, después de la misa mayor, librando los pleitos que pertenesçen a la dicha / abadía del dicho señor abat et en presençia de mí, Iohán Fernández de Tablada, notario público de la dicha çipdat, et ante los testigos que aquí se conternan este día ante el dicho Iohán Gutiérrez, vicario, paresçió, de la una parte, el onrrado $\beta$ varón et sabio Fernant Rodríguez, sacristán de la dicha eglesia de Fussiellos et canónigo en la eglesia de Palençia. Et de la otra parte, Pascual Ferrández, fijo de Domingo Martínez, vezino de Fuentes de Valdepero. Et luego, el dicho sacristán, / presentó, ante el dicho Iohán Gutiérrez, et por mí, dicho notario, una carta de çitaçión del dicho Iohán Gutiérrez, scripta en papel et sellada con el sello de çera bermeja del dicho señor abat, en las spaldas, el tenor de la qual carta es este que / se sigue:

(Sigue doc. núm. 178)

La qual, dicha carta de çitaçión, presentada por el $/^{9}$ dicho Fernant Rodríguez, sacristam, et leyda por mí, dicho notario, ante el dicho Iohán Gutiérrez, vicario.

El dicho sacristam presentó, luego, una carta de procuraçión signada de mí, el dicho notario, el tenor de la qual carta es este / que se sigue:

(Sigue doc. núm. 176)

La qual, dicha / carta de procuraçión, presentada et leyda ante el dicho Iohán Gutiérrez, vicario, por parte del dicho Fernant Rodríguez, sacristam, presentó eso mismo el dicho sacristam procurador dicho, un scripto de demanda ante el dicho Iohán Gutiérrez, ${ }^{\beta 3}$ et por mí, dicho notario, contra el dicho Pascual Ferrández, el tenor del qual scripto es este que se sigue:

(Sigue doc. núm. 177)

La qual, dicha demanda, presentada ante el dicho Iohán Gutiérrez, por parte del dicho Fernant Rodríguez, presentada et leyda por mí, dicho notario, el dicho 
Iohán Gutiérrez, vicario, dixo al dicho Pascual Fernández que respondía a ella, et ${ }^{42}$ el dicho Pascual Ferrández dixo que él, que cogiera pan en la dicha tierra et que le estaua defendido que non diese diezmo a los de la eglesia de Fussiellos et que ge lo defendieran los clérigos del dicho logar de Fuentes, / por rrazón que dezían que les pertenesçía et que él, que tenía el dicho pan del dicho diezmo, en fialdat para lo dar a quien lo ouiese de auer de derecho. Et el dicho sacristán dixo que le diese el dicho pan et que sy / algunno le demandasse, que el le sacaría a saluo, et pidió al dicho Iohán Gutiérrez, que le condenase en el dicho trigo del dicho diezmo.

Et el dicho Iohán Gutiérrez dixo que vista la demanda que el dicho Fernant Rodrí $/{ }^{45}$ guez, procurador, fazía et la rrespuesta del dicho Pascual Ferrández et conosçençia que fazía, dixo que pues non mostraua nin allegaua otra rrazón, por ssí, el dicho Pascual Ferrández, contra la dicha demanda que le / ponía el dicho Fernant Rodríguez, que le condepnaua et condepnó en el diezmo del trigo que cogiera el dicho Pascual Ferrández en la dicha tierra este dicho año, que lo dé et pague al dicho Fernant Rodríguez, sacristán, et al / dicho prior et cabillo de la dicha eglesia de Fussiellos, cuyo procurador él es. Et que ge lo dé et pague, de oy día que esta sentençia es dada, fasta nueue días primeros seguientes, so pena de descomonión. Et $/^{48}$ esta sentençia se dio estando presentes Pero Dez et Juan Caluo, clérigos del dicho logar de Fuentes.

Dada fue esta sentençia en Palençia, día et año et mes et era sobredicha. Testigos que fueron / pressentes rogados, llamados a esto: Bernal de Barras, capellán de los Quarenta Capellanes en la dicha eglesia de Palençia, et Alffonso Garçía, mantero, vezinos de Palençia.

Et yo, Iohán Fernández / de Tablada, notario público de la çipdat de Palençia, fuy presente a todo lo contenido en esta sentençia con los dichos testigos, et por ruego et rrequirimiento del dicho sacristam, procurador so/ ${ }^{51}$ bredicho, que me la demandó signada, la scriuí en la manera que pasó. Et fiz aquí este my $\operatorname{sig}($ signo $)$ no en testimonio. 
[Circa 1376, agosto, 5]

Toribio Fernández de la Rúa, vecino de Palencia, procurador del prior y cabildo de Santa María de Husillos, demanda a Briz Fernández y Toribio Fernández por la apropiación del diezmo de una tierra llamada del Congosto, sita en el término de Husillos, estimado en dos cargas de trigo.

B. AHDP, Ampudia y Abadía de Husillos, Pergaminos, carp. 211-11. Perg., 431 x 353 mm.; escr. precortesana; buena conservación, exceptuando las tres grandes roturas que tiene el pergamino. Tiene sello pendiente de cera, dentro de cuyo molde puede observarse, en cera roja, a Cristo o a María sentados en un trono. Inserto en sentencia del pleito dada en Palencia, el 5 de agosto de 1376, entre Santa María de Husillos y el cabildo de la catedral de Palencia, por el diezmo de una tierra llamada del Congosto, en término de Husillos. Véase doc. núm. 182.

Ante uos, el onrrado varón et ssabio don Alfonso Lóppez, deán de Palençia, vicario general en lo spiritual et temporal $/{ }^{6}$ en todo el obispado, por el onrrado padre et sseñor don Gutierre, por la graçia de Dios obispo de Palençia et chançeller mayor de la rreyna. Yo, Toribio Ferrández de la / Rua, vezino de Palençia, en nombre de la eglesia de Santa María de Fusiellos et del prior et cabillo de la dicha eglesia de Fusiellos, cuyo procurador sso, ésto es / lo que demando a Briz Ferrández et a Toribio Ferrández, ssu yerno, vezinos, otrossy, desta dicha çipdat et [...] que en este año en que estamos de la era de mille $/^{9}$ et quatroçientos et doze años. Digo que los sobredichos que cogieron pan, trigo en una terra [...] término del dicho logar de Fusiellos, a do / dizen el Congosto, que ha por linderos, la dicha terra: de la una parte, terra del préstamo [...] Magdalena, et de la otra parte, el camino que / viene de Fusiellos a Palençia et Magaz, cogieron el dicho pan en la dicha terra, non que[sieron nin que]ren dar el diezmo della a la dicha eglesia nin $/{ }^{12}$ al dicho prior et cabillo della; porque vos pido deán, ssennor et vicario sobredicho, en [nombre de la] dicha eglesia et prior et cabillo della, cuyo / procurador sso, que por vuestra sentençia difinitiva, juzgando assy, mandedes et costringades a los sobredi[chos], que den cuenta con paga a la mi parte, del diezmo / del pan que cogieron en la dicha terra, pues pertenesce a la dicha mi parte segunt dixe, que estimo el dicho diezmo en dos cargas de trigo. Et 
pído $/{ }^{15}$ uos que las mandedes dar a la dicha mi parte el dicho pan, do la dicha cuenta, con paga, non quesieren dar. Et sy ésto la otra parte me negare, pido / sser rreçebido a la proeua que yo me ofresco a lo prouar en nombre de la dicha mi parte, todo o parte dello, lo que cumpla a la entençión de la mi parte et a más, / non me obligo et querello las costas et pido abogado.

[Circa 1376, agosto, 5]

Alfonso Fernández de Cuéllar, procurador del cabildo de la catedral de Palencia, contesta a la demanda presentada por Toribio Fernández de la Rúa, procurador del prior y cabildo de Santa María de Husillos, por la apropiación por parte de Briz Fernández y Toribio Fernández, su yerno, del diezmo de la tierra llamada del Congosto. Alega que el diezmo pertenece al cabildo palentino porque dicha tierra se encuentra en término de Palencia.

B. AHDP, Ampudia y Abadía de Husillos, Pergaminos, carp. 211-11. Perg., 431 x 353 mm.; escr. precortesana; buena conservación, exceptuando las tres grandes roturas que tiene el pergamino. Tiene sello pendiente de cera, dentro de cuyo molde puede observarse, en cera roja, a Cristo o a María sentados en un trono. Inserto en sentencia del pleito dada en Palencia, el 5 de agosto de 1376, entre Santa María de Husillos y el cabildo de la catedral de Palencia, por el diezmo de una tierra llamada del Congosto, en término de Husillos. Véase doc. núm. 182.

Ante uos deán, sseñor et juez / ssobredicho, yo, el dicho Alfonso Ferrández, en nombre que de ssuso, rrespondiendo al dicho escripto de rrazones ante nos enpresentado por el dicho Toribio / Ferrández, procurador que sse dize de la dicha eglesia et cabillo, contra los dichos Briz Ferrández et Toribio Ferrández, ssu yerno, que niego el dicho escripto et todo lo con $/{ }^{21}$ tenido en él, en la manera et forma que por él sse contiene, con protestaçión que a ssaluo et guardado, sin que el derecho del cabillo et eglesia de Palençia / et de la dicha mi parte et mío, en ssu nombre, para poner et allegar buenas rrazones et defensiones, 
assy de ffecho commo de derecho, para que ssy el dicho / Toribio Ferrández alguna cosa [quesiere] prouar, porque prouado non le aproueche et aún oponiéndome al dicho pleito por parte del dicho cabillo de la eglesia de $/^{24}$ Palençia, digo que $\mathrm{p}[\ldots]$ exepçiones, que e la dicha terra et los que la labraron por tiempo que es dezmera et dezmaron al cabillo et eglesia de Palencia, / enteramient et a $\operatorname{ss}[\ldots]$ dadores et otro, ssin que el término que la otra parte dize ser de Fusiellos, que es término de la dicha eglesia et cipdat de Palencia $/^{26}$ et lo han et lo [...] en por ssuyo et lo paçen por ssuyo, con ssus ganados por siempre et tanto tiempo acá que memoria de viuos non es en / contrario. Et esto [sobre]dicho me ofresco a prouar sin por la parte auerssa me fuere negado et por ende, lo que la otra parte pide non lo deue auer, / et pido et querello las costas et pido abogado, las quales exepciones, la parte del dicho cabillo de Fusiellos, le nego.

1376, agosto, 5, martes. Palencia.

Sentencia pronunciada por Alfonso López, deán de la catedral de Palencia y vicario general en el obispado de Palencia, del pleito litigado por Toribio Fernández de la Rúa, vecino de Palencia, como procurador del prior y cabildo de Santa María de Husillos, con Gonzalo Ruiz, racionero de la catedral de Palencia, y Alfonso Ferrández de Cuéllar, vicario en dicha catedral, como procuradores del cabildo de la catedral de Palencia, por la apropiación por Briz Ferrández y Toribio Fernández, su yerno, del diezmo de la tierra llamada del Congosto, en término de Husillos, estimado en dos cargas de trigo, que se disputaban Santa María de Husillos y el cabildo catedralicio de Palencia, alegando los segundos que dicha tierra se encontraba en el término de Palencia. La sentencia es favorable a Santa María de Husillos, aunque el cabildo catedralicio apeló al papa. 
A. AHDP, Ampudia y Abadía de Husillos, Pergaminos, carp. 211-11. Perg., 431 x 353 mm.; escr. precortesana; buena conservación, exceptuando las tres grandes roturas que tiene el pergamino. Tiene sello pendiente de cera, dentro de cuyo molde puede observarse, en cera roja, a Cristo o a María sentados en un trono.

In Dey nomine, amen. Seppan quantos esta scritura vieren, commo ssobre pleito et demanda que es ante mí, Alfonso Lóppez, deán de Palençia, vicario general en lo / spiritual et temporal en todo el obispado, por el onrrado padre et ssennor don Gutierre, por la graçia de Dios obispo de Palençia et chançeller mayor de la / rreyna, entre el prior et cabillo de la eglesia de Santa María de Fusiellos et Toribio Ferrández de la Rua, vezino de la cipdat de Palençia, ssu procurador en $\beta$ ssu nombre, de la vna parte; et el cabillo de la eglesia de Palençia et Alfonso Ferrández de Cuéllar, vicario en la dicha eglesia de Palençia et Gonçalo Ruyz, / rracionero en la dicha eglesia, ssus procuradores en ssu nombre, de la otra parte. Et vista vna demanda puesta por parte del dicho cabillo de Fusiellos, / que es el tenor della, éste que sse ssigue:

(Sigue doc. núm. 180)

Et visto en commo por parte del cabillo de la eglesia de Palençia ffue tomado el pleito por los $/{ }^{18}$ dichos Briz Ferrández et Toribio Ferrández, et visto vn escripto presentado por ssu parte, que es el tenor del este que sse ssigue:

(Sigue doc. núm. 181)

Et visto en commo yo fallé / el pleito, contestado por amas las partes et rreçebí juramento de calupnia de amas las partes et rreçebilas a la proeua a amas las partes, et $/^{30}$ visto los dichos de los testigos et los contradichos dellos, et todas las otras cosas et cada una dellas, que amas las partes quesieron dezir et rrazonnar, / ffasta que concludieron et encerraron rrazones et me pedieron sentençia. Et yo, el dicho deán et vicario, visto et examinado bien et diligentmient el / processo deste pleito et auido mi conssejo con omes buenos, letrados, ssabidores en derecho et auido a Dios ante mis ojos, ffallo que el dicho prior ${ }^{33}$ et cabillo de la eglesia de Santa María de Fusiellos et el dicho Toribio Ferrández, su procurador en ssu 
nombre, que prouaron mejor et más complidamient ssu / entençión, que non el dicho cabillo de la dicha eglesia de Palençia nin ssus procuradores en ssu nombre. Et por ende, declarando et sentençiando por mi / sentençia, condeno al dicho cabillo de la dicha eglesia de Palençia et a los sus procuradores en ssu nombre a que den cuenta, en nombre de los dichos Briz Ferrández $\beta^{36}$ et Toribio Ferrández, de todo el pan que cogieron en la dicha terra et que paguen el diezmo a los dichos prior et cabillo de la dicha eglesia de Fusiellos, / de lo que montare en el pan que sse cogió en la dicha terra, o les den et paguen las dichas [dos cargas] de trigo, ffasta nueve días primeros segientes. / Et condeno al dicho cabillo de la eglesia de Palençia en las costa derechas et rreprouo [...]xaçion dellas et pongo plazo para las taxar $\beta^{39}$ para el jueues primero segient. Et por mi sentençia difinitiua iuzgándolo pronuncio assy [...]a.

En la cipdat de Palençia, martes, cinco días / de agosto, era de mille et quatroçientos et catorze años, en perssona de Gonçalo Ruiz, rracio[nero, et Marcho]s Gil, abogado, procurador del dicho cabillo / de Palençia, et d[...] Toribio Ferrández, procurador del dicho prior et cabillo de Fusiellos.

Et [agora] Toribio Ferrández, procurador de los dichos prior et ${ }^{42}$ cabillo de Santa María de Fusiellos, dixo que en lo que fazían, por la su parte, que consentía [...]o, otro que apellauan, por palabra, para ante nuestro / sñor el arçobispo de Toledo et protesto de apellar en escripto en ssu tiempo et en ssu [lu]gar. Et Marchos Gil, procurador del cabillo de la / eglesia de Palençia, apelló "tan quam ab iuque" para ante nuestro señor el PAPA. Et el dicho deán et vicario dixo que le otorgaua et otorgó la dicha apellaçión $/{ }^{45}$ por apelos rreuerendos et que le asignaua et asignó término a que saque el proçesso del pleito cerrado, seellado et signado fasta un mes primero segient / et donde a dos meses, que se presentasen con él ante dicho señor PAPA

Testigos que a esto ffueron presentes: Pero Sánchez et Nicolás Sánchez, notarios, et Dieg Ál/uarez de Palaçios et Iohán Alfonso de Haçeues, otrossy notarios, et Gonçalo Ferrández de Castro et Loppe Ferrández de Llantada, vezinos de Palençia, et Iohán Martínez et Ferrant Martínez / ${ }^{48}$ clérigos de Magaz, et Iohán Alfonso et Gonçalo Martínez, clérigos, et Iohán Mathe, alfajeme, vezinos de Bezerril, et Iohán de Castriello, clérigo de Torquemada. 


\section{LA ABADÍA DE SANTA MARÍA DE HUSILLOS: ESTUDIO Y COLECCIÓN \\ DOCUMENTAL $(904-1608)$}

Et yo, / Iohán Alfonso de Pedraça, notario público de la cipdat de Palençia, ffuy presente a esto que dicho es con los dichos testigos; et por mandado / del dicho deán et a pedimiento del dicho procurador de la dicha eglesia de Santa María et del prior et cabillo de Fusiellos, escriuí esta $/^{51}$ sentençia et fiz aquí este mío sig(signo)no en testimonio de verdats. Alfonso, deán de Palençia.

1376, octubre, 12, domingo. Husillos

El prior y el cabildo de Santa María de Husillos autorizan a Gutierre Gómez, abad de dicha iglesia y capellán mayor de la reina, a permutar con Juan González de Avellaneda, caudillo mayor de los escuderos del rey, las heredades que tenía Santa María de Husillos en Hoyales de Roa y Fuentelisendo, en tierra de Haza, por cinco casas en Valladolid, sitas unas en la calle de La Costanilla; y las otras en la calle que va de la iglesia de Santiago a la puerta que llaman del Campo.

B. AHDP, Ampudia y Abadía de Husillos, Pergaminos, carp. 208-16. Perg., 660 x 551 mm.; escr. precortesana; buena conservación. Llevaba pendientes tres sellos de cera, uno de los cuales, el central, perteneciente al obispo don Gutierre de Palencia, se halla perfectamente conservado. El segundo no conserva la leyenda, pudiendo pertenecer al abad de Husillos. Del tercero solamente queda la cinta.

Inserto en carta de permuta entre Santa María de Husillos y Juan González de Avellaneda, de Hoyales de Roa y Fuentelisendo por cinco casas en Valladolid, dada en Valladolid, a 7 de noviembre de 1376. Véase doc. núm. 186.

C. APA, $L P H$, ff. 100r-103r.

D. BN, $m s .705$, ff. 220r-229r.

REG. SAN MARTÍN PAYO, Apasionante historia de cinco casas, 207-215.

Sepan quantos este público instrumento vieren commo domingo, doze días / del mes de octubre, era de mille et quatroçientos et catorze años, estando en 
Fusiellos, en la eglesia de Santa María del dicho logar. Et estando en el cabillo de la dicha eglesia, a la ora de la terçia, el onrrado varón et sabio don Gutierre Gómez, abad de Fusiellos et capellán mayor de la rreyna / et su chançeller, et Iohán Ferrández, prior, et Ferrand Rodríguez, sacristán, et Diego Gonçález, chantre et canónigos et rraçioneros et medios rraçioneros de la dicha eglesia de Fusiellos, ayuntados a su cabillo, llamados de antenoche por el dicho prior et otro día por campana tañida, segund que lo an de uso $/{ }^{12}$ et de costumbre de se ayuntar en el dicho cabillo, espeçialmiente para el negoçio de yuso scripto. Et en presençia de mí, Iohán Ferrández de Tablada, notario público de la çibdat de Palençia, et ante los otros que aquí se conternan. Este dicho día, el dicho señor abad propuso al dicho cabillo et dixo que bien / sabían en commo, por muchas vezes, auían auidos diuersos tratos sobre fecho de permutaçión de los logares de Foyales et de Fuent Alisendo, que pertenesçían et eran de la dicha su abadía de Fusiellos, por rrazón que los dichos logares et cada uno dellos, auían rrendido et rrendían muy / poco, a él nin a los otros abades, sus antesesores que fueron de la dicha abadía por tiempo, segund que ellos sabían. Et que agora que él et Iohán Gonçález de Avellaneda, cabdiello mayor de los escuderos del rrey, que auían tratado que el dicho señor abad que diese al dicho Iohán Gonçález, en troque $/{ }^{15}$ et en camio los dichos logares de Foyales et de Fuent Alisendo, por dos pares de casas et por la meytad de otro par de casas que el dicho Iohán Gonçález auía en Valladolid, el un par de casas et la meytad del otro par de casas en la calle que dizen de La Costanilla, et el otro / par de casas en la calle que va de la eglesia de Santiago a la puerta que dizen del Campo, que rrendían, cada año, mucho más, que non los dichos logares de Foyales et de Fuent Alisendo. Et el dicho señor abat dixo que veyendo que la dicha permutaçión que el dicho Iohán Gonçález quería fazer con él / de las dichas casas por los dichos logares de Foyales et de Fuent Alisendo, eran muy grant provecho de la mesa de la dicha su abadía, para él et para los otros abades que veniesen después del, por las rrazones sobredichas et por otras muchas, por ende, que entendía que $/^{18}$ esta permutaçión, que el dicho Iohán Gonçález quería fazer con él, de las dichas casas por los dichos logares, que era buena et prouechosa para la dicha mesa de la dicha su abadía.

Et para esto que les pedía et pidió et demandaua et demandó, que le diesen su consentimiento et otorgamiento para / poder fazer la dicha permutaçión con el 
dicho Iohán Gonçález, de los dichos logares de Foyales et de Fuent Alisendo, por las dichas casas. Et luego, los dichos prior et cabillo, auido su trato et acuerdo deliberaçión, sobre esto que dicho es, dixieron que ellos, vyendo que esto / que era seruiçio de Dios et de la dicha eglesia et pro grande de la mesa de la dicha abadía, por las rrazones sobredichas et por otras muchas, que dauan et dieron su consentimiento et otorgamiento al dicho señor abad, tan complido et tan llenero commo de derecho ${ }^{21}$ lo podían et deuían dar, para que, el dicho señor abat, podiese fazer la dicha permutaçión con el dicho Iohán Gonçález. Et todas las otras cosas que çerca este fecho son neseçarias de fazer et que a ellos pertenesçía de fazer, que asy ge lo dauan et dieron et otorgauan et otor/garon. Et desto, en commo pasó, el dicho señor abad pidió et rrogó et mandó a mí, dicho Iohán Fernández, notario, que ge lo diese asy, signado con mío signo para guarda de la dicha permutaçión et rrogó a los buenos, que y estauan presentes, que fuesen dello testigos.

Fecho en el dicho / cabillo, día et año et mes et era sobredicha. Testigos que fueron presentes, rrogados a esto llamados: Tel Ferrández, hermano del dicho señor abat, et Ferrand Alfonso de Vayello et Toribio Ferrández de Maçuela, escuderos del dicho señor abat, et Iohán Garçía Çerçetilla, et Martín Pérez / $^{24}$ de la Carua, et Diego Ximón, vezinos del dicho lugar de Fusiellos.

Et yo, Iohán Ferrández de Tablada, notario sobredicho, fuy presente a esto todo contenido que aquí se contiene con los dichos testigos. Et por mandamiento et rrequirimiento del dicho señor abad, escriuí este público instrumen/to segunt que pasó. Et fiz aquí este mío signo en testimonio.

1376, octubre, 25. Valladolid.

Enrique II confirma, a petición de Gutierre Gómez, abad de Santa María de Husillos y capellán de la reina, un documento (1375, febrero, 12. Alcalá de Henares), inserto, por el que Juan Manrique, obispo de Orense y canciller mayor 
del rey, juntamente con su hermana, Teresa Manrique, reconoce el señorío que Santa María de Husillos tiene sobre Villaldavín, por donación de la reina Urraca en el año 1114.

A. AHDP, Ampudia y Abadía de Husillos, Pergaminos, carp. 201-25. Perg., 341 x 265 mm.; escr. precotesana; buena conservación en cuanto al texto, ya que el lugar de donde colgó el sello de plomo y la correspondiente cinta está rasgado.

B. APA, $L P H$, ff. 98r-99r.

C. AGS, Patronato eclesiástico, Inconexos, leg.159, ff. 105v-107v. Papel; escr. procesal; buena conservación.

D. ARCHV, Salas de lo Civil. Zarandona y Balboa (OLV). Caja 697.1. Traslado sacado del original, aportado como prueba en un pleito olvidado (1560) del concejo de Villaldavín con Santa María de Husillos, sobre la jurisdicción en primera y segunda instancia en Villaldavín, alegando el concejo pertenecer a la jurisdicción real (véase doc. núm. 286).

ED. SAN MARTÍN PAYO, Villaldavin, 125-127. Data la carta inserta en Ávila. Transcribe el documento a partir del original y no del Libro de los Privilegios de Husillos.

Sepan quantos esta carta vieren, commo nos don Enrrique, por la graçia de Dios rrey de Castiella, de Toledo, de León, de Gallizia, de Seuilla, de Córdoua, de Murçia, de Iahén, del Algarbe, / de Algezira, e sennor de Molina, vimos vna carta de don Iohán, obispo de Siguença, obispo que fue de Orense, nostro chançeller mayor, e de doña Teresa Manrrique su hermana, escripta en / papel et firmada de sus nonbres e seellada de sus sellos de çera en las espaldas, fecha en esta guisa.

(Sigue doc. núm. 175)

E agora, el dicho don Gutierre Gómez, abad de Fusiellos, capellán mayor de la dicha rreyna mi muger e su chançeller, pi/dionos merçed que le mandásemos guardar la dicha carta del dicho obispo e de la dicha doña Teresa, su hermana, en todo bien e conplidamente segund que en ella se contie $/{ }^{18}$ ne. E nos, el sobredicho rrey don Enrrique, por fazer bien e merçed e limosna al dicho abbad e a la dicha su eglesia, e porque es obra de piadat e por / muchos seruiçios e buenos que el dicho abbad a fecho e faze e de cada día a nos e a la dicha rreyna mi muger, touiémoslo por bien e mandamos que la / vala e sea guardada la dicha carta al 


\section{LA ABADÍA DE SANTA MARÍA DE HUSILLOS: ESTUDIO Y COLECCIÓN \\ DOCUMENTAL $(904-1608)$}

dicho abbad e a la dicha su eglesia e a los otros abades que después del fueren en la dicha su eglesia agora e de aquí adelante ${ }^{21}$ en todo bien e conplidamente segund que en ella se contiene. E defendemos firmemiente que alguno nin algunos non sean osados de yr nin pasar contra la dicha carta / agora ni de aquí adelante en algund tienpo por alguna manera.

E sobresto mandamos al conçejo e alcalldes e ombres buenos de Villandouín e a todos los / conçejos, alcalldes, jurados, juezes, justiçias, merynos, alguaziles, e otros ofiçiales qualesquier de todas las çibdades e villas e logares de nostros rregnos que agora $/^{24}$ son o serán de aquí adelante e a qualquier o qualesquier dellos a quien esta nostra carta fuer mostrada o el traslado della signado de escriuano público, sacado con / autoridat de juez o de alcallde, que guarden e cunplan e fagan guardar e cunplir agora e de aquí adelante al dicho don Gutierre Gómez, abad, e a la dicha su eglesia / e a los otros abbades sus susçesores la dicha carta del dicho don Iohán, obispo, e de la dicha doña Teresa su hermana, que va encorporada dentro en esta nostra $/^{27}$ carta en todo bien e conplidamiente segund que en ella se contiene e non le vayan nin pasen nin consientan yr nin pasar contra lo contenido en la dicha / carta nin contra parte della en algund tienpo por alguna manera. E los vnos nin los otros non fagan ende al por ninguna manera, so pena de la nostra merçed / e de seysçientos marauedís desta moneda vsual a cada vno.

E si non por qualquier por quien fincar de lo así fazer e conplir, mandamos al ombre que esta $/^{30}$ nostra carta mostrare que los enplaze que paresça ante nos del día que los enplazare, a nueue días primeros seguientes so la dicha pena a cada vno a dezir / por qual rrazón non conple nostro mandado, e de commo esta nostra carta les fuer mostrada e la conpliere, mandamos so la dicha pena a qualquier escriuano / público que para esto fuer llamado que de ende al que la mostrare testimonio signado con su signo porque nos sepamos en commo cunple nostro mandado. ${ }^{\beta 3} \mathrm{E}$ desto le mandamos dar esta nostra carta escripta en pargamino de cuero e seellada con nostro seello de plomo pendiente.

Dada / en Valladolid, veynte e çinco días de otubre, era de mill e quatroçientos e catorze años.

Don Gutierre, obispo de Palençia, / chançeller mayor de la rreyna, e Iohán Alffonso, dotor, oydores de la audiençia del rrey, la mandaron $/^{36}$ dar. Yo, Diego Ferrández, escriuano del rrey, la ffiz escriuir. 


\section{DAVID MARCOS DIEZ}

(Rúbricas) Pero Bernal. Iohán Ferrández.

[1374, diciembre, 4 - 1376, noviembre, 7]

Libro becerro en el que se relacionan las propiedades y rentas de Santa María de Husillos, repartidas en varios capítulos: abad, prior y cabildo, préstamos, capellanías, lámpara y cofradía del hospital. Asimismo se detalla el servicio en la sacristía de la iglesia de Husillos.

B. APA, $L P H$, ff. 192v-212r. En el f. 192v, al comienzo de su margen izq.: <Becerro>.

CIT. SAN MARTÍN PAYO, Las primeras donaciones de los condes de Monzón, 299-349.- El libro becerro de Husillos, 239-260.- Notas históricas de Husillos, 199-235.

El 22 de diciembre de 1183 se hizo la separación de las propiedades y rentas de Santa María de Husillos entre el abad y el cabildo. Desde dicho año hasta la realización de este documento tuvieron lugar numerosos cambios en las posesiones de las mesas abacial y capitular. De ahí que se hiciera necesaria la confección de un documento de relación de las propiedades y rentas de ambas mesas, aunque es extraño que teniendo en cuenta la importancia de un documento de este tipo para la administración y defensa de la hacienda del abad y cabildo, pasara tanto tiempo hasta que se realizó.

El documento nos ha sido transmitido por el Libro de los Privilegios de Husillos, en donde se copió desde un traslado. Sin embargo presenta problemas de datación tanto en su forma original como en el traslado, ya que la primera parte del documento, donde debían constar las fechas tanto del original como del traslado, no se conservaba en 1554, cuando se confeccionó el Libro de los Privilegios. Ante este problema hemos de hacer un análisis individualizado:

- Original:

El mismo documento proporciona algunos datos que delimitan la fecha en el que se realizó. Así ha de ser anterior al 7 de noviembre de 1376, fecha en que Santa María de Husillos permuta las heredades de Hoyales de Roa y Fuentelisendo por unas casas en Valladolid. Dicha permuta aún no se refleja en el documento a analizar (véase doc. núm. 186). Por otro lado comprobamos que en la enumeración de propiedades del cabildo en Fuentes de Valdepero aparecen las dos tierras que el 


\section{LA ABADÍA DE SANTA MARÍA DE HUSILLOS: ESTUDIO Y COLECCIÓN \\ DOCUMENTAL $(904-1608)$}

chantre Domingo González donó al prior y cabildo el 4 de diciembre de 1374 (véase doc. núm. 174). En conclusión, el documento original debió realizarse entre el 4 de diciembre de 1374 y el 7 de noviembre de 1376.

- Traslado:

Un documento de tanta importancia para los intereses del abad y del cabildo sin duda provocaría el deseo de éstos de realizar un traslado lo más rapidamente posible, más aún cuando se trataba de un documento básico para la gestión de la hacienda de ambas partes. De ahí que, como relata el propio documento, se hicieran dos traslados, uno para cada parte. El escribano que realiza el traslado, Juan Fernández de Tablada, aparece en otras dos escrituras de la colección que tienen como data: 4 de diciembre de 1374 y 25 de agosto de 1375. Por ello la fecha del traslado debe encuadrarse en estas fechas, que coinciden con la del original.

Por otra parte, suponemos que dicho traslado es el denominado "Becerro" por varios documentos, incluído el propio Libro de los Privilegios, y que aunque es datado en 1415, probablemente no se hizo la conversión de la fecha en dichos documentos desde la era hispánica, siendo la data resultante 1377. El testimonio documental más esclarecedor que apoya nuestra teoría es un listado de documentos presentado en la contaduría episcopal por la colegiata de Ampudia (1799, noviembre, 11) en el que se extracta la ejecutoria de un pleito sentenciado por juez apostólico entre el prior y cabildo de Santa María de Husillos con Juan de Curiel de la Torre por la posesión de varias propiedades y rentas. ${ }^{11}$ En dicho pleito el prior y cabildo presentaron un certificado de propiedad de las posesiones en litigio que se sacó del "libro de becerro, formado el año de 1415". Dicho certificado coincide plenamente con el documento a estudiar.

En el Libro de lo Privilegios se traslada el traslado perteneciente al prior y cabildo, deduciéndose que el original no se debía de conservar. Por otra parte, el documento que se traslada debía de estar mal conservado y parte de él roto, ya que no se signó. Probablemente el amplio uso que harían de sus respectivos ejemplares tanto el abad como el prior y cabildo en la gestión y defensa de sus patrimonios, hizo que en 1554 solamente se conservara en el archivo de Santa María de Husillos el ejemplar del prior y cabildo, que es el que se traslada en el Libro de los Privilegios, en no muy buenas condiciones, de ahí que no se validara; lo cual no quiere decir que el original y el traslado del abad no existieran. Probablemente estarían utilizándose en la gestión de algún negocio o como prueba en algún pleito, teniendo en cuenta además el extendido absentismo de los abades que podía provocar fácilmente la pérdida de su ejemplar.

Esta escritura no se sinó por estar rrota parte della y no se poder leer.

[...... A más el dicho abad todo el suelo de Fusiellos y todo el suelo que estoviere despoblado año y día, e puédelo dar, el abad, a quien lo pueble, si el señor que lo tovo ante poblado, no lo poblare antes que el abad lo dé.

\footnotetext{
${ }^{11}$ APA, Leg. 152, carp 1.
} 
Éstos son los suelos que an de pagar ençenso cada año:

Las casas de hijos de Joán Sánchez, dé çinco marauedís. Las casas de Bartholomé Pérez, que son agora de Gonçalo Ruiz, çinco marauedís. Las casas de Pero Fernández Casado, un marauedí. Las casas de Joán Hernández de Buzón y la herrén que conpró de Diego Fernández "El Romo", un marauedí. Et más, otro suelo çerca de la puerta Nueva que tenía Pero Fernández de Vallejo, en linde huerta del abad et la cal, çinco marauedís. Otro suelo que tenía Domingo Fernández, fijo de Antón Pérez, en linde casas de los moços del coro y casas de Domingo Martínez, çinco marauedís. Las casas del dicho Domingo Martínez, çinco marauedis. Otras casas que tiene Alfonso de Arbannejo, en linde casas de Gonçalo Ruiz y la huerta del sacristán, çinco marauedís. Otras casas de Gonçalo Gonçález en la cal Nueva, un marauedí. A más, unos molinos en la parada que dizen Cabe Casa; en la qual parada ay diez canales y, destas, son las siete del abad; de las quales siete, están los çinco aparejadas y las tres desaparejadas; a los quales siete molinos de abad, dizen así: Cabeun, Çorçancada y Montonçiello y Harrén Casiellas y Anulejos y Annal; y los otros tres, son los dos del cabillo y llaman Aluno, y el otro es de la obra y llámanle Uzo. En la pesquera destos dichos molinos, en que a el abad las dos partes, el dicho cabillo a la una parte. A más, un soto que tiene desde los dichos molinos de Cabecasa y llega hasta los molinos del cabieldo, que dizen Cabo de Viña, y çércale, en derredor, el rrío. Y a más, el rrío, en quanto tiene el soto en derredor.

Ésta es la eredad de Fusiellos y sus términos:

Primeramente, a una tierra que llaman la Serna del Molino, con las arrotura que fizo el abad don Pero Fernández, en que ay sesenta obradas, y esta tierra a por afrontaçiones: de la una parte, el molino de Cabo de Viña; y de la otra parte, molinos de Cabe Casa; y de la otra parte, el soto del (f.192v) dicho señor abad; y de la otra parte, las Paredejas, que dizen. A más, la serna del Moral, en que ay veynte obradas, que a por afrontaçiones: de la vna parte, la huerta que dizen de Canóniga; y de la otra parte, el camino que va a Monçón; y de la otra parte, el 


\section{LA ABADÍA DE SANTA MARÍA DE HUSILLOS: ESTUDIO Y COLECCIÓN \\ DOCUMENTAL $(904-1608)$}

arroyo que va al rrío, que llaman de Frieras. A más, la otra serna que dizen de la Puente Vieja, que ay çinquenta obradas, que a por afrontaçiones: de la vna parte, el camino que va a Monçón; y de la otra parte, la tierra de Mari Mora; y de la otra parte, Cubafarta, que dizen. A más, otra serna que dizen de Requexo, en que ay veynte y çinco obradas, que a por linderos: de la vna parte, camino que va a Monçón; y de la otra parte, tierra de Martín Pérez. Otra tierra camino de Monçon, [...] obradas, que a por linderos: de la una parte, [...] Pérez y de su yerno; y de la otra parte, tierra de Gonçalo Ruiz. A más, otra tierra que es allende la Puente Vieja, que llaman el Piquillo, en linde, la una parte, el camino de Monçon; y de la otra parte, el rrío; y en frente, la tierra de Rey. A más, otra tierra que dizen el Pico, en que a diez obradas, que a por linderos: de la vna parte, los términos que vienen de Monçon; y de la otra parte, tierra de Gonçalo Ruiz. A más, otra tierra a las Junqueras, en que a una obrada, en linde: de la vna parte, camino de Ribas; y de la otra parte, tierra que fue de Martín Díaz, que es agora de la capellanía de Santa Brígida, çerca del majuelo de Garçía Troxo. A más, otra tierra carrera de los Cabrones, en que a una obrada, que a por linderos: de la vna parte, tierra del Ospital; y de la otra parte, tierra de Santa Bríjida. A más, otra tierra al Finojal, en que ay una obrada, que a por linderos: de la vna parte, Joán Fernández de Buço; y de la otra parte, tierra de Los Monaziellos. A más, otra tierra de las Foyadas, que dizen, en que ay diez obradas, que a por linderos: de la vna parte, el camino de Fuente Quinava; y de la otra parte, el Arroyo de las Foyadas. A más, otra tierra a Mançanedo, en que a quatro obradas, que a por linderos: de la vna parte, tierra del Hospital; y de la otra parte, viña del cabillo. A más, otra tierra carrera de Santillán, en que ay quatro obradas, que a por linderos: de la una parte, el dicho camino de Santillán; y de la otra parte, tierra de la lánpara. A más, viña que dizen de la Sancta Profiada, en que a diez [obradas], a por linderos: de la vna parte, el camino que viene [...]; y de la otra parte, tierra de Mari Fernández Coronella. A más, la serna de La Rallosa, en que ay treynta obradas, que a por linderos: de la vna parte, tierra del prior; y de la otra parte, tierra de Joán Fernández de Potes; y de la otra parte, tierra de La Mula, del dicho Joán Fernández. A más, otra tierra pasadas las aceñas, contra Grijota, que dizen la Tierra Bermeja, en que ay diez obradas, que a por linderos: de la vna parte, el camino que va a Grijota. A más, otra tierra a do dizen la Galga, aliende el rrío, en que ay quatro obradas, que a por 
linderos: de la vna parte tierra de Joán Garçía Asturiano; y de la otra parte, tierra de Martín Pérez, fijo de don Antolín. A más, la Serna Maior del Congosto, en que a sesenta obradas, que a por linderos: de la vna parte, el camino que va a Palençia; y de la otra parte, tierra que fue de Fernando Díaz y es agora de Álvaro Ruiz de la Serna; y de la otra parte, tierra de la Obra de Santa María de Fusiellos. A más, otra tierra a las Fontaniellas, que a por linderos: de la vna parte, el camino de Palençia; y de la otra parte, tierra del Hospital de Fusillos; y de la otra parte, la Questa. A más, otra tierra camino de Palençia, que dizen el Pico, en que a tres obradas, que a por linderos: de la vna parte, el dicho camino; y de la otra parte, tierra de la capellanía de San Joán de Fusiellos. A más, la serna que dizen Longuera, en que a diez obradas, que a por linderos: de la una parte, la tierra de la huelga de Santa María Madalena; y de la otra parte, [...] de Castro. (f.193r) A más, otra tierra ay luego, que a por linderos: de la vna parte, tierra de fijo de don Fernando. A más y luego otra tierra a la huelga, en que a dos obradas, que a por linderos: de la vna parte, tierra de Garçi Fernández de Castro; y de la otra parte, tierra del préstamo de Santa María Madalena. A más, otra tierra a los Canpejones, en que a seis obradas, que a por linderos: de la vna parte, el camino de Palençia; y de la otra parte, tierra de la Obra de Santa María de Fusiellos. A más, otra tierra aliende del rrío, a la Vega, en que ay una obrada, [...]. A más, la serna del Sotillo, en que a diez obradas, que a por linderos: tierra del préstamo de Santa María Madalena; y de la otra parte, el camino que va para Fuentes; y de la otra parte, la huelga. A más, otra serna al majuelo de Fernán Gil, en que ay veynte obradas, que a por linderos: de la vna parte, tierra del prior de Fusiellos; y de la otra parte, el camino que va a Ribas. A más, otra serna que dizen Godina, en que ay treynta obradas, que a por linderos: de la vna parte, el arroyo de Frayres; y de la otra parte, tierra que fue de Juan Gil de Fuentes. A más, tres tierras en la Cotorra, en que a quarenta obradas, que a por linderos: el camino que va de Bezerril a Monçón; y de la otra parte, otro camino que atraviesa para Ribas. [...] a la eredad de Requexo, de allende el agua, en que a sesenta obradas, que a por linderos: camino que va a Fuentes; y de la otra parte, el sotillo del cabillo; y de la otra parte, la huelga que anda al derredor. 
Éstos son los solares de que a, el abad, llevar ençensos en Fusillos y lo que dio él a sus vasallos:

Primeramente, casas de Gonçalo Ruiz, do solían llamar el Olmeda, Cabeballaca, que a dar al abad [...]. Las casas que fueron de Martín Sánchez, de la Corredera al Olmeda, que an de dar al abad çinco marauedís. La casa de Joán Quintero, en linde casas de Gonçalo Ruiz, y a de dar en ençenso, çinco dineros. Las casas que fueron de Pero Fernández y son de Marcos, su hermano, en linde de huerta del abad y en linde de la çerca, an a dar en ençenso un marauedí. Las casas de Joán Fernández de Buzon, que son en linde del palaçio del Abad, çerca de la yglesia, y an a dar en ençenso, çinco dineros. Un suelo que es de Alvar Ruiz de la Serna y fueron de Fernando Díaz, e diógelas el abad Nuño Díaz, que son en linde casas de Gonçalo Ruiz. Unas casas de Juana Gutiérrez que son en la Olmeda, linde las casas de Gonçalo Ruiz, que fueron de Rui Pérez "El Molinero", diógelas el abad Nuño Díaz. Unas casas que fueron de Sancho Martínez, canónigo, y óvolas de Pero Martínez de Baños, fijo del prior Martín Garçía, diolas el abad Nuño Díaz a Pero Martínez. A más el abad en Santillán de la Cuesta, una yantar cada año y treynta y seis maravedís.

Villaudilla:

Villaudilla es toda suya, del abad, y a la jurisdiçión en lo spiritual y tenporal en esta manera que se sigue: la yglesia es toda suya y a de poner y capellán. A más el abad, el diezmo de todo el lugar y todo su término de pan y vino y de granado y menudo. y si labran su eredad, del dicho término, los de Paredes y los de Bezerril a la meytad del dicho diezmo y si labra en lo del abad, a él, todo el diezmo. A más el abad en el dicho lugar, los sacrilegios que y fueran fechos. Y a más, una yantar en el dicho lugar por rrazón de vigitaçión, él o su vicario, si va o ynbía a vegitar. A más el abad en el dicho lugar, unas casas de su morada, tejadas, fuera del cortixo.

Temporalidad: 
A de poner alcaldes y merino, quando él quisiere y fasta quanto tienpo quisiere, y a las penas y calonnas y omezillos que fueren fechos en el dicho lugar y en su término. A más en el dicho lugar, en cada un año, treynta marauedís de (f.193v) martiniega. A más, el pecho que dizen março, treynta marauedís, y cada suelo poblado, ocho dineros, y cada suelo de huerta, quatro dineros.

Éstos son los heredamientos que a el abad en Villaudilla y sus términos:

Primeramente, una tierra a Conejeras, en que a catorze obradas, la qual parte el término entre Paredes y Villaudilla. A más el abad, otra tierra en que [...] obradas, que llaman el Pico, carrera de Paredes. Otra tierra çerca desta, que llaman carrera Traviesa, en que ay vna obrada. Otra tierra de yuso, que llaman carrera de Paredes, que a en ella çinco obradas. Otra tierra linde desta, en que a dos obradas. Otra tierra linde desta, que llaman la de Las Majuelas, en que a una obrada. Otra tierra al Barro, en que a çinco obradas. Otra tierra carrera de San Fagún, en que a çinco obradas, que llaman El Silo. Otra tierra a La Quebrantada, en que a diez obradas. A otra tierra entre carrera de Bezerril e carrera de Fusiellos, en que a treynta obradas. A otra tierra a Las Lagunillas, carrera de Fusiellos, en que ay [...] obradas. Ay otra tierra de diez e seis obradas. Ay otra tierra y çerca, que llaman La Troxa, de dos obradas. Ay otra tierra que llaman Çima de La Loma, de çinco obradas. Otra tierra en término de Bezerril que llaman a Corteruelas, carrera de Palençia, de sesenta obradas. Otra tierra en término de Bezerril que llaman tierra de Nuño Gutiérrez, de catorze obradas. A otra tierra en término de Bezerril, linde el sendero de Viñaderos, en que ay çinco obradas. Otra tierra en término de Villaudilla, linde el sendero de Viñaderos, en que ay una obrada. Otra tierra que llaman Serna de Poza Nava, de çiento y diez obradas. Otra tierra carrera Malladas, a la dos obradas. Otra tierra carrera de Posa Nava de Padiella, de siete obradas. Otra tierra que llaman al Pico de don Ximeno, de doze obradas. Otra tierra de la otra parte, linde de la carrera de Pozo Nava, que llega a carrera de Padiella, de diez e seis obradas, que llaman agora Pico de Juan Alfonso. Otra tierra a Las Frieras, que llega a carrera de Padiella, de çinquenta obradas. Otra tierra çerca de la yglesia de Santa María, que llega de la rotura de conçejo, de ochenta obradas. Otra tierra a La Cava que dizen, de quarenta obradas. A más en las arroturas de 


\section{LA ABADÍA DE SANTA MARÍA DE HUSILLOS: ESTUDIO Y COLECCIÓN \\ DOCUMENTAL $(904-1608)$}

los prados, quarenta y çinco obradas. Otra tierra a Santa María, tras la casa de la yglesia, de quatro obradas. Otra tierra de la otra parte, çerca de la yglesia, de seis obradas. Otra tierra al Pico, carrera de Santa María, de tres obradas. Otra tierra çerca de la era, que llega carrera de Monçón, de dos obradas. Otra tierra linde de la era del Palomar, de dos obradas. Otra tierra carrera de Palençia, que llega a la carrera de Monçón, ençima de la tierra del Mollete, de dos obradas. Otra tierra en Escobares, de tres obradas. En la ferrenes menudas de en derredor de la villa ay quatro obradas. Otra tierra carrera de Frechiella, con un pedaçuelo de la otra parte, de dos obradas. Otra tierra a las viñas de los arenales, a La Solana, de una obrada. Otra tierra, linde del sendero que va a La Tuda, de obrada y media. Otra tierra que está entre las viñas, de media obrada. Otra dañosa de nueve obradas. Otra tierra de ocho obradas. Otra tierra carrera Traviesa, de media obrada. Otra tierra a La Açuda, de media obrada. Otra tierra en Las Viñas, que llaman tierra de Maça Ericas, de dos obradas. Otra tierra de media obrada, que es a Senderuela, que va a las viñas de Fuentes. Otra tierra de las Manguiellas, de media obrada. Otras dos tierras ençima de La Aguilera, de dos obradas, entre el Sendero de la Aguilera. A más en tres lugares, obrada y media. Otra tierra so La Aguilera, çerca del término de Fuentes, en que a una obrada. A más, una tierra a la Poza, en que a [...] obradas. A el abad viñas carrera de Los Arenales, en que ay tres quartas. A otra viña a las Manguillas del Val, en que ay quarta y media. A más el abad en Villaudilla que le an de fazer los vasallos, dende el lugar, tres sernas en el año. A el abad más en Villaudilla, un palaçio en par de la yglesia.

San Adrián:

Ésta es la eredad que a el abad de Fusiellos en Sant Adrián, çerca de Vega de Valdepero y de Fuentes. Primeramente, a una iglesia que dizen de (f.194r) Sant Estevan e casas con vn corral e vna aceña. A todo el diezmo granado y menudo del lugar de Sant Adrián e de todo su término. A más, primeramente, una tierra en Val de Nuño, en qua ay quinze obradas, qua a por linderos: de la vna parte, tierra de Alvar Alfonso de Fuentes; y de la otra parte, tierra de la orden de San Joán. Otra tierra que dizen a La Laguna, que a por afrontaçiones: de la una parte, camino que va a Foyal; e de la otra parte, tierra de Juan Diego; et de la otra parte, 
tierra de la cofradía de Vega, en que ay seis obradas. Otra tierra do dizen al Foyo, en que puede aver vna obrada, que a por afrontaçiones: de la vna parte, la carrera que va de Vega a Foyal; y de la otra parte, viña de los nietos de Domingo Ramos. Vna façuela en que ay fasta una obrada, do dizen al Foyo, que a por afrontaçiones: de cada parte al derredor, tierras del señor de Fuentes de Valdepero. Otra tierra camino que va de Palaçuelos a Palençia, en que ay media obrada, que a por afrontaçiones: de la vna parte, tierra de Juan Martínez, fijo de Rui Martínez; y de la otra parte, tierra de la muger de Martín Joán. Otra tierra al Foyo, en que ay quatro obradas, que a por afrontaçiones: de la vna parte, tierra del señor de Fuentes; y de la otra parte, viña que fue de los fijos de Juan Garçía de Petrel. Otra tierra a Valprade, en que ay doze obradas, que a por afrontaçiones: de la vna parte, tierra de Mençía López de Torquemada; e de la otra parte, tierra el camino que va de Fuentes de Valdepero a Palaçuelos; y de la otra parte, tierra de los fijos de Miguel Mocho. Otra tierra que llaman La Serna, que ay fasta çiento e diez obradas, que a por afrontaçiones: de la vna parte, tierra de la capellania que dexó Martín, clérigo de Quintanillar; e de la otra parte, tierra de Domingo Garçía de Fuentes; e de la otra, el rrío que dizen de Sant Adrián, que va de Palaçuelos a Palençia. Y más en la parte fazia Fuentes, a por afrontaçiones: tierra de fijos de Martín Joán de Fuentes et de doña Joana, fija de Domingo Pérez. Otra tierra que dizen El Pico de Casarejos, en que ay fasta çinco obradas, que a por afrontaçiones: de la vna parte, camino que va de Fuentes a Santo Adrián; e de la otra, camino que va de Quintanilla a San Adrián. Otra tierra a Casarejos, en que a dos obradas, que a por afrontaçiones: de la vna parte, camino que va de Fuentes a Sant Adrián; e de la otra parte, tierra de Pero Payo; e de la otra parte, Sancha Marina. Otra tierra que es el prado de la Presa, en que ay seis obradas, que a por afrontaçiones: de la vna parte, el camino que va de Fuentes a Palaçuelos; y de la otra parte, el prado del abad de Fusiellos, que dizen de La Presa. Otra tierra que está çerca del dicho prado, en que ay media obrada, que a por afrontaçiones: de la vna parte, tierra de Fernando, yerno de don Marcos de Palaçuelos; de la otra parte, el arroyo que viene de Palaçuelos. Más dos prados, el uno que dizen de La Presa y el otro prado que dizen de Sant Adrián.

Fuentes de Valdepero: 
A el abad en Fuentes de Valdepero, vn préstamo que es anexo al abadía, que ay de estimaçión diez marauedís de pan y vino, y los menudos liévalos el clérigo que pone el abad en la yglesia de San Pero; los quales diezmos, son la sesma parte de todos los diezmos del dicho lugar. A más el dicho abad en el dicho lugar de Fuentes, jurisdiçión y una yglesia que dizen San Pero, y a de dar, el dicho abad, el benefiçio de la dicha yglesia, quando vacare cura, y a de visitar, el abad, la dicha yglesia e anle de dar de comer el día que visitare, a él o al que vigitare por él, y non a procuraçión de dineros. Et a más, que todos los pleytos que perteneçen a la dicha yglesia, que los a de librar el dicho abad y son de su abdiençia. A más el abad, a de poner terçero en la dicha yglesia de San Pero y a de tomar quenta de lo de la dicha yglesia.

Eredad de Fuentes de Valdepero:

Primeramente, a vna tierra en El Llano, carrera la Cueua, en que ay ocho obradas, que a por linderos: tierra de Joán Miguel y la carrera que va a La Cueva. A más, otra tierra en Val de El Llano, en que ay quatro obradas, que a por linderos: tierra de Joán, fijo de Domingo Pérez y tierra de Joán Gómez. A más en El Llano, sobre El Pedrón, otra tierra en que $(f .194 v)$ a vna obrada, que a por linderos: tierra de Joán Delgado y tierra de Domingo Gonçalo. A más, otra tierra al Silo, por do van a San Christoval, que tiene Rui Gonçález. A más, otra tierra en Llano, sobre Val de Çecán, que a por linderos: tierra de Estevan, nieto de Pero Gutiérrez; e de la otra parte el sendero. A más ençima de carrera Cavejas, otra tierra en que a media obrada, en que a por linderos: el sendero; y de la otra parte, tierra de Joán Gómez. A más en Val, otra tierra en que a una obrada, que a por linderos: tierra de Toribio Carniçero; y de la otra parte, tierra del camarero. A más en la Laguna, otra tierra en que a dos obradas y media, que a por linderos: tierra de Juan, fijo de Domingo Pérez; y de la otra parte, tierra de fijos de Andrés Pérez. A más, otra tierra carrera del Río, que a por linderos: de la vna parte, la carrera; y de la otra parte, tierra de Joán de Fuentes. A más, otra tierra carrera de Requexo, en que a obrada y media, que a por linderos: tierra del señor de Monçón e tierra de la yglesia de San Estevan. A más tierras San Estevan, que a una obrada, que a por linderos: Martín, 
yerno de don Pero, e tierra de las fijas de [...]. A más a La Loma, en linde de la carrera, otra tierra en que a tres obradas, que a por linderos: tierra de Alfonso Garçía y la carrera que va a Monçón. A más tierras San Estevan, otra tierra en que a una quarta, que a por linderos: tierra de Gonçalo Delgado. A más al Foyo de San Pero, quatro tierras en que ay ocho obradas, que a por linderos: la carrera; y de la otra parte, la cantera y tierra de los hijos de Domingo Gonçalo y tierra de Pascual e tierra de Martín Fernández. A más so La Cueva, otra tierra en que ay quatro obradas, que a por linderos: la carrera e tierra de los fijos de Martín Joán. A más carrera de Palaçuelos, dos tierras en que ay una obrada, que a por linderos: tierra de Martín Tizón e tierra de Martín Joán y tierra de Toribio Carniçero; e la otra tierra a por linderos: tierra de Joán e de Domingo Pérez e tierra de Rodrigo, fijo de Domingo Martínez. A más a La Losa, otra tierra en que a media obrada, que a por linderos: tierra de Pero Díaz, clérigo, e tierra de los de Estrada. A más otra tierra a Palaçuelos, linde de tierra de Pero Martín y de tierra de Alfonso Garçía. A más otra tierra a so Rebiella en linde del prado, en que a tres obradas, que a por linderos: con la façuela, tierra de Alfón Garçía y tierra de los hijos de Estevan Rascacho e tierra de los hijos de Sancha y tierra de los de Estrada y tierras de Joán de Prasençio e tierra de los hijos de Joán de Oleo. A más a la Vega, quatro tierras en linde del prado, en la vna a tres obradas, que a por linderos: tierra de Joán Fernandez e tierra de los fijos de Alfonso Díaz; y la otra, a por linderos: a La Vega, linde de tierra de Joán Martínez e tierra de los fijos de Alfonso Díaz; la otra tierra en [que] a obrada y media, a por linderos: tierra de Domingo Garçía e tierra de Martín Joán. A más otra tierra en que a dos obradas, que a por linderos: tierra de Garçía Tirón e tierra de Pero "El Pastor". A más, otra tierra a carrera de Villalobón, que a por linderos: tierra de Pero Díaz e tierra de Rui Gonçález. A más dos tierras carrera de Palençia, en que a vna obrada, que a por linderos: el camino que va a Palençia e tierra de Pero Díaz y tierra del Camarero. A más otra tierra a la viña de Olalla, en que ay una obrada, que a por linderos: tierra de Pero Díaz e tierra de Rodrigo, su yerno. A más una tierra carrera de Villalobón, en que ay media obrada, que a por linderos: tierra de Martín, yerno de Domingo Estevan, y tierra de los nietos de Fernán Peláez. A más otra tierra carrera de Villalobón, en que ay media obrada, que a por linderos: tierra del fijo de Fernán Sánchez y tierra de Joán Gómez. A más otra tierra a Braçiellas, que a media obrada, que a por 


\section{LA ABADÍA DE SANTA MARÍA DE HUSILLOS: ESTUDIO Y COLECCIÓN \\ DOCUMENTAL $(904-1608)$}

linderos: tierra de Joán Merino y el sendero que va a Braçiellas. A más otra tierra al Mançanillo, en que a obrada y media, que a por linderos: la carrera del Val y tierra de los fijos de Yllana y tierra de Domingo Gonçalez y viña de Alfonso Abad. A más otra tierra a Labaniegos, en que a media obrada, que a por linderos: tierra de don Garçía y tierra del camarero.

Viñas que a el abad en término de Fuentes:

(f.195r) A el abad en término de Fuentes vna viña carrera del Río, en que ay tres arançadas, que a por linderos: tierra del señor de Fuentes e viña de Domingo Garçía y el camino que va a Fusiellos. A más otra viña en linde del camino del Monçón, en que ay seis quartas, que a por linderos: viña de Joán Felipe. A más, otra viña carrera del Río, en que a una alançada, que a por linderos: viña de Joán Fernández e tierra de Pero Mínguez e viña de Fernán Garçía. A más otra viña en Manblas, en que a una alançada, que a por linderos: viña de los capellanes e viña de Domingo, fijo de Domingo Pérez. A más otra viña en Manblas, en que a una arançada y a por linderos: viña de Domingo Garçía y el camino. Otra viña a la Cabaña de Braçiellas, en que a una quarta, que a por linderos: de la vna parte, viña de la cofradía de San Christóval. A más otra viña a Braçiellas, en que a media alaçada, que es en linde del sendero y en linde de viña de Joán Garçía. A más otra viña a La Monienca, en que a vna quarta, que a por linderos: de la vna parte, viña de Fernán Garçía y viña de Estevan Pérez.

Torre, çerca de Astudillo:

Ésta es la heredad que a el abad de Fusiellos en Torre, çerca de Astodiello. Primeramente, un solar con sus casas, más un ferrén en linde del camino que va a la fuente [...] obrada, más un huerto, más una era. Tierras: la vna en linde de los prados de Fuente, a en ella diez obradas. E la otra es en el páramo, çerca de Val de Olmos, en linde de las viñas de Val de Olmos; e de la otra parte, el camino que va a Espinosa, en que a ocho obradas. A más, vna tierra en que a catorze obradas, que a por linderos: de la vna parte, el majuelo de la orden de Santiago; et de la otra parte, el prado defesado. A más, tres pedaços de viña; los dos son carrera de 
las Çarças, que a en ellas dos alançada; y el otro pedaço es en Fondón del Prado y a en el tres alançadas y media. Más otra viña en que a çinco quartas, a Los Salzes, que esta en linde de la otra viña que es a Las Çarças.

Sant Sebastián:

Sant Sebastián es todo el lugar del abad y a toda la jurisdiçión en lo tenporal y espiritual. Primeramente, a la presentaçión de los clérigos y a de dar el cura. A más las dos partes de todo el diezmo del dicho lugar y la terçia parte es de los clérigos del dicho lugar. El abad a de proveer la iglesia de çera y azeyte y de sogas y de todo lo que oviere menester. A más todos los sacrilegios que fueren fechos en el dicho lugar. A más la visitaçión de la dicha yglesia. A todos los pleytos que perteneçen a la dicha yglesia y a los de oyr el abad.

\section{Tenporalidad:}

A de poner el dicho abad, alcaldes y merino quando él quisiere. A más todos los omeziellos y caloñas que fueren fechos en el dicho lugar y su término. Y a más, de yantar dieciocho maravedís. A más, la martiniega que son doze maravedís. A más de enfurçiones de cada suelo, diez et seis dineros. A más unos palaçios con sus corrales que son agora (en blanco)tos en el dicho lugar, çerca de la iglesia; y de la otra parte, la cal; y de la otra parte, el huerto de Pero Fernández, clérigo. A más vn prado en término de Majuelo, que llaman del Aguadada, está çercado, de las dos partes, de la eredad del abad; y de la otra parte, tierra que llaman de los Mayuelos; y de la otra parte, tierra de Domingo Ruiz. A más vna tierra tras el senderuelo, en que a tres cargas y media de senbradura, que a por términos: de la vna parte, el camino que va de Villa Carlon a Hérmides y el camino que va de San Sebastián a Bretadiello; y de la otra parte, el camino que va Arroyo. A más, otra tierra que es entre el camino que va a Villa Conançio y Castriella y llega hasta el prado, ay una carga de senbradura. Otra tierra en la que ay quatro obradas, que comiença al $(f .195 v)$ Veral e va la vega arriba, entre las viñas y el prado; y enfrente, en tierra que fue de don Gonçalo y de Domingo Ruiz. Otra tierra de la parte de suso del camino que va a Villa Conançio, cabe el monte, en que ay dos 


\section{LA ABADÍA DE SANTA MARÍA DE HUSILLOS: ESTUDIO Y COLECCIÓN \\ DOCUMENTAL $(904-1608)$}

obradas. Otra tierra que es linde del arroyo; y de la otra parte, tierra de Domingo Fernández; y de la otra parte, tierra de Martín, fijo de Joán Pérez de Hérmides, en que ay una obrada. Otra tierra al prado de Moyuelo, que a por linderos: tierra de Villa Conançio; y de la otra parte, el prado; e llega esta tierra fasta el lugar de Joán Fernández, fijo de don Fernando; y desde el lugar de Val de Fornos fasta el monte, según se sigue arriba, fasta el Val de Çevico. A otra tierra linde del dicho prado, de parte de La Escobar, que a por linderos: tierra de Los Clérigos; y de la otra parte, tierra de don Fernando que llaman El Barrancal; y de la otra parte del, ençima, enfruenta con el lugar que fue de don Galindo. Otra tierra en Val de la Carrera, linderos: el camino que va a Hérmides; y de la otra parte, tierra de los Clérigos; y de la otra, tierra que fue de Martín Perez, que fue de Elena Jordana.

Foyales y Fuent Alisendo:

Ésto es lo que a el abad en Foyales et Fuen Alisendo. Primeramente, amos los dichos lugares son del abad y toda la jurisdiçión e tenporal e viñas y huertas y montes y molinos y prados e fuentes, con entradas y con salidas. A de poner alcaldes y merino. A más el dicho abad, de cada yunta de buey, una fanega de trigo y otra fanega de çevada y un maravedí en dinero; y el que no toviere yunta de buey, a de dar una gallina. Y a de dar el abad, de su gramena, una carga de trigo y seis marauedís en dineros. Los alcaldes y el merino no an de pagar esto sobredicho que los otros pagan. A más el abad en el dicho lugar de Foyales, un solar de casa, que a por linderos: [...].

\section{Villandavín:}

Ésto es lo que a el abad en Villandavín. Primeramente, el dicho lugar es todo suyo y a de poner alcaldes y merino, en cada vn año o quando quisiere y por bien toviere. A más los omezillos y penas y caloñas que se fizieren en el dicho lugar. A más çiertos derechos de los vezinos, dende según manda el fuero. A más la iglesia es toda suya e los diezmos della. A más los sacrilegios y exçesos. Y a más de poner clérigo a petiçión del conçejo e de [...]. A más el abad, en el dicho lugar de Villandavín, una heredad que llaman la del Prado, en que a quarenta e más 
obradas, que a por linderos: [...]. A más todo el diezmo desta dicha heredad, aunque lo labren los de fuera del pueblo. A más un molino en el cuérnago de Carrión derribado.

Éstas son las iglesias que a el abad de Husillos en su abadía y el cabildo, que se siguen:

Primeramente, la iglesia de Santa María de Fusiellos e la yglesia de Sant Adrián. Es del abad la iglesia de Sancta Eugenia de Piña, de préstamo. Las iglesias de San Julián e de San Fagún de Paredes son del Cabildo. La iglesia de Sancta María de Çeruelo es del cabildo. La iglesia de Santa María çerca de Fuente Pudia, de préstamo. La iglesia de San Sebastián de Bezerril, de préstamo. La iglesia de San Pero de Fuentes es del abad. Santiago de Calabaçanos, de préstamo. Las iglesias de San Mamés, de San Román e de San Martín de Frechiella, de préstamo. La de Pozuelos, de préstamo. La de San Miguel de Fuentes de Don Bermudo, de préstamo. La iglesia de Sancta María de Castriello de Malçitas, de préstamo. La iglesia de Santa Olalla de Villaldavín es del abad. La yglesia de San Miguel de Villaudilla es del abad. Santa María Madalena de Villa Çalama es de préstamo. Sant Andrés de Fuente Quintana es del cabildo. San Joán de Villa Fruela es del abad. San Joán de Pajares es del cabildo. Santa María de Nava es del abad la visitaçión e la correçión, del o de su mandado. Santa María de (f.196r) Villa Gutierre es del cabildo. San Julián de Santillán de la Cuesta es del cabildo. La visitaçión de las dichas yglesias del cabildo es del prior.

Ésto es lo que a de fazer o mandar hazer o encomendar el abad de Fusiellos en algunas de las dichas iglesias:

Primeramente, a de poner casero o administrador o ermitaño en la iglesia de Santa María Madalena, que es en término de Fusiellos, y ale de tomar quenta de cada año, por sí o por otro, de lo que se da o manda en la dicha yglesia. A más el abad de poner casero o hermitaño o administrador en la iglesia de San Sebastián, que es çerca de Bezerril, y ale de tomar quenta de cada año, por sí o por otro, de lo que se da o se manda para la dicha iglesia. A más el abad la iglesia de San Mamés, 


\section{LA ABADÍA DE SANTA MARÍA DE HUSILLOS: ESTUDIO Y COLECCIÓN \\ DOCUMENTAL $(904-1608)$}

çerca de Frechiella, la iglesia de San Román, en este mismo término. Otra yglesia que está y çerca destas, en este mismo término, que llaman San Martín, en Pozuelos de Meanos. Dos yglesias, la vna de Santa María y la otra de San Miguel; y esta iglesia de San Miguel es toda de la yglesia de Fusiellos, con la meatad de todos los diezmos de los términos deste dicho lugar de Pozuelos; y en la de Santa María, a la quarta parte, el cabildo de Fusiellos. A más el abad de poner terçero en la yglesia de San Miguel, çerca de Fuentes de don Bermudo, y a de tomar quenta de cada año, por sí o por otro, de las cosas que perteneçen a la dicha yglesia. A más el abad de poner hermitaño o casero o administrador o aquel que entendiere que más cumple, en la yglesia de Santa María de Nava, que es en término de Villaudilla, y a la de visitar e tomar quenta, de cada año, de lo que se da o se manda para la dicha yglesia, por sí o por otro. A más, el abad, de poner hermitaño o casero o administrador en la iglesia de Santa María, çerca Fuent Pudia, o aquel que entendiere que más cumple, y a la de visitar e tomar quenta de cada año, por sí o por otro, de lo que se da o se manda para la dicha yglesia. A más, el abad, de poner hermitaño o casero, administrador en la yglesia de Santa María de Malçitas e a la de visitar e tomar quenta de cada año, por sí o por otro, de lo que se da o se manda a la dicha yglesia. A más el abad de poner hermitaño o casero, administrador en la yglesia de Sancta Eugenia, çerca de Piña de las Nueve Villas, et a la de visitar e tomar quenta de cada año, por sí o por otro, de lo que se da o se manda en la dicha yglesia. A más el abad, la colaçión del clérigo curado y capellán de la iglesia de Santiago de Calabaçanos, a presentaçión del préstamo.

Éstas son las tierras e las viñas que an todos los vasallos que a el abad de Fusiellos, ansí los que moran en el lugar como los que moran fuera del lugar:

Primeramente, Gonçalo Ruiz de Reynoso, treynta obradas de tierra y treynta y quatro quartas de viña e quatro suelos. Albar Ruiz de la Serna, çinquenta obradas de tierra y un solar. Flor Ordóñez, diez e nueve obradas de tierra e veynte y ocho quartas de viña y un solar de casas en lugar poblado. Joán Fernández de Buzón, sesenta obradas de tierra y sesenta y seis quartas de viña y seis suelos, los quatro despoblados. Garçi Fernández de Castro, noventa y çinco obradas de tierra y setenta quartas de viña y dos suelos. Fernán Martínez, canónigo de Palençia, 
veynte obradas de tierra y unas casas. Joán Pérez de Açeves, prior de Fusiellos, çinquenta y dos obradas de tierra y un solar. Joán Fernández de Tariego, veynte y çinco obradas de tierra. Joán Fernández, carretero, tres obradas y media y su sobrina, seis obradas. Fernán Garçía de Castrillo, seis quartas de viña. Diego Fernández "El Negro", çinco obradas. Martín de Palaçios, çinco obradas. Yuannes de la Puente, dos obradas.; él es muerto y no dexó herederos y agora son del abad. Joán Garçía, familiar, dos obradas de tierra. Pero de Vayello, una obrada de tierra e dos quartas de viña y un solar. (f.196v) Fernán Garçía, doze obradas de tierra e dos suelos, uno poblado e otro despoblado. Alfonso, fijo de don Estevan, vna obrada. Joán Fernández de Potes, veynte obradas de tierra y treze quartas de viña e unas casas. Gonçalo de La Dobla, nueve obradas de tierra. Doña Sancha, siete obradas de tierra e vnas casas. Joán Fernández del Carudo, siete obradas. Marcos Fernández, fijo de don Fernando, çinco obradas y ocho quartas de viña y dos suelos de casas. Marina Rodríguez de Grijota, dos obradas y media de tierra. Los hijos del chantre, veynte e dos obradas de tierra y catorze quartas de viña y dos suelos de casas. Joán Martínez de Fusiellos, ocho obradas de tierra e un solar. Martín Pérez de la Carva e Pero, su hermano, treynta obradas de tierra y diez quartas de viña e un solar. Joán Fernández Quintero, quatro obradas y un solar. Dona Joana de Robra, dos obradas de tierra e diez quartas de viña e un solar. Pero, fijo de Antolín Pérez, dos obradas y media. Doña Espeçiosa, dos obradas y un solar de casas. Fijos de Sancho Martínez, dos obradas de tierra e doze quartas de viña e unas casas. Pero Estevan, dos obradas de tierra. Diego Fernández de Estrada, dos obradas de tierra. En esta manera se an de derramar los pechos que a los clérigos e a las iglesias desta abadía de Fusiellos, caben, cuando los derraman en sueldo de tres meses, les cabe en esta manera: a la iglesia de Calabaçanos e a la iglesia de Fuentes de Valdepero y al clérigo de Fuentes e a los clérigos o clérigo de San Sebastián e a la iglesia de San Miguel de Fuentes de don Bermudo e a la iglesia de Santa María de Çilleruelo; en la déçima y en el subsidio caritativo an a pagar las dichas yglesias e clérigos de Fuentes de Valdepero e clérigos o clérigo de San Sebastián.

Cabildo de Fusiellos: 


\section{LA ABADÍA DE SANTA MARÍA DE HUSILLOS: ESTUDIO Y COLECCIÓN \\ DOCUMENTAL $(904-1608)$}

Los lugares e jurisdiçiones e posesiones e rrentas e pechos e derechos e diezmos e tierras e viñas e todas las otras cosas que perteneçen al prior y cabildo de la yglesia de Santa María de Fusiellos, son estas que se siguen:

Primeramente, en el dicho lugar de Fusiellos, an todo el diezmo granado y menudo. E las posesiones que an en el dicho lugar son éstas: las casas de canóniga con su huerta, en que morava el familiar e mora agora en ellas, Diego Díaz de Grijota, canónigo de Fusiellos. Vnas casas que tiene Gonçalo Gonçález, a la puerta Nueva, con su huerta, linderos: de la vna parte, la cal pública que va a la puerta Nueva; e de la otra parte, la huerta e ferrenal de la obra. Otras casas en que morava Domingo Fernández, canónigo, en linde de las casas del abad, y tiénelas agora Joán Fernández de Madrigal, conpañero en la dicha yglesia. Otras casas en que mora el chantre Domingo Gonçález, que son en linde de ferrenal de la obra, con su huerta, e çércola Domingo Gonçález, chantre, todo en derredor e fizo, en ella, casas; y las casas que el dicho chantre tiene de la dicha yglesia an por linderos: de la vna parte, casa e ferrenal e huerta de la obra; y de la otra parte, casa de la yglesia en que mora Joán Sánchez de Grijota, canónigo de Fusiellos. An más el dicho cabildo, una bodega en que están seis cubas y una carral y tiene delante un portal en que estan troxes para pan y un xarafiz con su viga y piedra y aparejamiento. Más otras casas que tiene el dicho Joán Sánchez, canónigo, en linde del chantre; e de la otra parte, casas que tiene Fernando Mínguez, que están yermas y tiénelas agora, el dicho Sánchez con las dichas sus casas. Más otras casas en que solía morar Joán Fernández, canónigo, y mora, agora, en ellas Joán Alfonso de Grijota, linderos: de la vna parte, casa que fueron de Fernán Domínguez, que tiene, agora, Joán Sánchez, canónigo; e de la otra parte, casas que tenía Pascual Martínez, en que mora agora, Joán Alfonso (f.197r) de Toledo, canónigo. Otras casa que fueron dadas por ençenso e son agora forezuelo e tiénelo Diego Díaz, canónigo, con otra casilla que está enfrente del, en que solía morar el portero; que está en linde, esta dicha casilla, de bodega y troxes de Canóniga. Otras casas que dizen de Domingo Ruiz, que llámanlas Casas Quemadas, que son en linde de La Proçesión; e de la otra parte, casas que tiene Joán Pérez de Açeves, canónigo, en que mora agora, don Toribio de Castriello de Villa Vega. Otras casas en que mora el dicho Joán Pérez e las abita, que son en linde de las Casas 
Quemadas; e de la otra parte, casas de Fernán Martínez, canónigo de Palençia. Otras casas que tiene Joán Pérez, prior, que son en linde de casas de Fernán Martínez; e de la otra parte, casas de Joán Fernández de Buzón, en que mora, agora, Martín Sánchez, conpañero en la dicha yglesia. Otras casas en la cal Nueva, que dexó Joán Rodríguez de Palaçios, que son en linde de las casas de Joán Garçía Çerçetilla, en que mora, agora, Sancho Fernández e Rui Fernández de Cantoral. Otras casas que son en el dicho lugar de Fusiellos, a la puerta del Río, que an por afrontaçiones: casas de la capellanía de San Joán; e de la otra parte, casas del préstamo de Santa María Madalena, en que mora agora, Garçía Fernández de Pernía. Otras casas que dexó Sancho Martínez, canónigo, que son en linde de casas de fijos de Sancho Martínez; y de la otra parte, casas de doña Espeçiosa. Otras casas con su huerta que tiene Joán Fernández, prior de Fusiellos "ad vitan", que son en linde de casas de la sacristanía e casas de Alfonso Garçía de Villoldo. Otras casas que dexó Joán Sánchez, canónigo, que son en linde casas de la capellanía de Pero Fernández; e de la otra parte, casas de Joán Fernández de Porras, que son, agora de Martín Fernández. Otras casas que dieron a Joán Martínez de Fusiellos, al Olmo, y es agora huerto, e tiénelo Diego Díaz. Otras casas palizas que fueron de Marina Garçía, criada que fue del chantre Joán Pérez, que Dios perdone, en linde de la puerta del Río; e de la otra, casas del.

Éstas son las casas de los ençensos:

Vnas casas de la capellanía de don Pero Fernández, abad que fue de Fusiellos, linde de casas de Joán Martínez; e de la otra parte, casas del cabildo en que mora, agora, Domingo Fernández de Rabia, conpañero en la dicha yglesia, y a de dar en ençenso tres marauedís. Otras casas que fueron de Joán Fernández de Porras, que son en linde casas del dicho cabildo; y de la otra parte, casas de Martín Gil e son, agora, de Martín Fernández, e an de dar en ençenso veynte marauedís. Otras casas de Martín Gil, canónigo, que son linderos: casas del dicho Joán Fernández de Porras; y de la otra parte, casas del cabildo, que an de dar de ençenso tres marauedís; y estas dichas casas dio el dicho Martín Gil, canónigo, en donaçión, a la capellanía de San Joán de Fusiellos, que las aya el capellán dende después de sus días, en presençia del abad y del cabildo, y pasó por ante Joán Fernández, 
sacristán de la dicha yglesia y notario de Palençia. Otras casas en la cal Luenga, que dio don Pero Fernández, abad, porque fiziesen la fiesta de San Quirze, en que mora agora Alfonso Fernández, fijo de Joán Fernández Quintero, por ençenso de çinco marauedís. An más en la parada que dizen de Casa, dos molinos, uno que llaman Uzo, el otro, Açeñuela; e an la terçia parte en la pesquera de los dichos molinos. E an más la terçia parte del canal y an a pagar la terçia parte de la costa de la Casa et de la pesquera e del canal e de las puntas. An más, vna parada que llaman de Cabo de Viña, en que ay siete molinos endereçados e una açeña que está en la dicha parada. Y otra açeña y otro molino en la Çespedera, çerca de la dicha parada. An más otra parada que llaman la Torrezilla, en que ay quatro rruedas de aceña molientes. An más otra parada que llaman de Pajares, en que a çinco rruedas de açeñas molientes y corrientes. An más en la parada de Tejada, dos canales. E más, (f.197v) un soto allende el agua que llaman el Sotillo, que tiene desde la heredad que llaman de Requexo, que es del abad, fasta La Quebrantada, con su heredad.

Ésta es la eredad que a el dicho cabieldo de Fusiellos en este término deste dicho lugar, de tierras e viñas, que son éstas que se siguen:

Primeramente, una tierra que llaman la Serna Longuera, que es a La Quebrantada, que a por linderos: tierra de Joán Fernández de [...]; e de la otra parte, tierra del cabieldo que fue viña. Otro pico de tierra que fue viña, que es a Tras Soto, que a por linderos: vna tierra que es de Joán Fernández de Buzón y el camino que va a La Quebrantada. Otra tierra a La Huelga en que a tres obradas que llaman La Holgatilla, que a por linderos: tierra de Joán Fernández de Buzón; e de la otra parte de ençima, tierra del préstamo de Santa María Madalena. Otra tierra a La Pedrera en que ay dos obradas, que a por linderos: de la vna parte, tierra de La Lánpara; de la otra parte, la cuesta, camino de Palençia. Otra tierra que llaman Vaçia Bolsas que es camino de Palençia, en que ay çinco obradas, que a por linderos: de la vna parte camino de Palençia; e de la otra parte, tierra de Nuño Álvarez, y esta tierra fue viña. Otra tierra a Las Minbreras, en que a dos obradas, que a por linderos: de la vna parte, tierra de fijos de Antolín Pérez; e de la otra parte, tierra de la capellanía del abad. Otra tierra que dizen de Los Benefiçiados, 
que es suya, que es entre la carrera Vieja e el camino de Palençia, en que a una obrada. Otra tierra a Oteruelo, en que a ocho obradas, en que a por linderos: un pico que es tierra de Joán Martínez, abad que fue; de la otra parte, tierra de Fernán Martínez, canónigo, y es, agora, de Martín Pérez. Y otra tierra en que ay siete obradas, que es carrera de Santillán, que a por linderos: camino de Santillán; y de la otra parte, tierra de Martín Pérez de La Carva. Otra tierra carrera de Santillán, en que ay doze obradas, que a por linderos: tierra de La Lánpara; y de la otra parte, tierra de Alfonso, fijo de don Estevan. Otra tierra carrera de Santillán, en que ay ocho obradas, a por linderos: tierra que fue de Blas de Santillán; e de la otra parte, sendero que va a San Andrés. Otra tierra en que a obrada y media, que es carrera de Santillán e a por linderos: tierra de Joán Fernández de Buzón que está en medio; e de la otra parte, tierra de Fernán Martínez que es de Martín Pérez. Otra tierra en que a una obrada, que es carrera de Santillán, que a por linderos: tierra de Gonçalo Ruiz de Reynoso; e de la otra parte, tierra de Fernán Martínez que es agora de Martín Pérez. Otra tierra en que a quatro obradas, que es a La Rallosa, que a por linderos: tierra del abad; e de la otra parte, camino que va a Grijota. Otra tierra so Mançanedo en que a obrada y media, que a por linderos: la viña del cabildo; e de la otra parte, el arroyo de Val de Lomudo. Otra tierra a Val de Lomudo en que ay seis obradas, que a por linderos: tierra de Flor Ordóñez; e de la otra parte, tierra del prior de Fusillos. Otra tierra que llaman el Pradillo, en que a seis obradas, que a por linderos: viña que llaman de Ximón Ruiz y es, agora, del cabildo; e de la otra parte, el arroyo de Val de Lomudo: otra viña a la Cabaña en que a ocho obradas, que a por linderos: tierra de Santa María Madalena en derredor; e de la otra parte, la carrera que va a San Andrés. Otra tierra a Las Foyadas, en que a quatro obradas, que a por linderos: tierra de Santa María Madalena; (f.198r) otra de Garçía Fernández de Castro, de parte del arroyo. Otra tierra de parte del arroyo en que a media obrada, que a por linderos: tierra de Garçía Fernández de Castro e el arroyo de Las Foyadas. Otra tierra del majuelo de Joán Fernández de [...], en que ay seis obradas, linderos: de la vna parte, camino que llaman de Mercaderos; e de la otra parte, el majuelo. Otra tierra en arroyo de Frailes, en que a dos obradas, que a por linderos: Flor Ordóñez; e de la otra parte, el arroyo. Otra tierra que llaman a La Red, en que ay doze obradas, que a por linderos: el arroyo de Frayles; e de la otra parte, tierra de Joán Fernández de 


\section{LA ABADÍA DE SANTA MARÍA DE HUSILLOS: ESTUDIO Y COLECCIÓN \\ DOCUMENTAL $(904-1608)$}

Buzón. Otra tierra a La Tejada, en que a doze obradas y está en él un pico della, una figuera, que a por linderos: viñas de Monçón. Otra tierra chiquilla que llaman Atacada, en que a media obrada, linderos: de la vna parte, el camino de Monçón; e de la otra parte, erederos de Monçón. Otra tierra a Lagunales, en que a dos obradas, que a por linderos: Garçía Fernández de Castro, que la ençierra. Otra tierra que llaman el Pico del Raedor, en que ay quatro obradas, que a por linderos: Flor Ordóñez; e de la otra parte, el Coxo. Otra tierra y luego de tres obradas, que a por linderos: la tierra del alvar de Sancta María Madalena; e del otro cabo, las eras. Otra tierra que llaman Huerta Canóniga, en que a quinze obradas, que a por linderos: de la una parte, la serna que llaman del Moral; e de la otra parte, la carrera que viene del tejo a la villa. Otra tierra que llaman de los Ferrenales, a puerta Nueva, en que ay dos obradas, que a por linderos: ferrenal del préstamo de Sancta María Madalena; e de la otra parte, ferrenal de Marcos Fernández, hijo de don Fernando. Otra tierra en que ay dos obradas, a la puerta Nueva, que a por linderos: ferrenal de la capellanía de San Joán; de la otra parte, un ferrenal del Hospital. Otra tierra que llaman El Parral, que ay tres obradas, que a por linderos las eras. Otro ferrenal de obrada y media, que está ay çerca, que a por linderos: tierra de la capellanía del abad; y de la otra parte, la cárcava.

Otro ferrenal en que ay una obrada, lindero la huerta que llaman de La Lánpara; y del otro cabo, la cava de la villa. Otra tierra a las eras, en que ay seis obradas, que a por linderos: el arroyo de Val de Lomudo; y de la otra parte, tierra de Sancta Bríjida. Otra tierra de seis obradas que es camino de Mercaderos, linderos: fijos de Pero Díaz; y del otro cabo, carrera de Mercaderos. Otra tierra majuelo de dos obradas, que a por linderos: el majuelo de Joán Fernández de Buzón; e de la otra parte, tierra de Martín de Palaçios. Otra tierra al fito, de dos obradas y media, lindero: la huelga que llaman de San Jaime; e de la otra parte, carrera de Mercaderos. Otra tierra de obrada y media carrera de los Canbrones, linderos: tierra de la capellanía de San Joán que la ençierra toda. Otra tierra carrera de los Canbrones, en que a obrada y media, linderos: la viña de Olalla del cabillo de Fusiellos; e de la otra parte, Marcos Fernández, hijo de don Fernando. Otra tierra y carrera de Ribas, en que ay quatro obradas, linderos: tierra del abad de Fusiellos; y de la otra parte, tierra de la capellanía de San Joán. Otra tierra a las Finqueras, en que ay una obrada, linderos: tierra de Joán Fernández de Buzón; e 
de la otra parte, tierra del abad de Fusiellos. Otra tierra carrera de Santillán, de obrada y media, linderos: tierra de los monaziellos de Fusiellos; e de la otra parte, tierra de Joán Martínez, abad de Fusiellos. Otra tierra en que ay una obrada, carrera de Santillán, linderos: Fernán Garçía, fijo del sacristán; e de la otra parte, carrera de Santillán. Otra tierra a La Solana, en que ay quatro obradas, linderos: Martín de Palaçios; e de la otra parte, el prior de Fusiellos. Otra tierra a los Canbrones, en que ay una obrada, linderos: tierra de fijo del chantre $(f .198 v)$ Joán Pérez; e de la otra parte, tierra del prior de Fusillos. Otra tierra cabe la viña de Pero Caraço, que es del cabildo, en que a obrada y media, linderos: viña del cabildo que llaman de Pero Caraço; e de la otra parte, Marcos Fernández, hijo de don Fernando. Otra tierra al Fito, en que a tres obradas, que a por linderos: tierra de la sacristanía; e de la otra parte, tierra del préstamo de Sancta María Madalena. Otra tierra en que a una obrada, camino de Tras Soto, linderos: tierra de Garçía Fernández de Castro. Quatro tierras que dio el chantre Domingo Gonçález, en que ay seis obradas; la vna tierra en que ay una obrada, que a por linderos: de la vna parte, tierra de Diego Fernández de Piña, notario e vezino de Palençia; e de la otra parte, el majuelo que fue de don Pero Fernández, abad de Fusiellos; e la otra tierra en que ay una obrada, linderos: de la vna parte, el sendero que va a Ribas; y de la otra parte, tierra que fue de Bernaldo de Amor. E otra tierra y luego, que ay dos obradas, que a por linderos: tierra del abad de Fusiellos. E otra tierra en que ay dos obradas, que es así como van a los molinos de Cabo de Viña a Santillán, que a por linderos: tierra de Alias Ruiz e de tierra de Joán Domínguez de Santillán. E otra tierra que fue viña, que fue de Martín Pérez de la Carva, que dio al dicho chantre el cabildo, que es a do dizen Tras Soto, linderos en derredor: tierra del cabildo de Fusiellos, de la mayor parte; e de la otra parte, viña herial del dicho Diego, chantre de Piña. An más el dicho cabildo de Fusiellos, vna tierra a la Monneca, que es a las Polientas, en que ay dos obradas, que a por linderos: la viña de Joán Fernández Armigote; e de la otra parte, viña de Alfonso Garçía; e llega al camino de Ribas. Un ferrenal que tiene el chantre, en que a una quarta, linde: la tierra de La Lánpara que fue de Jaymes Pérez y llega a la cava.

Éstas son las viñas que a el dicho cabildo en término del dicho lugar de Fusiellos, que se siguen: 
Primeramente, el majuelo que fue de Fernán Gil, seis arançadas, linderos: tierra de Nuño Álvarez; e de la otra parte, el camino que va a Villandavín. Otro majuelo en que a tres alançadas, en el Páramo, linderos: tierra del prior de Fusiellos; e de la otra parte, tierra de la capellanía de San Juan. Otra viña vieja en que ay tres arançadas, linderos: de la vna parte, viña de Flor Ordóñez; e de la otra parte, viña de Joán Pérez, prior de Fusiellos. Otra viña que llaman la Macaria, en que ay quatro arançadas, linderos: viña de la sacristanía de Fusiellos; e de la otra parte, viña del chantre de Fusiellos. Otra viña que llaman de Pero Caraço en que ay seis quartas, linderos: de la vna parte, tierra de los fijos del chantre de Fusiellos; e de la otra parte, tierra de la capellanía de don Pero Fernández, abad de Fusiellos. Otra viña que llaman Olalla, en que ay tres alançadas, linderos: de la vna parte, Nuño Álvarez de la Serna; y de la otra parte, tierra del cabieldo. Otra viña que llaman a Xuaro, en que ay quatro alançadas, linderos: viña de la sacristanía; e de la otra parte, viña de los fijos del chantre. Otra faza en que ay quatro quartas, a los Canbrones, linderos: viña de Fernán Garçía de Castrillo; e de la otra parte, viñas de fijos de Sancho Martínez. Otras dos faças en que ay tres quartas, linderos: de la vna parte, viña de Joán Fernández de Buzón; e de la otra parte, viña de la capellanía de Santa Bríjida. Un quadro en que ay seis quartas de viña, linderos: viña de Gonçalo Ruiz de Reynoso; e de la otra parte, viña de los fijos del chantre. Otro quadro en que ay seis quartas, que es en medio de poblaçión, linderos: viña de el dicho Gonçalo Ruiz de Reynoso; e de la otra parte, viña de Pero Fernández de Vallejo. Otra viña en que ay vna lançada, que es en medio de poblaçión, linderos: de la vna parte, viña de Juan Fernández de Porras; e de la otra parte, viña de los monaziellos de Fusiellos. Otra viña de Ximón Ruiz, en que a tres arançadas, linderos: de la vna parte, tierra del cabildo; $(f .199 r)$ y de la otra parte, viña de los fijos del chantre. Otra viña que llaman de los Perros, en que ay seis quartas, linderos: de la vna parte, viña de Flor Ordóñez; e de la otra parte, viña de Martín Pérez e de su yerno. Un majuelo de Val de Bermudo, en que ay seis alançadas, linderos: de la vna parte, viña de Martín Pérez e su yerno; e de la otra parte, viña de Juan Fernández de Buzón. Una viña en Abeça, en que ay quatro alançadas, linderos: viña de Fernán Garçía e de su madre; e de la otra parte, majuelo de Alfonso de Bezerril. Otra viña a La Cabaña, en Abeça, en que a media 
alançada, linderos: viña de Martín Pérez y su yerno; e de la otra parte, La Cabaña. Otra viña en Abeça, en que a una lançada, linderos: viña de Juan Fernández de Buzón; e de la otra parte, viña de muger de Gonçalo. Una viña Tras Soto, en que a veynte arançadas, linderos: de la vna parte, el rrío; e de la otra parte, el prior de Fusiellos. Otra viña en que a dos arançadas, Tras Soto, linderos: tierra de la sacristanía de Fusiellos; e de la otra parte, la viña maior de Tras Soto. Otra viña Tras Soto, en que ay media alançada, linderos: tierra del cabildo; e de la otra parte, viña maior de Tras Soto. Otra viña Tras Soto, en que a tres arançadas, linderos: viña de Joán Pérez, prior de Fusiellos; y de la otra parte, el camino que va a La Quebrantada. Otra viña Tras Soto, en que ay tres arançadas, linderos: tierra del dicho cabildo; e de la otra parte, el rrío. Otra viña en la Vega, en que a una lançada, linderos: tierra de Martín Pérez y de su yerno; y de la otra parte, tierra del cabildo. En la Vega, a las çarças, vna viña en que a vna lançada, linderos: tierra de Joán Asturiano; de la otra parte, el camino que va a Palençia. Otra viña en la Vega, en que a vna lançada, linderos: viña de los monaziellos; e de la otra parte, tierra de Pero Fernández, carretero, vezino de Palençia. Otra viña en Vega, en que ay seis quartas, linderos: tierra de la sacristanía de Fusiellos; e de la otra parte, tierra de Joán Fernández de Buzón. Otra viña en la Vega, en que ay seis quartas, linderos: viña de Joán Fernández de Tariego e tierra de Pero Fernández, carretero. Otra viña en que a media lançada, a La Huelga, linderos: tierra del préstamo de Sancta María Madalena; e de la otra parte, viña de Garçía Fernández de Castro. Otra viña en que a media lançada, a La Huelga, linderos: tierra de Joán Fernández de Buzón; e de la otra parte, viña de Nuño Alvarez de la Serna. Otra viña en que a media lançada, a La Huelga, linderos: tierra del cabildo; e de la otra parte, viña de los monaziellos de la iglesia de Fusiellos. Otra viña carrera de Palençia, que a una alançada, linderos: la carrera Vieja; e de la otra parte, tierra de Joán Fernández Carudo. Otra viña carrera de Palençia, en que ay tres quartas, linderos: tierra de Joán Fernández Carudo; e de la otra parte, tierra de Pero Fernández, carretero de Palençia. E a viña ferrén, la que a tres alançadas, linderos: viña de Joán Fernández de Buzo; e de la otra parte, tierra de Gonçalo Ruiz de Rinoso. Otra viña a Las Binbreras, en que a tres quartas, linderos: viña de Garçi Fernández de Castro; y de la otra parte, Las Minbreras. Otra viña a Los Olmillos, en que a tres alançadas, linderos: tierra de Joán Fernández de Buzón; e 
de la otra parte, tierra de Gonçalo Ruiz de Rinoso. Otra viña de Vazia Bolsas, en que ay quatro alançadas, linderos: tierra de Joán Fernández de Buzón; e de la otra parte, tierra del cabildo. Otra viña de Las Mangas, que llaman ansí, en que ay tres arançadas, linderos: tierra de Pero Fernandez, carretero de Palençia; e de la otra parte, tierra de Garçi Fernández de Castro. A más el dicho cabildo, otra viña en que a dos quartas, en linde la viña Xuara del dicho cabildo; e de la otra parte, viña de Alfón Garçía de Villoldo, (f.199v) que fue de Fernando Díaz. Otra viña en que a media quarta, linde de la Viña Vieja del dicho cabildo; e de la otra parte, viña de Mari Gómez, muger de Martín Fernández de Palaçios.

Ésto es lo que el cabildo de Fusiellos a en Monçón:

Primeramente, una huerta que llaman de Santa María de Fusiellos, que a por linderos: huerta que llaman de Joán Núñez de Ferrera; e de la otra parte, el arroyo; esta dicha huerta que dizen de Joán Núñez, dexola el dicho Joán Núñez al dicho cabildo de Fusiellos por aniversarios; así que son a más, del dicho cabildo de Fusiellos, con una terrezuela chiquilla que está çerca del molino, que es çerca de las dichas huertas. A más, estas tierras que se siguen: vna tierra a la huelga del Anadino, que a por linderos: tierra de Miguel Sánchez; e de la otra parte, tierra del señor de Monçón. A la huelga de Yuso, otra tierra, que a por linderos: tierra de Joán Martínez, fijo de don Pero de San Felizes; e de la otra parte, tierra de Pero Majadero. Otra tierra al sendero de Mata Sagrada, linde el camino que va de Palençia a Poblaçioneja. Otra tierra al arroyo de Cogujada, en linde tierra del señor de Monçón. Otra tierra en el Páramo, a do dizen el Espino, linde el camino que va de Monçón a Bezerrilejo. Otra tierra a Valdeseras, en linde tierra del señor de Monçón. Otra tierra camino de Villaximena, en linde tierra de [...]. Otra ferrén a Barrio Çid, en linde tierra de Miguel Sánchez. Otra tierra carrera de Palençia, que a por linderos: la dicha carrera; y de la otra parte, tierra de Fernán Garçía de Villandavín. Otra tierra a Nelazos, que a por linderos: la huelga y afrente en el sendero que viene de Ribas a Monçón. Otra tierra carrera de Bezerril, en linde la dicha carrera; y de la otra parte, el arroyo de Frades. Otra tierra cabe las viñas del Páramo, que es en linde de vna viña que hera de Joán Núñez "El Clérigo"; e de la otra parte, la carrera que va a Villaunbrales. Otra tierra que toma desde el dicho 
camino que va a Villunbrales e llega al camino que viene de Fusillos a Monçón; e de la otra parte, tierra del señor de Monçón. Otra terrezuela de la otra parte del dicho camino que viene de Fusillos a Monçón, que a por linderos: el dicho camino e tierra del señor de Monçón. Otra tierra y luego, que a por linderos: el dicho camino e tierra de Joán Fernández del Postigo. Otra tierra y luego, que llaman de La Figuera, que a por linderos: de la vna parte, el camino que va a Villunbrales; y de la otra parte, el dicho camino de Fusiellos.

Ésto es lo que el cabildo de Fusiellos a en Santillán de la Cuesta:

Primeramente, Santillán es todo del cabildo de Fusiellos y an toda la jurisdiçión espiritual y tenporal. Más es la iglesia suya y an de poner y capellán que la sirva; y el prior a la visitaçión de la yglesia. Y el cabillo a más en el dicho lugar, todos los diezmos de pan y vino, granado y menudo y las premençias e obladas del dicho lugar.

Tenporalidad:

A de poner el prior y el cabildo alcaldes y merino, quando ellos quisieren. E las penas e caloñas e omeziellos que fueren fechos en el dicho lugar son suyos. E an más, de poner cabañas e viñaderos en sus términos. E an más en el dicho lugar, en cada un año, de martiniega, noventa maravedís.

Éstos son los eredamientos que a el cabildo en el dicho lugar de Santillán y en sus términos:

Primeramente, la Serna Maior, en que a treynta obradas o más, linderos: tierra de Joán Mache y viñas de Toribio Fernández e viña de Diego Fernández, fijo de Joán Domínguez (f.200r) e dos tierras de Santa Brígida. Otra serna menor en que a doze obradas o más, linderos: tierra de Toribio Santos e tierra de Joán Calagrano "El Menor" e tierra de la muger de Alfonso Garçía y de sus hijos. Otra tierra al Palomar, en que a çinco obradas o más, linderos: tierra de Joán Calçado y el sendero que va al Palomar. Otra tierra al Moroco, en que a quatro obradas, 
linderos: tierra de Domingo Gonçález e tierra de Pero Gil e tierra de Martín Nicolás. Otra tierra entre amas las carreras que dizen El Pico, en que a obrada y media, linderos: las dichas tierras e tierra de Benito Cano. Las ferrenes en quatro lugares, linderos destas ferrenes: las eras de Santillán e tierra de Benito Cano e tierra de la suegra de Françisco Díaz, clérigo. Otra tierra [a] Arenillas, en que a çinco obradas, linderos: viña de Martín Cosin e viña de Domingo Gómez e la carreruela en medio. Otra tierra a Arenillas, en que a dos obradas, linderos: viña de Domingo Rol e viña de Doyague Pajuelo y viña de la muger de Fernán Martín, y es entre amos los caminos. Otra tierra a Otero de Lobos, en qua obrada y media, linderos: $[\ldots]$.

Las viñas que a el dicho cabildo de Fusiellos en el dicho término de Santillán son éstas que se siguen:

Primeramente, la viña que llaman La Calagrana, linderos: la carrera de la Cabaña y el Pico de Pero Estevan. Otra viña a do dizen Arenillas, linderos: viña que fue de Joán Martín Ferrero; y de la otra parte, viña de Domingo Gómez, fijo de Pero Mínguez. Otra viña a Val de Soña, que llaman La Gordera, linderos: el sendero de Val de Sonna; y de la otra parte, viña de Martín Fernández Nava, alcalde. Otra viña a Val de Sonna, que llaman El Pico, linderos: [...]. Otra viña que llaman La Cantera, linderos: el sendero de Val de Sonna y viña de Benito Fernández Pollas. Otra viña que llaman La Cabanna, linderos: Joán Calagrano. Otra viña que llaman de Val de Carajada, linderos: el sendero de Val de Carajada; y de partes de yuso, viña de Murgachon. Otra viña maior, y luego ençima, lindero la dicha viña. Otra viña y luego, linderos: viñas de Joán Dominguez Pedrón y de Joán de Palaçios. Otra viña y luego, linderos: viñas de Joán Rodríguez Pedrón e de Joán de Palaçios. Otra viña y luego, linderos: viñas de Miguel Martínez Diego, de parte de ayuso, y de Diego Corcho; y de la otra parte, el sendero de Val de Carajada. Otra viña a Las Quintanas, linderos: viña de Martín Nava; e de la otra parte de ençima, viña de Fernán Pérez, yerno de Joán Marguan, que anda al derredor; y de la otra parte, viña de doña Sancha, hija de Domingo Joán. Otra viña a Çeislo, linderos: viñas de Joán Domínguez, fijo de don Apariçio, y de Joán de Revenga; y de la otra parte, La Carra; e de parte de ençima, viña de Domingo Moro. Otra viña al 
arroyuelo, linderos: viñas de Joán Domínguez, fijo de don Apariçio, e de Joán Domínguez de la Puebla. Otro pedaçuelo y luego, linderos: viñas del dicho Joán Domínguez, fijo de don Apariçio, y de la cofradía de San Julián. Otra viña al sendero de Cabañuelo, linderos: el dicho sendero e viña de donna Mençía.

Ésta es la eredad que el dicho cabildo a en Fuente Quinava:

Primeramente, vna serna del camino del Rey, arriba, como van a Villunbrales, y llega fasta la tierra de Domingo Andrés y fasta la Fuente Vellosa e fasta el pedaçuelo e fasta el camino que va de Monçón a Santillán, en que ay quarenta obradas y más, linderos: los dichos caminos y las viñas de Vega e tierra de Diego Fernández. Otra serna del camino ayuso, en que ay otras quarenta obradas o más, linderos: el sendero de Los Novios y el camino que viene de Villunbrales a Fusillos y el dicho camino del Rey: otra serna çerca desta, en que ay veynte obradas o más, linderos: el dicho sendero de Los Novios y llega fasta $(f .200 v)$ el camino que viene de Monçón a Santillán.

Ésta es la eredad que el cabildo de Fusiellos a en Veza:

Primeramente la Viña Maior, en que ay quatro arançadas, linderos: viña de Joán Fernández Quintero e viña de la capellanía de don Pero Fernández, abad que fue de Fusiellos. Otra viña que llaman La Barla, en que ay tres alançadas, linderos: de la vna parte, viña de Joán Fernández Quintero; e de la otra parte, viñas de Joán Pérez de Açeves y de Joán de Ribas e viña de Santa Brígida. Otra viña en que a media alançada, linderos: viña del dicho Joán Fernández; de la otra parte, viña de Joán de Fusiellos, fijo de Joán Pérez, chantre.

Ésta es la eredad que el dicho cabillo de Fusiellos a en San Fagún El Viejo de Paredes:

Primeramente, an en el término de Paredes de Nava, do dizen San Fagún El Viejo, vna viña en que ay siete alançadas, que a por linderos: de la vna parte, Rui Pérez de Otero; y de la otra parte, vna era de la iglesia de Santa María de Fusiellos; y de 


\section{LA ABADÍA DE SANTA MARÍA DE HUSILLOS: ESTUDIO Y COLECCIÓN \\ DOCUMENTAL $(904-1608)$}

la otra parte, una carrera que pasa cabe la iglesia de San Fagún. Y luego, çerca la dicha yglesia de San Fagún, esta toda la eredad de tierras, que puede aver dozientas obradas o más, que a por linderos: Pero Garçía, fijo de Pero Garçía Calvo; y de la otra parte, Domingo Serrano; y de la otra parte, Domingo Díaz y Domingo Romo; e de la otra parte, carrera Viziera; y de la otra parte, carrera Castañares. Y más, una era que es linde de la viña y çerca de la dicha yglesia de San Fagún, que puede aver quatro quartas de tierra.

Ésta es la eredad que el dicho cabildo de Fusiellos a en Torquemada:

Primeramente, en la parada del río de Pisuerga, sobre la puente de Torquemada, en el açeña de Fuera, a veynte y quatro días, e dos días e dos noches; y destos dos días y dos noches, a las dos partes la iglesia de Fusiellos y la terçia parte Rui Gómez, fijo de Lope Garçía. Y en el açeña Vieja, a doze días, un día y una noche; y desto, a la dicha yglesia dos parte y el terçio Rui Gómez. Y en açeña Nueva, a doze días, vn día y una noche; y desto, a la dicha iglesia dos parte y el terçio Rui Gómez. Y en el açeña de dentro de la pesquera, a veynte y quatro días, dos días y dos noches.

Éstas son las tierras que a el dicho cabildo, de la dicha yglesia, en el dicho lugar de Torquemada y en su término:

Primeramente, tras San Nicolás, tres obradas, en surco de Joán Yníguez, çapatero. Otra fazuela tras Santa Cruz, en surco de Joán Alfonso, amas partes. Otra obrada carrera Matança, a man derecha, en surco de Joán Yniguez, escudero. Otra tierra en que a dos obradas, en Biello, en surco de Joán Sánchez de la Laguna. Una obrada en la era, en surco de Garçía Gómez, con su parte de la era. A más el dicho cabillo y yglesia en el dicho lugar de Torquemada, a la puerta del cortixo de Garçía López, dos suelos: el vno de la vna parte, en surco de donna Jitán; y de la otra parte, un surco de suelo que fue de Joán Gómez de Esganiellas. Y el otro suelo, en surco destos sobredichos, a San Nicolás.

Éstas son las viñas que an en el dicho término de Torquemada: 
Primeramente, una quarta en Requexo, en surco de viña de donna Jentín. Y otra quarta tras el huerto del Rico Ome, en surco de viña del abadesa. A Otero Mueso, media alançada, en surco de viña de don Gil del Erroyo. Çinco quartas en Arenas, en surco de Garçía Cardera. Otro pedaço de çinco quartas en las lomas de Villa Mediana, en surco de Garçi Layo. El majuelo de ençima de Val de Frades, que tiene Joán Pérez a medias, en que ay una alançada, que es de Pastor.

Ésto es lo que el dicho cabildo de Fusiellos a en Pozuelos Damayanos y perteneçe a la iglesia de Fusiellos:

Primeramente, en Pozuelos (f.201r) de Amayanos ay dos iglesias, a la vna llaman de Santa MarÍa y a la otra San Miguel; y esta iglesia de San Miguel, con la meytad de todo el diezmos deste dicho lugar de Pozuelos, es todo de la iglesia de Fusiellos. Y es préstamo e tiénele agora, Domingo Gonçález, chantre de Fusiellos, y ay tierras suyas, desta iglesia de San Miguel, que perteneçen al que a el préstamo. Y en la otra iglesia que llaman de Santa María a el cabildo de Fusiellos, la quarta parte, que es de la otra mitad del diezmo deste dicho lugar; y las otras tres parte, llévalas el clérigo dende y los prestameros de la yglesia de Palençia.

Ésto es lo que el dicho cabildo de Fusiellos a en Villacís:

A el dicho cabildo de Fusiellos en Villaçís, en la iglesia que llaman de San Mamés, la quarta parte del término desta dicha iglesia; y las otras tres partes son del abad de Benebibas. Y el dicho abad a de poner quien lo coja y tomar, por el trabajo, el rrediezmo; y a lo de fazer saber al dicho cabildo de Fusiellos, que y nonbre por su parte al obispo.

Ésto es lo que el dicho cabildo a en Villa Gutierre:

Primeramente, Villa Gutierre es toda suya, espiritual y tenporal. La iglesia es toda suya; a de poner capellán que la sirva. An más, todo el diezmo granado y menudo y a, el prior de Fusiellos, la visitaçión de la dicha yglesia. Y an más, el dicho 
cabildo, de fueros: de cada par de buey o de bestia, una carga de pan, mitad trigo y mitad de çevada; y el que ouiere vn buey o vna bestia, a de dar media carga del dicho pan. $\mathrm{Y}$ an de poner alcaldes y merino, quando ellos quisieren. $\mathrm{Y}$ an las penas y caloñas y omeziellos que fueren fechos en el dicho lugar. Y an más, un açeña copera moliente, que es çerca del lugar, en su término.

Éstas son las tierras que an el dicho cabildo de Fusiellos en el término del dicho lugar de Villa Gutierre:

Vna tierra a Santa Coloma, en que a doze obradas, linderos: Fernán Sánchez, çapatero; e de la otra parte, Joán de Cabria. A Los Casares vna tierra sobre las eras, en que ay seis obradas. Sobre el arroyo que va a la açeña, vna tierra de tres obradas, en linde del camino. Sobre el camino de la açeña, otra tierra de seis obradas, a Val Peral. Otra tierra de seis obradas en el llano del monte. Contra Monçón, dos tierras, en cada, çinco obradas. Tras el cortijo, otra tierra de seis obradas. Camino de Astudiello, seis obradas y más tres ferrenales, que son entre Los Casares. Y estas tierras fueron dadas a Garçi Álvarez y a Rui Gonçález porque morasen en el dicho lugar de Villa Gutierre.

Éstos son los que an heredamiento en Villa Gutierre:

Y no fazen fuero y an a pagar para el cortixo, esto que se sigue: los hijos del abad, veynte y çinco maravedís. Fijos de Pero Gómez, veynte y çinco maravedís. Fijos de Benito Pérez, çinquenta maravedís. Fernán Sánchez, carpentero, treynta maravedís. Garçi Pérez, veynte maravedís. Diego Fernández "El Romo", diez maravedís. Pero Fernández tiénelo de Joán de Cabria y a de pagar, por ello, veynte maravedís. Gonçalo, que mora en Villa Ximena, diez maravedís. La tierra de la iglesia, en que a çinco obradas, la rrenta della es para la lánpara.

Ésto es lo que el dicho cabildo a en Pozuelos Damianos:

An, el prior y el cabildo de la yglesia de Fusiellos, en Pozuelos la quarta parte de todos los diezmos del dicho lugar y termino que perteneçe a la iglesia de Sancta 
Maria, del dicho lugar de Pozuelo, y las otras tres partes perteneçen a la iglesia de Palençia.

Ésto es lo que el dicho cabildo a en Frechiella:

An, el prior y el cabillo de la dicha villa de Husiellos, en el término de Frechiella: vna tierra al Arroyo de Yuso, que es en la Reguera del Anegal, en que ay tres obradas que es en vega, linderos: tierra de Pero Rajo, moço, y tierra de fijos de Joán Pasqual $(f .201 v)$.

Ésta es la eredad de tierras que a el dicho cabildo de Fusiellos en Pajares:

A el cabillo a Pajares, a el canpo de Las Quintanas, vna tierra en que ay quinze obradas, lindero fijo de Garçía Díaz y Gil Fernández. Otra tierra a Matarrojas, que llaman tierra del Barquellora, que a tres obradas, linderos: Pero Fernández y Pero Gato. Otra tierra carrera Pajares, lindero, en que ay obrada y media, lindero Gil Fernández. Otra tierra a Torre de Pajares, en que a nueve obradas, lindero tierra de Toribio Gato. Otra tierra lindero de carrera de Pajares y linde Alfonso Maçías, en que a diez obradas. Otra tierra que dizen de Los Silos, en que ay doze obradas, linde a Joán Fernández de Palençia y tierra de Los Clérigos. Otra tierra que llega a Val de Quintaniella, linde Joán Fernández, arçipreste de Palençuela; y linde fijos de Ugo Bernal, en que a tres obradas. Otra tierra a Santa Gadea, linde Gutierre Garçía y linde Gonçalo Garçía, criado del arçediano de Campos. Otra tierra a la huelga de Pajares, en que ay quinze obradas, linde la era y Diego Pérez. Otra tierra linde la era y del yerno de Martín Díaz y Diego Pérez, en que ay ocho obradas. Otra tierra cabe la era de Pajares, linde Diego Pérez y Gil Fernández, en que a dos obradas. Otra tierra linde Miguel Sánchez y Diego Pérez, en que a obrada y media. Otra tierra que dizen tierra del Arbejal, linde de la fija de la Madalena y de Diego Pérez, en que a doze obradas. Otra tierra a do dizen La Natera, linde el arroyo y Joán Fernández e Joán Fernández, fijo de Diego Fernández, en que ay seis obradas. Otra tierra a la Viña Redonda, linde Pero Llorençio e Joán de Paredes, en que a çinco obradas. Otra tierra a Los Espinos, cabe las viñas, en que ay seis obradas. Otra tierra que llaman la tierra del Buey, en 
que ay seis obradas. Otra tierra linde carrera La Cuesta, en que ay vna obrada. Otra tierra allén del Arroyo, en que ay obrada y media. Otra tierra carrera Castro, que dizen del Corcobado, en que ay seis obradas, linde la dicha carrera. Otra tierra a las Lomas, linde Fernán Maçías et linde de Las Viñas, en la qual a dos obradas. Otra tierra cabo la viña de Rui Pérez, cabe la carrera que van a aguas, linde de Bartolomé Pérez y el yerno de Pero Moriel, en que a ocho obradas. Otra tierra a Val de Castro, en que a dos obradas, linde Santiago. Otra tierra carrera al Ferrero, linde Benito Pérez y Fernán Maçías, en que a tres obradas. Otra tierra a Val de Quintaniella, en que a diez obradas, linde Gil Fernández y Pero Alcalde. Otra tierra a la era de Quintaniella, linde Gil Fernández y Diego Pérez y Pero Sotil, en que a diez obradas. Otra tierra a las ferrenes, son éstas que son dentro, en Los Casares, que a dos obradas.

Ésta es la eredad que tiene Joán Andrés, arçipreste de Val Cañas, del dicho cabildo, que es en término de Grijota:

Dos tierras en que ay quatro obradas, çerca de las açeñas de Pajares, linderos: Pero Fernández Sancho et tierra que fue del arçipreste de Bezerril. Otra tierra et viña en Las Quintanas de Grijota, a do dizen Los Callones, en linde viña de los capellanes e viña de Alfonso Martínez Delgado. Otra viña en Las Quintanas, en Lino, e viña del Obispo.

Éstas son las viñas que a el dicho cabildo de Fusiellos en término de Las Frieras, que rrinden dozientos maravedís:

Un pico en que a una alançada, par del camino que va a Grijota por allende el rrío, linderos: este dicho camino y viña de Alfonso Fernández, cardador. Más, otras seis quartas, linderos: este dicho camino y viña de pendiente a al camino. Otras quatro arançadas, la viña Rala que dizen, linderos: (f.202r) el dicho camino e viña de Diego Martínez, notario de Palençia. A el cabildo otra viña que tienen los fijos de Fernán Gómez de Corral, linderos: viña de Santa María de las Misas; y de la otra parte, viña del cabildo de Fusiellos, esta viña a diez y seis alançadas. A el cabildo otra viña de dos arançadas, que llaman El Pico, linderos: viña el Ospital 
de Sancta María; y de la otra parte, [...]. Otra viña que dizen del Buey, de ocho alançadas, linderos del camino que viene de Castro Mocho a las açeñas de Pajares; y de la otra parte, viña de los Quarenta Capellanes de Palençia.

Ésto es lo que a el dicho cabillo en Santa Eufemia:

Primeramente, la iglesia es del cabildo. Los diezmos, así de pan como de granado y menudo. An de poner capellán. An más en San Christóval del Otero y luego, la meatad del diezmo del granado.

Ésta es la tenporalidad que el dicho cabildo de Fusiellos a en Santa Eufemia:

Primeramente, es el término todo suyo y llega fasta el camino de San Fagún y fasta la linde que sube a la cuesta y llega a la tierra de Françisco Fernández de San Miguel; la dicha heredad está junta, la maior parte della en derredor de la dicha yglesia y casa de Santa Eufemia y a por linderos: de la parte que está contra Fusiellos, el camino que va a Jigondo y el rrío de Carrión y la cuesta de San Christóval y llega a una tierra de San Christóval que está ayuso de las huertas, y llega a otra tierra de Martín Garçía y a otra tierra de Françisco Hernández de San Miguel y a otra tierra del obispo y a la tierra del obispo que está ençima del camino que va de Fusiellos a Palençia, a la mano siniestra; y de la otra parte desta a por linderos: otra tierra del obispo que llaman de San Fagún. A más otra tierra y luego de dos obradas, que a por linderos: la dicha tierra del obispo y tierra de Pero Fernández Sancho. Otra tierra de dos obradas çerca de la dicha tierra, que a por linderos: la dicha tierra del obispo que la çerca en derredor y la linde de la tierra de Santa Eufemia. Otra tierra çerca del dicho camino de Palençia y çerca del camino Travieso que va a Burgos, en que a obrada y media, que a por linderos: el dicho camino de Palençia y tierra del obispo e tierra que fue de Joán Fernández de Villamuriel. Otra tierra contra la dicha çibdad et allende del dicho camino Travieso, que a por linderos: tierra que fue de Martín Alonso, carniçero, y tierra que fue de Alfonso Sánchez, notario. Otra fazuela y luego, que a por linderos: la dicha tierra de Alfonso Sánchez y tierra de Pero Fernández Sancho y el camino de Palençia. Otra façuela ay luego de la otra parte del dicho camino, que a por 


\section{LA ABADÍA DE SANTA MARÍA DE HUSILLOS: ESTUDIO Y COLECCIÓN \\ DOCUMENTAL $(904-1608)$}

linderos: de amas partes, tierra de Joán Díaz, carniçero, y el dicho camino. En Berneguer a tres tierras que fueron viñas, en que ay dos obradas, y la una a por linderos: tierra de Martín Sánchez, conpañero en la iglesia de Fusiellos, et tierra de fijos de Alfonso Pérez, andado de Barajuela, y tierra de Françisco Fernández, fijo de don Suago; y la otra tierra a por linderos: tierra de San Christóual e tierra de Andrés Martín, pellijero; y la otra tierra a por linderos: la dicha tierra de San Christóval y la dicha tierra de Andrés Martín. An más a Los Foyos, una viña de çinco quartas, que a por linderos: viña de Estevan Pérez, carniçero, y viña de Joán Alfonso Paniagua. An más otra viña a Val de Quintaniella, que a por linderos: de la una parte, el camino que va de Quintaniella a la puente; y de la otra parte, viña de Diego "El Negro".

Éstas son las tierras e viñas que a el dicho cabildo de Fusiellos en Fuentes de Valdepero, que llaman de Sancta María:

Primeramente, una tierra en Escobares, en que a dos obradas, en linde de la carrera que va a Fusiellos. Otra tierra ay luego, en que a una quarta, linderos: Joán Gómez. Otra tierra carrera Requexo, en que a media quarta, $(f .202 v)$ linderos: Pero Gonçález Poya. A la puenta del, ençima, otra tierra en que a dos quartas, linderos: Alfonso, fijo de Pero Gonçález, e Fernán Felizes. Otra tierra a la linde Gorda, en que a una quarta, lindero Joán Tirón. Ençima desta linde Gorda, dos tierras en que a una obrada, linderos: de la una parte, Fernán Gil; e de la otra parte, tierras de San Pero a San Estevan. Otra tierra en que ay media quarta, lindero Joán Martín, hijo de Gonçalo Martín. Otra tierra a la Cabaña, en que a media obrada, lindero Sancho, hijo de Rui Pérez. Otra tierra en Valletariego, en que a una obrada, que a por linderos: Estevan. Dos tierras que dio el chantre Domingo Gonçález al prior y cabildo por aniversarios de su padre e de su madre, que es la una tierra do dizen el Val, en que a tres obradas, que a por linderos: de la una parte, tierra del abadesa de Tórtoles; y de la otra parte, la carrera del Val; y de la otra parte, tierra de Santos Coxo; y la otra tierra a La Momenta, en que a seis obradas, que a por linderos: de la una parte, viña de Toribio Magaz; e de la otra parte, el sendero que va a Muñeca; y de la otra parte, tierra de Martín Tiron. 
Éstas son las viñas que llaman de Santa María que se siguen:

Primeramente, en Rebiella, una viña en que a una lançada, que a por linderos: Joán Cascajo; y de la otra parte, el señor. A Pozuelo, una viña en que a una quarta, que a por linderos: Rui Gómez; e de la otra parte, tierra de Joán, fijo de Martín Yánnez. A La Momenta, otra viña en que a una quarta, lindero Domingo Garçía, fijo de Garçía Laso. En Val de Caçán, otra viña en que a una lançada, linderos: Sancho Fernández. A Escobares, otra viña en que a tres quartas, linderos: Joán Toribio; y de la otra parte, San Christóval de Monçón. Otra viña a carrera de Llano, en que a quarta y media, linderos: Joán Tiron. Otra viña carrera Callejas, en que a tres quartas, linderos: de la una parte, viña de Llorente Fernández de Vega; y de la otra parte, viña de Martin Tirón; y de la otra parte, la dicha carrera.

Éstas son las tierras que a el dicho cabiello de Fusiellos en Bezerrilejos:

La tierra de Los Casares, en que a dos obradas, linderos: Las Arroyadas. Otra tierra en que a media obrada, linderos: el camino de cabe Las Çarças; y de la otra parte, tierra de Diego Alfonso. Otra tierra que llaman El Alvar, en que ay quatro obradas, linderos: el arroyuelo y tierra de fijos de Garçía Martínez. Otra tierra al arroyuelo, en que ay una obrada, linderos: tierra de Sancho Pérez y tierra de Diego Alfonso. Otro pedaçuelo de la otra parte, al arroyuelo, en que ay media obrada, linderos: el dicho arroyuelo y tierra de Pero Garçía. Otra tierra çerca de la tierra de Álvaro Garçía, en que ay una obrada, linderos: Sancho Garçía. Al arroyo de La Piesga, una tierra grande en que ay çinco o fasta seis alançadas, linderos: el dicho arroyo de La Piesga y el camino que va a Bezerril. Al arroyo de Frades, otra tierra grande en que ay ocho obradas, linderos: el dicho arroyo y tierra de Diego Fernández Lenteja. Otra tierra grande carrera Palençia, en que ay diez obradas, linderos: camino de Palençia y camino que va a Bezerril. Otra tierra carrera de Hebra Mala, pasante el cuérnago a mano ynquierda, en que ay una obrada, linderos: Pero Garçía; y de la otra parte, Bezerrilejos. Al senderuelo que va a Santillán, a la mano derecha, una tierra en que ay seis obradas, linderos: la carrera de Santillán; y de la otra parte, tierra de Pero Fernández Lenteja. 
Éstas son las tierras y viñas y suelos que a el cabildo de Fusiellos en Villandavín:

A Valmenor, una tierra en que a dos obradas, linderos: Pero de Ribas y el sendero que entra en Valmenor. Otra tierra de un pico, en que a una obrada y media, que es en carrera de Villa Momana, linderos: Garçía Rodríguez y fijos de Rodrigo Alfonso. So Zerezo, en dos lugares, dos pedaços en que ay obrada y media, linderos: Sancta Cruz y Pero de Ribas. So las viñas de so La Calleja, dos obradas en linde Martín Fernández Muñón y el camino del Rey. Carrera del Prado, dos obradas lindero la dicha carrera. Al Vadiello, una obrada (f.203r) en linde el camino de San Zebrián y la heredad del abad de Fusiellos que dizen del Prado. Al arroyo de la Fuente, media obrada, linderos: Mençía Fernández y el dicho arroyo. Carrera de San Felizes, cabe la aldea, dos obradas linde del Corral Maior. A los Vallejos, una obrada en linde el arroyo. A la Vega una tierra que llega a la ponteziella de parte del rrío, contra Villandavín, ençima de Poza Caño, una viña que llega a la carrera de Villafruela. Más en el dicho logar, un solar yermo en linde erederos de Gutierre Pérez y la calle e que va de la fuente al Otero.

Ésto es lo que el dicho cabildo a en Çelleruelo:

Primeramente, Çelleruelo es todo suyo, espiritual e tenporal y todo el término. La yglesia es suya y an de poner capellán que la sirva. Y el prior de Fusiellos a la visitaçión de la iglesia. Y a más el cabildo, los diezmos del dicho lugar de granado y menudo.

Temporalidad:

A de poner, el prior y cabildo, alcaldes y merino, quando ellos quisieren, y las penas y caloñas y omeziellos, que fueran fechos en el dicho lugar, son suyos. Y el heredamiento de todo el término es del cabildo de Fusiellos.

Tierras del dicho cabildo: 
An el dicho cabildo, una tierra que dizen de La Quintana, en que puede aver fasta quarenta obradas, que a por linderos: la tierra de Alfonso Caro y el camino que va de Villa Martín a Çelleruelo. Más otras dos tierras a do dizen Los Picos de carrera Mazariegos, en los quales puede aver fasta veynte obradas y más, y an por linderos: dos senderos, al uno dizen el sendero de Mojasedas y al otro, el que va de Çelleruelo a Mazariegos. Y luego, otra tierra que ay en ella fasta quinze obradas, que a por linderos: el dicho sendero de Mojasedas y el sendero que va contra el villar. Y luego, otras tierras que están muchas suertes hechas, e dízenlas los Picos de carrera La Torre, en estos puede aver fasta treynta obradas o más. Destos son linderos: los caminos que van contra Pedraza y contra Rebiella y Santa Yugenia. Y luego, çierca destas tierras, ay otra tierra que dizen El Majuelo, que a por linderos: las ferrenes de Çelleruelo, en esta puede aver fasta diez obradas. Çerca desta, son otras tierras que llaman Los Ferrenes, en que puede aver fasta quinze obradas, que an por linderos: el cortijo de Çelleruelo. Çerca desto, ay otra tierra en que puede aver çinco obradas, que a por linderos: la tierra que dizen de La Lánpara y el camino que va contra Villa Ramiro. Çerca desta ay otra tierra que llaman del Palomar, en que ay fasta veynte obradas, que a por linderos: el camino que va de Çilleruelo a Autilla y a por linderos: el Prado de Çelleruelo y el camino que va de Çilleruelo a Palençia. Çerca desta tierra, ay otra tierra que dizen de Las Piedras, en que puede aver fasta diez obradas o más, que a por linderos: el dicho prado y el dicho camino. Otrosí, ay más una tierra que dizen de La Lánpara, linderos: el camino de Autilla. Ay más, que dixo Salvador Pérez de Bezerril que oyera dezir a omes de Villa Martín y de Rebiella y de Santa Eugenia, que avía en el término de Çelleruelo y de Villa Martín una viña que era desta dicha iglesia de Santa María de Fusiellos y que, desto, no sabían más.

Éstas son las tierras y viñas y suelos que a el cabildo de Fusiellos en Sant Felices:

Primeramente, carrera de San Felizes, como van de Bezerril a mano yzquierda, una tierra en que ay una obrada, linderos: de la una parte, el dicho camino; y de la otra parte, viña de Miguel Martín del Foyo. Carrera de Monçón, dos tierras en que ay quatro obradas, linderos: de la una parte, una tierra que yaze cabe; y de la otra parte, tierra de Miguel Martín, fijo de Martín Joán; y linderos de la otra tierra: 


\section{LA ABADÍA DE SANTA MARÍA DE HUSILLOS: ESTUDIO Y COLECCIÓN \\ DOCUMENTAL $(904-1608)$}

tierra del fijo de Domingo Joán Vayello; y de la otra parte, tierra de Joán Linazero. Otra tierra çerca destas, en que ay media obrada, linderos: de la una parte, tierra de Joán Rodréguez; y de la otra parte, la carrera de Monçón. Otra tierra al Prado de San Felizes, en que ay una obrada, linderos: de la una parte, el dicho prado; y de la otra parte, tierra de Miguel Martín, fijo de Martín Joán. A San Christóval, dos tierras en que ay dos obradas, linderos: (f.203v) de la una parte, tierra de la de Garçi Pérez, fijo de Martín Garçía; e de la otra tierra: lindero tierra de Pero Ojudo. Al Foyo de Valdemeneses, otra tierra en que ay una obrada, linderos: de la una parte, tierra de Domingo Romanes, fijo de "La Ruçia"; y de la otra parte, tierra de Fernán Garçía, fijo de Joán Domínguez. En Valdeyeçín, una tierra en que ay dos obradas, linderos: de la una parte, tierra de Antón Texedor; y de la otra parte, tierra de Martín Joán. En Val de La Caraça, dos tierras en que ay tres obradas, linderos: de la una parte, tierra de Domingo Joán Vayello; y de la otra parte, tierra de Joán Domínguez; y linderos de la otra parte: viña de Román Pérez; y de la otra parte, tierra de Domingo Martínez. So la yglesia de San Felizes, una tierra en que ay media obrada, linderos: de la una parte, tierra de Fernán Alfonso, fijo de Alfonso Garçía; y de la otra parte, tierra de la de Garçi Peréz, fijo de Martín Garçía. Otra tierra carrera de Monçón, en que ay una obrada, linderos: de la una parte, tierra de Domingo Garrón. Al Moral, dos tierras en que ay dos obradas, linderos: de la una parte, tierra de Domingo Martínez Calvo; y linderos de la otra tierra: tierra de Fernán Alfonso, fijo de Alfonso Garçía; y de la otra parte, tierra de Martín Alfonso. A Pozo Salso, quatro tierras en que ay dos obradas, linderos de la una tierra: tierra de Pero Ximón; y de la otra parte, tierra de Martín Joán; linderos de la otra tierra: tierra de la de Pero Ximón, de la una parte; y de la otra parte, tierra de Rui Fernández; linderos de la otra tierra: de la una parte, tierra de Rui Fernández; y de la otra parte, tierra de Pero Roxuelo. Al palaçio de San Felizes, un herrenal en que ay una obrada, linderos: de la una parte, tierra de Martín Fernández Sinesmal; y de la otra parte, tierra de Miguel Martín del Foyo. Al arroyo de Las Fuentes, tres tierras en que ay una obrada, linderos de la una parte, de la una tierra: tierra de Alfonso Romero; e de la otra parte, tierra de Martín Mochano; linderos de la otra tierra: de la una parte, tierra de Fernán Pérez Xabador; y de la otra parte, carrera que va a Las Fuentes; linderos de la otra tierra: de la una parte, tierra del camarero; y de la otra parte, 
tierra de Martín Fernández Muñón. A Los Çiruelos, una tierra de tres obradas, linderos: de la una parte, era de Domingo Roxo; y de la otra parte, tierra de Pero Garçía, fijo de Martín Miguel. En Val de La Hesa, una tierra en que ay quatro obradas, linderos: el dicho val, de la una parte; y de la otra parte, viña de Santa María de Fusiellos; en esta tierra ay linderos, que fue parada otro tienpo. A Faças, en este dicho Val de la Hesa, una tierra la cañada arriba en que ay quatro obradas, linderos: de la una parte, tierra de Antón Texedor; y de la otra parte, majuelo de la Garona en la qual ay una obrada. Otra tierra en Media Era, linderos: de la una parte, majuelo de Pero Garçía, clérigo; y de la otra parte, la carrera. En este dicho término de San Felizes, una viña en que ay de doze fasta quinze quartas, linderos: de la una parte, viña de Alfonso Garçía, fijo de Garçía Pérez Maçano; y de la otra parte, viña de Martín Joán, fijo de Miguel Martín; y de la otra parte, la dicha tierra de Santa María de Fusiellos, en que estan las dichas linderas.

Éstas son las tierras, viñas y suelos y vasallos que a el dicho cabildo de Fusiellos en Amayuelas de Yuso:

Primeramente, an de poner merino en los sus vasallos. Los heredamientos son éstos: dos partes de obrada en linde de las eras, linderos: los clérigos del Barrio de Yuso, de la una parte; e de la otra, el abadesa de Perales. Dos tierras carrera Molmo, en que ay obrada y media, linderos: de la una parte, tierra de la orden de Amayuelas de Yuso; y de la otra parte, tierra de doña Maior de Ribas; y linderos de la otra tierra: tierra del abadesa de Perales; y de la otra parte, tierra de Fernán Pérez, fijo de don Mateo. Otra tierra en Melgares, en que a obrada y media, linderos: de la una parte, la carrera que va de La Cava; y de la otra parte, tierra de Pero Gonçález. Otra tierra a Matilla, en que a una obrada, linderos: la carrera que va a La Nava; y de la otra parte, la carrera que va a Carrión. Otra tierra a Fuente Sacollán, en que a obrada y media, linderos: tierra de don Nicolás $(f .204 r)$ y el sendero que va a las viñas de Matilla que pasa por ello; y de la otra parte, tierra de Domingo Pérez de Ordejón. Otra tierra a Oteruelo de Vid, linderos: tierra de la Orden del Barrio de Suso; y de la otra parte, tierra del abadesa de Perales. Otra tierra a Poçilgas, en que ay dos partes de obrada, linderos: el sendero que va a otero de Noyas; y de la otra parte, tierra de la dicha abadesa de Perales. Otra tierra 
a Malçena, en que a dos partes de obrada, linderos: de la una parte, el abadesa de Perales; y de la otra parte, tierra del Santo Sepulcro. Otra tierra a La Huelga, en que a media obrada, linderos: de la una parte, doña Maior de Ribas; y de la otra parte, Diego Pérez, fijo de Sancho Gómez de Piña. Otra tierra [a] Arroyales, en que a dos obradas, linderos: de la una parte, tierra de Lope Martín de Rueda; y de la otra parte, tierra de doña Maior. Otra tierra a carrera de Monçón, en que a dos obradas, so El Atali, linderos: de la una parte, el abadesa de Perales; y de la otra parte, la dicha carrera e Joán Velasco. Otra tierra so Arenas, al arroyo, en que a dos obradas, linderos: de la una parte, el arroyo; y de la otra parte, las tierras de los aniversarios que tiene Alfonso Gutiérrez. Otra tierra en Bezanan, en que ay dos obradas, [linderos]: de la una parte, Joán Velasco; de la otra parte, Fernán Pérez, fijo de don Mateo; de la otra parte, los clérigos de San Viçente. Otra tierra so los majuelos, en que a obrada y media, linderos: de la una parte, tierra de la iglesia de San Viçente; de la otra parte, tierra del aniversario que tiene Domingo Conejo y Joán Martín. Otra tierra al Prado, carrera de Ribas, en que a una obrada, linderos: de la una parte, Gonçalo, fijo de don Joán; y de la otra parte, tierra de fijo de doña Sancha. Otra tierra a como serna, en linde del Prado, en que a media obrada, linderos: de la una parte, tierra de Joán Velasco; y de la otra parte, tierra del abadesa de Perales.

Las viñas que a el dicho cabildo de Fusiellos en término del dicho lugar de Amayuelas, son estas siguientes:

A los majuelos, primeramente, una viña en que a tres quartejones, linderos: de la una parte, viña del abadesa de Perales; y de la otra parte, viña de doña Maior de Ribas. En este mismo pago, una quarta, linderos: de la una parte, viña de doña Maior; y de la otra parte, el abadesa de Perales. Otra viña en este pago, en que a un quartejón, linderos: viña de don Nicolás; y de la otra parte, Domingo Pérez, fijo de Mari Mínguez. En este mismo pago, media quarta, linderos: Joán Velasco; y de la otra parte, fija de Martín Alfonso de Amayuelas de Suso. En este mismo pago, so los majuelos, otra viña en que a tres quartejones, linderos: la cofradía de Santa María; y de la otra parte, Joán Velasco. A La Nava, carrera de Poblaçión, una lançada en dos lugares, linderos: de la una parte, viña de la cofradía de San 
Joán; y de la otra, viña lindero viña de Fernán Barrial; y de la otra parte, viña de la cofradía de Santa María. A Los Arenales, a La Hormiga, otra viña en que a quarta y media, linderos: doña Gila; y de la otra parte, Pero Abad, clérigo. Otra viña en Arroyales, en que a tres quartas, linderos: el prado; y de la otra parte, la carrera que va a Hamusco. En este mismo pago, otra viña sobre la carrera, en que a quarta y media, linderos: la serna de doña Maior y la dicha carrera. Dos lineros a Lindera Sorda, linderos: la serna de doña Maior; y de la otra parte, la dicha carrera. Un prado a como serna, en que a, la dicha yglesia de Fusiellos, el diezmo; uno era en las Eras de Suso, en que an los señores, y ella, el diezmo. An más, el diezmo en los palaçios que están y luego.

Los solares que an en el dicho lugar son estos que se siguen:

Un solar en que mora Joán Velasco, linde casas de Mateo Redondo. Otro solar en que moran fijos de don Antolín. Otro solar en que mora Joán Calvo, linde casas de Alfonso, fijo de Joán Alfonso. Otro solar en que mora Pero López. Dos solares en que mora Pero Abad. Otro solar en que mora Joán Garçía. La meatad de otro solar en que mora Joán López. La quinta parte del solar (f.204v) en que mora Domingo Ybañes, fijo de don Álvaro. La quinta parte deste solar, que tiene Pero Fernández de la Posada.

Éstos son los préstamos que a la iglesia de Fusiellos:

Primeramente, el préstamo de Calabaçanos, ale Joán Fernández de Mexieses, prior en la dicha yglesia. El préstamo de Fuen Pudia, que es en la yglesia de Santa María de Castrillo, ale el dicho Joán Fernández, prior, y Domingo Gonçález, chantre en la dicha yglesia; y cada uno destos dos an la quinta parte, e Fernán Martínez de Palençia, canónigo de la dicha yglesia, a las otras dos partes. El préstamo de la eredad de Mazariegos, ale el dicho Fernán Martínez, con los diez y ocho maravedís de martiniega que a de dar el conçejo del dicho lugar de Mazariegos. El préstamo de San Miguel de Fuentes, avía las dos partes Joán Pérez de Açeves, prior que fue de Fusiellos, y la otra parte, es anexa a la sacristanía; y la estimaçión deste préstamo es veynte y çinco maravedís. A más, otro préstamo en 
el dicho lugar de Fuentes, que es en eredad que dizen del capiscol, et a lo Domingo Gonçález, chantre. A más otro préstamo en San Miguel de Pozuelos y es en eredad y ale el dicho Domingo Gonçález, chantre. A más en las iglesias de San Mamés y de San Román e de San Martín de Freciella, en eredad, y a lo [...]. A más otro préstamo en la yglesia de Santa María de Castriello, que es en heredamiento, y ale Domingo Fernández de Castriello, canónigo. A más en las yglesias de San Sebastián e en la yglesia de Bezerril, un préstamo que es en eredad, y avíale el dicho Joán Pérez, prior de Fusiellos. A más otro préstamo en Grijota, que es en eredamiento, y ale el dicho Domingo Gonçález, chantre. A otro préstamo en Çellanova y es en eredamiento e ale Toribio Fernández de Carrión. A otro préstamo en Santa María Madalena de Villa Çalama, que es heredamiento, y ale el dicho Domingo Gonçález, chantre. A más otro préstamo en Fusiellos, que son unas casas, y ale Martín Miguel. A más en la iglesia de Santa Eugenia de Piña otro préstamo, y avíale el dicho Joán Pérez, prior, e Joán Alfonso de Toledo e Joán Fernández de Grijota. A más doze eras para fazer sal en las salinas de Añana, con sus pozos y anziles, salvas de todo tributo y exenpçion rreal.

Éstas son las posesiones y diezmos y otras cosas que perteneçen a los préstamos que a la iglesia de Fusiellos en el obispado de Palençia y en otras partes:

Préstamo de Calabaçanos:

Primeramente, un solar de casas con su huerto y corrales, que están juntas con la dicha yglesia de Calabaçanos, saliente la puerta del dicho lugar. Una era que a por linderos: camino de Palencia que va a Dueñas; y de la otra parte, una çerca del dicho préstamo en que a tres obradas; la qual dicha tierra a por linderos: tierra del Quinto y tierra que fue de Alfonso Fernández. Otra tierra en la nava de Calabaçanos, en que ay veynte e quatro obradas, que a por linderos: de la una parte, la carrera que va a Magaz; e de la otra parte, tierra de los fijos de Rodrigo Alfonso de Tariego. Otra tierra carrera del Monte, en que ay una obrada, linderos: la dicha carrera. Otra tierra a Los Conchonares, en que a dos obradas, linderos: viña de Fernando Téllez; e de la otra parte, tierra que fue de Joán Rodríguez de Sesamo. Otra tierra en la nava, al Salguero, en que a dos obradas, linderos: de 
amas las parte, tierras de fijos de Rodrigo Alfonso de Tariego; y de la otra parte, tierra y exido del conçejo. Otra tierra en el dicho lugar, çerca desta, en que ay media obrada, linderos: tierra de los fijos de Rodrigo Alfonso de Tariego; y de la otra parte, las viñas. Otra tierra a Los Çernales, en que ay dos obradas, linderos: el sendero de Los Çernales; y de la otra parte, tierra que fue de Joán Rodríguez de Sesamo. Otra tierra ay luego, en que a çinco obradas, lindero el dicho sendero de los Çernales y tierra que fue de Alfonso de Corral y tierra que fue de Toribio Fernández, (f.205r) merino. Otra tierra a Bernal, en que a dos obradas, que a por linderos: de la una parte, tierra de la capellanía del dicho Joán Rodríguez; y de la otra parte, tierra de Martín Garçía de Baños. Otra tierra a Los Morales, en que ay una quarta, linderos: tierra que fue de Joán Rodríguez; e de la otra parte, carrera que va a Tariego. Otra tierra a la torre mocha que llaman El Quadrón, en que ay obrada y media, linderos: tierra que fue de Joán Rodríguez e tierra de la capellanía e tierra de fijos de Toribio Fernández, merino. Otra tierra a Los Picones, en que ay una obrada, linderos: tierra que fue de Joán Rodríguez y la carrera que va de Palençia a Tariego. Otra tierra carrera de Tariego, a do dizen a La Muela, que a seis obradas, linderos: la dicha carrera e tierra que fue de Joán Rodríguez. Otra tierra a Los Foyales, en que ay diez y ocho obradas, linderos: el sendero que viene de Baños al camino de Dueñas; e de la otra parte, el sendero de Val de Rey que va al prado de Sant Ysidro. Otra tierra al fito del camino de Burgos, en que ay quatro obradas, linderos: el dicho camino y el dicho sendero de Val de Rey en el término de Sant Ysidro. Una tierra al sendero de Val de Rey, en que ay dos obradas, linderos: el dicho sendero; y de la otra parte [...]. Otra tierra a do dizen La Mansyella, en que ay veynte et quatro obradas, linderos: el camino de Burgos y el dicho sendero de Val de Rey, que atraviesa por mitad de la dicha tierra, y el sendero que sale del camino de Dueñas. Otra tierra a La Mansiella, en que ay doze obradas, linderos: tierra de la cofradía de Santiago; e de la otra parte, tierra de Toribio, fijo de Joán Pérez. Otra tierra al camino de Dueñas, en que ay seis obradas, linderos: el dicho camino; y de la otra parte, tierra que fue de Alfonso de Corral. Otra tierra al camino de Cañamales, en que ay dos obradas, linderos: el dicho camino; y de la otra parte, la peña de la rribera del rrío de Carrión. Otra tierra a Cañamares, en que ay doze obradas. Otra tierra en término de Villamuriel, carrera de Fuente Rodrigo, en que ay siete obradas, linderos: tierra que fue de 
Joán Rodríguez; y de la otra parte, tierra de los capellanes del deán don Pero Martínez. Y otra que fue de Teresa Pérez, que es agora de los fijos de Joán Álvarez. Otra tierra a Fuente Amarga, que llaman La Sernilla, en que a diez obradas, linderos: el camino e viñas de herederos de Villamuriel e viña que fue de Nicolás Pérez. En el término de Calabaçanos, una viña que dizen del Majano, en que ay alançada y media, linderos: viñas que fueron de Fernando Téllez "El Moço". Otra viña en que ay media alançada, que es çerca de los caminos que departe los términos de Villamuriel y de Calabaçanos. En el dicho término de Villamoriel, en la nava, una viña en que a tres alançadas, linderos: el camino que va de Palençia a Baños; y de la otra parte, el camino que va de Villamuriel al término de Solvira. Y todos los diezmos de toda esta dicha eredad y tierras y viñas. Y otrosí, las dos partes de todos los diezmos del dicho lugar de Calabaçanos y de su término, ansí granado como menudo, perteneçen e son del dicho préstamo, salvo ocho cargas de pan que a de aver el clérigo curado de la dicha yglesia e lugar de Calabaçanos. Y el préstamo de la dicha yglesia a de presentar el dicho clérigo curado al abad de Fusiellos cuando vacare.

Préstamo de la iglesia de Santa María de Castrillo, çerca Fuente Pudia:

Primeramente, toda la heredad y prados que está junta; de la qual dicha eredad, son linderos de la parte de la carrera de Villa Verde: tierra de Pero Martínez Halloria e tierra de Martín Garçía; y otrosí, tierra, de la otra parte, de Domingo Fernández Cortés y dos tierras de aniversarios de las yglesias de Fuenpudia y tierra de Estavan Fernández y el camino que va de Valloria a la Torre que está entre el uno de los dichos prados de préstamos y el prado del conçejo de Fuenpudia; y la sobredicha eredad está junta y allende deste dicho prado de Fuenpudia. Otra tierra en que ay obrada y media, linderos: tierra de Fernán Gómez y tierra que fue de Domingo Gonçalez Chiquete. Otra tierra en que ay una obrada, a la Fuente (f.205v) de Castiello, linderos: viñas de Joán Martínez de la Lodera y la carrera [a] Castro e Faza Ortiz, tierra que fue de Miguel Ruiz e tierra de Pero Arenal e tierra de Fernán Gómez e tierra de Domingo Rodríguez Castrillo. Y otra tierra en Valdegestro, en que ay obrada y media, linderos: tierra que dizen de La Reyna e tierra de Gonçalo Fernández de Valloria. En el pago de 
Arenillas, una viña en que ay diez alançadas o más, linderos: viñas de fijos de Martín Ruiz de Turiso e viña de Joán Andrés, clérigo de Valloria, y viña de Joán Andrés, lego de Valloria, e viña de Alfonso Fernández, fijo de Domingo Fernández. Otra viña que es çerca de La Cabaña, en que ay quarta y media, linderos: viña que fue de Fernán Pérez, fijo de doña María, e viña de Pero Díaz Arconada. Otra viña en que ay una quarta, linderos: viña de Joán Fernández, fijo de Rui Fernández de Valloria, y la carrera que va a Monte Alegre y la carrera que va de Valloria a Castro e biña de fijos de Domingo Fernández. E todos los diezmos de la dicha heredad, tierras e viñas, perteneçen a los dichos préstamos.

Préstamo de Mazariegos:

Éstas son las tierras que son del préstamo que la iglesia de Fusiellos a en Mazariegos: primeramente, una tierra que es entre amas carres vegas, en que a una obrada, linderos: tierra de Joán, fijodalgo. Otra tierra carre vegas, en que ay quatro obradas, linderos: tierra de Domingo Díaz y tierra de fijo de Fernán Pérez. Otra tierra en que a dos obradas y media, carrera Palençia, linderos: tierra de Lope Fernández de Bezerril e tierra de Rui Pérez "El Moço"; y linde la carrera que va por medio. Otra tierra en que ay çinco obradas, carrera de Atalaya, en dos lugares, y pasa la carrera por medio de amas tierras, linderos: tierra de Toribio Yvañez y tierra de Antolín Pérez. Otra tierra en que ay quatro obradas, en tres lugares, al otero de Padiella: una tierra a la carrera, linde tierra de Alfón Diez; la otra tierra, lindero tierra de "La Lirona" e tierra de Domingo Antón; así que son aquí tres tierras, linde destos dichos linderos. Otra tierra carre sendero, en que ay una obrada, linde tierra de Martín Fernández Amo. Otra tierra a los majuelos de Las Quintanas y del Moro; la una tierra linde tierra de Pero Martínes; la otra tierra, linde Garçía Pérez de Bezerril e linde tierra de fijos de Garçía Oreja. Otra tierra a la vega, en que ay tres quartas, linde tierra de Miguel Martínez de Bezerril. Otra tierra a La Quinta, en dos lugares, en que ay quatro obradas, linderos: Miguel Antón e tierra de fijos de Antón Pérez. A más el que fuere prestamero del dicho prestamo, en cada año, en el conçejo de Mazariegos, por el día de San Martín, diez y ocho maravedís de martiniega. 
Préstamos de Fuentes de Don Bermudo:

En la iglesia de San Miguel de Fuentes de Don Bermudo y en el dicho logar de Fuentes y en sus iglesias a la dicha iglesia de Fusiellos, veynte y çinco maravedís de préstamos; y destos dichos veynte y çinco maravedís, perteneçen a la sacristanía de la iglesia de Fusiellos los dichos ocho maravedís y dos cornados; y los otros diez e seis e quatro cornados perteneçen a los préstamos de la dicha yglesia de San Miguel, çerca de Fuentes, que es del abad y yglesia de Fusiellos. Otro préstamo en el dicho lugar y término de Fuentes de Don Bermudo, que dizen del Capiscol; éstas son las tierras del préstamo que el chantre a en término de Fuentes de Don Bermudo y viñas que llaman, esta dicha eredad, del Capiscol: primeramente, una tierra a la Laguna Freyras, en que a diez y ocho obradas, linderos: Estevan Martín e Martín Muñoz. Otra tierra y luego, en que a quatro obradas, en que a por linderos: Román Çierço y la carrera de Autiello. Otra tierra al Bezerral, en que ay dos obradas, linderos: Joán Felipe e Joán Yzquierdo. Otra tierra en Avenar, en que ay diez quartas, linderos: Estevan Martín, Pero e Joán de Autiello. Otra tierra al oteruelo de Cantero Nava, en que ay dos obradas y media, linderos: la carrera (f.206r) Joán Maestro. Otra tierra de siete obradas carrera de Villa Lomos, linderos: Ximón Paz y la carrera de Villa Lomos. Otra tierra carrera Nava, en que ay ocho obradas, linderos: Joán Cabeça y la carrera Nava. Y luego otra tierra de dos obradas, linderos: Martín Garañon y Salvador Peláez. Otra tierra carrera Menor, en que ay veynte quartas, linderos: don Manche y la carrera Menor. Otra tierra y luego, en que ay diez obradas, linderos: tierra de la yglesia de San Pelayo y de la carrera Menor. Otra tierra a San Miguel, en que ay quatro obradas, linderos: tierra de la abadía de Fuentes y la iglesia de San Miguel. Y luego una ferrén, en que ay dos quartas, linderos: el çimenterio de la iglesia de San Miguel. Otra tierra carrera Paredes, en que ay quatro obradas, linderos: Martín Garçía Pachuelo y la carrera de Paredes. Una ferrén a San Estevan, en que ay tres quartas, linderos: Alvar Fernández e Rui Pérez. Otra tierra carrera Pozuelos, linderos: la dicha carrera de Pozuelos y María Pachuela. [A] La Cornella, una tierra en que ay diez obradas, linderos: los arroyos; ésta no se labra.

Éstas son las viñas: 
Primeramente, una viña al Quadro, en que ay dos quartas, linderos: el majuelo de Fernán Pérez. Otra viña en Cuevar Maior, en que ay tres quartas, linderos: Joán Martínez, clérigo, e hijos del "Serrano". Otra viña en Cueva Menor, en que ay dos quartas, linderos: fijos de Joán Cormaza. El majuelo de La Loma, en que ay tres arançadas, linderos: la Loma.

Préstamo de San Miguel de Palaçuelos Damianos, eredad:

Primeramente, una tierra carrera de Paredes, en que ay tres obradas, linderos: la dicha carrera y tierra de Toribio Fernández. Otra tierra carrera Peliella, en que ay tres obradas y media, linderos: la dicha carrera e tierra de Estevan Fagúndez de Frechiella. Otra tierra ay luego, en que ay ocho quartas, linderos: la dicha carrera e tierra de fijos de Joán de Fuentes. Una ferrén en linde de la dicha yglesia de San Miguel, en que ay tres quartas. Otra tierra al Lilio, en que ay çinco obradas, linderos: tierras de fijos de Domingo Facúndez e tierra de fijos de Domingo Yzquierdo. Otra tierra en que ay diez quartas, linderos: la carrera de Pozuelos y tierra de Pascual Nieto "El Moço". Otra tierra en que ay çinco quartas, a la Fuente de las Frieras, linderos: tierra de Domingo Yzquierdo y la dicha fuente. Otra tierra y luego en que ay tres obradas, en linde de la serna de San Román. Y con todos los diezmos de la dicha heredad. E otrosí, con la mitad de los diezmos de la otra eredad del término del dicho lugar de Pozuelos.

Préstamos en las iglesias de San Mamés y San Román, çerca de Frechiella, eredad:

Esta es la eredad del préstamo que Joán Alfonso de Toledo a en Frechiella, que vacó por muerte de Domingo Fernández de Castriello, canónigo que fue de Fusyellos: una tierra al Arroyo Ayuso, en que a seis quartas, linderos: tierra de Marcos Fernández. Otra tierra carrera de Fuentes, en que ay doze quartas, linderos: tierra de Miguel Díaz. Otra tierra Tras la cavaña, en que ay çinco quartas, linderos: tierra de Pascual Velasco. Otra tierra carrera Palomares, en que ay tres quartas, linderos: tierra de Pero Martínez "Páxaro". Otra tierra sobre la de 
La Salguera, en que ay tres quartas, linderos: tierra de Fernán Escudo. Otra tierra a la viña de Fernán Pérez, en que ay dos obradas, linderos: la dicha viña e tierra de Lucas Pérez. Otra tierra carrera Fonda, en qua ay doze quartas, linderos: tierra de Pero Abril. Otra tierra y luego, en que ay dos quartas, linderos: tierra de San Mançio. Otra tierra a Barrio Moro, en que ay dos quartas, linderos: tierra de Pero Ferrero. Otra tierra carrera de Pedregales, en que ay dos quartas, linderos: tierra de Ximeno Rodríguez. Otra tierra a la Laguna de la Dueña, en que ay ocho quartas, linderos: tierra de Joán Fernández. Y luego otra tierra a la carrera Mayor, en que ay çinco obradas, linderos: tierra de Diego Lucas. Otra tierra a la Laguna de la Dueña, en que ay dos quartas, linderos: tierra de Asensio Fernández. Otra tierra y luego, en que ay tres quartas. Otra tierra y luego, en que ay çinco quartas, linderos: tierra de Joán Moratón. Otra tierra carrera Llano, en que ay dos quartas. Otra tierra a las Viñas Dehexas, en que ay dos obradas, linderos: tierra de Joán Rachón y de Pero Caballero. Otros dos pedaçuelos y luego, en que ay tres quartas, linderos: tierra de Fernán Havero. Otra tierra a la carrera Maior, al Espino, en que ay dos obradas, linde Joán de Burgos. Otra tierra y luego adelante, en que ay çinco quartas, linderos: tierra de Pascual Velasco. Otra tierra y luego, en que ay çinco quartas, linde Joán Ruiz, clérigo. Otra tierra al sendero de Viñas Deexas, en que ay siete quartas, linderos: viña de Fernán Prieto. Otras dos tierras y luego, en que ay $(f .206 v)$ ocho quartas, linderos: tierra de Pero Çisneros. Otra tierra carrera Barrio, en que ay diez quartas, linderos: tierra de Diego Galiano. Y luego, de la otra parte de la carrera, otra tierra, en que ay dos quartas, linderos: viña de Joán Mateo, clérigo. Otra tierra a carrera Pedragales, en que ay çinco estadales, linderos: la tierra de Fernán Navero. Otra tierra en Pedragal, en que ay çinquenta estadales, linderos: tierra de fijos de Joán Çapatero. Otra tierra carrera Guaça, a La Traviesa, en que yo, el dicho Joán Alfonso, e dos obradas. Otra tierra a çerca de Çero, en que ay tres obradas, linderos: tierra de los fijos de Pero Álvarez. Otra tierra a Otero de Din, en que yo, el dicho Joán Alfonso, e quatro obradas y es de San Román, linderos: tierra de Pero Agúdez e de Joán de Guaça. Otra tierra a Lagunares, en que ay quatro quartas, linderos: tierra de Joán Andrés, clérigo. Otra tierra a las viñas de Rediella, en que ay tres quartas, linderos: tierras de Pero Garçía Galiano que eran de Santa Cristina. Otra tierra a las viñas de la Areniella, 
en que ay çinco quartas, linderos: viña de la casa de Santa María. Una viña a la Areniella, en que ay una quarta.

Otro préstamo en las dichas yglesias çerca de Frechiella, sobre el qual préstamo, andan en plito Joán Alfonso de Toledo, canónigo, con Joán Martínez, vicario de Grijota, otrosí canónigo de Fusiellos.

Primeramente, carrera Paredes, una tierra en que ay seis obradas, linderos: Pero Nicolás y la dicha carrera. Y luego otra tierra, en que ay dos obradas, a la tierra de San Mamés, linderos: tierra de Joán Miguel y tierra de San Pero de las Dueñas. Y luego una tierra, en que ay dos obradas, linderos: tierra de Marcos e tierra de Miguel, fijo de Joán. A la viña de Fernán Pérez, una tierra en que ay una obrada, linderos: la dicha viña y tierra de Lucas Pérez. Y luego el Salmoral, una tierra en que ay quatro quartas, linderos: tierra de Fernán Escudero y tierra de Joán Pagado. Y luego, a la Fuente de Barrio, una tierra en que ay quatro quartas, linderos: la tierra de Fernán Lidiçio y la dicha fuente. Carrera Viñuela, una tierra en que ay quatro obradas, linderos: la dicha carrera y tierra de Joán de Fuentes. El río Ayuso, una tierra en que ay tres obradas, linderos: la carrera de Fuentes y el rrío y tierra de la cofradía de Santa Cristina. Y luego otra tierra, en que ay quatro quartas, linderos: tierra de Marcos y el rrío. Carrera Palomares, una tierra en que ay obrada y media, linderos: tierra de Joán Paniagua y tierra de Joán Rachón, yerno de Abril. A la Laguna de la Dueña, una tierra en que ay dos obradas, linderos: la dicha laguna y tierra de Pero Calonge. Y luego otra tierra, en que ay quatro quartas, linderos: tierra de Mari Gonçález y tierra de Joán de Burgos. En Majuelos, tierra de Rodrigo, en dos pedaçuelos media obrada, linderos: tierra de doña Sancha de la Ballesta y tierra de Asensio Fernández. En El Perexil, una tierra en que ay una obrada, linderos: tierra de Pero Abril y tierra de Gonçalo Gómez. En El Melgar, una tierra en que ay una obrada, linderos: tierra de la cofradía de Santa Cristina y tierra de Asensio Fernández. A La Majadilla de carrera Llano, una tierra en que ay quatro quartas, linderos: tierra del yerno de Fernán Gil y La Majadilla. En la reguera de Golpejares, una tierra en que ay una obrada, linderos: tierra de Fernán Favera y tierra de Sancho. Carrera Maior, una tierra en que ay obrada y media, linderos: tierra de Joán, el de Lucas, y la dicha 
carrera. Y luego un pico de quatro quartas, linderos: viña de Fernán Prieto y tierra de Alfonso Paxaro. Carreruela del Barrio, una tierra en que ay tres obradas y media, linderos: tierra de Joán Martín y la carrera. A las piedras de San Martín, una tierra en que ay quatro obradas, linderos: tierra de Joán Paniagua y tierra de la cofradía de San Salvador. A la Fuente de Salguera, una tierra en que ay una obrada y media, linderos: tierra de Fernán Calçones y tierra de Joán de Burgos. A Otero del Uerto, una tierra en que ay siete obradas, linderos: tierra de Joán de Guaça y el sendero. Carrera de Guaza, a La Traviesa, una tierra en que ay dos obradas, linderos: la dicha carrera y tierra de Gonçalo Gómez. Al Xas, una tierra en que ay dos obradas, linderos: tierra de Pero Cavallero y tierra de Joán Rachón, yerno del arçipreste. Y luego a Otero del Orto, una tierra en que ay una obrada, linderos: tierra de la cofradía de San Salvador. A Otero de Çid, una tierra en que ay dos obradas, linderos: tierra de La Costadilla de Santa Christina y tierra de Palaçio. A San Román, una tierra en que ay ocho quartas, linderos: (f.207r) tierra de Joán Blanco y la carrera. Carrera Pedregales, una tierra en que ay media quarta, linderos: tierra de Joán Álvarez y tierra de Fernán Avero y la carrera. A la Torre de Jozdada, una tierra en que ay media quarta, linderos: tierra de Domingo Pérez Andrés y la carrera. En los Cascajuelos de Golpejares, una tierra en que ay quatro quartas, linderos: viña de Pero Calonge y viña de Domingo Cavallero. Y luego una tierra en que ay dos quartas, linderos: viña de Joán Marche Avero, y la carrera de Barrio. Carrera Maior, una tierra en que ay quatro quartas, linderos: tierra de Garçía Cabeça y la carrera. A las viñas de Arenillas, una tierra en que ay obrada y media, linderos: tierra de Asensio Fernández y el majuelo de Apariçio.

Otro préstamo en las dichas yglesias, çerca de Frechiella:

Primeramente, çerca de la iglesia de San Mamés, una tierra en que ay seis obradas, linderos: la carrera que va a Paredes y tierra de Pero Nicolás. Y luego a la cabeçera de la iglesia, una tierra en que ay dos obradas, linderos: tierra de San Pero de las Dueñas y tierra de Joán Miguel "Maço". Carrera Fonda, una tierra en que ay media obrada, linderos: tierra de la iglesia de San Mamés y la carrera Fonda. Y luego otra tierra en que ay obrada y media, linderos: tierra de Marcos y tierra de Miguel, fijo de Joán. A la viña de Fernán Pérez, otra tierra en que ay una 
obrada, linderos: la dicha viña y tierra de Lucas Pérez. Otra tierra carrera Viñuela, en que ay quatro quartas, linderos: tierra de Joán Martín Çebrián y tierra de María, fija de Pero Garçía. Carrera Viñuela, otra tierra en que ay quatro obradas, linderos: tierra de Joán de Fuentes y la carrera. Y luego otra tierra, en que ay dos quartas, linderos: tierra de Pero, fijo de Fernán Escudero, y tierra de viña. A la yglesia de la Dueña, una tierra en que ay obrada y media, linderos: Pero Calonge y la dicha laguna. Y luego adelante otra tierra, en que ay quatro quartas, linderos: tierra de Mari Gómez y la carrera y tierra de Joán de Burgos. Y luego un pedaçuelo, en que ay una quarta, linderos: tierra de Joán Calonge y tierra de Palaçio. Y luego otra tierra, en que ay dos obradas, linderos: tierra de Joán Roxo y tierra de Fernando, fijo de Perilares. Carrera Llano una tierra, en que ay una obrada, linderos: tierra de Jona, muger de Pero Santiago y tierra de Fernán Prieto. En la reguera de Golpejares otra tierra, en que ay una obrada, linderos: tierra de Sancho, fijo de Gil Sánchez, y tierra de Fernán Havero. Al Espino un pico, en que ay quatro quartas, linderos: viña de Fernán Prieto y viña de Alfonso Páxaro. A carrera Mayor, otra tierra en que ay obrada y media, linderos: la carrera y tierra de Joán, fijo de Lucas Pérez. Al Barrial otra tierra, en que ay obrada y media, linderos: tierra de Asensio Fernández y tierra de Gonçalo de Burgos. Carreruela del Barrio otra tierra, en que a tres obradas, linderos: la carrera y tierra de Joán Rachón, yerno del arçipreste. A las piedras de San Martín, quatro obradas y media, linderos: tierra de la cofradía de San Salvador y tierra de Joán Paniagua. A las Todiellas otra tierra, en que ay dos quartas, linderos: viña de la cofradía de Santa Christina e tierra de Joán Garçía. A Druso, a la fuente de Barrio, otra tierra en que ay quatro quartas, linderos: tierra de Fernando Leyviçio y la fuente. A la Laguna de la Dueña otra tierra, en que ay quatro quartas, linderos: tierra de aniversario de la iglesia de Santa María y la carrera. Al Espino otra tierra, en que ay una obrada, linderos: la carrera Maior y tierra de Pascual Velasco. Más, el quartillo de la eredad de San Román, y son fasta ocho obradas. En las viñas de Valpeseso dos obradas, linderos: tierra de Alfonso Fernández, clérigo, y la carrera.

Préstamo en la iglesia de San Sevastián y de Pajares, çerca de Bezerril, eredad: 


\section{LA ABADÍA DE SANTA MARÍA DE HUSILLOS: ESTUDIO Y COLECCIÓN \\ DOCUMENTAL $(904-1608)$}

Primeramente, la eredad de Pajares está junta y a por afrontaçiones: de la una parte, la carrera de Carrión, que es en el término de Bezerril; y de la otra parte, el fito del Monte de Paredes; y de la otra parte, el monte de Santa María de Fusiellos, que agora llaman algunos el monte de La Refierta; y de la otra parte, el Valle Luengo. Un solar que es de la dicha yglesia de Fusiellos, en el dicho lugar de Bezerril, que fue de don Rodrigo Álvarez de Astorias; (f.207v) el qual solar fue casa fuerte y esta en la plaça de Bezerril, çerca de la iglesia del dicho lugar. La eredad de San Sebastián está junta y a por afrontaçiones: tierra que fue de María Álvarez; y de la otra parte, el arroyo y la carrera de Mercaderos y otra tierra que fue de la dicha Mari Álvarez y el arroyo de San Sebastián; y de la otra parte, el canpo y la carrera de San Sebastián.

Viñas:

Y las viñas an por afrontaçiones: la carrera de Mari Álvarez; y de la otra parte, el arroyo y la carrera de Mercaderos y tierra que fue de Mari Álvarez y viña de Fernán Gómez y viña de Pero Díaz Corvo y viña de los clérigos y común de Bezerril y tierra de Domingo Martín, fijo de Pero Roxuelo. Y todos los diezmos desta dicha heredad, tierras y viñas, perteneçen al dicho préstamo.

Préstamo en Grijota, heredad:

Esta es la eredad del préstamo que es en Grijota y en término de Fusiellos, que llaman la eredad de Santa María: primeramente, el pozuelo en Piedra Fita. Oriella Nava, tres obradas, linderos: Joán Fernández. Otra tierra de dos obradas a Val, linderos: Toribio Fernández. Otra tierra de dos obradas carrera Pajares, lindero Fernán Garçía. Otra tierra en que ay tres quartas, lindero Pero Fernández de Ventosa. Otra tierra a La Huelga, con el picón de La Huelga a La Arena, en que ay tres obradas. Otra tierra a La Molle Çera, en que ay seis obradas. Otra tierra carrera Jigondo, en que ay media obrada. Y luego otra tierra en que ay dos obradas, lindero Joán Garçía de Burueva. Otra tierra a Las Callejas, en que ay obrada y media. Otra tierra linde de La Huelga, en que ay media obrada, lindero Joán Pérez. Oriella del soto otra tierra en que ay dos obradas. Sobre soto tres 
obradas. Otra tierra a La Torrezilla, en dos lugares quatro obradas; estas dos tierras son en término de Fusiellos. Una era carrera Morillo, en que ay una obrada, lindero la carrera. Otra tierra so las eras de Jiján, cabe el camino que viene del Pontido, çerca del arroyo, en que ay dos obradas y media o más.

Préstamo de Çelanova:

Ay más, otro préstamo en Çelanova y es en heredamiento y ale Domingo Gonçález, chantre en la dicha yglesia, y perteneçe a la dicha iglesia de Santa María de Fusiellos esto que se sigue: como van el arroyo de Frailes hasta la carreruela que sale de Poblaçioneja y va a Santillán de la Cuesta, que es término que se nonbra de Çelanova; y del otro cabo, el camino del Rey que va de Palençia a Carrión; y desta eredad se labra esto que se sigue: labrava Martín Toledano, vezino de Ribas, una tierra en linde del arroyo que viene de Val Mayor, del cabo, en que avía unas seis obradas. Y otra tierra que labrava el dicho Martín Toledano, al foyo donde se acoje el agua; y del otro cabo, tierra de doña Antonia de Villunbrales. Y otra tierra que labrava Domingo Arderon, en linde del arroyo, en que avía dos obradas. Y del otro cabo del camino, otra tierra en que ay dos obradas.

Préstamo de Santa María Madalena de Villa Çalama, eredad:

Esta es la eredad del préstamo de Sancta María Madalena, que es de Domingo Gonçález, chantre; la qual heredad, es en término de Fusiellos: primeramente, una tierra que llaman del Havar, en que ay siete obradas, linderos: el camino que va a Los Canbrones. Y luego una tierra, en que ay una obrada, linderos: tierra del Ospital. Otra tierra y luego, en que ay dos obradas, linderos: la tierra del Havar y el camino que va contra Monçón y la tierra de las Foyadas que es del cabildo. Otra tierra al Fito, en que ay doze obradas, linderos: el camino que va a Ribas y otro camino que va a Fuente Quinava. Otra tierra al Fito, camino de Santillán, en que ay tres obradas, linderos: el dicho camino y tierra del cabildo. Otra tierra a Lobaharta, en que ay seis obradas, linderos: el camino que va a Ribas y la Lobaharta. Otra tierra a Requexo, en que ay seis obradas, linderos: heredad del 
abad. Otra tierra a Santa María Madalena, en que ay dos obradas, linderos: la (f.208r) dicha yglesia y el camino que va a Palençia. Y luego otra tierra, en que ay quatro obradas, en linde de la dicha yglesia. Y luego otra tierra, en que ay una obrada, en linde desta dicha tierra de quatro obradas y la cuesta. Otra tierra a La Obratilla, en que ay dos obradas, linderos: tierra del abad. Otra tierra so San Christóval, en que ay ocho obradas, linderos: el camino que dizen del Congosto y la cuesta.

Préstamo de Fusiellos:

Unas casas con su huerto y corral, linderos: de la una parte, casas del cabildo en que mora Garçía Fernández de Pernía; de la otra parte, casas de Domingo Martín, molinero y huerto y un casar del cabildo; y de la otra parte, casas de los moços del coro; y linderos del huerto de la otra parte: casas y huerto de la capellanía de San Joán en que mora Joán Quintero.

Préstamo de Santa Eugenia de Piña, eredad:

A otro préstamo en la iglesia de Santa Eugenia de Piña y ale Joán Pérez de Azeves, prior, y Joán Alfonso de Toledo y Joán Pérez de Grijota.

Préstamo de Las Salinas de Anaya:

An más, otro préstamo en las salinas de Anaya, en que ay [...] fanegas de sal y ale Joán Pérez, prior de Fusiellos.

Esto es lo que perteneçe a la sacristanía de Fusiellos:

Primeramente, a en San Miguel de Fuentes de Don Bermudo un préstamo que es de estimaçión ocho maravedís y terçio. A más, el diezmo de lo que se ganare en las açeñas de Pajares. A más, el diezmo de los molinos de Casa, ansy en los del abad como en los del cabildo y de la obra. A más, toda la ofrenda de la iglesia de 
Fusiellos. A más, las premiçias de Fusiellos. A más, todas las aventuras del pueblo. A más, que le a de dar el cabildo para alunbrar, veynte y çinco maravedís.

Ésta es la eredad que perteneçe a la sacristanía:

Primeramente, allende el río, en la vega, una tierra en que a tres obradas, linderos: tierra de Martín Pérez e su yerno; y de la otra parte, tierra del cabieldo. Otra tierra tras soto, en que a dos obradas, linderos: de la una parte, viña del cabildo; y de la otra parte, tierra del cabildo. A más, otra tierra al sotillo, en la questa, en que ay tres obradas, linderos: de la una parte, tierra del abad; y de la otra parte, la cuesta. A más, otra tierra al Coxo, que es ferrenal, en que ay una obrada y está, en él, un palomar, que a por linderos: de la una parte, tierra de Marcos Fernández, fijo de Diego Fernando; e de la otra parte, tierra del préstamo de Santa María Madalena. A más, otra tierra que comiença cabe la tierra que dizen de Mari Díaz; y de la otra parte, el arroyo de Val de Bermudo. Otra tierra a Finojal, en que ay obrada y media, que a por linderos: de la una parte, tierra de Joán Fernández de Buzon; y de la otra parte, tierra del cabildo. A más, una viña y luego, en que a tres quartas, que a por linderos: viña de Pero Ruiz de Rinoso; y de la otra parte, viña del cabildo. A más, otra viña a Los Canbrones, en que ay seis quartas, que a por linderos: viñas del cabildo en derredor. A más, otra viña en que a media alançada, carrera de Los Canbrones, que a por linderos: carrera, de la una parte, e tierra del ospital de Fusiellos; y de la otra parte, la viña Macaria del cabildo.

Ésto es lo que a de fazer el sacristán en la iglesia de Fusiellos:

Primeramente, a de poner un capellán y proveer para que rrija la cura en la dicha yglesia y sirva el altar de Santa María. A más de poner canpanero en la dicha yglesia, que taniga las canpanas a las oras, de noche y de día y a la canpana del Ave María; y a de proveer las canpanas de sogas y de todo lo que fuere menester. A más, de fazer tañer, según costunbre de la dicha yglesia, de noche e de día por los benefiçiados, fasta que sea enterrado, al tienpo que moriese, y a las sus novenas; e que pague la persona, por el tañer, veynte maravedís y el canónigo, diez, y el rraçionero diez maravedís y el medio rraçionero çinco maravedís, y a 
más de aver dos çirios de los rredondos, y con los legos, avengase. A más de alunbrar la lánpara que está en el altar mayor, a las oras. A más de poner dos çirios de çera, de cada dos libras, y an de arder cada día a la misa mayor y a la del aniversario, quando la oviere, y las biésperas del día; y el día que (f.208v) fuere fiesta, dé nueve liçiones, y a las primeras bísperas y a los maytines, dé nueve liçiones, desde el salmo de "Bene Diçite" adelante, y la fiesta, de seis capas que ardan a todos los maytines; y a más de dar candelas delgadas para rrezar maytines. A más de poner çirio pascual en que aya diez libras, para que arda según la costunbre de Fusiellos. A más de proveer candelas para las tinieblas y a de aver en cada candela un quarterón. A más de dar çera para Santa María la Candelaria, a cada benefiçiado y capellán su candela, y a de aver, en las candelas de las personas, en cada una, media libra, y eso mismo en la del preste, y en las de los canónigos a quarterón, a los rraçioneros un quarterón, y a los medios rraçioneros medio quarterón, y de los capellanes, clérigos del coro medio quarterón; y a de fazer un çirio rredondo de dos libras para el abad, si viniere a la fiesta. A de proveer de ençienso a la yglesia, a las cruzes acostunbradas. A de fazer çerrar las puertas de la yglesia y de la proçesión y a de linpiar los altares y las ymágines y la yglesia y ornar los altares y fazer alinpiar la iglesia y conplir los ofiçios de cuaresma, y a de hechar fena en la yglesia dos vezes, la una por Todos Santos y la otra, por Navidad.

Estas son las capellanías que ay en la iglesia de Fusillos, que son de dar colaçión, del prior y del cabildo en uno, y del prior en su cabo, y del sacristán en su cabo, y del chantre en su cabo, que son éstas que se siguen:

Primeramente, la capellanía de San Joán de Pajares a colaçión del prior y cabildo, ala Joán Pérez de Açeves. La capellanía de Santillán a colaçión del prior y cabildo, ala Diego Díaz. La capellanía del abad don Garçía Pérez a colaçión del prior y cabildo, ala Gil Fernández. La capellanía de Santiago a colaçión del prior y cabildo, ala Pero Fernández. La capellanía de San Joán de Fusiellos a colaçión del prior, ala Martín Gil. La capellanía de Santa Brígida a colaçión del chantre, ala Gonçalo Gonçález. La capellanía de don Pero Fernández, abad, a colaçión del sacristán, ala Pero Fernández. La capellanía del pueblo, la colaçión es del abad, a 
presentaçión de sacristán. La capellanía de Sant Andrés de Fuente Quinava, la colaçión es del prior y cabildo. La capellanía de Santa Brígida, que es en la iglesia de San Julián de Santillán, a la colaçión el prior y el cabildo, ala clérigo de Bezerril. Yten, a en la dicha yglesia otras dos capellanias, de San Quirze, que dexó Gonçalo Gonçález, arçipreste de Burgos; y las posesiones, dellas, son dos pares de casas en Palençia y quarenta alançadas de viñas y fasta sesenta obradas de eredad en Fusillos.

Éstas son las tierras y biñas que pertenesçen y an algunas capellanías destas dichas:

Éstas son las tierras de la capellanía de San Joán de Fusillos: primeramente, allende el río, una tierra al Pico del Abad, en que a dos obradas, que a por linderos: de la una parte, el Pico del Abad; y de la otra parte, tierra de la capellanía de Santa Brígida. Otra tierra de parte del camino, en que a una obrada, linderos: de la una parte, tierra del abad; y de la otra parte, tierra que dizen de Vazia Bolsas, que es del cabildo de Fusillos. Otra tierra en que a una obrada, que es aliende el río, linderos: de la una parte, Munñón Álvarez de la Serna; y de la otra parte, Joán Asturiano. Otra tierra en la vega, que a una obrada, linderos: tierra de Garçía Fernández de Castro; y de la otra parte, tierra de Joán Fernández de Tariego. Otra tierra que dizen a Cabo de Viña, en que a ocho obradas, linderos: tierra de fijos de Sancha Martínez; y de la otra parte, el rrío. Otra tierra a las eras, en que a obrada y media, linderos: tierra de Garçía Fernández de Castro; y de la otra parte, el camino de Los Canbrones. Otra tierra en que a una obrada, que es a las eras, lindero tierra del préstamo de Santa María Madalena; y de la otra parte, tierra del cabildo. Otra tierra camino de Los Canbrones, en que a siete obradas, linderos: de la una parte, tierra del cabildo, y de la otra parte, el arroyo de Frayles. (f.209r) Otra tierra en que ay una obrada, que es al arroyo de Frailes, linderos: camino de Ribas. Otra tierra que dizen so La Cotorra, en que ay seis obradas, linderos: tierra de Joán Martínez, abad que fue de Fusiellos; y de la otra parte, tierra que fue de la dicha capellanía. Otra tierra a Las Piedras, en que ay quatro obradas, linderos: tierra del Ospital; y de la otra parte, tierra de arroyo de Frailes. Otra tierra camino de Judíos, en que ay dos obradas, linderos: viña del cabillo de 


\section{LA ABADÍA DE SANTA MARÍA DE HUSILLOS: ESTUDIO Y COLECCIÓN \\ DOCUMENTAL $(904-1608)$}

Fusiellos; y de la otra parte, el camino que llaman de Judíos. Otra tierra a la canbronera de Monçón, en que ay ocho obradas, linderos: tierra de la capellanía de Santa Brígida; y de la otra parte, tierra del prior de Fusiellos. Un ferrenal a la puerta Nueva, en que ay una obrada, linderos: tierra del cabillo, y de la otra parte, el camino que va a las eras. A más una viña a do dizen Maçanedo, en que a nueve alançadas, linderos: viña de Garçía Fernández de Castro; y de la otra parte, majuelo del prior. Otra viña a La Cotorra, en que ay seis arançadas, linderos: camino de Judíos; y de la otra parte, biña de Garçía Fernández de Castro.

Éstas son las tierras de la capellanía de Santa Brígida de Fusiellos:

Primeramente, allende el Río, una tierra en el Congosto, en que ay tres obradas, linderos: tierra de la capellanía de San Joán; de la otra parte, tierra de Gonçalo Fernández de Castro. Otra tierra carrera Vieja, en que ay una quarta, linderos: tierra de Joán Fernández Carudo; y de la otra parte, tierra de Pero Fernández, carretero. Otra tierra carrera Santillán, en que a dos obradas, linderos: tierra del cabildo; y de la otra parte, carrera que va a Santillán. Otra tierra al arroyo de Frailes, en que a dos obradas, linderos: tierra del Ospital de Fusiellos; y de la otra parte, el camino de los Canbrones. Otra tierra a Lobaharta, en que a quatro obradas, linderos: la Lobaharta; y de la otra parte, el arroyo de Frayles. Otra tierra al arroyo de Frailes, en que a dos obradas, linderos: tierra del Ospital de Fusiellos; y de la otra parte, el camino de los Canbrones. Otra tierra a Lobaharta, en que a quatro obradas, linderos: la Lobaharta; y de la otra parte, el arroyo de Frayles. Otra tierra en que a una obrada, a Los Linares, linderos: tierra de Flor Ordóñez; y de la otra parte, tierra del Ospital. Otra tierra a Lobaharta, en que a quatro obradas, linderos: tierra del cabildo de Fusiellos; y de la otra parte, tierra de la capellanía de don Pero Fernández, abad. Otra tierra a Tejada, en que a ocho obradas, linderos: de la una parte, tierra de Joán Fernández de Tariego; y de la otra parte, tierra de la capellanía de San Joán. Un ferrenal a Los Palomares, en que a obrada y media, linderos: ferrenal del cabildo de Fusiellos; y de la otra parte, tierras del dicho cabildo. Otra tierra a Laguna Salida, en que a dos obradas, linderos: el Foyo de la Laguna Salida y [...]. Otra tierra a Maçanedo, en que a una obrada, linderos: viña de la capellanía de San Joán; y de la otra parte, tierra de la 
lánpara del chantre. Una viña a Los Canbrones, en que a tres alançadas, linderos: de la una parte viña de Joán Fernández de Buzon; e de la otra parte, viña de Fernán Garçía de Castriello. Otra viña a Los Canbrones, que a media alançada, linderos: tierra de la capellanía del Abad, de la una parte; y de la otra parte, viña de Garçía Fernández de Castro. Otra viña a Poblaçión, en que ay una lançada, linderos: viña de Flor Ordóñez; y de la otra parte, viña de la lánpara de Santa María. Otra viña que llaman de Las Bragas, en que ay una lançada, linderos: viña de Garçía Fernández de Castro; e de la otra parte, viña de Gonçalo Ruiz de Rinoso.

Éstas son las tierras e biñas de la capellanía de don Pero Fernández, abad que fue de Fusiellos:

Primeramente, unas casas con su huerto en Fusiellos, linderos: casas del cabildo, de amas partes, en que mora, de la una parte, Joán Alfonso de Toledo; y de la otra parte, Joán Sánchez de Grijota, canónigos. Otras casas en el dicho lugar, que están a ençense por çinco maravedís cada año, pagar al día de San Martín, linderos: casas de la sacristanía; y de la otra parte, casas del abad. Allende el río, una tierra en que ay tres obradas, linderos: tierra de fijos del chantre Joán Pérez; y de la otra parte, las minbreras del conçejo de Fusiellos. Otra tierra a Las Pasaderas, en que ay tres obradas, linderos: la serna de Las Paredejas del abad y el camino que va a Cabo de Viña. A las eras, otra tierra en que ay tres obradas, linderos: tierra de la lánpara del Chantre; y de la otra parte, tierra del cabildo. Otra tierra en que ay media obrada, cabe la çerca de la villa, $(f .209 v)$ linderos: tierra de la lánpara del chantre; y de la otra parte, ferrenal del cabildo. Otra tierra a las eras, en que ay media obrada, linderos: tierra del cabildo; y de la otra parte, las eras. Otra tierra a par de las eras, en que ay media obrada, lindero Garçía Fernández de Castro y las eras. Otra tierra carrera de Santillán, en que ay dos obradas, linderos: tierra de la lánpara del chantre; y de la otra parte, tierra del cabildo. Otra tierra camino de Los Canbrones, en que ay dos obradas, linderos: tierra de los fijos del chantre; y de la otra parte, camino de Bezerrilejos. Otra tierra en que ay una obrada, que es camino de Los Canbrones, linderos: tierra de los fijos del chantre; y de la otra parte, viña de la capellanía de Santa Brígida. Otra tierra en que ay dos obradas, 
que es al arroyo de Frailes, linderos: tierra del prior de Fusiellos; y de la otra parte, el arroyo de Frailes. A Los Linares, una tierra en que ay una obrada, linderos: tierra de la capellanía de Santa Brígida y el arroyo de Frailes. Otra tierra en Palençia, en que ay diez obradas, linderos: la carrera que va a la puerta de Monçón; y de amas partes, tierras del cabildo de Palençia. En Aveça, dos viñas en que ay tres arançadas, linderos: viña del cabildo de Fusillos; y de la otra parte, viña de Gonçalo Garçía, yerno del sacristán. [...] linderos: viña de Domingo Ximón, vezino de Villunbrales; e de la otra parte, viña de "Gorrión" de Bezerril.

Capellanía de San Joán de Pajares:

Éstas son las tierras y viñas que son en el término de Pajares e diezman a la capellanía de San Joán de Pajares: primeramente, la tierra rredonda que fue de Pero Fernández, molinero. Tierras que fueron de Guiomar Alfonso. Tierras de Estevan Fernández, notario, fijo de Alfonso Fernández, çerrajero. Tierra que fue de Viçeynte Martínez. Tierra de Mari Fernández, casera que fue de Joán Gonçález de Aguilar. Otra tierra de la capellanía, tras la torre. Tierra de la capellanía de Joán Garçía Calentura. Tierra de Toribio Fernández, clérigo, cura que fue de Santa María de Aliende el Río. Tierra que fue de Fernán Pérez, ortolano. Tierra que fue de Alfonso López, alfayate. Tierra de Joán Fernández de Manquillos. Tierras de Pero Fernández Sancho. Tierra de Diego López, notario. Tierra de Alfonso Fernández, bienvel. Tierra de Joán Sobrino. Tierra de Yago Pérez, criado que fue de Joán Rodríguez de Sasamon. Tierra de Diego Pérez, clérigo de Grijota. Tierra de Pero Fernández "Cacharro". A dos pedaçuelos pequeños de la yglesia, en que ay media obrada.

Éstas son las viñas que son en el dicho término de Pajares, que diezman a la dicha capellanía de San Joán de Pajares:

Primeramente, en La Huelga, viña de Diego López, alcalde. Otra viña de Joán Martín Gomiro. Otra viña de Fernán Pardo. Otra viña de Fernán Pérez [de] Amayuelas. Otra viña de Rodrigo Alfonso de Tariego. Otra viña de la cofradía de San Miguel. Otra viña de Marcos Gil. Otra viña de la muger de Álvaro Fernández. 
Otra viña del nieto de Marcos Garçía. Otra viña de la lánpara de San Joán de Pajares. Tierra de Joán Martín Gomiro. Otra viña de la iglesia de San Joán de Pajares, en que ay diez quartas, linderos: viña de [...]. Y otra viña de los Quarenta Capellanes. Otra viña de Pero de Vega.

Las viñas de Las Frieras que diezman a la dicha capellanía de San Joán, son éstas que se siguen:

Primeramente, una viña del abad de Valladolid. Viñas de los Quarenta Capellanes de Palençia. Viña que fue de Joán Rodríguez de Sasamon. Viña de Alfonso Fernández, fijo del çerrajero. Viña de Pero Dente. Viña de la capellanía de Joán Garçía Calentura. Viña del ospital de Santa María. Viña de Alfonso Martín Delgado. Viña que fue de Martín Pérez, sochantre. Viña de los capellanes. Viña de Fernán Rodríguez, sacristán de Fusiellos. Viña de Alfonso Fernández, texedor. Viña de Santa María de las Misas. Viña de Diego Martínez, notario. Viña que fue de Guiomar Alfonso.

Capellanía del abad don Garçía Pérez:

Éstas son las posesiones que perteneçen a la capellanÍa que dexó el abad don Garçía Pérez, que tiene Gil Fernández, capellán: primeramente, en la cal de Joán Grillo, unas casas con su sobrado, que an por linderos: casas de Antón Martínez, clérigo de Soto, de la una parte; y de la otra parte, casas de Joán Alfonso, fijo de Pero Mínguez, y la cal pública de Joán Grillo. Al arroyo de Miguel Peláez, una viña en que ay seis quartas, que a por linderos: de $(f .210 r)$ la una parte, viña de los Quarenta Capellanes; de la otra parte, [...] del ospital; e de la otra parte, viña de Rui Fernández, merino. A La Rabeca, otra viña en que ay tres arançadas, que an por linderos: de la una parte, viñas de Domingo Fernández de Mazariegos; e de la otra parte, viña de Joán Martín de Castro. Una tierra a Golvira, en que ay [...] obradas, linderos: de la una parte, viña de Domingo Fernández "El Roxo"; e de la otra parte, tierra que fue de Martín Alfonso.

Capellanía de Santa Brígida de la yglesia de Santillán: 
Éstas son las posesiones que perteneçen a la capellanía de Santa Brígida de la iglesia de Santillán: primeramente, una tierra carrera del Molino, en que a tres obradas, linderos: el dicho camino que va a Sobradillos; y de la otra parte, viñas de Villunbrales. Otra tierra çerca desta, que ay tres obradas, linderos: viña de Toribio Tragón e tierra de doña Toribia e viña de Diego Cobo. Otra tierra a Castrejos, en que ay una obrada, linderos: el camino que va al Molino del Sobradillo e tierra de Benito Cano. Otra tierra a la Fuente Mayor, en que ay dos obradas, linderos: viña de Toribio Martín "Toro Santo" y el arroyo de la dicha fuente. Otra tierra al camino de Villunbrales, que llaman La Retuerta, en que ay una obrada, linderos: los arroyos, de amas partes. Otra tierra al postigo de Santillán, en que ay tres obradas, linderos: viña de Domingo Rodríguez y el camino de Bezerril y viña de Joán Reçelo. Otra tierra al arroyo de la Fuente Mayor, en que ay una obrada, linderos: viña de Bartolomé "El Regranado" e viña de Diego Fernández de Ribas. Otra tierra a Barriales, en que a una obrada o más, linderos: tierra de la muger del "Romo" y el camino que va a los dichos molinos. Otra tierra çerca desta, en que ay una obrada, linderos: tierra de Benito Cano y el dicho camino de Sobradillo. Otra tierra a Las Causas, en que ay una obrada, linderos: tierra de Domingo Gonçález. Otra tierra carrera de Bezerril, en que a dos obradas, linderos: tierra que fue de Pero Martín de Santillán y la dicha carrera de Bezerril. Otro pedaçuelo a la çerca, en que ay media obrada, linderos: tierra de Joán Rallo e tierra de Fernán Pérez Ojalvo. Otra tierra al Palomarejo, en que ay una quarta, linderos: tierra de Benito Cano e tierra de Pero Gil. Otro pedaçuelo a la era, que ay media obrada, linderos: tierra de Diego Pérez y el camino que va a Sobradillo. Otra tierra al postigo que va a Santillán, en que ay dos obradas, linderos: La Cárcava y el camino de Bezerril.

Viñas de la dicha capellanía:

Primeramente, una viña en que ay dos alançadas, linderos: viña de doña Urraca; y de la otra parte, el camino que va al Prado del Val. Otra viña al Prado, en que ay media quarta, linderos: viñas de la cofradía de San Julián, de amas partes. Otra viña çerca desta, en que ay media quarta, linderos: viña de la dicha cofradía y el 
camino que va al Prado. Otra viña a la Fuente del Ero, en que ay media quarta, linderos: viña de Domingo Rodríguez y tierra de la dicha capellanía. Y otras viñas erias.

Capellanía de San Julián de Santillán:

Perteneçen a la dicha capellanía, a las premiçias y los aniversarios y toda la ofrenda y todas las aventuras y el curazgo del dicho lugar.

Ésto es lo que perteneçe a la obra de la yglesia de Fusiellos, que es esto que se sigue:

Primeramente, un molino en la parada que dizen de Casa, çerca del dicho lugar de Fusiellos, que llaman Canóniga. A más en el dicho lugar de Fusiellos, una casa e un portal con su corral e huerto, que fizo y çercó Domingo Gonçález, chantre, linderos: casas del cabildo en que mora el dicho chantre; y de la otra parte, casas del cabildo que tiene Gonçalo Gonçález, a la puerta Nueva; y de la otra, la cal pública que va de la yglesia a la puerta Nueva. Y el dicho huerto, de la dicha obra, a por linderos: de la una parte, huerto de las casas do mora el dicho chantre; y de la otra parte, huerto de las casas que tiene el dicho Gonçalo Gonçález; y de la otra parte, la çerca de la villa. $(f .210 v)$

Ésta es la heredad que la dicha obra a en los términos de Fusiellos:

Primeramente, a en el Congosto, una serna en que a treynta obradas e más, que a por linderos: de la una parte, serna del abad de Fusiellos; e de la otra parte, una tierra que fue de Joán Rodríguez "Colmiello"; y de la otra parte, el camino del Congosto que va de Fusiellos a Palençia. Otra tierra a Los Canpejones, en que ay siete obradas, que a por linderos: de la una parte, Las Minbreras; y de la otra parte, tierra del abad de Fusiellos.

Ésta es la eredad que a la dicha obra en Poblaçioneja: 
Primeramente, al Canizar, tres tierra en que ay çinco obradas, linderos: carrera de Bezerrilejos. Dos tierras en que ay çinco obradas, linderos: Tras Casasola. Dos tierras en que ay dos obradas, linderos: [...].

Éstas son las tierras e biñas que perteneçen para alunbrar las lánparas de la iglesia de Fusiellos:

Primeramente, eredad de la lánpara del chantre: en el Congosto, una tierra de doze obradas, linderos: tierra del abad; e de la otra parte, el camino que va a Palençia. Otra tierra de dos obradas, que es en el Congosto, linderos: tierra de La Peroya de Muñón Álvarez de la Serna; y de la otra parte, tierra del cabildo. Otra tierra a Los Canpejones, de seis obradas, linderos: tierra del abad; y de la otra parte, Las Minbreras. En Valmaior, otra tierra de tres obradas, linderos: tierra de Joán Fernández "Carudo", que es agora de Fernán Rodríguez, sacristán; y de la otra parte, tierra de Muñón Álvarez de la Serna. Otra tierra en La Rallosa, en que ay seis obradas, linderos: tierra del ospital de Santa María de Fusiellos; y de la otra parte, viña de la capellanía de San Joán. Otra tierra carrera de Santillán, en que ay tres obradas, linderos: tierra del cabieldo; e de la otra parte, tierra de Joán Fernández de Tariego. Otra tierra en que ay dos obradas, carrera de San Andrés, linderos: tierra de Muñón Álvarez; e de la otra parte, el cabildo. Otra parte a Las Piedras, en que ay dos obradas, linderos: el camino de Ribas; y de la otra, el arroyo de Frayres. Otra tierra cabe la çerca, en que ay tres obradas, linderos: tierra de la capellanía del abad don Pero Fernández; y de la otra parte, ferrenal del cabildo. Otra tierra de obrada y media, que es carrera de Santillán, linderos: esta dicha carrera; e de la otra parte, tierra de Domingo Gonçález, chantre.

Ésta es la eredad de la lánpara de Santa María, de la obra:

Una tierra de obrada y media, carrera de Santillán, linderos: de la una parte, tierra de Gonçalo Ruiz de Reynoso; e de la otra parte, tierra de Joán Fernández de Buzón. Otra tierra a Maçanedo, en que a una obrada, linderos: tierra de Gonçalo Ruiz de Rinoso; y de la otra parte, tierra del cabildo. Otra tierra a Los Canbrones, en que a una obrada, linderos: tierra de Marcos Fernández, fijo de don Fernando; 
y de la otra parte, tierra de Garçi Fernández de Castro. Otra tierra carrera de Ribas, en que a obrada y media, linderos: tierra de Pero de Vayeello; e de la otra parte, el camino de Ribas. Un ferrenal a la puerta del Río, linderos: tierra del abad; y de la otra parte, camino que va al soto y al molino. Una viña a La Cotorra en que a una alançada, linderos: tierra del ospital; y de la otra parte, viña de la capellanía de San Joán. Otra viña en que a tres quartas, linderos: la viña Vieja que es del cabildo; y de la otra parte, tierra de Garçi Fernández de Castro. Otra viña en que ay tres quartas, carrera de Los Canbrones, linderos: viña de Joán Fernández de Buzon; y de la otra parte, tierra de la capellanía del abad don Pero Fernández.

Éstas son las tierras que a la cofadría del ospital de Santa María de Fusiellos:

Primeramente, una tierra al açeña del Azarón, en que ay doze obradas, que a por linderos: de la una parte, tierra de Martín Pérez de Carva; e de la otra parte, el camino que va a Palençia; y de la otra parte, el camino que va a Grijota. Otra de Val de Lomudo, en que a tres obradas, a por linderos: de parte de suso, tierra del abad de Fusiellos; de la otra parte, el arroyo. Otra tierra a Los Canbrones, en que a tres obradas, que a por linderos: de la parte de suso, tierra del dicho abad; y de la otra parte, tierra de Gonçalo Ruiz de Reynoso y otra tierra, de parte de yuso, que es de la capellanía de Santa Brígida. Otra tierra a Los Linares, en que a dos obradas y media, que a por linderos: de la una parte, tierra del préstamo de Santa María Madalena; y de la otra parte, el camino que va para Monçón. (f.211r)

Bezerrilejos:

A más el dicho cabildo de Fusiellos en Bezerrilejos, a Los Casares, una tierra en que ay dos obradas, linderos: el caminillo que viene de Villandavín y va a Monçón; e de la otra parte, tierra de Alfonso Pascual. Otra media obrada carrera del molino nuevo, linderos: tierra de Antón; y de la otra parte, el dicho camino. Más otras dos obradas en derecho de Casasola, allende el cuérnago, linderos: Mari Pérez, muger que fue de Pero Fernández de Monçón; y de la otra parte, tierra de Domingo Fernández "Lentejas". A más el dicho cabieldo de Fusiellos en la dicha huelga, una tierra con un pedaçuelo, en que ay dos obradas, linderos: viña de 


\section{LA ABADÍA DE SANTA MARÍA DE HUSILLOS: ESTUDIO Y COLECCIÓN \\ DOCUMENTAL $(904-1608)$}

Fernán Pérez de Mayuelas e de Pero Fernández Sancho. Otra tierra y luego, linderos: tierra de Pero Fernández Sancho e tierra del [...]. Otra tierra de una obrada, linderos: tierra de Diego López, alcalde, y el pico, que es viña, de fijos de Fernán Pardo. Otra tierra, en que ay dos obradas, linderos: viña de Fernán Pérez de Mayuelas; e de la otra parte del, ençima, tierra de Gonçalo Gil. Otra tierra, en que ay una obrada y luego, linderos: viña de Marcos Gil; y de la otra parte, La Huelga de Pajares y majuelo de Joán Martínez Gomiro.

Éstas son las viñas que el dicho cabieldo de Fusiellos a en La Huelga de Pajares:

A par de La Huelga, [a] el dicho cabildo, una viña de diez arançadas, linderos: La Huelga de Pajares; e de la otra parte, tierra de Pero Fernández "Caniho". A más otras seis quartas a par del río, linderos: viñas del cabillo de Palençia; y de la otra parte, el camino que va de la puente a las aceñas de Pajares. A par del río otra viña, a do ponen la cabaña, de dos alançadas, linderos: viña de Domingo Fernández, fijo de don Ramos; y de la otra parte, los fijos de Fernán Pardo. An más otra viña par de la puente, linderos: el camino que va a Pajares a la yglesia; e de la otra parte, viña que fue de Joán Lucas. En esta viña a media alançada. Otra viña de una quarta, al Val de Quintanilla, linderos: La Huelga y viña de Garçi Fernández, capellán de San Nicolás.

A más la dicha obra de Santa María de Fusillos en término de Ribas y en término de Poblaçioneja, ésto que se sigue:

Una obrada de tierra, la vega arriba, linderos: Joán Garçía de San Zebrián y tierra de Pero Garçía, hijo de Domingo Ramos. Otra tierra a La Loba, en que ay fasta diez obradas, linderos: Mari Pérez y tierra del monesterio de Santa Cruz. Otra tierra a Febra Mala, en dos lugares, en que ay tres obradas, linderos: Toribio Gil y el camino que va a Bezerril; et del otro cabo, los arroyos. Otra tierra a Febra Mala, que ay fasta seis obradas, linderos: tierra de la muger que fue de Fernando Mate; e de la otra parte, el camino que va a Bezerril. Otra tierra al camino de Sequillo, en que ay una obrada, linderos: tierra de Santa Cruz e tierra de Joán Fernández, merino de Ribas. Otra tierra al molino de La Huelga, en que ay tres 
obradas, linderos: Joán Fernández de Poblaçión e tierra de Fernán Lucas. Otra tierra a Las Quintanas, en dos lugares, en que ay çinco obradas, en abas a dos linderos: Domingo Fernández de Poblaçión; e de la otra parte, tierra del fijo de Diego Fernández. Otra tierra en linde la huerta de Flor Ordóñez, la [...]. Otra de María, fija de Marcos Fernández, en que ay obrada y media. Otra tierra en las Quintanas de Poblaçión, en dos lugares, en que ay tres obradas y media, linderos: tierra de la muger de Pero Fernández de Monçón; y del otro cabo, tierra de Domingo Fernández, fijo de Yvañes. Otra tierra camino del molino nuevo, en que ay obrada y media, linderos: tierra de Joán Fernández, merino, y tierra del monesterio de Santa Cruz. Otra tierra en Casasola, en que ay una obrada, linderos: tierra de Santa Cruz y tierra de Bezerrillejos. Otra tierra a La Requexada de Poblaçioneja, en que ay una obrada, linderos: tierra de Sancta Cruz y la huerta de Domingo "Lenteja". Otra tierra al Cañizal, en dos lugares, en que ay tres obradas, linderos: tierra de Sant Ypólite de Támara y tierra de Joán Gutiérrez e de la de Pero Fernández de Monçón. Otra tierra en Pumarejos, en que ay obrada y media, linderos: Domingo "Lentejas" y Martín Toledano. Otra tierra en Pumarejos, más ayuso, en que ay una obrada, lindero del cuérnago que va a Monçón y tierra de Bezerrilejos. Una haçuela de tierra en la $(f .211 v)$ huerta de Domingo Fernández "Lentejas". Otra hazuela en linde de la huerta del dicho Domingo Fernández; y de la otra parte, el cuérnago que va a Monçon. Otra terrezuela en los huertos de Poblaçioneja, en linde de huerto de Fernán Pérez de Bezerril; e de la otra parte, huerta del monesterio de Santa Cruz. Otra terrezuela a La Parra, en linde tierra del monesterio de Santa Cruz. Otra terrezuela en linde de huerto de Antón; e de la otra parte, huerta de Santa Cruz. Otra azoleja en linde de huerto de Toribio Fernández, ortolano. Otra hazuela en La Requexada en linde de huerto de Santa María de Poblaçión; y de la otra parte, tierra de Santa Cruz. Otra hazuela entre el huerto de Domingo Fernández "Lentejas" e de su hijo Pero.

1376, noviembre, 7, viernes. Valladolid. 
Gutierre Gómez, abad de Santa María de Husillos, con autorización del prior y cabildo, permuta con Juan González de Avellaneda, caudillo mayor de los escuderos del rey, con licencia de Gutierre I Gómez de Toledo, obispo de Palencia, las heredades que tenía Santa María de Husillos en Hoyales de Roa y Fuentelisendo, en tierra de Haza, por cinco casas en Valladolid, sitas: unas en la calle de La Costanilla, que habian estado arrendadas a don Santo, judio especiero, y a doña Iagonza, su mujer; y las otras en la calle que va de la iglesia de Santiago a la puerta que llaman del Campo, que habían estado arrendadas a Juan Alfonso, sellero, Mari García, su mujer, y a Rodrigo, su hermano, continuando todos los dichos inquilinos con el arrendamiento. La razón de la permuta para Husillos fue la nula rentabilidad que tenían las susodichas heredades.

A. AHDP, Ampudia y Abadía de Husillos, Pergaminos, carp. 208-16. Perg., 660 x 551 mm.; escr. precortesana; buena conservación. Llevaba pendientes tres sellos de cera, uno de los cuales, el central, perteneciente al obispo don Gutierre de Palencia, se halla perfectamente conservado. El segundo no conserva la leyenda, pudiendo pertenecer al abad de Husillos. Del tercero solamente queda la cinta.

B. APA, $L P H$, ff. 100r-103r.

C. BN, ms. 705, ff. 220r-229r. .

REG. SAN MARTÍN PAYO, Apasionante historia de cinco casas, 207-215.

In Dey nomine, amen. Sepan quantos esta carta o público instrumento vieren, commo en Valladolid, viernes, siete días de nouiembre, era de mille et quatroçientos et catorze años, estando en los palaçios del mucho onrrado padre et señor don Gutierre, por la graçia de Dios obispo de Palençia et chançeller mayor de la / rreyna, estando presente el dicho señor obispo et otrosy, estando y presentes el onrrado varón et sabio don Gutierre Gómez, abad de Fusiellos et capellán mayor de la rreyna, et Iohán Gonçález de Avellaneda, cabdiello mayor de los escuderos del rrey. Et en presençia de nos, Diego López, / notario público de la çibdat de Palençia, et Iohán Fernández, escriuano público de Valladolid et de los fechos et cuentas del conçejo desta dicha villa et de los testigos de yuso escriptos. Luego, el dicho don Gutierre Gómez, abad de Fusiellos, dixo que él que 
auía por suyos et de la su aba/ ${ }^{3}$ día de Fusiellos, dos logares que eran Foyales et Fuent Alisendo, que eran en tierra de Aça; los quales lugares dixo que eran tales de que él auía muy pequeña rrenta et se aprovechaua muy poco dellos él nin la dicha su abadía. Et por ende, que él et el dicho Iohán Gonçález que avían / tratado en vno, que el dicho abad, que diese al dicho Iohán Gonçález, en troque et en camio, los dichos logares de Foyales et de Fuent Alisendo, por dos pares de casas et por la meytad de otro par de casas que el dicho Iohán Gonçález auía aquí, en la dicha villa de Valladolit; el un par de casas et la me/ytad del otro par de casas, en la calle a do dizen La costanilla, et el otro par de casas en la calle que va de la eglesia de Santiago a la puerta que dizen del Campo. Las quales dichas casas dixo que eran de mucha mayor rrenta et más prouechosas a él et a la dicha su abadía que non $/{ }^{6}$ los dichos logares de Foyales et de Fuent Alisendo. Et dixo que él, nin los otros abades que fueron antes que él de Fusiellos, que non ouieran nin podieran aver tanto de rrenta, de los dichos logares, el año que más auían que abastase, con muy grandes quantías, a la rrenta que rrendía los / dichos dos pares et la meytad de las dichas casas, que el dicho Iohán Gonçález le daua por los dichos logares de Foyales et de Fuent Alisendo, et que las dichas casas que eran en muy buena villa et en dos logares, los mejores de la dicha villa de Valladolid. Et por ende, que él que ouiera / su trabtamiento sobre esto, deste dicho troque et camío con el cabillo de la su eglesia de Fusiellos. Et que el dicho cabillo que él dieran su consentimiento et otorgamiento para fazer el dicho troque et camio con el dicho Iohán Gonçález, segund que dixo que se contenía en un instrumento que el dicho abad $/^{9}$ y mostró et fiço leer por nos, los dichos notarios, escripto en papel et signado del signo de Iohán Fernández de Tablada, notario público de la çibdat de Palençia, segunt que por él paresçía, el tenor del qual es este que se sigue:

(Sigue doc. núm. 183)

El qual instrumento mostrado et leydo, luego, el dicho don Gutierre Gómez, abad, dixo que él, por las rrazones que dichas auía, que él, que entendía trocar et camiar, con el dicho Iohán Gonçález los dichos lugares de / Foyales et de Fuent Alisendo por los dichos dos pares de casas et la dicha meytad de las dichas casas. Et por ende, que pedía et pedió, por merçed, al dicho señor obispo, que fuese la su 
merçed de dar su consentimiento et abtoridat et liçençia a este dicho troque et camío. $/^{27}$ Et luego, el dicho señor obispo dixo que por visto el dicho trabtamiento et el dicho troque et camio que los dichos don Gutierre Gómez, abad, et Iohán Gonçález, querían fazer de los dichos logares de Foyales et de Fuent Alisendo et dos pares de casas et la dicha meytad de las dichas / casas et el pedimiento quel dicho don Gutierre Gómez, abad, le fazía, que él que fallaua quel dicho troque et camio que era muy prouechoso al dicho abad et a la dicha su abadía de Fusiellos, por las rrazones que de suso en este instrumento se contienen et por otras / muchas que a este fecho le mouían. Et por ende, dixo que él que daua et dio su liçençia et abtoridat et consentimiento a este dicho troque et camio que entre los dichos don Gutierre Gómez, abad, et Iohán Gonçález entendían et querían fazer, para que lo fiziesen segund $\beta^{30}$ que mejor et más complidamiente lo podía et deuía dar de derecho.

Et luego, el dicho don Gutierre Gómez, abad, con el dicho consentimiento, que el dicho su cabillo de la dicha su eglesia de Fusiellos le diera, segund se contiene por el dicho instrumento de suso es/crito. Et otrosy, con la dicha liçençia et consentimiento et abtoridat quel dicho señor obispo le diera, dixo que daua et dio, por sy et por sus suçesores, al dicho Iohán Gonçález, los dichos sus logares de Foyales et de Fuent Alisendo, en troque et en camio por los dichos / dos pares de casas et por la dicha meytad de las dichas casas, quel dicho Iohán Gonçález, auía aquí, en la dicha villa de Valladolid, en las dichas calles de La Costanilla et la calle que va de la eglesia de Santiago a la Puerta del Campo. De las quales dichas casas dixo que fue ${ }^{\beta 3}$ ra, el vn par que es en la dicha calle de la Costanilla, de don Santo, judío espeçiero, de que son linderos, de la una parte: casas de Mari Gonçález, muger que fue de Pero Garçía, espeçiero, et de la otra parte, casas de la eglesia de Santa María de Segouia, et de la otra parte, la dicha / calle de La Costanilla. Et la otra meytad de las dichas casas que eran, las que fueran de Iohán Alfonso, sellero, et de Mari Garçía, su muger, et de Rodrigo, su hermano, de que son linderos: de la una parte, casas de Iohana Ferrández, muger de Pero Aluin de Cabeçón; et de la otra parte, casas / de Alfonso Gonçález de Oterdesiellas; et de la otra parte, la calle pública de La Costanilla. Et el otro par de casas, que son en la dicha calle que va de la eglesia de Santiago a la dicha puerta que dizen del Campo, son las que fueron de Iohán Gonçález, del rregistro, et de Sancha 
Rodríguez, su $/^{36}$ muger, de que son linderos: de la una parte, casas de Gonçalo Ferrández, et de la otra parte, casas de Olalla Ferrández, et de la otra parte, la dicha calle pública.

Et que le daua et dio los dichos dos logares de Foyales et de Fuent Alisendo, en troque et en camio, con todos sus términos / et señorío et vasallos et heredades et montes et pastos et aguas corrientes et estantes et con todos sus derechos et pertenençias, que a él et a la dicha su abadía pertenesçían et pertenesçer deuían, en qualquier manera et por qualquier razón, asy de fecho commo / de derecho, en los dichos logares et en sus términos et en cada uno dellos, desde la foja del monte fasta la piedra del rrío et desde la piedra del rrío fasta la foja del monte.

Et que por esta carta o instrumento, le daua et dio et entregó, al dicho Iohán Gonçález, ${ }^{\beta 9}$ corporalmiente, todo el derecho et señorío et tenençia et posesión et propriadat que él et la dicha su abadía auían en los dichos logares de Foyales et de Fuent Alisendo et en cada uno dellos et en sus términos dellos et de cada uno dellos, para él et para sus / herederos por juro de heredat, para vender et enpeñar et dar et trocar et camiar et nagenar et para fazer dellos et en ellos et en cada uno dellos asy commo de su cosa propia mesma, libre et quita, podría fazer et auer, para que sean suyos et de sus / herederos, libres et quitos, por este troque et camio, que él agora fazía con él, por los dichos dos pares de casas et por la dicha meytad de las dichas casas, de los dichos linderos.

Et partose de todo el derecho quel et la dicha su abadía auían $/^{42}$ o podrían auer en los dichos lugares et en cada uno dellos, para agora et para sienpre jamás. Et otrosy, diole et otorgole todo su poder complidamiente para que él, por sy o otro por él, qual él quisiere, sin mandado et sin abtoridat de alcalle nin de / otro juez alguno, pueda entrar et tomar et entre et tome todo el señorío et derecho et tenençia et posesión et propiadat quel ha en los dichos logares de Foyales et de Fuent Alisendo et en cada uno dellos et en sus términos et vasallos de / ellos et de cada uno dellos.

Et puso, con el dicho Iohán Gonçález, et obligo a todos los bienes de la dicha su abadía de Fusiellos, asy esprituales commo temporales, por sy et por sus susçesores, para le fazer sanos los dichos logares de Foyales et de ${ }^{45}$ Fuente Alisendo et sus términos et vasallos et todos los otros derechos quel ha en los dichos logares et en cada uno dellos. Et le rredrar de todo omme o muger que ge 


\section{LA ABADÍA DE SANTA MARÍA DE HUSILLOS: ESTUDIO Y COLECCIÓN \\ DOCUMENTAL $(904-1608)$}

lo demandase o enbargase o contrallase, todos o partes dellos, a él o a sus / herederos, en qualquier manera o por qualquier rrazón que sea o ser pueda. Et de lo sacar, ende, a saluo et sin dampno, so pena de otros tales dos logares et vasallos et términos et derechos, commo los sobredichos Foyales et Fuent Alisendo, doblados, et en tan bue/nos logares.

Et otrosy, luego, el dicho Iohán Gonçález, dixo que daua et dio, al dicho don Gutierre Gómez, abad de Fusiellos, los dichos dos pares de casas et la dicha meytad de las dichas casas, que el auía et ha aquí, en la dicha villa de Valladolid, en las dichas calles $/^{48}$ et de los dichos linderos que de suso en esta carta o instrumento se contiene, con todas sus entradas et salidas et con todas sus pertenençias, quantas les pertenesçen et pertenesçer deuen, en qualquier manera et por qualquier rrazón que sea o ser pueda, asy de / fecho commo de derecho, en troque et en camío por los dichos logares de Foyales et de Fuente Alisendo, con sus términos et vasallos et sennorío et derechos, segund quel dicho abad ge los auía dado et entregado.

Et por esta carta et público instrumento, / dixo que daua et dio et entregó, al dicho don Gutierre Gómez, abad, para él et para sus susçesores, todo el derecho et sennorío et tenençia et posesión et propridat que él auía en las dichas casas de los dichos linderos et en cada una dellas. Et partiose $/^{51}$ dello para agora et para sienpre iamás et puso con el dicho don Gutierre Gómez, abad, et obligó, por sy et por sus herereros, todos sus bienes, muebles et rrayzes, ganados et por ganar, por doquier et en qualquier lugar que los él aya, para fazer sanas las / dichas casas de los dichos linderos et rredrar, al dicho abad et a sus susçesores, de qualquier omme o muger que ge las demandaren o enbargaren o contrallaren, todas o parte dellas, en qualquier manera et por qualquier razón que sea o ser pueda, / so pena de otras tantas casas commo las sobredichas, dobladas, et tan buenas et en tan buen logar. Et para todo esto, que dicho es, asy atener et guardar et complir et pagar, al dicho don Gutierre Gómez, abad, por sy et por sus susçesores.

Et $/^{54}$ el dicho Iohán Gonçález, por sy, rrenunçiaron et partieron, de sy, toda ley et todo fuero et todo derecho, escripto et non escripto, et toda esepçión et defensión, eclesiástico o seglar, et todo uso et toda costumbre et todas cartas et previlleios, de rey / et de rreyna o de otro sennor o sennora qualquier que sean, ganados o por ganar; que contrario sean a lo contenido en esta carta o instrumento o a parte 
dello, que les non valiese, a ellos nin a alguno dellos nin a los susçesores del dicho abad nin a los herederos / del dicho Iohán Gonçález nin a alguno dellos, más que sienpre fuesen tenudos et obligados de atener et guardar et cumplir et pagar lo que en este instrumento se contiene.

Et desto todo, en commo pasó, los dichos don Gutierre Gómez et Iohán Gonçález et cada uno $/^{57}$ dellos, pedieron a nos, los dichos Diego López et Iohán Ferrández, notarios sobredichos, que les diésemos dello dos instrumentos públicos, signados con nuestros signos et de cada uno de nos, para cada una de las dichas partes el suyo, o más sy mester los / ouiesen, para guardar de su derecho. Testigos que estauan presentes, rrogados, para esto que dicho es: Iohán Rodríguez, chantre de Palençia, et Alfonso Ferrández, abad de Lavanza, et Mosén Peyre, canónigo de Palençia, et Pero Ferrández, copero, et Rodrigo Ordónez, et Sancho / Diez de Rinoso.

Fecho día et mes et era dicha.

Et yo, Iohán Ferrández, escriuano público de Valladolid et de los ffechos et cuentas del conçejo desta dicha uilla a la merçed de nuestra señora la reyna ssusodicha, fuy presente a todo esto que sobredicho es con el dicho Diego López, ${ }^{60}$ notario, et con los dichos testigos. Et por ruego et otorgamiento, de los dichos don Gutierre Gómez, abat, et Iohán Gonçález, et por poder et abtoridat que yo he de nuestros señores, el rrey et la rreyna para escriuir por sobre scriba, ffiz escriuir, desto todo que ssobredicho es, dos cartas en un tenor, a / cada vna de las dichas partes la suya. Et ffiz escriuir esta para el dicho don Gutierre Gómez, abat. Et ffiz aquí este mío sig(signo)no en testimonio. /

Et yo, el dicho Diego López, notario público de la dicha çipdat de Palençia, fuy presente a esto que dicho es con el dicho Iohán Ferrández, escriuano, et con los dichos testigos. Et por ruego et rrequirimiento de los dichos don Gutierre Gómez, abbad, et Iohán Gonçález et por merçed que me fizo nuestro señor el rey, que pueda signar ${ }^{63}$ los escriptos que otro escriuiere por mi mandado, ffiz escriuir esta carta o público instrumento et otra tal. Et fiz, aquí, este mío sig(signo)no en testimonio. Gutierre, episcopus Palentinus. Gomez, abbas Fusellensis. /

Et después desto, este dicho día, viernes, siete días del dicho mes de nouiembre, de la dicha era de mille et quatroçientos et catorze años, estando en las dichas casas de los dichos linderos que fueron de los dichos Iohán Gonçález, del 
rregistro, et Sancha Rodríguez, su muger. Et estando / y presentes los dichos don Gutierre Gómez, abad de Fusiellos, et Iohán Gonçález de Avellaneda et Iohán Gonçález, del rregistro, en presençia de mí, Iohán Ferrández, escriuano público de Valladolid et de los fechos et cuentas del conçejo desta dicha villa, a la merçed de nuestra señora la rreyna, ${ }^{66}$ et de los testigos de yuso escriptos, luego, el dicho Iohán Gonçález de Avellaneda, tomó por la mano al dicho don Gutierre Gómez et metiolo en las dichas casas corporalmiente. Et dixo que le daua et entregaua et dio et entregó la tenençia et posesión de las dichas / casas et corral de los dichos linderos, por virtud del dicho troque et camio que auía fecho con él de las dichas casas por los dichos logares de Foyales et de Fuente Alisendo. Et luego, el dicho don Gutierre Gómez, echó fuera de las dichas casas al dicho Iohán / Gonçález de Avellaneda et quedose él en ellas et çerró las puertas et después abriolas. Et dixo, al dicho Iohán Gonçález, del rregistro, sy quería quedar en las dichas casas por él et de su mano para le rrecudir con ellas et con la tenençia et posesión dellas et con ${ }^{69}$ los alquileres dellas. Et el dicho Iohán Gonçález dixo que sy. Et luego, el dicho don Gutierre Gómez, tomó por la mano al dicho Iohán Gonçález et púsolo en las dichas casas, de su mano. Et el dicho Iohán Gonçález quedó en las dichas casas de mano del dicho don Gutierre / Gómez et puso, con él, de le rrecudir con ellas et con la tenençia et posesión dellas et con las rrentas et alquileres dellas. Et esto todo dixo, el dicho don Gutierre Gómez, que lo fazía con entençión de cobrar el señorío de las dichas casas. Et desto / todo, en commo pasó, el dicho don Gutierre Gómez, dixo que pedía a mí, el dicho Iohán Ferrández, escriuano, que le diese dello un público instrumento o dos o más, signados con mío signo, para guarda de su derecho. Testigos que estauan presentes: Pero Ferrández, copero mayor de $/^{72}$ nuestra señora la rreyna, et Pero Ruyz de Fuent Saldaña, et Diego Ferrández, mesonero, vezinos de Valladolid.

Et después desto, este dicho día, viernes, siete días del dicho mes de nouiembre de la dicha era de mille et quatroçientos et catorze años, estando / en la dicha meytad de las dichas casas que fueron de los dichos Iohán Alfonso, sellero, et María Garçía, su muger, et Rodrigo, hermano del dicho Iohán Alfonso. Et estando y presentes los dichos don Gutierre Gómez et Iohán Gonçález de Avellaneda et Iohán Alfonso et María Garçía, / su muger, en presençia de mí, el dicho Iohán Ferrández, escriuano, et de los testigos de yuso escriptos; luego, el dicho Iohán 
Gonçález, tomó por la mano, al dicho don Gutierre Gómez, et metiolo en la dicha meytad de las dichas casas, corporalmiente. Et dixo que le $/^{75}$ daua et entregaua et dio et entregó la tenençia et posesión de la dicha meytad de las dichas casas de los dichos linderos, por virtud del dicho troque et camio que auía fecho con él, de las dichas casas por los dichos logares de Foyales et de Fuente / Alisendo. Et luego, el dicho don Gutierre Gómez, echó fuera de la dicha meytad de las dichas casas, al dicho Iohán Gonçález et quedose él en ellas, et çerró las puertas et después abriolas. Et dixo a los dichos Iohán Alfonso et María Garçía, su muger, sy querían quedar / en las dichas casas, por él et de su mano, para le rrecudir con ellas et con la tenençia et posesión dellas et con las rrentas et alquileres dellas. Et los dichos Iohán Alfonso et María Garçía, su muger, dixeron que sy. Et luego, el dicho don Gutierre Gómez tomó por las manos a $/^{78}$ los dichos Iohán Alfonso et María Garçía, su muger, et púsolos en la dicha meytad de las dichas casas de su mano. Et los dichos Iohán Alfonso et María Garçía quedaron en la dicha meytad de las dichas casas, de mano del dicho don Gutierre Gómez. Et posieron con él de le / rrecudir con ella et con la tenençia et posesión della et con las rrentas et alquileres della. Et esto todo dixo el dicho don Gutierre Gómez, que lo fazía con entençión de cobrar el señorío de la dicha meytad de las dichas casas.

Et desto todo, en commo / pasó, el dicho don Gutierre Gómez, pedió a mí, el dicho Iohán Ferrández, escriuano, que le diese, dello, vn público instrumento o dos o más, signados con mío signo, para guarda de su derecho. Testigos que estauan presentes: Pero Ferrández, copero mayor de nuestra sennora la rreyna, $/^{81}$ et Rodrigo Rodríguez, canónigo, et Diego Alfonso, corredor.

Et después desto, este dicho día, viernes, siete días del dicho mes de nouiembre, de la dicha era de mille et quatroçientos et catorze años, estando en las dichas casas que fueron de los dichos don Santo et doña / Iagonça, su muger, et doña Míoro. Et estando y presentes los dichos don Gutierre Gómez et Iohán Gonçález de Avellaneda et don Santo et doña Iagonça, su muger, en presençia de mí, el dicho Iohán Ferrández, escriuano, et de los testigos de yuso escriptos. Luego, el dicho / Iohán Gonçález, tomó por la mano al dicho don Gutierre Gómez et metiolo en las otras dichas casas, corporalmiente, et dixo que le daua et entregaua et dio et entregó la tenençia et posesión de las dichas casas de los dichos linderos, por virtud del dicho troque ${ }^{84}$ et camio que con él auía fecho, de las dichas casas 
por los dichos logares de Foyales et de Fuent Alisendo. Et luego, el dicho don Gutierre Gómez echó fuera de las dichas casas al dicho Iohán Gonçález et quedose él en ellas et çerró las puertas et des/pués abriolas et dixo, a los dichos don Santo et donna Iagonça, sy querían quedar en las dichas casas, por él et de su mano, para le rrecudir con ellas et con la tenençia et posesión dellas et con las rrentas et alquileres dellas. Et los dichos don Santo et doña Iagonça, / su muger, dixeron que sy. Et luego, el dicho don Gutierre Gómez, tomó por las manos a los dichos don Santo et doña Iagonça, su muger, et púsolos en las dichas casas, de su mano. Et los dichos don Santo et doña Iagonça, quedaron en las dichas casas de mano ${ }^{87}$ del dicho don Gutierre Gómez. Et posieron con él de le rrecudir con ellos et con la tenençia et posesión dellas et con las rrentas et alquileres dellas. Et esto todo dixo, el dicho don Gutierre Gómez, que lo fazía con entençión de cobrar el señorío de las dichas casas. Et / desto todo, en commo pasó, el dicho don Gutierre Gómez, dixo que pedía a mí, el dicho Iohán Ferrández, escriuano, que le diese, dello, vn público instromento o dos o más signados con mío signo para guarda de su derecho. Testigos que estauan presentes: Pero Ferrández, copero mayor de / nuestra señora la rreyna, et Rodrigo Rodríguez, canónigo, et Diego Alfonso, corredor, et Çulemán, iudío corredor, fijo de don Çague de Palençia, vezinos de Valladolid.

Et yo, Iohán Ferrández, escriuano público de Valladolid et de los ffechos et cuentas del conçejo desta dicha villa, a la merçed $\rho^{90}$ de nuestra señora la rreyna ssusodicho, ffuy presente a todo esto que sobredicho es con los dichos testigos. Et a pedimiento del dicho don Gutierre Gómez et por poder et abtoridat que yo he de nuestro señor el rrey et la rreyna para escriuir por sobre scriba, ffiz escriuir este público / enstrumento. Et fiz aquí este mío sig(signo)no en testimonio.

1377, enero, 28. Palencia. 
Juan Fernández Simón y María Martín, su esposa, vecinos de Villaumbrales, venden a Domingo González, chantre en Santa María de Husillos, una viña de seis cuartas en término de Fuente Quintana, en el lugar que llaman Abeza, en precio de cuatrocientos maravedis.

$B$. APA, $L P H$, f. $103 \mathrm{r}-\mathrm{v}$.

C. BN, $m s .705$, ff. 229r-230v.

Fecho y sacado fue este traslado de la dicha escritura original en la villa de Husillos, a primero día del mes de diciembre de mil y quatroçientos y çinquenta y quatro años. Testigos que fueron presentes a lo ver, leer, corregir y conçertar con el original, Joán Ruiz Cabeça de Vaca y Pero Manuel, estantes en la dicha villa. Y yo, Santiago Gómez, notario público en la dicha villa, presente fui a lo que dicho es con los dichos testigos. Y del dicho pedimiento y mandamiento del dicho señor Pero Ruyz de Villoldo, alcalde mayor, que aquí firmó su nombre, lo escreví y fize aquí mi signo (signo) en testimonio de verdad.

Pero Ruiz de Villoldo (rúbrica). Santiago Gómez (rúbrica).

Sepan quantos esta carta vieren como nos, Joán Fernández Ximón, fijo de Joán Fernández Ximón, y yo Mari Martín, fija de Domingo Martín, su muger, vezinos y moradores en Villunbrales, otorgamos y conosçemos que vendemos a vos Domingo Gonçález, chantre en la iglesia de Sancta María de Fusiellos vna viña que nos auemos, la qual es de mí la dicha María Martín, que es en el término de Fuente Quinaua, que a por linderos: de la vna parte, viña del cabildo de Fusillos; y de la otra parte, viña de Joán Gutiérrez; $(f .103 r)$ y de la otra parte, viña de Joán, fijo de Saluador. Esta viña es a do dize Abeza y pone en ella seis quartas, la qual vos vendemos vendida, buena, sana, leal y verdadera con entradas y con salidas y con todas sus pertenençias por quatroçientos maravedís desta moneda vsual que agora corre que fazen diez dineros vn marauedí. Los quales rreçebimos de vos en buenos dineros y bien contados y los pasamos a nostro juro y poder, de los quales nos otorgamos por bien pagados. Y rrenunçiamos las leyes del derecho, la vna en que dize que los testigos de la carta deven ver fazer la paga de la cosa sobre que es fecho el contrato y la otra ley en que dize que el que faze la paga es tenudo del aprovar fasta dos años si estas leyes no rrenunçiaren y se partiere dellas a qual que rreçibe la paga. 


\section{LA ABADÍA DE SANTA MARÍA DE HUSILLOS: ESTUDIO Y COLECCIÓN \\ DOCUMENTAL $(904-1608)$}

Otrosí, renunçiamos que nos non podamos llamar a engaño por adjutorio del "al eyren? mayoris" diziendo que nos que fuimos engañados en más de la mitad del justo preçio. Pero si la dicha viña que vos vendemos vale más de los dichos quatroçientos maravedís de todo lo que más vale, vos fazemos donaçión dello entre biuos y obligamos todos nostros bienes e de cada vno de nos de uos fazer sanna esta dicha viña de a qualquier o qualesquier que vos la vinieren a enbargar contrallando en qualquier o qualesquier que vos la vinieren a enbargar contrallando en qualquier manera.

Y si por auentura vos la alguno demandare en juizio, nos obligamos por nos y por todos nostros bienes de tomar el pleyto y la boz por uos y el juizio tomarlo en nos a nostra costa y minsión fasta que el pleyto sea fenesçido. Desde oy día que esta carta es fecha en adelante nos despartimos y nos desapoderamos de la tenençia y señorío y propiedad de la dicha viña, y con esta carta vos apoderamos en ella para que la ayades por vestra para vender y enpenñar y dar y donar y trocar y fazer della y en ella commo de cosa vestra propia agora y para siempre jamás.

Fecha esta carta en la çiudad de Palençia, veynte y ocho días de enero, era de mil y quatroçientos y quinze años. Testigos que estauan presentes a esto: Pero Alfonso, vezino de Palençia, y Miguel Rodríguez, clérigo, su fijo, y Joán Alfonso, otrosí clérigo, vezinos de Grijota, y Rui Gonçález, fijo de Andrés Gonçález, criado y sobrino de Gonçalo Gonçález.

Y yo, Toribio Martínez, notario público de la çiudad de Palençia, fui a esto presente, rrequerido y rrogado, y fize esta carta y fize aquí este mío signo en testimonio. Toribio Martínez, notario.

188

1377, noviembre, 25. Grijota.

Juan Fernández, hijo de Domingo Pérez, vecino de Fuentes de Valdepero, dona a Santa María de Husillos una tierra con una pedrera, en término de 
Husillos, en el lugar que llaman Val Mayor, de una obrada y media aproximadamente.

A. AHDP, Ampudia y Abadía de Husillos, Pergaminos, carp. 207-18. Perg., 181 x 212 mm.; escr. precortesana; buena conservación.

B. AHDP, Ampudia y Abadía de Husillos, Pergaminos, carp. 207-19. Perg., 405 x 266 mm; escr. precortesana. Aunque el texto está perfectamente conservado, tiene dos roturas que suplimos con el Libro de los Privilegios de Husillos. Traslado sacado en Fuentes de Valdepero, el 21 de agosto de 1384, con motivo de la autorización del concejo de Fuentes de Valdepero a Santa María de Husillos para sacar piedra de unas canteras. Véase doc. núm. 206.

$C$. APA, $L P H$, ff. $103 \mathrm{v}-104 \mathrm{r}$. Traslado de $A$.

$D$. APA, $L P H$, ff. $34 \mathrm{v}-35 \mathrm{v}$. $<$ Y esta escritura por estar rota en algunas partes no se signó $>$. Traslado de $B$.

E. AGS, Patronato eclesiástico, Inconexos, leg.159, ff. 107v-108v. Papel; escr. procesal; buena conservación. Traslado de $C$.

$F$. BN, $m s .705$, ff. 230v-231v. Traslado de $C$.

Sepan quantos esta carta vieren commo yo, Iohán Ferrández, fijo de Domingo Pérez, vezino que sso de Fuentes de Valdepero, otorgo / e conosco que do e fago donaçión e por amor de Dios, de mi propia voluntad, a la eglesia de Sancta María de Fusiellos, / vna tierra con su pedrera que en ella es, que yo he en término del dicho lugar de Fusiellos, que es en logar por nombrado $\beta$ do dizen a Val mayor, en que ha quanto vna obrada o obrada e media, que ha por linderos: de la vna parte, tierra / de Esteuan, fijo de don Yague; e de la otra parte, tierra de nietos de Pero Garçía.

Esta dicha tierra e pedrera que estas / dichas afrontaçiones ençierran e con más si las y a, le do a la dicha eglesia de Sancta María, por el amor de Dios, con $/{ }^{6}$ sus entradas e con sus salidas e derechos e vsos e pertenençias, quantas le pertenesçe e pertenesçer deue de / derecho. E desde oy día que esta carta es fecha en adelante, me quito e desapodero del juro e la tenen/çia e açción e demanda e derecho e señorío que yo auía en la dicha tierra e en la dicha pedrera. E con $/^{9}$ esta carta apodero a la dicha eglesia en ello corporalmiente para que sea suyo, propio e libre e quito e esento, / para agora e para todo tiempo del mundo.

E para fazer sanna la dicha tierra e pedrera de qualquier ombre o muger que la de/mandare o enbargare o contrallar quesiere toda o parte della, obligo a todos los 
mis bienes muebles e rrayzes quantos $/^{12}$ oy día he e ffuere de aquí adelante, por doquier que los yo aya.

E sobre esto todo que dicho es, rrenun/çio a todos leys e fueros e derechos, escriptos e non escriptos, e todas las otras graçias e exepçiones que contra / esta carta podiere poner o aldegar a otro por mí, que me non vala asy en juyçio commo fuera de iuyçio.

E $/{ }^{15}$ porque esto sea firme e non venga en dubda, rrogué a Ferrnando Díez de Grijota, notario público de la çipdat de Palençia, / que escriuiese esta carta e la signase con ssu signo.

Que fue fecha en Grijota, veynte e çinco días de / nouienbre, era de mille e quatroçientos e quinze años. Testigos que a esto fueron presentes e llamados, Iohán Gutiérrez, es $/{ }^{18}$ criuano de Grijota, e Bartolomé Sánchez, clérigo, e Ferrnant Maçías, e Pero Garçía, fiio de Pero Garçía, vezinos / de Grijota.

E yo, Ferrnando Díez de Grijota, notario público sobredicho de la dicha çipdat de Palençia, / fuy presente a esto que dicho es con los dichos testigos, e por rruego del dicho Iohán Ferrández escriuí $/^{21}$ esta carta e fiz aquí este myo ssig(signo)no en testimonio de uerdat.

[1377]. Husillos.

Traslado sacado para el prior y cabildo de Santa María de Husillos por Juan Fernández de Tablada, notario público de Palencia, a petición del abad y los dichos prior y cabildo de dicha iglesia, del libro becerro en el que se relacionan las propiedades y rentas de Santa María de Husillos, repartidas en varios capítulos: abad, prior y cabildo, préstamos, capellanías, lámpara y cofradía del hospital. Asimismo se detalla el servicio en la sacristía de la iglesia de Husillos. 
C. AGS, Patronato eclesiástico, Inconexos, leg.159, ff. 139v-181v. En margen izq. del f. 139v: $<$ Libro de becerro donde están las rrentas y hacienda que tiene la yglesia y abbadía de Vsillos $>$. Papel; escr. procesal; buena conservación.

Esta escritura no se sinó por estar rrota parte della y no se poder leer.

(Precede doc. núm. 185)

El qual libro e quadernos, leydo por mí, dicho Joán Fernández, notario sobredicho, el dicho señor abad e prior e cabildo, sobredichos señores del dicho cabillo de Fusiellos, rrogaron e mandaron a mí, dicho Joán Fernández, que lo escriviese e tornase, todo, en pública forma y escriviese, desto, dos libros, amos de un tenor, el uno para para el dicho señor abad e el otro para los dichos señores prior y cabildo, e lo sinase de mío signo, porque ellos supiesen lo que avían en la dicha yglesia y lo que les perteneçía en todo, así a los dichos señores abad y cabildo, que agora era, como a los que avían de venir después dellos y de cada uno dellos, porque fiziesen fee agora e para en todo tienpo e para sienpre jamás, ante qualesquier omes y mugeres de qualquier estado e condiçión que fuesen que pareçiesen, porque no pudiesen ni puedan rrevocarlo ni yr contra ello ni contra parte dello, en ninguna manera e rrazón, según que la dicha yglesia y abad y prior y cabieldo les perteneçe e les fue dotado, según que en este libro se contiene. E rrogaron a los omes buenos que estavan presentes que fuesen dello testigos.

Fecho e presentado e leydo fue este libro en la dicha yglesia, en el cabieldo della, en la manera que dicha es, día y año y mes y era sobredicha. Testigos que fueron presentes, rrogados, a esto llamados e vieron el dicho libro donde este traslado fue sacado: Toribio Gonçález de Maçuela, criado del dicho señor abad, e Toribio Fernández, arçipreste de Castrejón y capellán en la dicha yglesia, y Alfonso de Revenga, e Joán de Ávila, e Joán de Madrigal, criado del dicho sacristán.

Y yo, Joán Fernández de Tablada, notario público de la çibdad de Palençia, fui presente con los dichos testigos e vi e ley el dicho quaderno donde este quaderno fue sacado y escrito; e escreví, por él, dos libros en un tenor para cada parte de los dichos señores, abad e prior y cabieldo, el suyo, y escreví, éste, para los dichos prior y cabildo en pargamino, que va todo escrito de mi mano y de mi letra, que son tres quadernos de pargamino e de un volumen, porque no sea falsado de otra 
letra. Y en cada plana escreví mi nonbre, [e] fize aquí este mi signo en testimonio. Joán Fernández.

1378, agosto, 26. Valladolid.

Enrique II toma a Santa María de Husillos bajo su amparo y protección, estipulando que su abad, canónigos, beneficiados y vasallos, sólo podrán ser presos y prendidos por deuda o fiadura verdadera que hubiera sido demostrada, siendo primeramente dicha deuda juzgada por fuero.

B. AHDP, Ampudia y Abadia de Husillos, Pergaminos, carp. 202-31. Perg., 412 x 496 mm.; escr. gótica redonda de privilegios; buena conservación. Mantiene el sello de plomo pendiente de hilos rojos, amarillos y blancos. Inserto en confirmación de Enrique III de 20 de febrero de 1392, del privilegio de confirmación que Juan I hizo del privilegio de Enrique II. Véase doc. núm. 214.

$C$. APA, $L P H$, ff. $127 \mathrm{v}-129$ r.

Sepan quantos esta carta vieren commo nos, don Enrrique por la graçia de / Dios rrey de Castilla, de León, de Toledo, de Gallizia, de Seuilla, de Córdoua, de Murçia, de Iahén, del Algarue, de Algezira et señor de Molina por fazer bien et merçed a vos, <don> Iohán Ferrández, abad de Fussiellos, ${ }^{6}$ resçebímos vos en nuestra guarda et en nuestra encomienda et en nuestro anparo et defendimiento, a vos et a la dicha eglesia de Santa María de Fussiellos et a todos los sus canónigos et benefiçiados et a sus omes et sus / vasallos et lugares por doquier que los vos avedes et que anden saluos et seguros por todas las [partes de nuestros] regnos. Et otrosí, por vos fazer más bien et merçed tenemos por bien que non sean nin seades presos / nin prendidos, vos nin los vuestros [canónigos], por debda que vuestro conçejo deva a otro nin un rrico omme a otro nin vn cauallero a otro nin un ome a otro, saluo por una debda verdadera conosçida o fia $/^{9}$ dura de que fuéredes fiador, seyendo, primeramente, la debda o la fiadura demandada et oyda et vençida por fuero et por derecho, por do deue et commo deue. 
Et por esta nuestra carta o por el tras/lado della signado de escriuano publico, mandamos a todos los conçejos, alcalles, jurados, juezes, justiçias, merinos, alguazilez, maestres de las órdenes, priores, comendadores et so comenda/dores, alcaydes de los castillos et casas fuertes et a todos los otros ofiçiales et aportellados de todas las çibdades et villas et lugares de nuestros rregnos que agora son o serán de aquí adelante et a qual ${ }^{12}$ quier o a qualesquier dellos a quien esta nuestra carta fuere mostrada o el traslado della signado como dicho es, que guarden et defiendan et anparen a vos, el dicho abad, et a la vuestra eglesia et a los canó/nigos et benefiçiados della et a los vuestros omes et vasallos et lugares et a todas las vuestras cosas, con esta merçed que nos vos fazemos. Et que vos non vayan nin passen contra ella nin contra parte / della, so pena de la nuestra merçed et de seysçientos maravedís desta moneda vsual a cada vno. Et demás, qualquier o qualesquier que fincar, de lo así fazer et conplir, mandamos al omme que les esta nuestra $/{ }^{15}$ carta mostrar o su traslado della, signado commo dicho es, que los enplaze, que parescan ante nos doquier que nos seamos, del día que los enplazare a nueve días primeros siguientes, a / dezir por qual razón non cumplen nuestro mandado. Et de cómo esta nuestra carta les fuere mostrada et la cumplieren, mandamos, so la dicha pena, a qualquier escriuano público que para esto fuere / llamado, que dé ende al que vos la mostrare, testimonio signado con su signo porque nos sepamos en commo se cumple nuestro mandado. Et desto vos mandamos dar esta nuestra carta sellada con ${ }^{18}$ nuestro sello de plomo colgado.

Dada en Valladolid, veynte et seys días de agosto, era de mille et quatrocientos et diez et seys años. Don Iohán, obispo de Siguença, chançeller mayor del rey, / la mandó dar. Yo, Alfonso Martínez, escriuano del rrey, la fiz escriuir. Gonçalo Ferrández. Vista episcopus Seguntinus.

1379, agosto, 10. Burgos. 


\section{LA ABADÍA DE SANTA MARÍA DE HUSILLOS: ESTUDIO Y COLECCIÓN \\ DOCUMENTAL $(904-1608)$}

Juan I confirma un privilegio de Enrique II por el que toma a Santa María de Husillos bajo su amparo y protección, estipulando que su abad, canónigos, beneficiados y vasallos, sólo podrán ser presos y prendidos por deuda o fiadura verdadera que hubiera sido demostrada, siendo primeramente dicha deuda juzgada por fuero.

B. AHDP, Ampudia y Abadía de Husillos, Pergaminos, carp. 202-31. Perg., 412 x 496 mm.; escr. gótica redonda de privilegios; buena conservación. Mantiene el sello de plomo pendiente de hilos rojos, amarillos y blancos. Inserto en confirmación de Enrique III de 20 de febrero de 1392. Véase doc. núm. 214.

C. APA, $L P H$, ff. $127 \mathrm{v}-129 \mathrm{r}$.

Sepan quantos esta carta vieren commo nos, don Iohán, por la graçia de Dios rrey de Castilla, de León, de Toledo, de Gallicia, de Se/3uilla, de Córdoua, de Murcia, de Iahén, del Algarue, de Algezira et señor de Lara et de Vizcaya et de Molina, vimos vna carta del rrey don Enrrique, nuestro padre, que Dios / perdone, scripta en pargamino de cuero et sellada con su sello de plomo colgado, fecha en esta guissa:

(Sigue doc. núm. 190)

Et agora, el dicho don Iohán Ferrández, abad de Fussiellos, et canónigos et benefiçiados / de la dicha su eglesia, pidiéronnos por merçed que les confirmásemos la dicha carta del dicho rey, nuestro padre, et ge la mandássemos guardar en todo, bien et conplidamente, segunt que de $/^{21}$ bien et conplidamente, segunt que en esta carta se contiene et segunt que mejor et más conplidamente les fue guardado en tiempo del dicho rey, nuestro padre que Dios perdone, et en el / nuestro fasta aquí.

Et por esta nuestra carta o por el traslado della, signado de escriuano público, mandamos et defendemos firmemente, que ninguno nin algunos non sean osados de / les yr nin pasar contra esto que sobredicho es nin contra parte dello, por ge lo quebrantar o menguar en alguna cossa, por ninguna manera, en algun tiempo. $\mathrm{Ca}$ qualquier o quales $/{ }^{24}$ quier que contra ello o contra parte dello les fuese o pasase, auría la nuestra yra et demás pecharnos y a en pena, mille maravedís desta 
moneda vsual por cada vegada para la nuestra cámara. / Et a los dichos abad et yglesia et canónigos et benefiçiados della et a sus ommes et a sus vasallos et lugares o a quien su boz, dellos o de qualquier dellos, touiese, todos los daños et / menoscabos que por ende reçibiesen, doblados. Et desto, le mandamos dar esta nuestra carta sellada con nuestro sello de plomo colgado.

Dada en las cortes que nos mandamos fazer $/^{27}$ en la muy noble çibdat de Burgos, diez días de agosto, era de mille et quatroçientos et diez et siete años. Yo, Luys Ferrández, la fiz escriuir por mandado del rrey. Marcos Alfonso, veedor. Aluarus, de/cretorum doctor.

1379, agosto, 22. Burgos.

Juan I, para salvación de su alma y en remisión de sus pecados y de los de sus antepasados y descendientes, y por consejo de los condes de su reino, exenta a Santa María de Husillos de toda imposición fiscal debida a la corona.

A. AHDP, Ampudia y Abadía de Husillos, Pergaminos, carp. 201-28. Perg., 306 x 273 mm.; escr. gótica de privilegios; buena conservación. Sello pendiente de plomo.

$B$. APA, $L P H$, ff. $111 \mathrm{r}-112 \mathrm{r}$.

C. AGS, Patronato eclesiástico, Inconexos, leg.159, ff. 122v-124r. Papel; escr. procesal; buena conservación.

Sepan quantos esta carta vieren commo nos, don Iohán, por la graçia de Dios rrey de Castilla, de Toledo, de León, de Galizia, de Seuilla, / de Córdoua, de Murçia, de Iahén, del Algarbe, de Algezira, e señor de Lara et de Vizcaya, rreynante en vno con la rreyna do/ña Leonor, mi muger, de consentimiento e consejo de los príncipes e condes de mi rregno, por salud de mi ánima e rremissión de $\beta^{\beta}$ mis pecados e de mis predecesores e sucesores, de mi libre e spontánea voluntad, dono e concedo e fago donaçión a la iglesia de Sancta / María de Fusillos e al abbad e prior e canónigos e beneficiados della que agora son o 
serán de aquí adelante para sienpre jamás, / de todos pedidos e ayudas, martiniegas, yantares, alcaualas, fonsados e fonsaderas, exaciones e de todos otros qualesquier $/{ }^{6}$ pechos e tributos a mí e a la corona rreal pertenescientes e pertenescederos, a los quales pechos e tributos o algunos dellos, la dicha / iglesia e los dichos abbad e prior e canónigos eran obligados a dar segund constituciones e ordenamientos rreales. E fago libres / e esentos a la dicha iglesia e a los dichos abbad e prior e canónigos e beneficiados e a los sus suscesores para sienpre de to $/{ }^{9}$ do seruicio e tributo rreal. E que a mí e a los mis sucesores rreyes, nunca fagades seruicio constrenidamente mas sienpre a / nostro sennor Dios e a la virgen María en la dicha su iglesia rrogar por mí e por mis antecessores e sucessores porque él, / por la su sancta misericordia e vestras oraçiones, corrobore e confirme por luengos tienpos el ceptro del mi rreyno e así a los $/{ }^{12}$ pasados e presentes commo a los venideros de mi generaçión de vida perdurable. E si alguno de mi generación o agena / contra esta carta o contra lo en ella contenido o parte dello, presumiere yr o venir por deffonper? e anularlo, sea / malditho e descomulgado e con Judas el traydor en el infierno dampnado, e peche a la corona rreal dos mille marauedís, e a la $/^{15}$ dicha iglesia e abad e prior e canónigos, otros mille marauedís. E esta mi carta vala e quede firme por sienpre jamás. E porque esto / sea firme e estable, mandamos dar esta nostra carta sellada con nostro sello de plomo colgado.

Dada en las cortes que nos / mandamos fazer en la muy noble çibdat de Burgos, a veynte e dos días de agosto, era de mille e quatrocien $/{ }^{18}$ tos e diez e siete años. E nos, el sobredicho rrey don Iohán, rreynante en vno con la rreyna donna Leonor / mi muger, en Castilla, en Toledo, en León, en Galizia, en Seuilla, en Córdoua, en Murçia, en Iahén, en Baeça, / en Badajoz, en el Algarbe, en Algezira, en Lara, en Vizcaya, en Molina, otorgamos esta carta e confirmámosla. $/^{21}$

El infante don Donis, fijo del rrey de Portogal, señor de Alua de Tormes, vasallo del rrey, conf.; don Fradrique, / duque de Benauente, hermano del rrey, conf.; don Alfonso, fijo del infante don Pero de Aragón, marqués de Villena, / conde de Ribagorça e de Denia, vasallo del rrey, conf.; don Alfonso, conde de Nuruenna, hermano del rrey, conf.; don $/^{24}$ Beltrán de Clauquin, condestable de Francia, vasallo del rrey, conf.; don Pero, primo del rrey, conde de Trastámara / e de Lemes e de Sarria, conf.; don Pero, arçobispo de Toledo, primado de las 
Espannas, conf.; don Ferrando, arçobispo de Seui/lla, conf.; don Rodrigo, arçobispo de Santiago, capellán mayor del rrey e notario mayor del rreno de León, conf.; don ${ }^{27}$ Iohán, obispo de Çiguenca, chanceller mayor del rrey, conf.; don Fernando, obispo de León, conf.; don Domingo, obispo de Burgos, / conf.; don Gutierre, obispo de Ouiedo, conf.; don Goncalo, obispo de Calaorra, conf.; don Alfonso, obispo de Astorga, confirma. / Don Hugo, obispo de Segouia, conf.; don Martín, obispo de Çamora, conf.; don Alfonso, obispo de Áuila, conf.; don Alfonso, $\beta^{30}$ obispo de Salamanca, conf.; don Nicholás, obispo de Cuenca, confirma; don Alfonso, obispo de Çibdat, conf.; don / Pero, obispo de Plasençia, conf.; don Ferrando, obispo de Coria, conf.; don Pero, obispo de Córdoua, conf.; don Fe/rrando, obispo de Badajoz, conf.; don Nicholás, obispo de Cartagena, conf.; don Francisco, obispo de Mondonnedo, conf.; ${ }^{\beta 3}$ don (en blanco), obispo de Palençia; don Iohán, obispo de Iahén, conf.; don (en blanco), obispo de Osma; don Iohán, obispo de / Tuy, conf.; don Fernando, obispo de Orens, conf.; don Pero Ferrández de Velasco, camarero mayor del rrey, conf.; don Ferrand / Osórez, maestre de la cauallería de Santiago, conf.; don Pero Núñez, maestre de Alcántara, conf.; don Pero Manrrique, adelan $/{ }^{36}$ tado mayor de Castilla, conf.; don Pero Royz Sarmiento, adelantado mayor de Galizia, conf.; don Pero Suárez / de Quiñones, adelantado mayor de León, conf.; Iohán Núñez de Villazán, justicia mayor del rrey; don Ferrand / Sánchez de [...], almirante mayor de la mar; Diego López Pacheco, notario mayor de Castilla; Pero Suárez ${ }^{39}$ de Toledo, alcalde mayor de Toledo; Pero Suárez de Guzmán, notario mayor del Andaluzía. /

1379, [agosto, 22]. Burgos.

Juan I confirma un privilegio de Enrique II (1371, mayo, 20. Valladolid), inserto, que confirma un privilegio de Alfonso XI (1331, diciembre, 18. Valladolid), inserto, confirmatorio a su vez de otro de Fernando IV (1305, mayo, 10. Medina del Campo), inserto, confirmatorio asimismo de uno de Sancho IV 


\section{LA ABADÍA DE SANTA MARÍA DE HUSILLOS: ESTUDIO Y COLECCIÓN \\ DOCUMENTAL $(904-1608)$}

(1290, julio, 31. Valladolid), inserto, que a su vez confirma los siguientes privilegios:

- Privilegio de Urraca I (1114, mayo, 28), inserto, por el que concede a Santa María de Husillos, Villaldavín y la pesquera de Deronnada.

- Privilegio de Sancho III (1158, mayo, 4. Carrión de los Condes), inserto, por el que confirma las posesiones que Santa María de Husillos recibió de Urraca I, los condes de Monzón y otros particulares.

- Privilegio de Sancho III (1158, junio, 28, Cuéllar), inserto, por el que confirma el coto de Santa María de Husillos que él mismo había donado.

- Privilegio de Alfonso VIII (1178, agosto, 15. Carrión de los Condes), inserto, por el que confirma a Santa María de Husillos, las villas, heredades y monasterios donadas por Urraca I, Sancho III, Fernando Ansúrez, Gonzalo Ansúrez y Nuño Ansúrez, condes de Monzón, y otros donantes.

- Privilegio de Alfonso VIII (1178, agosto, 15. Carrión de los Condes), inserto, por el que confirma a Santa María de Husillos el coto que donó Sancho III, su padre.

A. AHDP, Ampudia y Abadía de Husillos, Pergaminos, carp. 201-27. Perg., 784 x 685 mm.; escr. gótica de privilegios y precortesana; muy deteriorado, ha desaparecido, prácticamente, toda su parte izquierda. No conserva sello ni cuerda.

$B$. APA, $L P H$, ff. $104 \mathrm{r}-108 \mathrm{v}$.

C. ARCHV, Salas de lo Civil. Zarandona y Balboa (OLV). Caja 697.1. Traslado sacado del original, aportado como prueba en un pleito olvidado (1560) del concejo de Villaldavín con Santa María de Husillos, sobre la jurisdicción en primera y segunda instancia en Villaldavín, alegando el concejo pertenecer a la jurisdicción real (véase doc. núm. 286).

D. AGS, Patronato eclesiástico, Inconexos, leg.159, ff. 108v-116v. Papel; escr. procesal; buena conservación.

E. BN, ms. 705, ff. 231v-238r.

Aunque se omite la data del día y mes, el hecho de que el documento 166 tenga idéntica data tópica e histórica, y que tenga por data crónica el 22 de agosto de 1379, expediéndose en un contexto de petición de confirmación total por Santa María de Husillos de todos sus privilegios y heredades, hace que nos decantemos por esta data para los documentos 164 y 165. Para estos tres documentos, mantenemos el orden que figura en el Libro de Privilegios de Husillos. 
[E]n el nonbre de Dios Padre, et Fijo, et Spiritu Santo, que son tres personas et vn Dios uerdadero que biue et rregna por siempre jamás, et de la bien auenturada gloriosa santa María [su] madre, [a quien] nos tenemos por [señora et por abo]gada en todos nostros fechos, / et a onrra et a seruiçio de todos los santos de la corte celestial, queremos que sepan por este nostro priuillegio todos los ombres que agora son o serán de aquí adelante, commo [nos], don Iohán, por la [graçia] de [Dios rrey de] Castiella, de Toledo, / de León, de Gallizia, de Seuilla, de Córdoua, de Murçia, de Iahén, del Algarbe, de Algezira, et señor de Lara et de Vizcaya et de Molina, rreynante en vno con la rreyna doña Leonor, my mugier, viemos vn priui[llegio del] rrey don Enrrique, $\beta$ nostro padre, que Dios perdone, escripto en pargamino de cuero rrodado et seellado con su seello de plomo colgado, fecho en esta guisa.

(Sigue doc. núm. 163)

Et agora el abbad et prior et cabillo de la dicha yglesia de Sancta María de Fusiellos, enbiáronnos pedir merced que les confirmásemos este dicho priuillegio et ge lo mandásemos gu[ardar. E]t nos, el sobredicho rrey don Juan, por fazer bien et merced a los sobredichos $/^{60}$ [abad et prior et cabillo, et porque ellos sean tenudo]s de rrogar a Dios por las almas de los rreys onde nos venimos, et por la nostra vida et por la nostra salut, touiémoslo por bien et confirmámosles este dicho priuillegio, et mandamos que les vala et les seya guardado [en todo bien et] cumplidamiente commo en él se contiene et según que les fue guardado en / [tiempo del rrey don Alfonso nostro auuelo et del rrey don] Enrrique nostro padre, que Dios perdone et en el nostro fasta aquí.

Et defendemos firmemiente que alguno nin algunos non sean osados de les yr nin passar a los dichos abbad et prior et cabillo nin alguno dellos contra este dicho priuillegio nin contra parte del por lo quebrantar nin menguar todo nin parte dello en / [alguna manera. Ca qualquier o qual]esquier que lo fiziesen aurían la nostra yra et pechar nos y an la pena que en el dicho priuillegio se contiene, et a los dichos abbad et prior et cabillo de la dicha yglesia sobredicha o a quien su boz touiese todos los daños et menoscabos que por ende rrescibiesen doblados. Et 
porque esto sea firme et estable mandamosles en $/{ }^{63}$ [de dar este nostro priuillegio rrodado et seellado con nostro] seello de plomo colgado.

Dado este priuillegio en las cortes que nos mandamos fazer en la muy noble çibdat de Burgos, (en blanco) días de (en blanco), era de mille et quatrocientos et diez et siete años. Et nos, el sobredicho rrey don Iohán, rregnante en uno con la rreyna doña Leonor / [mi mugier en Castiella, en Toledo, en León, en] Gallizia, en Seuilla, en Córdoua, en Murcia, en Iahén, en Baeça, en Badajoz, en el Algarbe, en Algezira, en Lara, en Vizcaya et en Molina, otorgamos este priuillegio et confirmámoslo. /

( $1^{a}$ col.) [El infante don Donis, fijo del rrey de Portogal], señor de Alua et de Tormes, vassallo del rrey, conf.- [Don Alfonso, fijo del infante don Pero de A]ragón, marqués de Villena, conde de Ribagorça et de Denia, vassallo del rrey, conf.- Don Be[1trán de Claquin, cond] estable de Françia, vassallo del rrey, conf.

$\left(2^{a}\right.$ col. $)$ Don Fradrique, duque de Benauente, hermano del rrey, conf.- Don Alfonso, conde de Norenna, hermano del rrey, conf.- Don Pero, primo del rrey, conde de Trastámara, et de Lemos, et de Samas, conf.

( $3^{a}$ col.) Don Ferrando, arcobispo de Seuilla, conf.- Don Iohán, obispo de Çiguença, chanceller mayor del rrey, conf.- Don Domingo, obispo de Burgos, conf.- Don (en blanco), obispo [de Palençia], conf.- Don Goncal[o, obispo de Calahorra,] conf.- Don [...], obispo [de Osma], conf.- Don Hugo, [obispo de Segouia], conf.- Don Alfonso, [obispo de Ávila], conf.- Don Nicholás, [obispo de Cuenca], conf.- Don Pero, [obispo de Plasençia, conf.-] Do[n Pero, obispo de Córdoua, conf.-] Don Nicholás, [obispo de Cartaiena, conf.-] [Don Joán, obispo de Jaén, conf.- Don Alfonso, obispo de Cádiz, conf.- Don Pero [Fernández de Velasco, camarero del rrey, conf.- Don Pero Manrrique, adelantado maior de Castilla, conf.]

( $4^{a}$ col.) Don Iohán Sánchez Manuel, conde de Carrión, adelantado mayor del rregno de Murcia, conf.- Don Bernal de Boarni, conde de Medina, vasallo del rrey, conf.- Don Diego Gómez Manrrique conf.- Don Iohán Rodríguez de 
Castañeda conf.- Don Iohán Rodríguez de Villalobos conf.- Don Iohán Rodríguez de Arellano, señor de los Cameros, vasallo del rrey, conf.- Don Beltrán de Gueuara conf.- Don Sancho Ferrández de Touar, guarda mayor del rrey, conf.[Don Aruas], señor de Villalpando, vasallo del rrey, conf.- [Don Nuño] Núñez Daça conf.- Don Nuño Aluarez de Aça conf.

Don Pero, arcobispo de Toledo, primado de las Espannas, conf.- Don Rodrigo, arcobispo de Santiago, capellán mayor del rrey et notario maior del rreyno de León, conf.

(Signo rodado)

- Primer círculo concéntrico:

DON PERO GONÇÁLEZ DE MENDOÇA, MAYORDOMO MAYOR DEL RREY, CONFIRMA. DON IUAN HURTADO DE MENDOÇA, ALFÉREZ DEL RREY, CONFIRMA.

- Segundo círculo concéntrico:

SIGNO DEL RREY DON IOHÁN.

- Tercer círculo concéntrico:

Acuartelado con los escudos de León y Castilla.

( $5^{a} \mathrm{col}$.) Don Ferrnando, obispo de León, conf.- Don Gutierre, obispo de Ouiedo, conf.- Don Alfonso, obispo de Astorga, conf.- Don Martín, obispo de Çamora, conf.- Don Alfonso, obispo de Salamanca, conf.- Don Alfonso, obispo de Cibdat, conf.- Don frey Guillén, obispo de Coria, conf.- Don Ferrnando, obispo de Badajoz, conf.- Don Francisco, obispo de Mondonnedo, conf.- Don Iohán, obispo de Tui, conf.- Don Ferrnando, obispo de Orense, conf.- Don Pero, obispo de Lugo, conf.- Don F[ernando O]sórez, maestre de la cauallería de Santiago, conf.Don Pero Royz Sarmiento, adelantado mayor de Gallizia, conf.

( $6^{a}$ col.) Don Iohán Alfonso de Guzmán, conde de Niebla, conf.- Don Pero Ponce de León conf.- Don Aluar Pérez de Guzmán, alguazil mayor de Seuilla, conf.- 


\section{LA ABADÍA DE SANTA MARÍA DE HUSILLOS: ESTUDIO Y COLECCIÓN \\ DOCUMENTAL $(904-1608)$}

Don Ramir Núñez de Guzmán conf.- Don Gonçalo Núñez de Guzmán conf.- Don Pero de Villens, conde de Ribadeo, vasallo del rrey, conf.- Don Alfonso Téllez Girón conf.- Don (en blanco) Girón conf.- Don Alfonso Ferrnández de Monte Mayor, adelantado mayor de la frontera, conf.- Don Alfonso Ferrnández, señor de Aguillar, conf.- Don Pero Munyz, maestre de Alcántara, conf.; el prior de Sant Iohán, conf.- Don Pero Xuárez de Quiñones, adelantado mayor de León, conf.

Don Pero, obispo de Plazençia, notario mayor de los priuillegios rrodados, lo mandé fazer por mandado del rrey en el año primero que el [sobredicho rrey don Iohán] rregnó et se coronó et armó caua[1lero et fizo las] primeras cortes en la muy noble çiudat de Burgos. Yo Diego Ferrández, escriuano del dicho sseñor rrey, lo ffiz escriuir.

1379, [agosto, 22]. Burgos.

Juan I confirma un privilegio de Enrique II (1371, mayo, 20. Valladolid), inserto, confirmatorio de otro de Alfonso XI (1331, agosto, 16. Valladolid), inserto, confirmatorio a su vez de otro de Fernando IV (1312, marzo, 7. Valladolid), inserto, confirmatorio asimismo de otro de Sancho IV (1291, agosto, 16. Valladolid), inserto, confirmatorio de otro de Sancho III (1158, abril, 28. Carrión de los Condes), inserto, por el que concede a Raimundo, abad de Santa María de Husillos, y a los canónigos de dicha iglesia, el privilegio de los infanzones, exentándolos asimismo de todo servicio real.

A. ADHP., Ampudia y Abadía de Husillos, Pergaminos, carp. 201-26. Perg., 719 x 573 mm.; escr. gótica de privilegios y precortesana; buena conservación. Mantiene parte de la cinta pero no el sello.

B. AHDP, Ampudia y Abadía de Husillos, Pergaminos, carp. 202-29. Perg., 717 x 517 mm.; privilegio rodado; escr. gótica redonda de privilegios y precortesana; buena conservación. Todos los elementos decorativos están dibujados pero sin miniar. No conserva la cinta pero sí el sello de 
plomo, que está suelto. Inserto en confirmación de Enrique III del privilegio de Juan I, dada en Burgos, a 20 de febrero de 1392. Véase doc. núm. 213.

$C$. APA, $L P H$, ff. $108 \mathrm{v}-111 \mathrm{r}$.

$D$. APA, $L P H$, ff. $124 \mathrm{r}-127 \mathrm{v}$. Traslado de $B$.

E. AGS, Patronato eclesiástico, Inconexos, leg.159, ff. 116v-122v. Papel; escr. procesal; buena conservación. Traslado de $C$.

F. BN, $m s .705$, ff. 238r-242r. Traslado de $C$.

(Christus, alfa et omega). En el nombre de Dios Padre, e Fijo, e spiritu sancto que istus sson tres perssonas e vn Dios verdadero que biue e rregna por ssiempre jamás, e de la bien auenturada Uirgen gloriosa Sancta María ssu madre, a quien nos tenemos por sseñora e por abogada en todos nostros fechos, e / a onrra e a sseruicio de todos los sanctos de la corte celestial, queremos que ssepan por este nostro priuillegio todos los ombres que agora sson o serán de aquí adelante commo nos, don Iohán, por la graçia de Dios rrey de Castiella, de Toledo, / de León, de Galizia, de Seuilla, de Córdoua, de Murçia, de Iahén, del Algarbe, de Algezira, e sseñor de Lara e de Vizcaya e de Molina, rregnante en vno con la rreyna doña Leonor mi muger, vi/ ${ }^{3}$ emos vn priuillegio del rrey don Enrrique, nostro padre, que Dios perdone, escripto en pargamino de cuero rrodado e sseellado con ssu sseello de plomo colgado, ffecho en esta guisa.

(Sigue doc. núm. 164)

E agora el / el (sic) abat e el prior e el cabilldo de la dicha eglesia de Sancta María de Fusiellos, enbiáronnos pedir merced que les confirmássemos este dicho priuillegio e ge lo mandássemos guardar. E nos, el ssobredicho rrey don Iohán, por ffazer bien e merced a los sobredichos abbat e prior e ca/billdo, e porque ellos ssean tenudos de rrogar a Dios por las almas de los rreyes onde nos uenimos uenimos (sic), e por la nostra vida e por la nostra ssalud, touiémoslo por bien e confirmámosles este priuilegio. E mandamos que les vala e les ssea guardado bien e com $/^{45} \operatorname{com}($ sic)plidamiente commo en él sse contiene e ssegún que uos ffue guardado en tiempo del rrey don Alfonso nostro auuelo e del rrey don Enrrique nostro padre, que Dios perdone. E defendemos firmemente que alguno nin algunos non ssean osados de uos yr nin passar a vos los dichos / abbat e prior e 
cabilldo nin alguno de uos contra este dicho priuillegio nin contra parte del por lo quebrantar nin menguar todo nin parte dello en alguna manera por alguna razón. Ca qualquier o qualesquier que lo fiziessen aurían la nostra yra e pechar nos y an la pena que en el dicho priuile/gio sse contiene. E a los dichos abbat e prior e cabilldo de la eglesia ssobredicha o a quien ssu boz touiesse todos los daños e menoscabos que por ende rresçibiessen doblados. E porque esto ssea firme e estable, mandamos uos ende dar este nostro priuillegio rrodado e se ${ }^{48}$ ellado con nostro sseello de plomo colgado.

Dado el priuillegio en las cortes que nos mandamos ffazer en la muy noble çibdat de Burgos (en blanco) días de (en blanco), era de mille e quatrocientos e diez e ssiete años. E nos, el ssobredicho rrey don Iohán, rrey/nante en vno con la rreyna doña Leonor, mi muger, en Castiella, en Toledo, en León, en Gallizia, en Seuilla, en Córdoua, en Murçia, en Iahén, en Baeça, en Badajoz, en el Algarbe, en Algezira, en Lara, en Vizcaya, en Moli/na, otorgamos este priuillegio e confirmámoslo.

( $1^{a}$ col.) El infante don Donis, fiio del rrey de Portogal, sseñor de Alua e de Tormes, vassallo del rrey, conf.- Don Alfonso, fijo del infante don Pero de Aragón, marqués de Villena, conde de Ribagorça e de Denia, vasallo del rrey, conf.- Don Beltrán de Clauquin, condestable de Francia, vasallo del rrey, conf.

( $2^{a}$ col.) Don Fradrique, duque de Benauente, hermano del rrey, conf.- Don Alfonso, conde de Nuruenna, hermano del rrey, conf.- Don Pero, primo del rrey, conde de Trastámara e de Lemes e de Sarria, conf.

( $3^{a}$ col.) Don Ferrando, arcobispo de Seuilla, conf.- Don Iohán, obispo de Ciguença, chanceller mayor del rrey, conf.- Don Diego, obispo de Burgos, conf.Don (en blanco), obispo de Palençia, conf.- Don Gonçalo, obispo de Calahorra, conf.- Don (en blanco), obispo de Osma, conf.- Don Hugo, obispo de Segouia, conf.- Don Alfonso, obispo de Áuila, conf.- Don Nicolás, obispo de Cuenca, conf.- Don Pero, obispo de Plazencia, conf.- Don Pero, obispo de Córdoua, conf.Don Nicolás, obispo de Carthagena, conf.- Don Iohán, obispo de Iahén, conf.- 
Don Alfonso, obispo de Cádiz, conf.- Don Pero Ferrández de Velasco, camarero mayor del rrey, conf.- Don Pero Manrrique, adelantado mayor de Castiella, conf.

( $4^{a}$ col.) Don Iohán Sánchez Manuel, conde de Carrión e adelantado mayor del rregno de Murçia, conf.- Don Bernal de Bearni?, conde de Medina, vassallo del rrey, conf.- Don Diego Gómez Manrrique conf.- Don Iohán Rodríguez de Castañeda conf.- Don Iohán Rodríguez de Villalobos conf.- Don Iohán Ramírez de Arellano, sseñor de los Cameros, vasallo del rrey, conf.- Don Beltrán de Guyuara conf.; Sancho Ferrández de Touar, guarda mayor del rrey, conf.- Don Arnao, señor de Villalpando, vassallo del rrey, conf.- Don Nuño Núñez de Aça conf.- Don Nuño Áluarez de Aça conf.

( $5^{a} \mathrm{col}$.) Don Pero, arcobispo de Toledo, primado de las Espannas, conf.

\section{(Signo rodado)}

- Primer círculo concéntrico:

(Cruz) DON PERO GONÇÁLEZ DE MENDOÇA, MAYORDOMO MAYOR DEL RREY, CONFIRMA (cruz).

DON IUAN HURTADO DE MENDOÇA, ALFÉREZ MAYOR DEL RREY, CONFIRMA.

- Segundo círculo concéntrico:

SIGNO DEL RREY DON IOHÁN

Tercer círculo concéntrico:

Acuartelado con los escudos de León y Castilla.

$\left(6^{a} \mathrm{col}.\right)$ Don Rodrigo, arcobispo de Santiago, capellán mayor del rrey e notario mayor del rregno de León, conf.- Don Ferrando, obispo de León, conf.- Don Gutierre, obispo de Ouiedo, conf.- Don Alfonso, obispo de Astorga, conf.- Don Martín, obispo de Camora, conf.- Don Alfonso, obispo de Salamanca, conf.- Don Alfonso, obispo de Çibdat, conf.- Don Ferrando, obispo de Coria, conf.- Don Ferrando, obispo de Badajoz, conf.- Don Francisco, obispo de Mondonnedo, 
conf.- Don Ionán, obispo de Tuy, conf.- Don Ferrando, obispo de Orense, conf.Don Pero, obispo de Lugo, conf.- Don Ferrant Osórez, maestre de la cauallería de Santiago, conf.- Don Pero Ruyz Sarmiento, adelantado mayor de Gallizia, conf.

( $7^{a}$ col.) Don Iohán Alfonso de Guzmán, conde de Niebla, conf.- Don Pero Ponçe de León conf.- Don Alvar Pérez de Guzmán, alguazil mayor de Seuilla, conf.Don Ramyr Núñez de Guzmán conf.- Don Goncalo Núñez de Guzmán conf. don Pero de Uillens, conde de Ribadeo, uasallo del rrey, conf.- Don Alfonso Téllez Gyrón conf.- Don Alfonso Ferrández de Montemayor, adelantado mayor de la frontera, conf.- Don Alfonso Ferrández, sseñor de Aguylar, conf.- Don Pero Munnyz, maestre de Alcántara, conf.- Don Pero Suárez de Quiñones, adelantado mayor de León, conf.

( $\left.8^{a} c o l.\right)$ Iohán Núñez de Villazán, justiçia mayor del rrey. Don Ferrant Sánchez de Touar, almyrante mayor de la mar. Diego López Pacheco, notario mayor de Castiella. Pero Suárez de Toledo, alcallde mayor de Toledo e notario mayor de tierra de Toledo. Pero Suárez de Guzmán, notario mayor del Andaluzía.

Don Pero, obispo de Plaçenzia, notario mayor de los [priuillegios] rrodados, lo mandó fazer por mandado del rrey en el año primero que el sobredicho rrey don Iohán rregnó e se tornó e armó cauallero, e fizo las primeras cortes en la muy noble çibdat de Burgos.

E yo, Diego Ferrández, escriuano del dicho sseñor rrey, lo ffiz escriuir. [Marcos Alfonso, veedor.] Pero Rodríguez. [Aluar Martínez, tesorerus.]

1380, agosto, 17. Monzón de Campos.

El concejo de Monzón otorga poder a Juan Martínez de Rojas, señor de Monzón, para representarle en el pleito entre, de una parte, el dicho Juan 
Martínez de Rojas y el concejo de Monzón; y de la otra, Juan Fernández, abad de Santa María de Husillos, el prior y el cabildo de dicha iglesia, y el concejo de Husillos, sobre el arroyo de los Frailes y sobre términos y pastos entre ambos lugares. El señor de Monzón podría delegar su procuración en otra persona.

B. AHDP, Ampudia y Abadía de Husillos, Pergaminos, carp. 211-12. Perg., 559 x 541 mm.; escr. precortesana; regular conservación. El pergamino tiene cinco grandes roturas con alguna más de menor tamaño. Inserto en la sentencia del pleito entre, de una parte, Juan Martínez de Rojas y el concejo de Monzón; y de la otra, Santa María de Husillos y el concejo de Husillos, sobre el arroyo de los Frailes y sobre límites, dada en Monzón, el 8 de octubre de 1380. Véase doc. núm. 199.

Sepan quantos esta carta de poder vieren, commo nos, el concejo et omes buenos de Moçón, estando ayuntados a campana rrepicad[a] [...]a de la eglesia de Sant Saluador, del dicho lugar, segunt que lo a/ ${ }^{3}$ uemos de uso et de costumbre de nos ayuntar. E estando y presentes nos, Miguel Sánchez, alcalle, e Garçía Ferrández, coomerino del dicho lugar, otorgamos et conosçemos que damos todo nuestro poder complido, ssegunt que mejor et más complida[mient] lo nos podemos fazer de derecho, a Iohán Martínez de Rojas, nuestro / señor, para que él, por nos et en nuestro nombre, pueda librar et sentençiar et abenir et componer et comprometer todos los pleitos et demandas et querellas et contiendas que sson o esperan seer entre el dicho señor, Iohán Martínez, e nos, [el di]cho conçejo et omes buenos, de la una parte, e de don Iohán, ab/bat de Fusiellos, bachiller en decrettos, e del prior et cabillo de la su eglesia e del conçejo et omes buenos del dicho lugar de Fusiellos, de la otra parte. Espeçialmente sobre el arroyo que diçen de Frades, que es en el [dicho] término, e sobre los términos et pastos et rroças que son en $/{ }^{6}$ tre los dichos lugares de Moçón e de Fosiellos, et sobre todas las otras cosas et contiendas que son o esperan seer entre nos, el dicho conçejo et omes buenos de Moçón con el dicho señor abbat et prior et cabillo et [conçejo] et omes buenos de Fusiellos. E otrosy, le damos poder, / sy mester fuere, al dicho nuestro señor, Iohán Martínez, para que él por nos et en nuestro nombre, que lo pueda poner et comprometer en qualquier señor, eclesiástico o seglar o de otra persona o personas, qualquier o qualesquier que él ques[iere] et por bien touiere, para que lo libre o libren commo quesieren et / por bien touieren. E toda sentençia o mandamiento que sobre esta rraçón diere el dicho nuestro señor, Iohán Martínez, 
o aquel o aquellos a que lo él encomendare o poder diere para ello, nos lo auemos et abremos por firme et estable et valedero, para agora et para sienpre jamás, so la pena o $/^{9}$ penas quel dicho señor, Iohán Martínez, o al que lo él encomendare, sobre la dicha rraçón, posiere o posieren.

E para lo asy complir et atener et estar por ello, nos, el dicho conçejo et omes buenos de Moçón, obligamos a nos et a todos nuestros bienes et de cada uno de nos, mue/bles et rrayçes, ganados et por ganar.

E porque ésto sea firme et non uenga en dubda, rrogamos a Alfonso Ferrández, escriuano público del dicho logar de Moçón por el dicho señor Iohán Martínez, que escriuiese esta carta de poder et que la signase con su signo.

Fecha la / carta en el dicho lugar de Monçón, diez et siete días de agosto, era de mille et quatroçientos et diez et ocho años. Testigos rrogados que fueron presentes a esto: Iohán Ferrández, prior de Fusiellos, et Pero Martínez, clérigo de Moçón, e Iohán Ferrández de la Peña, alcayde del castiello de $/{ }^{12}$ Moçón, Et Iohán Martínez de Buyedo, moradores en Moçón. E yo, Alfonso Ferrández, escriuano público sobredicho, fuy presente a esto que dicho es con los dichos testigos; et por rruego del dicho conçejo et omes buenos de Moçón, escriuí esta carta et fiz aquí este mío signo en [testimonio].

1380, agosto, [10-19]. Husillos.

El prior y el cabildo de Santa María de Husillos otorgan poder a Juan Fernández, abad de dicha iglesia, para que en su nombre pueda tratar el pleito entre, de una parte, el abad, prior y el cabildo de Santa María de Husillos, y el concejo de Husillos; y de la otra, Juan Martínez de Rojas, señor de Monzón, y el concejo de Monzón, sobre el arroyo de los Frailes y sobre términos y pastos entre ambos lugares. 
B. AHDP, Ampudia y Abadía de Husillos, Pergaminos, carp. 211-12. Perg., 559 x 541 mm.; escr. precortesana; regular conservación. El pergamino tiene cinco grandes roturas con alguna más de menor tamaño. Inserto en la sentencia del pleito entre, de una parte, Juan Martínez de Rojas y el concejo de Monzón; y de la otra, Santa María de Husillos y el concejo de Husillos, sobre el arroyo de los Frailes y sobre límites, dada en Monzón, el 8 de octubre de 1380. Véase doc. núm. 199.

Sepan quantos esta carta de poder vieren, commo nos, el prior et cabiello de la eglesia de Santa $/{ }^{27}$ María de Fosiellos, estando ayuntados a nuestro cabiello a campana tanida, segund que lo auemos de vso et de costumbre de nos ayuntar en el logar acostumbrado. E nos, D[...], alcallde, et Martín Ferrández, merino, et Ferrando Díaz et Garçía Ferrández et Iohán Ferrández et Esteuan / Ferrández e conçejo et omes buenos del dicho logar de Fosiellos, estando ayuntados a nuestro conçejo a campana rrepicada, segund que auemos de vso et de costumbre de nos ayuntar, otorgamos et conosçemos que [damo]s todo nuestro poder, complidament, segunt que mejor et más / complidament lo nos podemos fazer de derecho, a don Iohán Ferrández, abad de Fosiellos et bachiller en decretos, nuestro señor, para que por nos et en nuestro nombre de nos, el dicho prior et cabiello et conçejo [et ome]s buenos del dicho lugar de Fosiellos, puedan librar $\beta^{30}$ et sentençiar et auenir et comprometer todos los pleitos et demandas et querellas et contiendas, que son o esperan seer entre nos, el dicho prior et cabiello et conçeio et omes buenos del dicho lo[gar de] Fosiellos, de la una parte, e de don Iohán Martínez / de Rojas, señor de Monçón, et conçejo et omes buenos del dicho logar de Monçón, de la otra parte, espeçialmente sobre el arroyo de Frades et términos et pastos et rroças et sobre toda[s las] otras cosas et contiendas que son o esperan ser entre / nos, el dicho prior et cabiello et conçejo et omes buenos de Fosiellos, con el dicho don Iohán Martínez et conçejo et omes bonnos del dicho logar de Moçón.

E otra, le damos poder, sy mester fuere, para que lo pueda poner et $\operatorname{com} /{ }^{33}$ prometer en qualquier sseñor, eclesiástico o seglar o de otra persona $\mathrm{o}$ personas qualquier o qualesquier, que él quesiere et por bien touiere, que lo libre o libren commo quesieren et por bien touieren.

E t[oda sentençi]a o mandamiento que sobresta rraçón, diere el dicho / señor abbat o aquel o aquellos a que lo él encomendare o poder, nos lo auemos et aueremos por firme et estable et valedero, para agora et para siempre jamás, so la pena o 
penas que el [dicho] señor abbat, o al que lo él encomendare sobre la dicha / rraçón, posier o posieren.

E para lo asy atener et complir, nos, el dicho prior e cabiello, obligamos todos los bienes de la nuestra mesa. E otrosy, nos, el dicho conçejo et omes [buenos de]l dicho logar de Fosiellos, obligamos a todos los $/^{36}$ nuestros bienes et de cada uno de nos, asy muebles commo rrayçes, por doquier que los oy día auemos et aueremos [de a]quí adelante.

E porque esto sea firme et non uenga e[n dubda, rrogam]os et [rrequerimos] a Fernando Díaz de Grijota, / notario público de la çipdat de Palençia, que escriuiese esta carta de poder et la signase con su signo.

Que fue fecha en el d[icho loga]r de Fosiellos, d[...] días de agosto, era de [mille et quatroçientos et diez et ocho años. Testigos que a esto fueron pre]/sentes et llamados: Iohán Heruas et Iohán Pérez de Reuenga et Diago Ferrández, fijo de Martín Ferrández que se deç[ía, vezinos] del dicho logar de Fos[iellos.

Et yo, Fernando Díaz de Grijota, notario público sobre $]^{39}$ dicho de la çipdat de Palençia, fuy presente a todo esto que dicho es con los dichos testigos. Et a rruego et rr[equerimi]ento del dicho prior et cabiello et conçejo et omes bueno[s del dicho log]ar de Fosiellos, escriuí esta carta de poder / et fiz aquí este mío signo en testimonio de uerdat.

1380, septiembre, 24. Soria.

Juan Fernández, abad de Santa María de Husillos y procurador del prior y cabildo de dicha iglesia, nombra a Pedro Díaz, vecino de Monzón, árbitro en el pleito entre, de una parte, el abad, prior y el cabildo de Santa María de Husillos, y el concejo de Husillos; y de la otra, Juan Martínez de Rojas, señor de Monzón, y el concejo de Monzón, sobre el arroyo de los Frailes y sobre términos y pastos entre ambos lugares. 
B. AHDP, Ampudia y Abadía de Husillos, Pergaminos, carp. 211-12. Perg., 559 x 541 mm.; escr. precortesana; regular conservación. El pergamino tiene cinco grandes roturas con alguna más de menor tamaño. Inserto en la sentencia del pleito entre, de una parte, Juan Martínez de Rojas y el concejo de Monzón; y de la otra, Santa María de Husillos y el concejo de Husillos, sobre el arroyo de los Frailes y sobre límites, dada en Monzón, el 8 de octubre de 1380. Véase doc. núm. 199.

Sepan quantos quantos esta carta vieren, commo yo, Iohán Ferrández, abbat de Fosiellos, canónigo en la eglesia de Palençia, por mí et por el poder que yo he del prior et cabiello de la iglesia de Santa María de Fosiellos e del / conçejo et omes buenos del dicho logar de Fosiellos, mis vassallos, por vna carta de poder signada de escriuano público, el tenor de la qual es este que se sigue:

(Sigue doc. núm. 196)

E yo, el dicho abbat, por el dicho poder que los sobredi[chos] me dieron et por mí, asy commo abbat et sseñor del dicho [logar] de Fossiellos, otorgo et conosco que comprometo et / do, todo mío poder complido a Pero Díaz, vezino de Mo[çón, para] que pueda librar et sentenciar con Iohán Ferrández, prior de la dicha eglesia de Fosiellos, al qual ha de tomar Iohán Martínez de Rojas, [sseñor] de Moçón, et el conçejo et omes buenos del dicho $/{ }^{42}$ logar de Moçón, por su árbitro arbitrador, amigo, a[migabl]e componedor, todos los pleitos et demandas et querellas que son o esperan ser entre mí, el dicho abbat et prior et cabiello et conçe[jo et om]es buenos del dicho mi logar de Fosiellos, de la una / parte, e el dicho Iohán Martínez de Rojas et el dicho co[nçejo et omes] buenos del dicho logar de Moçón, de la otra parte; espeçialment sobre el arroyo de Frades et términos et pastos et rroças et [sobre] todas las otras cosas et contiendas que son o esperan ser / entre amas et dos, las dichas partes, e para que 1[o libren et den] en ello, sentençia commo quesieren et por bien [tovieren]. Et toda sentencia o sentencias o mandamiento o mandamientos que el dic[ho Pero Dí]az diere con el dich[o Iohán Ferrández, a]mos a dos et acordados en vno, que valan et fagan fe ${ }^{45}$ en todo tiempo et en todo logar. E obligo todos [los mis bienes, t]emporales et espirituales, et los bienes del dicho prior et cabiello et del dicho conçejo, mis vasallos, según que los ellos obligaron por [la dich]a carta de poder que me dieron, para que yo et ellos, que lo aya/mos todo por firme et por estable et por 
ualeder[o, agora] et para siempre jamás, so pena de diez mille maravedís desta moneda vsual, por pena <et por> et postura que pongo sobre mí et sobre las $\mathrm{d}$ [ichas] mis partes et mis vasallos que me el dicho poder / dieron et por nombre de interese. Et la pena pagad[a o non toda]vía, que yo et las dichas mis partes, que fagamos et cumplamos todo lo que fuere judgado et sentenciado por el dicho Pero Díaz, a quien yo do el dicho poder et comprometo que lo libre con el di $/^{48}$ cho prior, commo dicho es.

E porque esto sea fir[me et non venga] en dubda, otorgué esta carta de poder ante Diego Martínez de Çamora, escriuano del rrey et su notario público en su corte et en todos sus rreynos, et rroguele que la signase / con su signo. Testigos rrogados que a esto fueron pres[entes]: [...] Ferrández, tesorero en la eglesia de Toledo, et Pero López de Espinosa, et Pero Sánchez de Cuesta, sus omes, et Alfonso Rodríguez de Moral, omme del dicho abbat.

Fecha et otorgada fue / esta carta en Soria, veynte et quatro días de s[etiembre, era de] mille et quatroçientos et diez et ocho años. E yo, el dicho Diego Martínez de Çamora, escriu[an]o del rrey et notario público sobredicho, a todo esto que dicho es fuy presente con los dichos $/^{51}$ testigos; e a otorgamiento et rruego del dicho abbat, escriuí esta carta de poder et fiz aquí mío signo, que es a tal commo este en testimonio de uerdats.

1380, septiembre, 29. Cavia.

Juan Martínez de Rojas, señor de Monzón, nombra a Juan Fernández de Meneses, prior de Santa María de Husillos, árbitro en el pleito entre, de una parte, el dicho Juan Martínez de Rojas y el concejo de Monzón, y de la otra, Juan Fernández, abad de Santa María de Husillos, el prior y el cabildo de dicha iglesia, y el concejo de Husillos, sobre el arroyo de los Frailes y sobre términos y pastos entre ambos lugares. 
B. AHDP, Ampudia y Abadía de Husillos, Pergaminos, carp. 211-12. Perg., 559 x 541 mm.; escr. precortesana; regular conservación. El pergamino tiene cinco grandes roturas con alguna más de menor tamaño. Inserto en la sentencia del pleito entre, de una parte, Juan Martínez de Rojas y el concejo de Monzón; y de la otra, Santa María de Husillos y el concejo de Husillos, sobre el arroyo de los Frailes y sobre límites, dada en Monzón, el 8 de octubre de 1380. Véase doc. núm. 199.

Sepan quantos esta carta vieren commo yo, Iohán Martínez de Rojas, por mí [et] por el poder que yo he del conçejo et omes buenos de Moçón, mis / uassallos, por vna su carta de poder, signada de escriuano público, el tenor de la qual es este que sse sigue:

(Sigue doc. núm. 195)

/ E yo, el dicho Iohán Martínez, por el dicho poder que los sobredichos me dieron, et por mí, asy commo señor del dicho logar de Moçón, otorgo et conosco que comprometo et do todo myo poder complido a Iohán Ferrández, prior de Fosiellos, para que pueda librar et sentençiar con él / Pero Díaz, vezino del dicho logar de Monçón, mi vassallo, al qual tomó el dicho Iohán Ferrández, abbat, señor del dicho logar de Fosiellos, e el prior et cabillo et conçejo et omes buenos del dicho logar de Fosiellos, por su árbitro arbitrador, amigo, amigable $/^{15}$ componedor, todos los pleitos et demandas et querellas que son o esperan seer entre mí, el dicho Iohán Martínez et conçejo et omes buenos del dicho logar de Moçón, de la una parte, e el dicho abbat et prior et cabillo et conçejo et omes buenos de Fosiellos, de la / otra parte, espeçialment, sobrel arroyo de Frades et términos et pastos et rroças et sobre todas las otras cosas et contiendas que son o esperan seer entre amas a dos las dichas partes. E para que lo libren et den en ello sentencia commo quesieren et por bien / touieren et toda la sentençia o sentençias o mandamiento o mandamientos que el dicho prior diere con el dicho Pero Díaz, amos a dos acordados en vno, que valan et fagan fe en todo tiempo et todo logar. Et obligamos todos nuestros bienes et a los bienes del dicho conçejo et omes $/{ }^{18}$ buenos, mis vassallos, segunt que los ellos obligaron por la dicha carta et poder que me dieron. Et para que yo et ellos que lo ayamos todo por firme et por estable et por ualedero, para agora et para siempre jamás, a pena de diez mille maravedís [desta moneda usual] / por pena et por postura, que pongo sobre mí et sobre las 


\section{LA ABADÍA DE SANTA MARÍA DE HUSILLOS: ESTUDIO Y COLECCIÓN \\ DOCUMENTAL $(904-1608)$}

dichas mis partes et mis vassallos que me el dicho poder dieron e por nobre de interesse. E la pena pagada o non todavía, que yo et las dichas mis partes, que fagamos et complamos todo lo / que fuere juzgado et sentençiado por los dichos Iohán Ferrández, prior, et Pero Díaz, a quien yo, el dicho Iohán Martínez, e el dicho abbat et prior et cabiello et conçeio et omes buenos, del dicho logar de Fussiellos, damos nuestro poder commo dicho es. E este poder que lo $/^{21}$ ayan los dichos Iohán Ferrández, prior, e Pero Díaz, para que lo libren fasta el día de Nabidat, primero que viene.

E porque esto sea firme et non uenga en dubda, otorgué esta carta de poder ante Françisco Ferrández, notario público de la çipdat de Palençia, que estaua present, et rroguele que la sig/nase con su signo. Testigos rrogados que a esto fueron presentes: Diego Ramírez de Maçuela e Pero López de Salzedo, escuderos del dicho Iohán Martínez, e Iohán Ferrández de Frómesta, armero, vezino de Burgos, e Pero Ferrández de Carrión, criado de Gonçalo Gonçález, arçipreste de / Burgos. Fecha et otorgada fue esta carta en Cauia, veynte et nueue días de setiembre, era de mille et quatroçientos et diez et ocho años. E yo, Françisco Ferrández, notario público sobredicho de la dicha çipdat de Palençia, que fuy present a esto todo que sobredicho es con los ${ }^{24}$ dichos testigos; e por rruego del dicho Iohán Martínez escriuí esta carta et fiz aquí este myo signo en testimonio de uerdat.

1380, octubre, 8. Monzón de Campos.

Sentencia pronunciada por Juan Fernández de Meneses, prior de Santa María de Husillos, y Pedro Díaz, vecino de Monzón, árbitros nombrados respectivamente por Juan Martínez de Rojas, señor de Monzón, y Juan Fernández, abad de Santa María de Husillos; del pleito entre, de una parte: el dicho Juan Martínez de Rojas y el concejo de Monzón; y de la otra: el abad, prior y cabildo de Santa María de Husillos, y el concejo de Husillos, sobre el arroyo de los Frailes y sobre términos y pastos entre ambos lugares. 
Establece que el arroyo de los Frailes pertenece a Santa María de Husillos, y que dicha iglesia y el concejo de Husillos puedan seguir trayendo el agua a través del arroyo de los Frailes y sacarlo por encima de Becerrilejos, en donde dicen Los Ortezuelos, del cuérnago que viene de Perales hacia Monzón de Campos.

A. AHDP, Ampudia y Abadía de Husillos, Pergaminos, carp. 211-12. Perg., 559 x 541 mm.; escr. precortesana; regular conservación. El pergamino tiene cinco grandes roturas con alguna más de menor tamaño.

Aunque se menciona varias veces que el pleito es por el arroyo de los Frailes y sobre los términos, pastos y rozas que había entre los lugares de Monzón y Husillos, en este documento solamente se resuelve el problema surgido por el arroyo de los Frailes.

In Dey nomine, amen. Sepan quantos esta carta de sentençia vieren commo nos, Iohán Ferrández de Mexieses, prior de la eglesia de Santa María de Fosiellos, e Pero Díaz, fijo de Pero Fijo, vezinos de Moçón, asy commo árbitros arbitradores, [amigos], amigables componedores; nos, amos a dos en uno et por el / poder que yo el dicho prior tengo et me dio Iohán Martínez de Rojas, sseñor de Moçón, por vnna su carta signada de notario público, el tenor de la qual es este que sse sigue:

(Sigue doc. núm. 198)

E otrosí, por el poder que yo, el dicho Pero Díaz, tengo et me dio Iohán Ferrández, abbat et señor de Fosiellos, por una su carta signada de notario público, / el tenor de la qual es este que se sigue:

(Sigue doc. núm. 197)

E nos, dichos Iohán Ferrández, prior de Fosiellos, e Pero Díaz, asy commo amigos, árbitros arbitradores, a/migables componedores, e por los poderes que nos dieron los dichos señores, don Iohán Ferrández, abbat de Fosiellos, e don Iohán Martínez de Rojas, señor de Monçón, viendo a di[...] nuestros ojos et auido nuestro consejo con ombres bonos et le/trados et sabidores en derecho, fallamos 


\section{LA ABADÍA DE SANTA MARÍA DE HUSILLOS: ESTUDIO Y COLECCIÓN \\ DOCUMENTAL $(904-1608)$}

que por los dichos de los testigos presentados ante nos et tomados por parte et en nombre de amas las dichas partes, que se prueua en commo el abbat et prior et [conçejo et] omes buenos et vezinos de Fosiellos, posseyeron el arroyo $/^{54}$ de Frades et es suyo por donaçión que les fue fecha et t[ra]xieron por él, sin enbargo alguno, fasta el dicho logar de Fosiellos, tanta agua quanta podría caber et cabríe por un foraco de piedra [en cuyo] foraco podría caber una cabesça de omme. E es[ta] / agua tománuanla los vezinos de Fosiellos et sacáuanla ençima de Bezerrilejos, a do dizen Los Ortezuelos, del cuérnago que viene de Perales contra Moçón, al qual cuérnago dizen Nos[...] [ar]bitrando, loando, juzgando, sentenciando, mandamos por nuestra / sentencia difinitiua, al dicho concejo et omes buenos et vezinos et moradores de Moçón, que los dexen a los dichos prior et cabiello et conçejo et vezinos de Fosiellos, rrepresar et tomar del dich[o cuérna]go la dicha agua et traher por el dicho arroyo de ${ }^{57}$ Frades, sin enbargo alguno, segund lo solían rrepresar et tomar et traher para el dicho logar de Fossiellos et para sus heredades et se prueua por los dichos testigos. E otrosy, ma[ndo], a los dichos prior et cabiello et concejo et omes buenos / vezinos de Fosiellos, que pongan la dicha piedra o otra piedra semejable foradada en el dicho arroyo de Frades [et] que llamen a ello a los del dicho concejo de Monçón. E que non [...] tomen más agua para Fosiellos et para sos hereda/des, más que quanto compiere por el dicho foraco de piedra. E otrosy, les mandamos a los dichos [...] de Fusiellos, que sy mester fuere de mondar la de $\operatorname{rr}[. .$.$] [del] dicho cuérnago, para$ que el agua uenga por desenbar $/{ }^{60}$ gadamente fasta los dichos Ortezuellos [...] ar et non se uaya a otras partes, que lo monden [...]e fagan mondar et rrepresar, amos los dichos conçejos de los dichos logares de Moçón e de Fosiellos et que paguen / en la costa que se feçiere, segunt que cada vna de las partes leuare el agua para cada uno de los dichos logares.

E todo esto contenido en esta dicha sentencia que nos damos et mandamiento que nos fazemos; mandamos / a amas las dichas partes et a cada una dellas, que lo cumplan et atengan, agora et para siempre jamás, segunt se, en ella, contiene, so la dicha pena contenida de los dichos diez mille maravedís, contenidos en los dichos poderes que los dichos se $/{ }^{63}$ ñores nos dieron et otorgaron, segunt que dicho es. 
E porque ésto sea firme et non uenga en dubda, nos, los dichos Iohán Ferrández, prior de Fosiellos, e Pero Díaz, vezino de Moçón, rrogamos et rrequerimos a Ferrando Díaz de Grijota, notario públi/co de la çipdat de Palençia, que escriuiese desto dos cartas de sentencia et las signase con su signo acostumbrado, et que diese a cada vna de las dichas partes la suya, para guarda [de su] derecho.

Fecha fue esta carta de sentençia et otorgada / en el dicho logar de Monçón por mí, el dicho Ferrando Díaz, notario, ocho días de octubre, era de mille et quatroçientos et diez et ocho años. Testigos que a esto fueron presentes, llamados et rogados, espeçialmente para esto que $\mathrm{di} /{ }^{66}$ cho es et que vieron todos los dichos poderes presentados ante el dicho Ferrando Díaz, notario, asy de los dichos señores abbat et Iohán Martínez commo de los dichos prior et cabiello e conçejo et omes buenos de los dichos logares de Moçón et de Fosiellos, / testigos: Fernant Garçía de Uillandavín, fijo que se dezía de Garçía Muñoz, e Iohán Ferrández, fijo que se deçia de Iohán Ferrández, e Rodrigo Alfonso, fijo que se dezía de Diego Alfonso de Val de Espina, veçinos et moradores en el dicho logar de Moçón. /

E yo, Fernando Díaz de Grijota, notario público sobredicho de la dicha çipdat de Palençia, fuy presente a todo esto que dicho es con los dichos testigos. E por rruego et rrequerimiento de los dichos Iohán Ferrández, prior, et Pero Díaz, escriuy esta carta ${ }^{69}$ de sentençia en que están encorporados los poderes et la sentençia que dieron los dichos amigos. E escriuí desto dos cartas, amas en un tenor, para cada parte la suya. Et en dos log[ares] desta carta de [sentençia], entre los della, en un lugar do di[ze] / "et prior", e en el otro logar diçe "los", ualan et non enpezcan, ca fue error. Et fiz aquí este myo ssig(signo)no en testimonio de uerdats.

1381, febrero, 12. Husillos.

El prior y el cabildo de Santa María de Husillos otorgan a Toribio García, hijo de Domingo García, vecino de Palencia, a Juana García, su mujer, y 


\section{LA ABADÍA DE SANTA MARÍA DE HUSILLOS: ESTUDIO Y COLECCIÓN \\ DOCUMENTAL $(904-1608)$}

a sus hijos, un solar de tienda sito en Palencia, para que construya una casa, con la condición de que pague, anualmente, un censo de cinco maravedís y que dicha casa sea de tapia, madera y teja.

A. AHDP, Ampudia y Abadia de Husillos, Pergaminos, carp. 209-26. Perg., 350 x 223 mms.; escr. precortesana. Mala conservación. Aunque el pergamino se encuentra en buen estado, la tinta ha desaparecido casi por completo, tanto por el anverso como por el reverso, sobre todo en la parte izquierda del documento.

$B$. APA, $L P H$, ff. $112 \mathrm{r}-\mathrm{v}$.

C. BN, ms. 705, ff. 242r-243v.

A pesar de las dificultades que existen para leer el documento, hemos podido completarlo, casi en su totalidad, gracias al Libro de los Privilegios de Husillos, el cual continúa omitiendo frases que considera superfluas, al igual que el manuscrito 705 . También han sido de gran utilidad otros instrumentos del mismo notario, Fernando Díaz de Grijota.

En el año 1554, cuando se realizó el Libro de los Privilegios de Husillos, esta escritura aún se debía poder leer, pues nada se dice en contra, aunque se cometan los fallos ya mencionados.

[Sepan quantos esta carta uieren, commo ] nos, el prior et cabilldo de la eglesia de Sancta María de Fusiellos, estando / [ayuntados a nostro cabilldo a campana tannida ] segund que auemos de vso et costumbre de nos ayuntar, otor/[gamos et conosçemos que damos a uos, Toribio], fijo de Domingo Garçía, vezinos que sodes de la çiudat de $\beta$ [ Palençia, un suelo de tienda que nos el dicho cabilldo hauemos en la çiudat ] de Palençia, que / [es en linde el corral que dizen de Esteuan de] Escudero; et de la otra parte, linde de casas de uos el dicho To/[ribio Garçía. De la otra parte, linde de] casas del cabilldo de Sanct Antolín de Palençia.

Este $/^{6}$ [dicho suelo y tienda que estas dichas afrontaçiones encierra, damos e otorgamos a uos con entradas et con / salidas et con todos sus derechos et pertenençias quantas le per/tenesçen de derecho. Desta manera para que en toda la uestra uida et la uida de Iohana Garçía uestra muger $/^{9}$ [ et fijos et fijas que oy día hauedes e hauredes de aquí adelante, et / con que dedes et paguedes en cada año a nos, el dicho prior] et cabilldo et a nostro maiordomo que / [ fuere por tiempo, çinco maravedís en censo] desta moneda usual que fazen diez dineros el maravedí del día $/^{12}$ [de Sanct Martín de nouiembre en] cada año, en que fagades en el dicho 
suelo una casa de tapia / [et de madera et de teja, et al cabo de dicho tiempo ] que la dexedes a los que los uinieren por [tiempo / bien fecha et] rretejada, la dicha casa a nos el dicho prior et cabilldo desembargada $/{ }^{15}[$ mente, so pena de diez maravedís de la dicha moneda por cada] vn día de quantos días estuuieren con [querella / [por pena et postura. Et obligamos a los bienes de la [nostra mesa / de uos no tirar] el dicho suelo por más ni por menos [ni $/{ }^{18}$ por el tanto. [...] / Et yo, el dicho Toribio Garçía, otorgo / [et conozco] que rreçibo de uos, el dicho prior et cabilldo, el dicho suelo de tienda por el $/^{21}$ [dicho tiempo de mi] uida et de uida de Iohanna Garçía, mi muger, et de mis fijos et fijas que / [dicho es ...] et adelante. Et me obligo de uos pagar en cada / [ año al dicho] día de sanct Martín de nouiembre, los dichos çinco maravedís de ençenso, et de fazer la $/^{24}$ [dicha casa] de tapia et de madera et teja segunt que dicho es, so la dicha pena de los dichos / [...] estudiéredes con querella por nombre de [...] et de / [...] la dicha casa visto?, fecho et rreparado et desembargamiente a uos el dicho $/^{27}[\ldots]$ que dicho.

Et por atener et complir todo quanto en esta carta se contiene, / [obligo todos] bienes muebles et rrayzes por doquier que los aya. Et por esta carta, / [do poder a qualquier] alcallde o merino o uicario o juez de qualsequier çipdat, villa o logar, que la ${ }^{30}$ [cumplan et fagan secuçión] della en todos mis bienes. Sy yo non compliere $\operatorname{nin}[\ldots]$ todo lo / que dicho es. [...].

Et porque esto sea firme et non uenga en dubda, amas / [las dichas partes rogamos a Ferrando] Díaz de Grijota, notario público de Palençia, que escriuiese ${ }^{\beta 3}$ dos cartas, ambas en un tenor, en la vna commo en la otra para ende [...] /

[Fecha esta carta en el] cabilldo de la eglesia de Sancta María de Fosiellos, doze días / [de febrero, era de $\mathrm{M} \mathrm{CCCC}^{\circ}$ XIX años.

Testigos que] a esto fueron presentes, Ferrand Martínez ${ }^{36}$ del Cerrojal et Sancho Ferrández de cantoral, vezinos de Fusiellos, et Garçía, fijo del dicho Ferrand [Martínez de Cantoral, / et Sancho Ferrández, uezino de Fusiellos, et Iohán de Siero, sobrino] del dicho Ferrand Martínez, vezinos de [Santillán de las Cuestas]. /

Et yo, el dicho Ferrando Díaz de Grijota, notario público de la dicha çipdat de Palençia, fuy [presente] ${ }^{\beta 9}$ a todo esto que dicho es con los dichos testigos; et por rruego [de ambas las dichas partes, escriuí / desto dos cartas tanto en la vna 
commo [en la otra para cada parte la suya. Et fize aquí este] / mío sig(signo)no [en testimonio de uerdat.]

1382, septiembre, 30. Palencia.

Testamento de Juan Martínez de Villaviudas, canónigo de la catedral de Palencia, sobrino de Sancho Martínez, abad de Santa María de Husillos, y de Fernán Martínez, abad de Hérmedes. Deja numerosas heredades en diversos lugares y dinero para misas y aniversarios a las principales iglesias de la ciudad de Palencia: San Antolín, San Miguel, San Francisco, San Lázaro, Nuestra Señora de Allende el Río; a las emparedadas de Palencia; a diversos criados y a varios miembros de su familia, entre otros: los susodichos Sancho Martínez y Fernán Martínez; sus primos Sanchuelo, monje del monasterio de Hornillos, Fernando y Leonor, todos ellos hijos del abad de Husillos; su tío Alfonso Martínez, hermano del abad de Husillos. Manda a Fernando Diez de Husillos, las casas, tierras y viñas que posee en Husillos, debiendo pasar éstas después de la muerte de éste al cabildo de Husillos, debiendo dicho cabildo rogar a Dios por su alma y por la de su tío Juan Martinez, difunto, abad que había sido de Husillos.

B. APA, $L P H$, ff. $112 \mathrm{v}-116 \mathrm{r}$.

C. BN, $m s .705$, ff. 243v-252r.

Fecho y sacado fue este traslado en la villa de Husillos a veynte nueve días del mes de noviembre de mil e quinientos y çinquenta y quatro años. Testigos que lo vieron corregir y conçertar: Joán Ruiz Cabeça de Vaca y Gaspar de Vedoya, clérigos, e Pero Manuel, estantes en la dicha villa. E yo, Santiago Gómez, escriuano público en la dicha villa, presente fui a lo que dicho es en vno con los dichos testigos. Y del dicho pedimiento y mandamiento, lo fize escrevir e fize aquí mi signo (signo) en testimonio de verdad.

Pero Ruyz de Villoldo. Santiago Gómez (rúbrica) 
Aunque el testador era canónigo de la catedral de Palencia y sus albaceas eran beneficiados en dicha iglesia, el hecho de que fuera sobrino del abad de Husillos, al que denomina varias veces como su señor, y que gran parte de sus posesiones las dejara a sus tíos y primos, hizo que el testamento se guardase en Santa María de Husillos, aunque inicialmente no se debió conservar en dicha iglesia, ya que un año más tarde el prior y cabildo ordenan sacar traslado de la cláusula por la que Juan Martínez de Villaviudas les dejaba unas casas, tierras y viñas en Husillos.

In Dei nomine, amen. Sepan quantos esta carta de testamento vieren, como yo, Juan Martínez, canónigo en la yglesia de la ciudad de Palencia, fijo de Andrés Pérez de Villauiudas, estando enfermo en mi cuerpo y sano el entendimiento y de la memoria, tal qual Dios me la quiso dar e temiendo mucho a la muerte, como es cosa natural a todos los omes y mujeres del mundo, otorgo y conozco que fago y ordeno mi testamento y manda. Lo primero, doy mi ánima a mi señor Jesucristo que la crió y por la su sangre sancta la ha de rredimir e a la bienaventurada virgen sancta María, su madre, que la ha de saluar, e otrosy, al señor san Miguel archángel que la quiera guiar y lleuar a buen lugar. Primeramente mando que mi cuerpo sea enterrado en la capilla del bienauenturado San Martín de la yglesia de San Antolín de la ciudad de Palençia. Mando por la mi ánima, a mi cura, veynte maraue(f 113r)dís. Item mando a la Cruzada e a la Trinidad e a Sancta Olalla, a cada orden diez marauedís. Item mando a la obra de señor San Antolín de Palencia, veynte marauedís. Item mando a todas las emparedadas de aquí, de Palençia y su término, a cada una, diez marauedís porque rruegen a Dios por mi ánima. Item mando al dicho cabildo de la dicha yglesia de Palencia, porque vengan a mi vigilia, al cumplimiento de mi enterramiento, trezientos marauedís. Item mándoles más, al dicho cabildo por las nouenas, cien marauedís. Item mando a los Quarenta Capellanes de la dicha yglesia de Palencia, porque vengan a mi vigilia y enterramiento y missa, quarenta marauedís. Item mando a los frayles de San Francisco desta ciudad, porque vengan a mi vigilia y enterramiento y missa, a cada orden, trezientos marauedís. Item mando a los clérigos de la yglesia de San Lázaro y a los clérigos de San Miguel, porque vengan a mi vigilia y enterramiento y a dezir sus missas a cada yglesia, diez marauedís. Item mando que lleven offrenda por mi ánima, a la yglesia de San Antolín, pan y vino y cera, dos años primeros siguientes. E mando a doña Mayor, mi casera, mujer que es de Alfón Fernández de Sanfagún, cien marauedís. E otrosy, a mis mansessores los que 


\section{LA ABADÍA DE SANTA MARÍA DE HUSILLOS: ESTUDIO Y COLECCIÓN \\ DOCUMENTAL (904 - 1608)}

entendieren en lo que a mi ánima cumple, duzientos marauedís. Item mando que den a mis manssessores de mis bienes para missas cantar, mill marauedís desta moneda usual, por mi ánima e por el alma de Fernán Martínez, abbad de Érmides, mi tío, que Dios perdone. Y por las ánimas de aquellos de quien yo soy tenudo de rrogar, que las fagan cantar mis mansessores en la dicha yglesia de San Antolín, a los capellanes y a los frayles de San Francisco, y otrosy a los de San Pablo y a los clérigos de San Miguel y a los clérigos de San Lázaro y a los clérigos de Sancta María de Allende el Río, de aquí de Palencia. Item mando e fago a mis mansessores rueguen por mi ánima por las horas desfallecidas, quinientos marauedís. Item mando que canten por mi ánima cinco treyntanarios de missas con sus candelas en la dicha yglesia de San Antolín de Palencia. Item mando que el día de mi enterramiento den a comer treynta pobres, pan y vino y carne o pan y vino y pescado, en qual día fuere. Item mando a la obra de la yglesia, desta dicha çiudad, veynte marauedís. Item mando que den a los cofrades de la cofradía de Estinno de esta dicha ciudad novecientos marauedís que el abbad, mi tío, tenía en guarda y en depósito, de la dicha cofradía. Item mando a los cofrades, en enmienda de la tardança que el dicho abbad, mi tío e yo, fizimos en los pagar, dozientos maravedís. Item mando a Fernando, mi primo, fijo del dicho Sancho Martínez, mi tío, la mitad de la heredad de tierras y viñas y ferrenales que yo he en término de Villamartín, con la mitad de las casas que yo he en el dicho lugar, con la mitad del derecho de los bueyes que labran en la dicha eredad. E otrosy, le mando más unas casas que yo he aquí, en Palencia, (f.113v) en Barrionuevo, a la carnecería nueua, linderos: corral y casas del cabildo de Palencia; y de la otra parte: la mi bodega pequeña del Foyo. $\mathrm{Y}$ esto sobredicho le mando con condiçión que sy el dicho Fernando finare sin hauer fijo legítimo heredero, que se venda toda la dicha heredad y casas e que lo den por las ánimas de aquellos a quien yo encomende a mis mansesores, para missas cantar. E mando que hasta que el dicho Fernando aya edad cumplida de veynte y cinco años, que esta dicha heredad y casas, las possea Alfón Martínez, mi tío, hermano del dicho abbad. E otrosy, mando que el rrento que rrindieren las dichas casas y heredad de Villamartín e las dichas casas de Barrionuevo, que lo rreciba el dicho Alfón Martínez, mi tío, e después que venga al dicho Fernando y a Benita García, su madre. Otrosy, sy por aventura el dicho Alfón Martínez, mi tío, no proveyere ni mantuviere bien al 
dicho Fernando, mi primo, y a la dicha Benita García, su madre, rruego e do poder al deán de la dicha yglesia de Palencia, el que ahora es o al que fuere por tiempo que le tire la dicha administración de las dichas casas y heredad y lo dé a quien lo mejor faga y cumpla, de lo qual encargo su conciencia. Item mando a la dicha Benita Garçía seys cargas de trigo. Item mando a Leonor, hermana del dicho Hernando, mi primo, fija del dicho Sancho Martínez, mi tío, la mi bodega pequeña que yo he aquí, en Palençia, con las casas del Cantalejo, las quales compró el abbad, mi tío, de los confrades de San Spiritus, que mando y tengo por bien que more en las dichas casas del Cantalejo, la dicha Benita García, madre del dicho Fernando, en su vida. E otrosy, mándole más a la dicha Leonor, mi prima, una tierra en que ay dos obradas, que yo he a la Pontezilla de Villalobón, en linde de tierra del cabildo e de la otra parte, tierra que fue de Pero Fernández, carnicero. Item mando más a la dicha Leonor, otra tierra mía que es a Laguna Falsa, término de Villalobón, una obrada de tierra e la dicha bodega y casas y tierras que las tenga el dicho Alfón Martínez, mi tío, según que lo mando. E sy la dicha Leonor finare sin dexar fijo legítimo heredero, que esto todo mando que se torne todo al cabildo de la dicha yglesia de Palencia e que el cabildo lo faga de aniversarios por mi ánima e por las ánimas de aquellos de quien yo tengo cargo. E sy por ventura la dicha Leonor, mi prima, se metiere en alguna orden de rreligión, mando que se mantenga dello por su vida y después de su muerte que lo aya la orden en que entrare, porque rrueguen a Dios por mi ánima.

Item mando al cabildo de la dicha yglesia de Palencia, por remissión de mis pecados y porque rrueguen a Dios por mí, una viña que yo he en término deste lugar en do dizen La Beata, en que ay diez alançadas de viña. Item mando más a Mari Fernández, una viña que es en este di(f.114r)cho término a do dizen Los Foyos, en que ay dos alançadas y media. Item mándole más dos pedaços de viñas que yo he en este dicho término a Las Frieras, en que ay quatro alançadas. E todo esto sobredicho le mando con condiçión que sy finare sin hijo, legítimo heredero, ruego e mando a mis mansessores que ordenen, destas posessiones sobredichas, una capellanía perpetua e que la manden cantar en la capilla de Corpore Christi, que es en el cabildo de la yglesia de Palencia o do mis mansesores vieren que más cumple y que presente un capellán idóneo y suficiente, al deán de Palencia que es 
agora o fuere por tiempo, que faga collación della al capellán que ellos presentaren.

Item mando a Sanchuelo, mi primo, hijo del dicho abbad, mi tío, una viña que yo he en término de Goluera, aquí, en término de Palencia, en que ay cinco alançadas, que es carrera de Torquemada, la qual compró el dicho abbad de los bienes que fueron de Alfón de Corral. Item mándole más la mi viña que yo he en término de Palencia, a Pradiellos en que ay dos arançadas. Item mándole más al dicho Sanchuelo, la mi viña que dizen de Los Beruechos e la tierra que es cerca de la ciudad de aquí, de Palencia, que le mando el dicho abbad, mi tío, con las cargas y condiciones que le mandó y se contienen en el dicho testamento que el dicho abbad, mi tío, fizo y ordenó.

Item mando al dicho Alfón Martínez, mi tío, hermano del dicho abbad, mi tío, la mi bodega mayor del Foyo, que yo he aquí, en Palencia, con todas sus pertenencias quantas le pertenesçen. Item mándole más, la mi viña que yo he a Las Solanas, en que ay doze arançadas. Item mándole más, una cama de rropa, la qual cama mando que le den tres almadraques, los mejores en que el dicho Alfón Martínez duerma e más un cabeçal y el cubertor de corderinas y la colcha que él tiene en la dicha su cama, e más un par de sábanas comunales. Item mándole más, dos mantas de pared que son de las armas de Hernán Martínez, su padre. Item mando que lleven offrenda al monasterio de San Francisco de Palençia, de pan y vino y çera, para siempre jamás, por las ánimas de Hernán Martínez, mi abuelo, y de doña Sancha, su mujer, mi abuela, según que ellos lo dexaron y mandaron por sus testamentos, que dexaron para esto la tierra de carrera de Enmedio en que ay quatro obradas e otra tierra en que ay dos obradas e una mesa en la carniçería mayor desta dicha ciudad, al cantón de la segunda puerta, y mando que lo tenga y mantenga e cumpla segun en los testamentos de los dichos mi abuelo y mi abuela se contiene.

Juanillo, mi sobrino, hijo de Francisca Martínez, mi hermana, por quanto es menor de edad, mando que lo tenga y administre el dicho Alfón Martínez, mi tío, hijo del dicho Fernán Martínez, mi abuelo, fasta que el dicho Juanillo sea de edad, y sy el dicho Juanillo finare antes de la edad dicha, mando que lo aya y cumpla y mantenga el dicho Alfón Martínez, mi tío. 
Item mando que el corral que yo tengo al Foyo, en esta dicha ciudad, que mora en él doña Mayor, mi casera, $(f .114 v)$ por su vida y pague, al cabildo de Palencia, diez maravedís < de censo $>$ en cada un año y después de su muerte que dexe el dicho corral libremente a los quarenta capellanes de la yglesia de Palencia, con la carga sobredicha del dicho censo, para que rrueguen a Dios por las ánimas del abbad, mi tío, y mía. Item mando más a la dicha doña Mayor, por seruizio que me fizo, diez cargas de trigo. Y mándole más el mi tabardo rroxo. Item mando a Mari Fernández, mi tía, muger de Alfón Garçía, mi tabardo de Villaforda de Çendal.

Item mando a Fernando Diez de Fusillos las casas y tierras y viña que yo he en Fusillos, que lo tenga con que se mantenga por toda su vida. Y después de su muerte, mando que se torne y sea para el cabildo de la dicha yglesia de Fusillos, porque rrueguen a Dios por el alma de Juan Martínez, mi tío, abbad que fue de Fusillos, y por la mía.

Item mando a Lope, hijo de Juan Fernández de Fuentes, el mi jubón nuevo y más cinco varas de paño de paymas. Item mando a Pero, hijo de Juan Fernández de Grijota, un juuón nuebo que lo rrecabdé de la legrama que yo tengo arrendada del cabildo y que le doy, más cinco varas de paño para una hopa.

Item mando a Sanchuelo, mi primo, y a Toriuillo, mi sobrino, senos sacos y senos pieles del dicho paño. Item mando a Juan de Aruello y a Juanillo, fijo de Sancho Fernández, sennos sacos del dicho paño. Item mando a Juan Fernández de Grijota quatro cargas de trigo y cinquenta marauedís que dize que le deuía el abbad, mi tío. Item mando a Gil Fernández de Valtanás quatro cargas de trigo y más cinquenta marauedís por un espada que me prestó.

Item mando a Juana de Çamora, mi collaça, cien marauedís que dize que le deuía el dicho abbad de su soldada; e mándole más, por lo que me ha seruido a mí, quinientos ${ }^{12}$ treynta marauedís. Item mando a Juana, andada de Juan Fernández de Vega, notario, por amor de Dios, ochocientos marauedís para con que sea buena mujer, por rremissión de mis pecados con tal condición que se case fasta un año. E sy no se casare fasta un año, que los dichos marauedís que los den mis mansesores por missas cantar aquí, en la ciudad de Palencia, a las personas que ellos que ellos quisieren y a ella no le den ninguna cosa. Y mando que le den más

\footnotetext{
${ }^{12}$ quinientos] Aparece tachado.
} 


\section{LA ABADÍA DE SANTA MARÍA DE HUSILLOS: ESTUDIO Y COLECCIÓN \\ DOCUMENTAL $(904-1608)$}

seis cargas de trigo y que le den más quarenta marauedís para una casa en que more. Item mando a María Rodríguez, mujer de Toriuio, tres cargas de trigo.

Item mando a Catalina, hija de Juan Fernández de Villamuriel, de Allén del Río, por cargo que tengo della, en remisión de mis pecados, trezientos marauedís con que se case y sea buena mujer. Y si no se quisiere casar fasta un año, que mis mansessores que lo den para missas cantar.

Item mando más a Bartolomé Pérez, mi cura, el mi tabardo de chipre claro, con su capote y con su hopa. Item mando a Pero Fernández, rracionero, criado del abbad, mi señor, el mi breuiario que fue del dicho abbad; y mándole más que de quatro sobrepellicos que yo tengo, que le den el mejor dellos. Item mando más al dicho Bartolomé Pérez, mi cura, un libro mío de penitencias que tengo y mándole más, que de los otros tres sobrepellicos, que tome el mejor dellos para sy.

Item mando a Alfón Fernández de Paredes, mi compadre, porque aya voluntad de ayudar a cumplir y pagar mi testamento, media dozena de cuchares $(f .115 r)$ de plata. Item mando a Sancho Díaz, notario público de Palencia, por su trabajo, dozientos marauedís. Item mando a Sanchuelo, hijo del dicho abbad, mi señor, monje que es del monesterio de Forniellos, mill marauedís para una possessión en que se mantenga en su vida. Y después de su muerte, que se quede al dicho manesterio, porque rueguen a Dios por mi alma.

Item mando que por rrazón que Pero Fernández, canónigo, hijo de Garci Fernández de Mazariegos, arrendó una açeña del cabildo de Palencia, que es en la Parada de Mercado, la qual aceña tenía arrendada el dicho abbad, mi señor, y el dicho Pero Fernández, alcançome de cierta quenta de maravedís de la dicha açeña, según paresçera por el arrendamiento de la dicha açeña, que él dando y pagando a los mis mansesores una taça de plata en que ay un marco y más cien maravedis de una capa de coro que le presté mando que descontando ésto que me deve, de lo que me alcança del dicho arrendamiento, que le den lo demás que fallaren fasta en cumplimiento de lo que me alcançó, sacando, dende, lo que me deue, como dicho es.

Item mando e do todo mi poder cumplido a los mis mansesores que fagan cuenta con el cabildo de la dicha yglesia de Palencia del año que yo fuy preposter. E sy alcançaren pan y dinero al dicho cabildo, mando que paguen, dellos, a las singulares personas, canónigos y racioneros. Y sy no huviere cumplimiento dello 
para ge lo pagar, mando que ge lo paguen de los mis bienes. Item mando que unas clementinas que yo tengo enpeñadas a Andrés Martínez, notario, criado del abbad de Santander, por ciento y quarenta y tres maravedís, mando que las quiten del. Otrosy mando que todas las prendas que yo tengo enpennadas a qualquier persona que sea, que se las quiten e que las vendan e que lo que más valieren sea para ayuda a pagar mi testamento. Item mando que den por el ánima de Gil Sánchez de Calabaçanos, por entrega que tengo del, cien maravedís para missas cantar. Item mando a mis mansessores e doles e otórgoles todo mi poder cumplido, para que enmienden y puedan enmendar este mi testamento y en todo lo que en él se contiene, creciendo o menguando, por rrazón que esto que yo mando y en este mi testamento se contiene, llega a muy gran quantía de maravedís, que en este tiempo las cosas no valen tanto.

Otrosy mando que hasta que los mis mansessores ayan cumplido y pagado este mi testamento y lo que yo mando, que mi heredero no sea tenudo, ni otra persona alguna, de entrar ni tomar tenencia ni possessión ni heredad en mis bienes, hasta que se pague y cumpla lo que dicho es. Item mando que por rrazón que me fue dicho y denunciado que Garçía Fernández Mazariegos, que dezía que pues yo eredara los bienes de mi padre y otrosy los bienes del abbad, mi tío, que él era tenudo de le dar e pagar algunas quantías de marauedís e otras cosas algunas, porque ge lo deuía, $(f .115 v)$ y dize que lo pidió e pagó por los sobredichos mi padre y abbad, digo que le yo non deuo alguna cosa e mando a mis mansessores, y a cada uno dellos, que le non den nada. Ca esto que él dize, digo que lo non sé ni creo que assy sea, quanto por esta rrazón ni por otra, yo no tengo carga ninguna del. Y si Dios me da vida y salud, yo ge lo defenderé todo lo mío. Item otrosy, mando que todo el finco de los mis bienes deste dicho año en que estamos, sea para ayudar e cumplir e pagar todo lo que se contiene en este mi testamento, e que mi heredero, ni otra persona alguna, no sean tenudos de lo tomar ni lleuar.

Estas son las deudas que yo, el dicho Juan Martínez, canónigo, conozco, por el mi testamento, que debo y mando que las paguen todas mis bienes. Item deuo a Pero Salincos, que Dios perdone, trezientos y quarenta marauedís y mando que los den a Fernán García, carnicero, su mansessor, para cumplir su alma. Item deuo a Fernán Alfón del Corral, de las campanas, de los trezientos y cinquenta y cinco marauedís que me huuo prestado para la vendimia, descontado lo pagado y más el 
alquiler de la cuba, finca que le deuo cínquenta y siete marauedís, mando que le paguen estos dichos marauedís. Item deuo a Juan Fernández, clérigo de Sanctisteuan, cinquenta marauedís del seruicio de la yglesia de San Pero de Población, y mando que ge los den. E todo este mi testamento e mis mandas e deudas, según que en él se contienen, e mis exequias y mi testamento cumplido e pagado, mando que todo lo qual que sobrare y remanesçiere de mis bienes, que lo aya y herede el dicho Alfón Martínez, mi tío, fijo del dicho Fernán Martínez, mi abuelo, al qual mando que lo herede.

E para todo este mi testamento cumplir, dexo por mis mansessores y testamentarios a Alfón Fernández de Paredes, escriuano del rey, e a Pero Fernández, rracionero en la yglesia de Palencia, criado del dicho abbad, mi señor, y a Bartolomé Pérez, cura de San Nicolás y capellán en la dicha yglesia, vezinos de Palencia. A todos tres en uno y a cada uno en su cabo, otórgoles todo mi poder cumplido y apodérolos en los mis bienes, muebles y rrayzes, para que vendan dellos y en ellos y cumplan y paguen este mi testamento, según que se en él contiene, y mis exequias y mi enterramiento. E rreuoco todos los otros testamentos e codicillos que he hecho y ordenado hasta este día, quier por palabra quier por escrito, saluo este que agora fago y ordeno.

Y porque esto sea firme y no venga en dubda, rrogué y requirió a Sancho Díaz, notario público desta dicha ciudad que está presente, que escriuiesse esta carta de testamento y la signasse con su signo.

Que fue fecha esta carta en la çiudad de Palencia, XXX días de setiembre, era de M CCCC XX años. Testigos rrogados que a esto que dicho es fueron presentes: Fernando Díaz de Fusillos y Alfón Méndez y Lope, hijo de Juan Fernández de Fuentes, e Martín Fernández de Çítores, fijo de Domingo, Juan y Pero, fijo de Juan Fernán(f.116r)dez de Grijota, e Rodrigo, fijo de Juan García de Briuiesca, criado de Pero Fernández, rracionero, y Domingo de Bretaniello, hijo de Pero Fernández, criado de Bartolomé Pérez, cura, vezinos de Palencia, y otros.

E yo, Sancho Díaz, notario público sobredicho de la dicha çiudad de Palencia, que a todo lo que sobredicho es fui presente con los dichos testigos, e rrogado e rrequerido del dicho Juan Martínez, canónigo, escriuí esta carta de testamento en estos dos pedaços de pergamino y van cosidos, en uno, con filo de lino y entre las costuras escrito mío nombre en quatro lugares y en dos lugares. Sobre rraydo está 
enmendado, a do dize "su" e a do dize "en linde", vala e no lo embarge, que fue fecho por error del que lo escriuió. Y en fin de todo esto, fize aquí este mío signo en testimonio de verdad. Sancho Díaz, notario.

1383, enero, 3, sábado. Palencia.

Traslado sacado por Sancho Díaz, notario público de Palencia, a petición de Juan Fernández de Meneses, prior de Santa María de Husillos, y de Pedro Fernández de Villesmalo, racionero en la catedral de Palencia y albacea testamentario de Juan Martínez de Villaviudas, ante Alfonso Martínez, canónigo en la catedral de Palencia y vicario general en el obispado de dicha ciudad, de una cláusula del testamento de Juan Martínez de Villaviudas por la que manda a Fernando Díaz de Husillos, las casas, tierras y viña que posee en Husillos, debiendo pasar a la muerte de éste a propiedad del cabildo de Santa María de Husillos, debiendo de rogar éste por el alma del dicho Juan Martínez de Villaviudas y de Juan Martínez, tío del anterior y abad que había sido de Santa María de Husillos.

$B$. APA, $L P H$, ff. $116 \mathrm{r}-117 \mathrm{r}$.

Fecho y sacado fue este traslado en la villa de Husillos a veynte y nueve días del mes de novienbre de mil y quinientos y çinquenta y quatro años. Testigos que fueron presentes a lo ver leer, corregir y conçertar, Gaspar de Vedoya e Joán Ruiz Cabeça de Vaca, clérigos, y Pero Manuel, estantes en la dicha villa. E yo, Santiago Gómez, escriuano público en la dicha villa, fui presente a lo que dicho es en uno con los dichos testigos. Y del dicho pedimiento y mandamiento, lo fize escreuir y fize aquí mi signo (signo) en testimonio de verdad.

Pero Ruyz de Villoldo. Santiago Gómez (rúbrica)

En la çiudad de Palençia, sábado, tres días del mes de henero, era de M CCCC XXI años. En presencia de mí, Sancho Díaz, notario público desta dicha 


\section{LA ABADÍA DE SANTA MARÍA DE HUSILLOS: ESTUDIO Y COLECCIÓN \\ DOCUMENTAL $(904-1608)$}

ciudad e de los testigos de yuso escritos, estando este sobredicho día en la dicha ciudad ante el honrrado varón y sabio don Alfón Martínez, maestre escuela, canónigo en la yglesia de Palencia, prouisor y vicario general en lo spiritual y temporal en todo el obispado de Palençia, dado por los honrrados varones y sabios deán y cabildo de la dicha yglesia de Palencia, aparescieron y luego presentes con la vna parte, Juan Fernández de Mixexes, prior en la yglesia de Sancta María de Fusillos, y con la otra parte, Pero Fernández de Villesmalo, rracionero en la dicha yglesia de Palençia, ansy como mansesor y testamentario, que fue y fincó de Juan Martínez de Villauiudas, canónigo que fue en la dicha yglesia de Palencia, que Dios perdone, según que se contiene por una carta de testamento que el dicho Juan Martínez fizo y ordenó al tiempo de su finamiento, la qual carta de testamento escriuió y signó y passó por ante mí, el dicho Sancho Díaz, notario. E luego, el dicho prior, dixo, al dicho señor prouisor, que en el dicho testamento que el dicho Juan Martínez, canónigo, fiziera y ordenara, que estauan y se contenían en él algunas cláusulas y cosas de que se entendía aprouechar e que pertenescía de hauer del a la dicha yglesia de Sancta María de Fusillos. E que le pedía y pidió que le mandasse e constriniesse al dicho Pero Fernández, rraçionero, ansy como mansesor del dicho Juan Martínez, canónigo, que mostrasse e paresciesse ante él la carta $(f .116 v)$ del dicho testamento del dicho Juan Martínez. E luego, el dicho Pero Fernández, rraçionero, dixo, respondiendo, que era verdad que el dicho Juan Martínez que finara, e que al tiempo de su finamiento e ante que fiziera y ordenara su testamento e que le dexara por su mansessor para cumplir lo que mandara, según que en el dicho su testamento se contenía e que él para cumplir el alma del dicho Juan Martínez. E otrosy, por mandado del dicho señor provisor, que mostrara y mostró y paresció y presente la carta del dicho testamento, que el dicho Juan Martínez, canónigo, que Dios perdone, fizo y ordenó. La qual es escritura signada por mí, el sobredicho notario, que comiença asy:

In Dei nomine, amen. Sepan quantos esta carta deste testamento vieren, como yo, Juan Martínez, canónigo en la yglesia de la ciudad de Palencia, fijo de Andrés Pérez de Villauiudas, estando enfermo de mi cuerpo y sano del entendimiento y de la memoria, tal qual Dios Padre me la quiso dar e temiendo mucho a la muerte, que es cosa natural a todos los omes y mujeres del mundo, que a ninguno 
perdona. Ende, otorgo e conozco que fago y ordeno mi testamento y mi manda, etc.

En la qual carta del dicho testamento se contenía y estaua y una cláusula que dezía en esta manera: Item mando a Fernando Díaz de Fusiellos las casas y tierras y viña que yo he en Fusiellos, que lo tenga en que se mantenga para toda su vida. Y después de su muerte, mando que se torne y sea para el cabildo de la yglesia de Fusiellos, para que rrueguen a Dios por el alma de Juan Martínez, mi tío, abbad que fue de Fusillos, y por la mía.

La qual dicha cláusula leyda, luego el dicho prior dixo que él, por sy y en nombre y en voz del prior y cabildo de la dicha yglesia de Fusillos, que pedía y pidió, al dicho señor prouisor, que mandasse a mí, el sobredicho notario, que me diesse licencia y autoridad para que yo sacasse e trasladasse, de la dicha cláusula que en el dicho testamento se contenía, un traslado y traslados, uno o dos o tres o más, los que le cumpliessen e menester huuiessen, por razón, que dixo, que hauía rreçelo que se perdería la dicha cláusula del dicho testamento, por agua o por fuego o por rrobo o por otra ocasión alguna. E que en el traslado o traslados, que yo ansí sacasse o trasladasse, que pusiesse y su decreto para que valiessen e fiziessen fe en todo lugar do paresciessen ansy como el mesmo original e la dicha cláusula del dicho testamento, para guarda del derecho del prior y cabildo de la dicha yglesia de Fusillos. Y desto, en como lo dezía y en qual día, que pedía e pidió a mí, el sobredicho notario, testimonio signado con mi signo. E luego, el dicho señor prouisor, dixo que vista por él bien y diligentemente la dicha carta de testamento e la dicha cláusula, en él contenida, no rrota ni cancellada ni en toda ni en parte della sospechosa, que él que daua y dio su licencia y autoridad a mí, el sobredicho notario, e que me mandaua e mandó que sacasse e trasladasse de la dicha cláusula del dicho testamento, un traslado o dos $(f .117 r)$ o tres o más, lo que al dicho prior y cabildo cumpliessen e menester ouiesse e que en el traslado o traslados, que yo ansy por la dicha cláusula sacasse e trasladasse, que ponía y puso y su decreto porque valiessen e hiziessen fe a doquier que paresciessen, tan bien e tan cumplidamente como el mismo original de la dicha cláusula en el dicho testamento contenida. E que de todo esto, en como passaua e passó a mí, el sobredicho notario, que diesse dello testimonio signado al dicho prior, para guarda de su derecho e de la dicha yglesia de Fusiellos. 


\section{LA ABADÍA DE SANTA MARÍA DE HUSILLOS: ESTUDIO Y COLECCIÓN \\ DOCUMENTAL $(904-1608)$}

Fecho día, mes y año y era sobredichos. Testigos que a esto fueron presentes e vieron el dicho testamento e oyeron leer la dicha cláusula en él contenida: Alfón Fernández, clérigo, e Juan García de San Cebrián, capellanes en la yglesia de Palencia, e Fernán Fernández de San Cebrián, criado del dicho señor maestre escuela, vezinos de Palencia, e otros.

E yo, Sancho Díaz, notario público sobredicho de la çiudad de Palencia, que a todo esto fuy presente con los dichos testigos. E rrogado e rrequirido del dicho señor prior e por mandado e licencia y auctoridad del dicho señor prouisor, saqué este traslado de la dicha cláusula del dicho testamento, e hize aquí este público instrumento, e hize aquí este mío signo en testimonio de verdad. Sancho Díaz.

\section{3}

1383, diciembre, 28, lunes. Grijota.

Juan Alfonso, vicario de Grijota y canónigo de Santa María de Husillos, Alfonso González, clérigo de Grijota y canónigo de Valladolid; y Sancha Díaz, casera que había sido de Diego Díaz, todos ellos vecinos de Grijota y albaceas testamentarios del dicho Diego Díaz, clérigo que fue de Grijota y canónigo de Santa María de Husillos, venden a Domingo González, chantre en la iglesia de Santa María de Husillos, unas casas en Grijota, en la colación de Santa María, en precio de cuatrocientos maravedis, para pagar las exequias, mandas y deudas que Diego Díaz había relatado en su testamento.

A. AHDP, Ampudia y Abadía de Husillos, Pergaminos, carp. 208-17. Perg., 264 x 322 mm.; escr. precortesana; regular conservación con algunas roturas.

$B$. APA, $L P H$, ff. $117 \mathrm{r}-118 \mathrm{r}$.

Sepan quantos esta carta vieren commo yo, Iohán Alfonso, vicario de Grijota e canónigo en la eglesia de Santa María de Fusiellos, capellán en la eglesia de Santo Antolín /de Palençia; e yo, Alfonso Gonçález, clérigo de Grijota, 
canónigo de Valladolit, asy commo manssesores que somos de Diego Díaz, clérigo que fue del dicho logar de /Grijota e canónigo que fue de Fusiellos; [e yo], Sancha Díaz, casera que fue del dicho Diego Díaz, vezinos que somos de Grijota. Para pagar las exequias $\beta^{3}$ e mandas et debdas que el dicho Diego [Día]z mandó en su testamento, otorgamos et conoscemos que uendemos a uos, Domingo Gonçález, chantre en la / dicha eglesia de Santa María de Fusiellos, unas casas que, el dicho Diego Díaz, auía en el dicho logar de Grijota, que son en la collaçión de Santa María, que an / por linderos: de la una parte casas de mí, el dicho Alfonso Gonçález, clérigo; e de la otra parte, casas de Ferrnant Martínez de Cantoral; e de la otra parte, la cal $/{ }^{6}$ mayor pública del conçejo. Estas dichas casas [que] estas dichas afrontaçiones ençierran et con más si las y a, uos uendemos, uendida bonna et sanna / et leal et uerdadera, conosçida e sin entredicho alguno et sin ning[una m]ala boz, con entradas et con salidas et con todos sus derechos et usos et pertenen/çias quantas les pertenesçen et pertenesçer deuen de derecho, por [quatroçie]ntos maravedís desta moneda vsual que agora corre, que fazen diez dineros el maravedí. De los $/^{9}$ quales dichos quatroçientos maravedís nos otorgamos por bien $\mathrm{p}$ [agad]os, para agora et para en todo tiempo del mundo. E los maravedís rresçibimos antel notario et los testigos desta / carta. E sobresto, rrenunçiamos las leyes del derecho, la vna en que dize que los testigos de la carta deuen uer fazer la paga de la cosa sobre que es / fecho el contrato o de la valía dello. E de la otra ley en que dize que fasta dos annos es el omme tenudo de prouar la paga que faze, saluo sy aquel o $/{ }^{12}$ aquellos que an de rresçibir la paga, [rr]enunçiaren estas dichas ley et se partieren dellas. E nos et cada uno de nos, rrenunçiámoslas et partímosnos / dellas, que sy las ante nos posiérenos o otro por nos, que $[n]$ os non ualan en juyçio nin fuera de juyçio. E con esta carta vos apoderamos en las dichas ca/sas, para que sean vuestras propias, libres et quitas et esentas, para uender et enpeñar et trocar et donar, enajenar e para fazer dellas et en ellas todo $/^{15}$ quanto quisiéredes et por bien touiéredes bien, asy commo de las vuestras cosas propias que más quitas et más esentas, en el mundo auedes. E obligamos a todos / los bienes que el dicho Diego Díaz dexó suyos, asy muebles commo rrayzes, para uos fazer sannas las dichas casas, de qualquier omme o muger que uos las / demandare o enbargare o contrallar quesiere, todas o parte dellas, si non, que los bienes del dicho Diego Díaz, uos sean tenudos a uos dar et 
pechar otras $/^{18}$ tales casas et tan bonnas et en tan bon logar o mejor dobladas, a uos tornar et dar los dichos quatroçientos maravedís doblados.

E yo, el dicho Alfonso / Gonçález, clérigo, obligo a todos los mis bienes, muebles et rrayzes, spirituales et temporales. E yo, la dicha Sancha Díaz, obligo a todos los mis bienes, muebles / et rrayzes, quantos oy día he et auere de aquí adelante, para uos fazer sannas las dichas casas de qualquier persona o personas que uos las demandare o en $/{ }^{21}$ bargare o contrallar quesiere, todas o par[te della]s. Sy non que los míos bienes et de cada vno de nos, vos sean tenudos a uos dar et pechar otras tales casas / et tan bonnas et en tan bon logar o mejor, dobladas, o los dichos quatroçientos maravedís doblados.

Fecha esta carta en Grijota, lunes, veynte et ocho días / de deziembre, era de mille et quatroçientos et veynte et un años. Testigos que a esto fueron presentes: Ferrant Gonçález, fijo de Ferrant Gonçález, e Pero Alfonso, fijo de Do/ ${ }^{24}$ mingo Ferrández, e Santiago, fijo de Diego Ferrández, cauallero, et otros vezinos de Grijota.

E yo, Ferrnando Díaz de Grijota, notario público de la çipdat de Palençia, / fuy presente, a todo esto que dicho es con los [di]chos testigos. E por rruego et otorgamiento de los sobredichos Iohán Alfonso, e Alfonso Gonçález, e / Sancha Díaz, escriuí esta carta e fize aquí este myo ssig(signo)no en testimonio de uerdad.

\section{4}

1384, mayo, 19, jueves. Husillos

Fernando Martínez de Cantoral, vecino de Santillán de la Cuesta, vende a Domingo González, chantre en Santa María de Husillos, unas casas con una huerta en Grijota; y un corral y casares en la colación de Santa María, en precio de seiscientos maravedis. 
B. AHDP, Ampudia y Abadía de Husillos, Pergaminos, carp. 207-21. Perg. 496 x 382 mm; escr. precortesana; buena conservación. Inserto en la donación que realiza Domingo González de dichas casas y corrales al prior y cabildo de Santa María de Husillos, dada en Husillos el 19 de agosto de 1384. Véase doc. núm. 205.

$C$. APA, $L P H$, ff. $119 \mathrm{v}-120 \mathrm{v}$.

D. BN, $m s .705$, ff. 252r-255v.

Sepan quantos esta carta vieren, commo yo, Fernand Martínez de Cantoral, vezino que so de Sanct Yllán, otorgo / e conosco que vendo a uos, Domingo Gonçález, chantre en la eglesia de Sancta María de Fusiellos, vnas casas con vna huerta que yo he en Grijota, et vn corral e casares que fueron de la Quinana, que son en la collaçión de Sancta María, que han por / linderos: de la vna parte, casas que fueron de Diego Díaz, canónigo que fue del dicho logar de Fusiellos, que son agora vestras; e de la otra parte casas que fueron de Domingo Ferrández, cauallero; e de la otra parte, la cal pública de conçejo; e de la otra $/^{6}$ parte, la Rronda. E los uendo más vna tierra que yo he en término del dicho logar Grijota, que es a La Natera que fue de Iohán Ferrández, fijo de Diego Ferrández, que es en linde tierra de Sanct Iohán de Pajares; e de la otra parte en linde la carrera que / dizen de la Vinna Mayor; e de la otra parte, en linde el arroyo de La Naua. Estas dichas casas e huerta e corral e casares e tierra que estas dichas afrontaçiones ençierran, e con más si las y ha, vos uendo, vendida buena e sana e leal / e uerdadera, sin entredicho alguno e sin nenguna mala boz, con entradas e con salidas e con todos sus derechos e vsos e pertenençias quantas les pertenesçen e pertenesçer deuen de derecho, por seyscientos maravedís desta moneda vsual que ago/ ${ }^{9}$ ra corre, que fazen diez dineros nouenos el maravedí. De los quales dichos seysçientos maravedís, me otorgo por muy bien pagado e entrego para agora e para en todo tiempo del mundo. E los yo rreçebí ante el notario e los testigos desta carta, que / passaron a mi parte e a mi poder, bien contados e escogidos. E sobre esto rrenunçio las leys del derecho, la vna en que dize que los testigos de la carta deuen ver ffazer la paga de la cosa sobre que es fecho el contrato o de la valía / della; e la otra ley en que dize que fasta doss años es el ombre tenudo de prouar la paga que faze, saluo si aquel o aquellos que han de rreçebir la paga rrenunçiaren estas dichas leyes e se partieren dellas. E yo rrenúnçiolas e párto $/{ }^{12}$ me dellas, que si las ante mí posiere o otro por mí, que me 
non valan, en juyzio nin fuera de juyzio. E desde oy día que esta carta es fecha en adelante, me parto e desapodero del juro e la tenençia e acción e demanda e derecho / e señorío e parte e propriedat que yo auía en las dichas casas e corral e casares e huerta e tierra, e con esta carta vos apodero en ello corporalmente, para que sea vestro proprio, libre e quito e exempto, para empeñar e vender e trocar e donar / e enagenar e para fazer dello e en ello, quanto quisiéredes e por bien touiéredes, bien así commo de las vestras proprias cosas que más quitas e más exemptas en el mundo auedes.

E obligo a todos los mis bienes, muebles e rrayzes, para uos ${ }^{15}$ lo fazer sano todo tiempo, de qualquier ombre o muger que vos lo demandare o embargare o contrallar quisiere, todo o parte dello, ssi non que vos de e peche otras tales casas e huerta e corral e casares e tierra commo lo sobredicho e en tan buen / logar o mejor, doblado, o que vos torne los dichos seysçientos maravedís, doblados.

Fecha la carta en Fusiellos, iueues, diez e nueue días de mayo del anno del nasçimiento de nostro Sennor Saluador Ihesu Christo de mille e trezientos e ochenta / e quatro años. Testigos que a esto fueron presentes: Iohán Garçía Çerçetilla, e Garçía, fijo del dicho Fernand Martínez de Cantoral, e Peydro, fijo de Martín Ferrández de Auia, criado del chantre, e Domingo Ximón, vezinos de Fosiellos, e otros. $/^{18}$

E yo, Ferrando Díaz de Grijota, notario público de la çibdat de Palençia, ffuy presente a todo esto que dicho es con los dichos testigos, e por rruego del dicho Fernand Martínez scriú esta carta en este pargamino de cuero; e está en ella vn / foraco e non le empezca. E fiz aquí este mío signo en testimonio de verdat.

1384, agosto, 19, viernes. Husillos

Domingo González, chantre de Santa María de Husillos, dona al prior, cabildo y beneficiados de Santa María de Husillos, unas casas en Grijota que había comprado a Fernando Martínez de Cantoral, a condición de que le hagan 
seis aniversarios a perpetuidad: uno por el alma de su padre, dos por la de su madre y tres por la suya propia. Hasta que llegara el momento de su muerte, estos tres últimos se debian decir por el alma de su madre.

A. AHDP, Ampudia y Abadía de Husillos, Pergaminos, carp. 207-21. Perg., 496 x 382 mm; escr. precortesana; buena conservación.

$B$. APA, $L P H$, ff. $119 \mathrm{v}-120 \mathrm{v}$.

C. BN, $m s .705$, ff. 252r-255v.

Sepan quantos esta carta de donaçión vieren commo yo, Domingo Gonçález, chantre de la eglesia de Sancta María de Fusiellos, otorgo e conosco por firme stipulaçión, que non por error nin por engaño nin por fuerça nin por falago nin por otro $/^{1}$ induzimiento alguno, más por mi propria voluntad e mi libre aluedrío, que fago donaçión solempne e pura entre biuos, a uos, el cabilldo, personas e canónigos e rraçioneros e benefiçiados de la eglesia de Sancta María de Fusiellos que agora sodes / e seredes de aquí adelante, de todos los bienes, así casas commo tierras e corrales e casares e huerta, que yo compré e he en Grijota, de Fernand Martínez de Cantoral, vezino de Sanct Yllán de la Cuesta, ssegund se contiene en vna carta de la $\beta$ dicha compra, scripta en pargamino de cuero e signada de notario público que dello tengo, el tenor de la qual es este que se sigue.

(Sigue doc. núm. 204)

E estas dichas casas e corral e casares e huerta e tierra vos do para que sean vestras e fagades, dello e en ello, assí commo de cossa vestra propia, para vos el dicho / cabilldo de la dicha eglesia, los que agora sodes e los que seredes de aquí adelante. E esta dicha donaçión vos fago con condiçión que me fagades, de aquí adelante, para siempre jamás, seys aniuerssarios cada año en la quaresma, vno en cada sema $/^{21}$ na. El vno por el ánima de mi padre, e los dos por el ánima de mi madre, e los tres por mi ánima. E estos tres, en quanto fuere mi vida en este mundo, que lo fagades por la ánima de mi madre; e después de mi vida, que los fagades / por la mi ánima para ssiempre jamás. E desde el día de oy que esta carta es fecha, me desapodero de la tenençia, possesión, señorío e propriedat que yo he en las dichas casas, corral e casares e huerta e tierra e en cada vno dello, e por / 
esta carta lo do e traspasso en vos, el dicho cabilldo, los que agora sodes e serán cabo adelante. E pongo con uusco de vos fazer sana esta dicha donaçión de quien quier que vos la contrallare o embargare en qualquier tiempo del mundo e ${ }^{24}$ por qualquier rrazón. E por más firmedumbre de lo así atener e complir e guardar, júrolo a Dios e a sancta María e a los sanctos euangelios que corporalmente tango con mis manos, de auer por firme e valedera esta dicha donaçión, et de / nunca yr contra ella nin contra parte della nin contra lo contenido en esta carta nin contra parte dello, agora nin en algún tiempo del mundo, e de vos la non tirar nin contrallar nin reuocar por algunos nin por alguno caso de aquellos en que / el derecho pone e manda commo pueden e deuen ser rreuocadas las donaçiones. E para lo así fazer e complir obligo a mis bienes, muebles e rrayzes, spirituales e temporales, auidos e por auer.

E nos, los dichos prior e cabilldo e ${ }^{27}$ benefiçiados de la dicha eglesia de Sancta María de Fusiellos, otorgamos e conosçemos que rreçebimos e tomamos de vos, el dicho Domingo Gonçález, chantre, la dicha donaçión con la dicha condiçión que vos fagamos los dichos aniuersa/rios commo dicho es. E para lo así atener e complir, obligamos los bienes de la mesa del dicho cabilldo.

E demás yo, Iohán Ferrández, prior, e Pero Ferrández de Villauermudo, e Alfonso Royz, e Martín Sánchez, e Fernand Martínez, e Sancho Ferrández de Villaumbra/les, canónigos de la dicha eglesia, que estamos presentes, juramos a Dios e a Sancta María e a los sanctos euangelios, que tañemos corporalmente con nostras manos, de fazer los dichos aniuerssarios e complir e atener lo que en esta carta se contien. $/^{30}$

E yo, el dicho Martín Sánchez, así commo procurador del dicho cabilldo e en su nombre de los que agora son e serán de aquí adelante, lo juro todo assy. E porque esto sea firme e non uenga e dubda, nos, amas las dichas partes, / rrogamos e rrequerimos a Iohán Ferrández de Aguilar, clérigo del obispado de Burgos e capellán del número de los Quarenta Capellanes en la eglesia de Palençia, notario público por la actoridat apostolical, que scriuiesse o feziese scriuir dos cartas / en vn tenor. La vna para mí, el dicho chantre; e la otra para el dicho cabilldo, signadas con su signo.

Fecha en Fusiellos, en el cabilldo de la dicha eglesia que es en la capiella de Sancta Bárbara, viernes, dizinueue días del mes ${ }^{\beta 3}$ de agosto del anno del 
nasçimiento de nostro sennor de mille e trezientos e ochenta e quatro annos, que es anno Domini millesimo trecentesimo octoagesimo quarto.

Testigos que estauan presentes, rrogados: Iohán Fernández Armigote, e / Alfonso Ferrández de Orbaneia, e Fernando, fiio de Domingo Ximón, vezinos de Fusiellos, e Pero Ferrández de Villaherreros, capellán de Sanct Iohán de Paiares, e Alfonso Gonçález de Olmedo, criado de don Iohán Gonçález, abbad de la dicha / eglesia de Fusiellos, e otros.

(Signo) Et yo, Iohán Ferrández de Aguilar de Campo, clérigo del obispado de Burgos, capellán del número de los Quarenta Capellanes en la eglesia de Palençia e notario público por la actoridat apostolical, ffuy presente a todo esto que dicho es con los dichos testigos. E por rruego e rrequerimiento de los dichos chantre e prior e benefiçiados, scriuí esta carta e fiz aquí mío signo acostumbrado en testimonio de uerdat (rúbrica).

1384, agosto, 21, domingo. Fuentes de Valdepero.

El concejo de Fuentes de Valdepero da autorización a Santa María de Husillos por un periodo de cuatro años para sacar piedra de ciertas canteras sitas en su término para arreglo de su iglesia, aceñas, pesqueras y molinos, merced a dos cartas presentadas por Juan González de Illescas, abad de Santa María de Husillos, y Juan Fernández de Meneses, prior de dicha iglesia, que se trasladan: una permuta (1245, mayo, 25) entre Domingo de Fuentes de Valdepero y Santa María de Husillos de una tierra en Fuentes de Valdepero, en el pago de La Laguna, por otra en Valmayor; y una donación (1377, noviembre, 25. Grijota) por Juan Fernández, de una tierra con su pedrera de una obrada y media, en Fuentes de Valdepero, en el pago de Valmayor.

A. AHDP, Ampudia y Abadía de Husillos, Pergaminos, carp. 207-19. Perg., 405 x 266 mm; escr. precortesana; buena conservación. 
B. APA, $L P H$, f. $34 \mathrm{v}-35 \mathrm{v}$. Al final del documento: $<\mathrm{Y}$ esta escritura por estar rota en algunas partes no se signó>.

Sepan quantos este público instrumento vieren, commo en Fuentes de Valdepero, en las casas do mora Iohán Martínez, fijo de Roy / Martínez, domingo, veynte e vn días del mes de agosto del año del nasçimiento de nostro Sseñor de mille e trezientos e ochenta e quatro años, que / es año a nativitate Domini, millesimo trecentesimo octoagesimo cuarto. En presençia de mí, Iohán Ferrández de Aguilar de Campo, clérigo del obispado de Burgos, $\beta$ capellán del número de los Quarenta Capellanes en la eglesia de Palençia e notario público por la actoridat apostolical, e de los testigos yuso scriptos, / estando ayuntados a conçejo a campana rrepicada, ssegunt que dixieron que lo han de vso e de costumbre de se ayuntar, Fernand Garçía, alcallde, e / Iohán Castajo, meryno, e Roy Gonçález, e Iohán Martínez, fijo de Gonçalo Martínez, e Domingo Ferrández Castajo, e Sancho Fernández, e Pero Ferrández Pollo, e Martín Delga $/{ }^{6}$ do, legos, vezinos e moradores en el dicho logar de Fuentes e otros muy muchos del dicho conçejo. Otrosí, estando presentes Pero Díaz e Fernand / Garçía e Toribio Ferrández, clérigos del dicho logar, speçialmente para esto que se sigue. Paresçieron y presentes los onrrados varones e ssabios don / Iohán Gonçález de Yliescas, abbad, e Iohán Ferrández de Mixiezes, prior de la eglesia de Sancta María de Fusiellos. E luego el dicho abbad fizo leer $/^{9}$ a altas vozes por el dicho Ferrand Garçía, clérigo, delante los dichos ombres buenos e conçejo, doss cartas scriptas en pargamino de cuero, la vna / de troque que don Domingo, del dicho logar, Fuentes, ouiera fecho con don Pero Martínez, abbad de Fusiellos, que fue sellada con dos seellos de çera blanca / pendientes en cuerdas de lino o de cáñamo de diuerssos colores, e paresçía ser partida por $\mathrm{A}, \mathrm{B}, \mathrm{C}$, segund que por ella paresçía, el tenor de la $/{ }^{12}$ qual es este que se sigue:

(Sigue doc. núm. 65)

E la otra carta de donaçión que fizo Iohán Ferrández, fiio $/^{27}$ de Domingo Pérez, vezino de Fuentes, a la dicha eglesia de Sancta María de Fusiellos, signada de 
notario público, segund que por ella paresçía, el tenor de la qual es este / que se sigue:

(Sigue doc. núm. 188)

Las quales leydas, luego, los dichos / abbad e prior, dixieron a los dichos [...e con]çejo, que pues las dichas tierras [e] canteras les pertenesçían, commo dicho es por las dichas $/{ }^{45}$ cartas, que les pedían que dexassen e desembarg[ada]monte e desembargadamonte (sic) vsar dellas con las dichas canteras, segund que de su cosa propia deuían e auían / de vsar. E otrossí, que les pedían e pedieron más, que por su graçia e merçed, que para aguisar la dicha eglesia de Sancta María de Fusiellos e las açeñas e pesqueras / e molinos de la dicha eglesia, que les diessen piedra de las canteras del dicho conçejo de Fuentes. E luego, los dichos ombres buenos del dicho conçejo dixieron $/^{48}$ que lo que les pertenesçía a los dichos señores abbad, prior e cabilldo e eglesia por rrazón de lo contenido en las dichas cartas e en cada vna dellas, que ge lo dexa/ ${ }^{49}$ uan e desembargauan e dexaron e desembargaron para que vsassen e feziessen dello e en ello así commo de cosa suya propia.

Otrosí, a lo que dezían que to/uiessen por bien e fuesse su mesura de les dar piedra de la cantera del dicho conçejo, dixieron que por seruiçio e onrra de la dicha eglesia e de los sobredi $/{ }^{51}$ chos abbad e prior que les plazía e ge lo dauan e dieron quanto la dicha eglesia e pesqueras e molinos della mester ouiessen, fasta quatro años complidos primeros / seguentes, guardando pro e onrra de su señor el adelantado e del dicho conçejo e otrosí, pan e vino. E desto todo en commo passó, el dicho prior, en nom/bre de la dicha iglesia, e los dichos ombres buenos del dicho conçejo, dixieron e rrequerieron a mí, dicho notario, que screuiesse o feziese screuir dello dos públicos ${ }^{54}$ instrumentos en vn tenor, para cada parte el suyo. Fecho vt suppra.

Testigos que estauan presentes rrogados: Iohán Ferrández de León, e Alfonso Gonçález del Olmedo, scuderos / del dicho abbad, e Garçía, criado del dicho prior; e Fernando Díaz, meryno de Fusiellos, e otros muchos.

(Signo) Et yo, Iohán Ferrández de Aguilar, clérigo del obispado de Burgos, capellán del número de los Quarenta Capellanes en la eglesia de Palençia / e 


\section{LA ABADÍA DE SANTA MARÍA DE HUSILLOS: ESTUDIO Y COLECCIÓN \\ DOCUMENTAL $(904-1608)$}

notario público por la actoridat apostolical, fuy presente a todo lo que dicho es con los dichos. E por rruego e rrequerimiento de los dichos $/^{57}$ prior e ombres buenos, screuí este público instrumento. E va scripto sobre raydo a los quarenta e vn renglones, do dize "veynte e çinco dí/as de nouiembre, era de mille e quatroçientos e quinze años", e non le empezca. E fiz aquí mío signo acostumbrado en testimonio de uerdat (rúbrica).

\section{7}

1386, abril, 9, lunes. Burgos.

Testamento de Gonzalo González, racionero de la catedral de Burgos y arcipreste de Burgos, hermano de Domingo González, chantre de Santa María de Husillos, por el cual, entre otras mandas, pide ser enterrado en Santa María de Husillos, en la capilla que mandó construir bajo la advocación de San Quirce. Entre sus mandas destina varias a Santa María de Husillos y a sus dominios: dos libras de aceite para las lámparas de la iglesia de Santa María de Husillos; quinientos maravedís para construir el puente de Cabo de Viña en Husillos; unas heredades en Oterdajos y Barrihuelo para el hospital que había mandado contruir en Husillos; unas casas en Palencia y unas viñas en Palencia, Villalobón, Villamuriel y Quintanilla, para dotar con dos capellanías perpetuas la capellanía de San Quirce. Asimismo, deja como heredero de los bienes que sobrasen a Domingo González, su hermano.

A. AHDP, Ampudia y Abadía de Husillos, Pergaminos, carp. 209-24. Perg., 675 x 649 mm.; escr. precortesana. Se compone de dos pergaminos cosidos el uno sobre el otro (497 x $649+199$ x 649 mm.). Del primer pergamino, las 47 primeras líneas están en aceptable estado de conservación. A partir de aquí la tinta se va haciendo desvaída, llegando a perderse en algunos lugares, por lo cual la lectura se hace bastante difícil e imprecisa su transcripción.

En el nombre de Dios et de Santa María. Sepan quantos esta carta de testamento vieren, commo porque la vida de los omes es muy breue et ninguno nin alguno, 
por sabiduría que en sy aya nin por grand poder que tenga, non puede saber el día nin la hora del su finamiento. Et porque contra la muerte non ha otro, sinon / la merçed de Dios et el bien que fiziere. Por ende yo, Gonçalo Gonçález, rraçionero en la iglesia de Burgos et arçipreste de Burgos, estando en mi seso et en mi memoria et en mi ssano entendimiento, qual Dios me lo quiso dar, et creyendo, firmemient, en la Santa Trinidat et en todos los artículos de la ffee cathólica, asy / commo fiel christiano deue creer, fago et ordeno mi manda et mi testamento et mi postremera voluntad en la manera que aquí dirá: Primeramient encomiendo el mi cuerpo a la tierra et la mi alma a Dios que la compró et crió por la su sangre preçiosa. Et pido por merçed, a la virgen gloriosa salua, señora Santa María, et a señor $\beta$ sant Miguel, ángel et arcángel con toda la corte del çielo, que rueguen a mi sseñor Ihesu Christo por mí, que me quiera perdonar, amén. Item mando que quando Dios touiere por bien de me leuar deste mundo al otro, do más auemos de durar, que entierren el mi cuerpo en la capiella que yo agora fiz fazer, dentro de la eglesia / de la bienauenturada uirgen gloriosa señora Santa María de Fusiellos, et me asignaren el prior et el cabillo de la dicha eglesia de Fusiellos, segund que passó por Françisco Ferrández, notario público de la çibdat de Palencia et escriuano de nuestro sseñor et rrey et su notario en la su corte et en todos los sus regnos, segund que / está ordenado et otorgado por los dichos sseñores prior et cabillo et mí, poniendo hy vn altar auitación de sseñor sant Quirze mártir, et vestimienta et ara et corporales et sáuanas et cálice de plata de marco et medio et más ampollas de estaño et una esquila para tañer al cuerpo de Dios et un libro $/ 6$ missal et vn "Te Ygitur". Item mando que lieuen, por mi alma, a la dicha eglesia de Santa María de Fusiellos, pan et vino et çera por dos años complidamient, et la obrada que sea, cada día, de vn quartal et vn dézimo de vino cada día et la çera, cada día, un çirio de dos libras; et que arda, cada día, fasta los dichos dos / años complidos, et a la missa et a las viésperas. Item mando que el día de mi enterramiento que den de comer pan et vino et carne o pescado, qual día fuere, a quarenta fijos de Dios, por el su amor et porque rrueguen a Dios por la mi alma. Item mando que den de comer a diez fijos de Dios, cada día, por todas las noue/nas, pan et vino et carne o pescado, segund los días que acahesçieren porque rrueguen, esso mismo, a Dios por la mi alma. Item mando al prior et cabillo de la dicha eglesia de Santa María de Fusiellos, por la vigillia et missa et nouenas, que 
me digan dozientos maravedís. Item mando al deán et cabillo de la eglesia de $\ell^{9}$ Santa María de la çibdat de Burgos, porque me digan vigillas, si aquí finare, en Burgos, et otro día missa de Requiem et salgan con el mi cuerpo fuera de la çibdat, a los que venieren a la dicha vigillia et missa et salieren con el mi cuerpo, trezientos maravedís. Item mando a los quarenta capellanes de la dicha eglesia / de Burgos, que me digan vigillia et otro día missa de réquiem et salgan con el mi cuerpo con los dichos sseñores deán et cabillo, et acabada la missa de réquiem, que salgan sobre la sepultura de mi sseñor, el obispo de Burgos, et digan un responso por la su alma et por la mía et por aquellos a que sson / tenidos de rrogar a Dios, çient maravedís. Item mando a los confradres de criazón, en esta dicha eglesia de Burgos, un tabardo et un caperote de los míos, segund que lo an de rregla et más çinco libras de çera, et mándoles porque me digan vigillia et missa de réquiem et salgan con los dichos señores deán et $/^{12}$ cabillo, con el mi cuerpo, et salgan sobre la sepultura de mi sseñor, el obispo, et digan un responsso, segund los quarenta capellanes, çient maravedís. Item mando a los couentos de las órdenes de Sant Pablo et de Sant Françisco et de Sant Agostín et de la Trinidat, de la dicha çibdat de Burgos, sy aquí en esta çibdat de Burgos, finare, para que me digan / vigillia et missa, cada unos en sus monesterios, et salgan con los dichos sseñores deán et cabillo a esterrar el mi cuerpo, a cada orden, çient maravedís; et sy aquí non finare que non dé cosa alguna de todo ésto a los dichos deán et cabillo et capellanes de los quarenta et de criazón et conuentos et, esto mismo, a las eglesias perrochiales et emparedadas de la / dicha çibdat de Burgos. Item mando a todos los clérigos de todas las eglesias perrochiales de la dicha çibdat de Burgos, que cada vno dellos, que me digan vigillia et missa de réquiem, en cada una de sus eglesias et salgan con el mío cuerpo con los dichos sseñores deán et cabillo, esta que se sigue:

A los clérigos de Sant Esteuan çinquenta maravedís; item a los clérigos $/{ }^{15}$ de Sant Martín çinquenta maravedís; item a los clérigos de Santa María de Vieja Rúa, et de Sant Pero, et de Sant Román, et de Sant Gil, et de San Nicolás, et de Sant Yago, et de Sant Gosmes, a los clérigos de cada una de las dichas eglesias, treynta maravedís. Item a los clérigos de Sant Llorent, rectores et sacristanes et capellanes de la dicha eglesia mando, porque digan vi/gillia et missa de réquiem et salgan con el mi cuerpo con los dichos sseñores deán et cabillo, çinquenta maravedís et 
que los partan entre ssy egualmientre. Item mando a los clérigos de Santa Gadea et de Santo Lesmes, a los clérigos de cada eglesia, quinze maravedís. Et si por auentura non finare en la dicha çibdat de Burgos, que les non den ninguna cosa por quantas [mandé] / fazer onrra al mío cuerpo. Item mando a los rectores et curas de la capiella de Sant Yago, de la dicha eglesia de Burgos, porque rrueguen a Dios por mi alma, treynta maravedís. Item mando que lieuen por mi alma, a la dicha capiella de Sant Yago, un año, cada día, vn quartal et vn dézimo de vino et candela de çera, et más, porque den $[\ldots] /{ }^{18}$ rea de missas por mi alma, treynta maravedís. Item mando a la abbadessa et monjas del monesterio de Santa Clara, çerca de Burgos, porque rrueguen a Dios por mi alma, çient maravedís. Item mando a todas las enparedadas de la dicha çibdat de Burgos, que son estas que se siguen: Santa María de Vieja Rúa, Sant Gil, Sant Peydro, et Sant Helizes, et $\mathrm{S}[$ anta Ma]/ría de Rebolledo, et Sant Martín de Salze, et Santa María de Gamonal, et Santa María de Fres del Val, a cada una dellas, tres maravedís, porque rrueguen a Dios por mi alma; et si non finare en la dicha çibdat, que non les den ninguna cosa. Item mando a Santa María de Ronçasdillos et a la Trinidat et a la Cruzada et a la obra de Sant Antolín / de Palençia, a cada vna, çinco maravedís. Item mando a mis mansessores que conpren mille varas de picote et que las den luego, por amor de dios, a pobres que las ayan mester, las quales yo nombro luego aquí, a quien lo den: A María, a Eluira, a Vrraca, a Sancha, a Benita, a María, a Martha, a Ysabel, a Catalina, a Françisca, a Mar ${ }^{21}$ garita, a Iohana, a Ynés, a Gadea, a Olalla, a Offemia, a Luzía, a Clara, moradoras en la cipdat de Palençia et en Fusiellos et en Carrión et en Castriello de Villa Vega; et a Peydro, et Andrés, et a Iohén, et a Yague, et a Bartolomé, et a Thomé, et a Mathe, et a Simón, et a Ber[ne]bé, et a Luchas, et / a Marchos, et a Esteuan, et a Clemeynte, et a Llorente, et a Vizeynte, et a Román, et a Blas, et a Martín, et a Gregorio, et a Nicolás, et a Benito, et a Gil, et Alfonso, et a Domingo, et a Françisco, moradores en los dichos lugares et en cada uno dellos; et que den, estas dichas mille varas de picote, a estos sobredichos / nombrados, segund que a cada uno montare, tanto al uno commo al otro. Item mando a todas las lámparas de la dicha eglesia de Santa María de Fusiellos, et de Sant Andrés de Fuente Quintana, et de Sant Iullán de Sant Illán de la Cuesta, et a Santa Agna, çerca de Monçón, et a Santa María Magdalena, çerca de Fusiellos, a ca/ ${ }^{24}$ da lámpara, dos libras de azeyte, saluo las 


\section{LA ABADÍA DE SANTA MARÍA DE HUSILLOS: ESTUDIO Y COLECCIÓN \\ DOCUMENTAL $(904-1608)$}

lámparas que ha de alumbrar la sacristanía de Fusiellos, que les non den ninguna cosa. Item mando, para ayuda a fazer la puente que dizen de Cabo de Viña, que es en término de Fusiellos, quinientos maravedís; et si el abbat et el cabillo et el conçejo non la fizieren fasta del día / que yo finare, fasta un año, que les non den ninguna cosa para fazer la dicha puente. Item mando a los quarenta capellanes de la eglesia de Sant Antolín de Palençia, que me digan vigillia et missa et fagan todos los otros ofiçios que manda la su rregla, que les den todo lo que manda la su rregla, et si lo non quisieren fazer, man/do que les non den ninguna cosa. Item mando a los confradres de Santa María del Sábbado, de la dicha eglesia de Palençia, que me digan vigillia et missa, treynta maravedís, et si más mandare la su rregla, que an de auer, que ge lo paguen. Item mando a los frayres de Sant Pablo, et de Sant Françisco, de la çibdat de Palençia, ${ }^{27}$ a cada orden dellas, que vayan de cada orden ocho frayres, al dicho lugar de Fusiellos, a me dezir vigillia et otro día, missa de réquiem, a cada orden çient maravedís. Item mando que los den de comer, a los dichos frayres, antenoche et otro día de mi enterramiento fecho. Item mando a los dichos frayres destas dos / órdenes de Sant Pablo et de Sant Françisco de Palençia, porque digan missas et rrueguen a Dios por mi alma, a cada orden, quinientos maravedís; et sobresto, en cargo ssus consçiençias. Item mando a las monjas del monesterio de Santa Clara de Palençia, porque rrueguen a Dios por mi alma, çient maravedís.

Item mando a las mon/jas del monesterio de Santa Clara, cerca de Castro Xeriz, porque rrueguen a Dios por mi alma, çient maravedís. Item mando a todas las enparedadas de Palençia, que son de las eglesias de Santa María de Allén del Río, et de Sant Iullán, et de San Esteuan, et de Sant Miguel, et de Sant Lázaro, et de Santa Marina, et de Santa María del Otrero, $/^{30}$ et de Santa María de Villa Moriel, et de Sant Pero de Poblaçión, si alguna enparedada y ouiere, et de Santa María de Villa Uerde, çerca de Magaz, a cada enparedada, çinco maravedís, porque rrueguen a Dios por mi alma.

Item mando a los clérigos de Sant Quirze, et de Santa Leocadia de Castriello de Villa Vega, et a los clérigos de Sant Andrés / de Villa Vega, que me digan vigillia antenoche et otro día missa de réquiem, çient maravedís. Item mando a la dicha eglesia de Sant Quirze, un cáliçe de plata en que aya marco et medio. Item mando a los dichos clérigos de Sant Quirze, et de Santa Localla, et de Sant Andrés, para 
missas cantar por mi alma et por las ánimas de que tengo car/ga de rrogar, quatroçientos maravedís.

Item mando a mis mansessores que compren, de mis bienes, terras o viñas o molino, en el dicho lugar de Castriello o en sus términos, que renda ocho cargas de pan en cada año. Et estas ocho cargas de pan, que las den por amor de Dios en el dicho lugar de Castriello, desdel día de Todos Santos, ${ }^{\beta 3}$ en cada año, fasta el día de Sant Iohán de junnio, segund que se da el pan, que y dan por el ánima de Pero Ferrández, abbat que fue de Fusillos, que Dios perdone; et este dicho pan que se dé en el ospital de sant Antolín, que fizo el dicho abbat en el dicho lugar de Castriello.

Item mando a las enparedadas de Santa María de las Pernia, a ca/da vna dellas, diez maravedís, porque rrueguen a Dios por mi alma. Item mando a çinco moças huérfanas que sean de mis parientes, más propicias para casamiento, a cada una dellas, quinientos maravedís.

Item mando a mis manssessores que enbíen, por mi alma, un omme a la casa santa de Iherusalém et a Sant Peydro et a Sant Pablo de Roma . Et los mis / manssessores que les den bien porque de mis bienes, al que enbiaren allá, et que le enbíen luego, lo más ayna que seer podiere; et si por auentura non fallaren quien vaya allá, mando a mis manssessores que ayan consejo con letrados, porque se distribúa lo que costare yr a Iherusalém et a Sant Peydro et a Sant Pablo de Roma et que lo $/^{36}$ den et paguen, por mi alma, en otra obra de piedat, do vieren et fueren consejados que cumple a salvamiento de mi alma.

Item mando a mis mansessores que enbíen a dos omes, por mi alma, el uno, a Santa María de Guadalupe et el otro, a Santiago de Galizia, et que los den de mis bienes porque vayan allá.

Item mando a / mi sobrino Pero, fijo de Gonçalo Ferrández de Castriello de Villa Vega, para ayuda con que aprenda et sea omme bueno, sieteçientos maravedís. Item mando a Sancha Alfonso, mi casera, por serviçio que me fizo et porque ruegue a Dios por mi alma, mille maravedís, et un pellote de paño que cueste la vara a veynte maravedís; et que la dicha San/cha Alfonso, que lieue la ofrenda por mi alma. Item mando a Françisco Ferrández, notario público de Palençia, mi cuñado, por serviçio que me fizo et porque rruegue a Dios por mi alma, quatroçientos maravedís. 


\section{LA ABADÍA DE SANTA MARÍA DE HUSILLOS: ESTUDIO Y COLECCIÓN \\ DOCUMENTAL $(904-1608)$}

Item mando a Peydro de Carrión, mi criado, por serviçio que me fizo, veynte et çinco cargas de trigo, a quatro fanegas la carga. Item mando $/^{39}$ las mis casas que yo he en Oterdajos, con sus huertas et la mi choça, que esta dentro del cortiio del dicho lugar, et la vez que yo he en el molino que dizen de Puente, que es çerca de las eras del dicho lugar de Oterdajos, et los mis herrennales et la meatad de toda la heredat de pan leuar que yo he en los térmi/nos del dicho lugar de Oterdajos et de Barrihuelo o en otros términos cercanos, con todas sus entradas et con todas sus salidas et con todas sus pertenençias, a mis señores deán et cabillo de la eglesia cathedral de Santa María de Burgos, por juro de heredat; et pídoles por merçed que me fagan memorias por mi alma, / que sean tres et que rrueguen a Dios por mi alma, et estas tres memorias que me las fagan quando la su merçed touiere por bien et que las fagan poner et escriuir en el su libro. Otrosy, les pido por merçed que me manden fazer aniuersarios por el bien et rreparamientos que yo fize et he fecho et fago et faré en las casas $/^{42}$ del cabillo en que yo moro aquí, en Burgos, a las canales; ca bien saben, los dichos señores, en qué estado las tomé et entré en ellas. Item mando la otra meatad de toda la otra mi heredat de pan leuar, que yo he en los términos del dicho lugar de Oterdajos et de Barrihuelo o en otros térmi/nos çercanos, para el ospital que yo tengo fecho en Fusiellos, que sea suyo, libre et quito, con todas sus entradas et con todas sus salidas et con todas sus pertenençias, para dar limosna de pan en el dicho lugar de Fusiellos, en el dicho ospital.

Item mando las mis casas que yo he en Palençia, las en que yo moro, que fu/eron de Ferrand Alfonso, portero que fue del cabillo de la eglesia de Palençia, con la casa que yo oue del cabillo de Palençia por permutaçión, segund que oy día las he et posseo, et todas las viñas que yo he en los términos de Palençia, et de Villa Moriel, et de Villalobón, et de Quintaniella, para dos capellanías perpetuas, $/^{45}$ para dos capellanes que canten, perpetuamente, en la dicha capilla de Sant Quirze, que yo fize fazer en la iglesia de Fusiellos. Otrosí, mando más para las dichas dos capellanías, las mis casas con su huerto que yo he en la dicha ciudad de Palencia, a donde vivo; las quales casas et huerto, oue yo comprado et compré de Aluar Diez de Villalobón. Et la collación de las dichas / dos capellanías, mando que sean de dar en mi vida mías e después de mi vida, que las prouea e faga collación, dellas, Domingo Goncález, mi hermano, chantre de Fusillos, e que después de su 
vida del dicho chantre, mi hermano, que las pueda dar y fazer collación et institución, de las dichas capellanías et de cada una dellas, del chantre que fuere por tiempo de la dicha eglesia de / Fusiellos et las pueda dar et fazer collaçión, dellas et de qualquier dellas, cada que vacaren, de fecho o de derecho, del día que vacare fasta e un mes complido estonçe seguiente, a clérigos que [...] et del dicho chantre, mi hermano, ssy fueren fallados ydóneos et sufiçientes para qualquier de las dichas capellanías, otramient a otres qualesquier cléri ${ }^{48}$ gos que fallen sufiçientes et ydóneos commo dicho es. Ca si el dicho chantre la non ouiere fecho, la dicha collaçión, dentro del dicho mes, commo dicho es, que el abad de Fusiellos que agora es o el que fuere por tiempo, sin presentaçión de otro alguno, pueda fazer et faga la dicha collaçión, dentro dos meses entonçe inmediato seguientes, a clérigo ydóneo et sufiçiente del di/cho linage, si se podiere fallar, otramient a otro qualquier clérigo ydóneo et sufiçiente. Et la dicha collaçión fecha por el dicho abbad, que las otras collaçiones de las dichas capellanías, [...] cabo al dicho chantre et las pueda fazer et faga cada que uacare, en la forma et manera que dicha es. Et estos dichos capellanes et cada uno dellos que agora / son et serán, cabo adelante, que sean tenidos por sienpre jamás de çelebrar, por sy, o fazer çelebrar, por otro, missas en la capiella et altar de Sant Quirze susodichas, a lo menos tres días en la semana. Et sy asy non lo fizieren, commo dicho es, quel chantre que agora es o el que fuere por tiempo en la dicha eglesia de Fusiellos, que lo pueda et deua fazer complir por qualquier otro $/^{51}$ capellán. El quel dé, por cada missa, un maravedí de la rrenta et bienes de qualquier de los dichos dos capellanes, que agora son o serán cabo adelantre, por quien fallesçiere de fazer et complir lo que dicho es. Et si el dicho capellán por quien fallesçiere en çelebrar o fazer çelebrar las dichas missas, commo dicho es, non quesiere pagar el dicho maravedí o maravedís, que el dicho chantre, / que agora es o será cabo adelantre, quel pueda tomar de sus bienes, doquier que los fallare, para pagar el dicho maravedí o maravedís cada que acahesçiere. Et otrosy, que estas dos capellanías que agora son [...] porque en las dichas capellanías et en qualquier dellas non puedan nin deuan auer nin tener, con la dicha capellanía, otro benefiçio eclesiástico en la dicha eglesia, saluo / media rraçión en la dicha eglesia de Fusiellos, si Dios ge la diere. Et si los dichos dos capellanes que agora son o serán cabo adelantre o qualquier dellos ganaren otro benefiçio qualquier [...] eglesia, 


\section{LA ABADÍA DE SANTA MARÍA DE HUSILLOS: ESTUDIO Y COLECCIÓN \\ DOCUMENTAL $(904-1608)$}

fuera de la dicha media rraçión, que por ese mismo fecho pierda la dicha capellanía. Et el dicho chantre que agora es o el que fuere por tiempo, que la pueda dar et la dé et ${ }^{54}$ pueda fazer collaçión, della, luego si quesiere o dentro un mes, a clérigo ydóneo et sufiçiente, en la forma et manera sobredichas. Otrosy, mando que si los dichos deán et cabiello [...] eglesia de Burgos, quesieren fazer algund guisa o tomar alguna cosa de mis bienes, lo que yo quiero et fío en la su merçed, que lo non farán nin querrán fazer, porque yo non les / deuo nin he, a día, cosa alguna fasta aquí, que los mis mansesores nin mis herederos que les non den nin rrecuden con ninguna nin alguna cosa de lo sobredicho que les yo mando en este $[\ldots]$ ninguna dello [...] yo lo rreuoco todo si lo asy fizieren quanto les mando en este mi testamento.

Et por esta mi carta de testamento et de mi postrimera voluntat, do to/do mío poder complidamient segunt que mejor et más complidamient lo yo deuo et puedo auer et fazer de derecho, a mis mansesores et cabeçaleros o a qualquier dellos, para que ellos o qualquier dellos [...] et puedan escoger dos o tres omes buenos letrados, en qualquier çibdat o villa o lugar que los fallaren et pudieren auer, para que los consejen et ayan con ellos su acuerdo, $/ /^{57}$ para que ordenen et puedan ordenar las dichas dos capellanías et hospital en el dicho lugar de Fusiellos, en aquella manera et forma que ellos vieren et entendieren que es más proueçio de Dios et a saluo de las almas de Domingo Gonçález, mi hermano, chantre de Fusiellos, et de la mía, por rrazón que yo non so omme tan letrado nin tan sabidu para lo ordenar.

Estos los dineros / et maravedís, et pan, et trigo, et çeuada, et çenteno, et comunna que me deuen et an a dar estas personas que se siguen: item déueme, Iohán Sánchez de Bustamante, dos mille maravedís et tengo contracto sobrel, que fizo Pero Gonçález de Muga, escriuano público de Burgos. Item deue más el dicho Iohán Sánchez, seys mille maravedís de otra parte, de los quales los tres mille maravedís son de Pero Ferrández, arçediano de Carrión, et los otros tres mille maravedís míos, fizo / el contracto el dicho Pero Gonçález de Muga, escriuano. Item deue Pero Gómez de Porras, çient maravedís; destos çient maravedís, son los çinquenta maravedís del dicho arçediano et los otros çinquenta maravedís míos. Item deue Garçi Sánchez de Bustamante, veynte et seys doblas de oro castellanas de la rrenta del monesterio de Várzena, del año de la era de mille et quatroçientos 
et diez et ocho años, que fue sede vacante. Et a de auer $/{ }^{60}$ el dicho arçediano de Carrión las treze doblas et yo las otras treze doblas. Item déueme Ferrand Gonçález, clérigo de Salarzar, de los préstamos de Salarzar et de Gelolledo, que recabdó por mí en los años pasados; son del año de la era de mille et quatroçientos et veynte et un años, segunt que está por su escripto puesto su nombre, de trigo treynta et seys cargas et media et de ceuada / sesenta cargas et de çenteno et de comunna sesenta et una cargas et media; et deste pan es a sacar lo que dio de pan a Iohán Ferrández de Castriello. Item deue más, el dicho Ferrant Gonçález, del año de mille et quatroçientos et veynte et un años, todo el trigo et ceuada et çenteno et comunna que ouo en los dichos terçios et desto a de dar cuenta, el dicho Ferrant Gonçález, quanto ouo et pagarlo. Item deue Alfonso Gonçález, arçipreste de / Santa Yllana, clérigo de la eglesia de Sant Miguel de Aguilar de Canpo, todo el pan et diezmos que se coguen en Vega, quaderno que passó por Françisco Ferrández, notario de Palençia, en que esta puesto el nombre del dicho Alfonso Gonçález. Item deue más, el dicho Alfonso Gonçález, arçipreste de los monesterios de Sant Miguel de Campoo et de Santa Cruz, del año de la era de de mill [et quatroçientos] et quinze años, dozientos maravedís. Sobresto ay contracto. Item deue $/^{63}$ más el dicho Alfonso Gonçález, arçipreste, quatroçientas et çinquenta fannegas de çenteno annejo de los años de mille et quatroçientos et diez et seys et de mille et quatroçientos et diez et siete años, que pasaron. Item deue más el dicho Alfonso Gonçález, arçipreste, dos cueros, el uno de buey et el otro de vaca, que quedaron en su casa, lo que vieren que pueden valer. Item deue más el dicho Alfonso Gonçález, arçipreste, ochenta maravedís que entró por mano, de dar para / el cabillo de Santa Yllana et que los auía a dar et pagar Iohán López Guadiana et estos maravedís rreçibió por sentençia de (en blanco), canónigo de Santa Yllana, et del arçediano de Carrión, prouisor del obispado de Burgos, et passó por Françisco Ferrández, notario público de Palençia. Item deue Martín Ferrández, vezino de Villa Diego, et [...], clérigo del dicho lugar de Villa Diego, quarenta et çinco cargas de pan, meatad trigo et / meatad çeuada, et a contracto et sentençia dello et que fizo Sancho Sánchez, escriuano del consistorio de la eglesia de Burgos. Item déueme Garçía Ruyz, escriuano de Villa Diego, fijo de Ferrand Garçía, treynta cargas de pan, meatad trigo et meatad çeuada, de la rrenta de Cobiellas et de Touarcio, que de mí arrendó en el año de mille et quatroçientos et 


\section{LA ABADÍA DE SANTA MARÍA DE HUSILLOS: ESTUDIO Y COLECCIÓN \\ DOCUMENTAL $(904-1608)$}

diez et nueue años, et él mismo, el dicho Garçía Ruyz, fizo el contracto. Et si alguna cosa $/{ }^{66}$ deste pan, paresçiere que ha pagado, deste año o de otro año que lo arrendó de mí, por quaderno de Sancha Alfonso, mi casera, que lo rreçibió, et el otro año que arrendó de mí estos dichos préstamos, fueron veynte et çinco cargas de pan, medio trigo et medio çeuada, que fue en el año de mille et quatroçientos et veynte años; et lo que fincare por pagar, destos años, que lo pague, et el contracto fizo el mesmo. Item deue Iohán Ferrández de Castrie/llo, rracionero en la eglesia de Santa María de Almaçán de Castro Xeriz, mi sobrino, todo el trigo et çeuada et çenteno et comunnal et dineros et auena, segunt que se contiene en dos escriptos, el uno que tiene él et el otro que tengo yo, los quales escriptos estan rrobrados del nombre de Iohán [...] de [...], et los menudos de lana et quesos et otros menudos, quitógelos, que ge los non demanden; et otrosy, de los diezmos que el dicho Iohán Ferrández me deue, que piensso que serán fasta / seysçientos maravedís, quítole la meatad dellos et la otra meatad, mando que los pague. Item tiene de mí en guarda, Martín Rodríguez, clérigo de Santa María del Campo, este pan de quatro et çinco annos, de trigo diez cargas, de ceuada diez cargas. Item déueme, Iohán Garçía de Camargo, caballero de Lara, sieteçientos et veynte et çinco maravedís, sobre una cadena de oro et un rreliquiario con una maçana cobierta de aljófar et una maçana de plata sobredorada con $/{ }^{69}$ piedras et aljófar et fallesçe, en ella, una pedrezuela et quatro sortijuelas con sus piedras que paresçen de oro, más yo non lo sé, et una çeriella de plata, que está todo en una caza; mando que dando el dicho Iohán Garçía o su mandado, a nos los dichos sieteçientos et veynte et çinco maravedís, quel den las dichas prendias. Item déueme Pero Martínez de la Henestosa, mille et quatroçientos et çinquenta maravedís, sobre estas prendias que se siguen: Ocho cuer/das de plata, un alhayte de aljófar, una guirlanda de foja con piedras pequennelas et granillos de aljófar, que están en una artequilla; et mando que dando el dicho Pero Martínez o su mandado, los dichos mille et quatroçientos et çinquenta maravedís, quel den las dichas prendias, libres et quitas. Item déueme Miguel Diez, arçipreste de Lerma, dos doblas castellanas que me entró por mano de me pagar por Iohán de Sant Pero, morador en Sallas, / çerca de Lerma. Item déueme Iohán Ferrández, arçipreste de Salas, diez et siete maravedís et medio que pagué por el diezmo de las cubas que me uendió. Item deue María Gonçález, muger que fue de Ferrant Garçía de Marmellar de Yuso, dos ouejas con sus 
corderos, carnero, que son ya borros de dos dientes et todas corderas deste año et más quatro corderos et corderas del año pasado que son agora de dos dientes. Item tiene Iohán Ferrández de Marmellar de $\mathrm{Su} /{ }^{72}$ so, este ganado que se sigue: ouejas parideras quarenta et dos, carneros tres, una cabra, un carnero morueco. Item tiene Pero Gonçález de Barrio Suso, de Marmellar de Yuso, treynta et ocho ouejas parideras, borros et borras honze, carneros tres. Item Pero Gonçález el Moço, vezino de $[\ldots]$ nos, treynta ouejas parideras et un carnero morueco. Item déueme omes de Marmellar de Yuso et Iohán Ferrández ar[...] de Marmellar de Suso et fue fiador Fe/rrand Garçía, pastor que fue mío en Marmellar de Yuso, veynte et tres cargas de pan, trigo et çeuada et çenteno et comunna, et fizo el contracto Françisco Ferrández, notario. Item a de fazer cuente conmigo, de quatro años acá, Alfonso Garçía de Sonlla, mi amigo, canónigo de Burgos, de todo lo que tiene et deue, et pídole por mesura, que tome al escriuano et a Pero Ferrández de Cabeçón, de todos los dichos quatro años o sy más o menos fuere, et si algo / se fallare por las dichas cuentas, que me alcançaren, mando a mis mansessores que lo paguen de mis bienes, et si algo se alcançare que me ouiere a dar, el dicho Alfonso Garçía, que tenga por bien de me lo pagar; et el dicho Alfonso Garçía tiene de mí çiertas pieças de plata et yo auíale de dar, a él, seysçientos maravedís, et yo paguel los quatroçientos maravedís et asy, finca que le deuo et he a dar doscientos maravedís, et véase todo entre ${ }^{75}$ mí et él, por cuenta, et él que deuiere, pague al otro. Item, a se de fazer cuenta con Ferrand Garçía, rraçionero, et con Iohán Sánchez de Tero et con Iohán Martínez, camarero, et con Ferrand Garçía (en blanco), de los años que fueron prepostes, et el pan que se fallare por cuenta que me deuen, que me lo paguen. Item déueme, Pero Garçía Marannon, vezino de Burgos, criado que fue de don Arnalt de Bernorio, sobre un contracto que tengo sobrel, que fizo / Alfonso Ferrández de Angullo, escriuano público de la çibdat de Burgos, mille et quatroçientos et quarenta et siete maravedís. Item déueme más, el dicho Pero Garçía, de otra parte, sin contracto, mille maravedís quel preste para pagar a Iohán Garçía, canónigo que fue de Burgos. Item déueme más, el dicho Pero Garçía, doblas de oro castellanas, de alquiler de las casas del préstamo de Per Angeler, canónigo de Burgos, que son a la seellería. Item déueme más, el dicho / Pero Garçía, los maravedís et doblas de oro que rreçibió de los préstamos de Juan de Baçinaco, canónigo de Burgos, que él et yo arrendamos de 


\section{LA ABADÍA DE SANTA MARÍA DE HUSILLOS: ESTUDIO Y COLECCIÓN \\ DOCUMENTAL $(904-1608)$}

don Arnalt de Bernorio, lo que él dixiere en su buena uerdat et en rrazón de sus préstamos, excargo su consçiençia. Item déueme más, el dicho Pero Garçía, de çenteno et comunna, quatro cargas et media. Item déueme más, de auena vna carga et tres fanegas, et desto todo sobredicho tengo $/^{78}$ yo, el dicho Pero Garçía, veynte cántaras de vino. Item déueme Iohán Gonçález de Villa Harmero et Iohán Gonçález, su fijo, et Iohán Alfonso de Arroyal, vezino que fue de Quintana Dueñas, et Gonçalo de Páramo, et Ferrand Pérez, pescador, vezinos de Quintana Dueñas, cada uno dellos, çient maravedís, segunt pasó por Pero Ferrández de Santa Gadea, notario apostolical. Item déueme Ferrand Alfonso et Iohán Gonçález, fijo de Iohán Gonçález, et Iohán Gonçález, su fijo, et Ruy / Pérez, fijo de Martín Pérez, et Domingo Ferrández, cura, et Ruy Garçía, fijo de Iohán Ferrández, vezinos de Quintana Dueñas, dos mille et çient maravedís, fizo el contracto Pero Martínez de Arroyuelo, escriuano público que fue de Burgos, et rreçibiéronlo por sentençia de Iohán Ferrández de Grijota, casero que fue del obispo don Domingo, que Dios perdone. Item déuenme Pero Ruyz, alcalle, et Iohán Calbo, su criado, vezinos de Burgos, quatroçientos maravedís de la rrenta de/

$<$ Françisco Fernández $>$. $<$ Françisco Fernández $>$

${ }^{81}$ casas que arrendaron del año de la era de mille et quatroçientos et un años, fizo el contracto [...] Royz, escriuano público que fue de Burgos; el contracto está aquí, en esta casa. Item déueme, Martín Ferrández de Fresneda, clérigo, treynta et ocho almuedes de trigo et çinco almuedes de centeno et quatro almuedes de ceuada; et está estimado este dicho pan $[\ldots] \mathrm{s}$, el al/mud de trigo a quinze maravedís et medio et el almud de çeteno a treze maravedís et medio et el almud de çeuada a siete maravedís et medio; et estos maravedís que monta este dicho pan, rreçibió el dicho Martín Ferrández por sentençia de abbad de Salas, vicario del obispo de Burgos, de lo dar et pagar aquí, en Burgos, fasta primero día de mayo, primero que viene, et / passó la sentençia por Sancho Sánchez, escriuano del consistorio. Item déueme, [...]ro López, clérigo de Muga, criado del coro de la eglesia de Burgos, quinientos et çinquenta maravedís de los préstamos de Iohán de Luçianos, canónigo, que arrendó de mí; et deue más, çinco cargas de trigo de las tercias de los años passados. 
Et para complir $/^{84}$ este mi testamento et mi postremera voluntat, fago mis mansessores a Domingo Gonçález, mi hermano, chantre de Fusiellos, et Alfonso Garçía de Villoldo, vezino de Palençia, et a Ruy Gonçález, mi sobrino, fijo de Andrés Gonçález de Villa Vega, vezino de Palençia, et a todos en uno et a cada uno por su / cabo. Et apodérolos en todos mis bienes, muebles et rrayzes, doquier que los yo he et a mí pertenesçen, para que cumplan et paguen et fagan todo lo que yo mando en este mi testamento et postremera voluntad se contiene. Et quiero et mando que non sean desapoderados de todos los mis bienes nin de parte dellos, los dichos mis mansessores nin alguno / dellos, por heredero que yo faga et establezca nin por otra persona alguna, et que yo escojo la industria et las personas dellos et non de otro alguno, para que fagan et cumplan todo lo que sobredicho es. Et do llanero et complido poder, a los sobredichos mis mansessores et a cada uno dellos, para que puedan demandar et rresçendir et negar $/^{87}$ et connosçer, en juyzio et fuera de juyzio, asy por mí comme contra mí, et fazer et complir todas las cosas que yo faría et diría, aunque sean tales que espeçial mandado rrequirán, so obligaçión de mis bienes espirituales et temporales. Et complido et pagado todo esto sobredicho que yo mando en este mi testamento et mi postremera voluntat, segunt / que en él se contiene, fago et dexo por mi heredero de todos los otros mis bienes que fincaren, asy muebles commo rrayzes, quantos oy día he et por doquier et en qualesquier lugares que los yo he, al dicho Domingo Gonçález, mi hermano, chantre de Fusiellos, para que los aya libres et quitos por juro de heredat.

Et rreuoco et desfago todas las otras mandas et testa/mentos et codiçillos que yo he fecho fasta el día de oy, quier por palabra, quier por escripto o en otra manera qualquier, et mando que non valga otro alguno, saluo este mi testamento et mi postremera voluntat que yo agora fago et ordeno por mi manda et por mi testamento. Et mando que si valier por manda o por testamento, sinon que vala ${ }^{90}$ por codiçillo, sinon en aquella manera et forma que deuiere valer de derecho.

Et porque todo esto sobredicho sea firme et valedero et non venga en dubda, rogué a Françisco Ferrández, escriuano público de la çibdat de Palençia et escriuano et notario público de nuestro sseñor el rey en la su corte et en todos los sus regnos, que está presente, que escriuiese esta / carta de testamento et que la signase con su signo. 


\section{LA ABADÍA DE SANTA MARÍA DE HUSILLOS: ESTUDIO Y COLECCIÓN \\ DOCUMENTAL $(904-1608)$}

Fecha et otorgada fue esta carta de testamento por el dicho Gonçalo Gonçález, arcipreste, en la muy noble çibdat de Burgos, lunes, nueue días de abril, año del nasçimiento de nuestro señor Ihesu Christo de mille et trezientos et ochenta et seys años.

Testigos que a esto todo sobredicho fueron pre/sentes, llamados et rrogados para esto: Iohán Pérez, clérigo et cura de la capiella de Santiago de la eglesia cathedral de Santa María de Burgos, et Martín Ferrández, fijo de Martín Ruyz de Valde Vielso, et Gil Ferrández, tomador, fijo de Ferrand Pérez, et Lope Gonçález, criado que fue de Iohán Gonçález, capiscol que fue de Burgos, et Iohán Ferrández de Burueua, escudero del rey, et Iohán Rodríguez $/^{93}$ de Auilés, et otros, vezinos et moradores en la dicha çibdat de Burgos.

Et yo, Françisco Ferrández, notario público sobredicho de la dicha çibdat de Palençia et escriuano et notario público de nuestro sseñor et rey en la su corte et en todos los sus regnos, que fu presente a todo esto sobredicho, segunt dicho es en esta carta de testa/mento se contiene, con los dichos testigos. Et por ruego et pedimiento del dicho Gonçalo Gonçález, arçipreste, escriuí esta carta de testamento en estos dos pedaços de pargamino, que estan cosidos con filo de lino. Et entre pedaço et pedaço escriuí mi nombre en tres lugares, et fiz aquí este mío $\operatorname{sig}($ signo $)$ no en testimo/nio de verdat.

En las 47 primeras líneas, en que la escritura está en mejores condiciones, algunas letras han sido repasadas con posterioridad y con otro tipo de tinta. Las líneas 48 y 49 están prácticamente repasadas enteras, salvo unas pocas letras. En algunos casos, el escriba se ha equivocado y ha puesto otra letra. Nosotros respetamos ésto al no poder, en algunos casos, saber la letra que en un principio existía.

A partir de la línea 49 ha sido posible la transcripción del documento gracias a la luz ultravioleta. Aún así existen partes rozadas y una gran mancha en las que es imposible la lectura.

1388, abril, 25 . 
Fernán Clemente, hijo de Pedro García Clemente, vecino de Grijota, vende a Domingo González, chantre de Santa María de Husillos, una tierra en término de Grijota que pertenecía a Vicente, su sobrino, con la tercera parte de la cebada que está plantada, en precio de trescientos sesenta maravedís.

B. APA, $L P H$, ff. $120 \mathrm{v}-121 \mathrm{r}$.

Fecho et sacado fue el dicho traslado en la villa de Husillos, a veynte et nueve días del mes de noviembre de mil y quinientos y çinquenta et quatro años.

Testigos que fueron presentes a lo ver, leer, corregir et conçertar, Gaspar de Vedoya e Joán Ruiz Cabeça de Vaca, clérigos, et Pero Manuel, estantes en la dicha villa.

Et yo, Santiago Gómez, escriuano público en la dicha villa, fui presente a lo que dicho es en vno con los dichos testigos. Y del dicho pedimiento et mandamiento, lo fize escrevir e fize aquí mi signo (signo) en testimonio de verdad.

Pero Ruyz de Villoldo (rúbrica). Santiago Gómez (rúbrica).

Sepan quantos esta carta vieren, como yo, como yo (sic), Fernán Clemente, hijo de Pero Garçía Clemente, vezino que soy de Grijota, otorgo e conozco que vendo a vos, Domingo Gonçález, chantre de Husillos, vna tierra de Vicente, mi sobrino, que es en término de Grijota, que fue de Juan Fernández de Grijota, arcipreste de Río de Obirua, que es en linde tierra de Hernán Garçía e de la otra parte, en linde tierra de Juan Carnicero. Esta dicha tierra que ha estas dichas afrontaciones, vos vendo con la tercia parte de la çeuada que en ella está e vos la vendo vendida buena e sano e leal e verdadera, con entradas y con salidas y con todos sus derechos y vsos e pertenencias, por trezientos e sesenta marauedís desta moneda vsual que agora corre, de los quales dichos marauedís me otorgo por bien pagado y entregado. E sobre esto rrenuncio las leyes del derecho, la vna en que dize que los testigos de la carta deven uer fazer la paga de la cosa sobre que es fecho el contrato; e la otra ley en que dize que fasta dos años sea el home tenudo de probar la paga que faze, saluo si aquel o aquellos que han de rreçebir la paga rrenunciaren estas dichas leyes e se partieren dellas. E yo rrenúnciolas y pártome dellas, que sy las ante mí pusieren, que me non valan, en juizio ni fuera de juizio. E obligo a todos los mis bienes, muebles y rrayzes, quantos oy día he y havré de aquí $(f .120 v)$ adelante, para vos fazer sanas las dichas tierras de 


\section{LA ABADÍA DE SANTA MARÍA DE HUSILLOS: ESTUDIO Y COLECCIÓN \\ DOCUMENTAL $(904-1608)$}

qualquier home o mujer que vos lo demandare, todas o parte dellas. Si no, que vos dé y peche otras tales tierras e tan buenas, en otro tal lugar o en mejor dobladas, o los dichos trezientos y sesenta marauedís, doblados.

Fecha esta carta a XXV días del mes de abril, año del nascimiento de nuestro señor Jesuchristo de M CCC LXXX VIII annos. Testigos que fueron presentes: Miguel Pérez, y Juan Carniçero, y Diego Díaz, vezinos de Grijota, e otros.

E yo, Fernando Díaz de Grijota, notario público de la ciudad de Palencia, fui presente a todo esto que dicho es con los dichos testigos. E por rruego del dicho Fernán Clemente escriuí esta carta e fize aquí este mi signo en testimonio de verdad.

1388, mayo, 3, domingo. Husillos.

Juan Carnicero, hijo de Pedro Carnicero, vecino de Grijota, vende a Domingo González, chantre en Santa María de Husillos, una tierra en término de Grijota de una obrada y media, en el pago que llaman Alerguera, en precio de cuarenta maravedis.

$B$. APA, $L P H$, f. $121 \mathrm{r}-\mathrm{v}$.

En este documento, a pesar de estar hecho, solamente, ocho días después, ya figura como límite de la tierra vendida la propiedad transferida por Fernán Clemente el día 25 de abril de 1338 (véase doc. núm. 208). Además está presente como testigo.

Fecho et sacado fue el dicho traslado en la villa de Husillos, a veynte et nueve días del mes de novienbre de mil e quinientos e çinquenta et quatro años. Testigos que fueron presentes a lo ver, corregir et conçertar, Gaspar de Vedoya et Joán Ruiz Cabeça de Vaca, clérigos, e Pero Manuel, estantes en la dicha villa.

Et yo, Santiago Gómez, escriuano público en la dicha villa, presente fui a lo que dicho es en vno con los dichos testigos. Et del dicho pedimiento et mandamiento lo fize escrevir et fize aquí mi signo (signo) en testimonio de verdad. 
Pero Ruyz de Villoldo (rúbrica). Santiago Gómez (rúbrica).

Sepan quantos esta carta vieren, como yo, Juan Carnicero, fijo de Pero Carnicero, vezino que soy de Grijota, otorgo e conozco que vendo a vos, Domingo Gonçález, chantre de Husillos, una tierra que yo he en término de Grijota que ha obrada y media, que es a do dizen Alerguera, en linde de tierra de vos, el dicho Domingo Gonçález, chantre, que fue de Hernán Clemente, e de la otra parte, tierra de Domingo Fernández Lorenço. Esta tierra que estas dichas afrontaciones encierra, vos vendo vendida buena, sana y leal y verdadera, con entradas y con salidas y con todas sus pertenencias por quarenta marauedís desta moneda vsual que agora corre, que fazen diez dineros un marauedí, de los quales me otorgo por bien pagado. Y sobre esto, renuncio las leyes del derecho, la vna en que dize que los testigos deuen ver fazer la paga de la cosa sobre que es fecho el contrato e la otra ley en que dize que fasta dos años es hombre tenudo a probar la paga que faze, saluo sy aquel o aquellos que han de rreçebir la paga rrenunciaren estas dichas leyes e se partieren dellas. E yo, rrenúnciolas e pártome dellas, que sy las ante mí pusiere, o otro por mí, que me non valan, en juizio ni fuera de juizio. E con esta carta, vos apodero en la dicha tierra para que sea vuestra propria, libre y quita, para vender y empeñar y trocar e para fazer della y en ella todo quanto quisiéredes e por bien tuuiéredes, ansy como de las vuestras cosas proprias. Obligo todos mis bienes, muebles y rayzes, quantos oy día he, para vos hazer sana la dicha tierra de qualquier hombre o mujer que vos la contrallare, si no, que vos de otra tal y tan buena y en tan buen lugar o en mejor, doblada, o los dichos quarenta marauedís, doblados.

Fecha esta carta en Fusillos, domingo, tres días de mayo, año del nascimiento de nuestro señor Jesuchristo de M CCC LXXX VIII años. Testigos que fueron presentes: Alfonso Gonçález, (f.121r) clérigo de Grijota, compañero en la yglesia de Sancta María de la villa de Husillos, e Fernán Clemente, e Pero Alfonso, vezino de Grijota, e otros.

E yo, Fernando Díaz de Grijota, notario público de la ciudad de Palencia, fui presente a todo esto que dicho es con los dichos testigos. E por rruego del dicho Juan Carnicero escriuí esta carta e fize aquí este mío signo en testimonio de verdad. 
1388, octubre, 2. Palencia

Juan I, atendiendo las reiteradas amenazas y desagravios a Santa María de Husillos por parte de los caballeros, hidalgos y concejos donde esta iglesia tenía heredades y derechos, pone bajo su protección sus propiedades y vasallos.

B. AHDP, Ampudia y Abadía de Husillos, Pergaminos, carp. 202-30. Perg., 326 x 331 mm.; escr. gótica redonda de privilegios y precortesana; bastante deteriorado, con dos grandes roturas que impiden la lectura de parte del texto. No conserva el sello ni la cinta; el lugar donde se sujetó está rasgado. Inserto en confirmación de Enrique III dada en Burgos, a 20 de febrero de 1392. Véase doc. núm. 212.

C. AHDP, Ampudia, Serie G, Pergaminos. Privilegios Reales, carp. 202-32. Perg., 551 x 469 mm.; escr. precortesana; buena conservación. Inserto en el traslado del privilegio de Enrique III confirmatorio del privilegio de Juan I, sacado en Palencia, a 14 de febrero de 1394. Véase doc. núm. 216.

$D$. APA, $L P H$, ff. $122 \mathrm{r}-123 \mathrm{v}$. Traslado de $B$.

Esta escritura se enmarca en el contexto general de ataques a bienes eclesiásticos que tuvo lugar especialmente en la segunda mitad del siglo XIV por los poderes laicos, reflejo de un período de crisis, a los que tuvo que hacer frente en numerosas ocasiones la propia realeza, poniendo bajo su amparo a las instituciones eclesiásticas

Don Iohán, por la graçia de Dios rrey de Castilla, de León. de Portogal, de Toledo, de Galizia, de Sevilla, de Córdoua, de Murçia, de Iahén, del Algarbe, de Algezira et señor de Lara et de Viz/ ${ }^{3}$ caya, a los adelantados de Castilla et de León et a los merinos, que agora son o serán de aquí adelante, que andudieren, por nos o por vos, en los ofiçios, et a todos los otros alcalles, juezes et justiçias et merinos de / las çibdades, villas et lugares de los nuestros rregnos et a qualquier o a qualesquier de uos, que esta nuestra carta fuere mostrada o el traslado della sacado con abtoridat de juez et signado de escriuano público, salud et / graçia. 
Sepades que Iohán Gonçález, abad de la eglesia de Santa María de Fusillos, et prior et cabiello, por sí et en nonbre de sus lugares et vasallos, se nos querellaron et dizen que algunos de los caualleros et es $/{ }^{6}$ cuderos et conçejos et moradores en los lugares de las merindades de Campos, de Monçón, et de Çerrato, et del obispado de Palençia, sennaladamente los conçejos et omes buenos de la cibdat de Palençia, / et de Paredes de Naua, et de Bezerril, et de Villunbrales, et de Fuentes de Don Bermuda, et de Fuentes de Val de Pero, et de Monçón, et de Val Despina, et de Calabaçanos, et de Villa Martín, et de Grijota, et de Ribas, et de Hamu/sco, et Pinna, et Santoyo, et Villa Mediana, et de Val de Sanze, et de Çivico Nabero, et de Tórtolas, et de Castro Verde de Cerrato, et señaladamente et el concejo del dicho lugar de Villunbrales, que les fazen injurias et agrauios $l^{9}$ et dannos, en las personas et en sus bienes et posesiones et en sus lugares et vasallos. Et los amenazan que les derrocarán sus lugares et que les destroyrán sus posesiones et paçerán las yeruas de sus términos contra su voluntad, / por ellos querer defender el su lugar de Sant Yllán de la Cuesta et los otros sus lugares et vasallos et términos et posesiones con derecho et rec[abdar] sus rentas et prosegir sus derechos. Por lo qual, non osan morar los / dichos sus vasallos en los dichos sus lugares nin los dichos abbad et prior et cabiello et benefiçiados nin sus procuradores demandar sus rentas [et sus de]rechos, temiéndose de desonrra o de muerte. Et en esto dizen $/{ }^{12}$ que la dicha eglesia de Fusillos et los dichos abbad et prior et cabildo et benefiçiados et moradores en los sus lugares, resçiben muy grande agrau[io et daño] et pérdida et menoscabo.

Et pidiéronnos, por merçed, que los re/çibiésemos en nuestra guarda et en nuestro defe[ndimi]ento, a la dicha eglesia, abbad, prior et cabildo et benefiçiados et sus procurad[ores et a todos sus lugares et] vasallos et moradores en ellos, los asegurásemos et pusié/semos seguro, entre ellos et los dichos caualleros et escuderos et conçejos et cada uno dellos et entre las singulares pers[onas, en los dichos conçejos]. Et nos, por ésto et porque las eglesias de los nuestros regnos son ${ }^{15}$ so nuestra guarda et defendimiento et deben beuir en paz et en sosiego, touímoslo por bien. Et por ende, nos resçebimos la dicha eglesia et a los [dichos abad et] prior et cabiello et a todos sus benefiçiados et procuradores et vasa/llos et sus lugares et moradores dellos et a todos sus bienes, muebles et rrayzes, doquier que los han, en nuestra guarda et en nuestro defendimiento. [Et los asegur]amos 


\section{LA ABADÍA DE SANTA MARÍA DE HUSILLOS: ESTUDIO Y COLECCIÓN \\ DOCUMENTAL $(904-1608)$}

de los dichos caualleros et escuderos [et] moradores en las / dichas merindades et obispado et de los conçejos et omes buenos de los dichos lugares et de las singulares personas dellos. Espeçialmente [aseguram]os al dicho lugar de Sant Yllán et a los vezinos et morado $/{ }^{18}$ res en él, del dicho conçejo de Villunbrales et de los vezinos et moradores en él. Et mandamos que este nuestro seguro, que así ponemos, que [sea guarda]do del día que fuer publicado en los dichos lugares pública/mente por las plaças, en manera que non pueda ninguno allegar ynorançia, so aquellas penas en que caen aquellos que quebrantan segur[o puestos p]or su rey et por su señor. Et por más conplimiento de / justiçia, mandamos a vos, los dichos cavalleros et escuderos et conçejos et omes buenos et a cada vnos de uos, en vuestros lugares et juredi[çiones, que d] edes tregua et seguro, de dichos et de fechos et de consejo, $/^{21}$ segund que es vso et costunbre de cada vno de vuestros lugares, a los sobredichos abad, prior et cabiello et benefiçiados et sus procuradores [et a los sus] vasallos et lugares et moradores en ellos, porque puedan / morar et beuir en cada vno de sus lugares, en paz et en sosiego et labrar sus posesiones et recabdar sus rrentas et derechos, seguramente. [El qual segur]o nos ponemos entre ellos et vos, los sobredichos. Et si / alguno o algunos de uos, los sobredichos, non quisiéredes dar nin otorgar la dicha tregua et segurança, nin quisiéredes paresçer ante los alcalles et [merinos de] cada lugar de los sobredichos, para dar et otorgar a los $2^{24}$ sobredichos abad, prior et cabiello et benefiçiados et sus procuradores et vasallos et moradores en los dichos sus lugares et a cada uno dellos la [dicha tregua] et seguro, mandamos a los dichos adelantados de / Castilla et de León et a los merinos que agora son o serán de aqui adelante, que andan por nos o por los dichos adelantados en los dichos ofiçio[s et a los] alcalles et merinos de cada uno de los dichos lugares et a to/dos los otros alcalles et merinos et justiçias de los nuestros regnos, que para ésto por el dicho abad o prior o cabildo o benefiçiados o por sus procuradores [o por sus vas]allos o por los moradores de los dichos sus lugares, fue $/{ }^{27}$ ren llamados et requeridos, que pongan la dicha tregua et seguro por escriuano público. Et fagan luego pregonar la dicha tregua et seguro por las [plaças et mer]cados de cada lugar de los sobredichos, porque todos las / veades et sepades. Et que vos enplazen la dicha tregua et seguro et las guardades entre vosotros, so aquella pena o penas que son de fuero et [de derecho]. Et si alguno o algunos de vos et de cada vno de uos, non 
/ guardades la dicha tregua et seguro et los quebrantamientos, de dicho et de fecho et de consejo, mandamos a los dichos ofiçiales et a ca[da uno dell]os, que proçedan et pasen contra vos et contra cada vno de uos $\beta^{30}$ penas que fallaren por fuero et por derecho et por las leyes de los ordenamientos fechas en esta razón, así commo contra aquellos [que quebrantan] tregua et seguro puesto por su rrey et por su señor natural, / que nos resçebimos en nuestra guarda et encomienda et defendimiento a los dichos eglesia, abad et prior et cabiello et benefiçiados et sus procur[adores et $\mathrm{su}$ ] s lugares et moradores dellos et a sus bienes et posesiones, / muebles et rrayzes.

Et tenemos por bien [et e]s nuestra merçed, que anden saluos et seguros por todas las partes de nuestros rregnos. Et [los unos et] los otros non fagades ende al, so pena de la nuestra merçed et de $/^{33}$ seys mille maravedís a cada vno de uos, desta $\mathrm{m}$ [oneda usual. Et] de commo esta nuestra carta vos fuere mostrada o el traslado della sacado et signado co[mmo dicho es] la cunpliéredes, mandamos, so la dicha pena, a qual/quier escriuano público que para esto fuer[e reque]rido, que dé ende al que vos lo mostrare, testimonio signado con su signo, por[que nos sepamo]s en commo conplides nuestro mandado.

Dada en la / çibdat de Palençia, dos días de otubr[e, año del na]sçimiento de nuestro Ssaluador Ihesu Christo de mille et trezientos et ochenta et ocho años. $\mathrm{N}$ [os, el rey. Et] yo, Ruy López, la fiz escriuir por mandado de nuestro señor $\beta^{36} \mathrm{el}$ rrey. Antonius Sancii, decretorum docto[rum].

1391, diciembre, 2. Palencia.

Francisco Fernández Forro, hijo de Lorenzo Fernández, vecino de Palencia, vende a Domingo González, chantre en Santa María de Husillos, una tierra en término de Husillos, allende el río, cerca de la iglesia de Santa María Magdalena, en precio de treinta maravedis. 
A. AHDP, Ampudia y Abadía de Husillos, Pergaminos, carp. 208-18. Perg., 246 x 243 mm.; escr. precortesana; regular conservación, con tres pequeñas roturas y alguna mancha que no impide la lectura del texto.

$B$. APA, $L P H$, ff. $121 \mathrm{v}-122 \mathrm{r}$.

Sepan quantos esta carta vieren, como yo, Françisco Ferrández Forro, ffijo de Llorenço Ferrández, vezino de la çibdat de Palençia, / otorgo et conosco que vendo a uos, Domingo Gonçález, chantre en la eglesia de Fusiellos, una tierra que he en término de / Fusiellos, allende del río, çerca de la eglesia de Santa María Madalena, linde, de la una parte, tierra de Alffonsso Garçía de Vi/ ${ }^{3} 11$ oldo, et de la otra parte, tierra de la dicha eglesia, et de la otra parte, el ssendero. Esta dicha tierra vos vendo, con entradas et con sa/lidas, todas sus pertenençias quantas a et le pertenesçen et pertenesçer deuen, assí de ffecho commo de derecho, por treynta / maravedís desta moneda vssual que agora corre, que ffazen a diez dineros nuevos el maravedí, los quales resçebí de uos en buenos dineros $/{ }^{6}$ bien contados et los passé a mi juro et a mi poder, de los quales me otorgo por bien pagado. Et renunçio las leys del / derecho, la una en que dize que los testigos de la carta deuen ver fazer la paga de la cosa sobre que es fecho el contra/to o de cosa que lo vala. Et la otra ley en que dize que el que ffaze la paga es tenudo de la prouar fasta dos años, $/^{9}$ si estas dichas leys non rrenunçiare et se partiere dellas aquel que resçibe la paga. Yo renunçio las dichas leys et / pártome dellas, que yo nin otro por mí, que las non podamos aldegar. Otrosí, renunçio que me non pueda llamar a engaño por / "ad iutorio" de la ley "rren mayoris precii" deziendo que yo so [...] engañado en más de la meytat del justo preçio. Pero si la ${ }^{12}$ dicha tierra vale más de los dichos treynta maravedís, de todo lo que más vale, yo vos fago donaçión dello, entre biuos. / Obligo todos mis bienes, auidos et por auer, de uos fazer sana et desenbargada esta dicha tierra de qualquier o qualesquier que / vos la veniere enbargando o contrallando en qualquier manera o por qualquier razón. Et si por aventura vos la alguno de $/{ }^{15}$ mandare iuyzio, yo me obligo por mí a por todos mis bienes de tomar el pleito y la boz por vos et el juyzio yo tomarlo / en mí, a mi costa et a mi mesión, fasta que el pleito ssea ffenesçido por ssentençia definitiva et por ssentençias de apelaçiones et por / ssentençias de suplicaçión [...] si el derecho fuere contra vos o contra mí por vos, que hos de otra tal tierra tan buena et en $\tan /{ }^{18}$ buen logar o mejor con él dello o ssessenta maravedís de la 
dicha moneda, qual vos más quisiéredes. Desde oy día que esta carta / es ffecha en adelante, me quito et desamparo et desapodero de la tenençia et possessión et propiedat de la dicha tierra et con / esta carta vos apodero en ella para vender et enpeñar et dar et donar et trocar et ffazer della et en ella commo de cosa vuestra propria $/^{21}$ esenta, agora et para sienpre jamás.

Et porque esto ssea firme et non benga en dubda, rrogué et rrequirí a Toribio Martínez / de Fuent Pudia, notario público de la cibdat de Palençia, que escriuiese esta carta et la signase con su signo.

/ Fecha en Palençia, dos días del mes de dezienbre, año del naçemiento de nuestro Saluador Ihesu Christo de ${ }^{24}$ mille et trezientos et noventa et un años. Testigos que estauan presentes: Toribio Ferrández, maestre carpintero, / et don Bartolomé de Santillán de la Cuesta, vezinos de Palençia, et Ruy Ferrández, fijo de Martín Ferrández, vezi/no de Fusiellos, et otros.

Et yo, Toribio Martínez de Fuent Pudia, notario público de la çibdat de / Palençia, ffue a esta presente que dicho es con dichos testigos, rrequirido, rrogado, escriuí esta $/^{27}$ carta. Et fiz aquí mío sig(signo)no en testimonio. Toribio Martínez, notario.

1392, febrero, 20. Burgos

Enrique III confirma un privilegio de Juan I (1388, octubre, 2. Palencia), inserto, por el que, tras las reiteradas quejas de Santa María de Husillos, pone bajo su protección sus propiedades y vasallos.

A. AHDP, Ampudia y Abadía de Husillos, Pergaminos, carp. 202-30. Perg., 326 x 331 mm.; escr. gótica redonda de privilegios y precortesana; bastante deteriorado, con dos grandes roturas que impiden la lectura de parte del texto. No conserva el sello ni la cinta; el lugar donde se sujetó está rasgado. 
B. AHDP, Ampudia y Abadía de Husillos, Pergaminos, carp. 202-32. Perg., 551 x 469 mm.; escr. precortesana; buena conservación. Traslado sacado en Palencia, a 14 de febrero de 1394. Véase doc. núm. 216

$C$. APA, $L P H$, ff. $122 \mathrm{r}-123 \mathrm{v}$. Traslado de $A$.

$D$. APA, $L P H$, f. $127 \mathrm{v}$. Traslado de $B$.

E. AGS, Patronato eclesiástico, Inconexos, leg.159, ff. 124r-127v. Papel; escr. procesal; buena conservación.

A pesar del deterioro del documento, ha sido posible completarle gracias a un traslado y al Libro de los Privilegios de Husillos, lo cual implica que en 1554, cuando se trasladó, se hallaba en perfectas condiciones, siendo las roturas posteriores a esta fecha. Por otro lado, en dicho libro se menciona un documento dado por Juan I en Palencia el 2 de octubre de 1388. Dicho privilegio real ya no está entre las escrituras de Santa María y en 1554 debía haber desaparecido puesto que no fue transcrito en el Libro de los Privilegios de Husillos.

Sepan quantos esta carta vieren, commo yo, don Enrrique, por la graçia de Dios rrey de Castilla, de León, de Toledo, de Galizia, de Seuilla, de Córdoua, de Murçia, de Iahén, del Algarbe, de Algezira et sennor de Vizca/ya et de Molina, vi vna carta del rrey don Iohán, mi padre et mi señor, que Dios dé santo parayso, escripta en papel et firmada de su nombre et sellada con su sello mayor con çera en las espaldas, fecha / en esta guisa:

(Sigue doc. núm. 210)

[Et] agora, el dicho abad et prior et cabiello et benefiçiados de la dicha eglesia de Santa María de [Fusillos, e]mbiáronme pidir merçed que les confirmase la dicha / carta et que la mandase guardar et conplir. Et yo, el sobredicho rey don Enrrique, con acuerdo et actoridat de los mis tutores et regidores de [los mis] regnos, por fazer bien et merçed, al dicho abad et prior / et cabiello et a la dicha su eglesia, tóuelo por bien et confirmoles la dicha carta et merçed en ella contenida. Et mando que les vala et [les se]a guardada bien et conplidamente commo en ella se contie ${ }^{39}$ ne et segunt que mejor et más conplidamente les valió et fue guardada en tiempo del rey don Iohán, mi padre et mi señor, que Dios perdo[ne. E]t defiendo firmemente que alguno nin algunos non sean osados / de les yr nin pasar contra esta dicha carta, confirmada en la manera que dicha es, nin contra lo en ella 
contenido nin contra parte dello, [para] ge lo quebrantar nin menguar, en algún tienpo nin por alguna / manera. Ca qualquier que lo fiziese, avría la mi yra et pecharme y a la pena contenida en la dicha carta, et a los dichos abad et prior et cab[iello] o a quien su boz touiere, todas las costas et daños et me ${ }^{42}$ noscabos que por ende resçibieren, doblados. Et demás, mando a todos los iustiçias et ofiçiales de los mis regnos, do estos acaesçieren, así a los que agora son commo a los que serán de aquí adelante et a cada / vno dellos, que ge lo non consientan, más que les defiendan et amparen con las dichas merçedes en la manera que dicha es. Et que prenden en los bienes de aquellos que contra ello fueren, por la dicha pena, et la guarden / para fazer della lo que la mi merçed fuere. Et que enmienden et fagan enmendar, a los dichos abad et prior et cabiello o a quien su boz touiere, de todas las costas et daños et menoscabos que por ende $/{ }^{45}$ resçibieren doblados, commo dicho es. Et demás, por qualquier o qualesquier por quien fincar de lo así fazer et conplir, mando al omme que le esta mi carta mostrare o el traslado della signado de escriuano / público sacado con abtoridat de juez o de alcalle que los enplaze, que parezcan ante mí en la mi corte, del día que les enplazare a quinze días primeros sigientes, so la dicha pena a cada uno, / a dezir por qual razón non cunplen mi mandado. Et mando, so la dicha pena, a qualquier escriuano público que para esto fuer llamado, que de, ende, al que la mostrare, testimonio signado con su $/^{48}$ signo. Et desto, los mandé dar esta mi carta escripta en pargamino de cuero et sellada con mi sello de plomo pendiente. La carta leyda, dádgela.

Dada en las cortes que yo mandé fazer en la muy / noble çibdat de Burgos, cabeça de Castilla, et mi cámara, veynte días de febrero, año del nasçimiento de nuestro señor Ihesu Christo de mille et trezientos et nouenta et dos años. Yo, Alfonso Ferrández de / Castro, la ffiz escriuir por mandado de nuestro sseñor el rey, con acuerdo et abtoridat de los ssus tutores et regidores de los ssus $/^{51}$ rregnos. (rúbrica)

Fernandus, bacalarius. 


\section{LA ABADÍA DE SANTA MARÍA DE HUSILLOS: ESTUDIO Y COLECCIÓN \\ DOCUMENTAL $(904-1608)$}

1392, febrero, 20. Burgos.

Enrique III confirma un privilegio de Juan I (1379, agosto, 22. Burgos), inserto, que confirma otro de Enrique II (1371, mayo, 20. Valladolid), inserto, confirmatorio de otro de Alfonso XI (1331, agosto, 16. Valladolid), inserto, confirmatorio a su vez de otro de Fernando IV (1312, marzo, 7. Valladolid), inserto, confirmatorio asimismo de otro de Sancho IV (1291, agosto, 16. Valladolid), inserto, confirmatorio de otro de Sancho III (1158, abril, 28. Carrión de los Condes), inserto, por el que concede a Raimundo, abad de Santa María de Husillos, y a los canónigos de dicha iglesia, el privilegio de los infanzones, exentándolos asimismo de todo servicio real.

A. AHDP, Ampudia y Abadía de Husillos, Pergaminos, carp. 202-29. Perg., 717 x 517 mm.; escr. gótica redonda de privilegios y precortesana; buena conservación. Todos los elementos decorativos están dibujados pero sin miniar. No conserva la cinta pero sí el sello de plomo, que está suelto.

$B$. APA, $L P H$, ff. $124 \mathrm{r}-127 \mathrm{v}$.

C. AGS, Patronato eclesiástico, Inconexos, leg.159, ff. 127v-134r. Papel; escr. procesal; buena conservación.

(Christus, alfa et omega) En el nonbre de Dios, Padre et Fijo et Spiritu Santo, que sson tres personas et un Dios verdadero, que biue et rregna por sienpre jamás, et de la bienauenturada gloriosa Santa María, su madre, a quien yo tengo por señora et /por abogada en todos mis fechos, et a honrra et a seruiçio de todos los santos de la corte çelestial. Quiero que sepan, por este mi preuilleio, todos los ommes que agora son o seran de aquí adelante, commo yo, /don [Enrrique], por la graçia de Dios, rey de Castilla, de Toledo, de León, de Gallizia, de Seuilla, de Córdoua, de Murcia, de Iahén, del Algarue et señor de Vizcaya et de Molina, reynante en uno con $\beta$ la reyna doña [Catalina], mi muger, vy vn preuilleio de rey don Iohán, mi padre et mi señor, que Dios dé santo parayso, escripto en pargamino de cuero, rrodado et sellado con su / sello de plomo colgado, fecho en esta guissa:

(Sigue doc. núm. 194) 
[Et] agora, el abad et el prior et cabiello de la dicha eglesia de Santa María de Fusillos, enbiáronme pedir merçed que les confirmase / el dicho preuilleio et ge lo mandase guardar et complir. Et yo, el sobredicho rey don [Enrrique], rreynante en vno con la rreyna donna [Catalina], mi muger, con acuerdo et actoridat de los mis tutores et rregidores de los mis rregnos, por fazer bien / et merçed a los dichos abbad et prior et cabiello, tóuelo por bien et confirmoles el dicho preuilleio et la merçed en él contenida. Et mando que les vala et les sea guardado segunt que mejor et más conplidamente les valió et $/^{78}$ fue guardado en tiempo del rrey don Enrrique, mi auuelo, et del rrey don Iohán, mi padre et mi señor que Dios perdone. Et defiendo firmemente que ninguno nin algunos non sean osados de les yr nin pasar contra este dicho / preuilleio, confirmado en la manera que dicha es, nin contra lo en él contenido nin contra parte dello, para ge lo quebrantar nin menguar, en algún tiempo nin por alguna manera, ca qualquier que lo fiziese auría la mi yra et pecharme y a la pena contenida / en el dicho preuilleio. Et a los dichos abbad et prior et cabiello et a quien su boz touiere, todas las costas et daños et menoscabos que por ende resçibieren, doblados. Et demás, mando a todas las iustiçias et ofiçiales de los mis regnos, to esto acaesçiere, así a los que agora $/^{81}$ son commo a los que serán de aquí adelante et a cada uno dellos, que ge lo non consientan, más que los defiendan et anparen con la dicha merçed en la manera que dicha es. Et que prenden en los bienes de aquellos que contra ello fueren por la dicha pena et la guarden para / fazer della lo que mi merçed fuere. Et que enmienden et fagan enmendar, a los dichos abbad et prior et cabiello o a quien su boz touiere, de todas las costas et daños et menoscabos que por ende resçibieren, doblados, commo dicho es. Et demás, por qualquier o qualesquier por / quien fincar de lo así fazer et complir, mando al omme que les este mi preuilleio mostrare o el traslado del signado de escriuano público, sacado con actoridat de juez o de alcalle que los enplaze, que parescan ante mí en la mi corte del día que los enplazare a quinze dí $/{ }^{84}$ as primeros siguientes, so la dicha pena a cada vno, a dezir por qual razon non cumple mi mandado. Et mando, so la dicha pena, a qualquier escriuano público que para esto fuere llamado, que de ende al que ge lo mostrare, testimonio signado con su signo. Et desto les mandé / dar este mi 
preuilleio escripto en pargamino de cuero, rrodado et sellado con mi sello de plomo pendiente.

Dado en las cortes que yo mandé fazer en la muy noble çibdat de Burgos cabeça de Castilla et mi cámara (en blanco) días de (en blanco), anno del nasçimien/to de nuestro Sennor Ihesu Christo de mille et trezientos et nouenta et dos años.

$\left(l^{a} \mathrm{col}\right.$.) El infante don Fernando, hermano del rrey, señor de Lara et duque de Peña Fiel et conde de Mayorga, conf. El infante don Iohán, fijo del rrey de Portogal, duque de Valençia et señor de Alua de Tormes, vasallo del rrey, conf. Don Enrrique, tío del rrey, señor de Alcalá et Morón et Cabra, conf. Don Enrrique Manuel, tío del rrey, señor de Monte Alegre, conf. Don Gastón de Bearne, conde de Medina Çelim, conf. Don Iohán García Manrique, arçobispo de Santiago, chançeller mayor del rrey et notario mayor del rregno de León, conf.

Don Gonzalo, obispo de Burgos, conf. Don Iohán, obispo de Calahorra, chançeller mayor de la rreyna, conf. Don Iohán, obispo de Palençia, conf. Don Iohán, obispo de Siguença, conf. Don Pero, obispo de Osma, conf. Don Gonzalo, obispo de Segovia, conf. Don Diego, obispo de Áuila, conf. Don Áluaro, obispo de Cuenca, conf. Don Fernando, obispo de Cartagena, conf. Don Iohán, obispo de Córdoua, conf. Don Pero, obispo de Plazençia, conf. Don Rodrigo, obispo de Iahén, conf. Don fray Rodrigo, obispo de Cadiz, conf. Don Gonçalo Núñez de Guzmán, maestre de la orden de la cauallería de Calatrava, conf. Don fray Sancho Martínez de Heredia, prior de Sant Iohán, conf. Don Gómez Manrique, adelantado mayor de Castilla, conf. Don Alfonso Yáñez Fajardo, adelantado mayor del rregno de Murçia, conf.

( ${ }^{a}$ col.) Don Alfonso, conde de Carrión, conf. Don Alfonso Enrríquez, tío del rrey, conf. Carlos de Arellano, señor de los Cameros, conf. Don Garçía Fernández Manrique conf. Don Iohán Rodríguez de Villalobos conf. Don Ruy Gonçalez de Castañeda conf. Don Beltrán de Guiuara conf. Don Pero Vélez, su fijo, conf.

Don Pero, arçobispo de Toledo, primado de las Españas conf. 
$(\text { Signo rodado })^{13}$

Diego López de Astúñiga, justiçia mayor de casa del rrey, conf. Diego Furtado de Mendoza, señor de La Vega, almirante mayor de la mar, conf. Iohán de Velasco, camarero mayor del rrey, conf. Sancho Ferrández de Touar, guarda mayor del rey, conf. Pero Afan de Ribera, notario mayor del Andaluzía, conf. Alfonso Tenorio, notario mayor del regno de Toledo, conf.

( $3^{a}$ col.) Don Fadrique, duque de Benavente, tío del rrey, conf. Don Alfonso, conde de Nurueña, tío del rrey, conf. Don Pero, conde de Trastámara et de Lemos et de Sarria, conf. Don Alfonso, fijo del infante don Pero de Aragón, marqués de Villena, conde de Riba Gorça et de Denia, vasallo del rrey, conf. Don Pero de Castro conf.

Don Arellano, obispo de León, conf. Don Guillem, obispo de Oviedo, conf. Don Alfonso, obispo de Çamora, conf. Don Carlos, obispo de Salamanca, conf. Don Gonzalo, obispo de Çibdat Rodrigo, conf. Don fray Alfonso, obispo de Coria, conf. Don Fernando, obispo de Badajoz, conf. Don Diego, obispo de Orense, conf. Don Iohán, obispo de Tuy, conf. Don Pascual, obispo de Astorga, conf. Don Françisco, obispo de Mondoñedo, conf. Don Lope, obispo de Lugo, conf.

Don Lorenço Suárez de Figuerola, maestre de la orden de la cauallería de Santiago, conf. Don Martín Yáñez, maestre de Alcántara, conf.

( $4^{a}$ col.) La eglesia de Sevilla vacat. Don Iohán Alfonso de Guzmán, conde de Niebla, conf. Don Pero Ponçe de León, señor de Marchena, conf. Don Aluar Pérez de Guzmán, señor de Orgaz, conf. Don Iohán Ramírez de Guzmán conf. Don Alfonso Ferrández, señor de Aguilar, conf. Don Ruy Ponçe de León conf. Aluar Pérez Osorio, señor de Villalobos et de Castro Verde, conf. Don Pero Suárez de Quiñones, adelantado mayor del rregno de León, conf. Diego Sarmiento, adelantado mayor de Gallizia, conf. El adelantado mayor de la frontera conf.

\footnotetext{
${ }^{13}$ En el siglo rodado solamente se marcan los círculos concéntricos.
} 
Yo, Sancho Núñez de Valdés, lo ffiz escriuir por mandado del rrey. Et con acuerdo et abtoridat de los sus tutores et rregidores de los sus rregnos, en el año segundo que el dicho rrey don Enrrique rregnó et ffizo las segundas cortes en la dicha çibdat de Burgos. Ferrand Áluarez. Fernando, bacalarius.

\section{4}

1392, febrero, 20. Burgos.

Enrique III confirma un privilegio de Juan I (1379, agosto, 10. Burgos), inserto, confirmatorio a su vez de otro de Enrique II (1378, agosto, 26. Valladolid), inserto, por el que toma a Santa María de Husillos bajo su amparo y protección, estipulando que su abad, canónigos, beneficiados y vasallos, sólo podrán ser presos y prendidos por deuda o fiadura verdadera que hubiera sido demostrada, siendo primeramente dicha deuda juzgada por fuero.

A. AHDP, Ampudia y Abadía de Husillos, Pergaminos, carp. 202-31. Perg., 412 x 496 mm.; escr. gótica redonda de privilegios y precortesana; buena conservación. Sello de plomo pendiente de hilos rojos, amarillos y blancos.

B. APA, $L P H$, ff. $127 \mathrm{v}-129 \mathrm{r}$.

[S]epan quantos esta carta vieren commo yo, don Enrrique, por la graçia de Dios rrey de Castilla, de León, de Toledo, de Gallizia, de Seuilla, de Córdoua, de Murçia, de Iahén, del Algarue, / de Algezira et señor de Vizcaya et de Molina, vy vna carta del rey don Iohán, mi padre et mi señor, que Dios dé santo paraysso, scripta en pargamino de cuero, sellada con su / sello de plomo colgado, fecha en esta guissa:

(Sigue doc. núm. 191) 


\section{DAVID MARCOS DIEZ}

E agora, el dicho abbad de Fussiellos et el prior et cabiello et benefiçiados de la dicha su eglesia, enbiáronme pedir merçed que les confirmase la dicha carta et ge la mandasse guardar et complir. Et yo, el / sobredicho rrey don Enrrique, con acuerdo et actoridat de los mis tutores et regidores de los mis regnos, por fazer bien et merçed al dicho abbad et prior et cabiello et benefiçiados et a la dicha su eglesia e a los sus ommes $\beta^{30}$ et vasallos et lugares, tóuelo por bien e confírmoles la dicha carta et la merçed en ella contenida, e mando que les vala et les sea guardada segunt que mejor et mas conplidamente les valió et fue guardada en / tiempo del rrey don Enrrique, mi auuelo, et del rrey don Iohán, mi padre et mi señor, que Dios perdone. E defiendo firmemente que ninguno nin algunos non sean osados de les yr nin pasar contra esta dicha carta, confirma/da en la manera que dicha es, nin contra lo en ella contenido nin contra parte della, para ge lo quebrantar nin menguar, en algunt tiempo nin por alguna manera. Ca qualquier que lo fiziese auría la mi yra et pecharme y a la pena $/^{33}$ contenida en la dicha carta et a los dichos abad et prior et cabiello et eglesia et a los benefiçiados della et a sus omes et a sus vasallos et lugares o a quien su boz, dellos o de qualquier dellos, touiese, todas las costas et daños / et menoscabos que por ende resçibiesen, doblados. Et demás, mando a todas las justiçias et ofiçiales de los mis regnos, do esto acaesçiere, así a los que agora son commo a los que serán de aquí adelante et a cada / uno dellos, que ge lo non consientan, más que los defiendan et anparen con la dicha merçed en la manera que dicha es. E que prenden en los bienes de aquellos que contra ello fueren, por la dicha pena, e la $/^{36}$ guarden para fazer della lo que la mi merçed fuere. Et que emienden et fagan emendar a los dichos abad et eglesia et prior et cabiello et benefiçiados della et a sus omes et a sus vasallos et lugares o / a quien su boz dellos o de qualquier dellos touiese, de todas las costas et daños et menoscabos que por ende resçibiesen doblados, commo dicho es. Et demás, por qualquier o qualesquier por quien fincar de lo así / fazer et complir, mando al omme que les esta mi carta mostrare o el traslado della signado de escriuano público, sacado con actoridat de juez o de alcalle que los enplaze, que parescan ante mí en la mi $/ 39$ corte, del día que los enplazare a quinze días primeros siguientes, so la dicha pena a cada uno, a dezir por qual razón non cumplen mi mandado. Et mando, so la dicha pena, a qualquier escriuano público / que para esto fuere llamado que de, ende, al que ge lo mostrare, testimonio 


\section{LA ABADÍA DE SANTA MARÍA DE HUSILLOS: ESTUDIO Y COLECCIÓN \\ DOCUMENTAL $(904-1608)$}

signado con su signo. Et desto, les mando dar esta mi carta escripta en pargamino de cuero et sellada con mi sello / de plomo pendiente. La carta leyda dádgela.

Dada en las cortes que yo mandé fazer en la muy noble çibdat de Burgos, cabesça de Castilla, mi cámara, veynte días de febrero, año del nas $/{ }^{42}$ çimiento de nuestro señor Ihesu Christo de mille et trezientos et nouenta et dos años.

Yo, Alfonso Ferrández de Castro, la ffiz escriuir por mandado de nuestro sseñor el rey con acuerdo et abtori/dat de los ssus tutores et regidores de los ssus regnos. (rúbrica) Ferrand Áluarez. Fernandus, bacalarius.

\section{5}

1394, enero, 10. Astudillo.

Diego Gómez de Santoyo, vecino de Astudillo, ratifica la donación que en su día hizo a Santa María de Husillos: unas casas que había comprado en 1376 a Martín Pérez, merino de Husillos.

A. AHDP, Ampudia y Abadía de Husillos, Pergaminos, carp. 208-12. Perg., 255 x 176 mm.; escr. precortesana; mala conservación, pues la tinta está muy desvahída, sobre todo al comienzo, donde ha desaparecido. Según podemos comprobar por la transcripción al Libro de los Privilegios, buena parte del encabezamiento de la escritura ha desaparecido con el pergamino, por ello, la parte que falta la suplimos con dicho libro.

$B$. APA, $L P H$, ff. $129 \mathrm{r}-\mathrm{v}$.

C. AGS, Patronato eclesiástico, Inconexos, leg.159, ff. 136v-137r. Papel; escr. procesal; buena conservación.

[Sepan quantos esta carta de donación uieren, como yo, Dia Gómez de Santoyo, uezino de Astudillo, otorgo y conozco que do en donadío, puramente, sin entredicho alguno, ratificando he hauiendo por firme una donación que yo, el dicho Dia Gómez, houe fecho al prior e cabildo de la yglesia de Sancta María de Fusillos. La qual dicha donación que yo, el dicho Dia Gómez, les houe fecho, fue y es de unas casas que yo compré en el dicho lugar de Fusillos, que son en 
frontero de huerto del abbad del dicho lugar de Fusillos y de la cerca y de la calle pública. Las quales dichas casas, yo, el dicho Dia Gómez, houe comprado en el año que andaua la era de César en M CCCC XIIII años. Las quales dichas casas yo compré de Martín Pérez, merino que era del dicho lugar de Fusillos, por deuda que deuía y hauía a dar Pero Capellán, cuyas fueron las dichas casas, de las quales yo, el dicho Dia Gómez, houe fecho donación al prior e cabildo de la dicha yglesia en el tiempo que las yo compré. E agora, por esta dicha, confirmo la donación, que yo hauía hecho de las dichas casas] / para que ssean suyas, del dicho prior et cabilldo, para agora et para [siempre / jamás, an]ssí a los que agora y sson benefiçiados commo a los que ffueren de $\beta^{\beta}$ [aquí adelante]. Et para que puedan aprouecharsse et leuar et rrecabdar las rrentas et / alquileres que rrendieren las dichas casas, agora et en todo tiempo del mundo. E otro/ssí, que ssean las dichas casas para el dicho prior et cabilldo de la dicha eglesia $/{ }^{6}$ de Santa María de Fussiellos, commo dicho es. Et por esta carta yo, el dicho / Die Gómez, me desatengo et me desapodero de las dichas casas et de todo / sseñorío et tenençia et possessión que yo he o puedo auer, a las dichas casas, $/ 9$ para agora et para en todo tiempo del mundo. Et otrossí, por esta dicha carta, vos do / e pongo a uos, el dicho prior et cabiello, en la tenencia e possessión de las dichas / [casas], ssegún que mejor et más complidamente auedes tenido et posseydo $/{ }^{12}$ [desde] el dicho tiempo acá, que las yo, el dicho Die Gómez, oue comprado et uos /oue ffecho la dicha donaçión. Et prometo de aver por ffirme et por estable / et ualledera esta dicha donaçión que uos yo fago, de las dichas casas, para ago/ra et para en todo tiempo del mundo, et de non yr nin venir contra ello nin contra $/{ }^{15}$ parte dello, agora nin en algún tiempo del mundo. Et ssi ffuere o ueniere con/tra ello o contra parte dello, que non ssea oydo, sobre ello, ante algún juez, que ssea / ecclesiástico nin sseglar, nin uos, el dicho prior et cabilldo, que non sseades tenu $/{ }^{18} \mathrm{dos}$ me rresponder ssobre esta dicha rrazón, a mí nin a otro alguno por mí. / Et porque esto sea ffirme et non uenga en dubda, yo, el dicho Die Gómez, rrogué et / mandé a Diego Martínez, escriuano público de la uilla de Astudiello, que escreuiesse o $/^{21}$ feziesse escreuir esta carta e la ssignasse con ssu ssigno.

Que es ffecha / en la dicha villa de Astudiello, diez días del mes de enero, año del nace/miento de nuestro Ssaluador Ihesu Christo de mille et trezientos et nouenta et quatro $/^{24}$ años. Testigos que ffueron presentes a todo esto que dicho es: 


\section{LA ABADÍA DE SANTA MARÍA DE HUSILLOS: ESTUDIO Y COLECCIÓN \\ DOCUMENTAL $(904-1608)$}

Fernando de Úrbel, / ffijo de Iohán de Úrbel, et Iohán Rezio, ffijo de Pero Rezio, et Fernando, ffijo de / [Domingo Ximón, vezinos] del dicho logar de Fusiellos.

Et yo, Diego Ferrández, escriua ${ }^{27}$ [no público de la uilla de] Astudiello, fui presente a todo esto que dicho es con los dichos / [testigos.

E por rruego e mandamiento] del dicho Die Gómez, ffiz escriuir esta carta et ffiz / [aquí este mi] sig(signo)no en testimonio de uerdat.

\section{6}

1394, febrero, 14, sábado. Palencia.

Traslado sacado por Juan Alfonso de Olmedo, notario público apostólico, a petición de Pedro Fernández Montero, canónigo de Santa María de Husillos, con licencia de Pedro García de Paredes, vicario del obispo de Palencia, de un privilegio de Enrique III (1392, febrero, 20. Burgos) por el que confirma otro privilegio dado por su padre Juan I (1388, octubre, 2. Palencia), inserto, en que toma a Santa María de Husillos bajo su protección, por las amenazas y desagravios que recibía de los caballeros, escuderos y concejos donde dicha iglesia tenía propiedades y derechos.

A. AHDP, Ampudia y Abadía de Husillos, Pergaminos, carp. 202-32. Perg., 551 x 469 mm.; escr. precortesana; buena conservación.

$B$. APA, $L P H$, f. $127 \mathrm{v}$. Solamente recoge el encabezamiento hasta: < ..como yo, don Enrrique, por la graçia de Dios $>$. Después dice: $<$ No se trasladó más porque la original está autorizada atrás, a fojas $122>$.

C. AGS, Patronato eclesiástico, Inconexos, leg.159, ff. 134r-136v. Papel; escr.. procesal; buena conservación.

[E]n la cibdat de Palençia, sábado, catorze días del mes de febrero, año del nascimiento de nuestro Ssaluador Ihesu Christo de mille et trezientos et nouenta et quatro años. En presençia de mí, Iohán Alfonso de Olmedo, notario pú/blico por la autoridad apostólica, et de los testigos de yuso escriptos. Este dicho día, 
estando ante Pero García de Paredes, vicario de nuestro sseñor el obispo de Palençia, paresçió antel dicho vicario, Pero Ferrández Montero, canónigo en la / eglesia de Santa María de Fosiellos. Et luego, el dicho Pero Ferrández Montero presentó et fizo leer por mí, el dicho notario, ante el dicho vicario, una carta de nuestro sseñor el rey, escripta en pargamino y sseellada con ssu $\beta$ ssello de plomo colgado con filos de sseda, el tenor de la qual carta es este que sse ssigue:

(Sigue doc. núm. 212)

La qual carta del dicho señor rey, mostrada et leyda ante el dicho vicario, luego, el dicho Pero Ferrández Montero, canónigo, dixo, al dicho vicario, que por quanto et temía de yr a varias partes fuera / de esta dicha çibdat, et de mostrar en otros muchos logares et ante muchas perssonas la dicha carta, que por aquesto auía rreçelo de la perder la dicha carta, por agua o por fuego o por robo o por fur $/{ }^{54}$ to o por otra ocasión alguna, por ende que pedía al dicho vicario, que diesse liçençia et poder et abtoridat a mí, dicho notario, para que sacasse o feziesse sacar, por la dicha carta, vn traslaudo o / dos o más signados de mío signo, quantos mester ouiesse et posiesse su decreto al traslaudo o traslaudos que yo, dicho notario, sacasse o feziesse sacar por la dicha carta, signados / con mi signo para que valiesen et feziesen ffe a doquier que paresçiessen, asy en juyzio commo fuera de juyzio, a tan bien et tan complidamiente commo el cuerpo original de la dicha carta del $/^{57}$ dicho señor rey. Et luego, el dicho vicario dixo que él que beya la dicha carta del dicho señor rey, non rota nin chançellada nin en algund logar della sospechoso, por ende que daua et dio po/der et abtoridat et licençia a mí, dicho notario, para que sacasse o feziesse ssacar por la dicha carta del dicho señor rey, vn traslaudo o dos o más, quantos mester fuessen, signados con / mi signo et los diesse al dicho Pero Ferrández. Et que enterponía su decreto en él para que valiesse et feziesse ffe a doquier que paresçiesse, signados con mi signo, asy en juyzio commo fuera de $/{ }^{60}$ juyzio, a tan bien et tan conplidamente commo el cuerpo original de la dicha carta del dicho señor rey faría paresçiendo. Testigos que estauan presentes que vieron et oyeron leer la / dicha carta original, onde este traslaudo fue ssacado: Lope Garçía Caranga et Ferrand Gonçález, notarios públicos de la dicha çibdat, et otros a esto llamados speçialmiente, rogados. 


\section{LA ABADÍA DE SANTA MARÍA DE HUSILLOS: ESTUDIO Y COLECCIÓN \\ DOCUMENTAL $(904-1608)$}

Et yo, Iohán Alfonso de Olmedo, notario público por la autoridat apostolical, porque vi et ley la dicha carta original onde este traslaudo fue sacado, fuy presente a todo / lo que dicho es con los dichos testigos. Et por liçençia et autoridat del dicho vicario, ocupado en otros negoçios, fiz sacar este traslaudo de la dicha carta a pedimi $/{ }^{63}$ ento del dicho Pero Fernández. Et en uno con la interposiçión de su decreto, signelo deste mi acostumbrado signo en testimonio de verdat. Non enpeezca que va / scripto sobre rraydo en el primero renglón en un logar a do dize: "por la autoridat apostolical" et en otro logar a do dize: "de Palençia paresçió antel dicho", ca non fue viçio. / Et so estos mis signos et subcripçión lo appruebo (signum: Iohannes Alfonso, notarius).

En la çibdat de Palençia, viernes, quatro días del mes.

1396, abril, 19, lunes.

Pedro Fernández, prior de Santa María de Husillos, exige, ante la puerta del Río de la dicha villa, a Gómez Manrique, adelantado mayor de Castilla, que si quiere entrar en el lugar ha de respetar las libertades de sus vecinos y no ejercer como tal adelantado; el cual promete no ejercer su oficio mientras se halle en Husillos, siendo solamente su intención aprovisionarse de víveres en dicho lugar.

$B$. APA, $L P H$, ff. $129 \mathrm{v}-130$ r. En el f. $129 \mathrm{v}$, en el margen izq.: < Compulsado año 1788 en el pleyto sobre jurisdicción del señor abad>.

Fecho et sacado fue el dicho traslado en la villa de Husillos, a treynta días del mes de novienbre de mil et quinientos y çinquenta et quatro años. Que lo vieron corregir et conçertar, Joán Ruiz Cabeça de Vaca et Gaspar de Vedoya, clérigos, et Pero Manuel, estantes en la dicha villa.

Et yo, Santiago Gómez, escriuano público en la dicha villa, presente fui a lo que dicho es en vno con los dichos testigos. Et del dicho pedimiento et mandamiento, lo fize escrevir et fize aquí mi signo (signo) en testimonio de verdad.

Pero Ruyz de Villoldo (rúbrica). Santiago Gómez (rúbrica). 
El día 19 de abril de 1396 fue miércoles y no lunes. Véase A. GIRY, Manuel de Diplomatique. La letra dominical correspondiente a 1396 es la A, y la Pascua cayó el 2 de abril.

En la villa de Fusillos, lunes, diez y nueue días del mes de abril del año del Señor de M CCC XC VI años. Este día, estando a las puertas de la dicha villa que dizen del rrÍo, estando a las dichas puertas Gómez Manrrique, adelantado mayor por nuestro señor el rey en Castilla, y estando ay Juan Fernández de Villabermudo, por ruego, e Martín Pérez de Villaudilla, y Gonçalo Fernández, canónigos en la yglesia de Fusillos, en presencia de mí, el notario, e testigos de yuso escritos. Luego, el dicho Pero Fernández, so prior, teniendo cerradas las dichas puertas, dixo, al dicho señor adelantado, que qué era lo que le plazía en el dicho lugar. El dicho adelantado dixo que él que querría entrar en el dicho lugar con su compaña. E luego, el dicho Pero Hernández, su prior, dixo que bien sabía en como la dicha yglesia tenía preuilegios en que adelantado ni merino ni justicia alguna no podía entrar en el dicho lugar, saluo si, primeramente, dimitiessen e dexassen los officios e quitaciones que ouiessen. E que sy él quería entrar en el dicho lugar, que cumplía que ante todas cosas, dimitiesse y dexasse el officio del adelantamiento, ante que entrasse por las dichas puertas. Y luego, el señor adelantado dixo que era verdad que la dicha (f.129v) yglesia hauía tales preuilegios e aunque ellos hauía visto otras vegado que le hizieran ansí de meter y dexar, el dicho officio del dicho adelantamiento, ante las dichas puertas. Mas que Dios no quisiesse que su voluntad fuesse de les passar ni yr ni quebrantar los dichos preuilegios y libertades, más de ge los guardar según que ge los guardaron sus antecesores, y el hauía guardado hasta oy día. E que, enguardándogelos, que demitía e demitió la jurisdición del oficio del adelantamiento e de justicia que del rrey hauía mientras en el dicho logar estuuiesse y en sus términos, dentro de los dichos. E que no entraua en el dicho logar como adelantado, más como otro home llano, a comer y beuer por su dinero, con su compaña, sy les plugiesse, e que ansy se lo diessen por testimonio signado.

E luego, el dicho Pero Fernández, su prior, dixo que pedía y pidió a mí, el dicho notario infra escripto, que de todo como passaua le diesse, ende, testimonio signado, para en guarda del derecho de la dicha yglesia, e que rrogaua a los homes buenos que estauan presentes que fuessen dello testigos. Testigos que estauan 


\section{LA ABADÍA DE SANTA MARÍA DE HUSILLOS: ESTUDIO Y COLECCIÓN \\ DOCUMENTAL $(904-1608)$}

presentes: Gonçalo Muñoz Barahona, y Rodrigo Áluarez de Santoyo, e Aluar Gutiérrez, su fijo, y Gonçalo Gómez, escriuano, criados del dicho adelantado, y García Fernández Cabeça, y Pero Gutierrez, y Pero Fernandez de Auia, vezinos de Fusillos, y otros.

E yo, Alfonso García de Villasur, canónigo en la dicha yglesia e notario público en el dicho lugar, fuy presente a todo lo sobredicho con los dichos testigos; y por mandado del dicho señor adelantado e a rrequirimiento e rrequirimiento (sic) del dicho Pero Fernández, su prior, escriuí este público instrumento. El qual signé con mi signo acostumbrado en testimonio de verdad. Alfonsus García, notarius.

\section{8}

1396, diciembre, 10. Palencia.

Revisión del testamento de Toribia Ferrández, mujer de Alfonso Fernández, por la que se cambia los beneficiarios de unas casas en Palencia: Juanillo y Toribillo, hijos de Gutierre Ferrández de Piña, notario público de dicho lugar, por Santa María de Husillos, con la condición de que ofrezcan por su alma un aniversario cada año.

B. AHDP, Ampudia y Abadía de Husillos, Pergaminos, carp. 209-25. Perg., 177 x 605 mm.; escr. precortesana; regular conservación, pues una gran mancha impide parcialmente su lectura. Inserto en la ejecución del testamento, dada en Palencia, a 9 de marzo de 1397. Véase doc. núm. 151.

$C$. APA, $L P H$, ff. 79 r-80r. Al final de la escritura: $<$ Esta escritura por no se poder leer en las partes en que van dejadas en blanco unas rrayas de tinta, no se signó>>.

D. AGS, Patronato eclesiástico. Inconexos, leg.159, ff. 81v-86r. Papel; escr. procesal; buena conservación.

E. BN, ms. 705, ff. 169v-170v.

Sepan quantos esta carta et público testimonio vieren, commo yo, To/ribia Ferrández, muger de Alfonso Ferrández, bolsero, vezino de Palençia, estando enferma del cuerpo et sana del mi entendimiento et de la mi memoria; por rrazón 
que yo vue fecho [et ordenado por] ante Alfonso Pérez, notario público desta dicha çiudat. Et por quanto en el dicho testamento dixe que mandaua et mandé estas mis casas, en que yo agora moro, a Iohanillo et a Toribillo, fijos de Gutierre Ferrández de Piña, $/^{6}$ notario público desta dicha çiudat. Por ende, yo, emendando en el dicho mi testamento, digo que yo que rreuoco et do por ninguna la dicha manda que fize, de las dichas mis casas [a los dichos Iuhanillo et] Toribillo, fijos del dicho Gutierre Ferrández. Et mándolas a la eglesia de Santa María de Fosiellos, para que sean soyas propias, libre et desenbargadamiente, por juro de heredat, por sienpre jamás, porque me fagan, / en cada año, vn aniuersario solene et rrueguen a Dios por la mi alma. Et de todos aquellos de quien yo tengo debdo et carga, de lo qual encargo sus conçiençias. Otrossy d[...] dicho Gutierre Ferrández, notario público, que pagadas las esequias et el mi enterramiento, que pueda fazer et faga de los otros mis bienes que rremaneçieren, lo que él quisiere et por bien touiere. Et porque esto sea firme / et non venga en dubda, rruego et mando a Sancho Díaz, notario público de la dicha çibdat de Palençia, que escriua desto que dicho he, signada de su signo para guardar de la [dicha eglesia].

Fecha esta carta en Palençia, diez días de deziembre del año del nascemiento del nuestro sennor Ihesu Christo de mille et trezientos et nouenta et seys años. Testigos rrogados que a esto fueron presentes: $\rho^{9}$ Toribio Garçía, fijo de Garçía Gutiérrez, et Diego Garçía de Valtomas, et Françisco Ferrández, capellán, et Andres Ferrández, texedor, criado de Martín Garçía, vezinos de Palençia, et otros. Et yo, el dicho San[cho Díaz, notario público] sobredicho de la dicha çibdat de Palençia que fuy presente a todo lo que dicho es con los dichos testigos. Et por rruego et otorgamiento de la dicha Toribia Ferrández, escriuí esta carta et fiz aquí este mío signo / en testimonio de verdat.

1397, marzo, 9. Palencia. 


\section{LA ABADÍA DE SANTA MARÍA DE HUSILLOS: ESTUDIO Y COLECCIÓN \\ DOCUMENTAL $(904-1608)$}

Ejecución del testamento de Toribia Ferrández, mujer de Alfonso Fernández, bolsero, vecinos de Palencia, por el que deja unas casas en Palencia a Santa María de Husillos, con la condición de que ofrezcan por su alma un aniversario cada año. Anteriormente había dejado dichas casas a Juanillo y Toribio, hijos de Gutierre Ferrández de Piña, notario público de Palencia, decisión que había revisado más tarde.

A. AHDP, Ampudia y Abadía de Husillos, Pergaminos, carp. 209-25. Perg., 177 x 605 mm.; escr. precortesana; regular conservación, pues una gran mancha impide parcialmente su lectura.

$B$. APA, $L P H$, ff. $79 r-80$ r. Al final de la escritura: $<$ Esta escritura por no se poder leer en las partes en que van dejadas en blanco unas rrayas de tinta, no se signó>.

C. AGS, Patronato eclesiástico. Inconexos, leg.159, ff. 81v-86r. Papel; escr. procesal; buena conservación.

D. BN, $m s .705$, ff. $169 \mathrm{v}-170 \mathrm{v}$.

Sepan quantos esta carta vieren commo yo, Gutierre Ferrández de Piña, notario público, vezino de la çibdad de Palençia, por mí mesmo et en boz et en nombre [de Iuhanillo et Toribillo], míos fijos, cuyo tutor de ley so, por rrazón que Toribia Ferrández, muger de Alfonso Ferrández, bolsero, vezino de la dicha çiudat, estando doliente de la dolençia que fino, et en / su sano entendimiento vuo fecho et ordenado et fizo et ordenó su testamento et su postremera voluntad por ante Alfonso Pérez de Carrión, notario público de la dicha çibdat [de Palençia], dixo que mandaua et mandó a los dichos mis fijos, vnas casas en que ella moraua et mora agora, que son en Palençia, a la Requexada de Sant Miguel; que an por linde/ros, de la vna parte: casas en que mora Andrés Ferrández, criado de Martín Garçía; et de la otra parte: corral et casas en que agora mora Fernand Garçía, criado de Orejero et Iuhán Lirón de[...] de casas que fueron de Martín Garçía "El Viejo". Et después desto, la dicha Toribia Ferrández, estando en su sano entendimiento, enmendando del dicho su testamento, que auía fecho por antel dicho $\beta^{3}$ Alfonso Pérez, notario, dixo que rrevocaua et rreuoca la dicha manda que fiziera a los dichos mis fijos de las dichas sus casas et que las mandaua et mandó a la eglesia de Santa [María de Fosiellos con todos] sus bienes muebles que ella agora auía et tenía, segunt que pasó por ante Sancho Díaz, notario público desta dicha çiudat. Las quales dichas casas et bienes, dixo que mandaua et mandó a la 
di/cha eglesia de Santa María de Fosiellos, con tal carga et con tal condiçión que le fiziesen en cada un año, un aniuersario solepne et rrogasen a Dios por la su alma et de en [...] de rrogar por sienpre jamás; de lo qual dicho testamento que por antel dicho Sancho Díaz passó, el tenor del es éste que se ssigue:

(Sigue doc. núm. 218)

Por ende, otorgo et connosco yo, el dicho Gutierre Ferrández, por mí mesmo et en boz et en nombre de los dichos Iohanillo et Toribillo, mis fijos asi commo su tutor [...]do et traspasso yo en vos, Martín Garçía, canónigo en la dicha eglesia de Santa María de Fusiellos, que estaua pressente así commo logarteniente de prior de la dicha eglesia et en su nombre, de la dicha eglesia. Et / para ella las dichas casas et bienes muebles que fueron de la dicha Toribia Ferrández, para que sean de la dicha eglesia de Fosiellos, libres et quitos, propiamente, por juro de hered[at, para sienpre] jamás, para fazer de las dichas casas et bienes et en ellos, todo lo que quisiéredes et por bien touiéredes, así de alto commo debaxo, compliendo et pagando su alma et sus esequias et su enterramiento. Et para $/{ }^{12}$ auer et leuar los frutos et rrentas et esquilmos de las dichas casas, con la carga et condiçión del dicho aniuersario, contenida en la dicha carta que la dicha Toribia Ferrández fizo, segunt que [...] por antel dicho Sancho Díaz, notario, que en esta carta va encorporada. Las quales dichas casas vos do et dexo et traspasso, con todos sus fueros et derechos et usos et costumbres et pertenençias et con todas sus entra/das et salidas, que an et deuen auer así de fecho commo de derecho. Et juro et prometo a buena fe, sin mal engaño, por mí et en nombre de los dichos mis fijos, de non yr ni venir contra las cosas contenidas en esta carta ni contra alguna dellas, por lo quebrantar nin menguar, en todo ni en parte, et de non dezir ni allegar cosa alguna contra ello nin contra parte dello, yo nin los dichos mis fijos / nin alguno dellos nin otrie ni otries por mí nin por ellos ni por qualquier dellos. Et si lo dexiéremos et allegáremos, que nos non vala en juyzio ni fuera de juyzio, ante ningunt ni algunt juez que en el mundo sea, eclesiástico ni seglar. Ca yo, por mí et en nombre de los dichos mis fijos, rrenunçio et quito et parto de mí et dellos et de cada uno dellos, todo el derecho et açión et demanda que a las di $/{ }^{15}$ chas casas et bienes auiemos et tenemos. Et desde aquí corporalmente, vos do et pongo en la 


\section{LA ABADÍA DE SANTA MARÍA DE HUSILLOS: ESTUDIO Y COLECCIÓN \\ DOCUMENTAL (904 - 1608)}

tenençia et posesión de las dichas casas et de todos los dichos sus bienes, para que sean vuestros en nombre de la dicha eglesia et para ella, commo dicho es. Et yo, el dicho Martín Gómez, por mí et en boz et en nombre del prior et cabillo de la dicha eglesia de Santa María de Fosiellos, tomo et rreçibo / las dichas casas et bienes que fueron de la dicha Toribia Ferrández, en nombre de la dicha eglesia de Fosiellos et para ella, con la dicha condiçión et carga de fazer el dicho aniuersario solene en cada año, para en todo tiempo et de rrogar a Dios por el alma de la dicha Toribia Ferrández et de todos aquellos que ella tiene carga. Et otrosí, que cumpla et paguen sus mandas et escritos et [...] / [...]. Et tomo et rresçibo el señorío et propiedat et la tenençia et posesión de las dichas casas et bienes et do las pongo, en ellas, a Gonçalo Ferrández, canónigo de la dicha eglesia, así commo su procurador que es del prior et cabillo de la dicha eglesia et en su nombre, de la dicha eglesia de Santa María de Fosiellos, et para ella.

Et otrosí, yo, el dicho Gonçalo Ferrández, procurador sobredicho en nombre ${ }^{18} \mathrm{de}$ la dicha eglesia et para ella, otorgo et connosco que tomo et rresçibo la dicha tenençia et posesión de las dichas casas et bienes que fueron de la dicha Toribia Ferrández, segunt et en la manera que dicha es de suso. Et de todo esto en commo ha pasado et pasa, estos todos, los sobredichos Gutierre Ferrández et Martín Gómez et Gonçalo Ferrández, rrogamos et mandamos al dicho Sancho / Díaz, notario que está presente, que escriuiese vna carta, signada con su signo, para guardar del derecho de la dicha eglesia de Santa María de Fusiellos.

Fecha esta carta en la dicha çibdat de Palençia, dentro en las casas que fueron de la dicha Toribia Ferrández, nueue días del mes de março del año del nasçemiento de nuestro señor Ihesu Christo de mill et trezientos et nouenta / et ssiete años. Testigos rrogados que a esto fueron presentes: Iohán Andrés, texedor, criado de Martín Garçía, et Gonçalo, fijo de Martín Ferrández de Allén del Río, et Iohán de Villa Luçión, bezinos et moradores en Palençia, et Iohán Ferrández de Fosiellos, sobrino del chantre, et otros.

Et yo, el dicho Sancho Díaz, notario publico de la dicha cibdat de Palençia que fuy pressente a todo lo que ${ }^{21}$ dicho es con los dichos testigos. Et por rruego et otorgamiento, de todos los sobredichos, escriuí esta carta et fiz aquí este mío sig(signo)no en testimonio de verdad. Sancho Díaz. (rúbrica) 
1402, junio, 12. Astudillo, corral de la iglesia de Santa Eugenia.

Sentencia pronunciada por Alfonso Fernández y Gonzalo Alfonso, alcaldes de Astudillo, del pleito litigado por Çag Çidicario de Villadiego, judío, hijo de Salarim, arrendador de las tercias reales, con Martín González, como procurador del concejo de Villagutierre Álvarez y Santa María de Husillos, por el pago de las tercias reales correspondientes a dicho concejo. La sentencia es favorable a los segundos.

A. AHDP, Ampudia y Abadía de Husillos, Pergaminos, carp. 211-9. Perg., 302 x 371 mm.; escr. precortesana; regular conservación.

$B$. APA, $L P H$, ff. 130r-131r.

Doze días del mes de junio, año del nasçimiento de nuestro Salvador Ihesu Christo de mille et quatroçientos et dos años. Este día, estando en la villa de Astudiello, / assí commo a la hora de las vísperas, ante Alfonso Ferrández et Gonçalo Alfonso, alcalles de la dicha billa, en presençia de mí, Martyn Gómez de Astudiello, notario público / de la çibdat de Palencia et escrivano público de la dicha villa de Astudiello, por mi señor Ferrant Sánchez de Tovar, et de los testigos de en ffin escrip/ $/$ tos. Et estando los dichos alcalles en juyzio, en el corral de la eglesia de Santa Eugenia de la dicha villa, oyendo et librando los pleitos de las terçias / que ha nuestro señor el rey pertenesçían en el açiprestadg[o de A]stodiello de çiertos logares, paresçieron y presentes ante los dichos alcalles, de la una parte: don Çag / Çidicario de Villa Diego, fijo de don Salarim, arendador de las terçias del dicho señor rey, del obispado de Palençia, del año que començó por el día $/{ }^{6}$ de la Ençenssión que passó de mille et quatroçientos et un años et se cumplió por el día de la Ençenssión deste año de la fecha desta sentençia.

Et luego, el / dicho don Çag [de]mandó al dicho Martyn Gonçá[lez] et dixo quel, que avía de aver las terçias que al dicho señor rey pertenesçían en Billa Gutierre / del dicho año. Et luego, el dicho Martyn Gonçález dixo [que él, en] nombre de los 
bezinos et moradores de Billa Gutierre et otrossy en nombre del cabiello de Fusillos, $/{ }^{9}$ que no las avían por qué pagar por quanto tenían et avían previlleios et cartas et libertades de nuestro señor el papa et de nuestro señor el rey, buldados et / plomados et sellados con sellos de plomo pendientes. Los quales enpresentó ay luego, por mí el dicho notario escrivano público, ante los dichos / alcalles, para guarda de su derecho, los quales levó en ssu poder, et dixo que pedía et pedió, a los dichos alcalles, que biessen los dichos previlleios $/^{12}$ et librassen lo que fallassen por derecho.

Et luego, los dichos alcalles dixieron que ellos que bían los dichos previlleios et los obedeçían con aquella rever/ençia que devían, et que ellos, avido ssu consejo et acuerdo con omes buenos letrados et sabidores en fuero et en derecho, que fallavan que el dicho logar / de Billa Gotierre que non avía porque pagar las dichas terçias, et que ellos que davan et dieron, al dicho Martyn Gonçález, en nombre del dicho logar de Billa Gotierre, por $/^{15}$ libre et por quito de las dichas terçias que al dicho señor rey pertenesçian en el dicho logar de Billa Gotierre. Et desto en commo passó, el dicho Martyn Gonçález, / [...], dixo que pedía et rrequería et pedió et rrequirió a mí, el dicho Martyn Gómez, escrivano público, que ge lo diesse assí todo signado con mi signo, / para guarda de derecho del dicho logar de Billa Gotierre et ssuyo, en ssu nombre.

Testigos que fueron presentes a esto que dicho es, llamados et rrogados $/^{18}$ para esto firmar ansí: Ferrand Cobbo, cantor de Páramos, et Alfonso Fernández, et Alfonso Gutiérrez, et Iohán et Ferrand Gómez, vicario, et don Mosse por poder, / judío, bezinos de Astodiello, et Iohán Sánchez, canónigo de Fusillos, et Iohán Martínez de Villa Gotierre, fiio de Iohán Martínez, et Pero Ferrández, clérigo de Billamediana en / Balde Çalze, e otros.

E yo, Martyn Gómez de Astudiello, notario et escrivano público sobredicho de la dicha villa de Astudiello, ffuy pressente a esto que dicho es et ${ }^{21}$ con los dichos testigos. Et ffiz escrivir esta carta desta ssentencia que y a. Et ffyz aquí este mío $\operatorname{ssyg}($ signo $)$ no en testimonio de verdat. 
1414, enero, 10, miércoles. Husillos.

Pedro Fernández, aguador, vecino de Villaumbrales, albacea testamentario de Alfonso Fernández Prieto, su hermano; y María Fernández, viuda del segundo, venden a Pedro Fernández Cabeza, canónigo de Santa María de Husillos, dos viñas que eran propiedad del difunto, sitas en término de Santillán; una en el lugar que llaman Cabañuelo, de una alanzada aproximadamente; y la otra en el lugar que llaman Valdesonque, de media alanzada. El precio se establece en trescientos veinte maravedís.

B. APA, $L P H$, f. $131 \mathrm{r}-\mathrm{v}$.

Fecho y sacado fue el dicho traslado en la villa de Husillos, treynta días del mes de noviembre de mil e quinientos y çinquenta y quatro años. Testigos que lo vieron corregir y conçertar, Joán Ruiz Cabeça de Baca e Gaspar de Bedoya, clérigos, y Pero Manuel, estantes en la dicha villa.

Y yo, Santiago Gómez, escriuano público en la dicha villa, fui presente a lo que dicho es en vno con los dichos testigos. Y del dicho pedimiento y mandamiento, lo escreví y fize aquí mi signo (signo) en testimonio de verdad.

Pero Ruyz de Villoldo (rúbrica). Santigo Gómez (rúbrica).

Sepan quantos esta carta vieren, como yo, Pero Fernández, aguero, vezino de Villaumbrales, mansesor que soi de Alfonso Fernández Prieto, mi hermano, y yo, María Fernández, muger que fui de Alfonso Fernández, otorgamos y conosçemos que vendemos a vos, Pero Ferrández Cabeca, canónigo en la yglesia de Santa María de Husillos, una viña que el dicho Alfonso Ferrández avía en término de Santillán, a do dizen Cabañuelo, en que a una alançada, poco más o menos, que a por linderos: de la vna parte, viña de Martín Juan, vezino de Villumbrales; y de la otra parte, el sendero que sale a la sierra; y de la otra parte, viña de Pero Gutiérrez, vezino de Fusiellos.

Y más vos vendemos otra viña que es en el dicho término a do llaman a Valdesonque, en que ay media alançada, poco más o menos, poblado y por poblar, que a por linderos: de la una parte, viña de Juan González, vezino de Villumbrales; y de la otra parte, viña de Alfonso de Canporredondo, vezino de 


\section{LA ABADÍA DE SANTA MARÍA DE HUSILLOS: ESTUDIO Y COLECCIÓN \\ DOCUMENTAL $(904-1608)$}

Fusillos. Estas dichas viñas que estas dichas afrontaçiones encierran, vos vendemos vendida buena, sana y verdadera, sin entredicho alguno y sin alguna mala boz, con entradas y con salidas, con usos y pertenencias quantas les perteneçen y perteneçerles debe de derecho, por trezientos y veinte maravedís desta moneda que agora corre que fazen dos blancas el maravedí; de los trezientos y veinte maravedís nos otorgamos por bien pagados, entregados a todo nuestra voluntad, para agora y para en todo tiempo del mundo.

Y sobre esto todo, renunçiamos las leyes del derecho, la vna en que dize que los testigos de la carta deven ver fazer la paga y la otra ley en que dize que fasta dos años es ome tenudo de provar la paga que faze, salvo si quien a de rreçebir la paga renunçiare estas leyes y se partiere dellas, y nos rrenunçiámoslas y partímosnos dellas y de cada una dellas.

Y desde oy día que esta carta es fecha en adelante, nos partimos e nos desapoderamos del juro y de la tenençia y açión y demanda y derecho y señorío y parte y propiedad que nos abíamos en las dichas viñas, y con esta carta vos apoderamos en las dichas viñas, corporalmente, que sean vuestras, libres y quitas, para envender, enpeñar, trocar y donar y enajenar y para fazer dellas y en ellas todo lo que quisierdes y por bien toviéredes. Y obligámosnos con todos nuestros bienes, muebles y raízes, para vos fazer sanas las dichas viñas, que qualquier ome o muger que vos las demandare o enbargare, sino que vos demos y pechemos otras tales viñas y tan buenas, en tan buen lugar o mejor o los dichos trezientos e veynte maravedís doblados, qual vos más quisierdes.

Fecha esta carta en la villa de Fusillos, miércoles, diez días de enero, año del nasçimiento de nuestro Saluador Ihesu Christo de mil y quatrocientos y catorze años. Testigos que fueron presentes a todo lo sobredicho: Alfonso Fernández de Cardaño, e Joán Fernández de la Montaña, e Garçía Fernández, familiar, vezinos de Fusillos, y Pero Ferrández Aguado, vezino de Bezerril, y otros a los sobredicho llamados espeçialmente y rogados.

Y yo, Toribio Ferrández, notario público, fui presente a todo lo sobredicho con los dichos testigos. Y rogado y requerido por amas las dichas partes, ocupado en otros negoçios, fiz por otro escrevir esta carta y fiz en ella este mío signo acostunbrado en testimonio de verdad. Gundisaluus Bernardinus. (f.131r) 
1420, abril, 3. Roma.

Mandato de Martín $V$ en relación a los diezmos y frutos de Becerril y Villaumbrales.

A. AHDP, Ampudia y Abadía de Husillos, Pergaminos, carp. 203-5. Perg., 178 x 264 mm.; escr. gótica de cancillería pontificia; buena conservación. Sello de plomo pendiente. Anverso: MARTINUS PAPA V; reverso: SANCTUS PAVLUS, SANCTUS PETRUS.

Martinus, episcopus, seruus seruorum Dei, dilecto filio et abbati monasterii / Sancte Crucis, prope Monzon, Palentini diocesis, salutem et apostilicam benedictione. Conquesti sunt nobis Petrus, / prior, et capitulum ecclesie Sancte Marie de Fusellis, Palentini diocesis, quod de Bezeril et de Villum/ ${ }^{3}$ brales, villarum dicte diocesis, vniuersitas super quibusdam domibus, agris, vineis, nemoribus, pratis, pa/scuis, terminis in dicta diocesis consistentibus terris, possessionibus decimis fructibus frumenti et vini / quantitatibus pecuniarum summis et rebus aliis ad dictam ecclesiam spectantibus muiriantur $/^{6}$ eisdem ideoque discietioni tue per apostolica scripta, mandamus quatinus vocatus qui fuerint evocandi / et auditis hinc inde propositis quod vistum fuerit appellatione remota decernas faciens quod / decieueris per censuram ecclesiasticam firmiter obseruari. Prouiso ne aliqua alia singularis per ${ }^{9}$ sona dicte vniuersitatis auctoritate presentium ad uidicium euocetur et ne in dictam villam inter/dicti sententiam proferas nisi a nobis super hoc mandatum receperis spetiale. Testes autem qui / fuerint nominati sise gratia odio uel timore sub axerint censura simili appellatione cessante compellas $/{ }^{12}$ ueritati testimonium perhibere.

Datum Rome, apud Sanctum Petrum, III nonas aprilis, pontificatus nostri anno quarto.

Pro ia de fonea?. Bonannus. 
1422, abril, 22, miércoles. Palencia.

Traslado sacado por Alfonso García de Villagarcía, notario público, con autoridad de Ferrán García de Medina de Pomar, arcediano de Campos y vicario general en el obispado de Palencia, a petición de Pedro González de Villafáfila, canónigo de Santa María de Husillos, de una carta (1179, noviembre, 18. Agnani) por la que Alejandro III exenta a Santa María de Husillos de la jurisdicción del obispo de Palencia y la hace dependiente de la Santa Sede. Asimismo confirma todas sus posesiones y bienes, privilegia las sepulturas en dicha iglesia y defiende sus posesiones y pertenencias de todo infractor.

A. AHDP, Ampudia y Abadía de Husillos, Pergaminos, carp. 203-4. Perg., 587 x 323 mm.; escr. cortesana; regular conservación.

A diferencia de otros traslados, se mantiene bastante fiel al original, excepto en algunos confirmantes. Llama la atención los motivos esgrimidos para la realización del traslado. Así, junto a los tradicionales peligros del fuego, agua y hurto, se añade también la peligrosidad de los caminos, lo que muestra que la escritura original debió salir en gran número de ocasiones del archivo de Husillos.

En la çibdat de Palençia, miércoles, veynte et dos días del mes de abril, año del nasçimiento del nuestro Saluador Ihesu Christo de mille et quatrocientos et veynte et doss años. Este dicho día, antel honrrado et dis/creto varón don Ferrand Garçía de Medina de Pumar, doctor en derechos, arçediano de Canpos en la eglesia de Palençia, prouisor et vicario general en lo spiritual et temporal en todo el obispado por el mucho honrrado en Christo padre / et señor don Rodrigo, por la graçia de Dios et de la santa iglesia de Roma, obispo de Palençia. Estando asentado "pro tribunali" en presencia de mí, el notario público et testigos de yuso escriptos, paresçió personalment Pero Gonçález de Villa Fáfila, canónigo de la 
eglesia $\beta^{3}$ seglar et collegial de Santa María de Fusillos, del dicho obispado. Et presentó, exhibió et mostró publicament antel dicho señor prouisor offiçial, una carta de privillegio del papa Alexandro terçio, escripto en pargamino de cuero et sellado / con su sello de plomo pendiente en filos de seda amarilla. E en el dicho sello estaua, de la vna parte, doss cabeças figuradas et sobre ellas unas letras abreuiadas, en las quales dezia: "Santus Paulus et Santus Petrus". Et de la otra parte, estaua escripto et dezía: "Allexan/der Papa tercius", non rrasa non rrota nin viçiada nin cancelada en alguna parte della sospechosa, más caresçiente de todo viçio et suspiçión, segund que prima facie paresçía, el tenor de la qual "de verbo ad verbum" es este que se ssigue:

(Sigue doc. núm. 37)

La qual dicha carta de preuillegio, segund dicho es, mostrada, el dicho Pero Gonçález, canónigo, dixo et expuso al dicho $/^{27}$ señor prouisor et official, que la dicha carta et preuillegio que era necesidat de mostrar, intimar et exhibir en muchas et diuerssas partes et lugares et ante muchas personas. E que por los peligros de los caminos et por otros muchos / inopinados casos, así commo por fuego, agua, furto o rrobo, que sse podría perder et, por ende, que pidía et pidió por mí, el dicho notario, ser trasladados et enxemplados "ad perpetuam rey memoriam" una vez, doss, tress o más traslados de la / dicha carta et privillegio et tornados en pública forma, interpuestos a ellos su autoridat et decreto del dicho señor prouisor.

E luego, el dicho sseñor official, tomó la dicha carta et preuillegio en sus manos et acatola et examinola bien et diligen $/{ }^{30}$ temente e viola non rota nin cançelada et sana et entera nin en alguna parte ssospechossa. E dixo que la petiçión del dicho Pero Gonçález, canónigo, que era justa et razonable et consona a la rrazón et ygualdat del derecho. Et dixo que mandaua et mandó a / mí, el dicho notario público ayusso esscripto, que trasladasse et enxemplasse et tornase, en pública forma, la dicha carta de preuillegio. Et dixo que quería et quisso, mandaua et mandó, que de aquí adelante que sea adhibida plenaria fe al traslado et traslados de la dicha carta de pre/uillegio, signados de mi signo, concertados con el dicho original de la dicha carta de preuillegio, así en juyzio commo fuera del, assy como 
al original mismo de la dicha carta de preuillegio. Al qual traslado et traslados, dixo que en la mejor manera et ${ }^{\beta 3}$ forma que podía et deuía de derecho, interponía et interpuso su autoridat ordinaria et decreto.

E desto todo, en commo pas[ó, el] dicho Pero Goncález, dixo que pidía et pidió a mí, el dicho notario, que le diese, ende, un público instrumento, doss o más, quantos menes/ter oviesse, para guarda de su derecho.

Esto todo fue fecho en la dicha çibdat, año, día, mes ssobredichos. Testigos que fueron pressentes a todo lo ssusodicho: Iohán Pérez de Bezerril, bachiller en decretos, Pero Garçía de Fuentes de don Bermudo, notario, et Iohán /Gonçález de Castro Mocho, notario, vezino de la dicha çibdat, et otros muchos.

Et yo, Alfonso Garçía de Villa Garçía, del obispado de Palençia, notario público por la autoridad apostolical, a la pressentaçión de la dicha carta de priuillegio et pedimiento et examinaçión della, et autoridad et $/^{36}$ decreto et a todas las otras cossas susodichas et a cada vna dellas, en vno con los dichos testigos, fuy pressente et assy lo vy et oy passar. Et por mandado del dicho señor prouisor et oficial esscriuí / este público instrumento et lo concordé, fielmente, con el original mesmo de la dicha carta de preuillegio, en que puse mi ssigno acostumbrado en testimonio de verdad. (Signo: ALFONSO).

\section{4}

1428, octubre, 14, jueves - 1428, octubre, 15, viernes. Palencia.

Sentencia y ejecución de ésta del pleito habido entre los concejos de Palencia y Husillos, representado este último por Santa María de Husillos, por la delimitación y amojonamiento de términos, siendo juez-comisario García López de León, escribano real; su acompañante, Juan González; procurador por Palencia, el bachiller Juan Martínez. Fue escrita por Alfonso Martínez de León, escribano del rey y notario público. Inserta provisión real de Juan II (1428, marzo, 22. Valladolid) por la que se comisiona al dicho García López de León para que proceda al apeo y amojonamiento de los términos de Palencia, Fuentes 
de Valdepero y Husillos, a pesar de las protestas del abad de Husillos, Fernando de Aguilar, que alegaba que el sobredicho García López no podía actuar como juez, ya que al tratarse de un señorio eclesiástico le correspondía a la justicia abacial juzgar el pleito.

En el período de probanzas, Santa María de Husillos presentó un traslado del privilegio del coto de Husillos de Sancho III, además de dos escrituras partidas por a, b, c; y una cláusula del libro que llamaban Becerro. Sin embargo el juez declinó tales pruebas, al considerar que las escrituras no estaban selladas ni signadas y que no presentaban el original de Sancho III.

A. AMP, Pergaminos, número 18. Perg., 659 x 429 [+55 mm.]. Escritura gótica de privilegios; buena conservación.

B. AHDP, Caja 144-1ª parte, Pleitos. Papel; 6 hojas; buena conservación.

REG. DEL VALLE CURIESES, Archivo Municipal de Palencia: Privilegios y cartas reales, núm. 43, 130. Regesta la provisión real de 22 de marzo de 1428.

1431, junio, 26. Palencia.

Traslado sacado por Alfonso González, sacristán de Santa María de Husillos y notario apostólico, con autorización de Alfonso Sánchez de Ferrán, vicario general de la diócesis de Palencia por el obispo Gutierre II Álvarez de Toledo, de la confirmación de Sancho IV (1291, agosto, 16. Valladolid) del privilegio de infanzones dado por Sancho III a los canónigos de Santa María de Husillos.

A. APA, Caja 152, Carpeta 1. Perg., escr. cortesana; regular conservación, con roturas que afectan al texto.

El privilegio original de Sancho III no se debía ya conservar en el año 1413, ya que se traslada la confirmación de Sancho IV. 
In Dei nomine, amen. Sepan quantos este público instrumento vieren, como en la çibdat de Palençia, a veynte e sseys días del mes de junio, año del nasçimiento del nostro Saluador Ihesu Christo de mill e quatroçientos y treynta e vn años, en presençia del honrrado e discreto varón Alfonso Sánchez / de Ferrán, bachiller en decretos, canónigo de la yglesia de Palençia e vicario general en lo spiritual e temporal en todo el obispado de Palençia por el mucho rreuerendo / in Christo Padre e Señor don Gutierre, por la graçia de Dios e de la santa yglesia de Roma, obispo de Palençia, estando asentado (...)? por audiencia. E de / mí, el notario público e testigos de yuso scriptos, paresçió ay presente el honrrado e discreto señor don Fernando de Aguilar, doctor en decretos, abbad de Fusillos e canónigo / en la dicha yglesia de Palençia, e mostró e presentó e fizo beer en público por mí el notario público ayuso scripto, por sy e en nombre de la su abba/día e yglesia secular e collegial de Santa María de Fusillos, e prior e cabildo e canónigos e singulares personas e benefiçiados della, ante el dicho señor / Alfonso Sánchez, bachiller, canónigo y vicario, un priuillegio e confirmaçión del rey don Sancho, rey que fue de Castilla, que Dios dé santo paraíso, / segund que por él paresçía scripto en pergamino de cuero e sellado de vn sello de çera blanca pendiente en filos de seda colorados e firmado con / tres nombres, non raso nin viçiado ni cançellado ni en alguna de su parte sospechoso, más caresçiente de todo viçio e suspeçión segund por [...] / el tenor del qual, "de verbo ad verbum" es este que se sigue.

(Sigue doc. núm. 84)

Luego el dicho señor don Fernando de Aguilar, abbat por sy e en el dicho nombre, dixo e expuso [...] señor Alfonso Sánchez, vna carta que él asy como abbad de la dicha abbadía e yglesia e prior e / cabildo e canónigos, singulares personas e benefiçiados della, se entendían ayudar e aprovechar del dicho priuillegio de confirmaçión e le enten/dían e avían de enbiar a çiertos logares e partes remotas e que temían que por furto, rapina, fuego o algund otro caso furtuyto perder el dicho / priuillegio e confirmaçión que lo examinasse con diligençia, e que diesse a mí, el infra scripto notario licencia e poderío e confirmaçión [...] / signo a los quales e a 
cada vno dellos quisiesse entreponer e enterponiesse su auctoridat de derecho para que valiessen e valan e feziessen e fagan [...] / original asy en juicio commo fuera de juyzio, en todo logar, tiempo e parte que fuese o fuesse produzidos, presentados o presentado. E luego el [...] / vicario tomó el dicho priuillegio e confirmaçión e violo e leyolo e palpolo e examinolo con diligençia, e dixo que veía e vio el dicho privillegio e c[onfirmaçión] / viçiado nin cançellado nin en algún de su parte sospechoso más caresçiente de todo viçio e suspeçión. Por ende dixo que daua e dio licencia e poder [...] / frasempto? notario para que sacasse del propio priuillegio e confirmaçión original, vno, dos, tres o más traslado e traslados conçertado e conçertados [...] / signados con my signo a los quales e a cada vno dellos dixo que interponía e interpuso su auctoridat e decreto para que valiesse e valgan e [...] / todo tiempo e logar que fuesen e sean presentados e presentado así commo el proprio original si fuese presentado, mostrado, o producido asy en [...] / fuera de juyzio. E desto todo en como passó el dicho señor abbad por sy e en el dicho nombre, demandó, pedió e requerió. E el dicho señor [...] / bachiller e vicario, quiso e mandó a my, el infrascripto notario, que feziesse ende vno, dos, tres o más instrumento o instrumentos sacados e conçertados $[\ldots]$ / dicho original, signados con my signo segund dicho es. Fecho fue todo esto en la dicha çibdat de Palençia, en su audiencia, año, día e mes [...]/ loco quipus super. Estando ay presentes los honrrados e discretos Juan Sánchez de Medina, notario, e Juan García de Ferrán, capellán del número de la dicha yglesia / de Palençia, e Juan de Santiago, criados, familiares del dicho señor abbad de Fusillos, e Juan Martínez de Palençia, raçionero en la yglesia de Palençia; e Pero Ferrández de / Cosuelo?, raçionero en la dicha yglesia de Fusillos, e otros.

E yo, Alfonso Gonçález de Aguilar de Canpo, clérigo de la diócesis de Burgos e sacristán de Fusillos et notario público por la auctoridat apostolical, fuy presente a todo esto que dicho es en vno con los dichos testigos. Por ruego e requerimiento del dicho señor abbad, por sy e en el dicho nombre e mandado del dicho Alfonso Sánchez, bachiller e vicario, escriví este traslado del dicho priuillegio e confirmaçión, conçertado, concordado e collaçionado fiel e diligentemente en el propio original, priuillegio e confirmaçión. E porque es verdat e no venga en dubda, puse aquí my nombre vna con el nombre del dicho señor Alfonso Sánchez, 
vicario, e signo acostumbrad, rogado e requerido en testimonio de verdat. E non enpezca enda va escriuido que dize "signifer".

(rúbrica) Alfonso Gonçález, sacristán, notario apostólico (rúbrica).

\section{6}

1433, abril, 3, viernes. Palencia, capilla de Santa María de la catedral de San Antolín.

Sentencia escrita por Fernando Martínez de Villavermudo, notario público apostólico de la diócesis de Palencia, y pronunciada por los jueces árbitros Pedro González de Gumiel, chantre de Santa María de Husillos, nombrado por la parte demandante, el prior y cabildo de Santa María de Husillos; y Alfonso Díaz de Támara, bachiller en decretos y canónigo en la catedral de Palencia, nombrado por la parte demandada, el deán y cabildo de la catedral de Palencia, del pleito sobre los diezmos de Santa Eufemia y San Juan de Pajares, siendo procuradores por los primeros, Alfonso Fernández, beneficiado de la iglesia de Husillos; y por los segundos, Martín Fernández de Carrión. La sentencia es favorable a Santa María de Husillos.

A. AHDP, Ampudia y Abadía de Husillos, Pergaminos, carp. 211-14. Perg., 422 x 363 mm.; escr. cortesana; buena conservación.

$B$. APA, $L P H$, ff. $134 \mathrm{v}-135 \mathrm{v}$.

En las escrituras en que se confirman las posesiones dadas por los condes de Monzón a Santa María de Husillos, aparece una iglesia de Santa Eufemia de Bervesca que creemos pudiera ser esta; la misma que, según el relato de la fundación de la abadía, fue dada por el abad de Husillos a los pobladores de Palencia para que la poblasen, pues la capital tenía muy malos fueros.

IN NOMINE DOMINI, AMEN. Sepan quantos este público instrumento de senteçia / vieren, commo en la ciudat de Palençia, viernes, tres días del mes de abril, año del nasçimiento del nostro Saluador Ihesu Xhristo de mille et 
quatroçientos et treynta et tres años, este dicho día en la / capilla de Santa María de la obra de la iglesia cathedral de señor Sanct Antholín de la dicha ciudat de Palençia et estando ende presentes sedendo pro tribunali los honrrados et discretos $\beta$ varones Pedro Gonçález de Guimel, chantre de la iglesia collegial de Sancta María de Fussiellos et Alfonso Díaz de Támara, bachiller en decretos, canónigo en la dicha iglesia de Palençia, juezes, / amigos, árbitros, arbitradores amigables, componedores et juezes de abenençia, tomados et nonbrados et scogidos entre partes, conuiene saber, de la vna parte demandante, los señores / prior et cabilldo de la dicha iglesia de Fussiellos; et de la otra parte defendiente, los señores deán et cabilldo de la dicha iglesia de Palençia. De et sobre rrazón de las déçimas de las tierras et he $/{ }^{6}$ redades de las iglesias de Sancta Eufemia et de Sanct Juan de Pajares, las quales tierras aquí ayuso serán declaradas. E estando otrosí ende presentes Alfons Fernández, benefiçiado en la dicha iglesia de Fu/siellos, procurador de los dichos señores prior et cabilldo de Fusiellos, e Martín Fernández de Carrión, procurador de los dichos señores deán e cabilldo de la iglesia de Palencia. E en presençia de / mí, el notario público et de los testigos infra scriptos, luego los dichos señores Pero Gonçález, chantre, et Alfonso Díaz, bachiller, juezes árbitros susodichos, en presençia de los dichos procuradores $/^{9} \mathrm{de}$ los dichos cabilldos, pro inniçiaron et rrezaron [vna] sentençia en vn scripto, el tenor de la qual "de verbo ad verbum" es este que se sigue:

VISTO VN PROCESO de pleito que es de la / vna parte demandante el prior et cabilldo de la iglesia de Fusiellos, e de la otra parte defendiente el deán et cabilldo de la iglesia de Palençia, de et sobre razón de las déçimas de las tierras de las iglesias de / Sancta Eufemia et Sanct Juan de Pajares, iglesias que son de los dichos prior et cabilldo de Fusiellos. Las quales dichas tierras son éstas que se siguen en esta manera e primeramente las tierras $/^{12}$ de la dicha iglesia de Sancta Eufemia son estas que se siguen: vna tierra de dos obradas linde tierra del dicho señor obispo de Palençia, et tierra de Diego de Torres et el camino que va a la dicha iglesia de Sancta Eufemia. $/{ }^{13}$ Otra quarta de tierra a do estaua Sanct Fagund el Viejo. Item otra tierra de vna obrada linde tierra del dicho señor obispo et tierra de Alfonso Garçía de Villalobón et el campio de Sancta Eufemia. Otra / tierra de dos obradas linde tierra de Juan Alfons de Paredes, notario, vezino de Palençia, con tierra del cabilldo de Palençia et tierra de Juan Alfons de Couillas, capellán en 
la dicha iglesia de Palençia. Item otra tierra $/{ }^{15}$ de media obrada linde tierras de Diego de Torres e de Juan Alfons de Paredes, notario, vezinos de Palençia e el camino de Sanct Eufemia. Otra tierra de media obrada linde el dicho camino et tierra que / fue de Pero Díaz Carniçero, que Dios perdone, vezino que fue de Palençia. Item otra tierra de seys obradas, linde tierra del dicho señor obispo de Palençia, el sendero que va a Sanct Xhristóual e el cami/no de Sancta Eufemia, et tierra que labra Pero de Villafranca, segund que do luego amojonada e linde tierra de la dicha uilla de Sancta Eufimia. Item otra tierra junta con ésta de otras seys obradas linde $/{ }^{1}$ ros al derredor, tierras de la dicha iglesia de Sancta Eufimia et el arroyo que desçiende de la fuente de la Virtud, et linde la dicha tierra que quedó amojonada. Item otra tierra de otras / de sola cassa de Sancta Eufimia e solo salzes linde el camino que va a Fusillos. Et llega esta dicha tierra fasta la puerta de la dicha iglesia de Sancta Eufimia. Item otra tierra de otras / doze obradas que se llama de Lámpara que llega a derredor de la capilla de la dicha iglesia de Sancta Eufimia, e llega fasta el pie de la cuesta de Sanct Christóual, e de la otra parte llega al aroyo $/^{21}$ que desçiende de la fuente de la Virtud. Otra tierra que se llama de So el Tortero de seys obradas, linde la cuesta de Sanct Christóual et el camino de Sancta Eufimia que va a Fusiellos, e la / caua que desçiende de la cuesta a la tierra de Juan Vengas, vezino de Palençia. Item otro pedaço de tierras segund se consiguen dende el camino de Sancta Eufimia que va a Fusiellos e debaxo el / rrío de Carrión e de cuesta tierra del dicho señor obispo, e sale con el pisón al arroyo que desçiende de las cueuas de Sanct Christóual, e acude a la dicha tierra del dicho Juan Vengas, en la qual $/^{24}$ dicho pedaço de tierras ay fasta veynte et quatro obradas poco más o menos e en medio destas dichas tierras yaze vna tierra del cabilldo de Palençia de tres obradas. Otra tierra / a Jigondo de ocho obradas linde tierra del dicho señor obispo et el camino que va a Jigondo cabe el rrío e tierra de los fijos de Gonçalo Martínez de Vayllo, vezinos de Palencia. Otra tierra ençima de / Jigondo de dos obradas, linde tierra del dicho señor obispo, e el prado de Mata Vacas. Item otra tierra çerca de los mojones de doze obradas, poco más o menos, linde el camino de Sancta Eu/ ${ }^{27}$ fimia que va a Fusiellos et el rrío de Carrión, et tierra del dicho señor obispo; e llega esta tierra fasta el sendero que va a los molinos de Sobradillo. 
Las tierras e heredades de la iglesia de / Sanct Juan de Pajares que tiene en término de Palençia, son estas que se siguen: vna tierra de dos obradas linde tierra de Pero Garçía de Perales, vezino de Grijota, e el camino que va a Palençia, et tierra de / de (sic) vna confradía de Palençia. Otra tierra de siete obradas, linde tierra de Diego Fernández de las Açeñas, e tierra de Andrés Gonçález e de Gonçalo Martínez su hermano, vezinos de Palençia, e tierra de la ${ }^{\beta 0}$ dicha confradía. Item otra tierra que se llama de La Natera en que ay fasta veynte obradas, poco más o menos, linde el arroyo de La Naua e tierra de los dichos Andrés Gonçález e Gonçalo Martínez / de la cal de Sanct Lázaro, e tierra de Toribio Muriel, vezinos de Palencia. Otra tierra de dos obradas, linde el camino por donde van los de Grijota a aguas, vinos, e al derredor heredades / [de] vezinos de Palençia; otra tierra de quatro obradas linde tierra de la mugier de Alfonso [Y]esero e tierra de Diego Fernández de las Açeñas, vezino de Palençia, e el camino que viene de las açeñas ${ }^{\beta 3}$ e va a Grijota. Otra tierra iunto [co]n esta de la otra parte de obrada e media, linde tierra que fue de Juan López, fijo de Diego López, e el dicho camino. Item otra tierra de dos obradas, linde / tierra de Diego de Toro, vezino de Palençia, e viña de Santa Marina de la dicha çiudat de Palençia. Item otra tierra de tres obradas a par desta dicha tierra, linde majuelo de la mu/gier que fue de Juan Fernández Cantarero, e tierra de Diego Fernández de las Açeñas e tierra de Diego de Toro, vezinos de Palençia. Otra tierra de quatro obradas, linde majuelo de Juan López, fijo de ${ }^{\beta 6}$ Diego López e el camino que va de Grijota a las açeñas de Pajares e el camino que va a la puente de don Guarín. Item otro pedaço de tierra de media obrada, linde viña de la iglesia de / Fusiellos e la pradera del rrío e el camino de Carrera Moros.

E visto todo lo rrazonado, dicho e alegado por amas las dichas partes, FALLAMOS que los dichos prior e / cabilldo de Fusiellos e su procurador en su nonbre, prouaron bien e complidamente toda su entençión çerca de los diezmos de las dichas tierras suso delindos. E por ende, fallamos que ${ }^{\beta 9}$ deuemos de adjudicar e adjudicamos los dichos diezmos de las dichas tierras de Sanct Juan e de Sancta Eufimia, aquí suso delindadas e declaradas, a los dichos prior e cabilldo de la / dicha iglesia de Fusiellos.

E mandamos a los dichos deán e cabilldo de Palençia e al dicho su procurador en su nonbre que non se entrometan a tomar e leuar de aquí adelante las dichas / de 
amas de las dichas tierras suso declaradas e delindadas, nin les molesten nin inquieren más sobrello a los dichos prior e cabilldo de Fusiellos; sobre lo qual ponemos perpetuo $/^{42}$ silençio a los dichos deán e cabilldo de Palençia e al dicho su procurador en su nonbre, a saluo quede a los dichos prior e cabilldo de la dicha iglesia de Fusiellos e al dicho su procurador en / su nonbre que puedan demandar a los arrendadores que han sido del deán e cabilldo de Palençia dende el año que Juan Rodríguez de Castro e Toribio Fernández de la Parrilla, canónigos, fueron / arrendadores que puede auer fasta seys o siete años poco más o menos los de amas que leuaron de las dichas tierras.

E otrosí eso mesmo quede a saluo al deán e cabilldo de la ${ }^{45}$ iglesia de Palençia e a su procurador en su nonbre de demandar algunas diezmas si han leuado de los términos de Palençia que non pertenescan a las dichas iglesias de Santa Eufimia e de / Sant Juan de Pajares so color de las dichas tierras.

E non fazemos condenaçión de costas por çiertas rrazones que a ello nos mouieron. E por esta nostra sentençia definitiua lo pro/nunçiamos e mandamos así e mandamos a las dichas partes e a cada vna dellas que lo atengan e guarden e cumplan así agora e de aquí adelante, so la pena contenida en el compromisso. ${ }^{48}$

La qual dicha sentençia ansí dada e pronunçiada e rezada por los señores Pero Gonçález, chantre, e Alfonso Díaz, bachiller. E luego los dichos Alfonso Fernández e Martín Fernández de Carrión, procuradores / de los dichos cabilldos e cada vno dellos, dexieron que en lo que era por ellos que consentían e consentieron e en lo que era contra ellos que apellauan, estando presentes a esto que / dicho es e cada cossa e parte dello: Alfonso Fernández, arçipreste de Ferrán?, e Iuan Garçía e Rodrigo Alfonso, clérigos de Monçón e Toribio Fernández de Palençuela, vezino de Palençia, e Fernand Gon $/{ }^{51}$ çález de Gomiel, hermano del dicho señor chantre, e otros testigos para estos llamados speçialmente e rogados. (rúbrica)

E yo, Fernand Martínez de Villauermudo de la dióçesis de Palençia, notario público por la actoridat / apostolical, a todo lo que dicho es fuy presente en vno con los dichos testigos. E vi e oy / a los dichos señores Pero Gonçález, chantre, e Alfonso Díaz, bachiller, dar e rezar e pronunçiar / ansí esta sentencia. E por rruego e requirimiento del sobredicho Alfonso Fernández, por / mi signo acostunbrado la signé en testimonio de verdat. (rúbrica) 
(signo)

Fernandus Martínez, notarius apostolicus.

1447, marzo, 22

Sentencia pronunciada por Fernando Álvarez de Villazilla, beneficiado en la catedral de Palencia y arcipreste de (en blanco), del pleito litigado por Pedro Vales, canónigo en Santa María de Husillos, como procurador del prior y cabildo de dicha iglesia, con Diego García de Ferezio, vecino de Ferezio?, sobre una tierra en término de la ciudad de Palencia, denominada de Carrecastro. La sentencia establece que el aprovechamiento de dicha tierra corresponde a Santa María de Husillos.

A. AHDP, Caja 144-1ª parte, doc 3. Papel; escr. cortesana; mala conservación, tinta desvaída que dificulta enormemente la lectura.

1447, julio, 8. Monzón de Campos.

Testamento de Marina Fernández, esposa de Rodrigo Alfonso de Valdespina. Entre otras cláusulas, manda a Santa María de Husillos un maravedí para aceite.

A. AHDP, Caja 63, Carpeta 5, Doc. 1. Papel; escr. cortesana; 1 hoja; buena conservación. 
1451, septiembre, 29, miércoles. Roma.

Carta de procuración de Juan de Carvajal, abad de Santa María de Husillos, a favor de Diego Ruiz de Camargo.

$B$. APA, $L P H$, ff. 131v-134r. Inserta en un testimonio notarial de la venta de unas casas de Santa María de Husillos a Martín González de Olmos, dado en Husillos entre el 1 de abril de 1454 y el 17 de junio de 1457. Véase doc. núm. 230.

In nomine Domini, amen. Per hoc presens publicum instrumentum cunctis pateat et sit notum quod anno Domini millessimo quadragentessimo quinquagessimo primo, indictione quarta, die vero mecurii XXIX, mensis setembris, pontificatus, sanctissimi in Christo, patris et domini nostri, domini Nicolai, divina providentia, pape quinti, anno quinto. Reverendisimus in Christo pater et dominus Ioannes, miseratione divina, Sancti Angeli sacrosancte romane ecclesie diaconus, cardenalis archidiaconus de Alcaraz in ecclesia toletana ac decanus ecclesie astoricensis, nec non abbas abbatie collegiate eclesie beata Marie de Fusellis, Palentine diocesis, et abbatie regularis beate Marie de Monteruela, ordinis cisterciensis, çamorensis diocesis, curator et comendator principaliter pro se ipso citra temporum atque suorum procuratorum per eum alias ad infra scripta constitutorum revocationem. In mei notariis publicum et testium infra scriptorum ad hec specialiter vocatorum et rogatorum, presentia personaliter constitutos, omnibus melioribus modo via, iure causa et forma quibus melius et efficatius potuit et debuit fecit constituit et creavit et soleniter ordinavit et presen $(f .132 r)$ tis instrumenti vigore constituit suum verum certum legitimum indubitatum procuratorem actorem factorem negotiorum que suorum gestorem ac nuntium specialem et generalem ita tumque specialitas generalitati non deroget nec e contra vestre, venerabilem virum domnum Didacum Roderici de Camargo, in decretis bachalarius, absentem tanque presentem solun et in solidum ad prossequendum et e pequentum et exequendum nonullas litteras appostolicas, tam 
provisorias dicte reverendissimo domino cardenali constituendas, per prefatum dominum nostrum papem de et super prenomintatis archidiaconatu, decanatu et abbatiis omnibus que et singuli prestimoniis, prestimonialibus portionibus et simplicibus benefitiis in dominio et distractu regnorum Castelle et Legionis ac alias ubi libet constituent et eorum quomodo libet factis et concessas quas que alias guerras per eundem reverendissimum dominum cardinalem constituent quacumque auctoritate obtentas posterunt ne obtinent, nec non processus quoscumque iude sequtos et sequturus coniunctim et divisim et quecumque alia instrumenta ac prossecutionem et executionem earumdem necessaria et opportuna ipsas que literas apostolicas et processas inde sequtus et alia instrumenta predicta executoribus sive sub executoribus quecumque benefitia ipso domino constituent debita nunc seu in posterum debent huiusmodi que benefitia sibi nomine quo supra conferri et assignari ac deisdem provideri postularint atque ipsorum benefitiarum intrant nascidendum adipiscendi, aprehendent et manutenent ipsa de benefitia nunc obtenta vel ut profertu obtinenda gubernanda et possident ac omnes terras, vines, domus et possessiones, castra, prata, pascua, virgulta ac omnia et singula bona mobilia ac res alias quascumque tam addictos archidiaconatu, decanatu et abbatia et benefitia, quod est totum iure quocumque vel titulo ad eundem reverendissimum dominum cardenalem constituent dictorum archidiaconatus, decanatus, abbatiarum nec non prefatorum prestimoniarum prestimonialium portionum simplitium benefitiorum ubicumque existent ut prefetur eidem reverendissimo patri domino cardinali ac constituenti competenti fructus, reditus et preventus iura obventiones et emolumenta quecumque adictorum benefitiorum provenientia seu provenienda seu ad eundem expectantia seu expectenda ac quocumque modo debita seu debenda, ac quibuscumque personis debitoribus levanda, exigenda, petenda, exigenda, recipienda et recuperanda et de fructibus perceptis per quoscumque ex dictis archidiaconatu, decanatu, abbatiis, prestimoniis prestimonialibus portionibus et simplicibus benefitiis predicti nomine predicto concordandi conveniendi tansfigendum et compromitendum, de iure vel de facto et compromissum, pena et iuramento valandum si eidem procuratori videbitur exire ipsos que archidiaconatum, decanatum, abbatias, prestimonia prestimoniales portiones et simplicia benefitia, huiusmodi fructibus quoque redditus et proventus ac emolumenta predicta et 
eorum possessione locandum et ad firmam possesionem dandum et concedendum ipsa que benefitia in divinis laudabiliter serviendum et agendum ipsum que, reverendissimum patrem dominum constituentem in omnibus et per omnia defendendum libellum seu libellos ac quascumque petotiones sumarias, dandum et recipiendum usque ad interlocutoriam quam definitivam promulgationem inclusive et sententiis ac quocumque alio gravamine illato vel inferendo provocandum et appellandi appostolos petem et recipiem appellatio et appella $(f .132 v)$ tiones intimandum causas pro sequem et ad finem debitum deducent et super expensis iurandum absolutionem benefitium simpliciter vel ad cautelam nec non restitutionem in integrum et quecumque alia iuris benefitia nec non quascumque literas, tam simplices quam legendi, gratiam seu iustitiam concernentes petendi obtinendum et impetrandum exquo contradicendi unum quoque vel plures procuratorem seu procuratores loco sui substituem eumque vel eos revocandu et onus procutionis huiusmodi in se reasumendi totiens quotiens sibi placuerit et visum fuerit expedire. Et generaliter omnia alia et singula facienda, dicenda, agenda, regenda et exercenda que in primissis et circa premissa necessaria sint seu quo modo libet oportunam, et que ipsemet reverendissimus pater dominus cardenalis constituens faceret posset si in premissis et personaliter interesset est si talia forent quem in iure exigant mandatum magis speciale quam presentibus est expressum. Promitens in super idem reverendus dominus cardinalis mihi notario publico infra scripto tamque publice et authentice persone solemniter stipulanti vice ac nomine omnium et singulorum quorum interes aut interesse poterit quo modo libet in futurum seratum gratum firmum stabile perpetuo habiturum totum id et quicquid per dictum suum procuratorem constitutum seu substituendos ab eodem factum actum dictum gestum procuratum ne fuerit in premissis et quo libet eorum, relevans nihilominus et relevare volens dictum suum procuratorem constitutum vel substituendos ab eo ab omini onere satisdandim iuditio quesisti et iudicatum solvi cum suis clausulis nominatis sub ypotheca et obligatione omnium et singulorum bonorum suorum presentium et futurorum mobilium et immobilium ac sub omni iuris et facti renuntiatione ad hec neccessaria pariter et cautella super quibus omnibus et singulis idem reverendus dominus cardinalis constituens petiit sibi a me, notario publico, a me, notario 
publico infra scripto. Unum vel plura publicum seu publica fieri atque confici instrumentum et instrumenta.

Acta fuerunt hec Rome, in domibus solite residentie prefati reverendissimo domini cardinalis sub anno, indictione, die, mense et pontum quibus supra presentibus, ibidem venerabilibus viris dominis Didaco Martin de Bonilla et Rodirico Manedo de Corduba, dicti reverendissimi domini cardinalis, familiaribus clericis abulensis diocesis e cordobensis civitatibus, testibus ad premissa vocatis specialiter et rogatis

Et ego, Iohanes Baltierra, clericus Constantiensis diocesis, publica, appostolica et imperiali auctoritatibus notarius, qui premissis omnibus et singulis, una cum prenominatis testibus interfui eaque sic fieri et audivi ac in notam sumpsi id circo hoc presens publicum instrumentum per alium fideliter scriptum ex inde confeci subscripsi et in hanc publicam formam redegi signo que et nomine meis solitis signavi, rogatus in fidem premissorum. Iohanes Valtierra.

1454, abril, 1. Husillos - [1457], junio, 17. Husillos

Testimonio notarial de la venta de unas casas que poseía Santa María de Husillos en dicho lugar de Husillos, a Martín González de Olmos, canónigo en dicha iglesia, en precio de tres mil maravedís.

\section{- 1454, abril, 1. Husillos.}

Testimonio notarial de la carta de licencia otorgada por Diego Ruiz de Camargo, provisor de Juan de Carvajal, abad de Santa María de Husillos, otorgada a Pedro Gómez de Gumiel, prior de Santa María de Husillos, y al cabildo de dicha iglesia, para poder vender o dar en censo una serie de propiedades que no les rentaban nada. Inserta carta de procuración (1451, septiembre, 29. Roma) del abad Juan de Carvajal al dicho Diego Ruiz de Camargo. 
- 1457, marzo, 31 - 1457, abril, 1-4. Husillos.

Pedro Gómez de Gumiel, prior de Santa María de Husillos, y el cabildo de dicha iglesia, deciden vender unas casas en Husillos en las que moraba la mujer de Diego Ordóñez y que rendían poco económicamente, para reparar las aceñas de Pajares, que se encontraban caídas, entre otras reparaciones. El acuerdo tiene lugar en tres días de reunión del prior y cabildo.

- [1457], junio, 17. Husillos.

Venta de dichas casas a Martín González de Olmos, canónigo de Santa María de Husillos, en precio de tres mil maravedis.

B. APA, $L P H$, f. $131 \mathrm{v}-134 \mathrm{r}$.

En el Libro de los Privilegios de Husillos aparece como fecha de la venta el año 1492.

Fecho e sacado fue este traslado en la villa de Husillos, a primero día del mes de diziembre de mil y quinientos y çinquenta y quatro años. Testigos que lo vieron corregir y conçertar, Joán Ruiz Cabeça de Vaca y Gaspar de Vedoya, clérigos, y Pero Manuel, estantes en la dicha villa.

Y yo, Santiago Gómez, escrivano público en la dicha villa, fui presente a lo que dicho es en vno con los dichos testigos. Y del dicho pedimiento y mandamiento, lo escreví y fize escrevir y fize aquí mi signo (signo) en testimonio de verdad.

Pero Ruyz de Villoldo (rúbrica). Santiago Gómez (rúbrica).

En la villa de Fusillos, primero día del mes de abril, año del nasçimiento de nuestro Salvador Ihesu Christo de mil e quatroçientos et çinquenta y quatro años. Dentro, en la capilla de Santa Bárbara, estando los señores prior y cabildo de la iglesia de Santa María de la villa de Husillos ayuntados a su cabildo, llamados de antenoche por su prior e otro día por canpaña tañida, según que lo an de uso y de costunbre de se ayuntar, estando presentes en el dicho cabildo, los onorables señores don Pero Gómez de Gumiel, prior, e don Garçía Ferrández de Corral, thesorero, e Alfonso Gonçález de Frómesta, e Martín Gonçález de Olmos, e Fernán Martínez de Ayon, e Joán Ferrández de Aguilar, e Martín Sánchez, e Juan Ferrández de Torquemada, e Diego Vélez, e Fernán Garçía de Valladolid, canónigos; e Diego Alfonso de Aguilar, benefiçiado, e otros. Estando presente el 
onorable señor Diego Ruiz de Camargo, bachiller en decretos, provisor en toda el abadía de Fusiellos por el muy reberendo señor don Joán de Carvajal, cardenal de Santángelo, abad de Fusyllos; luego, los dichos prior y cabildo, dixeron al dicho provisor, que por quanto ellos tenyan algunas posesyones que no rrentavan cosa alguna e otras que rrentavan poco, e que si las tales posesyones fuesen dadas a ençenso o vendidas, para que del preçio dellas fuesen rreparadas otras posesyones que rrentasen más, que se acreçentaran las rrentas; e venía dello gran provecho a la dicha yglesia e a la su mesa capitular. Por ende, que le pedían e pidieron por merçed, al dicho provisor, que les diese liçençia e autoridad para ençensuar e vender las dichas posesyiones a más tienpo o perpetuo, segund ellos entendiesen ser más provechoso.

E luego, el dicho provisor dixo que vista su petiçión ser justa e buena e tal que della, se podría rrecreçer e venir gran provecho a la dicha iglesia. Por ende, dixo que le plazía de les dar la dicha liçençia e autoridad, las quales dio en la forma que se sigue:

Sepan quantos esta carta vieren como yo, Diego Ruiz de Camargo, bachiller en decretos, probisor e prior en toda el abadía de Fusiellos, segund por un intrumento de procuraçión pareçe, el tenor del qual, "de berbo ad berbun”, es este que se sigue:

(Sigue doc. 229)

Por quanto vos, los dichos prior y cabildo, me suplicastes y rrogastes que vos diese liçençia y autoridad, ynterponiendo mi decreto, para que pudiésedes arrendar y açensuar, perpetuo o a tienpo, algunas posesiones de la yglesia y mesa. Y yo, el dicho Diago Ruiz de Camargo, bachiller y provisor susodicho ${ }^{14}$, porque se aumentase algún provecho a la dicha yglesia y mesa capitular de Fusiellos. Otrosí, para que pudiésedes vender o enpeñar algunas posesiones que non rrendían cosa alguna e otras que rrendían poco, porque del presçio dellas rreparásede $(f .133 r)$ otras posesiones que rrentarían mucho a la dicha yglesia y mesa capitular.

${ }^{14} \mathrm{Y}$ yo, el dicho Diago Ruiz de Camargo, bachiller y provisor susodicho] Aparece tachado. 
E yo, el dicho Diego Ruiz de Camargo, bachiller e provisor susodicho, viendo e sintiendo vuestra petiçión ser justa y buena e tal que della se puede seguir e rrecreçer gran provecho a las dichas yglesia y mesa capitular, por virtud del dicho poder a mí dado y otorgado por el muy rreverendo señor don Joán de Carvajal, cardenal de Sant Ángelo, abad de Husillos, otorgo y conozco por esta presente carta que vos doy e otorgo la dicha liçençia e abtoridad para que podades arrendar, ençensuar y vender y enajenar todas las posesiones que a vos, los dichos prior y cabildo, bien visto fuere de arrendar, açensuar y vender, porque, de la tal alienaçión, rredunda e se siga provecho a las dichas yglesia y mesa capitular. E do vos esta dicha liçençia e autoridad en la forma e manera que por vosotros a mí es pedida e ynterpongo, en ello, mi decreto en nonbre del dicho señor abad. E desta liçençia e autoridad que ansí vos do, rruego e rrequiero a Fernán Ruiz de Ariona, canónigo desta dicha yglesia, notario apostólico, que vos lo dé signado cada vez que lo oviéredes menester.

Que fue fecha e otorgada esta dicha liçençia, día y mes e año sobredichos. A lo qual fueron presentes por testigos, llamados y rrogados, que vieron dar la dicha liçençia al dicho señor bachiller Diego Ruiz de Camargo: Pero Alfonso, rraçionero de la dicha yglesia e maestre; Pero Carpintero e Joán Ruiz Hurtado, familiar del dicho señor bachiller.

E yo, Fernán Ruiz de Ariona, canónigo de Fusillos, notario público por la autoridad apostólica, que fui presente a todo lo que dicho es, en vno con los dichos testigos, e asy lo vi e oy pasar, e por rruego e otorgamiento del dicho señor bachiller, Diego Ruiz de Camargo, esta liçençia escreví y en esta pública forma la torné. E so testigo e fize, aquí, este mío signo en testimonio de verdad, rrogado e rrequerido. Fernandus Ruiz, apostolicus notarius.

In Dei nomine, amen. Sepan quantos este público instrumento vieren, como en la villa de Fusillos, postrimero día del mes de março, año del nasçimiento de nuestro Saluador Ihesu Christo de myll e quatrocientos y çinquenta y siete annos. Este dicho día, estando los señores prior y cabildo de la iglesia de Fusillos en la capilla de Sancta Bárbara, ayuntados a su cabildo a canpana tañida, según que lo an de uso y de costunbre de se ayuntar, estando presentes en el dicho cabildo: don Pero Gómez de Gumiel, prior, y don García Fernández de Corral, tesorero, y Alfonso Gonçález de Frómesta, e Martín Gonçález de Olmos, e Joán Fernández de 
Aguilar, e Martín Sánchez, e Joán Fernández de Torquemada, e Pero Vélez, Fernado de Baeça, e Alfonso de Braga, e Fernado de la Torre, canónigos, y Pero Alfonso e Pero de Garisa, benefiçiados. Estando todos ayuntados para aver deliberaçión si era bueno y provechoso de la su mesa capitular, vender las casas en que agora mora la muger de Diego Ordóñez para fazer algunos rreparos, asy de las aceñas de Pajares, que están caydas, como de otras posesiones de la yglesia que están de rreparar. E avido sobre ello su acuerdo e por todos en una concordia acordado, fallaron que era bueno de las vender, por quanto rrendían poco y se querían caer, y los maravedís que por ellas diesen podían más aprovechar a la dicha mesa capitular que las dichas casas; y ansí mesmo, se rrepararían las dichas posesiones y no se perderían e sería más provechoso a la dicha yglesia y mesa capitular. Y de como todos lo acordaron, mandaron a mí, Pero Gonçález Mate, canónigo, notario público, que lo diese asy signado. Testigos que fueron presentes, a lo susodicho llamados e rrogados: Alfonso de Uranga y Fernando de la Torre, canónigos, e yo, Pero Alfonso, e Pero de Uranga, benefiçiados.

E después desto, primero día del mes de Abril, todos los dichos señores, prior y cabildo, ayuntados a su cabildo en la capilla de Santa Bárbara por canpana tañida, según que lo an de vso y de costumbre de se ayuntar, para ver si era bueno $(f .133 v)$ e provechoso vender las dichas casas en que mora la dicha muger de Diego Ordóñez; y avido su acuerdo, hallaron que era bien de las vender por las rrazones susodichas. Testigos que fueron presentes: Alfonso de Braga e Fernando de la Torre, canónigos, e Pero Alfonso e Pero Garisa, benefiçiados.

Y después desto, a quatro días del dicho mes de abril, año susodicho, estando los dichos señores ayuntados a su cabildo en la capilla de Sancta Bárbara a canpana tañida, según que lo an de vso e de costunbre de se ayuntar, para ver si era bueno vender las dichas casas en que mora la dicha muger de Diego Ordónnez; e avido, sobre ello, su consejo, por las dichas rrazones ovieron su acuerdo que, porque era gran provecho para la dicha yglesia, vender las dichas casas, mandaron a mí, el dicho Pero Gonçález Mate, notario susodicho, que lo diese asy signado. Testigos que fueron presentes: Los dichos Alfonso de Uruenga e Fernando de la Torre, canónigos e Pero Alfonso e Diego Arisa, benefiçiados.

Y después desto, a diez e siete días del mes de junio, año susodicho del nasçimiento de nuestro Saluador Ihesu Christo de mil y quatroçientos y quarenta y 


\section{LA ABADÍA DE SANTA MARÍA DE HUSILLOS: ESTUDIO Y COLECCIÓN \\ DOCUMENTAL $(904-1608)$}

siete annos. Estando los dichos señores, prior y cabildo, ayuntados en su cabildo a canpana tañida, según que lo an de uso y de costunbre, en presençia de nos, los escrivanos e testigos ynfra escritos, los dichos señores prior y cabildo dixeron que, abiendo por rrato y firme todo lo susodicho, cada cosa e parte dello, por virtud de la dicha liçençia a ellos dada, que vendían e vendieron, las dichas casas donde mora la muger de Diego Ordóñez, a Martín Gonçález de Olmos por preçio e quantía de tres myl maravedís, sobre lo qual, le otorgavan e otorgaron una carta de venta, fuerte e firme, el tenor de la qual es este que se sygue:

Sepan quantos esta carta vieren, como nos, el prior y cabildo de la iglesia de Sancta María de Fusillos, estando ayuntados en nuestro cabildo en la capilla de Santa Bárbara a canpana tañida, según que lo avemos de vso e de costunbre de nos ayuntar a semejantes negoçios, por virtud de la dicha liçençia, por nuestro traslado dada, según de suso se contiene. Otorgamos e conosçemos que vendemos a vos, Martín Gonçález de Olmos, canónigo de Fusyllos, unas casas que nos avemos y tenemos en esta villa de Fusillos, donde mora la muger de Diego Ordóñez, que an por linderos: de la vna parte, casas del dicho prior y cabildo, y de la otra parte, casas de nos, el dicho cabildo, donde mora Alfonso Garçía de la Puerta, y la cal pública. Estas dichas casas que vos vendemos, vendida buena, sana, leal e verdadera, sin entredicho alguno e sin toda mala boz, por preçio e quantía de tres myl maravedís desta moneda vsual que agora corre en Castilla que dos blancas viejas o tres nuevas, fazen un maravedi; de los quales dichos tres mil maravedis, nos otorgamos por bien pagados y entregados a toda nuestra voluntad. Y en rrazón de la paga y de la entrega, rrenunçiamos las leyes del derecho, la vna en que diz que los testigos de la carta deven ver fazer la paga, y la otra ley en que diz que fasta dos años es el ome tenudo de provar la paga que fizo, salvo si el que la rreçibe rrenunçiare estas dichas leyes; e nos, ansy las rrenunçiamos e nos partimos dellas, que non queremos ayudarnos ny aprovecharnos dellas en esta rrazón. E si dixéremos o alegáremos, que vos no vendimos las dichas casas, que nos no vala ni sobre ello seamos oydos, en juizio ni fuera del, y que no rresçibimos de vos, el dicho Martín Gonçález de Olmos, los dichos maravedís.

E de oy día en adelante, nos partimos e quitamos del juro e tenençia y posesión que nos avíamos en las dichas casas y con esta carta vos apoderamos, corporalmente, en ellas a vos, Martín Gonçález de Olmos, para que sean vuestras, 
libres y quitas y exenptas, para vender y enpeñar, dar y donar e trocar, canbiar y enajenar, para que fagades, dellas e en ellas, como faríades de las otras cosas vuestras propias vos, y quien las de vos obiere y eredare.

E para vos fazer sanas e desenbargadas, de qualquier que vos las contrallare o enbargare, obligamos todos los bienes de la nuestra mesa capitular, por doquier que los ayamos, espirituales y temporales, presentes e futuros. Y si sanear $(f .134 r)$ o defender no pudiéremos o no quisiéremos, que vos demos otras tales casas y tan buenas e en tan buen lugar o mejor, o los maravedís que se fallaren que valen, con el doblo, qual vos más quisierdes. E demás, que vos pechemos e paguemos en pena, por nonbre de ynterese convençional estimada y consentida, quarenta maravedís de la dicha moneda, por cada un día que pasare después de que vos no sanearemos o fizieremos sanas las dichas casas. Y la pena pagada o non pagada, que todavía seamos tenudos y obligados a vos sacar a paz e a salvo y vos sanear las dichas casas, nos e nuestros susçesores. E partimos e rrenunçiamos todas las leyes e fueros e derechos, escritos o no escritos, viejos e nuevos, canónicos y çeviles, e todas exençiones e defensiones que nos o qualquier de nos podían dezir o alegar, para lo contenido en esta carta contrallar o enbargar. E si lo dixéremos, que nos non vala, en juizio ni fuera del, ante juez eclesiástico ni seglar. E otrosí, rrenunçiamos la ley e derecho que dize que general rrenunçiaçión que ome faga, non vala.

E porque esto sea firme e no venga en duda, otorgamos esta carta por ante Fernán Ruiz de Ariona, canónigo de la dicha yglesia, notario público por la autoridad apostólica, e por ante Pero Gonçález Mate, canónigo de la dicha yglesia, notario público; a los quales rrogamos que escriviesen esta carta o la mandasen escrivir e la signasen con sus signos.

Que fue fecha e otorgada en la villa de Fusillos, dentro de la capilla de Santa Bárbara, en el cabildo de la dicha yglesia, a diez e siete días de junio, año del nasçimiento de nuestro salbador Ihesu Christo de mil e quatroçientos y quarenta e siete años. A lo qual fueron presentes por testigos, llamados y rrogados: Pero Alfonso e Pero Arisa, benefiçiados e Joán de la Plaça y Pero, criado de Joán de Aguilar, vezinos de Husillos.

Y yo, Fernando Ruiz de Ariona, canónigo de Fusillos, notario público por la autoridad apostólica, fui presente a todo lo sobredicho que de mí faze mençión en 


\section{LA ABADÍA DE SANTA MARÍA DE HUSILLOS: ESTUDIO Y COLECCIÓN \\ DOCUMENTAL $(904-1608)$}

vno con los dichos testigos. E por rruego y otorgamiento de los dichos señores prior y cabildo y por mandamiento del dicho sennor Diego Ruiz de Camargo, provisor del reverendísimo señor cardenal de Sant Ángelo, abad de Fusillos, esta carta escreví e suscreví y en nota la rreçebí y en esta pública forma la torné e so testigo. Y fize aquí este mío signo en testimonio de verdad, rogado e rrequerido. Fernandus Ruiz, apostolicus notarius.

Y yo, Pero Gonçález Mate, canónigo en la iglesia de Fusillos, notario público en toda el abadía de Fusillos por el reverendísimo señor don Joán de Carvajal, cardenal de Sant Ángelo e abad de Fusillos, fui presente a todo lo sobredicho que de mí faze mençión, en uno con los dichos testigos. E por rruego e otorgamiento de los dichos señores prior y cabildo, esta carta por otro fielmente fize escrevir y en nota la rreçebí y en esta pública forma la torné e so testigo. E fize aquí este mío signo en testimonio de verdad.

Petrus Gonçález, notarius.

1462, febrero, 19. Monzón de Campos.

Testamento de Rodrigo Alfonso de Valdespina. Deja una huerta a su hijo, del mismo nombre. Según se dice en el dorso del documento, éste hizo testamento el 26 de septiembre de 1476, en el que manda a la fábrica de Santa María de Husillos varias pertenencias.

A. AHDP, Ampudia y Abadía de Husillos, Legajos y papeles, Caja 63, Carpeta 5-1. Escr. cortesana; papel; 1 hoja; mala conservación. Tinta desvaída que casi imposibilita la lectura.

Entre las mandas que Rodrigo Alfonso de Valdespina hizo a Santa María de Husillos el 26 de septiembre de 1476, posiblemente estaría la huerta que éste recibió de su padre en testamento. Junto con la heredad, los albaceas entregarían a Santa María de Husillos el testamento que acreditaba al difunto como propietario del huerto. 
1470, septiembre, 26. Palencia.

Sentencia pronunciada por Pedro Martínez de Becerril, bachiller, juez árbitro nombrado por las dos partes en litigio, de un pleito litigado por el prior $y$ cabildo de Santa María de Husillos con el concejo de Villaumbrales, sobre el término de Santillán de la Cuesta. Dispone que el concejo de Villaumbrales entrege anualmente a Santa María de Husillos, en censo anual por Santillán, trescientas cántaras de mosto y mil quinientos cincuenta maravedís.

Sobre las disputas entre el concejo de Husillos y de Villaumbrales por la vendimia en Santillán, dispone que los hombres de Husillos comiencen la vendimia tres días más tarde, sin causar daño a las viñas de los de Villaumbrales.

B. APA, $L P H$, ff. $137 \mathrm{r}-138$ r.

Fecho y sacado fue este traslado en la villa de Husillos, a primero día del mes de diziembre de mil y quinientos y çinquenta y quatro annos. Testigos que lo vieron corregir y conçertar, Joán Ruiz Cabeça de Vaca y Gaspar de Vedoya, clérigos, e Pero Manuel, estantes en la dicha villa.

E yo, Santiago Gómez, escrivano público en la dicha villa, presente fui, a lo que dicho es, en vno con los dichos testigos. E del dicho pedimiento y mandamiento, lo escreví y fize aquí mi signo (signo) en testimonio de verdad.

Pero Ruiz de Villoldo (rúbrica). Santiago Gómez (rúbrica).

In nomine Domini, amen. Sepan quantos esta carta de sentençia vieren, como por mí, el bachiller Pero Martínez de Bezerril, juez amigo, árbitro arbitrador, amigable conponedor, juez de avenençia, tomado y elegido entre partes, conviene a saber: de la vna parte los señores prior y cabildo de la iglesia de Santa María de Fusillos, y de la otra parte el conçejo y omes buenos, veçinos y moradores de la villa de Villunbrales, sobre rrazón del término de Santillán de la Cuesta. E por mí vistos los escándalos e trabajos y males y daños sobre el dicho término acontesçidos, e más que se esperavan acaesçer de aquí adelante, por lo 


\section{LA ABADÍA DE SANTA MARÍA DE HUSILLOS: ESTUDIO Y COLECCIÓN \\ DOCUMENTAL $(904-1608)$}

qual, por mí visto e acatado e con diligençia examinado y rresumiendo en mí el poder a mí dado por las dichas partes e cada una de ellas, de que en esta parte quiero usar y vso.

Primeramente mando que por quanto fasta aquí de treynta años a esta parte e más tiempo acá, el dicho conçejo e onbres buenos de Villunbrales davan en çenso, por rrazón del dicho término de Santillán, a los dichos prior y cabildo, treszientas cántaras de mosto, mando, así mismo, que se los den y paguen, en cada vn año para sienpre jamás, en el mes de otubre, según que antes lo solían dar y pagar.

Otrosy, por quanto ansí mismo le solían dar más y aliende el dicho conçejo a los dichos prior y cabildo, myl e doszientos maravedís. E acatado las dichas trezientas cántaras de mosto que así les an a dar, y asímismo acatado otros diezmos e derechos que los dichos prior y cabildo llevan e an de aver y llevar de la dicha villa de Villunbrales y de los vezinos y moradores della por rrespecto del dicho término de Santillán en que moran, a su quantía, mando que el dicho conçejo e omes buenos den e paguen, de oy día de la data desta mi sentençia en adelante, por siempre jamás, en cada un año, mill e quinientos y çinquenta maravedís. E que ge los paguen el día de san Martín de novienbre, según que antes solían pagar los dichos mill e dozientos maravedís.

Otrosy, mando que por rrespecto del dicho ençenso, el dicho término de Santillán quede libre y exento al dicho conçejo y omes buenos, vezinos y moradores de la villa de Villunbrales, para paçer y rroçar y labrar en rras del y en él y por él, todo lo que quisieren y por bien tovieren, ansy como de cosa suya propia, libre y esenta a "perpetuan rrey memorian", de oy en adelante de la dicha data desta mi sentençia. E que sea suyo, (f.137v) libre y esento, como dicho es, con el dicho çenso de las dichas trezientas cántaras de mosto y mil e quinientos y çinquenta maravedís, porque si lo quisieren vender y donar y canbiar, como dicho es.

Otrosy, por quanto avía quistiones y debates entre el dicho conçejo y omes buenos de Villunbrales y prior y cabildo, vezinos y moradores de Husillos, por rrazón de la vendimia, por quanto no consentían vendimiar los de Villunbrales a los de Fusyllos quando querían, las viñas que tienen los de Fusyllos en el dicho término de Santillán e de Villunbrales. Por ende, mando que los de Fusyllos puedan vendimiar e vendimien, las dichas viñas que ansy tienen de aquí adelante, en el dicho término de Santillán e de Villunbrales, tres días después que començaren a 
vendimiar los de Villunbrales. Y así que pasado el terçero día que ayan començado a vendimiar, luego dende en adelante, vendimien quando quisieren los de Fusillos, sin pena alguna, con tanto que si daño fizieren en las viñas de los vezinos de Villunbrales que estovieren por vendimiar, que lo paguen, según fuere apreçiado por los apreçiadores que a la sazón fueren de Villunbrales. Y que los tales apreçiadores juren primero que apreçien de lo apreçiar fielmente. E ansy apreçiado, el tal daño, que lo paguen al dueño fasta nueve días primeros siguientes, so pena del doblo, si al dicho plazo no lo pagaren, con tanto que sean primero rrequeridos o fecho saber a los alcaldes de Fusyllos, para que el que fizo el daño, lo vaya a ver apreçiar y pagar. Y si el dañador no pudiere ser avisado para que el de Villunbrales ge lo faga saber, que baste que ge lo notifiquen a los alcaldes de Fusyllos o a qualquier dellos, y que los dichos alcaldes sean tenudos a lo fazer y que dende en adelante, los de Villunbrales puedan apreçiar, y pasados los nueve días cobrar el tal daño.

Otrosy, mando que por quanto para lo susodicho e para convalidaçión dello, es menester liçençia y autoridad del señor abad de Fusyllos, por ende, mando a los dichos prior y cabildo, que fasta [...]nta días primeros siguientes, obiesen la dicha lizençia y consentimiento e rretificaçión del dicho señor abad, según y en la forma que de derecho es neçesaria. Y ansí avida, la notifique al dicho conçejo y omes buenos, para que ellos lo sepan e lo notifiquen a mí, para que se lo faga saber, porque se dé la forma que neçesaria sea para lo confirmar en corte de Roma. Y esto si el dicho abad estoviere en Castilla o si en corte de Roma o en otra parte fuera del término, que an aver, la dicha lizençia, en la forma susodicha, de seis meses. E que lo notifique al dicho conçejo o a mí, mostrando como la tienen, o el procurador del dicho conçejo si fuere en corte de Roma, porque allase de él saneamiento que cumpla.

Otrosy, mando que porque lo susodicho sea firme, agora y para siempre jamás, "yn perpetuan rrey memorian”, es neçesario confirmaçión del muy sancto Padre, por ende, mando que los dichos prior y cabildo den al dicho conçejo todas las firmezas y poderes que nesçesarios fueren para lo confirmar en corte de Roma. Y que ge lo den desde el día que por parte del dicho conçejo fueren rrequeridos fasta seis días primeros siguientes, açeto la dicha lizençia que la traygan y den en el dicho término por mí asignado, y antes si antes pudieren. Y que así la dicha 


\section{LA ABADÍA DE SANTA MARÍA DE HUSILLOS: ESTUDIO Y COLECCIÓN \\ DOCUMENTAL $(904-1608)$}

lizençia venga rretificada y contenido y aprovando el dicho conpromiso y esta mi sentençia, en la manera que de derecho deva, como dicho es. Y esto faga a su costa el dicho prior y cabildo y que el dicho conçejo, yubre y traya la dicha bulla a su costa y minsión de corte de Roma, por virtud de los dichos poderes y consentimiento de los dichos abad y prior y cabieldo.

Y que si por defecto de solenidad y poder que por parte del dicho prior y cabildo (f.138r) se deven de dar y otorgar la dicha bulla, çesare de venir, según deben, que los dichos prior y cabildo les paguen aquella costa que el dicho conçejo fiziere en la traer o que el dicho cabildo la traya a su costa, desde el día que por parte del dicho conçejo fueren rrequeridos, fasta ocho meses. Y si pagar quisieren la costa fecha, el dicho conçejo yubre, por ella, otra vegada. Y si por su culpa de los dichos prior y cabildo la dicha bulla çesare de venir, por ellos no dar sus poderes y cosas neçesarias, que por su parte devían, mando que no gozen de los dichos trezientos y çinquenta maravedís que les yo mando dar, aliende de los mil y dozientos maravedís que solían aver, fasta en tanto que la dicha bulla venga en forma, açeto esta primera paga, según que por esta mi sentençia se reza, que la paguen enteramente, los dichos mil y quinientos y çinquenta maravedís. Y si por culpa del dicho conçejo çesare de lo traer, que todavía paguen lo contenido en esta mi sentençia que son los dichos mil y quinientos y çinquenta maravedís, al dicho día de San Martín.

Y por esta mi sentençia arbitraria amigando, conponiendo, laudando, rreservando, en mí, el poder a mí dado por las dichas partes e por cada una dellas para declarar y añadir, si menester fuese, en esta mi sentençia, fasta veynte días primeros siguientes, ansí lo pronunçio y mando. Y mando a las dichas partes y a cada una dellas, que lo atengan e guarden y cumplan y paguen, so la pena del compromiso. Y cumplido y pagado, do por libres y quitos a la una parte, de la otra, y a la otra, de la otra, de todas las açiones y demandas y quistiones que fasta el día de oy avían y esperavan aver la vna parte, contra la otra; y la otra, contra la otra. Petrus, vacalarius.

Dada y pronunçiada fue esta dicha sentençia por el dicho bachiller Pero Muñoz Cacharro, juez arbitrario susodicho, en presençia de mí, Pero de Ponte, notario público por la autoridad apostólica, y de los testigos ynfra escritos de la çiudad de Palençia, en la yglesia maior en presençia de las dichas partes, veynte e seis días 
del mes de setienbre, año del nasçimiento de nuestro Salvador Ihesu Christo de mil y quatroçientos y setenta años. Estando presentes: Joán de Salamanca, racionero de la dicha iglesia de Palençia, y Gutierre Garçía, y Joán, vezino de Torquemada, testigos para esto que dicho es, llamados espeçialmente y rogados. Y yo, el dicho Pero de Porras, notario público por la autoridad apostólica, presente fui a todo lo que dicho es en uno con los dichos testigos y así lo vi y oy pasar y en nota lo tomé. De la qual esta carta de sentençia de mi mano propia saqué y en esta pública forma la torné y de mi acostunbrado signo signé, en testimonio de verdad, rogado et rrequerido. Va escrito en el margen do diz: "Petrus, vacalarius", no enpezca.

Petrus de Porras, apostolicus notarius.

1472, octubre, 21. Husillos

Estatutos acordados entre el abad Luis de Carvajal y el prior y cabildo de Santa María de Husillos, regulándose aspectos como la colación de beneficios, jurisdicción, fábrica, estudios de los beneficiados y escusados de los canónigos. Fueron escritos por Pedro González de Astudillo y Sancho González de Calahorra, canónigos de Santa María de Husillos y notarios apostólicos.

A. AHDP, Ampudia y Abadía de Husillos, Pergaminos, carp. 212-7. Perg., 733 x 382 mm.; escr. gótica de privilegios y cortesana. Documento decorado a tres tintas y con pan de oro. Su estado de conservación es bueno aunque presenta dos enormes roturas que afectan a gran parte del texto. Mantiene un pequeño sello de cera blanca y roja con su molde de madera, que parece representar el escudo de la familia Carvajal y que también se conserva sobre la portada de la actual iglesia parroquial de Santa María de Husillos; y otro mayor del que solamente queda el molde de madera y que pertenecería al cabildo de Husillos. Ambos penden de cintas de seda.

IN DEI NOMINE, AMEN. Sepan quantos este público instrumento vieren, commo en la iglesia collegial de Santa María de Fusillos, de la diócesis de 
Palençia, a veynte et / un días del mes de octubre, año del Señor de mill et quotroçientos et setenta et dos años. Estando el reuerendo señor don Luys de Carvajal, abbad de la dicha iglesia et abadía de Fussillos dentro / de la dicha iglesia, en la capilla de Santa Báruara e seyendo presente con su cabilldo e seyendo presentes en el dicho cabilldo los honrrados señores Fernando de Luerçi, assy commo presidente en $\beta$ la dicha iglesia, et el bachiller Pero Gonçález de Astudillo, et Alfonso Gonçález de Biruega, et Fernand Peres de la Torre, et Diego Garçía de Piña, et Juan de Bonilla, et Pero Ruyz Ruacho, et San/cho Gonçález de Calahorra, et Alfonso Martínez de Bonilla, et Pero Gonçález de Gomiel, canónigos; los quales dichos señores et canónigos fueron llamados de antenoche por su presiden/te et este dicho día por canpana tañida, segund lo han de uso et de costunbre de se ayuntar. E se ayuntaron para que el dicho reuerendo señor, don Luys de Carvajal, su abbad et su perlado $/{ }^{6}$ con ellos, puedan ver et determinar et deçedir todas et qualesquier quistiones que agora son et se esperan ser auer, entre el dicho señor abbad et susçessores et los dichos señores prior et cabilldo, ago/ra et in perpetuum, para lo qual primeramente llamada la graçia del Spiritu Santo et concordó el dicho señor abbad, con el dicho su cabilldo, todo lo de yuso escripto:

Primeramente ordenaron et estatuyeron que el / dicho señor abbad, pueda colar et cole en los tres primeros messes; conuiene a saber, março et junio et setiembre, que pertenesçe al ordinario de qualquier calongia o raçión o media raçión que en estos $\rho^{9}$ dichos tres messes vacaren en la dicha iglesia, sin consejo del dicho cabilldo, a quien él quisiere e que en la dicha collaçión <non> se faga mençión del dicho cabilldo. E que los dichos señores prior et cabilldo, colen / et puedan colar de qualquier de los dichos benefiçios que vacaren en el mes de dizienbre, que es el quarto mes del ordinario, sin consenso del dicho señor abbad. E assí en cada un año para siempre ja/más. E que el dicho señor abbad prouea, por sí solo, $\mathrm{d}[\ldots] \mathrm{s}$ los préstamos et thessorería de la dicha iglesia en todos los dichos quatro messes. E quando acaesçiere que el prioradgo vacare en qualquier $/{ }^{12}$ de los dichos quatro messes, que los dichos señor[es] [...] et cabilldo eligan et puedan elegir al tal prior et que el dicho señor abbad confirme et aprueue su eleçión.

Estatuyeron e ordena/ron que el dicho señor abbad aya et tenga un ca[...] [la] dicha iglesia por su prouissor, para librar sus pleitos. E este tal prouissor, aya dos messes de graçia, allende de los tres que le da / el statuto. E otrosy más, que aya el 
dicho se[ñor] [...] [fami]liar escussado en cada un año, el qual él eliga de los benefiçiados que fueren interessentes e aya fecha ressidençia para que $/{ }^{15}$ negoçie sus fechos. E si el tal familiar et es[cussado] [...] en los reygnos de Castilla, que le puedan tener por quanto tiempo quisiere con esta condiçión, que el tal familiar non pueda seruir / otro benefiçiado nin otro señor [...] ]or abbad et en sus negoçios e en otra manera que pierda la libertad et exençión. E sy estuviere en corte de Roma, que non / pueda ser mas exent[o] [...] señor abbad [...]l que assy ha seydo su familiar, saluo sy aquel tal ve[...] $/{ }^{18}$ a rrendir dentro d[...] canónigos o raçionero entero et sy fuere medio raçione/ro, que aya mille et quiniento[s] [...] familiar exento quando el quisiere et por bien toviere, couenién/dose con el tal familiar, que del día q[...] et no más, co[mmo] [dic]ho es, de toda su prebenda. $\mathrm{E}$ estos tales prouissor exenpto et fami $/{ }^{21}$ liar, commo dicho es, sean de los que auyan fech[o] [...]anera.

E otrosy, que el dicho señor abbad, por sy nin por otro, non pueda mandar fazer horas nin quitarlas ha ningund bene/fiçiado, por ninguna cossa que sea, saluo el dicho [...] essidente, en la dicha iglesia, segund que lo han de usso et de costunbre. Otrosy statuyeron et ordenaron que çerca de la corre/pçión et puniçión que se deua de fazer en los ben[...] syngulares del dicho cabilldo quando delinquieren, que en los cassos leues que el dicho señor abbad non pueda, < por $>$ sy nin por $2^{24}$ otro, entremeterse en ellos, saluo que quede a dis[...] ordenança del dicho cabilldo, para lo castigar et ponir o lo remitir commo ellos quissieren et por bien touieren, commo siempre fasta / agora lo fezieron. E en los cassos atroces que i[...] crahen al tal delinquiente, ha cárçel perpetua, a priuaçión o degradaçión o otros semejantes, que estos cassos el dicho señor / abbad con los dichos señores prior et cabilldo, lo [...] et pune et non por sy mismo. E que el dicho señor abbad non pueda, por sy nin por otro, en cárçel nin poner pena çeuil nin crimi ${ }^{27}$ nal ha ningund benefiçiado de delicto alguno que faga et diga, syn el dicho prior et cabilldo. E que el dicho señor abbad, por sy nin por otro, non pueda vessitar nin vessite al dicho cabilldo / nin personas singulares del, si ningund color que sea, saluo si algund benefiçiado delinquiere, que sea corregido et castigado por la forma susodicha.

Item statuyeron et orde/naron que los dichos señores, prior et cabilldo et personas syngulares del, que sean exenptos commo son e les sea guardada su libertad et 
franqueza, assy en sus personas commo en sus $\beta^{30}$ cassas et panyguados, seruidores et familiares en tal manera, que ningund su merino nin aguazil nin otro alguno que sea por mandado del dicho señor abbad nin de otra qualquier / justiçia, assy ecclesiástica commo seglar nin en otra qualquier manera que sea, non sean ossados de entrar nin entren en cassa de alguno de los benefiçiados o capellanes de la dicha / iglesia et de su morada, a sacar prenda nin prendar a persona alguna que biua con el dicho benefiçiado, por ninguna cossa que sea o a la dicha cassa se acoja.

Item statuyeron $/^{33}$ e ordenaron que los dichos señores, prior et cabilldo, pongan obrero para la dicha fábrica de la dicha iglesia et le tomen la cuenta quantas vezes quisieren et por bien touie/ren, syn que el dicho señor abbad entienda en ello nin su prouissor. E puedan quitar vno et poner otro, segund bien visto fuere por los dichos señores prior et cabilldo. Et aren/dar las rentas de la dicha fábrica de la dicha iglesia, segund que siempre lo fezieron. E el tal obrero sea benefiçiado de la dicha iglesia.

Estatuyeron et ordenaron que el dicho señor ${ }^{36}$ abbad, con el dicho su cabilldo, puedan denunçiar et declarar en sus buenas conçiençias, los canónigos o benfiçiados que fueren menester de enbiarlos al estudio e echarlos de la / <que a ellos $>$ dicha iglesia al dicho studio, por el tiempo bien visto fuere, et tornarlos quando fueren suffiçientes para estar en la dicha iglesia e que non lo pueda fazer el uno syn los otros. Et sy el dicho se/ñor abbad non estudiere nin ressidiere en la dicha su iglesia, que el dicho su prouissor lo pueda fazer por él con el dicho su cabilldo.

Item estatuyeron et ordenaron que el dicho ${ }^{39}$ señor abbad sea et esté contento con toda la heredat que oy día tiene et possee, que dizen de la Serna del Abbad, en los términos que dizen de la dicha su villa de Fussillos. E toda / la otra heredat restante, de los dichos términos, esté a dispossiçión et ordenança de los dichos señores prior et cabilldo, commo agora es et siempre jamás fue, saluo que el / dicho señor abbad pueda meter et plantar en esta dicha heredat que estudiere baldía, viñas quantas quisiere, para sy et non para otro, nin las pueda vender, tanto que el di ${ }^{42}$ ezmo de las dichas viñas quede para el dicho prior et cabilldo.

Estatuyeron et ordenaron que el dicho señor abbad aya et tenga toda la villa de Villandilla con todos sus / términos, commo la tyene et possee oy dya et siempre 
touo, syn ningund entredicho. Et sy alguna scriptura paresçiere en contrario, sea ninguna et de ningund valor et por tal la declaran / et denunçian desde agora.

Item estatuyeron et ordenaron que por quanto fasta agora ouo grandes debates sobre el pescar del río, que el dicho señor abbad aya et tenga ${ }^{45}$ en el rrío, desde el molino de la cassa, commo $<\mathrm{va}>$ enrrededor del soto del dicho sennor abbad, fasta la primera pesquera, veniendo del soto a la mano esquierda et en derecho de Los Fitos / a la mano derecha, desta otra parte, en el prado de los señores prior et cabilldo.

Estatuyeron et ordenaron que el dicho señor abbad aya para sy, que sean de su juris/diçión, todos los exçessos et sacrilleios et homeçidos que en esta su villa et abadía se cometieren, por qualesquier personas que se cometieren, assy clérigos commo legos, $/^{48}$ assy los desta iglesia commo los de fuera.

Item estatuyeron et ordenaron que sy las heras se partieren, que sean fechas tress partes et que el señor abbad aya la una / parte et los señores prior et cabilldo ayan las dos partes.

Item estatuyeron et ordenaron que cada un canónigo et dignidad tenga un hombre exenpto que more con el / dicho canónigo o dignidad en su cassa o fuera de su cassa et que more a soldada. Et el tal exenpto que $<$ non $>$ tenga bueyes nin mulas suyas, nin sean de los que agora biuen en esta $/{ }^{51}$ villa, saluo sy los dichos bueyes et mulas fueren de dicho canónigo o dignidad. Et que el tal exento sea libre de todo tributo del dicho señor abbad et conçejo, por todos / los dichos bienes que touiere.

E luego, los dichos señores abbad et canónigos dixeron que porque todos fuessen çiertos et seguros que se manternía, conpliría et guardaría todo et cada / una cossa et parte de lo en esta carta et estatutos contenido, para agora et in perpetuum, que de su propia, libre, mera et spontanea voluntad, sin premya nyn myedo nyn induzimy $/{ }^{54}$ ento alguno, que jurauan et juraron a Dios et a Santa María et a la señal de la cruz (signo: cruz) en que corporalmente con sus manos derechas, tanxieron et cada uno dellos tanxó et a las / palabras de los Santos Euangelios, doquier que están, et a las órdenes que resçibieron, que estarán, que darán, manternán et conplirán, para agora et in perpetuum, / todo et cada una cossa et parte de lo contenydo en esta carta et estatutos et non yrán nyn vernán contra ello 
nyn contra parte dello, por sy nyn por otra interpossyta per ${ }^{57}$ sona, en nyngund tiempo que sea.

E sy lo assy feziessen, atouiessen, guardassen et conpliessen, que Dios nuestro señor todo poderosso les ayudasse, en este mundo a los cuerpos / et en el otro, a las ánymas, donde más avyan de durar. E sy el contrario feziessen, él ge lo demandasse, mal et caramente, en este mundo a los cuerpos et en el otro, a las al/mas donde auyan de durar para syempre jamás.

E que deste juramento que assy fazyan, non podiessen nyn puedan pedyr nyn demandar absuluçión nyn relaxaçión, $/{ }^{60}$ a Padre santo nyn a cardenal nyn ha delegado de latere nyn ha nunçio apostólico nyn ha otra persona alguna que poderío touyesse nyn tenga, para ge lo absolver nyn / relaxar. E sy de su propia actoridat et motu ge lo absoluyessen, que ellos nyn alguno dellos, non podiessen ussar nyn gozar nyn ussasen nyn gozassen de la tal abssu/lución nyn relaxación.

E a la confussyón d[el di]cho juramento, los dichos señor abbad et canónigos et cada uno dellos, por ssy mesmo, respondieron et dixo: sí juro / ${ }^{63}$ et amen.

E desto todo, en commo passó, los d[ichos s]eñor abbad et canónigos, pedieron a nos, los dichos Pero Gonçález de Astudillo et Sancho Gonçález de Calahorra, ca/nónigos et notarios apostólicos, que ge lo diés[semos a]ssy, signado de nuestros signos, una, doss et más vezes, quantas menester ouyessen.

Que fue fecho et passó assy, en la dicha / villa de Fussyllos, en la dicha yglesia de n[uestra seño]ra Santa María, estando en el cabilldo segund susodicho es, dya, mess et año susodichos, estando presentes: $/{ }^{66}$ Rodrigo Camyno, et Juan de Ferrera, et [...]uajal, et Fernando Amor, Pero de Áuyla, et Rodrigo de Caruajal, et Rodrigo Alffonso de Aguilar, / benefiçiados en la dicha yglesia de F[ussiellos] [...]ara esto que dicho es, llamados espeçialmente et rrogados. L[uys] de Carvajal, abbas Fussellensis.

Et yo, [Pero Gonçále]z de Astudillo, notario público por la / actoridad [apostólica, prese]nte fuey a todo lo que dicho es en $/{ }^{69}$ uno con los [dichos] testigos, e así lo vy e oy pasar e otor/gar e en [nota 1]o rescebí. De la qual, por mandado e /pedimiento [e r] uego del dicho señor abbad, que aquí firmó $/^{72}$ su nombre e puso su sello, e de los dichos señores del /dicho cabildo, que posieron su sello, amos dichos sellos en çintas de seda / de diversos colores pendientes a mayor corroboraçión e firmeza de $/^{75}$ todo lo susodicho, este público instrumento e 
estatutos, por mano / de otro, ocupado yo de otros negoçios, fielmente escripto / saqué e en esta pública forma lo torné en uno con Sancho ${ }^{78}$ Gonçález de Calahorra, notario appostólico. E de este mi acostumbrado / signo lo signé, rogado e requerido. (Signo: PETRUS GONÇÁLEZ, APPOSTOLICUS NOTARIUS).

Et yo, el dicho Sancho Gonçález /de Calahorra, canónigo en la dicha ${ }^{81}$ iglesia de señora Santa María de Fusiellos, /notario público por la actoridad apostólica, / presente fuy a todo lo que dicho es en uno $/{ }^{84}$ con los dichos testigos e asy lo vy et loy pasar e otorgar et en nota lo tomé; /de la qual, a ruego e pedimiento de los dichos $/^{87}$ señor abbad e presidente e cabilldo, /este público instrumento e statutos, por mano de otro, yo ocupado de otros /negoçios, fielmente escripto saqué $\rho^{90}$ e en esta pública forma torné /et de mi acostumbrado signo lo ssigné, /una con el dicho Pero Gonçález de Astudillo, notario. ${ }^{93}$ Et con el dicho señor abbad, que aquí /firmó su nombre e puso su sello /et el sello de los dichos prior e cabilldo, $/^{96}$ pendientes en çintas de seda a colores /diversas, a mayor corroboraçión e firmeza / de todo lo susodicho, en testimonio $/ 99$ de verdat, rrogado et rrequerido. (Signo: SANCIUS GONÇÁLEZ DE CALAHORRA).

1474, abril, 28. San Cebrián de Campos.

Enrique IV exime a los vecinos y moradores de Husillos de cualquier condición y estado del pago de impuestos. Dicha exención tendrá efectos desde el primer día de enero de 1475. La razón de tal exención es la despoblación que sufre la villa de Husillos, esperando que con dicha exención se recupere la población.

B. APA, $L P H$, f. 244r-v. Inserto en traslado sacado en Valladolid, el 26 de julio de 1560. En Margen izquierda: <Compulsado en parte en el año de 1788 en el pleyto que en este año estaba pendiente en la Chancillería de Valladolid $>$. El documento se trasladó directamente en el Libro de los Privilegios de Husillos. Es posible que el documento original se aportase como prueba en el 


\section{LA ABADÍA DE SANTA MARÍA DE HUSILLOS: ESTUDIO Y COLECCIÓN \\ DOCUMENTAL $(904-1608)$}

pleito que se litigó en la Real Audiencia y Chancillería de Valladolid y que acabase por formar parte de los fondos documentales de dicho tribunal.

C. AGS, Patronato eclesiástico, Inconexos, leg.159, ff. 204r-206v. Papel; escr. procesal; buena conservación.

D. APA, Caja 152, Carpeta 1. Traslado de $B$, posiblemente del siglo XVIII. No traslada las correcciones y la mención del escribano. Papel; 3 hojas cosidas; escr. humanística.

Fecho y pasado, corregido y conçertado fue este dicho traslado de la dicha carta y probisión rreal original que de suso se haze minçión, que estaba escripta en papell y sellada y firmada de las dichas firmas, en la noble villa de Valladolid, a veynte seys días del mes de jullio, año del señor de mill e quinientos e sesenta años. Siendo presentes por testigos a la ver, sacar, corregir y conçertar con el dicho su oreginal, Francisco Caro e Juan de Villarroel e Bernardino de Montalvo, estantes en la dicha villa.

Va entre renglones o diz señora e o diz dicho valga, y no lespezca?.

Yo, Juan de Angulo, escriuano y notario público de la casa? rreal en todos los sus rreinos y señoríos que presente fui, en vno con los dichos testigos, e saqué el dicho traslado del dicho oreginal que de suso se haze minçión, e doi fee que va çierto y verdadero y concordate con el dicho oreginal, e los signé de mi signo.

(rúbrica) En testimonio de verdad. Fernán de Angulo (rúbrica).

Don Enrrique, por la graçia de Dios rrei de Castilla y de León, de Toledo, de Galicia, de Sevilla, de Córdoba, de Jahén, del Algarbe, de Gibraltar y señor de Bizcaya e de Molina, para hazer bien y merced a vos, el abad, prior y cabildo y todos los canónigos y beneficiados de la yglesia colegial de señora Santa María de Fusillos, que es en el obispado de Palençia, por la singular deboçión que yo he a la dicha vuestra yglesia por las santas rreliquias que en ella están y por los servicios que vuestros anteçesores e algunos de vos fizieron a los rreyes nuestros progenitores donde yo vengo y a mí eso mismo; e porque seays tenudos e obligados de rogar a nuestro Señor por mi vida y salud y por las ánimas del rrey don Juan mi señor y mi padre y de la rreyna doña María mi señora, mi madre, que Dios dé santo parayso, e de los otros rreyes mis anteçesores, tengo por bien y es mi merced que desde el primero día de enero del año que verná de mill e quatroçientos y setenta y çinco años, en adelante para siempre jamás y todos los vezinos y moradores de la dicha vuestra villa de Fusillos, de qualquier lei, calidad, sejo, estado e condiçión que sean ansí los que agora son como todos los que fueren de aquí adelante para siempre jamás, en general e cada vno en espeçial, 
sean libres e francos e quitos y esentos de pagar los mis pedidos y monedas en el año o años que las yo mandare echar y coger y repartir en mis rreynos e los rreyes que después de mí fueren, porque la dicha villa está muy despoblada, se pueble mejor de aquí adelante de lo que está. E los yo esimo y franqueo e por esta mi charta mando a cualesquier mis tesoreros y recaudadores e arrendadores e repartidores e ofiçiales e cojedores e otras qualesquiera personas que cojeren y rrecabdaren e olieren de coger y recabdar ansí en rrenta como en fialdad o en repartir los dichos mis pedidos y monedas del dicho obispado de Palencia e de su merindad, que les non demanden ni lieben ni consientan demandar ni llevar los dichos mis pedidos y monedas ni los emplazen ni fatiguen sobrello, pues que mi merced es que sean francos y libres y esentos de todo ello como suso es dicho.

E mando e defiendo a todas e qualesquiera mis justiçias e juezes, ansí del $<$ dicho $>$ obispado de Palençia y de su merindad como de la mi casa y corte y chancillería e de todas las çibdades, vyllas e lugares de los mis rreynos e señoríos que agora son y serán de aquí adelante, que non conozcan ni se entrometan de conoçer de pleitos ni demandas que les sean puestos e movidos antellos e ante qual de ellos por los dichos rrecabdadores e arrendadores e rreçebtores e fieles y cogedores sobre razón de los dichos pedidos y monedas o de qualquier cosa dello, ca yo les quito e pribo en esta parte de poderío e juredicción e esecuçión.

Y quiero y mando que todo lo que por las dichas justiçias e juezes fuere fecho y mandado e sentençiado e pronunçiado y ejecutado contra ellos o contra qualquier dellos e contra sus bienes contra el tenor y forma desta mi carta, que todo ello y cada cosa dello sea ensí ninguno y de ningund valor e non vala nin aya efeto nin esecución en juicio nin fuera del. E mando a los mis contadores mayores e sus ofiçiales que pongan y asienten el traslado desta mi carta signado de signo público en los mis libros de lo saluado. E que los yncudernos y condiçiones con que de aquí adelante mandaren arrendar y coger los dichos mis pedidos e monedas e vos den y torne esta dicha mi carta original e vos la sobrescriban. Y si necesario fuere vos den y libren sobrello mi carta de previlegio para esençión de la dicha vuestra villa e de los vezinos e moradores en ella presentes y futuros e las otras mis cartas e sobrecartas las más firmes y bastantes que menester hubiéredes en esta razón. E cada e quando sobrerende arrendar e poner en renta los pedidos y monedas del dicho obispado de Palençia e de su merindad, que saquen e salven fuera del dicho 


\section{LA ABADÍA DE SANTA MARÍA DE HUSILLOS: ESTUDIO Y COLECCIÓN \\ DOCUMENTAL $(904-1608)$}

arrendamiento la dicha vuestra villa de Fusillos e la non arriende, pues que robos fago merced e quita dellos como dicho es.

La qual dicha mi carta de previllegio e cartas e sobrecartas, mando al mi chançiller e notarios e a los otros ofiçiales que están a la tabla de los mis sellos, que libren e pasen e sellen.

Y mando a los ynfantes, duques, condes, marqueses e rricos omes, maestres de las órdenes e priores e comendadores, alcaldes de los castillos y casas fuertes y llanas y a los de mi consejo e oydores de la mi avdiençia, allcaldes y notarios e alguaciles e otras justiçias e ofiçiales de la mi casa e corte e chancillería y a todos los conçejos e corregidores, allcaldes, alguaciles, merinos, regidores, caballeros, escuderos y ofiçiales y omes buenos, ansí de la dicha çibdad de Palençia e de las villas e lugares de su merindad y obispado e de todas las otras çibdades o villas y lugares de los mis rreinos y señoríos, ansí rrealengos como abadengos e órdenes e behetrías que agora son y serán de aquí adelante e cada vno de vos e a otras qualesquiera personas mis basallos e súbditos y naturales de qualquier estado e condiçión e preeminencia o dinidad que sea a quien esta mi carta fuere mostrada o su traslado dellas signada de escriuano público, que vos guarden e qumplan e fagan guardar e qumplan esta dicha merced e franqueza que vos yo do e fago para sienpre jamás según que en esta dicha mi carta se contiene, e vos non vayan ni pasen ni consientan yr ni pasar contra ella ni contra parte della en algún tienpo ni por alguna manera. Lo qual todo e cada cosa y parte dello quiero y es mi merced y voluntad que se faga e cumpla, así no enbargante qualesquier leyes e fueros e derechos e ordenamientos e premáticas sançiones e husos e costumbres de mis rreynos que en contrario de lo susodicho sean o ser puedan; ni así mesmo no enbargante las leyes que dizen que las cartas dadas contra lei o fuero no deben ser obedesçidas e non qumplidas, e que las leyes e derechos valederos no pueden ser dero(f.244r)gados ni revocados salbo por cortes.

E yo, de mi propio motuo e çierta ciencia, poderío rreal absoluto de que quiero husar e huso en esta parte como rrey señor, aviéndolo aquí todo por ynserto e ymcorporado e dellos y de cada cosa dello fecha espresa y espiçial mención, despenso en todo ello e con cada cosa e parte dello e ansí mismo contra qualquiera cosa de qualquier natural efeto, calidad y misterio que lo pudiese o pueda embargar o prejudicar en qualquier manera, las rrogo e derogo en quanto a 
esto atañe o atañer puede. Y los vnos e los otros no fagan ende al por alguna manera so pena de la mi merçed e de pribaçión de los ofiçios e de confiscación de las órdenes de los que lo contrario fizieren para la mi cámara. E demás mando al ome que los esta mi carta mostrare que los emplaze que parezcan ante mí en la mi corte del día los emplazare fasta quinze días primeros siguientes. E mando so la dicha pena a qualquier escribano público que para esto fuere llamado, que dende al que la mostrare testimonio signado con su signo, porque yo sepa en como se cumpla mi mandado.

Dada en San Çebrián, veynte e ocho días del mes de abril, año del nasçimiento de nuestro señor Ihesu Christo de mill e quatroçientos setenta e quatro años.

Yo el rrey. E yo, Juan de Oviedo, secretario del rrey nuestro señor, la fize escribir por su mandado. Registrada. Diego de Córdoba. Juan de Vría, chançiller.

1474, junio, 8. Roma.

Sixto IV confirma los estatutos del abad y cabildo de Santa María de Husillos.

A. AHDP, Ampudia y Abadía de Husillos, Pergaminos, carp. 203-6. Perg., 264 x 479 mm.; escr. gótica de cancillería pontificia; buena conservación con alguna pequeña rotura, una de las cuales afecta a las líneas 7 y 8 . Sello pendiente de plomo (Anverso: SANCTUS PAULUS. SANCTUS PETRUS; reverso: SIXTUS PAPA IIII)

Sixtus, episcopus seruus seruorum Dei, dilecto filio abbati monasterii beate Marie de Beneuiuere, Palentine diocesis, salutem et apostolicam benedictione. / Ex superne dispositionis arbitrio romanum pontifex in suprema ecclesie militantis statione locatiis circa statum ecclesiarum libet et presertim collegiatarum necnon personarum in illis / diuinis laudibus insistentium continuo solicitus ad ea per que ecclesiarum collegiatarum et personarum huius modi oportunitatibus ac modis consulitur operosis studiis et remediis $\beta$ intendit ac illa que propterea processisse comperit ut firma perpetuo et illibata persistant cum a 
se petitium apostolicam mandat adiici muniminis firmitatem. Sane pro parte dilectorum / filiorum abbatis et capituli secularis et collegiate ecclesie beate Marie de Fusellis, palentine diocesis, nobis nuper exhibita petitio continebat quod ipsi cupientes nonnullis discordiis et / differentis que inter dictum abbatem et dilectos filios canonicos, dicte ecclesie iugebant uiam amputare conuocatis in loco capitulari dicte ecclesie illius capitularibus $/{ }^{6}$ personis more solito [a]d sonum campane pro bono pacis et concordie inter eos imposterim obseruande nonnulla statuta constitutionis et compositionis bonum et equitatem concernentia / inter se successiue $\mathrm{s}$ [tat]uerunt et ordinarunt ac iurarunt illa inuiolabiliter obseruare nec illis unquam contrauenire pro ut in quibusdam publicis instrumentis de super confectis / plenius dicitur contineri. Quare pro parte dictorum capituli asserentium statuta constitutionibus et compositiones huiuismodi prosperum regimen dicte ecclesie ac illius $/ 9$ personarum unionem et quitem concernere, ac sacris canonibus et sanctorum patrum decretis contraria non existere nobis fuit humiliter supplicatum ut statutis constitutionibus / et compositionibus predictis pro illorum subsistentia firmíori robur apostolice confirmationis adiicere, ac alias in premissis oportune prouidere de benignitate applica dignaremur.

Nos / igitur de premissis certam notitiam non habentes huiusmodi supplicationibus inclinati discretioni tue per apostolica scripta mandamus, quatinus si et postquam de premissis tibi legitime $/{ }^{12}$ constiterit statuta, ordinationes, et compositiones huiusmodi, dumodo sint honesta et pro ut illa concernunt omnia et singula in dictis instrumentis contenta, auctoritate uestra / approbes et confirmes suppleasque omnes et singulos defectos siqui forsan interuenerint in eisdem. Non obstantibus constutionibus et ordinationibus apostolicas aliisque ${ }^{15}$ statutis et consue/tudinibus dicte ecclesie iuramento confirmatione apostolica, uel quauis firmitate alia roboratis ceterisque contrariis quibuscunque.

Datum Rome, apud Sanctum Petrum, ${ }^{15}$ anno incarnationis Dominice millesimo quadringentesimo septuagesimo quarto, sexto idus iuni, pontificatus nostri anno quarto.

L. de Sabattariis.

${ }^{15}$ apostolicas aliisque] Escrito sobre raspado. 
1478, enero, 16. Palencia, catedral de San Antolín.

Sentencia escrita por Juan González de Matilla, clérigo de la diócesis de Oviedo y notario público apostólico, y pronunciada por los jueces árbitros Francisco Martínez, abad de Santa María de Husillos, Diego Jiménez de Tamayo y Juan de Porras, canónigos en la dicha abadía, de un pleito habido entre, de una parte, Pedro González de Gomiel, chantre, Juan de Medina, Alonso de Bonilla, Fernando Pérez, Juan de Montemayor, canónigos, por sí y en nombre del prior y cabildo; y de la otra, Fernando de Corral, tesorero, por los diezmos de Pajares. La sentencia establece que el tesorero reciba de la mesa capitular, dos mil cien maravedís, y que el prior y cabildo reciban la renta de los molinos de Pajares sin tener que pagar diezmo.

A. AHDP, Ampudia y Abadía de Husillos, Pergaminos, carp. 211-15. Perg., 232 x 263 mm.; escr. cortesana; buena conservación. Pergamino doblado al medio, lo que hace dos hojas. Están escritos los ff. 1r, 1v y $2 \mathrm{r}$; el $2 \mathrm{v}$ está en blanco y se ha usado como anverso donde poner distintas anotaciones.

B. APA, $L P H$, ff. $135 \mathrm{v}-137 \mathrm{r}$.

Equivoca el año de pontificado de Sixto IV, ya que dicho Papa lo fue entre 1471 y 1484.

IN DEI NOMINE, AMEN. Sepan quantos esta pública presente scriptura de sentençia, amistad / e concordia vieren, como estando en la noble çibdat de Palençia dentro en la iglesia cathedral / de Santo Antolín, a diez e seys días del mes de enero año del nasçimiento del nostro Saluador Ihesu / Christo de mill e quatroçientos e setenta e ocho años, luego después de viésperas e del pontificado / del sanctíssimo Ihesu Christo padre e señor, nostro señor Sixto por la diuinal prouidencia papa / quarto, año séptimo, e rreygnantes en estos rreygnos de Castilla e de León los illustríssimos / e muy esclareçidos señores el rrey don Fernando, e rreyna doña Ysabel, nostros señores, en pre/sençia de mí, el notario e 
testigos yuso scriptos, estando asentados "pro tribunali" en la capilla de la / Trinidat que es en la dicha iglesia de Sancto Antolín, el rreuerendo e circunspectos señores el señor / don Françisco Martínez, abbad de la iglesia collegial de Sancta María de Fusillos, e del consejo del rrey nostro señor, / e Diego Ximénez de Tamayo, e Juan de Porras, canónigos en la dicha iglesia de Palençia asy como / juezes árbitros, arbitradores e amigables conponedores, tomados e elegidos por virtud de vn / compromisso segund que pasó por ante Sancho Gonçález, canónigo en la dicha iglesia de Fusillos, / notario público e en él más largamente se contiene entre partes, conviene a saber: de la / vna parte, los venerables e circunspectos señores el prior e presydente e cabilldo de la dicha / iglesia collegial de Sancta María de Fusillos; e de la otra parte el honrrado e discreto varón / don Fernando de Corral, thesorero de la dicha iglesia de Fusillos, e por defensión de la dicha su / dignidat de e sobra rrazón de los diezmos de los molinos de Pajares.

E luego los dichos señores / abbad de Fusillos e canónigos, juezes susodichos, rresçebido primeramente por ellos rrelaçión de como / fueron çitados e llamados los dichos prior e cabilldo e thesorero partes "hinc inde collintigantes" para / oyr sentençia en la dicha causa para aquella hora. E estando ende personalmente don Pero Gonçález de / Gomiel, chantre e presidente, e Juan de Medina, e Alonso de Bonilla, e Fernand Pérez, e Juan de Monte / Mayor, canónigos en la dicha iglesia de Fusillos, por sy e en nombre de los dichos señores prior e cabilldo / de la vna e el dicho don Fernando de Corral, thesorero eso mismo en la dicha iglesia de la otra parte. Los / quales todos "ex utraque parte" pidieron e demandaron a los dichos señores juezes, que pronunçiasen e sentençia/sen en la causa susodicha por quanto ellos nin cada vno dellos non entendían más allegar de quanto / avía ya allegado e concluydo.

E luego, los dichos señores don Françisco, abbad, e Diego de / Tamayo, e Juan de Porras, canónigos e juezes ya dichos, dixieron que por quanto entre los / dichos señores prior e cabilldo e otros thesoreros de la dicha iglesia antepasados, e agora el / dicho don Fernando de Corral, moderno tesorero, de muchos tiempos e años a esta parte, oviesen / seydo e son movidos muchos e diuersos pleytos, questiones e injurias de e sobre los / dichos diezmos de los molinos de Pajares, a quien oviesen de pertenecer. E esta causa se / aya ventilado e tractado delante de diuersos juezes 
segund que en los actos e proçessos / de la dicha causas más largamente se contiene, de donde non seyendo / rresçindida e cortada la dicha causa se esperauan nasçer grandes scándalos e mayores / questiones e dampnos, odios e rrancores entre las dichas partes. E que por ende, ellos, / por atajar, quitar e cortar los dichos pleytos, questiones, querellas e injurias, scándalos, / (rúbrica) (f.1r) odios, rrancors e dampnos; et por reformar amistad e interponer paz entre las dichas partes de manera / que a esta causa non se envejezca la enemistad entrellos e biuan en pobreza e de cada día sean / vistos ser más depauperados por quitar e amputar tan grandes dampnos e males e mayor/mente entre eclesiásticas personas e amando el bien e vtilidat de las dichas partes e deseando ob/uiar a tan grandes males e scándalos, e por bien de concordia e amistad entrellos e de consentimiento / de los dichos don Pero Gonçález, chantre, e Juan de Medina, Ferrand Pérez, Alonso de Bonilla e Juan de Montemayor, / canónigos por sy e en el dicho nombre de los dichos señores prior e cabilldo e del dicho Fernando de Corral, / thesorero por sí, los quales "hinc inde" prometieron de rrato e firme segund que abaxo parecerá.

E / luego, los dichos señores juezes de consentimiento de las dichas partes asy presentes, rresumidos / en sy todos los actos e méritos de la dicha causa, e oydas las partes e vistas todas las cosas / e substançias della, terminaron, deçidieron, pronunçiaron, sentençiaron, declararon e dieron por su / sentençia diffinitiua "in scriptum”, la qual rrezó el dicho señor don Francisco, abbad de Fusillos, / vno de los dichos juezes e cada vno de los otros señores juezes asy la aprobaron e dixieron / ser de su intención. E todos tres asy la aprobaron junctamente e la firmaron de sus nombres / en esta manera que se sigue:

Vistos los debates e questiones que son entre los señores / prior e cabilldo de la iglesia de Husillos e el thesorero don Fernando de Corral sobre los diez/mos de los molinos de Pajares, los quales el dicho thesorero dize pertenesçerle por rrazón de los / cargos que pertenesçen de hazer a su offiçio asy en poner sacristán como en dar toda la çera / que es neççessaria para la dicha iglesia como en todos los otros oficios; e el dicho cabilldo dize / que solamente le son deuidos los diezmos de quatro rruedas de los dichos molinos e non de más / nin allende por quanto lo demasiado fue nuevamente hedificado, e que el dicho diezmo le deve ser / pagado 
en dinero al rrespecto de lo que el cabilldo arrienda los dichos molinos, e non en pan de / diez cargas vna como el dicho thesorero dize.

E vistos los debates que entre los susodichos ay así / sobre los fructos paztados de los dichos molinos como sobre las entradas que el dicho thesorero / es obligado a pagar al dicho cabilldo por bien de paz e concordia, por virtud del poder a nos / dado e otorgado por los susodichos prior e cabilldo e thesorero de consentimiento de anbas las dichas / partes, estando presentes los señores chantre don Pero Gonçález, e Fernand Pérez, e Juan de Medina, e Alonso / de Bonilla, e Juan de Montemayor, por sí e por los dichos señores prior e cabilldo; e el dicho don Fer/nando de Corral, thesorero por sy e su dignidat, determinamos, declaramos e por esta nostra / sentençia mandamos que el dicho tesorero e sus subçessores, por rrazón de los dichos diezmos / que dize que le pertenesçen en los dichos molinos aya de aver e aya en cada vn año, / agora e para syenpre jamás en la mesa capitular, doss mill e çient maravedís desta mo/neda corriente en Castilla e de León, los quales le sean pagados a él e a sus subçes/sores por matrículas segund e como pagan a los benefiçiados e canónigos de la dicha iglesia. /

E que el dicho prior e cabilldo de aquí adelante e para sienpre jamás, libre e desenbargada/mente la rrenta de los dichos molinos syn aver de pagar diezmo ninguno dellos en pan / nin en dineros al dicho thesorero nin a sus subcessores. Item que por rrazón de los / fructos pasados que se le deven al dicho thesorero de los dichos diezmos, le damos / (rúbrica) (f.lv) por libre e quito de todas e qualesquier deodas de entradas de su dignidat e colongía, asy de las que / se han de pagar en la plana como de todas las otras que se pagan al tienpo de la rreçepçión.

E si alguna / cosa se le ha leuado demasiado que quede a la determinaçión del señor abbad. E mandamos al / dicho prior e cabilldo que le non demaden al dicho thesorero que agora es las dichas entradas, pero que / sus subç̧essores que paguen las entradas e derechos acostunbrados.

Item mandamos que por / quanto cada vna de las partes tovo justa causa de litigar, que se vayan costas por costas e que cada / vno pague las que hizo e la guarda del proçesso de lo que cada vna de las partes presentó al nota/rio.

Franciscus, abbas. Didacus de Tamayo, canonicus Palentini. Iohannes de Porras, canonicus Palentini. 
La qual / dicha sentençia asy dada e rrezada por los dichos señores juezes, luego los dichos don Pero / Gonçález, chantre, e Juan de Medina, e Fernand Pérez, e Juan de Montemayor, e Alonso de Bonilla, ca/nónigos por sy e por los ya dichos señores prior e cabilldo e en su nonbre, e el dicho don Fer/nando de Corral, thesorero por sy "ex utraque parte", aprobaron, rratificaron e emologaron la dicha /sentençia e la ovieron por buena e valedera agora e para syenpre jamás.

E pidieron a mí, el / infra scripto notario, e cada vna de las dichas partes pidió que les diese de la dicha sentençia / vn instrumento, dos o más quantos necçessarios le fuesen. Que fue dada e pronunçi/ada la dicha sentençia en los lugares susodichos, día, mes e año e pontificado ya dichos.

Testigos / que fueron presentes: Juan del Castillo, criado del señor obispo, e Pero de Piedrahita, e Garçía / de Valderas, criados del dicho señor abbad de Fusillos, e otros para esto llamados e rro/gados.

E yo, Iohán Gonçález de Matilla, clérigo de la diócesis de Ouiedo / e notario público por la auctoridad apostólica, a todo lo que dicho / es e a cada cosa e parte dello en vno con los dichos testigos, presente / fue. E por mandado de los dichos señores juezes e a rruego e pedimiento / de los dichos señores chantre e canónigos por sy e en nonbre de los dichos se/ñores prior e cabilldo de la iglesia de Husillos de la vna e el dicho / thesorero por sy de la otra partes "hinc inde ibid convenientes", esta / pública escriptura de sentençia "manu propria" fielmente escreuí, e de mis / acostunbrados nonbre e sygnos la signé en fe e testimonio / de verdat, rrogado e rrequerido (rúbrica).

(signo) Iohannes Gunsissalui de Matilla, apostolicus notarius.

1483, marzo, 14. Husillos.

El abad de Santa María de Husillos, haciendo uso del poder que tiene para nombrar y deponer merino en Husillos, destituye de su cargo a Pedro Sánchez y nombra en su lugar a Juan Tejero, el cual prendió a Pedro de 


\section{LA ABADÍA DE SANTA MARÍA DE HUSILLOS: ESTUDIO Y COLECCIÓN \\ DOCUMENTAL $(904-1608)$}

Santillana, vecino del dicho lugar, por ciertas palabras deshonestas hacia el antiguo merino, el susodicho Pedro Sánchez.

$B$. APA, $L P H$, ff. $139 \mathrm{v}-140 \mathrm{r}$.

Fecho y sacado fue este traslado en la villa de Husillos, a primero día del mes de dizienbre de mil e quinientos y çinquenta y quatro años. Testigos que lo vieron corregir y conçertar, Joán Ruiz Cabeça de Vaca y Gaspar de Vedoya, clérigos, y Pero Manuel, estantes en la dicha villa.

Y yo, Santiago Gómez, escrivano público en la dicha villa, presente fui, a lo que dicho es, en vno con los dichos testigos. Y del dicho pedimiento e mandamiento, lo escreví y fize aquí mi signo (signo) en testimonio de verdad.

Pero Ruyz de Villoldo (rúbrica). Santiago Gómez (rúbrica).

Yo, Alfonso Áluarez de Ávila, escrivano del rrey nostro señor y su notario público en la su corte y en todos los sus rreynos y señoríos, doy fee que el señor abad de Fusillos me mandó que quitase la vara a Pero Sánchez, su merino de Husillos porque su merçed avía avido enojo del, y nonbrase el que más viese que era su seruiçio, según que muchas vezes él auía nombrado. Y yo, a petiçión de los alcaldes del dicho lugar de Husillos, los quales me rrequirieron que yo les diese merino, nombré por merino a Joán Tejero, vezino del dicho lugar de Husillos, al qual tomé juramento en forma que él vsaría bien y lealmente del dicho ofiçio. Y luego, por mandamiento de Diego Fernández de Cardaño, alcalde, prendió el dicho Joán Tejero, merino, a Pero de Santillana, vezino del dicho lugar (f.139v) por çiertas palabras que obo desonestas con Pero Sánchez, merino que antes era, el qual le lleuó preso. Y de cómo yo nombré al dicho Joán Tejero por merino e juró e fizo el dicho juramento e prendió al dicho Pero de Santillana.

Fueron testigos, Fernando del Corral, thesorero, y Diego Fernández de Cardaño, alcalde, y Pero Sánchez, vezinos del dicho lugar.

Que fue fecha en la villa de Husillos, a catorze días del mes de março, año del Señor de mil y quatroçientos y ochenta y tres años.

E yo, el sobredicho Alfonso Álvarez de Ávila, escrivano y notario público susodicho que a todo esto que dicho es presente fui con los dichos testigos. Y lo daré signado cada y quando demandado me fuere. Y porque esto es verdad, esta fe fize escrevir y la firmé de mi nombre. Que fue fecha día, mes y anno susodichos. 


\section{DAVID MARCOS DIEZ}

Alfonso Áluarez.

1483, abril, 28. Madrid.

Los Reyes Católicos, a petición del doctor Francisco Núñez, abad de Santa María de Husillos, liberan a dicha abadía de la encomienda que ejercía sobre ella el conde de Ribadavia y su alcaide de Fuentes de Valdepero. Recuerdan que existen varias leyes que impiden que, a excepción de los reyes, nadie puede ejercer encomienda en el abadengo, reiterando penas y sanciones para todos aquellos que incumplieran tal mandato.

B. APA, $L P H$, ff. $138 \mathrm{v}-139 \mathrm{v}$.

C. AGS, Patronato eclesiástico, Inconexos, leg.159, ff. 137r-139v. Papel; escr. procesal; buena conservación.

Fecho y sacado fue este traslado en la villa de Husillos, a primero día del mes de dizienbre de mil e quinientos y çinquenta y quatro años. Testigos que lo vieron corregir y conçertar, Joán Ruiz Cabeça de Vaca y Gaspar de Vedoya, clérigos, y Pero Manuel, estantes en la dicha villa.

Y yo, Santiago Gómez, escrivano público en la dicha villa, fui presente a lo que dicho es en vno con los dichos testigos. Y del dicho pedimiento y mandamiento, lo escreví y fize aquí mi signo (signo) en testimonio de verdad.

Pero Ruyz de Villoldo (rúbrica). Santiago Gómez (rúbrica).

Don Fernando y doña Ysabel, por la graçia de Dios rrey y rreyna de Castilla, de León, de Aragón, de Siçilia, de Toledo, de Valençia, de Galizia, de Mallorca, de Sevilla, de Çerdeña, de Córdova, de Córçega, de Murçia, de Jaén, de los Algarbes, de Algezira, de Gibraltar, conde y condesa de Barçelona, señores de Vizcaya y de Molina, duques de Atenas y de Neopatria, condes de Ruisellón y de Çerdenia, marqueses de Oristán y de Goçiano, a los del nostro consejo y oydores de la nostra audiençia, alcaldes, alguaziles della y de la nostra casa y corte e chançillería y a todos los corregidores, asistentes, alcaldes, alguaziles, y otras 
justiçias qualesquier de todas las çiudades, villas y lugares de los nostros rreynos e señoríos, y a cada vno y qualquier de vos en vestros lugares y jurisdiçiones a quien esta nostra carta fuere mostrada o el traslado della signado de escriuano público, salud y graçia. Sepades que el doctor Françisco Núñez, abad de Fusillos, nos hizo rrelaçión por su petiçión que ante nos en el nostro consejo presentó diziendo que el su lugar de Husillos a estado en encomienda del conde de Ribadavia y del su alcaide de Fuentes, y que él no quiere que el dicho su lugar aya de estar en encomienda alguna saluo en la nostra. E nos suplicó e pidió por merçed que quitásemos y sacásemos de la dicha comendaría al dicho su lugar de Fusillos, o que sobre ello le proveyésemos de rremedio con justiçia, o como la nostra merçed fuese. E nos tovímoslo por bien. E por quanto entre las leyes de nostros rreynos que en este caso fablan se contienen dos leyes, su tenor de las quales es este que se sigue: que ningún fidalgo ni rrico ome ni otro ninguno no pueda aver encomienda en labadengo en Castilla saluo el rrey, porque lo pueda guardar y defender ansí como lo suyo, porque todo quanto an los monesterios y los abadengos fue dado por limosnas de los rreyes nostros anteçesores y nos lo devemos guardar y defender ansí como aquello que perteneçe a la nostra corona rreal, porque son tenidos los rreligiosos a quien fuere dada la limosna de rrogar a Dios por las ánimas de los nostros anteçesores que fizieron las donaçiones y los monesterios de las limosnas y por la nostra vida y salud de los rreyes que después de nos vinieren. Y todos aquellos que lo non guardaren ayan la maldiçión de Dios y de aquellos rreyes que fizieron las merçedes e limosna e la nostra, contra aquellos que son contra voluntad de los finados.

El rrey don Alfonso, que Dios perdone, en las cortes de Alcalá de Henares fizo vna ley en que ordenó que ningún fijodalgo ni rrico ome ni otro alguno non pudiese aver encomienda en lo abadengo de nostros rreynos. Y otrosí, nos, en el ayuntamiento que fezimos en Medina del Canpo, agora puede aver nueve años, dimos juezes para que oyesen todos los que tenían las dichas encomiendas con los perlados y señores de los dichos lugares todo lo que dezir y alegar quisiesen, porque las tenían y devían provar.

Los quales juezes, oydas sus rrazones, fallaron que las non podrán tener de derecho, y mandaron por sus sentençias a aquellos que las tenían que las dexasen o que no vsasen más dellas; de lo qual, algunos perlados y abades y clérigos a 
quien atañía el fecho, llevaron algunas cartas de sentençias selladas con nostro sello de plomo. Y agora, por quanto supimos que no enbargan ante la dicha ley. Y otrosí, las dichas sentençias que en esta rrazón por nostro mandado fueron dadas, y que algunos duques y condes y caualleros y rricos omes fijosdalgo, y otras personas se an atrevido a entrar y tomar a tener, y tienen las dichas encomiendas en menospreçio de la ley y en traspasamiento de las dichas sentençias y en peligro de sus almas y de sus estados. Y por el temor de derecho no dexan de pecar, rrazón e derecho es que pongamos pena porque el tenor de Dios y de la nostra sean castigados los que contra esta dicha ley y nostras sentençias $(f .138 v)$ vinieren.

Y por ende, aprovamos y confirmamos la dicha ley y las dichas sentençias y mandamientos, y que firmemente se guarden la dicha ley y sentençia. Y ordenamos que qualesquier duques, condes, rricos omes, cavalleros, escuderos, y otras personas de qualquier encomiendas de qualesquier lugares y obispados y abadengos, que los dexen libre y desenbargadamente del día de la data desta carta fasta tres meses primeros siguientes, porque los señores de los dichos lugares puedan vsar dellos commo de suyos sin enbargo alguno, y de aquí adelante no tomen encomienda alguna de obispado ni de abadengo ni de monesterios ansí de mojes como de mojas, ni de iglesias ni de sacristanías. Y qualquier que lo contrario fiziere en las graçias y merçedes y donaçiones que tovieren de los rreyes donde nos venimos e de nos, que les sean enbargados y nos dende agora se lo enbargemos para que les non sean libradas ni los rrecudan con ellas en quanto las dichas encomiendas tovieren.

Y demás, queremos y mandamos que no puedan rreçebir ni demandar en juizio ni fuera de juizio a otra persona por desaguisado o desdén o deuda y otra sin rrazón alguna que le ayan fecho. $\mathrm{Y}$ estas penas queremos que ayan lugar avnque los perlados y cabildos y monesterios o abades o conventos o abadesas o monjas o otras personas qualesquier eclesiásticas les otorguen las dichas encomiendas. Y de su propia buena voluntad es nostra merçed que contra ésta no aproveche a los tenedores de las encomiendas ni vso ni costunbre ni previlegios ni merçed ni merçedes que tengan o les fueren dadas o les fizieren de aquí adelante, porque serían entreduzidos e guardados con pecado y con peligro de sus almas. 


\section{LA ABADÍA DE SANTA MARÍA DE HUSILLOS: ESTUDIO Y COLECCIÓN \\ DOCUMENTAL $(904-1608)$}

Y nos desde agora las rrevocamos e mandamos que non valan ni ayan fuerça ni valor.

Fueron otorgadas e publicadas estas dichas leyes en las cortes de Guadalajara, a veynte e seis días del mes de abril, año del nasçimiento de nostro señor Ihesu Christo de mil y trezientos y noventa años. Y yo, Bartolomé Rodríguez, la fize escrevir por mandado de nostro señor el rrey.

E por ende mandamos dar esta nostra carta para vos, porque vos mandamos que veades las dichas leyes y ordenanças que de suso van encorporadas, e las guardedes e cumplades y executedes y fagades guardar, conplir y executar en todo y por todo según que en ellas y en cada vna dellas se contiene. Y guardándolas y cumpliéndolas vos las dichas justiçias y corregidores y asistentes y alcaldes, non consintades ni deles lugar que contra el tenor y forma dellas el dicho conde de Ribadavia y su alcayde ni otras personas algunas de qualquier estado, condiçión e preheminençia y dignidad que sean, se entromentan en tomar ni ynponer tributos ni derramas ni otras exationes, ni llevarlos a velas ni a sierras ni a seruiçios ni fazer les otros agrauios ni desaguisados, más que los defendades y anparedes y no consintades ni dedes lugar que los vsurpen ni fatiguen. Y que dedes y fagades dar todo el fauor y ayudas que por parte del dicho dotor Françisco Núnnez, vos fuere pedido para tener, rregir y administrar el dicho lugar de Fusillos e vezinos del, de que el dicho dotor Françisco Núnnez está en posesión paçífica, avido por abad y administrador.

Al qual dicho abad de Fusillos y vezinos y moradores y vasallos del, y a las personas que tovieren cargo por el dicho doctor de cojer y rrecandar los fructos y rrentas del dicho lugar, nos como rreyes y señores y patrones e defensores de (f.139r) las iglesias y monesterios de nostros rreynos, por la presente tomamos y rreçebimos en nostra guarda y seguro y commo anparo, proteçión y defendimiento rreal, y los aseguramos del dicho conde de Ribadavia y del dicho su alcayde de Fuentes, y de todas las otras personas que ante vos las dichas justiçias fueren nombradas, para que les non fiera, ni manque, ni lisie, ni rroben, ni fagan otra fuerça, ni daño, ni desaguisado alguno en sus personas ni bienes ni en cosa alguna de lo suyo contra derecho. El qual dicho nostro seguro mandamos a vos las dichas nostras justiçias que guardedes y fagades guardar, y que ninguna persona no sea osado de quebrantarla, y que fagades así pregonarlo públicamente por las plaças y 
mercados y otros lugares acostunbrados de esas çiudades, villas y lugares por pregonero y ante escrivano público, porque venga a notiçia de todos y dello no puedan pretender ygnorançia.

Y fecho el dicho pregón, si alguno o algunos quebrantaren este nostro seguro, pasedes y proçedades contra ellos y contra sus bienes a las mayores penas çeviles y criminales que falledes por fecho y por derecho como contra aquellos que quebrantan seguro puesto por su rrey y rreyna y señores naturales. Y los vnos nin los otros non fagades ende al por alguna manera, so pena de la nostra merçed y de la privaçión de los ofiçios y confiscaçión de todos vestros bienes de los que lo contrario fizierdes para la nostra cámara y fisco. Y demás mandamos al ombre que vos esta nostra carta mostrare que vos enplaze que parezcades ante nos en la nostra corte doquier que nos seamos del día que vos enplazare fasta quinze días primeros siguientes, so la dicha pena so la qual mandamos a qualquier escriuano público que para esto fuere llamado o que de ende al que vos la mostrare, testimonio signado con su signo, porque nos sepamos como se cumple nostro mandado.

Dada en la villa de Madrid, veynte y ocho días de abril, año del nasçimiento de nostro Señor Ihesu Christo de mil y quatroçientos y ochenta y tres años. Yo el rrey. Yo la rreyna. Yo, Diego de Santander, secretario del rrey y de la rreyna nostros señores, la fize escrevir por su mandado. El notarius palentinus Joanes, doctor. Andrés, doctor. Antonius, doctor. Gouandius, liçenciatus.

1483, julio, 31, jueves. Husillos

Traslado sacado por Diego de Arroyuelo, a petición de Fernando Pérez, canónigo de Santa María de Husillos, de tres bulas de indulgencias concedidas por los papas Inocencio IV (1251, abril, 3. Lyón) y Juan XXII: (1322, marzo, 23. Aviñón) y (1334, abril, 13. Aviñón). 
A. AHDP, Ampudia y Abadía de Husillos, Pergaminos, carp. 204-11. Perg., 665 x 547 mm. Perg.; escr. gótica de privilegios; regular conservación con algunas manchas y una rotura que afecta a las líneas: 40, 41, 42, 43 y 44. No tiene sello, pero sí parte de la cinta morada y verde que lo sujetó.

El año del pontificado es erróneo, ya que Sixto IV comenzó su papado en 1471.

IN NOMINE SANCTE TRINITATIS, amen. / Nouerint vniuersi et singulis presentes literas siue presentes publicum transumpti instrumentum inspecturi visuri lecturi pariter et audituri episcopo, ego Petrus Gundisalui, magisther in decretis, bachalarius, ecclesie Fusellensis canonicus vene/rabili et circunspecti viri domini Francisci Nunnii, utriusque iuris doctori predicte ecclesie Fusellensis abbatis, ac in sua abbatia prouisor et officiali generali. Et ad instantiam discreti viri domini Fernandi Petri, predicte ecclesie ca/ ${ }^{3}$ nonici venerabilium et circunspectorum virorum dominorum abbatis, priori et capitulo eiusdem ecclesie predictorum, procuris pro ut de sue procurationis mandato michi legitimo constitit documento. Omnes et singulos sua comuniter / uel divisim interesse putantes eorumque procuratores siqui tunc erant in predicta villa Fusellensis uel in sua predicta abbatia pro eisdem ad videndum et audiendum quasdam literas sanctissimi in Christo patris et domini, nostri domini / Innocentii, felicis recordationis et alias duas literas a reuerendis in Christo patribus et dominis, dominis episcopis infra scriptis concessas in scriptis transumi et exemplari ac in publicam transumpti formam reddegi manda/ ${ }^{6}$ ri meamque auctem ordinariam per me ut moris est interponi uel dicendum et causam siquam habebat rationabilem quare premissa minime fieri debebant alegandum per meas citatorias literas in valius predicte / ecclesie Fusellensis a ffixas citari mandaui ad certum perentorium terminis competetem, videlicet ad diem et horam infra scriptis. Quibus aduenientes comparint personalis in indicio coram me supradictus dominis Fernan/dus Petri et predictas literas citatorias per eum primitus datas in citatorum in eisdem contentorum contumatia dictas literas apostolicas prefacti Sanctissimi domini nostri domini Innocencii Pape, vera bulla plumbea cum filis fericeis $\mathrm{ru} /{ }^{9}$ bei croceique colorum et alias predictas duas literas prefactorum reuerendorum dominorum episcoporum cum suis sigillis in cassis cereis cum suis filis pendents ut moris est bullatas sanas siquidem et integras, non viciatas, non cancella/tas nec in aliqua earum parte suspettas sed omni $\operatorname{pr}[\ldots]$ sus vicio et 
suspectione caren facto realim et in scriptis infra scripti tenoris produxit et putauit ipsas que transumi et exemplari ac in publicam transumpti formam / reddegi mandari per me instanter postulant. Tenor vero predictorum literarum aplicarum et aliarum literarum prefactorum reuerendorum dominorum episcoporum successive de verbo ad verbum secuntur et sunt tales:

(Sigue doc. núm. 67)

(Sigue doc. núm. 103)

(Sigue doc. núm. 124)

QUIBUSQUIDEM literis per notarium publicum infra scriptum letis et publicatis ut prefertur prenominatus $/^{51}$ domnus Fernandus Petri dixit et exposuit prelibato domino prouisori que prefactas literas in multis ac diuersis partibus transumere intendebat et tiniebat eas perdere incendio, aqua, furtu, rapina uel alio aliquo / furtuitu casu siue alies quouis modo id circo que petebat pro ut statim peciit pro conseruatione sui et dicte ecclesie, iuris ad perpetuam rei memoriam per me, notarium publicum infrascriptum, vnum, duo uel plura tran/sumptum seu transumpta transumere uel transumi facerem et cum dictis literis originalibus collationarem signoque et nomine meis solicitis et consuetis signarem cui seu quibus transumpto seu transumptis sic $/^{54}$ per me infrascriptum notarium collationatum et signatum uel collationatis et signatis suam auctem ordinariam interponer et pariter et decretum ut ipsis et eorum cuilibet in iudicio et ex qua merito debeat / plena fides adhiberi tanquam prefactis literis originalibus adhiberi possent et debent. Statim vero dicto domino prouisore et officiali pre insertas literas ad serecipientes et diligenter inspicientes et per eum visas sa/nas et integras, non viciatas, non cancellatas, nec in aliqua earum parte suspectas sed omni prorsus vicio et suspetione carente mandauit michi infrascripto notario ut de dictis literis originalibus vnum uel plu/ ${ }^{57} \mathrm{ra}$ transumptum seu transumpta conficerem transumerem et exemplarem seu transumi confici et exemplari facerem et cum dictis literis originalibus collationarem signoque et nomine meis solitis et con/suetis signarem cui seu quibus suam auctem iudicialem et 
ordinariam interposuit pariter et decretum ut ipsis et eorum cuilibet in iudicio et ex qua ubi cumque exhibite essent debeant plena fides adhiberi / de quibus omnibus et singulis supradictis domnus Fernandus Petri peciit et requisirit a me, notario publico infrascripto, fieri et tradi unum, duo uel plura instrumentum et instrumentam.

Acta fuerunt $/{ }^{60}$ hec in predicta villa de Fusellis intra dictam ecclesiam beate Marie in loco solito et consueto, hora terciarum, audiencie causarum consueta michi in ibi ad iura reddendam pro tribunali sedendo, sub anno a nati/uitate Domini millessimo quadrangentessimo octoagessimo tercio, indictione prima, die vero iouis ultima, mensis iullii, pontificatus sanctissimi in Christo patris et domini nostri domini Sixti, diuina prouidencia Pape quarti, anno / duodecimo. Presentibus ibidem discretis viris dominis Guterrio de Cauallos et Garsia Ferrandez et Antonio Sancii, incolis predicte ville de Fusellis, testibus ad premissa vocatis specialiter et rogatis.

Et ego, Didacus de Arroyuelo, publicus apostolica et ordinaria auctoritatibus notarius, quia predictarum literarum citatoriarum petitioni con $/{ }^{63}$ ccessione et in valuis affixione earumque et literarum aplicarum et aliarum preinsertarum putationi receptione contumatie acusation petitioni / ac literarum apostolicarum et aliarum exemplatione auctoritatisque et decreti interpositione omnibusque aliis et singulis dum sic ut premittitur age/rentur et fierent una cum prenominatis testibus presentes intersin eaque omnia et singula sic fieri vidi et audiui et in notam sumpsi ex $/{ }^{66}$ qua hoc presentes publicum instrumentum manu mea propria scriptum extraxi et in hanc publicam formam reddegi signoque et nomine meis / solitis et consuetis, una cum nomine dicti domini prouisoris et sigilli prelibati circunspecti domini abbatis, appensione signaui in fidem et testimo/nium omnium et singulorum premissorum rogatus et requisitus. (Signum: TIBI DABO CLAUES REGNI CELORUM).

1485, abril, 29. Valladolid. 
Los Reyes Católicos, a petición de Francisco Núñez, abad de Santa María de Husillos, oidor de la audiencia real y miembro del consejo real, ordenan al corregidor de Palencia, Francisco Maldonado, que amojone y deslinde el término de Villaudilla, propiedad de dicha abadia, cuyos límites eran constantemente violados por los vecinos de Paredes de Nava y Fuentes de Nava. Habiéndose puesto mojones e hitos, los vecinos de Paredes de Nava los derribaron, por lo que se insta al corregidor los vuelva a colocar.

B. AGS, RGS, 148504,173. 2 hojas. Papel; escr. cortesana; buena conservación.

\section{1}

1480, julio, 1. Husillos - 1486, julio, 8. Husillos.

Testimonio notarial dado por Sancho Pérez de Calahorra, clérigo de la catedral de Palencia, canónigo de Santa María de Husillos y notario apostólico, en relación al arrendamiento de los molinos de Cabo de Viña.

- 1480, julio, 1. Husillos.

Contrato de arrendamiento de los molinos de Cabo de Viña, propiedad del prior y cabildo de Santa María de Husillos, a Lope Martínez y Fernando Martínez Gato, vecinos de Husillos, como arrendadores principales; Francisco Ratado y Alonso Martínez, hijo del dicho Lope Martínez, vecinos de Villaumbrales, durante un periodo de diez años, en precio de 32 mil maravedís y 32 pares de buenas gallinas. Debían dejar los molinos y la casa que se hallaba en éstos, reparados y en perfectas condiciones al expirar el contrato.

- 1480, julio, 4. Husillos.

Juramento de los arrendadores por el que juran cumplir todo lo pactado en dicho contrato de arrendamiento.

- 1486, julio, 8. Husillos. 


\section{LA ABADÍA DE SANTA MARÍA DE HUSILLOS: ESTUDIO Y COLECCIÓN \\ DOCUMENTAL $(904-1608)$}

Traspaso de arrendamiento de seis ruedas de los molinos de Cabo de Viña, propiedad de Santa María de Husillos, que tenían como arrendadores principales a Lope Martínez, Alonso Martínez, hijo del anterior, y Pedro Martínez Gato, hijo del difunto Fernando Martínez Gato, y que habian cedido en arrendamiento a Rodrigo Sánchez de Aguilar, con las mismas condiciones y cláusulas que ellos tenían con la abadía. Este último traspasa su arrendamiento a Juan Rojo y Pero Ortiz “El Mozo”, vecinos de Grijota.

A. AHDP, Ampudia y Abadía de Husillos, Legajos y papeles, Caja 63-1 y 2. Papel; 8 hojas y 7 hojas cosidas; escr- cortesana; buena conservación.

1488, mayo, 10. Burgos.

Francisco Núñez, abad de Santa María de Husillos, canónigo de la catedral de Palencia y miembro del consejo real, da en censo a Juan Ruiz, vecino de Tardajos, ciertos heredamientos pertenecientes a esta iglesia en dicho lugar, en precio de nueve cargas de pan anuales, mitad trigo y mitad cebada.

A. AHDP, Ampudia y Abadía de Husillos, Pergaminos, carp. 209-27 b. Perg., 274 x 211 mm.; escr. gótica de privilegios; buena conservación; consiste en un cuaderno formado por tres pergaminos doblados al medio y cosidos a la mitad, lo que hace seis hojas. Los ff. 1r, 1v, 5v, 6r y 6v están en blanco.

A'. ARCHV, Pergaminos, Caja 61-13; escr. gótica de privilegios; buena conservación. (procedente de ARCHV, Salas de lo Civil. Zarandona y Balboa (F). CAJA 109-2). Carta de Juan Ruiz.

$B$. APA, $L P H$, ff. $140 \mathrm{r}-142 \mathrm{r}$.

Sepan quantos esta carta pública de çenso vieren commo yo, el dotor don / Françisco Núñez, abad de Husillos y canónigo en la yglesia / de Palençia, del consejo del rrey y de la rregna nostros señores, / digo que por quanto yo tengo y me perteneçen en el logar / de Tardajos y sus términos çiertos heredamientos 
perteneçientes / ha la dicha mi avadía, los quales dichos heredamientos so han andan / en rrenta y çenso ynfhitrosi de seys cargas y media de pan en ca/da vn año, asy en tienpo de los abades mis anteçesores commo después / que yo ove y fue probeydo de la dicha avadía. Y agora, por vtili/dat y provecho de la dicha avadía y agora, por vtilidat della / y por acreçentar sus rrentas, otorgo y conosco que do a çenso y / por nombre de çenso ynfeteosi perpetuamente para syenpre / jamás a vos, Juan Ruyz, vezino del dicho lugar de Tardajos, que esta/des presente, todos los dichos heredamientos perteneçientes / a la dicha avadía que yo he y tengo y me perteneçe en el dicho lo/gar de Tardajos y en sus términos, desde la piedra del rrío a la fo/ja del monte; y de la foja del monte a la piedra del rrío. Los quales / dichos heredamientos susodichos y declarados, vos do a çenso y / por nombre de çenso ynfetiosi con todas sus entradas y salidas / y pertenençias y vsos $\mathrm{y}$ costunbres quantas han y deven aver asy / de fecho commo de derecho, y segund commo perteneçen y pueden per/teneçer a la dicha avadía. Pero en tal manera y con tal con/diçión que vos, el dicho Juan Ruyz y vestros herederos y subçesores / y quien de vos o dellos tobiere y poseyere los dichos hereda/mientos, dedes y pagedes y den y pagen a mí el dicho don / Françisco Núñez, abad de Husillos y a los subçesores que después / de mí serán et suçederán abad y abades de la dicha avadía de Husillos / y a quien de mí o dellos lo oviere de aver, nueve cargas de pan, / meytad trigo meytad çevada, bueno y seco y linpio de dar y de / tomar, medido con la medida acostunbrada del dicho lugar / y puesto y pagado en el dicho logar de Tardajos en cada vn / año para sienpre jamás por el día de Santa María de setien/bre, so pena que me dedes y pagedes y los dichos vestros herede/ros y subçesores den y pagen las dichas nueve cargas del / (rúbrica) (f.1r) dicho pan de cada paga con el doblo por pena y postura que comigo / ponedes, que comiençe la primera paga por el día de Santa María / de setienbre primera que biene y dende en adelante en cada / vn año para sienpre iamás al dicho plazo y sola dicha pena / del doblo.

Los quales dichos heredamientos vos do a çenso y / por nombre de çenso en la manera que dicha es y con las condi/çiones seguientes. Primeramente que en todo tienpo del mun/do seades tenido y obligado vos, el dicho Juan Ruyz, y los dichos / vestros herederos y subçesores, de tener y tengades bien labrados / y rreparados los dichos heredamientos de las labores que / fueren menester a buestra costa y 
mesión y dellos; y así mes/mo, que lo tengades y tengan en todo tienpo del mundo a toda / buestra aventura y de los dichos vestros heredereros y subçesores, / de piedra o de niebla o de agua o tenpestad o de otro caso for/tituyto mayor o menor o ygual de los susodichos que en los / dichos heredamientos o en qualquier parte dellos acaesca o / pueda acaeçer así del çielo commo de la tierra. Y que por el tal / caso o casos non podades nin puedan fazer descuento algu/no del dicho çenso. Otrosí con condiçión que si vos, el dicho Juan / Ruyz y los dichos vestros herederos y subçesores que tobieren / y poseyeren los dichos heredamientos, fuerdes o fueren rrebel/des y non pagaredes o non pagaren el dicho çenso dos años con/tinos, vno en pos de otro, que en tal caso yo el dicho abad y el / abad o abades que fueren de la dicha abadía mis susçesores o / quien mi poder y suyo oviere por su propia avtoridat, pue/da y puedan entrar y tomar por yncomiso los dichos / heredamientos con las mejorías y rreparos que en ellos esto/vieren fechos y non envargante que ansí sean entrados y / tomados por yncomiso, que todavía seades tenido y obli/gado vos, el dicho Juan Ruyz y los dichos vestros herederos y / subçesores, y de pagar el dicho çenso que se deuiere do las pagas / pasadas, otrosy con condiçión que los dichos heredamientos / ni la paga desto dicho çenso non se pueda partir nin devedir / en partes ni en muchos herederos, saluo que sienpre esté y lo ten/ga vn heredero y non más. Y sy de otra manera se partiere y de/vidiere, que caya en la dicha pena de yncomiso.

Otrosí con / (rúbrica) (f.1v) condiçión que si vos, el dicho Juan Ruyz y los dichos vestros herederos / y subçesores y quien de vos y dellos oviere los dichos heredamien/tos, los quefierdes o quisieren vender y traspasar, que antes y pri/meramente lo fagades y fagan saber a mí, el dicho abad y a los / dichos mis subçesores que serán y subçederán en la dicha aba/día, para que si lo quesiere o quesieren tanto por tanto como / otro por ellos diere, que lo aya y ayan ante que otra persona / alguna sabida la verdat de lo que por ellos dieren. Y si de otra / manera se vendiere o trespasare, que la tal venta o trespa/saçión non vala. Y por el mesmo caso caya y yncurra en la dicha / pena de yncomiso.

Y seyendo rrequerido o rrequeridos yo y los / dichos mis susçesores si lo non quesiere o non quesieren tanto por / tanto, que lo podades y puedan vender y trespasar todavía pa/sando con el dicho çenso de las dichas nueve cargas de pan en / cada vn año para mí, el dicho abad y para los otros abades que / serán y 
subçederán en la dicha avadía, y con todas las otras / condiçiones y penas y posturas en esta carta contenidas y de/claradas, pero que los non podades nin puedan vender nin tras/pasar a yglesia ni a monesterio ni a vniversidat mi a cavallero / ni persona poderosa ni a otro alguno de los quel derecho de/fiende, saluo a persona llana y avonada y tal que syn pleyto / ni rebuelta alguna pague el dicho çenso y guarde y cumpla / todas las condiçiones en esta carta contenidas. Las quales asy te/nidas y guardadas y conplidas desde oy día en adelante que / esta carta es fecha y otorgada, me parto y quito y desapodero a / mí y a los dichos mis herederos, subçesores que después de mí se/rán y subçederán en la dicha avadía del señorío vtil y de la posesión natural que yo he y tengo y me perteneçe y pue/de perteneçer a todos los dichos heredamientos y a cada co/sa y parte dellos. Y por esta presente carta y por la tradiçión rreal / della, lo çedo y trenspaso y fago çesión y trenspasamiento de / todo ello a vos y en vos el dicho Juan Ruyz, rreteniendo en / mí el señorío direto y la posesión çevil dello y vos do poder / conplido para que por vestra propia avtoridat, syn liçençia / y mandado de juez ni de alcallde y syn caer por ello en pena alguna, po/dades entrar y tomar los dichos heredamientos y casa cosa y / parte dellos y los tener y poseer para vos y para los dichos vestros / herederos y subçesores y para quien vos y ellos quesierdes y por bien / (rúbrica) (f.2r) tobierdes por juro de heredat para sienpre jamás para vender / y enpeñar y dar y donar y troncar y canviar y enajenar y / trenspasar y fazer dellos y en ellos y en cada parte dellos / commo de cosa vestra propia libre y quita syn contrandiçión al/guna todavía pasando con el dicho çenso de las dichas / nueve cargas de pan en cada vn año para sienpre ja/más, a pagar al dicho plazo y so la dicha pena y con todas / las otras condiçiones en esta carta contenidas y con cada / vna dellas. Las quales seyendo así guardadas y conplidas, / pongo y prometo por firme y solenne estipulaçión con vos, / el dicho Juan Ruyz y con los dichos vestros herederos y subçe/sores, que vos non serán quitados nin tomados los dichos he/redamientos en ningund tienpo del mundo por mí ni por los / dichos mis subçesores que subçederán en la dicha abadía por / más ni por menos ni por al tanto que otro alguno de por / ellos de çenso ni por puja de diezmo nin de quinto nin de ter/çio que nos sea fecho nin por otra cavsa ni rrazón alguna que / sea o ser pueda. 


\section{LA ABADÍA DE SANTA MARÍA DE HUSILLOS: ESTUDIO Y COLECCIÓN \\ DOCUMENTAL $(904-1608)$}

Y otrosy de vos los fazer çiertos y sanos y libres / y desenbargados en todo tienpo del mundo de qualquier per/sona o personas de qualquier estado o condiçión que sean que vos / los demandaren o enbargaren o contranllaren todos o par/te dellos, por qualquier cavsa o título o rrazón que sean que di/gan aver o pretender açión o derecho a los heredamientos, / y de tomar el pleyto y la voz y demanda por vos y por los / dichos vestros herederos y subçesores y vos sacar a paz y a sal/vo y syn dapno de todo ello, so pena de vos dar y pagar el va/lor y estimaçión de los dichos heredamientos con el doblo y / con las costas y dapnos y menoscavos que se vos recrecieren, / por pena y postura y paramiento y por nonbre de propio yn/terese convençional avenido y ygualado que con vos pongo y / la dicha pena pagada o non pagada que todavía y sienpre sea / fyrme y valedero este dicho çenso y todo lo en esta carta conte/nido y cada cosa y parte dello.

Y conosco y otorgo que las di/chas nueve cargas de pan de çenso que vos, el dicho Juan Ruyz / y los dichos vestros herederos y subçesores avedes de dar y pa/gar en cada vn año para sienpre jamás a mí y a los dichos / mis herederos subçesores que serán y subçederán en la dicha / (rúbrica) (f.2v) abadía, que son el su justo y derecho preçio y que non pude aver nin / fallar quien más ni tanto diese por ellos avnque por ello se fizo a / sas diligençia en lo buscar.

Y a mayor abundamiento rrenun/çio y parto de mí y de los dichos mis subçesores, la ley del fuero / y del ordenamiento que fabla en rrazón de las ventas y compras / y de las cosas que se dan a ençenso quando son fechas o se fazer / por más o menos de la meytad del justo preçio, que me non va/lan para lo qual así atener y guardar y conplir en lo que a mí, el / dicho abad y a los dichos mis subçesores en la dicha abadía a/tañe. Y para pagar la dicha pena si en ella cayere y careyen, / obligo los bienes y propios y rrentas de la dicha abadía, mue/bles y rrayzes, espirituales y tenporales, avidos y por aver y / espeçialmente obligo los dichos heredamientos que vos así do / a çenso.

Y yo, el dicho Juan Ruyz que presente esto así otorgo y conos/co que tomo y rreçibo a çenso y por nonbre de çenso de vos, el dicho se/ñor don Françisco Núñez, abad de Husillos que estades presente, / los dichos heredamientos perteneçientes a la dicha vestra abadía / en el dicho lugar de Tardajos y en sus términos y por las dichas / nueve cargas de pan, meytad trigo meytad çebada que yo, el di/cho Juan Ruyz y los dichos mis herederos y subçesores dé y page / y den 
y pagen a vos, el dicho señor abad y a los dichos vestros subçe/sores que después de vos serán y subçederán en la dicha avadía, / de çenso perpetuo en cada vn año perpetuamente para sien/pre jamás. Y a quien de vos o dellos lo oviere de aver bien y con/plidamente pan linpio de dar y de tomar puesto y paga/do en el dicho lugar de Tardajos y medido con la medida acostun/brada del dicho lugar por el dicho día de Santa María de setien/bre de cada vn año, so la dicha pena del doblo, y que comiençe / la primera paga por el dicho día de santa María de setienbre pri/mero que biene, y dende en adelante en cada vn año para sienpre / jamás al dicho plazo, y so la dicha pena y con todas las otras / condiçiones y penas y posturas y estipulaçiones susodichas / y declaradas, y con cada vna dellas. Las quales yo he aquí por / dichas y rrepetidas y las otorgo y he por otorgadas en todo / y por todo commo en esta carta se contiene.

Para lo qual asy a/tener y guardar y conplir y pagar en la manera que dicha / es en lo que a mí atañe, obligo a mí mesmo y a todos mis bienes (rúbrica) $(f .3 r)$ muebles y rrayzes avidos y por aver. Y espeçial y espresamente obligo / y ypoteco por espeçial ypoteca los dichos heredamientos que asy to/mo y rreçibo en el dicho çenso para que en todo tienpo del mun/do y sienpre jamás estén obligados y ypotecados al dicho çen/so y por más conplimiento de derecho.

Y porque todo lo susodi/cho sea fyrme y valedero y aya su conplido y devido efeto, nos, / amas las dichas partes y cada vna de nos por esta carta, rroga / mos y pedimos y damos poder conplido a todas y qualesquier / justiçias, conbiene a saber: yo, el dicho abad a qualesquier jue/zes y vicarios eclesiásticos; y yo, el dicho Juan Ruyz, a qualquier / alcallde o merino o juez y jurado o justiçia o a otro ofiçial qual/quier del rrey y de la rreyna nostros señores de qualquier çibdat / o villa o lugar de los sus rregnos y señoríos ante quien esta carta / paresçiere y fuere pedido conplimiento della que nos constri/gan y apremien por todos los rremedios y rrigores del dere/cho y nos fagan atener y guardar y conplir y pagar to/do quanto dicho es y en esta carta se contiene y cada vna cosa y par/te dello a cada vna de nos, las dichas partes en lo que le a/tañe, así por vía de entrega y esecuçión commo por otra vía qual/quier que cunpla y fagan pago a qualquier de nos, las di/chas partes, que cunpla y fagan pago a qualquier de nos, / las dichas partes, que lo oviere de aver a tan bien de la pena / o penas si en ellas cayéremos commo del dicho prençipal, con / las costas y dapnos y menoscavos que se le rrecresçieren de 


\section{LA ABADÍA DE SANTA MARÍA DE HUSILLOS: ESTUDIO Y COLECCIÓN \\ DOCUMENTAL $(904-1608)$}

/ todo bien y conplidamente bien así commo si los dichos allcaldes / y juezes y vicarios o qualquier dellos ansí lo oviesen iuzga/do y sentençiado por su juyzio y sentençia defenetiba dada / y pronunçiada a nostro pedimiento y consentimiento, la qual / fuese por nos las dichas partes consentida y aprovada y / pasada en cosa juzgada, sobre lo qual todo que dicho es y / sobre cada cosa y parte dello rrenunçiamos y partimos de nos / y de nostro fabor y ayuda que non podamos dezir nin alegar / que en este contrato de çenso y otorgamiento del fuemos / ni somos engañados nin daneficados nin que dolo o lisión, / ynçendio en él. Y rrenunçiamos todo do lo malo y la esebçión del / mal engaño. Otrosí, rrenunçiamos todo benefizio de rrestituçión / "yn yntrigun" o en otra qualquier manera que nos conpetan o con/ (rúbrica) $(f .3 v)$ peter puedan.

$\mathrm{Y}$ otrosy, rrenunçiamos todas leys y fueros y ordena/mientos viejos y nuevos, canónicos y çeviles, comunes y muniçipa/les, eclesiásticos y seglares y todas cartas y merçedes y todas bulas / y rrescritos y todas costituçiones papales y sinodales, y todas / otras buenas rrazones y defensiones y esebçiones $\mathrm{y}$ alegaçiones / de que nos, las dichas partes y qualquier de nos y los dichos / nostros herederos y subçesores nos podamos ayudar y aprove/char contra lo en esta carta contenido, que non valan ni seamos oy/dos sobre ello en juyzio ni fuera del ante algund allcalde nin juez ecle/siástico nin seglar. En espeçial rrenunçiamos la ley del derecho en que / dize que general rrenunçiaçión de leys que omne faga non vala sal/vo rrenunçiando esta ley.

En testimonio de lo qual otorgamos dos cartas / de çenso de vn thenor para cada vna de nos las dichas partes. / La suya antel presente escribano, al qual rrogamos que las faga / o mande fazer fuertes y fyrmes a consejo o syn consejo de letra/dos y las signe con su signo y a los presentes que sean dello testi/gos.

Que fue fecha y otorgada en la muy noble y muy leal çibdat / de Burgos, a diez días del mes de mayo, año del nasçimiento del / nuestro Señor Ihesu Christo de mill y quatroçientos y ochenta y / ocho años. Testigos que fueron presentes llamados y rrogados pa/ra ello, Alonso de Villanueva, rregidor de la dicha çibdat, y el / vachiller Diego López de Ocaña, y Françisco de Çisneros, y Álba/ro de Revolledo, criados del dicho señor abad

Y yo, Juan Martínez de la Cos/tana, escribano público del número de la dicha çibdat de Burgos por / el rrey y por la rreyna nostros señores y su notario público 
en la su corte y / en todos los sus rregnos y señoríos, que a lo que dicho es presente fuy / en vno con los dichos testigos. Y a rruego y otorgamiento del dicho / don Françisco Núñez, abad de Husillos, y del dicho Juan Ruyz, esta carta / pública de çenso escrebí en estas tres fojas y media de pargami/no de cuero para el dicho señor abad, y por ende fize aquí este / mío sig(signo)no en testi/monio de verdad. (rúbrica) Juan Martínez (rúbrica).

1493, julio, 31, jueves. Husillos.

Fundación y estatutos de la cofradía de Nuestra Señora de Dehesa Brava, constituida en la iglesia colegial de Santa María de Husillos. Dicha fundación tiene como contexto los problemas económicos por los que estaba pasando la abadía, agravados por el desbordamiento del río Carrión, que dañaron el puente y cerca de la villa. El cabildo establece que los cofrades deben dar por su entrada medio real de plata o su valor, y los niños de menos de quince años, cinco maravedís o su valor, para subsidio de la reparación de dicho puente, cerca e iglesia de Santa María de Husillos. Fueron escritos por Diego de Arroyuelo, notario público apostólico.

A. AHDP, Ampudia y Abadía de Husillos, Pergaminos, carp. 209-27. Perg., 631 x 453 mm.; escr. gótica redonda de privilegios; buena conservación. No conserva el sello, aunque sí mantiene la cinta, morada y verde, que lo sustentó.

El día 31 de julio de 1493 fue miércoles y no jueves. Véase A. GIRY, Manuel de Diplomatique. La letra dominical correspondiente a 1493 es la F, y la Pascua cayó el 7 de abril.

IN NOMINE SANCTE TRINITATIS, AMEN. / Sepan quantos este público instrumento vieren, commo en la villa de Fusillos, dentro de la iglesia de Sancta María, en la capilla de Sancta Bárbara, juues, postri/mero día del mes de jullio, año del nasçimiento de nuestro Saluador Ihesu Christo de mill y 
quatrocientos y nouenta y tres años. Este dicho día, en presentia de mí, el notario públi/ ${ }^{3}$ co y testigos infra scriptos, paresçieron ay presentes, capitularmente ayuntados por campana tañida, segund por costumbre lo tienen, los venerables señores don / Fernando de Corral, thesorero, y don Pero Gonçález de Gomiel, chantre, y el bachiller Pero Gonçález de Astudillo, y Alonso Gonçález de Briuega, y Fernand Pérez de la Torre, y Diego Garçía de / Piña, y Sancho Gonçález de Calahorra, y Alonso Martínez de Bouadilla, y Fernando Amo, y Iohán Gutiérrez, escrivano, y Iohán Gonçález Picado, y Alonso Ruyz Ruacho, y Pero de Támara, ${ }^{6}$ y Iohán Sánchez de Santillana, y Alfonso Diago, y Francisco de Villa Escusa, y Fernando de Santillana, y Per Alonso de Sant Fagund, canónigos; y Fernand Ruyz de / Villoldo, y Toribio de Llantadilla, y Pero de Lomas, y Iohán de Villaumbrales, y Pero de Ávila, benefiçiados en la dicha iglesia, presentes y en nombre de los absentes. / Y con poder y licençia de los venerables y circunspectos señores don Françisco Núñez, doctor "in utroque" abbat, y don Pero Ruyz de Villoldo, bachiller en decretos, abbat $/^{9}$ de Lavanza y prior en la dicha iglesia. Et dixeron que por quanto ellos avían ordenado una cofradía y hermandat a honor de nuestra señora la Virgen María y porque fuesse / notorio a todos los fieles christianos y fuessen más inclinados a devotión, para aver de entrar en la dicha cofradía, querían que la ordenança, por ellos fecha, pasasse / por ante mí, el dicho infra scripto notario, y por mí fuesse leyda y publicada y de mi signo signada; por manera que, en qualquier logar que paresçiesse, feziesse fe. $/^{12}$

Et luego se levantó Fernand Pérez, canónigo en la dicha iglesia, procurador de los dichos señores, y sacó la dicha ordenança y diola a mí, el dicho notario, para que la / leyesse y publicasse. Y yo tomé la dicha ordenança y leyla en alta y intellegible boz ante los dichos señores y ante otros del dicho logar y de fuera, del su tenor / de la qual dicha ordenança, "de verbo ad verbum", es este que se sigue: In Dei nomine, amen. Por quanto nuestro Salvador Ihesu Christo dixo a sus discipulos: "Exemplum me $/{ }^{15}$ um do vobis, exemplum meum relinquo vobis, ut quem ad modum ego facio, ita et vos faciatis", que quiere dezir: "El mi enxiemplo os do, el mi enxieplo os / dexo, porque assí commo yo fago, assí vosotros fagays". Et el enxiemplo que nos dexó fue, segund en otra parte dize: "Manete in dilectionem mea", que quiere / dezir: "Estat en mi amor". Porque el que está en su amor, está en la caridat y quien está en la caridat, está en Dios, y Dio $<\mathrm{s}>$ está en 
él. Y para complir esta caridat que es $/{ }^{18}$ finchimiento de la ley, avemos de fazer lo que está escripto por el apostol, que dize: "Alter alterius onera portate et sic ad implebitis legen Christi", que quiere / dezir: "El uno al otro levat la carga y assí fenchires la ley de Ihesu Christo. Et por tanto nos, el cabildo de Sancta María de Dehesa Brava, otro tiempo llamada, y / agora llamada Sancta María de Fusillos, de la diócesis de Palençia, con grand necessidat, seguiendo el enxiemplo que Ihesu Christo nos dexó y demandando a los fieles $/{ }^{21}$ christianos la dicha caridat y ayuda para soportar la dicha carga; y porque sean dignos de henchir la ley de Ihesu Christo, les fazemos saber commo, para servicio de / la dicha iglesia, los dotadores y fundadores della grandes tiempos ha hedificaron una puente por donde podiessen passar a la dicha iglesia, assí los que con devotión / la fuessen a visitar por ganar las grandes indulgençias que en ella ay, commo para que por la dicha puente podiesse ser provehyda la dicha iglesia. Et ago $/{ }^{24} \mathrm{ra}$, este año en que estamos de noventa y tres, con el cresçimiento de las muchas aguas, el ryo de Carrión creció tanto que ovo de levar y desolar la dicha puente, / por manera que después acá, han peresçido en el dicho ryo personas y bestias y ganados. Et aún, demás desto, el dicho ryo rompió la ribera por donde solía / yr y llegó a la cerca del dicho logar y levó muy grand pedaço della, por donde se espera, si otro tal caso veniesse, lo que Dios no quiera, la dicha iglesia podría ve $/{ }^{27}$ nir en perdición.

Et assí mismo, la dicha iglesia es de tan grand tiempo fundada, que los hedificios della desfallesçen y ella non tiene reditos nin sustançia nin el di/cho cabildo y ministros della, para poder rehedificar la dicha puente y çerca nin para poder reparar la dicha iglesia y ornamentos y cosas della, sin que la carga susodi/cha nos ayden a levar los dichos fieles cristianos.

Para la qual ayuda assí demandar, ayuntados en nuestro cabildo commo de costumbre tenemos de nos yuntar, acordamos ${ }^{16} \beta^{30}$ de ordenar una cofradía y hermandat a honor de nuestra señora la Virgen María, para que los dichos fieles christianos que en ella querran, y nos querran / con caridat ayudar, puedan y sean dignos de conseguir y ganar las graçias y indulgençias otorgadas a la dicha iglesia y a la sancta capilla que en ella es fun/dada, otorgados por los sanctos padres apostólicos de Roma y por muchos cardenales y obispos.

\footnotetext{
${ }^{16}$ tenemos de nos ayuntar, acordamos] Escrito sobre raspado.
} 


\section{LA ABADÍA DE SANTA MARÍA DE HUSILLOS: ESTUDIO Y COLECCIÓN \\ DOCUMENTAL $(904-1608)$}

Et assí mismo, acatando commo si por negligençia de los que ago $/{ }^{33} \mathrm{ra}$ somos, la dicha iglesia padeciesse algun detrimento de nuestro señor Dios y de la Virgen María, gravemente nos sería demandado. Et otrosí, acatando commo los / que son devotos de nuestra señora la Virgen María, son socorridos en sus neçessidades y trabajos, porque ella es nuestro refugio y non tenemos otra fortaleza a que / nos socorrer, sinon debaxo de su manto.

Et assí mismo, acatando commo nuestro Salvador Ihesu Christo dixo, otrosí, a sus discipulos: "Sic luceat lucerna vestra coram homini $/{ }^{36}$ bus ut videant opera vestra bona et glorificent patrem vestrum qui in celis est", que quiere dezir: "Assí juzga la vuestra candela delante de los ommes porque vean las vuestras / buenas obras y glorifiquen al vuestro padre que es en los çielos". Et assí mismo, en otra parte dize: "Qui preseveraverit usque in finem, hic, salvus erit", que quiere dezir: "/Que el que perseverare en la su sancta fe, faziendo buenas obras fasta la fin, que este tal será salvo".

Et porque creemos y esperamos firmemente que los dichos ${ }^{39}$ fieles christianos, mirando todas estas susodichas cosas y con devoción y desseo de alcançar aquella gloria que les es permetida, a los que tales buenas obras fezi/eren, y perseveraren en ellas fasta la fin, ordenamos que los que con devoción querran entrar en esta sancta cofradía y hermandat, que dé cada uno por su entra/da, para ayuda y subsidio de la dicha puente y cerca y para los reparos del edificio y ornamentos de la dicha iglesia, medio real de plata o su valor, los que en dine $/{ }^{42}$ ro non lo podrán aver. A los quales dichos cofrades, que en la dicha cofradía querran entrar, les son otorgadas todas las gracias y indulgencias concedidas a la dicha / iglesia por los dicho $<\mathrm{s}>$ sanctos padres ${ }^{17}$. Et nos, los susodichos abbat y prior y cabildo, les fazemos participantes y consortes en todos los sacrificios, orationes, devotiones, / trentanarios, aniversarios, vigilias, obsequias, horas canónicas, limosnas, ayunos y en todos los otros bienes que en la dicha iglesia y en todos los logares $/^{45}$ de su abbadía se fazen y farán para siempre jamás y assí mismo a los sus finados por manera de sufragia, por los quales extendieron sus manos caritati/vamente para ayuda y subsidio de la dicha puente y iglesia.

E otrossí, ordenamos que los que con devoción de nuestra señora la Virgen María, quesieren meter en la dicha co/fradía sus fijos o fijas o criados o criadas

\footnotetext{
${ }^{17}$ iglesia por los dicho<s> sanctos padres] Escrito sobre raspado.
} 
pequeños, que sean de quinze años abaxo, que den por limosna por su entrada, para la reparación de la dicha iglesia, cin $/{ }^{48}$ co maravedís o su valor, porque tengan por abogada a nuestra señora que los guarde de los peligros deste mundo. Et a los tales cofrades, assí a los ommes o mugeres de hedat / commo a los dichos niños, ordenamos que en señal de hermandat les sean dadas señales de nuestra señora, las quales mandamos que les den los nuestros procuradores o / receptores.

Otrosí, ordenamos que los dichos nuestros procuradores fagan padrones en todos los logares de los cofrades que quesieren entrar en la dicha cofradía y $/^{51}$ los trayan a la dicha iglesia, porque vistos en nuestro cabildo, se faga dellos libro, porque quede por memoria para los que después de nos vernán, porque sean obliga/dos de rogar a Dios por ellos.

Otrosí, ordenamos que porque mayor memoria quede de los susodichos y los nuestros cofrades y hermanos se muevan más a / devoción y después los sus successores y todos los fieles christianos generalmente se inclinen a devotión, queremos que en las quatro fiestas de nuestra señora, la Virgen María, $/^{54}$ el segundo día de sus ochavas, se faga processión general en la dicha iglesia por todos los dichos cofrades, vivos y finados, y que esto quede por memoria para siempre / jamás. Et por tanto, suplicamos a todos los muy reverendíssimos y reverendos señores, padres, arçobispos y obispos et a todos los otros venerables y cir/cunspectos señores ecclesiásticos, constituydos en dignidat, que miradas las cosas susodichas quieran ayudar a la dicha iglesia, assí con sus limosnas commo ${ }^{57}$ con las otras cosas a que son obligados commo ministros de la casa de Dios. Et assí mismo, suplicamos a todos los nobles del estado millitar, a los quales Dios constitu/yó por defensores de la su santa fe y casa, que nos quieran ayudar estendiendo sus manos con caridat, commo a su estado pertenesce, y manden en sus logares a las / sus justicias que a los dichos nuestros procuradores non les sea fecho agravio nin mal, antes por ellos sean defendidos y amparados. Et a todos los otros fie $/{ }^{60}$ les christianos generalmente, que nos ayuden con sus limosnas porque tengan por abogada a nuestra señora, la Virgen María, para en todos sus trabajos, y ruegue / a nuestro señor que los quiera perdonar, yevar a la su iglesia con los sus sanctos donde ella, con él, vive y regna por siempre jamás, amen.

Et assí por mí leyda / y publicada la dicha ordenança, luego, el dicho Fernand Pérez, en nombre de los susodichos señores, dixo que ge lo diesse assí signado. 


\section{LA ABADÍA DE SANTA MARÍA DE HUSILLOS: ESTUDIO Y COLECCIÓN \\ DOCUMENTAL $(904-1608)$}

Que fue fecha y ${ }^{63}$ publicada esta dicha ordenanca en el logar, día, mes y año susodichos, estando presentes los honrrados varones Pero de Villa Muera y Gutierre de / Çavallos, vezinos de Fuentes, y Fernand Merino, y García Fernández, y Fernando Ortega, vezinos de la dicha villa de Fusillos, testigos para esto que dicho es, / specialmente llamados y rogados.

Et yo, Diego de Arroyulo, escrivano y notario público por las auctoridades apostólica y ordinaria que a todo lo que $/{ }^{66}$ dicho es, presente fue en uno con los dichos testigos, y assí lo vi y oy passar y en suma lo tomé y en mi registro asen/té, del qual esta presente scriptura de ordenança y cofradía saqué. Y a ruego y pedimiento de los dichos señores / thesorero y chantre, canónigos y cabildo, y del dicho Fernand Pérez en su nombre, por mi mano scriví y de mis acostum/ ${ }^{69}$ brados nombre y signo, signé en testimonio de verdat, rogado y requirido. (Signo: TIBI DABO CLAUES REGNIS CELORUM)

\section{4}

[Circa 1496, agosto, 1]

Petición por parte de Francisco Núñez de Madrid, abad de Santa María de Husillos, y Garci López de Prestines, abad de Hérmedes, a Alonso de Burgos, obispo de Palencia, para que diese su licencia y consentimiento al acuerdo llegado por ambos abades, por el que la abadía de Hérmedes tomaría en censo las propiedades que Santa María de Husillos tenía en San Sebastián de Hérmedes, en precio anual de cuarenta cargas de pan, mitad trigo y mitad cebada, de la medida mayor. Éstas debían ser pagadas en Hérmedes de Cerrato, en el día de San Miguel (29 de septiembre).

El abad de Hérmedes debía mantener reparada la iglesia de San Sebastián, correspondiendo a éste la provisión del beneficio de dicha iglesia. El pacto debía ser corroborado por bula pontificia. 
B. APA, $L P H$, ff. 142r-151r. Inserta en carta de censo entre Santa María de Husillos y la abadía de Hérmedes, dada en Valladolid, a 13 de octubre de 1497. Véase doc. núm. 250.

Reuerendísimo e muy magnífico señor. El dotor don Françisco Núñez, abad de Husillos, canónigo en la vestra yglesia de Palençia y don Garçi López de Prestines, abad de Hérmides en la dicha vestra yglesia e canónigo en la yglesia de Burgos, besamos vestras manos y nos encomendamos a vestra señoría; a la qual plega saber que yo, el dicho abad de Husillos, tengo vn lugar que se llama San Sebastián que es de la dicha mi abadía de Husillos, en el qual yo tengo jurisdicción çebil e criminal, mero y misto ynperio. $Y$ de tiempo ynmemorial yo y los abades mis anteçesores an llevado y llevan todos los diezmos, ganados e menudos que diezman los vezinos e moradores que biven en el dicho lugar sin dar parte a persona alguna. Ansy mismo, sabrá vestra señoría que del dicho tiempo ynmemorial acá, los términos del dicho lugar de Sanct Sebastián, montes, prados, e los términos del dicho lugar de Hérmides, montes, prados son comunes e no deslindados ni limitados ni amojonados e çeto, çiertos montes e prados que tiene la dicha mi abadía de Husillos y la dicha abadía de Hérmides. Y así mismo, sabrá vestra señoría que el dicho lugar de Sanct Sebastián estuvo e a estado despoblado por espaçio de treynta años. Y de seis o siete años a esta parte yo he poblado el dicho lugar y hecho fazer y hedificar casas en él, y biben e moran agora quinze vezinos e más. Los quales pagan enteramente el diezmo de todo lo que cojen en los términos del dicho lugar. Tanbién sabrá vestra merçed que la dicha mi abadía tiene en el dicho lugar çiertos heredamientos propios de tierras de pan llevar e prados que rrinden y estavan rrendados a los dichos labradores, por diez cargas de pan. Y en los diezmos que pagan, suele aver, vn año con otro, veynte e çinco o treynta cargas de pan sin más los menudos. E agora sabrán vestras merçedes sobre el paçer, rroçar e contar en los dichos términos, prados, montes, entre mí e el dicho abad de Hérmides e entre los conçejos del dicho lugar de Sanct Sebastián y de Hérmides a avido y ay çiertas diferençias, quistiones y pleytos e contiendas en que la vna parte y la otra, an gastado y esperan gastar asaz quantías de maravedís. Y sobre el dicho paçer y rroçar e cortar en los dichos términos y montes, está el pleyto pendiente ante el presidente y oydores de la audiençia del rrey e de la rreyna nostros señores. E agora sabrá vestra señoría que por nos quitar de los 


\section{LA ABADÍA DE SANTA MARÍA DE HUSILLOS: ESTUDIO Y COLECCIÓN \\ DOCUMENTAL $(904-1608)$}

dichos pleytos, debates e contiendas, e por el bien e vtilidad e provecho de nostras abadías, somos conçertados y ygualados en esta manera: que yo, el dicho abad de Husillos, aya de dar y dé, en çenso perpetuo, el dicho lugar de San Sebastián, e los vasallos del, e diezmos, e jurisdiçión çevil, e criminal, y heredamientos, e montes, e prados, e todo lo que de la dicha abadía perteneçe e pertenesçer pueden por mí o por mis susçesores al dicho abad de Hérmides e a sus susçesores y al concejo, allcaldes e omes buenos del dicho lugar de Hérmides, y a qualquier dellos "yn solidum" por preçio e quantía de quarenta cargas de pan, mytad trigo mytad çevada de la medida mayor, pagadas en el dicho lugar de Hérmides en cada vn año para sienpre jamás, por el día de san Miguel de setienbre. Con tal pacto y condiçión que el dicho abad de Hérmides que agora es, por sí e por sus susçesores, para la paga del dicho çenso, aya de obligar y obligue los bienes de la dicha su abadía, $(f .142 v)$ eredamientos, diezmos e préstamos anexos a la dicha abadía, y todos y qualesquier fructos e rrentas a ella devidos e perteneçientes, de manera que en heleçión e escogimiento de mí e de mis susçesores, para siempre jamás, aya de ser e sean de cobrar el dicho çenso de las dichas quarentas cargas de pan del dicho abad de Hérmides e sus susçesores, y de los frutos y rrentas de la dicha abadía o a el conçejo e onbres buenos del dicho lugar de Hérmides. E que yo, el dicho abad e míos susçesores, para sienpre jamás, podamos cobrar, si quisiéremos, las dichas quarenta cargas de pan de çenso de los diezmos y eredamientos que la dicha abadía ay tiene en el dicho lugar de Hérmides, o de los diezmos que le son devidos e le perteneçen en el lugar del Castro Verde e su tierra, sin aver de pedir liçençia, ni avtoridad, ni mandamiento, ni consentimiento, para cobrar las dichas quarenta cargas de pan de çenso del dicho abad ni de sus susçesores, para sienpre jamás, saluo que por nostra propia avtoridad, yo e mis suçesores, para sienpre jamás, podamos rreçebir, aver e cobrar las dichas quarenta cargas de pan de çenso de los dichos lugares de las dichas rrentas e diezmos perteneçientes a la dicha abadía de Hérmides.

Yten con tal pacto y condiçión que a mí, el dicho abad de Hérmides e a mis susçesores, quede el cargo de rreparar la yglesia del dicho lugar de San Sebastián y de la tener bien rreparada y adereçada, y no a mí, el dicho abad de Husillos, ni a mis susçesores. Y así mismo, que den a mí, el dicho abad de Hérmides y a mis susçesores, la provisión y colaçión del benefiçio de la yglesia del dicho lugar de 
San Sebastián. Yten con tal pacto y condiçión que yo, el dicho abad de Hérmides y el conçejo del dicho mi lugar, seamos obligados en todo este año de noventa y siete, de traerla en la bulla de nostro muy sancto padre de confirmaçión y aprovaçión del dicho çenso, en forma, sin ybidenten. E así trayda, yo, el dicho abad de Husillos e mis susçesores, seamos obligados a pagar ocho dineros de coro para ayuda del gasto de la dicha bulla al dicho abad de Hérmides o al dicho conçejo, ocho días después que la dicha bulla fuere notificada. Y no la trayendo en el dicho término que yo, el dicho abad de Hérmides e mis susçesores, o el dicho conçejo, seamos obligados a dar y pagar a mí, el dicho abad de Husillos o a mis susçesores, doze ducados de oro para la expediçión de la dicha bulla, ocho días después que fueren rrequeridos. La qual dicha bulla a de venir cometida al deán de Palençia, que es o fuere, o a los arçedianos de Çerrato o de Alcor, o a qualquier dellos. E que nos, los dichos abades y el dicho conçejo, seamos obligados a otorgar qualesquier escripturas que fueren neçesarias para la aprovaçión e confirmaçión del dicho çenso para los juezes a quien fuere cometido por el nostro muy sancto padre.

E yo ansí mesmo, el dicho abad de Hérmides digo a vestra señoría que yo soy contento y me plaze de rreçebir y tomar en çenso perpetuo el dicho lugar de San Sebastián para mí e para mis susçesores para sienpre jamás, por las dichas quarenta cargas de pan, mytad trigo e mitad çevada, de la medida maior, con todas las cláusulas e firmezas susodichas. E con tal pacto y condiçión que el dicho abad de Husillos o sus susçesores, puedan aver e rreçebir e cobrar en cada vn año las dichas quarenta cargas de pan del conçejo, alcaldes y omes buenos de mi lugar de Hérmides o de los fructos y rrentas pertenesçientes a la dicha mi abadía y préstamos anexos en el dicho lugar de Hérmides o del dicho lugar de Castro Verde e su tierra, o de los rrenterros dezmeros de los dichos lugares de Hérmides o Castro Verde y su tierra, de qual él o sus susçesores más quisieren aver y cobrar por su propia autoridad sin esperar ni pedir liçençia ni consentimiento de mí ni de mis susçesores.

Los quales dichos rrenteros e dezmeros, queriendo el dicho abad e sus susçesores cobrar las dichas quarenta cargas de pan de mí y de mis susçesores, (f.143r) sean obligados a acudir con ellos al dicho abad y a sus susçesores. $\mathrm{Y}$ dándogelas $\mathrm{y}$ pagéndogelas, yo, e los dichos mis susçesores, seamos obligados e tenudos ge las 
rreçebir en quenta. Y el arrendador o arrendadores a quien yo y mis susçesores arrendaremos los fructos e rrentas de la dicha abadía y para las así aver y cobrar de los frutos e rrentas de la dicha mi abadía, ansí de los de Hérmides commo de los préstamos del dicho lugar de Castro Verde e su tierra, yo, por mí e por mis susçesores, damos poder cumplido al dicho abad de Husillos y a sus susçesores. Y para cunplimiento de todo lo sobredicho y cada cosa e parte dello, yo, por mí e por mis susçesores, ypoteco y espeçialmente obligo todos los fructos e rrentas devidos y perteneçientes a la dicha mi abadía, ansí en el dicho mi lugar de Hérmides commo en el dicho lugar de Castro Verde e su tierra, por quanto yo conozco e confieso que es mucha vtilidad e provecho de la dicha mi abadía de Hérmides y del conçejo y onbres buenos del dicho mi lugar de Hérmides, tomar el dicho lugar de San Sebastián en çenso perpetuo por las dichas quarenta cargas de pan, ansí por nos quitar de los dichos debates e quistiones que en sobre los dichos términos, montes y prados y sobre el paçer y rroçar y cortar en ellos. Y porque estando poblado el dicho lugar de San Sebastián commo agora lo está, de los diezmos y heredamientos que perteneçen a la dicha abadía de Husillos se puede pagar las dichas quarenta cargas de pam; y caso que no bastasen e los lugares se despoblasen, el dicho mi lugar de Hérmides e la dicha mi abadía, rrende mucho benefiçio e vtilidad y provecho en tener todos los términos, montes e prados e pastos sin comunidad ni cargo. Y porque, muy rreverenda señoría, para dar yo, el dicho abad de Husillos, el dicho mi lugar de San Sebastián en çenso perpetuo, por mí e por mis suçesores, por las dichas quinientas cargas de pan en cada vn año, e ansí mismo para yo el dicho abad de Hérmides le rreçebir e tomar en çenso perpetuo por las dichas quarenta cargas de pan, para mí e para mis suçesores, y para obligar y ypotecar para la paga dello los frutos e rrentas de la dicha mi abadía en la manera que dicha es, es neçesaria abtoridad, liçençia e consentimiento de vestra señoría rreverendísima.

Por ende, amos, vmilmente, le suplicamos y pedimos por merçed, le plega darnos la dicha liçençia e abtoridad e consentimiento a mí, el dicho abad de Husillos, por poder dar a çenso perpetuo el dicho lugar de San Sebastián, con la jurisdicción çevil y criminal y heredamientos, diezmos, prados, y montes e términos a la dicha mi abadía de Husillos, pertenesçientes por preçio y quantía de las dichas quarenta cargas de pan, mytad trigo, mytad çevada, de la medida maior, al dicho abad de 
Hérmides que agora es e a sus susçesores para sienpre jamás, e al conçejo y omes buenos del dicho lugar de Hérmides y a cada vno dellos, "yn solidum"; de manera que de qualquier dellos, qual más yo y mis suçesores, quisiéremos, podamos aver, rreçebir y cobrar las dichas quarenta cargas de pan, según y como dicho es, y con las dichas condiçiones arriba contenidas.

Y a mí, el dicho abad de Hérmides, para que por mí y mis susçesores pueda rreçebir e rreçiba, en çenso perpetuo el dicho lugar de San Sebastián con toda la jurisdiçión çevil y criminal, términos, montes, prados y diezmos a la dicha abadía de Husillos perteneçientes. E para la paga de las dichas quarenta cargas de pan, pueda obligar y obligue ypotecar y ypoteque los fructos e rrentas y heredamientos a la dicha mi abadía devidos e pertenesçientes. E para que dellos, el dicho abad de Husillos o sus suçesores, quisieren aver y cobrar las dichas quarenta cargas de pan, las puedan aver y rreçebir y cobrar por su propia avtoridad sin mi liçençia y consentimiento e de mis susçesores, en lo qual vestra señoría hará lo que deve y a nosotros nos hará mucha merçed y señalado benefiçio, y mucha vtilidad $\mathrm{y}$ provecho a las dichas nostras abadías. Su rreverendísima y muy magnífica persona, nostro señor prospere y guarde.

1496, agosto, 5. Valladolid

Alonso de Burgos, obispo de Palencia, aprueba el pacto entre Francisco Núñez de Madrid, abad de Santa María de Husillos, y Garci López de Prestines, abad de Hérmedes, por la que la abadía de Hérmedes tomaría en censo las propiedades que Santa María de Husillos tenía en San Sebastián de Hérmedes, en precio anual de cuarenta cargas de pan, mitad trigo y mitad cebada, de la medida mayor. Éstas deben ser pagadas en Hérmedes, en el día de San Miguel (29 de septiembre). 
El abad de Hérmedes debía mantener reparada la iglesia de San Sebastián, correspondiendo a éste la provisión del beneficio de dicha iglesia. El pacto debía ser corroborado por bula pontificia.

Inserta petición al dicho Alonso de Burgos de aprobación del pacto entre los dos abades.

$B$. APA, $L P H$, ff. 142r-151r. Inserta en carta de censo entre Santa María de Husillos y la abadía de Hérmedes, dada en Valladolid, a 13 de octubre de 1497. Véase doc. núm. 250.

En la muy noble e leal villa de Valladolid, çinco días del mes de agosto, año del nasçimiento de nostro Señor Ihesu Christo de mill e quatroçientos e noventa e seis años. Estando presente el rreverendo e muy magnífico señor don Alonso de Burgos, por la graçia de Dios obispo de Palençia, conde de Pernía, capellán mayor y confesor, y del consejo del rrey e de la rreyna nostros señores; en presençia de mí, Françisco Sánchez de Collados, escriuano e notario público por la avtoridad apostólica y rreal, escriuano mayor del cabildo de la iglesia colegial de nostra señora Santa María la Maior de la dicha villa de Valladolid, e del número de la dicha villa e su tierra $(f .142 r)$ por el rrey e la rreyna nostros señores e de los testigos de yuso escritos, paresçieron presentes los rreverendos señores el señor don Françisco Núñez de Madrid, abad de Husillos, canónigo en la yglesia de Palençia, del consejo del rrey e de la rreyna nostros señores, e don Garçi López de Prestines, abad de Hérmides en la dicha yglesia de Palençia, canónigo en la iglesia maior de Burgos. Los quales dichos señores abades de vna voluntad y concordia, presentaron ante el dicho señor obispo y leer hizieron por mí, el dicho Françisco Sánchez de Collados, vna petiçión escrita en papel, su thernor de la qual "de berbo ad berbum" es este que se sigue:

(Sigue doc. núm. 244)

E ansí presentada la petiçión sobredicha por los dichos señores abades ante el dicho señor obispo, e leyda por mí, (f.143v) el dicho Françisco Sánchez de Collados, escrivano, luego el dicho señor rreverendísimo obispo, dixo que lo oya; $\mathrm{y}$ por quanto le constava $\mathrm{y}$ era $\mathrm{y}$ es público $\mathrm{y}$ notorio los grandes pleytos $\mathrm{y}$ 
diferençias y debates y contiendas que entre los dichos señores abades de Husillos y de Hérmides e sus vasallos, vezinos de los dichos sus lugares de Hérmides e San Sevastián, a avido y esperavan aver de aquí adelante por las causas y rrazones contenidas en la petiçión sobredicha; e las grandes costas y daños que en seguimiento dello se les a seguido y espera seguir; y como las dichas partes an tenido y tienen nesçesidad de la dicha yguala y concordia, y como la yguala y asiento que por la petiçión sobredicha, los dichos señores abades tienen fecho y asentado, les es cosa muy neçesaria, vtil e provechosa, para ellos y para los otros abades que después dellos susçedieren en las dichas sus abadías, e para los dichos sus vasallos, vezinos y moradores de los dichos sus lugares de Hérmides y San Sebastián, que en ellos son y serán para sienpre jamás, ansí por se quitar de los dichos pleytos, costas y debates y contiendas que por las dichas causas y rrazones an seido y son entre ellos, y podrían ser, como porque estava ynformado çierto y çertificado en como la dicha iguala, pacto y convenençia, fecha y asentada la petiçión sobredicha por los dichos señores abades, que está justa y derechamente fecha para hequiedad y concordia y paçificaçión de las dichas partes y de cada vna dellas. Por ende, dixo que dava y dio, conçedía y conçedió, y otorgava y otorgó, licençia y facultad y auctoridad cumplida. Y expresó consentimiento a los dichos señores abades de Fusillos y Hérmides, que ende estavan presentes, para hazer y otorgar todo lo contenido en la dicha petiçión suso encorporada, por ellos presentada, y cada vna cosa y parte dello.

E para fazer y otorgar todos los contratos y obligaçiones rreales y personales y escrituras que para efecto de lo contenido en la dicha su petiçión son e fueren neçesarias, e con todas las sustançias, fuerças e firmezas e poderíos e desaforamientos e rrenunçiaçiones e sumisiones, y con todas las otras cosas las que otorgar quisieren e fueren nesçesarias para las dichas partes e para cada vna dellas, en lo qual, su señoría, dixo que ynterponía e ynterpuso su avtoridad e decreto para que valgan e fagan fee en juizio e fuera del en aquella mejor manera e forma que pueden valer. Y que así lo otorgava y otorgó por ante mí, el dicho Françisco Sánchez de Collados, escriuano, para que yo lo dé signado con mi signo. Y los dichos señores abades lo açetaron y lo pidieron por testimonio a mí, el dicho escriuano, e rrogaron a los presentes que fuesen dello testigos. Que son testigos que fueron presentes, llamados y rrogados a lo que dicho es: el señor 
liçençiado Sancho de Maluenda, y Alonso de Vega, maiordomo del dicho señor obispo, y Christóval de Merodio, camarero de su señoría.

Y yo, Françisco Sánchez de Collados, escriuano e notario público susodicho, fui presente en vno con los dichos testigos al otorgamiento de la dicha liçençia. Y por rruego y mandado del dicho señor obispo y pedimiento de los dichos señores abades de Fusillos y Hérmides y de cada vno dellos, la presente escritura de liçençia fize escrevir según que ante mí pasó y la signé de mío signo en testimonio de verdad. Françisco Sánchez, escriuano.

1496, agosto, 5. Valladolid

Garci López de Prestines, abad de Hérmedes, da licencia y autoridad al concejo de Hérmedes de Cerrato para que un apoderado en su nombre tome en censo a Santa María de Husillos el lugar de San Sebastián de Hérmedes.

$B$. APA, $L P H$, ff. 142r-151r. Inserta en carta de censo entre Santa María de Husillos y la abadía de Hérmedes, dada en Valladolid, a 13 de octubre de 1497. Véase doc. núm. 250.

Sepan quantos esta carta de liçençia y autoridad vieren commo yo, don Garçi López de Prestines, abad de Hérmides y canónigo en la iglesia de Burgos, digo que por quanto entre el rreverendo señor dotor don Françisco Núñez, abad de Fusiellos, del consejo del rrey y rreina nostros señores cuyo es el lugar de San Sebastián, que está presente, y el conçejo, alcaldes y onbres buenos del mi lugar de Remides, a avido y se esperan aver grandes daños, diferençias, debates y quistiones sobre el paçer e rroçar y cortar en los términos, prados y montes de los dichos lugares de Érmides y San Sebastián y sobre la comunidad de los dichos términos, sobre lo qual está pleyto pendiente antel presidente y oydores de la audiençia del rrey y rreyna nostros señores. Y por nos quitar de los dichos pleytos 
$\mathrm{y}$ de las dichas diferençias y quistiones e por la vtilidad y provecho de las dichas nostras dignidades abaçeales y de nos el conçejo y alcaldes y omes buenos del dicho mi lugar de Ermides, el dicho señor abad de Husillos y yo y vosotros los dichos conçejo y alcaldes y omes buenos del dicho abad de Hérmides, por mí y mis susçesores, y vos el dicho conçejo, alcaldes y ombres buenos del dicho mi lugar de Érmides por vos y cada vno de vos y por vestros suçesores ayamos (f.147r) de tomar e tomemos a çenso perpetuo para agora e para sienpre jamás del dicho señor abad de Husillos e de sus susçesores el dicho lugar de San Sebastián con toda su jurisdicción çevil y criminal, mero y misto ynperio, prados, términos, montes e heredamientos e diezmos e tributos e derechos pertenesçientes al dicho señor abad y a su dignidad abaçeal en el dicho su lugar de San Sebastián, por preçio de quarenta cargas de pan, mitad trigo mitad çevada, de la medida maior puestas e pagadas en cada vn año por sienpre jamás en el dicho mi lugar de Hérmides por el día de san Miguel de setienbre de cada vn año. Con tal pacto y condiçión que en heleçión y escogimiento sea del dicho señor abad de Husillos que agora es y de sus susçesores de aver y cobrar las dichas quarenta cargas de pan de çenso de mí e de mis susçesores e de los fructos e rrentas de la dicha mi abadía de Érmides o de vos los dichos conçejo, allcaldes, y onbres buenos del dicho mi lugar de Hérmides o de qualquier de nos, que el dicho señor abad e sus susçesores quisieren e por bien tovieren. $\mathrm{E}$ asy mismo con tal pacto y condiçión que yo y mis susçesores y vos, el dicho conçejo, alcaldes y onbres buenos del dicho my lugar de Hérmides y cada vno de nos seamos tenudos y obligados a tener bien rreparada e servida la dicha yglesia de San Sebastián, por ende en la mejor manera e forma que puedo e de derecho devo, doy, otorgo y conozco que doy liçençia e facultad a vos, el conçejo, alcaldes, onbres buenos del dicho mi lugar de Hérmides para que podades tomar e tomedes a çenso perpetuo el dicho lugar de San Sevastián con jurisdiçión çevil e crimynal, mero, mysto ynperio, prados, términos e montes $\mathrm{y}$ heredamientos, diezmos, pechos e tributos perteneçientes al dicho señor abad de Husyllos y a su dignidad abaçeal por preçio e quantía de las dichas quarenta cargas de pan, mitad trigo, mitad çevada, e de la medida más puestas y pagadas en el dicho lugar de Hérmides por el día de san Miguel de setienbre cada vn año para sienpre jamás. E que para la paga del dicho çenso que asy tomáredes del dicho señor abad de Husillos e de sus susçesores el 
dicho lugar de San Sebastián, podades obligar los bienes del dicho conçejo y los bienes particulares de vos y de cada vno de vos y de vestros erederos e susçesores. E para que podades poner pena o penas quales vos quisierdes y por bien tovierdes si no pagardes el dicho çenso de las dichas quarenta cargas de pan al dicho señor abad de Husillos e sus susçesores en el término e plazo susodicho, queriéndolas él o sus susçesores más cobrar de vosotros y de cada vno de vos que non de mí ni de mis susçesores ni de las rrentas de la dicha mi abadía, e para que para tomar a çenso el dicho lugar de San Sebastián del dicho sennor abad de Husillos e de sus sucesores, podades constituyr e constituyades vn procurador, dos o más quantos que ni sierdes e por bien tovierdes, firmes e bastantes para ello e para cada cosa dello. E para que açerca de todo lo sobredicho podades fazer e fagades todo lo que vos bien pareçiere e visto fuere, e prometo de lo aver por rato grato e firme e valedero para agora e para sienpre jamás todo lo que vos a vestros procuradores fizierdes e hizieren açerca del tomamiento del dicho çenso del dicho lugar de San Sebastián por las dichas quarenta cargas de pan e den oy, y ni venir contra ello en ningund tienpo ni por alguna manera yo ny mis susçesores ni alguno de vos.

Y para lo así atener e guardar y cumplir y no yr ni venir contra ello en la manera que dicha es, obligo mis bienes espirituales e temporales, muebles e rraízes avidos e por aver. En firmeza de lo qual otorgué la presente escriptura de liçençia e todo lo en ella contenido ante Françisco Sánchez de Collados, escriuano e notario público por la avtoridad apostólica e rreal e escriuano mayor del cabilldo de la yglesia colegial de nostra señora Santa María la Mayor de la muy noble villa de Valladolid y del número de la dicha villa e su tierra por sus altezas, al qual rrogué y pedí que la escriviese o fiziese escrevir y signase con su signo y a los presentes que dello fuesen testigos.

Que fue fecha y otorgada esta carta en la dicha villa de Valladolid, a çinco días del mes de agosto, año del nasçimiento de nostro Señor Ihesu Christo de mil y quatroçientos y noventa $\mathrm{y}$ seis años. $(f .147 v)$ Que son testigos que fueron presentes, llamados y rrogados a lo que dicho es: el liçençiado Sancho Ruiz de Malvenda, e frey Garçía de Chinchilla, y San Joán, criados del señor obispo de Palençia.

E yo, Françisco Sánchez de Collados, escriuano e notario público susodicho, fui presente en vno con los dichos testigos a lo que dicho es. E por otorgamiento del 
dicho señor abad de Hérmedes, esta escritura de liçençia fize escrevir en que fize este mío signo en testimonio de verdad,

1497, febrero, 27. Valladolid.

Los Reyes Católicos mandan cumplir la sentencia arbitraria entre el concejo de Hérmedes y la abadía de Santa María de Husillos, sobre el aprovechamiento de unos montes y términos disputados por dicho concejo de Hérmedes y San Sebastián de Hérmedes, lugar de Santa María de Husillos, y que dicho abad de Husillos se había negado a cumplir.

B. AGS, RGS, 149702,178. 3 hojas. Papel; escr. cortesana; buena conservación.

\section{8}

1497, abril, 28. Burgos.

Los Reyes Católicos, a petición de Pedro Tejedor, procurador del concejo de Hérmedes, mandan que la sentencia dada anteriormente sobre los agravios habidos por la abadía de Santa María de Husillos a dicho concejo, y que un alcalde real favorable al abad de Husillos, Francisco Núñez, del consejo real, mostraba dilación en cumplir, sea ejecutada por persona de la corte.

B. AGS, RGS, 149704,95. 3 hojas. Papel; escr. cortesana; buena conservación. 
1497, octubre, 11. Hérmedes de Cerrato.

El concejo de Hérmedes de Cerrato da poder al licenciado Sancho Ruiz de Malvenda, oidor de la audiencia real, vecino de Valladolid, para tomar en censo a Santa María de Husillos, el lugar de San Sebastián de Hérmedes. Inserta licencia (1496, agosto, 5. Valladolid) dada por Garci López de Prestines, abad de Hérmedes, a dicho concejo para que puedan nombrar un apoderado.

B. APA, $L P H$, ff. 142r-151r. Inserta en carta de censo entre Santa María de Husillos y la abadía de Hérmedes, dada en Valladolid, a 13 de octubre de 1497. Véase doc. núm. 250.

Sepan quantos esta carta de poder vieren commo nos, el conçejo, alcaldes, rregidores y el merino y ofiçiales y omes buenos del lugar de Hérmides, estando ayuntados ante conçejo e llamados a canpana rrepicada según que lo emos de vso y de costunbre de nos ayuntar, y estando en el dicho conçejo nombradamente ayuntados por Yzquierdo el Viejo y Alonso de Pero Sánchez, alcaldes del dicho lugar, y Pero Garçía, merino, e Rodrigo de Gonçalo, rregidores, y Pero de bartolomé, merino, y Pero Texedor, procurador del dicho conçejo, y Pero Garçía Duque, y Alonso Moreno, y Pero Duque "El Moço", y Per Arroyo, y Martín Sánchez, cura, y Joán Sánchez, clérigos, e Pero de Joán Duque, y Alonso Espos, y Pero Martín, y Joán Espeso, y Martín Garçía, y Bartolomé Garçía, y Joán Martín, e Pero Rojo, e Joán Rojo, e Juan Rojo, su fijo, y Pero Yzquierdo "El Moço", y Pero Antón, y Alonso de Pero Sánchez, y Joán de Bartolomé, y Bartolomé Sánchez, y Alonso de Ayuso, y Martín Ruiz Prieto, y Martín, su fijo, y Bartolomé, çerrajero, y Pero Prieto, e Rodrigo, rregidor, y Alonso de Corrales, y Pero de Fernando y otros omes buenos del $(f .146 v)$ dicho lugar, dezimos que por quanto entre nos y el conçejo y onbres buenos del lugar de San Sebastián, que es del abadía de Husillos, an avido y ay y se espera aver grandes debates y diferençias y quistiones sobre el paçer y cortar y pastar en los términos, montes e prados deste dicho lugar y del lugar de San Sebastián, y sobre la comunidad de los términos de los dichos lugares sobre lo qual está pleyto pendiente antel presidente y oydores 
del audiençia del rrey y de la rreyna nostros señores, ansí mesmo sobre la comunidad de los dichos términos an avido $\mathrm{y}$ ay se esperan aver muchas diferençias y quistiones entre los señores dotor don Françisco Núñez, abad de Fusillos, del consejo de sus altezas, cuyo es el dicho lugar de San Sebastián, e don Garçi López de Prestines, abad de Hérmides, nostro señor. Y por quitar las dichas diferençias y quistiones sobre la dicha comunidad y términos entre los dichos señores abad de Fusillos y de Hérmides y entre nos, el dicho conçejo y onbres buenos del dicho lugar de San Sebastián, e por nostra vtilidad y bien e provecho y porque nosotros seamos señores de todos los términos y montes deste lugar de San Sebastián, e non ayamos de tener ni tengamos comunidad de persona alguna, está acordado y concordado que el dicho señor abad don Garçía López de Prestines, nostro señor, y nos, ayamos de tomar y tomemos en çenso perpetuo para él y para sus susçesores y para nos e para nostros susçesores el dicho lugar de San Sebastián del dicho señor abad de Husillos con la jurisdicçión çevil y criminal, alta y baxa, mero y justo ynperio con los montes, prados e pastos axidos y términos, diezmos e rrentas y pechos y derechos y auçiones con todo lo qual dicho señor abad pertenezca o pertenesçer pueda en el dicho lugar por preçio y quantía de quarenta cargas de pan, mitad trigo mitad çevada, de la medida maior que agora se vsa en estos rreynos de Castilla y León, puestas en el dicho lugar de Hérmides con tal pacto y condiçión que la voluntad y eleçión sea del dicho señor abad de Husillos y de sus susçesores para siempre jamás de cobrar las dichas quarenta cargas de pan de çenso por mitad de la dicha medida maior del dicho abad de Hérmides, nostro señor, o de sus susçesores o de nos o de nostros susçesores para siempre jamás o de qualquier de nos. Y que el dicho abad nostro señor o sus susçesores o nos o nostros susçesores o qualquier de nos seamos tenudos y obligados a tener rreparada la iglesia del dicho lugar de San Sebastián y servirla, por ende con liçençia y autoridad del dicho don Garçi López de Prestines, abad de Hérmides, nostro señor, su tenor de la qual, "de berbo ad berbun", es este que se sigue.

(Sigue doc. núm. 246) 


\section{LA ABADÍA DE SANTA MARÍA DE HUSILLOS: ESTUDIO Y COLECCIÓN \\ DOCUMENTAL $(904-1608)$}

Françisco Sánchez, otorgamos y conosçemos por esta carta que damos e otorgamos nostro poder libre e llenero e bastante según que lo nos avemos e más cumplidamente lo podemos e devemos dar e otorgar a vos, el onrrado señor liçençiado Sancho Ruiz de Maluenda, oydor del abdiençia del rrey e de la rreyna nostros señores, vezino de la villa de Valladolid que estáis avsente bien ansy como si fuésedes presente para que por nos e por nostros susçesores para sienpre jamás, podades tomar e tomedes en çenso perpetuo para sienpre jamás del dicho señor dotor don Françisco Núñez, abad de Husillos, que agora es y de sus susçesores, el dicho lugar de San Sebastián que es de la dicha su abadía de Husillos con la jurisdiçión çevil y crimynal, mero y misto ynperio, montes, prados y términos, heredamientos, diezmos, aguas corrientes y manantiales con todo y qualquier derecho y açión, pechos y derechos y tributos al dicho señor abad de Husillos y a su abadía devidos e perteneçientes al dicho lugar de San Sebastián por preçio e quantía de quarenta cargas de pan, mytad trigo mytad çevada, de la medida mayor puestas y pagadas en cada vn año para siempre jamás en el dicho lugar de Hérmides por el día de san Miguel de setienbre de cada vn año. E para otorgar sobre la dicha rrazón qualquier o qualesquier carta o cartas de çenso las más fuertes e firmes que en tal caso ser pueda, y para que en la paga del dicho çenso podades obligar y obliguedes ypotecar ypotequedes de los bienes del dicho conçejo y todos nostros bienes muebles y raíces, avidos y por aver, doquier y en qualquier lugar que nos y qualquier de nos los ayamos y tengamos, e nos o qualquier de nos para siempre jamás e nostros susçesores los ayan e tengan y podades poner y pongades la pena y penas que a vos pareçiere y bien visto fuere, si nos y cada vno de nos e nostros susçesores y cada vno dellos "in solidun" no diéremos al dicho señor abad de Husillos y a sus susçesores las dichas quarenta cargas de pan en el dicho término en cada vn año para siempre jamás. E para que el contrato de çenso que vos, el dicho señor liçençiado ansí en nostro nombre fizierdes y otorgardes del dicho lugar de San Sevastián con todo lo susodicho del dicho señor abad de Husillos y de sus susçesores sea firme e valedero para sienpre jamás, y quan conplido y bastante poder commo nos avemos y podemos aver para todo lo susodicho y para cada parte dello y otro tal y tan cumplido bastante, vos damos, otorgamos, e traspasamos a vos, el dicho señor liçençiado Sancho Ruiz de Maluenda para en la dicha rrazón y cada cosa e parte dello. 
Y por esta carta de poder, prometemos y otorgamos de aver por firme y estable e valedero para agora e para sienpre jamás el çenso que vos ansí en nostro nombre fizierdes del dicho señor abad de Husillos del dicho lugar de San Sebastián por las dichas quarenta cargas de pan en la manera que dicha es, ansí commo si nos mismos fiziésemos y tomásemos el dicho çenso del dicho señor abad y fiziésemos todo lo susodicho y cada cosa e parte dello presentes seyendo. Y para aver por rrato y firme y estable e valedero todo lo que vos el dicho señor liçençiado fizierdes en nostro nombre açerca del dicho çenso y todas las sus misiones y firmezas y cláusulas que en el dicho tomamiento del dicho çenso vos fizierdes, obligamos a nos y a cada vno de nos e de nostros susçesores doquier que los nos ayamos e tengamos y a los bienes del dicho conçejo y a los bienes muebles e rraízes de nos y de cada vno de nos y ellos los ovieren o tovieren y demás desto, por esta carta prometemos y otorgamos de no yr ni venir contra el çenso que vos ansí en nostro nombre tomardes en nyngún tiempo ny en ninguna manera nos nin otro por nos $(f .148 r)$ ni ninguno ni alguno de nostros susçesores. Y si contra ello fuéremos o viniéremos o yntentáremos de yr o venir o pasar, que no nos vala ni sobre ello seamos oydos en juizio ni fuera del ante algún alcalde ni juez eclesiástico ni seglar. Y demás desto, si nos o alguno de nos o nostros suçesores o qualquier de nos, fuéremos o viniéremos contra el dicho çenso, que yncurramos y cayamos en pena de quinientos castellanos de oro, la mitad para la cámara y físco del rrey y la otra mitad para el dicho señor abad de Husillos y para sus susçesores. Y demás desto que dicho es, por esta carta pedimos e damos poder cumplido a todas y qualesquier justicias, ansí de la casa y corte y chançillería de los dichos el rrey e la rreyna nostros señores como de otras quales quier çibdades, villas y lugares de todos los sus rreynos y señoríos y qualquier o qualesquier dellos que nos constringan y apremien a que tengamos y guardemos todo lo que por vos, el dicho señor liçençiado en nostro nombre, fuere fecho açerca del tomamiento del dicho çenso, bien ansy y a tan conplidamente como si por los dichos juezes e justas y qualquier dellas lo oviésemos ansí lleuado por su juizio y sentençia y aquella fuese padada en cosa juzgada por cada vno de nos consentida. Para lo qual todo y cada cosa e parte dello rrenunçiamos e partimos de nos y de nostro favor y ayuda todas las leyes, todos los fueros y derechos, ansí canónicos commo çeviles y ordenamientos viejos e nuevos, escriptos e non escriptos, e todas las cartas e 
previlegios y alvalaes de merçed de rrey o rreyna o de prínçipe heredero o de otro señor o señora o juez qualquiera que sea ganadas o por ganar antes desta carta o después della, e todas las exençiones e defensiones e rreplicaçiones e otras qualesquier buenas rrazones de que aprovecharnos podamos para yr o venir o pasar contra lo contenido en esta nostra carta de poder o contra alguna cosa o parte dello y la ley e derecho que dize que general rrenunçiaçión non vala. Y porque esto sea firme y non venga en duda, rrogamos al presente escriuano que nos lo dé signado con su signo. $\mathrm{Y}$ a los presentes rrogamos que dello fuesen testigos.

Que fue fecha y otorgada esta carta de poder en el dicho lugar de Hérmides por el dicho conçejo y onbres buenos del, a onze días del mes de otubre, año del nasçimiento de nostro Saluador Ihesu Christo de mil e quatroçientos e noventa y siete años.

Testigos que fueron presentes a todo lo que dicho es: Alfonso Sánchez, escrivano, vezino de la villa de Castro Verde, escrivano de la cámara del rrey e rreyna nostros señores e su notario público en la su corte y en todos los sus rreynos e señoríos, fui presente a todo lo que dicho es en vno con los dichos testigos.

Y porque es verdad, lo firmé de my nombre e fize aquí este mío signo en testimonio de verdad. Alfonso Sánchez. Nos, los dichos don Garçi López de Prestines, abad de Hérmides por mí e por mis susçesores y de los dichos mis vasallos de Hérmides, y el liçençiado Sancho Ruiz de Malvenda, tanbién por los dichos vezinos e moradores del dicho lugar de Hérmides e por los que después dellos vernán y suçederán, e por cada vno dellos para sienpre jamás.

1497, octubre, 13. Valladolid.

Carta de censo otorgada por Francisco Núñez de Madrid, abad de Santa María de Husillos, por si y en nombre de su abadía, a Garci López de Prestines, abad de Hérmedes, por sí y en nombre de su abadía, con aprobación del obispo 
de Palencia, sobre la iglesia de San Sebastián de Hérmedes y sus heredades, así como la jurisdicción civil y criminal de dicho lugar, en precio de cuarenta cargas anuales de pan, mitad trigo y mitad cebada, de la medida mayor. Éstas deben ser pagadas en Hérmedes de Cerrato, en el día de San Miguel (29 de septiembre). Inserta carta de licencia de Alonso de Burgos, obispo de Palencia.

\section{$B$. APA, $L P H$, ff. $142 \mathrm{r}-151 \mathrm{r}$.}

Fecho y sacado fue este traslado en la villa de Husillos, a dos días del mes de diziembre de mil e quinientos e çinquenta e quatro años. Testigos que lo vieron corregir y conçertar, Joán Ruiz Cabeça de Vaca y Gaspar de Vedoya, clérigos, y Pero Manuel, estantes en la dicha villa.

E yo, Santiago Gómez, escrivano público en la dicha villa, (Pero Ruyz de Villoldo) presente fui a lo que dicho es en vno con los dichos testigos. Y del dicho pedimiento y mandamiento, lo escreví y fize aquí mi signo (signo) en testimonio de verdad. Santiago Gomez.

Pero Ruyz de Villoldo (rúbrica). Santiago Gómez (rúbrica).

Sepan quantos esta carta e público instrumento de çenso ynfitiosis vieren, commo yo, el dotor Françisco Núñez, oydor de la abdiençia del rrey e de la rreyna, nostros señores, abad de Husillos e canónigo en la yglesia de Palençia, por mí mismo como tal abad de Husillos y en boz e en nombre de la dicha mi abadía e abades que después de mí vernán y susçederán en ella para siempre jamás, y por virtud de la liçençia, e para hazer e otorgar todo lo ynfra escripto que esta carta es e será contenido, he y tengo del muy magnífico e muy rreuerendo señor don Alonso de Burgos, obispo de Palençia, conde de Pernía, que es escrita en papel e signada de escriuano público, su thenor de la qual es este que se sigue.

(Sigue doc. núm. 245)

Por ende yo, el dicho abad de Husillos, por mí y en boz y en nombre de la dicha mi abadía y por los abades que después de mí en ella vernán e suçederán para sienpre jamás de mi propia, libre, agradable voluntad, otorgo y conozco que do a censo y por nombre de çenso infetiosis para sienpre jamás a vos, el venerable don Garçi López de Prestines, abad de Hérmides en la dicha yglesia de Palençia, que estades presente y al conçejo, alcaldes y ombres buenos, vezinos y moradores en 


\section{LA ABADÍA DE SANTA MARÍA DE HUSILLOS: ESTUDIO Y COLECCIÓN \\ DOCUMENTAL $(904-1608)$}

vestro lugar de Hérmides vestro o vasallos, lugar que es de la dicha vestra abadía, que son ausentes, e a cada vno de uos $(f .144 r)$ "in solidun" en persona de vos, el onrrado Sancho Ruiz de Maluenda, oidor del audiençia del rrey y de la rreyna nostros señores, vezinos que sois de la muy noble y leal villa de Valladolid, y como su procurador y por poder espeçial que dellos tenéis y mostráis para rreçebir y tomar a çenso perpetuo todo quanto de yuso en esta carta es y será contenido, el qual poder de yuso yrá ynserto la mi yglesia y lugar que se llama San Sebastián que es de la dicha mi abadía de Husillos con toda su jurisdiçión çevil y criminal, alta y baxa, mero y misto ynperio, y todos los términos y pastos, montes y prados y exidos, casas y casares y rrentas y diezmos ansí de ganados como de menudos y todas las otras y qualesquier casas y auçiones y derechos a la dicha mi yglesia y lugar perteneçientes y exidos y términos y pechos y derechos e todo lo otro que en qualquier manera e causa a la dicha yglesia de San Sebastián pertenezcan y pertenesçer puedan y deban en qualquier manera e por qualquier rrazón o causa que sea o ser pueda, desde la piedra del rrío fasta la foja del monte, y desde la foja del monte fasta la piedra del rrío, y con todos los vezinos y moradores que agora son y moran en el dicho mi lugar de San Sebastián y biven y moraren de aquí adelante perpetuamente para sienpre jamás, y con todas sus entradas y salidas, vsos y derechos y costunbres e servidunbres quantas an y tienen e deven aver e tener, ansí de fecho commo de derecho, e según que a mí y a la dicha mi abadía pertenesçen e pertenesçer pueden e deven en qualquier manera. Lo qual ansy vos doy a çenso ynfetiosis a vos, el dicho abad de Hérmides y a los dichos vezinos y moradores del dicho lugar de Hérmides y a cada vno de vos "yn solidun" y a vestros susçesores que después de vos vernán e suçederán por abades de la dicha vestra abadía de Hérmides, y a los vezinos e moradores que son e serán de aquí adelante y a qualquier de vos para sienpre jamás en el dicho vestro lugar de Hérmides desde oy día de la fecha desta carta en adelante perpetuamente para siempre jamás, en tal manera e con tal condiçión vos doy a çenso la dicha yglesia e lugar de San Sebastián e todo lo otro susodicho a vos, el dicho abad de Hérmides, y los otros abades que después de vos vernán e susçederán por abades de la dicha vestra abadía y el dicho conçejo y omes buenos vezinos y moradores del dicho vestro lugar de Hérmides que agora son y los que después dellos vernán e suçederán por vezinos y moradores del dicho lugar o qualquier de vos para 
sienpre jamás, que dedes y paguedes y den y paguen de çenso perpetuo por nombre de çenso dello a mí y a los abades que después de mí vernán e suçederán para sienpre jamás en la dicha mi abadía de Husillos, y aquel o aquellos que por mí o por ellos o por qualquier dellos lo ovieren de aver y de rrecaudar la qualquier manera en cada vn año perpetuamente para sienpre jamás, quarenta cargas de pan, mitad trigo metad çevada, buen pan nuevo, seco, linpio, de dar y de tomar medidas por la medida mayor, puestas en el dicho lugar de Érmides por el día de san Miguel de setienbre que será en cada vna non para sienpre jamás. Y que comiençe la primera paga por el día de san Miguel de setienbre del año primero venidero del señor de mil y quatroçientos y noventa y ocho años. Y dende en adelante en cada vn año el dicho día de San Miguel de setiembre, so pena del doblo de cada vna paga.

Otrosí, con tal pacto y condiçión que yo, el dicho abad de Husillos y mis susçesores, podamos aver y rreçebir y cobrar en cada vn año las dichas quarenta cargas de pan del dicho conçejo, allcaldes y omes buenos del dicho lugar de Hérmides o de los fructos y rrentas perteneçientes a la dicha abadía de Hérmides o préstamos anexos en el dicho lugar de Érmides o en el dicho lugar de Hérmides y Castro Verde y su tierra o de qual yo y mis susçesores más los quisieremos ava y cobrar por nostra $(f .144 v)$ propia autoridad sin esperar ni pedir liçençia ni consentimiento del dicho abad de Hérmides ni de los dichos sus susçesores. Los quales dichos rrenteros y dezmeros, queriendo yo el dicho abad y mis susçesores cobrar dellos las dichas quarenta cargas de pan nos serán obligados a acudir con ellas y dándonoslas y pagándolas a mí, el dicho abad o a los dichos mis susçesores, el dicho abad de Hérmides e sus susçesores sean obligados e tenudos a ge la rreçebir en quenta. Y así mesmo al arrendador y arrendadores a quien el dicho abad e sus susçesores arrendaren los fructos e rrentas de la dicha abadía para agora e para sienpre jamás, e demás desto que si por ventura vos, el dicho abad de Hérmides y los dichos vezinos e moradores del dicho vestro lugar de Hérmides e vestros suçesores y suyos o qualquier de vos o dellos seyendo rrequeridos por mi parte o del abad o abades que después de mí vinieren en cada vn año, no diéredes e pagáredes o no dieren e pagaren las dichas quarenta cargas de pan deste dicho çenso al dicho plazo de suso contenido e según dicho es y estoviere por pagar el dicho çenso por espaçio de tres años contínuos, vno en pos 
de otro que cumplidos y espeçificados los dichos tres años que yo el abad o abades que después de mí vinieren e suçedieren en la dicha mi abadía de Husillos y a qual o aquellos que por mí o por ellos ovieren causa de aver y de rrecaudar el dicho çenso en qualquier manera o por qualquier rrazón, título, causa, que ser o ser pueda que pueda y puedan entrar e tomar por mi propia avtoridad e suya para mí o para ellos si quisieren todo el dicho lugar y yglesia de San Sebastián e vezinos e moradores del e todo lo otro a ello anexo que así de suso faze mención. E vos así yo doy a çenso en todas las lavores e hedifiçios, labranças e mejoras que en ello fueren fechos y sea todo yncomiso para mí e para los abades que después de mí vernán e suçederán por abades de la dicha mi abadía de Fusyllos, para fazer dello e de cada vna cosa e parte dello todo lo que quisiere como de cosa propia de la dicha mi abadía e demás de lo susodicho que yo, el dicho abad o los dichos mis susçesores o qualquier de nos, podamos entrar y tomar, amojonar e limitar por nostra avtoridad la mitad de todo el término, pastos, e montes e abrevaderos así la mitad de los dichos montes que son del conçejo commo de los que son del abad e prados y exidos y huertas y viñas. La mitad del qual dicho término, montes e prados e pastos commo dicho es, finque e quede para mí, el dicho abad e para mis herederos e susçesores, y el señorío y propiedad dellos e para fazer dellos commo de cosa propia, libre, mía y de la dicha abadía quedando todavía en su fuerça e vigor el dicho çenso de las dichas quarenta cargas de pan y quedando obligado vos, el dicho abad e vestros susçesores, y vos el dicho conçejo y qualquier de vos e vestros susçesores, para dar e pagar a mí, el dicho abad e a mis susçesores, todo el dicho pan que así fuere devido de los dichos tres años e todo lo que adelante se deviere en todos los años adelante venideros para syenpre jamás, e no enbargante que ansí sea entrado e tomado como dicho es que todavía ayades y ayan de pagar el pan del dicho çenso devido de las pagas pasadas, e seades e sean obligados a lo pagar entera y cumplidamente. $Y$ otrosí en tal manera y con tal condiçión vos doy a çenso la dicha yglesia e todo lo susodicho, que si vos el dicho abad de Hérmides, e vezinos e moradores del dicho vestro lugar de Hérmides o vestros susçesores o suyos que después vernán por abades de la dicha vestra abadía e vezinos suçedientes en el dicho vestro lugar de Hérmides quisiéredes o quisieren vender o traspasar lo susodicho que ansí vos doy a çenso como de susodicho es, que lo fagades y fagan primeramente saber a mí, el dicho abad de Husillos o al 
abad o abades que después de mí vernán e suçederán en la dicha mi abadía de Husillos, porque si lo quisiéremos tanto por tanto como o otros dello dieren, que lo pueda y puedan aver para mí o para ellos para la dicha mi abadía, ante que otro alguno e fasta lo (f.145r) así fazer por la vía susodicha, que lo non podades ni lo puedan vender ni traspasar ni enajenar. E si lo vendierdes e traspasardes o henejenardes sin lo ansí fazer saber a mí o a mis susçesores commo dicho es, que la tal venta o traspasaçión o henajenaçión sea en sí, ninguna e de ningún valor e hefeto, e por el mismo caso lo ayades o ayan perdido todo lo susodicho que ansy vos do a çenso e lo pueda e puedan entrar por yncomiso como dicho es. E si lo non quisieren o no quisieren tanto por tanto como dicho es, que lo podades e puedan vender, traspasar y henajenar, e fazer dello como de cosa propia de la dicha vestra abadía porque lo no podades ni puedan vender ni traspasar ni enpeñar ni henajenar a yglesia ni a monesterio ni a cofradía ni a omes ni a mugeres poderosas ni cavallero ni escudero ni a dueña ni a aquellos que el derecho defienden, salvo a persona llana e abonada tal que sin pleyto ni otra rrazón alguna de alvenga?, yo y los abades que después de mí vernán e suçederán y aquello o aquellos que por mí o por ellos ovreren causado puedan ver e cobrar llanamente el dicho çenso en cada vn año al dicho plazo y que la manera que dicha es.

Y otrosí que lo non podades ni puedan vender ni traspasar ni henajenar sin la carga del dicho çenso que sea para mí e para los otros abades mis susçesores de la dicha abadía de Husillos. Y demás desto que en todo tiempo del mundo tengades e tengan de rreparar la dicha yglesia del dicho lugar de San Sebastián e la tengades e tengan bien rreparada y adereçada de todas las cosas que oviere menester a vestra costa y minsión de los bienes e propios e rrentas e diezmos, pechos e dineros a la dicha vestra abadía e conçejo e omes buenos de Hérmides e personas singulares que de yuso avedes de obligar de todas las cosas que oviere menester, porque yo y los abades que después de mí vinieren ayan más çierto e mejor parado el dicho çenso. Y si por tiempo fuere destruyda o cayda la dicha yglesia o parte della, que todavía seades tenudos y obligados vos el dicho abad de Hérmides e los abades que después de vos vernán e suçederán en la dicha vestra abadía y conçejo y omes buenos del dicho lugar de Hérmides e sus susçesores e qualquier de vos o dellos a a quien por tiempo lo toviere y poseyere esto que yo vos do a çenso en qualquier manera de labrar de nuevo la dicha yglesia de todo lo 


\section{LA ABADÍA DE SANTA MARÍA DE HUSILLOS: ESTUDIO Y COLECCIÓN \\ DOCUMENTAL $(904-1608)$}

que oviere menester e de pagar el dicho çenso sin fazer dello desquento alguno, agora sea destruída o cayda por fuego o por agua o por vejez o por otro caso fortuito en qualquier mayor o menor o ygual o menor, y que no se pueda poner ni pongades cuento ninguno.

Y otrosí, que quede a vos, el dicho abad de Hérmides y a vestros susçesores que después de vos vernán y suçederán por abades de la dicha vestra abadía la provisión de poder prover y colar el benefiçio de la dicha yglesia del dicho lugar de San Sebastián a quien quisierdes y quisieren. Y otrosí que en todo el año de noventa y ocho primero venidero vos, el dicho abad de Hérmides o el dicho conçejo y omes buenos del dicho vestro lugar de Hérmides o qualquier de vos, ayades de fazer traer y trayades bulla de nostro muy santo padre de confirmaçión e aprovaçión de todo lo en esta carta contenida en forma válida de derecho si quisierdes y así trayda yo, el dicho abad de Husillos y mis susçesores, seamos obligados a vos pagar ocho ducados de oro para ayuda del gasto de la dicha bulla y vos los paguemos a vos, el dicho abad de Hérmedes o al dicho conçejo de Hérmides o qualquier de vos o a quien en vestro poder o suyo oviere en ocho días después de la dicha bulla fuere notificada. Y no la trayendo en el dicho tiempo que vos, el dicho abad de Hérmides o vestros susçesores o el dicho conçejo de Hérmides, seades e sean obligados a dar y pagar a mí, el dicho abad de Husillos o a mis susçesores, doze ducados de oro para la expediçión de la dicha bulla ocho días después que fuéredes rrequeridos. La qual dicha bula yo, el dicho abad de Husillos, sea obligado a la traer en todo el año de noventa y nueve, so pena de pagar los dichos doze dineros con el doblo y aya de venir y vengan cometida a los reverendos señores el deán de la dicha yglesia de Palençia que es o fuere $(f .145 v)$ y a los arçedianos de Çerrato e Alcor que son o fueren o a qualquier dellos. Y que así vos, el dicho abad de Hérmides y el dicho conçejo de Hérmides, e yo, el dicho abad de Husillos, seamos tenudos y obligados a otorgar qualesquier escrituras que fueren neçesarias para la aprovaçión e confirmaçión del dicho çenso para ante los juezes a quien fuere cometida por nostro muy sancto padre dentro de vn mes después que fuere venida la dicha bulla "yn forma in euidentem vtilitatem", y todo esto que dicho es seyendo así tenido guardado y cumplido e pagado así según e por forma y manera que dicha es e en esta carta se contiene desde oy día que esta carta es fecha e otorgada en adelante, me parto y quito a mí e a mis 
susçesores que después de mí vernán e suçederán por abades de la dicha mi abadía de Husillos del juro y de la tenençia e posesión e señorío e propiedad y de todo el derecho, vso y costunbre que hemos y tenemos e nos pertenesçe a la dicha yglesia e lugar de San Sebastián e a todo lo susodicho, término y prados, pastos y montes y exidos e todo lo que así de suso yo vos doy y a çenso y cada parte dello así vtile commo directo.

Y por esta presente carta vos doy traspaso y vos pongo en la tenençia e posesión y señorío de todo ello y de cada parte dello, e vos do poder cumplido por la tradiçión rreal desta carta y por ante el presente escriuano ante quien pasa para que lo entredes y tomedes vos, el dicho abad, o otro por vos o dellos por vestra propia autoridad o suya sin mandamiento de juez ni de alcalde y sin caer por ello en pena alguna. Y me constituyo por vestro poseedor en vestro nonbre dello y de cada parte dello fasta tanto que lo ayades y ayan entrado y tomado todavía fincando a saluo a mis susçesores de lo entrar e tomar, no pagando el dicho çenso como dicho es. Y para que sea vestro propio e del dicho conçejo y omes buenos de Hérmides y de quien de vos o dellos quisierdes y por bien tovierdes por juro de heredad para vender y enpeñar y dar e trocar y canbiar y henajenar e traspasar e fazer dello y de cada cosa e parte dello ansí commo de cosa vestra propia e suya todavía pasando con la dicha carga del dicho çenso e con las dichas condiçiones çensuales de susodichas y según de susodicho es.

E por ende, yo por mis susçesores e por mí, pongo con vos, el dicho abad de Hérmides y con vestros susçesores y con el dicho conçejo y omes buenos de Érmides, personas singulares e particulares del y con sus suçesores que en el dicho lugar vernán y suçederán por vezinos e moradores del para sienpre jamás y con qualquier de vos, no tomar ni tirar de esto susodicho que ansy yo vos do a çenso yo ni mis suçesores que en la dicha mi abadía de Husillos vernán e suçederán después de mí en ello por más ni por menos ni por el tanto que otro alguno de çenso dellos ni por puja de diezmo, ni de terçio ni de quinto ny por la mitad más de justo preçio.

Y otrosí, de vos lo hazer sano çierto y seguro en todo tiempo del mundo, yo y mis susçesores a vos, el dicho abad de Hérmides y a vestros susçesores y a vestro conçejo y omes buenos de Hérmides y a los suyos y a quien vos o dellos lo oviere de aquí adelante en qualquier manera de todas y qualesquier persona o personas, 
cabildos, vniversidades, pueblos, y comunidades ansí eclesiásticos como seglares de qualquier condiçión, preeminençia o dignidad que sea que vos lo demandaren, enbargaren o contrallaren en qualquier manera todo lo susodicho que así vos yo do a çenso y cada parte dello por qualquier rrazón que sea o ser pueda y de tomar yo e mis susçesores el pleyto y la boz e la demanda por vos y por ellos del día que fuere rrequerido yo o mis susçesores o de quien de mí o dellos oviere causa en mi presençia o suya o ante las puertas de mi contínua morada o suya, faziéndolos saber a alguno de mi casa o suya si los oviere, si non a los vezinos más çercanos fasta nueve días primeros siguientes. E los seguiré e seguirán a mi costa y mynsión o suya, y de los bienes propios e rrentas de la dicha mi abadía de Husillos e vos sacar y los sacar a paz e a saluo (f.146r) e sin daño alguno de todo ello e vos fazer y hará e harán çierto y sano e seguro, libre e desenbargando todo lo susodicho que ansí yo vos do a çenso y cada vna cosa e parte dello por manera que lo ayáis e tengáis y ayan e tengan e poseáis e posean paçíficamente e sin contradición alguna, e vos sacar a paz e a saluo y sin daño alguno de todo ello e si arrendrar e defender non vos quisiere o no pudiere o no quisiere que vos dé e peche y pague el valor y estimaçión de todo lo susodicho que ansí vos do a çenso con el doblo con más las labranças e labores, mejorías e rreparos en ella fechas e con más todas las costas e daños y menoscabos que en la dicha rrazón fizierdes y se vos rrecreçieren por pena y postura y paramiento e por nombre de propio ynterés e convençional que sobre todos los bienes propios y rrentas de la dicha mi abadía y de mis susçesores espirituales y temporales, muebles e rraízes, avidos e por aver con vos, el dicho abad de Hérmedes y con el dicho conçejo de Hérmides, y con vos, el dicho liçençiado Sancho Ruiz de Malvenda, en su nombre y por ellos, pongo y la dicha pena y postura pagada o no pagada o graçiosamente rremytida que en cabo y todavía sea y quede firme y valedero todo lo en esta carta contenido y lo aya yo y mis herederos e susçesores de lo asignar, dar y cumplir y mantener.Y que dello no me pueda ni se puedan escusar diziendo que no fui o no fueron rrequeridos en tiempo o no o nosotros enpeçados a defender y dada sentençia contra vosotros o por culpa o maliçia del juez que dio la tal sentençia o que no fueron rrequeridos ante de la publicaçión de los testigos ny por otra causa alguna qualquier que sea de las que los derechos pónenla en qualquier manera que ello sea y pase, quiero y me plaze de vos lo sanear so la dicha pena, para lo qual 
todo susodicho y cada vna cosa y parte dello ansí a tener y guardar y cumplir y pagar la dicha pena en ella cayendo obligo a todos los bienes y fructos y rrentas, pechos, derechos, y bienes muebles y rraízes, espirituales e temporales de la dicha mi abadía de Husillos y de mis susçesores avidos y por aver.

Y yo, el dicho don Garçi López de Prestines, abad de la dicha abadía de Hérmides, que estoy presente por mí mismo como tal abad y por los dichos mis susçesores que serán en la dicha abadía del dicho lugar de Hérmides, lugar que es de la dicha mi abadía e por virtud de la liçençia e auctoridad a mí dada por el dicho señor obispo que de suso va incorporada. Y yo, el dicho liçençiado Sancho Ruiz de Maluenda, oydor del audiençia del rrey y de la rreyna nostros señores, vezino de la muy noble villa de Valladolid, en boz e en nombre del dicho conçejo y onbres buenos, alcaldes y personas singulares, vezinos y moradores en el dicho lugar de Hérmides; y por virtud del poder espeçial que para fazer y otorgar todo lo que en esta carta es y será contenido dellos, e y tengo que es signado de escrivano público su tenor del qual es este que se sigue.

(Sigue doc. núm. 249)

E por virtud del sobredicho poder que dellos he e tengo que de suso va encorporado así, otorgamos e conosçemos que tomamos e rreçebimos nos y cada vno de nos "yn solidun" a çenso ynfetiosis de vos, el dicho señor dotor don Françisco Núñez, abad de Fusillos que estáis presente, la dicha yglesia e lugar de San Sebastián con todas sus pertenençias perpetuamente para siempre jamás con todos los pactos y condiçiones, posturas y obligaçiones, penas prinçipales y açesorias y rrepetiçiones que son las siguientes: que si caso fuere que yo, el dicho abad de Hérmides o sus sucesores, siendo rrequeridos por parte de vos, el dicho señor abad de Husillos, o de los otros que después de vos vernán e suçederán en la dicha vestra abadía en cada vn año, non vos diéremos y pagaremos el dicho çenso de las dichas quarenta cargas de pan o estoviere para pagar el dicho çenso por espaçio de tres años contínuos vno en pos de otro, que pasados y cumplidos los dichos tres años, que vos, el dicho señor abad de Husillos, o los otros (f.148v) abades susçesores vestros o aquel o aquellos que por vos o por ellos los oviere de auer, podáis e puedan entrar y tomar por vestra propia avtoridad o suya todo el 


\section{LA ABADÍA DE SANTA MARÍA DE HUSILLOS: ESTUDIO Y COLECCIÓN \\ DOCUMENTAL $(904-1608)$}

dicho lugar y yglesia de San Sebastián e vezinos y moradores del e todo lo otro anexo que de suso se haze mençión que nos dais e otorgais a çenso con todas las lavores, hedifiçios, labrancas e mejorías que en ello fuere fecho, e sea todo yncomiso para vos, el dicho señor abad de Husillos, e para los abades que después de vos vernán e suçederán; y demás de lo susodicho que vos o vestros susçesores en la dicha vestra abadía de Husillos, podáis entrar o tomar, amojonar, limitar por vestra propia avtoridad la mitad de todo el término, pastos y montes $\mathrm{y}$ abrevaderos, ansí de los montes que son del dicho conçejo como de los que son de mí, el dicho abad de Hérmides, y prados y exidos y huertas y viñas. Lo qual quede y finque para vos, el dicho señor abad de Husillos, y para vestros erederos e susçesores, y el señorío e propiedad dellos para que podáis hazer dellos como de cosa vestra propia, quedando todavía en su fuerça e vigor este dicho çenso de las dichas quarenta cargas de pan, y quedando obligado yo y mis susçesores y los vezinos y moradores e personas singulares del dicho conçejo e sus susçesores y qualquier o qualesquier de mí o dellos para dar y pagar a vos, el dicho abad de Husillos y a vestros sucesores, todo el dicho pan que así vos fuere devido de los dichos tres años y todo lo que adelante se deviere en todos los años venideros para siempre jamás.

Otrosí, en tal manera y con tal condiçión rreçebimos yo, el dicho abad de Hérmides por mí y por mis susçesores que en la dicha mi abadía suçedieren, e yo, el dicho Sancho Ruiz de Maluenda en nombre del dicho conçejo e personas singulares, vezinos y moradores del dicho lugar de Hérmides cuyo poder tengo que de suso está encorporado de vos, el dicho señor abad de Husillos a çenso perpetuo, la dicha iglesia e lugar de San Sebastián e todo lo otro sobredicho que yo, el dicho abad de Hérmides y los vezinos del dicho lugar de Hérmides e mis susçesores y suyos si quisiéremos o quisieren vender o enajenar otras pasado susodicho que de vos, señor abad de Husillos, rreçebimos a çenso perpetuo, que primeramente lo hagamos saber a vos, el dicho señor abad de Husillos, o a vestros sucesores, para que si lo quisierdes tanto por tanto commo otro o otros por ello nos dieren que lo podáis y puedan aver para vos y para ellos, e fasta vos lo así fazer saber por la vía susodicha que no lo podamos ni puedan vender ni traspasar ni enajenar; y si lo vendiéremos, traspasáremos, enajenáremos, sin vos lo fazer 
saber, que la tal venta o traspasaçión o henajenaçión sea en sí ninguna y de ningún valor y efecto.

Y por el mismo caso yo, el dicho abad de Hérmides y los otros abades que después de mí vernán en el dicho conçejo de Hérmides, o los vezinos y moradores del dicho lugar o los que suçederán en él, ayamos perdido y perdamos por comiso el dicho lugar con todo lo sobredicho que con ello rreçebimos a çenso perpetuo, y lo podáis entrar y tomar por comiso como cosa vestra propia. Y si no lo quisiéredes o quisieren vos ni los dichos susçesores tanto por tanto como dicho es, que yo y los otros abades que después de mí suçedieren y el dicho conçejo de Hérmides y vezinos y moradores del, lo podamos vender y enpeñar y enajenar y traspasar y fazer dello como de cosa propia, pero que no podamos vender ni traspasar ni henajenar lo susodicho a iglesia ni a monesterio ni a cofradía ni a omes ni mugeres poderosas, ni cavalleros, ni escuderos, ni a dueña, ni aquellos que el derecho defiende, saluo a persona llana y abonada y tal que sin pleito ni otra rrazón alguna de aluenga vos, el dicho señor abad o vestros susçesores o vasallos o aquel o aquellos que por vos o por ellos ovieren causa, puedan aver y cobrar llanamente el dicho çenso en cada vn año (f 149r) de la manera que dicha es.

Otrosí, que no lo podamos vender ni henajenar ni traspasar ni enpeñar sin la carga del dicho çenso en ningún tiempo del mundo. Y yo y los otros abades que después de mí suçedieren en la dicha abadía de Hérmides seamos y el dicho conçejo y omes buenos del dicho lugar de Hérmides que son y serán para sienpre jamás cuyo poder yo, el dicho liçençiado Sancho Ruiz de Malvenda, tengo sean tenudos y obligados para sienpre de tener y que ternemos rreparada la dicha iglesia de San Sevastián de todas las cosas que oviere menester a costa y mensión de los bienes y propios, rrentas e diezmos, pechos y derechos de la dicha abadía y a costa del conçejo y onbres buenos del dicho lugar de Hérmides y de los bienes que de yuso por este contrato yo, el dicho abad de Hérmides, e yo, el dicho liçençiado Sancho Pérez de Malvenda, en nombre de los dichos mis partes, obligáremos y ypotecáremos, porque vos, el dicho señor abad de Husillos y vestros sucesores, ayáis e tengáis más çierto y mejor parado el dicho çenso.

Y si por tiempo lo que Dios no quiera, fuere destruyda o caída la dicha iglesia o parte della que todavía yo, el dicho abad de Hérmides y mis sucesores, y el dicho 
conçejo y moradores del mi dicho lugar de Hérmides que son o serán para siempre jamás, seamos e sean tenudos y obligados de labrar de nuevo la dicha iglesia de todo lo que oviere menester y de vos pagar el dicho çenso sin fazer dello discuento alguno, agora sea caída por agua o por fuego o por vejez.

Otrosí, que en todo el año venidero del señor de mil e quatroçientos y noventa y ocho años, yo, el dicho abad de Hérmides o el dicho conçejo y omes buenos del dicho lugar, seamos tenudos y obligados a traer y que traeremos la bulla de nostro muy santo padre de confirmaçión y aprovaçión en forma y valedera en derecho de todo lo contenido en esta escritura. Y ansí traída que vos, el dicho señor abad de Husillos o a vestros sucesores, doze ducados de oro para la expediçión de la dicha bulla. Y dándovoslos y pagándovoslos que vos, el dicho abad de Husillos y vestros sucesores, seáis obligados a traer la dicha confirmaçión en todo el año de mil y quatroçientos y noventa y nueve, so pena de nos lo pagar con el doblo. Y que la dicha bulla aya de venir y venga cometida al deán de la iglesia de Palençia que es o fuere, y a los arçedianos de Çerrato o de Alcor. Y que así yo, el dicho abad de Hérmides o los moradores de mi dicho lugar, y yo, el dicho liçençiado Malvenda, obligo a vos, el dicho señor abad de Husillos, seamos y seáis tenudos y obligados de otorgar qualesquier escrituras que fueren nesçesarias para la aprovaçión e confirmaçión deste dicho çenso para ante los juezes a quien fuere cometida por nostro muy santo padre dentro de vn mes primero después que fuere venida la dicha bulla en forma "sibe euidentem vtilitatem".

Y yo, el dicho abad de Hérmides, por mí y por mis susçesores; e yo, el dicho liçençiado Malvenda, en boz e en nombre del dicho conçejo, por virtud del poder suso encorporado que dellos tengo, prometemos y obligamos yo, el dicho abad de Hérmides por mí e por mis sucesores, y yo, el dicho abad y mis sucesores, vos daremos y pagaremos al dicho señor abad de Husillos y a vestros susçesores o a quien por vos o por ellos ovieren de aver, las dichas quarenta cargas de pan de la dicha rrenta y çenso perpetuo, mitad trigo mitad çeuada, buen pan seco linpio de dar y tomar medidas por la media mayor, puestas y entregadas en el dicho lugar de Hérmides en cada vn año perpetuamente para siempre jamás, por el día de san Miguel de setiembre. Y que comiençe la primera paga el día de san Miguel de setienbre primero del año primero $(f .149 v)$ venidero del señor de mil y quatroçientos y noventa y ocho años. Y dende en adelante que cada vn año por el 
dicho día e so la dicha pena del doblo e con las otras penas e posturas y condiçiones susodichas. E que vos las demos e paguemos yo, el dicho abad y los abades que después de mí vinieren y los vezinos e moradores del dicho mi lugar de Hérmides e sus susçesores aquellos que por tiempo tovieren e poseyeren la dicha yglesia de San Sebastián con todo su partido según de susodicho es, y cada vna cosa e parte dello en qualquier manera en cada vn año por el dicho día de san Miguel e so la dicha pena del doblo por pena e penas e por postura valedera e por nombre de propio interese que con vos, el dicho señor abad de Husillos y con los otros abades vestros susçesores, ponemos yo, el dicho abad de Hérmides, por mí e en nombre de los otros abades que después de mí suçedieren en la dicha abadía; y yo, el dicho liçençiado Sancho Ruiz de Maluenda en nombre de los dichos mis partes y las dichas penas e yntereses y cada vna dellas pagadas e non pagadas e graçiosamente rremitidas todavía este contrato, quede firme e valedero para agora e sienpre jamás. Y que yo, el dicho abad de Hérmides, y mío susçesores e el dicho conçejo e personas singulares, vezinos y moradores del dicho lugar de Hérmides, y cada vno y qualquier dellos seamos e sean tenudos y obligados expresamente de vos pagar las dichas quarenta cargas de pan de çenso en cada vn año para sienpre commo dicho es, e de mandar e guardar y cumplir todas las otras condiçiones e posturas e cosas susodichas e cada cosa e parte dello según y como dicho es. Para lo qual todo atener y guardar y conplir y pagar en quanto a mí, el dicho abad y mis susçesores, atañer e guardar y cumplir y pagar. Y ansí mismo, yo, el dicho liçençiado Sancho Ruiz de Malvenda, en nombre del dicho conçejo y onbres buenos del dicho lugar de Hérmides e a sus susçesores, obligamos y espeçialmente a la dicha yglesia e lugar de San Sebastián con todos sus términos e montes y exidos, prados y pastos con todos sus heredamientos que ansy nos dades a çenso con las mejorías y labranças e lavores e mejoras que ellos fueren fechos con la mytad del dicho término.

Y otrosí, yo, el dicho abad don Garçi López, obligo a los bienes propios y rrentas e diezmos de la dicha mi abadía de Hérmedes y de mis susçesores y anexos a ella y los fructos e rrentas perteneçientes a la dicha mi abadía de Hérmides e de mis susçesores e préstamos anexos en el dicho lugar de Hérmides e del dicho lugar de Castro Verde e su tierra. 
E yo, el dicho liçençiado Maluenda, por virtud del sobredicho poder, obligo a todos los vezinos y moradores y conçejo y onbres buenos e personas singulares e particulares del dicho lugar de Hérmides y a todos sus bienes, ansy muebles como raíces, avidos e por aver, así nos los dichos abad de Hérmides don Garçía López y el liçençiado Sancho Ruiz de Malvenda, le obligamos todo lo susodicho y cada vna cosa e parte dello de mancomún y a cada vno por sí y por él todo "yn solidum", rrenunçiando la ley "de duobus reis debendi", y la avténtica presente "hoc yta de fide iusoribus".

Y con tal condiçión que vos, el dicho señor abad de Husillos y vestros susçesores, podáis e puedan rresçebir, aver y cobrar en cada vn año, las dichas quarenta cargas de pan del conçejo, alcaldes y onbres buenos del dicho lugar de Hérmides o de los fructos e rrentas perteneçientes a la dicha mi abadía e préstamos anexos en el dicho mi lugar de Hérmides o del dicho lugar de Castro Verde e su tierra, qual vos, el dicho abad de Husillos o vestros susçesores, más las quisiere de saver e cobrar por vestra propia avtoridad o suya sin esperar liçençia ni consentimiento de mí, el dicho abad de Hérmides ni de mis susçesores. Y que los rrenteros y dezmeros queriendo vos, el dicho señor abad de Husillos o vestros susçesores, sean obligados a acudir con ellas a vos, el dicho señor abad de Husillos, o a vestros susçesores. Y dándovoslas y pagándovoslas yo, el dicho abad de Hérmides y mis suçesores, seamos tenudos y obligados a ge la rreçebir en quenta y el arrendador o arrendadores a quien yo, el dicho abad de Hérmides y mío susçesores, arrendamos o arrendaremos los frutos e rrentas de la dicha mi abadía, ansí de los de Hérmides como de los préstamos del dicho lugar de Castro Verde y su tierra para lo aver (f.150r) y cobrar yo, por mí e por mío susçesores do poder cumplido a vos, el dicho abad de Husillos y a vestros susçesores para lo poder aver y cobrar e rreçebir e rrecaudar y lo obligo ypoteco. E que la obligaçión y ypoteca espeçial no pare perjuizio a la general, ni la general a la espeçial y sobre todo lo susodicho por más conplimiento de derecho nos, anbas las dichas partes, por nos e nostras partes e susçesores, damos poder cumplido por esta carta, y pedimos por ella a todos e qualesquier justicias, ansí del rrey e de la rreyna nostros señores e de los sus rreynos e señoríos e a todos e qualesquier justiçias e juezes eclesiásticas de la santa madre iglesia a la jurisdicçión de los quales e de cada vna dellas expresamente con los bienes obligados nos sometemos ante quien 
esta carta fuere mostrada e pedido cumplimiento della; por qual de nos, las dichas partes y nostras partes e por nostros susçesores que nos contrangan, conpelan y apremien, ansí por vía de entrega y execuçión commo por otra vía, forma y manera mejor que cumpla e fagan plazo a qualquier de nos, las dichas partes y anteçesores e suçesores de todo quanto oviéremos de aver y pena e penas y costas y daños y todo lo que oviéremos de aver según el tenor e forma desta carta, no lo guardando y cumpliendo commo en ella es contenido bien y complidamente bien ansí commo si fuese sentençia difinitiva de juez ordinario, dada a nostro pedimiento e consentimiento, e della no fuese apelado ni suplicado.

Sobre lo qual todo, rrenunçiamos nostro propio fuero e jurisdiçión e domiçilio e demás partes e susçesores e la ley "sit convenerit" que dispone sy alguno no se sometiere a jurisdicción estraña ante del pleito contestado, se pueden rrepetir e declinar la jurisdicción. E otrosy, rrenunçiamos las ferias de pan e vino, coger e de conprar e vender y todos los días feriados e días de mercados e plazo de consejo de abogado y la demanda por escrito y el traslado desta carta. E que no la podamos ni puedan dezir que al otorgamiento desta carta fuymos ni somos legos y engañados e dagnificados ni que dolo dio causa a ello ni yndiçión en ello ni en parte dello.

E otrosí, rrenunçiamos todo benefiçio de rrestituçión "yn yntegrum” e qualquier otro rremedio de derecho de que nos pudiésemos aprovecharnos, e nostras partes e susçesores presente o por venir. Y otrosy, rrenunçio el derecho que no sabe que le compete o puede competer presente o por venir e nos rectificados de los dichos leyes e derechos los rrenunçiamos e partimos nos dellas y nostras personas e susçesores e suyos e que no seamos ni sean sobrello oydos en juizio ni fuera del en tiempo del mundo ni por alguna manera ante ningund juez eclesiástico ni seglar.

E otrosí, rrenunçiamos todas cartas e merçedes e previlegios e libertades del rrey o de rreyna e de prínçipes o de perlados espeçiales e generales ganados e por ganar que de ellas ni de alguna cosa de ellas nos ni alguno de nos ni nostros partes e suçesores ni otro alguno por nos ni por ellos nos non podamos ni puedan ayudar ni aprovechar.

Y otrosí, rrenunçiamos todo auxilio ordinario e extrahordinario, todo fuero e ley de partida de que nos pudiésemos aprovechar. E otrosí, rrenunçiamos la ley del 


\section{LA ABADÍA DE SANTA MARÍA DE HUSILLOS: ESTUDIO Y COLECCIÓN \\ DOCUMENTAL $(904-1608)$}

derecho en que dize que general rrenunçiaçión de leyes que ome faga que non vala. En testimonio de lo qual e porque esto sea çierto e non venga en duda, otorgamos escrituras de vn tenor, tal la vna commo la otra, para cada vna de las partes la suya, ante Françisco Sánchez de Collados, escriuano y notario público por las auctoridades apostólica y rreal, y escriuano maior del cabildo de la yglesia colegial de Valladolid e del número de la dicha villa e su tierra por el rrey e por la rreyna nostros señores, que está presente. Al qual rrogamos e pedimos que la synase con su signo y a los presentes que fuesen de los otros.

Que fue fecha e otorgada en la dicha villa de Valladolid, treze días del mes de otubre, año del nasçimiento de nostro Sennor Ihesu Christo de mil e quatroçientos y noventa y siete años. Que son testigos que fueron presentes, llamados e rrogados a lo que dicho es: el bachiller Diego Ramírez e Joán de Sedano, canónigo de Husillos, y Agustín de la Puente $(f .150 v)$ de Valdevieso, criado del abad de Hérmides, y Alonso de las Eras, criado del señor abad de Husillos, y Andrés de Nájara, mi criado.

Va escrito en la marjen desto avto que vna plana o dize: "el dicho conçejo de Hérmedes", en comienço de vn rrenglón en la margen o dize: "y yo, el”. Y va escrito en otra marjen o dize: "a los bienes del dicho conçejo, e a los bienes muebles e rraízes de nos e de cada vno de nos". Y va enmendado o dize: "nos"; y o dize: "mos"; y o dize: "vía". E va entre rrenglones o dize: "mía" vala no enpezca.

E yo, Françisco Sánchez de Collados, escriuano e notario público sobredicho, fui presente en vno con los dichos testigos al otorgamiento del dicho avto de çenso perpetuo ynfetiosis. E por rrazón e otorgamiento de los dichos rreuerendos señores abades de Husillos y Hérmides, e del dicho señor liçençiado Sancho Ruiz de Malvenda ge lo otorgaron, lo fize escrevir para el dicho señor abad de Husillos con todas las otras escrituras sobredichas en él incorporadas, asy las dichas liçençias otorgadas por los dichos muy rreuerendo e muy magnífico señor obispo de Palençia a los dichos señores abades, para otorgar este dicho çenso como la que otorgó el dicho abad de Hérmides al dicho conçejo que amas e cada vna dellas pasaron ante mí, el dicho escribano. E de mi signo están sygnadas. Y el dicho poder del dicho conçejo y omes buenos, vezinos e moradores del dicho lugar de Hérmides para el dicho señor liçençiado Sancho Ruiz de Maluenda que 
va signado de escriuano público, e todo va escrito con el dicho presente contrato de çenso perpetuo en doze fojas de pargamino destas e tales commo está y con ésta en que va mío signo. E debaxo de cada plana van rraya de tinta e en ella mi señal acostumbrada, e lo sigue de mío signo en testimonio de verdad. Françisco Sánchez. $(f .151 r)$.

1498, noviembre, 9. Husillos.

Escritura de rectificación escrita y signada por Sancho González de Calahorra, canónigo de Husillos y notario público apostólico, de un contrato de censo perpetuo enfiteusis otorgado por Alfonso de Burgos, obispo de Palencia, entre el prior y cabildo de Santa María de Husillos, con licencia del abad Francisco Núñez, y García López de Prestines, abad de Hérmedes, de la iglesia y lugar de San Sebastián, con toda su jurisdicción y heredades. La rectificación suponía que el censo pasaba de ser de 25 cargas de pan anuales a 40 cargas de pan, mitad trigo mitad cebada, de la medida mayor, a pagar el día de San Miguel (29 de septiembre). Se esperaba que con dicha rectificación acordada se pudiesen evitar posibles pleitos.

B. APA, $L P H$, ff. 159r-161r. Inserto en traslado sacado en Palencia, a 31 de marzo de 1516. Véase doc. núm. 261.

In Dei nomine, amen. Sepan quantos este público instrumento de rratificaçión e aprovaçión e consentimiento vieren, como nos, el prior e cabilldo e canónigos de la yglesia colegial de Husyllos, de la diócesis de Palençia, estando ayuntados en nuestro capítulo y cabildo, dentro de la iglesia y en la capilla de Santa Bárbara, lugar acostumbrado que tenemos $(f .159 r)$ de nos ayuntar, seyendo llamados a canpana tañida, según que lo avemos de vso e de costumbre de nos ayuntar para hazer e otorgar las cosas a nuestro cabildo pertenecientes e 
cumplideras e semejantes que estas estando en renombradamente por nuestros nombres Pero González de Gumiel, chantre, e Diego García de Piña, e Fernando Pérez, e Francisco de Villafrías, e Francisco Fumo, e Alonso de Vidoblo, e Diego Pérez, e Francisco de Palentinos, e Jorge Gordón, e Pero González de Calahorra, rraçioneros, e Juan Martínez de Villunbrales e Martín de Grijota, beneficiados en la yglesia de Husillos, por ende nos los dichos prior e cabildo e canónigos por nos mesmos e en boz e en nombre de nuestros suçesores en la dicha yglesia de Santa María de Husyllos que después vernán e suçederán por prior e canónigos della, e por virtud de la liçencia que para hazer e otorgar lo en este público ynstrumento emos e tenemos del rreverendo señor doctor don Francisco Núñez, oydor del abdiençia del rrey e de la rreyna nuestros señores, abad de la dicha abadía de Husillos, emos e tenemos que pasó y es sygnada de escribano público que de suso encabeça deste avto está syndada de escribano público ante quein el dicho señor abad la concedió e otorgó a la qual nos rreferimos commo si aquí dentro deste avto fuese ynserta de berbo ad berbun e siéndonos mostrado e leydo delante sy la dicha e liçencia como en el contrato de çenso de que en ella se haze mención de cómo el dicho señor abad de Husyllos por sy e por sus susçesores e por nos e por los nuestros dio a çenso perpetuo ynfetiosis la yglesia e lugar de San Sebastián con toda su justicia çevil e criminal mero y misto imperio e con todos sus términos e montes e aguas estantes e manantiales e con todo lo otro a la dicha yglesia e lugar perteneciente e beneficio de la dicha yglesia perteneciente desde la piedra del rrío hasta la foja del monte e desde la foja del monte hasta la piedra del rrío, e con todas sus entradas e salidas e açiones e derechos e vsos e costumbres e derechos vtil e decreto la qual asy dio a çenso perpetuo ynfetiosis al venerable señor don Garçía López de Prestines, abad de Hérmides en la iglesia de Palençia, por sí e por sus susçesores, que en la dicha su abadía e a sus susçesores que después dellos vernán e suçederán por vecinos e moradores por preçio e quantía de quarenta cargas de pan mentad trigo meytad çebada, buen pan seco e linpio, de dar e de tomar, puestas en el dicho lugar de Hérmides, medidas de la medida mayor en cada vn año a pagar para el día de San Myguel de setiembre al dicho señor abad de Husillos e a sus suçesores que después dell viniesen e suçediesen por abades de la dicha abadía de Husillos e que por él o por ellos oviese causado çierta pena e conçiertas condiçiones e penas posturas e principales e açesorias e 
rreparaçiones segund que más por este uso e más conplidamente se contiene en el sobredicho contrato de çenso que ansy el dicho señor abad de Husillos de lo susodicho hizo e otorgó al dicho señor abad de Hérmedes y al dicho conçejo e omes uenos de Hérmedes en persona del dicho su procurador en la dicha carta contenido e al dicho su procurador por ellos e en su nombre lo qual todo por nosotros visto con la licencia que para ello ansy mismo dio y concedió e otorgó el muy magnífico señor don Alonso de Burgos, obispo de Palençia, conde de Pernía e asimismo en el sobredicho contrato estava e está ynserta a lo qual todo nos rreferimos e por nos visto todo lo vno e otro e las causas y rrazones $(f .159 \mathrm{v})$ exprimidas e declaradas en el dicho contrato de çenso e en las susodichas licencias y en cada vna dellas ser e aver pasado asy e a todo ello muy público e notorio e ser todo ello al dicho abad de Husillos e sus susçesores e a nosotros e a los nuestros mucho más vtil e provechoso e a lo asy vender e dar a çenso a la dicha yglesia e lugar de San Sebastián con todo lo susodicho a ello anexo e conexo e en la dicha carta de çenso dicho e declarado e aver commo ovimos de todo ello fezimos el dicho señor abad e nosotros con él todos juntamente nuestros tratados e diligençias según que en tal caso de derecho se devía fazer por ser valledero e firmeza e avn allende de todo ello, nosotros entre nosotros avemos mucho fablado e platicado e sobreello fecho muchas diligençias e tratados e visto commo la dicha yglesia e lugar de San Sebastián e todo lo susodicho rentaba hasta aquí veynte e çinco cargas de pan e si agora dan dellas de çenso perpetuo quarenta cargas de pan e allende dello se escusan muchas costas y daños e pleytos que es cosa más vtil e provechosa asy avérgelo dado e dar a çenso al dicho señor abad de Hérmides, por ende de nuestras propias, libres e agradables voluntades todos juntos de vna visión e concordia ni alguno no discrepante rretificamos e aprovamos e damos por bueno e firme e valedero el dicho contrato de çenso con todo lo en él contenido e cada vna cosa e parte dello e prometemos e otorgamos por firme e solene estipulaçión ante el presente escribano e testigos desta carta por nos e por nuestros susçesores de lo aver e avremos por firme e valedero todo quanto en la sobredicha carta de contrato de çenso es contenido e de no yr ni venir contra ello ni contra parte dello por nos ni alguno de nos ni contra esta dicha rretificaçión ni consentimiento que nos asy por nos e por ellos fazemos sola pena en la sobredicha carta de çenso ponemos e la pena pagada o no pagada o 
graciosamente rremitida que en cabo todavía sea e quede e finque firme e valedero todo esto que nosotros agora otorgamos el dicho contrato de çenso fecho e otorgado por el dicho señor abad de Husillos por sy e en nuestro nonbre e de sus susçesores e nosotros so obligación de los bienes obligados en la dicha carta de çenso e de nos mismos e de los frutos e rrentas de nuestras dignidades e calongías de Husillos e de nuestros suçesores e de los suyos espirituales e temporales avidos e por aver que para ello obligamos e so aquellas rrenunçiaçiones de leyes e derechos e poderío a las justiçias enla sobredicha carta de çenso contenidas e aquellas e nos e nuestros susçesores e bienes obligados sometemos este testimonio de lo qual e porque esto sea çierto e no venga en duda, otorgamos esta carta e público ynstrumento de rretificaçión e consentimiento e obligación e porque esto sea firme e no venga en duda otorgamos esta carta e público ynstrumento de rretificaçión e consentimiento e obligación e porque esto sea firme e no venga en duda, otorgamos esta carta e público ynstrumento antel notario público e testigos de yuso escriptos.

Que fue fecha e otorgada e pasó ansy en la yglesia de Husillos, a nueve días del mes de noviembre, año de mill e quatroçientos e noventa e ocho años. Testigos que fueron presentes, los dichos Juan Martínez de Portiello e Martín de Grijota, benefiçiados de la dicha yglesia de Husillos, Santiago Garçía de Calahorra.

E yo, Sancho González de Calahorra, clérigo de la diócesis de Palençia e canónigo de la yglesia de Husillos, notario público por la autoridad apostólica, presente fui a todo lo que susodicho es en vno con los dichos testigos, e asy lo vi e oy pasar, e en nota lo tomé; de la qual este público ynstrumento, por (f.160r) mano de otro fielmente escripto, saqué y en esta pública forma torné, e de mi acostumbrado signo signé en testimonio de verdad, rrogado e rrequerido.

1500, abril, 22. Husillos - 1500, abril, 27. Husillos. 
Testimonio notarial de Sancho González de Calahorra, canónigo de Santa María de Husillos y secretario del prior y cabildo de dicha iglesia, en el que se da en censo a Francisco de Bivero y Constanza de Barreda, su mujer, un solar en Valladolid, sobre el cual se habian levantado unas casas que habian sido destruídas en 1498 por una crecida del río Esgueva.

- 1500, abril, 22. Husillos.

Pedro Carrillo, vecino de Husillos, criado y familiar de Francisco Núñez, abad de Santa María de Husillos, en nombre de éste pide licencia al prior y cabildo de dicha iglesia para dar en censo un solar en Valladolid, sito en la calle de La Costanilla, a Francisco de Bivero y Constanza de Barreda, su mujer, en precio anual de dos mil quinientos maravedís.

- 1500, abril, 24. Husillos.

El prior y el cabildo de Santa María de Husillos toman en consideración la petición de Pedro Carrillo.

- 1500, abril, 27. Husillos.

El prior y el cabildo de Santa María de Husillos dan su licencia a Francisco Núñez, abad de dicha iglesia, para poder dar en censo el solar.

A. AHDP, Ampudia y Abadía de Husillos, pergaminos, leg. $\mathrm{n}^{\circ}$ 63. Husillos (1447-1568), doc. 4-1. Perg., 305 x 215 mm.; escr. cortesana; buena conservación. Se trata de un cuaderno formado por cuatro pliegos de pergamino doblados al medio, lo que hace un total de ocho folios. Entre los folios $7 \mathrm{v}$ y $8 \mathrm{r}$ se han introducido y cosido seis folios de papel. La mayor parte de las letras mayúsculas están miniadas en rojo y azul. Los ff. 7v, 8r y 8v están en blanco. Los cuatro primeros folios de papel contienen una renovación de censo del año 1685; los dos últimos contienen una renovación de censo del año 1723.

Inserto en la carta de dicho censo, dada en Valladolid, a 28 de abril de 1500. Véase doc. núm. 253. $B$. APA, $L P H$, ff. $151 \mathrm{r}-156 \mathrm{r}$.

REG. SAN MARTÍN PAYO, Apasionante historia de cinco casas, 215-229.

En la villa de Husillos, de la diocisi de Palencia, a veynte et dos días del / mes de abril, año del nascimiento de nuestro Señor Ihesu Christo de mill et / 
quinientos años. Estando en la iglesia colegial de nuestra señora Sancta /María de Husillos, ayuntados a capítulo el prior y cabildo de la dicha / yglesia, a do et segund lo tienen de uso et de costumbre de se ayuntar, pa/ra celebrar y otorgar autos y escripturas y negocios tocantes y pete/nescientes al dicho cabildo, especialmente llamados para el caso yn/fra escripto. $\mathrm{Y}$ estando presentes en el dicho cabildo los venerables señores don Pe/ro Goncález de Gomiel de Yçan, chantre, et Fernando Pérez, Sancho Goncáles, Fernando / Amo, Francisco de Villescusa, Alonso Doydobro, Diego de Prado, Jorge de Gordón, e / Francisco de Polientes, canónigos; e Pero Goncález de Calahorra e Gómez de Lo/mas, rracioneros; e Juan Martínez, et Juan de Portillo, e Martín de Grijota, Damián / de Ávila e Felizes de las Heras, medios racioneros, y otros beneficiados de la dicha / iglesia, por ellos y em boz et en nombre de los otros beneficiados de la dicha iglesia, que / están ausentes, bien como sy fuesen presentes a boz de cabildo. En presencia de / mí, el notario ynfra escripto, y de los testigos de yuso escriptos, pareció presente Pero /Carrillo, vezino de la dicha villa y criado y familiar del reverendo señor, el doctor / Francisco Núnez, abbad de Husillos, del consejo del rey et de la reyna nuestros seño/res, propuso et dixo a los dichos señores, que bien sabían en commo podía aver quarenta / o cincuenta años que siendo abbad desta abbadía de Husillos el reverendíssimo / señor de buena memoria, el cardenal de Sant Ángelo, que sancta gloria aya, un pro/curador suyo avía dado et dio a Juan Rodríguez de Toro, prior de la iglesia de Valladolid, / por vida suya y de un heredero, un suelo de casas que la dicha abbadía tiene en la / dicha villa de Valladolid, en la calle que dizen de La Costanilla, que ha por linderos: de / la una parte, casas de la dicha iglesia de Valladolid, et de la otra parte / (en blanco) e por delante la dicha calle pública, por precio et quantía /de docientos maravedís en cada un año. Por quanto el dicho solar estava sin hedificio nin/guno porque la dicha calle de la dicha Costanilla, se avía quemado. El dicho prior nom/bró por heredero a Juan Ramiro, vezino de la dicha villa de Valladolid; el qual tenía et poseya / las casas quel dicho prior avía hedificado en el dicho suelo. Y asy teniéndolas el año pa/sado, de mill et quinientos y noventa y ocho años ${ }^{18}$, el río de Esgueva, que pasa por la dicha / villa de Valladolid, avía llenado del todo las dichas casas, con otras muchas que con ellas / estavan, de manera que solo avía

\footnotetext{
${ }^{18}$ quinientos] Se trata de un error, ya que es cuatrocientos.
} 
quedado el suelo dellas et ningún otro hedi/ficio. Y que asy mismo, sabían commo el dicho señor abbad avía pedido et demandado al / dicho Juan Ramiro ante los señores presidente et oydores del audencia de los dichos / señores rrey et reyna nuestros señores, que hiziese et hedificase unas casas en el dicho sue/lo, segund et commo antes estavan quel dicho rrío de Esgueva las levase. Et ante todas co/sas pedió a los dichos sennores que compeliesen y apremiasen al dicho Juan Ramiro / que exiviese el contrato que tenía de las dichas casas, porque él non le tenía ni le podía / aver, nin sabía quien hera el escrivano por ante quien avía pasado, por aver tanto tiempo / que se avía celebrado y otorgado.

El dicho Juan Ramiro respondió quel non tenía / el dicho contrato. Y porquel dicho señor abbad no podía provar el thenor del, él lo dexó / en juramento deçisorio del dicho Juan Ramiro; el qual, en presencia de los dichos seño/res presidente y oydores, juró et absolvió el dicho juramento et dixo quel non tenía el / dicho contrato nin sabía del, ni nunca en sus manos, nin poder avía venido. Y commo el / dicho señor abbad vio que no tenía contrato para demandar al dicho Juan Ramiro, de/xó de proseguir la dicha su demanda. Et porque estando por hedificar el dicho suelo, / la dicha abbadía perdería la rrenta et viendo asy mismo commo para hazer et hedificar $(f .3 v)$ las casas en el dicho suelo se requería grand costa de dineros, asy para el cimiento et bóve/da que en él se avía de hazer de cal y canto, que avía de azer sobre el agua, la qual costa/va veynte et ocho mill maravedís y más a hazer, commo para los hedificios de madera et plega/dura, teja et barro y otros materiales a ello nescesarios, y para los maestros que lo suso/dicho ayan de açer. Et que sy los dichos hedificios non se ficiesen en el dicho suelo, nunca / rrentaría cosa alguna. E deseando el dicho señor abbad utilidad de la dicha su abba/día, porque non perdiese la dicha rrenta del dicho suelo, pues que non se podía hazer / y hedificar en él las dichas casas por la grand costa que para ello se requería, avía / procurado por la dicha villa de Valladolid donde está situado el dicho suelo, et por otras / partes y lugares, quien lo quisiese tomar a rrenta o "ad vitan", o a çenso perpetuo, con / cargo que hiziese y hedificase casas en el dicho suelo, porque rrentasen alguna cosa / para la dicha abbadía, y que non avían hallado ni podido hallar quien lo quisiese tomar / en manera alguna, salvo Francisco de Bibero et doña Costança de Barreda, su / muger, vezinos de la dicha villa de Valladolid, que lo avían querido y querían 


\section{LA ABADÍA DE SANTA MARÍA DE HUSILLOS: ESTUDIO Y COLECCIÓN \\ DOCUMENTAL $(904-1608)$}

tomar / a çenso perpetuo, con obligaçión et cargo de lo armar et hedificar a su costa et misión, / et de pagar de rrenta perpetua en cada un año para siempre a la dicha abbadía, por rrazón / del dicho suelo et de las casas que en él fizieren et hedificaren, dos mill et quinientos / maravedís de buena moneda usual corriente en estos rreynnos de Castilla, de rrenta et censo / perpetuo en cada un año para siempre. Et que no avían hallado quien tanto ni más pre/cio por ello les diese ni prometiese.

Por ende, que en nombre del dicho señor abbad / les notificava et notificó a los dichos señores, prior y cabildo, para que viesen si les / parecía que hera ebidente provechoso et suficiente causa para otorgar çenso del dicho / suelo al dicho Francisco de Bibero et doña Costança de Barreda, su muger, en el dicho pre/çio. Et diesen, para ello, su asseenso et consentimiento o que dixiesen en ello et cerca del/lo lo que les pareciese que se devía de hazer para mayor utilidad y provecho de / la dicha abbadía.

Et que el dicho señor abbad de Husillos estava presto y aparejado de se con/formar con su parescer dellos. Et pediolo por testimonio a mí, el dicho notario. Y los / dichos señores, prior y cabildo, dixieron que avían bien visto et oydo et entendido to/do lo susodicho et propuesto por el dicho Carrillo et en nombre del dicho señor abbad. / Y que ellos verían et querían ver, en el dicho negoçio, et tener et aver, sobre ello, su dili/gençia et yquisiçión et tratados; et que por ellos y por cada uno dellos rresponderían / lo que les paresciese que se devía de hazer para mayor otilidad et provecho de la di/cha abbadía.

Et que este presente abcto sea avido por primero tratado, el quel otorga/ron ante mí, el dicho escrivano. Que son testigos, que a ello fueron presentes: Juan de / Ávila et Juan de Avia, sacristán de la dicha yglesia, et Antón, su hijo, et otros, todos vezinos / de la villa de Husillos.

E después desto, en la dicha iglesia de Husillos, a veynte et quatro días del mes de a/bril del dicho año del señor de mill y quinientos años, estando ayuntados / a capítulo los señores prior y cabildo de la dicha yglesia, conviene a saber: los ve/nerebles señores don Pero Goncález de Gomiel, chantre, e Fernand Pérez, Sancho / Goncález, Fernand Amo, Francisco de Villescusa, Alonso de Hydobro, Diego de / Prado, Jorge de Gordon e Francisco de Polentinos, canónigos, e Pero Gómez de / Calahorra et Gómez de Lomas, rracioneros, e Juan Martínez e Juan de 
Portillo, Mar/tín de Grijota, Damián de Ávila e Felizes de las Eras, medios rracioneros, e otros / beneficiados de la dicha iglesia. En presencia de mí, el dicho escrivano et notario públi/co infra escripto, y de los testigos de huso escriptos, paresció y presente, el dicho Pero / Carrillo, criado y familiar del dicho señor abbad de Husillos, y altas y entendidas bo/zes, propuso et dixo que bien sabían commo por el abto primero antes deste, en nombre / del dicho señor abbad, avía propuesto sobre rrazón de un suelo que la dicha abbadía / tenía en la villa de Valladolid, en la calle de La Costanilla de la dicha villa, el qual estava $(f .4 r)$ derelinquido y caydo sobre el rrío de Esgueva. Et commo no avía allado quien lo quisiese tomar a / rrenta ni a vita, ni a en censo, salvo Francisco de Bibero et doña Costanca de Barreda, su muger, / vezinos de la dicha villa de Valladolid. Et avían prometido de dar por ello, en cada un año, dos / mill y quinientos maravedís de çenso perpetuo con cargo de lo armar et hedificar. E que avían di/cho que le rresponderían y que él era venido por la rrespuesta dello; por ende, que en el dicho / nombre les pedía et pidió que si estavan determinados en ello, que le diesen su pareçer.

Y los / dichos señores prior y cabildo dixieron que lo oyan et que avían visto y platicado e / ablando en el dicho negoçio, et que les pareçía que era buen partido, útile et provechoso / para la dicha abbadía, lo que el dicho Francisco de Bibero et la dicha su muger façían, pu/es que el dicho suelo estava derelinquido et para azer, et hedificar, en él, casas, rrequería / mucha costa; e porque no estando armado no rrentaría cosa alguna a la dicha abba/día, pero que todavía querían más ver et platicar en el dicho negoçio, et aver sobre ello / su ynformaçión; et por ellos avida, que darían su rrespuesta. Et que este segundo tratado, / el qual otorgo ante mí, el dicho escrivano, para que yo lo diese signado de mi signo. / Y el dicho Pero Carrillo lo pidió por testimonio. Que son testigos que fueron presen/tes: Alonso de Ávila et Juan de Avia, sacristán de la dicha yglesia, e Diego Fernández / Cardaño e Santtiago Amo e otros, todos vezinos de la dicha villa de Husillos.

E después desto, en la dicha iglesia colegial de Husillos, a veynte et siete días del / mes de abril del dicho año del sennor de mill y quinientos años, estando / ayuntados a capítulo los señores prior y cabildo de la dicha yglesia en lu/gar $<\mathrm{a}>$ costumbrado et em presencia de mí, el notario et testigos de yuso escriptos, / estando presentes los dichos venerables señores don Pero Goncález de Gomi/el, 
chantre, e Fernand Pérez, Sancho Goncález et Fernand Amo, Francisco de Villescusa, / Alonso de Ydobro, Diego de Prado, Jorge de Gordon e Francisco de Polentinos, / canónigos, e Pero Gonçález de Calaorra e Gómez de Lomas, rraçioneros, e Juan / Martínez e Juan de Portillo, Martín de Grijota, Damián de Ávila e Felizes / de las Heras, medios rraçioneros, paresçió presente el dicho Pero de Carrillo, criado / y familiar del dicho señor abbad de Husillos; el qual, altas et entendidas bozes, di/xo en el dicho cabildo a los dichos sennores, que bien sabían commo por los autos / primero et segundo antes deste, avían dicho et propuesto, en nombre del dicho señor / abbad, çerca et en rraçón del dicho suelo que la dicha abbadía tenía sobre el suelo de / La Costanilla de la dicha villa de Valladolid, que las quería tomar a çenso perpetuo Francis/co de Bibero et doña Costança de Barreda, su muger, con cargo de lo armar y hedificar / et de pagar de tributo, en cada un año para siempre jamás a la dicha abbadía, los / dichos dos mill y quinientos maravedís, para que los dichos señores, prior y cabildo, / viesen si era cosa provechosa para la dicha abbadía o no, o otorgar el dicho çense; / a lo qual era venido al dicho cabildo. Por ende, que en el dicho nombre les pedía et / pidió le diesen et rrespondiesen lo que en ello tenían acordado, porque el dicho señor / abbad estava presto de se conformar con su pareçer del dicho cabildo.

Et los dichos se/ñores prior y cabildo, dixeron que lo oyan et que avían visto et platicado en ello et que / les pareçía que el dicho partido era útile y provechoso et mucho neçesario para la dicha / abbadía. Por quanto a ellos era notorio todo lo dicho et rrelatado por el dicho Pero / Carrillo, asy de como en tiempo del dicho señor cardenal, el suelo de las dichas casas/ se a mandado al dicho prior por vida suya et de un heredero, por los dichos doçientos / maravedís. Et de commo el dicho señor abbad avía demandado et pedido, al dicho Juan Ramiro, / ante los dichos señores presidente et oydores. Et de como, el dicho contrato no se avía / podido allar. Et del juramento quel dicho Juan Ramiro avía absuelto.

Et asy mesmo, les / era notorio los gastos que eran necesarios para edificar y açer las dichas casas, que / eran grandes o que no avía bienes de la dicha abbadía de que se podía açer et complir. / Et asy mesmo, les era notorio commo después quel dicho señor abbad tenía et poseya $(f .4 v)$ la dicha su abbadía, su merced avía acrecentado et mejorado los bienes y rrenta del/la en gran cantidad. Et que sy su merced viese que no hera útile no provechoso fazer / y otorgar el dicho censo, que 
non lo haría ni otorgaría. Et por mayor certinidad / de todo lo susodicho, puesto que a ellos les fuese notorio, ellos se quisieron / informar de personas de fee y de creer, de las quales uvieron informaçión, / ser verdad todo lo susodicho y ser muy útile y provechoso dar, el dicho suelo, (en blanco) / perpetuo al dicho Francisco de Bibero et a la dicha su muger para la dicha abbadía. / Y que sobre esto avían muchas vezes platicado sobre lo susodicho, y avían / allado ser útile y provechoso a la dicha abbadía todo lo susodicho.

Por ende, / dixeron que en la mejor manera que podían et de derecho devían, viendo la / ebidente utilidad que hera a la dicha abbadía dar, el dicho solar de casas a en/censo perpetuo al dicho Francisco de Bibero et a la dicha su muger por los dichos / dos mill y quinientos maravedís, que ellos davan su assenso y consentimiento al / dicho señor abbad, para hazer y otorgar el dicho contrato de censo del dicho / suelo a los dichos Francisco de Bibero et doña Costança de Barreda, su muger. E / asy lo otorgaron ante mí, el dicho escrivano, para que yo lo dé signado con mi sy/no. Y el dicho Pero Carrillo pidiolo por testimonio. Testigos que a ello fueron / presentes: Diego Ferrández Cardaño e Juan de Avia, sacristán de la dicha iglesia, e An/tón, su hijo, et Pero de Aguilar, fijo de Pero Ferrández de Aguilar, et otros, todos vezinos / de la dicha villa de Husillos.

E yo, Sancho Gonçález de Calahorra, clérigo de la diócisis/de Palencia, et canónigo de la dicha iglesia de Husillos, e secretario de los dichos / sennores prior et cabildo de la dicha iglesia, presente fui a todo lo que susodi/cho es en uno con los dichos testigos. Et asy lo vi et oy pasar e en nota lo tomé; /de la qual este público instrumento, con mano de otro fielmente escripto ba, que / et en esta pública forma torné e de mi acostumbrado signo signé et rrubliqué, en / testimonio de verdad, rrogado et rrequerido.

1500, abril, 28. Palencia. 


\section{LA ABADÍA DE SANTA MARÍA DE HUSILLOS: ESTUDIO Y COLECCIÓN DOCUMENTAL $(904-1608)$}

El doctor Francisco Núñez, abad de Santa María de Husillos, con autorización del prior y cabildo, da en censo perpetuo de 2500 maravedís anuales, un solar en Valladolid sito en la calle de La Costanilla, a Francisco de Bivero y Constanza de Barreda, su mujer, los cuales aceptan, entre otras cláusulas, construir unas casas y repararlas o reedificarlas en caso de que éstas se caigan por efecto de inundación. La carta de censo fue otorgada por Alonso Rodríguez, escribano público de Palencia.

A. AHDP, Ampudia y Abadía de Husillos, Pergaminos, leg. $\mathrm{n}^{\circ}$ 63. Husillos (1447-1568), doc. 4-1. Perg., 305 x 215 mm.; escr. cortesana; buena conservación. Se trata de un cuaderno formado por cuatro pliegos de pergamino doblados al medio, lo que hace un total de ocho folios. Entre los folios $7 \mathrm{v}$ y $8 \mathrm{r}$ se han introducido y cosido seis folios de papel. La mayor parte de las letras mayúsculas están miniadas en rojo y azul. Los ff. $7 \mathrm{v}, 8 \mathrm{r}$ y $8 \mathrm{v}$ están en blanco. Los cuatro primeros folios de papel contienen una renovación de censo del año 1685 ; los dos últimos contienen una renovación de censo del año 1723.

$B$. APA, $L P H$, ff. $151 \mathrm{r}-156 \mathrm{r}$.

REG. SAN MARTÍN PAYO, Apasionante historia de cinco casas, 215-229.

In Dei nomine, amen. Sepan quantos / esta carta de en/çense vieren, como yo, el doctor don Françisco Núñez, abbad de Husillos, / del consejo del rrey et de la rreyna nuestros señores, vezino de la noble çib/dad de Palençia; estando presente por mí et en nombre del abbad o abbades, / que fueren o serán de aquí adelante del abbadía de Husillos, otorgo et conos/co que de mi buena voluntad, sin premia, ni fuerca, ni engaño, ni induçimiento, / ni infinta alguna; et porque entiendo que es útile et provechoso a la dicha ab/badía et a mis subcesores et abbad o abbades et subcesor o subcesores, que / después de mí fueren o serán en la dicha abbadía, que do a encense et por / ençense perpetuo, para agora e para siempre jamás a vos, Françisco de Bi/vero e a doña Costança de Barreda, vuestra muger, vezinos que soys de la no/ble villa de Valladolid, que estays presentes, un solar de casas que la / dicha abbadía de Husillos e yo, commo abbad que soy della, tengo et poseo / en la dicha villa de Valladolid, en la calle que diçen de La Costanilla, que an / por linderos: de la una parte, casas de la del licenciado de Burgos, que tiene agora a çen/so Alonso de Dueñas, platero; e de la otra parte, casas que son de la yglesia mayor de la / dicha villa de Valladolid, que tiene e 


\section{DAVID MARCOS DIEZ}

avita la de Alonso de León; e por delante, la dicha calle / pública de La Costanilla; et por las espaldas del dicho solar de casas, el río que diçe Es/gueva, en la dicha villa de Valladolid. El qual dicho solar de casas, vos do a ençenso con / todas sus entradas et salidas et pertenençias et usos et costumbres et servidumbres, / e segund que a la dicha abbadía et a mí pertenesçen et pertenesçer deven, en qualquier / manera et por qualquier causa o rraçón que sea o ser pueda, para que vos, los dichos / Françisco de Bibero e doña Costança de Barreda, vuestra muger, et vuestros fijos et sub/cesores e quien por tiempo las oviere de aver, las labredes et rreparedes et tengades en/hiestas et reparadas, en todo tiempo del mundo a vuestra costa et misión a toda vuestra aventu/ra, no embargante qualquier caso fortuito que en ellas acaesca.

E demás desto, que / vos et ellos deys et paguéys de ençenso por ellas, a mí o al abbad o abbades, subçesor / o subcesores que despues de mí subcedieren en la dicha abbadía de Husillos, o quien por / mí o por ellos o por la dicha abbadía lo oviere de aver o cobrar et recabdar, dos mill et / quinientos maravedís desta moneda usual corriente en estos rreynnos de Castilla, o de / la moneda que corriere al tiempo de la paga o pagas en cada un año, perpetuamente pa/ra siempre iamás, pagados en esta manera. La meytad de los dichos dos mill et quini/entos maravedís, al día de Nabidad; et la otra meytad, al día de Sant Juan de junio de cada un a/ño, et que sea la primera paga que avedes de fazer. E començará a correr desde el día de / Nabidad, que será en el año primero que viene, del nascimiento de nuestro Salvador Ihesu Christo de / mill et quinientos et un años. E la segunda paga al día de Sant Juan de junio del dicho / año de mill et quinientos et un años. Et dende en adelante en cada un año, a los dichos / plazos de Nabidad et Sant Juan, perpetuamente, para siempre jamás, so pena de çinquenta / doblas de la dicha moneda usual corriente en Castilla o que corriere al dicho tienpo, / segund dicho es, que me dedes et pechedes en cada un año a mí o al abad o abbades, subce/sor o subcesores que después de mí subcedieren en la dicha abbadía de Husillos, por cada / un día de quantos días pasaren de qualquier de los dichos plazos pasados en adelan/te, por pena et postura et paramiento et por nombre de interese convençional, que conmigo / et con el dicho abbad o abbades, subcesor o subcesores que despues de mí, en la dicha ab/badía, subcedieren. Et demás desto, que cayáys et incurráys en todas pas otras penas, / estableçidas 


\section{LA ABADÍA DE SANTA MARÍA DE HUSILLOS: ESTUDIO Y COLECCIÓN \\ DOCUMENTAL $(904-1608)$}

contra los que reçiben posesyón de encense et lo non pagan por la forma et / manera que son et están obligados. Que sy vos, los dichos Francisco de Bivero et doña $\mathrm{Co} /$ stança de Barreda, vuestra muger, et vuestros fijos et herederos et subcesores et quien por tiempo o/viere, las dichas casas fuerdes o fueren reveldes en pagar los dichos maravedís del dicho encenso dos $(f .2 v)$ años contínuos, uno en pos de otro, que yo o el abbad o abbades, suçesor o subcesores que des/pués de mí subcedieren en la dicha abbadía, o otro qualquier en mi nombre o dellos o de qual/quier dellos o de la dicha abbadía, podamos sy quisiéremos por nuestra propia autoridad, / syn liçençia ni mandamiento de juez ni de justiçia et sin pena et sin otra solenidad alguna, /entrar et tomar e ocupar el dicho solar de casas et la tenençia et posesión et propiedad et / señorío del, para la dicha abbadía, con todas las mejoras et reparos et edifiçios que desde aquí / adelante en ellas fezieren.

Et demás desto, que yo o el abbad o abbades, subcesor o sub/cesores que subcedieren, en la dicha abbadía, podamos aver et cobrar et ayamos et cobremos / de vosotros et de vuestros bienes o de aquellos en quien el dicho solar de casas subcedieren, / lo que a mí o a ellos nos avéys o avierdes et fuéredes obligados a dar et pagar del dicho / encense et de los ençenses que deviéredes. Et con más, todas las costas et daños et me/noscabos et con las penas que sobrello et sobre la cobrança del dicho encenso a mí/o a los que después de mí subcedieren en la dicha abadía o a quien por mí o por ellos / lo ovieren de aver, se nos recreçieren. Et con las condiciones seguientes: primeramen/te con condiçión que vos, los dichos Francisco de Bivero et doña Costança de Barreda, vuestra / muger, en todo este año de mill et quinientos años, ayáys de hazer et agáys en el / dicho solar, unas casas de tres sobrados en el alto, a vuestra costa et misyón. Ansy mesmo, ayáys / de pagar et pagéys veynte et ocho mill maravedís que cupieron al dicho solar de çierto hedificio / de cantería que agora nuevamente se fizo sobre Esgueva.

Otrosy, que no podáys de/xar las dichas casas que se hizieren en el dicho suelo, syno a uno de vuestros fijos. Y otro tan/to ayan de azer et agan los subcesores de vos, los dichos Francisco de Bibero et de la dicha / doña Costança de Barreda, vuestra muger, agora sean subcesores estraños o legítimos descen/dientes de vos, los dichos Francisco de Bibero et de la dicha doña Costança de Barreda, / vuestra muger. Otrosy, con condición que sy las dichas casas que ansy avéys de labrar / y 
hedificar vos, los dichos Francisco de Bibero et la dicha doña Costança de Barreda, vuestra / muger, peresçieren, lo que Dios no quiera, por algund caso fortuyto de fuego o de agua / o de otro qualquier caso fortuyto, que vos, los dichos Francisco de Bibero et la dicha do/ña Costança de Barreda, vuestra muger, o los dichos vuestros subcesores, seáys obligados ha/zer et hedificar, en el dicho suelo, a vuestra costa et misión, unas casas tales et tan buenas co/mo las que agora hedificáredes.

Otrosy, con condiçión que sy vos, los dichos Fran/cisco de Bibero et la dicha donna Costança de Barreda, vuestra muger, et vuestros subcesores legití/mos o estrannos, ovierdes o ovieren de vender las dichas casas, que ante todas co/sas ayays et ayan de rrequerir a mí, el dicho abbad de Husillos que agora so o aquel, o aquel/los que después de mí subcedieren en la dicha abbadía, si quieren comprar las dichas / casas. Y sy las quisiéremos, tanto por tanto, que antes las deys a mí o a los que después / de mí subcedieren, que a otro ninguno.

Otrosy, con condición que sy yo, el dicho ab/bad de Husillos, o el que que después de mí en la dicha abbadía subcediere, dixere que non las / quiere comprar, que vos, los dichos Francisco de Bibero et la dicha doña Costança de Barre/da, vuestra muger et vuestros subcesores, las podáys et puedan vender a quien quisiéredes et por bien / toviéredes, con tanto que todo lo porque las vendiéredes, ayáys de dar et deys a mí, el di/cho abbad, o aquel o aquellos que después de mí subcedieren en la dicha abbadía, en / la veyntena parte.

Otrosy, con condiçión que vos, los dichos Francisco de Bibero / y la dicha doña Costança de Barreda, vuestra muger, ayáys de dar fianças llannas y abona/das, para que sy las dichas casas que ansy agora nuevamente se hedificaren en el / dicho suelo, perescieren por algún caso fortuyto o por otro qualquiera, que dentro de / un año primero siguiente después que las dichas casas perescieren, las tornéys a / hazer a vuestra costa et misyón, segund et commo agora se hedificaron. Y entre tanto, que pa/guéys el dicho encense de los dichos dos mill et quinientos maravedís. Con las quales / condiciones susodichas, yo, el dicho dotor Francisco Núñez, abbad de Husillos, y / por virtud de la autoridad et liçençia que tengo del prior et cabildo de la dicha yglesia $(f .3 r)$ de Husillos y por virtud de los tratados que entre mí y los dichos prior et cabildo an ynterve/nido, el thenor de los quales tratados, "de verbo ad verbum", es este que se sigue: 
(Sigue doc. núm. 252)

Veyendo ser útile et provechoso a la dicha abbadía de Husillos, dar el dicho / suelo a encenso perpetuo, con las dichas condiciones, a vos, los dichos Francisco / de Bibero et a la dicha doña Costança de Barreda, vuestra muger, et a vuestros subcesores, / os lo do et otorgo para agora et para siempre jamás. E desde oy día en adelante / que esta carta es fecha et otorgada, parto et quito et desapodero a mí et a la dicha ab/badía, del señorío et propiedad, et tenencia, et posesión de las dichas casas. Et por / esta presente carta las do et entrego et cedo et traspaso a vos, el dicho Francisco de Bi/bero et a la dicha doña Costança de Barreda, vuestra muger, et en vuestros fijos et herede/ros et subcesores, presentes et por venir, para que le entréys et toméys, quando qui/sierdes et por bien tovierdes, por vuestra autoridad propia, sin autoridad de juez / ni de alcalde.

Et sean vuestras et de vuestros herederos et subcesores, de aquí adelante, libres / et quitas por juro de heredad para siempre jamás, para que las podáys vender et / empeñar et trocar et cambiar et donar et enagenar et fazer del et en él et en cada co/sa et parte dellas commo de cosa vuestra propia, libre et quita, todavía pasando con / la dicha del dicho encense que yo he la dicha abbadía avemos de aver / a ellas perpetuo en cada un año, para siempre jamás, como dicho es.

Pero que non / las podáys vender a iglesia ni monesterio, ni ospital, ni a persona ecclesiástica et / poderosa. Et que aviéndolas de vender commo dicho es, que lo agays primera/mente saber a mí, el dicho abbad, o abbad, o abbades, o subçesores que después / de mí en la dicha abbadía subcedieren. Et non las queriendo que vos, los dichos / Francisco de Bibero et la dicha doña Costança de Barreda, vuestra muger, et vuestros he/rederos et subcesores o quien por tiempo oviere las dichas casas, las podades / vender et hazer dellas et en ellas commo de vuestra cosa propia, libre et quita, toda/vía pasando con la dicha carga del dicho encense, commo dicho es et con las $(f .5 r)$ dichas condiçiones, et en la manera que dicha es. Et dando et pagando a mí et a los / que después de mí subcedieren en la dicha abbadía, la veyntena parte de lo que va/lieren, cada vez que fueren vendidas et quantas vezes se vendieren. E para ate/ner et guardar et complir todo lo susodicho et lo que a mí et a los que después de / mí subcedieren, toca et atañe. 
Et para vos no quitar el dicho solar de casas agora ni en / tiempo alguno que sea por puja de tercio nin de quarto, ni de quinto, nin sesmo, ni / por más de justo et dicho precio; et ansy mesmo, para vos las fazer sanas et de paz / de qualquier o qualesquier persona o personas que vos las contrallaren o en/bargaren o demandaren en qualquier manera o por qualquier razón; et para to/mar el pleyto et defensión por vos o por qualquier de vos o por quien por tiempo de / vos o de qualquier de vos las oviere en qualquier manera, et lo seguir a mi costa / et misión, et de la dicha abbadía. Para lo qual obligo a mí mesmo con todos mis bie/nes, ansy muebles commo rrayzes et de la dicha abbadía, quantos oy día avemos / et tenemos et en qualquier lugar que los oviéremos de aquí adelante, espiritua/les et temporales. Et sy ansy non lo toviere et guardare et compliere, yo o el que despu/és de mi subcedieren en la dicha abbadía, segund que dicho es, que vos demos et / paguemos de los bienes de la dicha abbadía que para ello espresamente obligo, / de cinquenta doblas, por pena et postura, et paramiento, et por nombre de interese / convencional, que con vos pongo por mí et en el dicho nombre. Et la dicha pena pagada / o no pagada, que todavía, siempre sea obligado yo o los que después de mí sub/cedieren en la dicha abbadía, de atener et guardar, et complir todo lo susodicho en / lo que a nosotros conviene.

E otrosy, por esta presente carta, compli/do en el dicho nombre bastante, tal qual de derecho para ello se requiere a vos, los / dichos Françisco de Bibero et doña Costança de Barreda, vuestra muger, et a cada uno de / vos, et a los dichos vuestros subcesores para que sy agora o en alguns tiempo fasta / aquí, an fecho o tienen fechos algunos agravios e perjuyzios en el dicho solar / de casas que ansy os doy, por mí et en el dicho nombre a ençense alguna persona / o personas de qualquier ley, estado, condiçión que sean o en alguna parte del, que / lo podades demandar et demandedes, ansy en juyzio como fuera del, para que sean / desagraviados et desfechos los tales agravios e perjuyzios.

Et que los podades pe/dir et demandar por vía et forma et manera que compliere. Et yo, por mí et en el dicho / nombre del que después de mí subcediere en la dicha abbadía, vos fago para ello / procuradores bastantes commo en cosa vuestra propia. Et si yo o el que después de mí / subcediere, non guardáremos nin compliéremos todo lo susodicho et de cada / cosa et parte dello en lo que a mí o a ellos atañe o conviene o conveniere, et si fuéremos /o veniéremos contra ello et 


\section{LA ABADÍA DE SANTA MARÍA DE HUSILLOS: ESTUDIO Y COLECCIÓN \\ DOCUMENTAL $(904-1608)$}

contra alguna cosa o parte dello, en algund tiempo o por / alguna manera, yo, por mí et en el nombre del abbad o abbades que después de mí en la / dicha abbadía subcedieren, doy et otorgo todo mi poder complido por esta carta, a to/dos et qualesquier juezes et justicias, ansy de la casa e corte et chancellería del / rrey et de la rreyna nuestros señores, commo sy estoviésemos dentro de la jurediçión de las / cinco leguas et desta çibdad de Palencia, et de todas las otras çibdades, et villas, et / lugares de los sus rreynos et señoríos, et todos et qualesquier offiçiales et ecclesiá/sticos et seglares de qualquier çibdad o villa o lugar o iurediçión que sean ante / quien esta carta paresçiere et fuere pedido complimiento della, que nos lo fagan / ansy atener et guardar, et complir, et pagar, a mí et a los dichos mis subcesores que / subcedieren en la dicha abbadía, en la manera et forma que sobredicha es et en esta / carta se contiene, bien et complidamente, ansy commo sy los dichos alcaldes et juezes / o qualesquier dellos ansy lo ovieren juzgado et sentençiado.

E yo $<\mathrm{e}>$ los dichos mis / subcesores que en la dicha abbadía subcedieren, ansy lo oviésemos tomado et reçe/bido dellos o de qualquier dellos, por juyzio et sentençia difinitiva, et fuese pasada, $(f .5 v)$ la tal sentençia contra mí et contra los dichos que después de mí en la dicha abba/día subcedieren en cosa juzgada, et por mí et por ellos consentida et aprovada.

Et sobre / esto que dicho es, por mí et en el dicho nombre, rrenunçio, espresamente, et aparto e / quito de mí et dellos et de nuestro fabor, que no nos podamos llamar lesos ni / dagnificados, no engañados en este contrato censual ni en cosa alguna del, en él con/tenido, ni pedir beneficio de restituçión "in integrun", ni en otro benefiçio alguno. / Et aunque lo aleguemmos et pidamos, que nos non vala; ni yo ni ellos nos poda/mos dello, aprovechar para yr o venir e pasar, yo o el que después de mí en / la dicha abbadía subcediere, o otro por mí, o por ellos, para en contrario de lo que / susodicho es, ni contra cosa alguna o parte dello.

E otrosy, rrenuncio por mí /et en el dicho nombre, todas cartas de previlleiios et franquezas et libertades, / ansy de nuestro muy sancto padre commo de rrey o de rreyna, o de infante heredero, o / de otro señor o señora o perlado qualquier que sea, que fueren ganadas antes / desta carta o después della, et todas leyes, fueros et derechos, et ordenamientos / viejos et nuevos, canónicos e ceviles, et 
ecclesiásticos et seglares, escriptos o / non escriptos, et todas ferias de pan et de vino coger et de comprar et vender, et / todo otro tiempo feriado et non feriado, et la demanda por escripto o por palabra / et el treslado della. Et desta carta, plazo et consejo de abogado, et todas excesiones, / et defensiones, et opiniones de doctos, et otras qualesquier buenas rrazones / que podríamos dezir o alegar por mí o por ellos, o otro por nos, que nos non / vala ni seamos sobrello oydos en juyzio ni fuera del, ante ningund nin algund / juez que en el mundo sea et ecclesiástico ni seglar.

E nos, los dichos Francisco / de Bibero et doña Costança de Barreda, su muger; e yo, Juan de Bibero, hermano / de vos, el dicho Francisco de Bibero, como vuestro fiador et de la dicha doña Costança / de Barreda, vuestra muger, vezinos que somos de la noble villa de Valladolid, estando / presentes. E yo, la dicha doña Costanca de Barreda, con licencia et autoridad y /espreso consentimiento de vos, el dicho Francisco de Bibero, mi marido, que presente / estays, la qual yo vos pido et demando que me dé et otorgue para que yo, por / mí misma, juntamente con vos, pueda fazer et otorgar, et faga et otorgue todo lo que / en esta carta de ençense será contenido et a cada una cosa et parte dello.

Et yo, el dicho / Francisco de Bibero, marido de vos, la dicha doña Costança de Barreda, mi muger, estan/do presente de vuestro rruego et pedimiento, otorgo et conosco por esta presente carta, / que vos doy et otorgo la dicha licencia et autoridad et espreso consentimiento.

Et quie/ro, et consiento et me plaze que por vos misma et juntamente comigo, podades fa/zer et otorgar, et fagades, et otorguedes esta carta de ençense et todo quanto en ella será con/tenido et cada una cosa et parte dello. Et yo, la dicha doña Costança de Barreda, ansy / la rreçibo. Por ende, yo, el dicho Françisco de Bibero, et yo, la dicha doña Costança de Bar/reda, por virtud de la dicha liçencia a mí de suso dada et otorgada. E yo, el dicho Juan / de Bibero, hermano de vos, el dicho Francisco de Bibero, commo vuestro fiador et de la dicha / doña Costança de Barreda, vuestra muger; todos los tres juntamente de mancomún e a boz / de uno et de cada uno de nos, et de qualquier de nos por él todo, rrenunciando la / ley “de duobus reyes devendi" et la auténtica presente "de fides iusoribus"; otorgamos e / conosçemos por esta presente carta, que tomamos et rrecebimos de vos, el dicho señor / doctor Françisco Núñez, abbad de la dicha abbadía de Husillos et del 


\section{LA ABADÍA DE SANTA MARÍA DE HUSILLOS: ESTUDIO Y COLECCIÓN \\ DOCUMENTAL $(904-1608)$}

consejo de sus alte/zas, a ençense et por nombre de ençenso et por encenso el dicho solar de casas suso / nombradas et declaradas, que son en la dicha villa de Valladolid, en la dicha calle et sobre / el rrío de Esgueva que los dichos linderos encierran, por los dichos dos mill et quinien/tos maravedís de la dicha moneda usual que agora se usa en estos rreynos de Castilla, o de / la moneda que corriere al tiempo de cada paga para siempre jamás, commo dicho es.

Et / a las pagas de Sant Juan et Nabidad, commo dicho es et en esta carta se contiene. Et que vos (f.6r) las demos nos et cada uno de nos, et nuestros herederos, et subcesores o aquel o aquellos / que por tiempo las oviere de nos o de otro por nos et de cada uno de nos en qualquier / manera de ençenso en cada un año, por siempre jamás, a los dichos plazos et so las / dichas penas. Las quales tomamos et rreçebimos a bueltas desto con todas las otras / condiciones et posturas, et penas, et paramientos que dichas son et en esta carta se con/tiene. Para lo qual, todo sobredicho en lo que a nos atañe, ansy atañer et guardar et / complir, et para vos pagar el dicho ençenso en cada un año a los dichos plazos / et so las dichas penas, et posturas, sy en ellas cayéremos.

Y para lo asy tener et / guardar et complir, nos et cada uno de nos, obligamos a todos nuestros bienes, muebles / er rrayzes, avidos et por aver et do quiera que nos los ayamos et tengamos o doquier / que nos los toviéremos o oviéremos de aquí adelante, ansy para la paga de los dichos / dos mill et quinientos maravedís de censo, como para hazer la dicha casa a nuestra costa / et misión, sy por un caso fortuito, se perdiere o cayere, o derribarren; et para to/das las otras cosas contenidas en esta dicha carta de çenso. Para lo qual espresa/mente, ypotecamos y obligamos todos los dichos nuestros bienes, muebles et rrayzes, / avidos et por aver, especialmente nos, el dicho Francisco de Bibero et doña Costança de / Barreda, ypotecamos et obligamos el dicho solar de casa et lo que agora, nueva/mente, o de aquí adelante, hedificare, et a nosotros mismos, et a cada uno de nos, et de /nuestros herederos de qualquier de nos, por sy et por él todo, rrenunciando todas las / otras rrenunciaçiones et cada una dellas de suso contenidas, en lo que a nosotros / et a nuestros subcesores atañe, que nos non valan. 
Et damos poder, por esta carta, a las sobredi/chas justicias et officiales suso nombrados et a cada uno dellos, para que nos lo fagan, to/do et cada cosa et parte dello, ansy atener et guardar, et complir, et pagar en la manera / sobredicha.

E yo, la dicha donna Costança de Barreda, rrenuncio, en la dicha rrazón, / el previlleiio et auxilio, et leyes de "senatus consulto Veliano", que fablan en fabor et ayu/da de las mugeres, seyendo, del e de sus fuercas, certa et certificada por el escrivano / desta presente carta. Et otros qualesquier leyes, fueros et derechos que en mi fabor et / ayuda sean, en espeçial no $<\mathrm{s}>$, amas las dichas partes, rrenunciamos la ley et derecho en / que dize que general rrenunçiación que ome faga que non vala.

Et porque esto sea cier/to et firme et non venga en dubda, otorgamos nos, amas las dichas partes, dos car/tas, amas en un thenor, para cada una de nos, las dichas partes, la suya, ante el es/crivano et testigos de huso escriptos, al qual, rrogamos que la escriviese o feçiese escrevir / et la signase con su signo.

Que fue fecha et otorgada en la noble cibdad de Palençia, a veynte / et ocho días del mes de abril, año del nascimiento de nuestro Salvador Ihesu Christo de mill et / quinientos años.

Testigos que fueron presentes al otorgamiento desta dicha carta de encen/se: Alonso de Alarcón et Garçía de Valderas et Juan Alonso de Morales, clérigo, criados / del dicho abbad de Husillos et vezinos de la dicha çibdad de Palençia.

Et yo, Alonso Rodrígez, escrivano del rrey e de la rreyna nuestros señores, e su notario público / en la su corte e en todos los sus rreynos e señoríos, e escrivano público del / número de la dicha çibdad de Palençia que presente fui a todo lo que dicho es, en uno con los / dichos testigos. E de rruego e otorgamiento de los dichos don Françisco Núñez, abad de Ho/syllos, e de los dichos Françisco de Bivero e de la dicha doña Costança de Barre/da, e del dicho Juan de Bivero, su fiador, esta carta dençense escriví e fiz, / segund que ante mí pasó. E los tratados que en ella van encorporados / pasaron ante Sancho Gonçález, clérigo, vezino de Hosyllos. En myo poder / quedó el rregistro dellos. Et por ende fiz aquí este mío sygno a tal / en testimonio de (signo) verdad. Alonso Rodrígez.

(Sigue doc. núm. 254) 
1500, abril, 28. Palencia.

Constanza de Barreda, mujer de Francisco de Bivero, jura ante la señal de la cruz que respetará las cláusulas del censo entre Santa María de Husillos y los susodichos sobre un solar en Valladolid, sito en la calle de La Costanilla, en precio anual de dos mil quinientos maravedis. La carta de juramento fue otorgada por Alonso Rodríguez, escribano público de Palencia.

A. AHDP, Ampudia, Pergaminos, legajo no 63. Husillos (1447-1568), doc. 4-1. Perg., 305 x 215 mm.; escr. cortesana; buena conservación. Se trata de un cuaderno formado por cuatro pliegos de pergamino doblados al medio, lo que hace un total de ocho hojas. Entre los folios 7v y 8r se han introducido y cosido seis folios de papel. La mayor parte de las letras mayúsculas están miniadas en rojo y azul. Los ff. 7v, 8r y 8v están en blanco. Los cuatro primeros folios de papel contienen una renovación de censo del año 1685; los dos últimos folios de papel contienen una renovación de censo del año 1723.

Inserto en la carta de dicho censo, dada en Valladolid, a 28 de abril de 1500. Véase doc. núm. 253. B. APA, $L P H$, ff. $151 \mathrm{r}-156$ r.

REG. SAN MARTÍN PAYO, Apasionante historia de cinco casas, 215-229.

Sepan quantos esta carta de juramento vieren, commo yo, doña Costança / de Barreda, muger del dicho Francisco de Bibero, mi marido, estando pre/sente et por virtud de la dicha licençia a mí dada et otorgada por el dicho / Francisco de Bibero, mi marido, que presente está, para fazer et otorgar la dicha / carta de ençense et todo lo en esta carta de juramento contenido, digo, que para / mayor validaçión et firmeza de la dicha carta de encense, que yo juro a Dios / et a santa María et a esta señal de (signo: cruz) con que mi mano derecha corporalmente toco, / e a las palabras de los santos et evangelios donde quier en qualquier lugar que / más largamente son escriptas, que yo guardaré et aterné et compliré et pagaré / la dicha carta de encense et todo lo en ella contenido, ni reclamaré della, ni de parte / della, ante ningund juez ecclesiástico ni seglar, ni me aprovecharé de 
las leyes et de/rechos et previlleios ni axilio et leyes de "senatus consulto Veliano", que fabla en fabor / et ayuda de las mugeres, ni de todas las otras leyes que cerca de la dicha carta de / encense son et están rrenunciadas en ella. Et sy ansy lo fiziere et guardare et com/pliere, que Dios todopoderoso me ayude en este mundo, el cuerpo, y en el otro, el / ánima, donde más tengo de durar; el contrario açiendo, que Él me lo demande, / mal y caramente, commo aquel que se perjura el su sancto nombre en vano. Et / otrosy, juro, en la forma susodicha de no demandar yo ni otro por mí abso/luçión ni rrelaxaçión ni despensaçión deste juramento ni de parte del, nuestro / muy sancto padre, ni otro juez, ni perlado alguno que sea, ni usaré ni me apro/vecharé ni otro por mí de la tal asoluçión ni relaxaçión ni despensaçión, aunque / por su sanctidad o por otro juez o perlado me sea concedida et otorgada, ni a [o]tro / por mí. Et demás desto, doy todo poder complido a todos et quales/quier juezes et justicias de los rreynos et señoríos de Castilla, ansy ecclesiásticos /commo seglares, ante quien esta carta de juramento pareciere, a la juredición de los qua/les et de cada uno dellos me someto.

Et rrenunçio sobrello mi propio fuero et jure/diçión et domecilio et qualquier previlleio que cerca dello me competa et competer / pueda en qualquier manera, para que me lo agan todo ansy atener et guardar, et / complir segund que en la dicha carta de encense conviene por toda censura et clesiás/tica et rremedios del derecho; et fagan entrega et secuçión en mi persona et en los di/chos mis bienes bien, ansy commo sy de los dichos juezes o de qualquier dellos / lo oviese ansy tomado et rrecebido por juyzio et sentençia difinitiva, et fuese por mí / consentida et pasada en cosa juzgada.

Sobre lo qual, rrenunçio todas las leyes, / fueros et derechos et ordenamientos que por mí son o están rrenunciadas en la / dicha carta de ençense. E otrosy, renuncio la ley et derecho en que [di]z que general renun/çiación que ome faga que non vala.

Et porque esto sea çierto et firme et non venga en / dubda, otorgué esta carta de juramento en la manera que dicha es, antel escrivano / et testigos de yuso escriptos, al qual rrogué que la escriviese o feziese escrevir e / la signase con su signo. 
Que fue fecha et otorgada en la noble cibdad, a vente / et ocho días del mes de abril, año del nascimiento de nuestro Señor et Salvador Ihesu Christo / de mill y quinientos años.

Testigos que fueron presentes et vieron jurar et otorgar /esta dicha carta de juramento a la dicha doña Costança de Barreda, muger del dicho Françisco / de Bibero, en la manera que dicha es: Alonso de Alarcón, et Garçía de Valderas, et / Juan Alonso de Morales, clérigo, criados del dicho abbad de Husillos et vezinos de / la dicha çibdad de Palençia.

Et yo, Alonso Rodrígez, escrivano del rrey e de la rreyna / nuestros señores, e su notario público en la su corte e en todos los sus / rreynos e señoríos, e escrivano público del número de la dicha çibdad de Palencia, / que presente fuy a todo lo que dicho es, en uno con los dichos testigos. E de rruego / e otorgamiento de la dicha doña Costança de Barreda, esta carta de juramento escri/ví, segund que ante mí pasó. E por ende fiz aquí este mío / sygno a tal, en testimonio (signo) de verdad. Alonso Rodrígez.

1501, julio, 10. Granada.

Los Reyes Católicos mandan que se corrobore a Antonio de Acuña, capellán real, como abad de Santa María de Husillos, ante la oposición de ciertas personas.

B. AGS, Cámara de Castilla, CED., 5,176,2. 1 hoja. Papel; escr. cortesana; buena conservación. 
Pedro de Monzón y María, su esposa, vecinos de Monzón, venden a Diego Merino de Prado, canónigo de Santa María de Husillos, y a Pedro de Ávila, vecino de Husillos, un majuelo y tres tierras en término de Monzón, en precio de cuarenta y siete mil maravedis.

A. AHDP, Ampudia y Abadía de Husillos, Legajos y papeles, caja 63, carp. 3-1. Papel; 2 hojas unidas; escr. procesal; buena conservación.

1503, agosto, 28. Husillos.

Testamento de Hernando de Amo, canónigo de Santa María de Husillos, mandando a dicha iglesia sus casas en Husillos a cambio de un aniversario el día de Santiago.

A. APA, Libro 189, ff. 330-332. Papel; escr. procesal; buena conservación

1503, diciembre, 29. Monzón de Campos.

Pedro de Ávila, vecino de Husillos, traspasa a Diego Martínez de Prado, canónigo en Santa María de Husillos, su parte en la mitad de tres tierras y majuelo que había comprado junto al susodicho a Pedro de Monzón y María, su esposa, en término de Monzón, el 15 de marzo de 1502.

A. AHDP, Ampudia y Abadía de Husillos, Legajos y papeles, caja 63, carp. 3-1. Papel; 2 hojas unidas; escr. procesal; buena conservación. 
Aunque este documento aparece cosido al anterior y está catalogado con una misma signatura, corresponden a dos actos jurídicos diferentes, aunque relacionados.

1505, diciembre, 23. Valladolid.

Ejecutoria del pleito litigado por Juan Alonso Mesonero "El Viejo" y Antón García Mellado, vecinos de Becerril de Campos, con el prior y cabildo de Santa María de Husillos, sobre cierta deuda en maravedís que los primeros debian por el arrendamiento del molino de Pajares. Los dichos Juan Alonso y Antón García argumentaban que ellos y los herederos de Francisco Pico tenían arrendado dicho molino por cierto tiempo, y que los canónigos de Husillos les habian apartado de ellos por fuerza y armas, aduciendo que no habian pagado parte del arrendamiento. Los vecinos de Becerril lo justificaban diciendo que cuando habian iniciado el contrato de arrendamiento, habian hecho reparamientos en el molino, según era costumbre, por valor de veinte mil maravedis. Por sentencia de revista del presidente y oidores de la Chancillería de Valladolid, se condena "in solidum" a los susodichos vecinos de Becerril a pagar al prior y cabildo de Santa María de Husillos doscientos mil maravedís y doscientos pares de gallinas.

B. ARCHV, Registro de Ejecutorias, caja 203.9. Papel; 10 hojas; escritura procesal.

1513, octubre, 28. Husillos. 


\section{DAVID MARCOS DIEZ}

Alonso Yago, vecino de Amusco, en virtud del poder que tiene de su hijo Pedro Yago, canónigo de Santa María de Husillos, residente en Roma, vende a Suero González de Benavides, tesorero de dicha iglesia, parte de unas casas en Husillos, sitas en la plaza de dicha villa, que tiene por linderos: de una parte, casas del abad de Husillos; y de la otra, casas del dicho Suero González de Benavides, en precio de tres mil quinientos maravedís, que se deben pagar el día de Navidad próximo.

Estas casas las había heredado Pedro Yago del bachiller Alonso Yago, canónigo de la catedral de San Antolín de Palencia.

$B$. APA, $L P H$, ff. $157 \mathrm{v}-159 \mathrm{r}$.

Fecho y sacado fue este traslado en la villa de Husillos, a quatro días del mes de diciembre de mill e quinientos e çinquenta e quatro años. Testigos que lo vieron corregir y conçertar: Gaspar de Vedoya e Juan Ruiz Cabeça de Vaca, clérigos; y Pero Manuel, estantes en la dicha villa. E yo, Santiago Gómez, escribano público en la dicha villa, fui presente a lo que dicho es en vno con los dichos testigos. Y del dicho pedimiento y mandamiento lo escreví e fize aquí mi signo (signo) en testimonio de verdad.

(rúbrica) Pero Ruyz de Villoldo (rúbrica).

(rúbrica) Santiago Gómez (rúbrica).

1513, noviembre, 16. Roma.

Conservatoria del papa León X a favor de Santa María de Husillos, protegiendo sus posesiones y hacienda.

$B$. APA, $L P H$, ff. $225 \mathrm{r}-226 \mathrm{v}$.

C. AGS, Patronato eclesiástico, Inconexos, leg.159, ff. 200v-204r. Papel; escr. procesal; buena conservación. 


\section{LA ABADÍA DE SANTA MARÍA DE HUSILLOS: ESTUDIO Y COLECCIÓN \\ DOCUMENTAL $(904-1608)$}

Fecho y sacado fue este traslado a diez y ocho días del mes de enero de mill y quinientos y çinquenta y çinco años. Testigos que lo vieron leer, corregir y conçertar con el original: Gaspar de Vedoya y Juan Ruiz Cabeça de Vaca, clérigos. Y yo, Santiago Gómez, escriuano público en la dicha villa, fui presente a sacar el dicho traslado en vno con los dichos testigos. Y del dicho pedimiento y mandamiento lo fize escreuir y fize aquí mi signo (signo) en testimonio de verdad. (rúbrica) Pero Ruyz de Villoldo (rúbrica). (rúbrica) Santiago Gómez (rúbrica).

1516, marzo, 31. Palencia.

Traslado sacado por Tristán Destilla, vecino de Palencia y notario público apostólico, ante Gonzalo Zapata, deán de la catedral de Palencia, de una escritura de rectificación escrita y signada por Sancho González de Calahorra, canónigo de Husillos y notario apostólico (1498, noviembre, 9. Husillos), de un contrato de censo perpetuo enfiteusis otorgado por Alfonso de Burgos, obispo de Palencia, entre el prior y cabildo de Santa María de Husillos, con licencia del abad Francisco Núñez, y García López de Prestines, abad de Hérmedes, de la iglesia y lugar de San Sebastián, con toda su jurisdicción y heredades. La rectificación suponía que el censo pasaba de ser de 25 cargas de pan anuales a 40 cargas de pan, mitad trigo mitad cebada, de la medida mayor, a pagar el día de San Miguel de septiembre. Se esperaba que con dicha rectificación acordada se pudiesen evitar posibles pleitos.

Dicha escritura de rectificación fue presentada por Diego González de Castromocho, canónigo de Husillos, como procurador de García Fernández de Bovadilla, abad de Husillos y protonotario apostólico.

B. APA, $L P H$, ff. $159 \mathrm{r}-161 \mathrm{r}$.

Fecho y sacado fue este traslado en la villa de Husillos, a quatro días del mes de diciembre de mil y quinientos y çinquenta y quatro años. Testigos que lo vieron corregir y conçertar, Joán Ruiz Cabeça de Vaca y Gaspar de Vedoya, clérigos, e Pero Manuel, estantes en la dicha villa. Y yo, 
Santiago Gómez, escribano público en la dicha villa, fui presente a lo que dicho es en vno con los dichos testigos, e del dicho pedimiento y mandamiento lo escreví y fize aquí mi signo en testimonio de verdad.

(rúbrica) Pero Ruyz de Villoldo (rúbrica).

(rúbrica) Santiago Gómez (rúbrica).

1522, febrero, 6. Támara de Campos.

García Fernández de Támara "El Viejo”, por sí y en nombre de Pedro de Támara, su hijo; Alonso Fernández de Támara, clérigo y beneficiado de la iglesia de San Hipólito de Támara; y García de Támara "El Mozo”, por sí y en nombre de los hijos de Juan de Támara, difunto, como su tutor, todos vecinos de Támara, venden a Suero González de Benavides, tesorero de Santa María de Husillos, unas casas sitas en Husillos, que habian heredado del bachiller Diago, canónigo que habia sido de la catedral de San Antolín de Palencia.

Dichas casas tienen por linderos: de una parte, casas del abad y del tesorero. Por delante: las calles públicas de Husillos. Las venden con el censo perpetuo que tenían, en precio de tres mil quinientos maravedís.

\section{$B$. APA, $L P H$, ff. $156 \mathrm{r}-157 \mathrm{v}$.}

Fecho y sacado fue este traslado en la villa de Husyllos, a tres días del mes de diciembre de mill e quinientos y quatro años. Testigos que lo vieron corregir y conçertar: Gaspar de Vedoya y Joán Ruiz cabeça de Vaca, clérigos; e Pero Manuel, estantes en la dicha villa. E yo, Santiago Gómez, escribano público en la dicha villa, fue presente a lo que dicho es en vno con los dichos testigos. Y del dicho pedimiento y mandamiento lo escreví y fize aquí mi signo (signo) en testimonio de verdad.

(rúbrica) Pero Ruiz de Villoldo (rúbrica).

(rúbrica) Santiago Gómez (rúbrica). 
1522, mayo, 12. Palencia.

Carta de venta por la que Suero González de Benavides, tesorero de Santa María de Husillos, vende a García Fernández de Bovadilla, protonotario apostólico y abad de Santa María de Husillos, unas casas en dicho lugar de Husillos, con un censo sobre éstas a perpetuidad de doscientos maravedís anuales, en precio de seis mil ochocientos maravedis.

A. AHDP, Ampudia y Abadía de Husillos, Legajos y papeles, caja 63, carp. 3-2. Papel; 4 hojas cosidas más una cuartilla; escr. procesal.

$B$. APA, $L P H$, ff. $161 \mathrm{r}-162 \mathrm{v}$.

1522. Valladolid.

Pleito olvidado entre el concejo de Valdespina y Santa María de Husillos, sobre la posesión de cierta parte del término de Villagutierre Álvarez. El pleito en la Real Audiencia y Chancillería de Valladolid se originó por apelación del concejo de Valdespina a la sentencia dada en primera instancia por Jerónimo de Porras, bachiller de Palencia, a favor de Santa María de Husillos.

A. ARCHV, Salas de lo Civil, Zarandona y Balboa (OLV). Caja 1159.2. Papel; 35 hojas; escr. procesal; buena conservación. 
1527, diciembre, 4. Villaumbrales.

Alonso Rodríguez, vecino de Villaumbrales, vende por juro de heredad a Juan Ruiz, canónigo de Santa María de Husillos, en nombre del cabildo de dicha iglesia, dos viñas sitas en término de Villaumbrales, en Los Calzes. Una hace nueve cuartas aproximadamente, y la otra hace dos cuartas aproximadamente, perfectamente delimitadas, en precio de ocho mil maravedis, que fueron pagados en ducados de oro y reales de plata.

$B$. APA, $L P H$, ff. $162 \mathrm{v}-163 \mathrm{v}$.

Fecho y sacado fue este traslado en la villa de Husillos, a seis días del mes de diciembre de mil y quinientos y çinquenta y quatro años. Testigos que lo vieron corregir e conçertar Joán Ruiz Cabeça de Vaca y Gaspar de Vedoya, clérigos, y Pero Manuel, estantes en la dicha villa.

E yo, Santiago Gómez, escribano público en la villa, presente fui a lo que dicho es en vno con los dichos testigos e del dicho pedimiento y mandamiento lo escreví e fize aquí mi signo (signo) en testimonio de verdad.

(rúbrica) Pero Ruyz de Villoldo (rúbrica).

(rúbrica) Santiago Gómez (rúbrica).

1533, octubre, 3. Palencia - 1533, octubre, 27. Husillos.

Testimonio notarial de Antón de Ayala, escribano público de Palencia, ante Francisco Rodríguez de Madrid, corregidor de Palencia y juez de residencia, sobre la ejecución de la carta ejecutoria del pleito litigado por el prior de Santa María de Husillos, Antón Ruiz de Villoldo, y el cabildo de dicha iglesia, con el concejo de Becerril y Nicolás Gutiérrez, vecino de dicha villa, sobre que los segundos habian cegado el cauce del arroyo de los Frailes, de donde Santa María de Husillos regaba sus tierras, que tomaba agua de un cuérnago del río Carrión. Los acusados alegan que el arroyo provocaba un menor caudal de dicho cuérnago, donde se asentaban cinco molinos del concejo 


\section{LA ABADÍA DE SANTA MARÍA DE HUSILLOS: ESTUDIO Y COLECCIÓN \\ DOCUMENTAL $(904-1608)$}

de Becerril y uno del concejo de San Cebrián que se había construído hacía dos años, y que la menor fuerza del agua afectaba negativamente a dichos molinos. El concejo de Becerril también alegaba que el dicho arroyo de los Frailes era de su propiedad.

Por sentencia de revista de 17 de febrero de 1533 de los oidores de las salas de lo civil de la Real Audiencia y Chancillería de Valladolid, se condena al concejo de Becerril y a Nicolás Gutiérrez a limpiar el cauce del arroyo y a no impedir que Santa María de Husillos haga uso de dicho arroyo, otorgándose carta ejecutoria de la sentencia el 7 de marzo de 1533.

El 3 de octubre de 1533 se notifica a los condenados la sentencia, dando el corregidor confirmación y ejecución de ésta el día 27 de dicho mes.

B. APA, $L P H$, ff. $163 \mathrm{v}-170 \mathrm{v}$.

La carta ejecutoria de la sentencia se conserva en: ARCHV, Registro de ejecutorias, caja 448-34. Papel; 12 hojas.

Fecho y sacado fue este traslado en la villa de Husillos, a siete días del mes de diziembre de mi e quinientos e çinquenta y quatro años. Testigos que lo vieron corregir y conçertar, Joán Ruiz Cabeça de Vaca e Gaspar de Vedoya, clérigos, e Pedro Manuel, estantes en la dicha villa. E yo, Santiago Gómez, escrivano público en la dicha villa, presente fui a lo que idcho es en vno con los dichos testigos. E del dicho pedimiento y mandamiento lo escreví y fize aquí mi signo (signo) en testimonio de verdad.

(rúbrica) Pero Ruiz de Villoldo (rúbrica)

(rúbrica) Santiago Gómez (rúbrica).

\section{8}

1533, noviembre, 6, jueves. Husillos.

Carta de donación y cesión por la que Francisco de Carvajal, abad de Santa María de Husillos, citando como una de las razones la pobreza de la 
abadía de Santa María de Husillos, que apenas tiene bienes propios, dona todo el dinero que le deben.

A. AHDP, Ampudia y Abadía de Husillos, Legajos y papeles, caja 63, carp. 5-3. Papel; 4 hojas; escr. procesal; buena conservación.

1536, febrero, 27. Husillos.

Concordia entre Francisco de Carvajal, abad de Santa María de Husillos, y el prior y cabildo de dicha iglesia, sobre jurisdicción y otros temas económicos. Dicha concordia tiene como precedente las disputas surgidas a raiz de unos capítulos y estatutos, de la sentencia de avenencia del pleito habido anteriormente entre el abad Francisco Núñez de Herrera y el prior y cabildo. De la inclusión de los capítulos de dicha sentencia que traen disputa y de la concordia en éstos, surgen nuevas capitulaciones en diversos temas y asuntos: jurisdicción y corrección de las dignidades, canónigos, racioneros y medios racioneros, y encarcelamiento de éstos; provisión y colación de prebendas; visitación de la iglesia y beneficiados; reparación de las ermitas del cabildo; familiares de los beneficiados excusados de hacer sernas al abad; administración de la fábrica de la iglesia; derechos de pasto en la villa y término de Husillos; soto del abad; excesos y privilegios de los beneficiados; casas de los beneficiados; pesca en el río Carrión; número de familiares que el abad puede tener; horas y regimiento del coro.

Fue escrita por Antonio de Castro, canónigo de Husillos y secretario del prior y cabildo de dicha iglesia; y Antonio Amigo, vecino de Palencia, ambos notarios públicos apostólicos.

A. AHDP, Ampudia y Abadía de Husillos, Legajos y papeles, caja 144 (pleitos), $1^{\mathrm{a}}$ parte, doc 9. Dos partes. $1^{\text {a }}$ : Papel; 17 hojas; regular conservación. $2^{\text {a }}$ : Papel; 11 hojas; buena conservación. 


\section{LA ABADÍA DE SANTA MARÍA DE HUSILLOS: ESTUDIO Y COLECCIÓN \\ DOCUMENTAL $(904-1608)$}

Concordia de don Francisco Carvajal, abad de esta yglesia de Usillos y el cabildo sobre puntos de jurisdicción y otras cosas económicas.

In Dey nomine, amen. Sea notorio y manifiesto a todos los que las presentes letras e presente público instrumento de concordia e conçierto vieren, como estando dentro de la iglesia collegial de Nostra Señora Sancta María de la villa de Husillos, de la diócesis de Palençia, en el coro de abaxo, que es dentro de la capilla mayor de la dicha iglesia, a veinte e siete días del mes de hebrero, año del nasçimiento de nostro Salbador Ihesu Christo de mill e quinientos e trinta e seys años, en presencsia de nos, el bachiller Antonio de Castro, canónigo en la dicha iglesia de Husillos e secretario de los reuerendos señores prior e cabildo de la dicha iglesia; e Antonio Amigo, vezino de la çibdad de Palencia, notarios públicos por la auctoridad apostólica e los testigos ynfrascriptos, parescieron ay personalmente y entre los [...] el señor don Francisco de Carbajal, abad de la dicha iglesia, por sy, de vna parte; e de la otra, don Antonio Ruiz de Villoldo, prior de la dicha iglesia, e los rreuerendos señores, dignidades e canónigos de la dicha iglesia, siendo llamados a cabildo para lo ynfrascripto del día antes por su llamada, so pena. E oy dicho día a campana tañida según e como lo an e tienen de vso e de costumbre de se ayuntar y a las cosas e autos semejantes, e estando ende presentes los dichos señores don Francisco de Carbajal, abad susodicho, e don Antonio Ruiz de Villoldo, prior, e don Juan Rodríguez Manso, chantre, e Toribio Martínez de Valdespina, e Francisco López, e Martín Fernández, e Diego Sánchez, e Antón Guilén, e Antonio Arias, e el bachiller Antonio de Castro, e Andrés de Castro, e Agustín Ortiz, e Bartolomé Alonso, e Francisco Bustillo de Colmenares, e Diego Arias, e Juan de Verzosa, e Luys de Miranda, e García (f.1r) de Bustamante, medios rraçioneros de la dicha iglesia, e todos los dichos señores juntos de su ánimo, voluntad e concordia, "nemine discrepante", dixeron que por quanto entre las dichas partes ha habido e se esperaban aver e mover muchos pleytos e differençias e enojos e costas e gastos e otras cosas dello dependientes e anexas e conexas de y sobrerazón de la jurisdicsión del dicho señor abad e de los dichos señores prior e cabildo como sobre otras cosas que dello abían resultado e se esperaban resultar, e queriendo apartarse, arredrarse e quitarse de todos los dichos gastos, diferençias, debates, gastos, costas e enojos e vexaçiones e 
molestias, e queriendo como quieran estar e permanecer en toda paz e concordia de tal manera que Dios nuestro Señor sea sabido e la dicha iglesia [...] servyda, rregida e gobernada como cumple al serviçio de Dios nostro señor e saneamiento de sus consçiencsias, que por quanto en el [...] de don Francisco Núñez de Herrera, abad que fue de la dicha iglesia, y el prior y cabildo de la dicha iglesia, que a la saçón eran, se abía dado e pronunçiado vna sentençia arbitraria por çiertos juezes árbitros por las dichas partes, nombrados por vía de concordia e compromiso, en la qual abía e ay çiertos capítulos de los quales e de algunos dellos an resultado los dichos pleytos e differençias que agora por bien de paz e concordia, tenyendo a Dios nuestro señor delante de sus ojos, queriendo guardar e conserbar la paz que Dios nuestro Señor nos encomendó, e para dar exemplo a los que después dellos vernán, capitularon, estatuyeron, establesçieron e ordenaron que en todas las dichas partes se guarden e cumplan y executen ansí por la dicha jurisdiçión como sobre todas las otras cosas e capítulos canónicos infrascriptas, los capítulos e ordenaçiones y estatutos siguientes: $(f .1 v)$

Primeramente, quanto toca de la jurisdiçión del dicho señor abad e de los dichos prior y cabildo y en qué casos cada vna de las partes devían conosçer como se contenya e contiene en lo primero e vltimo capítulos de la dicha sentencia arbitraria que son los siguientes:

Quanto a la primera differençia que ay entre los dichos señor abad e prior e cabildo sobre la correçión e puniçión de los beneficiados de la dicha iglesia, conformándonos con el libro de bezerro de la dicha iglesia e con los vsos e costumbres della, pronunçiamos e declaramos e mandamos que el dicho abad e sus suçessores e provisores por ellos puestos e no otro alguno, puedan e deban conosçer todas e qualesquier causas çiviles, criminales, lebes e atrozes y graves e todos y qualesquier benefiçiados, dignidades, canónigos, rraçioneros e medios rraçioneros, capitulares, de la dicha yglesia de Husillos; e que los puedan punir e castigar e corregir de su offiçio o a petiçión de parte, quexándose al dicho abad o a sus provisores alguna persona de los dichos benefiçiados.

Quanto al vltimo capítulo que entre los dichos abad e prior e cabildo tienen sobre la juridiçión que el dicho prior e cabildo de la dicha iglesia juntamente tienen, conformándonos con vn privilegio que Raymundo, obispo de Palençia, obo dado e dio a los dichos prior e cabildo de la dicha iglesia do dize: "si quis autem de 
sepe dictis canonicis querimoniam habererit, querella priori et capitula exposita eorum iudicio emendationem accipiat", siguiendo las palabras de la ley del fuero que distinguen quales pleytos se pueden demandar por acusaçión e quales por querella, fallamos que debemos declarar e declaramos e mandar e mandamos que si alguna persona, clérigo o lego se quexare a los dichos prior e cabildo que algún benefiçiado de la dicha iglesia $(f .2 r)$ le es en cargo de deuda o de compra o de venta o de labor alguna que aya fecho o de otra cosa qualquier en que no deba aver justiçia de muerte nin pena de cuerpo ni destierro nin pedimiento de su aber, que los dichos prior e cabildo, sabida la verdad de fecho sobre que es la dicha quexa, simplemente sin figura de juiçio sin dar dilaçión alguna puedan façer emienda e satisfaçión al tal benefiçiado de la dicha quexa compeliéndole a ello, so pena de punto o de otra manera qual los dichos prior e cabildo vieren que sea más cumplidera e necessaria para que el querelloso rresçiba emienda e sea satisfecho. Pero sy la quexa de tal benefiçiado fuere diçiendo que a hecho alguna cosa contra la persona del rey, en perdimiento de su rreyno o de su señorío, o matado o ligado o dado yervas o ponzoñas para mal hacer o a hecho falsa moneda o otra falsedad o adulterio, forzando mujer, o furto o que es hereje o a dejado la fee cathólica o a hecho otra cosa desaguisada, qualquiera que sea porque deba de rresçebir pena de destierro o pérdida de su aber, que en tales casos como dicho es no pueda dar queja del tal benefiçiado a los dichos prior e cabildo nin puedan nin devan conoscer dello salbo el abad o sus provisores; e que ellos lo puedan corregir, punyr e castigar según que dicho es en el primero capítulo desta nuestra sentençia. Quanto a estos sobredichos dos capítulos de la dicha sentencia arbitraria se concordó conçerto e capítulo e ordenó que se guarde e cumpla e execute lo siguiente:

que todos los casos atrozes contenidos en el dicho vltimo capítulo queden e sean e pertenezcan el conosçimiento e puniçión dellos al dicho señor abad. E ansy mysmo $(f .2 v)$ declararon por casos atroçes allende de los contenydos en el dicho vltimo capítulo, los siguientes:

Quando dos clérigos o más se apuñalaren en la yglesia o en otro lugar público; ansí mismo si algún benefiçiado pusiere mano a la espada o puñal e diere con ella a otro benefiçiado aunque no saque sangre; ansí mismo quando alguno fuere público concubinario y no de otra manera; ansí mismo todos los otros casos 
semejantes e más grabes que den la puniçión e castigo dellos al dicho señor abad e a sus provisores.

Otrosí queda declarado entre las dichas partes e conçertado e capitulado e estatuydo que todos los casos leves e çeviles e todas las ynjurias de palabra, pertenezía el conosçimiento y punyçión dello a los dichos prior e cabildo, e declararon por casos lebes allende de los susodichos:

Quando algún benefiçiado diere empujón a otro benefiçiado, si de dicho empuxón non subçdyere effusión de sangre o lesión o quebrantamiento de miembro. Otrosí declararon por casos lebes quando alguna persona, clérigo o lego pidiere a algún beneficiado de la dicha iglesia alguna cosa que le sea debida, que reconosçamiento de los dichos casos pertenezía a los dichos prior e cabildo sin tela de juyçio. Otrosí declararon pertenesçer a los dichos prior e cabildo quando algún benefiçiado hechare mano de espada o puñal para otro si no le tocare; ansí mysmo si le tocare e fuere en lugar sancto, con tanto que no aya effusión de sangre; ansí mismo declararon pertenesçer a los dichos prior e cabildo quando algún beneficiado amagare a otro con pale, puñada o bofetada sy no le tocare; (f.3r); ansí mismo declararon pertenesçer a los dichos prior y cabildo el conocimiento e puniçión de todos los otros casos semejantes de los susodichos e todos los otros más lebes e más bajos que estos.

$Y$ todo lo susodicho declararon, estatuyeron e ordenaron que se guarde e cumpla y executre por las dichas partes e cada vna dellas lo que les pertenesçe en quanto toca a los dichos primero e último capítulos de la dicha sentençia arbitraria.

Otrosí estatuyeron, capitularon, conçertaron e ordenaron las dichas partes que si en algún caso de todos los susodichos o de otros tocantes a la dicha juridiçión suçediere en que aya dada o diferencia, si es lebe, grave o atroz o a qual de las dichas partes pertenesçe el conosçimiento e punición de tal caso; e si no se conçertaren que los letrados de las dichas partes determinen conforme a esta concordia a quien pertenesçe el conosçimiento e punición de tal caso; e que por lo que los dichos letrados determinaren, estén ambas las dichas partes e no lo contradigan nin passen contra ello.

Otrosí estatuyeron e declararon e ordenaron e capitularon que en todo lo susodicho quede a eleçión de actor pedir justicia ante qual de las dichas partes quisiere, pero si el tal actor perdiere la quexa que conozcan los dichos prior e 
cabildo en los casos que conforme a esta dicha concordia pueden conosçer. No obstante la prebençión porque los delictos no queden sin puniçión e castigo. ( $f .3 \mathrm{v})$ Otrosí porque en la dicha sentençia arbitraria no abía capítulo alguno que dispusiese como abían de ser encarçelados los benefiçiados de la dicha iglesia quando algún delicto hiçiesen, estatuyeron, acordaron, capitularon e ordenaron que cada e quando que algún benefiçiado hiçiese algún delicto porque meresçiese prisión, que la dignidad sea encarçelado en casa de otra dignidad, y el canónigo en casa de otro canónygo, y el raçionero en casa de otro raçionero, y el medio raçionero en casa de otro medio raçionero, que viban y estén en la dicha villa de Husillos o en otro lugar sy la dicha yglesia a él se trasladase. Pero si el delicto fure tal que aya cometido homiçidio o mutilaçión de miembro o otros delictos semejantes a éstos, que en tal caso el tal benefiçiado se ponga en la dicha iglesia de Husillos con prisiones de manera que esté a buen recado.

Otrosí en quanto toca al capítulo de la prouisión y collaçión de la dicha sentencia arbitraria de las prebendas de la dicha iglesia que es este que se sigue: quanto a la séptima differençia que ay entre los dichos abad, prior e cabildo sobre las collaçiones de las calongías, raçiones y medias raçiones de la dicha iglesia, conformándonos con el libro del bezerro, pronunçiamos, declaramos y mandamos que las collaçiones que se vbieren de hacer por el dicho abad, de las veinte calongías y dos raçiones y ocho medias raçiones en los quatro meses conçedidos por los ordinarios por las reglas de canzellería, que el dicho abad las haga vna con (f.4r) el prior e cabildo de la dicha iglesia. Y que el dicho abad aya de llebar e llebe enteramente los derechos acostumbrados de las dichas collaçiones, y que los dichos prior e cabildo se contenten con los derechos que lleban por la posesión.

En quanto a lo que toca a este dicho capítulo, estatuyeron, conçertaron, capitularon e concordaron que el dicho señor abad pueda libremente por su vida proveer todas las prebendas que vacaren en la dicha iglesia todos los quatro meses sin perjuiçio de derecho de cabildo; y el dicho señor abad promete y queda de dar la primera prebenda que vacare en la dicha iglesia a quien los dichos prior y cabildo quysieren para que la den a persona que sirba y aproveche en la dicha iglesia.

$<$ Visitaçión> Quanto al capítulo de la visitaçión que está en la dicha sentencia arbitraria que es este que se sigue: quanto a la terzera differençia que es entre los 
dichos abad, prior y cabildo sobre la visitaçión de la dicha yglesia e benefiçiados della, conformándonos con el derecho común e con el dicho libro de bezerro, pronunçiamos, declaramos y mandamos que el dicho abad y sus sucçessores ayan e tengan la visitaçión de la dicha iglesia y beneficia más si a ellos bien visto fuere, sin pedir licencia a los dichos prior y cabildo; y por rracón de la visitaçión que lleben de la procuraçión de la moneda que al presente o por sy visitaren por otro, çiento e veinte maravedís; de la qual procuraçión mandamos que paguen los dichos prior y cabildo $(f .4 v)$ las tres partes de su mesa capitular y la quarta parte la fábrica de la dicha iglesia; mandamos eso mesmo que demás de vna vez visitaren en el año que no llebe más de una procuraçión.

En quanto a este dicho capítulo, estatuyeron, conçertaron e ordenaron que el dicho señor abad los pueda visitar según dicho es con tanto que la dicha visitaçión haga "de moribus et vita" y no de [...] e suffiçiençia.

$<$ Familiares $>$ Quanto al capítulo de los familiares que está en la dicha sentençia arbitraria, que es este que se sygue: quanto a la quinta differençia que es entre los susodichos abad, prior y cabildo sobre los familiares que el dicho abad puede tener, conformándonos con la común opinión de los doctores que en este caso hallan, declaramos, pronunçiamos e mandamos que el dicho abad o sus successores puedan nonbrar e nombren, tener o tengan dos familiares de los benefiçiados de la dicha iglesia que ayan de ser e sean sus familiares e contínuos comensales. Los quales dichos sus familiares, hecha su rresidencia, ayan de gozar e gozen enteramente de todos los fructos, pan, vino e dineros e de sus prebendas, según e como gozan los otros beneficiados de la dicha iglesia, excepto de los maravedís que manualmente se distribuyen a los benefiçiados de la dicha iglesia en algunos días señalados del año, pues que de derecho los fructos de la prebenda de Husillos según agora se reparten son distribuçiones cotidianas. Sobre el qual número y nominaçión de los tales familiares, encargamos la conçiençia del dicho abad que agora es $(f .5 r)$ o de sus subçessore para que atento el número de los benefiçiados de la dicha su yglesia, el culto [...] a esta causa no sea disminuydo.

En quanto al dicho capítulo, estatuyeron, declararon, establesçieron, ordenaron e capitularon que el dicho señor abad pueda tener por sus famyliares dos benefiçiados que le quisieren de la dicha iglesia o vna dignidad en lugar dellos, con tanto que no pueda tomar el prior. Y que los dichos famyliares que ansy 


\section{LA ABADÍA DE SANTA MARÍA DE HUSILLOS: ESTUDIO Y COLECCIÓN \\ DOCUMENTAL $(904-1608)$}

tomare no sean de los [...] sino de los presentes e ynteressentes e admitidos, e que sean vetos? famyliares e contínuos comensales; e que el famyliar o familiares que ansí tomare no pueda ganar lo que pierde el rresidente no haçiendo la residencia de la mayor parte de año. Y que para el nonbramiento de los tales familiares, los dichos prior e cabildo encargaron la conçiençia al dicho señor abad que es o por tiempo fuere, que [...] que no padezca detrimento el culto dibino; e que el tal familiar e familiares pueda tener donde su persona estubiere.

Otrosí, porque tuvieron differençia el dicho señor abad con los dichos prior e cabildo sobre qué provisor abía de tener en la dicha iglesia el dicho señor abad, quando de su propria voluntad, e prometió que aunque de derecho podía poner el provisor que quisiese en la dicha iglesia e villa de Husillos; pero conformándose con la voluntad de los dichos prior y cabildo, prometió de aquí adelante de poner provisor, canónigo o dignidad de la dicha iglesia $(f .5 v)$ de Husillos en la dicha iglesia e villa sin perjuyçio de sus subçessores. E los dichos prior e cabildo açeptaron la dicha promesa e dixeron que les pertenesçe por estatuvo, vso e costumbre que no pueda ser provisor en la dicha yglesia, syno canónygo della.

Quanto toca a otros capítulos que están en la dicha sentencia arbitraria que son los siguientes:

$<$ Reparo de las hermitas $>$ Quanto a la quarta differençia que es entre los dichos abad e prior e cabildo sobre el rreparo de las dichas hermitas que son de dicho cabildo, conformándonos con el estatuto fecho por el abad don Joán González de Yliescas, declaramos e mandamos que la reseçión, reparaçión e administraçión de las possessiones e bienes de la dicha mesa capitular, que la mande façer el dicho prior con consentimiento del dicho cabildo, por manera que sea provecho e serbiçio de la dicha iglesia. E si sin su consentimiento algo çerca desto el dicho prior hiçiere sea en sy ninguno; y en esto no queremos que entienda el dicho señor abad con ellos, salbo en el caso quando hiçiere su visitaçión, que entonzes pueda apremiar a los dichos prior e cabildo a la dicha reparaçión e reseçión para que sean reparadas y [...] pie sus yglesias e possessiones a costa de la renta de la dicha su mesa o de aquel o aquellos a cuya culpa las dichas sus yglesias, cassas o possessiones se perdieren o menoscabaren. E que este dicho capítulo se entienda quanto a las hermitas que al presente están en pie. Va tistado? o diz que no le empezca. $(f .6 r)$ 
$<$ Familiares de los beneficiados $>$ Quanto a la sexta differençia que es entre los dichos abad, prior e cabildo sobre los familiares que tienen los dichos benefiçiados que diçen que an de ser escusados de haçer las sernas al dicho señor abad, pronunçiamos, declaramos e mandamos que cada vn benefiçiado de la dicha iglesia, pueda tener vn escusado que no sea de los heredados de los de la dicha villa, que en villa, bienes proprios o rraíçes tengan, e que aquel tal sea escusado de haçer serna por su persona o bienes al dicho señor abad, e no sea obligado a contribuir en pecho o repartiçión alguna con los del dicho conçejo real ni conzejil con tal que aquel sea contínuo conmensal e biba en casa de tal benefiçiado y con él y en ella, y no en otra casa apartada de la casa del tal benefiçiado; e que a sus proprias expenssas del dicho su señor sea mantenido él e su mujer e hijos en su serbiçio, estantes, no enbargante que serna alguna faga para sy o tenga bienes muebles proprios suyos o de su muger en casa de dicho su señor, puesto que de la dicha su serna o bienes proprios después que con él vbiere adquiera en la dicha villa e términos qualesquier bienes raíçes; por los quales mandamos no sea obligado a contribuir en cosa alguna con el dicho conzejo en serbiçio del señor abad, salbo en quanto al pedido real, quando se hechare, e que de todo lo otro el tal famyliar sea escussado.

$<$ La fábrica $>$ Quanto a la octaba differençia que ay entre los dichos abad, prior e cabildo sobre la fábrica de la dicha yglesya, conformándonos con el pribilegio, vso e costumbre, pronunçiamos, declaramos y mandamos que la fábrica e $(f .6 v)$ administraçión della e poner obrero para que sus bienes e rrentas administre e recaude, la tenga e ponga de aquy adelante los dichos prior e cabildo, y ellos le tomen la quenta de lo que rresçibere e cobrare, expendiere e gastare; e que sean obligados el día que el dicho cargo le dieren del tomar juramento en forma para ello, siendo llamado en su cabildo; e que lo pongan e nombren el día que nombren los otros oficios; e que le manden haçer ynventario de todos los bienes que le dyeren y encomendaren en que jure de poner e ponga en el dicho ynventario qualesquier bienes, rrentas, penas e moradas que a la dicha fábrica acresçieren durante el tiempo de su administración; e que así lo ponga e escriba en el dicho ynbentario para las rrecaudar e dar cuenta dellas al tyempo que el dicho offiçio le fuere quitado; e que el quitar del pertenezca a los dichos prior e cabildo que lo pusieron e no a otro por justa e neçessaria vtilidad e probecho de la dicha yglesia; 
e si vieren que el tal obrero es hombre negligente e no conbiene para el dicho ofiçio, que en tal caso los dichos prior e cabildo le pueda quitar e poner otro con tanto que el dicho obrero no lo pueda ser nin serbir más de los años, salbo sy fuere elegido por tal obrero segunda o más vezes por los dichos prior e cabildo, reserbando como reserbamos al dicho señor abad o a su visitador que en la dicha su visitaçión que hiçieren puedan entender en ver el dicho ynventario e cuentas (f.7r) e alcanzes passados e façer pagar lo que a la dicha fábrica fuere devido por los dichos prior y cabildo; e por el obrero o obreros que los años passados obieron sido o por qualesquier otras personas, clérigos o legos que a la dicha fábrica alguna cosa devieran; e que todo se cobre e convierta en obra tan pidadosa porque la dicha yglesia e los condes que la fundaron e dotaron e otras personas eclesiásticas e seglares que sus bienes o parte dellos por su devoçión les dejaron, porque rogasen a Dios por ellos e por remedio de sus ánymas, no padezca por defecto de sus ministros, más permanezca para siempre. Sobre lo qual, porque todo lo susodicho e non tenydo en este dicho capítulo se haga con pronta e sancta limpieza de lo que a cada vno dellos nos yncumbe a los dichos abad, prior e cabildo y al obrero que fuere, les encargamos las conçiençias.

$<$ Pasto $>$ Quanto a la nona differençia que es entre los dichos abad, prior e cabildo, sobre el término e sobre el paresçer e rrozar de la dicha villa, conformándonos con el dicho privilegio antiguo e con los vsos e costumbres passados de la dicha villa e yglesia, declaramos e mandamos que el término, prado, montes y pastizos de la dicha villa de Husillos e la guarda del, pertenezca a los dichos prior e cabildo, e que ellos con sus ganados e los vezinos de la dicha villa que en ella moran o moraren de aquí adelante, los puedan pasçer e rrozar, pues que son obligados a pagar la martyniega e a yantar e entrada al merino de Campos, guardando los panes e viñas e huertos e los prados del cabildo que son acotados e dehesados según la forma de sus cotos. E que puedan los $(f .7 v)$ dichos prior e cabildo e cada vno dellos e cada vezino de dicho conzejo a quien el dicho prior e cabildo mandare pasçar, e qualesquier hombres e ganados mayores e menores de fuera que en el dicho término hallaren roturando, paçiendo o rozando e llebarlos las penas e cotos según que en los tales casos por sus vsos e costumbres se suelen llevar e aplicarlos a aquellos a quien la ordenanza, vso e costumbre, disponen. Pero mandamos que ninguno sea osado, aunque sea bezino 
de la dicha villa, no turbará en el dicho término sin liçençia de los dichos prior y cabildo por su enzenso según que entre sy se abenieren. Empero queremos e mandamos que el señor abad, morando e residiendo en Palençia, aunque no viba en la dicha villa, por rraçón de señores e premiçiençia que tiene en la dicha villa, pues que los alcalldes e merino que él a de poner y deue nombrar por ser suya la dicha villa y tener en ella y en sus téminos juridiçión çibil e criminal, pueda meter en sus términos a su costa vacas, e traer e paçer en el término de la dicha villa vos tanto ganado proprio como el vezino que más traxere en la dicha villa, clérigo o lego, y pazer y rrozar en el término della por prinçipio del mes de henero de cada vn año; la qual tasa le ponemos porque se puedan comportar los vezinos de la dicha villa e la tengan poblada e la vengan otros a poblar, porque los dichos prior y cabildo aumenten los diezmos e primiçias de su yglesia, e el concejo sea sobrellebado mucho más en sus tributos e pechos. Empero, mandamos al dicho señor abad, prior e cabildo que en ningún caso puedan mandar meter ganado alguno mayor nin menor en el dicho término de qualquier otro, este año por recabar el ganado de los dichos sus vasallos e vezinos, salbo en su coto o prado. $(f .8 r)$

$<$ El soto $>$ Quanto a la décima differençia que es entre los dichos abad, prior e cabildo, sobre el soto que el dicho señor abad tiene en la dicha villa, pronunçiamos, declaramos e mandamos que el dicho abad pueda haçer de su soto lo que quisiere e por bien tobiere e arrendar la yerba o dexarla de arrendar si quisiere, pero aportámosle y encargámosle la conçiençia que si le oviere de arrendar, que tanto por tanto sin gozar de dolo nin fraude lo dé e arrende a los dichos prior e cabildo e al conzejo de la dicha villa.

$<$ Exçessos y privilegios> Quanto a la honzena differençia que es entre los dichos abad, prior e cabildo sobre los exçessos e sacrilegios, conformándonos con el dicho libro antiguo e con el estatuto del dicho abad don Juan González; e en las palabras dellos declaramos e mandamos que los sacrilegios que se cometieren por qualesquier benefiçiados de la dicha iglesya e los exçessos que ellos cometieren e sus capellanes, los aya el dicho señor abad o quien de obrero, causa, donaçión o merçed; pero que los sacrilegios en que cayeren qualesquier legos, vezinos de la dicha villa e en su término e lugares o yglesia de su priorazgo, los aya e sean de dicho prior de Husillos o de quien él quisiere; e que la pena de sacrilegio sea 
seteçientos e beinte maravedís de la moneda vieja; y la pena de exçesso sea del doble destos, según el dicho libro antiguo.

$<$ Cassas de los benefiçiados $>$ Quanto a la déçimasesta differençia que es entre los dichos abad prior e cabildo sobre las cassas de los dichos benefiçiados que diçen ser esentas e que nyngún merino nin sayón pueda entrar en ellas, conformándonos con el dicho privilegio de Raymundo, obispo que fue desta çibdad de Palençia, pronunçiamos, declaramos y mandamos que ningund alcalde $(f .8 v)$ nin merino nin regula de la dicha villa de Husillos, non pueda non pueda (sic) entrar nin entre a sacar nin prendar personas alguna que esté en casa de los dichos benefiçiados, ni aprendar nin sacar prenda de sus cassas, pero que el señor abad o su provisor pueda entrar y entre en casa de los dichos benefiçiados y sacar la tal persona o personas de sus cassas y prendar y sacar prendas de ellas, quando el caso le requiriere. $\mathrm{Y}$ eso mesmo declaramos e mandamos si algún benefiçiado de la dicha iglesia delinquiere y el dicho abad o su provisor le quisiere punir e corregir e castigar, le pueda sacar de la dicha su cassa, ca en tal caso pues de derecho no le valdría la ymunidad de la yglesia, mucho menos le debe valer su cassa.

Quanto a la deçimaséptima differençia que es entre los dichos abad, prior e cabildo que es sobre çierta tabla del rrío Carrión e del pescado del desde vnos hytos que están debaxo del dicho soto hasta los molinos de Cabo de Viña, que son de los dichos prior e cabildo, sobre lo qual an venido muy grandes debates e ynovaçiones en los tiempos passados por poritar la dicha quistión, declaramos que la tabla de dicho rrío e pescado del en quanto tiene el dicho soto alrededor, fue y es de dicho señor abad e de su dignidad; e la otra tabla de dicho rrío debaxo otro susodicho que es desde los hytos que están fincados fasta las canales de los molynos de Cabo de Viña e la pesca del pertenesçe a los dichos prior e cabildo. E mandamos que el dicho señor abad nin sus subçessores, mayordomos nin factores, $(f .9 r)$ por sy nin por otros alguno "duecte ni ynduecte" no quiten a los dichos prior e cabildo la quasi possessión, derecho, vso e costumbre en que están de la dicha tabla del rryo de pescar e arrendar e haçer della e en ella lo que auisieren e por bien tobieren.

En quanto a los dichos capítulos de la dicha sentençia arbitraria que son los ocho capítulos próximos passados, estatuyeron, ordenaron, concordaron e establesçieron que se guarden e cumplan como en ellos o en cada vno dellos se 


\section{DAVID MARCOS DIEZ}

contiene.

$<$ El quitar de las horas> Quanto al quitar de las horas e regimyento del coro, estatuyeron, concordaron e capitularon, que estando el dicho señor abad en el dicho coro personalmente e biendo que no se haçe lo que se debe haçer o ay algún defecto en el derecho de las horas o desonestidad de algún benefiçiado, que el dicho señor abad pueda mandar al presidente del dicho cabildo que haga suplyr los dichos defectos; e que no lo haçiendo el dicho presydente, que el dicho señor abad, como perlado, pueda mandar que se suplan los tales defectos.

$<\mathrm{VIII}^{\circ}>$ Los quales dichos capytulos, estatutos, ordenanzas e capitulaçiones e concordia que de suso van ynsertos y cada vno de los dichos señores don Françisco de Carbajal, abad susodicho, por sy e en nombre de los abades que después del subçedieran y los dichos prior e cabildo, dignidades, canónigos, raçioneros e medios raçioneros que de suso van nombrados e declarados por sy e en nombre de todos los ausentes, e por los que después de ellos vernán e subçedieren en sus lugares, dignidades, calongías, raçiones e medias raçiones, e cada vno del por sy e por lo que les tocaba e [...] e atañe, vistos e leydos públicamente ante las dichas partes los dichos capítulos $(f .9 v)$ que de suso van ynsertos e cada vno dellos por sy; e en presençia de nos, los dichos notarios e los testigos ynfrascriptos, según e como en ellos se contiene, dixeron que para agora e para siempre jamás de sus proprias, libres e espontáneas voluntades e ánimos deliberados no ynduzidos, atraydos ni persuadidos para ello por fuerza nin por otro ynduçimiento alguno, estatuyeron e establesçieron, ordenaron e capitularon para quedare las dichas partes e cada vna dellas para agora e para siempre jamás, se guarde e cumpla y execute todos los dichos capítulos que de suso van ynsertos e cada vno dellos según e de la forma que en ellos e en cada vno dellos se contiene, espressa, declara e [...] con las limitaçiones, declaraçiones e voluntades e concordia que en cada vno dellos se contiene e en ellos está expressado, concordado e capitulado; e que querían e quisieron e que era y es su voluntad determinada que cada e quando que alguna differençia sobre los dichos capítulos e alguno dellos o tocante a qualquier cosa o parte dellos, subçediere o acaesçiere ser juzgados e sentençiados por los dichos capítulos e concordia, e por lo en ellos e en cada vno dellos contenido. <Obligaçión> E que para más e mayor observaçión, guarda e cumplymiento de los dichos capítulos e de cada vno dellos, 


\section{LA ABADÍA DE SANTA MARÍA DE HUSILLOS: ESTUDIO Y COLECCIÓN \\ DOCUMENTAL $(904-1608)$}

las dichas partes e cada vno dellos, por sy e por lo que les tocava e toca, dixeron que en las mejores forma e manera que podían e debían e podieron e devieron, prometieron, quedaron e se obligaron por sus personas e bienes muebles e rayçes, espyrituales, temporales, presentes e futuros de tener, guardar, cumplir e mantener todo lo susodicho e non tenido en los dichos capítulos e en cada vno de los según e de la forma e manera que en ellos e en cada vno dellos se contiene, para agora e para siempre jamás; e por ellos e por los dichos sus subçessores, según dicho es, e que contra ellos nin contra alguno dellos nin parte alguna de qualquier de ellos yrían nin $(f .10 r)$ vernían nin yrán nin vernán nin pasarán por sy nin por ynterpósitas personas agora ni en tiempo alguno nin por alguna manera, so pena de caer e yncurrir e que qualquier de la dichas partes que contra los dichos capítulos e cada vno dellos e lo en ellos e en cada vno dellos contenido fuere e viniere e pasare e ynterntare de yr, venir e pasar público e secreto de qualquier manera que sea, caya e yncurra en pena de mill ducados de oro largos, aplicados en esta manera: la mitad de ellos, para la fábrica de la dicha iglesia de Santa María de la dicha villa de Husillos; e la otra mitad, para la parte obediente; e que guardare, obseruare, cumpliere e tubiere los dichos capítulos e cada vno dellos, e lo en ellos e en cada vno dellos contenido, capitulado, establesçido e hordenado; e que querían e quisieron que la dicha pena sea en llave e en sus personas e bienes dellos e de cada vno dellos executada como sy en ella fueran o fuesen condepnados por juez competente por su sentençia definitiba. E la tal sentençia fuese pasada en cosa juzgada e por ellos e cada vno dellos consentida, aprobada e no apelada. E para tener, guardar, complir e obseruar e pagar e para que ansy se lo hagan tener, guardar, complir e obseruar e pagar las dichas partes e cada vno dellos por sy e por lo que les tocava e toca, dixeron que davan e dieron todo su poder complido, libre e lleno e bastante a todos e qualesquier juezes executores y subexecutores, comisaris y subcomisarios, delegados e subdelegados, hordinarios $\mathrm{y}$ estrahordinarios, de todas e qualesquier curias e avdiençias de todas e qualesquier çibdades, villas, partes e lugares, ante quien esta presente escriptura de capitulaçión e concordia pareçiere e fuere della e de lo en ella contenido, e de la dicha pena que sobre sy pusieron pedido execuçión e complimiento de justiçia, a la jurediçión de los quales e de cada vno dellos se sometieron con las dichas sus personas e bienes, renunçiando como espresamente renunçiaron en este caso su 
jurediçión e $[\ldots](f .10 v)[\ldots](f .11 r)$ quier leys, fueron e derechos, estatutos e hordenamientos canónycos e çibiles, eclesiásticos, apostólicos e reales e todas cartas e merçedes, privillejos, franquezas e libertades, apostóliccas e reales, e la demanda en escripto e el traslado della e desta carta e de su registro e plaço, e consejo de abogado e plaço mudado e días feriados e todas ferias de pan e vino coger e de comprar e de vender e todo otro tiempo feriado e todas otras qualesquier exçepçiones e defensiones e buenas razones que por ellos podrían dezir e alegar para se ayudar e aprovechar para yr o venir contra lo que dicho es e qualquier cosa e parte dello; e la ley e derecho que diz que general renunçiaçión de leys que hombre faga que non vala, sy no proçede en espeçial e por mayor firmeza, observançia, guarda e completamiento de todo lo susodicho e cada vna cosa e parte dello, los dichos señores don Françisco de Carvajal, abbad por sy e por los dichos susçesores e los dichos prior e cabildo, por sy e por los dichos suzesores, e cada vno dellos por sy e por lo que les toca e atañe e tocar puede en qualquier manera çerca de lo susodicho e sobre lo susodicho, juraron a Dios e a Santa María e a las palabras de los santos evangelios e por las sagradas hórdenes que avían resçibido e por vna señal de cruz, a tal como ésta (signo: cruz), que corporalmente tocaron con sus manos derechos, que como buenos fieles e cathólicos christianos, temiendo a Dios e guardando sus ánimas e conçiençias, ternán, guardarán e cumplirán e manternán todo $(f .11 v)$ contenido en los dichos suso ynsertos capítulos e en cada vno dellos e lo en ellos e en cada vno dellos contenido libre realmente e con hefecto syn ynconviniente alguno e que contra ello nin parte dello no yrán, vernán nin pasarán ellos nin alguno dellos, agora ni en tiempo alguno nin por alguna manera, so pena de reparos e ynfames e fee mentidos e de ser avidos e tenidos e comúnmente reputados por personas de menosvaler; e que sy ansy lo hizieren, guardaren, complieren e mantubieren que Dios que es todopoderoso, les ayude en este mundo a los cuerpos e en el otro a las ánimas donde más han de trazar. E que si lo contrario fezieren, que él [...] demande mal e caramente como a malos christianos que se perjuran, jurando el santo nombre de Dios, [...] a la confusyón. del qual dicho juramento dixeron e respondieron e cada vno por sy respondió e dixo: sy juro e amén; e prometieron e se obligaron segund dicho es que no yrán nin vernán agora ni en tiempo alguno ellos ni otro por ellos contra lo susodicho nin contra este dicho juramento, nin 
pedir absoluçión nin relaxaçión del [...] muy santo padre [...] penitençiario nin arçobispo ni obispo nin nunçio nin otro perlado ni juez que para se le relaxar poder e facultad tenga. E pues toca que la tal absoluçión e relaxaçión les sea con pedimiento e propio motu e en otra qualquier manera, vna, dos o tres e más vezes, dixeron que heran y es su voluntad de no vsar ni des(f.12r)aprovechar de la tal absoluçión nin relaxaçión, so la dicha pena de perjuros e de la dicha pena de mill ducados de oro arriba contenidos, por quanto su fin y hefecto prençipal hera y es de tener, guardar, complir e mantener todo lo susodicho e cada vna cosa e parte dello, en todo e por todo syn diferençia alguna como dicho es. E para que todo lo susodicho e cada vna cosa e parte dello sea por ellos e cada vno dellos mexor e más eficazmente complido, guardado y hefectuado, dixeron que desde agora por entonçes e de entonzes por agora pedían e suplicaban e pidieron e suplicaron a nostro muy santo padre e a otra persona que para ello su poder e facultad tenga, que tenga por bien de conformar e aprobar esta presente escriptura de concordia e capítulos della e todo lo en ella contenido; e sobre ello mande dar e de sus letras apostólicas de confirmaçión e aprovaçión e supleçión de qualesquier defeitos que ansy de hecho como de derecho en ella ayan yntervenido e sobre ello hazer e haga todo lo demás que para su validaçión perpetua sea necesario; en testimonio de lo qual otorgaron en presente pública escriptura de estatutos, concordia e hordenaçiones segund e en la manera que dicha es ante nos, los dichos notarios e los testigos ynfraescriptos, día e mes e año susodichos. E por más coroboraçión e seguridad e guarda e cumplimiento de todo ello, lo firmaron de sus nombres en me[...] registros $[\ldots](f .12 v)[\ldots]$ presentes por testigos: el licenciado Pedro González de Tamayo e Fernando López e Albaro de Torres e Antón de Ayala, vecinos de la dicha çibdad de Palençia; e Pedro Álbarez de Muraba, e Pedro de Aguilar, e [...] de Báscones, vecinos de la dicha villa de Husillos. Para ello llamados e rrogados.

Francisco de Carvajal, abad (rúbrica). 
1537, abril, 9. Husillos

Testamento de María Velázquez, viuda de Juan de Ávila, dejando a Santa María de Husillos un majuelo a cambio de enterrarse en dicha iglesia y de la celebración anual de unas misas en su memoria.

A. APA, Libro 189, ff. 323-326. Papel; escr. procesal; buena conservación.

1537, octubre, 4. Husillos.

Codicilo de Diego Sánchez por el que entre otras mandas, deja a Juan de la Peña un majuelo, que después de su muerte debía pasar al cabildo de Santa María de Husillos a cambio de unas misas por el dicho susodicho Diego Sánchez.

A. APA, Libro 189, ff. 239. Papel; escr. procesal; buena conservación.

1537, noviembre, 3. Husillos.

Testamento de Juan de la Peña, vecino de Husillos, por el que pide ser enterrado en la iglesia de Santa María de Husillos, pagando lo acostumbrado.

A. APA, Libro 189, ff. 237-238. Papel; escr. procesal; buena conservación. 
1540, marzo, 3. Husillos.

Cláusula del testamento de Martín Fernández de Grijota, canónigo de Santa María de Husillos, en que deja al cabildo de dicha iglesia unas casas en Husillos a cambio de memorias perpetuas por su alma.

A. APA, Libro 189, f. 362. Papel; escr. procesal; buena conservación.

1540, mayo, 12. Roma.

Bula de Paulo III dirigida al abad de Santa María de Valladolid, instándole a reconocer la renovación de un censo que Francisco de Carvajal, abad de Santa María de Husillos, tenía sobre unas casas en la calle de La Costanilla de Valladolid, pasando de tener un precio anual de mil trescientos maravedis a tres mil maravedis y ocho gallinas anuales.

B. APA, $L P H$, ff. 226v-235r. Inserto en testimonio notarial del censo. Véase doc. núm. 278.

Fecho y sacado fue este traslado a veynte y vn días del mes de henero de mill e quinientos y çinquenta y çinco años. Testigos que fueron presentes a lo ver, leer, corregir y conçertar con el original, Luis López, clérigo, y Alonso de Torres, criados de su señoría. Y yo, Santiago Gómez, escribano público en la dicha villa de Husillos, fui presente a lo ver, corregir y conçertar con el original, y del dicho pedimiento y mandamiento lo escreví y fize escrevir y fize aquí mi signo (signo) en testimonio de verdad.

(rúbrica) Pero Ruyz de Villoldo (rúbrica).

(rúbrica) Santiago Gómez (rúbrica). 


\section{DAVID MARCOS DIEZ}

\section{5}

1540, julio, 23. Valladolid.

Ejecutoria del pleito litigado por Francisco de Carvajal, abad de Santa María de Husillos, con el concejo de Villaldavín, sobre el derecho de pasto de ganado del abad de Husillos en término de dicho concejo. Por sentencia del adelantado mayor de Campos, que había recibido la acusación del concejo diciendo que Francisco de Rodas con criados del abad de Husillos había introducido hasta cuatrocientas cabezas de ganado ovino en el término de Villaldavín, paciendo éstos los pastos y también los viñedos, y que habiendo requerido Francisco Miguélez, alcalde de Villaldavín, a los susodichos, éstos, que iban armados y a caballo, atacaron e injuriaron al dicho alcalde. La sentencia del adelantado establece que el abad de Husillos debía abstenerse de hacer pastar sus ganados en el término de Villaldavín.

El abad de Husillos apeló la sentencia del adelantado mayor de Campos a la Real Audiencia y Chancillería de Valladolid, que da carta de emplazamiento al concejo de Villaldavín, que no sigue el pleito

Los oidores de las salas de lo civil, por sentencia de vista dada el 1 de julio de 1540, revocan la sentencia del alcalde mayor, estableciendo que Francisco de Carvajal, abad de Husillos, pueda hacer pacer sus ganados, mayores y menores, de día y de noche, en los términos de Villaldavín, excepto en las tierras de cereal y viñas.

El concejo de Villaldavín apela la sentencia, alegando que el abad de Husillos no tenía ningún derecho sobre la villa y que no era señor de dicha villa, que era de patrimonio real con su jurisdicción civil y criminal y los términos y pastos eran concejiles; que el dicho abad no nombraba regidores y oficiales en el concejo y que si el abad o alguno de sus antecesores lo habian hecho, había sido desde hacía poco tiempo y por la fuerza. 
Por sentencia de revista dada el 13 de julio de 1540, el presidente y oidores confirman la sentencia de vista. En 23 de julio de 1540 se otorga carta ejecutoria de la sentencia a petición del abad.

B. ARCHV, Registro de ejecutorias, caja 534.40. Papel; 9 hojas; escr. procesal.

C. APA, $L P H$, ff. $176 \mathrm{r}-180 \mathrm{v}$.

1540, agosto, 3. Valladolid.

Ejecutoria del pleito litigado por Francisco de Carvajal, abad de Santa María de Husillos, y Gonzalo de Oviedo, su procurador en su nombre, con el concejo de Husillos y Gregorio Treceño, su procurador en su nombre, sobre que teniendo dicho abad nueve cargas de pan mediado de censo perpetuo y tributo sobre el dicho concejo y doscientos cincuenta maravedís de martiniega anuales pagaderos el día de Nuestra Señora de agosto, el año anterior de 1536 el concejo se había substraído de pagar. El abad presenta la causa en la Real Audiencia y Chancillería de Valladolid aduciendo que es causa de iglesia y perlado y por ser contra concejo. El pleito entra en la Chancillería por caso notorio de corte.

El concejo de Husillos alega que el abad no tenía derecho de censo ni martiniega sobre Husillos, que no había presentado ninguna escritura justificando los derechos que reclama, y que no se habia hecho el tributo de forma inmemorial como la abadía alega, sino de pocos años atrás y sin tener el concejo obligación. Por sentencia de vista dada el 15 de julio de 1539 por los oidores se sentencia a favor del abad Francisco de Carvajal: se reconoce el derecho del tributo al abad, debiendo de cobrar éste lo que le han dejado de pagar en un plazo de nueve días desde que se presente la carta ejecutoria.

El concejo recurre la sentencia aduciendo entre otras razones que el abad no ha presentado ninguna escritura justificando su señorio y derechos sobre la villa. 
Estando el pleito concluso para sentencia de revista, el abad confiesa que ha recibido las nueve cargas de pan en concepto de servicio por el concejo, información que le habían comunicado ciertos canónigos.

Por sentencia de revista dada por el presidente y oidores en Valladolid el 13 de julio de 1540, se confirma la sentencia de vista. Se otorga al abad carta ejecutoria de la sentencia el 3 de agosto de 1540.

B. ARCHV, Registro de ejecutorias, caja 536.13. Papel; 4 hojas; escr. procesal; buena conservación.

$C$. APA, $L P H$, ff. $183 \mathrm{v}-187 \mathrm{r}$.

1540, agosto, 23. Husillos.

Carta de poder otorgada por Francisco de Carvajal, abad de Santa María de Husillos, a Antonio de Valladolid, Antonio Caro y Antonio Pérez, vecinos de Valladolid, procuradores de causas, para actuar en su representación ante el abad de Santa María de Valladolid o su provisor en su nombre, presentándole una bula pontificia por la que se autoriza la renovación del censo de unas casas sitas en la calle de La Costanilla de Valladolid a Lorenzo Velázquez, vecino de Valladolid, en precio de tres mil maravedís anuales.

B. APA, $L P H$, ff. 226v-235r. Inserto en testimonio notarial del censo. Véase doc. núm. 278.

Fecho y sacado fue este traslado a veynte y vn días del mes de henero de mill e quinientos y çinquenta y çinco años. Testigos que fueron presentes a lo ver, leer, corregir y conçertar con el original, Luis López, clérigo, y Alonso de Torres, criados de su señoría. Y yo, Santiago Gómez, escribano público en la dicha villa de Husillos, fui presente a lo ver, corregir y conçertar con el original, y del dicho pedimiento y mandamiento lo escreví y fize escrevir y fize aquí mi signo (signo) en testimonio de verdad.

(rúbrica) Pero Ruyz de Villoldo (rúbrica).

(rúbrica) Santiago Gómez (rúbrica). 
1540, agosto, 27. Valladolid - 1540, septiembre, 13. Valladolid.

Testimonio notarial de Cristóbal de Villanueva, notario apostólico de Valladolid, de renovación de un censo entre la dignidad abacial de Santa María de Husillos y Lorenzo Velázquez, vecino de Valladolid, para sí y para sus herederos, sobre unas casas sitas en la calle de La Costanilla.

Dichas casas habian sido encensadas por Luis de Carvajal, abad de Husillos, a Fernando Rodríguez Çejuel, en precio anual de 1300 maravedís, en carta de censo otorgada en Husillos a 12 de febrero de 1475. Habían pasado a los descendientes de éste, que finalmente las cedieron a Lorenzo Velázquez. El abad otorga nuevo contrato de censo con éste último el 13 de septiembre de 1540, en precio de tres mil maravedís y ocho gallinas anuales, que debía comenzar su efecto el día 25 de diciembre de 1540. Dicha renovación de censo fue autorizada previamente por Pedro Ortiz de Escota, racionero en Santa María de Valladolid, a Antonio Caro, vecino de Valladolid, en nombre y como procurador de Francisco de Carvajal, abad de Husillos, que presentó un poder de procuración del abad (1540, agosto, 23. Husillos), inserto, y una bula de Paulo III (1540, mayo, 12. Roma), inserta, autorizando la renovación del censo.

B. APA, $L P H$, ff. 226v-235r.

Fecho y sacado fue este traslado a veynte y vn días del mes de henero de mill e quinientos y çinquenta y çinco años. Testigos que fueron presentes a lo ver, leer, corregir y conçertar con el original, Luis López, clérigo, y Alonso de Torres, criados de su señoría. Y yo, Santiago Gómez, escribano público en la dicha villa de Husillos, fui presente a lo ver, corregir y conçertar con el original, y del dicho pedimiento y mandamiento lo escreví y fize escrevir y fize aquí mi signo (signo) en testimonio de verdad.

(rúbrica) Pero Ruyz de Villoldo (rúbrica).

(rúbrica) Santiago Gómez (rúbrica). 


\section{DAVID MARCOS DIEZ}

1540, septiembre, 13. Valladolid.

Francisco de Carvajal, abad de Santa María de Husillos, concierta la renovación de un censo con Antonia de Solórzano y Juan Núñez, su marido, vecinos de Valladolid, sobre unas casas propiedad de la mesa abacial de Husillos sitas en Valladolid en la calle de La Puerta del Campo. Dicho censo era "ad vitam” por la vida de la dicha Antonia de Solórzano y por cinco vidas más, y lo obtuvo por sucesión de Ana de Escalantera, mujer que fue de Alonso de Salamanca, ambos difuntos, y tía de la susodicha, en precio anual de trescientos cincuenta maravedis.

El abad de Husillos, considerando que las casas estaban arrendadas por tantas vidas y por tan bajo precio, acuerda con los censatarios la renovación del censo, presentando letra apostólica autorizando dicha renovación, transformándole a perpetuidad para ellos y sus herederos, en precio anual de cinco mil maravedis y tres pares de gallinas: dos mil quinientos maravedís y las gallinas a pagar en Navidad; y los restantes dos mil quinientos maravedís a pagar el día de San Juan de junio.

Entre otras condiciones, se establece que los sucesores debian renovar el censo dentro de los treinta días siguientes a que expirara el anterior contrato.

\section{B. APA, $L P H$, ff. $235 \mathrm{r}-238 \mathrm{v}$.}

Fecho y sacado fue este traslado a veynte y ocho días del mes de henero de mill e quinientos y çinco años (sic). Testigos que lo vieron corregir y conçertar, Luis López, clérigo, y Alonso de Torres. E yo, Santiago Gómez, escribano público en la dicha villa de Husillos, fui presente a sacar el dicho taslado en vno con los dichos testigos. Y del dicho pedimiento y mandamiento lo escreví y fize aquí mi signo (signo) en testimonio de verdad.

(rúbrica) Pero Ruyz de Villoldo (rúbrica).

(rúbrica) Santiago Gómez (rúbrica). 
1540, diciembre, 16. Husillos

Testamento de María Sánchez de Aguilar, mujer de Diego de Fresno, dejando a Santa María de Husillos unos majuelos en Husillos, a cambio de enterrarse en la iglesia de Husillos y de la celebración anual de unas misas en su memoria.

A. APA, Libro 189, ff. 319-322. Papel; escr. procesal; buena conservación.

1540, diciembre, 22. Valladolid.

Ejecutoria del pleito litigado por Santa María de Husillos con el concejo de Husillos sobre el derecho jurisdiccional en dicha villa, fallado a favor de la primera. Dicho pleito se habia iniciado en Husillos y habia llegado a la Real Audiencia y Chancillería de Valladolid en apelación. El motivo era que el 1 de enero de 1517, Juan de Paredes de Martilla, vecino de Palencia, por poder de García Fernández de Bovadilla, abad de Husillos, nombraba alcalde ordinario en la villa de Husillos, merino y regidores. Pedro López de Lomas, en nombre del concejo de Husillos, alega que la jurisdicción civil y criminal en Husillos pertenece al rey, que los alcaldes ordinarios son nombrados por el concejo en nombre del rey, y que las sentencias dadas por éstos siempre se habian apelado a la Real Chancillería de Valladolid o al alcalde mayor del Adelantamiento de Castilla, y que nunca se habian apelado ante el abad. Por ello suplica al rey la revocación de la intención del abad. 


\section{DAVID MARCOS DIEZ}

Presenta el concejo también reclamación sobre ciertos desagravios cometidos por el abad: la imposición de tasa a los vecinos que entran con más de doscientas cabezas de ganado en el término de Husillos, alegando que dicho término es de propiedad concejil y que siempre ha sido libre la circulación de ganado; la prohibición de cazar en dicho término, y la imposición por el abad de ofrecer hospedaje, siendo como son los vecinos libres de tal obligación.

Francisco de Valladolid, procurador del abad de Husillos, responde en la Chancillería de Valladolid que el señorí jurisdiccional de la villa de Husillos pertenece al abad, y que los vecinos tratan de eximirse de dicha jurisdicción. En cuanto a la tasa de ganado, dice que existe una ordenanza concordada entre el abad y el concejo de Husillos, estableciendo dicha tasa debido al efecto negativo en el término de Husillos que causaba el hecho de que hubiera vecinos, que enumera en uno o dos, con gran cantidad de cabezas de ganado, protegiéndose de esta manera el interés de la mayor parte de los vecinos de Husillos.

Por sentencia de vista dada por los oidores de las salas de lo civil el 1 de octubre de 1540, se sentencia a favor del abad. El concejo de Husillos recurrió la sentencia, y por sentencia de revista de los oidores, que no aceptan la apelación, de 10 de diciembre de 1540, se confirma la sentencia.

El abad Francisco de Carvajal suplica carta ejecutoria de las sentencias, otorgándose el 22 de diciembre de1540.

B. ARCHV, Registro de ejecutorias, caja 540.40. Papel; 8 hojas; escr. procesal; buena conservación.

C. APA, $L P H$, ff. $170 \mathrm{v}-175 \mathrm{v}$.

D. ARCHV, Salas de lo Civil. Pérez Alonso (OLV). Caja 136-1. Traslado sacado del Libro de los Privilegios de Husillos, aportado como prueba en un pleito olvidado (1735-1736) del concejo de Husillos con Marcelo Antonio de Tovar, canónigo, cura mayor y procurador de la colegiata de Ampudia, y gobernador de la iglesia de Santa Maria de Husillos, sobre la nulidad de las elecciones de los oficios de justicia en la villa de Husillos. 
1541, junio, 25. Husillos.

Permuta de una huerta de Santa María de Husillos, sita en Monzón de Campos, denominada Los Cañamares, por otra de Juan de Rojas, marqués de Poza, sita en dicho lugar, denominada Hernán Sancho.

A. AHDP, Ampudia y Abadía de Husillos, Legajos y papeles, caja 63, carp. 5-4. Papel; 12 hojas; escr. procesal; buena conservación.

1541, julio, 8. Valladolid.

Ejecutoria del pleito litigado por Francisco de Carvajal, abad de Santa María de Husillos, y Pedro de Ampudia, su procurador, con el concejo de Husillos y Gregorio de Treceño, su procurador, sobre el derecho de tránsito y paso del ganado del abad por el término de Husillos.

El concejo y vecinos de Husillos habian prendido al abad cuarenta y cuatro cabezas de ganado. El abad solicita a la Real Audiencia y Chancillería de Valladolid que le amparase en su derecho de hacer pacer a su ganado mayor y menor de día y noche en el término de Husillos y que se le restituyese el ganado prendido. El concejo alega que el abad no es señor de la villa ni tenía jurisdicción sobre ella, ni había vivido ni morado en Husillos, y que aunque era abad de la iglesia colegial de Santa María de Husillos, la silla y residencia de dicha dignidad la tenía en la catedral de Palencia, y que en dicha ciudad vivía y era vecino, alegando también que tampoco sus predecesores tuvieron aprovechamiento del término de Husillos, y que si alguna vez lo habían tenido, había sido porque habían empleado la fuerza.

Por sentencia de vista de los oidores de la Real Audiencia y Chancillería de Valladolid dada el 10 de mayo de 1541, se establece que el abad y sus sucesores 


\section{DAVID MARCOS DIEZ}

puedan hacer transitar por el término de la villa de Husillos tanto ganado como dos vecinos de dicha villa, de los que más ganado tuvieren.

El concejo de Husillos recurre la sentencia, alegando que tenían otro pleito con el abad sobre su derecho jurisdiccional en la villa, y que aun siendo señor, no era vecino de Husillos, no teniendo por tanto derecho a introducir ganado, y que en cualquier caso tal privilegio acarrearía la pobreza en los vecinos de la villa al destrozar su término.

Por sentencia de revista dada por el presidente y oidores el veintiocho de junio de 1541, se confirma la sentencia de vista anteriormente dada. Se otorga carta ejecutoria de la sentencia el ocho de julio de 1541.

B. ARCHV, Registro de ejecutorias, caja 547-8. Papel; 4 hojas; escr. procesal; buena conservación.

$C$. APA, $L P H$, ff. $180 \mathrm{v}-183 \mathrm{r}$

284

1544, octubre, 16

Testamento de María de Meneses, mujer de Diego Sarmiento, señor de Villadeciervos, dejando por heredera de sus bienes a la fábrica de la iglesia de Santa María de Husillos, a condición de que se trasladase el cabildo a otro lugar.

A. APA, Libro 189, ff. 289-300. Papel; escr. procesal; buena conservación.

1544, diciembre, 4. Palencia. 


\section{LA ABADÍA DE SANTA MARÍA DE HUSILLOS: ESTUDIO Y COLECCIÓN \\ DOCUMENTAL $(904-1608)$}

Sentencia escrita por Francisco Fernández, notario, y pronunciada por Francisco de Tariego, provisor del obispado de Palencia por Luis Cabeza de Vaca, obispo de Palencia, en el pleito juzgado en la audiencia episcopal de Palencia entre, de una parte, Francisco de Carvajal, abad de Santa María de Husillos, y de la otra, los clérigos de Fuentes de Valdepero y Pedro de Elices, fiscal del obispado, sobre el derecho de visita de la iglesia de San Pedro, sita en extramuros de dicha villa. La sentencia establece que la visita pertenece al obispo y al abad de Husillos alternativamente, no pudiéndose visitar dos veces en el mismo año.

B. APA, $L P H$, f. $187 \mathrm{r}-\mathrm{v}$.

Fecho y sacado fue este traslado a onze días del mes de diziembre de mill e quinientos y çinquenta y quatro años. Testigos que lo vieron corregir y conçertar, Joán Ruiz Cabeça de Vaca e Gaspar de Vedoya, clérigos, e Pero Manuel, estantes en la dicha villa. Y yo, Santiago Gómez, escribano público en la dicha villa, fui presente a lo que dicho es en vno con los dichos testigos, e del dicho pedimiento y mandamiento lo escreví e fize aquí mi signo (signo) en testimonio de verdad.

(rúbrica) Pero Ruyz de Villoldo (rúbrica)

(rúbrica) Santiago Gómez (rúbrica).

1546, diciembre, 17. Valladolid - 1547, marzo, 16. Valladolid.

Recurso de fuerza admitido por la Real Audiencia y Chancillería de Valladolid de un pleito litigado por Francisco de Carvajal, abad de Santa María de Husillos, y Juan Pedro de Salazar, su procurador en su nombre, con el prior y cabildo de dicha iglesia, sobre la jurisdicción ordinaria de los segundos. Juzgado en segunda instancia por Juan Fernández de Avanza, canónigo de la catedral de Burgos y juez apostólico, su sentencia revocó la anterior favorable al abad, condenándole a mil ducados de pena y a guardar cierta concordia con el prior y cabildo, no otorgando apelación al abad, que entonces recurre a la Chancillería 
de Valladolid, admitiendo dicho tribunal fuerza por parte del juez apostólico y mandando que otorgue la apelación, absolviendo al dicho abad y su provisor.

A. ARCHV, Salas de lo Civil, Zarandona y Balboa (OLV). Caja 530-8. Papel; 13 hojas; escr. procesal; buena conservación.

Circa principios 1547 - 1547, octubre, 7. Valladolid.

Recurso de fuerza rechazado por la Real Audiencia y Chancillería de Valladolid, de un pleito entre Antonio Guillén, canónigo y provisor del cabildo de Santa María de Husillos, con el fiscal del obispo de Palencia, a quien se habia apelado una sentencia dada por Francisco de Carvajal, abad de Santa María de Husillos, por una media ración en dicha iglesia en la que había intervenido simonía y se había concedido a Pedro Juárez, en contra del prior y cabildo de dicha iglesia, a los que el abad había conminado a aceptar la elección, so pena de excomunión en cierto término. Estos apelaron la elección al provisor de la catedral de Palencia a través de su provisor, el cual dio carta inhibitoria contra el provisor del cabildo de Husillos. Éste apeló dicha inhibición, dando lugar a su excomunión por el provisor catedralicio. El provisor de Husillos interpuso recurso de fuerza en la Chancillería de Valladolid.

Por audiencia pública de 7 de octubre de 1547, el presidente y oidores de la Chancillería de Valladolid rechazan el recurso de fuerza, instando a proseguir el pleito en sus cauces legales.

A. ARCHV, Salas de lo Civil. Zarandona y Walls (OLV). Caja 3884.18. Papel; 17 hojas; escr. procesal; buena conservación. 
1548, septiembre, 18. Grijota.

Memoria y enumeración, perfectamente delimitadas, de las tierras y bienes pertenecientes a Diego Sarmiento y su mujer, María de Meneses, que pasaron a propiedad de Santa María de Husillos a través de Gaspar de Haya, canónigo y obrero de dicha iglesia. El traspaso se hizo a consecuencia de la ejecución del remate de una fianza de trescientos cincuenta mil maravedís en dichas tierras. La ejecución se hizo ante Fernán Rojo, alcalde ordinario de Grijota, y fue redactada por Francisco de Burieva, escribano y notario, ante el obispo de Palencia.

B. APA, ff. 189r-191r.

Fecho y sacado fue este traslado, a doze días del mes de diziembre de mill e quinientos e çinquenta y quatro años. Testigos que lo vieron leer, corregir y conçertar, Gaspar de Vedoya e Juan Ruiz Cabeça de Vaca, clérigos, e Pero Manuel, estantes en la dicha villa. E yo, Santiago Gómez, escribano público en la dicha villa, presentefui a lo que dicho es en vno con los dichos testigos, e del dicho pedimiento y mandamiento lo escreví e fize aquí mi signo (signo) en testimonio de verdad.

(rúbrica) Pero Ruyz de Villoldo (rúbrica).

(rúbrica) Santiago Gómez (rúbrica).

1548, octubre, 19. Husillos.

Blas Herrero, vecino de Husillos, vende por juro de heredad al prior y cabildo de Santa María de Husillos, una viña majuelo sita en el término de la villa de Husillos, donde dicen La Cuesta Redonda de Cardaño, perfectamente delimitada, en precio de once mil maravedís y un cuarto de trigo. La carta fue otorgada por Juan de Nieves, escribano. 
B. APA, $L P H$, ff. $187 \mathrm{v}-188 \mathrm{r}$.

Fecho y sacado fue este traslado a doze días del mes de diziembre de mill e quinientos e quatro años. Testigos ue lo vieron corregir, Joán Ruiz Cabeça de Vaca y Gaspar de Vedoya, clérigos, e Pero Manuel, estantes en la dicha villa. E yo, Santiago Gómez, escribano público en la dicha villa, fui presente a lo que dicho es en vno con los dichos testigos e del dicho pedimiento e mandamiento lo escreví e fize aquí mi signo (signo) en testimonio de verdad.

(rúbrica) Pero Ruyz de Villoldo (rúbrica).

(rúbrica) Santiago Gómez (rúbrica).

1549, enero, 19. Husillos.

Carta de censo otorgada por Juan de Nieves, escribano, por la que Diego Moro, vecino de Villaumbrales, recibe del prior y cabildo de Santa María de Husillos, una viña y tierra eriosa en término de Villaumbrales, sita donde dicen El Hoyo de Rabagudo, perfectamente delimitada, en censo perpetuo, debiéndola mantener podada y trabajada, debiendo ser juzgado el estado de trabajo de la viña y tierra por dos hombres buenos, uno nombrado por el dicho Diego Moro y el otro por el prior y cabildo. Si no la mantuviera perfectamente trabajada, la debe devolver y pagar los daños. Debía pagar en censo y diezmo anualmente, tres reales y medio que hacen ciento diecinueve maravedis, pagaderos el día de San Martín de noviembre.

$B$. APA, $L P H$, ff. $188 \mathrm{r}-189 \mathrm{r}$.

Fecho y sacado fue este traslado a doze días del mes de diziembre de mill e qunientos e çinquenta y quatro años. Testigos que lo vieron leer, corregir $(f .188 v)$ y conçertar, Joán Ruiz Cabeça de Vaca y Gaspar de Vedoya, clérigos, y Pero Manuel, estantes en la dicha villa. E yo, Santiago Gómez, escribano público en la dicha villa, fui presente a lo que dicho es en vno con los dichos testigos y 
del dicho pedimiento y mandamiento lo escreví e fize aquí mi signo (signo) en testimonio de verdad.

(rúbrica) Pero Ruyz de Villoldo (rúbrica).

(rúbrica) Santiago Gómez (rúbrica).

1550, septiembre, 13. Valladolid.

Testimonio notarial escrito por Cristóbal Montesino, notario apostólico de Valladolid, de renovación de un censo de unas casas que la mesa abacial de Santa María de Husillos poseía en Valladolid, en la calle de La Puerta del Campo, que estaban encensadas por Antonia de Solórzano, mujer de Joán Núñez, vecino de Valladolid, en precio de 350 maravedís, y que por la poca cuantía de dicho censo, el abad Francisco de Carvajal había hecho nuevo contrato de censo en precio de cinco mil maravedís.

B. APA, $L P H$, ff. $235 \mathrm{v}-238 \mathrm{v}$.

Fecho y sacado fue este traslado a veynte y ocho días del mes de henero de mil y quinientos y çinquenta y çinco años. Testigos que lo vieron corregir y conçertar, Luis López, clérigo, y Alonso de Torres. E yo, Santiago Gómez, escribano público en la dicha villa, presente fui a façer el dicho traslado en vno con los dichos testigos. Y del dicho pedimiento y mandamiento lo escreví y fize aquí mi signo (signo) en testimonio de verdad.

(rúbrica) Pero Ruyz de Villoldo (rúbrica).

(rúbrica) Santiago Gómez (rúbrica).

1537-1550. 
Memorial con los capitulos que se hicieron para trasladar la iglesia colegiata de Husillos a Tordesillas, con respuesta a los citados capitulos, enumerando los perjuicios que de su traslado se seguirían a la dignidad episcopal. Se da noticia también de los intentos de traslado anteriores a Carrión de los Condes y a Peñafiel.

El intento de traslado a Carrión debió ser entre el 11 de mayo de 1524 y el 3 de julio de 1525 , período de pontificado de Antonio de Rojas. El intento a Peñafiel probablemente fue posterior a éste, teniendo lugar entre 1525 y 1537.

A. ACP, Arm. III, leg. 13, doc. 6. En f. 5r, en el margen: <los agrauios que se siguerían de pasar de la iglesia de Husillos a Tordesillas>. Cuadernillo de Papel; 9 hojas; escr. humanística; buena conservación.

CIT. AUSÍN ÍÑIGO, Intento y memoriales para trasladar la iglesia de Husillos a Tordesillas, $359-362$.

Ésta es la resolución y conclusión que se toma de los capítulos y réplicas que hasta esta final conclusión ha avido sobre la traslación de la yglesia de Husillos a esta villa de Tordesillas, a la yglesia de nuestra señora Santa María della.

I. Primeramente, que la justicia y regidores y procurador en nombre de la villa de Tordesillas ante todas cosas supliquen al muy ilustre señor el obispo de Palencia, tenga por bueno de trasladar la dicha yglesia colegial de la villa de Husillos a la yglesia de Santa María desta villa de Tordesillas, y para ello se aya el consentimiento de su señoría ylustrísima porque la intención y propósito de los que entendemos en la dicha translación es de no perjudicar en nada a la plazia y jurisdicción de su señoría y que la dicha translación se haga siendo dello su señoría servido.

II. Yten que el abbad, prior y cabildo de la dicha yglesia colegial de Husillos, y el arcipreste y beneficiados todos de la yglesia de Santa María de la dicha villa de Tordesillas a donde se ha de trasladar e colocar la dicha yglesia de Husillos, y la justicia y regidores de la dicha villa de Tordesillas, y los perrochianos de la dicha yglesia de Santa María, dé sin expreso consentimiento para en nombre de ambas 


\section{LA ABADÍA DE SANTA MARÍA DE HUSILLOS: ESTUDIO Y COLECCIÓN \\ DOCUMENTAL $(904-1608)$}

las dichas partes se suplique a Su Santidad todo lo necesario para la dicha trasladación segund que más largamente yrá expresado en el poder que ambas las dichas partes para ello dieren.

III. Iten que el dicho señor abbad, prior y cabildo de la dicha yglesia colegial de Husillos dé su expreso consentimiento para que la dicha su yglesia colegial se traslade y pase a la dicha yglesia de Santa María de Tordesillas con todas sus rentas, diezmos, juros, censos, frutos, réditos y emolumentos, proventos, presentes y futuros, y con todas las gracias, prerrogativas, franquezas e liuertades, esenciones y con las ordenanzas, estatutos e loables costumbres e vsos que al presente tienen e hasta aquí han tenido e han gozado la dicha yglesia de Husillos e beneficiados della, para que vsen y gozan dello en la dicha yglesia de Husillos e beneficiados della para que vsen y gozan dello en la dicha yglesia de Tordesillas como vsan e gozan en la dicha yglesia de Husillos. E que Su Santidad dé licencia a los dichos abbad, prior y cabildo para que hecha la dicha translación puedan llevar e lleven de la dicha yglesia de Husillos a la dicha yglesia de Tordesillas qualesquier reliquias, plata, cinzes?, cálices, ornamentos, órganos, canpanas y sillas que les paresciere ser necesario para la dicha yglesia de Tordesillas, dexando en la dicha yglesia de Husillos lo necesario conforme al seruicio que en ella ha de aver y la calidad del lugar en que está. $(f .1 r)$

IIII. Iten que porque en la dicha yglesia de Husillos después de la del prelado, que es el abbad della, no hay más de tres dignidades, las dos en vn choro y vna en el otro, que por ygualar los choros en dignidades como están yguales en el número de canónigos y razioneros y medios razioneros, y por honrra de la yglesia todos los contenidos en el primer capítulo suplican a Su Santidad instituyan, crie y exija de nuevo en la dicha yglesia "yn eventum" que la dicha translación se passe por vna nueva y quarta dignidad de número que se llame arcipreste. E del nombre quel dicho arcipreste escogiere el qual tenga "statum in choro et locum in capitulo", él y sus subcesores como lo tienen las otras dignidades de la dicha yglesia de Husillos.

V. Iten que porque en la dicha yglesia de Tordesillas hay cinco beneficiados presbiterales y dos diaconales y dos subdiaconales y seys de grados, suplican a $\mathrm{Su}$ Santidad por todos los beneficiados de las dichas dos yglesias estigna? y consuma todos estos dichos beneficios. Y así extinguidos de los cinco beneficios de preste, 
críe y exija cinco canonicatos y preuendas, y de los dos de euangelio dos medias raciones, y de los dos de epístola y seys de grados, ocho medias raciones con que gozan como hasta aquí de sus quartas y sestas partes respective de ración y preuenda. Y así eregidos y criados se acrezcan y añadan todos al número de los canónigos y racioneros y medios razioneros de la dicha yglesia colegial de Husillos y gozen de las calongías y medias raziones como dicho es, yqualmente y según que los otros canónigos de la dicha yglesia de Husillos y con la misma carga y censión dellos.

VI. Iten que porque la mayor jurisdición y priminencia y prouecho o ynterese quel muy ylustre señor el obispo de Palencia tiene en la dicha yglesia de Tordesillas ssel? prouee de los dichos beneficios del capítulo antes deste cada e quando e como quiera que vacaren y lleuar vn tercio de las dézimas de la dicha yglesia, que porque la dicha yglesia sea mejor seruida y honrrada con personas estudiosas e calificadas en letras, no obstante que los dichos beneficios sean criados en calongías y medias raziones como dicho es, que su señoría los provea como hasta aquí conforme a las constituciones signodales desta diócesis de Palencia a los hijos legítimos naturales y patrimoniales de la dicha yglesia de Tordesillas más aviles y suficiente cada y quando y como quien la que vaguen. E quanto a la parte que su señoría tiene en los diezmos, la tenga, lleue y goze hecha la dicha translación como hasta aquí y quanto a estas dos cosas tenga jurisdición y derecho el señor obispo de Palencia en prouee los dichos beneficios y lleuar los diezmos. Y en todo lo demás que den los dichos abbad y prior y cabildo de Husillos, bienes y rentas y anejos y proprios della. Y la dicha yglesia de Tordesillas tan libres y esentos de la jurisdición del dicho señor obispo de Palencia y de la del arcidiano del Alcor como agora lo son los dichos abbad, prior y cabildo (f.1v) de la dicha su yglesia colegial de Husillos que ha de ser de Tordesillas, y assí lo suplican todos los contenidos en el primer capítulo a Su Santidad.

VII. Iten que porque en las dichas dos yglesias de Husillos y Tordesillas hay muchas memorias, aniuersarios y missas perpetuas instituydas con diuersas cargas, las quales por ser tantas y aver perecido las dotes dellas y ser tan tenues que comodamente no se pueden fazer ni dezir conforme a la voluntad de los testadores que las instituyeron, suplican a Su Santidad ambas las dichas partes de poder y facultad a los dichos abbad, prior y cabildo para que reduzcan las dichas 


\section{LA ABADÍA DE SANTA MARÍA DE HUSILLOS: ESTUDIO Y COLECCIÓN \\ DOCUMENTAL $(904-1608)$}

memorias a menor y más conueniente número de tal manera que se cumpla con los defuntos y se descarguen las consciencias de los viuos.

VIII. Otrosí que porque en la dicha yglesia de Tordesillas hay algunas capellanías dotadas de derecho de patronazgo de clérigos e de derecho de legos cuyos patronos no se saben ni son ciertos ni hay memoria de ellos, a cuya causa no hazen sus memorias como ni quando se deuerían hazer e se defraudan los defuntos de los sufragios que deuerían de auer de la yglesia, se suplique a $\mathrm{Su}$ Santidad por las dichas partes las aplique y anneje a la mesa capitular de los dichos prior y cabildo para que las haga como mejor conuenga al descanso de los muertos y descargo de los viuos.

IX. Iten que porque las dichas dos yglesias de Husillos y Tordesillas y las fábricas dellas sean mejor sustentadas y reparadas, se suplique a Su Santidad haga perpetua annexión y translación de la fábrica de la dicha yglesia de Husillos y sus rentas a la fábrica de la dicha yglesia de Tordesillas, con que la dicha yglesia de Tordesillas y su fábrica sean obligados a sustentar y reparar la dicha yglesia de Husillos perpetuamente.

$X$. Yten que porque de la dicha yglesia de Tordesillas de nuestra señora Santa María como de yglesia más principal que es que las otras yglesias de la dicha villa de Tordesillas, acostunbran a salir y salen todas las procesiones generales y especiales ordinarias y extraordinarias por qualquier cosa que se hagan en cada vn año, exceto vna sola procesión que sale de la yglesia de señor San Pero el martes, de las ledanías menores, se suplique a Su Santidad pues la dicha yglesia de nuestra señora de Tordesillas es parrochial se convierta en colegial, que a mayor abundamiento "motu proprio" et ex cierta sciencia y gracia especial la críe, exija y nombre de nuevo portal yglesia mayor y principal de la dicha villa de Tordesillas con todas las prerrogativas y preminencias y esenciones necesarias y con la antiguedad y mayoridad sobre todas las otras yglesias y monasterios, hermitas y santuarios de la dicha villa de Tordesillas y su arciprestazgo para que della como de tal yglesia mayor salgan todas las procesiones sin excebir alguna perpetuamente en cada vn año, y no de otra yglesia de la dicha villa ni de fuera della. (f.2) Y para que los oficios de los días de las tales procesiones los hagan y digan los beneficiados de la dicha yglesia mayor y colegia,l y para que en ninguna yglesia ni monesterio de la dicha villa hagan señal de canpana a ninguna ora ni 
oficio ni fiesta ni memoria hasta que la dicha yglesia mayor y colegial haga la tal señal y prencipio della allende que la dicha yglesia de nuestra señora lo tiene por concordia, vso y costumbre y para esto especialmente discierna Su Santidad censuras.

XI. Iten que en quanto a lo que toca a la orden y lugar que se ha de tener en todas las procesiones do concurrieren los curas y beneficiados de las otras yglesias parrochiales de la dicha villa de Tordesillas con los dichos prior y cabildo de la dicha yglesia colegial de nuestra señora, se suplique a Su Santidad que por vida de los curas y beneficiados presentes de las dichas parrochias les será guardada a los vnos y a los otros la antigüedad de las prouisión y colación, justitución que cada vno tuviere de su beneficio, calongía o rración o media ración quarta o otra parte della, preferiendo ser el más antiguo al menos antiguo. Y conforme a esto tome cada vno el lugar que le viniere entre los beneficiados de la dicha yglesia colegial, quedando sienpre aparte el más principal lugar para las dignidades de la dicha yglesia colegial, avnque sean menos antiguas. Enpero que después de la muerte de todos los dichos curas y beneficiados presentes de las dichas parrochias vayan los dichos abbad, prior, y cabildo, dignidades, curas, racioneros y medios racioneros de la dicha yglesia colegial anque no tengan más de quartas o sestas parts de ración o prebendas juntos en las tales procesiones en la orden de sus antigüedades se prefieran todas y todo el cabildo colegial a todos los curas clérigos de las dichas parrochales, anque vengan a ser más antiguos que qualesquier de la dicha colegial y quanto a los lugares, sillas y asientos y botos de choro y capítulo y procesiones que convenieren de hazer los dichos abbad, prior y cabildo de la colegial, de por sí se guarde asímismo la primera prouisión y collación que cada vno tuviere de su canonicato, beneficio, ración o media ración, quarta o sesta. Y conforme a ellas tome el asyento e lugar que le veniere y el voto que le cupiere sin contradición ni alteración alguna, quedando sienpre como dicho es el más principal lugar y primeros votos para las dichas dignidades.

XII. Iten se suplique a Su Santidad que pues de las dichas dos yglesias se ha de hazer vn cuerpo y cabildo, ansí mismo junte y encorpore en vn cuerpo y globo y vna mesa capitular todos los frutos y rentas, juros, censos, emolumentos, réditos,

prouentos y diezmos presentes y futuros que las dichas dos yglesias y beneficiados dellas an y tienen en ellas y les son deuidos y pertenecientes en cada 
vn año perpetuamente para que se diuidan por preuendas y raciones yguales como cada vno lo deuiere de aver, con tanto $(f .2 v)$ que porque al presente parece que los dichos beneficiados de la dicha yglesia de nuestra señora de Tordesillas exceden en renta a los canonicatos de Husillos que por vida de los dichos beneficiados de la dicha yglesia de Tordesillas que agora son, Su Santidad los reserue los annejos de los dichos beneficios a cada vn beneficiado los de su beneficio, y que en bacando el tal beneficio como quiera que vaque ora sea por muerte, ora por cesión, resignación o ascensión, puntación o de otra qualquier manera que vaque a el tal annejo o annejos del del (sic) tal beneficio o beneficios, "ipso facto" queden encorporados e consumidos en la dicha mesa capitular. E muertos todos los dichos beneficiados que agora son, queden todos los dichos annejos de sus beneficios consumidos y encorporados en la dicha mesa capitular de tal manera quel subcesor ni subcesores del tal o de los tales beneficios no ayan de aver annejos algunos si no su preuenda entera o media, quarta o sesta parte, como los otros canónigos y beneficiados de la dicha yglesia, e conforme a la qualidad del benefico que tuviere.

XIII. Yten que "yn eventun" que la dicha translación se haga, se suplique a $\mathrm{Su}$ Santidad de poder, licencia e facultad a los dichos abbad, prior y cabildo y beneficiados de la dicha yglesia colegial de Tordesillas para que puedan hazer y hagan, instituyan y ordenen todos e qualesquier estatutos, ordenanzas, dispusiciones e concordias necesarias para el buen servicio e regimiento de la dicha colegial, quitando, añadiendo e menguando, revocando, añadiendo y mudando los que agora tienen las dichas dos yglesias e cada vna dellas, no obstante que están jurados por las partes e conformados por la sede apostólica, pues por razón de la dicha translación e mudanza converná ansí quedando en su fuerza e vigor todo lo arriba capitulado y las nuevas concordridas? particulares que sobre esta rrazón se hizieren, e las esenciones e liuertades que qualquier beneficiado tuviere. Y ansí echos y ordenados los tales estatutos y ordenanzas, $\mathrm{Su}$ Santidad examine "pro ex tune" de facultad a juezes que los aprueven y confirmen. E para que así criada la dicha yglesia de nuestra señora de Tordesillas colegial, los dichos abbad, prior y cabildo, dignidades, canónigos, razioneros y medios racioneros, se puedan llamar e nombrar, llamen yninbres? tales beneficiados de la dicha colegial de Tordesillas, quales agora se nonbran de 
Husillos.

XIIII. Yten se suplica a Su Santidad, echa la dicha translación de poder y facultad y licencia por su bula o signo evidente a los dichos abbad, prior y cabildo de la dicha yglesia de Husillos, para que puedan vender y trocar y dar a encenso infatuosi perpetuo o por vida los, bienes muebles y rrayzes $(f .3)$ y réditos spirituales y las mismas posesiones, términos y heredades con sus jurisdiciones que tiene la dicha yglesia que les paresciere que conviene y es necesario venderse y tocarse o censuarse por razón de la dicha mudanza e translación. E porque no se podrán así regir e sustentar como hasta aquí por la distancia del lugar, contando que conviertan lo que así vendieren en otras posesiones y rentas de más prouecho y evidente hutilidad, conforme a derecho e como más convenga al saneamiento de las tales posesiones e avnmento de las rentas dellas.

Y los quales dichos capítulos, nos los diputados, ansy por parte de la yglesia de Husillos e por parte de la yglesia de Santa María de Tordesillas, hizimos en presencia del señor licenciado Alderete del consejo de sus magestades, regidor de la dicha villa de Tordesillas. E a su merced paresció estauan bien e como convenían e ordenamos que ante todas cosas se comunicaban con el muy ylustrísimo reverendísimo señor el obispo de Palencia, e con el abbad, prior y cabildo de la dicha yglesia de Husillos e con el arcipreste e beneficiados de la dicha yglesia de nuestra señora de Tordesillas. $(f .3 v)$

El caso de que dentro de la diócesis y obispado de Palencia ay vna yglesia colegial que se dize la abbadía de Usillos, donde ay el abbad y otras dos dignidades y ciertos canónigos y racioneros y medios racioneros, el abbad tiene juresdición en cebil y criminal en primera ynstancia sobre estos beneficiados y sus cabsas. Este lugar de Usillos está vna legua de Palencia, adonde el obispo y sus oficiales tienen quenta quando algún agrabio haze el abbad de Usillos o su prouisor o a la juresdición del ordinario y rremediase fácilmente. Agora el abbad de Usillos y su cabildo tratan con el rregimiento y vezinos de la villa de Tordesillas y con los beneficiados de una yglesia de la dicha villa de Tordesillas que se dize de Santa María, donde ay diez y ocho beneficios patrimuniales y otros tantos beneficiados que los tienen la colación de los quales pertenece al obispo y los da por examen com los otros beneficios de todo el obispado conforme a la bbula de Alejandro. Dízese que tratan de pasarse esta iglesia y cabildo de Usillos 
a la dicha iglesia de Santa María de la villa de Tordesillas, y que la yglesia de Santa María y su fábrica y los diez y ocho beneficiados que ay en ella que son subjetos en cebil y criminal a la juresdición ordinaria del obispo de Palencia, sean hesentos y subjetos al abbad y canónigos y racioneros y medios racioneros de la dicha yglesia a la yglesia de nuestra señora vnida con la de Usillos, y las fábricas de las dos que sea vna y dellas se rreparen las dichas dos yglesias.

Y dizen que tratan que en la dicha yglesia de Santa María de la dicha villa de Tordesillas aya otra dignidad que sea vn acipreste que ay en Tordesillas que tiene jurisdición, pedanía de ciento y veynte maravedís en la villa de Tordesillas y en los lugares del dicho aciprestazgo que son diez o doze, y dizen y se jatan que arán esta traslación y vnión de yglesias y hesención de personas y vienes y rentas de la menera que dicha tengo, y con otras cláusulas y maneras yn consultas.

El perjuicio y daños que a la dignidad episcopal y al obispo de Palencia se le siguen que agora de presente parecen sin los que después el tienpo mostrará son estos.

Lo primero es que la villa de Usillos donde agora está la dicha yglesia colegial está vna legua de Palencia adonde se tiene la rrazón y cuenta que dicha tengo, y esta villa de Usillos es lugar de sesenta vezinos, y la villa de $(f .4 r)$ Tordesillas donde se quiere pasar el dicho abbad de Usillos con su cabildo está catorze leguas de Palencia y dentro de la mesma diócesis, y en ésta ay mill vecinos y en ella ay cinco yglesias parrochiales todas con sus beneficios y beneficiados son subjetos a la juresdición ordinaria del obispo, y tan lejos no se podría tener la quenta que digo con el abbad ni su prouisor para que entungran? lugar y entre tantas personas eclesiásticas y iglesias, no hagan perjuicio en muchas cosas de la jurisdición del ordinario.

Yten de hazerse este acipreste de Tordesillas dignidad en la dicha yglesia colegial y esentos, era grandísimo perjuicio de la dignidad episcopal porque usurparía la juresdición ordinaria y en la dicha villa de Tordesillas y en los lugares de su aciprestazgo y donde la tiene pedanía ayudándose él y el abbad la harían ordinaria y se benderán a esentar la dicha villa de Tordesillas con todos los lugares de su aciprestazgo de la juresdición del ordinario como ha hecho o pretende Valladolid, con los lugares que abía del aciprestazdo de ella.

Yten que esentar diez y ocho beneficiados que ay en la dicha yglesia de Santa 
María y la iglesia y sus bienes y los bienes de los beneficiados y capellanías y aniuersarios y memorias y execuciones de testamentos y todo de la juresdición cebil y criminal de Su Santidad es grandísimo agrabio a su dignidad.

Yten que Su Santidad tiene en el dicho aciprestazgo dos mill ducados de rrentas eclesiásticas y rrecebiría gran daño en ellos y en la cobranza dellos.

Yten la visitación y procuración de la dicha yglesia de Santa María y beneficiados y uienes de ella y otros muchos agrabios que de presente no parezen y el tienpo mostrará.

Yten se sigue de la dicha traslación los agrabios siguientes, al arcediano del Alcor en cuyo arcedianazgo está la dicha villa de Tordesillas con su aciprestazgo. $(f .4 v)$ Vistos los capítulos que así se dieron de parte de la villa de Tordesillas, parece que ante todas cosas se deue saber la voluntad determinada que se tiene en este negocio, porque si no obstan los inconvenientes que en ello ay, quiere condescender a las inportunidades de los que lo piden escusado, será el trabajo de responder a los capítulos. Pero si suso está dubdoso y quiere ser informado de los prejuyzios que a su dignidad y autoridad y aun rentas y a sus subcesores pueden seguirse, será bien responder particularmente a los capítulos más prejudiziales.

I. Al primero capítulo nos paresce que en ninguna manera su señoría deue ni [...] de buenamente dar el tal consentimiento, porque avnque allí dize que su intención no es prejudicar en nada la perglacia? y jurisdición de Su Santidad, bien se vee claro en los capítulos siguientes que su intención es contraria de lo que dizen, mayormente que pues Su Santidad de derecho no puede enajenar vna posesión por pequeña que sea sin consentimiento de su cabildo, a fortiori no podía ni devría enajenar ni quitar de su jurisdición vna yglesia principal de su obispado con tanta copia de clérigos como en ella ay, los quales todos por esta translación se harían exentos de su jurisdición y visitación, y con esto se podría responder a todos los otros capítulos.

IIII. E en el quarto capítulo alliende de los inconvenientes susodichos ay otro, y es que agora el acipreste es subjeto a Su Santidad en cebil y criminal, y echo dignidad de yglesia colegial será exento. Y con esto no podiendo ser castigado por Su Santidad y sus prouisores y visitadores, vsurparía a su plazer los bienes de las yglesias de su aciprestazgo y los dispensaría a su voluntad, sabiendo quel perlado no le puede yr a la mano, y daría las cuentas como y quando quisiese, y así no 
sólo perdería Su Santidad desta manera la jurisdición de Tordesillas de Santa María, más tanbién la de Velliza, Villilla, Matilla, Arenillas, Vercero, Verceruelo, Torrecilla, Villavieja, Villamarzal, Sant Miguel del Pino, y todas las otras de la villa e del aciprestazgo como están predidas y enajenadas las del abbadía de Valladolid. Y porque más claro parezca la intención quel acipreste en esto tiene, mírense las palabras del capítulo en que dize quel acipreste escoja el nonbre de la dignidad que quisiere, porque sabe que llamándose acipreste podría ser subjeto como los otros arciprestes y querrá llamarse arcidiano de Tordesillas para ser más exento con el nonbre.

V. E el quinto capítulo es muy prejudicial a la dignidad episcopal y contrario a la bula alejandrina y constituciones de los hijos patrimuniales, porque a la ora que los beneficios se extingan y hagan canonicatos y raciones, luego muy presto cesarán de ser patrimoniales. Y como tales canonicatos y raciones se proveerá en Roma o por expectatiuas o por el abbad como agora se haze en Husillos. E se al principio no se obsta, al fin verná la cosa a lo que dezimos.

VI. El sesto capítulo está respondido en el quinto, pero allí mostra (f.5r) más claramente lo que pretenden en dezir que la mayor jurisdición e preheminencia quel obispo tiene es proueer los beneficios y no hazen cuenta del castigo de los delinquentes y de la visitación de las personas e yglesias e de la administración de las fábricas, y quieren proueer a sola la províción de los beneficios que durará muy poco como dicho es.

En fin, concluyen que proueydos los beneficios en todo lo demás queden todos los clérigos y yglesias exentos de la jurisdición de su señoría y del arcidiano del Alcor, en lo qual y a su señoría vee el prejuyzio suyo y de sus subcesores y del arcidiano y de los suyos a los quales no deue ni puede Su Santidad preludiar, e basta que se le ayan exentado e salido de su jurisdición poco a poco la abbadía de Valladolid y sus lugares y la de Husillos sin que agora por su consentimiento se pierda la de Tordesillas y con ella poco a poco las otras de la villa y tierra como dicho es.

Iten en el mesmo capítulo dize que quanto a la parte que Su Santidad tiene en los diezmos, la tenga y la lleue como hasta aquí y hazen cuenta que avn en esto hazen servicio y gracia a su señoría. Pero si bien se mira adelante le podrá ser muy prejudicial porque envoluiendo su tercio con el tercio de los canónigos y clérigos, 
auiéndolo ellos de cobrar, forzado a de ser Su Santidad defravdado y poco a poco se yrían entrando en ello como se ha echo en otros cabos.

IX. E del nono capítulo vea Su Santidad si cunple a su yglesia de Tordesillas envoluer los maravedís de la fábrica de Santa María con la fábrica de la yglesia de Husillos, porque podría ser venir la de Husillos a tal necesidad o ruyna que se oviese de hazer o reparar con los bienes de la de Tordesillas y a ella no le queda de nada.

XII. En el capítulo doze de ver tanbién lo que se ha dicho antes desto, quanto la vnión de las fábricas e mucho más en lo que dize que vacando qualquiera de los beneficios que agora son patrimuniales por muerte o procesión, resignación, acensión o permutación o de otra qualquier manera que vaque, que los anexos del tal beneficio se consuman en su mesa por donde parece que tienen intención contra la bula alejandrina e prouisiones del consejo que los beneficios patrimuniales se puedan permutar e resignar, a lo qual su señoría no a de dar consentimiento.

Y así mismo es bien que sepa su señoría que esta mudanza no la procuran los clérigos solamente de Santa María ni ellos solos pretenden la excensión como aquí dize. Antes es cierto que es procurado por todos los otros clérigos de la villa, los quales andando el tienpo ligeramente podrá aver del papa lo mesmo que estos. Y esto se sabe porque muchos les an oydo dezir que de aquí adelante ni el obispo ni el provisor ni visitador no terná que hazer con los clérigos de Tordesillas ni el fiscal los podrá llamar ni prender como hasta aquí. De manera que haziéndose esta translación Su Santidad no tenía perdida la jurisdición más de en la yglesia de Husillos, y agora la perderá en cinco de Tor $(f .5 v)$ desillas, e por ventura en diez de la tierra, porque conoscidamente la intención de los clérigos y regidores y vezinos de la dicha villa es tener dentro en su casa vn obispo o abbad exento que conozca de todas sus cosas de primera instancia, lo qual Su Santidad vea quan prejudicial es.

Iten es bien que sepa Su Santidad que ya otra vez el abbad y cabildo de Husillos yntentaron de hazer esta translación a la villa de Carrión y el señor patriarca don Antón de Rojas, siendo obispo lo resistió con toda diligencia, poniendo en ello a los señores del consejo real, los quales dieron sus prouisiones para que no se hiziese la tal translación en su perjuyzio y de la dignidad episcopal. Tanbién dizen 
que se a intentado esto en Pennafiel y no an salido con ello, y no es de menos calidad la villa de Tordesillas que las otras.

1554, junio, 15. Valladolid.

Poder otorgado por Francisco de Carvajal, abad de Santa María de Husillos y vecino de Placencia, a su tio Gutierre de Carvajal, obispo de Placencia, para que pueda elegir y nombrar provisor, alcalde mayor, alcaldes ordinarios, justicias, regidores, guardas y otros oficiales en la villa de Husillos y en los demás lugares de dicha abadía. Le da poder igualmente para nombrar uno o más visitadores que visiten dicha abadía y sus beneficiados y las demás iglesias y beneficiados de éstas pertenecientes a Husillos, pudiendo nombrar los dichos visitadores, mayordomos y sacristanes en dichas iglesias.

\section{$B$. APA, $L P H$, ff. $1 \mathrm{r}-2 \mathrm{v}$}

In Dei nomine, amen. Notorio sea a todos los que este presente público instrumento de poder vieren, como nos, don Francisco de Carauajal, vezino de la çibdad de Plazencia, abbad en la colegial yglesia de Nuestra Señora Santa María de Husillos, otorgamos y conocemos por esta presente carta, que (fol. 1) damos y otorgamos todo nuestro poder cumplido bastante el que de derecho en tal caso se requiere a vuestra señoría, el muy ilustrísimo señor don Gutierre de Carauajal, obispo de Plazençia, para que por nos y en nuestro nonbre y como nos mismo, vuestra señoría pueda poner y elegir provisor y alcalde mayor y ordinarios y otras qualesquier justiçias y rregidores y guardas y otros ofiçiales qualesquier, ansí en la dicha villa de Husillos y en su término como en los otros lugares y sus términos de la dicha mi abadía. Otrosí, damos y otorgamos el dicho nuestro poder para que vuestra señoría pueda poner visitador o dos o más, los quales puedan visitar y visiten la dicha yglesia de Husillos y benefiçiados della y todos los otros 
benefiçiados y iglesias de la dicha nuestra abadía que por vso y costumbre se suelen visitar. El qual dicho visitador o visitadores puedan poner el mayordomo o mayordomos y sacristanes que le pareçiere ser necesarios en las dichas iglesias o qualquier dellas, y quitar éstos y poner otros.

Y para que vuestra señoría pueda hazer y proveer todo aquello que nos haríamos e proveeríamos presente siendo aunque sean tales cosas y de tal qualidad que según derecho requieran y deuan auer nuestra presençia personal e otro más speçial poder y mandado que quan cumplido y bastante yo le he y tengo para todo lo susodicho y cada cosa y parte dello otro tal y tan cumplido, doy y otorgo a vuestra señoría con libre y general administración y rrelieuo a vuetra señoría en forma de derecho.

Y para auer por firme y valedero todo lo en este poder contenido, obligo mi persona y bienes espirituales y temporales, muebles y raízes, auidos y por auer.

Que fue fecha y otorgada esta presente carta en la villa de Valladolid, a quinze días del mes de junio del año de mil y quinientos y çinquenta y quatro años. Testigos que fueron presentes: Diego de Vega de Vargas, y Pedro Manuel Pimentel, y Joán de Arlançón, estantes en esta dicha villa, y el dicho señor abad don Francisco de Carauajal.

Y yo, Gaspar de Vedoya, clérigo de la diócesi de Toledo, notario público apostólico por la autoridad apostólica, presente fui con los dichos testigos al otorgamiento desta carta, en fee y testimonio de lo qual fiz aquí este mi signo a tal en testimonio de verdad. Gaspar de Vedoya, apostólico notario.

1554, julio, 27. Valladolid.

Ejecutoria de la sentencia del pleito litigado por Pedro Lagasca, obispo de Palencia, y Contreras, fiscal del rey, con Francisco de Carvajal, abad de Santa María de Husillos, sobre el derecho del obispo a visitar la abadía y su jurisdicción ordinaria sobre ésta. 


\section{LA ABADÍA DE SANTA MARÍA DE HUSILLOS: ESTUDIO Y COLECCIÓN \\ DOCUMENTAL $(904-1608)$}

Siguiendo las cláusulas del concilio de Trento sobre las visitas eclesiásticas, Carlos I ordenó mediante cédula real al obispo de Palencia la visita de la abadía de Santa María de Husillos. Juan de Espinosa, procurador del abad, argumentó que el abad tenía jurisdicción sobre los miembros de la comunidad, y que el obispo tenía solamente jurisdicción en grado de apelación (segunda instancia). Suplica al rey le otorgue provisión real con inserción de las cláusulas del concilio de Trento para su cumplimiento por la abadía y que anule la provisión otorgada al obispo, exponiendo que tres meses antes había realizado una visita con resultados perjudiciales para dicha abadía. El fiscal argumenta que la provisión del obispo está sujeta al derecho y a lo estipulado en Trento; y que los resultados de la visita del obispo, como son los excesos cometidos y los canónigos que están detenidos, eran debidos a la ociosidad y relajamiento de la abadía. Por sentencia del consejo real de 14 de junio de 1554, se reconoce la jurisdicción ordinaria del abad sobre su iglesia y se conmina al obispo a que libere los presos. El abad solicita a continuación, carta ejecutoria de la sentencia.

B. APA, $L P H$, ff. $191 \mathrm{r}-192 \mathrm{v}$.

Fecho y sacado fue este traslado a doze días del mes de deziembre de mill e quinientos y çinquenta e quatro años. Testigos que lo vieron leer, corregir y conçertar, Joán Ruiz Cabeça de Vaca e Gaspar de Vedoya, clérigos, e Pero Manuel, estantes en la dicha villa.

E yo, Santiago Gómez, escribano público en la dicha villa, presente fui a lo que dicho es en vno con los dichos testigos. E del dicho pedimiento e mandamiento lo escreví e fize aquí mi signo (signo) en testimonio de verdad.

(rúbrica) Pero Ruiz de Villoldo (rúbrica)

(rúbrica) Santiago Gómez (rúbrica).

Don Carlos, por la divina clemencia emperador senper augusto, rrey de Alemania. Doña Joana, su madre y el mismo don Carlos, por la graçia de Dios, rreyes de Castilla, de León, de Aragón, de las Dos Siçilias, de Iherusalem, de Navarra, de Granada, de Toledo, de Valençia, de Galicia, de Mallorca, de Sevilla, de Çerdeña, de Córdova, de Córcega, de Murçia, de Jaén, de Los Algarves, de Algezira, de Gibraltar, de las Yndias, de la Tierra Firme del Mar Océano, condes de Flandes y de Tirol. A vos, don Pero de Lagasca, obispo de Palençia, conde de 
Pernía, del nuestro consejo; y a vuestros provisores y vicarios y otros juezes y clérigos de dicho obispado, y a cada vno de vos a quien esta nuestra carta fuere mostrada. Salud y graçia. Bien sabéis el pleyto que vos, el dicho obispo y licenciado Contreras, nuestro procurador fiscal, avéis tratado ante los del nuestro consejo con don Francisco de Carvajal, abad de la yglesia de Husillos y cabildo de la dicha yglesia, sobre razón que el dicho fiscal por vna petición que en el nuestro consejo presentó, dixo que por vna nuestra çédula (f.191r) vos avíamos encargado a vos, el dicho obispo e deán y cabildo de vuestra yglesia catredal, fiziese de cumplir y ejecutar en ella y en vuestra diócesis lo que se avía determinado en el conçilio tridentino. Y cumpliéndolo en la dicha çédula y conçilio contenido, avíades ynbiado a visitar la iglesia colegial de la dicha villa de Husillos, porque la dicha iglesia y ministros della pretendían ser exenptos de la jurisdicción ordinaria y no se avían querido dexar visitar ni cumplir la dicha çédula como pareçía por çiertos testimonios de que hazía presentaçión. E nos suplicó lo mandásemos proveer de manera que oviese hefeto lo mandado por la dicha nuestra çédula. E por los del nuetro consejo visto, mandaron dar sobrecarta della para que el prior y cabildo de la dicha yglesia de Husillos dexasen y consintiesen a vos, el dicho obispo y a vuestros ofiçiales, visitar la dicha yglesia y ministros della con aperçebimiento que se proveer cabo que conviniese según que más largamente en la dicha sobrecarta se contiene. Contra lo qual Joán de Espinosa, en nombre de don Francisco de Caravajal, abad de Husillos, presentó en el nuestro consejo vna petición que dixo que el dicho su parte tenía jurisdicción temporal y espiritual en la dicha abadía y en sus miembros, y era juez ordinario dellos de sus clérigos e benefiçiados, de tal manera que vos, el dicho obispo no avíades tenido ni teníades jurisdicción espiritual si no era en grado de apelación de las sentencias que los sus provisores davan.

Y él avía fecho visitar la iglesia colegial e clérigos de la dicha abadía e corregido y castigado los excesos que avían fecho y podía aver, tres meses poco más o menos que avía visitado la dicha yglesia e clerecía como constava por çierta información de que hazía presentaçión. E siendo esto ansí se le devía dar provisión inscrito en ella lo decretado en el sacro conçilio para que lo forme a ello la clerecía de la dicha abadía no se eximiese ni vsase de exeçión alguna rrespeto de su parte, que hera su ordinaria e del grado por virtud del dicho conçilio. E 
porque no estávamos ynformados de lo susodicho, avíamos dado las dichas provisiones a pedimiento de vos, el dicho obispo, lo qual era en gran daño e perjuizio suyo, porque sería daros jurisdicción donde nunca la avíades tenido e quitarla a él, lo qual no era nuestra intençión ni la del dicho conçilio. Por ende, que nos suplicava le mandásemos dar nuestra çédula e privisión rreal ynscrito lo decretado en el dicho conçilio para que aquello signaidase? e cumpliese por la clerecía de la dicha abadía: Y ansí mesmo mandásemos a vos, el dicho obispo, que no vsásedes de las provisiones que se os avían dado en la dicha abadía y sus miembros y rrevocásedes lo que oviésedes fecho por virtud dellos, e la traxésedes e presentásedes originalmente ante los del nuestro consejo, e se rasgasen de manera que no quedase memoria dellos. Y para que nos constase de su justicia fazía presentaçión de çierta información e mandamiento e de vna sentencia de rremisión fecha por el provisor de vos, el dicho obispo, por la qual constava tener el dicho abad su jurisdicción ordinaria en primera instancia, e vos e vuestro provisor en grado de apelación. E porque los clérigos de la dicha abadía andavan avsentando e no servían en la yglesia ni se dezía ofiçio de vino en ella por temor que vos, el dicho obispo, los ynbiávades a prender e teníades presos muchos dellos, mandásemos que en el entretan que este negoçio se veya por los del nuestro consejo, no vsásedes de las provisiones que se os avían dado e soltásedes los presos libremente o a lo menos dando fianças de estar a derecho. Contra lo qual el dicho fiscal presentó en el nuestro consejo otra petición de rrespuesta en que dixo que no avía lugar de se proveer cosa alguna de lo pedido por parte del dicho abad, porque no se pedía por partes en tiempo y en forma e las provisiones que os avían dado a vos, el dicho obispo, eran muy justas y ordinarias como se avía dado a todos los perlados destos rreynos, e ninguna causa ni razón (f.191v) avía para que se mandase sobreseer, pues vos el dicho obispo non avíades fecho ni hazíades agravio alguno. E si algunos clérigos teníades presos, sería por excesos e delitos que avían cometido e avían de ser corregidos y castigados por vos conforme al dicho conçilio. Y ansí çesava e no avía lugar lo en contra pedido e se lo devíamos denegar.

Después de lo qual el dicho Joán de Espinosa, en el dicho nombre, presentó ante los del nuestro consejo vna petición en que dixo que vos, el dicho obispo, os entrometíades a conocer en primera instancia e a visitar la dicha yglesia de 
Husillos e clérigos della, no lo podiendo ni deviendo fazer por peteneçer como perteneçen al dicho su parte la primera instancia e visitación de la dicha abadía como pareçía por çiertas escripturas y proçesos y avtos y visitas que él y los abades pasados hizieron de que ante nos hizo presentaçión, e se ofreçía a dar más información dello siendo necesario. Y pues el dicho conçilio no se entendía en este caso, nos suplicó vos mandásemos no os entrometiésedes en la dicha visitación.

Entretanto que esta causa se veya y determinava por nos, mandamos que las provisiones que se os avían dado no se entendiesen con el dicho abad su parte, pues hera juez ordinario en la dicha abadía. De lo qual se mandó dar traslado a vos, el dicho obispo e el dicho fiscal.

Contra lo qual Antonio de Quintela en vuestro nombre, presentó vna petición en que dixo que para que nos constase de cómo teníades jurisdicción y la avíades tenido otra, los canónigos de la dicha villa de Husillos fazíades presentaçión de vn proçeso fecho contra Salaya, canónigo de la dicha yglesia de Husillos, por el provisor del obispo vuestro antecesor, lo qual se notificó a la parte del dicho abad de Husillos, el qual concluyó sin embargo de ello e sobrello el dicho pleito fue concluso y por los del nuestro consejo todo visto dieron e pronunçiaron en él un abto del tenor siguiente:

En la villa de Valladolid, a catorze días del mes de junio de mill e quinientos e çinquenta e quatro años, visto por los señores del consejo de su majestad el negoçio que es entre don Pero de Lagasca, obispo de Palençia, y el fiscal de su majestad, de la vna parte, y don Françisco de Caravajal, abad de Husillo sy su procurador en su nombre, de la otra, sobre la visitación de las yglesias y personas eclesiásticas de la abadía de Husillos, dixeron que mandavan y mandaron que el dicho obispo de Palençia en quanto a la visitación de la dicha abadía e Husillos no vse de las provisiones y çédulas que le están dadas e si algunas personas sobre ello tiene presos, los suelte libremente.

El qual dicho avto se notificó a los procuradores de las dichas partes en sus personas. E pareçe que ninguno suplicó del dentro del testimonio que hera obligado ni después del. Y agora a el dicho Joán de Espinosa, en nombre del dicho don Francisco de Carvajal, abad de Husillos, nos suplicó e pidió por merçed que porque lo contenido en el dicho auto fuese mejor guardado y conplido, le 


\section{LA ABADÍA DE SANTA MARÍA DE HUSILLOS: ESTUDIO Y COLECCIÓN \\ DOCUMENTAL $(904-1608)$}

mandásemos dar nuestra carta executoria dello, ynserto en ella el dicho avto para que vos, el dicho obispo, la guardásedes y cumpliésedes o como la nuestra merçed fuese.

Lo qual visto por los del nuestro consejo, fue acordado que devíamos mandar dar esta nuestra carta para vos en la dicha razón. Y nos tovímoslo por bien, porque vos mandamos que veáis el dicho avto que de suso va incorporado y llegado, deis y cumplais e hagais guardar y cumplir en todo e por todo según y como en él se contiene. Y contra el tenor e forma del ni de lo en él contenido no vais ni paseis ni consintais yr ni pasar en tiempo alguno (f.192r) ni por alguna manera e non fagades ende al.

Dada en la villa de Valladolid, a veynte e siete días del mes de julio de mill e quinientos e çinquenta y quatro años. El licenciado Montalvo, el licenciado Otalora, el licençiado Arrieta, el licenziado Perosa.

Yo, Domingo de Çavala, escribano de cámara de su çesárea y católicas magestades, la fize escrevir por su mandado con acuerdo de los del su consejo. Registrada. Martín de Vergara. Martín de Vergara por chançiller.

1554, noviembre, 19. Husillos - 1554, noviembre, 22. Husillos.

Testimonio notarial de una información "ad perpetuam rei memoriam" escrito por Santiago Gómez, escribano público de Husillos, ante Pedro Ruiz de Villoldo, alcalde mayor en Husillos por Francisco de Carvajal, abad de Santa María de Husillos, y a instancia de Juan de la Torre, fiscal de la abadía, en nombre de la fábrica de dicha iglesia, de ciertas casas, tierras y viñas que posee dicha fábrica en las villas y términos de Husillos y Monzón, junto con los derechos de entrada de las dignidades, canónigos y racioneros de Husillos, detallándose de esta manera: "vnas casas con su palomar en la dicha villa de Husillos en que vive el canónigo Terradillos, que lindan por ambas partes con casas del cabildo, e por detrás la çerca de la villa, e por delante la plaçuela y 


\section{DAVID MARCOS DIEZ}

otras casas que son junto a la dicha yglesia, que lindan con casas del cabildo que tiene el canónigo Castro, y por delante la calle Pública e por detrás la claostra dela dicha yglesia; y otras casas en la villa de Monçón, las quales tiene dadas “ad vitam" por arrendamiento; y vna tierra que es en el término de Husillos, a do dizen Allende, linderos: tierras de la abadia de Husillos, la qual al presente tiene en renta Pedro de Movellán, vecino de Fuentes de Valdepero, por medio ducado de renta (f.212r) en cada vn año; e otrosy tiene sobre la dignidad de la tesorería de la dicha yglesia de Husillos tres reales en cada vn año para ayudar a las esteras del coro. Tiene más doze o treze obradas de tierra poco más o menos en término desta villa de Husillos en esta manera: a do dizen El Portillo, vna tierra que hará siete quartas, linderos: tierra de los herrenales del cabildo y tierra de la capellanía que tiene Benavides que llaman la tierra de Las Mangas; y otra tierra a aliende do dizen Las Mimbreras, que faze quatro obradas y media, que lindan con Las Mimbreras e con tierras del abad que se dize la Serna y con tierra martiniega del conçejo y otra tierra que es a Val Mayor, que fará obrada e media, que linda con tierra de Pero Ruiz de Villoldo y la carrera que viene de Valmayor. Otra tierra a do dizen La Solana que se llama la tierra del Españo que hará dos obradas y media que linda por todas partes con tierras conçegiles. Otra tierra a do dizen Vaziabolsas que haze dos obradas poco más o menos, que linda con tierras de las sernas del abad y con tierra martiniega del conçejo e tierras conçegiles; y ten vna viña en el término de Monçón al Moscatel del conde de Monçón que haze çinco quartas, linderos: tierras de herederos de Monçón; y ten otra viña en el término desta villa de Husillos al paso de Bragas, que haze tres quartas poco más o menos, linderos: de la vna parte tierras conçegiles e viñas de Pero Fernández e guindalera de los herederos de Diego de la Torre; y ten más dos tierras en término de Monçón; y ten más los derechos de las entradas del abad e benefiçiados que es que deve el abad cada vez que toma posesión del abadía diez mill maravedís a la dicha fábrica, y de cada dignidad, si tiene anexo canonicato quatro mill maravedis; e si tiene raçión entera anexa a la dicha dignidad paga quatro mill maravedís, e si no tiene anexa canongía ni raçión ni media raçión pagados mill maravedís, como vn canónigo; y el raçionero paga como vn canónigo, dos mill maravedís; y el medio raçionero paga mill maravedís, todo para la dicha fábrica”. 
Fueron testigos del interrogatorio: Diego del Fresno, vecino de Husillos; Pedro Yago, canónigo de Husillos; Pedro Hernández, vecino de Husillos; Bartolomé Alonso, canónigo de Husillos; García de Benavides, racionero de Husillos; Andrés de Castro, canónigo de Husillos; Joán Ortega de Fresno, vecino de Husillos.

$A$. APA, $L P H$, ff. 212r-214r.

B. AGS, Patronato eclesiástico, Inconexos, leg.159, ff. 181v-185v. Papel; escr. procesal; buena conservación.

1554, junio, 15 - 1554, noviembre, 19. Husillos / 1554, noviembre 19 - 1554, noviembre, 30. Husillos.

Testimonio notarial escrito por Santiago Gómez, escribano público de Husillos, por el que Gutierre de Carvajal, obispo de Placencia y tío de Francisco de Carvajal, abad de Santa María de Husillos y vecino de Placencia, por poder otorgado por este último en Valladolid el 15 de junio de 1554, inserto, visitó Santa María de Husillos y ordenó sacar traslado notarial de las escrituras de la abadía, aduciendo a su pérdida progresiva de importancia por el paso del tiempo debido al descuido y desidia, y con ello la pérdida de numerosas rentas con que fue dotada.

Da cuenta de cómo el obispo nombró como procurador fiscal del abad a Juan de la Torre, que se presentó ante Pedro Ruiz de Villoldo, alcalde mayor de Husillos, al que entregó un escrito en el que le instaba a autorizar y estar presente en los traslados de las escrituras de Husillos, y que mandara dar edictos en los lugares de la abadía que creyera conveniente para hacerlo constar a los posibles perjudicados. El alcalde mayor publica el edicto con el memorial de las escrituras a trasladar en la puerta de la iglesia de Husillos y de Villaldavín. Al no haber alegaciones de ningún perjudicado, se procede al traslado de las escrituras 
por Santiago Gómez, en presencia de Pedro Ruiz de Villoldo y a requerimiento de Juan de la Torre.

A. APA, $L P H$, ff. $1 \mathrm{r}-2 \mathrm{v}$.

B. AGS, Patronato eclesiástico, Inconexos, leg.159, ff. 5r-8r. Papel; escr. procesal; buena conservación.

Causa el tiempo oluido de las cosas y el mismo nos a mostrado el remedio para que las pasadas las tengamos como presentes por las escrituras; y así sabemos de la creación del mundo y del delluuio y del naçimiento y pasión de nuestro Redentor como si nos halláramos presentes, y de otras muchas cosas que la memoria de los honbres no pudieran retener. Y vsando deste rremedio, el primero abbad desta iglesia de Husillos llamado don Remón, dexó tantas escrituras de preuilegios y donaçiones a esta yglesia que si no fuera por el descuido y negligencia de sus susçesores en poner tan mal rrecaudo en los dichos preuilegios y donaçiones, de cuya causa vnos se han perdido y otros tan maltratados que no se pueden leer ni dar fe a ellos, fuera vna de las más rricas dignidades de abadía deste rreyno. Y con la pérdida de las escrituras se an perdido la mayor parte de las rrentas de que fue dotada. Y porque este yerro y descuido no pasase adelante, el muy illustrísimo señor don Gutierre de Carauajal, obispo de Plazençia, visitando la dicha abbadía por poder de don Françisco de Carauajal, abad de Husillos, su sobrino, por el amor y obligación que le tenía, hizo pareçer ante sí todos los preuilegios, donaçiones y otras escrituras que se hallaron en los archivos desta abadía. Y de los que se pudieron leer y dar fee, mandó se sacasen traslados autorizados en este libro para que quando fuese menester alguna escritura se viese pora aquí y no se sacasen las escrituras originales; las quales mandó estouiesen en vna caxa con tres llaues en poder del prior y de vn canónigo, el más antiguo, y del secretario del cabildo, en cada vno la suya. Y si en algún tiempo por mandamiento de su majestad o de su rreal consejo o chancillerías o de otro juez que para ello tenga poder, fuere mandado exibir alguna escritura original o fuere menester presentalla, lo lleue el secretario del dicho cabildo a presentar. Y si le fuere mandado dexar y no la pudiere boluer, sea obligado a traer conocimiento del secretario o escribano ante quien la presentó y ponelle en el 
dicho archivo, so pena de si de otra manera el dicho cabildo mandare dar ni sacar ninguna escritura por el mismo caso, yncurran en pena de doscientos ducados para la fábrica de la dicha iglesia de Husillos y queden obligados al daño si la tal escritura se perdiere a quien tocare el ynterese della, y que se notifique al cabildo y secretario porque no pretendan ignorancia.

Testigos que fueron presentes: el licenciado Laguna, y Joán Ruiz Cabeça de Vaca, y Luis López, clérigos, criados de su señoría el obispo de Plazençia. Por mandado de su señoría, Santiago Gómez, su secretario.

$<$ Poder del abbad a su señoría $>$

(Sigue doc. núm. 269)

Por virtud del qual dicho poder suso incorporado, su señoría nonbró por fiscal de la dicha abbadía y visita de la dicha iglesia de Husillos a Joán de la Torre, estante en la dicha villa, y pedió poder bastante para vsar del dicho ofiçio.

En la villa de Husillos, a diez y nueue días del mes de nouienbre, año del nacimiento de nuestro saluador Ihesu Christo de mil y quinientos y çinquenta y quatro años, ante el muy noble señor Pero Ruiz de Villoldo, alcalde mayor en la dicha villa de Husillos y en toda su abadía por el muy magnífico señor don Francisco de Carauajal, abbad de Husillos, y en presençia de mí, el escriuano público y testigos, pareçió presente Joán de la Torre, estante en la dicha villa, fiscal del dicho señor abad en la dicha abbadía, nombrado por el muy illustrísimo señor don Gutierre de Carauajal, obispo de Plazençia, por el poder que su señoría tiene del dicho don Francisco, abbad de Husillos, para la visitación que de la dicha abadía se haze, y presentó vn escrito del tenor siguiente.

Muy noble señor: Joán de la Torre, procurador del muy magnífico señor don Francisco de Carauajal, abad de Husillos y toda su abbadía y su procurador fiscal en ella por lo (fol. 1v) que toca a la conseruaçión y perpetuidad de los bienes, derechos y otras cosas tocantes a la dicha abadía, y por aquella vía que mejor de derecho lugar aya, digo que la dicha dignidad abacial tiene muchas escrituras a ella y a sus bienes y derecho tocantes, entre las quales ay algunas muy antiguas. $Y$ que por su antigüedad podrían no poder de leer andando el tiempo, de manera que 
se viçiasen y algunas podrían perderse, de lo qual la dicha abadía rreçebiría gran perjuizio; porque pido a vuestra merced mande ver las dichas escrituras, que por mí ante vuestra merced serán presentadas. $\mathrm{Y}$ ansí vistas mande al presente escribano saque o haga sacar vn traslado, dos o más de las dichas escrituras. Y signadas en pública forma me lo mande dar, interponiendo vuestra merced a los tales traslados, su autoridad y decreto judicial, para que en todo tiempo hagan entera fee. Para lo qual y para ello mande poner sus editos en las partes y lugares desta abbadía que vea que conuengan para que venga a notiçia de todos y les pueda parar perjuizio con término competente.

E presentado el dicho escrito dixo y pidiolo en él contenido. Y el dicho señor alcalde mayor dixo que lo auía y ouo por presentado y mandó fixar sus cartas de hedito en vna de las puertas de la yglesia de la dicha villa de Husillos, y otro en vna de las puertas de la iglesia de la villa de Villandauín, con término de seis días primeros siguientes. Los quales dichos editos se dieron forma. Testigos que fueron presentes: Diego de Vega y Pedro Manuel, criados de su señoría, estantes en la dicha villa.

$<$ Edito $>$ Pero Ruiz de Villoldo, alcalde mayor en esta villa de Husillos y su abadía y términos y jurisdicción, por el muy magnífico señor don Francisco de Carauajal, abad de la dicha abadía, por la presente hago saber a todas y qualesquier personas, vezinos y moradores desta villa de Husillos y de otras partes qualesquier a quien toca y atañe lo contenido en esta carta y tocar y atañer puede en qualquier manera, que ante mí pareçió Joán de la Torre, físcal de la dicha abbadía en nonbre del dicho señor abad, y me hizo rrelaçión por su petición diziendo que la dicha abadía tiene privilegios y donaçiones y otras escrituras antiguas tocantes a la fundaçión de la iglesia desta villa de Husillos y a sus bienes y de la dicha abadía y a los términos y eredades della y deslindos como se contiene en vna memoria que ante mí presentó de todas las dichas escrituras, de las quales diz que tiene necesidad de sacar algunos traslados autorizados porque no perezcan las dichas escrituras originales para en guarda y conseruaçión del derecho de la dicha yglesia y abadía. Por tanto, si alguna persona de vos, las sobredichas, pretende que agora o en algún tiempo le podrían perjudicar los traslados que ansí se pide se saquen de las dichas escrituras o de alguna dellas, y se quiere hallar presente a lo ver, sacar, 


\section{LA ABADÍA DE SANTA MARÍA DE HUSILLOS: ESTUDIO Y COLECCIÓN \\ DOCUMENTAL $(904-1608)$}

corregir y conçertar con el dicho original, parezca ante mí en esta villa de Husillos dentro de seis días primeros siguientes del día de la fixaçión deste edito, que les doy por tres términos y todos por plazo y término perentorio a lo uer, sacar, corregir y conçertar con el original, con aperçebimiento que les hago que si en el dicho término pasado no pareciendo sus rrebeldías acusadas se hará en su ausencia y les parava y podrá parar tanto perjuizio como si en sus presençias se hiziese. Y porque venga a notiçia de todos y dello no puedan pretender ynorançia, mandé fixar la presente con el dicho memorial en vna de las puertas de la iglesia de la dicha villa donde esté fixada el dicho término. Fecha en la villa de Husillos, a diez y nueue días del mes de nouienbre de mil y quinientos y çinquenta y quatro años. (fol. 2) Pero Ruiz de Villoldo. Por su mandado, Santiago Gómez.

$<$ Fixaçión $>$ En la villa de Husillos, a (en blanco) días del mes de nouienbre del dicho año de mil y quinientos y çinquenta y quatro años. Yo, el presente escribano, doy fee que puse y fixe la carta de edito de suso contenida con el memorial de las escrituras de que en ella se haze mención en las puertas de la iglesia de Santa María de la dicha villa de Husillos. Testigos que fueron presentes a lo ver, fixar.

Y otro tal edito como éste se lleuó a la villa de Villandauín para fixar en las puertas de la iglesia de la dicha villa con el dicho memorial. El qual se fixó y estuvo afixado según pareçió por fee de (en blanco).

$<$ Rebeldía $>$ E después de lo susodicho en la dicha villa de Husillos, a (en blanco) días del dicho mes de nouienbre del dicho año de mil y quinientos y çinquenta y quatro años, ante el dicho señor alcalde mayor y en presençia de mí, el dicho escriuano y testigos, pareçió presente el dicho Joán de la Torre, fiscal sobredicho, y acusó la rrebeldía de los dichos editos a las personas en ellos contenidas que no pareçen, y pidió al dicho señor alcalde mayor los aya por rebeldes y en su ausencia mande sacar los dichos traslados de las dichas escrituras como pedido tiene. Y el dicho señor alcalde mayor dixo que auía y ouo por acusada la dicha rebeldía y auía y ouo por rrebeldes las personas contenidas en el dicho edito. Y vistas las dichas escrituras, dixo que mandaua y mandó a mí, el dicho escriuano, saque o haga sacar de cada vna dellas vn traslado, dos o más, los que por el dicho 
Joán de la Torre me fueren pedidos y signados de mi signo en pública forma, en manera que haga fee, se los dé y entregue para en guarda y conseruaçión del derecho de la dicha iglesia y abadía. A los quales dichos traslados y a cada vno dellos, yendo signados de mi signo como dicho es, dixo que ynterponía y ynterpuso su autoridad y decreto judicial en tanto quanto podía y de derecho deuía para que valgan y hagan fee para agora y para siempre jamás, doquier que pareçieren en juicio y fuera del, y lo firmó de su nombre. Testigos que fueron presentes: Joán Ruiz Cabeça de Vaca y Luis López, clérigos, y Joán de Vargas Çapata, criados de su señoría, estantes en la dicha villa. Pero Ruiz de Villoldo.

E luego, yncontinenti, yo, el dicho escribano, por virtud del dicho mandamiento, saqué y hize sacar de las escrituras contenidas en el dicho memorial que por el dicho Joán de la Torre me fue pedido traslado dellas, de cada vna vn traslado según y de la manera que en los originales de donde las saqué están escritas, su tenor de los quales dichos traslados y de las escrituras de donde se sacaron es este que se sigue.

$<$ Fixaçión $>$ Pero Ruiz de Villoldo, por su mandado, Santiago Gómez.

1554, diciembre, 8. Husillos.

Estatutos mandados realizar por Gutierre de Carvajal, obispo de Placencia, tío de Francisco de Carvajal, abad de Santa María de Husillos. Dichos estatutos fueron ordenados durante la visita que realizaba el primero a la abadía y como remedio a las deficiencias encontradas, estando formados por veintiuna cláusulas en las que se dispone sobre los objetos litúrgicos y las reliquias, el servicio litúrgico, la administración de sacramentos, la sacristía, el coro, las votaciones en el cabildo, el vestido, la prohibición de tratar con mujeres sospechosas y de realizar oficios viles. 
$A$. APA, $L P H$, ff. $239 \mathrm{r}-242$ r.

Crió Dios todas las cosas en orden y con orden como dize San Pablo y ansí los que desta quisieron salir luego, fue con ellos el castigo diuino como fue en Lucifer, que no quisiendo guardar aquel estado y orden en que Dios le hauía criado a la hora, fue echado a los infiernos con todos sus secuaces, y como gente que no quiso guardar orden perpetuamente lo están sin ella como dize el Evangelio "vbi nullus ordo". Et assy están hechos enemigos de todas las cosas que orden guardan y assy procuró de ordenar a nuestro padre Adán, haziéndose no guardasse la orden que Dios le hauía dado en el paraíso terrenal, y luego que se desordenó le fue dado el castigo. Y no satisfecho con esto siempre anda "circuit querens quem deuoret" especialmente aquellos que vel que más orden guardan o lo deurían guardar, como son las personas eclesiásticas. Y ansy hauemos de tener más cuydado y velar para no caer en manos de tan ruin y çeuil enemigo. Y porque las ouejas se descuydan muchas vezes $\sin$ orden entrando do no deuen, se ordenaron pastores que velasen sobre ellas, que vnas vezes con ejemplo y otras con doctrina y otras con el cayado las hiciese boluer a orden. Y de la vna parte destas siruen las constituciones synodales y ordenamientos. Y aunque ay hartos hechos por el derecho canónico, por no cabellos todos se ponen constituciones y rreglas para que tiniéndolas más "pre manibus" vean lo que deuen hazer y de qué se deuen apartar, aunque no con tanto rigor como el derecho lo tiene ordenado. Y porque por falta de pastor que desto aya tenido cuidado paresçe a hauido algún descuydo en el seruiçio desta yglesia de Huyllos, nos, don Gutierre de Caruajal, obispo de Plazençia, por asegurar la conciençia de don Francisco de Caruajal, abbad de Husillos, mi sobrino, por cuyo poder visito esta abbadía, mandamos, so pena de excomunión, se guarden y cumplan los statutos y cosas siguientes en esta yglesia de Husillos por el prior y cabildo y personas eclesiásticas y seglares desta yglesia y abbadía, so las penas en ellas contenidas.

1. Primeramente, que de quinze a quinze días en inuierno y de ocho a ocho días en verano, el cura renueve el sanctíssimo sacramento, consumiendo las reliquias que estuuieren en la custodia y limpiándola muy bien y cubriendo el sanctíssimo sacramento con paños muy limpios como conuiene a tal lugar o a lo menos como nuestra flaqueza puede. Y si el cura que lo contrario hiziere, demás de incurrir en 
las censuras puestas, caya en pena de quatro rreales para la fábrica de la dicha yglesia por cada vez que fuere en lo susodicho negligente. Y so la dicha pena, mandamos al dicho cura siempre tenga el sagrario cerrado con llaue, la qual no encomiende a nadie sino que él la trayga siempre consigo si no fuere en tiempo que estuviere ausente o impidido justamente o con enfermedad y sea necesario rrenouar el sanctíssimo sacramento o administrallo a algún enfermo. Y que en el sagrario donde está el sanctíssimo sacramento no tenga otra cosa alguna, so la dicha pena.

2. Otrosy, mandamos al dicho cura que la chrisma y olio y olio (sic) infirmor? (f.239r) esté siempre en chrismeras y ampollas limpias y sanas y se rrenueue en cada año, so pena por cada cosa con que lo contrario hiziere de quatro rreales para la dicha fábrica. Las quales chrismeras y ampollas mandamos las tenga en vna alacena con llaue junto a la pila del bautismo; y en otro seno más baxo de la dicha alacena tenga la sobrepelliz y estola y manual para administrar los sanctíssimos sacramentos. Y la llaue de la dicha alacena la trayga consigo como dicho es de la custodia, so las dichas penas.

3. Otrosy, que cada mes tenga cuydado el dicho cura de labar las pilas del bautismo y fregalla para que siempre esté muy limpia y no se críe moho ni otra cosa suzia en ella y esté tapado el sumidero muy bien porque del no salga como de parte húmida ninguna cosa suzia. Y que cada vez que huuiere de administrar el sacramento del bautismo, no lo administre sin primero labar la dicha pila, puesto que la aya labado vn día antes; y siempre esté la dicha pila cubierta con su paño y tapador y su capilla cerrada con llaue, por manera que ninguno pueda entrar dentro por los inconvenientes que de lo contrario se podrían recrecer. Y por cada vez que lo contrario hiziere, cayga en pena de dos rreales para la dicha fábrica.

4. Otrosy, mandamos al dicho cura que las reliquias que están en esta yglesia estén con la limpieza y guarda que conuiene a tan sanctas reliquias y su custodia cerrada con llaue, la qual no dé a persona ninguna, so la dicha pena. So la qual le mandamos no muestre a nadie las dichas reliquias si no fuere por mandado de su prelado o juez o por mandado del prior y cabildo desta yglesia, so pena de quatro rreales por cada vez que lo contrario hiziere.

5. Otrosy, mandamos al dicho cura tenga gran cuydado de administrar los sacramentos a quien los huuiere menester y que por negligencia ni descuydo no se 


\section{LA ABADÍA DE SANTA MARÍA DE HUSILLOS: ESTUDIO Y COLECCIÓN \\ DOCUMENTAL $(904-1608)$}

le muera ninguno sin ellos. Y que por esto no salga de la dicha villa a parte ninguna sin dexar cargo a otro sacerdote que para administrar sacramentos tenga licencia, so pena que sy alguno por su culpa muriere sin administralle todos los sacramentos, esté por cada negligencia que hiziere él o su substituto quinze días en la cárcel con prisiones y pague vn ducado para dezir de misas por el ánima del tal difunto.

6. Otrosy, mandamos al dicho cura y a otro qualquier clérigo, so la dicha pena de excomunión y de vn ducado para la dicha fábrica, no sea osado de administrar el sacramento del bautismo en casa ninguna si no fuere en caso de extrema necessidad.

7. Otrosy, mandamos al dicho cura y a otro qualquier clérigo de missa, no sea osado de dezir missa en casa particular en esta villa ni su jurisdición, si no fuere en la yglesia, atento la incidencia que en qualquier casa particular puede hauer ni dar ornamentos ni cáliz ni rrecaudo alguno para que otro lo haga, so pena de quatro rreales por cada vez que en cada vna cosa destas contraviniere aunque se ofrezca estar enfermo alguno, pues basta lleuarle el sanctíssimo sacramento.

8. Otrosy, mandamos al dicho cura que haga tabla o memorial de todos los $(f .239 v)$ vezinos y personas desta villa que se deuan confesar, repartiéndolos por las semanas de toda la cuaresma por yguales partes. Y el primer día de cuaresma durante el offertorio declare públicamente con voz alta que lo puedan todos entender por sy o por otra persona, las personas que en la semana siguiente y en los días que han de venir a confessarse para que se aperçiban. Y de ay adelante sea hecho aperçebimiento cada domingo por manera que ocho días antes tengan cuydado de recorrer sus conciencias. Y no haziendo lo susodicho según dicho es, cayga en pena de quatro rreales para la fábrica por cada vez que dexare de hazer la dicha publicación. Y el vezino que no se viniere a confesar el día que le fuere señalado, en pena de vn rreal para la dicha fábrica, y no sea confessado hasta ser passados los señalados en sus días sy al dicho cura no le sobrare tiempo y por su voluntad le quisiere confesar.

Y los que vn día confessare los comulgue otro a los que tuuiere bullas por el inconveniente que se podría recrecer delatando la comunión. Y el que no viniere a comulgar el día y le cupiere, incurra en otro rreal de pena para la dicha fábrica. Y porque podrían estar algunos ausentes desta villa al tiempo que los publicasen 
venirse a confesar, luego que fuere venido a la dicha villa mandamos dentro de ocho días se vaya a confesar y rreçebir el sanctíssimo sacramento, so pena de dos rreales para la fábrica de la dicha yglesia y que no sea admitido a los diuinos oficios hasta tanto que se confiesse y comulgue.

Y passados los ocho días que se les da de término para confesarse y comulgarse, siendo rrebelde en no lo hazer, mandamos al dicho cura a los tales por sy o por otro los publique en la yglesia cada domingo y fiesta por no confesados. Y para que sobre esto se tenga quenta, mandamos al dicho cura haga sus padrones según dicho es. Y quinze días después de passada pascua de flores, entregue el dicho padrón al abbad con su oficcial, poniendo y señalando los no confesados y que y no ayan rreçebido el sacramento de la comunión para que se prouea en su rremedio lo que conuiene.

9. Otrosy, por quanto el prinçipal cargo y cuydado que el cura deue tener es que sus feligreses vayan a parayso y ésto no pueden conseguir sin saber los artículos de la fe y firmemente creellos, mandamos al dicho cura que esto tenga especial cuydado y para ello enseñe la doctrina cristiana cada domingo en la yglesia a todos los que vinieren aprender della. Y para esto mandamos, so pena de excomunión y de vn rreal de plata, a todos los vezinos desta villa envíen sus hijos y criados y criadas a aprender la dicha doctrina christiana que sean de seys años arriba los que no la supieren, so pena que el que no los enbiare cayga en pena por cada vez de vn rreal para la dicha fábrica. Y el que tuuiere impedimento para no lo poder hazer por la necessidad que de sus hijos o criados tuuiere, venga a lo dezir al dicho cura. Y porque los de mayor edad según el mundo es podría ser no viniesen a aprender la dicha doctrina, mandamos que porque no se puedan excusar de no saber lo que tanto les conuiene, que mientras el ofertorio se hiziere el dicho cura, por sy o por otro, diga en voz alta que todos lo entiendan desde la tribuna o choro el credo en rromançe para que todos lo puedan aprender. Y para más cumplimiento de lo dicho mandamos al dicho cura y a todos los clérigos que tuuieren licencia de administrar $\mathrm{sa}(f .240 r)$ cramentos, que no desposen a nadie ni le velen sy primero no supiere el "Aue María” y "Pater Noster", "Credo" y "Salue Regina", porque de señales de obras de la fe que profesaron en el bautismo; y el que no lo supiere no le desposen ni velen. Y el clérigo que lo contrario hiziere desposando o velando contra esta nuestra prohiuiçión, caya en pena de vn ducado 


\section{LA ABADÍA DE SANTA MARÍA DE HUSILLOS: ESTUDIO Y COLECCIÓN \\ DOCUMENTAL $(904-1608)$}

para la dicha fábrica. Y el cura que faltare de enseñar la dicha doctrina y dezir el “Credo" según está dicho, cayga en pena por cada vez que no lo cumpliere de vn rreal para la dicha fábrica.

10. Otrosy, mandamos al dicho cura y cabildo que la missa mayor de cada domingo o fiesta de guardar se diga especialmente por el pueblo y no por otro alguno, pues por esto se dan los diezmos y primicias a la dicha yglesia y sus seruidores. Y esto sin meter colleta ni conmemoración por otro ninguno más de su oraçión general.

Otrosy, mandamos al dicho cura que por administrar los sacramentos no pueda lleuar ni lleue derechos ningunos ni otro clérigo que por ellos administrare, si no fuere por el del bautismo, la torta y vela que se suele offreçer y el capillo para el sacristán. Y en las velaciones, las velas o ofrenda que se suele dar. Y por el de la extrema vnçión, los derechos que se suelen lleuar por el plato y no otra cosa ninguna. Y sy esto lo solía lleuar el sacristán, lo lleue, so pena que sy otra cosa alguna lleuare por la administración de los dichos sacramentos o por el de la confissión lleuare algo, cayga en pena por cada vez que contraviniere de vn rreal de plata para la dicha fábrica.

11. Otrosy, mandamos, porque es justo como dize el apóstol, que el que siruiere al altar del altar, viua y atento la variedad de los tiempos y (...)? de las cosas ansy se altere la sustentación a los que siruen en la yglesia, pues no son de menos condiçión que los otros que siruen en el mundo antes de más, pues no ay peón ni labrador que por yr a las viñas o a otra hazienda no pida tres y quatro rreales con el comer, que aunque no tanto es justo que la limosna que se da a vno que se ocupa en celebrar la salud spiritual y temporal de alguno se le dé alguna congrua sustentación. Y por tanto mandamos que de aquí adelante ningún clérigo reciba menos de a veynte y cinco maravedís, assy por missas votiuas como funerales, y con las funerales la ofrenda que se acostumbra a dar. Y quen la missa que se huuiere de dezir por alguno votiua o funeral no meta coleta ni conmemoración por otro alguno de quien huuiere rreçebido limosna, pues no puede cumplir con lo que deue a dos por vna missa, so pena que lo contrario haziendo "in foro concientia", sea obligado a restituir con el doblo a qual a quien defraudó, metiéndole en colleta o conmemoración, y más incurra puediéndossele probar en pena de vn ducado para la fábrica de la yglesia. 
12. Otrosy, mandamos que para el seruicio de la yglesia se ponga sacristán por la persona que es obligada a ello, que no sea casado, háuil y suficiente, para poder seruir el dicho officio; y que tenga vn mochacho en la dicha sacristía que pueda seruir a las missas y ayudar a vestir los ministros. Y que de la fábrica se dé a este mochacho vna ropa morada cada año; y de la mesa capitular, pues se lleuan todos los diezmos, provean de tener otro vestido de (f.240v) la misma manera, los quales puedan seruir como moços de coro para dezir sus versos y otras cosas del seruiçio del coro. $\mathrm{Y}$ en las missas y procesiones lleuen los çirios y el sacristán la cruz, porque es cosa de afrenta e ignominia que desto siruan los capitulares, porque no es cosa justa ni decente y puedan seruir, entramos mochachos de ayudar a dezir las missas y el otro seruiçio de la yglesia.

13. Otrosy, mandamos al dicho sacristán tenga mucho cuydado de tener muy limpios los altares e yglesia y todos los otros ornamentos, so pena sy en esto fuere descuydado que sea despedido y no se le pague el terçio de su salario.

14. Otrosy, mandamos tenga cuydado de tañer a todas las horas según es vso y costumbre de tañerse en todas las yglesias catedrales y de tener en conçierto el rrelox para que sepa a las horas que ha de tañer y se han de dezir las horas y otros diuinos oficios, so la dicha pena sy en ello fuere negligentes.

15. Otrosy, tenga el dicho sacristán mucho cuydado de la limpieza de los corporales y hijuelas y manteles, so la dicha pena.

16. Otrosy, por quanto somos informados se tiene mucho descuydo en el seruicio del coro, no tiniendo rrespecto ni obediencia a su prior ni por nadie que en su ausencia está en el choro, y en él se tratan muchos negocios acabadas algunas horas, no siendo lugar para aquello sino para dezirse los diuinos oficios y alabar a Nuestro Señor, de cuya causa algunas vezes en el tal lugar vienen a hauer quistiones y discordias, porque mandamos y ordenamos que dentro del dicho choro en ausencia del abbad se obedezca en todo y por todo al prior de la dicha yglesia o al que presidiere en su lugar. Y que lo que aquel mandare y ordenare, se cante y diga y se le pida licencia, ofreciéndose necessidas alguna de salir de las horas. Y que sin su licençia ninguno se pueda salir, so pena que en qualquier cosa que hiziere contra lo proueydo y mandado dentro del dicho choro, cayga e incurra en las penas que el dicho prior o presidente le pusiere. Y mandamos sean executadas y multadas sin esperar otra cosa ninguna. $\mathrm{Y}$ sy alguno se tuuiere por 
agrauiado de lo que ansy el dicho prior o presidente mandare, ocurra al abbad o a su juez, mas que por esto no se dexe de ejecutar la dicha pena hasta que sea visto. Y lo mismo guarden y cumplan en guardar el silençio que allí se deue tener.

Y so pena de vn ducado para la dicha fábrica, mandamos que ningún capitular sea osado después de dicha prima ni otra hora ninguna tratar en el choro de algún negoçio, sino que para ello, o se entren en el capítulo, pues lo tienen tan cerca, o se vayan a la claustra a tratillo, en la qual dicha pena cayga e incurra cada capitular por cada vez que lo contrario hiziere.

17. Otrosy, so la dicha pena, mandamos que pues es ofiçio del sochantre entonar los salmos e ymnos y otras cosas, y del semanero capitular y dezir su oración, que ninguno se entrometa a capitular ni dezir oraçión si no fuere el semanero o a quien él lo dexare encargado por su ausencia. Y que ninguno diga ni entone antíphona ni salmo sino quien el sochantre lo encomendare.

18. Otrosy, so la dicha pena, mandamos por quanto estamos informados que (f.241r) en el votar en cabildo no se tiene orden ni concierto ninguno, de cuya causa algunas vezes se recresden inconvenientes, que quando en cabildo se entrare el qual hagan cada semana ordinariamente vna vez al viernes para platicar en las cosas del seruiçio de la yglesia y su hazienda, proponga el prior con el que presidiere el negoçio y sobre ello cada vno comiençe a votar y dezir su parecer en sus lugares por su antigüedad. Y después de hauello dicho no tornen a hablar en ello sin que primero ayan votado todos los demás capitulares. Y votado el negocio se assienten los votos por el secretario del cabildo. Y lo que la mayor parte huuiere votado y mandado, aquello se execute y cumpla ansy en los negocios del seruicio de la yglesia y de hazienda como en los de justicia, saluo en los de graçia, que hauiendo vn voto contrario no se pueda hazer. Y baste para impedir que no se haga el tal negocio de (...)?.

Y porque la decencia del háuito es muy necessaria, mayormente en las personas eclesiásticas, y con que más muestran la sinceridad del alma, mandamos cerca de los dichos trages y vestidos se guarde en orden siguiente:

19. Primeramente, que ninguno de ninguna qualidad, preminencia o dignidad que sea ecclesiático, trayga çapato ni alcorque ni otro género de calçado de ninguna seda ni della ni de cuero, trayga çapatos acuchillados, so pena de perder el dicho 
calçado y de dos rreales, la mitad para la dicha fábrica y la otra mitad para el denunciador.

Otrosy, que ninguno trayga calças ni jubón de color que no sea muy honesta de negro o pardo. Y que el que lo contrario traxere, lo tenga perdido y más cayga en pena de quatro rreales aplicados según de suso, aunque permitimos a las dignidades puedan traer de verano vn jubón de casa.

Otrosy, que por ninguna vía puedan traer vestido ninguno de seda ni rropa ninguna de color que no sea negra o de color de buriel, agora sea yendo camino como a casa como en el lugar, so pena de tener perdida la dicha rropa, la qual aplicamos a los pobres del hospital, aunque permitimos a las dignidades traer vecas de tafetán.

Otrosy, mandamos que en la yglesia ni por el pueblo ningún clérigo sea osado a andar en cuerpo sin traer sobre el sayo o hopa? otra rropa. Y que los sayos no sean menos largos de hasta la rrodilla que puestos de rrodillas bese en el suelo. Y el que lo contrario hiziere, tenga perdida la rropa, aplicada según de suso; y el que anduviere en cuerpo, cayga en pena de dos rreales para la fábrica.

20. Otrosy, mandamos so pena de excomunión y de vn marco de plata, la mitad para la dicha fábrica y la otra mitad para los pobres del dicho hospital, ninguno se sirua de mujer sospechosa en su casa. Y declaramos ser mujer sospechosa la que por tal estuviere declarada. Y mandado por el abbad o su juez y le fuere amonestado, la eche de su casa. Y so la dicha pena que ningún clérigo sea osado seruirse en los diuinos oficios de sus hijos sy los stuuiere ni traellos por la mano en lugares públicos, por el mal ejemplo que se da de lo susodicho.

21. Otrosy, mandamos que ningún clérigo especialmente de orden sacro, vse (f.241v) officio çeuil de arar y sembrar ni rrozer ni otro officio que trayga a vilipendio a la orden que tiene, so pena de dos rreales por cada vez que lo contrario hiziere aplicados para la dicha fábrica y hospital y denunciador, tercia parte para cada vno.

Las quales dichos statutos-ordenaciones mandamos al provisor que es o fuere de la dicha abbadía, las haga guardar y cumplir según y como en ellas se contiene, so la pena dellas. 


\section{LA ABADÍA DE SANTA MARÍA DE HUSILLOS: ESTUDIO Y COLECCIÓN \\ DOCUMENTAL $(904-1608)$}

Fechas en la dicha villa de Husillos, a VIII ${ }^{\circ}$ días del mes de diciembre del año de MDLIIII ${ }^{\circ}$ años.

(rúbrica) El obispo de Plazencia (rúbrica).

Por mandado de su señoría illustrísima, Gaspar de Vedoya (rúbrica).

\section{8}

1555, enero, 1. Husillos - 1555, enero, 18. Husillos.

Inventario de propiedades de la fábrica, mesa abacial, hospital y mesa capitular de Santa María de Husillos, mandado realizar por Gutierre de Carvajal, obispo de Plasencia y tío de Francisco de Carvajal, abad de Santa María de Husillos. El motivo fue el grave estado de deterioro y pérdida en que se encontraba el dominio y la documentación de Santa María de Husillos que lo justificaba.

A. APA, $L P H$, ff. $214 \mathrm{r}-224 \mathrm{v}$.

B. AGS, Patronato eclesiástico, Inconexos, leg.159, ff. 185v-200v. Papel; escr. procesal; buena conservación.

C. ARCHV, Salas de lo Civil. Pérez Alonso (OLV). Caja 136-1. Traslado sacado de A, aportado como prueba en un pleito olvidado (1735-1736) del concejo de Husillos con Marcelo Antonio de Tovar, canónigo y cura mayor de la colegiata de Ampudia, gobernador de la iglesia de Husillos y procurador de la colegiata de Ampudia, sobre la nulidad de las elecciones de los oficios de justicia en la villa de Husillos.

En el capítulo de las rentas del hospital de Husillos, se indica que el año en que se escribe el documento es 1555. Como la fecha del traslado del siguiente documento escrito en el Libro de los Privilegios es el 18 de enero de 1555, la fecha en que se escribió debe estar comprendida entre el 1 y el 18 de enero de 1555 .

Hace relación en el capítulo de las rentas del abad de una escritura del fuero de Husillos que dio el abad Gutierre Pérez a los vecinos de Husillos. 
En cada posesión se da referencia del número de folio del Libro de los Privilegios en que el documento está trasladado. No obstante hay un buen número de posesiones en las que no hay referencia, y aunque en ocasiones se debe a una omisión descuidada o intencionada del amanuense del inventario, otras veces tales documentos justificativos no habrían sido trasladados al Libro de los Privilegios descuidadamente, ya que posteriormente a este documento solamente aparece en el Libro de los Privilegios el censo de las casas de la Calle de La Costanilla de Valladolid, o bien porque dichos documentos estarían perdidos, destruídos o fuera de la abadía.

Y aunque por las dichas escrituras pareçe que la dicha iglesia de Husillos fue dotada de muchas y grandes posesiones, por negligencia y descuido de los pasados se ha perdido la mayor parte dello; porque aunque en alguna de las escrituras arriba contenidas consta de las dichas donaçiones, a tanto tiempo que está perdidas que por ninguna vía se puede rrecuperar, speçialmente estando muchas de las dichas escrituras por el dicho descuido vnas rrotas y otras tan maltratadas que no se pueden leer, y otras sin autoridad ninguna; de cuya causa no hay que fazer cuenta de lo que fue dotada la dicha abadía, sino de lo que al presente tiene y posee. E para que dello aia claridad, su señoría mandó poner en este libro las rrentas que al presente posee la fábrica desta iglesia y mesa abacial y capítulo, faziendo relaçión en cada partida de la escritura y título que para ello tiene la dicha yglesia, que son los siguientes:

Renta de la fábrica.

Tiene vnas casas con su palomar en la villa de Husillos, en que vive el canónigo Terradillos, que rrentan al presente dos mil e doscienctos maravedís. No parece quien las dexase. A por linderos de anbas partes: casas de cabildo; y por detrás, la cerca de la villa; y por delante, la plazuela. Poseelas por virtud de la probanza que está en este libro a fojas CCXII.

Tiene sesenta y ocho maravedís de censo perpetuo sobre unas casas y suelo que el cabildo dio a censo a Juan Santos, labrador, vecino de Husillos, que eran de la fábrica de la dicha yglesia, que lindan con casas del cabildo y con casas del canónigo Sebastián de Mena, y con casas de Alonso de Aguilar; por delante la calle que va a la puerta nueva según parece por una escritura de censo fecha a primero de julio de mil quinientos cincuenta y tres años, que pasó ante Andrés de Castro, secretario del cabildo, que está en este libro. (f.214r) 


\section{LA ABADÍA DE SANTA MARÍA DE HUSILLOS: ESTUDIO Y COLECCIÓN \\ DOCUMENTAL $(904-1608)$}

Tiene más unas casas junto a la iglesia, linderos: casas del cabildo, que tiene el canónigo Castro, y por delante la calle pública, y por detrás las otras de la iglesia; las quales al presente rentan cuatro reales; y quien las dexase a la iglesia no se sabe más de poseer ellas por virtud de la información que está en este libro a folio CCXII.

Tiene más otras casas en la villa de Monzón, las cuales tiene dadas “ad vitam” por arrendamiento; rrentan en cada vn año doscientos y veinte un maravedís; no se sabe quien las dexase a la iglesia, más de poserellas por virtud de información que está en este libro a folio CCXII.

Tiene más vna tierra en término de Husillos, a do dizen Aliende, linderos: tierras del abadía de Husillos; las cuales al presente tiene a rrenta Pedro de Movellán, vecino de Fuentes de Valdepero, por medio ducado de rrenta en cada vn año. La cual dicha tierra no se sabe quien la dexase a la dicha yglesia, más de poseer ella por virtud de la información que está en este libro a folio CCXII.

Tiene sobre la dignidad de la tesorería de la dicha iglesia de Husillos, tres reales en cada vn año para ayuda a las esteras del coro. Título ni escritura dello no parece, más de llevar por virtud e la información que está en este libro a folio CCXII.

Tiene más doce o trece obradas de tierras poco más o menos en termino desta villa de Husillos, en esta manera: a do dicen El Portillo, una tierra que era siete cuartas, lindes: tierra de los Herreros del Caballero y tierra de la capellanía que tiene Benavides que llaman la tierra de Las Mangas; y otra tierra aliende do dizen Las Mimbreras, que hace quatro obradas; y más que lindan con Las Mimbreras y con tierras de labrar que se dicen La Serna, y con tierra martiniega del concejo. Otra tierra que es a Valmayor, que hera obrada y más, que lindan con tierra de Pedro Ruiz de Villoldo y la carretera que viene de Valmayor y conçegil. Otra tierra a do dizen La Solana, que se llaman la tierra del Espino, que hera dos obradas y media, que linda por todas partes con tierras concejiles. Otra tierrra do dizen Vazias Bolsas, que haze dos obradas poco más o menos, que linda con tierras de las sernas del abad y con tierra martiniega del concejo y con tierras concejiles; las cuales al presente rentan cinco reales y cuatro cargas de pan por mitad trigo y cebada; y quien en las dexase a la iglesia no hay memoria más de que las posee por virtud de la información que está en este libro a folio CCXII. 
Tiene más vna viña en término de Husillos al pago de Beça que hace quatro cuartas, que lindan por las dos partes con viñas de los herederos de Diego de la Torre y de la otra parte con viña de Pedro Ruiz de Villoldo; y de otra parte viñas heriales perdidas. La qual dexó a la iglesia la de Joana de Ávila, vecina que fue de Husillos, según parece por una escritura de testamento que pasó ante el [canónigo] Castro, notario canónigo de Husillos, que está en este libro a folio (en blanco).

Tiene más vna viña en término de Monçón, al Moscatel del marqués de Monzón, que haze cinco quartas, linderos: tierras de herederos de Monçón, no se sabe quien la dexase, más de poseer a por la información que está en este libro, a folio CCXII.

Tiene otra viña en término desta villa de Husillos, al pago de Bragas, que haze tres cuartas poco más o menos, linderos de vna parte: viñas conçegiles y tierras de Pero Fernández y guindalera de los herederos de Diego de La Torre. La qual dizen que dexó a la dicha iglesia Joán de Ávila, vezino que fue de Husillos, avnque no pareçe escritura dello más de que la iglesia la posee por virtud de la información que está en este libro a folio CCXII.

Tiene más vna huerta en la claostra de la iglesia.

Tiene más vn pajar y vn herrén en esta villa de Husillos, que linda de la vna parte: casas de los herederos de Diego de La Torre; y de la otra parte: casas de Juan de Hamusco y su muger, y por delante la calle pública. La qual dizen que dio a la iglesia la de Joán de Ávila, según pareçe por su testamento que pasó ante el bachiller Castro que está en este libro a fojas (en blanco).

Tiene más quatro viñas en término de Grijota que dexó a la iglesia doña María de Meneses entre la erençia de sus bienes, según pareçe por su testamento que está en este libro a folio (en blanco), que es la vna viña al horno a do dize Acarraval que haze (en blanco), lindero: viña de Domingo Fernández Moço; y tierra que era de doña María, difunta; y otra viña en Salpino, que haze (en blanco), linde: viña de Garçía Alonso y tierra de Toribio [...], vezinos de Grijota (f.214v); y otra viña a Çid Ferrero, que haze (en blanco), lindero: viña de Joán de San Román e viña de Floristán González, vecinos de Grijota. Otra viña en el baño a carremolino, que haze (en blanco), lindero: el camino de carremolino y viña de los herederos de Francisco de Bureva, difunto, según pareçe por vn apeo de las dichas viñas y otras 


\section{LA ABADÍA DE SANTA MARÍA DE HUSILLOS: ESTUDIO Y COLECCIÓN \\ DOCUMENTAL $(904-1608)$}

tierras fecho en Grijota, a diez y ocho de setiembre de mil y quinientos y quarenta y ocho años por ante Francisco de Bureva, escribano, que está en este libro a folio (en blanco). Las quales dichas viñas al presente están rrendadas a Antón Garçía, vezinos de Palençia, por ocho años y ochenta y quatro maravedís cada año.

Tiene más vna huerta en término de Monçón, al molino de la medio, linderos (en blanco) que al presente está arrendada a Joán Marrón, vecino de Monçón “ad vitam”, por quatro rreales cada vn año. La qual se obo en trueco de otra huerta que la dicha iglesia tenía según pareçe por la escritura de trueco que está en este libro a folio (en blanco).

Tiene más dos tierras en término de Monçón, a Santa Ana, que hazen (en blanco). Tienen por linderos: la vna (en blanco). Las quales están arrendadas al presente en dos [...] de pan por mitad. No se sabe quien las dexase a la iglesia más de que las posee la iglesia por la información que está en este libro a folio CCXII.

Tiene más la terçia parte de la eredad de Ribas porque las otras dos partes son del cabildo de Husillos aunque no ay escritura por donde conste desta división. Los linderos y lo que haze la dicha eredad y el apeo della se veía en lo de las rrentas de la mesa capitular. Rrenta esta terçia parte al presente: tres cargas y çinco quartos y dos çelemines de pan por mitad.

Tiene más setenta y dos tierras en término de Grijota de la erençia de doña María de Meneses como se contiene en vna posisión que de las dichas tierras se tomó ante Francisco de Bureva, escribano que está en este libro a folio (en blanco). Las quales hazen (en blanco). Están arrendadas al presente en veynte y vna cargas de pan mediado.

Tiene más los derechos de las entradas del abad y benefiçiados que es quenta del abad cada vez que toma posesión de la abadía, diez mil maravedís a la dicha fábrica; y cada dignidad si tiene anexo canonicato, quatro mil; y si tiene rraçión entera anexa, la dignidad quatro mil; y si tiene media rraçión anexa a la dignidad, tres mil; y si no tiene anexa canonjía ni rraçión, ni media rraçión, paga dos mil, como vn canónigo; y el rraçionero paga como el canónigo, dos mil maravedís; y el medio rraçionero, paga mil maravedís. Desto no ay escritura ni conçesión ninguna más de que ay costumbre inmemorial según pareçe por la información que está en este libro a folio CCXII. 
Tiene más las sepulturas que se da por cada vna limosna lo siguiente: los que se entierran en el claustro, onbre o muger, çinquenta maravedís; y es niño o niña, veynte y çinco; el que se entierra en el primer lecho, da de limosna trescientos maravedís; y en el quinto, seteçientos; en el terçero, quinientos; en el quarto, seisçientos; y en el quinto, seteçientos (sic); y en el sexto, ochoçientos; y en el séptimo, noueçientos; y en el otavo, mil; y en el noveno, que es sobre la grada, seis ducados; y en el décimo, tres mil maravedís; y en el vndéçimo, quatro mil; y dentro de la capilla, doze mil maravedís. Y todos los defuntos a bien y allanan las sepolturas a su costa.

Tiene más la limosna que se da por el paño de seda y cruz de plata que se lleua para el entierro, dos rreales de antigua costumbre.

Tiene ansímismo de limosna que el abad haze a la dicha fábrica, vn marco de plata de cada colación en esta manera: de cada dignidad y canónigo y rraçionero, vn marco de plata; y de medio rraçionero, medio marco; y si la dignidad tiene anexa canongía o rraçión, paga dos marcos de plata; y si tiene anexa media rraçión, paga marco y medio. Lo qual confirmó el muy ilustrísimo obispo de Plazençia, don Gutierre de Caravajal, por el poder que tiene del abad por vna escritura que está en este libro a folio (en blanco) (f.215r).

\section{$<$ Rentas de la abadía $>$}

Tiene el abad de Husillos la villa de Husillos con su término y juridiçión çevil y criminal, mero y misto ynperio, en que pone alcalde mayor y dos alcaldes ordinarios, y otros dos de la Hermandad, y dos regidores, y vn merino, y dos cuadrilleros, y escribano a su voluntad sin tener el conçejo que nombrar ni otra persona alguna. Son en la dicha villa treynta y çinco vezinos poco más o menos. Paresçe que son solariegos conforme a vna escritura que está en este libro a folio 3 , la qual dicha villa y sus términos donaron a la dicha abadía los condes de Monçón y Peñafiel, y el rrey Ramiro, y la rreyna doña Teresa, su muger, hermana de los dichos condes, como consta por vn testamento y donaçión de los dichos condes y rreyes que está en este libro a fojas V y folio VI y folio VIII. Fecho era de noveçientos y ochenta y ocho; y por otra confirmaçión del rrey don Joán, fecha era de mil y quatroçientos y diez y siete, que está a folio XIIII; y por otra confirmaçión del rrey don Fernando Quarto El Enplazado, fecha era de mil y 
trescientos y quarenta y tres que está en este libro a folio XLIII; y por otra confirmaçión del rey don Alonso, fecha era de mil y doscientos y diez y seis, que está en este libro a folio XIX; y por confirmaçión del rrey don Alonso onzeno, que ganó las Algeciras, que es fecho era de mil y trescientos y sesenta y nueve, que está en este libro a fojas LX; y por confirmaçión del rrey don Sancho el tercero, fecho era de mil y çiento y noventa y seis, que está en este libro a folio XVI; y por confirmaçión del rrey don Alonso otauo que ganó a Cuenca, fecha era de mil y doscientos y diez y seis, que está en este libro a folio (en blanco); y por la escritura del fuero de Husillos que dio el abad Gutierre Pérez a los vezinos de Fusillos, que está en este libro a folio (en blanco); y por el apeamiento original de los términos de Husillos, que fue fecha era de nueveçientos y ochenta y ocho, que está en este libro a folio (en blanco); y por el previlegio original del rey don Sancho el terçero, que es fecho era de mil y çiento y noventa y seis, que está en este libro a folio (en blanco); y por la executoria de su majestad, fecha a veynte y dos de diziembre de mil y quinientos y quarenta años, que fue era de mil y quinientos y setenta y ocho, que está en este libro a folio CLXX.

A más el dicho abad todo el suelo de Fusillos y todo suelo que estuviere despoblado, año y día, y puédelo dar el abad a quien lo pueble si el señor que lo tuuo antes poblado no lo poblare antes que el abad; lo de según pareçe por el libro becerro de la iglesia de Fusillos que está en este libro a folio CXCII.

Tiene en la dicha villa de Husillos sobre el conçejo de la dicha villa çiento y veynte maravedís que dizen de martiniega, y más mil de cargas de pan por mitad de çenso perpetuo en cada vn año; lo qual pareçe deven de pagar los dichos vezinos de Husillos en recompensa de los fueros y tributos que solían dar a los privilegios susodichos della que pagavan a los condes de Carrión en cuyo derecho suçedieron los abades de Husillos. Ay desto cartas executoria de su majestad que está en este libro a folio CLXXXIII.

Tiene más en el dicho término de Husillos vn término que se llama Las Sernas, que a por linderos: de la vna parte, los herrenales del cabildo y el camino que va a Monçón, y la carrera que está junto a la mora de Pedro Ruiz de Villoldo; y de la otra parte, el prado de Lobaharta, que es del común. La qual dicha serna tiene arrendado el conçejo con otros pedaços siguientes que se dizen Las Sernas en doscientas fanegas de pan por mitad. Y los otros pedaços de tierra que ansí mismo 
se llaman la serna del abad que andan con este arrendamiento son los siguientes: un pedaço de tierra que alinda con esta misma serna de arriba por vna parte; y por otra parte la çerca el río por parte de arriba; y por parte de abaxo, tierras conçegiles; y otro pedaço es hazia los molinos de Cabo de Viña, que lindan por vna parte con el lugar y de otra parte con el Soto del Abad; y de la parte de abaxo con el prado conçegil; y de la otra parte $(f .216 r)$ con el camino que va a Palençia. Otro pedaço linde deste y con vna carrera que va a las eras por entre los herrenales del cabildo y la dicha serna; y de vn lado hazia el molino linda con el arroyo de Frailes; y de la otra parte el camino que va a Palençia. Otro pedaço es al arroyo de Frailes, linde de vna parte tierras conçegiles; y de la otra parte, hazia Monçón, el arroyo de Frailes. Otro pedaço que es a do dizen La Solana, linde el camino de Harruqueros y por las otras partes tierras conçegiles. Otro pedaço es aliende a do dizen El Rocín, linderos: el camino que va de La Quebrantada a Palençia, que es en tierra de Pedro Ruiz de Villoldo y el dicho pedaço; y del otro lado hazia el molino linda con tierras del dicho Pedro Ruiz de Villoldo; y por la parte de hazia el soto linda con vna senda que va del molino a Valmayor; y de partes de abaxo hazia Palençia linda con tierra de la capellanía de la Madalena; y otro pedaço es hazia Palençia, que está parte del en el dicho término de Husillos y parte en el término de Palençia, que linda por la vna parte con el rrío de Carrión y por la parte de abaxo tierras del obispo de Palençia; y del otro lado hazia las cuestas con el camino que va a Palençia. Otro pedaço es linde deste al pie de las en estas que linda por la parte de abaxo con el exido de la çibdad de Palençia, y de la parte de arriba con tierra del hospital de la villa de Husillos; y por la otra parte con el camino que va a Palençia. Este pedaço está en término de Palençia. Otro pedaço junto al camino de Harruqueros, que a por linderos el dicho camino y de la otra parte tierras conçegiles; y el camino que va de Husillos a Grijota. Llámase este pedaço la serna Bermeja.

Tiene más al do dizen La Porfiada, otro pedaço de tierra que hera dos obradas, poco más o menos, que linda con el camino de Harruqueros y con vna senda que viene de Grijota a las eras; y por otra parte con vna tierra de los herrenales del cabildo. 


\section{LA ABADÍA DE SANTA MARÍA DE HUSILLOS: ESTUDIO Y COLECCIÓN \\ DOCUMENTAL $(904-1608)$}

Tiene más otro pedaço de tierra que puede hazer hasta vna obrada a do dizen Vazia Bolsas, linderos: vn hoyo que a hecho el agua grande, y tierra de la lánpara, y por otra parte vna lindera aneja.

Tiene más en este término de Husillos çiertas tierras que diz Los Arenales que hazen (en blanco) obradas. Rentan al presente seis cargas de pan mediado. Tienen por linderos (en blanco).

$<$ Soto $>$ Tiene más el soto que dizen del abad que al presente está arrendada la yerva del en seis mil y quinientos maravedís.

$<$ Tabla del río> Tiene más el señorío del rrío desde la puente del lugar hasta las açeñas del Cabo, que rrenta al presente mil y quinientos maravedís.

Tiene más por carta executoria que puede traer tanto ganado en el término de esta villa como dos vecinos, los que más traxeren, que podrán ser fasta seteçientas cabezas de ganado ovejuno, que es fecha a ocho de julio de mil y quinientos y quarenta y vno, que está en este libro a folio CXXX.

Tiene más doscientos maravedís de çenso perpetuo sobre las casas de Alonso de Ávila.

Tiene de çenso treynta maravedís y vna gallina sobre las casas de Fernando de la Portilla.

Tiene de çenso sobre las casas de Diego de La Torre, treynta maravedís y vna gallina.

Tiene de çenso sobre las casas de Catalina de La peña, que poseen los herederos de Diego de la Torre, otros treynta maravedís y vna gallina.

Tiene de çenso sobre las casas de Pedro Cortés, treynta maravedís y vna gallina.

Tiene más la dicha abadía en el lugar de Fuentes de Nava, vn término con su jurisdicción çevil e criminal que se arreienda en cada vn año en çinquenta e nueve mil maravedís. Está deslindado y amojonado y más tiene todos los diez años del pan y vino y semillas que este término se cojeren que suele valer el dézimo y ochoçientas fanegas de trigo y quatroçientas de çevada. Lo qual posee por vna carta de venta que hizo del dicho lugar (f.216v) Fernán Gutiérrez, fecha en era de mil y doscientos e sesenta e seis, que está en este libro a fojas XXVIII. Y por otra carta de conpra fecha en otubre era de mil e doscientos y sesenta y siete que está en este libro a fojas (en blanco). 
Está junto a este término vna dehesa que se llama Villa Abrojo que es de particulares, de la qual tiene el abad la quarta parte del diezmo de todo lo que en ella se coje, ansí de vino como de todo lo demás: Lo qual lleua por la información que está en este libro a fojas (en blanco). (no está en colección)

Tiene más en el dicho término de Fuentes de Nava vna tierra que llaman la del Abad, la qual posee por la información que está en este libro a fojas (en blanco), que tiene por linderos (en blanco), que haze (en blanco) obradas. Rrenta al presente quatro cargas de pan mediado.

Tiene más en término de Astudillo çiertas tierras que hazen (en blanco). Y çiertas viñas que hazen (en blanco) que lindan (en blanco).

Está arrendado este año todo esto en dos mil maravedís. Poseeló por vna carta de donaçión de la dicha eredad que dio (en blanco), fecha a veynte y tres de agosto era de mil y doscientos y ochenta y dos, que está en este libro a fojas (en blanco), y por vn previlegio del rrei don Pedro con confirmaçión de todos los rreyes sus anteçesores de todos los bienes de que fue dotada la iglesia de Husillos desde que se fundó, fecho a veinte y ocho de noviembre, era de MCCCLXXXIX, que está en este libro a folio (en blanco).

Tiene más en Fuentes de Valdepero vna eredad que dize Sant Adrián, que haze (en blanco) obradas. Tiene por linderos (en blanco). Renta al presente diez y ocho cargas de pan por mitad. Poseelá por (en blanco).

Tiene más en este dicho lugar de Fuentes de Valdepero la novena parte y algo más de todos los diezmos del dicho lugar de trigo y çebada y çenteno y semillas y vino. Suele valer treynta cargas de trigo y diez de çebada y nueve mil maravedís el vino. Poseeló por (en blanco).

Tiene más el lugar de Villandavín con su término y juridiçión çeuil y criminal, mero y misto ynperio, de proveer alcaldes y alguacil y escribano y ponerlos y quitallos a su voluntad. Son vasallos solariegos según pareçe por la donaçión de la rreyna doña Vrraca, era MCLII, que está en este libro a folio XI.

Puede traer en el término del dicho lugar todo quanto ganado quisiere por virtud de vna carta executoria que está en este libro a folio CLXXVI.

Tiene más en el dicho lugar çiertas tierras que hazen (en blanco), que an por linderos (en blanco), que rrentan al presente çinco cargas y media de pan por mitad. 


\section{LA ABADÍA DE SANTA MARÍA DE HUSILLOS: ESTUDIO Y COLECCIÓN \\ DOCUMENTAL $(904-1608)$}

Tiene más en este lugar el prado que dizen de Cos. Haze (en blanco) obradas. Tiene por linderos (en blanco). Vale (en blanco).

Tiene más de çenso sobre el dicho lugar de suelos (en blanco) maravedís.

Tiene más en el dicho lugar (en blanco) gallinas (en blanco).

Tiene más en término de Becerril vna tierra que se dize Los Corrales, que haze (en blanco) $(f .217 r)$ obradas, que tiene por linderos (en blanco), que rrenta de presente quatro cargas de pan por mitad y quatro gallinas.Poseelá por (en blanco). Tiene más çiertas tierras de particulares de Becerril que caen en el término de Villabrojo que pagan la mitad del diezmo al abad. Poseelá por (en blanco). Rrenta al abad nueve cargas de pan por mitad.

Tiene más en çiertas tierras que tienen los vezinos de Paredes de Nava, la Villa Abrojo la quarta parte del diezmo que se coje en las dichas tierras que rrentan seis cargas de pan por mitad. Poseeló por (en blanco).

Tiene en Hérmides de çenso perpetuo en cada vn año sobre el conçejo, quarenta cargas e pan por mitad. Poseeló por vna escritura de çenso perpetuo que está en este libro a folio CXLII.

Tiene en Tardajos de çenso perpetuo sobre la hazienda de Juan de Vegara, siete cargas y media de pan por mitad. Poseeló por (en blanco).

Tiene en la villa de Valladolid diez mile quinientos maravedís y catorze gallinas de çenso perpetuo sobre vna casa en La Costanilla, frente de la fuente [...] mill maravedís y sobre otras casas en medio de La Costanilla, 2500 maravedís, y en vn mes o a la puerta de [...], Los quales posee (en blanco).

Tiene en Mazariegos en çiertas tierras de particulares el diezmo dellas, que son (en blanco). Suele valer el dicho diezmo vn año con otro dos cargas de pan por mitad.

Tiene más de entrada de cada prebenda que entra a residir de nuevo vn marco de plata. Y porque la iglesia de Husillos es pobre y no tiene de qué se rreparar ni sustentar, el dicho abad hizo graçia de las dichas entradas a la dicha fábrica según pareçe por vna escritura que está en este libro a folio (en blanco).

Provee en sus meses todos los benefiçios de la iglesia de Husillos.

Provee los préstamos y beneficios siguientes: 
El beneficio curado de Calabaçanos poseeló al presente Jijón, benefiçiado en Quintana de la Puente.

El préstamo de la iglesia de Calabaçanos dize que está anexo al convento de las monjas de Calabaçanos.

El préstamo de San Miguel de Fuentes de Don Bermudo que tiene al presente el canónigo Gonzalo Terradillos.

Otro préstamo en la dicha iglesia que tiene al presente Joanes de Berbiesca, canónigo de Valladolid.

Otro préstamo en la dicha iglesia que posee al presente el arcediano del Alcor.

Otro préstamo en Santa Eugenia de Piña extramuros, que tiene al presente Pedro de Villazán, rraçionero en la iglesia de Palençia.

Otro préstamo en San Sebastián de Pajarejos, en Becerril; tiénele al presente vn hijo del liçenciado Escudero, letrado de la corte.

El préstamo de Mazariegos poseeló al presente el prior de Husillos.

Otro préstamo o benefiçio en Fuentes de Valdepero, fuera de la villa; dizen que está vnido a la iglesia del dicho lugar.

El préstamo de Nuestra Señora del Castillo en Enpudia dize que está vnido a las iglesias de Henpudia $(f .217 v)$.

El préstamo de San Mamés en Frechilla, poseeló al presente Antón del Canpo, que bibe en Sancta María del Canpo.

Otro préstamo en San Miguel de Fuentes de Nava, poseeló el tesorero de Husillos.

Diezen que está anexo al seruiçio de la sacristía de Husillos para los gastos.

Otro préstamo que es eredamiento y a la iglesia de Fuentes de Don Bermudo, que dizen que es anexo a la chantría de Husillos.

$<$ Hospital $>$

Ay en la dicha villa de Husillos vn hospital para los pobres que está frontero de la iglesia de la dicha villa. Tiene el dicho hospital la casa en que se alvergan los pobres que es en la dicha villa frontero de la dicha iglesia en la plaça que lindan con casas del cabildo y con casas de la tesorería y con la fragua del conçejo y con la carneçería de la dicha villa, que nuevamente se a hecho junto al dicho hospital. Tiene más el dicho hospital çiertas tierras que puedan hazer veynte obradas poco más o menos, según se contiene en vna escritura de apeo signada de Diego del 
Fresno, escribano de la dicha villa de Husillos, la qual está en el libro del dicho hospital; y al presente rentan las dichas tierras çinco cargas de pan por mitad trigo y çevada.

Tiene más vna viña en término de Husillos a do dizen Marcuendo, que faze quatro cuartas, linderos: viñas de Pero González y tierras del conçejo de la dicha villa. La qual al presente rrenta real y medio cada año. A la de poder y arar el hospital a su costa este año de çinquenta y çinco, porque con esta condiçión se arrendó.

Tiene más en término de Villunbrales a do dizen Los Calzes, vna viña que hera dos quartas poco más o menos, la qual está perdida, y a muchos años que no se halla por ella cosa alguna de rrenta.

Adviértese que el cura de Calauazanos que por tiempo es a de dar allurción? 400 reales que tiene reciuidos de antecesor y hacer scriptura de obligación.

Relación de curas en Calabazanos entre 1647 y 1751. (f.218r)

$<$ Renta de la Mesa Capitular $>$

La rrenta que tiene la mesa capitular de la iglesia de Husillos es la siguiente:

La eredad y término de Paredes que se llaman Sahagún el Viejo, la qual dexó al dicho cabildo y iglesia (en blanco), según pareçe por (en blanco); la qual eredad haze (en blanco) obradas según pareçe por vn apeamiento original que está en este libro a folio (en blanco). Renta al presente quarenta cargas de pan por mitad trigo y çeuada.

Tiene más en término de Palençia la eredad de Santa Eufemia, la qual dexó a la dicha iglesia de Husillos (en blanco) según pareçe por la donación que está en este libro a folio (en blanco). La qual faze (en blanco) obradas según pareçe por vn apeo que está en este libro a fojas (en blanco). Rrenta al presente diez cargas de pan por mitad trigo y çeuada.

Tiene más dos tierras en término de Palençia, que son a la Huelga de Pajares, las quales dexó a la iglesia (en blanco) según pareçe (en blanco) que rrentan al presente dos fanegas y media de pan por mitad de trigo y çebada.

Tiene más çinco tierras en esta manera. Vna en Jigondo, término de Grijota, y otra a la puente de don Guarín, término de Palençia, y tres a San Juan de Pajares, 
término de Palençia. Las quales dexó a la dicha iglesia (en blanco). Fazen (en blanco) obradas. Rentan al presente vna carga de trigo.

Tienen más tres tierras en término de Palençia junto a Pajares, que les dexó (en blanco), según pareçe (en blanco), que hazen (en blanco) obradas, que rrentan al presente tres fanegas e media de pan por mitad trigo e çevada.

Tienen más otra tierra a do dizen Las Fueras, término de Palençia, linde del arroyo de La Nava e camino de Los Moledores, que les dexó (en blanco), que haze (en blanco) obradas. Renta al presente tres fanegas de pan por mitad trigo y cebada.

Tienen más otras tres tierras junto a Pajares en el término de Palençia, que les dexó (en blanco), que haze (en blanco) obradas. Rrenta al presente vna fanega de pan por mitad trigo y cebada.

Tiene más otra tierra en término de Palençia junto a la puerta de Santa Marina que les dexó el abad don Pero Fernández, según pareçe por (en blanco). Lo qual dexó en capellanía; y al presente la posee el rraçionero Benavides, que haze (en blanco) obradas. La qual renta al presente çinco cargas de pan mitad trigo mitad cebada. Tienen más la eredad de Villamartín que es en término de Villamartín que llamaron Nuestra Señora de Cilleruelo, que les dexó (en blanco). La qual eredad al presente rrenta diez y ocho cargas de pan por mitad trigo y cebada $(f .218 v)$

Tiene más sobre vn préstamo que es a provisión del abad, que al presente le posee el prior que tiene la dicha iglesia en el primero año los medios frutos, y de la otra mitad la déçima, y de allí adelante en cada vn año la déçima según pareçe por vn previlegio del papa Alexandro, que está en este libro a folio (en blanco).

Tiene más vna tierra en término de Castromocho a do dizen La Laguna, que les dexó (en blanco). La qual faze (en blanco) obradas; y rrenta al presente media carga de trigo y vna gallina.

Tiene más en Enpudia vna yglesia que llaman Santa María de Castillo, dos cargas de pan por mitad en el diezmo de la dicha yglesia según pareçe por vna concordia. Está en este libro a folio (en blanco) Paganló los clérigos de Enpudia.

Tienen más en término de Frechilla vna tierra, se llama de Santa María, que les dexó (en blanco), la qual haze (en blanco) obradas. La qual al presente renta tres fanegas de trigo. 


\section{LA ABADÍA DE SANTA MARÍA DE HUSILLOS: ESTUDIO Y COLECCIÓN \\ DOCUMENTAL $(904-1608)$}

Tienen más sobre el préstamo de San Román, de San Mamés en término de Frechilla, el primero año que vaca los medios frutos, y de los otros medios la déçima, y de allí adelante en cada año la déçima de toda la rrenta. Poseeló al presente Antonio del Canpo. Renta al presente vna carga de trigo.

Tienen más vna heredad que se dize San Joán de Pajares, que es en término de Palençia y Grijota, que les dexó (en blanco). Renta al presente veynte y quatro cargas de pan por mitad y veinte y quatro gallinas a rreal cada gallina.

Tienen más en el dicho término vna tierra que se dize La Natera, que les dexó (en blanco) la qual haze [obradas]. La qual al presente rrenta dos cargas de pan por mitad.

Tienen más en término de Villandavín vna eredad que poseen, la qual hazen (en blanco) obradas. Renta al presente çinco cargas y dos quartos de trigo.

Tienen más en término de Castrillo vna eredad que dizen de Santa María y haze (en blanco) obradas. Rrenta al presente dos cargas y seis quartos de pan por mitad y quatro gallinas a rreal por cada gallina.

Tienen más en término de Amayuelas vna eredad y tierras, las quales poseen (en blanco) que hazen (en blanco) obradas. Lo qual renta al presente tres cargas y media de pan por mitad.

Tienen más en el término de Ribas vna eredad, la qual poseen por (f.219r), que haze (en blanco) obradas.

La qual al presente renta onze cargas de pan por mitad y onze gallinas a rreal. Es la terçia parte de la fábrica de la iglesia de Husillos.

Tiene más en término de Monçón çiertas tierras, las quales poseen por (en blanco). Haze (en blanco). Las quales dichas tierras al presente rrentan dos cargas y media de pan.

Tienen más vn término redondo con su monte y jurisdicción çevil y criminal, mero y misto ynperio, que se dize Villa Gutierre, lo qual poseen (en blanco). Renta al presente la eredad yervaje del veynte e quatro cargas de pan por mitad, y tienen en el dicho heredamiento vna casa. Lo qual está apedado y amojonado con los pueblos comarcanos según pareçe por vna escritura que está en este libro a folio (en blanco).

$<$ Préstamo de Piña $>$ Tienen más sobre vn préstamo en Piña en la iglesia de Sancta Eugenia, que posee el rraçionero Villazán, rraçionero de Palençia, el primero año 
que se provee los medios frutos y de los otros medios la décima parte, y dende en adelante en cada vn año la déçima de todo lo que rrenta. Poseenló por el previlegio del papa Alexandro, que está en este libro a folio (en blanco). Renta al presente nueve quartos y vn çelemín de pan por mitad y dos gallinas y media.

Tienen más en Fuentes de don Bermudo sobre el préstamo que es anexo a la chantría de Husillos, el primero año que se provee la mitad de los frutos, y de la otra mitad la déçima y dende en adelante la déçima de todo lo que rrenta. Renta al presente vna carga y çinco çelemines de trigo.

Tienen más sobre el préstamo de Fuentes de Nava de la iglesia de (en blanco) que es anexo a la tesorería de Husillos, el primero año que se provee la mitad de todos los fructos y de la otra mitad la déçima parte, y dende en adelante la déçima de todos los fructos. Vale al presente (en blanco).

Tiene más sobre otro préstamo de Fuentes de Nava en la iglesia de (en blanco); el primero año que se provee la mitad de los frutos y de la otra mitad la déçima y dende adelante en cada año la déçima de todos los frutos. Poseeló al presente el canónigo Gonzalo de Terradillos, canónigo de Husillos. Vale al presente (en blanco).

Tiene más sobre el préstamo de Fuentes de Nava en la iglesia de (en blanco); el primero año que se provee la mitad de los frutos y de la otra mitad la déçima y dende en adelante en cada año la déçima de todos los frutos. Poseeló al presente Joán Rodríguez de Vieso, canónigo de Valladolid. Vale al presente (en blanco).

Tienen más en Husillos los diezmos de los [...] del término de Husillos. Pposeenlós por el previlegio del papa Alexandro, que está en este libro a folio (en blanco). Vale al presente XXII mil maravedís.

Tienen más en el dicho término de Husillos vn sotillo, lo qual poseen por (en blanco) $(f .219 v)$. Está arrendada la caça en siete ducados y la yerva en quatroçientos y çinquenta maravedís.

$<$ Ojo. Tabla del prior $>$ Tienen más la pesca del río que comienza desde el término de Monçón a do dizen Minbres Pardos hasta la Boca del Soto del Abad; y desde el prado del molino de Cabo de Viña hasta llegar al dicho molino donde llaman La Cola. Lo qual poseen por (en blanco) y rrenta al presente siete ducados.

$<$ Ojo $>$ Tienen más de çenso sobre el conçejo de Husillos, quinientos y setenta y quatro maravedís. Los quales dexó al dicho cabildo Francisco López, canónigo 
que fue en esta iglesia por çierta memoria que se le haze según pareçe por (en blanco).

$<$ Ai testamento del dicho en el libro grande de cláusulas de esta yglesia de Ampudia a folio 714> Tienen más sobre la hazienda de Pedro Ruiz de Villoldo, vezino de Husillos, trescientos maravedís de çenso perpetuo en cada vn año, que dexó Pedro Ruiz de Villoldo, su padre, al dicho cabildo por vna memoria que se le haze día de Sant Antolín en la su capilla de Santo Alfonso, según pareçe por (en blanco).

Tienen más de las oes que se cantan antes de Navidad sobre el abad de Husillos, ochenta maravedís en cada vn año; y sobre el prior y tesorero y chantre, quarenta maravedís sobre cada vno; y sobre quatro canónigos los más antiguos a veinte maravedís cada vno. Poseenlós por (en blanco).

Tienen más de rrenta de las mochas que tienen en su sotillo y ribera dos reales.

Tienen más de çenso perpetuo sobre las casas de los herederos de Calahorra, que son en la villa de Husillos, que lindan con casas de la capellanía de San Joán y casas de cabildo y capellanía que llaman de Buytrón, veynte maravedís y dos gallinas muertas o a veynte maravedís por cada vna a escoger del que paga. Poseenló por (en blanco).

Tienen más vnas casas en la dicha villa de Husillos, que al presente tiene el canónigo Pedro de Ávila "ad vitam", que lindan con la calle del Buitrón y con casas de los herederos de Calahorra y herrén de la tesorería. Poseenlás por (en blanco).

Tienen más otras casas frontero destas que an por linderos: la dicha calle del Buitrón y la canóniga del cabildo; las quales al presente posee el rraçionero Arias. Rentan quatroçientos maravedís cada año y diez y seis granos a real. Poseenlás por (en blanco).

Tienen más sobre las casas de la capellanía de San Joán, que son en la dicha villa de Husillos, frontero de la iglesia y casas del cabildo y la calle del Buitrón, seis maravedís de çenso perpetuo en cada vn año. Las quales posee al presente el canónigo Terradillos; las quales poseen por (en blanco).

Tienen más sobre otra casa que al presente es herrén al que es de la capellanía de San Joán, que al presente posee el canónigo Terradillos, que lindan con casas del cabildo y la calle del Buitrón y casas de los erederos de Calahorra, onze 
maravedís y dos gallinas, a veinte y siete maravedis cada gallina de çenso perpetuo en cada vn año. Lo qual poseen por (en blanco).

Tienen más dos pares de casas en la villa de Husillos, al corral de Cardaño, que an (f.220r) por linderos: casas del cabildo y casas de la obra. Rentan (en blanco). Poseenlás por (en blanco).

Tienen otras casas linde destas que dizen de la parra y casas de la obra. Rentan $\mathrm{CCCC}^{\circ} \mathrm{XCII}$ maravedís y doze gallinas. Poseenlás por (en blanco).

Tienen más otras casas que lindan con casas del canónigo Castro y casas de la obra que rentan cada año çinco ducados, que las tiene el canónigo Bustamante. Poseelás por (en blanco).

Tienen más otras casas que lindan con casas del canónigo Pedro de Ávila y con casas de la abadía y con vn alcalde que viene de la plaça para la puerta nueva en que bive Gaspar Manso, chantre. Rentan IIDCLXXX maravedís y treynta gallinas, a rreal cada gallina. Poseenlás por (en blanco).

Tienen más otras casas que lindan con casas del raçionero Çarraon y la calle pública que va a salir a la puerta nueva, que al presente rentan dos ducados y onze gallinas a rreal. Poseenlás por (en blanco).

Tienen más sobre vn suelo y casas que posee el canónigo Pedro de Áuila, quatro gallinas a rreal cada vna de çenso perpetuo en cada vn año. Lo qual poseen por (en blanco).

Tienen más çinquenta maravedís y dos gallinas a veynte y siete maravedís cada gallina de çenso perpetuo sobre las casas y suelo que al presente tiene Pedro Santos y Blas Herrero en la dicha villa de Husillos. Poseenló por (en blanco).

Tienen más vn pajar que al presente tiene el canónigo Haya, que a por linderos: casa de Pedro [...] y calle que viene de la plaça pública [...] los suelos de Villoldo y casas del cabildo. Renta çinco maravedís en cada año de rreconoçimiento. Poseenló por (en blanco).

Tienen más de çenso perpetuo dos gallinas, a real cada vna, sobre las casas de Costança de Vascones, muger que fue de Joán de la Peña, que lindan con casas de Pedro [...], frontero suelos de Pedro Ruiz de Villoldo. Poseenló por (en blanco). Tienen más de çenso perpetuo çinco gallinas, a real cada vna, sobre las cosas y suelo que al presente posee Pedro Fernández, que an por linderos: las casas de 


\section{LA ABADÍA DE SANTA MARÍA DE HUSILLOS: ESTUDIO Y COLECCIÓN \\ DOCUMENTAL $(904-1608)$}

Juan de la Peña y casas del cabildo y calle pública que va a la puerta del río. Lo qual poseen por (en blanco).

Tienen más de çenso perpetuo sobre las casas de la de Pedro de Aguilar y [...] y dos gallinas, a veynte e siete maravedís cada vna. Poseenló por (en blanco).

Tienen más vnas casas que an por linderos: casas de Pedro Ruiz de Villoldo y casas del cabildo y calle que viene de la plaça a la puerta del río, las quales rentan (en blanco); y poseenlás por (en blanco).

Tienen más otras casas junto a éstas que al presente posee Joán Ponçeración, que rentan (en blanco). Poseenlás por (en blanco). (f.220v)

Tienen más otras casas que an por linderos: huerta de Pero Ruiz de Villoldo y casas del cabildo. Tienelás Pedro de Toranço por su vida. Rentan doscientos maravedís y quatro a veynte maravedís cada vna. Poseenlás por (en blanco).

Tienen más otras casas que se llaman del Moral, que an por linderos: casas de Martín de Pereda; y por otra parte, casas del cabildo y calle pública, que viene de la iglesia de la puerta del río, en que al presente bive el canónigo Bartolomé Alonso, que rentan çien maravedís y çinco gallinas a real. Poseenlás por (en blanco).

Tienen más otras casas que alindan con las casas sobredichas del cabildo y de la otra parte: casas del cabildo y la calle pública que viene de la iglesia al río. Tienelás el canónigo Valdeviejo. Rentan MDC maravedís y diez y siete gallinas a rreal. Poseenlás por (en blanco).

Tienen más otras casas del cabildo y la calle pública que viene de la iglesia al río. Tienelás el canónigo Valdeviejo. Rentan MDC maravedís y diez y siete gallinas a rreal. Poseenlás por (en blanco).

Tienen más otras casas linde de estas y con casas de la fábrica y la calle pública de la yglesia al río; las quales tiene el canónigo Castro. Poseenlás por (en blanco). Tienen más sobre las casas y colmenas que posee el raçionero Benavides por su vida, que lindan con casas de la tesorería y casas de Francisco Delgado y suelos de Pedro Ruiz de Villoldo y casas de Alonso de Ávila, treszientos maravedís. Poseenlás por (en blanco).

Tienen más otras casas en que biue el canónigo Pedro Yago, que lindan con casas de los herederos de Pedro Áluarez de Miranda y casas del cabildo. Rentan dos gallinas y çinco maravedís. Poseenlás por (en blanco). 
Tienen más de çenso perpetuo sobre las casas de Pedro Áluarez de Miranda que se llaman de La Higuera, quatro gallinas al real. Poseenló por (en blanco).

Tienen más otras casas en que bive el canónigo Diego Sánchez que lindan con casas del cabildo y la calle pública, que viene de la iglesia al rrío. Poseenlás por (en blanco).

Tienen más otras casas en que bive el canónigo Gaspar de Haya, que an por linderos: casas del cabildo y casas de Ortega de Fresno y la calle pública, que rentan treszientos maravedís. Poseenlás por (en blanco).

Tienen más otras casas a do dizen La Laguna, que al presente tiene el prior, que lindan con casas del cabildo y casas de Pedro Fernández y casas de Ortega de Fresno, que rentan doszientos y noventa y dos maravedís y doze gallinas a real. Poseenlás por (en blanco).

Tienen más en Hamusco vnas casas que les dexó el prior Alonso Guacho para vna memoria que se le haze el día de San Jorge. Rentan treszientos maravedís de çenso perpetuo, que lindan con la iglesia de Hamusco. Poseenlás por (en blanco). Tienen más vn majuelo en el término de Husillos, a do dizen Abeça, que al presente posee el thesorero de Husillos, que linda con el camino que va a Husillos de Villaumbrales, que renta quatro ducados. El qual dexó Diego de Fresno por çierta memoria según pareçe, por (en blanco) $(f .221 r)$

Tienen más otro majuelo en el dicho término que al presente tiene arrendado Fernán Becerra, vecino de Villumbrales, que linda con majuelos del canónigo Terradillos y majuelos del cabildo y de la de Pedro de Aguilar, que rentan treynta reales. Poseenló por (en blanco).

Tienen otro majuelo en el dicho pago de Beça que al presente posee el canónigo Haya, que lo compró del dicho cabildo, que linda con el camino real que va de Palençia a Carrión, que renta $\operatorname{CCCLXXX}^{\circ}$ IIII $^{\circ}$ maravedís y doze gallinas a real. Poseenló por (en blanco).

Tienen otro majuelo en el dicho pago de Beça con vna cueua y bastón que tiene la de Pedro de Aguilar. Renta treszientos maravedís y después de sus días es del cabildo. Dá esta renta por vna memoria que se le haze día de La Madalena por su marido. Poseenló por (en blanco). 


\section{LA ABADÍA DE SANTA MARÍA DE HUSILLOS: ESTUDIO Y COLECCIÓN \\ DOCUMENTAL $(904-1608)$}

Tienen más otro majuelo en el dicho pago de Beça que linda con viña de Pedro de la Portilla y viñas de Juan Xuárez, vecino de Villumbrales, y el paramillo, que renta (en blanco); y tienenló por (en blanco).

Tienen otro majuelo al dicho prado de Beça con su cueva y bastón que tiene por su vida el canónigo Pedro Yago. Linda (en blanco). Renta çien maravedís. Poseenló por (en blanco).

Tienen más dos viñas al dicho pago de Beça que al presente tiene el raçionero Ponçe "ad vitam". Lindan (en blanco). Rentan veynte rreales y diez gallinas a real cada vna. Poseenlás por (en blanco).

Tiene más vna viña en el término de Villunbrales que tiene Pedro Fernández "El Moço”, que linda con (en blanco). Renta tres reales y medio y tres gallinas a real cada vna. Poseenlás por (en blanco).

Tiene otra viña en término de Husillos a do dizen Mançanedo, que faze tres quartas. Linda con (en blanco). Renta al presente çinco maravedís porque está en remisión. Poseenlá por (en blanco).

Tiene otra viña en término de Husillos a do dizen Mançanedo, que faze tres quartas. Linda con (en blanco). Renta al presente çinco maravedís porque está en remisión. Poseenlá por (en blanco).

Tiene otra viña en el dicho término al pago de Elvira Sanz que haze (en blanco), linde con (en blanco). La qual al presente tiene el canónigo Gaspar de Haya "ad vitam”. Renta una pieza o vn real. Poseenlá por (en blanco).

Tienen otra viña que es en el dicho término, al pago de Bragas, que haze (en blanco). Linda con (en blanco). La qual renta vna gallina o vn rreal. Poseenlá por (en blanco).

Tienen otra viña en término dicho a Maçanedo, que haze nueve quartas, que linda con viña de Fernando de Llano e con viña de Pero Ruiz de Villoldo, y con el camino que va a Becerril. Renta al presente dos gallinas o dos reales. Poseelá al presente Francisco Delgado, vecino de Husillos. Poseenlá por (en blanco).

Tienen otra viña junto a ésta que hazen tres quartas, que linda con (en blanco). Renta al presente XXV maravedís. Tienelá “ad vitam” Joán Santos, por sí y vn heredero. Poseenlá por (en blanco). (f.221v)

Tienen más diez e ocho mil de çenso perpetuo sobre diez y ocho quartas de viña de Alonso de Ávila, su hijo, vecinos de Husillos, según pareçe por (en blanco). 
Tienen más treynta maravedís de çenso perpetuo sobre el majuelo de Pedro Manso, vecino de Becerril, según pareçe por (en blanco). Está el majuelo junto al prado de Val de Bermudo.

Tienen XXV maravedís de çenso perpetuo sobre veinte y çinco quartas de viñas de los herederos de Diego de la Torre en el término de Husillos, según pareçe por (en blanco).

Tienen XXIII maravedís de çenso perpetuo sobre XXIII quartas de viñas de Gonzalo Terradillos, canónigo, en término de Husillos, según pareçe por (en blanco).

Tienen XX maravedís de çenso perpetuo sobre XX quartas de viña de la de Pedro de Aguilar, vecino de Husillos, según pareçe por (en blanco).

Tienen más XVIII maravedís de çenso perpetuo sobre XVIII quartas de viñas del raçionero Benavides, en el término desta villa, según pareçe por (en blanco).

Tienen más XVII maravedís de çenso perpetuo sobre vna viña de Pedro Xuárez, vecino de Villumbrales, en término de Husillos, según pareçe por (en blanco).

Tienen más XIII maravedís de çenso perpetuo sobre las viñas de Pedro de la Mota en término de Husillos, según pareçe por (en blanco).

Tienen más XI maravedís de çenso perpetuo sobre XI quartas de viñas de Joán de Ortega de Fresno, en el dicho término según pareçe por (en blanco).

Tienen más IX maravedís de çenso perpetuo sobre nueve quartas de viñas de Pedro de Terradillos de la capellanía de San Joán, que al presente posee por (en blanco).

Tienen más otros IX maravedís de çenso perpetuo sobre nueve quartas de viñas de Pedro de Ávila, canónigo desta iglesia, según pareçe por (en blanco).

Tienen más VIII maravedís de çenso perpetuo sobre vna viña de ocho quartas de Diego Moro, vecino de Villunbrales, en término de Husillos, según pareçe por (en blanco).

Tienen más otros VIII maravedís de çenso perpetuo sobre vnas viñas de Alonso de Aguilar, vecino de Husillos, en el dicho término, según pareçe por (en blanco). Tienen más VIII maravedís de çenso sobre VIII quartas de viña de Martín de Pereda, vecino de Husillos, en el dicho término, según pareçe por (en blanco). 


\section{LA ABADÍA DE SANTA MARÍA DE HUSILLOS: ESTUDIO Y COLECCIÓN \\ DOCUMENTAL $(904-1608)$}

Tiene más otros VIII maravedís de çenso perpetuo sobre VIII quartas de viñas de Juan de los Ríos, ausente, las quales tiene al presente Pedro Ruiz de Villoldo, en término de Husillos, según pareçe por (en blanco).

Tienen más VII maravedís sobre VII quartas de viñas de Fernando de la Portilla, de çenso perpetuo sobre el dicho término, según pareçe por (en blanco).

Tienen otros VII maravedís de çenso perpetuo sobre vna viña de siete quartas de viña de Diego Alonso, vecino de Monçón, en término de Husillos, según pareçe por (en blanco).

Tienen más otros VII maravedís sobre otras siete quartas de viñas de María, muger de Cristóbal de San Zebrián, vecino de Husillos, según pareçe por (en blanco).

Tienen otros VI maravedís de çenso perpetuo sobre seis quartas de viñas de Juan de la Peña, difunto, en término de Husillos, según pareçe por (en blanco). (f.222r) Tienen más otros seis maravedís sobre seis quartas de viña de Diego de Fresno en el dicho término, según pareçe por (en blanco).

Tienen mas çinco maravedís de çenso perpetuo sobre çinco quartas de viña de Pedro de La Portilla, vecino de Husillos, en el dicho término, según parece por (en blanco).

Tienen más otros çinco maravedís de çenso perpetuo sobre vna viña de la cofradía de San Quirze en el dicho término, según pareçe por (en blanco).

Tienen más çinco maravedís de çenso perpetuo sobre çinco quartas de viñas de Pedro González de Francisco, en el término de Husillos, según pareçe por (en blanco).

Tienen más quatro maravedís de çenso perpetuo sobre quatro quartas de viña de Francisco de Támara, vecino de Husillos, en el dicho término, según pareçe por (en blanco).

Tiene más otros quatro maravedís de çenso perpetuo sobre vna viña de quatro quartas del ospital, según pareçe por (en blanco).

Tienen más otros quatro maravedís sobre quatro quartas de viñas de Juan Herrero, vecino de Husillos, en el dicho término, según pareçe por (en blanco).

Tienen más otros quatro maravedís de çenso perpetuo sobre vna viña de quatro quartas de Antonio de Martín, vecino de Husillos, según pareçe por (en blanco). 
Tienen más tres maravedís de çenso perpetuo sobre vna viña de Fernando de Llano, de tres quartas, en el dicho término, según pareçe por (en blanco).

Tienen más tres maravedís de çenso perpetuo sobre vna viña de tres quartas de Francisco Delgado, vecino de Husillos, según pareçe por (en blanco).

Tiene más otros tres maravedís de çenso perpetuo sobre vna viña de tres quartas de Pedro Cortés, vecino de Fuentes de Valdepero, en el término de Husillos, según pareçe por (en blanco).

Tienen más dos maravedís de çenso perpetuo sobre dos quartas de viña de Juan de Valloria, estante en Valladolid, en término de Husillos, según pareçe por (en blanco).

Tienen más otros dos maravedís de çenso perpetuo sobre vna viña de La Peña, viuda, vecina de Husillos, en el dicho término, según pareçe por (en blanco).

Tiene más vna cueua que al presente poseelá de Pedro de Aguilar, dos maravedís de çenso perpetuo, y después de los derechos de la dicha muger de Pedro de Aguilar es del dicho cabildo, según pareçe por (en blanco).

Tienen más otros dos maravedís de çenso perpetuo sobre la cueua de Alonso de Ávila en el término de Husillos, según pareçe por (en blanco).

Tiene más otros dos maravedís de çenso perpetuo sobre la cueva de Diego de la Torre de Francisco, según pareçe por (en blanco).

Tienen más otros dos maravedís de çenso perpetuo sobre la cueva de Pedro Fernández, vecino de Husillos, según pareçe por (en blanco).

Tienen más vna cueua a la qual tiene arrendada el canónigo Pedro Yago por sus días en remisión por çinco maravedís. Poseenlá por (en blanco). (f.222v)

Tienen más vna viña en término de Fuentes de Valdepero que haze (en blanco) a do dizen Los Molares, que linda (en blanco). La qual tienen arrendada a Santiago Casado, vecino de Fuentes de Valdepero, en tres [...] y dos gallinas o vn rreal cada gallina, según pareçe por (en blanco).

Tienen más otras tres viñas en término de Fuentes de Valdepero. Fazen (en blanco). Tienelás el beneficiado Miguel, raçionero desta iglesia, benefiçiado en Fuentes de Valdepero. Dá de reconocimiento çinco maravedís. Poseenlás por (en blanco). 


\section{LA ABADÍA DE SANTA MARÍA DE HUSILLOS: ESTUDIO Y COLECCIÓN \\ DOCUMENTAL $(904-1608)$}

Tienen más XXXV maravedís de çenso perpetuo sobre vna viña en término de Fuentes de Valdepero, que tiene Bastián de Piña y Andrés de Piña, su hermano, vecinos de la dicha villa, según pareçe por (en blanco).

Tienen más XX maravedís de çenso perpetuo sobre vn majuelo de Bastián de Amor, vecino de Fuentes de Valdepero, que fue primero tierra del cabildo, en el término de Fuentes de Valdepero, según pareçe por (en blanco).

Tiene más VIII maravedís de çenso perpetuo y más el diezmo sobre vna viña en el término de Fuentes de Valdepero, que al presente posee Pedro Çellinos, vecino de Fuentes. Es al vallo do diz en La Muñeca, según pareçe por (en blanco).

Tienen VI maravedís de çenso perpetuo más el diezmo sobre vna viña en el término de Fuentes, que al presente poseelá de Bastián Caluo, según pareçe por (en blanco).

Tienen tres maravedís de çenso perpetuo y más el diezmo sobre vna viña que tiene Alonso Casado, vecino de Fuentes de Valdepero, según pareçe por (en blanco).

Tiene en el término de Palençia vna huerta a Buen Consejo, que linda con huerta de los capellanes de Palençia; la qual al presente renta MDCL maravedís y çinquenta gallinas, a rreal cada vna. Poseenlá por (en blanco). Es el diezmo del cabildo de usillos y entra en el arrendamiento.

Tienen vna viña y vna tierra en el término de Palencia, que al presente tiene arrendado por su vida Miguel Campanero, de Palençia que es a do diz en Las Fueras, que haze (en blanco). Linda con (en blanco), y el diezmo dello es del cabildo de Husillos. Renta ocho reales y quatro gallinas a real por cada vna. Poseenló por (en blanco).

Tienen más vna tiera y vn quartejón de viña en término de Palençia, a Las Fueras, que haze (en blanco) que linda (en blanco). Renta tres reales e vna gallina o vn rreal. Poseenló por (en blanco).

Tienen vna viña junto a la puente de Don Guarín, en término de Palençia, que haze (en blanco), que linda (en blanco). Tienenlá arrendada a Alonso Cano, vecino de Palençia, por su vida por quatro reales y tres gallinas o a real por cada vna. Es el diezmo del cabildo de Husillos. Poseenlá por (en blanco). 
Tienen otra viña en el dicho término a Los Hoyos, de seis quartas que linda con (en blanco). Renta quatro reales y dos gallinas con su diezmo. Tienelá Miguel Campanero, vecino de Palençia. Poseenlá por (en blanco). (f.223r)

Tienen otra viña en el dicho término por baxo de la puente de Don Guarino, que hace ocho quartas, linderos (en blanco), según pareçe por (en blanco). Renta quatro reales e tres gallinas con su diezmo. Tienelá Pedro Estevan, vecino de Palençia. Poseenlá por (en blanco).

Tienen otra viña en el dicho término de Palençia, a la puente de Don Guarín, que haze tres arançadas y media, que lindan (en blanco), que rentan seis reales y quatro gallinas con su diezmo. Tienelá Pedro de Medina, calderero, vecino de Palencia, según pareçe por (en blanco).

Tienen más XXV maravedís de çenso perpetuo sobre vn moscatel de Miguel Caluo, en término de Palencia, según pareçe por (en blanco).

Tienen más XX maravedís de çenso perpetuo sobre vn suelo en la çibdad de Palençia a la rinconada de San Miguel, que posee Pedro de Fuentes Tapiada, vecino de Palençia, según pareçe por (en blanco).

Tienen más XX maravedís de çenso perpetuo sobre vna tierra del ospital de Santo Antolín de la çibdad de Palençia, según pareçe por (en blanco).

Tienen çien maravedís de çenso perpetuo sobre dos viñas en el término de Palençia que poseenlá: vna, Vítores Cantarero; e la otra, Garçía Cantarero, según pareçe por (en blanco).

Tien más çien maravedís de çenso perpetuo sobre çiertas viñas en término de Palençia, que al presente posee Andrés Saluador, eredero del canónigo Saluador de Francisco, según pareçe por (en blanco).

Tienen çinquenta y vn maravedís de çenso perpetuo sobre vna viña que es en término de Fuentes de Valdepero, que al presente posee Joán de Ribas, vecino de Palençia, según pareçe por (en blanco).

Tiene más otros XL maravedís de çenso perpetuo sobre vnas viñas en el término de Palençia que al presente posee el capellán Villalobos, vecino de Palençia, según pareçe por (en blanco).

Tienen más XXXI maravedís de çenso perpetuo sobre vnas viñas que al presente poseen los herederos de Pedro Álvarez de la Rúa, según pareçe por (en blanco). 


\section{LA ABADÍA DE SANTA MARÍA DE HUSILLOS: ESTUDIO Y COLECCIÓN \\ DOCUMENTAL $(904-1608)$}

Tienen más otros XXX maravedís de çenso perpetuo sobre vnas viñas en término de Palençia que al presente posee Tovar, sobrino del canónigo Carvajo de Francisco, según pareçe por (en blanco).

Tienen más XXIIII maravedís de çenso perpetuo sobre otra viña en el término de Palençia que al presente posee Francisco del Hierro Texedor, vecino de Palençia, según pareçe por (en blanco).

Más otros XX maravedís sobre otra viña del término de Palençia que al presente poseee Antonio de Medina, estante en Roma, según pareçe por (en blanco).

Tienen más otros XX maravedís de çenso perpetuo sobre otra viña en el término de Palençia que al presente posee Juan [...], vecino de Palençia, según pareçe por (en blanco).

Tienen más otros diez maravedís de çenso perpetuo sobre otra viña que es de la cofradía de San Miguel de Palencia, que los paga el mayordomo della según pareçe por (en blanco).

Tienen más otros tres maravedís de çenso perpetuo y más el diezmo sobre vna viña en el término de Palençia que al presente poseen los herederos de Bartolomé de Montoya, según pareçe por (en blanco) $(f .223 v)$

Tienen vna viña en término de Grijota a Los Olmillos, que haze (en blanco) quartas, que linda (en blanco). Renta al presente çinquenta maravedís. Tienelá al presente Francisco Sánchez, vecino de Grijota. Poseenlá por (en blanco).

Tienen sobre el préstamo de Calabaçanos treszientos maravedís por razón de la déçima de cada vn año, según pareçe por (en blanco).

Tienen más en el préstamo de la iglesia de Villacís vn ochauo que al presente renta XID CXXV maravedís.

Tienen más el préstamo de Villunbrales que al presente renta XLID maravedís.

Tienen más de çenso perpetuo sobre el conçejo de Villunbrales, portazgo del término de Santillán, IDd? maravedís en cada vn año y trescientas cántaras de mosto, según se contiene en (en blanco).

Tienen tres viñas en el término de Villunbrales que hazen (en blanco), que lindan (en blanco). Rentan al presente quinientos y noventa y quatro maravedís y nueve gallinas a real con su diezmo. Poseenlás por (en blanco).

Tienen más XXV maravedís de çenso perpetuo sobre vna tierra que se dio a Joán de Cueva, vecino de Villunbrales, para meter viña, según pareçe por (en blanco). 
Tienen más CXIX maravedís de çenso perpetuo sobre vna viña en término de Villunbrales al [...] que al presente tiene Diego Moro, vecino de Villunbrales, según pareçe por (en blanco).

Tienen sobre el préstamo de San Sebastián de Pajarejos en el término de Becerril en cada vn año, çiento y noventa maravedís, según pareçe por (en blanco).

Tienen más el ochauo de dos prestamillos en la iglesia de San Mamés en Frechilla y Fuentes de Nava, que vale al presente MDdII.

Tienen más sobre el préstamo de La Mejorada quatroçientos maravedís por razón de las déçimas de los quatro ochavillos, según pareçe por (en blanco).

Tienen más sobre el préstamo de San Miguel de Fuentes de don Bermudo vn ducado por razón de la déçima por concordia, el qual posee el arcediano del Alcor, según pareçe por (en blanco).

Tienen más dos huertas en término de Ribas al Valle de Ayuso y Poblaçioneja que posee (en blanco); las quales tienen dadas por vida a Andrés del castillo y Rodrigo Pascual con diezmo y todo por treynta reales y diez gallinas a real.

Tienen otra huerta en término de Monçón que llaman Las Minbreras, la qual poseen por (en blanco). Renta al presente CCCLXXX maravedís y onze gallinas a rreal. Tienelá dada por vida con diezmo y todo a Andrés de Modragón, vecino de la dicha villa.

Tiene otra huerta en el dicho término de Monçón a do dizen Los Hoyos. Renta al presente con su diezmo nueve mill maravedís. Tieneló por su vida Francisco de Hojeda, vecino de Monçón. Poseenlá por (en blanco).

Tienen otras huertas en término de Monçón que llaman la huerta de San Pablo, que poseen por (en blanco). Renta al presente MDCCCC. Tienelá Andrés Tomé y Alonso Tomçe y Elvira Rodríguez por sus vidas, con sus diezmos y todo.

Tienen otra huerta en el dicho término que se dize de Santa María que posee por (en blanco) (f.224r). Renta al presente nueve mill maravedís con su diezmo y todo. Tienelá Joán Lucas y Diego de Guardo por su vida, con diezmo y todo.

Tienen otras huertas en el dicho término a do diz en el Molino de en Medio, y do diz en Las Minbreras, que poseen por (en blanco), que renta al presente quinze ducados con diezmo. Tienelá Diego de Guardo por su vida con su diezmo. 
Tienen otra huerta en el dicho término do diez en Los Mançanos de Hamusco, que poseelá por (en blanco). Renta XXX maravedís por çierta concordia. Poseelá el prior de Fusillos.

Tienen en el término de Sahagún el Viejo de Paredes vna viña que haze doze quartas, que linda (en blanco). Renta al presente vn ducado y quatro gallinas a real. Poseenlá por (en blanco).

Tienen otras dos viñas en el dicho término que hazen doze quartas, las quales poseen por (en blanco).

Tienen otras dos viñas en el dicho término que hazen doze quartas, las quales poseen por (en blanco). Rentan al presente diez reales con su diezmo. Tienenlás Rodrigo de San Villo, vecino de Fuentes por su vida (en blanco).

Tienen otras dos tierras en el dicho término, en vna que se dize del Paco y la otra junto con ella que hazen obrada y media, que lindan (en blanco). Rentan dos reales con su diezmo. Poseenlás por (en blanco).

Tienen otra viña en el dico término que haze (en blanco). La qual renta con su diezmo siete rreales. Poseenlá por (en blanco).

Tienen en el río de Carrión en el término de Husillos vna casa de molinos de nueve ruedas que rentan vn año con otro quatroçientos ducados.

Tienen en el dicho río otra casa de molinos que se dize de Pajares en término de Palençia con nueve ruedas, que valen comúnmente en cada vn año treszientos ducados.

Tienen más el diezmo de todas las viñas del término de Husillos, que valdrá doscientos y çinquenta cántaras de vino.

Tienen todo el diezmo del pan de todas las eredades y tierras sobredichas que valdrá vn año con otro doscientas cargas de pan por mitad trigo y çebada.

1560. Valladolid. 
Pleito olvidado del concejo de Villaldavín con Santa María de Husillos, sobre la jurisdicción en primera y segunda instancia en Villaldavín y su término, alegando el concejo pertenecer a la jurisdicción real.

A. ARCHV, Salas de lo Civil, Zarandona y Balboa (OLV), Caja 697-1. Papel; 501 hojas; escr. procesal; buena conservación.

1561, febrero, 3. Husillos.

Cláusula del testamento de Juan Ponce, racionero de Santa María de Husillos, dejando una viña a dicha iglesia a cambio de una memoria anual por su alma.

A. APA, Libro 189, ff. 366-367. Papel; escr. procesal; buena conservación.

1561, junio, 10, martes. Husillos.

Memorial de lo que deben pagar a la fábrica de la iglesia de Santa María de Husillos, en calidad de limosna, las dignidades, canónigos, racioneros y medios racioneros, en la posesión de sus beneficios. El abad, diez mil maravedís. Las otras dignidades: prior, tesorero, chantre, teniendo dos prebendas, cuatro mil maravedís. Los canónigos, que tienen una prebenda, dos mil maravedís. Por media ración, mil maravedís.

A. AHDP, Ampudia y Abadía de Husillos, Legajos y papeles, caja 63, carp. 5-6. Papel; 2 hojas; escr. procesal; regular conservación. 
1562, julio, 9. Valladolid.

Ejecutoria del pleito litigado por Francisco de Carvajal, abad que fue de Santa María de Husillos, vecino de Placencia, y Domingo de Carvajal, abad actual, con Juan de Guevara, difunto, vecino de Tardajos, sobre ciertas heredades sitas en Valladolid, que hacian más de cien fanegas de sembradura; y sobre rentas y frutos en cuantía de unas doscientas fanegas de trigo, obligándose al dicho Juan de Guevara a devolver dichas heredades, frutos y rentas.

B. ARCHV, Registro de ejecutorias, caja 1024.23. Papel; 16 hojas; escritura procesal.

1560 - circa 1562, septiembre, 30. Valladolid.

Pleito fenecido del cabildo de Santa María de Husillos con Isabel de Montoya, viuda de Diego de Sarmento, vecino de Palencia, sobre ejecución de bienes de dicha Isabel de Montoya por 7144 maravedis de réditos de un censo de 100.000 maravedis de principal.

A. ARCHV, Salas de lo Civil, Pérez Alonso (F). Caja 74-4. Papel; 100 hojas aprox.; escr. procesal; buena conservación. 
1562, septiembre, 30. Valladolid.

Ejecutoria del pleito litigado por el cabildo de Santa María de Husillos con Isabel de Montoya, vecina de Palencia, sobre ejecución de bienes de Isabel de Montoya para el pago de una deuda de 7144 maravedís de un censo de cien mil maravedís de principal.

B. ARCHV, Registro de ejecutorias, caja 1029-13. Papel; 8 hojas; escr. procesal.

1562 - 1563, abril, 28. Valladolid.

Pleito olvidado entre Domingo de Carvajal, abad de Santa María de Husillos, con los hijos y herederos de Juan de Guevara, difunto, por ejecución de bienes de varias heredades de Husillos encensadas al dicho Juan de Guevara y después a sus hijos, que no había pagado el censo durante dos años seguidos.

A. ARCHV, Salas de lo Civil, Zarandona y Balboa (OLV). Caja 154-4. Papel; 2 piezas; escr. procesal; buena conservación.

306

1569, octubre, 2. Husillos.

Visita del abad Francisco de Vargas Carvajal a su abadía de Santa María de Husillos, visitando el Santísimo Sacramento, pila bautismal, reliquias, altares, y bienes de la iglesia: cruces, cálices, ornamentos, capas, sábanas, corporales, 
aras, camas, tapices, frontales, vinajeras, candeleros, libros y ropas de Nuestra Señora. Todo lo cual se vio en perfectas condiciones y se encargó de la continuación de su cuidado al sacristán Juan Portilla.

A. APA, Libro 48. Husillos. Cuentas de la fábrica (1569 - 1593). Papel; escr. procesal; buena conservación.

1572, junio, 13. Husillos.

Visita de Pedro de Espinosa, provisor de Francisco de Vargas Carvajal, abad de Santa María de Husillos, a dicha iglesia, visitando el Santísimo Sacramento, pila bautismal, reliquias, altares, y bienes de la iglesia: cruces, cálices, ornamentos, capas, sábanas, corporales, aras, camas, tapices, frontales, vinajeras, candeleros, libros y ropas de Nuestra Señora.

A. APA, Libro 48. Husillos. Cuentas de la fábrica (1569 - 1593). Papel; escr. procesal; buena conservación.

308

1573, agosto, 11. Husillos.

Testimonio notarial de Francisco de Barreda, vecino y escribano público de Husillos, por el que el cabildo de Santa María de Husillos autoriza la puesta en venta de unas casas de dicho cabildo, sitas en la plaza pública de dicha villa de Husillos. 
A. AHDP, Ampudia y Abadía de Husillos, Legajos y papeles, Caja 64, carp. 3-1. Papel; 10 hojas; escr. procesal con rasgos de escr. humanística; buena conservación.

1575, abril, 4. Husillos.

Testamento de Gaspar de Haya, canónigo de Santa María de Husillos, dejando varias heredades, censos y pertenencias a Santa María de Husillos, mandando enterrarse en la iglesia de Santa María de Husillos y que se celebren unas misas anuales por su memoria.

A. APA, Libro 189, ff. 263-279. Papel; escr. procesal; buena conservación.

1575.

Declaraciones de la Congregación del Concilio de Trento a favor del abad de Santa María de Husillos, contra el obispo de Palencia, sobre jurisdicción y visita. Considerando la exención de la abadía, el obispo no podría visitarla a través de su vicario o provisor, como había intentado, sino personalmente.

A. AHDP, Ampudia y abadía de Husillos, Legajos y papeles, Caja 144, $1^{\text {a }}$ parte, Doc. 15. Papel; 8 hojas; escr. humanística; regular conservación. 
1577, marzo, 24. Husillos.

Visita del abad Francisco de Reinoso a su abadía de Santa María de Husillos, visitando el Santísimo Sacramento, pila bautismal, olio y crisma, oro, ornamentos, tapicería y otros objetos de la sacristía. Hace la visita sobre un inventario realizado en 1571. Comprobando que faltan varios objetos, ordena al tesorero, Hernando Ruiz Moreno, los reponga de inmediato. Asimismo ordena hacer un inventario de las reliquias.

A. APA, Libro 48. Husillos. Cuentas de la fábrica (1569 - 1593). Papel; escr. procesal; buena conservación.

1577, marzo, 28. Husillos.

Visita del abad Francisco de Reinoso al hospital de la villa de Husillos. Comprobando sus escasos recursos y renta, manda que no se gaste nada de su hacienda y rentas hasta que no pague sus deudas.

A. APA, Libro 48. Husillos. Cuentas de la fábrica (1569 - 1593). Papel; escr. procesal; buena conservación.

1577, mayo, 19. Husillos. 
Testamento de Francisco de Támara, vecino de Husillos, dejando a Santa María de Husillos unas viñas en Husillos, a cambio de enterrarse en dicha iglesia $y$ de la celebración anual de unas misas en su memoria.

A. APA, Libro 189, ff. 359-360. Papel; escr. procesal; buena conservación.

1578, marzo, 15. Valladolid.

Censo enfiteusis de una casa perteneciente a la mesa abacial de Santa María de Husillos, de un conjunto de diez casas sitas en la calle de la Puerta del Campo y de la Boerica de Valladolid, otorgado por el abad Francisco de Reinoso a Lorenzo Velásquez, en precio de tres mil maravedís y ocho gallinas anuales a pagar la mitad del dinero el día de San Juan, y la otra mitad más las gallinas el día de Navidad.

A. APA, Libro 196. Papel; 68 hojas; escritura procesal; encuadernación en pergamino; buena conservación.

1578, abril, 4. Valladolid.

Censo enfiteusis de una casa perteneciente a la mesa abacial de Santa María de Husillos, de un conjunto de diez casas sitas en la calle de la Puerta del Campo y de la Boerica de Valladolid, otorgado por el abad Francisco de Reinoso a María Rubia, viuda de Juan de Mara, en precio de cinco mil maravedís y seis 
gallinas anuales a pagar la mitad del dinero el día de San Juan, y la otra mitad más las gallinas el día de Navidad.

A. APA, Libro 194. Papel; 150 hojas aprox.; encuadernación en pergamino; escr. procesal; buena conservación.

1578, abril, 14. Valladolid.

Censo enfiteusis de dos casas colindantes pertenecientes a la mesa abacial de Santa María de Husillos, de un conjunto de diez casas sitas en la calle de la Puerta del Campo y de la Boerica de Valladolid, otorgado por el abad Francisco de Reinoso, en precio de once mil maravedís anuales a pagar la mitad del dinero por San Juan y la otra mitad por Navidad. Dichas casas se dan en censo a los que ya las tenían encensadas, Juan Nüñez y Antonia Solórzano, su mujer, con los que la abadía había pleiteado por la renta, ya que era muy antigua y baja. La abadía gana el pleito y concierta con los susodichos un nuevo censo.

A. APA, Libro 193. Papel; 100 hojas aprox.; encuadernación en pergamino; escr. procesal; buena conservación

1578, abril, 14. Valladolid.

Censo enfiteusis de una casa perteneciente a la mesa abacial de Santa María de Husillos, de un conjunto de diez casas sitas en la calle de la Puerta del Campo y de la Boerica de Valladolid, otorgado por el abad Francisco de Reinoso 
a Catalina Sanz, vecina de Valladolid, en precio de cinco mil maravedís anuales a pagar la mitad del dinero el día de San Juan y la otra mitad por Navidad.

A. APA, Libro 195; Papel; 100 hojas aprox., encuadernación en pergamino; escr. procesal; buena conservación.

1578.

Carta del cabildo de Husillos en relación a unas casas sitas en Husillos que el canónigo Mena había sacado de la mesa capitular y que por su negligencia se habian hundido, pasando por ello necesidades económicas. El cabildo acuerda ayudar económicamente a dicho canónigo.

A. AHDP, Ampudia y Abadía de Husillos, Legajos y papeles, caja 64, doc. 4-1. Papel; 4 hojas; escr. procesal; buena conservación.

1579, marzo, 17. Husillos.

Pedro de Monzón y Antonio López, canónigos, por comisión del prior y cabildo de Santa María de Husillos, toman cuenta ante Francisco Martínez, racionero, secretario del prior y cabildo, de los bienes y objetos de la sacristía de dicha iglesia a Hernando Ruiz Moreno, tesorero. Se inventarían los siguientes objetos: platas, cruces de madera y metal, cálices, ornamentos, casullas sueltas sin almaricas, estolas, manípulos, albas, sábanas y ropa blanca, corporales, palias, hijuelas, paños, cuadros para los altares y Santísimo Sacramento, frontales, camas, capas, ropas de Nuestra Señora, tablas de la consagración, 
mangas de cruces, tapices, candeleros, misales y libros guardados en el coro y en la librería. Hernando Ruiz Moreno alega que los libros no están a su cargo, a excepción de los misales. Se ordena a dicho tesorero el cuidado de los bienes inventariados.

A. APA, Libro 48. Husillos. Cuentas de la fábrica (1569 - 1593). Papel; escr. procesal; buena conservación.

1579, abril, 5-6. Husillos.

Visita del abad Francisco de Reinoso a su abadía de Santa María de Husillos, visitando la custodia del Santísimo Sacramento, pila bautismal y sacristía. Su provisor, Francisco Martínez, visita la sacristía, siendo tesorero Hernando Ruiz Moreno, sobre inventarios anteriores. Da constancia de que faltan algunos objetos, instando al tesorero a que en el plazo de tres días dé cuenta de ellos, procediendo de lo contrario contra él. El día seis dicho provisor visita el hospital, dando constancia de que sus mayordomos no estaban presentes, por lo que no pudo inspeccionar los inventarios de todas sus pertenencias, ordenando que al día siguiente se le presentaran dichos inventarios en su casa.

A. APA, Libro 48. Husillos. Cuentas de la fábrica (1569 - 1593). Papel; escr. procesal; buena conservación.

1579. Valladolid. 
Pleito olvidado litigado por Francisco de Reinoso, abad de Santa María de Husillos, con María Gómez, por un censo perpetuo de unas casas que la dicha María Gómez había concertado con Francisco Carvajal, abad que fue de Husillos, en renta anual de 5000 maravedis, teniendo una deuda con Francisco de Reinoso de 30000 maravedís, habiendo remate de los bienes de la dicha María Gómez.

A. ARCHV, Salas de lo Civil, Zarandona y Balboa (OLV). Caja 1909-5. Papel; 100 hojas aprox., escr. procesal; buena conservación.

1581, septiembre, 21. Husillos.

Permuta entre el concejo de Husillos y Santa María de Husillos, de la casa llamada de La Herrería.

A. AHDP, Ampudia y Abadía de Husillos, Legajos y papeles, caja 64-3. Papel; 9 hojas; escr. procesal; buena conservación.

1583, enero, 8. Valladolid.

Censo enfiteusis de una casa perteneciente a la mesa abacial de Santa María de Husillos, de un conjunto de diez casas sitas en la calle de la Puerta del Campo y de la Boerica de Valladolid, otorgado por el abad Francisco de Reinoso 
a Francisco Martínez, cabestrero, en precio de cuatro mil maravedís anuales a perpetuidad. El dicho Francisco Martínez alegó que era necesario reparar la casa para poder morar en ella.

A. APA, Libro 192. Papel; 100 hojas aprox.; encuadernación en pergamino; escr. procesal; buena conservación.

1584, agosto, 12. Valladolid.

Censo enfiteusis de una casa y un mesón pertenecientes a la mesa abacial de Santa María de Husillos, de un conjunto de diez casas sitas en la calle de la Puerta del Campo y de la Boerica de Valladolid, otorgado por el abad Francisco de Reinoso a Cristóbal de Torres y María de Dueñas, su mujer, como principales, y Cristóbal Taladrero, su fiador, en precio de cinco mil cuatrocientos maravedís anuales a perpetuidad, a pagar la mitad el día de San Juan, y la otra mitad en Navidad.

A. APA, Libro 197. Papel; 254 hojas; encuadernación en pergamino; escr. procesal; buena conservación.

1584, agosto, 22. Valladolid.

Censo enfiteusis de una casa perteneciente a la mesa abacial de Santa María de Husillos, de un conjunto de diez casas sitas en la calle de la Puerta del Campo y de la Boerica de Valladolid, otorgado por el abad Francisco de Reinoso 
a Antón de Segovia, cabestrero, y Francisca Lorenza, su mujer, vecinos de Valladolid, como principales, y Lorenzo de Carranza como fiador, en precio de seis mil maravedís anuales a perpetuidad, a pagar la mitad el día de San Juan y la otra mitad en Navidad.

A. APA, Libro 198. Papel; 230 hojas; encuadernación en pergamino; escr. procesal; buena conservación.

1585, mayo, 7. Husillos.

Visita de la sacristía de Santa María de Husillos por Roque Giraldo, prior y presidente del cabildo de dicha iglesia, Gaspar de Villadiego, canónigo, y Juan de la Portilla, racionero, ambos contadores, siendo tesorero Hernando Ruiz Moreno.

A. APA, Libro 48. Husillos. Cuentas de la fábrica (1569 - 1593). Papel; escr. procesal; buena conservación.

1586, marzo, 24. Palencia.

Donación de Francisco de Reinoso, abad de Santa María de Husillos, a la fábrica de dicha iglesia, de una casa sita en Husillos, denominada de Los provisores, otorgada ante Francisco de Herrera, escribano del número de Palencia. 
A. AHDP, Ampudia y Abadía de Husillos, Legajos y papeles, caja 64, doc. 4-2. Papel; escr. procesal; 4 hojas; buena conservación.

328

1586, abril, 2. Palencia.

Donación de Francisco de Reinoso, abad de Santa María de Husillos, a dicha iglesia, de unas casas en la villa de Husillos donde los abades puedan morar, pues hasta ese momento la dignidad abacial no tenía casa de residencia en Husillos, siendo ésta una de las causas del absentismo abacial. También dona al prior y al cabildo un solar junto a la iglesia abacial. La donación se otorga ante Francisco de Herrera, escribano público de Palencia.

A. AHDP, Ampudia y Abadía de Husillos, Legajos y papeles, caja 64, doc. 4-3. Papel; 6 hojas; escr. procesal; buena conservación.

1588, enero, 14. Husillos.

Testimonio realizado, en comisión del cabildo de Santa María de Husillos, por el prior y presidente Roque Giraldo, y Gaspar de Villadiego, canónigo y contador, ante Antonio López, canónigo y secretario de dicho cabildo, de los objetos que se entregan al tesorero Juan de Palencia.

A. APA, Libro 48. Husillos. Cuentas de la fábrica (1569 - 1593). Papel; escr. procesal; buena conservación. 
1588, abril, 8. Husillos.

Estatutos y constituciones de Santa María de Husillos, establecidos por Francisco de Reinoso, abad de dicha iglesia, juntamente con el prior y cabildo. Están formados por veintisiete constituciones que regulan y reglamentan variados aspectos como el número de prebendas, las funciones del prior, tesorero y sacristán, horas canónicas, chantre y coro, reliquias, obrero, hábitos y costumbres de los beneficiados, vestimentas, prohibición de asistir a las corridas de toros, semanero, disposición en el coro, celebración de oficios y cantidades ganadas por éstos, nombramiento de oficiales por el cabildo, confesión y comunión de los beneficiados, residencia obligatoria para ganar la renta de la mesa capitular, beneficiados presos, estudiantes, enfermos, enterramiento de los beneficiados, el cabildo y el voto en éste, oficio de mayordomo de las rentas de la mesa capitular y del procurador general, sede vacante, jurisdicción $y$ encarcelamiento de los beneficiados, romerías, derechos que se entregan a la fábrica y al secretario en la posesión de la dignidad abacial y de los beneficios, derechos por sepulturas en la iglesia, oficio del secretario.

A. AHDP, Ampudia y Abadía de Husillos, Asociaciones, Libro 249. Papel; 21 hojas; escr. gótica de ejecutorias; encuadernación en pergamino de cantoral; buena conservación.

CIT. FRANCIA LORENZO, Notas de Archivo 1, 28-30.

Todos los beneficiados de Husillos. De Husillos. Colegial. Estatutos. Estatutos. Capitular. Estatutos de la yglesia. (f.1r)

Statvtos i costituciones stablecidas por don Francisco de Reynoso, abad de la yglesia colegial de la su villa de Husillos, juntamente con el prior y cabildo de la dicha yglesia y con su consejo y consentimiento para el buen gobierno della, ansí en lo que toca al seruicio del altar y coro y oficios de los preuendados y otros 
ministros, como al cabildo y conseruación de la hazienda de la mesa capitular y fábrica. $(f .2 r)$

Don Francisco de Reynoso, abad desta nuestra iglesia colegial y villa de Husillos y queriendo cumplir con nuestro oficio y juntamente con los nuestros amados prior y cabildo desta nuestra santa yglesia y con su consentimiento y consejo, hemos hecho juntar los estatutos y constituciones que había y podían seruir para estos tiempos, añadiendo los que nos han parecido ser necesarios para el buen gobierno de la dicha nuestra santa yglesia ansí en lo tocante al seruicio del altar y coro y oficios de las dignidades y otros preuendados y ministros della, como en lo que toca a la orden que se ha de guardar en hacer los cabildos y gobierno de la yglesia y mesa capitular, para que estando reducidos a un volumen y puestos por orden todos los beneficiados los tengan en su poder y por ellos sepa cada uno la obligación de su oficio; y son los siguientes:

Constitución 1. Del número de las prebendas que hay en esta santa iglesia.

$<$ Número de prebendas $>$ La renta de la mesa capitular se distribuye en veinte y dos preuendas enteras en esta manera: tres dignidades, que son prior, thesorero y chantre; y quince canónigos. Uno de estos canonicatos está extinto para el santo oficio de la Ynquisición. Dos raciones enteras que valen cada una tanto como un canonicato, salvo que no tienen voto, ni boz, ni asiento en cabildo. Cuatro medias raciones que valen cada una medio canonicato, que son por todas las dichas veinte $\mathrm{y}$ dos preuendas enteras. $\mathrm{Y}$ todos los que las tienen son obligados a residir en las oras canónicas y oficios diuinos y a ejercer los oficios que están añejos a cada una dellas, exceto la preuenda que tiene el Santo Oficio, porque ésta está eximida, como dicho es.

Constitución 2. Del oficio del prior.

$<$ Oficio del prior $>$ El prior es la primera dignidad después de la abacía $(f .3 r)$. Está a su cargo mandar llamar a los cabildos y presidir en ellos y proponer los negocios que se ouieren de tratar y resoluer lo que se votare y hazer que el secretario lo asiente. Ha de guardar los estatutos que hablan cómo se han de hacer los cabildos y de la orden que se a de tener en juntarlos y votar y tratar los 
negocios y mandar ejecutar las penas en ellos contenidos contra los que no los guardaron. Ha de presidir en las diputaciones que el cabildo ordenara y asistir a las cuentas de la hazienda y tener cuidado de los pleitos y de todo lo que toca a la hazienda de la mesa capitular para proponerlo en cabildo cuando convenga y hacer ejecutar lo que allí se ordenare. Ha de hazer este oficio por su propia persona, salvo quando estuviere enfermo o encarcelado por negocios suyos o tocantes al cabildo o a su dignidad, o quando estuviere ausente de esta villa, porque entonces quando él faltare hará el dicho oficio la dignidad o canónigo más antiguo de los que tienen voto y se hallare en la yglesia.

El prior a de llebar el pendón de la cruz quando se canta el himno de "Vexilla Regis", y ofrecer el primero quando ouiere ofrenda, y presedir en el coro y en las procesiones que se hizieren en la yglesia y fuera della, y procurar que los preuendados y otros ministros que allí se hallaren estén con silencio y canten. Ha de guardar y hazer guardar los statutos y constituciones que hablan de la asistencia y seruicio del coro, y penar conforme a ellos a los que no los guardaren. Ha de decir la primera antifona de la "O", estando ausente el prelado y en su ausencia del prior, la dirá la dignidad o canónigo más antiguo.

Constitución 3. Del Officio del thesorero.

Luego que el thesorero tomare la posesión de su dignidad, se le entregará el oro, plata, seda y brocas, tapicería, ornamentos, libros y misales y todo lo demás que está en el $(f .3 v)$ thesoro y sacristía desta nuestra yglesia por ynuentario ante el secretario de nuestro cabildo por peso y medida lo que se pudiere pesar y medir, de lo qual todo se dará por entregado, y se obligará la forma a dar quenta dello. Y quando alguna cosa se hiziere de nuevo, el obrero desta nuestra santa yglesia se lo entregará delante del dicho secretario y de dos preuendados nonbrados por el cabildo, los quales todos lo firmaron. Y lo mismo se hará cada y quando que se renouó, deshizo o añadió o se quitó algunas cosas de las que están hechas o se hizieren, asentándolo en la misma forma, de manera que el dicho ynuentario quede muy claro y muy distinto de todo lo que en la dicha sacristía ay y es a su cargo. Y si el dicho therorero no quisiere hazer lo suso dicho, le penen y multen hasta en tanto que lo haga, y el cabildo nonbre persona que a costa del dicho therorero haga el dicho officio hasta tanto que el dicho thesorero haga y cumpla lo 


\section{LA ABADÍA DE SANTA MARÍA DE HUSILLOS: ESTUDIO Y COLECCIÓN \\ DOCUMENTAL $(904-1608)$}

que aquí se ordena y manda. Y si alguna cosa faltare de las que por el dicho ynuentario se ouieren entregado al dicho thesorero, lo pague dentro de veinte días después de la verificación de la dicha falta en la misma manera y de la misma forma, peso y medida y hechura que era al tiempo que se le entregó. Y si fuere cosa que se enuegezca o puede perder el peso, calidad o hechura, lo pague como se aberiguare baldría al tiempo que se perdió. Y si no se pudiere aberiguar, lo pague conforme a la entrega que se le hizo, teniendo respecto al tiempo que a que sirue y a lo que pudo perder en el dicho tiempo de su valor. Y de lo que fuere a cargo del dicho tesorero, se harán dos libros de todos los dichos bienes firmados de los sobredichos. El vno esté en el archiuo desta santa yglesia. Y el otro en poder del dicho thesorero.

A cargo del dicho thesorero está nonbrar sacristanes para que siruan la sacristía y tanan las campanas y ayuden $<$ Quenta de lo que se le entregare. Ynuentario. Nombra sacristán $>(f .4 r)$ a las misas, de manera que aya seruicio suficiente para todo lo dicho y para linpiar los altares, barrer la yglesia, claustro y capítulo y coro y todo lo demás, yncluso dentro de la puerta principal de la yglesia. A de dar 50 cargas para las campanas, y ostias para las misas que se dixeren en la dicha yglesia, todas las que fueren menester. A de tomar fianças de los tales sacristanes que nonbrare para asegurar lo que se les entregare, porque si alguna cosa faltare por negligencia o descuido de los dichos sacristanes, a deuer a quenta del dicho thesorero y la yglesia lo a de cobrar del los quales sacristanes que ansí nonbrare con clases ábiles y suficientes para exercitar sus officios con cuydado y diligencia. Y si los que ansí nonbrare no lo fueren y el cabildo le requiriere, ponga otros que lo sean. Si dentro de vn mes después que fuere requerido no lo hiziere, el cabildo le pene y multe y ponga otros en su lugar y los pague de lo que el dicho thesorero ouiere de auer. $\mathrm{Y}$ el dicho thesorero reciua fianzas dellos, porque siempre a de ser a cargo del dicho thesorero lo que se les entregare.

A cargo del thesorero es adornar y tener bien linpios los altares y enrramar la yglesia con rramos respadañas y tomillo las fiestas principales como son la Epifanía, Purificación, Anunciación de nuestra Señora, la Resurreción, la Ascensión de nuestro Señor, Pascua de Spiritu Santo, San Juan, San Pedro, Santiago, la Asumpción y Natiuidad de Nuestra Señora, San Lorencio, Todos los Santos y Natiuidad de nuestro Señor. 
Terná el thesorero mucho cuydado que los hornamentos y todas las demás cosas que están en la sacristía y en la yglesia estén bien tratadas y linpias y bien conpuestas y cada cosa en su lugar. Y podrá salir del coro cada y quando que quisiere a preuenir y proueer y uer las cosas tocantes al seruicio de la yglesia y sacristía tan solamente sin que pierda ora ninguna. Por ello con que se [...] siempre en el coro y esté con su hábito.

$<$ Fianzas al sacristán. Linpiar los altares. Ramos. Hornamentos limpios $>$ $(f .4 v)$

$<$ La cera que está obligado a dar $>$ Es tanbién a cargo del dicho therorero de dar y proueer toda la cera que se gastare en el altar mayor para las misas mayores y memorias que el cabildo haze en todo el año y para las vísperas y maitines ordinarios y solemnes. Y el día de la purificación de nuestra señora de cada un año está obligado a dar a las dignidades de la dicha yglesia a cada una dellas vna bela de cera de a media libra, y a los canónigos y rracioneros enteros de a quarterón, y a los medios rracioneros de a medio cuarterón. Y ansí mismo a de dar belas de cera para las tinieblas y dos blandones y cirios para el monumento, que ardan entre tanto que estubiere encerrado el santísimo sacramento.

Tanbién a de dar el cirio pasqual de pascua de flores que pese diez libras y encienso todo lo que se gastare y fuere menester en todas las solemnidades de las fiestas para las vísperas y misa y procesiones de las dichas solemnidades.

$<$ Tortas $>$ Y tener a cargo del thesorero de dar el día de los defunctos a cada una de las dignidades que se hallaren en los maytines y misa de los defunctos doce tortas; y a cada canónigo y rracionero entero, seis tortas; y al medio rracionero, tres tortas, con que no excedan las dichas tortas de media carga de trigo.

$<$ Officio de cura $>$ Y tener a cargo del dicho thesorero de exercer el officio de cura por su persona o dar persona que por él lo sirua que sea ábil y suficiente y aprobado por el abad. 
$<$ Tañer a las oras $>$ Es tanbién a cargo del dicho thesorero de tañer a todas las oras canónicas y a los cabildos ordinarios y extraordinarios, y a poner persona que lo haga con diligencia, y cuydar a las oras y medias oras y en la forma y manera que adelante yrá declarado, que es la que se sigue: desde el día de San Miguel de setiembre hasta el Sábado Santo, se començará a tañer a prima a las ocho y se quedará a las ocho y media. Y en el otro tiempo del año, a las siete y media de la mañana, y se quedará a las ocho. Y quando ouiere sermón o procesión que el cabildo salga fuera de la yglesia, de tañer a media ora antes y siempre haziendo señal con el esquilón y campana, vna ora, y en dando la ora se tocará $(f .5 r)$ con el esquilón que para esto ay, y se tañerá con él media ora hasta que la dicha media ora haga señal, y hecha lo dexará. Y el semanero o a quien lo ouiere encomendado començará la prima sin dilación alguna. Y no se hallare allí ni otro a quien lo aya encomendado pueda aquella ora y comiénzela vn preuendado de los que se hallaren presentes. Y acabada la prima se proseguirá en las otras oras según la costumbre desta yglesia hasta ser acabadas sin que aya ynterpolación. Y se tañerá a ellas según y como se fuese hazer, no pareciendo otra cosa al cabildo. Quando la nona se dixere a la tarde, se comenzará a tañer a las dos de la tarde y se tañerá media ora un quarto en hazer señal y otro en quedar hasta que la dicha media ora haga señal. Y hecha comenzará el semanero como en la prima y so la misma pena.

$\mathrm{Y}$ en tanto que se dice la pena, se tañerá a vísperas para que acabada se pueda comenzar?. Y quando la nona se ouiere dicho por la mañana se tañerá a vísperas a la misma ora de las dos, media ora en hazer señal y quedar hasta que la dicha media ora haga señal según y en la forma que se tañó a nona; y las completas se dirán siempre ynmediatamente después de las vísperas.

$<$ Cuando se [...] el tañer $>$ Desde principio de nouiembre hasta fin de febrero se començará a tañer a maytines a las quatro oras de la tarde. Y desde principio de marzo hasta fin de abril, a las cinco. Y desde principio de mayo hasta fin de agosto, a las seis. Y desde principio de setiembre hasta en fin de otubre, a las cinco. Y siempre se tomará media ora entera hasta que la dicha media ora haga señal.

Todos los días de pitanza y fiestas principales que ay maitines solemnes, se tañerá un ora antes. 
Tañenerá con la solemnidad que rrequiere el officio de cada vn día a la oración se tañerá dos uezes al día, vna al tiempo que [...] en la misa mayor, y otra en acabando de tañer a maytines; y consecutiuamente? se tañerá luego por las ánimas de purgatorio, hechando el esquilón en pino como se suele hazer. Y en en (sic) los días que ouiere sermón, se tañerá a él con la campana grande hechando la horpino? la noche antes en acabando los maytines $(f .5 \mathrm{v})$

$<$ Annexos a la thesorería $>\mathrm{El}$ dicho thesorero tiene para los dichos cargos y para ayuda de llebarlos, dos mill y cien maravedís de censo perpetuo cargados sobre los molinos de Pajares, los quales le paga el cabildo en fin de cada vn año y en las quentas finales que hazen con el mayordomo en el qual se los libran.

Yten tiene más el préstamo annexo a la thesorería que está en la villa de Fuentes de Naba.

Yten tiene más y lleba el yngreso de la yglesia todo el año, exceto las fiestas principales de pitanzas, que se reparte la ofrenda en dos partes. La vna lleba el dicho thesorero o la persona que por él haze el officio de cura. Y la otra lleban los tres beneficiados que celebran los tales días de pitanza.

$<$ La iglesia linpia $>$ Terná mucho cuidado que la yglesia esté barrida y muy limpia, y que antes que barra la riegue y la limpiará en ynbierno de ocho a ocho días y en berano de quatro a quatro días. Y terná siempre proueídas las pilas de agua bendita.

$<$ Anales $>$ Yten lleba el thesorero o su cura los anales de los defuntos que mandan se les lleue dentro del año, en los quales no tiene ninguno parte aunque sea día de pitanza.

$<$ Primicias $>$ Yten lleba todas las primicias e las demás auenturas que el dicho cura touiere en la dicha yglesia pertenecientes al dicho curado.

$<$ No se saque ornamento sin licencia $>$ Yten que el tesorero, ni ningún benenficiado desta yglesia, ni el sacristán ni otra persona alguna, saquen, ni permitan sacar ningún ornamento, cálices misales, capas, albas ni otra cosa alguna 
de la sacristía desta yglesia sin licencia del cabildo, so pena que el que lo contrario hiziere y lo mandare dar pague dos ducados aplicados para la fábrica desta yglesia, exceto que se podrá sacar sin la dicha licencia lo que fuere menester para yr a dezir misa al humilladero término desta villa. Y si alguno lo quisiere sacar fuera del término, bastará que la dicha licencia se pida en el coro a qualquiera ora, aunque sea a los maitines. Y dándola, los beneficiados que allí se hallaren presentes se podrá sacar y llebar sin pena ninguna y no de otra manera. $(f .6 r)$

$<$ Chantre $>$ Constitución 4 del officio del Chantre.

Al officio del chantre yncumbe asistir en el coro y en las procesiones y regir y gobernar en lo que toca al canto o poner persona que por él lo haga; y no lo haziendo, será multado por el presidente o por el cabildo conforme a la falta que ouiere.

$<$ Tabla $>$ El sábado de cada semana haga tabla y fígela en la parte donde es costumbre, en la qual ponga los que an de seruir al altar y tomar capas y hazer otros oficios en el coro en la semana siguiente, y de quien y conosca de rejar cada vn día de la dicha semana y ponga en ella todas las memorias y aniuersarios que se ouieren de hazer en la tal semana. La qual tabla el dicho chantre o su sochantre leerá en alto e ynteligible boz el biernes antes a la prima después de la preciosa para que todos lo sepan.

$<$ Collación del Chantre $>$ Es a cargo del chantre de pagar seis ducados a todos los beneficiados que se hallaren en las vísperas del segundo día de pascua de Spiritu Santo, y en la misa del día siguiente que es la colación que antes daua y se conmutó y concordó en los dichos seis ducados. Y si no lo cumpliere, el prior o presidente lo mande pagar a su quenta al mayordomo de molinos. Lo qual se gana por persona tanto al medio racionero como a la dignidad.

$<$ Quienes se han de vestir con el abad> Terná el chantre cuidado quando el prelado dixere misa que el thesorero o el dicho chantre con el canónigo más antiguo siruan de diácono y subdiácono, preueniéndoles siempre el día antes. 
$<$ Chantre o sochantre en el coro $>$ Terná cuidado el chantre o su sochantre de registrar en el coro lo que se ouiere de cantar al facistor y hazerlo a cada día antes que se comiencen las oras, porque mientra ellas no se haga rruido ni bullicio que las perturben. Y estará en el coro en las oras menores antes que se comience el hino, so pena que no estando él o su chantre, sea multado por el presidente. Y en las misas entrará antes del yntroitu; y en las vísperas, antes que se comience la primera antífona, so pena que no lo haciendo sea multado por el presidente como dicho es. Entonará todo lo que se ouiere de cantar en el coro y procesiones y en todas las demás $(f .6 v)$ partes donde el cabidlo estubiere y fuere con pausa, conforme a la solemnidad de cada fiesta; y terná mucho cuidado de detener el coro quando se apresure y de que se guarde la dicha pausa.

$<$ En qué se a de ouedecer al chantre $>$ Todos los preuendados y ministros de la yglesia ouedezcan al chantre o a su sochantre en lo que toca a su officio en el coro y procesiones; y si auisados los dichos preuendados no hizieren lo que están obligados, el presidente los multará conforme al defeto que hiziere.

$<$ Asiento de forasteros $>$ Terná cuidado el chantre o su sochantre de poner en su lugar a las personas ecclesiásticas que de fuera entraren en el coro, y que no esté en el lego ninguno sin licencia del presidente. La qual no se dará sino a persona que lo merezca.

$<$ A de hazer llebar todo recado quando el cabildo fuere fuera $>$ Quando el cabildo saliere fuera de la yglesia en procesión abiendo de decir misa donde fuere, terná cuidado el chantre o su sochantre de mandar llebar los libros y las demás cosas necesarias para el officio.

$<$ Cómo a de encomendar en el coro $>$ Cuando el chantre o su sochantre encomendaren a algún preuendado desta yglesia que diga leción, verso o resposo o antífona o que cante al facistor, el tal beneficiado lo dirá con todo reposo y buena composición. Y no lo pudiendo hazer, el tal encomendado lo pidierá con la misma crianza al beneficiado más cercano que lo haga por él, so pena que el que 
hiziere lo contrario pierda la distribución de aquella ora. Y si el chantre o su sochantre a cuyo cargo es no fueren a hazer la dicha encomienda con tiempo, la qual an de hazer quitado el bonete y con todo respecto, si no lo hiziere, pierda la ora.

$<$ Reliquias. Constitución de los reliquiarios $>$ El prior y cabildo desta nuestra yglesia nonbren cada principio de año dos beneficiados que sean honbres religiosos y de buena conciencia y les entregarán las llabes de las reliquias para que fielmente las guarden y las enseñen los días que es costumbre, y generalmente las enseñen a todos los que $(f .7 r)$ las quieren uer y venieren de fuera y benerarlas. Y quando los dichos beneficiados se ausentaren desta villa, dexarán las llabes. Y mandamos que las santas reliquias que ay en esta yglesia, se tengan en fiel custodia y deuida beneración. Y que para esto, cada uez que el cabildo nonbrare reliquiarios, se les entreguen las dichas reliquias que ay y ouiere en la forma que de parte? están. A los quales mandamos no las den enprestadas ni de otra manera las dichas reliquias ni parte alguna dellas, so pena de excomunión.

Late sentir y es nuestra voluntad, que nuestro prouisor no pueda alzar ni quitar la dicha censura que se haga ynuentario de las reliquias y se ponga auténtico en los archiuios.

$<$ Obrero $>6^{\text {a }}$ Constitución del obrero.

El obrero tenga gran quenta con su officio y mucha diligencia y cuidado en que las cosas de la yglesia estén linpias y puestas cada cosa en su lugar. Procurará que los paños blancos de la yglesian anden muy limpios. Y quando traxere officiales y obreros que trabaxaren en la dicha yglesia, trabaxen como deuen y hagan lo que están obligados, y compre siempre que pudiere a sus tiempos los materiales necesarios para las obras que se hizieren. Y quando se ouiere de comenzar alguna obra o hazer algún gasto que no sea de los ordinarios, consultarlo a con el prelado en esta villa, y no de otra manera, para que se acierte mejor. Y lo mismo hará en la prosecución de las obras quando le pareciere que conbiene. 
$<$ Lámparas y relox $>$ Tenga mucho cuidado que la persona a quien diere cargo de tener quenta del relox y de las lámparas traya bien concertado el relox y muy limpias las lámparas y encendidas.

$<$ Quenta el obrero $>$ El obrero que fuere nombrado dará quenta con pago a los officiales que el cabildo para ello touiere nonbrados en cada vn año y por ninguna causa se dilaten las quentas de un año para otro $(7 v)$

$<$ Hábito y costumbres $>7^{\mathrm{a}}$ constitución de hábito y costumbres

Todos los preuendados y ministros desta santa yglesia trayan las barbas y cabello cortado y las coronas auiertas y el hábito honesto. No trayan lechuguillas ni polainas olorosos ni seda como es ropa de tajetan raio terciopelo. Y si auisados por el corretor que para ello el cabildo tubiere nombrado, que emiende algún defeto de los susodichos, no lo hiziere por la primera uez, pierda la misa de aquel día; y la segunda, todas las oras del tal día que se le auisare; y por la tercera, toda la semana.

$<$ Cómo se a de entrar en la yglesia $>$ En la yglesia ningún beneficiado entre sin sobrepelliz mientras que las oras se dixeren, so pena que el que lo contrario hiziere por cada bez que entrare sin ella, pierda un día de lo ganado, saluo los maytines.

$<$ Sobrepellices $>$ Encargamos a todos los beneficiados desta yglesia que tengan cuidado con que las sobrepellices que traxeren, sean de olanda o ruan o lienzo, de manera que sean onestas y las trayan muy linpias y con el aseo que conbiene.

$<$ Toros $>$ Que ningún beneficiado desta yglesia pueda uer toros publica [...] en esta villa ni fuera della en plaza pública, ni baya al lugar donde se corrieren, ni entre en el día que se corrieren, so pena de seis días las oras de lo ganado, excepto los beneficiados que estubieren dos días antes o pasando de [...]. Y entrando en el dicho lugar no sabiendo que los ay, porque en tal caso no yncurre en la dicha pena con que el que entrare en el mesmo día que se corriere no lo sabiendo se salga luego del dicho lugar. Y no se saliendo, sea visto yncurrir en la dicha pena. Y los 
que estubieren dos días antes, si se les verificare que los an visto, yncurran en la dicha pena, y no de otra manera. La execución de todo lo dicho cometemos al cabildo desta nuestra yglesia.

$<$ No se puede tomar de gran estado en el pueblo día de fiesta $>$ Que ningún beneficiado tome de gracia los días de fiesta o domingo que sean de guardar estando en esta villa de Husillos, so pena que pierda el tal día. Ni pueda jugar mientras las oras los tales días, so pena que el que jugare mientra ellos estando en esta villa de Husillos, pierda tres días las oras de lo ganado.

$<$ Silencio $>$ Guárdese el silencio en el coro con mucho cuydado. Y si alguno como (f.8r) amonestado por el presidente no quisiere callar, sea priuado de aquella ora. Y si todauía perseuerare, sea multado con mayor pena. La qual no pueda remitir el presidente vna uez mandado quitar, si no fuere en cabildo pleno. Y el cabildo uerá lo que conbiene. $\mathrm{Y}$ encargamos mucho al presidente no quite ora a ningún beneficiado sin que primero le haga preuendado.

$<$ Officio de semanero $>$ Todos los preuendados que tomaren semanas y fueren señalados en la tabla, lo harán por sus personas, y no pudiéndolo, encomendarán a otro que por ellos lo haga, con que el domingo diga la misa mayor, y ninguno que no la dixere no pueda tomar semana si no fuere con quien el cabildo tubiere dispensado. Y si fuere fuera después de auer dicho el domingo misa y no lo encomendare ny dejare substituto para que diga las misas y capitule y siga los demás oficios, pague por cada día que hiziere la dicha, fasta vn real, el qual applicamos para el beneficiado que dixere la misa y capitulare por él.

$<$ Orden en la presidencia $>$ De aquí adelante en el choro y procesiones desta santa yglesia, el canónigo que fuere presbítero preceda en la silla y lugar al que fuere diácono. Y el diácono al subdiácono. Y el subdiácono al que no lo fuere. Y la misma orden guarden los racioneros y medios racioneros, entren sin perjuicio de la antiguedad de cada vno, para que siendo ordenado pueda voluer y buelua al lugar de su antiguedad. Con que es nuestra voluntad por algunas razones que a ello nos mueuen, que esta constitución no se entienda ni perjudique a los 
beneficados presentes que están en su posesión sino a los beneficiados que de aquí adelante vinieren y tomaren posesión, con los quales se guarde y cumpla esta constitución como en ella se contiene.

$<$ Quando se toman capas y quando se dexan $>$ Desde el día de los defuntos hasta el Sábado Santo exclusive, las dignidades, canónigos y racioneros y medios racioneros han de traer en la yglesia capas negras encima de las sobrepellices de paño de ante o anascote están esta? o carilla? sin forro ninguno, salbo las capillas que se podrán aforrar de terciopelo raso o tafetan?, o otra seda negra tenga falda bastantemente. Y han las de traer cogidas como ordinariamente se suele hazer. Y el que sin ella en el dicho $(f .8 v)$ tiempo entrare en el coro, pierda las oras que estubiere sin ella, excepto tomando de gracia, que en tal caso puede entrar con sobrepelliz y tanbién desde las vísperas de la nauidad de nuestro Señor hasta el día de los rreyes y las vísperas y día de la Purificación, Concepción y Anunciación de nuestra Señora y todas bezes que el cabildo saliere fuera de la yglesia en procesión. Y tanbién las personas con quien el cabildo dispensare por enfermedades o por otras rrazones que para ello les mouiere, porque estos an de ir sin ellas y delante de todos aunque sean divinidades, porque ninguna sobrepelliz baya ni esté entre las capas, ansí en el coro como en las procesiones. Ni los tales beneficiados estén en las sillas altas sin capas.

$<$ Cómo se a de entrar $>$ Los preuendados y ministros desta yglesia, quando entraren en el coro hincarán la rodilla al santísimo sacramento pudiéndolo buenamente hazer y teniendo salud para ello. Y el que no pudiere, ynclinará la cabeza lo más que pudiere. $\mathrm{Y}$ antes que se pongan en sus sillas, quitado el bonete y abaxando la cabeza, harán ynclinación al prelado estando frente, y a ambos los coros y todos los demás ministros, harán lo mismo. Y hecho esto, todo cada vno se hará a su silla y lugar. Y encargamos esto se haga y cumpla con mucho cuidado.

$<$ Quanto se pierde a las oras $>$ Las dignidades, canónigos, rracioneros y medios racioneros que se hallaren en el coro el día de fiestas y domingos de guardar al vltimo chirie de la misa y los demás días que no fueren fiesta de guardar, antes 
que se acabe la epístola, y en las oras del día al Gloria Patri del primer salmo, y en los maytines solemnes al Gloria Patri del veinte exuliamus, y en los demás maytines ordinarios al Gloria Patri del primer salmo, pierdan la distribución de la tal ora.

Y después que entraren en el coro, el que saliere de la misa antes de la bendición del sacerdote y de las demás oras sin exceptar ninguna antes del fidelium anime, pierdan la distribución de aquellas oras si no fuere el que saliere con licencia del presidente; la qual solamente sea de conceder para spiritual o corporal necesidad o negocios de la yglesia. Los que lo contrario hizieren, pierdan la distribución de aquella ora, excepto los contadores, presidente y secretario, que sólo presentarse en el coro sin otra licencia ninguna se podrá yr a hazer quentas, y el secretario a preuenir y a hazer en el capítulo todas las cosas tocantes a la yglesia y cabildo y su mesa capitular, todas las ueces que el dicho secretario $(f .9 r)$ tubiere cosas en que se ocupar de lo dicho y los beneficiados que ban o fueren fuera desta villa o negocios de la yglesia y cabildo como son mayordomo de rentas y molinos, obrero y procurador y otras personas que ban a negocios por orden del cabildo, todos los dichos cumplan con decirlo antes que se partan al tal negocio al presidente, scriptor y secretario.

$<$ Silencio en el coro $>$ Los preuendados y otros ministros de la yglesia se juntan en la yglesia y procesiones para alabar a Dios con el corazón y cantando con la boz. $\mathrm{Si}$ algunos en esto fueren negligentes, amonésteles el presidente que canten, y que no parlen ni rezen ni estén diuertidos en otras cosas ni lean en libro alguno ni en carta ni en otro papel. Y si no lo hizieren, múlteles en el estipendio de aquella ora. Y creciendo la desobediencia, les penarán y multarán con mayores penas. Y encargamos al presidente que no quite a ningún beneficado ora ninguna sin que primero le haga preuención.

$<$ Cómo se an de zelebrar los oficios $>8^{\text {a }}$ Constitución como se an de celebrar los officios en la yglesia.

En las misas que llaman mayores: la gloria yn excelsis Deo y el credo, quando se ouiere de decir, y el prefacio y el pater noster, se diga cantando los chiries santus. Y los agnus Dei se podrán decir alternando con el órgano. Y por ninguna cosa se 
diga de otra manera, saluo los días que ouiere sermón, que se podrá dexar de cantar el prefacio, pero no el Pater Noster, si no fuere con licencia del presidente y todos los oficios de unos, ansí los que pertenecen a la misa como a las otras oras se digan cantados con la solemnidad que cada vno requiere, saluo que los maytines de las fiestas simidúplex y dúplex y simples que no son de guardar y feriales se dicen rezados y los maytines de pitanzas se dicen con solemnidad cantados todas las fiestas dobles y dominicas se dicen rezados hasta la capítula, y de la capítula adelante, cantados. En los quales maytines ordinarios, se distribuyan y repartan treinta y quatro maravedís entre los presentes hinteresentes. Y estos dichos maravedís $(f .9 v)$ marauedís (sic) no los gana ni puede ganar el enfermo ni el ocupado ni el preso ni en otra manera alguna si no fuere estando [...] a ellos.

$<$ Officio de Nuestra Señora $>$ En el jueves y viernes y sábado de la semana santa, la prima tercia y sesta nona y vísperas y completas y por todo el año, las oras menores de Nuestra Señora se canten en tono alto bien pronunciado y con sus pausas, de manera que el un coro aguarde y entienda al otro y en ninguna manera se digan atropelladas. Y desto encargamos se tenga dello mucho cuidado.

$<$ Acompañamiento del semanero $>$ Quando el semanero saliere del coro para yr a decir la misa mayor, acompañarle an el diácono y subdiácono y el beneficiado que les a de seruir al altar. $\mathrm{Y}$ hecha reuerencia al santísimo sacramento, yrán a la sacristía a donde se bestirán con mucho silencio, lebantando los corazones a Dios nuestro Señor y disponiéndose para ofrecerle a aquel altísimo sacrificio. Y vestidos y bien compuestos, saldrán al altar quando el coro comenzare a decir el Gloria Patri con el aconpañamiento de acólitos y ciriales que suele, y guardará con cuidado las ceremonias de la misa ansí en esto como en decir la misa ynacabada. Y auiéndose desnudas, se volberán al coro por la misma orden que fueren acompañando al preste el diácono y subdiácono y acólitos. El qual acompañamiento encargamos le hagan con el preste, el diácono y subdiácono en quanto pudiere ser, y dexarle an en su silla. Y quando entrare en el coro el preste, los que en él están se lebantarán con los vonetes quitados por beneración del ynefable sacrificio que a ofrecido. $Y$ el que faltare en alguna cosa destas sea 
aduertido para que lo haga. Y lo mismo se guarde quando se fuere a encensar al altar con los que celebran a la misa de la solemnidad.

$<$ Ofrecer $>$ En las mayores fiestas y solemnidades, que son los días que abajo yrán declarados, el prelado, si se hallare en el coro con el cabildo, bayan en procesión hasta el altar a ofrecer, yendo y uolbiendo el prelado delante de todos de tal manera que no se pasen ni esperen unos a otros, ofreciendo primero el prelado. Y luego el presidente y ansí consecutibamente todos por sus antiguedades. Y lo que se ofreciere se reparta en la forma y manera que está declarado y se acostumbra. Y ninguno dexe de ir a ofrecer los tales días, so pena (f.10r) de medio real, el qual sea y se reparta en la forma dicha. Y la misma ofrenda se haga los dichos días aunque el prelado esté ausente. Entiéndase que todos an de salir del coro y boluer a él, sola dicha pena.

Las solemnidades de las fiestas que el prior y cabildo celebran con capas, maytines y procesiones son las siguientes:

La Epifanía, Santiago, La Purificación, San Lorencio, La Anunciación de Nuestra Señora, La Asumpción de Nuestra Señora Pascua de Resurrección, La Natiuidad de Nuestra Señora, Pascua de Spiritu Santo, La fiesta de Todos los Santos, San Juan, La Natiuidad de Nuestro Señor, San Pedro.

$<$ Perlado $>$ Las fiestas de pontifical que a de decir misa el prelado y en su ausencia el prior son las siguientes:

Juebes Santo, Uiernes Santo, Sábado Santo, primer día de Pascua de Flores, Miércoles de Ceniza, Corpus Christi, primero día de Pascua de Spiritu Sancto, Nuestra Señora de Agosto, Todos los Santos. la misa del gallo, la misa del día de la Natiuidad de Nuestro Señor, San Pedro.

$<$ Thesorero $>$ Las fiestas de pitanza que a de decir el thesorero son las siguientes: La Epifanía, Anunciación de Nuestra Señora, Domingo de Ramos, Anunciación de Nuestra Señora, Acensión de Nuestro Señor.

$<$ Chantre $>$ Las misas que a de decir el chantre:

San Juan, Santiago, San Lorencio, Natiuidad de Nuestra Señora. (f.10v) 
Todos los dichos días dirán las dignidades los primeros días tan solamente y no más en la forma y manera que ban declarados. Y no los diciendo por estar ausentes o enfermos o por otra qualquiera causa, las dirá el canónigo más antiguo. Y fuera de los dichos días harán los semaneros sus oficios y dirán los aniuersarios que en sus semanas les tocare, porque no son pitanza ni an de ser de las dignidades ni canónigos antiguos, sino del semanero que le tocare.

$<$ Cómo a de salir el cabildo fuera de la yglesia $>$ Quando el cabildo saliere fuera de la yglesia en procesión o en otra qualquiera manera, yrá con toda solemnidad cantando y guardarán su orden. Y si ouiere de decir misa, el semanero llebará los bestidos y ornamentos decentes del color que la tal solemnidad pediere. Y el semanero aunque la procesión se haga por la tarde, yrá con capa como suele. Y el preuendado o otro ministro que no guardare silencio, orden y ceremonias deuidas ansí en la procesión como estando en la misa, o se saliere y no estubiere presente a los dichos oficios, será multado en lo que ganare como si estubiere en el coro, excepto saliendo con licencia del presidente a necesidad special o corporal. Y a la buelta de la dicha procesión, todos los dichos beneficiados y ministros de la dicha yglesia buelban a ella guardando la misma solemnidad con que salieron, si al perlado o al cabildo no pareciere otra cosa. $(f .11 r)$

Todos los beneficiados salgan de la capilla mayor con la cruz quando el cabildo fuere en procesión, ansí en las procesiones generales y particulares como en entierros y en otras cosas que capitularmente sale el cabildo con la cruz, so pena que el que no saliere con ella pierda la distribución que en ella se ganare. Y el que dixere misa entre tanto que se haze la dicha procesión, pierda la distribución, porque en las solemnidades es justo nadie falte a ellas. Y en esto con ninguno se dispense si no fuere con el thesorero o con la persona que hiziere el oficio de cura que estando ocupado en su ministerio lo ganara.

$<$ Cómo se a de dar la paz en el coro. La paz al provisor $>$ Yten por quanto algunos beneficiados quando ban a dar la paz al coro estando presente el prouisor le dan paz a él primero y la quitan al presidente, siendo suya, mandamos que de aquí 
adelante den paz primero al presidente y segundo al prouisor, estando en el coro, que si estubiere en la yglesia darán primero al cabildo y después al prouisor.

Ningún beneficiado desta yglesia baya baya (sic) con hábito a entierro fuera della ni a otra parte ninguna donde no fuere el cabildo, so pena de dos reales, saluo el cura o el thesorero o quien toca hazerlo.

Todas las fiestas dobles y votos de concejo, días de Nuestra Señora (f.11v) Señora (sic), se dirá la misa mayor con diácono y subdiácono aunque no sean fiestas de guardar, y toda la semana santa y el día de los finados, los días que ouiere enterramientos, obsequias o cabo de año.

$<$ Quando se toman capas $>$ Iten que tomen capas todas las pascuas y día de pitança a las primeras vísperas. Y los caperos que las tomaren, conuiden cada vno a entonar las antífonas y salmos cada vno a los de su coro, alternando y comenzando por los beneficiados más modernos, y no se confundan los coros aunque el vn coro entone más vezes que el otro.

$9^{a}$ Constitución. De la orden que an de guardar los officiales que el cabildo nonbra.

El cabildo nombrará en el primer cabildo general de cada vn año los officiales que son menester para las quentas y buena gobernación de la yglesia y su mesa capitular. Los quales procurarán que sean honbres de buena conciencia y cuidado, porque dellos principalmente depende el buen seruicio de la yglesia y buena gobernación de las demás cosas. Los quales luego que fueren nonbrados por la mayor parte del cabildo, juren ante el presidente del cabildo que harán fielmente cada vno su officio y en el quento y desquento guardarán a cada vno su justicia y le darán realmente lo que ouiere de auer y ganaren.

Los dichos officiales no pueden ser remouidos sin legítima causa el año que fueren nonbrados $(f .12 r)$

Constitución de confesión y comunión.

Las fiestas principales que todos los beneficiados desta yglesia son obligados a confesar y comulgar son las siguientes: 
Juebes Santo, Pascua de resurrección, Pascua de Spiritu Santo, San Pedro, Asumpción de Nuestra Señora, Todos los Sanctos, Natiuidad de Nuestro Señor.

Todas las dichas fiestas confesarán y comulgarán todos los beneficiados desta yglesia que se hallaren presentes los dichos días, so pena que el que no lo hiziere pierda tres días de lo ganado. Con que si el beneficiado touiere alguna causa legítima para no lo poder hazer, el tal día como se confiese ý diga la causa al presidente cumpla por aquel día con que el día siguiente lo haga y no lo haziendo, yncurra en la dicha pena de los tres días.

$<$ Enfermos $>$ Yten todos los beneficiados que estubieren enfermos los tales días estén obligados a confesarse y se confiesen y el primer día que salieren y quebraren la tal enfermería comulguen sola pena arriba dicha. Tanbién cumplen como lo hagan el segundo día.

$<$ Los ausentes $>$ Yten todos los beneficiados que qualquiera de los dichos días estubieren ausentes desta yglesia y villa estén obligados a confesar y comulgar dentro de quatro días después que sean binidos, so pena que el que no lo hiziere pierda los dichos tres días con que si el tal beneficiado confesare y comulgare en la parte donde estubiere las tales fiestas trayendo razón de como lo a hecho cumpla y lo mismo se entiende con los que estubieren presos. $(f .12 v)$

10. Constitución. Cómo ganan los prevendados la renta de la mesa capitular.

$<$ Cómo se gana la renta de la mesa capitular $>$ Todos los beneficiados antiguos que no sean primeros residentes, están obligados a residir en cada un año, medio año y un día, para ganar la gruesa que es pitanzas, leña, centeno, gallinas, bino. Y el que no la hiziere, no gana ninguna cosa de lo dicho. Y para ganar el centeno están obligados a hallarse a los cabildos de las rentas los dos días vltimos de la pascua de Spiritu Santo y el domingo de la Trinidad. Y el que no se hallare a los dichos cabildos no gana el centeno, aunque aya hecho la dicha residencia.

$<$ Residencia de modernos $>$ Todos los beneficiados modernos que tomaren posesión en esta yglesia están obligados a residir para hazer su residencia vn año 
y un día, en el qual dicho tiempo no puede ganar más de vnos frutos aunque haga la dicha residencia en dos años. Y para ganar el centeno están obligados a asistir y hallarse a nueue cabildos de rentas en tres años. Y entre tanto que lo aya hecho, no gana el dicho centeno, contándose desde el día de su posesión.

Todos los días principales que están dichos a maytines y procesión, se gana vn real por preuenda por mitad, exceto la cenica?, que se ganan dos reales por preuenda. Y a los maitines y procesión de nuestra señora de agosto, se ganan quatro reales por mitad. Y a los maitines y procesión de la Natiuidad de Nuestro Señor, se ganan otros quatro reales. En los quales maytines y procesión el preuendado que no se hallare a ellos, pierde seis gallinas por mitad, no estando preso o ocupado por el cabildo.

$<$ Memorias $>$ Yten que de aquí adelante no se admita ni reciua memoria a ningún particular menos de que dé de contado veinte mill maravedís o el balor dellos bien saluados en juro, censo o posesión que lo balga.

Toda la demás renta de la mesa capitular se gana y reparte en todo el año y lo ganan los beneficiados que residieren. Y si alguno pierde algún día fuera de los tres meses que tiene la gracia, pierde lo que le toca por el tal día o días que falta de residir.

$<$ Gracia $>$ El preuendado y antiguo residente podrá tomar en cada vn año tres meses de gracia, juntos o interpolados, como quisiere, para sus negocios [...] (f.13r) sin pedir licencia para ello. Y sea contado y ganará enteramente su preuenda, excepto pitanzas y memorias, entierros y cabo de años y otras cosas que se ganan por presencia. La qual dicha gracia gozarán abiendo hechos o pudiendo hazer la residencia de seis meses y un día en cada un año y no de otra manera.

$<$ Para tomar de gracia qué se ha de fazer $>$ Ningún beneficiado desta yglesia puede tomar gracia ni gozar della si no fuere presentándose el primer día del año nueuo de cada un año en esta yglesia y asistiendo en la prima del tal día. Y presentándose y residir el tal día en la dicha prima, podrá gozar de su gracia, excepto los beneficiados que estubieren presos o ocupados en negocios del 
cabildo o con licencia particular del dicho cabildo, que en tal caso podrán gozar de la dicha gracia sin que se presenten.

$<$ Ocupados $>$ Los preuendados que estubieren ausentes desta yglesia ocupados en negocios que sean en utilidad de la dicha yglesia o del cabildo, serán contados como residentes todo el tiempo que durare la dicha ocupación y ganen enteramente sus preuendas y todas las distribuciones quottidianas que ganan los presentes hinteresentes, saluo si el cabildo no concertare con él o con ellos otra cosa. Y ningún beneficiado baya a ningún negocio sin orden del cabildo.

$<$ Presos $>$ Los beneficados que estubieren presos o enfermos sean abidos por presentes hinteresentes para ganar enteramente sus preuendas sin que pierdan alguna cosa, exceto que los enfermos ni los presos no ganan maytines ordinarios ni los presos memorias. Todo lo demás ganan como presentes hinteresentes.

$<$ Estudiantes $>$ El prelado con el cabildo podrá dar licencia para ir al estudio a los beneficiados que la pidieren teniendo necesidad de estudiar para tener la suficiencia necesaria para seruir sus preuendas mucho a Nuestro Señor y a la yglesia con sus letras. Y aún a los tales les podrán competir que bayan a estudiar. Y no se dará la dicha licencia a los que fueren mayores de treinta años, ni se pueda prorogar más de hasta siete años el theólogo, y cinco años al canonista. La qual dicha licencia se dará solamente por vn año, y al principio y al fin del ynbiarán testimonio auténtico como están matriculados y an estudiado con cuidado aquella facultad para lo que se les dio licencia. Y entonces se les podrá prorogar por otro año. Y ansí se haga todos los años. Y el prelado y el cabildo les podrá rebocar la dicha licencia quando les pareciere y uieren que conuiene. Y esta licencia no la podrá dar el prelado sin el cabildo ni el cabildo sin el prelado. $(f .13 v)$

Ganarán ganarán (sic) los estudiantes la mitad de lo que valieren las preuendas que tubieren contando en ellas todo lo que ganaren los presentes hynteresentes, excepto que no ganan pitanzas, memorias, procesiones, ni maitines, leña, ni centeno, ni gallina. 


\section{LA ABADÍA DE SANTA MARÍA DE HUSILLOS: ESTUDIO Y COLECCIÓN \\ DOCUMENTAL $(904-1608)$}

$<$ Cómo ganan los que resignan $>$ Quando alguna dignidad, canónigo o rracionero o medio rracionero resignan su preuenda, será contado y ganará los frutos de su preuenda enteramente bien y ansí como si no obiera resignado, hasta el día que la persona en quien resignó su preuenda tomare la posesión actual y jurídicamente. Y el cabildo y el cabildo (sic) y sus mayordomos le acudirán con los dichos frutos como a verdadero poseedor con tanto que haciéndose la dicha resignación en corte romana, dentro de quatro meses el nuebamente proueído tome la posesión, y hazíendose "yn partibus" dentro de vn mes. Y pasado el dicho tiempo, los frutos de la tal preuenda se acrezcan a la mesa capitular.

$<$ Házese frutos al que tiene pleito sobre su preuenda $>$ Quando algún beneficiado desta yglesia siendo poseedor trienal y pacífico de su preuenda maliciosamente o destra manera fuere citado para Roma o "in partibus" o molestado sobre la dicha su preuenda, y quisiere yr a Roma o a la parte donde a sido citado en siguimiento de su pleito, gane enteramente todos los frutos de su preuenda como presente hinteresente, con que primero fuese parta pida licencia y dé quenta al cabildo, y que la dicha licencia le sea dada y concedida por la mayor parte del cabildo, y no de otra manera. Y siéndole concidida como dicho es, yrá en seguimiento del tal pleito, hinbiará testimonio de cómo asiste al dicho pleito y está en seguimiento del.

\section{$11^{\text {a }}$ Constitución de enfermería}

$<$ Enfermería $>$ Quando algún preuendado desta yglesia estubiere enfermo en esta villa o pidiere de enfermería, la pedirá al escriba de las de las (sic) oras o a la persona que hiziere el officio. Los quales desde el punto que la pidiere se la hará con que la guarde y no salga de su casa si no fuere para benir uía recta a la yglesia a residir y presentarse en el coro diciéndose las oras, so pena que el que no lo hiziere pierda todos los días que ouiere gozado la tal enfermería. Y el día que tomare de enfermería, no puede quebrar la enfermería ni salir de su casa, so pena de perder las oras que a ganado el tal día. Entiéndese que a los maytines no se puede quebrar la enfermería, sino a las demás oras. 
$<$ Otrosí $>$ Quando algún beneficiado desta yglesia pidiere de enfermería para (f.14r) fuera de la villa por sí o por tercera persona, lo pedirá en el coro o en cabildo a los beneficiados que estubieren presentes acabando de dezir qualquiera de las oras del día antes que se comiençen aunque sea a los maytines lo podrá pedir a los que estubieren presentes y los beneficiados que allí se hallaren a qualquiera de las dichas oras se la concederán con que baya a curarse donde ouiere médico y botica ynbiando dentro de ocho días fe o cédula del médico que le curase y de cómo tiene necesidad de curarse, y con que guarde la enfermería y no salga de la casa donde el primer día que fue se apeó si no fuere para uenir uía recta a esta yglesia a presentarse. Y si no lo hiziere pierda todo lo que ouiere ganado en la tal enfermería.

$<$ Otrosí $>$ Si algún benecifiado estubiere enfermo de quebrado o lisiado o de otra enfermedad, para remedio de la qual tiene necesidad yr muy lejos desta villa donde entiende hallar a persona que le cure, se le concederá pidiéndola en la forma arriba dicha, aunque sea lugar a donde fuere que no aya médico ni botica mas de tan solamente el algibista o la persona que ba a buscar para su enfermedad, porque sería posible estar en algún lugar pequeño como de ordinario lo están y no auer botica ni médico, con que siempre enbíe fee y razón de cómo se están curando.

$<$ Otrosí $>$ Ningún beneficiado desta yglesia puede tomar de gracia ni gozar della estando enfermo sin que primero benga a la yglesia y se presente en el coro, si no fuere con particular licencia del cabildo. La qual no se dará si no fuere con muy justa causa. Y esta licencia no se dará si no fuere pidiéndola en cabildo y constando de la necesidad que tiene.

Para ganar los enfermos las letanías y los maytines de la noche de Nauidad y las tinieblas, an de tomar tres días antes la tal enfermería. Y el que no la tomare no lo gana.

$<$ Otrosí> El día que qualquier beneficiado pidiere de enfermería, no gana pitanza ni memoria ni entierro ni cabo de año que en tal día se hiziere. 
$<$ Trien al posesor no enseña los recados $>$ Todos los beneficiados desta yglesia siendo poseedores trienales que ayan estado quieta y pacíficamente en su posesión no estén obligados a enseñar sus recaudos al prelado ni a mi prouisor ni ellos se los puedan pedir. Y si se les pidieren, el cabildo defienda al tal beneficiado y salga al pleito y tome la boz por él.

$<$ Ordenar $>$ Todos los beneficiados que se fueren a ordenar con licencia particular del cabildo ganan como presentes hinteresentes sin que se les quite cosa alguna todos los días que gastare en ida y buelta y eslada?, señalándoles los días necesarios respeto del lugar donde fueren a ordenarse. Todos $(f .14 v)$

$<$ Possesión que tienen beneficios $>$ Todos los beneficiados los beneficiados (sic) antiguos desta yglesia que gozaren gracia an de tener para gozalla posesión del cabildo que balga mill maravedís, siendo dignidad con dos preuendas; y siendo canónigo o rracionero entero, que balga quinientos maravedís. Y siendo medio racionero, docientos y cinquenta maravedís. Y el que no la tubiere y gozare della pagará la dicha cantidad.

$<$ Primer residente no tiene gracia $>$ Los primeros residentes no tienen gracia ni la pueden gozar si el cabildo no se la conceda. La qual no se concederá si no fuere por causa muy legítima.

$<$ Que ninguno salga de la yglesia mientras el cabildo los viernes y lunes o los días que le ubiere, siendo hechos fiestas $>$ Todos los beneficiados votantes y no votantes que se hallaren todos los viernes y los primeros lunes de cada mes y año, residirán en esta yglesia. Y en tocando la campana del cabildo, los votantes uendrán al cabildo. Y los que no lo fueren a residir en el coro donde ninguno saldrá del hasta en tanto que el cabildo sea hecho, so pena que el que lo contrario hiziere el día del viernes de cada semana sea multado en medio real. Y los primeros lunes de cada mes en vn real, executados sin remisión.

$12^{\mathrm{a}}$ Constitución. Cómo se an de enterrar los beneficiados y de las misas que se les an de decir. 
$<$ Difuntos. Tañer. Entierro $>$ Quando algún preuendado desta yglesia muriere, entendida su muerte se tañerá por él dando por la dignidad abacial doscientas campanadas solas sin que ande otra ninguna campana. Y por las demás dignidades a ciento; y por el canónigo o racionero entero, cincuenta; y por el medio racionero, veinte y cinco, para diferenciar de los que no son preuendados. E a su tiempo harán el entierro honrras y cabo de año como es uso y costumbre. Y en todos los dichos oficios arderá la cera necesaria y abra el cabildo para distribuir entre los presentes hinteresentes por el entierro, honrras, nouenas y cabo de año. Por la dignidad abacial, treinta ducados y más la limosna de las misas, diáconos y capas. Por las dignidades, a quince ducados y más la dicha limosna. Por el canónigo o racionero entero, diez ducados. $\mathrm{Y}$ por el medio racionero, cinco ducados. Y esta orden se guardará con todas las personas que se enterraren con el cabildo y pidieren ser enterrados como canónigos. Y los que no quisieren pagar los dichos derechos los enterrará el cura, excepto que el abad a de pagar los dichos derechos aunque no se entierre en esta yglesia, y se le a de hazer el officio como si se enterrare en ella. $(f .15 r)$

$<$ Al beneficiado pobre el cabildo le entierra $>$ Quando algún beneficiado desta yglesia muriere sin dexar bienes aunque poder pagar los derechos de sepultura, entierro, nouenas, honrras y cabo de año, el cabildo lo hará muy cumplidamente, y se pagará de la media preuenda que el tal beneficiado ganare después de muerto, y todas las demás cosas annexas al dicho sufragio, porque para estos gastos specialmente se les da y haze la dicha media preuenda.

$<$ No gana el que no se entierra en esta yglesia $>$ Ningún beneficiado desta yglesia que no se enterrare en ella no gana la dicha media preuenda ni se le a de hazer, porque no se le a de dar ni ganar enterrándose fuera della.

$<$ Misas al difunto $>$ Quando el abad o algún beneficiado desta yglesia siendo preuendado en ella muriere en esta villa o fuera della, el abad y todos los preuendados desta yglesia, cada uno le diga o haga decir vna misa rezada. Y el scriptor de las oras, entendida la muerte del tal beneficiado difunto, acordará al 


\section{LA ABADÍA DE SANTA MARÍA DE HUSILLOS: ESTUDIO Y COLECCIÓN \\ DOCUMENTAL $(904-1608)$}

dicho abad y a todos los demás beneficiados, auisándoles esta obligación y que dentro de ocho días digan o hagan decir la dicha misa y le auisen y den razón como lo an dicho. Y los que no estubieren ordenados, darán la persona que la dixo por ellos. Y los que contrario a esto hizieren, el cabildo, a costa de lo que an ganado o ganaren, la mandará decir y pagar aunque estén ausentes. Y la dicha misa se dirá por todos los beneficiados aunque no se entierren en ella.

$<$ Cómo gana el difunto y el nueuo residente $>$ El beneficiado que sucediere en la preuenda del tal beneficado que murió, veniendo a residir dentro del año que gana el difunto, no gana más de la mitad de la preuenda con más las pitanzas, memorias, entierros y cabo de años. Porque desto el difunto no auer cosa alguna más de tan solamente la media preuenda. La qual salida para que no le falte para su entierro y las demás cosas annexas a esto. Y queremos y es nuestra voluntad que la dicha media preuenda desde agora esté hipotecada specialmente para que della se paguen los gastos y el entierro, honrras y cabo de año, sepultura, paños y cruz y las demás cosas a ello annexas. Y el beneficiado ansí vino como muerto gana las pitanzas y memorias en que se ouiere hallado presente aunque no haga residencia.

$<$ No se entierra en el claustro $>$ Ninguna persona grande ni pequeña se entierre dentro del claustro. Y encargamos al cabildo y al obrero desta yglesia no lo permita ni consienta.

$<$ Lo que gana el difunto $>$ Gana el beneficiado muerto, de media preuenda, trigo, ceuada de molinos, diezmos y renta tan solamente y si ouiere hecho residencia de medio año y un día. Gana todo lo que puede ganar el vino hasta el día que murió $(f .15 v)$

$13^{\mathrm{a}}$. Cómo se an de acompañar y honrrar los beneficiados enfermos y muertos.

$<$ Cómo se belan los beneficiados> Quando algún beneficiado desta yglesia estubiere muy al cabo que le ayan dado el santísimo sacramento, le belarán dos beneficiados desta yglesia todas las noches que dello tubiere necesidad hasta en 
tanto que nuestro señor sea seruido de llebarle de esta vida o librarle de la tal enfermedad. La qual bela se hará en esta forma: comenzando de los rracioneros más modernos hasta acabar en el prior, belando dos beneficiados desde prima noche hasta media noche, y otros dos beneficiados desde media noche hasta la mañana. Lo qual hagan y cumplan cada vn beneficiado, so pena de dos ducados aplicados seis reales para la persona que por él seruiere, y todo lo demás restante para la fábrica desta yglesia. La qual dicha pena se execute sin remisión. La execución de la qual sometemos al prior o presidente que a la sazón fuere y el nonbrar y hechar la bela.

$<$ Acompañamiento de beneficiados $>$ Todas las uezes que algún beneficiado desta yglesia falleciere en esta villa o fuera della y se enterrare en esta yglesia, dos beneficiados de los más cercanos de la casa del tal difunto le acompañarán y honrrarán en el entierro, honrras, nouenas y cabo de año con manteos, beniendo siempre con la cera. Y por el trabajo los darán los herederos del tal difunto una gallina a cada uno o tres reales por ella. Y no se las dando, el cabildo les mandará pagar seis reales de lo mejor parado de lo que ouiere ganado o ganare el tal difunto. Y desta manera quitamos y abrazamos de que el cabildo no baya ni benga por la cera como solía más de tan solamente el día del entierro que a de ir con él y voluer con los diliosos al responso. Y en los demás días yrá el cura a dar las gracias juntamente con los nonbrados.

$<$ Quien viste a los beneficiados $>$ Todas las vezes que algún beneficiado desta yglesia muriere, le bestirán dos rracioneros, los más modernos, y no los auiendo, lo harán los canónigos más modernos. Lo qual cumplirán mandándoselo el prior o presidente, so pena de dos ducados a cada uno de los que lo contrario hizieren aplicados la mitad para la fábrica desta yglesia y la otra mitad para las personas que le vestieren. Y porque sería posible que los beneficiados a quien toca el bestirle, sabiendo que el tal beneficiado quando en esta billa muriere alguna persona y se enterrare fuera della pidiendo al cabildo la saque hasta las puertas, a de pagar quatrocientos maravedís, $(f .16 r)$ a de faltar brevemente. Porque no se lo manden ausentarse encargamos al prior o presidente a quien cometemos la execución desta pena, que biendo ay necesidad y que el tal beneficiado faltara 
dentro de vn día o dos, preuenga y mande a los tales beneficiados no se partan del lugar sin hazer el tal officio o dexar personas que por ellos lo hagan. Y si lo contrario hizieren siendo preuenidos paguen la dicha pena repartida como arriba está dicho.

$14^{\mathrm{a}}$ Constitución. Cómo se a de hazer el cabildo.

$<$ Cabildo ordinario $>$ Hágase cabildo ordinario vn día en la semana, conbiene a saber, el viernes. Y si este día fuere fiesta, se podrá anteponer o posponer. Y no se haga más si no se ofreciere algún negocio muy importante y a la yglesia o a la mesa capitular o dar posesión, de manera que no se pueda esperar su despacho hasta el primer cabildo ordinario, porque en tal caso el prior o presidente podrá llamar a cabildo aunque sea fuera del dicho día. Sobre lo qual les encargamos la conciencia que no manden llamar sin mucha necesidad y que no manden llamar para negocios de ningún particular podiendo esperar al cabildo ordinario.

$<$ Que se llame el día antes $>$ El día antes que se ouiere de juntar a cabildo el prior o presidente, a quien esto yncumbe mandará llamar a todos los capitulares que se hallaren en esta villa dando vna cédula al escritor, la qual contenga los negocios que se ouieren de hazer para que todos consideren lo que conbiene y bengan preuenidos para poder mejor dar sus votos.

$<$ Cabildo special $>$ Todos los primeros lunes de cada mes se hará cabildo special, en el qual se tratará del seruicio del altar y coro y de la reformación de los beneficiados y de otras cosas que sean spirituales; y en ninguna manera se trate de otras cosas que no sean spirituales. Y si no ouiere cosa spiritual se salgan sin tratar de otra cosa. Si fuere fiesta se hará el día siguiente. Y si el prelado estubiere en este pueblo, se le yntime el cabildo spiritual.

$<$ Cómo se a de dar posesión $>$ No se dará posesión a ningún beneficiado que la beniere a pedir si no fuere sido llamados del día antes. Y el prior o presidente que lo contrario en esto hiziere, pague vn ducado de pena para la fábrica. 
$<$ Asientos $>$ Todos los capitulares guarden sus asientos ansí en el coro como en el cabildo, y hallen y den sus pareceres y votos por su orden con la modestia, breuedad y claridad que pudieren. Y ninguno bote ni hable hasta que llegue a él el voto ni después de $(f .16 v)$ auer horado hasta que todos ayan dicho su parecer. Y encargamos al prior o presidente que haga guadar esta constitución, porque seruirá mucho conserbar la paz. Y para que en menos tiempo se acaben más negocios y los beneficiados se puedan voluer al coro y propuesto algún negocio, no se proponga otro hasta que aquel se acabe y resuelba. Y en los negocios graues, conberná que los preuendados digan primero sus pareceres que voten fundándolos en rrazón o derecho cada uno en su lugar y que después voten brevemente, conforme a lo que cada uno ouiere entendido y le parece.

$<$ Cosas de gracia. Cómo se votan $>$ No es justo que los más hagan gracia de la hazienda de los menos contra su voluntad, porque lo que es de todos lo deuen dar. Por ende, quando algún beneficiado de la yglesia o otra qualquiera persona de fuera de ella pidieren alguna gracia en cabildo porque fuera del no se puede hazer, vótese por abas secretas. Y contradiciendo alguno no se haz la dicha gracia. Y una bez negada no se proponga otra bez, directa ni indirectamente. $\mathrm{Y}$ el prior o presidente no consienta que se vote de otra manera, aunque todo el cabildo lo quiera; ni negado una uez lo torne a proponer otra dentro de tres meses. Y si proponiendo el prior o el presidente algún negocio pareciéndole que se vote públicamente y diciendo que no es gracia, en tal caso si a algún capitular le pareciere que lo es y contradixiere la manera del votar diciendo que es gracia, en tal caso no se pase con el negocio adelante hasta en tanto que se determine si es gracia o no.

$<$ Ojo. Propuesto vn negocio no se proponga otro $>$ Auiéndose propuesto y votado algún negocio en cabildo aunque no sea de gracia, el prior o presidente no lo propongan otra uez, so pena de seis reales para la dicha fábrica, si no fuere con mucha causa y ur[gente] necesidad, y estando presentes todos los capitulares que votaron en el [cabildo por] primera uez, sin que falte ninguno, siendo llamados el día antes, con pena a todos los que comodamente pudieran ser auidos. $\mathrm{Y}$ en tal caso, pareciendo a las dos partes tercias del cabildo, se tratará del y no de otra 
manera. Y lo que en contrario se hiziere y tratare del tal negocio, sea en sí ninguno y de ningún efecto.

$<$ El número de beneficiados que se an de hallar en el cabildo para votar $>$ El prior o presidente no propongan negocio alguno en cabildo aora sea de gracia y de justicia ni consienta que se trate y determine no estando presentes por lo menos cinco capitulares, saluo para hazer alguna notificación, uer cartas o intimación de bullas apostólicas o letras ordinarias, que para esto bastará que sean los que estubieren en la yglesia o buenamente puedan ser auidos. (f.17r)

$<$ No tiene voto el que no está ordenado de orden sacra $>$ El cabildo no admita ni consienta que preuendado alguno entre a uotar en cabildo sin que primero muestre los recaudos como está ordenado de orden sacro.

$<$ Cómo se an de reprenhender los beneficiados $>$ El prior, ni presidente, ni otra qualquiera persona que presida en cabildo, no reprehenda públicamente en el dicho cabildo a beneficiado alguno ni a otro ministro de la yglesia sin acuerdo del dicho cabildo.

$15^{\text {a }}$. Officio de mayordomo de dinero.

$<$ Mayordomo de dinero $>$ El officio del mayordomo de las rentas del dinero de la mesa capitular, se dará a quien por menos salario lo hiziere, con que sea persona abonada y de fianças a contento del cabildo. Y siempre se procurará que dé a beneficiado por fiador si fuere posible. El qual con el dicho beneficiado sea obligado a los plazos y términos que estubiere obligado a los beneficiados y ministros de la yglesia. Y no lo haziendo, les puedan poner el punto en el qual anden hasta que paguen lo que por el dicho cabildo se les mandare, conforme a las condiciones. Y si el mayordomo no hallare o diere beneficiado por fiador de fianzas y haga contrato por do le puedan ejecutar, y entre tanto que no pagare, le corra el punto por manera que desde el día que le pusieren el punto le corra hasta el día que enteramente hiziera pago. Y esta constitución sea habida por puesta en la aceptación de la mayordomía y en la obligación que el mayordomo hiziere. 
Quando algún beneficiado deuiere al cabildo qualesquier maravedís por alcances de quentas o por otra qualquiera razón que parezca deuerlos, el cabildo le pondría el punto. Y lo mismo se le podrá poner a pedimiento de los mayordomos, siendo rentas y cosas del cabildo. Y tanbién se le podrá poner el punto. Y lo mismo se le podrá poner a pedimiento de los mayordomos, siendo rentas y cosas del cabildo. Y tanbién se le podrá poner quando un beneficiado pidiere en cabildo a otro beneficiado y al tal beneficiado confesare debérselos. En el qual, los vnos y los otros corran ansí a los mayordomos como a los tales beneficiados, hasta en tanto que ayan hecho enteramente pago.

$16^{\mathrm{a}}$. Officio de procurador.

$<$ Procurador $>$ El procurador general del cabildo tenga sus memoriales de todos los pleitos que la yglesia y cabildo tienen. Y el primer cabildo de cada mes dé quenta del estado en que están los dichos pleitos y quales se siguen y quales no para que el cabildo sepa lo que pasa y prouea cerca $(f .17 \mathrm{v})$ cerca $(s i c)$ dello lo que conbenga. Y asista siempre a los cabildos ordinarios. Y si en ellos se hiziere algo que sea contra constitución, lo contradiga y haga sobreello sus diligencias.

$17^{\mathrm{a}}$ Constitución de sede bacante

$<$ Sede vacante $>$ Quando acaeciere bacar la dignidad abacial por muerte o en otra qualquiera manera, el prior y cabildo harán oraciones públicas y particulares y proueerán que se hagan en las yglesias desta abadía para que Nuestro Señor prouea a esta yglesia de buen pastor, como lo ordenó el santísimo concilio de Trento en el c. $1^{\mathrm{o}}$, s. 24.

Dentro de dos días después que bacare la silla abacial, el prior y cabildo nonbren un preuendado por prouisor que sea ydóneo quanto se pudiere, y elíjase por la mayor parte del cabildo por uotos secretos, y que sea sacerdote. Y de la misma manera elixirán secretario y alcaide de la Casa del Soto para que tenga quenta con ello.

Nonbrarán ansí mesmo fiscal y todos los demás oficios que el abad nonbra y tiene por costumbre de nonbrar.

En auiendo sede vacante, el prior y cabildo mandarán visitar la casa abacial y arán recuento de las alajas que en ella ouiere pertenecientes a la dignidad. Y de las 
scripturas que en ella hallaren, las recogerán y guardarán en el archiuio desta yglesia para las dar y entregar al perlado que sucediere.

$18^{\text {a }}$. Constitución de jurisdictión y carcelería.

$<$ Jurisdictión $>$ Declaramos que se guarde y cumpla la concordia hecha entre don Francisco de Carvajal, nuestro predecesor, y el prior y cabildo desta dicha nuestra yglesia hecha y otorgada el año de mill y quinientos y treinta y seis sobre la jurisdición que el cabildo tiene y en qué casos a de conocer, y la forma que se a de guardar en el encarcele a los beneficiados que declara el cabildo conozca de cosas (f.18r).

$<$ Horden que a de guardar el abbad y su prouisor en encarcelar los beneficiados. Ojo, que ningún beneficiado sea presso por el abbad ni su prouisor en [...] que se sigue se an guardan aprisonar los beneficiados $>$ lebes como son palabras, amenaças con armas ofensibas y defensibas y otras cosas como no aya efusión de sangre. Y que ningún beneficiado sea preso en casa del fiscal ni en cárcel pública ni en la yglesia ni se le heche cadena si no fuere por delito grabe que aya cometido, como es homicidio, latrocinio o mutilación de miembro o por otros delitos semejantes a estos; porque en tal caso, el beneficiado se aprisionará en la yglesia o en casa del fiscal, y se pondrá a buen recaudo en todos los demás casos fuera de los dichos: la dignidad se encarcelará en casa de otra dignidad que más propinqua esté a su casa; y el canónigo en casa de otro canónigo; y el rracionero en casa de otro rracionero.

Las casas más cercanas de los tales beneficiados en la forma y manera que la dicha concordia lo declara a la qual nos remitimos y mandamos poner aquí originalmente, que es la que se sigue, de manera que de las casas y delitos que el cabildo a de conocer que son en la forma dicha son y se entienden dentro ${ }^{19}$ de las puertas de la yglesia adentro y no de otra manera. $\mathrm{Y}$ la dicha concordia original es esta que se sigue:

$<$ Va añadido en la margen horden que an de guardar el abbad en encarcelar su prouisor a los beneficiados y señalado con una cruz en esta forma (signo) la prosecución del tipo: valga y la raja de en forma de cruz que está en medio desta

\footnotetext{
${ }^{19}$ dentro] tachado.
} 
escriptura valga porque se escribió después de dada. Y para maior rectitud, conforme yo Gaspar de Villodrigo, canónigo y secretario y notario apostólico, lo firmé de my nombre y signé de my signo a pedimiento y por mandado del prior y cauildo, estando juntos y conjugados en [...] como lo an de uso y costumbre (signo). Gaspar de Villodrigo, notario apostólico> (f.18v)

\section{Constitución de Romerías}

$<$ Romerías. Ojo, no gana centeno $>$ Los beneficiados que fueren en romería a Jerusalem, Roma, Santiago, Nuestra Señora de Guadalupe, Santo Toriui, el Crucifixo de Burgos, Nuestra Señora de la Peña de Francia, ganen enteramente el tiempo y días que aquí ban declarados con que antes que se partan lo pidan en cabildo, exceto que los tales romeros no ganan pitanzas, memorias, entierros ni cabo de año. En todo lo demás sean auidos por presentes hinteresentes y ganen como el que más ganare. $\mathrm{Y}$ an de traer razón y testimonio como dixo misa o confesó y comulgó. Ni tampoco gana centeno los días que se conceden pidiendo licencia como dicho es al cabildo.

Son los siguientes:

A Roma, vn año aunque no sea el año santo.

A Nuestra Señora de Guadalupe, vn mes.

A Nuestra Señora de la Peña de Francia, veinte días.

A Señor Santiago, dos meses.

Al Crucifixo de Burgos, ocho días.

A Santo Toribio, quince días.

Todas las dichas romerías se an de conceder en cada vn año, con que en vn año no se puedan tomar dos romerías, más de tan solamente vna.

$20^{\text {a }}$ Constitución de los derechos que lleba la yglesia quando se toman posesiones. $<$ Derechos de la fábrica y secretario quando se toma posesión $>$ El prelado quando toma posesión del abadía paga a la fábrica de la yglesia diez mill maravedís, y al secretario tres escudos de a quatrocientos maravedís cada uno. 


\section{LA ABADÍA DE SANTA MARÍA DE HUSILLOS: ESTUDIO Y COLECCIÓN \\ DOCUMENTAL $(904-1608)$}

La dignidad paga a la yglesia dos mill maravedís, y siendo con dos preuendas quatro mill maravedis; al secretario, vn escudo de a quatrocientos maravedís, y con dos preuendas, dos escudos.

El canónigo paga a la fábrica dos mill maravedís, y al secretario vn escudo de a quatrocientos.

El rracionero entero paga dos mill maravedís, y al secretario vn escudo de a quatrocientos.

$<$ Ba borrado medio renglón. No balga ni se puede leer $>(f .19 r)$

El medio racionero paga a la yglesia mill maravedís, y al secretario vn escudo de a quatrocientos.

$21^{\text {a }}$ Constitución de los derechos que a de llebar el sacristán por el tañer por los beneficiados difuntos.

$<$ Derechos de tañer por los beneficiados $>$ Por el abad tañendo todo lo dicho, doce reales.

Por el canónigo o racionero entero o medio racionero, ocho reales.

$22^{a}$ Constitución sobre la leña del monte

$<$ Leña del monte $>$ Todos los beneficiados desta yglesia que ouieren hecho o pudieren hazer la residencia de medio año y un día, gana el repartimiento que se les hiziere de la leña del monte. Y lo a de traer a esta villa en la esta manera que le sacare del monte y tenello en su casa tres días sin que lo pueda vender ni dar graciosamente hasta que pasen los dichos tres días, so pena que el que lo contrario hiziere pague vn ducado para la fábrica desta yglesia. Y para ganarlo a de tener casa o posesión del cabildo o yglesia; y no a de estar en compañía de otro, porque estándolo, no lo gana ni se le a de dar por gracia ni justicia, si no es a los que la constitución dice.

$23^{\mathrm{a}}$ Statuto de remisiones

$<$ Remisiones $>$ Todos los beneficiados que edificaren en casas del cabildo se sacarán remisiones. De nuevo: de diez, vno; y de viejo: de veinte, uno.

$24^{\mathrm{a}}$ Comemoración de San Llorente. 
Todos los días que no ouiere fiesta doble se hará conmemoración de San Llorente a la misa, vísperas y maytines por auerle tomado esta yglesia por patrón y tener en ella tan gran reliquia suya.

$25^{\mathrm{a}}$ Los días que está obligado el prelado a pagar los sermones a las órdenes que predicaren.

$<$ Sermones $>$ La dignidad abacial desta yglesia está obligada y a de pagar a las órdenes de San Francisco y San Pablo y Compañía del Nombre de Ihesus de la ciudad de Palencia, vn ducado por cada sermón $(f .19 v)$ de los de tabla que hizieren en esta yglesia en cada vn año, que son quince sermones. Y la fábrica los a de dar de comer y posada, que son los siguientes:

San Pablo:

1. El día de la Epifanía.

2. El segundo domingo de Quaresma.

3. El quarto domingo de Quaresma.

4. El día de San Pedro Apóstol.

5. El día de Todos Santos.

San Francisco:

1. El primer domingo de Quaresma.

2. El segundo día de Pascua de Resurreción.

3. El tercero domingo del aduiento.

4. El día de San Lorencio.

5. El segundo día de la Natiuidad de nuestro Señor.

La Compañía del Nombre Ihesus:

1. El tercero domingo de Quaresma.

2. El día de la Acensión de Nuestro Señor.

3. El segundo día de Pascua de Pentecostés.

4. El día de la Asumpción de Nuestra Señora.

5. Primero domingo del Aduiento.

$26^{\mathrm{a}}$ Derechos de las sepulturas: 
$<$ Derechos de sepulturas $>$ En el primer lecho en entrando por la puerta de la yglesia no se enterrará nadie, saluo los pobres que no tubieren con que pagar la limosna de la sepultura y tanbién los pobres que murieren en el hospital. Y si algún beneficiado se quisiere enterrar en el dicho primer lecho pague quatrocientos maravedís. (f.20r)

Todas las personas, ansí clérigos como legos, que se enterraren en el segundo lecho, pagarán por la primera sepultura cien maravedís, contando siete pies desde las primeras losas que atrauiesan la yglesia. Y de allí adelante, docientos maravedís; y ansí se irá multiplicando y añadiendo cien maravedís en cada sepultura, de manera que por la primera sepultura son ciento; segunda, docientos; tercera, trecientos; y ansí hasta llegar a la capilla.

En la capilla mayor pagará de derechos quatro mill maravedís. Y el abad pague seis mill maravedís.

En la capilla de Nuestra Señora pagará de derechos dos mill maravedís, todos los dichos derechos y limosna aplicados para la fábrica desta yglesia.

$<$ Seruicio de las misas mayores $>$

Porque ay algunas faltas en ayudar las misas mayores y algunos, por escusarse de este trabajo, al tiempo de seruir el tal ministerio se ban a decir misa por no le hazer, mandamos que de aquí adelante el racionero o canónigo que le tocare el tal ministerio le haga y asista a él o le encomiende, so pena de vn día las oras el que lo contrario hiziere.

$<$ Se lean los statutos $>$ Por quanto los beneficiados desta yglesia no guardan ni cumplen los statutos por no lo sauer ni auérselos enseñado, mandamos que de aquí adelante todos los primeros cabildos de cada vn año se lean estando todos juntos y congregados, ansí votantes como no votantes, para que venga a noticia de todos y sepan lo que están obligados a hazer.

\section{$27^{\mathrm{a}}$ Officio de secretario}

$<$ Secretario $>$ El secretario a de estar en todos los cabildos que se hizieren y asistir en las quentas de la hazienda y fábrica desta yglesia y en las diputaciones y en todas las visitas de posesiones que se hizieren. Y está a su cargo de asentar todos 
los actos y acuerdos capitulares que se hizieren. Es a su cargo tanbién hazer los libros a todos los mayordomos de la hazienda que a cada uno se le carga, y hazerles el cargo de todo lo que ouieren de cobrar.

Tanbién es a su cargo de referir en los acuerdos capitulares en los primeros cabildos que se ouieren hecho para que se sepa lo que se hizo en el cabildo pasado, hyntimar las cosas y acuerdos del cabildo a las personas a que qual tocare. Todo lo arriba dicho lo a de hazer o dar persona que por él lo haga estando enfermo, ausente o ocupado en cosas que no pueda asistir al dicho officio. (f.20v)

Otorgamiento destas Constituciones:

En el capítulo dentro de la yglesia colegial de la villa de Husillos, a ocho días del mes de abril de mill y quinientos y ochenta y ocho años, estando juntos y congregados en su cabildo y ayuntamiento según lo tienen de uso y costumbre llamados por campana tañida el abad, prior y cabildo de la dicha yglesia, special y nonbradamente don Francisco de Reynoso, abad, y don Juan de Palencia, thesorero; don Alonso del Hoyo, chantre; Diego de Carrión, Andrés de Fresno, Antonio López, Gaspar de Villadiego, Miguel de Quiñones, Juan Sánchez, todos canónigos votantes de la dicha yglesia. En presencia y por ante mí, el ynfra scripto notario y testigos de yuso scriptos, que para esto fueron llamados y rogados, el dicho don Francisco de Reynoso, abad, juntamente con los dichos prior y cabildo. Y de su consentimiento establesció, ordenó e hizo leer y publicar las constituciones retro scriptas que son por tas veinte y ocho y más la concordia original entre don Francisco de Carbajal, abad que fue de la dicha yglesia, y el dicho prior y cabildo, la qual quieren que se guarde y cumpla como en ella se contiene. Con que si el señor abbad quisiere poner prouisor que no sea beneficiado, lo pueda hazer.

$\mathrm{Y}$ es la primera constitución del número de las preuendas desta yglesia y la postrera del officio del secretario.

Y el dicho don Francisco de Reynoso, abad, y los dichos prior y cabildo, se obligaron y prometieron por sí y por las ausentes y por sus sucesores, que guardarán y cumplirán la dicha obligación y validación de la scriptura y contrato de las dichas constituciones. 
Y contra lo en ellas contenido no eran ni bendrán agora ni en tiempo alguno ni por alguna manera, y reuocaron y annullaron todas otras qualesquier constituciones desta yglesia, en quanto son o fueren contrarias a estas y a lo en ellas contenido, porque quieren y es su voluntad que estas se guarden. Y declararon que no es su yntención de obligarse a sí ni a sus succesores por virtud de las dichas constituciones a nueua culpa, aliende de aquella que el derecho diuino y canónico les obligan en los casos que las dichas constituciones hablan.

Y el dicho don Francisco de Reynoso, abad, y los dichos prior y cabildo ansí lo ordenaron y establecieron ante mí, $(f .21 r)$ el notario ynfrascripto. Y por mayor firmeza el dicho Francisco de Reynoso, abad por sí, y el dicho don Juan de Palencia, thesorero presidente, en nombre del dicho cabildo y beneficiados del, lo firmaron de sus nombres, estando presentes por testigos el licenciado Martínez y Alonso Brabo, criados del dicho don Francisco de Reynoso, y don Antonio de Fuenmayor, estantes en esta villa de Husillos.

Don Francisco de Reinoso, abad (firma). Por el cabildo, don Juan de Palencia, thesorero (firma).

Pasó ante mí, Antonio López (firma).

1589, octubre, 8. Husillos.

Donación de Francisco de Reinoso, abad de Santa María de Husillos, otorgada ante Francisco de Barreda, escribano público de Husillos, a la fábrica de dicha abadía, de cuatrocientos seis mil maravedís que tiene en censo a vecinos de la villa de Husillos, a razón de veinticinco mil maravedís al millar al año. Hace la donación movido por la gran pobreza que tiene la abadía, que apenas puede hacer frente a los gastos. 
A. AHDP, Ampudia y Abadía de Husillos, Legajos y papeles, caja 64, doc. 4-4. Papel; escr. procesal; buena conservación.

1591. Husillos

Elenco de donaciones y censos que Francisco de Reinoso, abad de Santa María de Husillos, donó a la fábrica de dicha iglesia, sobre la heredad realenga del término de Husillos, que previamente había comprado a Felipe II con su propio dinero. Dichos censos son sobre los vecinos de dicha villa, que les dio a razón de a veinticinco mil el millar; y cada censo rentaba de principal, quince mil cincuenta y cuatro maravedís; y de réditos, seiscientos cuatro maravedís anuales. Dichos censos se hicieron el año anterior de 1589 ante Francisco de Burueba, escribano del rey. El elenco se compone de una donación a la fábrica de la iglesia y de treinta censos.

A. APA, Libro 48. Husillos. Cuentas de la fábrica (1569 - 1593). Papel; escr. procesal; buena conservación.

Este elenco da constancia de cómo Felipe II intervino sobre la hacienda de Santa María de Husillos merced a las bulas pontificias que tenía en lo que se ha llamado primera desamortización

1592, agosto, 10. Valladolid.

Cédula real de Felipe II por la que habiendo sido informado de que la abadía de Santa María de Husillos vale hasta dos mil ducados de renta al año, que su abad es Francisco de Reinoso, que es consistorial y que por dicha razón es 
de su patronazgo y le pertenece su provisión, ordena al corregidor de Palencia hacer información de dicha abadía en base a un cuestionario de preguntas en relación con la fundación, orden de los canónigos, rentas, elección del abad, derechos y obligaciones, privilegios pontificios de los que dispone, reliquias e información especial sobre el pie de San Lorenzo, entre otras. Para dicha información ordena al abad que se permita sacar traslado de los documentos que el corregidor considerara.

B. AGS, Patronato Eclesiástico, leg. 159, 2122. Papel; escr. humanística; buena conservación.

\section{4}

1592, octubre, 20. Monasterio de Nuestra Señora de La Estrella (La Rioja).

Cédula real de Felipe II a Francisco de Reinoso, abad de Santa María de Husillos, agradeciéndole su licencia y la del cabildo de dicha iglesia para el traslado de la reliquia del pie de San Lorenzo, custodiada en Husillos, al monasterio de San Lorenzo del Escorial. En agradecimiento, insta a Francisco de Reinoso a que traslade personalmente dicha reliquia.

A. APA, Leg. 152, carp. 3. Papel; escr. humanística bastarda; roturas y manchas que no impiden la lectura.

El monasterio de Nuestra Señora de La Estrella se ubica en San Asensio (La Rioja). La donación de la reliquia por el abad, prior y cabildo, es efectuada el 5 de octubre de 1592.

El rey.

Venerable abbad de la iglesia collegial de Husillos. Muy particular contentamiento he recibido de entender por vuestra carta la buena voluntad con que vos y los desse cabildo hauéis acudido a darme la reliquia del pie del bienaventurado San Lorenzo, lo qual extiendo que es razón y os lo agradezco mucho, y me queda dello la memoria que es justo para favorecer las cosas dessa 
abbadía en todo lo que se ofreciere y huuiere lugar. Y pues vos haueis sido el instrumento deste don, holgaré también que vos le lleueis al al (sic) monasterio de San Lorenzo, remitiéndoos si será agora o para quando, plaziendo yo esté allá; pero antes disponerlo en execución, me lo auisaréis para que yo ordene lo que se haurá de hazer en el recibirle y entregarle. Del monasterio de Nuestra Señora de la Estrella. A XVIII días de octubre de 1592 años.

Yo el rey. Por mandado del rey nuestro señor, Jerónimo Gassol (rúbrica).

\section{5}

1592, agosto, 19, miércoles. Palencia - 1593, enero, 19. Husillos.

Traslado del testimonio notarial de Hernando de Castro, escribano del número y apostólico, sobre las informaciones que realizó en Santa María de Husillos, por orden de Juan de Chacón, corregidor de Palencia, y del licenciado San Román de Tapia, teniente-corregidor de Palencia.

- 1592, agosto, 19. Miércoles. Palencia. Juan Chacón manda a Hernando de Castro que al día siguiente se preparara para acompañarle a hacer un servicio real, sin informarle el lugar ni el asunto.

- 1592, agosto, 20. Jueves. Husillos. Juan Chacón presenta a Hernando de Castro la cédula real, la cual se extracta, informándole del asunto que van a tratar.

- 1592, agosto, 20. Jueves. Husillos. Juan Chacón presenta a Francisco de Reinoso la cédula real, el cual obecede, le presenta el archivo, sito en la sacristía, y le informa de que tiene en su casa de Palencia un libro becerro con todas las escrituras del archivo autorizadas. Extracta varios privilegios reales de confirmación de propiedades y rentas a Santa María de Husillos, y da referencia de ciertos legajos de sentencias y ejecutorias, censos, ventas, estatutos, un libro becerro de propiedades y documentos pontificios. Finalmente le muestra al corregidor el Libro de los Privilegios de Husillos.

- 1592, agosto, 20. Husillos. Francisco de Reinoso, por requerimiento de Juan Chacón, ante Hernando de Castro, muestra las reliquias de Santa María de 
Husillos, estando los tres de rodillas en la capilla de Santa María de dicha iglesia, de las cuales hace el dicho escribano un inventario.

- 1592, agosto, 20. Husillos. Interrogatorio a varios testigos sobre Santa María de Husillos, tomando como preguntas las sugeridas en la cédula real de Felipe II, siendo los dichos testigos: García de Bustamante, canónigo; Bernabé García, canónigo y provisor; Gaspar de Villadiego, canónigo; Alonso de Hugo, chantre y canónigo; Pedro de Monzón, canónigo; Bartolomé de Grijalva, vicario.

- 1593, enero, 19. Husillos. El licenciado San Román Tapia, teniente-corregidor de Palencia, ordena a Hernando de Castro, escribano, sacar traslado de la cédula real, autos e información realizada, para enviar al rey.

B. AGS, Patronato Eclesiástico, leg. 159, 2122. Papel; escr. procesal; buena conservación.

El día 19 de agosto de 1592 fue sábado y no miércoles. Véase A. GIRY, Manuel de Diplomatique. La letra dominical correspondiente a 1592 es la A, y la Pascua cayó el 26 de marzo.

1593, enero, 19. Palencia.

Información realizada por el licenciado San Román de Tapia, tenientecorregidor de Palencia, dando su opinión y parecer sobre el posible patronazgo real de Santa María de Husillos, en base a las informaciones realizadas. Entiende que la casa real participa de la dotación de dicha iglesia, teniendo en cuenta que la reina Urraca I hizo algunas donaciones a Santa María de Husillos, y a su instancia también los condes de Monzón; que fue de canónigos regulares de San Agustín; que aunque algunos opinan que es consistorial, en realidad los abades han sido proveídos por resignación papal. Por todo, y teniendo en cuenta que su 
renta anual excede de los sesenta y seis florines y dos tercios, opina que Santa María de Husillos es de patronazgo real.

B. AGS, Patronato Eclesiástico, leg. 159, 2122. Papel; escr. procesal; buena conservación.

1596, febrero, 20. Husillos.

Visita de la sacristía de Santa María de Husillos por el abad Francisco de Reinoso, tomando cuenta de sus bienes al tesorero Juan de Palencia.

A. APA, Libro 48. Husillos. Cuentas de la fábrica (1569 - 1593). Papel; escr. humanística bastarda; buena conservación.

1592, agosto, 10. Valladolid - 1596, octubre, 2. Palencia.

Expediente sobre la declaración de patronazgo real de Santa María de Husillos, promovido por Felipe II, siendo abad de Husillos Francisco de Reinoso. Las informaciones sobre dicha abadia son mandadas realizar por el rey a Juan Chacón de Narváez, corregidor de Palencia.

- 1592, agosto, 10. Valladolid.

Cédula real de Felipe II por la que ordena a Juan Chacón, corregidor de Palencia, hacer información sobre la abadía de Santa María de Husillos, con el fin de establecer el patronazgo real sobre dicha iglesia (Véase doc. núm. 333). 
- 1592, agosto, 20. Husillos. Memorial de las reliquias de Santa María de Husillos, visto por Juan Chacón de Narváez, corregidor de Palencia.

- 1592, agosto, 21. Palencia. Carta de Juan Chacón a la cámara dando cuenta de su actuación hasta el momento, enviando el memorial de reliquias que ha ordenado realizar, demandando se le dé pautas sobre si debe mandar realizar traslado del libro de los privilegios de Husillos, informando asimismo que muchas de las escrituras que este contiene se quemaron hace muchos años en un incendio.

- 1592, septiembre, 1. Nota de oficio de Juan Chacón informando sobre la conveniencia de sacar traslado de unas escrituras del archivo de Santa María de Husillos.

- 1592, octubre, 10. Nota de oficio de la cámara real ordenando saque los traslados e informe sobre su coste.

- 1593, enero, 13. Palencia.

Memorial de Juan Chacón, informando sobre Santa María de Husillos: fundación, orden, reliquias y elección del abad. Asimismo informa de que el notario Hernando de Castro ha trasladado varias escrituras del archivo de la abadía, por lo que solicita se le pague por sus servicios nueve mil maravedís librados de las penas de cámara de Palencia.

- Felipe II ordena se pague al notario Hernando de Castro nueve mil ducados librados en las penas de cámara de Palencia.

- 1592, agosto, 19. Miércoles. Palencia /1593, enero, 19. Husillos.

Traslado del testimonio notarial de Hernando de Castro, escribano del número y apostólico, sobre las informaciones que realizó en Santa María de Husillos, por orden de Francisco de Chacón, corregidor de Palencia, y del licenciado San Román de Tapia, teniente-corregidor de Palencia (Véase doc. núm. 335).

- Información realizada por el licenciado San Román de Tapia, tenientecorregidor de Palencia, dando su parecer afirmativo sobre el patronazgo real de Santa María de Husillos (Véase doc. núm. 336).

- 1596, octubre. Información dada por la cámara sobre la fundación de Santa María de Husillos, según consta en la "Corónica general de España" de Ambrosio de Morales, en el Libro 216, capítulo 44, folio 258.

- 1596, octubre, 2. Madrid. 
Carta de Pedro de Reinoso, señor de Autillo y sobrino de Francisco de Reinoso, informando de que en enero de 1595, su tío le había promovido ante el papa su resignación como abad de Husillos, estando actualmente a espera de la bula pontificia de nombramiento. Informa asimismo que sobre la pretensión real de que dicha abadía es de patronazgo real, existe en Husillos un libro becerro y escrituras que pueden aclararlo.

- Traslado sacado por Hernando de Castro de ciertos privilegios y donaciones del Libro de los Privilegios de Husillos.

A. AGS, Patronato Eclesiástico, leg. 159, 2122. Papel; escr. procesal; buena conservación.

1596, diciembre, 30. Madrid

Felipe II, en base a bulas pontificias dadas a su abuela y padre, Juana Iy Carlos I respectivamente, declara a la abadía de Santa María de Husillos de patronazgo real, con facultad de presentación de los abades. Utilizando la información mandada realizar anteriormente, hace relación de la historia de la abadía, del valor de su renta, y del derecho que tenía la realeza sobre las iglesias de Castilla merced a bulas pontificias. Entre otros datos, relaciona que fue de canónigos regulares de San Agustín y que tiene un valor de renta de hasta dos mil ducados.

A. AGS, Patronato Real, caja 39, doc. 61, f. 167r-v. Papel; escr. procesal; buena conservación.

El rey.

Por quanto hauiendo sido informado que la abadía de la iglesia colegial de la villa de Vsillos, que fue monasterio de canónigos reglares de la orden de San Agustín y está junto la ciudad de Palençia era consistorial, y que por esta razón y otras era de mi patronadgo real, y que también me pertenecía la prouisión della conforme a 
las bulas y indultos que tengo de Adriano Sesto, Clemente Séptimo y Paulo Terçio y por las quales conçedieron a el emperador y reyna doña Juana mis señores, abuela y padre, que santa gloria ayan, y a todos los reyes de Spaña, sus suçesores, el derecho de patronadgo de qualesquier iglesias y conuentos de religiosos, abadías, prioratos, dignidades y otras prebendas consistoriales destos reynos, de qualquier manera que vacaren, aunque sea por [...] y en corte romana, para que fuesen de la naturaleza y condiçión de los patronadgos que tengo por fundaçión y dotaçión; y que por vna regla de cançelería están reservados por consistoriales los dichos monasterios, dignidades, conuentos de religiosos y otras prebendas cuya renta excediere de doçientos florines alario?, como quiera que también se entiende ay diversas dignidades y prebendas consistoriales de çinquenta, cuarenta y treynta florines, porque regularmente se platica entre curiales que para ser consistoriales basta ser de tanta suma que llegue a la tasa acostumbrada, que es sesenta y seys florines y dos terçios; y que todos los prioratos, dignidades y prebendas de la orden de San Augustín son consistoriales y hauidos y tenidos por tales y de mi patronadgo real conforme a las dichas bulas como se ha declarado en diversos prioratos y otras dignidades; y que asimismo se entendía ser la dicha abadía de mi patronadgo por hauerla fundado o dotado los señores reyes mis predeçesores y héchole algunas dotaçiones y mercedes, mandé dar vna mi çédula que mi corregidor de la dicha çiudad de Palençia hiziese información sobre esto, el qual la hizo y por ella y copia auténtica de privilegios reales, donaçiones y otras escripturas que embió y por la Chrónica General que de Spaña que hizo Ambrosio de Morales, mi chronista, consta que en la era de noueçientos y ochenta y ocho, año del nacimiento de nuestro Señor de noueçientos y çinquenta, el conde don Fernando Ansúrez (con ayuda de don Gonçalo Ansúrez) y Nuño Ansúrez, herederos condes de Monçón y Peñafiel, y de la señora reyna doña Teresa, su hermana, muger del rey don Sancho el Gordo, todos tíos del rey don Ramiro, fundó vna iglesia de la aduocaçión de Nuestra Señora en Dehesa Braua, que era de el dicho conde don Fernando Ansúrez, y estaua junto a Monçón, su condado (que es donde está agora la dicha iglesia colegial de Vsillos); y que dio a la dicha iglesia y monasterio su villa de Vsillos y otros lugares, y que el dicho don Gonçalo Ansúrez le dio a Pajarejos, y la dicha reyna doña Teresa a Santillán, San Julián de la Cuesta y otros lugares con sus 
iglesias, términos, heredamientos y juros. Y que fundada y dotada la dicha iglesia y monasterio, la encomendaron y dieron a canónigos reglares de la orden de San Agustín para que la siruiesen. Y que después, estando el señor rey don Alonso, hijo del rey don Fernando, primer emperador, en Carrión haziendo cortes, llegó allí el cardenal Raymundo del título de Santa Cruz, que se entendió venía en romería a Sanctiago de Galicia y con intençión de quedarse en Spaña. Y que viéndose viejo, suplicó al dicho rey don Alonso le diese alguna iglesia donde pudiese poner las reliquias que traya y estar él hasta que falleçiese y hazerle assí mismmo merced. Y que deseando el dicho rey dar algo al dicho cardenal y no se hallando entonçes con ello, entendido por el conde don Pedro Ansúrez y sus hermanos, dieron al dicho rey la dicha iglesia de Nuestra Señora, que el conde don Ansúrez, su padre, hauía fundado en Dehesa Braua con todos los pueblos, heredamientos y rentas con que la fundaron y dotaron para que la diese al dicho cardenal, en la qual se haría vna muy buena dignidad. Y suplicaron al dicho rey lo huuiese assí por bien y que él lo confirmase como lo hizo y lo dio y proveyó todo al dicho cardenal Reymundo, que fue el primer abad que huuo en la dicha iglesia y monasterio, donde está enterrado. Y que la reyna doña Vrraca, muger del dicho rey don Alonso, dotó la dicha iglesia y monasterio y le dio dos iglesias suyas que tenía en Frechilla y a San Fagún el Viejo y otros lugares y heredamientos. Todo lo qual confirmó el dicho rey don Alonso y dio su priuilegio dello a la dicha iglesia y monasterio, firmado de su real mano. Y que esta abadía es simple y vale de renta al año hasta dos mil ducados y que es consistorial, y que el abad tiene en la dicha villa de Vsillos y su jurisdicción spiritual y temporal y en la de Calabazanos la spiritual y en otra villa la jurisdicción temporal, y que se ha despachado por resignación (167r) de vnos en otros.

Y que assí mismo por ley de mis reynos está declarado que los señores reyes de Castilla por derecho y antigua costumbre y justos títulos son patrones de todas las iglesias catedrales destos mis reynos y les perteneçe la presentaçión de las prelaçías y abadías consistoriales dellos, aunque vaquen en corte romana.

Visto todo lo sobredicho por el presidente y los de mi consejo de la cámara y las demás cosas de que constó sobre esto y conmigo consultado y con su acuerdo y parecer, por la presente en conseruaçión de mi derecho, declaro que el patronadgo de la dicha abadía de la iglesia colegial de Vsillos es mío y pertenece a mí y a los 
reyes de Castilla, mis suçesores, que por tiempo fueren en ella para siempre jamás. Y que como tal patrón siempre que vacare la dicha abadía en qualquier manera nos toca y perteneçe presentar persona para ella. En conformidad de lo qual mando se notifique al cabildo de la dicha iglesia colegial de Vsillos que de aquí adelante no reçiban ni admitan en tiempo alguno a la dicha abadía a ninguna persona, si no fuere con título y presentaçión mí o de los reyes mis suçesores, con aperçibimiento que haziendo lo contrario se proveerá sobre ello en la forma que conuenga. Y que esta mi çédula y la respuesta de la notificación que se hiziere al dicho cabildo se ponga en el archiuo de las scripturas de mi fortaleza de Simancas.

Fecha en Madrid, a XXX de deziembre de mil y quinientos y noventa y seis años. Yo el rey.

Por mandado del rey nuestro señor, Francisco Gonçález de Heredia (rúbrica)

Vuestra merced, con acuerdo y pareçer del presidente y consejo de la cámara, declara que por los derechos y títulos aquí contenidos es del patronadgo real el abadía de la iglesia colegial de la villa de Vsillos y que toca a vuestra merced y a los señores reyes sus suçesores, la presentación y prouisión della en qualquier manera que vacare.

1597, febrero, 27. Husillos.

Testimonio notarial escrito por Hernando de Castro, escribano del rey, de rentas y del número en Palencia, y notario público apostólico, de acatamiento de la cédula real de Felipe II declarando a la abadía de Santa María de Husillos de patronazgo real, por Baltasar de Chaves, prior de dicha iglesia, y por otras dignidades y canónigos, los cuales informan asimismo haber cumplido la real provisión de nombramiento de Sancho González de Heredia como abad. 
A. AGS, Patronato Real, caja 39, doc. 61, f. 168r-v. Papel; escr. procesal; buena conservación.

En la villa de Vsillos, a veynte y siete días del mes de hebrero de mill y quinientos y noventa y siete años, estando dentro de la iglesia colegial de Nuestra Señora Sancta María de la dicha villa, yo, Hernando de Castro, escriuano del rey nuestro señor y del número y rentas de la ciudad de Palencia y sus partidos, y notario público por autoridad apostólica, hago fee que ha pedimiento del licenciado Francisco Fernández de Heredia, vecino de la ciudad de Valladolid, en nombre de su majestad y del señor licenciado Ruy Pérez de Ribera, fiscal de su consejo real en su real nombre, y por virtud de su poder que nuestro intimé, ley y notifiqué a don Baltasar de Chaues, prior de la dicha iglesia, y a don Juan de Palencia, tesorero, y a don Alonso de Loyo, chantre della, y al licenciado Bernabé Garçía, Gaspar de Villadiego, Juan Sánchez, Matheo de Cabia, Rodrigo de Palencia y Francisco Martínez, todos dinidades y canónigos "in sacris" de la dicha iglesia que dixeron ser la mayor parte del cabildo della, estando juntos en su capítulo y cabildo, llamados para este effecto por campana como lo tienen de costumbre, la cédula declaratoria de su majestad, firmada de su real nombre y referendada de Francisco González de Heredia, su secretario, atrás escritta toda ella de "verbo ad uerbum" como en ella se contiene y para el effecto en ella contenido. Los quales, hauiéndola oydo y entendido, el dicho prior la tomó en sus manos, besó y puso sobre su cabeza, el qual con los demás la obedecieron con el acatamiento deuido; y en su cumplimiento dixeron estauan prestos de hacer y cumplir lo que por ella su majestad les manda como lo an hecho en el cumplimiento de la real prouisión y presentación que les a sido notificada en raçón de la prouisión hecha de la abadía de la dicha iglesia en el licenciado Sancho Gonçález de Heredia; y lo harán adelante todas las veces que vacare la dicha abadía, admitiendo tan solamente como admitirán al que fuere presentado por su magestad; que esto respondieron, siendo testigos: Juan de Heredia, Miguel González, Antonio de Palençia y Juan Aparicio, vecinos de la dicha villa.

En fee de lo qual fize my signo que es tal (signo) en testimonio de verdad. Hernando de Castro (rúbrica). 
1598, febrero, 19. Husillos.

Visita de la sacristía por Baltasar Chaves, prior; Gaspar de Villadiego, canónigo y provisor; y Bartolomé González, obrero, ante Martín de Cañizal, secretario del prior y cabildo, tomando cuenta de sus bienes al tesorero Juan de Palencia.

A. APA, Libro 48. Husillos. Cuentas de la fábrica (1569 - 1593). Papel; escr. humanística bastarda; buena conservación.

Principios 1598 - 1598, noviembre, 18. Valladolid

Pleito fenecido litigado por el prior y cabildo de Santa María de Husillos con el concejo de Palencia, sobre cierta cantidad de trigo perteneciente a los primeros que el concejo de Palencia habia retenido en el molino de San Juan de Pajares para su aprovisionamiento.

Por sentencia de revista de 18 de noviembre de 1598, se confirma la sentencia de vista por la que se revoca la sentencia del corregidor de Palencia, en la que mandaba embargar el trigo del molino de San Juan de Pajares para la alhóndiga de Palencia.

A. ARCHV, Salas de lo Civil, Varela (F). Caja 1367-7. Papel; 53 hojas; escr. procesal; buena conservación. 


\section{DAVID MARCOS DIEZ}

1599, septiembre, 15, miércoles. Husillos.

Sentencia definitiva del pleito litigado en la audiencia episcopal de Palencia por el prior y cabildo de Santa María de Husillos con Juan Albo, cura y beneficiado de la iglesia parroquial de San Martín de Ribas, sobre el derecho de los diezmos de las heredades que Husillos tiene en Ribas, fallado a favor de los primeros. Se ordena que Juan Albo restituya al prior y cabildo el pan y demás cosas substraídas pertenecientes a dicho diezmo.

B. APA, $L P H$, f. 245 r.

El día 15 de septiembre de 1599 fue sábado y no jueves. Véase A. GIRY, Manuel de Diplomatique. La letra dominical correspondiente a 1599 es la G, y la Pascua cayó el 8 de abril.

1599, octubre, 15. Valladolid.

Renovación de censo enfiteusis de dos casas pertenecientes a la mesa abacial de Santa María de Husillos, de un conjunto de diez casas sitas en la calle de la Puerta del Campo y de la Boerica de Valladolid, por Juan de Salinas, vecino de Valladolid y tratante de madera, en precio de trescientos maravedís anuales a perpetuidad, doscientos maravedís sobre la casa mayor y cien sobre la menor, a pagar la mitad el día de San Juan, y la otra mitad en Navidad.

A. APA, Libro 200. Papel;100 hojas aprox; encuadernación en pergamino; escr. humanística bastarda; buena conservación. 
1602, marzo, 6. Husillos.

Visita a la sacristía de Santa María de Husillos por Baltasar Chaves, prior, y Gaspar de Villadiego, canónigo y provisor, ante Gabriel de Bricar, secretario del prior y cabildo, y notario apostólico, tomando cuenta de sus bienes al tesorero Juan de Palencia.

A. APA, Libro 48. Husillos. Cuentas de la fábrica (1569 - 1593). Papel; escr. humanística bastarda; buena conservación.

Esta visita y la de 1598 se hacen sobre el inventario de bienes de la sacristía de la visita de Francisco de Reinoso de 1596.

1604, enero, 17.

Carta de Francisco Gómez de Sandoval, duque de Lerma, al abad y cabildo de Santa María de Husillos, solicitando el traslado de la abadía de Husillos a Ampudia, garantizando ventajas tanto para la iglesia como para los beneficiados. Envía como procurador a Prudencio de Sandoval.

A. APA, Acuerdos capitulares (1593-1606), Libro 227. Papel; escr. humanística bastarda; buena conservación.

Ha muchos días que tengo deuoción a esa yglesia por saber que fue suelo de mis pasados y fundaçión suya. Y deseando agora haçer una collegial en la mi villa de Empudia, e puesto los ojos en esa. Querría que vuestras mercedes lo quisiesen ansí y pasarse a Ampudia con las ventajas que an de creer y fiar de mí, 
que haré así en la yglesia como en cada uno de vuestras mercedes. Para esto enbío al padre fray Prudencio de Sandoual como cosa mayor que tratará el orden que se a de tener, siendo vuestras mercedes seruidos dello. Désele entero crédito, que yo tendré por bueno lo que [... Dios] guarde a nuestro señor. Marqués de Denia, 17 de henero de 1604 años. El duque.

1604, febrero, 24. Husillos.

El prior y cabildo de Santa María de Husillos aprueban la unión de su abadía con la iglesia de San Miguel de Ampudia, merced a una petición de Francisco Gómez de Sandoval, duque de Lerma, datada el 17 de enero de 1604, ofreciendo un aumento de renta en las prebendas de los beneficiados. Dan poder a Alonso Manrique y Pedro Gómez Murillo para realizar la petición al papa.

A. APA, Leg. 152, carp. 2-1. Papel; escr. humanística; buena conservación.

Conoçida cosa sea a todos los que esta escritura todo lo en ella contenido vieren, como en la villa de Husillos, a veinte y quatro días del mes de febrero de este presente año de mill y seiscientos y quatro, por ante mí, Gaspar de Villadrigo, notario apostólico por autoridad apostólica, aprovado los señores prior y cabildo de la yglesia collegial de Nuestra Señora de Dehesa Brava de la villa de Husillos, estando juntos y congregados en el capítulo de la dicha su yglesia a son de canpana tañida como lo tienen de vso y costumbre para tratar de las cosas tocantes al seruicio de Dios nuestro señor y administración de su mesa capitular y fábrica; llamados por escritor de las oras el día antes con pena de dos ducados para tratar specialmente de todo lo que en esta escritura se tratare y declarare, estando specialmente los señores don Baltasar de Chaues, prior, don Juan de Palán?, tesorero, García de [...], Gaspar de Villadiego, Rodrigo de Paya, Raphael 
Fernández, Andrés Pérez, Bartolomé González, Martín Muñoz y Francisco de La Madriz, todos canónigos y racioneros, que haçen en número la mayor parte de todos los prebendados de esta iglesia, ansí estantes como los que no lo son, todos por sí y por los ausentes, por los quales prestaron cauçión del rato que estarán e pasarán por todo lo que en esta escriptura fuere dicho y declarado que no irán ni contravendrán en cosa alguna contra ellos, dixeron que por quanto su excelencia don Francisco Gomes de Sandoual, duque de Lerma, marqués de Denia, por vna letra suya dada en Denia, a los diez y siete de henero de este año de seiscientos y quatro, con sobre escrito al prior y cabildo de esta sancta yglesia, muestra tener deseo de transferir esta sancta yglesia de Husillos en la villa de Empudia y vnirla con la yglesia de San Miguel de la dicha villa por auer sido ésta de Husillos fundación de sus progenitores. E para ello pide a los dichos señores presten su consentimiento e den su poder para que Su Santidad confirme la dicha unión, con protesta que hace de contribuir para todos los gastos que se recrecieren e allar rentas las prevendas ultra de la renta que tienen con la congrua que vaste según la calidad de sus personas.

E visto por los dichos señores capitulares todo lo dicho contenido en la dicha carta e confiados del valor de su excelencia, unánimes de su propria, mera y espontánea voluntad, no inducidos ni forçados, dijeron que consentían y consintieron que la dicha unión se haga de las dichas dos yglesias como su excelencia lo pide con condiçión que todas las rentas desta dicha yglesia de Husillos, ansí diezmos como primicias, trigo, ceuada, centeno, vino, menudos, aniversarios, memorias, sin quitar cosa alguna, se junte con las rentas que tubiere la yglesia de Empudia, ansí mesmo diezmos, primicias, trigo, ceuada, centeno, vino, menudos y aniversarios, memorias, rentas de cofradrías, y todo lo demás sin faltar cosa alguna de todo ello, se haga vn cuerpo de hacienda y se reparta por yguales partes entre los benefficiados de esta yglesia y los que hubiere en la dicha villa de Empudia, sin que vno lleue más que otro, dando a cada vno respectivamente según su preuenda con más todo lo que su excelencia fuere seruido de dar para aumentos de las dichas preuendas; y con condiçión que los beneficiados, ansí dignidades como canónigos y racioneros que al presente lo son en esta yglesia de Husillos, puedan resignar, permutar, dar en coadjutoria las dichas sus preuendas o en aquella vía o forma que de derecho aya lugar a qualquier persona que les diere gusto y 
contento, sin que para ello sea necesario el consentir de su excelencia ni de otra persona que por indulto apostólico fuere patrón y presente noción de las dichas preuendas. E con estas condiciones "et non alias nec alio modo", dijeron que consentían y consintieron se hiçiesen y haga la unión de las dichas dos yglesias según y de la manera que dicho tienen.

E para que la dicha unión la confirme Su Santidad, dieron y otorgaron su poder tan vastante como de derecho se requiere y es necesario a los señores don Alonso Manrique y a Pedro Gómez Murillo, estantes en corte romana y a cada vno por sí "in solidum" que puedan pareçer y parezcan ante Su Santidad en el dicho su nonbre, e suplicar tenga por bien esta dicha translación según y de la manera que dicho es. E sobre ello puedan presentar e presenten la súplica o sùplicas que fueren necesarias y prestar qualquier consenso e le estiendan según la expedición de la bulla e letras apostólicas que para lo dicho fueren necesarias "iuxtas formam suplicationis", e jurar en ánima de los dichos constituyentes que en esta dicha translación no interviene ni espera intervenir "labe fraude" de simonía ni otra (...)? ni corruptela reprouada.

E para que puedan decir e procurar todo lo demás que para lo susodicho fuere necesario, con protesta que hicieren que todo lo que los dichos sus procuradores hicieren, lo tendrán por bueno, rato, firme, estable y valedero para siempre jamás, e les releuaron de la carga de la satisdación y fiaduría con la cláusula "iuditio sisti iudicatum solui", y con las demás acostumbradas, para lo qual que lo a ello anejo e dependiente se obligaron de su propria, mera y espontánea voluntad, no inducidos ni confultos en la mejor forma que de derecho aya lugar, que lo firmaron de sus nombres, siendo testigos: Antonio de Támara; Francisco de Bureba; Alonso Martín, estantes en esta dicha villa (...)? ut supra. El prior Chaues, el tesorero Palacio, el canónigo Bustamante, el canónigo Villado, el canónigo Rodrigo de Palacio, Raphael Fernández, el canónigo Pérez, el canónigo Gonçález, el canónigo Muñoz, el raçionero Francisco Gómez.

Va borrado no enmendado: propria; borrado: y los; enmendado: la dicha; y bueno, vala.

Ante my, Gaspar de Villadiego. E yo, Gaspar de Villadiego, notario apostólico que presente fui a todo lo supradicho, en fe dello lo firmo y signo de my 
acostumbrado signo que es a tal en testimonio de verdad (signo: magis amica veritas). Gaspar de Villadiego (rúbrica).

[Circa 1604, abril, 10]

Carta de Felipe III al duque de Escalona, embajador de España en la Santa Sede, comunicándole su decisión de donar el derecho de patronazgo sobre Santa María de Husillos a Francisco Gómez de Sandoval, duque de Lerma, ordenándole que haga petición al papa Clemente VIII, en su nombre, de trasladar dicha abadía a Ampudia, transformando asi la iglesia parroquial de dicha villa en iglesia colegial.

B. AHN, Consejo, Patronato de Castilla, Libros de Iglesia, t. 6, fol. 20v.

ED. CERVERA VERA, La iglesia colegial de San Pedro en Lerma, 126.- FRANCIA LORENZO, Notas de archivo 1, 30-32.

El rey. Duque primo: el duque de Lerma me ha hecho relación que por ser la villa de Ampudia vna de las principales de su casa y estado y en quien cabrá bien qualquier acrecentamiento, desea que Su Santidad tenga por bien de eregir en colegial la iglesia parrochial de aquella villa, que como yo lo e visto es muy capaz para ello, y que se traslade a ella la colegial de la uilla de Husillos (que está quatro leguas de Ampudia y son ambas en la diócesis de Palencia) con su abad, prebendados y renta; y que de ella y de la que agora tiene la dicha iglesia parrochial de Ampudia se haga vn cuerpo y masa con que quede doctada, para lo qual tiene el dicho duque los consentimientos que yrán aquí; y porque yo soy patrón de la abadía de dicha iglesia colegial de Husillos y como tal presento personas para ella, y el dicho duque me suplicó le hiciese gracia y merced y a los sucesores en su casa y estado, del patronazgo y derecho que tengo de presentar a 
esta abadía que agora está vaca por fallecimiento del inquisidor Cortázar, y que asemismo por lo que me toca tuuiese por bien que la dicha iglesia colegial de Husillos y sus prebendados y renta se traslade a la de Ampudia, y que del valor dello y de el de los beneficios que tiene patrimoniales, se erixa una iglesia colegial y mandar scriuir a Su Santidad y a vos sobre ello, para que en mi nombre lo pidiésedes a Su Santidad que en memoria y reconocimiento de haberle hecho yo merced del dicho patronazgo y derecho de presentar a la dicha abadía de Husillos, se hará perpetuamente en cada año en la de Ampudia el día de San Phelipe, el que yo mandare, vna fiesta solemne por mí y los reyes mis sucesores; y yo, acatando a los grandes, contínuos y agradables seruicios que el dicho duque me ha hecho y haze, y que en la dicha iglesia de Husillos ay tradición que de predecesores del dicho duque, e tenido por bien por lo que me toca, hazerle gracia, merced y donación perpetua del derecho que tengo de presentar a la dicha abadía de que le e mandado dar mi título y prouisión y que, con licencia y beneplácito de Su Santidad, se traslade la dicha iglesia con sus prebendados y renta a la parrochial de Ampudia, que se ha de eregir en colegial. Y os encargo y mando que en recibiendo ésta deys a Su Santidad mi carta que va con ella en vuestra creencia y cuenta de lo dicho, y le supliquéis en mi nombre con instancia, se sirua tenerlo por bien y aprobarlo, atento a las causas que os dará Don Alonso Manrique, a quien el duque tiene cometido el despacho desto, mandando se erixa en colegial la dicha yglesia parrochial de Ampudia, y que se mude, passe y traslade a ella la dicha iglesia colegial de Husillos con sus prebendados y renta. Y que para más augmento de su dote se sirua Su Santidad expedir de todo ello sus bulas en la más cumplida y favorable forma que ser pueda y acostumbra en estas materias.

1604, abril, 10. Valladolid. 
Carta de Felipe III al papa Clemente VIII pidiéndole que reciba en audiencia al duque de Escalona, embajador de España en la Santa Sede, en relación a la creación de las iglesias colegiales de Ampudia y Lerma, esperando su aceptación.

B. AHN, Consejo, Patronato de Castilla, Libros de Iglesia, t. 6, fol. 21.

ED. CERVERA VERA, La iglesia colegial de San Pedro en Lerma, 126.- FRANCIA LORENZO, Notas de archivo 1, 30-32.

Muy Santo Padre. Al duque de Escalona del mi consejo y mi embaxador, scriuo que en mi nombre habla a Vuestra Beatitud sobre las erectiones de las iglesias colegiales de Lerma y Ampudia. Suplico a Vuestra Señoría le oyga y dé entero crédito a lo que cerca desto dixere y propusiere de mi parte, y mande hazer en ello la prevención que espero (por ser como entenderá Vuestra Señoría del seruicio de nuestro Señor y augmento de su culto diuino) que en ello reciviré singular gracia de Vuestra Beatitud, cuya muy santa persona nuestro Señor guarde y sus días acreciente, a bueno y perpetuo regimiento de su universal iglesia.

Scripta en Valladolid, a diez de abril de 1604. De Vuestra Señoría Muy humilde y deuoto hijo, don Felipe, por la gracia de Dios rey de Castilla, de León, de Aragón, de las Dos Sicilias, de Hierusalén, de Portugal, de Navarra y de las Yndias. Que sus muy santos pies y manos besa.

El rey. Francisco González de Heredia. Señalada de los dichos.

1606, septiembre, 25. Roma.

Bula de Paulo V autorizando el traslado de la abadía de Santa María de Husillos a la iglesia parroquial de San Miguel de Ampudia, propiedad del duque de Lerma. 
A. APA (museo de Arte Sacro de Ampudia)

B. AHN, Diversos y Colecciones, Códice 1028

C. ARCHV, Salas de lo Civil. Masas (F), Caja 2787-1. Traslado desde A, aportado como prueba en un pleito fenecido (1774) de la colegiata de Ampudia con el concejo de Husillos por la posesión de ciertas heredades.

D. APA, Leg. 152, carp. 2-4.

1608, abril, 17. Palencia.

Protesta de los representantes del deán y cabildo catedralicio de Palencia sobre el traslado de la abadía de Santa María de Husillos a Ampudia, realizado a petición de Francisco de Rojas y Sandoval, duque de Lerma.

A. ACP, Arm. III, leg. 13, doc. 18. Papel; 2 hojas; escr. humanística; buena conservación.

Aunque en el documento se expresa que el obispado está vacante por muerte de Martin de Axpe y Sierra, por el episcopologio palentino (tanto el del Diccionario de Historia eclesiástica ${ }^{20}$ como el de C. Reglero ${ }^{21}$ ) comprobamos que su sucesor, Felipe de Tassis y Acuña, fue promovido a la silla episcopal el 11 de febrero de 1608.

In Dey nomine, amen. Notorio sea a los que este público ynstrumento de presentación, de petición y protesta vieren, como en la ciudad de Palencia, estando dentro de la capilla capitular de la sancta yglesia cathedral de la dicha ciudad, a diez y siete días del mes de abril de mill e seiscientos y ocho años, ante los señores licenciados don Francisco de Valberde Alderete, deán, y Juan Rodríguez de Sancta Cruz, canónigos de la dicha sancta yglesia, prouisores generales deste obispado, sede vacante por muerte de la buena memoria del señor don Martín de Axpe y Sierra, obispo que fue del dicho obispado. E por ante mí,

\footnotetext{
${ }^{20}$ ALDEA - MARÍN - VIVES, DHEE, III, 1870-1871.

${ }^{21}$ REGLERO, La iglesia de Palencia en la Edad Media.
} 
Lucas Gallardo, vecino de la dicha ciudad, notario público por la auctoridad apostólica e testigos ynfraescriptos, parescieron presentes los señores don Francisco de Fuenmayor, arcediano de Campos, doctor; Alonso Gómez Melende, doctoral; licenciado don Francisco de Alcaraz Godinez; licenciado González y el licenciado Francisco Álbarez, todos canónigos de la dicha sancta yglesia de Palencia, diputados por el deán y cabildo de la dicha sancta yglesia, para el expediente y prosecución de los negocios que en ella se ofrecen. Los quales estando ansí juntos y congregados por sí y en nombre del señor licenciado don Gaspar de Peralta, canónigo de la dicha yglesia, ausente diputado del dicho cabildo, presentaron y [...] ante mí el dicho notario, vn pedimiento, protesta y apelación firmada de sus nombres, su tenor de lo qual, “de verbo ad verbum”, es el siguiente.

Don Francisco de Fuenmayor, arcediano de Campos; el licenciado Pero González; el licenciado don Francisco de Alcaraz Godinez; el licenciado Francisco Álbarez; y el licenciado don Gaspar de Peralta, dignidad y canónigos desta sancta yglesia de Palencia, diputados por el deán y cabildo della para el expediente y prosecución de los negocios y causas que en ela se ofrecen este año de mill e seiscientos y ocho y por comisiones pacialmente a nos dada para lo ynfraescripto, lo qual le dimos y rrogamos al presente notario que aquí la ponga y decimos serán si que el señor don Francisco de Rojas y Saldoval, duque de Lerma, que a la sazón a trasladado en estos tiempos la abbadía e yglesia collegial de Husillos a la parroqial de la villa de Hempudia, y hecho de las dos sola una, eximiéndola de la jurisdición hordinaria deste ovispado y haciéndola ynmediata a la sancta sede apostólica, y ha quitado y sacado en cierta forma la dicha dignidad y abbadía de Husillos desta sancta yglesia y del coro della, donde siempre a tenido silla con obligación de rresidir para ganar y pacer frutos por entero. Y la dicha translación y mudanza se a hecho con effecto en días próximos pasados, de manera que ya en la dicha villa de Husillos no ay tal abbadía ni yglesia collegial como antes solía, y es notorio todo lo qual siendo como es en evidente perjuicio y notable agravio desta sancta yglesia, deán y cavildo della, se a hecho e yntentado ante su sanctidad sin citar ni llamar la dicha yglesia ni al señor obispo que a presidido en ella, para que pudieran salir a defender y alegar su derecho y jus(f.1r)ticia ynformando a su sanctidad en lo que les para y puede parar yr perjuicio y atento 
esta dicha sancta yglesia queda cabsa y danificada totalmente por la dicha translación y mudanza, ansí la cobranza de sus rrentas como en la dicha exempción de yglesia e dignidad y en rrazón de heso en sus derechos y esenciones y en muchas cosas y casos que protestamos, expresar y declarara su tiempo y lugar. Y que al dicho señor duque en estos tiempos es persona tan poderosa y válida de su magestad el rrey don Felipe tercero nuestro señor, como es notorio, por lo qual no ay communidad ni particular por rico y afortunado que sea que se pueda atreuer ni atreua contradecir ni oponerse a su excelencia, ni estorbarle sus yntentos en lo que quiere y pretende por el justo temor que a todos causa su potencia ayudada del dicho fauor particularmente a personas eclesiásticas, a quienes más propio el no divirtirse del rrecoximiento de sus yglesias a pleitos y negocios esteriores mayormente no abiendo de ser de effecto. Por tanto aten traslado dichas causas y otras de justo temor, nos los dichos en nombre del dicho deán y cabildo desta sancta yglesia, en aquella vida y forma que el derecho nos concede y más nos conviene y a lugar, decimos e le protestamos contra lo susodicho en todo y en parte, y contradecimos la dicha translación y mudanza y todo lo en virtud della hecho por el dicho señor duque, en quanto es y puede ser en agravio y perjuicio desta sancta yglesia, cavildo y fábrica della y de las rrentas de su mesa capitular. Y de todo hello apelamos, siendo necesario, y protestamos contra hello las beces necesarias y en la forma que nos es permitido y de derecho se rrequiere, para que no pueda parar perjuicio en todo ni en parte ni pueda tener ni tenga firmeza ni effecto permanente durante el dicho perjuicio y agravio. Y de seguir esta apelación y protesta en tiempo más oportuno ante su sanctidad o donde por derecho deuamos y más nos conbenga, y para que entre tanto no pare perjuicio lo hecho por el dicho señor duque ni parte dello, así lo protestamos, decimos y declaramos ante vuestras mercedes, como personas públicas y graves que el derecho rrequiere, y de todo hello pedimos al presente notario nos dé testimonio en pública forma para la guarda del derecho desta sancta yglesia y cabildo della y de sus rrentas y mesa capitular y de sus preuilegios, derechos y exsempciones, y a los presentes hacemos testigos. Y siendo necesario a vuestras mercedes, suplicamos ynterpongan a hello su decreto y auctoridad judicial para mayor fuerza y firmeza desta diligencia y protesta, y de todo pedimos testimonio. Don Francisco de Fuenmayor; el doctor Gómez; el licenciado don Francisco de 
Alcaraz Godinez; el licenciado don Gaspar de Peralta; el licenciado González; el licenciado Francisco Álvarez.

E ansí presentado el dicho pedimiento, protesta y apellación suso ynserta en la manera que dicha es, luego los dichos señores don Francisco de Fuenmayor, arcediano de Campos, y consortes canónigos de la dicha sancta yglesia $(f .2 r)$ de Palencia, diputados del cabildo della, dixeron e pidiéronlo en la dicha petición contenidos justicia y apelación del, protestaron como se contiene en el dicho pedimiento e pidieron testimonio para enguarda del dicho cabildo. E visto por los dichos señores provisores, cubrieron por pie sentado el dicho pedimiento y por ffecha la dicha protesta y apelación, e dixeron que la oyan. E mandaron a mí, el dicho notario, lleve testimonio de la dicha protesta y apelación para su guarda de su derecho. A lo qual ynterpusieron su auctoridad hordinaria y decreto judicial para que ualga y haga ffee en juicio y fuera del, doquier que parezca. Y así lo proueyeron e mandaron e firmaron. Testigos: Andrés Pérez, vecino de Villalba del Alcor, y Hernando de Población, tiniente de alcayde de la cárcel episcopal deste obispado, vecino y estante en la dicha ciudad de Palencia; el licenciado don Francisco de Valberde Alderete, deán; el licenciado Sancta Cruz. Por sí, ante mí, Lucas Gallardo, notario.

Yo, el dicho Lucas Gallardo, lego, vecino de la dicha ciudad de Palencia, notario público por la audencia apostólica que fuy presente a lo que dicho es en vno con los dichos señores. Por ende, del dicho pedimiento y de mandamiento de los señores prouisores generales deste obispado de Palencia, sede vacante, fielmente lo signé y subscriuí en testimonio de verdad, compulsé assí.

Lucas Gallardo (rúbrica y signo). 


\section{DAVID MARCOS DIEZ}


LA ABADÍA DE SANTA MARÍA DE HUSILLOS: ESTUDIO Y COLECCIÓN

DOCUMENTAL (904 - 1608)

\section{III \\ ÍNDICES}




\section{DAVID MARCOS DIEZ}




\section{LA ABADÍA DE SANTA MARÍA DE HUSILLOS: ESTUDIO Y COLECCIÓN \\ DOCUMENTAL (904 - 1608)}

\section{1. ÍNDICE DE PERSONAS}

ABDALLA, hijo de Avin Amus Lemmi, rey de Granada, vasallo de Alfonso XI, conf.: 113

Abdeket, conf: 2

Abenmalisot, rey de Niebla, vasallo de Alfonso X, conf.: 71

Abo Abdella, conf.: 2

Abo Hamor.: 2

Aboabdille Abennazar, rey de Granada, vasallo de Alfonso X, conf.: 71

Abril (Aprilis): 29; ts.: 65; hermano de Domingo, ts.: 53 ; villicus: 52

Adán (Adam): 297; ts.: 64; de Fesiella, ts.: 57; hijo de Domingo Rodríguez: 88; ob. de Placencia, conf.: 71

Adeltarius, conf:: 2

Adriano VI: 339

Agustín de la Puente de Valdevieso, criado del abad de Hérmedes, ts.: 250

Agustín Ortiz: 269

Alardo, ts.: 31

Alberto (Alberti, Albertinus), 24; presbíter de la Santa Iglesia Romana, cardenal, canciller: 37

Alderete, licenciado, miembro del consejo real, regidor de Tordesillas: 292

Alejandro (Alexander, Alexandri, Alexandro) II, papa: 136; III: 32, 37, 136, 223, 298; can., conf.: 42

Alfonso (Adefonso, Adefonso, Adefonsus, Adephonsus, Aldefonsus, Alfonssillo, Alfonso, Alfonso, Alfonsus, Alifonsus, Alonso, Ildefonso), 207; alférez real, conf.: 82; conde de Carrión, conf.: 213; conde de Nurueña, hermano de Juan I, conf.: 193, 194; criado de Bernal de Barras: 176; hermano de Juan I, conf.: 192; deán de la catedral de Palencia: 165; hijo del infante don Pedro de Aragón, marqués de Villena, conde de Ribagorza y de Denia, vasallo de Juan I, conf.: 163, 164, 192, 193, 194; hijo de Adán Pérez: 145; hijo de Cidón Pérez: 140; hijo de Esteban: 185; hijo de Francisco Gordo de Paredes de Nava, ts.: 112; hijo de Juan Alfonso: 185; hijo de Pedro González: 185; hijo de Urraca I: 18, 19; hijo del infante de
Molina, conf.: 97, 100; hijo del infante don Fernando, vasallo de Alfonso XI, conf.: 113; hijo del infante don Juan, conf.: 100; hijo del infante don Pedro de Aragón, marqués de Villena, conde de Ribagorza y de Denia, vasallo de Enrique III, conf.: 213; infante, hijo de Fernando III: 63; infante, hijo de Fernando IV, sincr.: 100; infante, hijo de Sancho IV: 82; , ob. de Astorga y not. mayor del reino de León, conf.: 97, 100, 163, 164, 192, 193, 194; ob. de Cádiz, conf.: 193, 194; ob. de Cartagena, conf.: 134, 135; ob. de Ciudad Rodrigo, conf.: $97,100,134,135,163,164,192$, 193, 194; ob. de Coria, conf.: 82, 97, 100, 113, 213; ob. de Mondoñedo, conf.: 134, 135; ob. de Salamanca: 192, 193, 194; ob. de Salamanca, not. mayor de Andalucía, conf.: 163, 164; ob. de Zamora, conf.: 213; tío de Enrique III, conf.: 213

Alfonso VI, 14, 15, 17, 19, 22, 339; hijo de Fernando I: 339; rey de Castilla, Toledo, León, Galicia, Sevilla, Córdoba, Murcia, Jaén, Algarbe, señor de Vizcaya y de Molina: 114; reinante en Toledo y Castilla, sincr.: 16

Alfonso VII, 27; "imperator Hispanie": 21; emperador de Hispania: 24, 27, 28, 29; emperador en León, Galicia, Castilla, Toledo, y Almería: 25; emperador de Toledo, León, Galicia, Castilla y Nájera: 14; emperador en Toledo, León, Zaragoza, Nájera, Castilla, Galicia, sincr.: 21;padre de Sancho III: 30; emperador: 82; reinante en Hispania, sincr.: 26; rey de Castilla y León: 29; rey, conf.: 6; rey de Hispania, sincr.: 20

Alfonso VIII: 61, 82, 97, 114, 135, 193, 298; "rex hispanorum": 34; reinante en Toledo y Castilla, sincr.: 33, 35, 42, 43, 44, 45, 47; reinante en Castilla, Toledo y Extremadura, sincr.: 40; reinante en Toledo, Extremadura, y Castilla, sincr.: 46; 
reinante en Toledo, Nájera y Castilla: 31; rey: 35, 38; rey de Castilla: 36

Alfonso IX, reinante en León, Galicia, Asturias y Extremadura, sincr.: 41

Alfonso X, 71, 76, 92, 101; reinante, sincr.: 73; rey de Castilla, Toledo, León, Galicia, Sevilla, Córdoba, de Murcia, de Jaén, y del Algarbe: 76

Alfonso XI: 113, 114, 131, 132, 134, $135,163,164,193,194,213$; reinante en Castilla, Toledo, León, Galicia, Sevilla, Córdoba, Murcia, Jaén, Baeza, Badajoz, el Algarbe, Vizcaya y Molina, sincr.: 101, 113, 114, 131; rey: 101, 298

Alfonso Abad: 185

Alfonso Álvarez de Ávila, escribano real y not. público: 237

Alfonso Bravo, criado de Francisco de Reinoso, abad de Husillos, ts.: 330

Alfonso Cano, vecino de Palencia: 298

Alfonso Capellán, hortelano: 162

Alfonso Caro: 185

Alfonso Casado, vecino de Fuentes de Valdepero: 298

Alfonso de Aguilar, vecino de Husillos: 298

Alfonso de Alarcón, criado de Francisco Núñez, abad de Husillos, ts.: 253, 254

Alfonso de Arbañejo: 185

Alfonso de Ávila, ts.: 252, 298

Alfonso de Ayuso: 249

Alfonso de Becerril: 185

Alfonso de Bonilla, can. de Husillos: 236

Alfonso de Braga, can. de Husillos, ts.: 230

Alfonso de Burgos, ob. de Palencia: 244, 245, 250; ob. de Palencia, conde de Pernía: 251; ob. de Palencia, conde de Pernía, capellán mayor y confesor, miembro del consejo de los Reyes Católicos: 245ob. de Palencia: 244, 245, 250, 251, 162; conde de Pernía: 251

Alfonso de Camporredondo, vecino de Husillos: 221

Alfonso de Corral: 185, 201

Alfonso de Corrales: 249

Alfonso de Dueñas, platero: 253

Alfonso de Hugo, chantre y can. de Husillos: 335

Alfonso de las Eras, criado del abad de Husillos, ts.: 250
Alfonso de León: 253

Alfonso de Loyo, chantre de Husillos: 340

Alfonso de Molina, conf.: 71

Alfonso de Palencia: 91

Alfonso de Pedro Sánchez, alcalde de Hérmedes de Cerrato: 249

Alfonso de Portugal, infante, vasallo de Fernando IV, conf.: 97

Alfonso de Quintanilla, caballero, ts.: 111

Alfonso de Revenga, ts.: 189

Alfonso de Salamanca, can. de la catedral de Palencia, ts.: 63

Alfonso de Uruenga, can., ts.: 230

Alfonso de Vega, mayordomo del obispo, ts.: 245

Alfonso de Vidoblo, racionero de Husillos: 251

Alfonso de Villanueva, regidor de Burgos, ts.: 242

Alfonso del Hoyo, chantre de Husillos: 330

Alfonso Diago, can. de Husillos: 243

Alfonso Díaz, 185; bachiller: 226; not. mayor de Andalucía, conf.: 97

Alfonso Díaz de Támara, bachiller en decretos y canónigo de la catedral de Palencia, juez: 226

Alfonso Díez: 185

Alfonso Doydobro, can. de Husillos: 252

Alfonso Enríquez, hijo de Enrique II, señor de Lorena, conf.: 163, 164, 213

Alfonso Espos: 249

Alfonso Fernández, 141, 185; alcalde de Astudillo: 220; arcipreste de Ferrán, ts.: 226; beneficiado de Husillos, procurador: 226; bolsero, vecino de Palencia: 218; cardador: 185; clérigo de Frechilla, ts.: 145; clérigo, capellán en la catedral de Palencia, ts.: 202; clérigo: 185; escribano público de Monzón: 195; escribano público de Paredes de Nava: 126; hermano de Juan Fernández, conf.: 97; hijo de Aparicio, clérigo: 126; hijo de Domingo Fernández: 185; hijo de doña Marina: 140, 145; hijo de Juan Fernández Quintero: 185; hijo de Pedro Fernández: 159; hijo del cerrajero: 185; procurador: 226; señor de Aguilar, conf.: 193, 194, 213; tejedor: 185; tendero de paños 


\section{LA ABADÍA DE SANTA MARÍA DE HUSILLOS: ESTUDIO Y COLECCIÓN \\ DOCUMENTAL (904 - 1608)}

de color, hijo de Alfonso Pérez, ts.: 155; ts.: 132, 220

Alfonso Fernández "Bienvel": 185

Alfonso Fernández de Angulo, escribano público de Burgos: 207

Alfonso Fernández de Cardaño, ts.: 221

Alfonso Fernández de Carrión, hermano de Pedro Fernández, abad de Husillos: 143

Alfonso Fernández de Castro: 212, 214

Alfonso Fernández de Cuéllar, procurador: 181; vicario en la catedral de Palencia, procurador: 182

Alfonso Fernández de Estrada, ts.: 152, 153,156

Alfonso Fernández de Montemayor, adelantado mayor de Andalucía, 164; conf.: 163; adelantado mayor de la Frontera, 194; conf.: 193

Alfonso Fernández de Orbaneja, ts.: 205

Alfonso Fernández de Paredes, compadre de Juan Martínez de Villaviudas: 201; escribano real, albacea de Juan Martínez de Villaviudas: 201

Alfonso Fernández de Támara, clérigo y beneficiado de la iglesia de San Hipólito de Támara: 263

Alfonso García, 185; archidiácono, conf.: 56; conf.: 71; hijo de Alfonso, clérigo: 126; hijo de García Pérez Manzano: 185; mantero, ts.: 179; not.: 217 ; sutori, ts.: 157

Alfonso García "El Mozo", clérigo: 126

Alfonso García de Sigüenza, criado de Rodrigo Galván, can., ts.: 168

Alfonso García de Sonlla, can. de la catedral de Burgos: 207

Alfonso García de Valera, ts.: 57

Alfonso García de Villada, vecino de Palencia: 155

Alfonso García de Villagarcía, not. público apostólico: 223

Alfonso García de Villalobón: 226

Alfonso García de Villasur, can. de la catedral de Palencia y not. público de Palencia: 217

Alfonso García de Villoldo: 185, 207, 211

Alfonso García Turri, clérigo: 126

Alfonso Gómez, maestro de las heridas, hombre de Alfonso Martínez, alcalde del rey en las merindades de Castilla, ts.: 144
Alfonso Gómez Melende, doctoral, can. de la catedral de Palencia: 351

Alfonso González: 140, 145; arcipreste de Santa Illana, clérigo de San Miguel de Aguilar de Campóo y de Santa Cruz: 207; clérigo de Grijota y can. de Santa María de Valladolid: 203; clérigo de Grijota, compañero de Husillos, ts.: 209; sacristán de Husillos y not. apostólico: 225

Alfonso González de Aguilar de Campóo, clérigo de la diócesis de Burgos, sacristán de Husillos y not. público apostólico: 225

Alfonso González de Biruega, can. de Husillos: 233, 243

Alfonso González de Frómista, can. de Husillos: 230

Alfonso González de Olmedo, criado de Juan González, abad de Husillos, ts.: 205

Alfonso González de Tordesillas: 186

Alfonso González del Olmedo, escudero de Juan González de Illescas, abad de Husillos, ts.: 206

Alfonso Gutiérrez, escribano público de Palencia: 111; not. público de Palencia: 109, 110, 185; ts.: 45, 220

Alfonso Jufre de Teneyto, almirante mayor de la mar y guarda mayor del rey, conf.: 113

Alfonso López, abad de Lebanza, vicario de Gutierre, ob. de Palencia y not. mayor de Andalucía: 148, 149; ts.: 142 ; alfayate: 185 ; conf.: 71 ; deán de la catedral de Palencia y vicario del obispo de Palencia Gutierre I Gómez de Toledo: 162, $165,166,168,180,182$

Alfonso López de Haro, conf.: 134, 135

Alfonso Macías: 185

Alfonso Manrique, procurador: 347, 348

Alfonso Martín, hijo de Martín Cidón, clérigo de Amayuelas: 140, 145; ts.: 347

Alfonso Martín Delgado: 185

Alfonso Martínez, 129; abogado, ts.: 148, 149, 176; alcalde del rey en las merindades de Castilla: 144; can. de la catedral de Palencia y vicario general en el obispado de dicha ciudad, maestre escuela: 202; diácono: 126; escribano real: 190; hermano de Sancho Martínez, abad de Husillos: 201; hijo de Alfonso 
Martínez, ts.: 112; hijo de Juan Martínez de San Cebrián, ts.: 168; hijo de Lope Martínez: 241; maestre escuela, can. de la catedral de Palencia, provisor y vicario: 202; ob. de Palencia: 17; ts.: 91

Alfonso Martínez de Bobadilla, can. de Husillos: 243

Alfonso Martínez de Bonilla, can. de Husillos: 233

Alfonso Martínez de León, escribano del rey y not. público: 224

Alfonso Martínez de Lorena, ts.: 57

Alfonso Martínez Delgado: 185

Alfonso Méndez, ts.: 201

Alfonso Moreno, clérigo: 249

Alfonso Núñez, hijo de don Miguel, ts.: 91

Alfonso Pájaro: 185

Alfonso Pascual: 185

Alfonso Pérez, 85, 91, 185; can. de la catedral de Palencia: 80; clérigo de iglesia de San Juan de Paredes de Nava: 126; clérigo de la iglesia de San Juan, hijo de Domingo Mínguez: 125; clérigo de San Juan de Paredes de Nava: 125; clérigo del coro de Santa María de Husillos, ts.: 110; clérigo, hijo de Diego Asensio: 126; clérigo: 126; hermano de Diego Pérez: 91; hijo de Domingo Mínguez, clérigo: 126; hijo de Pedro Juan, clérigo: 126; hijo de Rodrigo Pérez, ts.: 91; not. público de Palencia, ts.: 148, 149, 218; portero, ts.: 90, 91; procurador: 127 ; ts.: 91

Alfonso Pérez de Carrión, not. público de Palencia: 219

Alfonso Pérez de Guzmán conf.: 134, 135, 163, 164

Alfonso Pérez de Logroño, ts.: 102, 106, 112

Alfonso Pérez Girón, ts.: 63

Alfonso Pérez Guzmán conf.: 97

Alfonso Rodríguez, 100, 253; arcediano de Carrión, ts.: 112; chantre: 95; escribano público de Palencia: 253, 254; vecino de Villaumbrales: 266

Alfonso Rodríguez de Moral, hombre de Juan Fernández, abad de Husillos, ts.: 197

Alfonso Romero: 185

Alfonso Ruiz, 84; can. de Husillos: 205; not. público de Palencia: 105, 111, 112, 125, 127; ts.: 97
Alfonso Ruiz Ruacho, can. de Husillos: 243

Alfonso Sánchez, escribano, vecino de Castroverde de Cerrato: 249; hijo de Sancho Fernández de Toledo, ts.: 107; not.: 185; serrajero, ts.: 112

Alfonso Sánchez de Ferrán, vicario general de la diócesis de Palencia: 225

Alfonso Simón, ts.: 44

Alfonso Suárez de Deza, adelantado mayor del reino de Galicia, conf.: 100

Alfonso Téllez, conf.: 71

Alfonso Téllez de Haro, conf.: 113, 134, 135

Alfonso Téllez Girón, conf.: 134, 135, 193, 194

Alfonso Tenorio, not. mayor del reino de Toledo, conf.: 213

Alfonso Tonze: 298

Alfonso Yago, can. de la catedral de San Antolín de Palencia: 260; vecino de Amusco: 260

Alfonso Yáñez Fajardo, adelantado mayor del reino de Murcia, conf.: 213

Alfonso Yesero: 226

Almanrico (Almanrricus), conde, conf.: 27, 28, 30; conde, dominante en Toledo: 31

Álvaro (Alvar, Aluar, Albarus), 91; capellán de Pedro González de Marañón, ts.: 57; clérigo de San Felices, hermano de Pedro Iohanis, ts.: 53; hijo de Juan Pérez, ts.: 98; doctor en decretos: 191; hijo de Diego Pérez, cabrero, ts.: 112; ob. de Cuenca, conf.: 213; ob. de Mondoñedo, conf.: 82, 113; ob. de Palencia, conf.: 97

Álvaro Alfonso de Fuentes: 185

Álvaro Curiel, vecino de Palencia y procurador del prior y cabildo de Husillos: 106

Álvaro de Revolledo, criado de Francisco Núñez, abad de Husillos: 242

Álvaro de Torres, ts.: 269

Álvaro Díaz, conf.: 71; príncipe, conf.: 14

Álvaro Díaz de Haro, conf.: 113, 134, 135

Álvaro Díez de Villalobón: 207

Álvaro Eunici de Peñafiel, ts.: 55 


\section{LA ABADÍA DE SANTA MARÍA DE HUSILLOS: ESTUDIO Y COLECCIÓN \\ DOCUMENTAL (904 - 1608)}

Alvaro Fernández, 185; ts.: 112; hijo de Juan Ibáñez, ts.: 112

Álvaro García de Albornoz, mayordomo mayor del rey, conf.: 163, 164

Álvaro García, 185; hijo de Teresa: 127

Álvaro Gómez, sobrino de Juan Álvarez, ob. de Osma: 91

Álvaro Gutiérrez, hijo de Rodrigo Álvarez de Santoyo, criado de Gómez Manrique, ts.: 217

Álvaro Martínez, tesorero: 194

Álvaro Núñez, alférez: 16

Álvaro Pérez, can. de Santa María de Valladolid: 96; conf: 27, 28, 30; can., ts.: 112; mayordomo real: 8; racionero, canciller, ts.: 105

Álvaro Pérez de Guzmán, alguacil mayor de Sevilla, conf.: 193; conf.: 194; señor de Orgaz, conf.: 213

Álvaro Pérez Osorio, señor de Villalobos y de Castroverde, conf.: 213

Álvaro Rodríguez, merino mayor: 54, 55; ts.: 54

Álvaro Rodríguez de Guzman, conf.: 36; hermano de Pedro Rodríguez, conf.: 35

Álvaro Ruiz de Cardeñosa: 119, 122

Álvaro Ruiz de la Serna: 185

Alvito (Aluitus), ob. de León: 12

Ambrosio de Morales, 338; cronista: 339

Ana de Escalantera, mujer de Alfonso de Salamanca: 279

Anaya (Anaia), fórmula de testigos, conf.: 12, 20, 24, 25, 26, 43

Andrea (Andreas), conf.: 41; capiscol, conf.: 25; ob. Coronensis: 124; precentor de Husillos, ts.: 24; sacristán de Husillos, ts.: 24; sacristán, conf.: 25

Andrequina, esposa de Gerardo: 45; mujer de Rodrigo Gutiérrez: 16

Andrés (Andree, Andreo), 207; doctor: 238; hermano de Domingo Antolín, ts.: 53; ob. de Orense, conf.: 163, 164; yerno de Juan Llorente, ts.: 107; pertiguero de Santiago, conf.: 71

Andrés de Castro, 269; can. de Husillos, ts.: 295; secretario del cabildo de Husillos: 298

Andrés de Fresno, can. de Husillos: 330

Andrés de Modragón: 298

Andrés de Nájera, criado de Francisco Sánchez de Collados, ts.: 250
Andrés de Piña, hermano de Bastián de Piña: 298

Andrés del Castillo: 298

Andrés Fernández, criado de Martín García: 219; tejedor, criado de Martín García, ts.: 218

Andrés González: 226

Andrés Martín, pellejero: 185

Andrés Martínez, not., criado del abad de Santander: 201

Andrés Pérez, 185; beneficiado de Husillos: 347; criado de Juan Álvarez, ob. de Osma: 91; vecino de Villalba del Alcor, ts.: 351

Andrés Salvador: 298

Andrés Tomé: 298

Ansur (Anxur, Asur, Assur) Díaz: 17

Ansur Muñoz: 6

Ansur Núñez, conf.: 3, 5, 7, 9, 10

Ansúrez, conde: 339

Antolín: 116, 185; ts.: 57

Antolín Abad, clérigo: 126

Antolín Pérez, 185; vecino de Husillos, padre de Pedro Fernández: 170

Antón, 91; hijo de Juan de Avia, ts.: 252; ob. Ciudad Rodrigo, conf.: 82; ob. de Albarrazín, conf.: 97

Antón Clemente, carnicero de Juan Álvarez, ob. de Osma: 91

Antón de Rojas, patriarca, ob. de Palencia: 292

Antón de Segovia, cabestrero: 325

Antón Fernández Ferrero: 159

Antón Patalla, hijo de Yáñez, ts.: 117

Antonia de Solórzano, 279; mujer de Juan Núñez, vecino de Valladolid: 291, 316

Antonia de Villaumbrales: 185

Antonio (Antoni), 185; doctor: 238; hijo de Fernando Lego, ts.: 119; hijo de Juan de Avia, sacristán de Husillos, ts.: 252; hijo de Pedro Pagom, ts.: 44

Antonio Amigo, vecino de Palencia, not. público apostólico: 269

Antonio Arias: 269

Antonio Caro, procurador: 277; vecino de Valladolid: 278

Antonio de Acuña, capellán real, abad de Husillos: 255

Antonio de Ayala, escribano público de Palencia: 267; ts.: 269

Antonio de Castro, bachiller, can. de Husillos, secretario del prior $\mathrm{y}$ cabildo de Husillos, not. público apostólico: 269 
Antonio de Fuenmayor, ts.: 330

Antonio de Martín, vecino de Husillos: 298

Antonio de Medina: 298

Antonio de Palencia, ts.: 340

Antonio de Quintela: 294

Antonio de Támara, ts.: 347

Antonio de Valladolid, procurador: 277

Antonio del Campo: 298

Antonio García: 298

Antonio García Mellado: 259

Antonio Guillén, 269; can. y provisor del cabildo de Husillos: 287

Antonio López, 330; can. de Husillos: 319,330 ; can. y secretario del cabildo de Husillos: 329

Antonio Martínez, clérigo de Soto: 185

Antonio Pérez, 185; procurador: 277

Antonio Ruiz de Villoldo, prior de Husillos: 267, 269

Antonio Sánchez, ts.: 239; doctor en decretos: 210

Antonio Tejedor: 185

Aparicio (Apparitio), 50; hermano del arcipreste, ts.: 57; ob. de Albarracín, conf.: 82; ob. de Burgos, conf.: 71

Arbas, señor de Villalpando, vasallo de Juan I, conf.: 193

Arderico (Adericus), ob. de Tuy, conf.: 14; ob. de Palencia, 4, 44, 45, 46; sincr.: 47

Ardicio (Ardicius), diácono, cardenal de San Teodoro, conf.: 37

Arellano, ob. de León, conf.: 213

Ariano (Arianus), ob. de Oviedo, conf.: 14

Arias, racionero de Husillos: 298

Arias Díaz, conf.: 82, 97

Arias Gómez de Cisneros conf.: 97

Aricer Ambrosio Bocanegra, almirante mayor de la mar, conf:: 163

Arnal (Arnalt) de Bernorio: 207

Arnaldo, 24, 25; Arnaldo, ts.: 64

Arnao, señor de Villalpando, vasallo del rey, conf.: 194

Arrieta, licenciado: 294

Arsenio (Arsenius), hermano del ob. de Zamora: 24; laico, ts.: 24

Ascarico (Ascaricus), diácono: 1

Asensio Fernández: 185

Aurelio (Aurelius), presbíter, ts.: 1

Auriolo: 12

Aznar (Aznarii), 43; hermano de Pedro Payán: 73; ob. de Calahorra, conf.: 71
BALTASAR Chaves, prior de Husillos: 340, 341, 345, 347

Bamerio, diácono, cardenal de San Jorge, conf.: 37

Bartolo (Bartolot), conf.: 41

Bartolomé (Bartolomei), 50, 207; cerrajero: 249; ob. de Silves, conf.: 82

Bartolomé "El Regranado": 185,

Bartolomé Alonso, 269; can. de Husillos, 298; ts.: 295

Bartolomé de Grijalva, vicario: 335

Bartolomé de Montoya: 298

Bartolomé de Santillán de la Cuesta, ts.: 211

Bartolomé García: 249

Bartolomé González, beneficiado de Husillos: 347

Bartolomé González, obrero de Husillos: 341

Bartolomé Pérez, 185; can., ts.: 112; cura y capellán de San Nicolás: 201; cura: 201

Bartolomé Rodríguez: 238

Bartolomé Sánchez, 249; clérigo, ts.: 188; hijo de Domingo Martínez: 140, 145

Bastián Calvo: 298

Bastián de Amor, vecino de Fuentes de Valdepero: 298

Bastián de Piña: 298

Beatriz (Beatrice), hija de Alfonso X: 71; reina, mujer de Fernando III, 50, 52, 53, 55; sincr.: 54, 57

Bebián (Veuián) Martínez, prior de Husillos: 88; clérigo del ob. Tello de Palencia, ts.: 63

Bellid (Bellii, Belit, Beliter), fórmula de testigos, conf.: 7, 12, 20, 24, 25, 26, 43

Bellid Muñoz, 6, conf.: 7

Bellid Núñez, conf.: 3, 5, 9

Beltrán de Claquin, condestable de Francia, vasallo de Juan I, conf.: 193; duque de Molina, conde de Longa Villa y de Boria, conf.: 163, 164; condestable de Francia, vasallo de Juan I, conf.: 192, 194

Beltrán de Guevara conf.: 134, 135, 193, 194, 213; vasallo del rrey, conf.: 163

Beltrán Ibáñez de Mendoza, conf.: 113

Benavides, racionero de Husillos: 298

Benita: 207

Benita García, madre de Fernando: 201 


\section{LA ABADÍA DE SANTA MARÍA DE HUSILLOS: ESTUDIO Y COLECCIÓN \\ DOCUMENTAL $(904-1608)$}

Benito, 91, 207, ob. de Ávila, conf.: 71

Benito Abad, clérigo: 126

Benito Cano: 185

Benito Cascón: 145

Benito Fernández, not., vecino de Palencia: 173

Benito Ioannes de Foyales, ts.: 54

Benito Martínez, diácono: 126

Benito Pérez: 185

Benito Pérez, clérigo: 126

Benito Pérez Cura, clérigo: 126

Benito Vascón: 140

Berengario (Berengarius), conf.: 25; ob. de Salamanca, conf.: 21; presbíter en Husillos, ts.: 26; sacristán de Husillos, conf.: 33

Berengario de Otella, ts.: 43

Berenguel Bernald, can. de la catedral de Palencia, ts.: 24

Berenguela (Beringuela), emperatriz, mujer de Alfonso VII: 21; hija de Alfonso X: 71; madre de Fernando III, sincr.: 63, 65; mujer de Alfonso VII: 6; reina, conf.: 6

Berenguer: 25

Berenguer Bernardo: 24

Bermudo (Vermudo) Rodríguez, príncipe, conf.: 14

Bernabé: 207

Bernabé García, can. y provisor de Husillos: 335; licenciado, can. de Husillos: 340

Bernal: 185

Bernal Cason, ob. de Cuenca, conf.: 164

Bernal de Barras, capellán de la catedral de Palencia: 176; capellán de los Cuarenta Capellanes de la catedral de Palencia, ts.: 179

Bernal de Bearni, conde de Medina, vasallo de Juan I, conf.: 193, 194

Bernal de Pumea: 116

Bernal del Pumar San Esteban, can. de Husillos, procurador: 105; sacristán de Husillos: 104

Bernal Pérez, ts.: 132

Bernal Víciense, ts.: 105

Bernal Zason, ob. de Cuenca, conf.: 163

Bernardo (Bernaldus, Bernar, Bernardi, Bernardos, Bernered), canciller real: 6; abad de Husillos: 21; archiácono palentino, canciller real: $27,28,30$; archidiácono, ts.: 24; Bernardo, arzob. de Toledo, 14; arzob. de Toledo, conf.: 18; conf.: 19; caballero, ts.: 58 ; ts.: 54 ; ob. de
Badajoz, conf:: 97; ob. Prenestino, conf.: 37

Bernardo de Amor: 185

Bernardo Gutiérrez Quexada, adelantado mayor en tierra de León y Asturias, conf.: 97

Bernardo Iohannis, archidiácono, conf.: 33

Bernardo Simón, archidiácono, conf.: 33

Blas: 207

Blas Abad, clérigo: 126

Blas de Santillán: 185

Blas Herrero, 298; vecino de Husillos: 289

Bonifacio (Bonifacius, Bonifatius) VIII, ob. Corlumense: 124; papa: 89, 94

Boso (Bosus), "potestas" en Saldaña y en Carrión: 31; merino en Saldaña, conf.: 28; merino de Carrión, conf.: 30; merino en Saldaña, conf.: 27

Briz de Santillán de la Cuesta: 116, 117, 122

Briz Fernández: 180, 181, 182

Bruno Díaz, can. de la catedral de Palencia: 95

Bustamante, can. de Husillos: 347

CALVO: 50

Carlos I, 294, 339, emperador: 294; ob. de Salamanca, conf.: 213

Carlos de Arellano, señor de los Cameros, conf.: 213

Castro, can. de Husillos: 295; not., can. de Husillos: 298

Catalina, 207; hija de Juan Fernández de Villamuriel: 201; reina, mujer de Enrique III: 213

Catalina de La peña: 298

Catalina Sanz, vecina de Valladolid: 317

Cenebruno (Celebruni, Cerebrunus), arzob. de Toledo: 34, 35; arzob. de Toledo, conf:: 36; ob. de Segovia, conf.: $27,28,30$

Cid, fórmula de testigos, conf.: 20,24 , $25,26,43$; ts.: $5,7,17,25$

Cimilio (Cimilius), presbíter, cardenal, ts.: 37

Cite Dotent, ts.: 20

Clara: 207

Clemente (Clementis), 207; IV: 94; VII: 339; VIII: 348, 349

Cobo (Cobus), clérigo de Haza, ts.: 54

Constanza (Costanza), reina, mujer de Alfonso VI: 16, 19; reina, mujer de Fernando IV: 97; sincr.; 100 
Constanza de Barreda, mujer de Francisco de Bivero: 252, 253, 254

Constanza de Vascones, mujer de Juan de la Peña: 298

Contreras, fiscal del rey: 294

Cortázar, inquisidor: 348

Cristóbal (Christóbal), sacristán: 91

Cristóbal de Merodio, camarero de Alfonso de Burgos, ob. de Palencia, ts.: 245

Cristóbal de Torres: 324

Cristóbal de Villanueva, not. apostólico de Valladolid: 278

Cristóbal Montesino, not. apostólico de Valladolid: 291

Cristóbal Taladrero, fiador de Cristóbal de Torres: 324

Cúnigo, ob. de Ávila, conf.: 30

DAMIÁN de Ávila, medio racionero de Husillos: 252

David, presbíter: 1

Diacon, clérigo: 126

Diego (Diac, Diago, Didaco, Didacus, Dig), abad de Sahagún, conf.: 14; juez delegado del papa: 125, 127; bachiller, can. de la catedral de Palencia: 263; electo en la iglesia de León, conf.: 18, 19; electo en la iglesia de León, conf.: 19; hijo de Martín Pérez, ts.: 126; hijo de Pedro Pérez: 123; maestre, arcediano de Campos y can. de Husillos, ts.: 63; ob. de Ávila, conf.: 213; ob. de Burgos, conf.: 163, 164, 194; ob. de Cartagena, conf.: 82; ob. de Coria, conf.: 163, 164; ob. de León, conf.: 134, 135; ob. de Orense, conf.: 213; ob. de Zamora, conf.: 100; precentor: 44; señor de Vizcaya, alférez real, conf.: 97 ; ts.: 65

Diego "El Negro": 185

Diego Abad "El Mozo", clérigo: 126; hijo de Juan Pérez, clérigo: 126; ts.: 102; vicario de Paredes de Nava, ts.: 112; vicario: 126

Diego Alfónsez: 52

Diego Alfonso, 185; caballero de Quintanilla de Valdeolmillos: 112; corredor, ts.: 186; vecino de Monzón: 298

Diego Alfonso de Aguilar, beneficiado de Husillos: 230

Diego Alfonso de Quintanilla de Valdeolmillos, caballero, ts.: 112
Diego Arias: 269

Diego Arisa, beneficiado, ts.: 230

Diego Cobo: 185

Diego Corcho: 185

Diego de Arroyuelo, not. público apostólico: 239, 243

Diego de Carrión, can. de Husillos: 330

Diego de Córdoba: 234

Diego de Corral, hijo de Juan Esteban, ts.: 112

Diego de Fresno: 298

Diego de Guardo: 298

Diego de la Torre de Francisco: 295, 298

Diego de Prado, can. de Husillos: 252

Diego de Santander, secretario real: 238

Diego de Tamayo, can. de la catedral de Palencia: 236

Diego de Toro: 226

Diego de Torres: 226

Diego de Vega, criado, ts.: 296

Diego de Vega de Vargas, ts.: 293

Diego del Fresno, escribano de Husillos: 298

Diego del Fresno, vecino de Husillos, ts.: 295

Diego del Otero: 50

Diego Díaz, 185; ts.: 208

Diego Díaz de Forela, escudero, ts.: 58

Diego Díaz de Grijota, can. de Husillos: 152, 156, 185, 204; clérigo de Grijota y can. de Husillos: 203

Diego Fernández: 24, 50, 185; alcalde de Villaumbrales: 140; capellán, ts.: 112; duque: 71 ; escribano real: 140 , 145, 163, 164, 184, 193, 194; hijo de Fernando Iohannes de Cigales, ts.: 158; hijo de Juan Domínguez: 185; hijo de Martín Fernández, ts.: 196; hijo de Mileno, ts.: 122; hijo de Pedro Pérez, ts.: 118; hijo de Toribio, 119, ts.: 120; merino de Burgos, conf.: 27, 30; mesonero, ts.: 186; not. público de Villaumbrales: 140

Diego Fernández "El Negro": 185

Diego Fernández "El Romo": 185

Diego Fernández Cardaño, ts.: 252

Diego Fernández de Astudillo, carpintero, ts.: 170

Diego Fernández de Cardaño, alcalde de Husillos: 237; ts.: 237

Diego Fernández de Estrada: 185

Diego Fernández de las Aceñas: 226 


\section{LA ABADÍA DE SANTA MARÍA DE HUSILLOS: ESTUDIO Y COLECCIÓN \\ DOCUMENTAL (904 - 1608)}

Diego Fernández de Piña, alcalde de Palencia: 174; not. de Palencia: 170; not. y vecino de Palencia: 185

Diego Fernández de Ribas: 185

Diego Fernández Lenteja: 185

Diego Frolez, alférez, conf.: 21

Diego Froyat, conf.: 82

Diego Galiano: 185

Diego García, conf.: 82; escribano, hijo de García Pérez, criado del electo, ts.: 127; racionero de la catedral de Palencia, ts.: 112

Diego García de Ferezio: 227

Diego García de Piña, can. de Husillos: 233, 243; racionero de Husillos: 251

Diego García de Valtomas, ts.: 218

Diego Gómez, 91; conf.: 71; not. mayor del reino de Toledo, conf.: 134, 135

Diego Gómez de Castañeda, conf.: 97, 100

Diego Gómez de Santoyo, can. de Husillos, ts.: 158; vecino de Astudillo: 215

Diego Gómez de Toledo, not. mayor del reino de Toledo, conf.: 163

Diego Gómez Manrique, conf.: 193, 194

Diego González, chantre de Husillos: 183

Diego González de Castromocho, can. de Husillos, procurador: 262

Diego Gutiérrez de Zaballos, almirante mayor de la mar, conf.: 97

Diego Hurtado de Mendoza, señor de La Vega, almirante mayor de la mar, conf.: 213

Diego Ibáñez, hijo de Fernán Legon, 120, ts.: 121; hijo de Fernán Legon, vecino de Grijota: 122; hijo de Juan de Fuentes, ts.: 116

Diego Ibáñez Legon, ts.: 120

Diego Iohanis, not. público de Palencia: 80

Diego Jiménez, hijo de Fernando Lego, ts.: 118

Diego Jiménez de Tamayo, can. de Husillos, juez: 236; can. de la catedral de Palencia: 236

Diego López, alcalde: 185; hijo de Diego, conf.: 113; not. público de Palencia: 143, 147, 148, 149, 185, 186

Diego López de Astúñiga, justicia mayor de la casa del rey, conf.: 213

Diego López de Faro, alférez real: 63
Diego López de Ocaña, bachiller, ts.: 242

Diego López de Salcedo, conf.: 82; merino mayor de Castilla, conf.: 71

Diego López de Torquemada, 110; procurador: 111, 112

Diego López Pacheco, not. mayor de Castilla: 192, 194

Diego Lucas: 185

Diego Martín: 91

Diego Martín de Bonilla: 229

Diego Martínez, escribano público de Astudillo: 215; hijo de Pedro Rojo, ts.: 172; not. de Palencia: 185; procurador: 172

Diego Martínez de Hinojosa, conf.: 82

Diego Martínez de Prado, can. de Husillos: 258

Diego Martínez de Zamora, escribano real, not. público en la corte real: 197

Diego Merino de Prado, can. de Husillos: 256

Diego Moro, vecino de Villaumbrales: 290, 298

Diego Muñiz, maestre de la orden de la caballería de Santiago, conf.: 100

Diego Muñiz Masedo, conf.: 30

Diego Muñoz, conf.: 6; mayordomo del emperador, conf.: 21 ; merino de Alfonso VII: 26; merino: 25

Diego Ordóñez: 230

Diego Patallo, ts.: 118

Diego Pérez, 91, 185; ts.: 25; casero de Santa María de Duero: 91; clérigo de Grijota: 185 ; escribano: 80 ; escribano, ts.: 93; escribano público de Grijota: 115, 116, 117, 118, 119, 120, 122, 123; hijo de Domingo Santos, clérigo: 126; hijo de Juan Sánchez: 99; hijo de Pedro Arroyo: 118; hijo de Pedro Fernández, clérigo: 126; hijo de Sancho Gómez de Piña: 185; not. público de Grijota: 121; racionero de Husillos: 251

Diego Pérez Alfanguen: 91

Diego Pérez de la Flor, alcalde de Palencia: 132

Diego Procallo, ts.: 121

Diego Ramírez, conf.: 82, 97, 100; ts.: 250

Diego Ramírez de Mazuela, escudero de Juan Martínez de Rojas, señor de Monzón, ts.: 198

Diego Rodríguez de Camargo: 229

Diego Románez: 72 
Diego Ruiz de Camargo, 229; bachiller en decretos, provisor en Husillos: 230

Diego Sánchez, 269, 271, 298; clérigo de San Pedro: 159; príncipe, conf.: 14

Diego Sarmiento, 288; adelantado mayor de Galicia, conf.: 213

Diego Semenez, conf.: 36

Diego Semeniz, conf.: 35

Diego Simón, ts.: 183

Diego Vélez, can. de Husillos: 230

Domingo (Dominico, Dominicus), 207; deán de la catedral de Palencia, provisor y vicario general de Vasco, ob. de Palencia: 138; fiador: 65; hermano de Pedro Cari de Sahagún: 52; hijo de Abril de Fuente Quintana: 53; hijo de Domingo Pérez: 185; hijo de Fabri: 52; hijo de Juan García de Grijota: 116; hijo de Martín Yáñez de Fuentes: 88; hijo de Pedro Fáñez, ts.: 65; maestro de la catedral de Palencia, ts.: 63; de Burgos, conf.: 192, 193; ob. de Placencia, conf.: 82, 97, 100; prior de Husillos: 40; vecino de Fuentes de Valdepero e hijo de Pedro Ruiz de Quintanilla: 65

Domingo "Lenteja": 185

Domingo Abad, 91; camarero del abad de Husillos, ts.: 90; clérigo de Juan Álvarez, ob. de Osma, ts.: 91; hermano de Diego Abad Cura, clérigo: 126

Domingo Abad Calagraño, clérigo: 126

Domingo Abad Chaperete, clérigo: 126

Domingo Abad de Villa Opdio, clérigo: 126

Domingo Abril, can. de Husillos: 74, 75, 77; clérigo del abad de Husillos: 63; escribano de Palencia: 74, 75; escribano del concejo de Villaumbrales: 88

Domingo Alfonso, criado de Juan Pérez de Aceves, prior de Husillos, ts.: 136; escribano, teniente de Fernando Pérez, not. público de Villalón de Campos: 107; ts.: 137

Domingo Andrés: 52, 53, 185

Domingo Antolín, hermano de Andrés, ts.: 53

Domingo Antón: 185

Domingo Arderon: 185

Domingo Arnaldi: 54

Domingo Arnaldo, ts.: 44, 57
Domingo Bartolomé, can. de la catedral de Palencia y medio racionero de Husillos: 95; deán de la catedral de Palencia: 106

Domingo Becerril: 53

Domingo Caballero: 185

Domingo Conejo: 185

Domingo de Bretaniello, hijo de Pedro Fernández, criado de Bartolomé Pérez, cura, ts.: 201

Domingo de Carvajal, abad de Husillos: 305

Domingo de Fuentes de Valdepero: 206

Domingo de Haza la Vieja, ts.: 57

Domingo de Zavala, escribano de cámara del rey: 294

Domingo Díaz: 185

Domingo Díaz Lobote, clérigo: 126

Domingo Díez, merino de Villaumbrales, ts.: 144; merino, hijo de Pedro Díez, procurador: 140, 145

Domingo E1 Ferrero, ts.: 57

Domingo Escudero, ts.: 73

Domingo Esteban, ts.: 57

Domingo Estébanez, ts.: 73

Domingo Fernández, 185; caballero: 204; can.: 185; clérigo de Santa María la Antigua, ts.: 157; cura: 207; deán de la catedral de Palencia: 141, 142; deán de la catedral de Palencia y vicario general de la diócesis de Palencia por su obispo Reginaldo de Maubernand: 136, 137, 145, 146, 147; escribano: 140, 145; hijo de Antón Pérez: 185; hijo de Domingo Mínguez, clérigo: 126; hijo de don Andrés, clérigo: 126; hijo de Fernando Lobo: 145; hijo de Ibáñez: 185; hijo de Juan, ts.: 170; hijo de Ramos: 185; hijo de Toribio, vecino de Grijota: 121, 123; maestro, vecino de Villaumbrales: 133; personero, ts.: 126

Domingo Fernández "El Rojo": 185

Domingo Fernández "Lentejas": 185

Domingo Fernández Castajo: 206

Domingo Fernández Cortés: 185

Domingo Fernández de Castrello: 109

Domingo Fernández de Castrillo, 151; can. de Husillos, 151, 152, 156, 185; ts.: 156

Domingo Fernández de Mazariegos: 185

Domingo Fernández de Medina de Ríoseco, criado de Pedro Fernández de la Torre, ts.: 155 


\section{LA ABADÍA DE SANTA MARÍA DE HUSILLOS: ESTUDIO Y COLECCIÓN \\ DOCUMENTAL $(904-1608)$}

Domingo Fernández de Población: 185

Domingo Fernández de Rabia, compañero en Santa María Husillos: 185

Domingo Fernández Lorenzo: 209

Domingo Fernández Mozo: 298

Domingo Gallo, vecino de Villaumbrales: 133

Domingo García, 185; hijo de García Laso: 185

Domingo García de Fuentes: 185

Domingo Gómez: 185

Domingo González, 185; cantor de Husillos, 152; ts.: 156; chantre de Husillos: 156, 162. 169, 170, 174, 185, 187, 203, 204, 205, 207, 208, 209, 211

Domingo González Chiquete: 185

Domingo Gonzalo: 185

Domingo Ibáñez, hijo de Álvaro: 185

Domingo Ioannes "el Alfayate", ts.: 55

Domingo Iohán de Palacios, hijo de Toribio Sebastián del Postigo, ts.: 98

Domingo Iohanis: 50; ts.: 54

Domingo Iohanis, hijo de Uraze Martini: 52

Domingo Izquierdo: 185

Domingo Juan Vayello: 185

Domingo Lozano, ts.: 43

Domingo Lupi, ts.: 43

Domingo Macho: 88

Domingo Martín, can. de Husillos: 75; hijo de Santos Lucía: 140, 145; molinero: 185

Domingo Martín de Valdenebro, ts.: 57

Domingo Martínez, clérigo: 126; hermano de Martín Pérez de Tablada, abogado, ts.: 112; hijo de Pedro [...]: 173; vecino de Villamediana, ts.: $128 ; 52,185$

Domingo Martínez Cabezudo, clérigo: 126

Domingo Martínez Calvo: 185

Domingo Martínez de Meneses, ts.: 63

Domingo Miguel, conf.: 41

Domingo Miguel de Villielas, ts.: 57

Domingo Mínguez, hijo de doña Urraca: 88

Domingo Moro, 16, 185; escribano real: 8; hijo de Nicolás Moro: 140, 145

Domingo Pajares, 43; ts.: 43

Domingo Pedro: 53

Domingo Pelayo: 50

Domingo Peralejo, vecino de Grijota: 119
Domingo Pérez, 185; can. de Husillos: 93; capellán, 106, ts.: 105; carretero, ts.: 107; criado del prior Miguel de Husillos: 60; diácono de la iglesia de San Martín de Paredes de Nava: 126; escriba del ob. de Palencia, conf.: 56; hijo de Pedro Gil, clérigo: 126; hijo de Pedro Pardo: 60; hijo de Pedro Rojo: 115; sacristán de la catedral de Osma: 91; sobrino de Pascual: 88

Domingo Pérez Andrés: 185

Domingo Pérez Carrizo, clérigo: 126

Domingo Pérez de Ordejón: 185

Domingo Pérez Llorente, clérigo: 126

Domingo Rallo, hijo de Bartolomé Rallo: 140,145

Domingo Ramírez: 50

Domingo Ramos: 185

Domingo Rodríguez: 185

Domingo Rodríguez Castrillo: 185

Domingo Rol: 185

Domingo Romanes, hijo de "La Rucia": 185

Domingo Romant: 49

Domingo Romo: 185

Domingo Roxo: 185

Domingo Ruiz: 185

Domingo Ruiz de Porras, can. de Husillos: 115, 116, 117, 118, 119, $120,121,122,123$

Domingo Santos, ts.: 126

Domingo Serrano: 185

Domingo Simón, ts.: 204; vecino de Villaumbrales: 185

Domingo Velasco, can. de Husillos: 91

Domingo Vermúdez: 25

Domingo Vicente: 49

Domingo Yáguez: 25; cocinero de Juan Álvarez, ob. de Osma: 91

Donis, infante, hijo de Juan I, rey de Portugal; señor de Alba y de Tormes, vasallo de Juan I de Castilla, conf.: 192, 193, 194

Doyague Pajuelo: 185

Durant Martínez, clérigo: 126

EDUARDO (Edoart), hijo de Enrique III de Inglaterra: 71

Egidio (Egidius): 103

Egidio Pérez de Marañón, ts.: 54

Egidiolo Bocanegra de Guevara, almirante mayor de la mar, conf.: 134, 135

Elena Jordana: 185

Elías (Alias) Ruiz: 185 
Elisabet: 44

Elvira, 50, 91, 207; condesa, madre de Orem Díaz: 51; hija de Pedro Gutiérrez de Frechilla y madre de Martín Fernández: 45; mujer de Fernán Álvarez: 91

Elvira García, hija de Mayor: 42

Elvira Rodríguez: 298

Elvira Sanz, pago de Husillos: 298

Eneco (Echnicus, Enico, Enigo, Enneco, Ennego, Ennico, Enuxus), 74; can. de Husillos: 75, 77; cantor de Husillos: 47

Eneco Pérez, ts.: 24; hijo de Ordoño Martínez, ts.: 54

Eneco Pérez de Gamarra, ts.: 57

Enrique (Anrric, Enrricus, Enrrique, Henrric), conde, conf.; 134, 135; conf.: 71; infante, hijo de Fernando III: 91; infante, hijo de Sancho IV: 82; tío de Enrique III, señor de Alcalá, Morón y Cabra, conf.: 213; tío y tutor de Fernando IV: 92; ob. Albanensis, conf:: 37

Enrique II, rey de Castilla, León, Toledo, Galicia, Sevilla, Córdoba, Murcia, Jaén, Algarbe, Algeciras, y señor de Molina: 184, 190; reinante en Castilla, León, Galicia, Sevilla, Córdoba, Murcia, Jaén, Algarbe, Algeciras, Badajoz y Molina, sincr.: 163,164

Enrique II: 163, 164, 171, 175, 184, 190, 191, 193, 194, 213, 214

Enrique III, reinante en Castilla, León, Toledo, Galicia, Sevilla, Córdoba, Murcia, Jaén, Algarbe, Algeciras, y señor de Vizcaya y de Molina: 213, 214; rey de Castilla, León, Toledo, Galicia, Sevilla, Córdoba, Murcia, Jaén, Algarbe, Algeciras, y señor de Vizcaya y de Molina: 212

Enrique III: 212, 213, 214, 216

Enrique IV, 234; reinante en Castilla, León, Toledo, Galicia, Sevilla, Córdoba, Jaén, Algarbe, Gibraltar, y señor de Vizcaya y de Molina: 234

Enrique Enríquez, conf.: 134, 135

Enrique Manuel, tío de Enrique III, señor de Montealegre, conf.: 213

Ermengaudo (Ermengaudus), conde, mayordomo del emperador: 24

Ermildo Rodríguez: 35

Escalona, duque de, embajador de España en la Santa Sede: 348, 349
Especiosa: 185

Esteban (Esteuanos, Stefanus, Stephano, Stepahnus, Steuano), 12, 131, 207; abad de Husillos: 68; clérigo de Haza, ts.: 54; hijo de Pedro Pagom, ts.: 44; hijo de Yague: 188; maestre: 73; maestro, abad de Husillos y capellán del papa: 68, 69, 70; maestro, ts.: 64; nieto de Pedro Gutiérrez: 185; ob. Lucensis: 103

Esteban de Escudero: 200

Esteban Domínguez, can. de la catedral de Palencia, ts.: 142

Esteban Fagúndez de Frechiella: 185

Esteban Fernández, 185, 196; ballestero del rey, ts.: 112; maestre escuela en la catedral de Palencia, ts.: 166; not. público de Palencia: 155; not., hijo de Alfonso Fernández, cerrajero: 185; pertiguero mayor en tierra de Santiago, conf.: 82 ; porcionero de Husillos: 75; semiporcionero: 74; semiporcionero de Husillos: 77; vecino de Villamediana, ts.: 128

Esteban López, clérigo: 126

Esteban Martín: 185

Esteban Pérez, carnicero: 185; clérigo de Ampudia, ts.: 112

Esteban Rascacho: 185

Esteban Salomón, hijo de Esteban Salomón: 43

Esteban Sánchez, can. de la catedral de Palencia, ts.: 162

Etavida (Ethavida) de Ribas: 24

FACINUS, presbíter, ts.: 1

Facundo (Facundus) Pelaiz: 35

Fadrique, duque de Benavente, tío de Enrique III, conf.: 213

Fagín Peláez: 27

Fagún Pérez, alfajeme, ts.: 107

Falcón Álvarez, hermano de Rodrigo Álvarez: 12

Federico (Frederic), conf.: 71

Felices de las Heras, medio racionero de Husillos: 252

Felipe (Filipe, Philipe), electo de Sevilla, conf.: 71; hijo de Juan Pastor: 140, 145; infante, hermano de Fernando IV, conf.: 97; infante, señor de Cabrera y de Ribera, y pertiguero de Santiago, conf.: 100

Felipe II: 332, 333, 334, 338, 339, 340

Felipe III: 348, 349, 351

Felipe IV, rey de Francia: 82 


\section{LA ABADÍA DE SANTA MARÍA DE HUSILLOS: ESTUDIO Y COLECCIÓN \\ DOCUMENTAL (904 - 1608)}

Felipe de Castro, vasallo de Enrique II, conf.: 163,164

Fernando (Fernán, Ferdinando, Fernand, Fernandus, Fernant, Ferrán, Ferrandillo, Ferrandus, Ferrnandus, Ferrnant), 185, 201; abad de Husillos: 2, 73; abad de San Pedro de La Espina: 81; arcipreste de Torre de Astudillo: 64; arzob. de Sevilla, conf.: 97, 100, 192, 193, 194; bachiller: 212, 213, 214; can. de Husillos: 151; conde, conf.: 14, 21, 35, 36; conde de Husillos, ts.: 53; conf.: 71; criado del maestre Andrés, ts.: 73; criado del prior Miguel de Husillos: 60; hijo de Alfonso VIII, sincr.: 46; hijo de Deciembre: 127; hijo de Domingo Simón, ts.: 205, 215; hijo de don Diego, conf.: 100, 113; hijo de Fernando Pérez, merino de Husillos: 88; hijo de Perilares: 185; hijo de Sancho Martínez, abad de Husillos: 201; hijo del infante don Fernando, conf.: 97, 100; hijo de Pedro IV, rey de Aragón, primo y vasallo de Pedro I de Castilla, adelantado mayor de la frontera, conf.: 135; hombre de Rodrigo Álvarez de Carrión, alcalde del adelantamiento de Castilla, ts.: 128; infante de Aragón, hijo de Pedro IV, rey de Aragón, primo y vasallo de Pedro I de Castilla, adelantado mayor de la Frontera, conf.: 134; infante, hermano de Enrique III, señor de Lara y duque de Peñafiel y conde de Mayorga, conf.: 213; infante, hijo de Sancho IV: 82; maestre, not. del rey en Castilla, conf.: 71; ob. de Astorga, conf.: 163, 164; ob. de Ávila, conf.: 82; ob. de Badajoz, conf.: 192, 193, 194, 213; ob. de Burgos, conf.: 82; ob. de Cartagena, conf.: 213; ob. de Córdoba, conf.: 97, 100; ob. de Coria, conf.: 192, 194

Fernando, ob. de León, conf.: 82, 192, 193, 194; ob. de Orense, conf.: 192, 193, 194; ob. de Oviedo, conf.: 97, 100; ob. de Segovia, conf.: 97, 100; precentor real, conf.: 33; prior de Santa María de Benavides, procurador del abad y cabildo de dicha iglesia: 105; yerno de Marcos de Palazuelos: 185
Fernando "el Católico": 236; "el chiquillo": 91; "el Molinero": 116; "el Padellano", ts.: 66

Fernando I, 13; emperador: 17; rey de Castilla: 15; rey de León y Castilla, sincr.: 12

Fernando II, rey de León y Galicia: 31; rey de León, hermano de Sancho III de Castilla: 29

Fernando III, 57, 61, 62, 93; reinante en Castilla, Toledo, León y Galicia, sincr.: 54, 55, 57; reinante en Castilla, Toledo, León, Galicia, Córdoba: 62; reinante en Castilla, Toledo, León, Galicia, Córdoba y Murcia, sincr.: 65; reinante en Toledo y Castilla, sincr.: 50, 52, 53; reinante en Toledo, Castilla, León, Galicia y Córdoba, sincr.: 63; rey de Castilla y Toledo: 93; rey de Castilla, Toledo, León, Galicia y Córdoba: 61

Fernando Alfonso, 207; beneficiado de la catedral de Palencia, ts.: 142; can. de Husillos, procurador: 110, 111; escribano público del concejo de Valladolid: 91; hijo de Alfonso García: 185; portero del cabildo de la catedral de Palencia: 207

Fernando IV, 92, 97, 100, 101, 113, 114, 134, 135, 163, 164, 193, 194, 213, 298; reinante en Castilla, Toledo, León, Galicia, Sevilla, Córdoba, Murcia, Jaén, Baeza, Badajoz, Algarbe y Molina, sincr.: 97; rey de Castilla, Toledo, León, Galicia, Sevilla, Córdoba, Murcia, Jaén, Baeza, Badajoz, del Algarbe y Molina, sincr.: 100; rey de Castilla, Toledo, León, Galicia, Sevilla, Córdoba, Murcia, Jaén y del Algarbe, señor de Molina: 92, 97, 100

Fernando Alfonso de Vayello, escudero de Gutierre Gómez, abad de Husillos, ts.: 183

Fernando Alfonso del Corral: 201

Fernando Alumpuus: 52

Fernando Álvarez, 91， 213， 214; beneficiado de la catedral de Palencia, ts.: 63; hermano de Juan Álvarez, ob. de Osma: 91; hijo del conde Álvaro: 51; not. público de Palencia: 161, 162; ts.: 54

Fernando Álvarez de Villacilla, beneficiado de la catedral de Palencia: 227 
Fernando Amo, can. de Husillos: 243, 252; beneficiado de Husillos, ts.: 233

Fernando Annaiat, can. de la catedral de Palencia, ts.: 24

Fernando Ansúrez, conde de Monzón: 4, $5,6,8,9,17,27,97,82,114,135$, $137,138,163,167,193,339$

Fernando Armili, armiger, ts.: 55 ; ts.: 54

Fernando Avero: 185

Fernando Barrial: 185

Fernando Becerra, vecino de Villumbrales: 298

Fernando Calzones: 185

Fernando Clemente, 209; hijo de Pedro García Clemente, vecino de Grijota: 208; ts.: 209

Fernando Cobo, cantor de Páramos, ts.: 220

Fernando Comes, hijo de Pedro Soleri: 52

Fernando de Aguilar, abad de Husillos: 224, 225

Fernando de Baeza, can. de Husillos: 230

Fernando de Becerril, hijo de Gonzalo Martínez, ts.: 170

Fernando de Castro, escribano: 335; escribano del número y apostólico: 338; escribano del rey, de rentas y del número de Palencia, y not. público apostólico: 340; mayordomo mayor del rey, conf.: 134, 135; not.: 338

Fernando de Corral, tesorero de Husillos: 236, 243

Fernando de la Portilla: 298

Fernando de la Torre, can. de Husillos: 230; ts.: 230

Fernando de Luerci, presidente del cabildo de Husillos: 233

Fernando de Llano: 298

Fernando de Población, teniente de alcaide de la cárcel episcopal de Palencia, ts.: 351

Fernando de Santillana, can. de Husillos: 243

Fernando de Úrbel, hijo de Juan de Úrbel, ts.: 215

Fernando del Corral, tesorero de Husillos, ts.: 237

Fernando Díaz, 185, 196; merino de Husillos, ts.: 206
Fernando Díaz de Grijota, not. público de Palencia: 196, 199, 200, 203, 204, 208, 209

Fernando Díaz de Husillos, 201, 202; ts.: 201

Fernando Díez, 176; escribano, ts.: 93; hijo de Domingo Díez, clérigo: 126

Fernando Díez de Grijota, not. público de Palencia: 188

Fernando Domínguez: 185

Fernando Egidii, semiporcionero de Husillos: 74, 75, 77

Fernando Enríquez, hijo de Enrique Enríquez, conf.: 134, 135

Fernando Escudero: 185

Fernando Escudo: 185

Fernando Favera: 185

Fernando Felices: 185

Fernando Fernández, clérigo de Villalón de Campos, juez árbitro: 105, 107; hermano de Juan Fernández de Limia, conf.: 82; soldado: 54

Fernando Fernández de Limia, conf.: 97, 100

Fernando Fernández de San Cebrián, criado de Alfonso Martínez, ts.: 202

Fernando Fernández de Tañer, escudero, ts.: 58

Fernando García, 185, 207, 208; alcalde de Fuentes de Valdepero: 206; carnicero: 201; clérigo: 126; clérigo de Fuentes de Valdepero: 206; conf.: 71; criado de Orejero: 219; hijo de García Martínez de Villaldavín, ts.: 162; hijo de Juan Domínguez: 185; hijo del sacristán: 185; pastor: 207; racionero: 207; ts.: 55

Fernando García de Castrillo: 185

Fernando García de Fita, conf.: 18, 19; ts.: 9

Fernando García de Medina de Pomar, 223; arcediano de Campos y vicario general en el obispado de Palencia: 223

Fernando García de Valladolid, can. de Husillos: 230

Fernando García de Villaldavín, 185; hijo de García Muñoz, ts.: 199

Fernando García Pellica, conf.: 18, 19

Fernando Gil: 185

Fernando Gómez, 185; vicario: 220; not. mayor del reino de Toledo, conf.: 97, 100

Fernando Gómez de Corral: 185 


\section{LA ABADÍA DE SANTA MARÍA DE HUSILLOS: ESTUDIO Y COLECCIÓN \\ DOCUMENTAL (904 - 1608)}

Fernando González, 207; clérigo: 126; clérigo de Salazar: 207; hijo de Fernando González, ts.: 203; hijo de García González, ts.: 174; merino mayor en tierra de León, conf.: 82; not. público de Palencia, ts.: 216

Fernando González de Gomiel, hermano, de ts.: 226

Fernando González de Rojas, infante, hijo de Alfonso X, ob. de Palencia, sincr.: 73

Fernando Gutiérrez, 298; hijo de Gutierre, ts.: 126; nieto de Diego de Fuente Quintana: 52; sobrino del conde Poncio: 29

Fernando Gutiérrez de Guzmán, ts.: 57

Fernando Havero: 185

Fernando Ibáñez, conf.: 71

Fernando Ibáñez de Frómista, ts.: 90

Fernando Iohanis: 50, 52

Fernando Leyvicio: 185

Fernando Lidicio: 185

Fernando López, ts.: 269

Fernando Lucas: 185

Fernando Macías, 185; ts.: 188

Fernando Martín, 185; abad de Hérmedes: 151; hijo de Domingo Martín: 140, 145

Fernando Martín Ibáñez, lego: 127

Fernando Martínez, 91, 135, 185, 201, 204; abad de Hérmedes: 201; abuelo de Juan Martínez de Villaviudas: 201; can. de Husillos: 205; can. de Husillos, procurador: 104, 110; can. de la catedral de Palencia: 185; can. de la catedral de Palencia, ts.: 147; carnicero, ts.: 112; not. apostólico: 226

Fernando Martínez de Ágreda, lugarteniente del not. de los privilegios rodados: 134, 135

Fernando Martínez de Ayón, can. de Husillos: 230

Fernando Martínez de Cantoral, 161, 205; vecino de Santillán de la Cuesta: 204

Fernando Martínez de Palencia, can. de Husillos: 185

Fernando Martínez de Villavermudo, not. público apostólico: 226

Fernando Martínez del Cerrojal, ts.: 200

Fernando Martínez Gato: 241

Fernando Mate: 185

Fernando Merino, ts.: 243

Fernando Navero: 185
Fernando Núñez de Arévalo, físico, ts.: 90, 91

Fernando Ortega, ts.: 243

Fernando Osórez, maestre de la orden de Santiago, conf.: 163, 164, 192, 193, 194

Fernando Páez, maestre de Alcántara, conf.: 82

Fernando Papon, ts.: 66

Fernando Pardo: 185

Fernando Peláez: 185

Fernando Pérez, 185; archidiácono de Haza, ts.: 54, 55; can. de Husillos: 236, 239, 243, 252; casero del abad de Husillos: 98; gran comendador del Hospital, conf.: 82; hijo de Fernando Pérez de Torre Cubero, ts.: 127; hijo de María: 185; hijo de Mateo: 185; hortelano: 185; merino: 128; pescador: 207; racionero de Husillos: 251; soldado de Villa Izán, ts.: 53; ts.: 97; yerno de Juan Marguan: 185

Fernando Pérez de Amayuelas: 185

Fernando Pérez de Becerril: 185

Fernando Pérez de Deza, prior de San Juan, conf.: 134, 135

Fernando Pérez de la Torre, can. de Husillos: 233, 243

Fernando Pérez de Mayuelas: 185

Fernando Pérez Ojalvo: 185

Fernando Pérez Ponce, maestre de Alcántara, conf.: 134, 135

Fernando Pérez Ponz, conf.: 82, 97, 100

Fernando Pérez Portocarrero, merino mayor de Castilla: 128, 129, 130, 131,132

Fernando Pérez Sarmiento, ts.: 127

Fernando Pérez Xabador: 185

Fernando Ponce: 43

Fernando Prieto: 185

Fernando Rodríguez, can. de Husillos, 150, 152, 177; can. de Husillos, procurador: 153 ; can. de la catedral de Palencia: 151; conf.: 27, 28, 30; hijo de Fernando Rodríguez, ts.: 157; hijo de Rodrigo Díaz y hermano de Álvaro Rodríguez: 29; procurador, 156; procurador de Gutierre Gómez, abad de Husillos: 153; procurador de Santa María de Husillos: 178; sacristán, 169, 176, 185; sacristán de Husillos, 174, 176, 183, 185; sacristán de Husillos, can. de la catedral de Palencia: 169; sacristán de Husillos, can. de la catedral de 
Palencia, procurador: 179; sobrino de Juan Álvarez, ob. de Osma: 91; vicario y procurador: 156

Fernando Rodríguez Cejuel: 278

Fernando Rodríguez de Saldaña, adelantado mayor de Castilla, conf.: 100

Fernando Rodríguez de Valbuena, mayordomo real, conf.: 113

Fernando Rodríguez de Villalobos, conf.: 134, 135

Fernando Rojo, alcalde ordinario de Grijota: 288

Fernando Románez: 24

Fernando Ruiz, 85; escribano: 84; escribano de los autos en el obispado de Palencia: 96; hermano de Alfonso Téllez Girón, conf.: 134, 135; not. apostólico: 230; sobrino de Juan Álvarez, ob. de Osma: 91

Fernando Ruiz de Ariona, can. de Husillos, not. público apostólico: 230

Fernando Ruiz de Castro, conf.: 71

Fernando Ruiz de Saldaña, 91; conf.: 97

Fernando Ruiz de Villalobos, conf.: 163, 164

Fernando Ruiz de Villoldo, beneficiado de Husillos: 243

Fernando Ruiz Moreno, tesorero de Husillos: 311, 319, 320, 326

Fernando Sánchez de [...], almirante mayor de la mar: 192

Fernando Sánchez de Peñaranda, hijo de García Fernández: 159

Fernando Sánchez de Tovar, 220; almirante mayor de la mar: 194; guarda mayor del rey, conf.: 163, 164

Fernando Sánchez, 44, 185; carpintero: 185; hijo de Domingo Fernández: 145; hijo de Domingo Sánchez: 140; not. mayor de Castilla: 131; zapatero: 185

Fernando Téllez: 185

Fernando Téllez "El Mozo": 185

Fernando Tiváñez: 91

Fernando Tolas: 91

Fernando Zapatero: 53

Flor Ordóñez: 185

Florente el abad: 8; el freire: 16

Floristán González: 298

Fortunio, abad de Santo Domingo de Silos: 14; conf.: 14

Fradrique, duque de Benavente, hermano de Juan I, conf.: 192, 193,
194; maestre de Santiago, conf.: 134, 135

Francisca (Françisca): 207

Francisca Lorenza, mujer de Antón de Segovia: 325

Francisco (Françisco), 207; maestre escuela, ts.: 112; ob. Ceretimensis: 103; ob. de Mondoñedo, conf.: 163, 164, 192, 193, 194, 213

Francisco Alfonso, sobrino de Juan de Pumar, ts.: 112

Francisco Álvarez, licenciado, can. de la catedral de Palencia: 351

Francisco Bustillo de Colmenares: 269

Francisco de Alcaraz Godinez, licenciado, can. de la catedral de Palencia: 351

Francisco de Barreda, escribano público de Husillos: 308, 331

Francisco de Bivero: 252, 253

Francisco de Bureba, 298; ts.: 347

Francisco de Burieva, escribano y not.: 288

Francisco de Burueba, escribano del rey: 332

Francisco de Carvajal, abad de Husillos: 268, 269, 274, 275, 276, 277, 278, 279, 283, 285, 286, 287, 291, 294, 295, 297, 298, 321, 330; abad de Husillos, vecino de Placencia: 293, 296

Francisco de Chacón, corregidor de Palencia: 338

Francisco de Cisneros, criado de Francisco Núñez, abad de Husillos: 242

Francisco de Fuenmayor, arcediano de Campos, doctor, can. de la catedral de Palencia: 351

Francisco de Fuentes, ts.: 98

Francisco de Herrera, escribano del número de Palencia: 327, 328

Francisco de Hojeda, vecino de Monzón de Campos: 298

Francisco de La Madrid, beneficiado de Husillos: 347

Francisco de Palentinos, racionero de Husillos: 251

Francisco de Polientes, can. de Husillos: 252

Francisco de Reinoso, abad de Husillos: $311,312,314,315,316,317,320$, $321,323,324,325,327,328,330$, $331,332,333,334,335,337,338$,

Francisco de Rodas: 275 


\section{LA ABADÍA DE SANTA MARÍA DE HUSILLOS: ESTUDIO Y COLECCIÓN \\ DOCUMENTAL (904 - 1608)}

Francisco de Rojas y Sandoval, duque de Lerma: 351

Francisco de Támara, vecino de Husillos: 298, 313

Francisco de Tariego, provisor del obispado de Palencia: 285

Francisco de Valberde Alderete, licenciado, deán de la catedral de Palencia, provisor: 351 ; ts.: 351

Francisco de Valladolid, procurador: 281

Francisco de Vargas Carvajal, abad de Husillos: 306

Francisco de Villaescusa, can. de Husillos: 243, 252

Francisco de Villafrías, racionero de Husillos: 251

Francisco del Hierro Tejedor, vecino de Palencia: 298

Francisco Delgado: 298

Francisco Díaz, clérigo: 185

Francisco Fernández, capellán, ts.: 218; hijo de Suago: 185; not.: 285; not. público de Palencia, 136, 137, 138, 198, 207; not. público de Palencia, ts.: 147; not. público de Palencia, cuñado de Gonzalo González: 207

Francisco Fernández de Palencia, not. público de Palencia: 137

Francisco Fernández de San Miguel: 185

Francisco Fernández Forro, hijo de Lorenzo Fernández, vecino de Palencia: 211

Francisco Fumo, racionero de Husillos: 251

Francisco García, capellán del hospital de San Antolín, ts.: 112

Francisco Gómez de Sandoval, duque de Lerma, marqués de Denia: 346, 347, 348

Francisco Gómez, racionero de Husillos: 347

Francisco González de Heredia, 339, 349; secretario real: 340

Francisco López, 269; can. de Husillos: 298

Francisco Maldonado, corregidor de Palencia: 240

Francisco Martínez, abad de Husillos, juez: 236; cabestrero: 323; can. de Husillos: 340; provisor: 320; racionero de Husillos, secretario del prior y cabildo de Husillos: 319
Francisco Martínez de Puerta del Sol, carnicero, ts.: 112

Francisco Miguélez, alcalde de Villaldavín: 275

Francisco Núñez de Herrera, abad de Husillos: 269

Francisco Núñez de Madrid, abad de Husillos, 236, 238, 242, 244, 245, $250,251,253,262$; can. de la catedral de Palencia, miembro del consejo real: 242; abad de Husillos, miembro del consejo real: 249; abad de Husillos, doctor en derecho: 239, 243, 253; abad de Husillos, oidor de la audiencia real y miembro del consejo real: 240, 251

Francisco Pico: 259

Francisco Ratado: 241

Francisco Rodríguez de Madrid, corregidor de Palencia, juez de residencia: 267

Francisco Sánchez, 249; vecino de Grijota: 298

Francisco Sánchez de Collados, escribano y not. público: 246; escribano, not. público apostólico, escribano mayor del cabildo de Santa María la Mayor de Valladolid: 245, 250

Franco Pérez, semiporcionero de Husillos: 77

Frola Díaz, conde de Astorga, conf.: 18, 19

Frola Díez, conf.: 9

Frola Díez de Ávila, conf.: 4; ts.: 3

GABRIEL de Bricar, secretario del prior y cabildo, not. apostólico: 345

Gadea: 207

Galgano (Galganus), Alerienensis episcopus: 124

Galindo: 185

García (Garçía, Garsia, Garsias), 185; alcalde de Monzón, hijo de don Sancho, ts.: 98; archidiácono, conf.: 56; celerero de Matallana, ts.: 63; clérigo de Haza, ts.: 54 ; clérigo, ts.: 55; conde de Nájera, conf.: 14; conde, conf.: 36; criado de Juan Fernández de Meneses, prior de Husillos, ts.: 206; hijo de Fernando Martínez de Cantoral, ts.: 200, 204; hijo de Juan González, procurador del concejo de Fuentes de Valdepero: 98; merino mayor: 8; ob. de Cuenca, 
conf.: 134, 135; ob. de Jaén, conf.: 97, 100; ob. de León, conf.: 113; ob. de Sevilla, conf.: 82; ob. de Sigüenza, conf.: 82; precentor, conf.: 33; rey, tenente de Monzon: 24; sacristán de Husillos: 40

García Abad, procurador de los clérigos de la iglesia de Santa Olalla de Paredes de Nava: 96; clérigo de la iglesia de Santa María de Paredes de Nava: 125, 126; procurador: 127

García Alfonso, clérigo: 126

García Alonso: 298

García Álvarez: 185

García Cabeza: 185

García Cantarero: 298

García Cardera: 185

García de Benavides, racionero de Husillos, ts.: 295

García de Bustamante, 269; can. de Husillos: 335

García de Chinchilla, criado del ob. de Palencia, ts.: 246

García de Fornellis, conf.: 33

García de Haza, ts.: 55

García de Támara "El Mozo": 263

García de Valderas, criado de Francisco Martínez, abad de Husillos, ts.: 236, 253, 254

García Díaz: 185

García Enéquez, miembro de la escuela de la reina Urraca I, conf.: 18, 19

García Estébanez Pérez, hijo de García Pérez, ts.: 132

García Fernández, 50, 76, 91, 196; capellán de San Nicolás: 185; coomerino de Monzón: 195; criado de Lope García, sacristán, ts.: 112; familiar, ts.: 221; hijo de Juan García: 140, 145; mayordomo: 54, 55; mayordomo real: 57 ; socio de Husillos, ts.: 54; ts.: 64, 239, 243

García Fernández Cabeza, ts.: 217

García Fernández de Bovadilla, abad de Husillos, protonotario apostólico: 262, 264281

García Fernández de Castro: 185

García Fernández de Corral, tesorero de Husillos: 230

García Fernández de Pernía: 185

García Fernández de Támara "El Viejo": 263

García Fernández de Toledo, not. mayor de Castilla, conf.: 113
García Fernández Manrique, conf.: 97, $113,134,135,163,164,213$; adelantado de Castilla: 145

García Fernández Mazariegos: 201

García Ferrández de Villamayor conf.: 97

García Garcíaz de Aza, conf.: 27, 28, 30

García Gómez: 86, 91, 185

García Gómez, can. de la catedral de Palencia: 86,87

García González, hijo de Diego Ibáñez, clérigo: 126; hijo de Ordoño Martínez, ts.: 54

García González de Ferrera, merino real: 53

García Gutiérrez de Sigüenza, ts.: 112

García Ibáñez, can., ts.: 64, 112; clérigo: 126

García Laso, lego: 127

García Layo: 185

García López, 91, 185; maestre de Calatrava, conf.: 97, 100

García López de León, escribano real, juez: 224

García López de Prestines, abad de Hérmedes: 246, 249, 250, 251, 262; can. de la catedral de Burgos: 244, 245, 246

García Martínez, 185; ts.: 45; arcediano del Alcor, ts.: 166

García Martínez Gasco, clérigo: 126

García Núñez: 10

García Ordóñez, hijo de Ordoño Martínez, ts.: 54

García Oreja: 185

García Pérez, 92, 94, 185; abad de Husillos: 95, 97, 100, 109, 185; cebadero: 91; hijo de Martín García: 185; hijo de Martín Pérez, clérigo: 126; hijo de Pedro Rey, clérigo: 126; hombre de Juan Pérez, lego: 127; prior de Husillos: 130; prior del Hospital, conf.: 97; racionero de la catedral de Palencia, ts.: 112

García Pérez Cebadero, ts.: 91

García Pérez Cevadón: 91

García Pérez de Becerril: 185

García Pérez de Husillos, cebadero, ts.: 90

García Pérez de Toledo, not. del rey en Andalucía, conf.: 71

García Pérez Peláez, clérigo: 126

García Porrado: 50

García Rodríguez, 52, 185; marido de Teresa Díaz: 53 


\section{LA ABADÍA DE SANTA MARÍA DE HUSILLOS: ESTUDIO Y COLECCIÓN \\ DOCUMENTAL (904 - 1608)}

García Ruiz, can. y vicario del obispo Álvaro Carrillo de Palencia: 96; escribano de Villadiego, hijo de Fernando García: 207; merino mayor: 16

García Sánchez, conde de Castilla: 5; conde de Castilla, conf.: 7; conde de Castilla, cuñado de Sancho III el Mayor de Navarra: 6

García Sánchez de Bustamante: 207

García Sánchez de Castilla, conde, cuñado de Sancho III el Mayor de Navarra: 7

García Suárez, canciller real, conf.: 100; merino mayor del reino de Murcia, conf.: 71

García Tirón: 185

García Troxo: 185

Garcilaso de la Vega, justicia mayor de la casa del rey, conf.: 113

Garnerio, deán de San Antolín de Palencia, conf.: 33

Gaspar de Haya, can. de Husillos: 298, 309; can. y obrero de Husillos: 288

Gaspar de Peralta, licenciado, can. de la catedral de Palencia: 351

Gaspar de Vedoya, 297; clérigo de la diócesis de Toledo, not. público apostólico: 293

Gaspar de Villadiego, can. de Husillos, 330, 335, 340, 347; can. de Husillos, contador: 326, 329; can. de Husillos, provisor: 341,345 ; not. apostólico: 347

Gaspar Manso, chantre de Husillos: 298

Gastón, vizconde de Beart, vasallo de Alfonso X, conf.: 71

Gastón de Bearne, conde de Medinaceli, conf.: 213

Gerardo (Geraldus): 21; esposo de Andrequina: 45; magíster, not. real: 38

Gervás de Palencia, conf.: 18, 19

Gil, 97, 207; hijo de don Rendol, ts.: 73; hijo de Pedro Bermúdez, alfayate, ts.: 66; hijo de Pedro González de Marañón, señor de Haza: 57; laico, ts.: 45; ob. de Badajoz, conf.: 82 ; ob. de Osma, conf.: 71; ob. de Tuy, conf.: 71 ; preste, ts.: 45 ; ts.: 57

Gil Álvarez de Albornoz, abad de Husillos, cardenal: 143, 145, 146

Gil de Villegas, escudero, ts.: 58

Gil Fernández de Baltanás: 201
Gil Fernández, 185; capellán, 185; capellán del número de los Cuarenta Capellanes de la catedral de Palencia: 143, ts.: 145; tomador, hijo de Fernando Pérez, ts.: 207

Gil Gómez, comendador de Olamo: 51

Gil González: 92

Gil Pérez de Peniella, ts.: 57

Gil Sánchez de Calabazanos: 201

Gila: 185

Giraldo, ob. de Palencia, conf.: 100

Gisberto (Guysberte), bizconde de Castel Novo, almirante mayor de la mar, conf.: 100

Gómez (Gomecius, Gumez), 75; arzob. de Santiago, conf.: 134, 135; conde, conf.: 34,35 , 36; doctor: 351 ; hijo de Fernando Pérez de Blas: 161; ob. de Burgos, 14, conf.: 14

Gómez de Gil de Fuentes, can. de Palencia: 91

Gómez de Lomas, racionero de Husillos: 252

Gómez de Monzón: 74, 75, 77, 86, 87; fundador de la capilla de Santiago de Santa María de Husillos: 159; juez: 73

Gómez de Villalobón, ts.: 93

Gómez García, 91; conf.: 35; sobrino de Juan Álvarez, ob. de Osma: 91

Gómez González, mayordomo real, conf.: $27,28,30$

Gómez Manrique, adelantado mayor de Castilla, conf.: 213, 217; arzob. de Toledo, canciller mayor del rey, conf.: 163, 164

Gómez Pérez de Fuentes, ts.: 31

Gómez Ruiz de Sandoval: 99; hijo de Rodrigo Gómez: 99

Gómez Velasco de Fuentedueña, ts.: 57

González (Gonçáles), can. de Husillos: 347; licenciado, can. de la catedral de Palencia: 351; licenciado: 351

Gonzalo (Gonzalo, Gonçaluus, Gondisaluus, Gondissaluo, Gondissaluus, Gonsaluo, Gondissaluus, Gonzaluo, Gundissaluo, Gundissaluus): 33, 54, 91; abad de Arbas: 91; abad de Husillos: 41, 47, 149; arzob. de Toledo, 40, 134, 135; arzob. de Toledo, canciller de Castilla, León y de Andalucía, conf.: 82, 97; cantor, conf.: 56; conde, conf.: 6; ob. Dumiense: 14, conf.: 14; hermano de 
Gómez García: 91; hijo de Francisco Gordo de Paredes de Nava, ts.: 112; hijo de Juan: 185; hijo de Martín Fernández de Allén del Río: 219; hijo de Pedro Soleri: 52; hijo de Pedro González de Marañon, señor de Haza: 57; hijo del infante don Pedro, conf.: 100; infante, hijo de Alfonso III, diácono: 1; laico, ts.: 45; maestre, abad de Alfaro: 82; maestre, abad de Arbas y not. mayor de Andalucía, conf.: 100; maestre, abad de Arbas: 97; maestre, conf.: 97; ob. de Burgos, conf.: 213; ob. de Cádiz y de Algeciras, conf.: 163; ob. de Cádiz, conf.: 164; ob. de Calahorra, conf.: 134, 135, 192, 193, 194; ob. de Ciudad Rodrigo, conf.: 213; ob. de León, conf.: 97, 100, 163, 164; ob. de Orense, conf.: 100, 113; ob. de Osma, conf.: 134, 135; ob. de Segovia, conf.: $35,36,213$; ob. de Zamora, conf.: 97; torreonero, ts.: 93

Gonzo, maestre, clérigo del ob. Tello de Palencia, ts.: 63

Gonzalo "el Corredor", ts.: 73

Gonzalo "el de María Quintanilla", ts.: 73

Gonzalo Alfonso, alcalde de Astudillo: 220; criado de Juan Núñez de Ferrera: 159; hijo de Pedro Alfonso, clérigo: 126; Gonzalo Alfonso, 159; not. público de Palencia: 139, 142, 144,145

Gonzalo Alfonso de Valdespina, hombre de Sancho Ruiz de Torre, ts.: 168

Gonzalo Alfonso de Villafranca, hijo de Bernabé Martínez: 159

Gonzalo Ansúrez, conde de Monzón: 3, $5,6,8,17,27,35,82,97,114,135$, 137, 163, 167, 193, 339; conf.: 3

Gonzalo Bernardino: 221

Gonzalo de Aguilar, conf.: 100

Gonzalo de Burgos: 185

Gonzalo de Córdoba, ts.: 63

Gonzalo de La Dobla: 185

Gonzalo de Marañón, conde, alférez real, conf.: 36 ; conf.: $27,28,30$

Gonzalo de Oviedo, procurador: 276

Gonzalo de Páramo: 207

Gonzalo de Santa María de Cilleruelo, ts.: 43

Gonzalo de Santa María de Husillos, ts.: 107

Gonzalo Díaz, conf.: 3, 4, 5, 6, 7, 9
Gonzalo Díaz de Castro, ts.: 54

Gonzalo Domínguez, mayordomo real: 46

Gonzalo Facundo, prior de Husillos: 74, $75,77,87$; ts.: 54

Gonzalo Falcón, 91; criado de Juan Álvarez, ob. de Osma: 91

Gonzalo Fernández, 100, 186, 190, 219; can. de Husillos: 217, 219; clérigo de Vellosiello, capellán de los Cuarenta Capellanes de la catedral de Palencia, ts.: 174; clérigo, cura de la iglesia parroquial de San Miguel de Villalón, juez árbitro: 105; clérigo, vecino de Villalón de Campos, juez árbitro: 107; hijo de Juan García, ts.: 140; Fernández, procurador: 219

Gonzalo García, 185; criado del arcediano de Campos: 185; hombre de Marco Díaz, vicario del ob. Juan de Palencia, ts.: 102; hombre de Mateo Díaz: 106

Gonzalo Fernández de Castro: 185

Gonzalo Fernández de Ribiella, soldado: 54

Gonzalo Fernández de Valoria: 185

Gonzalo Garcíez Darada, escudero, ts.: 58

Gonzalo Gil: 185

Gonzalo Giles, merino de Campos: 46

Gonzalo Gómez, 185; criado del abad de Husillos, ts.: 150; escribano, criado de Gómez Manrique, ts.: 217; not, ts.: 158; criado de Gutierre Gómez, abad de Husillos: 161

Gonzalo González, 185; arcipreste de Burgos: 185; racionero y arcipreste de Burgos, hermano de Domingo González, chantre de Husillos: 207

Gonzalo Ibáñez, maestre del Temple, conf.: 82; ts.: 112

Gonzalo Ibáñez de Aguilar, conf.: 82, 97,113

Gonzalo Martín, conf.: 41

Gonzalo Martínez, clérigo: 126; escribano del ob. de Palencia, ts.: 105; hermano de Andrés González: 226

Gonzalo Martínez de Bahíllo: 226

Gonzalo Morant, merino mayor de León, conf.: 71

Gonzalo Muñoz, can. de la catedral de Palencia, ts.: 40

Gonzalo Muñoz Barahona, criado de Gómez Manrique, ts.: 217 


\section{LA ABADÍA DE SANTA MARÍA DE HUSILLOS: ESTUDIO Y COLECCIÓN \\ DOCUMENTAL (904 - 1608)}

Gonzalo Núñez, príncipe, conf.: 14

Gonzalo Núñez de Guzmán, conf.: 193, 194; maestre de la orden de Calatrava, conf.: 213

Gonzalo Núñez de Monzón: 91

Gonzalo Peláez de Raneros, conf.: 41

Gonzalo Pérez de Torquemada, abad de Husillos: 46

Gonzalo Pérez de Valrrodrigo, ts.: 54

Gonzalo Pérez de Villanubla, ts.: 157

Gonzalo Pérez de Villarodrigo,. Ts.: 57

Gonzalo Pérez, 44, 92; abad de Husillos: $40,42,45,50,54,55,57,59,93$; abad de Husillos, sincr.: 53; can. de Santa María de Trianos, ts.: 63; dominante en la iglesia de Husillos: 52; Gonzalo Pérez, hijo de Isabel: 44; hijo de Pedro González de Marañón, ts.: 57; hombre de Marco Díaz, vicario del ob. Juan de Palencia, ts.: 102; maestre de Alcántara, conf.: 97, 100

Gonzalo Ramírez, conf.: 71

Gonzalo Rodríguez, mayordomo real: $45,47,53$; conf.: 27 ; merino en Burgos, conf: 28

Gonzalo Romazo: 52

Gonzalo Ruiz de Fontorida, escudero, ts.: 58

Gonzalo Ruiz de Reinoso: 185

Gonzalo Ruiz de Toledo, 91; not. mayor del reino de Castilla y mayordomo del rey, conf.: 100

Gonzalo Ruiz Girón, conf.: 113

Gonzalo Ruiz, 60, 185; capellán de Santillán de la Cuesta: 96; mayordomo real: 16; racionero de la catedral de Palencia, procurador: 182

Gonzalo Sánchez, abad de Haro, ts.: 112; conde, conf.: $3,9,10$; conf.: 4

Gonzalo Sánchez de Mante Tarilo, conf.: 18,19

Gonzalo Sisamon, ts.: 44

Gonzalo Talavera, ts.: 66

Gonzalo Tarugón, ts.: 66

Gonzalo Terradillos, can. de Husillos: 298

Gonzalo Zapata, deán de la catedral de Palencia: 262

Gorrión de Becerril: 185

Govandio (Gouandius), licenciado: 238

Graciano (Gratianus), diácono, cardenal de los Santos Cosme y Damián, conf.: 37

Gratón, presbítero: 1
Gregorio (Gregorius): 207; can. de la catedral de Palencia, ts.: 40

Gregorio X: 78

Gregorio de Treceño, procurador: 276, 283

Gualterio, mayordomo de Husillos: 25

Guillén, ob. de Coria, conf.: 193; ts.: 125

Guillén Iohán, abad de Lebanza: 127

Guillén Pérez, abogado: 96

Guillermo (Guiielmo, Guilelmus, Guilielmus, Guillermus): 24, 103; criado de Fernando de Casa, ts.: 66; ob. de Oviedo, conf.: 213; ob. de Segovia, conf: $28,30,34$; ob. Putenensis: 103; ob. Taurisiensis: 124; sacristán, ts.: 24

Guillermo de Sacramenta, ts.: 55

Guillermo Iohanis: 53

Guillermo Robet, ts.: 44

Guillermo Sancte Iuste: 103

Guiomar Alfonso: 185

Gutierre (Goter, Gotierre, Guter, Guterius, Guterre, Guterrius, Gutier), abad de Husillos: 151, 154; archidiácono del Alcor: 165; arzob. de Toledo, canciller mayor de Castilla, conf.: 100; ob. de Oviedo, conf.: 192, 193, 194; ob. de Palencia y canciller mayor de la reina: 168 , 180; ob. de Palencia, conf.: 163, 164

Gutierre I Gómez de Toledo, ob. de Palencia: 166, 186

Gutierre II Álvarez de Toledo, ob. de Palencia: 225

Gutierre de Carvajal, ob. de Placencia: 293, 298; ob. de Placencia y tío de Francisco de Carvajal: 296, 297, 298

Gutierre de Marañón, alférez real, conf.: 35

Gutierre de Zavallos, ts.: 239, 243

Gutierre Díaz, conf.: 41; dominante en Pozuelos de Amianos: 45; merino mayor: 45 ; merino real: 46,47 ; ts.: 63

Gutierre Egidii: 53

Gutierre Fernández, 26, 219; conf.: 6, 21, 27, 28, 30; "potestas" en Castilla, 31; príncipe: 24 ; ts.: 20

Gutierre Fernández de Cabañas, escudero, ts.: 58

Gutierre Fernández de Piña, not. público de Palencia: 218, 219

Gutierre García, 185; conf.: 10; ts.: 232 
Gutierre Gómez de Toledo, abad de Husillos: 150, 151, 154, 156, 157, 158, 161, 162, 165; abad de Husillos y canciller de la casa de la reina: 158 ; abad de Husillos, canciller y capellán mayor de la reina Juana: 171, 166, $175,177,183,184,186$

Gutierre González, ts.: 55

Gutierre González Quexada, ts.: 63

Gutierre Gutiérrez, ts.: 20

Gutierre Pérez, 92, 185; abad de Husillos: 298; conf.: 10; escribano de rey en el concejo de Pozuelos de Amianos: 16

Gutierre Pérez de Avia, conf.: 18, 19; ts.: 9

Gutierre Pérez de Reinoso, conf.: 30

Gutierre Pérez de Villodrigo, ts.: 57

Gutierre Pérez Orco, conf.: 21

HABHANEZ, conf: 2

Habibi, conf.: 2

Haya, can. de Husillos: 298

Herberto, prior, ts.: 24

Hernando de Amo, can. de Husillos: 257

Hernando de Castro, escribano del número y apostólico: 335

Hugo (Hugonis, Ugo), maestro, canciller del emperador: 21; ob. de Segovia, conf.: 192, 193, 194

Hugo Bernal: 185

IAPEL González, ts.: 54

Ibáñez (Ibannes) de la Puente: 185

Ilán García, mayordomo real, conf.: 71

Illana: 185

Inés (Ignés), 207; hija de Pedro González de Marañón, señor de Haza: 57

Inocencio (Innocentius, Inocencius) II: 23

Inocencio III, papa: 48

Inocencio IV, papa: 67, 68, 69, 70, 239

Isabel, 207; criada de Juan Núñez de Ferrera: 159; madre de Gonzalo Pérez: 44

Isabel "la Católica", reina: 236, 238

Isabel de Montoya, viuda de Diego Sarmiento, vecina de Palencia: 303, 304

Izquierdo el Viejo, alcalde de Hérmedes: 249

JACOB (Jacob), marido de María Pérez: 50
Jacobo (Iacobu): 12

Jacobo Iohán, can. de la catedral de

Palencia, ts.: 142

Jaime (Jaymes) de Catuxo, ts.: 73

Jaime de Garzón, juez: 73

Jaime Pérez: 185

Jentín: 185

Jerónimo de Porras, bachiller de Palencia: 265

Jimena (Xemena, Ximena), conf.: 10; reina de Navarra, 5, 6, 7; conf.: 3, 4, 7,9

Jimeno (Semeno, Ximeno), arzob. de Toledo, canciller mayor de Castilla, conf.: 113

Jimeno Rodríguez: 185

Jitán: 185

Jocelmo (Jocelmus), ob. de Sigüenza, conf.: 35

Jordano (Iordanus), archidiácono de Palencia, ts.: 46

Jorge de Gordón, can. de Husillos: 252

Jorge Gordón, racionero de Husillos: 251

Joscelmo (Ioscelmus), ob. de Sigüenza, conf.: 36

Juan (Ioan, Iohán, Iohanne, Iohannes, Iohanni, Joan): 25, 44, 52, 88, 123, 176, 185, 207, 220; "magister scolaris", electo de Cuenca, conf.: 35,36; Juan, abad de Husillos: 102; abad de Sandoval: 41; abad de Santa María de Lebanza, ts.: 125; arzob. de Santiago, capellán mayor del rey, canciller del reino de León, conf.: 113; arzob. de Santiago, conf.: 71; arzob. de Sevilla, conf.: 113; arzob. de Toledo, conf.: 27, 28, 30; Juan, canciller real y ob. de Osma: 54, 55; capellán de la catedral de San Antolín de Palencia: 44; clérigo de Haza, ts.: 54; criado de Pedro Arnaldo: 25; diácono, cardenal de San Ángel, conf.: 37; doctor, not. de Palencia: 238; el de Lucas: 185; electo en Oña, conf.: 14; fiel del infante don Manuel, adelantado mayor en el reino de Murcia, conf.: 82; hermano de Alfonso, hijo del infante don Juan, conf.: 100; hermano de Diego Pérez: 91; hermano de Domingo Arnaldo, ts.: 57; hermano de García Pérez: 91; hermano del conde Enrique, conf.: 134, 135; hijo de Domingo Pérez: 


\section{LA ABADÍA DE SANTA MARÍA DE HUSILLOS: ESTUDIO Y COLECCIÓN \\ DOCUMENTAL (904 - 1608)}

185; hijo de Domingo y de María: 116; hijo de Abril, ts.: 43; hijo de Gutierre Fernández de Piña: 218, 219; hijo de Juan Izquierdo, vecino de Grijota: 118; hijo de Juan: 121; hijo de Lucas Pérez: 185; hijo de Luis, conf.: 135; hijo de Marte: 55; hijo de Martín Yáñez: 185; hijo de Pedro Antolínez de Grijota, ts.: 162; hijo de Pedro Verzerlejo: 60; hijo de Salvador: 187; hijo de Sancho Fernández: 201; hijo del infante don Manuel, adelantado mayor de la Frontera y en el reino de Murcia, conf.: 113; hijo del infante don Manuel, conf.: 97; hijo del infante don Manuel, mayordomo del rey, conf.: 100; hijo de Juan I, rey de Portugal, duque de Valencia y señor de Alba de Tormes, vasallo de Enrique III de Castilla, conf: 213; hijodalgo: 185; infante de Aragón, hermano de Fernando, conf.: 134; infante de Aragón, hermano de Fernando, vasallo del rey, conf.: 135; infante, hijo de Enrique II, conf.: 163, 164; infante, hijo de Enrique II, sincr.: 163, 164; infante, tío de Fernando IV, adelantado mayor de la Frontera y señor de Vizcaya, 101, conf.: 100; mayordomo de Husillos: 40; merino de Villamuriel, ts.: 73; not. pontificio: 20; ob. Colonensis: $124 ; 113,134,135,163,164$; ob. de Calahorra, canciller mayor de la reina, conf.: 213; ob. de Ciudad Rodrigo, conf.: 113; ob. de Córdoba, conf.: 163, 164, 213; ob. de Jaen, conf.: 134, 135, 163, 184, 192, 193, 194; ob. de Lugo, conf.: 100, 113; ob. de Mondoñedo, conf.: 71; ob. de Orense, conf.: 71, 134, 135; ob. de Osma, canciller real: 57; ob. de Osma, conf.: 100: 27, 28, 30, 82, 97; ob. de Oviedo, conf.: 113; ob. de Palencia: 103; ob. de Palencia, conf.: 213; ob. de Palencia, canciller mayor del infante don Pedro: 127; ob. de Placencia, conf.: 163, 164; ob. de Salamanca, conf.: 134, 135; ob. de Segovia, conf.: 163, 164; ob. de Sigúenza, conf.: 163, 164, 213; ob. de Sigüenza, canciller mayor del rey, conf.: 190, 192, 193, 194; ob. de Tui, conf.: 97, 100, 134, 135, 163, 192,
193, 194, 213; ob. de Tuy, canciller de la reina, conf.: 82; ob. Terealensis: 124; presbíter, cardenal de San Juan y San Pablo, ts.: 37; preste, ts.: 45; sobrino de Juan Martínez de Villaviudas, hijo de Francisca Martínez: 201; tío del rey Fernando IV, conf.: 97; ts.: 54, 73, 201, 232

Juan "el Catalán", ts.: 57

Juan "el Gallego", ts.: 73

Juan I, rey: 191, 192, 193, 194, 210, $212,213,214,216,234,298$; reinante en Castilla, Toledo, León, Galicia, Sevilla, Córdoba, Murcia, Jaén, Baeza, Badajoz, Algarve, Algeciras, Lara, Vizcaya y Molina, sincr.: 192, 193, 194

Juan II Fernández de Limia, ob. de Palencia: 109, 111, juez árbitro: 112

Juan II, rey: 224

Juan XXII: 103, 124, 239.

Juan Abad, 116; can. de Husillos y procurador: 104, 105, 107, 108; capellán, ts.: 110 ; capellán de Santillán de la Cuesta: 88; hijo de Álvaro, clérigo: 126; hijo de Fernando, clérigo: 126; hijo de Martín Álvarez, clérigo: 126; ts.: 31

Juan Abinar, vecino de Villaumbrales, ts.: 133

Juan Albo, cura y beneficiado de la iglesia parroquial de San Martín de Ribas: 343

Juan Alfónsez de Toledo, can. de Husillos, 152; ts.: 157, 158

Juan Alfonso, 185; clérigo, 126; ts.: 187; conf.: 82; doctor, oidor de la audiencia real: 184; escribano: 127 ; hijo de Alfonso López de Haro, conf.: 134, 135; hijo de Alfonso Pérez de Guzmán, conf.: 100; hijo de Felipe Pérez, clérigo de Amayuelas, ts.: 145; hijo de Fernando Domínguez, clérigo: 126; hijo de Pedro Mínguez: 185; ob. de Palencia: 80; ob. de Palencia, conf.: 82; sellero: 186; vicario de Grijota y can. de Husillos: 203

Juan Alonso de Morales, clérigo, criado de Francisco Núñez, abad de Husillos, ts.: 253, 254

Juan Alfonso de Alborquerque, adelantado mayor del reino de Galicia, conf.: 82; canciller mayor del rey y mayordomo mayor de la 


\section{DAVID MARCOS DIEZ}

reina, conf.: 134, 135; mayordomo mayor de la reina, conf.: 113, 135

Juan Alfonso de Arroyal: 207

Juan Alfonso de Benavides, justicia mayor de la casa del rey, conf.: 134 , 135

Juan Alfonso de Covillas, capellán en la catedral de Palencia: 226

Juan Alfonso de Grijota, 185; can. de Husillos: 156

Juan Alfonso de Guzmán, 113; conde de Niebla, conf.: 163, 164, 193, 194, 213

Juan Alfonso de Haro, alférez real, conf.: 100; conf.: 97, 163, 164; señor de los Cameros, conf.: 100, 113

Juan Alfonso de Olmedo, not. público apostólico: 216

Juan Alfonso de Paredes, not., vecino de Palencia: 226

Juan Alfonso de Pedraza, not. público de Palencia: 169, 174

Juan Alfonso de Toledo, can. de Husillos: 185

Juan Alfonso Paniagua: 185

Juan Álvarez, 185; electo de Osma: 80; ob. de Osma: 90, 91

Juan Andrés, archipresbítero de Baltanás: 151; arcipreste de Val Cañas: 185; can. de Husillos: 152, 156; clérigo de Valoria: 185; clérigo: 185; lego de Valoria: 185; merino: 24; tejedor, criado de Martín García: 219

Juan Aparicio, ts.: 340

Juan Armegot, ts.: 44

Juan Arnaldo: 53

Juan Asturiano: 185

Juan Benito: 99

Juan Blanco: 185

Juan Cabeza: 185

Juan Calagrano "El Menor": 185

Juan Calonge: 185

Juan Calvo, 185; criado de Pedro Ruiz: 207; hombre de Alfonso Martínez, alcalde del rey en las merindades de Castilla, ts.: 144

Juan Calzado: 185

Juan Carnicero, 208; hijo de Pedro Carnicero, vecino de Grijota: 209; ts.: 208

Juan Cascajo: 185

Juan Castajo, merino de Fuentes de Valdepero: 206
Juan Chacón de Narváez, corregidor de Palencia: 335, 338

Juan Cipriani, ts.: 20

Juan Cipriani de Valdespina: 52

Juan Comes: 52

Juan Cormaza: 185

Juan Cristóbal, hijo de Juan Cristóbal: 56

Juan de Amusco: 298

Juan de Arlanzón, ts.: 293

Juan de Arvello: 201

Juan de Autillo: 185

Juan de Avia, sacristán de Husillos, ts.: 252

Juan de Ávila, 298; not. real: 3; ts.: 189, 252;

Juan de Bacinaco, can. de Burgos: 207

Juan de Bartolomé: 249

Juan de Berbiesca, can. de Santa María de Valladolid: 298

Juan de Bonilla, can. de Husillos: 233

Juan de Burgos: 185

Juan de Cabria: 185

Juan de Carvajal, abad de Husillos, cardenal de San Ángel: 229, 230

Juan de Castro, criado del hospital de San Antolín de Palencia, ts.: 169

Juan de Espinosa, 294; procurador: 294

Juan de Ferrera, beneficiado de Husillos, ts.: 233

Juan de Fuentes: 185

Juan de Guaza: 185

Juan de Guevara: 305

Juan de Heredia, ts.: 340

Juan de la Peña, vecino de Husillos: 271, 272, 298

Juan de la Portilla, racionero de Husillos, contador: 326

Juan de la Torre, fiscal de la abadía: 295; procurador fiscal: 296

Juan de los Ríos: 298

Juan de Lucianos, can.: 207

Juan de Madrigal, criado del sacristán de Husillos: 189

Juan de Manquillos: 50

Juan de Mazariegos, fraile de San Francisco, ts.: 112; fraile del monasterio de San Francisco de Palencia, ts.: 112

Juan de Medina, can. de Husillos: 236; ts.: 46

Juan de Montemayor, can. de Husillos: 236

Juan de Nieves, escribano: 289, 290

Juan de Oleo: 185 


\section{LA ABADÍA DE SANTA MARÍA DE HUSILLOS: ESTUDIO Y COLECCIÓN DOCUMENTAL (904 - 1608)}

Juan de Ortega de Fresno: 298

Juan de Oviedo, secretario real: 234

Juan de Palacio, procurador del concejo de Fuentes de Valdepero: 98

Juan de Palán, tesorero de Husillos: 347

Juan de Palencia, can. de la catedral de

Palencia, ts.: 64; tesorero de

Husillos: 329, 330, 337, 340, 341, 345

Juan de Paredes: 185

Juan de Paredes de Martilla, vecino de Palencia: 281

Juan de Paz: 99

Juan de Porras, can. de Husillos, juez: 236; can. de la catedral de Palencia: 236

Juan de Portillo, medio racionero de Husillos: 252

Juan de Prasencio: 185

Juan de Revenga: 185

Juan de Ribas, 185;: vecino de Palencia: 298

Juan de Rojas, marqués de Poza: 282

Juan de Salamanca, racionero de la catedral de Palencia, ts.: 232

Juan de Salinas, vecino de Valladolid, tratante de madera: 344

Juan de San Pedro, morador en Salas: 207

Juan de San Román: 298

Juan de Santa Marta: 43

Juan de Santiago, criado y familiar de Fernando de Aguilar, abad de Husillos: 225

Juan de Santillán de la Cuesta, hijo de Martín Yáñez: 88

Juan de Santo Domingo: 91

Juan de Sedano, can. de Husillos, ts.: 250

Juan de Siero, sobrino de Fernando Martínez, ts.: 200

Juan de Támara: 263

Juan de Uría, canciller: 234

Juan de Valoria: 298

Juan de Vargas Zapata, criado, ts.: 296

Juan de Vegara: 298

Juan de Velasco, camarero mayor del rey, conf.: 213

Juan de Verzosa: 269

Juan de Vezella, can., conf.: 42

Juan de Villa Lución: 219

Juan de Villaumbrales, beneficiado de Husillos: 243

Juan de Zorita, ts.: 57
Juan del Castillo, criado del ob. de Palencia, ts.: 236

Juan del Pumar, ts.: 112

Juan Delgado: 185

Juan Díaz, arcipreste de Coruña, capellán de Juan Álvarez, ob. de Osma: 91; can. de la catedral de Palencia: 106; carnicero: 185

Juan Díaz de Cifuentes, conf.: 113

Juan Diego: 185

Juan Domínguez, 50, 185; alcalde de Villaumbrales: 140; capellán, 106; ts.: 112; escribano: 80; hijo de Aparicio: 140, 185; hijo de Pedro Guerra, ts.: 57; not. público de Palencia: 95; sayón: 26

Juan Domíngez Cortés, hijo de Domingo Calagruno: 140, 145

Juan Domínguez de la Puebla: 185

Juan Domínguez de Santillán, 185; capellán del abad, ts.: 107

Juan Espeso: 249

Juan Felipe: 185

Juan Fernández, 163, 164, 171, 184, 185, 196, 206; abad de Husillos, 190, 195, 196, 198, 199, procurador del prior y cabildo: 197; arcipreste de Palenzuela: 185; arcipreste de Salas: 207; can. de Husillos: 185; can. de Palencia: 80 ; carretero: 185 ; clérigo de la iglesia de San Juan: 126; clérigo de San Esteban: 201; escribano público de Torrelobatón: 159; escribano público de Valladolid: 186; hijo de Alfonso, ts.: 162; hijo de Diego Fernández: 185, 204; hijo de Domingo Alvar, clérigo: 126; hijo de Domingo Pérez, 206; hijo de Fernando, 185; hijo de Fernando, lego: 127; hijo de Juan de Melgar, ts.: 162; hijo de Juan Fernández, ts.: 199; hijo de Juan Fernández, conf.: 97; hijo de Juan Ferrero: 140, 145; hijo de Llorente Fernández, primo de Fernando Rodríguez: 169; hijo de Miguel, clérigo: 126; hijo de Rodrigo Fernández de Valoria: 185; mayordomo real, conf.: 82; merino de Campos: 128; merino de Ribas: 185; not. público de Palencia: 102, 106, 132, 150, 176; prior de Husillos: 154, 156, 157, 166, 168, 183, 185, 205, ts.: 195; prior y sacristán de Husillos: 153, 156, 158; sacristán de Husillos, 149, 157, 158, 185, ts.: 150; 
tejero, ts.: 112; ts.: 157; vecino de Fuentes de Valdepero: 188

Juan Fernández Armigote, 185; ts.: 205

Juan Fernández Cantarero: 226

Juan Fernández Carudo: 185

Juan Fernández de Aguilar de Campóo, clérigo de la diócesis de Burgos, capellán del número de los Cuarenta Capellanes en la catedral de Palencia, not. público apostólico: 205, 206; can. de Husillos: 230

Juan Fernández de Amusco, 151; can. de Husillos: 152, 156

Juan Fernández de Avanza, can. de la catedral de Burgos, juez apostólico: 286

Juan Fernández de Burueva, escudero del rey, ts.: 207

Juan Fernández de Buzón: 185

Juan Fernández de Castrillo, racionero de Santa María de Almazán de Castrojeriz, sobrino de Gonzalo González: 207

Juan Fernández de Frómista, armero, ts.: 198

Juan Fernández de Grijota, 185, 201; arcipreste de Río de Obirva: 208; casero del ob. Domingo: 207

Juan Fernández de Husillos, sobrino del chantre: 219

Juan Fernández de la Montaña, ts.: 221

Juan Fernández de la Peña, alcaide del castillo de Monzón, ts.: 195

Juan Fernández de Limia, conf.: 82

Juan Fernández de Madrigal, beneficiado de Husillos: 185

Juan Fernández de Manquillos: 185

Juan Fernández de Meneses, clérigo de la catedral de Palencia, procurador: 143; prior de Husillos, 173, 285, 202, 206, árbitro: 198, 199; sacristán de Husillos: 148, 149

Juan Fernández de Palencia: 185

Juan Fernández de Población: 185

Juan Fernández de Porras: 185

Juan Fernández de Porto, merino de Campos: 128, 129, 130

Juan Fernández de Potes: 185

Juan Fernández de Rojas: 91

Juan Fernández de Sigüenza, ts.: 112

Juan Fernández de Tablada, not. público de Palencia: 150, 158, 166, 174, 176, $179,183,189$

Juan Fernández de Támara, hombre de Juan, abad de Lebanza, ts.: 125
Juan Fernández de Tariego: 185

Juan Fernández de Toledo, ayo del rey, not. mayor de Andalucía y canciller del sello de la poridad, conf.: 135

Juan Fernández de Torquemada, can. de Husillos: 230

Juan Fernández de Vega, not.: 201

Juan Fernández de Villabermudo, can. de Husillos: 217

Juan Fernández de Villamuriel: 185

Juan Fernández del Carudo: 185

Juan Fernández del Postigo: 185

Juan Fernández del Pozo, ts.: 169

Juan Fernández Quintero: 185

Juan Fernández Simón, hijo de Juan Fernández Simón: 187

Juan Gallego: 91

Juan García, 92; asturiano, familiar de Husillos, ts.: 139; can. de Burgos: 207; clérigo de Monzón, ts.: 226; clérigo de Torre, ts.: 170; escribano de los autos en el obispado de Palencia: 96; familiar: 185; hijo de Juan García, ts.: 140; hijo de Pedro Nieto, clérigo de Rebenga, ts.: 145; yerno del portero: 127

Juan García Asturiano: 185, 207

Juan García Cercetilla, 185, ts.: 183, 204

Juan García de Burueva: 185

Juan García de Camargo, caballero de Lara: 207

Juan García de Ferrán, capellán del número de la catedral de Palencia, criado y familiar de Fernando de Aguilar, abad de Husillos: 225

Juan García de Petrel: 185

Juan García de San Cebrián, 185; capellán en la catedral de Palencia, ts.: 202

Juan García Malrrique, conf.: 113

Juan García Manrique, arzob. de Santiago, canciller mayor, not.mayor del reino de León, conf.: 213; adelantado mayor de Castilla, conf.: 134, 135;

Juan García Trecetilla, ts.: 152, 153, 156 Juan Gil de Fuentes: 185

Juan Gómez, 185; clérigo de Piña, ts.: 99

Juan Gómez de Esganiellas: 185

Juan González, 186; alfajeme, ts.: 112; ballestero: 127; hijo de Juan González de Villarmero: 207; procurador, juez: 224; vecino de Villumbrales: 221 


\section{LA ABADÍA DE SANTA MARÍA DE HUSILLOS: ESTUDIO Y COLECCIÓN \\ DOCUMENTAL $(904-1608)$}

Juan González de Avellaneda, caudillo mayor de los escuderos del rey: 183, 186

Juan González de Castromocho, not: 223

Juan González de Illescas, abad de Husillos: 206

Juan González de Matilla, clérigo de la diócesis de Oviedo, not. público apostólico: 236

Juan González de Villarmero: 207

Juan González de Zaia, procurador de Vasco, ob. de Palencia: 137

Juan González Mesía, prior de la orden de San Juan, conf.: 164

Juan González Picado, can. de Husillos: 243

Juan Grillo: 185

Juan Guillén, can. de la catedral de Palencia: 96; físico, beneficiado de la catedral de Palencia, ts.: 136, 137, 138

Juan Gutiérrez, 185, 187; can. de Husillos, 150, 152, 156; can. de Husillos, escribano: 243; escribano de Grijota, ts.: 188; porcionero de la catedral de Palencia: 151; racionero en la catedral de Palencia, vicario de Gutierre Gómez, abad de Husillos: 177, 178, 179

Juan Gutiérrez Mesía, prior de la orden de San Juan, conf.: 163

Juan Hernández de Buzón: 185

Juan Herrero, vecino de Husillos: 298

Juan Hervás, 176, ts.: 196

Juan Hurtado de Mendoza, alférez mayor del rey, conf.: 193, 194

Juan Íñiguez, escudero: 185; zapatero: 185

Juan Iohánez, capellán, ts.: 110

Juan Iohannes, laico, ts.: 45

Juan Izquierdo, hijo de Juan Izquierdo, vecino de Grijota, 100, 117, 185, ts.: 122

Juan Juárez: 298

Juan Laurenti: 44

Juan Legón: 123

Juan Linazero: 185

Juan Lirón: 219

Juan Llagues: 88

Juan Llorente, clérigo, hijo de Juan Llorente, ts.: 107 ; ts.: 107

Juan López, 185; cuñado de Lope Jiménez: 72; hijo de Diego López: 226; hijo de Martín López, clérigo:
126; hombre de Juan, abad de Husillos, ts.: 102

Juan López Guadiana: 207

Juan Lucas: 185, 298

Juan Mache: 185

Juan Macías, ts.: 115

Juan Manrique, ob. de Orense y canciller mayor: 175 ; ob. de Orense y Sigüenza, canciller mayor del rey, oidor de la audiencia real: 184

Juan Marche Avero: 185

Juan Marcos, hijo de Diego Rodríguez de Piña, ts.: 99

Juan Marrón, vecino de Monzón: 298

Juan Martín, 185, 249; can. de Husillos: 74, 75, 77; clérigo del abad de Husillos, 63, ts.: 64; escribano: 63; hijo de Aparicio: 145; hijo de Gonzalo Martín: 185; hijo de Juan Ferrero: 140, 145; miembro de la cámara del rey, not. de los privilegios rodados: 135; semiporcionero de Husillos: 74, 75

Juan Martín Cebrián: 185

Juan Martín de Castro: 185

Juan Martín Gomero: 185

Juan Martínez, 52, 91, 133，134，185; abad de Husillos: 185, 202; arcipreste de Campos: 91; bachiller, juez: 224; camarero: 207; can. de Husillos: 150, 152, 156, 158; can. de Husillos y procurador: 152, 158; can. de la catedral de Palencia, ts.: 145; clérigo: 185; criado de Juan Pérez de Aceves, prior de Husillos, conf.: 136; difunto, abad de Husillos: 201; escribano público;: 172; escribano público de Becerril de Campos: 172; escribano público de Villaumbrales: 133; hermano de Pedro de Hayuelas: 91; hijo de Gonzalo Martínez: 206; hijo de Martín Cidón: 140; hijo de Pedro de San Felices, 185, ts.: 162; hijo de Rodrigo Martínez: 185, 206; Juan Martínez, hombre de Juan Pérez de Aceves, prior de Husillos, ts.: 139, 145; medio racionero de Husillos: 252; miembro de la cámara del rey, not. de los privilegios rodados: 134; procurador: 158; semiporcionero de Husillos: 77; ts.: 137; vecino de Villamediana, ts.: 128; vicario de Grijota y can. de Husillos: 154, 185; vicario de Grijota, ts.: 150

Juan Martínez de Buyedo: 195 
Juan Martínez de Husillos: 185

Juan Martínez de la Costana, escribano público del número de Burgos: 242

Juan Martínez de la Lodera: 185

Juan Martínez de Luna, vasallo de Enrique II, conf.: 163, 164

Juan Martínez de Palencia, racionero en la catedral de Palencia: 225

Juan Martínez de Portillo, beneficiado de Husillos, ts.: 251

Juan Martínez de Rojas, señor de Monzón: 195, 196, 197, 198, 199

Juan Martínez de Villagutierre, hijo de Juan Martínez: 220

Juan Martínez de Villaumbrales, beneficiado de Husillos: 251

Juan Martínez de Villaviudas, can. de la catedral de Palencia, sobrino de Sancho Martínez, abad de Husillos: 201; can. de la catedral de Palencia, hijo de Andrés Pérez de Villaviudas: 202

Juan Martínez de Villazán, justicia mayor de la casa del rey, conf.: 164

Juan Martínez Gomiro: 185

Juan Mate, clérigo: 126

Juan Mateo, clérigo: 185

Juan Merino: 185

Juan Meto: 52

Juan Miguel: 185

Juan Miguel "Mazo": 185

Juan Núñez, 316; conf.: 100; adelantado mayor de la Frontera, conf.: 97; maestre de la orden de Calatrava y not. mayor de Castilla, conf.: 134, 135; marido de Antonia de Solórzano: 279

Juan Núñez de Ferrera, 162, 185; hijo de Díaz Gómez: 159; vecino de San Esteban de Gormaz, hijo de Díaz Gómez y nieto de Gómez de Monzón: 159

Juan Núñez de Lara, alférez real, conf.: 113

Juan Núñez de Villazán, justicia mayor de la casa del rey, conf: 163, 192, 194

Juan Ortega de Fresno, vecino de Husillos, ts.: 295

Juan Osórez, maestre de la orden de Santiago, conf.: 97

Juan Pagado: 185

Juan Paniagua: 185

Juan Pedro de Salazar, procurador: 286
Juan Pérez, 65. 84, 85, 185; can. de Husillos, procurador: 105; camarero de Juan II Fernández de Limia, ob. de Palencia, ts.: 111; can. de Husillos, procurador: 104, 110; can. y mayordomo del cabildo de Husillos: 162; chantre de Husillos: 139, 185; clérigo, ts.: 128 ; clérigo y cura de la capilla de Santiago de la catedral de Santa María de Burgos, ts.: 207; conf.: 71; fiador: 65; gener de Juan Castellano: 53; hijo de García Pérez: 155; hijo de Pedro, prior de Ferrin, ts.: 108; portero, ts.: 112; prior de Husillos: 128, 129, 130, 161, 162, 185; tesorero de la catedral de Jaén, lugarteniente de Fernando Rodríguez, camarero del rey: 113; ts.: 64; yerno de Martín Velasco: 65

Juan Pérez "El Amo": 99

Juan Pérez Bacon: 52

Juan Pérez Bastardo, arcediano de Campos, 159, albacea del testamento de Juan Núñez de Ferrera: 162

Juan Pérez de Aceves, arcipreste de Becerril, ts.: 102; prior de Husillos: $128,132,136,137,138,139,143$, $145,146,147,150,151,153,154$, $156,158,160,161,162,166,185$; prior de Husillos y procurador: 136, 137, 138, 143

Juan Pérez de Astorga: 29

Juan Pérez de Becerril, bachiller en decretos: 223; hijo de doña María: 98 Juan Pérez de Cuenca, escribano: 71

Juan Pérez de Grijota: 185

Juan Pérez de Palencia, caballero, ts.: 58

Juan Pérez de Palenzuela, merino de Cerrato: 128, 129, 130

Juan Pérez de Revenga, ts.: 196

Juan Pérez Lorito, clérigo: 126

Juan Ponce, racionero de Husillos: 300

Juan Ponderación: 298

Juan Portilla, sacristán de Husillos: 306

Juan Puchero, ts.: 43

Juan Quintero: 185

Juan Rachón, yerno de Abril: 185

Juan Rallo: 185

Juan Ramírez, 24; hermano de Pedro Núñez de Guzmán, conf.: 97, 100

Juan Ramírez de Arellano, señor de Los Cameros, vasallo del rey, conf.: 163, 164, 194,

Juan Ramírez de Guzmán, conf.: 134, 135,213 


\section{LA ABADÍA DE SANTA MARÍA DE HUSILLOS: ESTUDIO Y COLECCIÓN DOCUMENTAL (904 - 1608)}

Juan Ramiro, vecino de Valladolid: 252

Juan Ramón, ts.: 73

Juan Rana, tenente de Villagarcía, conf: 21

Juan Recelo: 185

Juan Recio, hijo de Pedro Recio, ts.: 215 Juan Rodríguez, 185; capellán de Santa María de Husillos, 109; hijo de Martín Fernández: 159; hijo de Rodrigo Díez: 159; sobrino de Juan Álvarez, ob. de Osma: 91; vecino de Villamediana, ts.: 128; ts.: 108

Juan Rodríguez "Colmillo": 185

Juan Rodríguez de Arellano, señor de los Cameros, vasallo de Juan I, conf.: 193

Juan Rodríguez de Avilés, ts.: 207

Juan Rodríguez de Castañeda conf.: 164, 193, 194

Juan Rodríguez de Castro, can.: 226

Juan Rodríguez de Cisneros, adelantado mayor de tierra de León y de Asturias, conf.: 134, 135; conf.: 113

Juan Rodríguez de Palacios: 185

Juan Rodríguez de Santa Cruz, can. de la catedral de Palencia, provisor del obispo: 351

Juan Rodríguez de Sasamón: 185

Juan Rodríguez de Toro, prior de Santa María de Valladolid: 252

Juan Rodríguez de Torquemada, not. mayor de Castilla, conf.: 163; not. mayor del reino de Toledo, conf.: 164

Juan Rodríguez de Villalobos, conf: 163, 164, 193, 194, 213

Juan Rodríguez Manso, chantre de Husillos: 269

Juan Rojo, 185, 241, 249; hijo de Juan Rojo: 249

Juan Ruiz, 242; can. de Husillos: 266; clérigo: 185; vecino de Tardajos: 242

Juan Ruiz Cabeza de Vaca, clérigo, criado de Gutierre de Carvajal, ob. de Placencia, ts.: 296

Juan Ruiz de Baeza, conf.: 134, 135

Juan Ruiz Hurtado, familiar de Diego Ruiz de Camargo, ts.: 230

Juan Sánchez, 91, 113, 173, 185; can. de Husillos: 185, 220, 330, 340; clérigo: 249; hombre de Rodrigo Álvarez de Carrión, alcalde del adelantamiento de Castilla, ts.: 128; not. público de Palencia: 112
Juan Sánchez Barahona, escudero de Fernando Pérez Portocarrero, merino mayor de Castilla, ts.: 128

Juan Sánchez de Bustamante: 207

Juan Sánchez de Grijota, can. de Husillos: 185

Juan Sánchez de la Laguna: 185

Juan Sánchez de Medina, not.: 225

Juan Sánchez de Saia, not. de Palencia, procurador de Vasco, ob. de Palencia: 111, 112, 136, 138

Juan Sánchez de Santillana, can. de Husillos: 243

Juan Sánchez de Soria, not. público de Palencia, ts.: 125

Juan Sánchez de Tero: 207

Juan Sánchez Manuel, conde de Carrión,adelantado mayor del reino de Murcia, conf.: 163, 164, 193, 194

Juan Santos, labrador, vecino de Husillos: 298

Juan Simón, hijo de Simón: 140, 145

Juan Sobrino: 185

Juan Suárez, can. de la catedral de Palencia, ts.: 63; pintor, ts.: 63

Juan Subtor, ts.: 55

Juan Tejero, merino de Husillos: 237

Juan Tirón: 185

Juan Toribio: 185

Juan Valtierra, clérigo: 229

Juan Velasco: 99, 185.

Juan Velázquez, bestiario de Uclés: 51. Juan Vengas, vecino de Palencia: 226.

Juan Zapatero: 185

Juana (Iohana, Iohanna): 201, 207

Juana I: 294, 339

Juana de Ávila: 298

Juana de Robra: 185

Juana de Zamora, collaza de Juan Martínez de Villaviudas: 201

Juana Fernández, mujer de Pedro Alvín de Cabezón: 186

Juana García, 200; mujer de Toribio García: 200

Juana Gutiérrez: 185

Juana, hermana de Sancho, hijo de Alfonso XI: 167, 168; hija de Domingo Pérez: 185; mujer de Diego Fernández, duque: 71 ; mujer de Pedro Santiago: 185; reina, mujer de Enrique II, 171; sincr.: 163, 164; reina, mujer de Fernando III, sincr.: 63,65

Juliana (Iuliana), 25; mujer de Pedro Arnaldo: 25 
Justa (Iusta) Coxa: 27, 35

Justa Fernández: 17

Justo (Iusti), 43: ts.: 43

LAGUNA, licenciado, clérigo, criado de Gutierre de Carvajal, ob. de Placencia, ts.: 296

Laguo, laico, ts.: 45

León X: 261

Leonardo (Leonart), ob. de Ciudad Rodrigo: 71

Leonor (Alienor, Alionore, Allionor, Elionor): 34; hija de Sancho Martínez, abad de Husillos: 201; infanta, hija de Fernando IV, sincr.: 100; reina, mujer de Alfonso VIII: 35, 36; reina, mujer de Alfonso VIII, sincr.: $33,40,42,43,44,45,46$; reina, mujer de Juan I, 192, 194; reina, mujer de Juan I, sincr.: 193

Licinio, presbíter: 6

Licino, presbíter: 7

Lope (Lop, Lopo, Loppe, Lup, Lupus), conf.: 41; capiscol de Husillos, ts.: 26; conde, "signifer regis", conf.: 27 , 28,30

Lope de Aranda, ts.: 57

Lope de Aulinus, conf.: 41

Lope de Mendoza conf.: 97, 100, 113

Lope Díaz, alférez del rey: 53, 54, 55; clérigo: 126; merino real en Castilla, conf.: $34,35,36$; merino de la casa real: 40

Lope Díaz de Cifuentes conf.: 135

Lope Díaz de Cisneros, conf.: 134

Lope Díaz de Faro, alférez real: 57

Lope Fernández, hombre de Juan Martínez, can. de la catedral de Palencia, ts.: 145

Lope Fernández de Becerril: 185

Lope García, hijo de Diego López de Torquemada: 112

Lope García Caranga, not. público de Palencia, ts.: 216

Lope García de Torquemada, sacristán de Palencia, ts.: 112, racionero de Husillos, ts.: 95

Lope González, criado de Juan González, capiscol de Burgos, ts.: 207

Lope Gordo, conf.: 34

Lope Jiménez: 72

Lope López, conf.: 6, 21

Lope Martín de Rueda: 185

Lope Martínez: 241
Lope Pérez, fraile de Uclés: 51

Lope Rodríguez de Baeza, conf.: 100

Lope Rodríguez de Villalobos, conf.: 97

Lope Ruiz de Baeza, conf.: 113

Lope, electo de Córdoba, conf.: 71; hijo de Juan Fernández de Fuentes, ts.: 201; maestre, prestamero: 56 ; ob. de Lugo, conf.: 213

Lope Sánchez, príncipe, conf.: 14

López de Manquillos, not. real: 4

Lorenzo (Laurentius, Llorencio), cantor, ts.: 31 ; ob. de Salamanca, conf.: 113; selero, ts.: 66

Lorenzo de Carranza, fiador de Antonio de Segovia: 325

Lorenzo Suárez de Figuerola, maestre de la orden de Santiago, conf.: 213

Lorenzo Velásquez: 314

Lorenzo Velázquez, vecino de Valladolid: 277, 278

Luba, conf.: 2

Lubla, conf: 2

Lucas: 207

Lucas Gallardo, lego: 351; vecino de Palencia, not. público apostólico: 351

Lucas Pérez: 185

Lucía (Luçía): 207

Lucina: 5

Lucino, preste: 5

Lucio III, papa: 39

Luis Cabeza de Vaca, ob. de Palencia: 285

Luis de Carvajal, abad de Husillos: 233, 278

Luis de Miranda: 269

Luis Fernández: 191

Luis López, clérigo, criado de Gutierre de Carvajal, ob. de Placencia, ts.: 296

LLORENTE: 207

Llorente Fernández de Vega: 185

MA[...]NETE García, clérigo: 126

Magdalena (Madalena): 185

Mahomat Abenaçar, rey de Granada, vasallo del rey Fernando IV, conf.: 97

Mahomat Abenmahomat Abenhut, rey de Murcia, vasallo de Alfonso X, conf.: 71

Mahomat Aboabdille, rey de Granada, conf.: 82

Manche: 185

Manrico, presidente en la catedral de León: 41 


\section{LA ABADÍA DE SANTA MARÍA DE HUSILLOS: ESTUDIO Y COLECCIÓN \\ DOCUMENTAL (904 - 1608)}

Manuel, conf.: 71

Marciel, abad de Santa María de Matallana, ts.: 63

Marco (Marcho) Díaz, can. y vicario del ob. Juan de Palencia: 102; can. de Husillos: 74, 75, 77; porcionero de Husillos: 74, 75, 77

Marcos (Marchos): 185, 207; hermano de Pedro Fernández: 185

Marcos Alfonso, veedor: 191, 194

Marcos Fernández, hijo de Diego Fernando: 185

Marcos García: 185

Marcos Gil: 185; abogado, procurador: 182

Margarita: 207

María (Mari, Maríe): 207, 298; esposa de Pedro de Monzón: 256; hija de Marcos Fernández: 185; hija de Pedro García: 185; madre de Fernando IV: 92; madre del ob. Juan Álvarez: 91; mujer de Cristóbal de San Cebrián, vecino de Husillos: 298; mujer de Gómez de Monzón: 74, 75, 77, 86, 87; mujer de Juan de Santillán: 88; mujer de Pedro de Monzón: 258; mujer de Pedro González de Marañon, señor de Haza: 57; mujer de Pedro Pérez: 117; reina, abuela de Alfonso XI: 101; reina, mujer de Alfonso XI, 113; sincr.: 114; reina, mujer de Juan I: 234; reina, mujer de Sancho IV: 82; viuda de Pedro Fernández Portugal: 117

María Álvarez: 49, 173, 185

María Andrés, mujer de Palea: 24

María de Dueñas, mujer de Cristóbal de Torres: 324

María de Meneses, mujer de Diego Sarmiento, señor de Villadeciervos: 284, 288, 298

María Díaz: 185

María Fernández, 201; casera de Juan González de Aguilar: 185; tía de Juan Martínez de Villaviudas, mujer de Alfonso García: 201; viuda de Alfonso Fernández Prieto: 221

María Fernández Coronella: 185

María García, mujer de Juan Alfonso, sellero: 186

María Godesteiz: 27, 35

María Gómez, 185, 321; mujer de Martín Fernández de Palacios: 185
María González, 185; mujer de Fernando García de Marmellar de Yuso: 207; mujer de Pedro García, especiero: 186

María Gutiérrez, mujer de Fernando Ponce: 43

María Iohanis: 50

María Martín, 99, 187; hija de Domingo Martín, mujer de Juan Fernández Simón: 187; mujer de Juan Fernández Simón: 187

María Mora: 185

María Pachuela: 185

María Pérez, 50. 185; mujer de Pedro Fernández de Monzón: 185; mujer de Jacob: 50

María Rodríguez, mujer de Toribio: 201

María Rubia, viuda de Juan de Mara: 315

María Sánchez de Aguilar, mujer de Diego de Fresno: 280

María Velázquez, viuda de Juan de Ávila: 270

Marina Fernández, esposa de Rodrigo Alfonso de Valdespina: 228

Marina García, criada de Juan Pérez, chantre: 185

Marina Rodríguez de Grijota: 185

Marta: 207

Marte: 44

Martín (Martines, Martino, Martinu), 207; abad de San Pelayo de Cerrato, ts.: 46; arzob. de Toledo: 42; capellán real: 6; clérigo de Quintanillar: 185; conde, conf.: 14; hijo de Cid Juanes: 65; hijo de Domingo Arnaldi: 54; hijo de Juan Pérez de Hérmedes: 185; hijo de Martín Ruiz Prieto: 249; hijo de Rodrigo Corbato: 145; not. real: 18, 19, 27, 28, 30; ob. de Astorga y not. de Castilla, León, y de Andalucía, conf.: 82; ob. de Cartagena, conf.: 97; ob. de Córdoba, conf.: 134, 135; ob. de Zamora, conf.: 163, 164, 192, 193, 194; ob. electo en la iglesia de Coimbra, conf.: 14; prior de Husillos, ts.: 64 ; sacristán de Husillos: 43; socio de Husillos, ts.: 54; yerno de Domingo Esteban: 185

Martín V, papa: 222

Martín Alfat, ts.: 44

Martín Alfonso, 185: carnicero: 185; conf.: 71; hijo de Alfonso Téllez de Alborquerque: 81 
Martín Alfonso de Amayuelas de Abajo: 185

Martín Alfonso Téllez de Alborquerque: 79

Martín Bernáldez: 20

Martín Cosin: 185

Martín de Aspe y Sierra, ob. de Palencia: 351

Martín de Cañizal, secretario del prior y cabildo: 341

Martín de Grijota, beneficiado de Husillos, 251, ts.: 251; Martín de Grijota, medio racionero de Husillos: 252

Martín de Leyto, hijo de Martín de Leyto: 145

Martín de Orella, sacristán de Husillos, conf.: 42

Martín de Palacios: 185

Martín de Pereda, vecino de Husillos: 298

Martín de Roa: 91

Martín de Vergara: 294

Martín Deleyto, hijo de Martín Deleyto: 140

Martín Delgado, lego: 206

Martín Díaz, 185; clérigo, criado y procurador de Nuño Díaz, abad de Husillos: 127

Martín Domínguez de Otiela: 52

Martín Donez, ts.: 20

Martín Ermegaudi, archidiácono, conf.: 33

Martín Fernández, 185, 207, 269; can. de Husillos, procurador: 110, 112; clérigo, ts.: 128; electo de León, conf:: 71; escribano, hijo de Martín Cidón, procurador: 140, 144, 145; fiador: 66; hijo de Elvira: 45; hijo de Martín Cidón: 140, 145; hijo de Martín Ruiz de Valdevielso, ts.: 207; lego: 127; merino: 196; vecino de Villadiego: 207; yerno de Gonzalo Rodríguez, ts.: 132

Martín Fernández Amo: 185

Martín Fernández de Carrión, procurador: 226

Martín Fernández de Cítores, hijo de Domingo, ts.: 201

Martín Fernández de Fresneda, clérigo: 207

Martín Fernández de Grijota, can. de Husillos: 273

Martín Fernández de Guzmán conf.: 163,164
Martín Fernández de Paredes, ts.: 148, 149

Martín Fernández de Toledo, ayo del rey, not. mayor de Andalucía y canciller mayor del sello de la poridat, conf.: 134

Martín Fernández Muñón: 185

Martín Fernández Portocarrero, adelantado mayor del reino de León y de Asturias, conf.: 100

Martín Fernández Sinesmal: 185

Martín Fidel Izquierdo: 99

Martín Garañon: 185

Martín García, 91, 185, 249; ts.: 57; can. de Husillos: 219; compañero y procurador del cabildo de Husillos: 96

Martín García "El Viejo": 219

Martín García de Baños: 185

Martín García de Praduelo, caballero, ts.: 58

Martín García Pachuelo: 185

Martín Gil, 185; adelantado mayor del reino de Murcia, conf.: 134; conf.: 135; can. de Husillos, 185; can. de Husillos, juez, vicario: 161; can. de Husillos, lugarteniente del prior Juan Pérez de Aceves: 162; can. de Husillos, procurador: 160; conf.: 71; Martín Gil, procurador: 162

Martín Gómez, 219; clérigo y criado del abad de Husillos: 106

Martín Gómez de Astudillo, not. público de Palencia, escribano público de Astudillo: 220

Martín González, procurador: 220; ts.: 43

Martín González de Olmos, can. de Husillos: 230

Martín Ibáñez, clérigo: 126

Martín Iohanis: 52

Martín Jimeno, clérigo, ts.: 117

Martín Juan, 185; hijo de Miguel Martín: 185

Martín Juan de Fuentes: 185

Martín Lozano, laico, ts.: 45

Martín Mateo de Carrión, capellán del obispo, ts.: 46

Martín Mochano: 185

Martín Monteroso, conf: 41

Martín Muñoz, 185; beneficiado de Husillos: 347

Martín Nafarro: 57

Martín Nicolás: 185

Martín Nicolás de Montealegre, ts.: 173 


\section{LA ABADÍA DE SANTA MARÍA DE HUSILLOS: ESTUDIO Y COLECCIÓN \\ DOCUMENTAL (904 - 1608)}

Martín Nozaniz, mayordomo en Campos, conf.: 21

Martín Pedriz Gordo: 24

Martín Peláez, deán de la catedral de Palencia: 63; frade de la orden de Vélez, ts.: 57

Martín Peláyez, archidiácono, conf.: 56; hermano de Uclés, ts.: 55

Martín Pérez, 185; alcalde de Husillos, ts.: 139; can. de la catedral de Palencia, ts.: 24; hijo de Antolín: 185; merino de Husillos: 122, 215; not. público de Palencia: 108, 130; sochantre de Husillos: 185; ts.: 152, 153, 156

Martín Pérez de Carva: 176, 185; ts.: 162,183

Martín Pérez de la Carva de Millanés, vecino de Husillos: 170

Martín Pérez de Villa Eriaz, ts.: 127

Martín Pérez de Villaudilla, can. de Husillos: 217

Martín Pérez Grande: 24

Martín Prieto, hortelano, ts.: 155

Martín Rodríguez, clérigo de Santa María del Campo: 207

Martín Ruiz, not. público de Palencia: 93

Martín Ruiz de Turiso: 185

Martín Ruiz Prieto: 249

Martín Sánchez, 35, 185; can. de Husillos: 230; can. de Husillos, procurador: 205; compañero en Santa María de Husillos: 185; cura: 249; hijo de Juan Sánchez, clérigo: 126; medio racionero de Husillos, ts.: 156

Martín Sánchez Chaperete, clérigo: 126

Martín Sánchez de Burgos, escudero de Fernando Pérez Portocarrero, merino mayor de Castilla, ts.: 128

Martín Sánchez de Villaudilla, ts.: 112

Martín Tirón: 185

Martín Tocino: 91

Martín Toledano, vecino de Ribas: 185

Martín Velasco: 66

Martín Yáguez, 88; ts.: 25; capellán del ob. de Osma: 88; maestre de Alcántara, conf.: 213

Martínez, licenciado, clérigo del coro en la catedral de Palencia, ts.: 112; licenciado, criado de Francisco de Reinoso, abad de Husillos, ts.: 330

Martino, miembro de la iglesia de Coimbra: 14
Mateo (Mate, Mathe, Matheus): 72, 207; arzob. Duracensis: 103; hijo de Rodrigo Corbato: 140; ob. de Cuenca, conf.: 71; presbíter, cardenal, ts.: 37

Mateo de Cabia, can. de Husillos: 340

Mateo Díaz, abad de Hérmedes: 106

Mateo Redondo: 185

Mauricio (Mauricius), ts.: 44

Mauro (Maurus): 54

Mayor de Ribas: 185

Mayor Sánchez, mujer de Gómez Ruiz de Sandoval: 99

Mayor, 50, 185; casera de Juan Martínez de Villaviudas, mujer de Alfonso Fernández de Sahagún: 201; hija de la Malva: 88; viuda de García Anaiz: 42

Melen Suárez, maestre de la orden de Alcántara, conf.: 163, 164

Mena, can. de Husillos: 318

Mencía, reina: 72, 185

Mencía Fernández: 185

Mencía López de Torquemada: 185

Micaela, sayón: 44

Micer Ambrosio Bocanegra, almirante mayor de la mar, conf.: 164

Miguel (Michael, Migel): 52, 60, 66, 91; hijo de Juan: 185; ob. de Lugo, conf.: 71; ob. de Osma, conf.: 35, 36; ob. de Oviedo, conf.: 82; prior de Husillos: 50, 52, 60; racionero de Husillos: 298; sub prior, ts.: 55 ; ts.: 57

Miguel Antón: 185

Miguel Campanero, vecino de Palencia: 298

Miguel Cidez: 24, 34

Miguel de Quiñones, can. de Husillos: 330

Miguel Díaz, 60, 185; ts.: 65

Miguel Díez, arcipreste de Lerma: 207

Miguel Feliz, merino en Burgis, conf.: 21

Miguel Fernández, porcionero de Husillos, ts.: 157

Miguel González, ts.: 340

Miguel Martín, hijo de Martín Juan: 185; ts.: 57

Miguel Martín del Foyo: 185

Miguel Martínez, 24; merino en Santa María de Husillos: 26

Miguel Martínez de Becerril: 185

Miguel Martínez Diego: 185

Miguel Mocho: 185 
Miguel Pérez, 24; escribano público de Monzón: 98, 99; ts.: 208

Miguel Rallo, hijo de Bartolomé Rallo: 140, 145

Miguel Rodríguez, clérigo, hijo de Pedro Alfonso, ts.: 187

Miguel Románez: 24

Miguel Rubio de Otella: 52

Miguel Ruiz: 185

Miguel Sánchez, 185; alcalde de Monzón: 195

Miguel Zapatón de Haza, escudero, ts.: 58

Míoro: 186

Miro (Mirus), archidiácono, ts.: 20; can. de Husillos, ts.: 24; ob. de Palencia: 12,13

Momaduena, mujer de Anaia: 12

Montalvo, licenciado: 294

Mosse, judío, vecino de Astudillo: 220

Mudarro Pérez, can. de la catedral de Palencia, ts.: 147

Muñoz, can. de Husillos: 347

Muñoz Alfonso, ts.: 25

Muñoz Álvarez de la Serna: 185

NICOLÁS (Nicholaus, Nycholaus, Nocolaus): 185, 207; "magister scole" y canónigo de Husillos, conf.: 47; alfayate: 52; archidiácono, ts.: 24; magíster, can., conf.: 42; ob. de Cartagena, conf.: 163, 164, 192, 193, 194; ob. Carpatensis; ob. de Cuenca, conf.: 192, 193, 194; operario de Santa María de Husillos, ts.: 31

Nicolás Gutiérrez: 267

Nicolás Iohanni, conf.: 41

Nicolás Martínez de Valladolid, ts.: 125

Nicolás Pérez: 91

Nina, ts.: 12

NUÑO (Nunnius, Nunno): 26, 57; arzob. de Sevilla, conf.: 134, 135; conde, conf.: 34; señor de Vicaya, alférez mayor del rey, conf.: 134, 135

Nuño Álvarez: 185

Nuño Álvarez de Haza, conf.: 193, 194

Nuño Álvarez de la Serna: 185

Nuño Ansúrez, conde de Monzón: 8, 10, $27,35,82,97,114,135,137,163$, 167, 193, 339

Nuño Díaz, abad de Husillos: 112, 125, 127, 130, 185; abad de Husillos, procurador: 111

Nuño Díaz de Castañeda, almirante de la mar, conf.: 82
Nuño García, conf.: 5, 9

Nuño González, conf.: 71, 82

Nuño Guillén, conf.: 71

Nuño Gutiérrez (Nunnius): 6, 185; conf.: 7

Nuño Guz, conf.: 3

Nuño Meléndiz, hijo de Melendi Núñez: 29

Nuño Núñez, conf.: 10

Nuño Núñez de Haza, conf.: 113, 135, 193, 194

Nuño Pérez, can. de la catedral de Palencia: 91; conf.: 27, 28, 30; hijo del conde don Pedro: 51; "potestas" en Avia y en Ferreras: 31; prior de Husillos, 107, 110, procurador: 111

Nuño Téllez, ts.: 20

OBECO, abad: 2

Obteo Bermídez: 12

Odón (Odone), maestro, precentor: 40

Ofemia: 207

Olalla: 207

Olalla Fernández: 186

Ordón Pérez Rábiela, escudero, ts.: 58

Ordoño (Ordonius), alfayete, ts.: 66; diácono: 1; prior del hospital del rey, capellán, conf.: 27,28

Ordoño Álvarez, abad de Husillos: 78

Ordoño García, conf.: 35, 36

Ordoño García de Villacisla, ts.: 55

Ordoño Muñoz, 52; ts.: 53

Orem Díaz, condesa de Urgel, hermana de Fernando Álvarez: 51

Ortega de Fresno: 298

Osmundo (Osmundus), ob. de Astorga: 14, conf.: 14

Osorio, conde: 29

Osorio Martínez, conde, conf.: 21

Otalora, licenciado: 294

PABLO: 91

Palacio, tesorero de Husillos: 347

Palea: 24

Pamachi, conf.: 37

Pascasio (Pascasius, Paschasius), electo en la iglesia de Burgos, conf.: 18, 19

Pascasio de Mazariegos, marido de Sol de Villaldavín: 50

Pascasio Pérez: 109

Pascual (Pasqual, Pasquale) 97, 185; hijo de Juan Pastor: 140; hijo de Juan Pérez: 88; ob. de Astorga, conf.: 213; ob. de Córdoba, conf.: 82; ob. de 


\section{LA ABADÍA DE SANTA MARÍA DE HUSILLOS: ESTUDIO Y COLECCIÓN DOCUMENTAL (904 - 1608)}

Cuenca, conf.: 97, 100; ob. de Jaén, conf.: 71

Pascual Fernández, 178; hijo de Domingo Martínez, vecino de Fuentes de Valdepero: 177, 179

Pascual Martínez: 185

Pascual Nieto "El Mozo": 185

Pascual Pérez, clérigo: 126; hombre de Fernando Ruiz: 96

Pascual Velasco: 185

Paulo (Paulus), abad de Santa María la Real de Valdeiglesias: 81

Paulo III, papa: 274, 278, 339

Paulo V: 350

Pedro (Peidro, Per, Pero, Petro, Petrus): 185; abad de Tordesillas, clérigo del ob. Tello de Palencia, ts.: 63; abad de San Pedro de Arlanza: 14; arzob. de Aquensis, conf.: 14; arzob. de Sevilla, conf.: 163, 164; arzob. de Toledo, conf.: 192, 193, 194, 213; bachiller: 232; "cognatus" de Gonzalo: 54; conde de Carrión, conf.: 14; conde de Trastámara, Lemos y de Sarria, conf.: 213; conde, prior de Husillos, ts.: 24; conde, tenente de Monzón y de la Torre: 20; conde: 29; conf.: 34; de la iglesia de Orense: 14; de la iglesia de Santiago de Compostela: 14; diácono: 1; electo en Burgos: 21; electo en la iglesia de Santiago, conf.: 14; electo en San Pedro de Cardeña, conf.: 14; hermano de Tello, señor de Aguilar, conf.: 134, 135; hijo de Abril de Fuente Quintana: 53; hijo de Arnaldo, ts.: 55; hijo de Diego, conf.: 134, 135; hijo de Domingo Fernández "Lentejas": 185; hijo de Fernando Escudero: 185, hijo de Juan Fernández de Grijota, ts.: 201; hijo de Martín Fernández de Avia, criado de Domingo González, chantre de Husillos, ts.: 204; hijo de Pedro Ovieco de Grijota: 52; hijo del conde Rodrigo, conf.: 35; hijo del maestre don Fradrique, hermano de Enrique II, conde de Trastamar, señor de Lemos y de Sarria, conf.: 163, 164; infante, hermano de Fernando IV, conf.: 97, 100; infante: 101; merino de Santa María de Cilleruelo: 43; not. real: 34; ob. de Astorga, conf.: 71; ob. de Ávila, conf.: 97, 100; ob. de Burgos, conf.: 27, 28, 30, 35, 36, 97,
100; ob. de Cádiz, conf.: 97, 100; ob. de Cartagena, conf.: 71; ob. de Córdoba, conf.: 192, 193, 194; ob. de Coria, conf.: 134, 135; ob. de León, conf.: 14; ob. de Lugo, conf.: 134, 135, 193, 194; ob. de Orense, conf.: 97; ob. de Osma, conf.: 213; ob. de Oviedo, conf.: 71; ob. de Palencia, 20, 61, conf.: 21, 71; ob. de Placencia, not. mayor de los privilegios rodados: 193; ob. Montismaranensiss: $124 ; \quad$ ob. Taracenensis: 103

Pedro: 24, 25, 33, 43, 207; ob. de Placencia, conf.: 192, 193, 194, 213; ob. de Placencia, not. mayor de los privilegios rodados: 194; ob. de Salamanca, conf.: 71, 97, 100; ob. de Segovia, conf.: 21; ob. de Sigüenza, conf.: 71, 134, 135; ob. de Zamora, conf.: 134, 135; ob. electo en la iglesia de Orense, conf.: 14; ob. de Coria, conf.: 71; ob. de Orense, conf.: 82; porcionero: 74 ; primo de Juan I, conde de Trastámara, de Lemos y de Samas, conf.: 192, 193, 194; prior de Ferri, ts.: 107; prior de Ferruz, de la orden de Sancta María de Monte-Sión: 105; prior de Husillos, conf.: 42, 47; prior de San Pedro de La Espina: 81; prior, conde en Husillos: 25; sacristán de Husillos, conf.: 47; semiporcionero de Husillos: 75; sobrino de Gonzalo González, hijo de Gonzalo Fernández de Castrillo de Villavega: 207; ts.: 54,57

Pedro "El Pastor": 185

Pedro I, 134, 135, 145; reinante en Castilla, Toledo, León, Galicia, Sevilla, Córdoba, Murcia, Jaén, Baeza, Badajoz, Algarbe, Algeciras y Molina, sincr.: 134, 135

Pedro I Pérez, ob. de Palencia: 20, 24

Pedro II de Agen, ob. de Palencia: 24

Pedro Abad, clérigo: 185; ts.: 55

Pedro Abad Cura, clérigo: 126

Pedro Abril: 185

Pedro Afan de Ribera, not. mayor de Andalucía, conf.: 213

Pedro Agadez: 185

Pedro Alcalde: 185

Pedro Alfonso, 97, 99; beneficiado de Husillos: 230, ts.: 230; hijo de Domingo Fernández, ts.: 203; hijo de 
Juan Alfonso: 159; racionero de Husillos, maestre, ts.: 230 ; ts.: 187 , 209

Pedro Alfonso de Sahagún, can. de Husillos: 243

Pedro Alfonso de Villaumbrales: 88

Pedro Álvarez, 185; clérigo: 63; conf.: 82; príncipe, conf.: 14

Pedro Álvarez de la Rúa: 298

Pedro Álvarez de Miranda: 298

Pedro Álvarez de Muraba, ts.: 269

Pedro Angeler, can. de Burgos: 207

Pedro Ansúrez, conde de Carrión, 17, 339; conf.: 18, 19

Pedro Antolínez, clérigo: 126

Pedro Antón: 249

Pedro Aquense: 14

Pedro Arenal: 185

Pedro Armegot, ts.: 44

Pedro Arnaldi, prepósito, canónigo de Husillos, conf.: 47

Pedro Arnaldo: 25; sacristán: 73

Pedro Arnalli, tesorero de Husillos: 52

Pedro Arroyo, clérigo: 249

Pedro Balzán: 29

Pedro Belleti, sacristán de Husillos: 77

Pedro Bermúdez, alfayate, ts.: 66

Pedro Bernabé: 171

Pedro Bernal: 184

Pedro Bernáldez, archiácono, conf.: 20

Pedro Briz, clérigo: 123

Pedro Buyl, vasallo de Enrique II, conf.: 163, 164

Pedro Caballero: 185

Pedro Calonge: 185

Pedro Capellán: 215

Pedro Carandia de San Cebrián, ts.: 63

Pedro Carazo: 185

Pedro Carpintero, ts.: 230

Pedro Carrillo, vecino de Husillos, criado y familiar de Francisco Núñez, abad de Husillos: 252

Pedro Castrillejo, hijo de Juan Castrillejo: 140

Pedro Castrillo, hijo de Juan Castrillo: 145

Pedro Cautivo, merino del obispo, ts.: 31

Pedro Cellinos, vecino de Fuentes: 298

Pedro Cidez, conf.: 33; ts.: 31

Pedro Cidez de Facinas, conf.: 18, 19; ts.: 9

Pedro Cisneros: 185

Pedro Comes, hijo de Pedro Soleri: 52

Pedro Cornero: 91
Pedro Cortés, vecino de Fuentes de Valdepero: 298

Pedro Cutral, ts.: 44

Pedro de Aguilar, 298; hijo de Pedro Fernández de Aguilar, ts.: 252; ts.: 269

Pedro de Ampudia, procurador: 283

Pedro de Arazuri, conf.: 35, 36

Pedro de Ávila, beneficiado de Husillos, 243; ts.: 233; can. de Husillos: 298; vecino de Husillos: 256, 258

Pedro de Bartolomé, merino: 249

Pedro de Becerril, prior de Santa María de Husillos: 44

Pedro de Burgos, maestro, ts.: 57

Pedro de Cardona, abad de Husillos, canciller real: $35,36,37,38$

Pedro de Carrillo, criado, familiar de Francisco Núñez, abad de Husillos: 252

Pedro de Carrión, criado de Gonzalo González: 207

Pedro de Castro conf.: 213

Pedro de Corral: 134, 135

Pedro de Elices, fiscal del obispado de Palencia: 285

Pedro de Encinas: 91

Pedro de Espinosa, provisor de Francisco de Vargas Carvajal, abad de Husillos: 307

Pedro de Fernando: 249

Pedro de Fuentes Tapiada, vecino de Palencia: 298

Pedro de Garisa, beneficiado de Husillos: 230

Pedro de Hayuelas: 91

Pedro de Juan Duque: 249

Pedro de La Cruz, notario real: 35, 36

Pedro de la Mota: 298

Pedro de la Portilla, vecino de Husillos: 298

Pedro de Lagasca, ob. de Palencia, conde de Pernía: 294

Pedro de Lara, conde, conf.: 35,36

Pedro de Lomas, beneficiado de Husillos: 243

Pedro de Malavilla: 42

Pedro de Medina, calderero, vecino de Palencia: 298

Pedro de Megarda, ts.: 55

Pedro de Monzón, 256, 258; can. de Husillos: 319, 335

Pedro de Movellán, vecino de Fuentes de Valdepero: 295, 298

Pedro de Piedrahita, ts.: 236 


\section{LA ABADÍA DE SANTA MARÍA DE HUSILLOS: ESTUDIO Y COLECCIÓN \\ DOCUMENTAL $(904-1608)$}

Pedro de Ponte, not. público apostólico: 232

Pedro de Reinoso, señor de Autillo y sobrino de Francisco de Reinoso: 338

Pedro de Ribas: 52, 185

Pedro de Santillana, vecino de Husillos: 237

Pedro de Támara, can. de Husillos: 243; hijo de García Fernández de Támara "El Viejo": 263

Pedro de Terradillos: 298

Pedro de Toranzo: 298

Pedro de Uranga, beneficiado, ts.: 230

Pedro de Vayello: 185

Pedro de Vega: 185

Pedro de Villa Muera, ts.: 243

Pedro de Villafranca: 226

Pedro de Villazán, racionero de la catedral de Palencia: 298

Pedro de Villens, conde de Ribadeo, vasallo de Juan I, conf.: 193, 194

Pedro Dente: 185

Pedro Díaz, 25, 52, 185; almirante de la mar, conf.: 82; clérigo de Fuentes de Valdepero: 206; clérigo del camarlengo: 63; clérigo: 126, 185; laico, ts.: 24; sacristán: 95; vecino de Monzón, árbitro: 197, 199

Pedro Díaz Arconada: 185

Pedro Díaz Carnicero: 226

Pedro Díaz Corvo: 185

Pedro Díaz de Manquillos, conf.: 18

Pedro Díez, sacristán de Husillos: 91

Pedro Díez Corbo: 173

Pedro Domínguez, 43, 91; hijo de Pedro Criador: 65; sacristán de Husillos, mayordomo de Juan Álvarez, ob. de Osma: 91; sacristán de Husillos, mayordomo del abad de Husillos, ts.: 90; sacristán de Husillos, ts.: 64, 91

Pedro Domínguez de Monzón, ts.: 31

Pedro Duque "El Moço", clérigo: 249

Pedro Enríquez de Harana, conf.: 82, 97, 100

Pedro Esteban, 185; arcediano de Nájera, can. de la catedral de Palencia, ts.: 112; vecino de Palencia: 298

Pedro Fechor, ob. de Salamanca, conf.: 82

Pedro Fernández: 151, 185, 295, 298; abad de Husillos, 138, 185, 207; abad de Husillos, tío de Domingo González: 174; aguador, vecino de Villaumbrales, albacea testamentario de Alfonso Fernández Prieto, su hermano: 221; arcediano de Alcor, not. mayor de los privilegios rodados: 164; arcediano de Carrión: 207; arcediano del Alcor, not. mayor de los privilegios rodados: 163; can. de la catedral de Palencia, ts.: 147; can., hijo de García Fernández de Mazariegos: 201; carnicero: 201; carretero: 185; clérigo de Villamediana en Valdesalze: 220; clérigo, hijo de Esteban, ts.: 117; clérigo: 185; compañero en Santa María de Husillos, ts.: 162; copero mayor de la reina, ts.: 186; criado del maestre Andrés, ts.: 66; hermano de Domingo Fernández: 121, 123; hijo de Diego Ibáñez, clérigo: 126, ts.: 122; hijo de Diego, clérigo: 126; hijo de Fernando Pérez de Piña, abad de San Salvador de Sevilla, can. de la catedral de Palencia, ts.: 112; hijo de Fernando Pérez, clérigo: 126; hijo de Fernando Rodríguez, conf.: 97; hijo de Juan, clérigo: 126; maestre de la orden de Santiago, conf.: 82; mayordomo real: 41; merino de Lope García, procurador del concejo de Fuentes de Valdepero: 98; molinero: 185; prior de Husillos: 217; racionero de Husillos, ts.: 156; racionero de la catedral de Palencia, albacea de Juan Martínez de Villaviudas, criado de Sancho Martínez, abad de Husillos: 201; sacristán de Husillos, procurador: 110, 111; soldado: 54, yerno de Martín Pérez de la Carva Milanés: 170

Pedro Fernández "Cacharro": 185

Pedro Fernández "Caniho": 185

Pedro Fernández "El Moço": 298

Pedro Fernández Aguado, vecino de Becerril, ts.: 221

Pedro Fernández Cabeza, can. de Husillos: 221

Pedro Fernández Casado: 185

Pedro Fernández de Avia, ts.: 217

Pedro Fernández de Carrión, 109; criado de Gonzalo González, arcipreste de Burgos, ts.: 198

Pedro Fernández de Castrillo de Villavega, sacristán, procurador: 112

Pedro Fernández de Castrillo, clérigo, ts.: 138 ; ts.: 136,137 
Pedro Fernández de Castro, conf.: 100; pertiguero mayor de tierra de Santiago, conf.: 113; racionero de la catedral de Palencia, ts.: 112

Pedro Fernández de Cosuelo, racionero de Husillos: 225

Pedro Fernández de la Posada: 185

Pedro Fernández de Monzón: 185

Pedro Fernández de Ordejón: 155

Pedro Fernández de Santa Gadea, not. apostólico: 207

Pedro Fernández de Torre, hortelano, vecino de Palencia: 155

Pedro Fernández de Vallejo: 185

Pedro Fernández de Velasco, camarero mayor del rey, conf.: 163, 164, 193, 194

Pedro Fernández de Ventosa: 185

Pedro Fernández de Villaherreros, capellán de San Juan de Pajares, ts.: 205

Pedro Fernández de Villavermudo, can. de Husillos: 205

Pedro Fernández de Villesmalo, racionero de la catedral de Palencia y albacea testamentario de Juan Martínez de Villaviudas: 202

Pedro Fernández Montero, can. de Husillos: 216; can. de la catedral de Palencia: 216

Pedro Fernández Pollo, lego: 206

Pedro Fernández Sancho: 185

Pedro Ferrero: 185

Pedro García, 188, 207; capellán de Juan Álvarez, ob. de Osma: 91, ts.: 91; clérigo: 185; hijo de Domingo Ramos: 185; hijo de Martín Miguel: 185; hijo de Pedro García Calvo: 185; hijo de Pedro García, ts.: 188; mayordomo de la curia real, conf.: 34; merino, regidor de Hérmedes: 249; yerno de don Nuño de Correziella de Escudo, ts.: 57

Pedro García de Fita, ts.: 3, 4

Pedro García de Fuentes de Nava, not.: 223

Pedro García de Paredes, vicario del ob. de Palencia: 216

Pedro García de Perales: 226

Pedro García Duque, clérigo: 249

Pedro García Galiano: 185

Pedro García Marañón, vecino de Burgos, criado de Arnal de Bernorio: 207

Pedro Garisa, beneficiado, ts.: 230
Pedro Gato: 185

Pedro Gil: 185

Pedro Gil de Tordoseles, ts.: 57

Pedro Gómez, 97, 185; ts.: 57

Pedro Gómez de Gumiel, prior de Husillos: 230

Pedro Gómez de Porras: 207

Pedro Gómez de Uclés, maestro: 51

Pedro Gómez Murillo, procurador: 347

Pedro Gómez Vicente: 117

Pedro González, 163, 298; chantre: 226; conde de Lara, conf.: 18, 19; hijo de Antolín, clérigo: 126; hijo de Gonzalo Pérez, ts.: 57; licenciado, can. de la catedral de Palencia: 351; maestro en decretos, bachiller, can. de Husillos: 239; not.: 230

Pedro Gutiérrez, archidiácono de Palencia, ts.: 40; conf.: 34, 35, 36; hermano de Uraze Martín: 52; ts.: 217

Pedro González "el Alfayate", ts.: 54

Pedro González "el Mozo": 207

Pedro González de Astudillo, can. de Husillos, bachiller, not. apostólico: 233, 243

Pedro González de Calahorra, racionero de Husillos: 251, 252

Pedro González de Francisco: 298

Pedro González de Gomiel, can. de Husillos: 233; chantre de Husillos: 236, 243, 251, 252; chantre de Husillos, juez: 226

Pedro González de Marañón, 93; hermano de Gonzalo Pérez, abad de Husillos: 58; señor de Haza: 57

Pedro González de Mendoza, mayordomo mayor del rey, conf.: 193, 194

Pedro González de Muga, escribano público de Burgos: 207

Pedro González de Tamayo, licenciado, ts.: 269

Pedro González de Villafáfila, can. de Husillos: 223

Pedro González Mate, can. de Husillos, not. público: 230

Pedro González Poya: 185

Pedro Guzmán, conf.: 71

Pedro Hernández, vecino de Husillos, ts.: 295

Pedro Hernández Aceves: 91

Pedro Ibáñez, clérigo de Fuentes de Valdepero: 66; hijo de Diego Ibáñez, ts.: 126; hijo de Diego Ibáñez, vecino 


\section{LA ABADÍA DE SANTA MARÍA DE HUSILLOS: ESTUDIO Y COLECCIÓN \\ DOCUMENTAL (904 - 1608)}

de Grijota: 120; maestre de la orden de Calatrava, conf.: 71 ; ts.: 121

Pedro Ibáñez de Valladolid, ts.: 57

Pedro Ibáñez Vicente, ts.: 115

Pedro Iohanes, prepósito de Husillos, ts.: 26

Pedro Iohanis, cantor de Husillos: 74; hijo de Juan Bernalli: 52; nieto del prior Miguel de Husillos: 52

Pedro Iohanis de San Felices: 52

Pedro Iohanis de San Julián: 52, 53

Pedro Iohannes, laico, ts.: 45

Pedro Iohannis, cantor de Husillos: 75, 77; ts.: 31

Pedro Iohannis de Ultra Flumen, conf: 33

Pedro Izquierdo "El Mozo": 249

Pedro Jiménez, ts.: 118,119

Pedro Juárez, 287; vecino de Villaumbrales: 298

Pedro Juliánez: 25

Pedro Lagasca, ob. de Palencia: 294

Pedro López, 185; conde, conf.: 6; not. mayor de Castilla, conf.: 97; ob. de Lugo, conf.: 163, 164

Pedro López de Espinosa, ts.: 197

Pedro López de Lomas, procurador: 281

Pedro López de Manquillos, conf.: 19; notario real: 9

Pedro López de Padilla, justicia mayor de la casa del rey, conf.: 100

Pedro López de Salcedo, escudero de Juan Martínez de Rojas, señor de Monzón, ts.: 198

Pedro López de Villa Flavista, conf.: 19

Pedro López de Villaplan Visaia, conf.: 18

Pedro Lorenzo: 185

Pedro Majadero: 185

Pedro Manrique, adelantado mayor de Castilla, conf.: 163, 164, 171, 192, 193, 194

Pedro Manso, vecino de Becerril: 298

Pedro Manuel, criado, ts.: 296

Pedro Manuel Pimentel, ts.: 293

Pedro Martín, 55, 185, 249; archidiácono, conf.: 56; can. de la catedral de Palencia: 80; not. del abad de Husillos: 47; sobrino del prior Miguel de Husillos: 60; ts.: 54

Pedro Martín de Rica Posada, vasallo de Pedro González de Marañón, ts.: 57

Pedro Martín de San Oyo: 51

Pedro Martín de Santillán: 185
Pedro Martínez, 134, 185, 207; abad de Husillos: 61，63，64，65，66，206; abad de Hérmedes: 125, 127; capiscol de Husillos: 8, 16; clérigo de Monzón, ts.: 195; deán: 185; ts.: 31

Pedro Martínez "Pájaro": 185

Pedro Martínez de Arroyuelo, escribano público de Burgos: 207

Pedro Martínez de Baños, hijo del prior Martín García: 185

Pedro Martínez de Becerril, bachiller, juez: 232

Pedro Martínez de Guzmán, conf.: 100

Pedro Martínez de Haza, escudero, ts.: 58

Pedro Martínez de la Henestosa: 207

Pedro Martínez Enzinas Falcón: 91

Pedro Martínez Gato, hijo de Fernando Martínez Gato: 241

Pedro Martínez Halloria: 185

Pedro Martínez Nepote, hombre de García Pérez, abad de Husillos, procurador: 109

Pedro Martínez Recio, ts.: 172

Pedro Memez: 24

Pedro Mengarde, ts.: 54

Pedro Michaelis: 50

Pedro Miguélez, abad de Santa María de Benavides: 107, 108

Pedro Mínguez: 185

Pedro Monse, hijo de Miguel, ts.: 115

Pedro Moriel: 185

Pedro Muñiz, maestre de Alcántara, conf.: 193, 194; maestre de Calatrava, conf.: 163

Pedro Muñoz, hijo del conde Muñoz: 29

Pedro Muñoz Cacharro, bachiller, juez: 232

Pedro Nicolás, 185; alcalde de Villaumbrales: 140

Pedro Núñez, alférez real: 8; conf.: 71; hijo de Álvaro Pérez de Guzmán, conf.: 134, 135; maestre de Alcántara, conf.: 192

Pedro Núñez de Guzmán conf.: 97, 113; adelantado mayor de Galicia, conf.: 134, 135

Pedro Ojudo: 185

Pedro Ordóñez de Hornillos, capellán de los Veinticuatro Capellanes, ts.: 127

Pedro Ordóñez, clérigo y procurador de Nuño Díaz, abad de Husillos: 127

Pedro Ortiz "El Mozo": 241

Pedro Ortiz de Escota, racionero de Santa María de Valladolid: 278 
Pedro Otón, prepósito, ts.: 24

Pedro Ovieco de Grijota, padre de Pedro: 52

Pedro Padilla: 91

Pedro Pagom, padre de Esteban y Antonio, ts.: 44

Pedro Pascález de Palencia, conf.: 18, 19; ts.: 31

Pedro Pastor, vecino de Villaumbrales, ts.: 133

Pedro Payán: 73

Pedro Peláez, clérigo: 63

Pedro Peláyez, can. de Husillos: 74, 75, 77; conf.: 41

Pedro Pérez, 16, 91, 141; can. de Husillos: 63; casero de Roa: 91; chantre de Husillos, procurador: 110, 111; clérigo: 126; comendador de Cuenca: 51; conf.: 41; hijo de Antolín Pérez: 185; hijo de Pedro Dueña, ts.: 118, 119; hijo de Pedro Mamadueño: 117, ts.: 120, 121, 122; hijo del escribano, ts.: 123; ts.: 43

Pedro Pérez de la Carva, hermano de Martín Pérez de la Carva: 185

Pedro Pérez de Palencia, ts.: 31

Pedro Ponce, 63; conf.: 100, 113; mayordomo real, conf.: 97 ; canciller del obispo, ts.: 40

Pedro Ponce de León conf.: 134, 135, 193, 194; señor de Marchena, conf.: $163,164,213$

Pedro Prieto: 249

Pedro Quintana, merino: 44

Pedro Raimúndez, ts.: 44

Pedro Raimundo de Grijota, ts.: 31

Pedro Rodríguez, 164, 194; conf.: 36; hermano de Álvaro Rodríguez de Guzmán, conf.: 35; hijo del conde Poncio, conf.: 34; not. público de Palencia: 80

Pedro Rodríguez de Azagua, conf.: 35, 36

Pedro Rodríguez Hispano, abad de Husillos, maestro, clérigo de la cámara apostólica: 89; abad de Husillos, ob. de Burgos, capellán de San Acisclo de Pontuelles, can. de las catedrales de Salamanca y de Oviedo, beneficiado de la catedral de Palencia: 94

Pedro Rojo: 249

Pedro Roxuelo: 185

Pedro Ruiz, 16, 91; alcalde: 207; ts.: 112

Pedro Ruiz de Fuensaldaña, ts.: 186
Pedro Ruiz de Rinoso: 185

Pedro Ruiz de Vallarna, ts.: 112

Pedro Ruiz de Villamediana, caballero, ts.: 111

Pedro Ruiz de Villoldo, 295, 298; abad de Lebanza, prior de Husillos, bachiller en decretos: 243; alcalde mayor de Husillos: 295, 296; padre de Pedro Ruiz de Villoldo: 298

Pedro Ruiz Ruacho, can. de Husillos: 233

Pedro Ruiz Sarmiento, adelantado mayor de Galicia, conf.: 192, 193, 194

Pedro Salincos: 201

Pedro Sánchez, beneficiado de la catedral de Palencia, ts.: 142; hijo de doña Luca, hombre de Alfonso Martínez, alcalde del rey en las merindades de Castilla, ts.: 144; merino de Husillos: 237; not. público de Palencia: 166, 168, 173; vecino de Husillos, ts.: 237

Pedro Sánchez de Cuesta, ts.: 197

Pedro Sancho de la Sombría: 57

Pedro Santos: 298

Pedro Simón: 185

Pedro Sobrino, sacristán, conf.: 33

Pedro Sotil: 185

Pedro Suárez de Guzmán, not. mayor de Andalucía: 192, 194

Pedro Suárez de Quiñones, adelantado mayor de la tierra de León, conf.: 163, 164, 192, 193, 194, 213

Pedro Suárez de Toledo, alcalde mayor de Toledo, 192; alcalde mayor de Toledo, not. mayor de tierra de Toledo: 194

Pedro Suprinus, ts.: 24

Pedro Tejedor, procurador de Hérmedes: 249

Pedro Téllez: 25

Pedro Tornero, clérigo de Juan Álvarez, ob. de Osma, ts.: 91

Pedro Vales, can. de Santa María de Husillos, procurador: 227

Pedro Vélez, can. de Husillos: 230; hijo de Beltrán de Guevara, conf.: 213

Pedro Vicente, ts.: 123

Pedro Vidones, capellán del número de los Veinticuatro Capellanes de la catedral de Palencia: 130

Pedro Yago, can. de Husillos, 298, ts.: 295; hijo de Alfonso Yago, can. de Husillos: 260 


\section{LA ABADÍA DE SANTA MARÍA DE HUSILLOS: ESTUDIO Y COLECCIÓN \\ DOCUMENTAL (904 - 1608)}

Pedrosa (Perosa), licenciado: 294

Pelayo (Pelagius, Pelay), conf.: 5; ts.: 7

Pelayo Belídez de Magaz: 24

Pelayo Bermúdez, conf.: 10

Pelayo Cautivo, sobrino de Petro Balzan: 29

Pelayo de Lara: conf.: 3

Pelayo de Ponte: 24

Pelayo Gallego, conf.: 41

Pelayo García de Lara, ts.: 4

Pelayo García, conf.: 9

Pelayo Michola: 41

Pelayo Pérez, conf.: 71; ts.: 31; maestre de la orden de Santiago, conf.: 71

Pérez: 116; can. de Husillos: 347; hijo de Pedro Fáñez, ts.: 65

Pérez Alfonso, yerno de Juan Domíguez: 106

Pérez Fernández: 171

Pexon de Segovia, can. de Husillos, ts.: 24

Ponce (Ponçe, Poncio, Poncius, Ponz), conde, 29, conf.: 27, 28, 34; conde, mayordomo real: 25 ; magíster, prior de Husillos, conf.: 33; magíster, ts.: 31; mayordomo del conde: 26; racionero de Husillos: 298

Ponce de Minerba, conde: 29

Ponce Guitardo, abad de Husillos: 16, $18,19,20,61$

Ponce Raimundo: 24

Prudencio de Sandoval, procurador: 346

RADULFO (Radulfus), abad, ts.: 1

Rafael Fernández, can. de Husillos: 347

Raimundo (Raimundus, Raymundo, Raymundus, Reimundus, Remondo, Reymanus), abad de Husillos: 3, 4, 7, $8,9,10,27,28,31,84,100,113$, 134, 164, 194, 213, ; abad de Husillos, cardenal de Santa Cruz, 10, 339; archidiácono, ts.: 24; canciller: 34; conde de Barcelona: 27, 28, 30; escribano, mayordomo de la catedral de Palencia, ts.: 40; not. del ob.: 40; ob. de Palencia, 14, 25, 40, 269, conf.: $14,27,28,30,34,35,36$; ob. de Segovia, conf.: 71

Raimundo II de Minerva, ob. de Palencia: 26, 31, 32, 33, 40

Raimundo Catalán, cantor de Husillos, conf.: 42

Raimundo de Cauriz, ts.: 55

Raimundo Giliberti, abad de Husillos: $26,31,33$
Ramerio, diácono, cardenal de San Adrián, conf.: 37

Ramiro (Ramir, Ramirus, Randimiro), conde: 29; soldado: 54

Ramiro II, rey de León y Oviedo, sincr.: 2

Ramiro III, rey: 6, 7, 298, 339

Ramiro Núñez de Guzmán conf.: 163, 164, 193, 194

Ramiro Peláyez, ts.: 55

Ramón (Remón, Remond, Romón), arcediano de Cerrato: 162; prior, ts.: 45

Ramón de Fuentes, fiador: 65

Ramón González, conf.: 71

Ramón González el Niño, conf.: 71

Ranosindo (Ranosindus), diácono: 1

Rebel: 88

Reginaldo de Maubernand, ob. de Palencia: 146, 147

Reyes Católicos: 238, 240, 247, 255

Riaçar Abotasi, rrey de Granada, vasallo de Fernando IV, conf.: 100

Riano Patiño: 91

Ricardo, sacristán de Husillos, ts.: 26, 31

Ricardo Milhaud, cardenal, legado pontificio: 14

Ricardo de Olea, can. de Husillos, ts.: 24

Rika, emperatriz, mujer de Alfonso VII: 26

Roberto, ob. de Silves, conf.: 71

Rodrigo (Rodericus, Roi, Roy, Ruderico, Ruy), 185; archidiácono de Campos: 75; arzob. de Santiago, canciller y not. Mayor del reino de León, conf.: 100; arzob. de Santiago, capellán mayor de Enrique II, canciller y not. mayor del reino de León, conf.: 163 , 164, 192, 193, 194; arzob. de Santiago, conf.: 82; arzob. de Toledo: 57; cantor, ts.: 54; capellán de la reina, can. de Husillos, ts.: 64; clérigo, ts.: 55; conde de Asturias, conf.: 18, 19; escriba: 43; hermano de Juan Alfonso, sellero: 186; hijo de Domingo Martínez: 185; hijo de Juan García de Briviesca, criado de Pedro Fernández, racionero, ts.: 201; hijo de Mayor: 42; hijo de Pedro Calzas, ts.: 65; merino: 42; nieto de Carofuso: 116; ob. de Astorga, conf.: 134, 135; ob. de Cadiz, conf.: 213; ob. de Calahorra, conf.: 27, 28, 35, 36, 97; ob. de Jaén, conf.: 213; ob. de Lugo, conf.: 97; ob. de Mondoñedo, 
conf.: 97, 100; ob. de Tuy, conf.: 113; ob. de Zamora, conf.: 113; regidor: 249; vizconde de Limoges, vasallo de Alfonso X, conf.: 71; yerno de Pedro Díaz: 185

Rodrigo Alfonso, 185; conf.: 71; clérigo de Monzón, ts.: 226; hijo de Alfonso Pérez: 140, 145; hijo de Diego Alfonso de Valdespina, ts.: 199

Rodrigo Alfonso de Aguilar, beneficiado de Husillos, ts.: 233

Rodrigo Alfonso de Tariego: 185

Rodrigo Alfonso de Valdespina: 231

Rodrigo Álvarez, 49, 172; conf.: 71, 82, 97, 100; hermano de Falcón Álvarez: 12

Rodrigo Álvarez de Asturias, 185; merino mayor de tierra de León y de Asturias, conf.: 113

Rodrigo Álvarez de Carrión, alcalde del adelantamiento de Castilla: 128, 129

Rodrigo Álvarez de Haza, conf.: 97

Rodrigo Álvarez de Santoyo, criado de Gómez Manrique, ts.: 217

Rodrigo Andrés, ts: 55

Rodrigo Antonino de Cobas, ts.: 55

Rodrigo Arnaldo, can. de la catedral de Palencia, ts.: 24

Rodrigo Camino, beneficiado de Husillos, ts.: 233

Rodrigo Cristóbal, hijo de Juan Cristóbal: 56

Rodrigo de Arco, escudero de Fernando Pérez Portocarrero, merino mayor de Castilla, ts.: 128

Rodrigo de Arnelejas, capellán de Fuente Quintana: 53

Rodrigo de Carvajal, beneficiado de Husillos, ts.: 233

Rodrigo de Fiterio pertinente de Husillos: 52

Rodrigo de Gonzalo, regidor de Hérmedes: 249

Rodrigo de Husillos, conf.: 56

Rodrigo de Palacio, can. de Husillos: 347

Rodrigo de Palencia, can. de Husillos: 340

Rodrigo de Paya, can. de Husillos: 347

Rodrigo de Peñafiel, ts.: 54

Rodrigo de Ronada, vecino de Piña, ts.: 99

Rodrigo de San Villo, vecino de Fuentes: 298
Rodrigo Díaz, abad de Santa María de Valladolid: 84, 85

Rodrigo Díaz de Cane[...], escudero, ts.: 58

Rodrigo Díaz Surdi, conf.: 18, 19

Rodrigo Fernández, 185; conf.: 21; hijo de Lorenzo Fernández de Cantoral, hermano de Sancho Fernández, ts.: 161; hijo de Marcos Pérez, ts.: 169; hijo de Martín Fernández, ts.: 211; merino: 185; prior del Hospital, conf.: 100 ; ts.: 20,45

Rodrigo Fernández de Cantoral: 185

Rodrigo Fitero, capiscol de Husillos, ts.: 64

Rodrigo Frolaz, conf.: 71

Rodrigo García, hijo de Juan Fernández: 207

Rodrigo García de Torrecilla, ts.: 54, 57

Rodrigo García de Villafuertes, ts.: 57

Rodrigo Gil de Villalobos, conf.: 100

Rodrigo Gómez, 86, 185; arcipreste de La Cuesta, 136; beneficiado de la catedral de Palencia, ts.: 137, 138; can. de la catedral de Palencia: 86, 87; can. de la catedral de Palencia y de Husillos, ts.: 95; conf.: 21, 71; hijo de Lope García: 185; ts.: 150

Rodrigo Gómez de Tapia, ts.: 162

Rodrigo Gómez Manzanedo, conf:: 97

Rodrigo González: 6, 185. 206; alférez real, conf.: 34; arcipreste de la Cueza, beneficiado de la catedral de Palencia, ts.: 137; can. de la catedral de Palencia y de Husillos, ts.: 63; can. de la catedral de Palencia: 80; conf.: 5, 7, 9, 10; hermano de Sancho: 52; hijo de Andrés González, criado y sobrino de Gonzalo González, ts.: 187; mayordomo: 63; príncipe, conf.: 14; sobrino de Gonzalo González, hijo de Andrés González de Villavega: 207; tenente de Monzón: 53; ts.: 45; Gutiérrez, 16, 91; conf.: 34; dominante en Monzón: 33; mayordomo de la curia real, conf.: 35, 36, 40; mayordomo de la reina: 40; señor de Monzón: 40

Rodrigo González de Castañeda conf.: 134, 135, 213

Rodrigo González de Luzio, ts.: 57

Rodrigo González de Saldaña, conf.: 113 


\section{LA ABADÍA DE SANTA MARÍA DE HUSILLOS: ESTUDIO Y COLECCIÓN \\ DOCUMENTAL (904 - 1608)}

Rodrigo González Manzanedo, conf.: 100,113

Rodrigo Jiménez, arzob. de Toledo, sincr.: 55

Rodrigo Latronis, abad de Husillos: 59, 60

Rodrigo López: 210

Rodrigo López de Mendoza, almirante de la Mar, conf.: 71

Rodrigo Manedo de Córdoba: 229

Rodrigo Martín, dominante en Pozuelos de Amianos: 45

Rodrigo Martín de Tapia, not. público de la diócesis de Burgos: 152

Rodrigo Martínez, casero de Cruña: 91; hijo de Rodrigo Pérez de Villaudilla, ts.: 112; hombre de Rodrigo Álvarez de Carrión, alcalde del adelantamiento de Castilla, ts.: 128 ; not. de Palencia: 174; ts.: 132

Rodrigo Martínez de Cuéllar, escudero de Fernando Pérez Portocarrero, merino mayor de Castilla, ts.: 128

Rodrigo Martínez de Piña, can., ts.: 112

Rodrigo Martínez de Tapia, not. público de la diócesis de Burgos: 153; not. público de Palencia: 156, 158, 170

Rodrigo Ordóñez, príncipe, conf.: 14

Rodrigo Pardo: 91

Rodrigo Pascual: 298

Rodrigo Pelas: 91

Rodrigo Pérez, 92, 185; cantor de la catedral de Palencia: 74, 75; escribano del rey y not. público: 128 ; escribano real: 128; hermano de Gonzalo Pérez, abad de Husillos, 54, ts.: 55; hijo de Martín Pérez: 207; maestre de Calatrava, conf.: 82 ; not. público del rey: 128; sacristán de Husillos y can. de Palencia, ts.: 95

Rodrigo Pérez "El Molinero": 185

Rodrigo Pérez "El Mozo": 185

Rodrigo Pérez de Binia, ts.: 127

Rodrigo Pérez de Bovar, ts.: 112

Rodrigo Pérez de Celobres, ts.: 136

Rodrigo Pérez de Colobriz, clérigo, ts.: 138

Rodrigo Pérez de Cololres, ts.: 137

Rodrigo Pérez de Colombes, hombre de Nuño Díaz, abad de Husillos: 130; ts.: 127

Rodrigo Pérez de Otero: 185

Rodrigo Pérez de Ribera, licenciado, fiscal del consejo real: 340

Rodrigo Pérez de Villalobos, conf.: 113
Rodrigo Pérez Ponce, conf.: 113

Rodrigo Pérez Ponce de León conf.: 134, 135

Rodrigo Ponce de León, conf.: 213

Rodrigo Rodríguez, archidiácono de Campos: 74; camarero del abad de Husillos, ts.: 90 ; can., ts.: 186; conf.: 71; ts.: 64

Rodrigo Rodríguez de Lucio: 51

Rodrigo Rodríguez Malrrique, conf.: 82

Rodrigo Rojas, clérigo de Juan Álvarez, ob. de Osma, ts.: 91

Rodrigo Sánchez, cantor de Husillos: 50

Rodrigo Sánchez de Aguilar: 241

Rodrigo Simón, arzob. de Toledo: 54

Rodrigo Suárez, merino mayor de Galicia, conf.: 71

Román: 207

Román Pérez: 185

Román Zierzo: 185

Romeo (Romeus): 53

Romer García: 91

Romero, fiador: 66

Romez Ruiz, conf.: 71

Roque Giraldo, prior y presidente de Husillos: 326, 329

Ruberico, ob. de Calahorra, conf.: 163, 164

SADERMÍN, capellán de San Miguel, ts.: 73

Salaya, can. de Husillos: 294

Salomón (Salomonis): 43

Salvador (Saluatore), 74; can. de Husillos: 75, 77

Salvador de Francisco, can. de Husillos: 298

Salvador Medea: 60

Salvador Peláez: 185

Salvador Pérez, capellán de los veinticuatro capellanes de la catedral de Palencia, ts.: 112; clérigo de Becerril de Campos: 172, 173; procurador: 172

San Dionisio (San Dionis de Francia): 17

San Juan, criado del ob. de Palencia, ts.: 246

San Román de Tapia, licenciado, teniente-corregidor de Palencia: 335, 336, 338

Sancha (Sancia, Sanctia, Santia): 185, 207; hermana de Juan Álvarez, ob. de Osma: 91; hija de Domingo Juan: 185; hija de María Corneja: 99; 
mujer de Fernando Martínez, abuela de Juan Martínez de Villaviudas: 201; sobrina de Urraca I, conf.: 18 , 19

Sancha Alfonso, casera de Gonzalo González: 207

Sancha Berengaria, hija de Salomón: 43

Sancha Bermúdez, conf.: 3, 4

Sancha de la Ballesta: 185

Sancha Díaz, casera de Diego Díaz: 203

Sancha Fernández: 50

Sancha Marina: 185

Sancha Martínez: 185

Sancha Pérez, esposa de Pedro Rodríguez: 63

Sancha Rodríguez, mujer de Juan González: 186

Sancha Ruiz: 91

Sancha Salomón, hija de Salomón: 43

Sancho (Sanctio, Santio, Sancius, Sanctius, Sanchius, Sanchuelo, Santius): 185

Sancho, armiger de Villa de Rey, ts.: 53; electo de Toledo y canciller real, conf.: 71; hermano de Enrique II, conde de Albuquerque, señor de Haro y de Ledesma, alférez mayor del rey, conf.: 163, 164; hermano de Rodrigo González: 52; hermano de Tello, señor de Aguilar, conf.: 134, 135; hijo de Alfonso XI, hermano de Enrique II, conde de Alburquerque, señor de Haro y Ledesma, y conde de Paredes: 167, 168

Sancho, hijo de Gil Sánchez: 185

Sancho, hijo de Juan Pérez, ts.: 99; hijo de Ordoño Martínez, ts.: 54; hijo de Pedro Martín, ts.: 99; hijo de Rodrigo Pérez: 185; hijo del infante don Pedro, conf.: 82, 97; monje del monasterio de Hornillos, hijo de Sancho Martínez, abad de Husillos: 201; ob. de Ávila, conf.: 34, 35, 36, 134, 135; ob. de Cádiz, conf.: 134, 135; ob. de Oviedo, conf.: 134, 135, 164; ob. de Placencia, conf.: 134, 135; preste, ts.: 45 ; ts.: 64

Sancho "el Ferrero": 140, 145

Sancho I, rey de León: 339

Sancho III, rey de Castilla: 27, 28, 29, $30,35,36,82,84,97,100,113,114$, $134,135,163,164,194,213,225$, 298 ,
Sancho III el Mayor, rey de Navarra : 5, 6, 7, 11, 15; reinante en Castilla, Pamplona y Monzón; sincr.: 6, 7

Sancho IV: 82, 84, 85, 97, 100, 113, $114,134,135,163,193,194,213$, 225

Sancho VI, rey de Navarra: 27, 28, 30

Sancho Antolín de Cobas, ts.: 55

Sancho Aznar, ts.: 31

Sancho Bermúdez, conde de León, conf.: 18,19

Sancho Díaz, not. público de Palencia: 201, 202, 218, 219

Sancho Fernández, 185; hijo de Lorenzo Fernández de Cantoral, ts.: 161; hijo de Pascual Abad, ts.: 172; lego: 206; vecino de Husillos, ts.: 200

Sancho Fernández de Cantoral, ts.: 200

Sancho Fernández de Tovar, guarda mayor del rey, conf.: 193, 194, 213

Sancho Fernández de Villaumbrales, can. de Husillos: 205

Sancho García, conde de Castilla y Monzón: 6

Sancho González, abad de Husillos: 83, $86,87,148,236,252$; clérigo, vecino de Husilos: 253

Sancho González de Calahorra, can. de Husillos y not. apostólico: 233, 243, 251, 252, 262; clérigo de la diócesis de Palencia, can. de Husillos, secretario del prior y cabildo de Husillos: 252

Sancho González de Heredia, abad de Husillos: 340

Sancho Martín, hijo de Martín Cidón: 145

Sancho Martínez, 185, 201; can. de Husillos: 185

Sancho Martínez de Heredia, prior de San Juan, conf.: 213

Sancho Martínez de Leyva, merino mayor de Castilla, 84; conf.: 82

Sancho Martínez de Xodar, adelantado de la Frontera, conf.: 71

Sancho Mudarra, escribano: 131

Sancho Núñez de Valdés: 213

Sancho Pérez, 185; conf.: 10; lego, vecino de Villalón de Campos, juez árbitro: 107

Sancho Pérez de Calahorra, clérigo de la catedral de Palencia, can. de Husillos, not. apostólico: 241 


\section{LA ABADÍA DE SANTA MARÍA DE HUSILLOS: ESTUDIO Y COLECCIÓN \\ DOCUMENTAL (904 - 1608)}

Sancho Pérez de Villalón, criado de doña Juana, madre de doña María, juez: 105

Sancho Rodríguez, archidiácono de Cerrato: 80

Sancho Ruiz, criado de Juan Núñez de Ferrera: 159

Sancho Ruiz de Malvenda, licenciado, oidor de la audiencia real, vecino de Valladolid: 249, 250; ts.: 245, 246

Sancho Sánchez de Velasco, adelantado mayor de Castilla, conf.: 97; merino mayor: 63; escribano del consistorio de la catedral de Burgos: 207

Sancho Vermúdez, conf.: 9

Santa Cruz, licenciado, ts.: 351

Santiago, 185; carpintero, morador en Piña de Campos, ts.: 110; hijo de Diego Fernández, caballero: 203; hombre de Nuño Díaz, abad de Husillos: 130

Santiago Amo, ts.: 252

Santiago Casado, vecino de Fuentes de Valdepero: 298

Santiago García de Calahorra: 251

Santiago Gómez, 296; escribano público de Husillos: 295, 296; secretario de Gutierre de Carvajal, ob. de Placencia: 296

Santo, judío, especiero: 186

Santos Coxo: 185

Santos Ollero, lego: 127

Santos Pérez, hombre de Juan Pérez de Aceves, prior de Husillos, ts.: 145

Sape Pelaio, ts.: 2

Saracino, juez: 2

Savaricus, diácono: 1

Scipio, conf: 2

Sebastián: 43

Sebastián de Mena, can. de Husillos: 298

Sebastián Pérez, escribano público de Monzón: 99

Severo (Severus), diácono: 1

Sigefredo (Sigefredus), miembro de la iglesia de Nájera: 14; ob. electo en la iglesia de Nájera, conf.: 14

Simón (Symón): 207; ts.: 66; archidiácono del Alcor: 80; criado del prior Miguel de Husillos: 60; fraile, ts.: 63; ob. de Badajoz, conf.: 100; ob. de Sigüenza, conf.: 97, 100

Simón Paz: 185

Simón Pérez: 91

Simón Ruiz, conf.: 71
Sixto (Sixtus) IV: 235

Sol de Villaldavín, mujer de Pascasio de Mazariegos: 50

Speciosa, mujer de Abo Hamor: 2

Suero González de Benavides, tesorero de Husillos: 260, 263, 264

Suero Pérez, electo de Zamora y not. del rey en León, conf.: 71; maestre de Alcántara, conf.: 113; ob. de Cádiz, conf.: 82

TELLO (Tel, Tell, Tellius, Tellus): 88; chantre de la catedral de Palencia, ts.: 63; presidente del cabildo de la catedral de Palencia: 52; señor de Aguilar, conf.: 134, 135

Tello de Quintanuela, caballero, ts.: 58

Tello Fernández de Mante Cea, conf.: 18,19

Tello Fernández, hermano de Gutierre Gómez, abad de Husillos, ts.: 183

Tello Gutiérrez, justicia mayor de casa del rey, conf.: 82, 97

Tello Pérez, conf.: 34, 35, 36

Tello Pérez de Valverde, ts.: 63

Tello Téllez, electo en Palencia: 8, 16; ob. de Palencia, conf.: 49, 50, 56, 59, 63, 64; ts.: 63; sincr.: 53

Teodino (Theodinus), ob. Portuensis, conf.: 37

Teresa (Taresa), 50; mujer de don Sebastián: 99; viuda de García Calvo: 127

Teresa Ansúrez, reina de León: 6, 7, 298; reina, mujer de Sancho I: 339

Teresa Díaz, hija de Diego de Fuente Quintana, mujer de García Rodríguez: 53

Teresa Fernández: 50

Teresa Manrique, hermana de Juan Manrique, ob. de Orense: 175, 184

Teresa Pérez: 185

Terradillos, can. de Husillos: 295, 298

Terrin Alfaat, ts.: 44

Tesaviatio, maestro, conf.: 56

Tiburcio, maestro, electo de Coimbra, ts.: 63

Tomás (Thomas), ob. Iteranensis: 124

Tomé: 207

Toribia: 185

Toribia Fernández, mujer de Alfonso Fernández: 218; mujer de Alfonso Fernández, bolsero: 219

Toribio (Toribillo, Toriuillo, Turibio): 99, 298; hijo de Gutiérrez: 109; hijo 
de Gutierre Fernández de Piña: 218, 219; hijo de Juan Pérez: 185; padre de Domingo Fernández: 121, 123; sobrino de Juan Martínez de Villaviudas: 201

Toribio Abad, clérigo: 116; clérigo de Grijota, hijo de Lázaro: 119

Toribio Carnicero: 185

Toribio de Castrillo de Villa Vega: 185

Toribio de Lantadilla, beneficiado de Husillos: 243

Toribio de Vega, ts.: 112

Toribio Fernández, 180, 185; arcipreste de Castrejón, capellán en Santa María de Husillos, ts.: 189; clérigo: 124; clérigo, cura de Santa María de Allende el Río de Palencia: 185; clérigo de Fuentes de Valdepero: 206; hijo de Egidio Pérez, ts.: 174; hijo de Toribio Fernández, ts.: 173; hortelano: 185; maestre carpintero, ts.: 211 ; merino: 185; not. público: 221; yerno de Briz Fernández: 182

Toribio Fernández de Carrión: 185

Toribio Fernández de la Parrilla, can.: 226

Toribio Fernández de la Rúa, 176; procurador del prior y cabildo de Husillos: 181; vecino de Palencia, procurador del prior y cabildo de Husillos: 180; vecino de Palencia: 182

Toribio Fernández de Mazuela, escudero de Gutierre Gómez, ts.: 183

Toribio Fernández de Palenzuela, ts.: 226

Toribio García, hijo de Domingo García, vecino de Palencia: 200; hijo de García Gutiérrez, ts.: 218

Toribio Gato: 185

Toribio Gil: 185

Toribio González de Mazuela, criado del abad de Husillos, ts.: 189

Toribio Ibáñez: 185

Toribio Magaz: 185

Toribio Martín "Toro Santo": 185

Toribio Martín de Ampudia, not. público de Palencia, ts.: 148

Toribio Martínez, not. público de Palencia: 187

Toribio Martínez de Ampudia, not. público de Palencia, 211; ts.: 149

Toribio Martínez de Valdespina: 269

Toribio Miguel: 115

Toribio Muriel: 226
Toribio Pérez, hijo de Domingo Pérez, diácono de la iglesia de Santa María de Paredes de Nava: 126

Toribio Procallo, ts.: 122

Toribio Tragón: 185

Tovar, sobrino del can. Carvajo de Francisco: 298

Tristán Destilla, vecino de Palencia, not. público apostólico: 262

Tuldusi, presbíter: 2

URRACA (Vrraca, Vrracha): 185, 207; condesa, conf.: 10; hija de Juan Ravabello: 65; hija de Pedro González de Marañón, señor de Haza: 57; mujer de Adán: 88; mujer de Domingo Gallo, vecina de Villaumbrales: 133; mujer de Domingo Pérez: 115

Urraca "La Soriega": 88

Urraca I, reina: $18,19,27,35,82,97$, 114, 135, 163, 175, 184, 193, 336; condesa de Castilla, 5, 6, 7; conf.: 3, $4,7,9$

Urraca Fernández, infanta: 17

VALDEVIEJO, can. de Husillos: 298

Valeriano (Valeriamis), ob. colocensis: 103

Vasal, fiel, conf.: 41

Vasco, ob. de de Segovia, conf.: 134, 135; ob. de Palencia, canciller mayor de la reina: 137, 138, 145; ob. de Palencia, 139; not. mayor del reino de León y canciller mayor de la reina, conf.: 134, 135, 136

Vela de Navarra, conde, conf.: 27, 28, 30

Vasco Fernández de Toledo, ob. de Palencia: 141, 142

Vasco Rodríguez, maestre de la orden de Santiago, conf.: 113

Vela, conf.: 82

Velasco de Valdezat, ts.: 57

Velasco, ob. de Segovia, conf.: 82

Veldi, ts.: 2

Vellida, judía de Valladolid: 91

Vicente (Uincentius, Viçeynte): 207; abad de San Pedro de Arlanza.: 14; ob. Maranensis: 124; sobrino de Fernán Clemente: 208; ts.: 118, 119, 121

Vicente Martínez: 185

Vidal "el abate": 16

Vilielmo, ob. de Segovia, conf.: 27 
Villado, can. de Husillos: 347

Villalba, ts.: 57

Villalobos, capellán: 298

Violante, reina, mujer de Alfonso X, sincr.: 73

Vítores Cantarero: 298

XEMEN Ibáñez, ts.: 57

YAGO Pérez, criado de Juan Rodríguez de Sasamón: 185

Yagonza, mujer de Santo, judío: 186

Yague: 207

Yáñez, yerno de Juan Díaz de Potes, vecino de Palencia, ts.: 93

Yáñez Domingo de Villaumbrales: 88

Yenego López, criado de Lope García, sacristán, ts.: 127
Yolanda (Yolant), reina, mujer de Alfonso X: 71

ZACARÍAS (Sacharias), ob. Suationensis: 103

Zag (Çag) Zidicario de Villadiego, judío, hijo de Salarim, arrendador de las tercias reales: 220

Zalama, presbíter, hermano de Abo Hamor: 2

Zarraon, racionero: 298

Zulemán, judío, corredor, hijo de don Zague de Palencia, ts.: 186

[...] Fernández, tesorero de la catedral Toledo, ts.: 197

[...]z de Gamarra, escudero, ts.: 58 


\section{DAVID MARCOS DIEZ}




\section{LA ABADÍA DE SANTA MARÍA DE HUSILLOS: ESTUDIO Y COLECCIÓN \\ DOCUMENTAL (904 - 1608)}

\section{2. ÍNDICE DE LUGARES}

ABEZA (Abeça, Aveça), pago: 185, 187,298

Acarraval, pago: 298

Agnani (Anagnie), 136, 223; dat. doc.: 37

Aguadada, prado: 185

Aguilar de Campóo: 91

Alcalá de Henares: 184; dat. doc.: 175

Alcañizes, dat. doc.: 92

Alcor, pago: 250

Alerguera, pago: 209

Algeciras: 298

Aliende, pago: 298

Almería: 25

Amayuelas de Abajo (Amayuelas de Yuso, Amayuellas): 79, 81, 99, 185; término: 298

Ampudia (Fonte Pudeda, Fonte Pudia, Hempudia): 2, 37, 185, 185, 298, 346, 347, 348, 349, 351

Amusco (Hamusco): 185, 210, 298

Annillo: 3

Aranda de Duero (Arandam): 14

Arenas, pago: 185

Arenillas, pago: 185, 292

Arganza: 14

Arlar, término: 3

Arroyales, pago: 99, 185

Arroyo, pago: 25, 185

Astorga, diócesis vacante: 113

Astudillo (Astodiello), 4, 185, 215, 220; dat. doc.: 215, 220; término: 298

Atalaya, camino: 185

Aterada, pago: 116

Aucensem, diócesis: 14

Autilla del Pino: 185

Autillo, camino: 185

Avacin (Auacin): pago

Avenar, pago: 185

Ávila, diócesis: 70

Aviñón (Auinion), 239; dat. doc.: 103, 124,

Ayuso, arroyo: 185

BADAJOZ (Badailoz, Badalloz): 29, 82

Baeza (Baeça): 82

Baños de Cerrato: 185

Barcelona (Barchinonie): 29

Barguilla (Barguiella): 56

Barriales: 185

Barrihuelo: 207

Barrio, fuente de: 185; pago: 185

Barrio Cid, pago: 185
Barrio Moro, pago: 185

Barrio, camino: 185

Báscones de Ojeda (Bastones, Váscones): 91, 159

Bayona: 82

Becerril de Campos (Becerril, Becerril, Bezerril): 5, 8, 49, 60, 137, 146, 147, 167, 185, 210, 222, 259, 298; camino de: 185; dat. doc.: 172; término: 185

Becerrilejos (Bezerrileios, Bezerrileyos): 5, 37, 72, 185, 199; camino de: 185

Berneguer: 185, pago

Bezanan, pago: 185

Bezerral, pago: 185

Boadilla del Camino (Bouadiella del Camino): 72

Boca del Soto del Abad, pago: 298

Bragas, pago: 295, 298

Braziellas, pago: 185

Brevesca (Berbesca), pago: 37

Buen Consejo, pago: 298

Buezo, pago: 14

Burgos, 185, 207, 213, 214, 216; dat. doc.: 71, 171, 191, 192, 193, 194, $207,212,213,214,242,248$; diócesis, 14; diócesis vacante: 134, 135

CABAÑA DE BRAZIELLAS, pago: 185

Cabañuelo, pago: 221; sendero: 185

Cabevallaca, pago: 185

Cabo de Viña (Cab de Vinea, Caput de Uinea, Capite Vinee), pago: 25, 30, 36,40

Calabazanos: 37, 185, 210, 298, 339; término: 186

Calahorra, 298; diócesis vacante: 100

Calatañazor

(Canatanazore, Cañatamaçor): 14, 91

Calce, pago: 159

Callejas, camimo: 185

Campejones, pago: 185

Campo, camino: 49

Canellas, camino: 7

Cangas: 91

Canizar, pago: 185

Canóniga, pago: 185

Cantero Nava, otero: 185

Cañamales, camino: 185

Cañizal, pago: 185

Capiscol, pago: 185

Carejas (Karelias): 1 


\section{DAVID MARCOS DIEZ}

Carnoten: 70

Carrevitrera (Carre Uitrera), camino: 3

Carrera Moros, camino: 226

Carrión (Carrione), camino: 49; río: 5 , 7, 9, 24, 40, 46, 112, 155, 185, 243, 267, 269, 298

Carrión de los Condes (Carrionem): 5 , $9,17,27,82,84,97,113,114,134$, 135, 163, 164, 185, 193, 194, 207, 213, 292, 298, 339; camino: 7, 173, 185; dat. doc.: 27, 28, 35, 36, 85

Casarejos, pago: 185

Casasola, pago: 185

Cascajuelos de Golpejares: 185

Castañares, camino: 185

Castellanos (Castellas): 79, 81

Castilla (Castella, Kastella): 6, 12, 13, 14, 16, 21, 25, 29, 36, 253, 339

Castrejos, pago: 185

Castrillo (Kastrelo, Castrelu, Castrello, Castriella): 2, 27, 185, 298

Castrillo de Villavega: 207

Castro, camino: 185

Castromocho (Castro Mocho): 185; término: 298

Castroverde de Cerrato (Castro Verde, Castro Viridi): 37, 185, 210, 244, 250

Catalaunen, diócesis.: 70

Cavia, dat. doc.: 198

Caztaila: 29

Ceislo (Çeislo), pago: 185

Celada (Celata, Cellata): 37

Celanova (Cellanova, Cellam Nouam Celamnouam, Çellanova): 19, 27, 35, 37, 185

Cerezo, pago: 185

Cerrato: 91, 250

Cevico Navero (Çivico Nabero): 210

Chartres: 89

Cid Ferrero, pago: 298

Cilleruelo (Çelleruelo, Santa María de Cilleruelo, Sancte Marie de Cellerolo): 37, 38, 40, 43, 92, 101, 185, 298

Cisneros (Cenisarios): 1

Clermont, dat. doc.: 32

Clunia (Cluniam): 14

Cobiellas: 207

Coca: 51

Cogujada, arroyo: 185

Cojo, pago: 185

Colio: 91

Colunga: 91

Conejeras, pago: 185
Congosto: 14; camino: 185; pago: 185

Corcibarbas: 70

Corral Mayor, pago: 185

Corrales: 7, 91

Coxo, pago: 185

Cuadro, pago: 185

Cubafarta, pago: 185

Cuéllar (Colar): 30, 82, 97, 114, 135, 163, 193; dat. doc.: 30

Cuenca (Concam): 35, 36, 298; diócesis vacante: 82

Cuesta Redonda de Cardaño, pago: 289

Cueva Menor, pago: 185

Cuevar Mayor, pago: 185

DE LA VIRTUD, arroyo: 226

Dehesa Braua: 5, 339

Denia: 347

Druso, pago: 185

Dueñas (Donnas): 5, 185

Duero (Dorium), río: 14

Duesos, pago: 91

EL ARNAL, pago: 49

El Atali, pago: 185

El Burgo de Osma (Osma), 192; diócesis: 14; diócesis vacante: 163, 164

El Espino, pago: 185

El Hedero, pago: 117, 122

El Hoyo de Rabagudo: 290

El Llano, pago: 185

El Melgar: 185

El Pedrón, pago: 185

E1 Perejil: 185

El Pico, camino: 185

E1 Portillo: 295, 298

El Rocín, pago: 298

El Sendero, pago: 118

El Sotillo: 177, 179

Eras de Suso, pago: 185

Ermildo Rodríguez, mujer de: 27

Escobares, pago: 185

Esgueva, río: 252, 253

España (Spaña): 70, 339

Espega (Spega), pago: 14

Espina (Spina): 41

Espino: 185

Espinosa: 185

Évora (Evoram): 29

FAZA ORTIZ, pago: 185

Fazas, pago: 185

Febra Mala, pago: 185

Ferrero, camino: 185 


\section{LA ABADÍA DE SANTA MARÍA DE HUSILLOS: ESTUDIO Y COLECCIÓN \\ DOCUMENTAL (904 - 1608)}

Finojal, pago: 185

Fito, pago: 185

Florencia (Florentie), dat. doc.: 78

Fonda, camino: 185

Fondón del Prado, pago: 64, 185

Fontanillas, pago: 185

Fortuño, otero: 7

Foyal, pago: 185

Foyales (Foiales): 54, 57, 185

Foyo, pago: 185

Foyo de San Pedro, pago: 185

Foyo de Valdemeneses, pago: 185

Frailes, arroyo: 19, 27, 35, 63, 185, 195, 196, 197, 198, 199, 267, 298

Frama las Abejas, pago: 91

Francia: 70

Frechilla (Frechela): 17, 27, 35, 185, 298, 339

Frieras, arroyo: 185

Fuente Amarga, pago: 185

Fuente de Barrio, pago: 185

Fuente de Castrello, pago: 2, 185

Fuente de las Frieras, pago: 185

Fuente de Salguera, pago: 185

Fuente del Ero, pago: 185

Fuente Fierro, pago: 91

Fuente Mariella, pago: 91

Fuente Mayor, pago: 185

Fuente Quintana (Fonte Quinana, Fuent Quinana, Fuent Quintana, Fuentequinana, Fuente Quinava): $10,37,52,53,161,185$; camino: 60 , 185; término: 187

Fuente Rodrigo, camino: 185

Fuente Sacollán, pago: 185

Fuente Santillán, pago: 99

Fuente Vellosa, pago: 185

Fuentelisendo (Fontem Aldesendo, Fuent Aldesendo): 55, 57, 59, 93, 183, 185, 186; dat. doc.: 55

Fuentes de Nava (Fontes de dun Uermudo, Fuentes de don Bermudo): 27, 37, 185, 210, 298; término: 298

Fuentes de Valdepero (Fontes, Fontibus de Vallepero): 5, 37, 90, 91, 110, $111,112,169,174,177,179,185$, 206, 210, 238, 285, 298; dat. doc.: 206; término: 206, 224, 298

GALGA, pago: 185

Galicia: 14, 21, 25, 29, 339

Gil del Arroyo, pago: 185

Golpejares, pago: 185

Golvera, pago: 201

Golvira, pago: 185
Granada: 29, 255

Grijota (Ecclesia Auta, Ecclesiota, Glisota, Grigota, Griiota): 9, 17, 24, $37,88,117,185,203,204,205,206$, 210, 298; dat. doc.: 188, 203, 288; término: 185, 208, 209, 298

Guadalajara: 238

Guadalquivir (Gadalquivir), río: 29

Guaza, camino: 185

Gutierre Álvarez (Guterre Áluarez, Billa Gutierre, Uillam de Guterre Aluariz, Vilagoterre, Villa Gutierre, Villagutierre Álvarez,): 4, 6, 7, 27, 35, 37, 59, 185, 220, 298; término: 265

HARRUQUEROS, camino: 298

Haza (Aça, Aça la Uieia, Aza): 54, 55, 57, 58, 59, 93, 183, 186; dat. doc.: $54,56,58$

Hebra Mala, camino: 185

Hedero, pago: 120

Hérmedes de Cerrato (Érmedes, Érmidas, Érmides): 56, 185, 244, 245, 246, 249, 250, 251, 298; dat. doc.: 249

Hermosilla, pago: 4

Hornillos de Cerrato (Forniellos, Hornillos): 90, 91

Hoyales de Roa (Foyades, Foyales): 57, $59,93,183,186$

Hoyo de Andrinos: 5

Husillos (Fuselos, Fusellos, Fusiellos, Fusillos, Fustillos, Fusyllos, Hosyllos, Husiellos, Usillos): 5, 14, 26, 31, 37, 40, 47, 48, 83, 86, 87, 94, $109,110,112,115,117,118,119$, $120,121,122,123,128,129,131$, $140,141,144,145,158,166,174$, $175,176,177,179,180,185,196$, 200, 201, 202, 207, 217, 230, 232, $233,234,237,250,251,252,253$, 257, 259, 260, 262, 263, 264, 269, 273, 276, 278, 280, 281, 292, 293, 295, 296, 297, 298, 305, 308, 312, $313,318,327,328,331,339,343$, 347, 348, 351; camino: 185; coto: 224; dat. doc.: 14, 31, 74, 75, 77, 80, $83,104,109,139,143,152,153$, 156, 161, 174, 183, 189, 196, 200, 204, 205, 209, 221, 230, 233, 237, $239,241,243,251,252,257,260$, 267, 268, 269, 270, 271, 272, 273, 277, 280, 282, 289, 290, 295, 296, 297, 298, 300, 301, 306, 307, 308, 
$309,311,312,313,319,320,322$, $326,320,330,331,332,335,337$, 340, 341, 343, 345, 347; suelo: 185 ; término: $85,116,180,182,185,188$, 207, 211, 224, 269, 281, 283, 289, 295, 298, 332

\section{INTRIAGO (Yntrago), pago: 91}

JAÉN (Jahén): 82; diócesis vacante: 82 Jas, pago: 185

Jerez de la Frontera, dat. doc.: 76

Jerusalén (Iherusalém): 207

Jigondo, camino: 185; pago: 185 , 226, 298

Jiján: 185

Juan Maestro, camino: 185

Judíos, camino de: 60, 185

LA AGUILERA, pago: 185

La Arena, pago: 185

La Arenilla, pago: 185

La Azuda, pago: 185

La Beata, pago: 201

La Cabaña, pago: 60, 185

La Calera, camino: 50

La Cárcava, pago: 185

La Carra, pago: 185

La Cava, pago: 185

La Cornella, pago: 185

La Cotorra, pago: 185

La Cova, viña: 43

La Cruz, camino: 3

La Cuesta, camino: 185; pago: 177, 185

La Escobar, pago: 185

La Fuente, arroyo: 185

La Holgatilla, pago: 185

La Huelga, pago: 185

La Laguna, pago: 185, 206, 298

La Lirona: 185

La Loba, pago: 185

La Losa, pago: 185

La Majadilla de Carrera Llano, pago: 185

La Mansilla (La Mansiella, Mansyella), pago: 185

La Mejorada, pago: 298

La Mollecera, pago: 185

La Momenta, pago: 185

La Monienca, pago: 185

La Muela, pago: 185

La Muñeca (Moneca, Monneca), pago: 298

La Natera, pago: 204
La Nava (Naua): 3; arroyo: 9, 204, 226, 298; camino: 185; pago: 185

La Obratilla, pago: 185

La Parra, pago: 185

La Pedrera, pago: 185

La Peña: 298

La Piesga, arroyo: 185

La Poza, pago: 185

La Quebrantada, pago: 185, 298

La Quinta, pago: 185

La Rabeca, pago: 185

La Rallosa, pago: 115, 117, 120, 121, $122,123,185$

La Requejada, pago: 185

La Reyerta (La Refierta), monte: 146, 147, 167, 168, 185

La Segadora, pago: 99

La Solana, pago: 185, 295, 298

La Tejada, pago: 185

La Torrecilla, pago: 185

La Traviesa, pago: 185

La Troxa, pago: 185

La Tuda, pago: 185

La Vega, pago: 25; término: 50

Labaniegos, pago: 185

Ladrón (Latrone), valle: 7

Laguna de la Dueña, pago: 185

Laguna Falsa, pago: 201

Laguna Freiras, pago: 185

Laguna Salida, pago: 185

Lagunales, pago: 185

Las Arroyadas, pago: 185

Las Bimbreras, pago: 185

Las Callejas, pago: 185

Las Causas, pago: 185

Las Finqueras: 185

Las Foyadas, arroyo: 185; pago: 185

Las Frieras, pago: 185, 201; término: 185

Las Fuentes, arroyo: 185

Las Fueras, pago: 298

Las Junqueras, pago: 185

Las Lagunillas, pago: 185

Las Lomas, pago: 185

Las Majuelas, pago: 185

Las Mimbreras, pago: 185, 295, 298; soto: 26

Las Pasaderas, pago: 185

Las Piedras, pago: 185

Las Polientas, pago: 185

Las Quintanas, arroyo: 3

Las Quintanas de Grijota, pago: 88, 185

Las Sarzas (Las Sarças), camino: 64

Las Sernas, pago: 298

Las Solanas, pago: 201 


\section{LA ABADÍA DE SANTA MARÍA DE HUSILLOS: ESTUDIO Y COLECCIÓN \\ DOCUMENTAL (904 - 1608)}

Las Viñas, pago: 185

Las Zarzas, camino: 185; pago: 185

Ledesma: 91

Leges: 91

Leh, fuente: 4

León (Legione): 6, 7, 12,13, 14, 21; diócesis: 107; sede diocesana: 12

Lerma: 349

Lerones (Lerrones): 81

Letrán (Laterani), dat. doc.: 23, 48, 94

Liébana: 91

Lilio, pago: 185

Limoges, diócesis: 94

Linderos Viejos, pago: 46

Lisboa (Lixbonam): 29

Llano, camino: 185

Lobaharta, pago: 185

Longuera, pago: 185

Lorigo: 91

Los Arenales, pago: 185, 298

Los Arnales, pago: 99

Los Cabrones, carrera de: 185

Los Calzes, pago: 266, 298

Los Cambrones, pago: 185

Los Campejones, pago: 185

Los Casares, pago: 185

Los Cernales, pago: 185

Los Ciruelos, pago: 185

Los Conchonares, pago: 185

Los Espinos, pago: 185

Los Fitos, pago: 233

Los Foyales, pago: 185

Los Foyos, pago: 185, 201, 298

Los Linares: 185

Los Manzanos, pago: 298

Los Mayuelos, tierra: 185

Los Molares, pago: 185, 298

Los Moledores, camino: 298

Los Novios, sendero: 185

Los Olmillos, pago: 185, 298

Los Ortezuelos, pago: 199

Los Palomares, pago: 185

Los Paños, camino: 4

Los Picones, pago: 185

Los Picos de Carrera Mazariegos, pago: 185

Los Prados, camino: 99

Los Salzes, pago: 185

Los Vallejos, pago: 185

Lugo, diócesis vacante: 82

Lyon (Lugdim, Lugduni), 239; dat. doc.: 67,70

MADRID, 339; dat. doc.: 238, 239

Magaz de Cerrato: 180
Majuelo, pago: 185

Majuelos, pago: 185

Malcena: 185

Malladas, camino: 185

Mamblas, pago: 185

Manguillas del Val, pago: 185

Manzanedo, pago: 185

Manzanillo, pago: 185

Marcuendo, pago: 298

María Álvarez, camino: 173

Mata Vacas, pago: 226

Matanza, camino: 185

Matarrojas, pago: 185

Materiolum, pago: 14

Matiella, camino: 99

Matilla, pago: 185, 292

Mayor, camino: 185

Manzanedo, pago: 298

Mazariegos (Mazaregos): 3, 37, 185, 298

Media Era, pago: 185

Medina de Silves: 29

Medina del Campo: 114, 135, 163, 193, 238; dat. doc.: 97

Melgar de Fernamental (Melgar de Fernán Armentales): 91

Melgar, heredad: 50

Melgarejo, pago: 145

Melgares, pago: 99, 185

Menor, camino: 185

Mentanges (Mentanches): 29

Mercaderos, arroyo: 173; camino: 49, $116,173,185$

Mérida (Emeritam): 29

Mértola: 29

Mesella: 14

Miguel Peláez, arroyo: 185

Mimbres Pardos, pago: 298

Miranda, otero: 5

Mojasedas, sendero: 185

Molino, camino del: 185

Molino de en Medio, pago: 298

Molmo, camino: 185

Monte, camino del: 185

Monte del Rey: 4

Montealegre (Monte Alacri): 34, 185

Monzón de Campos (Monçonem, Monteson, Montesone, Montson, Montsoy, Monzón, Munzum): 5, 6, 7, $8,9,12,14,17,30,37,46,114,185$, 199, 210, 282, 295, 298, 339; camino : 185; dat. doc.: 195, 199 , 228, 231, 256, 258; suburbio: 1; término: 159, 162, 256, 258, 295, 298 
Moral, pago: 185

Morillo, camino: 185

Moro, pago: 185

Moroco, pago: 185

Moscatel del marqués de Monzón: 298

Motera: 37

Moyuelo, prado: 185

Muñeca (Monneca), pago: 185

Murello: 14

NÁJERA (Nágara): 14, 21

Nelazos: 185

Niebla (Nebla, Neblam): 29

Noyas, otero: 185

OLALLA, pago: 185

Olmeda, pago: 185

Opera, pago: 59

Orense (Aurien): 70

Orilla Nava, pago: 185

Oterdajos, pago: 207

Otero de Cid, pago: 185

Otero de Lobos, pago: 185

Otero del Obispo: 24

Otero del Orto, pago: 185

Otero del Verto, pago: 185

Otero Mueso, pago: 185

Oteruelo, arroyo: 119; pago: 145, 185

Oteruelo de Vid, pago: 185

Oviedo: 89

Ovis, pago: 91

PADIELLA, camino: 185; otero: 185

Pajarejos (Paliareios): 6, 7, 8, 27, 35, 137, 339

Pajares (Paiares, Paliares, Pallares, San Joan de Pajares, San Juan de Pajares): 6, 7, 9, 17, 27, 34, 35, 37, 59, 76, 92, 101, 128, 138, 167, 168, 185, 230, 236, 298; camino: 185; campo de: 34; pago: 173, 185; término: 49,185

Palacios de Campos (Palacio, Palacios): 4, 37; pago: 7

Palazuelos, 185; camino: 185; pago: 185

Palencia (Palentia): 4, 5, 9, 17, 20, 21, 24, 31, 37, 46, 61, 162, 168, 176, $180,185,192,194,200,201,207$, 210, 218, 219, 223, 234, 269, 310, 333, 338, 342, 351; camino: 185; dat. doc.: $21,22,62,64,66,86,93,95$, $96,102,105,106,111,112,125$, $127,130,136,137,138,142,144$, $145,148,149,155,162,165,166$, $169,170,173,178,179,182,187$,
201, 202, 210, 211, 216, 218, 219, $223,224,225,232,236,253,254$, 262, 264, 267, 285, 327, 328, 335, 336, 338, 351; diócesis: 13, 95, 210 , 222, 234, 235; sede diocesana: 11, 12, 15, 17, 22, 23, 32, 39; término: 181, 201, 207, 224, 226, 298

Palenzuela, dat. doc.: 128

Palomar, pago: 185

Palomarejo, pago: 185

Palomares, camino: 185

Pamplona (Pampilona): 6

Páramo, pago: 185

Paredejas, pago: 185

Paredes de Nava (Paredes, Parietes): 3, $102,146,147,167,168,185,210$, 240, 298; camino: 50, 185; dat. doc.: 126, 167; monte: 49, 167, 173, 185; término: 185

Payo: 91

Pedragal, pago: 185

Pedraza de Campos (Petraza): 2, 185

Pedregales, camino: 185

Peliella, camino: 185

Pembes: 91

Peñafiel (Pennafiele): 7, 292, 298, 339

Peñaranda de Duero (Pennam de Aranda): 14

Perales: 185,199

Perusa (Perusii), dat. doc.: 68, 69

Pico de don Jimeno, camino: 185

Pico del Abad, pago: 185

Piedra Fita, pago: 185

Piña de Campos (Pinna, Piña de las Nueve Villas): 185, 210, 298

Piquera (Pyquera), pago: 159

Pisuerga, río: 185

Población de Campos (Populacione): 37, 60, 185; camino: 99

Poblacioneja (Poblacionciela, Poblacioncilla): 72, 185, 298; término: 185

Pocilgas, pago: 185

Pontezilla, pago: 201

Pontido, pago: 185

Portugal (Portugalis): 29

Posa Nava de Padiella, camino: 185

Pospinom, arroyo: 3; fuente: 3

Pozo Nava, camino: 185

Pozo Salso, pago: 185

Pozuelo, pago: 185

Pozuelos, camino: 185

Pozuelos de Amianos (Pozolos Damianos, Pozuelos Damayanos, 


\section{LA ABADÍA DE SANTA MARÍA DE HUSILLOS: ESTUDIO Y COLECCIÓN DOCUMENTAL (904 - 1608)}

Pozuelos de Meanos, Puzolus): 16, $27,45,185$

Pradiellos, pago: 201

Prado, camino: 185; pago: 99

Prado del Val, pago: 185

Prado Moral: 4

Praga (Pragen).: 70

Puente Vieja: 185

Pumarejos, pago: 185

QUINTANA DEL PUENTE (Quintana de la Puente): 298

Quintana Dueñas, pago: 207

Quintana Mediana, pago: 1

Quintanas de Población, pago: 185

Quintanilla de Valdepero (Quintanella, Quintanellam,

Quintanilla, Quintaniella): 5, 17, 33, 37, 46, 90, $91,110,111,112,185,207$

REBIELLA, pago: 185

Redilla, pago: 185

Reguera del Anegal, pago: 185

Requejo (Requexo), camino: 185; pago: 91, 185

Revilla de Campos (Rebiella): 91, 185

Rey, camino del: 185

Ribas de Campos (Ribas, Ripis), 5, 37, 185, 210, 298, 343; camino: 185; término: 185,298

Río, camino del: 185

Roma: 17, 232, 233, 278; dat. doc.: 89, 222, 229, 235, 261, 274, 350,

Romío: 60

SAHAGÚN: 29; camino: 185; dat. doc.: 29

Sahagún el Viejo (Sanct Fayum, Sancti Facundi, Sancto Facundo, Sanctus Facundum de Paredis, Sanctus Facundum): 3, 5, 17, 35, 37, 40, 46, 48, 96, 102, 339; camino: 185; pago: 185; término: 298

Salamanca (Salamantinis): 70

Salguero, pago: 185

Salinas de Añana: 185

Salmoral, pago: 185

Salpino, pago: 298

San Adrián de Valdepero (San Adrián, Sancti Adriani, Sanctum Adrianum): 27, 35, 37, 66, 76, 92, 101, 185; arroyo: 185

San Andrés, camino: 185; pago: 185

San Cebrián de Campos (Sant Cibrián), dat. doc.: 234
San Cebrián de Meneses (Sant Cibrián de Meneses): 63; dat. doc.: 63

San Cristóbal (Sanctus Christoforum), pago: 30, 36, 46, 185, 226

San Cristóbal de Monzón, pago: 185

San Cristóbal del Otero, iglesia: 185

San Elices (Sanct Yliçes), pago: 167

San Esteban de Gormaz (Sant Esteuan de Gormaz): 91, 159, 162

San Felices: 17, 185; camino: 50, 185

San Miguel, iglesia: 185

San Ovio (Sancto Ouio): 37

San Sebastián, arroyo: 173, 185; camino: 49, 173, 185; pago: 173, $185,246,249,250,251$

San Sebastián de Hérmedes (Sant Sebastián de Çerrato, Sant Sebastián de Hérmidas, Sancti Sabastiani de Remides, Sanctum Sebastianum de Hermidas): 17, 27, 35, 37, 128, 129 , 185, 244, 245, 246, 247, 249, 262

San Sebastián de Pajarejos, pago: 298

San Servián, camino: 185

San Yarre (Sant Iarre), pago: 60

Sancta Eufemia, camino: 226

Sandoval (Saltus Noualis, Saltum Noualem), dat. doc.: 41

Santa Ana, pago: 298

Santa Coloma: 185

Santa Eufemia, pago: 185, 298; término: 46

Santa Gadea, pago: 9, 185

Santa María, arroyo: 50; colación de Grijota: 203, 204; monte: 49; pago: 298

Santa María de Husillos (Santa María de Husiellos), monte: 173, 185; término: 46

Santi Vañeo, pago: 91

Santiago de Compostela: 207, 339; diócesis vacante: 97

Santiago de Quintanilla (Sancti Iacobi), pago: 24

Santillán de la Cuesta (Sant Illán, Sant Yllán, Sancti Iuliani, Sancto Luliano, Santillán): 6, 7, 10, 17, 24, 31, 35, $37,38,40,48,52,53,73,88,119$, $128,129,140,141,142,143,144$, 145, 161, 185, 204, 205, 210, 339; camino: 122; término: $133,139,140$, $141,142,144,221,232$

Santoyo: 210

Saxo Albo: 70

Segovia: 132; dat. doc.: 131

Senderuela, pago: 185 


\section{DAVID MARCOS DIEZ}

Sequillo, camino: 185

Serna de Congosto, pago: 26, 185

Sevilla (Sibilia): 29; diócesis: 94; diócesis vacante: 213

Silo, pago: 185

Silves: 29

Simancas: 339

Soareños, valle: 99

Sobradillos, pago: 185

Solajeras de Santillán, pago: 88

Solvira, pago: 185

Soria: 91; dat. doc.: 197

Sotros: 91

TÁMARA DE CAMPOS (Támara): 263; dat. doc.: 263

Tamariz de Campos (Tamariz): 51

Tardajos: 242, 298

Tariego de Cerrato (Tariego): 185

Tejada (Tegata), pago: 12, 185

Todiellas, pago: 185

Toislo, pago: 145

Toledo: 14, 16, 21, 25; dat. doc.: 38; diócesis: 70

Tordesillas: 292

Torquemada (Ture Cremata): 46, 90, 91, 185; camino: 201

Torre de Astudillo (Turre de Astudelo, Turre de Astudello, Turre de Studelu): 27, 35, 37, 48, 59, 64, 185

Torre de Jozdada, pago: 185

Torre de Pajares: 185

Torrecilla: 292

Torrelobatón: 159, 162; dat. doc.: 159

Torremormojón: 185

Tórtoles de Esgueva (Tórtolas): 210

Tovarcio, pago: 207

Tras Casasola, pago: 185

Tras el Soto, pago: 170

Tras Soto, camino: 185; pago: 185

Travieso, camino: 185

VACIABOLSAS (Vazias Bolsas), pago: 295, 298

Vadiello, pago: 185

Val (Ual), camino: 185; pago: 88

Val Bermudo, pago: 116

Val de Bermudo, arroyo: 185

Val de Carajada, pago: 185

Val de Castro, pago: 185

Val de Cazán, pago: 185

Val de Cevico, pago: 185

Val de Dios, pago: 91

Val de don Padre, término: 50

Val de El Llano, pago: 185
Val de Emperador: 17

Val de Fornos: 185

Val de Frades, pago: 185

Val de la Caraza, pago: 185

Val de la Carrera, pago: 185

Val de la Hesa, pago: 185

Val de Lomudo, arroyo: 185; pago: 185

Val de Nuño, pago: 185

Val de Olmos: 64, 185

Val de Quintanilla, pago: 185

Val de Rey, sendero: 185

Val de Santillán, pago: 145

Val de Soña, pago: 185

Val de Tao (Ual de Thau), término: 50

Val de Zecán, pago: 185

Val Mayor, pago: 185, 188; término: 65

Val Peral, pago: 185

Valdegestro, pago: 185

Valdeolmillos: 4

Valdeperal: 4

Valdesauce (Val de Sanze): 210

Valdeseras, pago: 185

Valdesona, pago: 145

Valdesonque, pago: 221

Valdespina (Val Despina): 210

Valdeyecín, pago: 185

Valepretioso, pago: 7

Valera: 91

Valladolid, (Vallem Oletti, Vallis Oletti): $61,84,134,135,150,154,156,157$, $163,164,166,183,186,194,213$, $214,224,225,249,250,252,253$, 254, 279, 291, 292, 296, 298, 303, $314,315,316,317,324,344$; dat. doc.: $61,82,84,90,100,101,113$, $114,134,135,141,150,154,157$, 158, 163, 164, 184, 186, 190, 240, $245,246,247,250,259,265,275$, 276, 278, 279, 281, 283, 286, 287, 291, 293, 294, 299, 302, 304, 305, $314,315,316,317,321,323,324$, $325,333,338,342,344,349$

Valle Longo, pago: 49

Valle Luengo (Valle Longo), pago: 49, $159,173,185$

Valletariego, pago: 185

Valmayor, pago: 185, 206, 295, 298

Valmenor, pago: 185

Valoria (Valloria): 185

Valpeseso, pago: 185

Valprade: 185

Valverique: 91

Vega de Valdepero (Beça, Bega, Beza, Vega, Veza): 91, 110, 111, 112, 159, 185, 207, 298; pago: 185 


\section{LA ABADÍA DE SANTA MARÍA DE HUSILLOS: ESTUDIO Y COLECCIÓN DOCUMENTAL (904 - 1608)}

Velliza, pago: 292

Veral, pago: 185

Vercero, pago: 292

Verceruelo, pago: 292

Verdún (Verdunen).: 70

Vertadillo (Bretadiello): 185

Verzaña, pago: 99

Vieja, camino: 185

Villa Alarigo: 48

Villa Anadino, pago: 159

Villa Lomos, camino: 185

Villa Momana, pago: 185

Villa Ramiro, pago: 185

Villacarralón (Villa Carlón): 185

Villacastín: 37

Villacid de Campos (Villacis): 105, 185

Villaconancio (Villa Conançio): 185

Villafruela (Villa Fruela): 167; camino: 185

Villagarcía de Campos (Uillam Garsiam, Villa Garcia, Ville Garsi): 21,37

Villagonzalo (Villagonçalo): 91

Villagudiel (Uilla Godiel, Uillam Godel): 33, 63; camino: 50

Villajimena (Villa Ximena, Villaximena): 4, 37, 185

Villaldavín (Uilla de Don Daui, Uillam Don Daui, Uillam Dumdaui, Vilandavid, Villa Aluín, Villa Dondauin, Villandauin, Villandouin): $18,27,35,37,50,82,97,128,159$, $167,175,114,128,129,135,163$, 175, 184, 185, 193, 296, 298, 299; término: 275,298

Villalobón, camino: 185; término: 201, 207

Villalón de Campos: 107; dat. doc.: 107

Villálvarez (Uillam Albarrez, Villan Alberez): 33, 37

Villamartín (Uilla Martín, Uillam Martim, Villa Martino): 9, 43, 185, 201, 210, 298

Villamarzal: 292

Villamediana (Villa Mediana): 128, 185, 210; dat. doc.: 128
Villamuriel de Cerrato (Uilla Morel, Villamoriel): 24, 207, 185; monte: 24; término: 185, 207

Villanueva de Carazo (Villa Nueua de Caraço): 91

Villarroañe: 41

Villasoña (Villa Soña): 91

Villatello (Villa Tello): 105

Villatoquite (Uilla Toquit): 42

Villaudilla (Abaudella, Villabdela, Villabdella, Villabdellam, Villa Abdela, Villam de Abdella, Villaudela): 6, 7, 20, 27, 35, 37, 40, $59,61,62,125,126,127,128,129$, $171,185,240$

Villaumbrales (Villunbrales): 5, 10, 17, $37,133,139,140,141,142,143$, $144,145,185,187,210,222,232$, 298; dat. doc.: 133, 140, 266; término: 139, 140, 141, 142, 144, 266, 290

Villaverde (Villa Verde): 91; camino: 185

Villavieja: 292

Villazalama (Uillam Zaleimam, Villa Çalama, Zalama): 5, 30, 36, 185

Villazopeque (Villa Çopeque): 159

Villella (Villiella, Villilla): 91, 292

Villoldo: 298

Vimueras, soto: 26

Viña Alarigo: 26; arroyo: 26

Viña Colubreram: 5

Viña Mayor, camino: 204

Viña Redonda, pago: 185

Viñaderos, sendero: 185

Viñas Dehesas, pago: 185

Viñuela, camino: 185

Viziera, camino: 185

Vocikellas: 14

YUSO, arroyo: 185

ZAMORA, dat. doc.: 79

Zaragoza (Cesaraugusta): 21

Zarzadillo (Çarçadillo): 4 
DAVID MARCOS DIEZ 


\section{LA ABADÍA DE SANTA MARÍA DE HUSILLOS: ESTUDIO Y COLECCIÓN \\ DOCUMENTAL $(904-1608)$}

\section{3. ÍNDICE DE MATERIAS E INSTITUCIONES}

ABAD: $62,64,189,191,214,269$, 301, 336, 338, 346; capellanía del: 185

abadengo: 238

abadía: 64

absentismo: 328

absolución: 68,286

acatamiento: 108,340

accidente: 62

aceite: $112,207,228$

aceña: $24,56,66,77,86,185,206$, 230

Aceñuela, molino: 185

acreedor: 47

acuerdo: 244

adelantado mayor de Campos: 275

Adelantamiento de Castilla: 281

administración de sacramentos: 297

administrador: 40

alba: 319

albacea: 81

alcaide: 238

alcalde: 62

alcalde mayor: 281, 293

alcalde ordinario: 281, 293

aldea: $59,93,161$

alhóndiga: 342

Allén del Río, barrio de Palencia: 201

altar: 306, 307, 319

Aluno, molino: 185

amenaza: 210, 216

amojonamiento: 224,240

amparo: 190, 191, 214

Ampudia, concejo: 185

animal de tiro: 31

aniversario: $25,33,42,45,59,74$, 79, 81, 87, 162, 174, 201, 205, $218,219,257$,

Annal, molino: 185

Anulejos, molino: 185

apelación: 182, 265, 275, 281, 286, 287, 294

apeo: 46

apropiación: 181

aprovechamiento: 247

aprovisionamiento: 217

ara: 306,307

árbol: 31,62

archivo: 335,338

arrendamiento: $66,161,172,173$, $186,241,259,295$ arroyo: 19

Atacada, tierra: 185

Audiencia episcopal de Palencia: 285,343

áureo: $35,38,43,52$

auto: 335

autorización: 144, 151, 156, 183, $253,308,350$

aval: 41

avenencia: 46, 62, 98, 139, 140, 141, $142,143,144,145$

Avia, monasterio: 91

Azarón, aceña: 185

azor: 91

BARBECHO: 66

Bárcena, monasterio: 207

Barrial, viña: 60

Barrio de Suso, orden: 185

barrio: 44

Barrionuevo, barrio de Palencia: 201

Becerril de Campos, común: 172, 173; concejo: 267

Benavento, monasterio: 94

Benavides, monasterio: 295, 298

beneficiado: $60,171,191,214,269$, 293, 330, 346, 347

beneficio: 70, 89, 94, 233, 244, 245, 301

Bénévent-1'Abbaye, monasterio: 94

bestia: 91

Biblia: 91

bien: 32

bodega: 60,201

Brazacorta, monasterio: 91

Briviesca (Uiruiescar), molino: 9

Buen Consejo, aceña: 155

buey: $62,91,161,185$

Buitrón, calle de Husillos: 298; capellanía: 298

bula: $67,103,124,136,274,277$, 350

Burgos, capilla de San Yago de la catedral: 207; catedral de Santa María: 207

CABALLERO: 62, 85, 216

caballo: $62,91,159$

Cabe Casa, molino: 185

Cabeun, molino: 185

cabildo: 189, 297, 328, 330, 334 
Cabo de Viña, molino: 25, 59, 119 , 185, 241, 298; puente: 207

cabra: 207

Calahorra, catedral: 70

cáliz: 306, 307, 319

caloña: 31,66

cama: 306, 307, 319

cámara real: 338

camino real: 128

camisa: 112

Campo, puerta de la muralla de Valladolid: 183, 186

Campos, arcipreste: 91; merindad: 210

canciller: 150

candelero: 306, 307, 319

canongía: 70; huerta: 185

canónigo: 33, 40, 45, 47, 50, 54, 55, $80,84,113,131,134,149,164$, 171, 191, 194, 213, 214, 225, 233, 259, 269, 294, 295, 298, 301, 333, 340

cantera: 206

capa: $306,307,319$

capellán: 107

capellanía: $54,59,74,86,87,88,90$, $91,159,185,189,295,298$,

capilla: 159,165

carga: 170,173

cargo: 129,130

carnero: $25,31,161$

carnicería: 201

Carrión de los Condes, Cortes: 17

carta: 87

Casa Real: 336

Casa, molino: 59, 185

casa: $1,31,40,44,47,66,88,91$, $131,145,165,183,185,186,200$, 201, 202, 203, 204, 205, 207, 215, $219,230,252,253,257,260,263$, 264, 269, 273, 274, 277, 278, 279 , 291, 295, 298, 308, 314, 315, 316, $317,318,321,322,323,324,325$, 328,344 ,

casulla: 319

cauce: 267

caza: 281

cebada: $31,127,207,208,242,244$, $245,250,251,262$

cédula real: $333,334,335,338,340$

celebración de oficios: 330

censo: $64,185,200,232,242,245$, 246, 249, 250, 251, 252, 253, 254, $262,263,264,274,276,277,278$,
279, 290, 291, 298, 303, 304, 305, $309,314,321,331,332,335$

censo enfiteusis: $315,316,317,323$, $324,325,344$

centeno: 207

cera: 159

cerca: 243,295

cereal: 145,275

Cero, cerca: 185

Cerrato, merindad: 210

cesión: 268

Chancillería de Valladolid: 265, 267, 275, 276, 281, 283, 286, 287; presidente de la: 275,287

chantre: 301,330

Cima de La Loma, tierra: 185

cinta: 112

citación: 178

cláusula: 202

clérigo: $68,126,127,172,177,179$, 185,285

codicilo: 271

cofradía: 185,243

colación: 233,269

colegiata: 292

comisión: 329

Comitisa, tierra: 43

compañía: 112

compra: 62

compromiso: $105,111,125$

comunión: 330

concejo: $26,111,112,146,147,168$, 210,216

concesión: 84

concierto: $139,140,145$

Concilio de Husillos: 14; de Lyon: 94; de Trento: 294

Concordia: 269

conducho: 91

confesión: 330

confirmación: 5, 6, 13, 15, 22, 27, 30, $32,35,36,37,48,82,84,92,97$, $100,101,113,114,134,135,136$, 152, 154, 157, 163, 164, 184, 191, 193, 194, 212, 213, 214, 223, 225, 235

Congosto, tierra: 180, 181, 182

Congregación del Concilio de Trento: 310

consagración: 319

constitucion: 330

contador: 165

convenio: 64 


\section{LA ABADÍA DE SANTA MARÍA DE HUSILLOS: ESTUDIO Y COLECCIÓN \\ DOCUMENTAL $(904-1608)$}

coro: $60,269,295,297,298,319$, 330

corona: 192

corporal: 306, 307, 319

corral: $88,185,204$

corrección: 269

corregidor: 333

corrida de toros: 330

Corteruelas, tierra: 185

costumbre: 330

coto: $5,7,30,36,82,97,114,135$, 163 ,

criado: $60,201,275$

crisma: 311

crónica: 91

cruz: $306,307,319$

Cruzada: 159, 174, 201, 207

cuadro: 319

cuérnago: 199

cuestionario: 333

cueva: 298

custodia: 320

DEÁN: 351

decanía: 22, 32, 39

decreto: 91

demanda: $177,180,181$

denario: $4,5,74,87$

dependencia: 37

derecho: 32, 39, 48, 95, 129, 130, $210,216,283,333$

desagravio: 210,216

desembargo: 167, 168

deshonrra: 112

despoblación: 171, 234

deuda: 38, 47, 85, 190, 191, 201, 203, 214, 259, 304, 312, 321,

diezmo: 40, 48, 96, 102, 105, 106, $107,108,125,126,127,139,140$, $141,143,144,145,177,178,179$, $180,181,182,185,222,226,236$, $290,298,343$

difunto: 40,54

dignidad: 80, 269, 283, 295, 298, 301,340

dinero: 60, 201, 268

diócesis: 13

divisa: 12

documento: 333

Don Guarín (Domno Guarino, Don Guarí, Don Guarino), puente: 9, 17,298

donación: $1,2,3,4,6,8,9,10,15$, $16,18,19,21,23,25,26,27,34$,
$36,42,51,54,55,56,71,74,77$, $82,88,90,97,99,137,138,165$, $167,174,188,205,206,215,268$, $327,328,331,332,336$

dotación: 54, 74, 86, 87, 88, 90, 91

ducado: 266, 296, 298, 333, 338

EDICTO: 296

ejecución de bienes: 303, 304, 305

ejecutoria: $259,267,275,276,281$, 283, 294, 304, 335

El Arnal, heredad: 49

El Barrancal, tierra: 185

El Burgo de Osma, altar de San Pedro de la catedral: 91; cabildo de la catedral: 91 ; catedral: 91

El Cuadrón, torre: 185

El Pico de Casarejos, tierra: 185

El Silo, tierra: 185

El Sotillo, soto: 185

El Vado, mojón: 46

elección: 150, 151, 152, 153, 154, $156,157,158,293,333,336,338$

emigración: 101

encarcelamiento: 269,330

encomienda: 238

enfermo: 330

enterramiento: $74,87,159,270,272$, $280,309,313,330$

entrada: 131, 295

Entramas Aguas, tierra: 60

Era del Obispo, heredad: 64

ermita: 269

escritura: 296

escudero: 216

escusado: 40, 233

esparto: 112

estatuto: 47, 83, 95, 148, 233, 235, 243, 297, 330, 335

estera: 295, 298

Estiño, cofradía de Palencia: 201

estola: 319

estudiante: 330

estudio: 233

exceso: 269

excomunión: $68,69,287$

excusado: 269

exención: $28,37,68,84,113,128$, 134, 136, 164,171, 192, 194, 213, $223,234,310$,

exequia: 203

expediente: 338

explotación: 62

ezebro: 24 
FÁBRICA: 60, 233, 269, 295, 298, $301,327,330,331$

familiar: 68,269

Fenal, molino: 63

Fernando, tierra: 185

fiador: 31,170

fiadura: 85,214

fianza: 38,288

Final, molino: 63

fiscal: 294

florín: 336

fortaleza: 161

fragua: 298

Fresnillo de la Dueñas, monasterio: 91

Friera, tierra: 43

frontal: $306,307,319$

fruto: 41, 47, 222, 298

Fuencaliente, monasterio: 91

Fuentes de Valdepero, concejo: 98, 206; hospital: 24

fuero: $17,20,31,61,62,190,191$, 214, 298

fundación: 333, 338

GALLINA: 25, 259, 274, 278, 279, 298, 214, 315

gallo: 24

Gamonal, pago: 133

ganado: 1, 35, 46, 145, 275, 281, 283

ganado mayor: 275

ganado menor: 275

ganado ovino: 275

Godina, serna: 185

guarda: 293

guerra: 20

guindalera: 298

Gutiérrez Álvarez, concejo: 220

HABITANTE: 76, 92, 101, 145

hábito: 330

Harrén Casiellas, molino: 185

Haza, concejo: 54

helguera: 34

heredad: $27,35,40,41,42,48,49$, $52,53,59,64,66,72,81,82,90$, $91,97,114,135,159,163,172$, 183, 185, 186, 193, 201, 210, 250, $251,262,305,309,332,343$

heredamiento: 339

heredero: 29, 47, 51, 88, 259, 278, 284

herencia: 51
Hérmedes, abad: 165; concejo: 246, 247, 249; monasterio: 244, 245

herrén: 185, 298

herrenal: 295

hidalgo: 112,210

hijuela: 319

homicidio: 31,62

hora canónica: 269, 330

hortelano: 40

hospedaje: 281

Hospital: 207, 298, 312; tierra: 185

Hospital del rey: 27

huebra: 17

huerta: 24, 72, 155, 159, 162, 204, 231, 282, 298

huesa: $17,31,62$

humandero: 145

Husillos, cofradía del hospital: 185, 189; concejo: 98, 196, 197, 198, 199, 224, 232, 276, 281, 283, 322; hospital: 185, 320; puerta del Río: 217

IGLESIA: $1,2,21,37,48,51,59$, 60, 70, 89, 201, 206, 243, 269, $270,280,293,298,339$

iglesia colegial: 349

imposición fiscal: 192

impuesto: 234

indulgencia: 67, 103, 124, 239

infante: 150

infanzón: 28, 84, 100, 113, 134, 164, 194, 213, 225

información: $333,335,336,338$; “ad perpetuam rei memoriam": 295

infractor: 37, 136, 223

infurción: 66

inhibición: 287

interrogatorio: 295

inventario: 298, 311, 320

JARAFIZ: 185

Juan García Calentura, capellanía de: 185

jubón: 201

juez: 69, 105

juez árbitro: 111, 125

juicio: 63

juramento: 254

juriscicción: $10,11,37,54,62,131$, $136,185,223,233,250,251,262$, 269, 281, 283, 286, 294, 299, 310, 330

juro: 339 


\section{LA ABADÍA DE SANTA MARÍA DE HUSILLOS: ESTUDIO Y COLECCIÓN \\ DOCUMENTAL $(904-1608)$}

juro de heredad: $71,90,266,289$

justicia: 128, 293

LA BOERICA, calle de Valladolid: $314,315,316,317,323,324,325$, 344

La Cárcava, tierra: 43

La Cespedera, molino: 185

La Costanilla, calle de Valladolid: $183,186,252,253,254,274,277$, 278,298

La Dueña, iglesia: 185

La Huelga, tierra: 159

La Laguna, tierra: 65

La Magdalena, capellanía: 298

La Mula, tierra: 121, 123, 185

La Natera, tierra: 185

La Peña, majuelo: 60

La Presa, prado: 185

La Rallosa, serna: 185

La Red, tierra: 185

La Serna, majuelo: 60; tierra: 185

La Torrezilla, molino: 185

labrador: 131, 145, 161

laico: 68

lámpara: 112, 189, 207

Las Eras, tierra: 60

Las Foyadas, tierra: 185

Las Mimbreras, pago: 185

Las Quintanas, pago: 88

Las Zarzas, camino: 185

leña: 66

Lerma, duque de: 350

leyenda: 91

libra: $3,4,8,9,10,16,18,19,33$; áurea ditrina: 2

librería: 165,319

libro: 91, 306, 307, 319

libro becerro: 185, 189, 335

licencia: 46, 142, 143, 161, 186, 216, $244,246,262,334$

límite 13

limosna: 40, 298, 301

littera gratiosa: 94

Los Beneficiados, tierra: 185

Los Clérigos, tierra: 185

Los Monaziellos, tierra: 185

Los Prados, heredad: 64

Luenga, calle de Husillos: 185

lugar: 32

MADERA: 200, 319

magíster: 33 majuelo: 99, 185, 256, 258, 270, 271, 280

Majuelos de la Serna, viña: 59

manda testamentaria: 159, 203

mandato: 92, 101, 129, 130, 131, 132, 240, 247, 255

Manguiellas, tierra: 185

Manicis, tierra: 43

manípulo: 319

maravedí: 17, 20, 21, 24, 25, 26, 28, $31,41,43,44,45,46,50,51,53$, $59,60,63,64,66,72,73,74,77$, $86,87,91,112,116,118,119$, $120,121,122,123,133,155,169$, $185,187,203,208,209,211,221$, $228,232,253,254,256,259,264$, 274, 277, 278, 279, 289, 290, 291, $298,303,304,314,315,317,321$, $323,324,325,331,338,344$,

marca: 16,18

marco: 112

martiniega: 128, 129, 185, 276, 295

marzadga: $40,59,62$

matutina: 74,87

mayordomo: 38, 293, 320; de las rentas: 330

Maza Ericas, tierra: 185

Mazariegos, concejo: 185

media annata: $83,85,148$

media ración: 287

medida toledana: 173

medio racionero: 269,301

memoria: 273, 280, 288, 300, 309, 313

memorial: 292

menudo: 48

merino: 31, 40, 131, 237, 281

mesa abacial: 298, 314, 315, 316, 317, 323, 324, 325, 344; capitular: 298, 318

mesón: 324

mesquero: 145

metal: 319

misa: 54, 91, 201, 270, 271, 280, 309,313

misal: 60,319

mocha: 298

molino: 40, 56, 59, 63, 77, 86, 91, 185, 206, 259, 298

Mollete, tierra: 185

monaguillo: $35,60,82,97,114,135$, 163

monte: 247,298

Montoncillo, molino: 185 
Monzón, concejo: 195, 196, 197, 198, 199; merindad: 210; puente: $17,24,30,36,40$

Moral, serna: 185

moscatel: 298

mosto: 232

mueble: 47

mujer: 297

multa: 31

NOMBRAMIENTO: $78,150,160$, 176

Nuestra Señora de Allende el Río, iglesia de Palencia: 201

Nuestra Señora de Dehesa Brava, cofradía de Husillos: 243

Nueva, calle de Husillos: 185

OBISPO: $37,223,294,310$

objeto litúrgico: 297

oblación: 40

obligación: 333

obrada: 99

obrero: 40,330

oferción: 31

oficial: 293,330

oficio: 297

olio: 311

oposición: 255

orden: 76,338

orden religiosa: 333

ordenanza: 281

ornamento: 306, 307, 311, 319

oro: $3,5,8,9,10,16,18,19,33,41$, 91, 311

Otero, huerta: 17

oveja: 133,207

Oviedo, capellán de San Acisclo de Pontuelles: 94; catedral: 70

PACTO: 29,245

pago: 59

paja: 66

pajar: 298

Pajares, aceña: 9, 185, 226; helguera: 9; heredad: 172; iglesia: 185; molino: 185 , 259; pesquera: 77 , 86

palacio: 37

Palacios, molino: 40

Palazuelos Damianos, heredad: 185

Palencia, cabildo de la catedral: 44, 46, 56, 63, 95, 109, 155, 165, 181, 200, 236, 351; capilla de San
Martín de la catedral: 201; capilla de Santa María de la catedral; capilla de San Alfonso de la catedral: 298; catedral de San Antolín: 20, 24, 40, 49, 64, 70, $80,94,137,140,142,162,168$, 201, 207, 287; concejo: 224, 342; Cuarenta Capellanes de la catedral: $145,155,185,201$; obispo: 136; obra de la catedral: 207

palia: 319

palomar: 295, 298; era: 185

pan: $25,31,48,74,87,127,173$,

$180,207,242,244,245,250,251$, $262,276,343$

paño: 319

Papa: 182, 347

pared: 62

paso: 283

pasto: $98,139,140,141,143,144$, 145, 195, 196, 197, 198, 199, 275, 283

patronazgo: 333

patronazgo real: $336,338,339,340$, 348

pecho: 66

pedrera: 65,188

Pedro Fernández, capellanía: 185

Pedro Payo, tierra: 185

pena: 286

pena de cámara: 338

peregrino: 41

permuta: $24,45,59,65,183,186$, 206, 282, 322,

perro: 31

pertenencia: 32,39

pesca: 233,269

pesquera: $18,40,206$

petición: 244

Pico, tierra: 185

Pico de Juan Alfonso, tierra: 185

Pico del Raedor, tierra: 185

piedra: 206

pila bautismal: $306,307,311,320$

Piquillo, tierra: 185

pitanza: 74,87

Plano, heredad: 50

plata: $8,12,16,18,112,319$

pleito: $17,57,61,73,93,96,102$, 104, 105, 106, 107, 108, 110, 111, $125,126,127,128,145,176,178$, 179, 182, 195, 196, 197, 198, 199, $220,224,226,332,336,259,265$, 


\section{LA ABADÍA DE SANTA MARÍA DE HUSILLOS: ESTUDIO Y COLECCIÓN \\ DOCUMENTAL $(904-1608)$}

$267,269,275,276,281,283,285$, 286, 287, 294, 304, 316, 343

pleito fenecido: 303,342

pleito olvidado: $299,305,321$

poblamiento: $139,140,141,143,144$

pobre: 41

pobreza: 331

poder: $104,141,142,156,162,195$, 196, 249, 260, 277, 281, 293, 296

pontificado: 39

Pontón Angosto, puente: 46

porción: 74, 87, 94

porcionero: 40

portal: 60

posesión: 27, 37, 101, 136

pozo: 62

Pradillo, tierra: 185

Prado, heredad: 185

prebenda: 269, 301, 330, 347

precentor: 33

Predicadores de Palencia: 91

prenda: $30,85,128$

prendido: 190, 191, 214

preso: 190, 191, 214, 294, 330

prestamero: 95

préstamo: 41, 70, 106, 149, 185, 189 , 298,

prestimonio: 47

prior: $40,150,151,152,153,158$, $189,301,328,330,343,347$

privilegio: $15,28,61,84,100,113$,

$114,131,132,134,135,163,164$,

191, 193, 194, 212, 213, 335,

procesión: 60

procuración: 126, 139, 172, 195, 229

procurador: $68,105,111,150,152$,

$160,176,177,182,330$

propiedad: $59,73,185,210,212$, 216, 298

protección: 39, 190, 191, 210, 212, 214

protesta: 351

provisión: 269

provisor: 277, 287, 293, 310

Puente Vieja, serna: 185

puente: 36,243

Puerta del Campo, calle de Valladolid: 291, 314, 315, 316, $317,323,324,325,344$

QUEBRANTAMIENTO: 112

queso: 31

RACIONERO: 269, 295, 298, 301 ratificación: 23,215

real provisión: 340

reconocimiento: $108,175,184$

rectificación: 251, 262

recurso: 312

recurso de fuerza: 286, 287

regidor: 281, 293

reina: 150

reliquia: 297, 306, 307, 311, 330, $333,334,338$

remate de bienes: 288,321

renovación: 274, 277, 278, 279, 291, 344

renta: $47,89,161,185,312,316$, $321,330,333,339,347$

reparación: 269,323

requerimiento: 146,147

Requexo, heredad: 185; serna: 185

residencia: 330

revocación: 286

Rey, tierra: 185

río: 62

Río, puerta de Husillos: 185

Rivadavia, conde de: 238

roboración: 26

romería: 330

Ronada (Deronada, Derronada, Derronnada, Derunada, Ronadas, Runada), pesquera: 5, 18, 27, 30, 35, 36, 82, 97, 114, 135, 136, 193 ropa: $1,131,306,307,319$

SÁBANA: 306, 307, 319

sacristán: 185, 293, 330

sacristanía: 156, 158, 166, 189, 297, $311,319,320,326,335,337,341$, 345

sagrario: 60,64

Sahagún el Viejo, heredad: 298; iglesia: 27, 185, 226

Salas, monasterio: 207

salina

salterio: 91

San Acisclo de Pontuelles, iglesia: 94

San Adrián, heredad: 66, 298; iglesia: 185

San Agustín, canónigos regulares de: 336, 339

San Andrés, iglesia de Villavega: 207

San Andrés de Fuente Quintana, iglesia: 185, 207

San Antolín, barrio de Palencia: 44; cofradía: 99; hospital de Palencia: 207, 298 
San Baudilio (San Boal, Sancti Basilio, Sancti Baudili), iglesia de Villagarcía de Campos: 21, 37

San Cebrián de Campos, concejo: 267

San Cosme y San Damián, iglesia de Burgos: 207

San Cristóbal, cofradía: 185

San Elices, monasterio de Burgos: 207

San Esteban, iglesia de Burgos: 207; iglesia de Palencia: 207; iglesia de San Adrián de Valdepero: 185

San Felices, palacio: 185

San Francisco, monasterio de Palencia: 201, 207

San Gil, iglesia de Burgos: 207

San Hipólito (Sant Ypólite), iglesia de Támara de Campos: 185

San Isidro, prado: 185

San Jacobo de Calabazanos, iglesia de Calabazanos: 27

San Juan, capellanía de Santa María de Husillos: 185; cofradía: 185; iglesia de Pajares: 185, 204, 226, 342; iglesia de Paredes de Nava: $125,126,127$; iglesia de Villafruela: 185; orden: 185

San Julián de la Cuesta, altar de Santa Brígida de la iglesia de San Julián: 88; capellanía de San Quirce: 185; capellanía de Santa Brígida: 142, 145, 185; iglesia: 27, 88, 185, 207, 339

San Juan de Pajares, molino: 342

San Juan de Torrelobatón, cofradía: 159

San Lázaro, iglesia de Palencia: 201, 207

San Lesmes, iglesia de Burgos: 207

San Llorente, iglesia de Burgos: 207

San Lorenzo, reliquia: 333, 334

San Lorenzo del Escorial, monasterio: 334

San Mamés (Sanctum Mametem), iglesia: 35, 91; iglesia de Frechilla: 27, 185, 298; iglesia de Villacid: 105, 107, 108, 185

San Martín (Sancto Martino, sanctus Martinum): 35, 37; iglesia de Burgos: 207; iglesia de Frechilla: 27, 185; iglesia de Paredes de Nava: 125, 126, 127; iglesia de
Ribas de Campos: 343; iglesia de Pozuelos de Amianos: 185

San Martín de Salce, monasterio de Burgos: 207

San Miguel (Sanctus Micahelem), cofradía de Palencia: 185, 298; helguera: 34; iglesia de Ampudia: 347, 350; iglesia de Fuentes de Nava: 27, 35, 185, 298; iglesia de Fuentes de Valdepero: 37; iglesia de Palencia: 201, 207, 298; iglesia de Pozuelos de Amianos: 27, 35, 185; iglesia de Villaudilla: 185

San Miguel del Pino: 292

San Nicolás, iglesia de Burgos: 207

San Pablo, monasterio de Palencia: 207

San Pedro, iglesia de Burgos: 207; iglesia de Fuentes de Valdepero: 27, 35, 37, 48, 59, 185, 285; iglesia de Población de Campos: 201, 207; monasterio de Fuentes de Valdepero: 40

San Pedro de Arlanza, monasterio: 91

San Pedro de Fuentes, monasterio: 40; iglesia: 185

San Pedro de Gomel: 91

San Pedro de la Espina (Sant Pero del Espinna, Spina), monasterio: 81

San Pedro de las Dueñas: 185

San Pedro de Soria, iglesia: 91

San Pedro de Val Rozado: 17

San Pedro y San Pablo, iglesia de Roma: 207

San Pelayo, iglesia de Fuentes de Nava: 185; iglesia de Villaumbrales: 140

San Quirce, cofradía: 298; iglesia: 207

San Román (Sancto Romano, Sanctum Romanum): 9, 24, 35, 185; iglesia de Burgos: 207; iglesia de Frechilla: 27, 185, 298

San Salvador, cofradía: 185; iglesia de Becerril de Campos: 35, 185; iglesia de Monzón de Campos: 195; iglesia de Oviedo: 91

San Sebastián, heredad: 49, 172; iglesia de San Sebastián de Hérmedes: 244, 245, 250, 251; monasterio: 7; iglesia próx. a Becerril de Campos: 27, 185 


\section{LA ABADÍA DE SANTA MARÍA DE HUSILLOS: ESTUDIO Y COLECCIÓN \\ DOCUMENTAL $(904-1608)$}

San Vicente, iglesia: 185

San Yago, iglesia de Burgos: 207

Santa Ana, iglesia próx. a Monzón: 207

Santa Brígida, capellanía: 185

Santa Catarina, capellanía: 91

Santa Clara, monasterio próx. a Burgos: 207; monasterio de Palencia: 207; monasterio próx. a Castrojeriz: 207

Santa Cristina, cofradía: 185

Santa Cruz de la Zarza (Santa Cruz de Monzón), monasterio: 109, 159, 185, 222

Santa Eufemia de Brevesca (Sancta Enfimia, Sanctam Eufemiam de Beruesca, Sancte Euphemie), iglesia: 17, 27, 35, 27, 185, 226

Santa Eugenia (Sanctam Eugeniam), iglesia de Astudillo: 220; iglesia de Becerril de Campos: 49, 172, 298; iglesia de Piña de Campos: $27,35,37,185$

Santa Eulalia de León (Sant Ellalia de León): 71

Santa Gadea, iglesia de Burgos: 207

Santa Leocadia, iglesia de Castrillo de Villavega: 207

Santa María de Aliende el Río, iglesia de Palencia: 185, 207

Santa María de Benavides (Benebiuas), monasterio: 104, $105,107,185$

Santa María de Castrillo (Sancte Marie de Castrello), iglesia próx. a Ampudia: 27. 35, 37, 185, 298

Santa María de Covadonga,Sancta María de Cauadoga: 91

Santa María de Dehesa Brava (Nuestra Señora de Dehesa Braua): 17, 347

Santa María de Frías del Val, monasterio de Burgos: 207

Santa María de Gamonal, monasterio de Burgos: 207

Santa María de Guadalupe, monasterio de Cáceres: 207

Santa María de Husillos (Beate Marie de Fusellis, Sancta Maria de Fuselensis, Sancta Maria de Fusellos, Sancte Marie de Fusellis, Sancte Marie de Fusillos), abad: 57, 59, 85, 93, 128, 131, 152, 185, 197, 199; altar de Santa María: 60; altar mayor: 112; cabildo: $26,31,40,47,48$, $52,53,54,57,59,61,64,65,72$, $73,74,75,77,81,85,86,87,88$, 90, 93, 96, 99, 100, 102, 104, 106, $107,109,110,112,113,128,139$, $141,143,144,145,148,151,152$, $153,154,158,161,174,176,177$, $178,179,182,183,185,186,187$, 189, 195, 196, 198, 199, 200, 201, $202,205,226,232,233,235,241$, $253,259,262,266,269,271,273$, 289, 290, 303, 304, 308, 318, 319, $329, \quad 342, \quad 343, \quad 346, \quad 347$; capellanía: 298; capellanía de San Andrés de Fuente Quintana: 185; capellanía de San Juan de Pajares: 185; capellanía de Santa Brígida: 185; capellanía de Santiago: 75, 185; capellanía de Santillán de la Cuesta: 185; capellanía del abad García Pérez: 185; capellanía del abad Pedro Fernández: 185; capellanía del pueblo: 185 ; capilla de San Quirce: 207; capilla de Santa Bárbara: 205, 233, 243, 251; capilla de Santa Brígida: 74; capilla de Santiago: 74, 77, 86, 87; coto: 7, 193; fábrica: 40, 231, 284, 332; iglesia, iglesia colegial, monasterio: $1,2,3,4,5,6,7,8,9$, $10,11,13,14,15,16,17,18,19$, $20,21,22,23,24,25,26,27,30$, $32,33,34,35,36,37,38,39,42$, $45,47,49,50,58,62,65,67,68$, $70,76,79,82,83,85,91,92,97$, $98,101,103,105,107,111,114$, $124,126,127,129,130,131,132$, $135,136,137,138,139,140,142$, $145,146,147,149,156,158,159$, $162,163,167,168,172,175,182$, 183, 184, 185, 186, 188, 189, 190, 191, 192, 193, 197, 199, 206, 207, 210, 212, 214, 215, 216, 218, 219, $220,223,224,225,226,227,228$, $230,232,234,235,237,243,244$, $245,246,247,249,251,254,257$, $261,265,267,268,270,272,278$, 280, 281, 282, 284, 286, 287, 288, 291, 298, 299, 301, 306, 309, 310, $311,313,314,315,316,317,320$, $322,323,324,325,326,330,332$, $333,335,336,337,338,339,340$, $344,345,347,348,350,351$; 
lámpara: 185; obra: 185; prior: $85,86,104,106,128,131,174$, 176, 183, 185, 197, 198, 199, 200, 205

Santa María de la Estrella, monasterio, dat. doc.: 334

Santa María de la Pernía, monasterio: 207

Santa María de la Vid, monasterio: 91

Santa María de las Misas: 185

Santa María de Nava, iglesia de Fuentes de Nava: 48, 59; iglesia en término de Villaudilla: 185

Santa María de Rebolledo, monasterio de Burgos: 207

Santa María de Ronzasdillos, monasterio: 207

Santa María de Sandoval, monasterio: 41

Santa María de Valladolid, cabildo: 156; iglesia colegial: 274, 277, 292

Santa María de Vieja-Rua, iglesia de Burgos: 207;

Santa María de Villaldavín, iglesia: 159

Santa María de Villanueva, iglesia: 91

Santa María de Villaverde, iglesia próx. a Magaz de Campos: 207

Santa María del Campo: 298

Santa María del Otero, iglesia de Palencia: 207

Santa María del Rivero, iglesia de San Esteban de Gormaz: 159

Santa María del Sábado, cofradía de la catedral de Palencia: 207

Santa María Magdalena, iglesia de Población de Campos: 185; iglesia de Villazalama: 185, 207, 211; tierra: 185

Santa María, catedral de Segovia: 186; cofradía: 99, 185; heredad de Castrillo: 298; hospital: 185; iglesia, 2, 185; iglesia cerca de Monzón: 37; iglesia de Ampudia: 27, 35; iglesia de Cilleruelo (Sanctam Mariam de Cellerolo, Sancte Marie de Celleroso): 27, 28, 35, 38, 40, 45, 48, 185; iglesia de Castrillo de Malcitas: 185; iglesia de Gutiérrez Álvarez: 185; iglesia de Paredes de Nava: 125,
126, 127; iglesia de Pozuelos de

Amianos: 185; iglesia de

Tordesillas: 292; iglesia de

Villaldavín: 27; iglesia de

Villamuriel de Cerrato: 207

Santa María, iglesia de Pozuelos de Amianos: 106

Santa Marina, iglesia de Palencia: 207; puerta de Palencia: 298

Santa Olalla, iglesia de Paredes de Nava: $96,102,125,126,127$; iglesia de Villaldavín: 185; orden: 159

Santa Profiada, viña: 185

Santa Rosa, monasterio: 91

Santa Sede: 37, 68, 109, 136, 223

Santiago, cofradía: 185; iglesia de Calabazanos: 37, 185; iglesia de Valladolid: 183, 186; orden: 185

Santiago de Compostela, catedral: 70,91

Santillán de la Cuesta (San Julián), concejo: 31

Santísimo Sacramento: 306, 307, $311,319,320$

Santo Domingo de Caleruela, monasterio: 91

Santo Domingo de Silos, monasterio: 91

Santo Jacobo, iglesia de Calabazanos: 35

Santo Spiritus, cofradía de Palencia: 201

saya: 112

sayón: 31,40

secretario del cabildo: 330

Sede Apostólica: 89

sede vacante: 330

semanero: 330

sentencia: 57, 61, 73, 93, 96, 102, $106,107,108,112,127,128,179$, $182,199,220,224,226,227,232$, 236, 247, 265, 269, 275, 276, 281, $283,285,286,287,294,335,342$, 343

señorío: $58,175,184$

sentencia de revista: 342

sentencia de vista: 342

sepultura: $37,136,223,298,330$

serna: 1, 17, 31, 62, 66, 269

Serna de Poza Nava, tierra: 185

Serna del Molino, tierra: 185

Serna Longuera, tierra: 185

servicio: $75,77,86,150$ 


\section{LA ABADÍA DE SANTA MARÍA DE HUSILLOS: ESTUDIO Y COLECCIÓN \\ DOCUMENTAL $(904-1608)$}

servicio litúrgico: 297

servicio real: $28,84,100,113,134$, $164,194,213,335$

Simón Ruiz, viña: 185

simonía: 287

Sobradillo, molino: 226

socio: 47

soga: 112

solar: $37,45,49,62,185,200,252$, $253,254,328$

solariego: 17

Solbella, tierra: 43

sólido: 27,36

Soria, cabildo de la catedral: 91

sortija: 91

Sotillo, serna: 185

Soto, 26, 185, 269; heredad: 91

subsidio: 68

sueldo: 12,30

suelo: 62,298

suspensión: 68

TABLA: 319

tapia: 200

tapicería: 311

tapiz: 306, 307, 319

teja: 200

temporalidad: 185

tercias reales: 220

término: 25, 31, 39, 98, 224, 247, 339

terraza: 25,31

territorio: 11

tesorería: 295, 298

tesorero: 298, 301, 330

testamento: $47,60,79,81,91,149$, 159, 162, 201, 202, 203, 207, 218, $219,228,231,257,270,272,273$, 280, 284, 298, 300, 309, 313,

testigo: 109

testimonio: 47, 329

testimonio notarial: $156,158,162$, $166,230,241,252,267,278,291$, $295,296,308,335,340$

tienda: 24,200

tierra: $24,37,43,50,59,60,65,99$, $115,116,117,118,119,120,121$, $122,123,123,159,169,170,174$, $177,178,179,180,181,185,188$, 201, 202, 206, 208, 209, 211, 256, 258, 288, 295, 298

Tierra Bermeja, tierra: 185

tocino: 25

Toledo, arzob.: 139, 140
Topi, huerta: 46

Tórtoles de Esgueva, monasterio: 185

Tovistilo (Touistlo), viña: 60

tránsito: 283

traslado: 86, 87, 93, 102, 130, 132, $136,137,138,147,148,149,166$, $168,189,202,216,223,225,239$, 262, 284, 292, 296, 333, 335, 338, $346,350,351$

traspaso: 258

tributo: 128,276

trigo: $31,127,170,177,179,180$, $182,207,242,244,245,250,251$, $262,289,342$

Trinidad, orden: 159

troj: 185

UNIÓN: 347

usufructo: 64

Uzo, molino: 185

VACIABOLSAS, tierra: 185

vado: 40

Val (Ual), viña: 60

Val Sonera, viña: 60

Valdespina, concejo: 265

Valladolid: 193

vasallo: 191, 210, 212, 214

vecino: $31,128,145,171,234$

Vega, cofradía: 185

vendimia: 201, 232

venta: $12,43,44,50,52,53,63,72$, $115,116,117,118,119,120,121$, $122,123,133,155,169,170,187$, 203, 204, 208, 209, 211, 221, 230, $256,263,264,266,289,308,335$

vestido: 297

vestimenta: 60,330

vicario: $68,145,310$

Vieja, camino: 185

villa: $3,4,8,10,16,18,19,22,31$, $32,33,35,37,39,40,48,55,59$, $82,97,114,135,163,193,295$,

Villaldavín, concejo: 175, 275, 299

Villaramiro, camino: 43

Villaudilla, concejo: 61, 62

Villaumbrales, concejo: 139, 140, 141, 142, 143, 144, 145, 210, 232; término: 143

Villaverde, huerta: 159

vinajera: 306, 307

vino: $25,31,48,74,87,161$ 


\section{DAVID MARCOS DIEZ}

viña: $1,24,25,31,37,49,50,59,60$, $64,66,73,88,98,116,133,185$, 187, 201, 202, 207, 221, 232, 266, 289, 290, 295, 298, 300, 313

Viñales del Pozo (Uineis de Pozo), heredad: 50

viñedo: $24,99,145,275$

visita: $269,285,293,294,296,297$, $306,307,310,311,312,320,326$, $337,341,345$

visitador: 293

viuda: 62 vívere: 217

votación: 297

voto: 330

YANTAR: 17, 62, 66, 128, 129, 131, 185

yegua: 91

yuguería: 91

ZAMORA, catedral: 70

Zorzancada, molino: 185 
LA ABADÍA DE SANTA MARÍA DE HUSILLOS: ESTUDIO Y COLECCIÓN DOCUMENTAL (904 - 1608)

5

\section{BIBLIOGRAFÍA CITADA}


DAVID MARCOS DIEZ 
ABAJO MARTín, Teresa, Documentación de la catedral de Palencia (10351247), Burgos 1986 (= ABAJO, Documentación Catedral de Palencia)

AGAPITO REVILlA, Juan, La Catedral de Palencia, Palencia 1986 (= AGAPITO REVILLA, La catedral de Palencia).

ALDEA VAQUERO, Quintín - MARÍN MARTÍNEZ, Tomás - VIVES GATELL, José, Diccionario de historia eclesiástica de España, 4 vols., Madrid 1972 (= ALDEA - MARÍN - VIVES, DHEE)

ALONSO ÁVILA, María Ángeles, En torno a la visigotización de la provincia palentina, "Publicaciones de la Institución Tello Téllez de Meneses", 53 (1985), 267-295 (= ALONSO ÁVILA, La visigotización de la provincia palentina).

ALONSO MARTÍN, María Luz, La sucesión mortis causa en los documentos toledanos de los siglos XII-XV, "Anuario de Historia del Derecho Español", 50 (1980), 941-970 (= ALONSO MARTíN, La sucesión mortis causa).

- La compraventa en los documentos toledanos de los siglos XII-XV, "Anuario de Historia del Derecho Español", 49 (1979), 455-518 (= ALONSO MARTíN, La compraventa en los documentos toledanos).

ANTÓN, Francisco, Monasterios medievales de la provincia de Valladolid, Valladolid 1942 (= ANTÓN, Monasterios medievales).

ARRANZ GUZMÁN, Ana, Abades y monasterios en las Cortes castellanas, "Anuario de estudios medievales", 27, 1 (1998), 487-504 (= ARRANZ GUZMÁN, Abades y monasterios en las Cortes castellanas).

ARRIBAS GONZÁLEZ, Soledad - FEIJÓO CASADO, Ana María, Guía del Archivo de la Real Chancillería de Valladolid, Valladolid 1998 (= 
ARRIBAS - FEIJÓO, Guía del Archivo de la Real Chancillería de Valladolid).

ASOCIACIÓN DE ARCHIVEROS DE LA IGLESIA EN ESPAÑA, Documentos pontificios. Tipología, Oviedo 1996 (= Documentos pontificios).

AUSÍN ÍÑIGO, Margarita, Intento y memoriales para trasladar la iglesia de Husillos a Tordesillas: año 1547. Págs. 359-362. En Actas del II Congreso de Historia de Palencia, Tomo III-I. Edad Moderna, Palencia 1990 (= AUSÍN ÍNIGO, Intento y memoriales para trasladar la iglesia de Husillos a Tordesillas).

AZEVEDO SANTOS, $O$ “beta invertido" em cartas de escrita francesa, en Actas del VIII coloquio del Comité Internacional de Paleografia Latina (Madrid-Toledo 29 septiembre-1 octubre 1987), Madrid 1990

BARÓN FARALDO, Andrés, Grupos y dominios aristocráticos en la Tierra de Campos Oriental : siglos X-XIII, Palencia 2006 (= BARÓN FARALDO, Grupos y dominios aristocráticos).

BERGANZA, Francisco de, Antigüedades de España, propugnadas en las noticias de sus reyes, en la crónica del Real Monasterio de San Pedro de Cardeña, en historias, cronicones y otros instrumentos que hasta ahora no han visto la luz pública, 2 vols., Madrid 1719-1721 (= BERGANZA, Antigüedades).

BERGER, Elie, Les registres d'Inoccent IV, publiés ou analysés d'apres les manuscrits originaux du Vatican et de la Bibliotheque Nationale., 4 vols., París 1884 (= BERGER, Inoccent IV).)

BLANCO LOZANO, Pilar, Colección diplomática de Fernando I :(1037-1065), León 1987. 
BOÜARD, A. de, Manuel de diplomatique française et pontificale. L'acte privé, París 1948 (= BOÜARD, Manuel de diplomatique)

CAAMAÑO, Carmen, El fuero romanceado de Palencia, "Anuario de Historia del Derecho Español”, 11 (1934), 503-521 (= CAAMAÑO, El fuero romanceado de Palencia).

CABEZA RODRÍGUEZ, Antonio, Ingresos percibidos por los eclesiásticos de la catedral de Palencia durante la época moderna. Operaciones efectuadas en torno al reparto de las prebendas, en Actas del II Congreso de Historia de Palencia. III. Edad Moderna y Contemporánea, Palencia 1990, 483498 (= CABEZA, Ingresos percibidos por los eclesiásticos de la catedral de Palencia).

CABRILLANA CIÉZAR, Nicolás, La crisis del Siglo XIV en Castilla: la Peste Negra en el obispado de Palencia, "Hispania", 5 (1968), 245-258 (CABRILLANA, La peste negra en Palencia).

CALVO, Aurelio, El monasterio de Gradefes, León 1945 (= CALVO, Gradefes).

CALlEJA PUERTA, Miguel, El conde Suero Bermúdez, su parentela y su entorno social. La aristocracia asturleonesa en los siglos XI y XII, Oviedo 2001 (= CALLEJA, El conde Suero Vermúdez),

CAMPELO, José, y SUÁREZ, Manuel, Historia Compostelana, Santiago de Compostela 1950 (CAMPELO y SUÁREZ, Historia Compostelana).

CARLÉ, María del Carmen, La sociedad castellana del siglo XV: la inserción de la Iglesia, "Anuario de estudios medievales", 15 (1985), 367-414 (= CARLÉ, La sociedad castellana del siglo XV: la inserción de la Iglesia).

CARRIEDO TEJEDO, Manuel, El solar de Fuentes de Valdepero durante los primeros siglos de la Reconquista (VIII-X), "Horizontes, Revista de la 
Asociación de Amigos del Castillo de Fuentes de Valdepero", 4 (1998), 10-11 (= CARRIEDO, El solar de Fuentes de Valdepero).

- Poncio, obispo de Husillos, "Horizontes, Revista de la Asociación de Amigos del Castillo de Fuentes de Valdepero", 7 (2001), 13-14 (= CARRIEDO, Poncio, obispo de Husillos).

- La importancia del Concilio Legatino de Husillos (1088), "Horizontes, Revista de la Asociación de Amigos del Castillo de Fuentes de Valdepero", 8 (2002), 29-31 (= CARRIEDO, Concilio de Husillos).

- Un obispo poco conocido de Palencia en 940-944: Julián de Bobastro, "Horizontes, Revista de la Asociación de Amigos del Castillo de Fuentes de Valdepero", 9 (2003), 43-44 (= CARRIEDO , Un obispo poco conocido de Palencia).

CASADO LOBATO, María Concepción, Colección diplomática del Monasterio de Carrizo, 2 vols., León 1983 (= CASADO LOBATO, Carrizo).

CASTÁN LANASPA, Documentos del Monasterio de Villaverde de Sandoval (siglos XII - XV), Salamanca 1981 (= CASTÁN, Documentos de Sandoval).

- La formación y explotación del dominio del monasterio de Villaverde de Sandoval $($ siglos XII $-X I I I)=$ León y su Historia , IV. Miscelánea Histórica, León 1977, 213 - 217 (Colección "Fuentes y Estudios de Historia Leonesa", núm. 18 (= CASTÁN, El dominio del monasterio de Sandoval).

CASTRO ALONSO, Manuel de, Episcopologio Vallisoletano, Valladolid 1904 (= CASTRO ALONSO, Episcopologio Vallisoletano).

CASTRO SÁNCHEZ, Marcial de, Vida del illustrissimo Sr. D. Francisco de Reynosso : obispo de Córdoba, por Gregorio de Alfaro, 2 vols. Palencia 2001 (edición facsímil). El vol.2 contiene: Vida de Don Francisco de Reinoso: obispo de Córdoba y abad de Husillos (1534-1601). (= CASTRO SÁNCHEZ, Vida de Francisco de Reinoso). 
CASTRO TOLEDO, Jonás, Colección diplomática de Tordesillas, 909 - 1474, Valladolid 1981 (CASTRO TOLEDO, Colección diplomática de Tordesillas).

CASTRO Y CASTRO, Manuel de, El Real Monasterio de Santa Clara de Palencia y los Enríquez, Almirantes de Castilla, 2 vols., Palencia 19821983 (CASTRO Y CASTRO, Santa Clara de Palencia).

CATALÁN MARTÍNEZ, Elena, El derecho de patronato y el régimen beneficial de la iglesia española en la Edad Moderna, "Hispania Sacra”, 56 (2004), 135-168 (= CATALÁN, El derecho de patronato).

CERVERA VERA. Luis, La Iglesia colegial de San Pedro en Lerma, Burgos 1981 (= CERVERA VERA, La iglesia colegial de San Pedro en Lerma).

CORIA COLINO, Jesús - FRANCIA LORENZO, Santiago, Colección de Documentos para la Historia de Palencia, II. Reinado de Fernando IV (1295-1312), Palencia 1999 (= CORIA COLINO - FRANCIA LORENZO, Reinado de Fernando IV).

- Colección de Documentos para la Historia de Palencia, III: Reinado de Sancho IV (1284-1295), Palencia 2004 (= CORIA COLINO - FRANCIA LORENZO, Reinado de Sancho IV)

CRUZ PÉREZ, Aurora, y GUERRA ARAGÓN, José Ignacio, Las excavaciones arqueológicas en el claustro de la Abadía de Santa María de Husillos (Palencia), en Actas del III Congreso de Historia de Palencia, Tomo I. Prehistoria, Arqueología e Historia Antigua, Palencia 1995, 493-504 (= CRUZ y GUERRA, Excavaciones arqueológicos en el claustro de Husillos). 
DEL ÁlAMO, Juan, Colección diplomática de San Salvador de Oña (822-1284), 2 vols., Madrid 1950 (= DEL ÁLAMO, Colección de San Salvador de Oña).

DÍAZ IBÁÑEZ, Jorge, La incorporación de la nobleza al alto clero en el reino de Castilla durante la Baja Edad Media, "Anuario de estudios medievales", 35, 2 (2005), 557-604 (= DÍAZ IBÁÑEZ, La incorporación de la nobleza al alto clero).

DÍAZ MARTÍN, Vicente, Colección Documental de Pedro I de Castilla (13501369), 2 vols., Valladolid 1997 (= DÍAZ MARTíN, Pedro I).

- La organización de la iglesia hispana en los siglos centrales de la Edad Media. “Asociación de Amigos de la Catedral”, 1994, 29 (=La organización de la iglesia hispana en la Edad Media).

DIGARD, Georges; FAUCON, Maurice; THOMAS, Antoine, Les Registres de Boniface VIII, París 1884 (= DIGARD - FAUCON - THOMAS, Boniface VIII).

DOMÍNGUEZ SÁNCHEZ, Santiago, Documentos de Bonifacio VIII (1294-1303) referentes a España, León 2006 (= DOMÍNGUEZ SÁNCHEZ, Bonifacio VIII).

EGIDO LÓPEZ, Teófanes, Historia de las diócesis españolas. Iglesias de Palencia, Valladolid y Segovia (coordinación), Madrid 2004 (= EGIDO, Historia de las diócesis españolas. Iglesias de Palencia, Valladolid y Segovia).

ESCALONA, Raimundo, Historia del Real Monasterio de Sahagún, 1782 (= ESCALONA, Historia del Real Monasterio de Sahagún).

FAYA DÍAZ, María Ángeles, Los señoríos eclesiásticos del obispado de Palencia en el siglo XVI, en Actas del II Congreso de Historia de Palencia, 
II, Historia Medieval (1995), 755-771 (FAYA, Los señorios eclesiásticos del obispado de Palencia).

FELBER, Howard Lewis, The marriage of Urraca of Castilla and Alfonso I of Aragon: an attempt at federal union of christian Spain, University of Kansas, Ph. D. 1974 (= FELBER, The marriage).

FERNÁNDEZ, Luis, Colección diplomática de la abadía de Santa María de Benevívere (Palencia), 1020-1561. Madrid 1967 (L. FERNÁNDEZ, Benevívere).

- Colección diplomática del Real Monasterio de Santa María de Benavides (Boadilla de Rioseco. Palencia), "Publicaciones de la Institución Tello Téllez de Meneses”, 20 (1959), 143-193 (L. FERNÁNDEZ, Benavides).

FERNÁNDEZ DE AYALA AULESTIA, Manuel. Práctica y formulario de la Chancillería de Valladolid, dirigido a la Real Chancillería, presidente y jueces de ella. Valladolid 1998 (edición facsímil). (= AULESTIA, Práctica y formulario de la Chancillería de Valladolid).

FERNÁNDEZ DE MADRID, Alonso, Copilación o catálogo de los Obispos que por escrituras antiguas hallamos haber precidido en la iglesia de Palencia con algunas concurrencias notables, que en tiempo de cada uno acaecieron (Silva Palentina. Edición de Jesús San Martín Payo), Palencia 1976 (= FERNÁNDEZ DE MADRID, Silva Palentina).

FERNÁNDEZ DEL PULGAR, Pedro, Teatro Clerical, apostólico y secular de las iglesias catedrales de España, desde la fundación primitiva y predicación del Evangelio por el Apóstol Santiago y sus discípulos, y prehemiencia del Estado eclesiástico secular y regular. Historia secular y eclesiástica de Palencia, desde la reedificación por el rey don Sancho el Mayor hasta el tiempo presente, Madrid, 1679-1680 (Ed. facsímil, 3 vols., Palencia 1980), (= FERNÁNDEZ DEL PULGAR, Historia secular $y$ eclesiástica de Palencia). 
FERNÁNDEZ ESPINAR, Ramón, La compraventa en el Derecho medieval español, “Anuario de Historia del Derecho Español”, 25 (1955), 293-528 (= FERNÁNDEZ ESPINAR, La compraventa en el Derecho medieval español).

FERNÁNDEZ FLÓREZ, José Antonio, Colección diplomática del Monasterio de Sahagún (857-1300). 4, (1110-1199), León 1991 (= FERNÁNDEZ FLÓREZ, Sahagún, IV).

FÉROTIN, Marius, Recueil de chartes d l'abbaye de Silos, París 1897 (FÉROTIN, Recueil de Silos).

FITA, Fidel, Texto completo del concilio de Husillos, "Boletín de la Real Academia de la Historia", 49 (1945), 410-413 (FITA, Texto completo del concilio de Husillos).

FLORIANO CUMBREÑO, Antonio, Curso general de paleografía y diplomática españolas, Oviedo 1946 (= FLORIANO, Paleografía y diplomática).

- Diplomática española del período astur (718-910), Oviedo 1951 (= FLORIANO, Diplomática Astur).

FRANCIA LORENZO, Santiago, Notas de archivo, 1, (Anecdotario para la pequeña historia de un pueblo), Palencia 1985 (= FRANCIA LORENZO, Notas de archivo 1).

- Notas de archivo, 2, (Gentes de estas tierras), Palencia 1987 (= FRANCIA LORENZO, Notas de archivo 2).

- Archivo Capitular de Palencia. Catálogo. Serie II. Volumen I. Actas capitulares (1413-1467), Palencia 1989 (= FRANCIA LORENZO, Actas Capitulares de la catedral de Palencia).

- Por tierras palentinas: notas de archivo III, Palencia 1991 (= FRANCIA LORENZO, Notas de archivo 3). 
- Pleito entre Husillos y Fuentes de Valdepero (a. 1306), "Horizontes, Revista de la Asociación de Amigos del Castillo de Fuentes de Valdepero", 5 (1999), 2 (= FRANCIA LORENZO, Pleito entre Husillos y Fuentes de Valdepero).

GAIBROIS DE BALLESTEROS, Historia del reinado de Sancho IV de Castilla, 3 vols., Madrid 1922-1928 (= GAIBROIS, Sancho IV)

GAMBRA, Andrés, Alfonso VI: cancillería, curia e imperio, I. Estudio, y II. Colección diplomática, León, 1997-1998 (= GAMBRA, Alfonso VI, I-II).

GARCÍA COLMENARES, Pablo, La desamortización y remodelación de la ciudad de Palencia (1836-1838), Valladolid 1984 (Tesis Doctoral) (= GARCÍA COLMENARES, La desamortización de Palencia).

GARCÍA COLMENARES, Pablo - MORENO LÁZARO, Javier - SÁNCHEZ GARCÍA, José Luis, Historia de Palencia: siglos XIX y XX, Valladolid 1996 (= COLMENARES, MORENO, SÁNCHEZ, Historia de Palencia).

GARCÍA DE CORTÁZAR Y RUIZ DE AGUIRRE, José Ángel, El dominio del Monasterio de San Millán de la Cogolla (siglos X a XIII): introducción a la historia rural de Castilla altomedieval, Salamanca 1969 (= GARCÍA DE CORTÁZAR, El dominio del Monasterio de San Millán de la Cogolla).

GARCÍA GALLO DE DIEGO, Alfonso, Del testamento romano al medieval: las líneas de su evolución en España, "Anuario de Historia del Derecho Español”, 47 (1977), 425-498 (= GARCÍA GALLO, Del testamento romano al medieval).

- El Concilio de Coyanza: contribución al estudio del Derecho Canónico español en la Alta Edad Media, "Anuario de Historia del Derecho Español”, 20 (1950), 275-633 (= GARCÍA GALLO, El Concilio de Coyanza). 
GARCÍA GUINEA, Miguel Ángel, El arte románico en Palencia, Palencia 1961 (= GARCÍA GUINEA, El arte románico en Palencia).

- El Castellar, Villajimena (Palencia): memoria de excavaciones, "Publicaciones de la Institución Tello Téllez de Meneses”, 23 (1963), 123-158 (= GARCÍA GUINEA, El Castellar).

- Románico en Palencia. Guía, Palencia 2002 (= GARCÍA GUINEA, Románico en Palencia).

GARCÍA LARRAGUETA, Santos, El apeo, documento diplomático, “Anuario de estudios medievales", 17 (1987), 617-639 (= GARCÍA LARRAGUETA, El apeo, documento diplomático).

GARCÍA TURZA, Javier, Introducción a la Diplomática Monástica de San Millán de la Cogolla en el siglo XIII, “Memoria ecclesiae”, 6 (1995), 345361 (= GARCÍA TURZA, Diplomática monástica de San Millán).

GARCÍA Y GARCÍA, Antonio, Concilios y sínodos en el ordenamiento jurídico del reino de León, en El reino de León en la alta Edad Media, I, León 1988, 353-494 (GARCÍA Y GARCÍA, Concilios y sínodos).

GARRACHÓN BENGOA, Ambrosio, Palencia y su provincia: Guía - Catálogo - Prontuario del turista, Valladolid 1920 (= GARRACHÓN BENGOA, Palencia y su provincia).

- Palencia. Guía del turista, Palencia 1930-1931 (= GARRACHÓN BENGOA, Palencia. Guía del turista).

GARRIDO GARRIDO, José Manuel, Documentación de la catedral de Burgos (804-1183), Burgos 1983 (= GARRIDO, Documentación catedral de Burgos).

GARRIGA, Carlos, Recopilación de las ordenanzas de la Real Audiencia y Chancillería de Valladolid, Madrid 2007 (= GARRIGA, Ordenanzas de la Chancillería de Valladolid). 
GIRY, A., Manuel de Diplomatique, París 1894 (= GIRY, Manuel de Diplomatique).

GONZÁLEZ Y GONZÁLEZ, Julio, Regesta de Fernando II, Madrid 1943 (= J. GONZÁLEZ, Fernando II).

- El Reino de Castilla en la época de Alfonso VIII, 3 vols., Madrid 1960 (= J. GONZÁLEZ, Alfonso VIII).

- La Extremadura castellana al mediar el siglo XIII, "Hispania”, 127 (1974), 265379 (= J. GONZÁLEZ, La Extremadura castellana).

- Cuestiones de repoblación en tierras palentinas, en Palencia en la Historia, Palencia 1982, 545-566 (= J. GONZÁLEZ, Cuestiones de repoblación).

- Siglos de Reconquista, en Historia de Palencia, I, Palencia 1984, 155-215 (J. GONZÁLEZ, Siglos de Reconquista).

- Reinado y diplomas de Fernando III, 3 vols., Córdoba 1980-1986 (J. GONZÁLEZ, Fernando III).

GUIJARRO GONZÁLEZ, Susana, Las escuelas y la formación del clero de las catedrales en las diócesis castellano-leonesas (siglos XI al XV), en La enseñanza en la Edad Media: X Semana de Estudios Medievales, Nájera 1999, 61-96 (= GUIJARRO, La enseñanza en la Edad Media).

GUTIÉRREZ APARICIO, Julián, Grijota: Pueblo con Historia, Palencia 2004 (= GUTIÉRREZ APARICIO, Grijota: pueblo con Historia)

GUTIÉRREZ CUÑADO, Antolín, Un rincón de Castilla: reseña histórica del Real Monasterio de Santa María de la Espina y descripción de la fundación actual "Escuela Primaria y de Agricultura con Asilo de Huérfanos", Valladolid 1989 (= GUTIÉRREZ CUÑADO, Un rincón de Castilla).

HERNÁNDEZ, Francisco Javier, Los cartularios de Toledo. Catálogo documental, Madrid 1985 ( F. J. HERNÁNDEZ, Cartularios de Toledo). 
HERRERO DE LA FUENTE, Marta, Colección diplomática del Monasterio de Sahagún (857-1300). II (1000-1073), León 1988; III (1074-1109) (= HERRERO DE LA FUENTE, Sahagún, II, III).

HERRERO JIMÉNEZ, Mauricio, Colección Documental del Monasterio de Villaverde de Sandoval (1132-1500), León 2003 (= HERRERO JIMÉNEZ, Sandoval).

HINOJOSA, Eduardo de, Documentos para la historia de las instituciones de León y de Castilla, (Siglos X-XIII), Madrid 1919 (= HINOJOSA, Documentos para las instituciones de León y de Castilla).

IBN HAYYAN DE CÓRDOBA, Crónica del califa Abdarrahaman III an-Nasir entre los años 912 y 942 (al-Muqtabis V). Traduc. De Ma . Jesús Viguera y Federico Corriente, Zaragoza 1981 (= IBN HAYYAN, al-Muqtabis V).

Inventario artístico de Palencia y su provincia, 2 vols., Madrid 1978 (= Inventario artístico de Palencia y su provincia).

IZQUIEDO MISIEGO, José Ignacio, La villa de Ampudia: apuntes de geografía e historia, Palencia 1990 (= IZQUIERDO MISIEGO, La villa de Ampudia).

- Historia de Ampudia, Ampudia 2004 (= IZQUIERDO MISIEGO, Historia de Ampudia).

KAGAN, Richard L., Pleitos y pleiteantes en Castilla: 1500 - 1700, Valladolid 1991 (= KAGAN, Pleitos y pleiteantes en Castilla).

LA FUENTE Y CONDÓN, Vicente de, Historia eclesiástica de España, vol. IV, Barcelona 1859 (LA FUENTE, Historia eclesiástica de España).

LABBÉ, Philippe, Collectio Maxima Conciliorum, VI, Roma 1964 (= LABBÉ, Collectio). 
LARGO MUÑOYERRO, José Antonio, San Pelayo de Arenillas: abadía, priorato y parroquia, Palencia 2000 (LARGO MUÑOYERRO, San Pelayo de Arenillas).

LEÓN TELLO, Pilar, Judios de Toledo, Madrid 1979, 2 vol. (= LEÓN TELLO, Judíos de Toledo).

LIZOAIN GARRIDO, José Manuel, Documentación del monasterio de Las Huelgas de Burgos (1231-1262), Burgos 1985 (= LIZOAIN, Las Huelgas de Burgos).

LOAISA, Garsias, Collectio conciliorum Hispaniae, Madrid 1593 (= LOAISA, Collectio).

LOBATO YANES, Elena, Urraca I. La Corte Castellano-Leonesa en el siglo XII, Palencia 2000 (= LOBATO YANES, Urraca I).

LLORENTE, Juan Antonio, Disertación sobre el poder que los reyes españoles ejercieron hasta el siglo duodécimo en la división de obispados y otros puntos de disciplina eclesiástica, Madrid 1810 (= LLORENTE, Disertación).

MALDONADO Y FERNÁNDEZ DEL TORCO, José, Las relaciones entre el Derecho canónico y el Derecho secular en los concilios del s. XI, “Anuario de Historia del Derecho Español”, 14, 1942-1943, 227-381 (= MALDONADO, Las relaciones).

MANSI, Giovanni Domenico, Sacrorum Conciliorum, nova et amplissima collectio, Venecia 1775 (= MANSI, Collectio). 
MANSILlA RAMOS, Demetrio, Catálogo documental del Archivo Catedral de Burgos (804-1416), Madrid 1971 (= MANSILLA, Catálogo catedral de Burgos).

MANSILLA REOYO, Demetrio, Iglesia castellano-leonesa y curia romana en los tiempos del rey San Fernando, Madrid 1945 (= MANSILLA, Iglesia castellano-leonesa).

MARCOS DIEZ, David, Los archivos monásticos y sus fondos documentales: las abadias de Husillos y de Lebanza (Palencia). en Actas de las I Jornadas de Archivos Históricos en Granada (1999) (= MARCOS DÍEZ, Los archivos monásticos y sus fondos documentales).

- Documentación vaticana de la colección diplomática de la abadía de Santa María de Husillos (Palencia), "Boletín de la Academia de España en Roma” (2000), 116-119 (= MARCOS DÍEZ, Documentación vaticana diócesis de Palencia en el Archivo Vaticano).

- El Archivo de la Real Audiencia y Chancillería de Valladolid: las transferencias de la documentación y los procedimientos, en Actas del Congreso de Archivos Judiciales, 497-506, Sevilla 2007 (MARCOS DIEZ, El Archivo de la Real Chancillería de Valladolid).

MARCOS MARTÍN, Alberto, Economía, sociedad, pobreza en Castilla: Palencia, 1500-1814, 2 vols., Palencia 1985 (= MARCOS MARTíN, Economía, sociedad, pobreza en Castilla).

MARÍN MARTÍNEZ, Tomás - RUIZ ASENCIO, José Manuel, Paleografía y Diplomática, UNED, Madrid 1978 (= MARÍN - RUIZ ASENCIO, Paleografía y Diplomática).

MARTÍN MARTÍN, José Luis, Beneficios y oficios del clero rural castellano (siglos XIII-XV), “Anuario de estudios medievales”, 35, 2 (2005), 557-604 (= DÍAZ IBÁÑEZ, Beneficios y oficios del clero rural castellano). 
MARTÍNEZ DÍEZ, Gonzalo, Libro becerro de las behetrias. Estudio y texto crítico, León 1981, 3 vols (= MARTíNEZ DÍEZ, Becerro de las behetrías).

-El obispado de Palencia en el siglo X, en Liber Amicorum, Oviedo 1986, 339348 (= MARTÍNEZ DÍEZ, El obispado de Palencia en el siglo X).

- Los condados de Carrión y Monzón: sus fronteras, en Actas del I congreso de Historia de Palencia. I. Fuentes documentales y Edad Media, Palencia 1987, 245-274 (= MARTíNEZ DÍEZ, Los condados de Carrión y Monzón).

- Los cinco diplomas relativos a la restauración de la diócesis palentina por Sancho el Mayor, "Publicaciones de la Institución Tello Téllez de Meneses", 68 (1997), 161-190 (= MARTíNEZ DÍEZ, Cinco diplomas relativos a la restauración de la diócesis de Palencia).

- El condado de Castilla (711-1038). La historia frente a la leyenda, 2 vols. Valladolid 2005 (= MARTÍNEZ DÍEZ, El condado de Castilla).

- Sancho III el Mayor, Madrid 2007 (= MARTÍNEZ DÍEZ, Sancho III el Mayor).

MARTÍNEZ LLORENTE, Mariano, Sancho III el Mayor (1004-1035) y Palencia en el milenario de un reinado, Palencia 2003 (= MARTíNEZ LLORENTE, Sancho III el Mayor).

MENÉNDEZ PIDAL, Ramón, Los orígenes del español, Madrid 1929 (= MENÉNDEZ PIDAL, Los orígenes del español).

MILLARES CARLO, Agustín, La cancillería real en León y Castilla hasta fines del reinado de Fernando III, "Anuario de Historia del Derecho Español", 3, 1926, 227-306 (= MILLARES, La cancillería real).

MÍNGUEZ FERNÁNDEZ, José María, Colección diplomática del Monasterio de Sahagún (Siglos IX-X), León 1976 (= MÍNGUEZ, Sahagún, I). 
MOLINA, Luis, Las campañas de Almanzor a la luz de un nuevo texto, en Alcántara, II (1981) (= MOLINA, Las campañas de Almanzor a la luz de un nuevo texto).

MOLINA, Monserrat, Las tierras de Palencia durante la monarquía goda, en Historia de Palencia, I, Palencia 1984, 129-154 (= MOLINA, Las tierras de Palencia durante la monarquía goda).

MONTERDE ALBIAC, Cristina, Diplomatario de la reina Urraca de Castilla y León (1109 - 1126), Zaragoza 1996 (= MONTERDE ALBIAC, Diplomatario).

MORALES, Ambrosio de, Viaje de Ambrosio de Morales por orden del Rey Felipe II a los Reinos de Galicia, León y Principado de Asturias, Oviedo 1977 (edición facsímil) (= MORALES, Viaje Santo).

- Coronica general de España, Córdoba 1586 (= MORALES, Crónica general de España).

MORET, José de, Anales del Reino de Navarra, 1891 (= MORET, Anales).

MORETA VELAYOS, Salustiano, Rentas Monásticas en Castilla: Problemas de Método, Salamanca 1974 (= MORETA, Rentas monásticas en Castilla).

MOXÓ, Salvador de, Las desamortizaciones eclesiásticas del siglo XVI, "Anuario de Historia del Derecho Español”, 31 (1961), 327-362 (= MOXÓ, Las desamortizaciones eclesiásticas del siglo XVI).

NARGANES QUIJANO, Faustino, El señorio de abadengo en Palencia a mediados del siglo XVI, "Publicaciones de la Institución Tello Téllez de Meneses", 76 (2005), 261-284 (= NARGANES, El señorío de abadengo en Palencia). 
NARGANES QUIJANO, Faustino, y HERRERO MARCOS, Jesús, Palencia Monumental. Monumentos histórico-artísticos y bienes de interés cultural de la provincia, Palencia 1999 (= NARGANES y HERRERO, Palencia Monumental).

NIETO SORIA, José Manuel, La conflictividad en torno al diezmo en los comienzos de la crisis bajomedieval castellana, 1250-1315, "Anuario de estudios medievales", 14 (1984), 211-236 (NIETO SORIA, La conflictividad en torno al diezmo).

Norma Internacional General de Descripción Archivística: Adoptada por el Comité de Normas de Descripción, Estocolmo, Suecia, 19-22, septiembre de 1999. Madrid 2000 (= Normas ISAD-G).

OLIVA HERRER, Hipólito Rafael, La Tierra de Campos a fines de la Edad Media: economía, sociedad y acción política campesina, Valladolid 2002 (=OLIVA HERRER, La Tierra de Campos a fines de la Edad Media).

ORLANDIS ROVIRA, José, Sobre la elección de la sepultura en la España medieval, "Anuario de Historia del Derecho Español”, 20 (1950), 5-49 (= ORLANDIS ROVIRA, Sobre la elección de la sepultura en la España medieval).

- Traditio corporis et animae: (La familiaritas en las Iglesias y Monasterios españoles en la Alta Edad Media), "Anuario de Historia del Derecho Español”, 24 (1954), 95-280 (= ORLANDIS ROVIRA, La familiaritas en las Iglesias y Monasterios).

- Los monasterios familiares en España durante la Alta Edad Media, "Anuario de Historia del Derecho Español”, 26 (1956), 5-46 (= ORLANDIS ROVIRA, Los monasterios familiares en España durante la Alta Edad Media).

- Laicos y monasterios en la España Medieval, “Anuario de estudios medievales”, 17 (1987), 95-104 (= ORLANDIS ROVIRA, Laicos y monasterios en la España medieval). 
PALACIO SÁNCHEZ-IZQUIERDO, María Luisa, Monasterio de San Zoilo y monasterios palentinos, en Palencia en la Historia, Palencia 1982, 145166 (PALACIO, Monasterio de San Zoilo y monasterios palentinos).

PARDO RODRÍGUEZ, María Luisa, La Diplomática señorial en la Corona de Castilla, "Anuario de estudios medievales", 22 (1992), 233-246 (= PARDO RODRÍGUEZ, La Diplomática señorial).

- La confirmación en los documentos señoriales de la Baja Edad Media: aportación a su estudio, "Historia, instituciones, documentos", 12 (1985), 247-276 (= PARDO RODRÍGUEZ, La confirmación en los documentos señoriales de la Baja Edad Media).

PÉREZ CELADA, Julio A., Documentación del Monasterio de San Zoilo de Carrión (1047-1300), Palencia 1986 (= PÉREZ CELADA, Documentación de San Zoilo de Carrión, I)

- Documentación del Monasterio de San Zoilo de Carrión (1301-1400), Palencia 1987(= PÉREZ CELADA, Documentación de San Zoilo de Carrión, II).

PÉREZ DE ÚRBEL, Historia del Condado de Castilla, 3 vols., Madrid 1945 (= PÉREZ DE ÚRBEL, Historia del condado de Castilla).

- Sancho El Mayor de Navarra, Madrid 1950 (= PÉREZ DE ÚRBEL, Sancho el Mayor)

PLAZA BORES, Ángel de la, Guía del investigador. Archivo General de Simancas, Madrid 1992 (= PLAZA BORES, Guía del Archivo General de Simancas).

POLANCO PÉREZ, Arturo, Los Capellanes del $n^{\circ} 40$ de la catedral de Palencia: origen y evolución institucional, Palencia 2003 (= POLANCO PÉREZ, Los capellanes del $\left.n^{\circ} 40\right)$. 
PORTILLO CAPILLA, Teófilo, Vida administrativa en las catedrales en los siglos XII al XVI, "Memoria ecclesiae", 4 (1993), 85-99 (PORTILLO, Vida administrativa en las catedrales).

PRIETO PRIETO, Alfonso, Documentos referentes al orden judicial del Monasterio de Sahagún, "Anuario de Historia del Derecho Español”, 45 (1975), 489-542 (= PRIETO PRIETO, Documentos referentes al orden judicial de Sahagún).

PROCTER, Evelyns., Curia y cortes en Castilla y León 1072-1295, Madrid 1988 (= PROCTER, Curia y cortes).

QUINTANA PRIETO, Augusto, Peñalba (estudio histórico sobre el monasterio berciano de Santiago de Peñalba), León 1963 (= QUINTANA PRIETO, Peñalba).

- La documentación pontificia de Inocencio IV (1243-1254), 2 vols., Roma 1987 (= QUINTANA PRIETO, Inocencio IV).

RECUERO ASTRAY, MANUEL-RODRÍGUEZ PRIETO, $\mathrm{M}^{\mathrm{a}}$ ÁNGELESROMERO PORTILLA, PAZ, Documentos medievales del Reino de Galicia: Doña Urraca (1095-1126), Santa Comba (La Coruña) 2002 (= RECUERO, Documentos de Galicia: Doña Urraca).

REGLERO DE LA FUENTE, Carlos, El monasterio de San Isidoro de Dueñas en la Edad Media. Un priorato cluniacense hispano (911-1478). Estudio y colección documental, León 2005 (= REGLERO, San Isidro de Dueñas).

- La iglesia de Palencia en la crisis del siglo XIV: (1313-1379), “Asociación de amigos de la catedral” (1994), 46 (= REGLERO, La iglesia de Palencia en la crisis del siglo XIV).

- La iglesia de Palencia en la Edad Media, en Historia de las diócesis españolas. 19, Iglesias de Palencia, Valladolid y Segovia, Madrid 2004 (= REGLERO, La iglesia de Palencia en la Edad Media). 
REILLY, Bernard F., The Chancery of Alfonso VII of Leon-Castilla: The Period 1116 - 1135. Reconsidered, "Speculum”, 51 (1976), 243 - 261 (REYLLY, The Chancery).

- The kingdom of Leon-Castilla under Queen Urraca: 1109-1126, Princeton University Press, New Jersey 1982 (= REYLLY, Queen Urraca).

- El reino de León y Castilla bajo el rey Alfonso VI (1065-1109), Toledo 1989 (= REILLY, El reino de León).

RODRÍGUEZ DE DIEGO, José Luis, Colección diplomática de Santa María de Aguilar de Campoo (852-1230), Salamanca 2004 (= RODRÍGUEZ DE DIEGO, Colección diplomática de Santa María de Aguilar).

- El tumbo del monasterio cisterciense de La Espina, Valladolid 1982 (= RODRÍGUEZ DE DIEGO, El tumbo del monasterio de La Espina).

RODRÍGUEZ FERNÁNDEZ, Justiniano, Palencia: (panorámica foral de la provincia), Palencia 1981 (= RODRÍGUEZ FERNÁNDEZ, Palencia: panorámica foral)

ROSCALES OLEA, Graciliano, Monasterio de Santa María de la Vega: cartulario e historia: trayectoria transparente de un hundimiento, Palencia 2000 (= ROSCALES OLEA, Santa María de la Vega).

ROYER DE CARDINAL, Susana, El monasterio leonés de Santa María de Trianos y su articulación con otras instancias eclesiásticas (s. XII-XV), "Hispania Sacra”, 59 (2007), 7-33 (= ROYER DE CARDINAL, Santa María de Trianos).

RUBIO, José Antonio, "Donationes post obitum” y “donationes reservato usufructo" en la alta Edad Media de León y Castilla, "Anuario de Historia del Derecho Español”, 9 (1932), 1-32 (= RUBIO, "Donationes post obitum" y “donationes" reservato usufructo"). 
RUIZ ALBI, Irene, Cancillería y colección diplomática de la reina Doña Urraca (1109-1126), León 2004 (= RUIZ ALBI, Cancillería y colección diplomática de la reina Urraca).

RUIZ ASENCIO, José Manuel, Campañas de Almanzor contra el reino de León (981-986), “Anuario de estudios medievales”, 5 (1968), 31-64 (= RUIZ ASENCIO, Campañas de Almanzor).

- Documentos y códices altomedievales de San Román de Entrepeñas, en Actas del I congreso de Historia de Palencia. 2. Fuentes documentales y Edad Media, Palencia 1987, 9-50 (= RUIZ ASENCIO, San Román de Entrepeñas).

- Escribas y bibliotecas altomedievales hispanos, en X Semana de Estudios Medievales, Nájera 2000, 151-174 (= RUIZ ASENCIO, Escribas y bibliotecas altomedievales).

- La medida del tiempo en la España cristiana en el año 1000, en Año mil, año dos mil. Dos milenios en la Historia de España, Madrid 2001, 93-116 (= RUIZ ASENCIO, La medida del tiempo en la España cristiana).

RUIZ ASENCIO, José Manuel - RUIZ ALBI, Irene - HERRERO JIMÉNEZ, Mauricio, Colección documental del monasterio de San Román de Entrepeñas (940-1608), León 2000 (ASENCIO - ALBI - HERRERO, San Román de Entrepeñas).

RUIZ DE LOAIZAGA ULIBARRI, Saturnino, Documentos vaticanos de la diócesis de Palencia en la Edad Media (siglos XIV-XV), "Publicaciones de la Institución Tello Téllez de Meneses", 77 (2006), 359-386 (= LOAIZAGA, Documentos vaticanos de la diócesis de Palencia).

SÁENZ DE AGUIRRE, José, Collectio maxima Conciliorum omnium Hispaniae et novi orbis, 6 vols., Roma 1753-1755 (= SÁENZ DE AGUIRRE, Collectio). 
SÁEZ, Emilio, Fueros de San Julián y Villamuriel (Palencia), "Anuario de Historia del Derecho Español”, 15 (1944), 557-561 (= SÁEZ, Fueros de San Julián y Villamuriel).

- Colección documental del archivo de la catedral de León, I (775-952), León 1987 (= SÁEZ, Colección documental de la catedral de León, I)

SÁEZ, Emilio - SÁEZ, Carlos, Colección documental de la catedral de León, II (953-985), León 1990 (= SÁEZ, E.-SÁEZ, C., Colección documental de la catedral de León, II).

SÁEZ SÁNCHEZ, Carlos, Colección diplomática de Sepúlveda, vol. II (10761485), Segovia 1991 (= C. SÁEZ, Colección de Sepúlveda).

SAN MARTÍN PAYO, Jesús, La más antigua estadística de la Diócesis Palentina, "Publicaciones de la Institución Tello Téllez de Meneses", 7 (1951), 1-120 (= SAN MARTÍN PAYO, La más antigua estadística de la diócesis de Palencia).

- El cabildo de Palencia, "Publicaciones de la Institución Tello Téllez de Meneses”, 34 (1973), 229-248 (SAN MARTÍN PAYO, El cabildo de Palencia).

- Santa María de Husillos y su colección diplomática: (hasta su traslado a Ampudia, a. 1608), "Publicaciones de la Institución Tello Téllez de Meneses”, 43 (1979), 151-171 (= SAN MARTÍN PAYO, Santa María de Husillos y su colección diplomática).

- Catálogo del Archivo de la Catedral de Palencia, "Publicaciones de la Institución Tello Téllez de Meneses”, 50 (1983), 49-77 (= SAN MARTÍN PAYO, Catálogo Catedral de Palencia).

- Cardenales abades de Santa María de Husillos, "Publicaciones de la Institución Tello Téllez de Meneses”, 51 (1984), 49-77 (= SAN MARTÍN PAYO, Cardenales abades de Santa María de Husillos).

- Apasionante historia de cinco casas que poseían en Valladolid los abades de Husillos, "Publicaciones de la Institución Tello Téllez de Meneses", 58 
(1988), 153-248 (= SAN MARTÍN PAYO, Apasionante historia de cinco casas).

- Las primeras donaciones de los condes de Monzón a Santa María de Husillos,

"Publicaciones de la Institución Tello Téllez de Meneses", 59 (1988), 299349 (= SAN MARTÍN PAYO, Las primeras donaciones de los condes de Monzón)

- Villaldavín en la Colección Diplomática de Santa María de Husillos, "Publicaciones de la Institución Tello Téllez de Meneses", 61 (1990), 107138 (= SAN MARTÍN PAYO, Villaldavín).

- El libro becerro de las propiedades de Santa María de Husillos, en Actas del II congreso de Historia de Palencia. II. Fuentes documentales y Edad Media, Palencia 1990, 239-260 (= SAN MARTín PAYO, El Libro Becerro de Husillos)

- Notas históricas sobre la abadía de Husillos, "Publicaciones de la Institución Tello Téllez de Meneses”, 64 (1993), 197-236 (= SAN MARTÍN PAYO, Notas históricas de Husillos).

SÁNCHEZ ALBORNOZ, Claudio, Serie de documentos inéditos del reino de Asturias, "Cuadernos de Historia de España", 1-2 (1944), 298-351 (= SÁNCHEZ ALBORNOZ, Documentos de Asturias).

- Despoblación y repoblación en el Valle del Duero, Buenos Aires 1966 (SÁNCHEZ ALBORNOZ, Despoblación y repoblación en el Valle del Duero).

SÁNCHEZ BELDA, Luis, Cartulario de Santo Toribio de Liébana, Madrid 1948 (= SÁNCHEZ BELDA, Santo Toribio de Liébana).

- La confirmación de documentos por los reyes del occidente español, "RABM", LIX (1953), 85-116 (= SÁNCHEZ BELDA, La confirmación de documentos).

SÁNCHEZ HERRERO, José, Las diócesis del reino de León: siglos XIV-XV, León 1978 (= SÁNCHEZ HERRERO, Las diócesis del reino de León). 
SANCHO CAMPO, Ángel, Husillos. Iglesia de Santa María, Palencia 1994 (= SANCHO CAMPO, Husillos. Iglesia de Santa María).

SANCHO PRADILLA, Gregorio, La abadía de Husillos, "Castilla artística e histórica : Boletín de las Sociedad Castellana de Excursiones", 5 (19111912), 293-301 (= SANCHO PRADILLA, La abadía de Husillos).

SANDOVAL, Prudencio de, Historia de los reyes de Castilla y de León don Fernando el Magno, don Sancho, don Alfonso Sexto, doña Urraca y don Alfonso Séptimo, Pamplona 1615 (SANDOVAL, Cinco reyes).

SERRANO, Luciano, El obispado de Burgos y Castilla primitiva, desde el siglo $V$ al XIII, 3 vols., Madrid 1935 (= SERRANO, Obispado de Burgos).

- Cartulario de San Pedro de Arlanza (= SERRANO, Cartulario de Arlanza).

SOTA, Francisco, Chrónica de los Príncipes de Asturias y Cantabria, Madrid 1681 (= SOTA, Crónica).

SOTO RÁBANOS, José María, Disposiciones sobre la cultura del clero parroquial en la literatura destinada a la cura de almas: siglos XIII-XV, "Anuario de estudios medievales", 23 (1993), 257-356 (= SOTO RÁBANOS, Disposiciones sobre la cultura del clero parroquial).

TERESA LEÓN, Tomás, Paredes de Nava, villa señorial: (su Historia y tesoro artístico), "Publicaciones de la Institución Tello Téllez de Meneses”, 27 (1968) (=TERESA LEÓN, Paredes de Nava).

TORRES AGUILAR, Manuel, El origen del sistema de "iglesias propias", “Anuario de Historia del Derecho Español”, 5 (1928), 83-217 (= TORRES AGUILAR, El origen del sistema de “iglesias propias”). 
TRENCHS ODENA, José, Diplomatario del Cardenal Gil de Albornoz: Cancillería Pontificia: 1351-1353, Barcelona 1976 (TRENCHS ODENA, Diplomatario del Cardenal Gil de Albornoz).

VACA LORENZO, Ángel, La estructura socioeconómica de la Tierra de Campos a mediados del siglo XIV, "Publicaciones de la Institución Tello Téllez de Meneses”, 39 (1977), 233-398. Continúa en el vol. 42 (1980), 202-387 (=VACA LORENZO, La estructura socioeconómica de la tierra de Campos).

- Documentación Medieval de la Villa de Astudillo (Palencia), "Publicaciones de la Institución Tello Téllez de Meneses”, 48 (1983), 31-100.

- El Obispado de Palencia desde sus orígenes hasta su definitiva restauración en el siglo XI, "Hispania sacra", 52 (2000), 21-72 (= VACA LORENZO, El obispado de Palencia desde sus orígenes).

VALDEÓN BARUQUE, Julio, La crisis bajomedieval en tierras palentinas, en Actas del III congreso de Historia de Palencia. II. Historia Medieval, Palencia 1995, 333-346 (= VALDEÓN, La crisis bajomedieval en tierras palentinas).

VALlE CURIESES, Rafael del, Archivo Municipal de Palencia: Privilegios y cartas reales concedidos a la ciudad en la Edad Media (Regesta y comentarios). Pág. 115-154. En Actas del I Congreso de Historia de Palencia, Tomo II. Fuentes Documentales y Edad Media (= DEL VALLE CURIESES, Archivo Municipal de Palencia: Privilegios y cartas reales).

VIELVA RAMOS, Matías, La antigua abadía de Husillos (Palencia), "Castilla artística e histórica: Boletín de la Sociedad Castellana de Excursiones", 1 (1903-1904), 19-20 (= VIELVA, La antigua abadía de Husillos).

VIGNAU, Índice de los documentos del monasterio de Sahagún, Madrid 1874 (= VIGNAU, Índice de los documentos de Sahagún). 
VIGURI CANTERO, Miguel de, Paredes de Nava en el Antiguo Régimen: epigrafia y documentos, Palencia 2002 (= VIGURI, Paredes de Nava).

VILLA CALVO, Nicolás, Mendunia: historia documentada del condado de Monzón, Monzón de Campos 2002 (= VILLA CALVO, Historia del condado de Monzón)

VILLACORTA RODRÍGUEZ, Tomás, El cabildo Catedral de León: estudio histórico-jurídico, siglo XII-XIX, León 1974 (= VILLACORTA, El cabildo Catedral de León).

VONES LUDWIG, Die, Historia Compostelana und die Kirchenpolitik der Nordwestspanischen Raumes 1070-1130, Ein Beitrag zur Geschichte des 12 Jahrhunderts, Colonia 1980 (= VONES, Historia Compostelana).

YÁÑEZ CIFUENTES, María de Pilar, El monasterio de Santiago de León. Estudio histórico documental, León 1972 (= YÁÑEZ CIFUENTES, El monasterio de Santiago de León).

YÁÑEZ NEIRA, Damián, El monasterio de La Espina y sus abades, "Archivos Leoneses: revista de estudios y documentación de los Reinos HispanoOccidentales", 51 (1972), 69-149 (= YÁÑEZ NEIRA, El monasterio de La Espina y sus abades).

ZABALZA DUQUE, Manuel, Colección diplomática de los Condes de Castilla : edición y comentario de los documentos de los condes Fernán González, García Fernández, Sancho García y García Sánchez, Valladolid 1998 (= ZABALZA, Colección diplomática de los condes de Castilla).

ZABALZA DUQUE, Manuel - CRUZ, fray Valentín de la, Sancho III el Mayor. Apéndice documental, en Orcástegui Gros, Carmen; Sarasa Sánchez, Esteban, Sancho III el Mayor (1004-1035), Burgos 2000 (= ZABALZA DE LA CRUZ, Sancho III el Mayor). 


\section{ANEXOS}

\section{Mapas de las heredades de Santa María de Husillos ${ }^{1}$}

\footnotetext{
${ }^{1}$ Los mapas se han elaborado utilizando como base fragmentos seleccionados de la cartografía digital ofrecida por la "Infraestructura de Datos Espaciales de Castilla y León", accesible gratuitamente en $w w w . j c y l . e s$.
} 


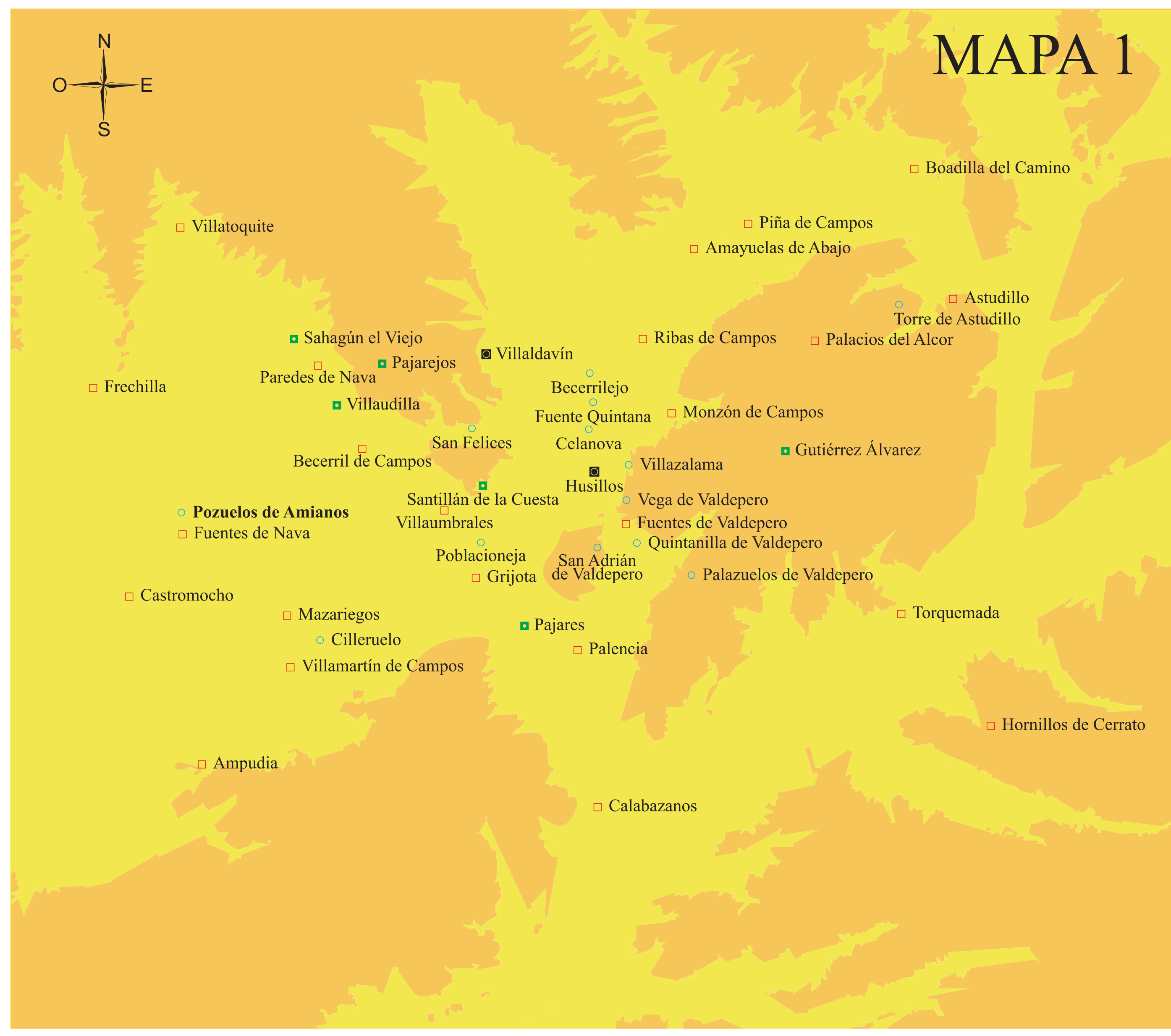

\section{LEYENDA:}

$\square$ Lugares en los que Santa María de Husillos poseía heredades y derechos

ø Lugares en los que Santa María de Husillos ejercía el dominio señorial

- Despoblados en los que Santa María de Husillos poseía heredades y derechos

- Despoblados en los que Santa María de Husillos ejercía el dominio señorial

Despoblados sin localizar: Castellanos, Tejada, Villa Alarigo, Villagudiel, Villálvarez, Villaverde 

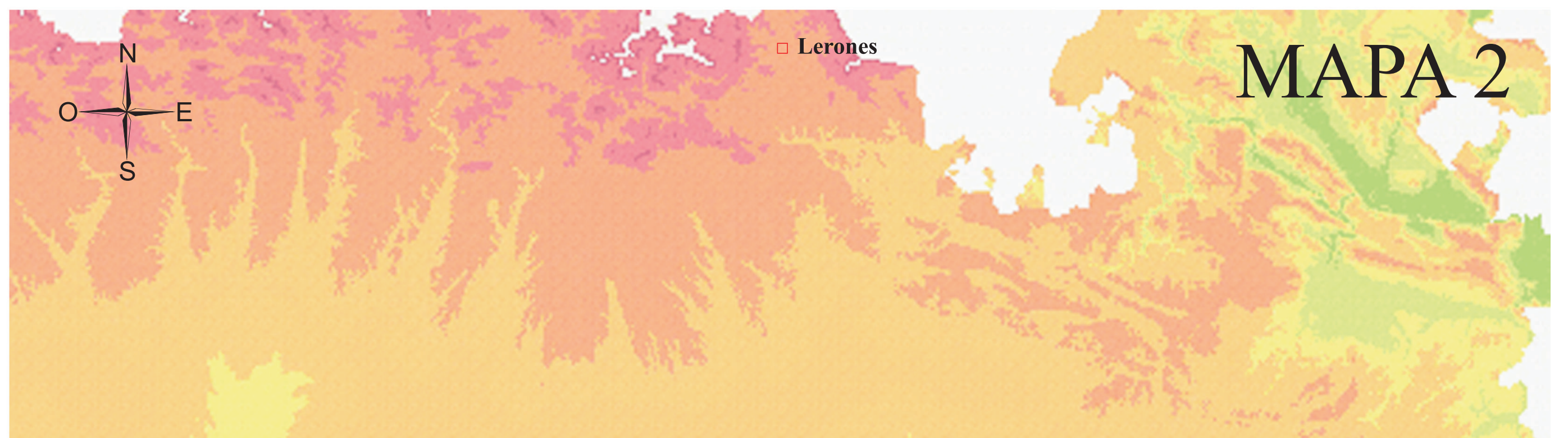

$\square$ Tardajos

$\square$ Villacid de Campos

- San Sebastián de Hérmedes

$\square$ Villagarcía de Campos

$\square$ Valladolid

Q Hoyales de Roa

a Fuentelisendo

\section{LEYENDA:}

$\square$ Lugares en los que Santa María de Husillos poseía heredades y derechos

o Lugares en los que Santa María de Husillos ejercía el dominio señorial

- Despoblados en los que Santa María de Husillos poseía heredades y derechos

- Despoblados en los que Santa María de Husillos ejercía el dominio señorial

Despoblados sin localizar: Castellanos, Tejada, Villa Alarigo, Villagudiel, Villálvarez, Villaverde 